\title{
Archaeological investigations at the last Spanish Colonial mission establised on the Texas frontier: Nuestra Senora del Rufugio (41RF1), Refugio County, Texas
}

Cynthia L. Tennis

Follow this and additional works at: https://scholarworks.sfasu.edu/ita

Part of the American Material Culture Commons, Archaeological Anthropology Commons, Environmental Studies Commons, Other American Studies Commons, Other Arts and Humanities Commons, Other History of Art, Architecture, and Archaeology Commons, and the United States History Commons

Tell us how this article helped you.

This Article is brought to you for free and open access by the Center for Regional Heritage Research at SFA ScholarWorks. It has been accepted for inclusion in Index of Texas Archaeology: Open Access Gray Literature from the Lone Star State by an authorized editor of SFA ScholarWorks. For more information, please contact cdsscholarworks@sfasu.edu. 


\section{Archaeological investigations at the last Spanish Colonial mission establised on the Texas frontier: Nuestra Senora del Rufugio (41RF1), Refugio County, Texas}

\section{Licensing Statement}

This is a work produced for the Texas Department of Transportation (TxDOT) by the report producer. TxDOT and the report producer jointly own all rights, title, and interest in and to all intellectual property developed under TXDOT's contract with the report producer. The report may be cited and brief passages from this publication may be reproduced without permission provided that credit is given to both TXDOT and the report producer. Permission to reprint an entire chapter, section, figures or tables must be obtained in advance from either the Supervisor of the Archeological Studies Branch, Environmental Affairs Division, Texas Department of Transportation, 125 East 11th Street, Austin, Texas, 78701 or from the report producer. 


\title{
Archaeological investigations at the last Spanish Colonial mission established on the Texas frontier: \\ Nuestra Señora del Refugio (41RF1), ^ Refugio County, Texas
}

\section{Volume I Archaeological Investigations}

\author{
by \\ Gynthia L. Tennis
}

I. Waynne Cox

J. Philip Dering

Anne A. Fox

Douglas S. Frink

Michael D. Glascock

Robert J. Hard
Contributions by

David V. Hill

Lee Meadows Jantz

Richard L. Jantz.

John G. Jones

David R. McDonald
Texas Department of Transportation Environmental Affairs Division Archeological Studies Program, Report No. 39

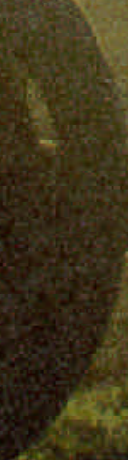

Barbara A. Meissner

Hector Neff

Lynette Norr

Timothy K. Perttula Elizabeth J. Reitz

Steve A. Tomka

$\begin{array}{ll} & \text { Barbara A. Meissner } \\ & \text { Hector Neff } \\ & \text { Lynette Norr } \\ & \text { Timothy K. Perttula } \\ & \text { Elizabeth J. Reitz } \\ & \text { Steve A. Tomka }\end{array}$

Center for Archaeological Research The University of Texas at San Antonio Archaeological Survey Report, No. 315 


\title{
Archaeological investigations at the last Spanish Colonial mission established on the Texas frontier: \\ Nuestra Señora del Refugio (4IRfI), Refugio County, Texas

\author{
Volume I \\ Archaeological Investigations
}

\author{
by \\ Cynthia L. Tennis
}

I. Waynne Cox

Contributions by

J. Philip Dering

David V. Hill

Lee Meadows Jantz

Richard L. Jantz

John G. Jones

Douglas S. Frink

Michael D. Glascock

David R. McDonald

Robert J. Hard

With a Foreword by Al McGraw.

\author{
Barbara A. Meissner \\ Hector Neff \\ Lynette Norr \\ Timothy K. Perttula \\ Elizabeth J. Reitz \\ Steve A. Tomka
}

Texas Antiquities Committee Permit No. 2025

Raymond P. Mauldin and Cynthia L. Tennis Principal Investigators

and

\section{Britt Bousman and Robert J. Hard \\ Former Principal Investigators}

Prepared for:

Texas Department of Transportation Environmental Affairs Division Archeological Studies Program, Report No. 39

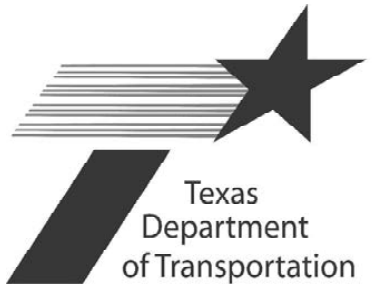

Prepared by:

Center for Archaeological Research The University of Texas at San Antonio Archaeological Survey Report, No. 315

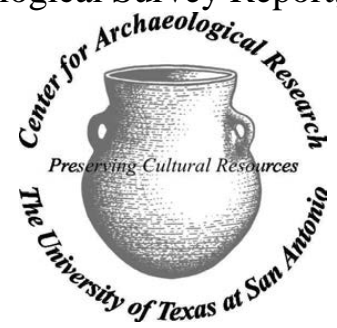




\author{
Archaeological Investigations at the \\ last Spanish Colonial mission \\ established on the Texas frontier: \\ Nuestra Señora del Refugio (41RF1), Refugio County, Texas
}

\author{
Copyright ${ }^{{ }^{\circ}} 2002$ \\ Texas Department of Transportation (TxDOT) and Center for Archaeological Research, \\ The University of Texas at San Antonio (CAR-UTSA)
}

\begin{abstract}
All rights reserved
TxDOT and CAR-UTSA jointly own all rights, title, and interest in and to all data and other information developed for this project under Contract(s) 57-0XXA3003, 57-8XXA3008, and 57-0XXPF001. Brief passages from this publication may be reproduced without permission provided that credit is given to TxDOT and CAR-UTSA. Permission to reprint an entire chapter, section, figures or tables must be obtained in advance from the Supervisor of the Archeological Studies Program, Environmental Affairs Division, Texas Department of Transportation, 125 East 11th Street, Austin, 78701. Copies of this publication have been deposited with the Texas State Library in compliance with the State Depository requirements.
\end{abstract}

Printed by Kwik Kopy Printing on Main, San Antonio, Texas

2002

jointly published by

Texas Department of Transportation

Environmental Affairs Division

Archeological Studies Program

Nancy A. Kenmotsu, Ph.D., Supervisor

Archeological Studies Program, Report No. 39

A. McGraw, Series Editor

and

Center for Archaeological Research

The University of Texas at San Antonio

Archaeological Survey Report, No. 315

Printed on acid-free, $60 \mathrm{lb}$. paper

ISBN: 1-930788-18-5 


\title{
Abstract:
}

\section{Mission Nuestra Señora del Refugio}

\author{
Volume I \\ Archaeological Investigations
}

Between 1998 and 1999, the Center for Archaeological Research, The University of Texas at San Antonio, conducted archaeological investigations at the Spanish Colonial-period Mission Nuestra Señora del Refugio, located in Refugio County, in southern Texas. This project was conducted under Texas Antiquities Permit No. 2025. The initial phase of the excavations concentrated along US 77, in the TxDOT right-of-way, and the subsequent work conducted led to the exhumation of 165 burials, the discovery of the location of the 1796 church and the associated mission compound features.

The excavations and subsequent analyses were guided by several research questions focused on shedding light, through skeletal and biological analyses, on the characteristics of the Karankawa Indians, identifying the influence of the Spanish material culture upon Native American technology (ceramic and lithic), and studying the effect of proselytization and mission life upon the diet, subsistence, health, and physiology of mission neophytes.

This report presents the results of a variety of specialized studies including a concise history of the 35-year occupation of the mission based on the archival study of more than 600 documents. It summarizes the excavation and contents of two Colonial trash pit features, and a possible third trash feature, a small midden accumulation, various architectural features, and reports on the results of the excavation of 37 burial features containing the remains of at least 165 individuals. The analysis of the Spanish Colonial ceramics and artifacts indicates that Mexican-made wares and artifacts continued to be provisioned to the mission well into the nineteenth-century, and probably up to the date of its closing, but in decreasing numbers. At the same time, a variety of Native American ceramic wares continued to be made and used at this mission. However, the Native American ceramics from Refugio tend to have distinctive characteristics that may result from cultural contact with other nearby Native American populations, and the desire and/or need to produce wares for the Spanish colonists and missionaries in their midst. The results of the lithic analysis support the view that Native American technology was in transition during the occupation of the mission and at least in part the factors that may be responsible are changes in the subsistence practices of the Native populations and the impact of non-traditional raw materials, tools and weapons on native tool kits. The faunal analysis of the extensive collection suggests that there was very little change in the dominant component of the subsistence strategy, large bovids, during the use of the mission. However, the use of domesticated species declines slightly over time while the consumption of freshwater fish, as a percentage of all fish consumed, increases during the late part of the occupation. The exceptionally comprehensive analysis of the skeletal population indicates that about three quarters of the burial population from the mission were Native American and the remainder was of European and/or a mix of European and Native American ancestry. 


\title{
Mission Nuestra Señora del Refugio Volume Contents
}

\author{
Volume I: \\ Archaeological Investigations \\ Chapter 1: Introduction \\ Chapter 2: Environment \\ Chapter 3: Mission History \\ Chapter 4: The People of Mission Refugio \\ Chapter 5: Post-1830 History \\ Chapter 6: Previous Archaeology \\ Chapter 7: Methodology
}

Chapter 8: Findings: Trash and Midden; Architectural; Burial; and Skeletal Biology

Chapter 9: Artifacts: Non-Native Ceramics; Other Historic; Native Ceramics; Lithics; and Faunal I \& II

Chapter 10: Summary and Conclusion

Volume I - CD:

Archaeological Investigations Appendices

Appendix A: Translations: 1796 Inventory; 1792-1810 Supply Inventories; and 1820 Inventory

Appendix B: Records: Baptismal; Burial; and Census

Appendix C: Artifact Data

Appendix D: Oxidizable Carbon Ratio Data

Appendix E: Botanical Remains Data

Appendix F: Pollen and Phytoliths Analysis

Appendix G: Petrographic Ceramic Analysis

Appendix H: Instrumental Neutron Activation Analysis-Non-Native Ceramics

Appendix I: Burial Artifact Data

Appendix J: Paste and Temper Analysis-Native Ceramics

Appendix K: Rim Sherds and Decorated Sherds-Native Ceramics

Appendix L: Instrumental Neutron Activation Analysis-Native Ceramics

Appendix M: Faunal Provenience and Measurements

Appendix N: Archaeological Form Samples

Volume II:

Osteological Analyses

Section A: Introduction

Section B: Preparation of Sample and Methods for Analysis

Section C: Individual Burials

Section D: Bone Inventory

Section E: Demography

Section F: Bone Pathology

Section G: Dental Pathology

Section H: Dental Metrics and Morphology

Section I: Metric Analysis of Postcranial Remains

Section J: Metric Analysis of Cranial Morphology

Section K: Dietary Variation, Ethnicity and Mobility

Section L: Summary and Conclusion

Volume II:

Appendices

Appendix IIA: Burial Descriptions

Appendix IIB: Inventory and Coding Forms

Appendix IIC: Individuals with Enthesophytosis

Appendix IID: Individuals with Antemortem Fractures

Appendix IIE: Isotopic Analysis 


\section{Table of Contents:}

\section{Mission Nuestra Señora del Refugio}

Abstract

\section{Volume I \\ Archaeological Investigations}

Figures

Tables

Foreword

Acknowledgments

Chapter 1: Introduction

Project History 2

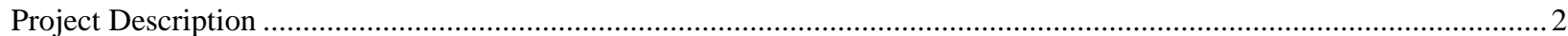

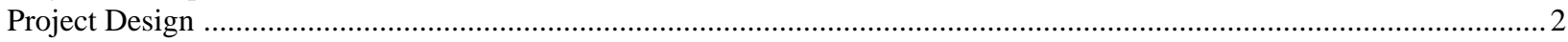

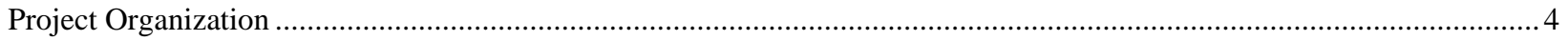

Chapter 2: Environmental and Cultural Setting

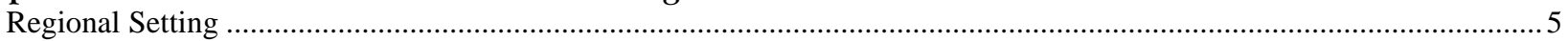

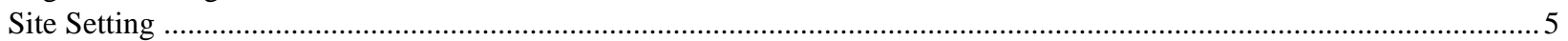

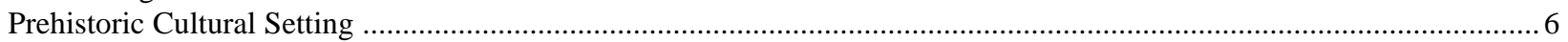

Chapter 3: Mission History by David R. McDonald

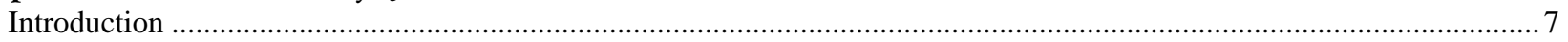

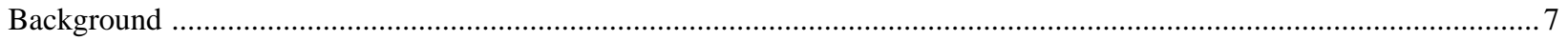

Section A: 1789-1794; The Founding of Refugio and Ministry of Fr. Mariano Garza .............................................. 10

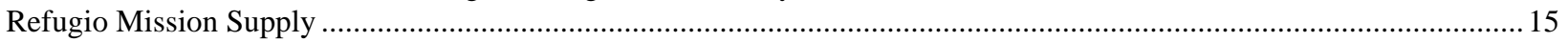

Section в: 1794-1796; The Ministry of Fr. Manuel de Silva …............................................................................... 18

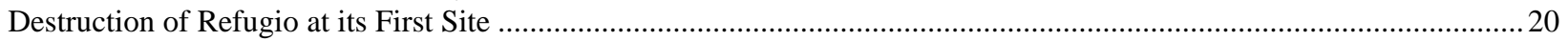

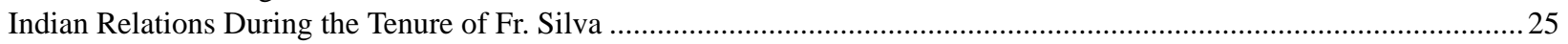

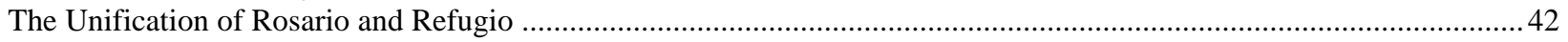

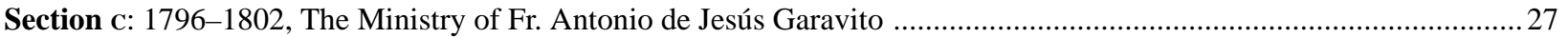

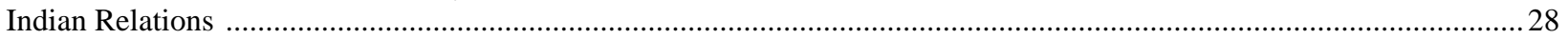

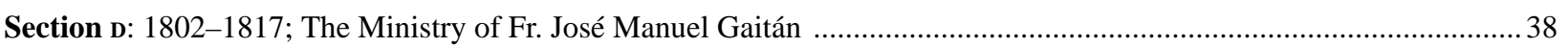

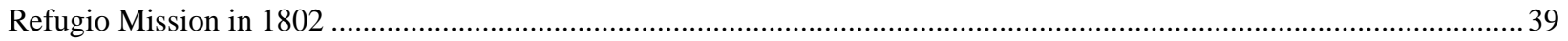

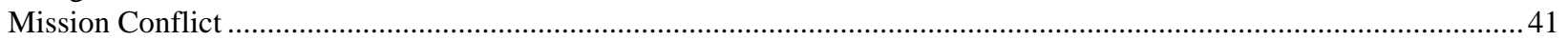

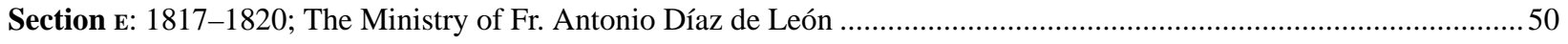

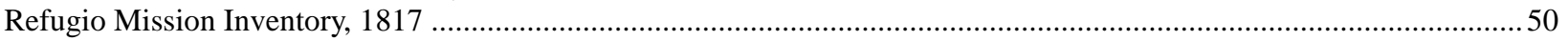

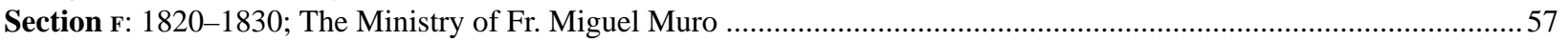

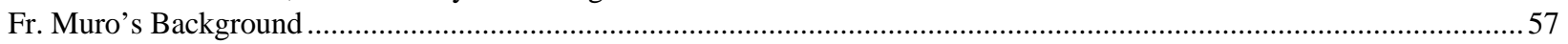

Chapter 4: The People of Mission Refugio

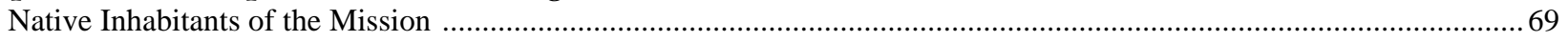

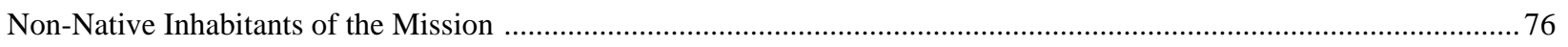

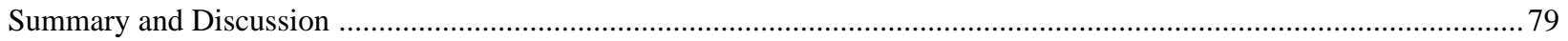

Chapter 5: Post-1830 History by I. Waynne Cox

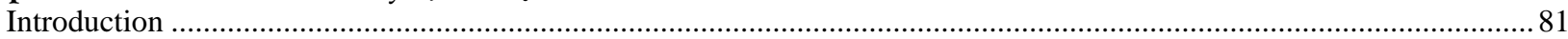

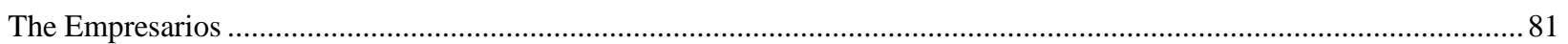

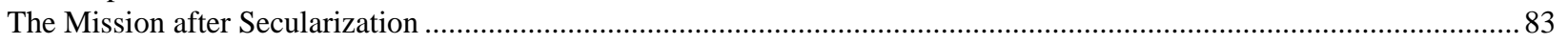

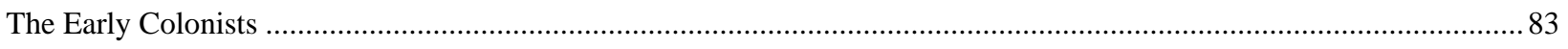

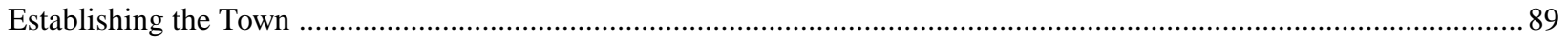

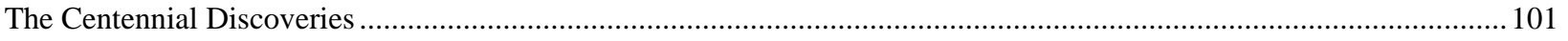

Chapter 6: Previous Archaeology

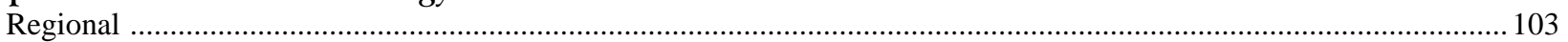

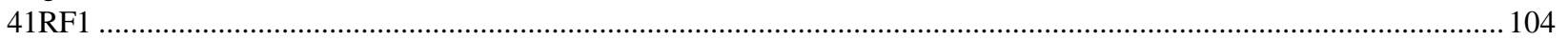

Chapter 7: Methodology

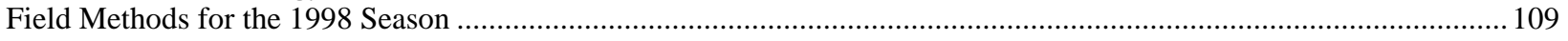

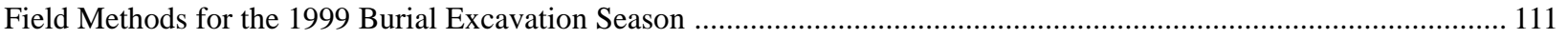




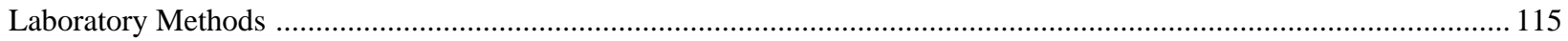

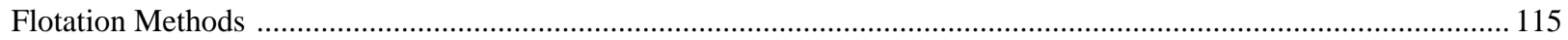

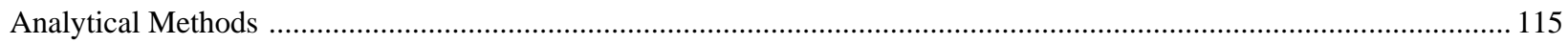

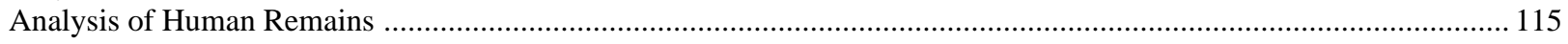

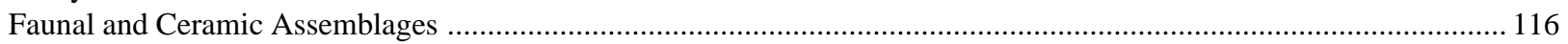

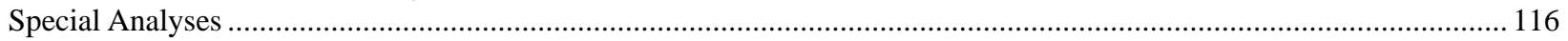

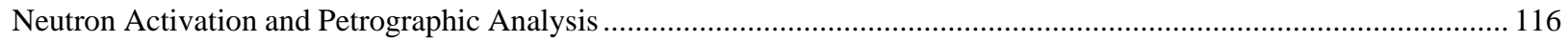

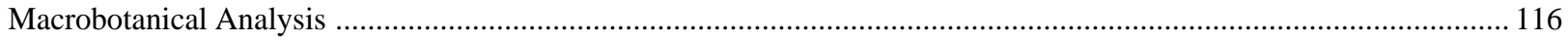

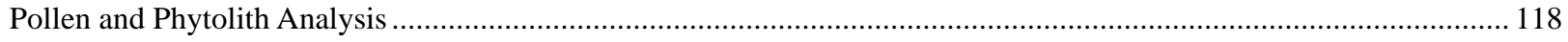

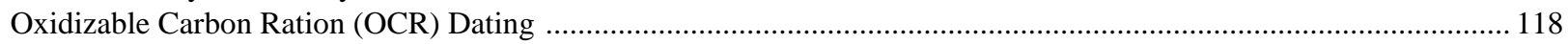

Chapter 8: Findings - Section A: Trash and Midden Features

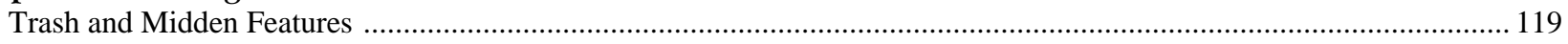

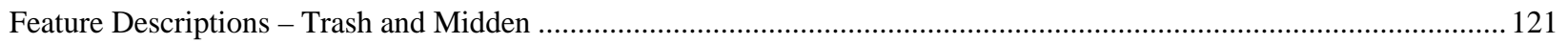

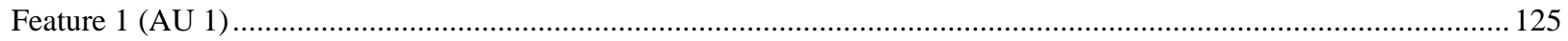

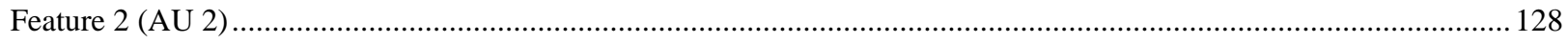

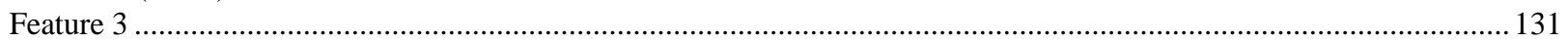

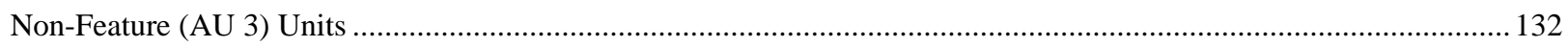

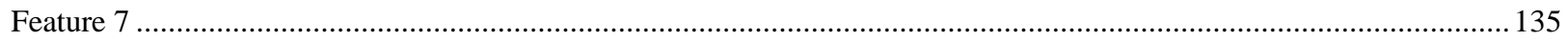

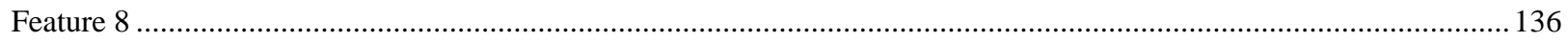

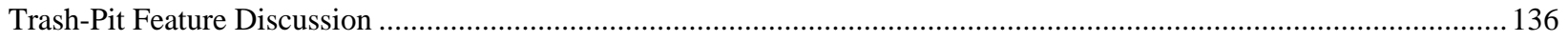

Chapter 8: Findings - Section B: Architectural Features

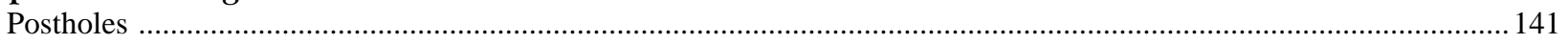

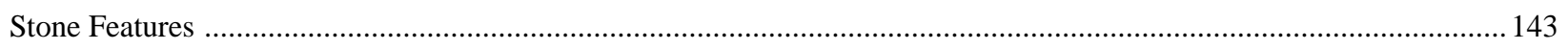

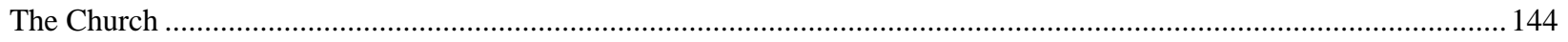

Conjectures on the Configuration of Mission Refugio ............................................................................................. 147

Chapter 8: Findings - Section c: Burial Features

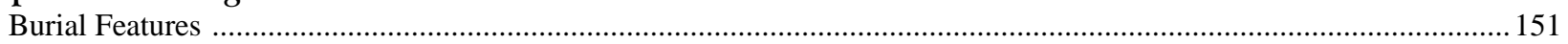

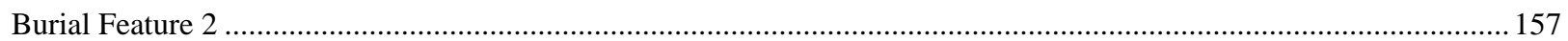

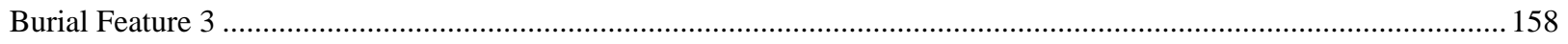

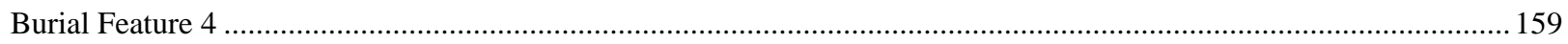

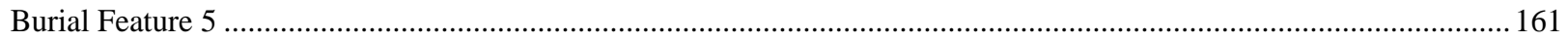

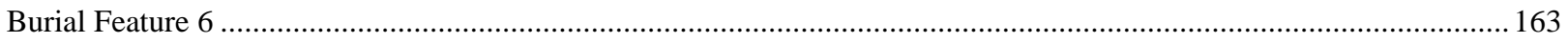

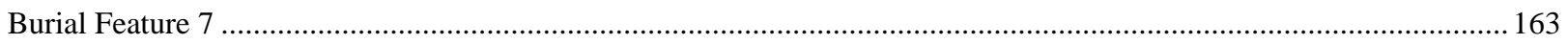

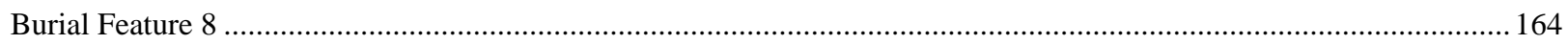

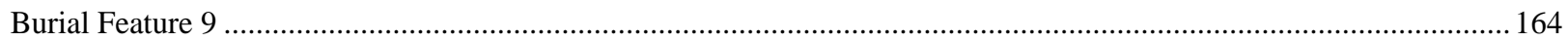

Burial Feature 10

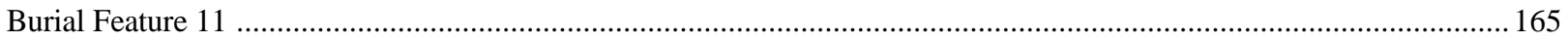

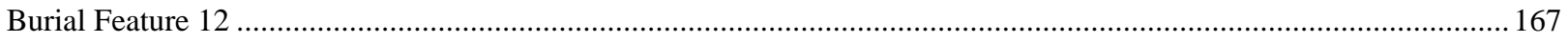

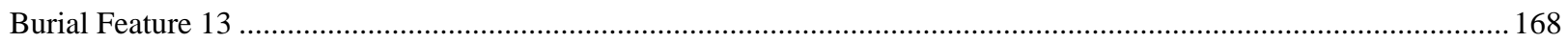

Burial Feature 14

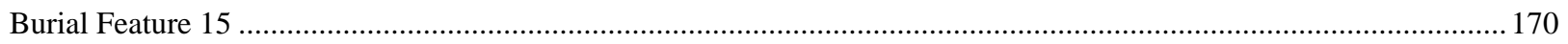

Burial Feature 16

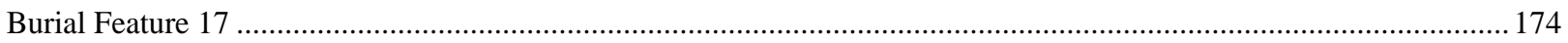

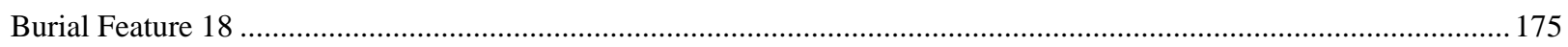

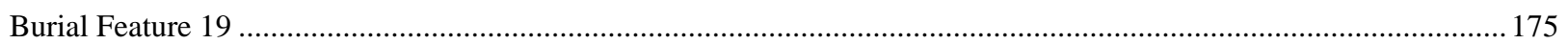

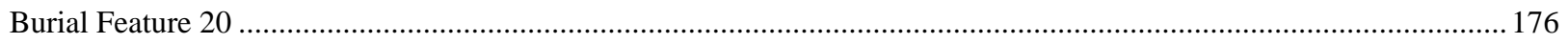

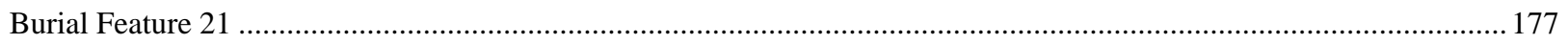

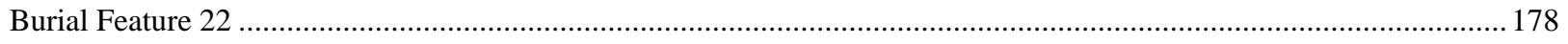

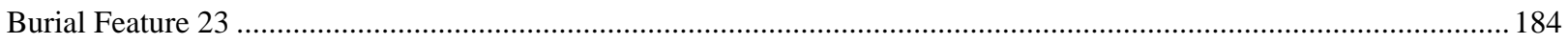

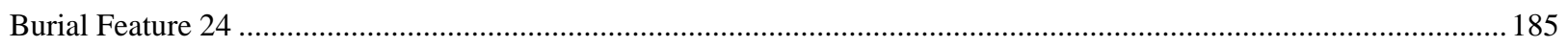

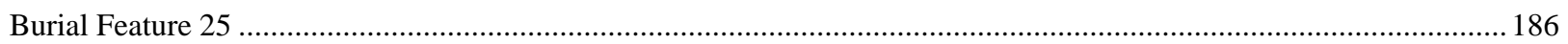

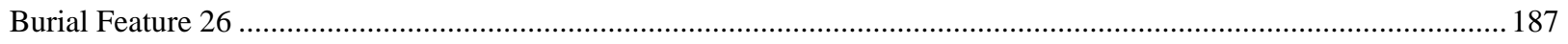




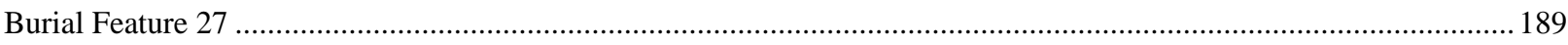

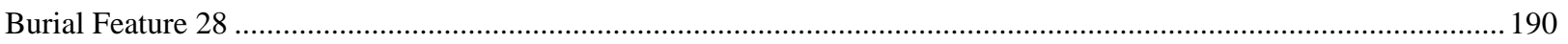

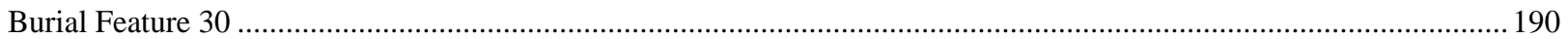

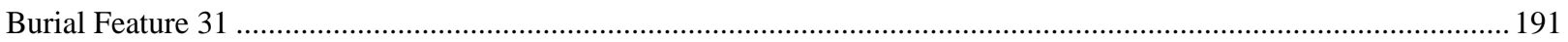

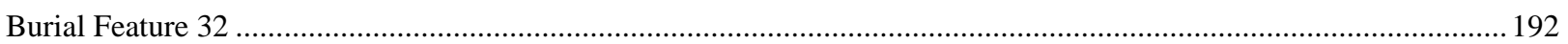

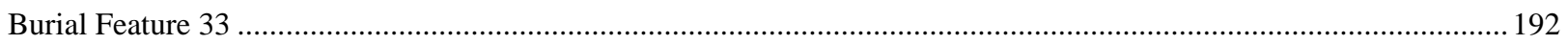

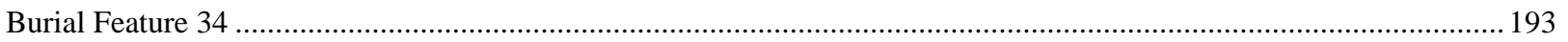

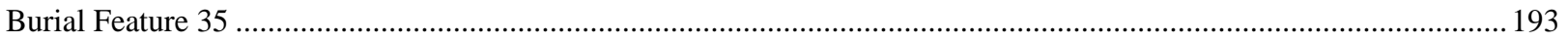

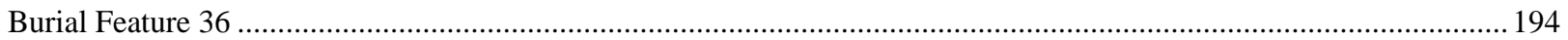

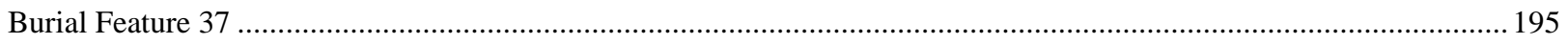

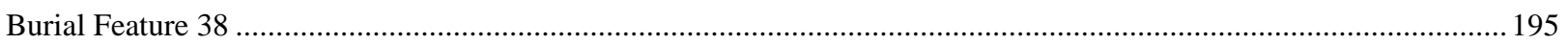

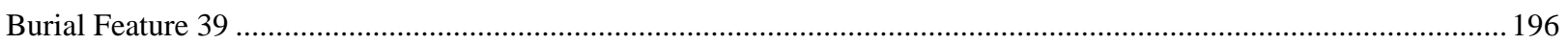

Chapter 8: Findings - Section D: Skeletal Biology by L. Meadows Jantz and R. L. Jantz

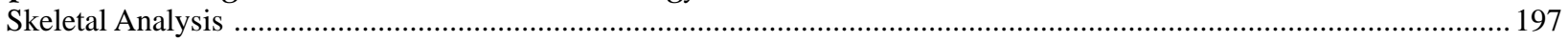

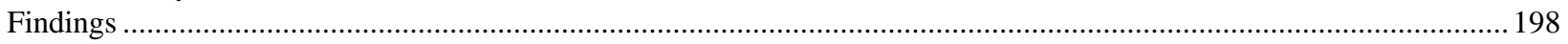

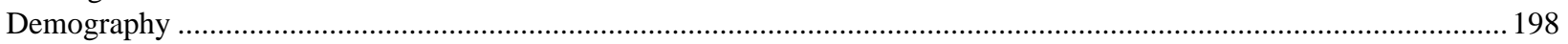

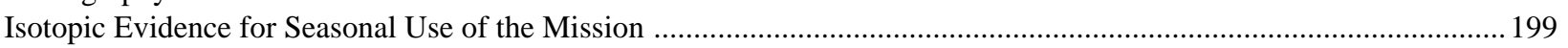

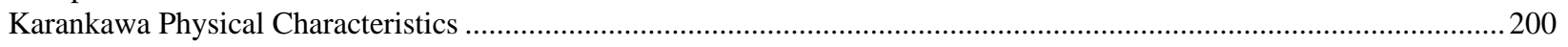

Chapter 9: Artifacts - Section A: Ceramics by Anne A. Fox

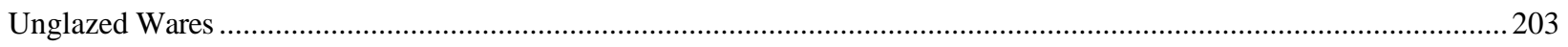

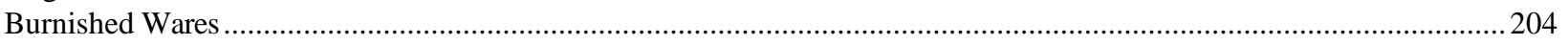

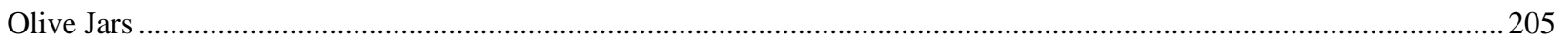

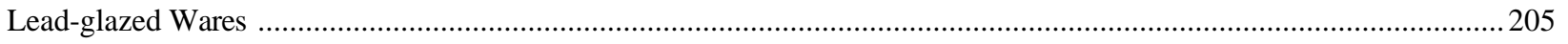

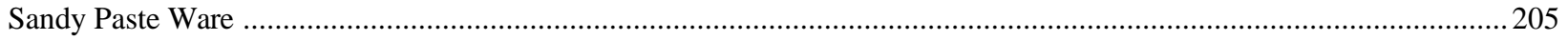

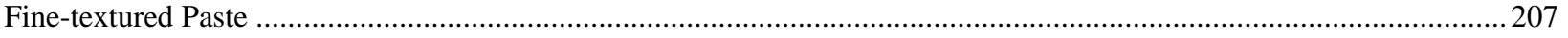

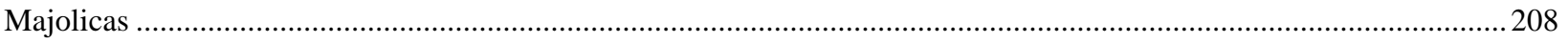

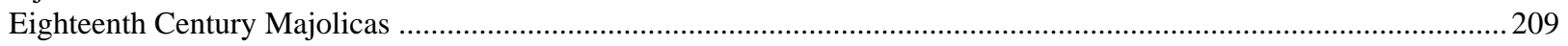

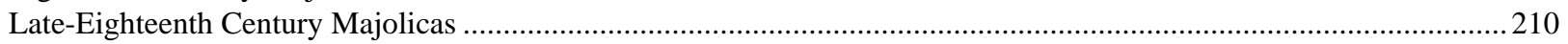

Late-Eighteenth to Early-Nineteenth Century Majolicas ........................................................................................ 211

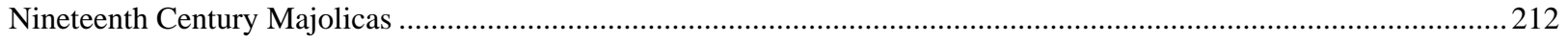

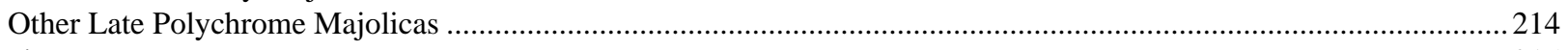

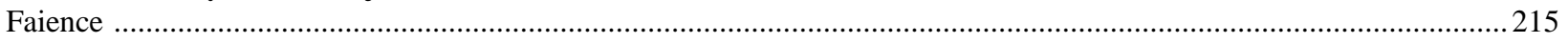

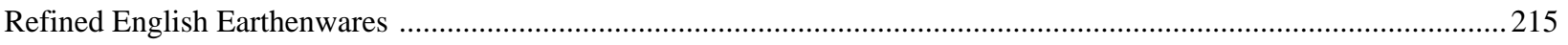

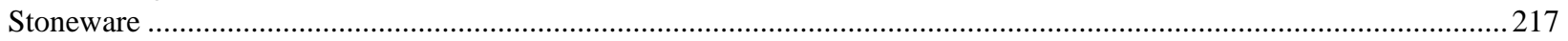

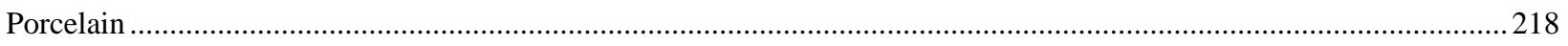

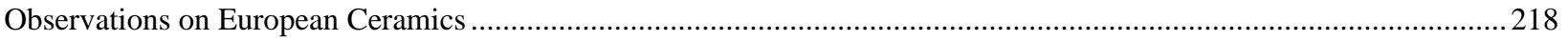

Chapter 9: Artifacts - Section B: Other Historic Artifacts by Barbara A. Meissner and Steve A. Tomka

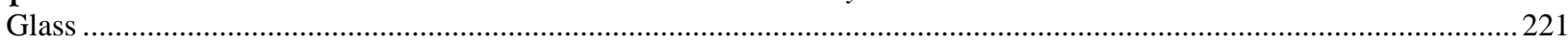

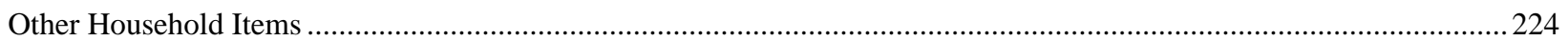

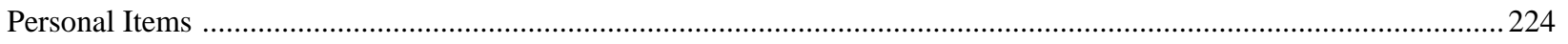

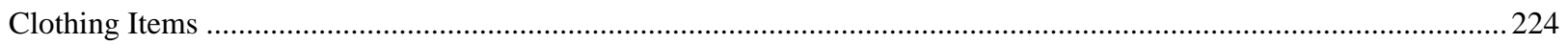

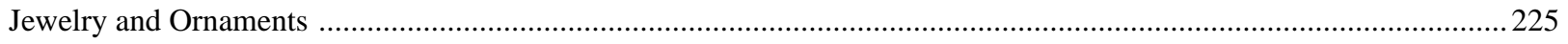

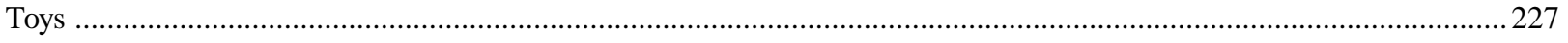

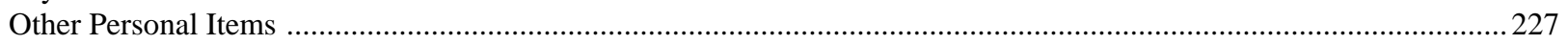

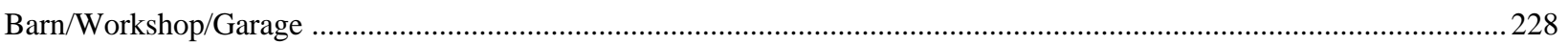

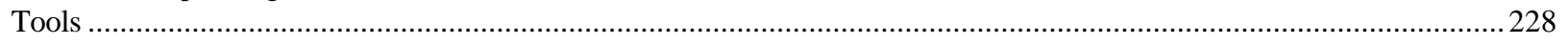

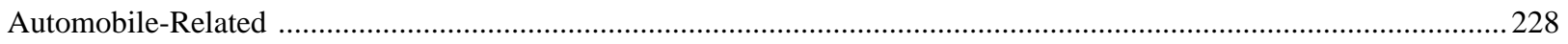

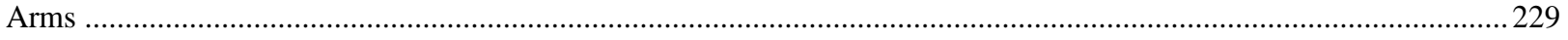

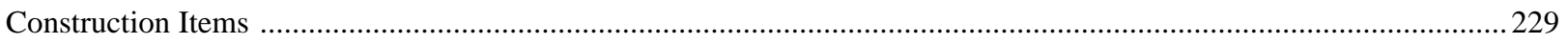

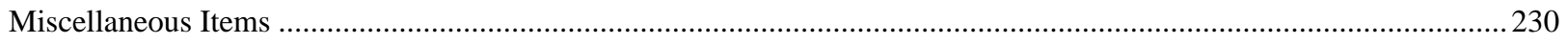

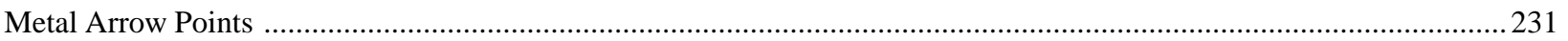


Chapter 9: Artifacts - Section c: Native Ceramics by Timothy K. Perttula

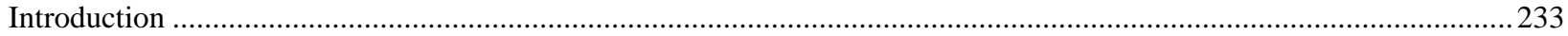

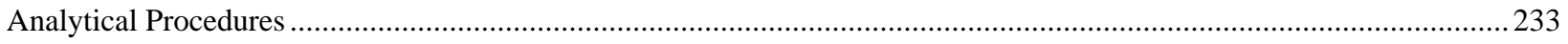

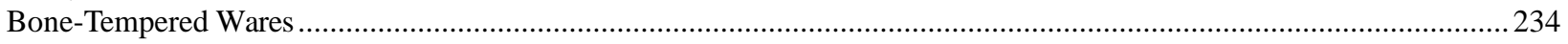

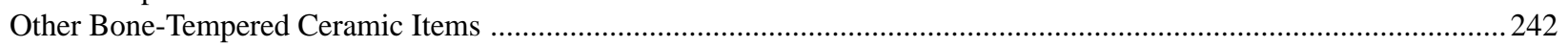

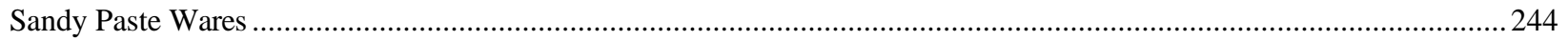

Results of the Instrumental Neutron Activation Analysis ..........................................................................................2 247

Comparisons between the AU 1, AU 2, AU 3, and TxDOT Ceramics ........................................................................2248

Temporal Functional and Cultural Affiliations of the Mission Refugio Native American Ceramics ................................253

Research Issues Concerning Native American Ceramics ............................................................................................225

Chapter 9: Artifacts - Section D: Lithics by Steve A. Tomka

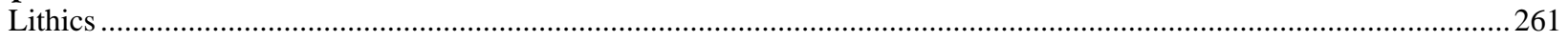

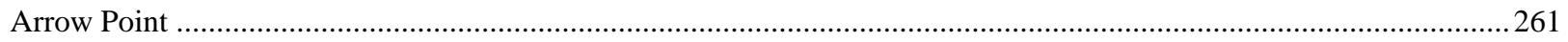

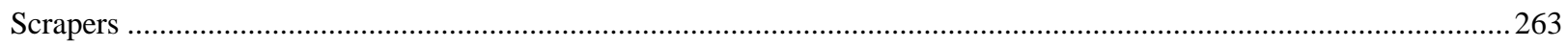

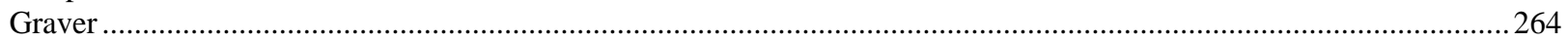

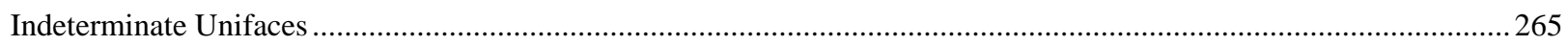

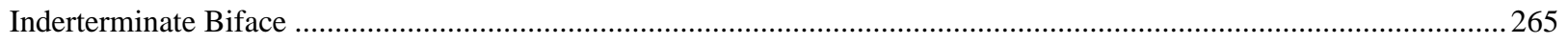

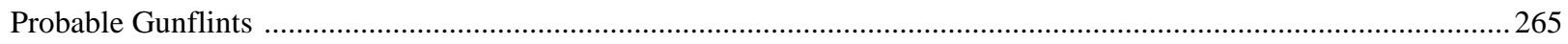

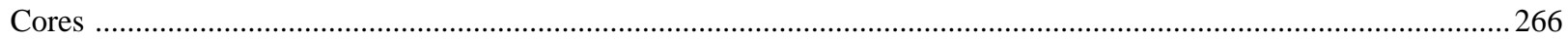

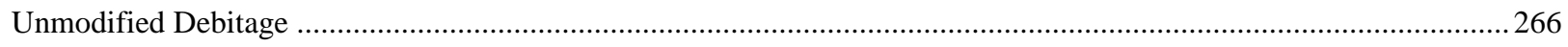

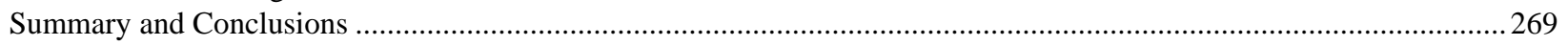

Chapter 9: Artifacts - Section E: Faunal by Jennifer J. Z. Webber, J. Matthew Compton, and Elizabeth J. Reitz

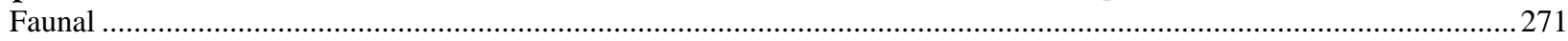

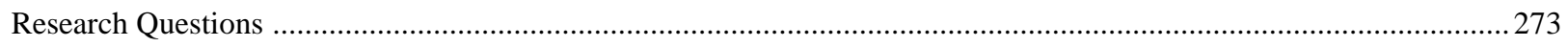

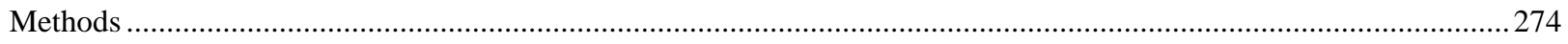

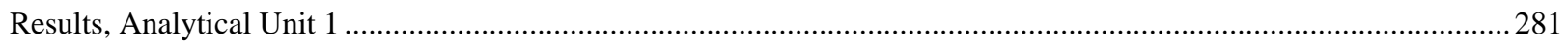

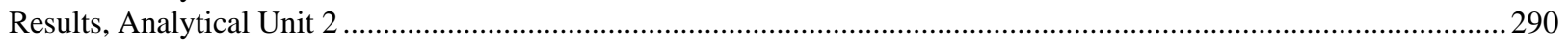

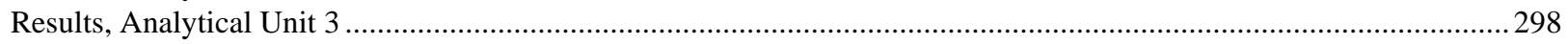

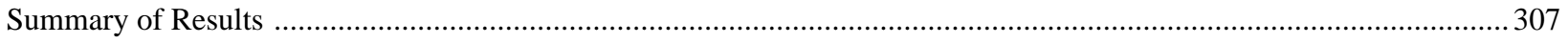

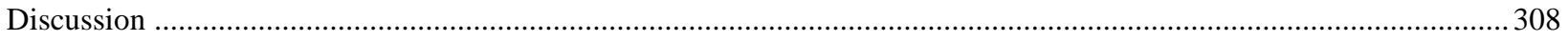

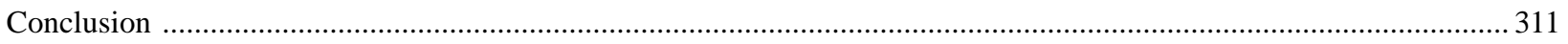

Chapter 9: Artifacts - Section E-1: Vertebrate Fauna from the Phase II Excavations by Barbara A. Meissner

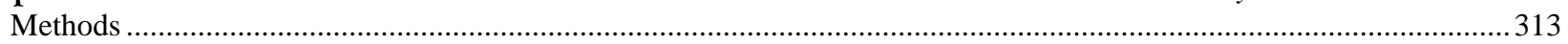

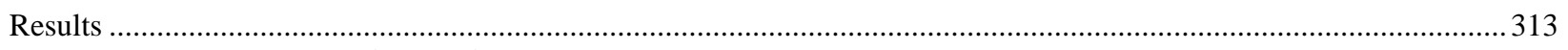

Chapter 10: Discussion and Conclusions by Robert J. Hard

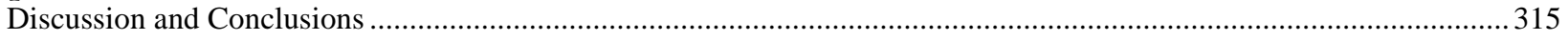

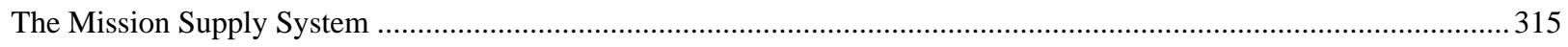

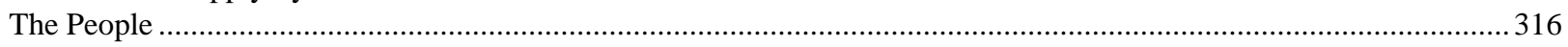

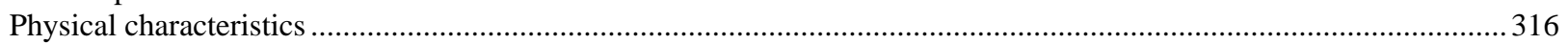

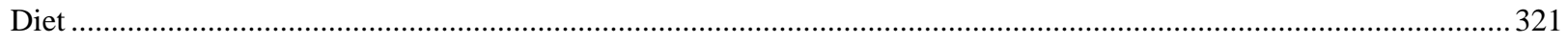

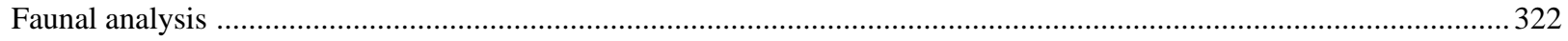

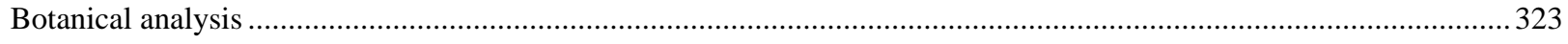

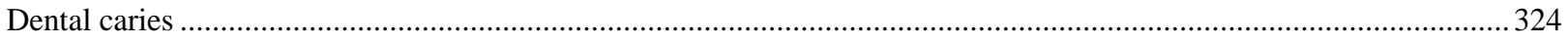

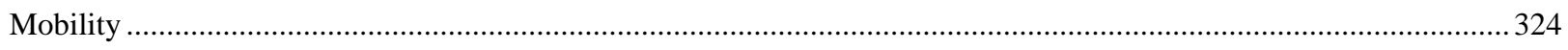

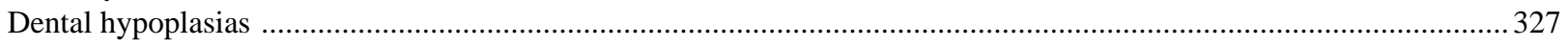

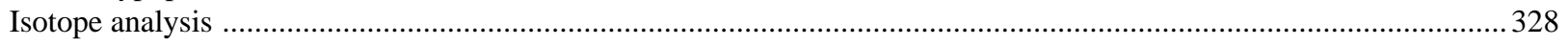

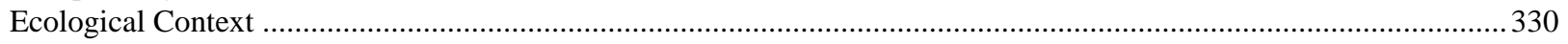

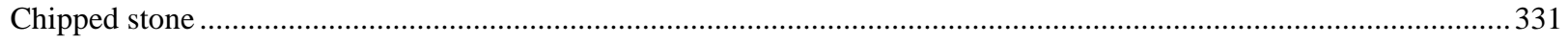

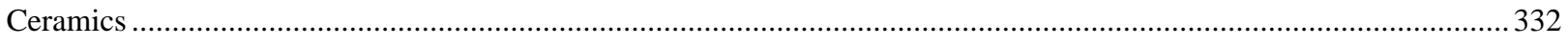

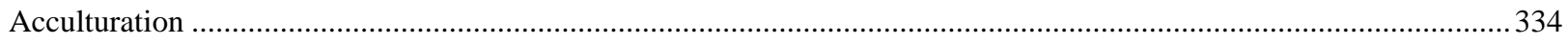

References

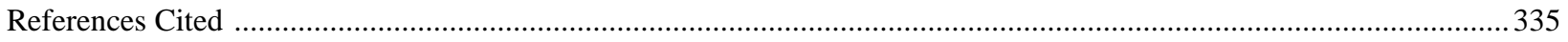




\section{Figures:}

\section{Mission Nuestra Señora del Refugio}

\section{Archaeological Investigations}

Figure 1-1. Location of Mission Nuestra Señora del Refugio, 41RF1, Refugio County, Texas. ............................................. 1

Figure 3-1a. Copy of Stephen F. Austin's [1821] map of Matagorda Bay. ............................................................................ 13

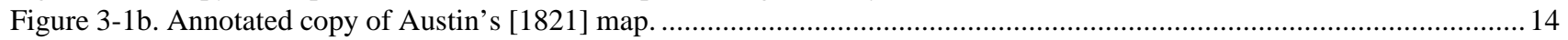

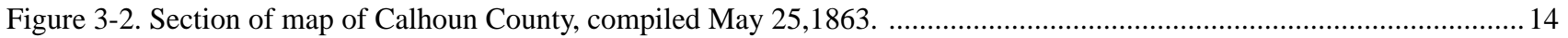

Figure 4-1. Range areas for principal tribes of the Karankawa along the Texas gulf coast. ..............................................69

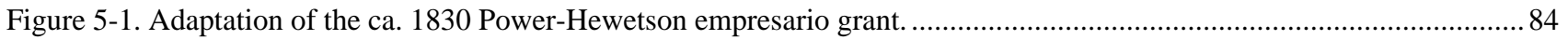

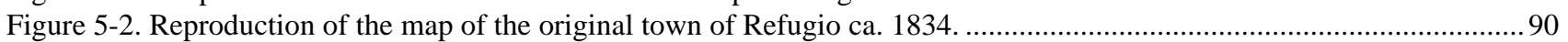

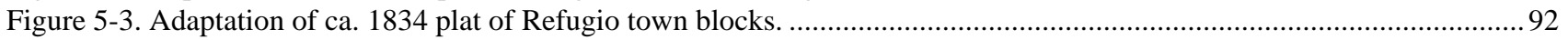

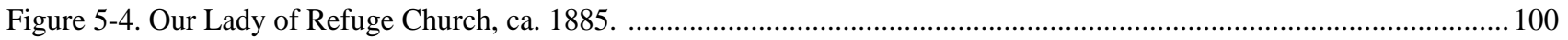

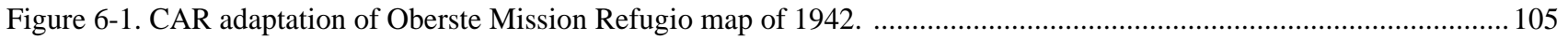

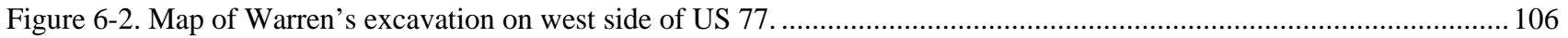

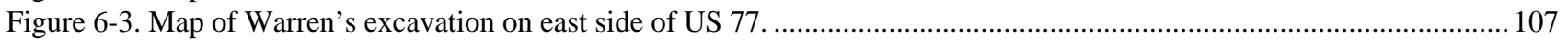

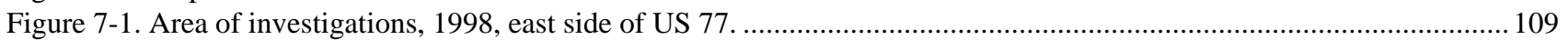

Figure 7-2. Excavation units, east side of US 77, 1998 season. ......................................................................... 110

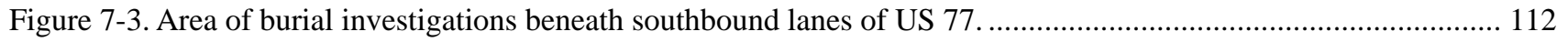

Figure 7-4. Archaeological monitoring of Gradall excavations at Mission Refugio......................................................... 113

Figure 7-5. During archaeological excavations heavy precipitation was received in the Refugio area. ................................114

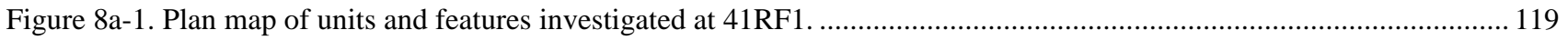

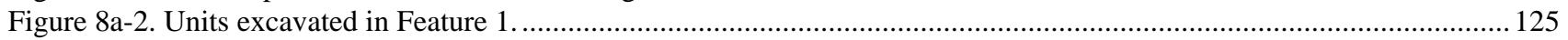

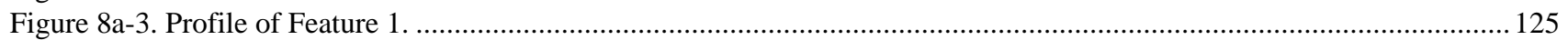

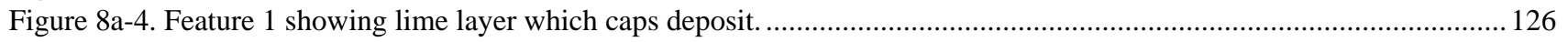

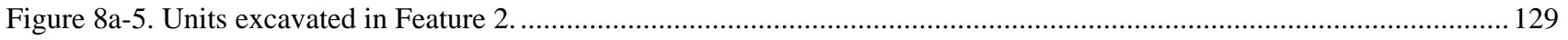

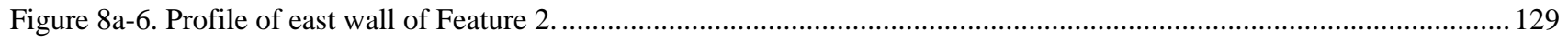

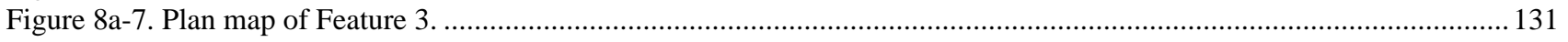

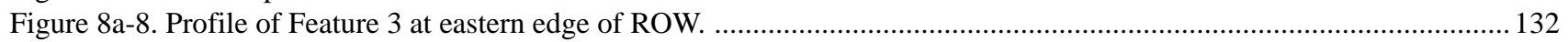

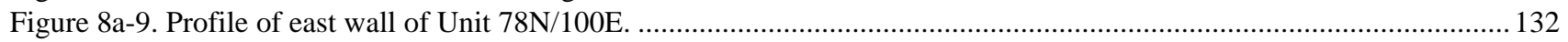

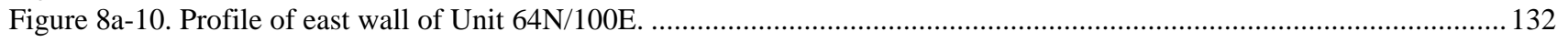

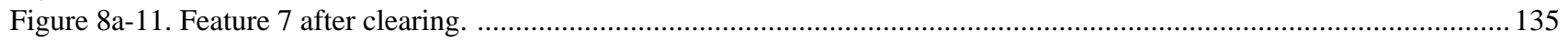

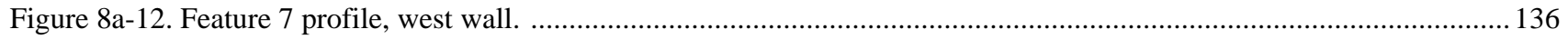

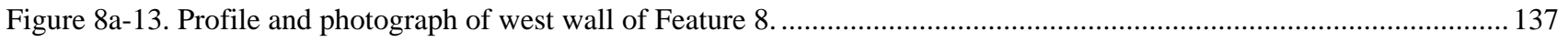

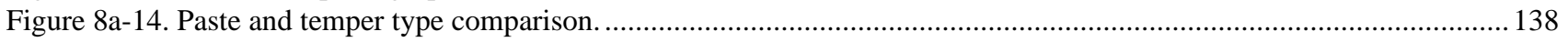

Figure 8a-15. Proportion of asphaltum decorated sherds in each AU, by paste and temper type. ........................................ 138

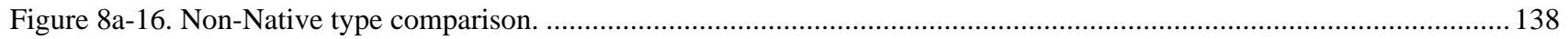

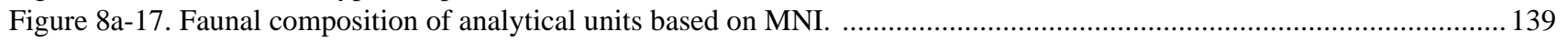

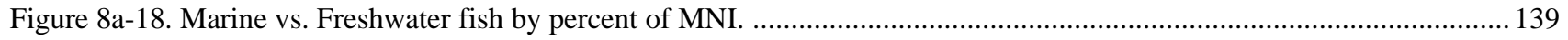

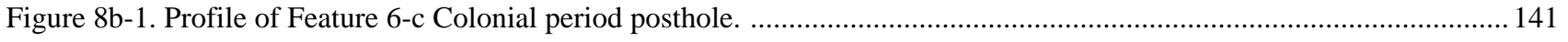

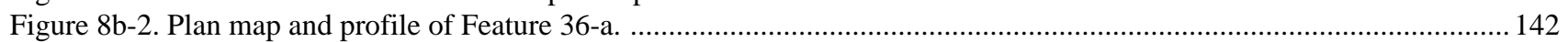

Figure 8b-3. Feature 39a-d, semicircular grouping of Colonial period postholes......................................................... 142

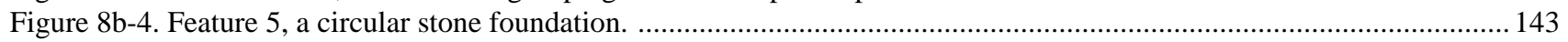

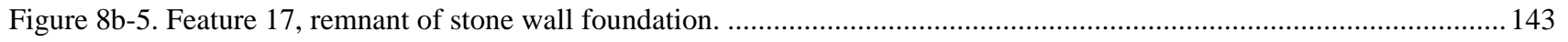

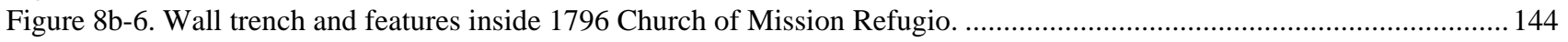

Figure 8b-7. Foundation trench of apse and south transept of Mission Refugio. ............................................................... 145

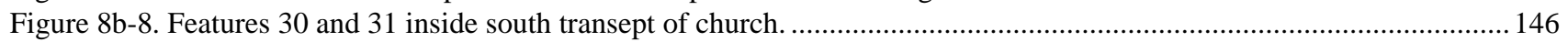

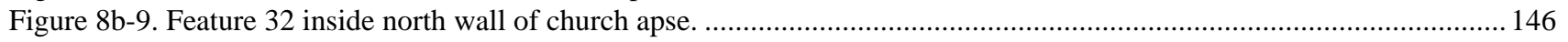

Figure $8 \mathrm{~b}-10$. Feature 34 in foreground showing its relationship to north and east walls of the church apse. ...................... 146

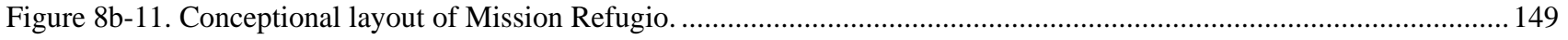

Figure 8c-1. Plan map of burial features within the Church at Mission Refugio. ......................................................... 151

Figure 8c-2. Plan map of Burial Feature 2 indicating Burials 6 and 15 . ................................................................... 157 
Figure 8c-3. Crucifix, medallion and wooden bead found with Burial 15....................................................................... 157

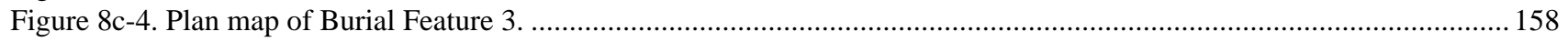

Figure 8c-5. Plan map of Burial Feature 4. ……………................................................................................... 159

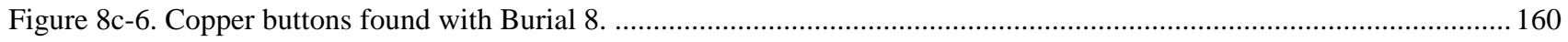

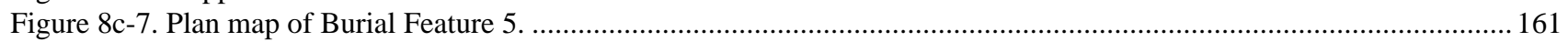

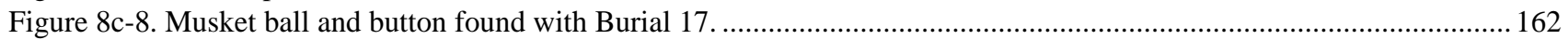

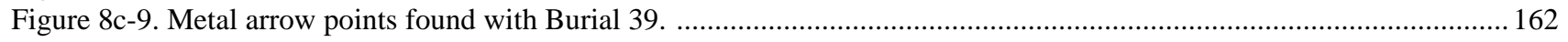

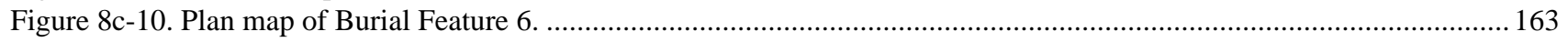

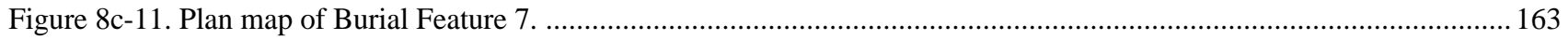

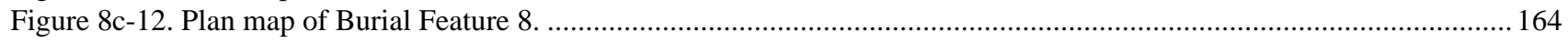

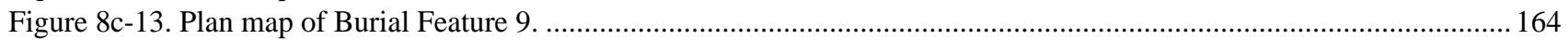

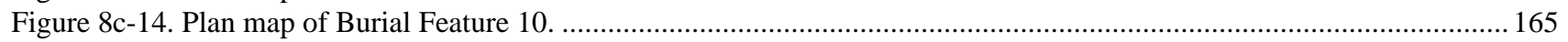

Figure 8c-15a. Glass beads recovered from immediate vicinity of Burial 44 ............................................................... 165

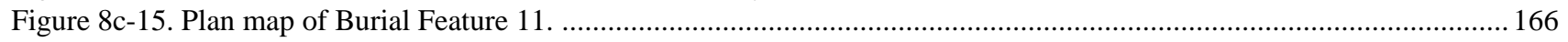

Figure 8c-16a. Glass beads recovered from immediate vicinity of Burial 46. ................................................................ 167

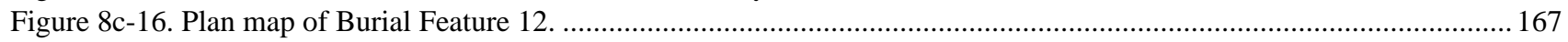

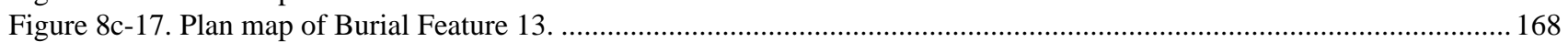

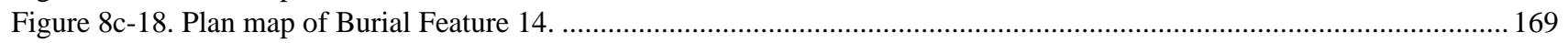

Figure 8c-18a. Beads found in Burial Feature 14. ………….................................................................................. 170

Figure 8c-19. Plan map of Burial Feature 15............................................................................................................ 170

Figure 8c-19a. Cloth covered copper piece found with Burial 48 in Burial Feature 15....................................................... 171

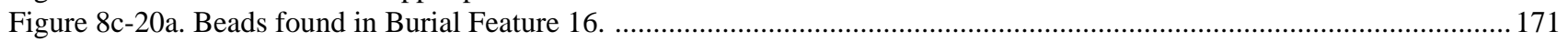

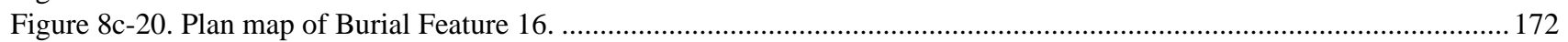

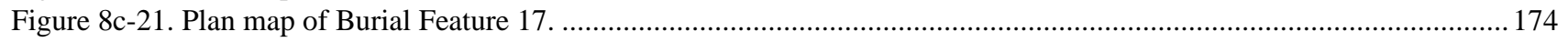

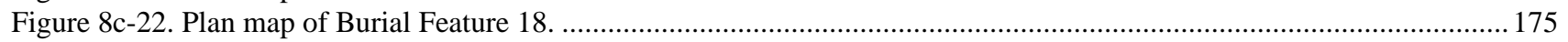

Figure 8c-23. Plan map of Burial Feature 19...................................................................................................... 175

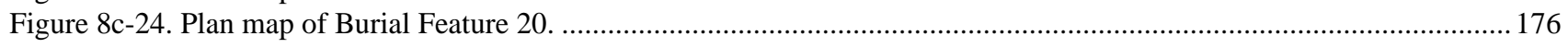

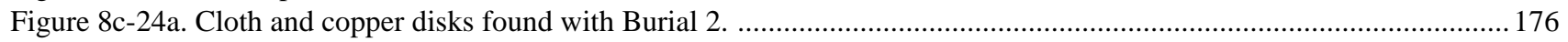

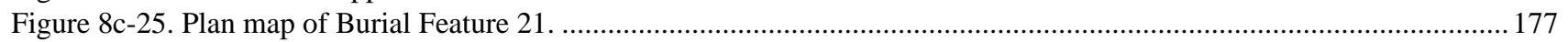

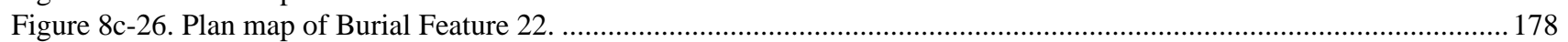

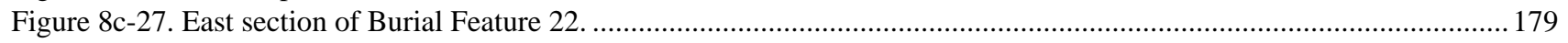

Figure 8c-27a. Array of beads recovered with Burial 97, Burial Feature 22 …............................................................... 180

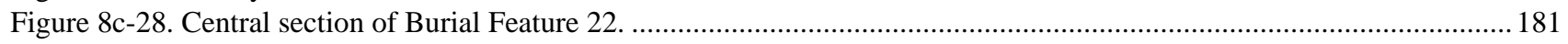

Figure 8c-28a. Lead musket ball and fragments found with Burial 28. ............................................................................ 182

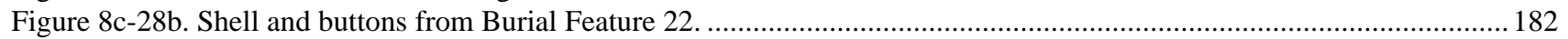

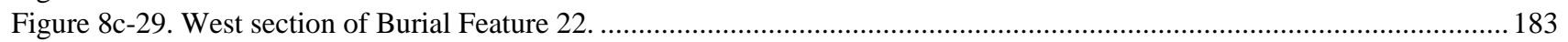

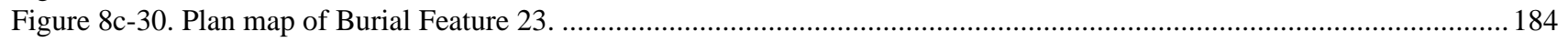

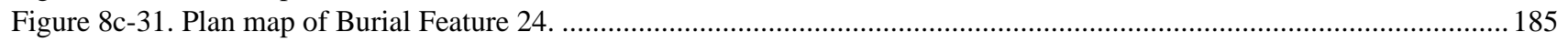

Figure 8c-31a. Bone beads, metal ring, bell, and shells found with Burial 68. .............................................................. 186

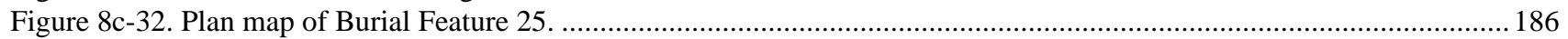

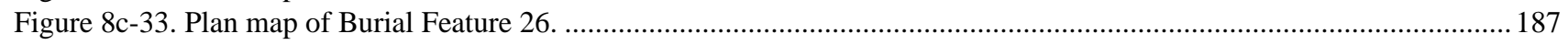

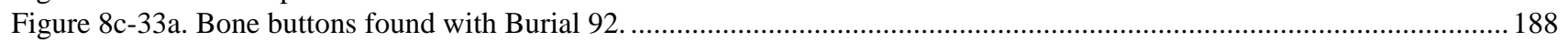

Figure 8c-34. Plan map of Burial Feature 27. …………...................................................................................... 189

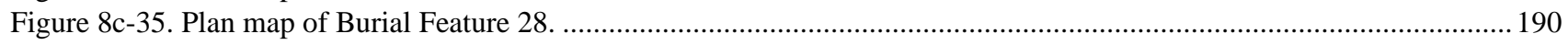

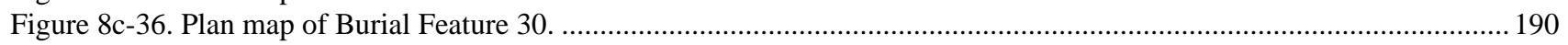

Figure 8c-36a. Metal arrow point and beads found in Burial Feature 30 …..................................................................... 191

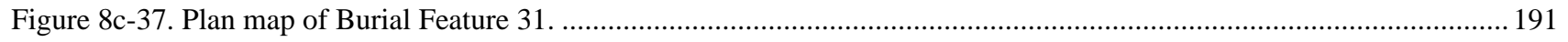

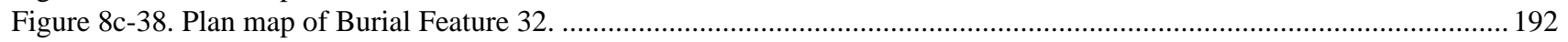

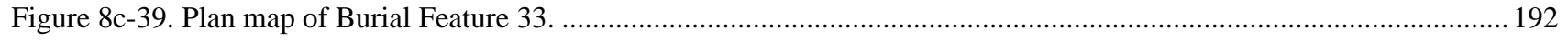

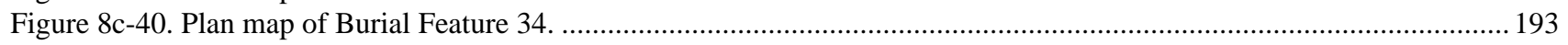

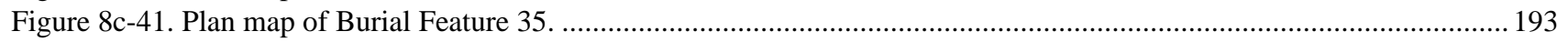

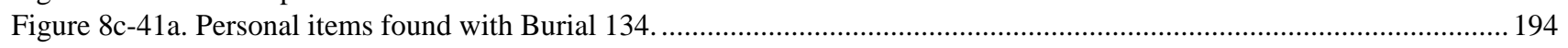

Figure 8c-42. Plan map of Burial Feature 36....................................................................................................... 194

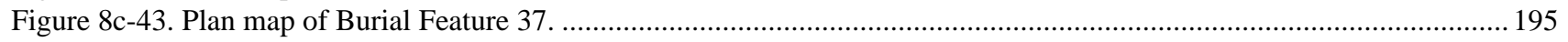


Figure 8c-44. Plan map of Burial Feature 38. 195

Figure 8c-45. Plan map of Burial Feature 39.

Figure 8d-1. Plot of three diet clusters surrounded by their one standard deviation ellipses. ............................................199

Figure 9a-1. Sandy-paste lead glazes.

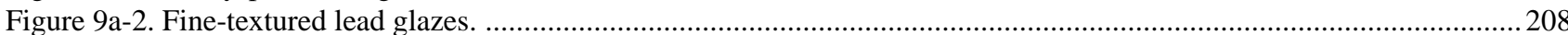

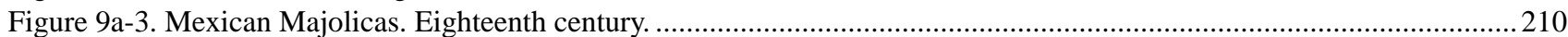

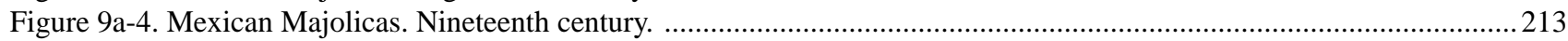

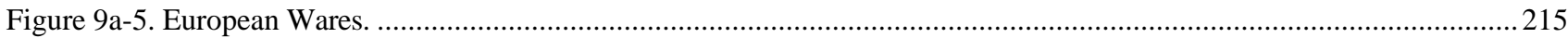

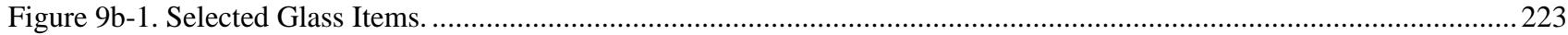

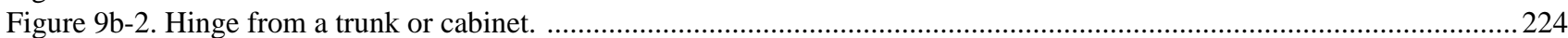

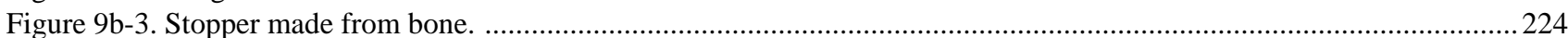

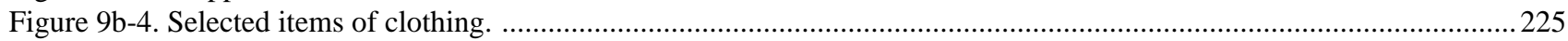

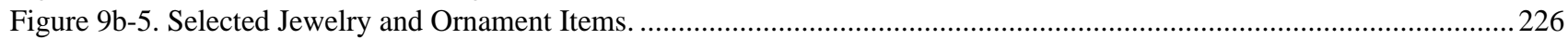

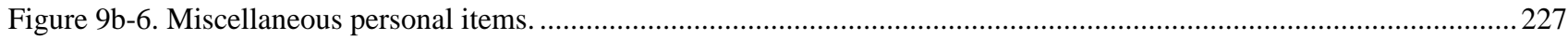

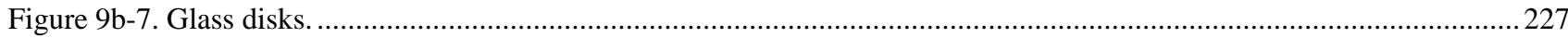

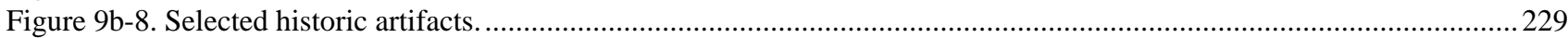

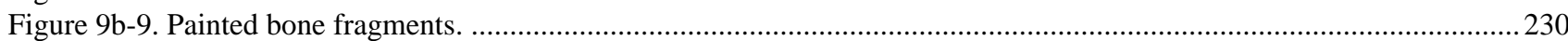

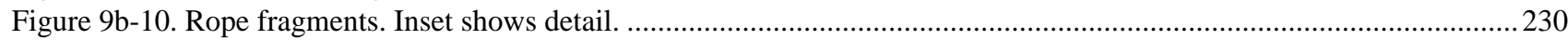

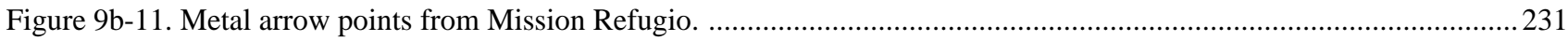

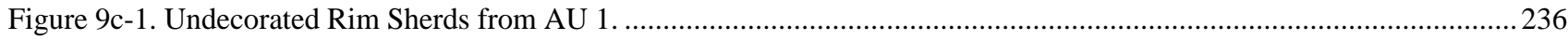

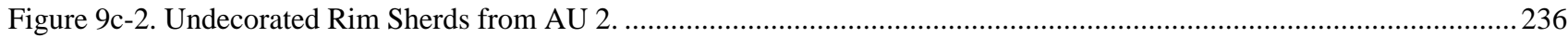

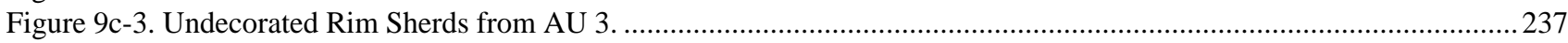

Figure 9c-4. Undecorated Rim Sherds and red and black-on-buff decorated body sherd, TxDOT excavations. ......................237

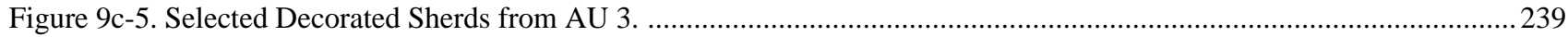

Figure 9c-6. Decorated Sherds, Loop Handles, Ceramic Foot, and Ceramic Disk, AU 3 ...................................................240

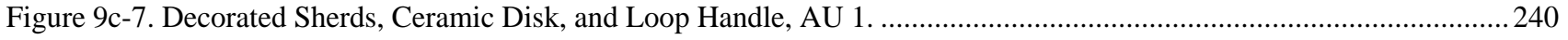

Figure 9c-8. Black-on-buff bone-tempered rim and base sherds from a single vessel section............................................242

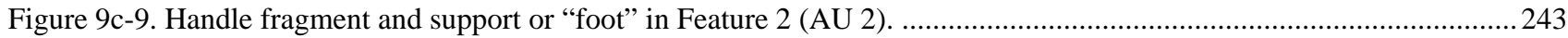

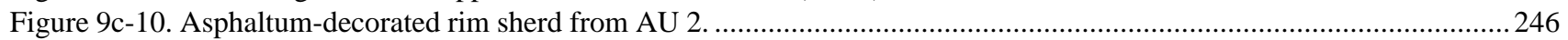

Figure 9c-11. Location of Selected Spanish Colonial Sites in southern Texas. .................................................................25

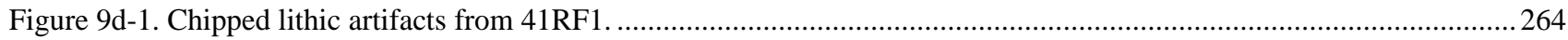

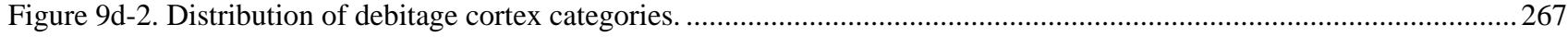

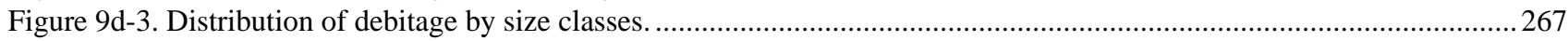

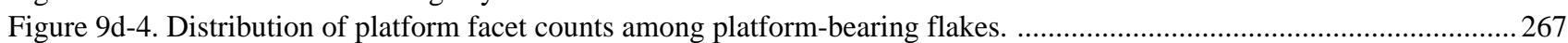

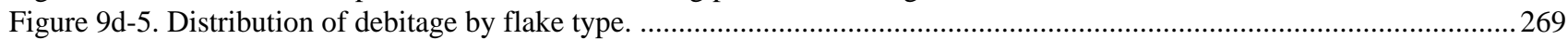

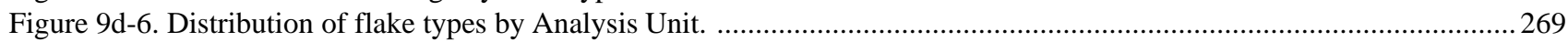

Figure 9d-7. Distribution of bipolar and other debitage, by excavation level. ...........................................................269

Figure 9e-1. Analytical Unit 1: Horse/burro (Equus sp.) elements represented. .............................................................286

Figure 9e-2. Analytical Unit 1: Pig (Sus scrofa) elements represented. ..........................................................................28

Figure 9e-3. Log Ratio Diagram of Pig (Sus scrofa) elements represented, Analytical Units 1, 2, and 3.............................286

Figure 9e-4. Analytical Unit 1: Deer (Odocoileus virginianus) elements represented. ......................................................287

Figure 9e-5. Log Ratio Diagram of Deer (Odocoileus virginianus) elements represented, Analytical Units 1, 2, and 3..........287

Figure 9e-6. Analytical Unit 1: Bovinae elements represented. ..............................................................................28

Figure 9e-7. Log Ratio Diagram of Bovinae elements represented, Analytical Units 1, 2, and 3....................................28

Figure 9e-8. Analytical Unit 1: Probable Cow (Bos cf. taurus) elements represented. ..........................................................289

Figure 9e-9. Analytical Unit 1: Sheep/goat (Caprinae) elements represented. ......................................................................289

Figure 9e-10. Log Ratio Diagram showing size of large Bovidae, Analytical Units 1, 2, and 3.........................................290

Figure 9e-11. Analytical Unit 2: Horse/burro (Equus sp.) elements represented. ........................................................295

Figure 9e-12. Analytical Unit 2: Pig (Sus scrofa) elements represented. …..............................................................295

Figure 9e-13. Analytical Unit 2: Deer (Odocoileus virginianus) elements represented. ....................................................295

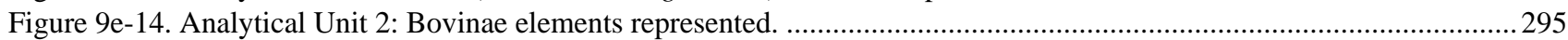

Figure 9e-15. Analytical Unit 2: Probable Bison (Bison cf. bison) elements represented. ......................................................296

Figure 9e-16. Analytical Unit 2: Probable Cow (Bos cf. taurus) elements represented. .........................................................296

Figure 9e-17. Analytical Unit 2: Sheep/Goat (Caprinae) elements represented. ..............................................................296 
Figure 9e-18. Analytical Unit 3: Horse/burro (Equus sp.) elements represented. ...........................................................303

Figure 9e-19. Analytical Unit 3: Pig (Sus scrofa) elements represented. ........................................................................303

Figure 9e-20. Analytical Unit 3: Deer (Odocoileus virginianus) elements represented. ....................................................303

Figure 9e-21. Analytical Unit 3: Bovinae elements represented. ..............................................................................304

Figure 9e-22. Analytical Unit 3: Probable Bison (Bison cf. bison) elements represented. ......................................................304

Figure 9e-23. Analytical Unit 3: Probable Cow (Bos cf. taurus) elements represented. .........................................................304

Figure 9e-24. Analytical Unit 3: Sheep/goat (Caprinae) elements represented. ..............................................................305

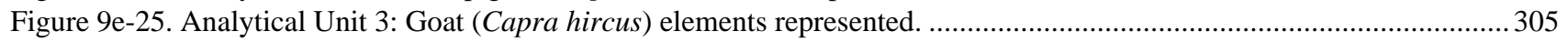

Figure 9e-26. Analytical Unit 3: Sheep (Ovis aries) elements represented................................................................. 306

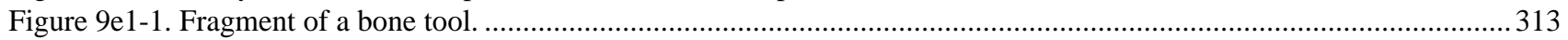

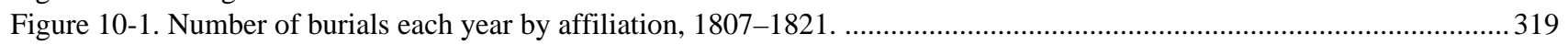

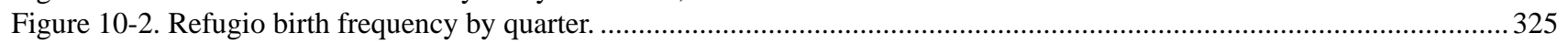

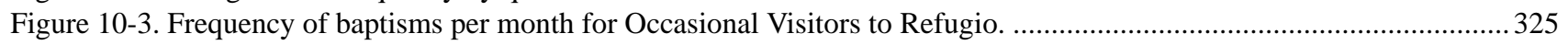

Figure 10-4. Comparison of frequency of baptisms per month for Residents versus Seasonal Visitors. ...............................326

Figure 10-5. Frequency of family months of absence from Mission Refugio..............................................................326

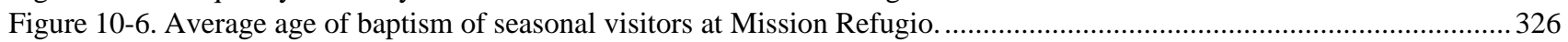

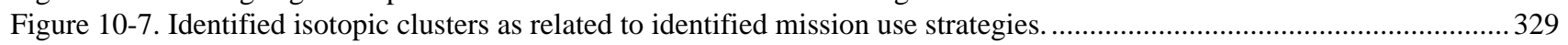

Figure 10-8. Resource fluctuations compared with monthly conceptions and family months of field use.............................. 330

Figure 10-9. Departure from fishing cycle and conception decline as related to plant availability...................................330

Figure 10-10. Relation of availability of terrestrial mammals to intensity of field use ....................................................331

Figure 10-11. Relationship between all conceptions and baptisms of Seasonal Visitors. ............................................331

Figure 10-12. Comparison of rim forms, bone temper versus sandy paste from Mission Refugio. .........................................333 


\section{Tables:}

\section{Mission Nuestra Señora del Refugio}

\section{Archaeological Investigations}

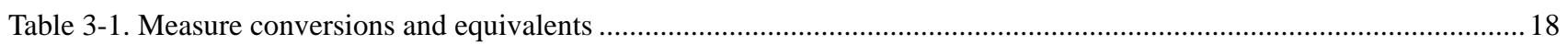

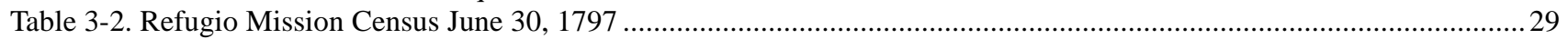

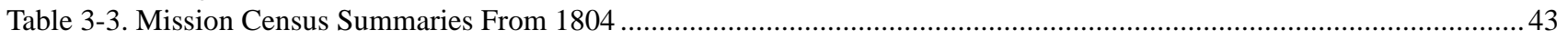

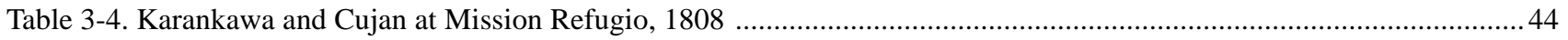

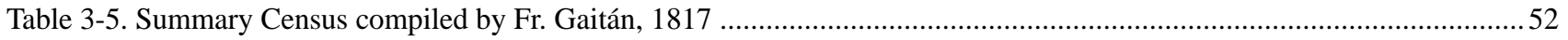

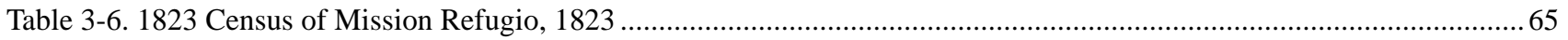

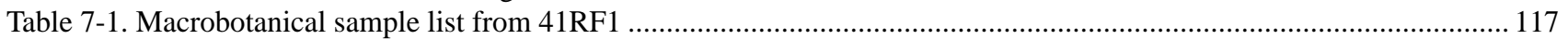

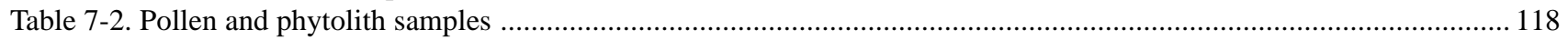

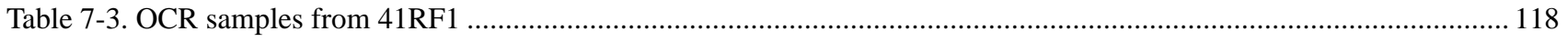

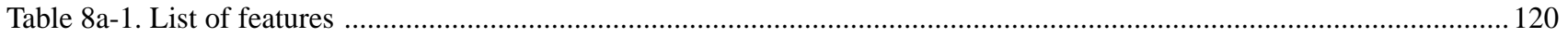

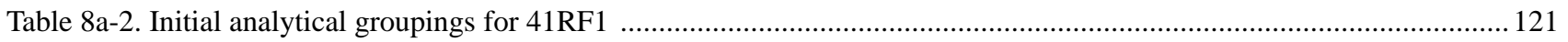

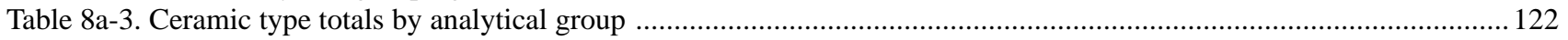

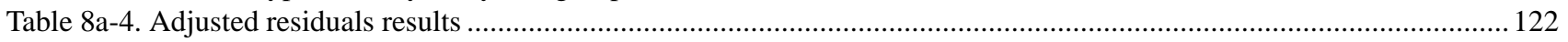

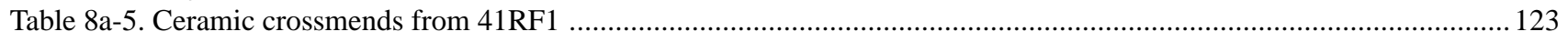

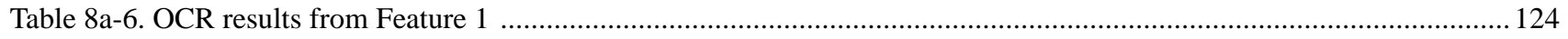

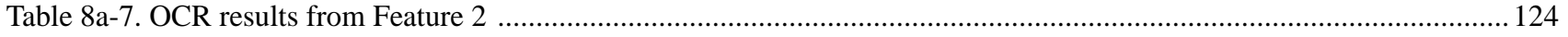

Table 8b-1. Descriptions of mission structures from various church inventories ............................................................... 148

Table 8c-1. List of Burials recovered from Mission Refugio ..................................................................................... 152

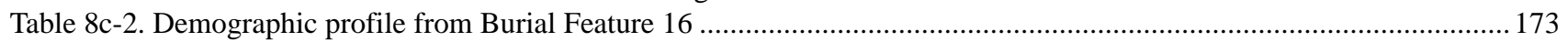

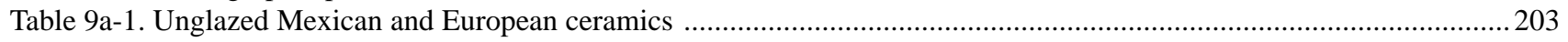

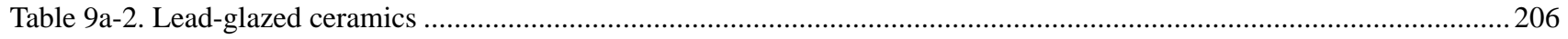

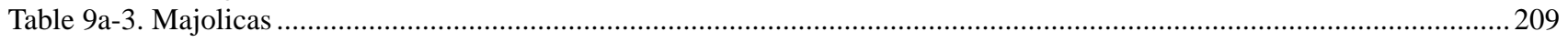

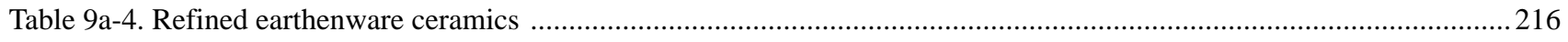

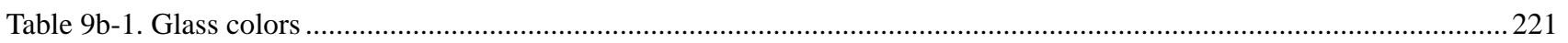

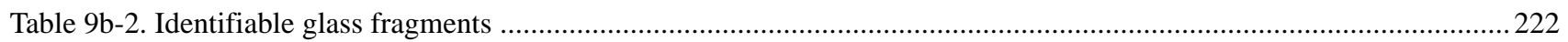

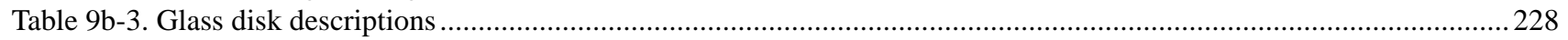

Table 9b-4. Items from the Barn, Workshop, and Garage categories ..........................................................................228

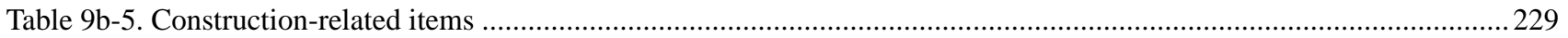

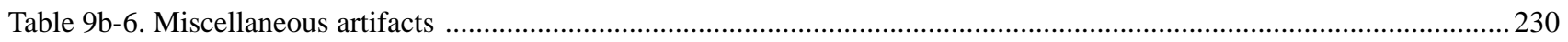

Table 9b-7. Metric dimensions of the three metal arrow points from Mission Refugio .......................................................2232

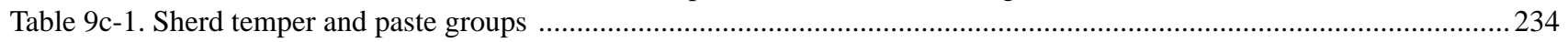

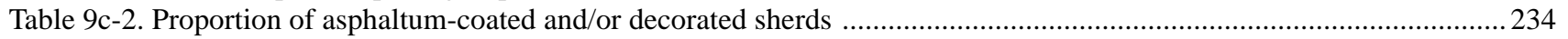

Table 9c-3. Thickness of different paste/temper classes .................................................................................................2235

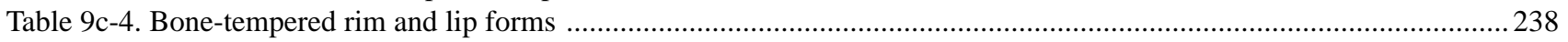

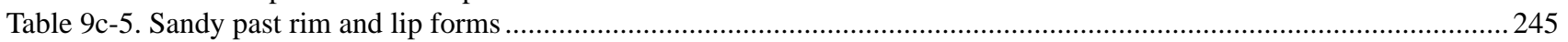

Table 9c-6. Sandy paste-bone-tempered rim and lip forms .............................................................................................2245

Table 9c-7. Differences in ceramic attributes by paste/temper groups and excavated contexts ..............................................2 249

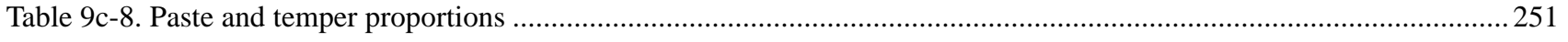

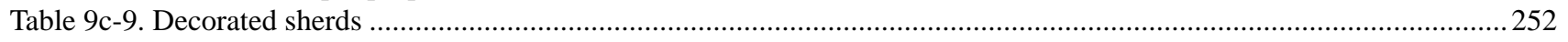

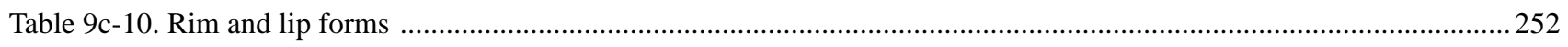

Table 9c-11. Oxidation conditions, rim and decorated sherds ..................................................................................253

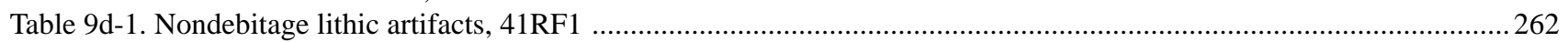

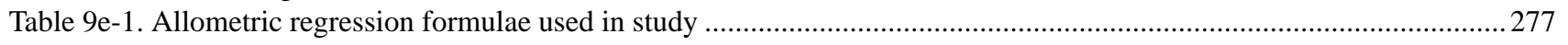

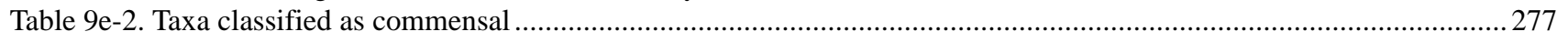

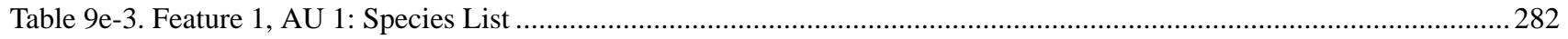

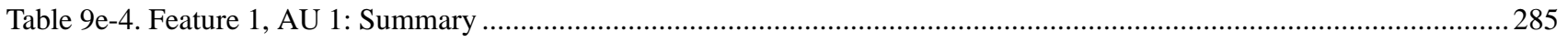

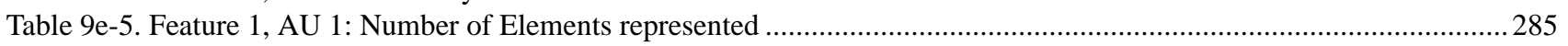

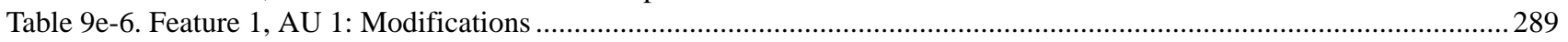




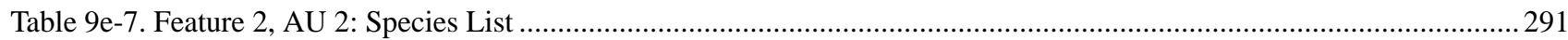

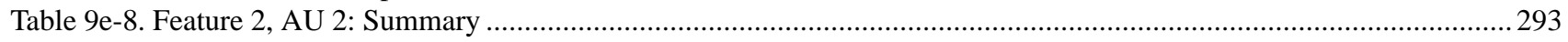

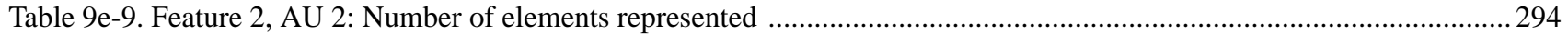

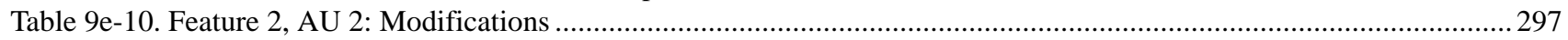

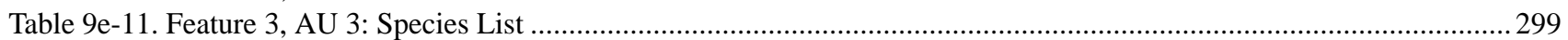

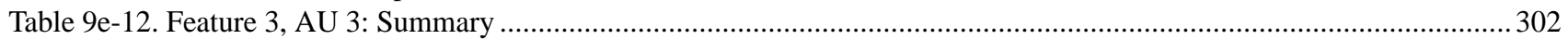

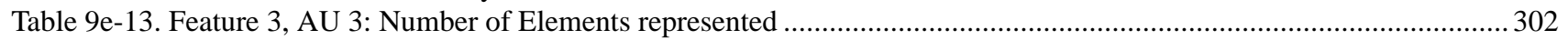

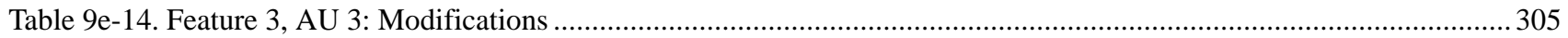

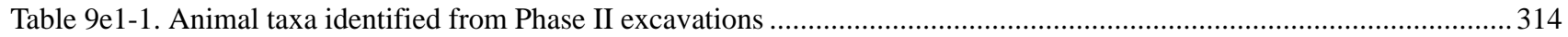

Table 10-1. Ancestry derived from burial records compared with that from the osteological analysis .................................318

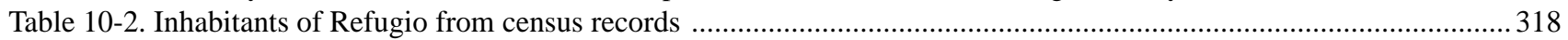

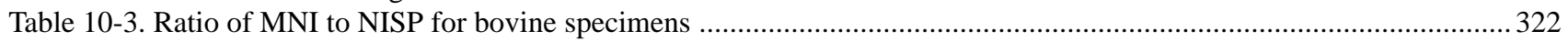

Table 10-4. Isotope values of clusters based on Meadows Jantz and Norr and dietary inferences ........................................328

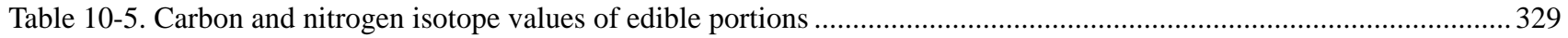




\title{
Foreword:
}

\section{Mission Nuestra Señora del Refugio}

\section{Archaeological Investigations}

A the end of the eighteenth century, a small Spanish Colonial mission was established near the Gulf of Mexico in what later became modern Texas. Located near the Mission River about twenty miles from the coast, the inhabitants of the historic mission intended to attract local bands of Native Americans and convert them to Christianity. Throughout its existence, the mission of Nuestra Señora del Refugio, Our Lady of Refuge, suffered from a lack of supplies and was poorly protected against hostile raiders. The difficulties of the religious ministers were compounded by the lack of cooperation from the Native Americans that the mission itself was designed to attract. Consisting of small groups of highly mobile hunters and gatherers who exploited the bays and estuaries along the gulf coast, these independent peoples often looked upon the small settlement as a commissary rather than a source of cultural conversion or religious salvation. Over two centuries later, the hardships and determination of the mission's isolated inhabitants and the contrasting adaptations of native groups threatened by cultural upheaval have formed a unique thread in the region's historic fabric. Today, the daily lives and struggles of these peoples have largely faded from the historical record.

In 1997, the Texas Department of Transportation (TxDOT) in coordination with the Federal Highway Administration, the Texas Historical Commission and the community of Refugio began archeological investigations in the historically sensitive areas of US Highway 77 in preparation for the rebuilding of the existing highway. Refugio and its surrounding area were recognized as having the potential to contain unidentified archeological remains significant in the state's history. TxDOT's studies, in compliance with the Texas Antiquities Code, were conducted to address the requirements of Section 106 of the National Historic Preservation Act.

Subsequently, archeologists from the department's Environmental Affairs Division, Archeological Studies Program working with TxDOT's Corpus Christi District staff identified subsurface features associated with the early mission in the highway right-of-way. The findings continued and culminated in 1999 with the discovery of the mission's cemetery or campo santo. The identification of the cemetery and the remains of both settlers and Native Americans greatly increased the complexity of the department's concern and responsibility in appropriately addressing a myriad of cultural, legal, community, and governmental issues. The resolution of these issues and the success of TxDOT's efforts was the result of an ongoing partnership with a large number of interested parties including many members of the public, the community of Refugio, Our Lady of Refuge Catholic Church, federally recognized Native American tribes, the Texas Historical Commission, several other state agencies and a number of TxDOT offices in Austin, Corpus Christi and Refugio. The archeological excavation that followed was conducted by the Center for Archaeological Research, The University of Texas at San Antonio, under contract to TxDOT. Their work, completed under difficult conditions, is presented in the following pages.

On behalf of the Texas Department of Transportation, we are pleased to present this summation of findings and believe that it offers a substantial contribution to the understanding of the region's history and to the appreciation of our multi-cultural heritage.

\author{
Series Editor \\ Archeological Studies Program
}

\author{
At McGraw
}





\title{
Acknowledgments:
}

\section{Mission Nuestra Señora del Refugio}

\author{
Archaeological Investigations
}

From: $\quad$ Al McGraw,

Series Editor,

Archeological Studies Program,

Texas Department of Transportation

The activities conducted by the Texas Department of Transportation (TxDOT) that led to the 1999 discovery of the Spanish Colonial mission church (41RF1) began earlier in 1997 along US Highway 77 in Refugio. Throughout the life of the project the success of the effort involved the participation and support of a number of organizations, agencies and individuals. Cultural resources coordination began in the planning stages of the transportation project, continued throughout construction and will conclude with the formal reburial of the early mission's inhabitants.

Much of the burden of this multi-year coordination and its resultant emerging partnerships was placed on the staff of the Advanced Project Development and Public Information sections of TxDOT's Corpus Christi District office and the staff of the Archeological Studies Program of the Environmental Affairs Division, Austin. These offices - acting as focal pointsestablished dialogue with interested parties and the public, developed strategies and methodologies to address the scope of federal and state compliance issues and matched these requirements with complex construction schedules. The involvement of TxDOT's Corpus Christi District staff under the general direction and support of Billy D. Parks, P.E., District Engineer, included Paula Sales-Evans, P.E., Mary Perez, Becky Kureska, Gina Salazar, Kari Brown and others. Continual support was also provided by the staff of TxDOT's Refugio Maintenance Office, Rosendo Moreno, supervisor.

The coordination conducted by the staff of the Archeological Studies Program, Environmental Affairs Division was completed under the direction of the division's director, Dianna Noble, P.E. and Ann M. Irwin, Director of Cultural Resources Management. Nancy A. Kenmotsu, Ph.D., supervised cultural resources coordination of the complex project. A number of other staff contributed a substantial amount of time and effort to various aspects of TxDOT's coordination and these include: John W. Clark, Jr., Timothy Meade, Al McGraw, Dianne Dismukes, Jim Abbott, Jesus Gonzales and Steven Ahr. TxDOT's coordination included the support of and consultation with the staff of the Federal Highway Administration, The Texas Historical Commission and other state agencies. Federally recognized Native American Indian Tribes were also consulted including: the Mescalero Apache Tribe, Tonkawa Tribe of Oklahoma, The Comanche Tribe of Oklahoma, the Kiowa Tribe of Oklahoma and the Alabama-Coushatta Tribe of Oklahoma.

Many others also played important roles in the success of this project and deserve recognition. Rey Jaso, Mayor of the city of Refugio and County Judge Roger Fagan supported and assisted the ongoing activities. Police Chief Wallace Maley and his officers were conscientious in their attention to safeguarding the cemetery area during the fieldwork. Maxine Reilly, director of the Refugio County Museum, provided valuable information for archival studies as did many members of the local community. Monsignors Clarke and Freeman, Father John Vega, John Grezorcyk and others of Our Lady of Refuge Catholic Church, generously made available facilities at the church. Kinga Perzynska of the Catholic Archives of Texas, Austin, allowed access to the published sources and unpublished research files within the archives. The Haas Anderson Construction company provided field support including pumping equipment during rainy days. Local resident George Owens acted as an informal docent. To these individuals and organizations as well as any we may have inadvertently excluded, we offer our appreciation for their cooperation.

The involvement of the Center for Archaeological Research, The University of Texas at San Antonio (CAR-USTA), for archeological testing, excavation and the final report documentation on the site substantially expands the number of individuals that contributed to the US Highway 77 project. The extent of CAR-UTSA's effort and its contributions may be found within the acknowledgments from CAR-UTSA that follow. 


\section{Mission Nuestra Señora del Refugio}

\section{Archaeological Investigations}

From: Steve Tomka,

Interim Director,

Center for Archaeological Research,

The University of Texas at San Antonio

A project of this size and import requires months-if not years-of work to reach completion. From the time the first archaeological samples are collected to the final printing of the report, thousands of hours are devoted to it. This report then represents the culmination of one of the most comprehensive studies of Spanish Colonial missions in Texas and provides an important contribution to mission-period archaeology. This publication is the product of dozens of hard-working individuals who contributed and collaborated even prior to the first day of July in 1998 when the Mission Refugio excavations began.

As with all projects that are conducted over such a lengthy interval of time, changes occur. Many of the people who played pivotal roles in either the initial project stages, mid-project analyses and organization and/or any other facets of the project may have come and gone, but the contributions they made and the roles they played deserve to be acknowledged.

Dr. Robert J. Hard, former director of CAR and one of the initial co-principal investigators of the Refugio project was here from the beginning and through much of the analysis and writing. He read and digested the large amount of data and added new insights in his summary chapter that concludes the report. His oversight, leadership and willingness to continue working on the project to conclusion are greatly appreciated. Dr. C. Britt Bousman, former assistant director of CAR and the other initial co-principal investigator on the project was involved throughout the 1998 field season and through much of 1999. He was instrumental in handling public relations and advising project staff of day-to-day operations. His experience and good nature in dealing with the operation of such a project proved to be a valuable asset. Cynthia L. Tennis, author and former project archaeologist and co-assistant director of CAR, also deserves thanks. Her oversight of the project fieldwork, coordination of a large number of team members, and continued participation after joining the staff of the Texas Department of Transportation is appreciated.

Thanks are extended to Dr. Robert Ricklis for his review of much of this documentation and his constructive comments and suggestions. Similar thanks are owed to Dr. Nancy Kenmotsu, from the environmental division of the Texas Department of Transportation, for her review comments, guidance and skillful management of this project.

The hard-working crew members that labored painstakingly with care and respect to excavate the site during all or parts of the 1998 and 1999 field seasons consisted of (in alphabetical order):

$\begin{array}{llll}\text { Nesta Anderson } & \text { Jeffrey Francis } & \text { Richard S. Jones } & \text { Clemente Murguia } \\ \text { Christopher Barrett } & \text { Timothy Gibbs } & \text { Brian Langner } & \text { Gloria Murguia } \\ \text { Diane Cargill } & \text { Jennifer Giesecke } & \text { Anthony Lyle } & \text { David Nickels } \\ \text { Jeffrey Durst } & \text { Bobby Gonzales } & \text { Ruth Mathews } & \text { Joe Sanchez } \\ \text { Donna Edmondson } & \text { Kevin Hanselka } & \text { Preston McWhorter } & \text { Bryant Saner } \\ \text { Owen Ford } & \text { Christopher Horrell } & \text { Barbara Meissner } & \text { Debora Weksler } \\ \text { Anne A. Fox } & \text { Brett Houk } & \text { Kristi Miller } & \text { José Zapata }\end{array}$

This crew worked under the direction of Cindy Tennis, project archaeologist, and Diane Cargill, senior crew chief.

Back in the CAR laboratory, archaeological materials were processed and readied for analysis, and later curation by an army of capable technicians that included (in alphabetical order): 


$\begin{array}{ll}\text { Christopher Barrett } & \text { Antonia Figueroa } \\ \text { Maureen Brown } & \text { Jeffrey Francis } \\ \text { Laura Burgess } & \text { Anne A. Fox } \\ \text { Thomas Castanos } & \text { Connie Gibson } \\ \text { Heide Castañeda } & \text { Christopher Horrell } \\ \text { Jeffrey Durst } & \text { Brian Langner } \\ \text { Donna Edmondson } & \text { Carol Leezer }\end{array}$

$\begin{array}{ll}\text { Jennifer Logan } & \text { Fedra Papavasiliou } \\ \text { Anthony Lyle } & \text { Jessica Renaud } \\ \text { Ruth Mathews } & \text { Rick Robinson } \\ \text { Kristi Miller } & \text { John Spencer } \\ \text { Patricia Moses } & \text { Carol Villalobos } \\ \text { Cynthia Munoz } & \text { Jessica West } \\ \text { Gloria Murguia } & \text { José Zapata }\end{array}$

These technicians were under the direction and guidance of Maureen Brown, Anne A. Fox, and Marybeth S. F. Tomka, each laboratory coordinators over the course of the project's duration. Marybeth S. F. Tomka also supervised the curation preparation of the Refugio collection.

For illustrative expertise, the drafting staff of the Mission Refugio project worked long hours creating the accurate and informative drawings and illustrations present in this report. Their hard work and talent in producing such illustrations provides a valuable contribution to the publication and is greatly appreciated. The drafting/illustration staff who created the Mission Refugio artwork include (in alphabetical order):

Christopher Butler

Bruce Moses

Richard Young

A team of experts participated in the analysis of the large quantity of materials (i.e., human remains, Native and Colonial ceramics, historic artifacts, faunal remains) and special samples (i.e., isotopes) obtained from the site and the supporting research efforts (i.e., archival research). Dr. David R. McDonald spent long hours researching the archival resources -copying, indexing, transcribing and translating documents associated with the occupation of Mission Refugio. His dedication and scholarship are clearly evident in his valuable contributions to this volume. Thanks also go to I. Waynne Cox for adding the post-1830 archival history chapter to the report. Gratitude and appreciation is extended to Dr. Timothy Perttula for conducting the analysis of the Native American ceramics from the site, Dr. David V. Hill for the petrographic analysis of bone tempered ceramics, and Drs. Hector Neff and Michael D. Glascock for their Instrumental Neutron Activation analysis of the Native American ceramics. Anne A. Fox carried out the analysis of the Colonial-period materials and her expertise is greatly appreciated and was invaluable to the project. Barbara Meissner conducted the analysis of the remaining historic artifacts and her versatility is greatly appreciated. A great deal of appreciation is also extended to Jennifer J. Z. Webber, J. M. Compton, and Elizabeth Reitz for their contributions from the University of Georgia, to Amanda McDaniel, Kelly Orr, Barnet Pavao-Zuckerman, and Jayson Wright, for conducting the identification and analysis of the large number of faunal remains recovered from the site. Dr. Reitz's willingness to share the immense number of original analysis cards to aid in the creation of a faunal database is particularly appreciated.

Drs. L. Meadows Jantz and R. L. Jantz, from the University of Tennessee, conducted the meticulous study of the large number of human remains recovered from Mission Refugio. They were aided in their analyses by N. P. Hermann, Corey S. Sparks, Doug Owsley, Derinna Kopp, and Katherine Weisensee. Dr. Lynette Norr, conducted valuable isotopic analyses of the human skeletal remains from the Refugio site. The expertise of all these individuals and their dedication to scholarship is greatly appreciated.

Thanks are also extended to Douglas S. Frink, who conducted the oxidizable carbon ratio analyses of the Refugio samples, and Drs. J. Philip Dering and John G. Jones, of the Paleoethnobotanical Laboratory of Texas A\&M University for carrying out the macrobotanical and pollen and phytolith analyses, respectively.

And finally, a great deal of thanks needs to be extended to Maryanne King and Johanna Hunziker, editors of the manuscript. It is through their tireless work and dedication to excellence that a large stack of manuscript drafts has been converted into a beautifully designed, easy-to-read report. 
On the cover:

The remains of the Spanish Colonial mission at Refugio have long ago disappeared from the historic landscape. The photograph of Mission San José in San Antonio captures the cultural setting of the mission period.

Photograph courtesy of the Texas Department of Transportation. 


\section{Chapter 1:}

\section{Introduction}

In July 1998, the Center for Archaeological Research (CAR), The University of Texas at San Antonio (UTSA) was awarded a contract by the Texas Department of Transportation (TxDOT) for archaeological investigations at the Spanish Colonial period site 41RF1 located in Refugio County, Texas. This project involved conducting mitigative excavations in advance of a construction project designed to widen US 77 through Refugio, Texas where it bisects portions of site 41RF1, or Mission Nuestra Señora del Refugio. The initial phase of this investigation, conducted in the summer of 1998, focused on excavations conducted along the TxDOT right-of-way (ROW) on the east shoulder of US 77. Two mission period trash pits were identified and excavated, and another possible trash pit was documented, but not excavated due to its location on the easternmost boundary of the ROW. Subsequent investigations, conducted in the summer of 1999 within the roadway of US 77, led to the exhumation of 165 Spanish Colonial period burials, the discovery of the location of the 1796 church, and to other associated mission compound features.

The Spanish Colonial site of Mission Nuestra Señora del Refugio, 41RF1, is located at the southern edge of the town of Refugio, Refugio County, southern Texas (Figure 1-1). Mission Refugio, first founded in 1793, represents the last of the Spanish missions to be established in Texas. The mission-when moved to its final location-existed for 35 years (1795-1830). It was founded for the Karankawa

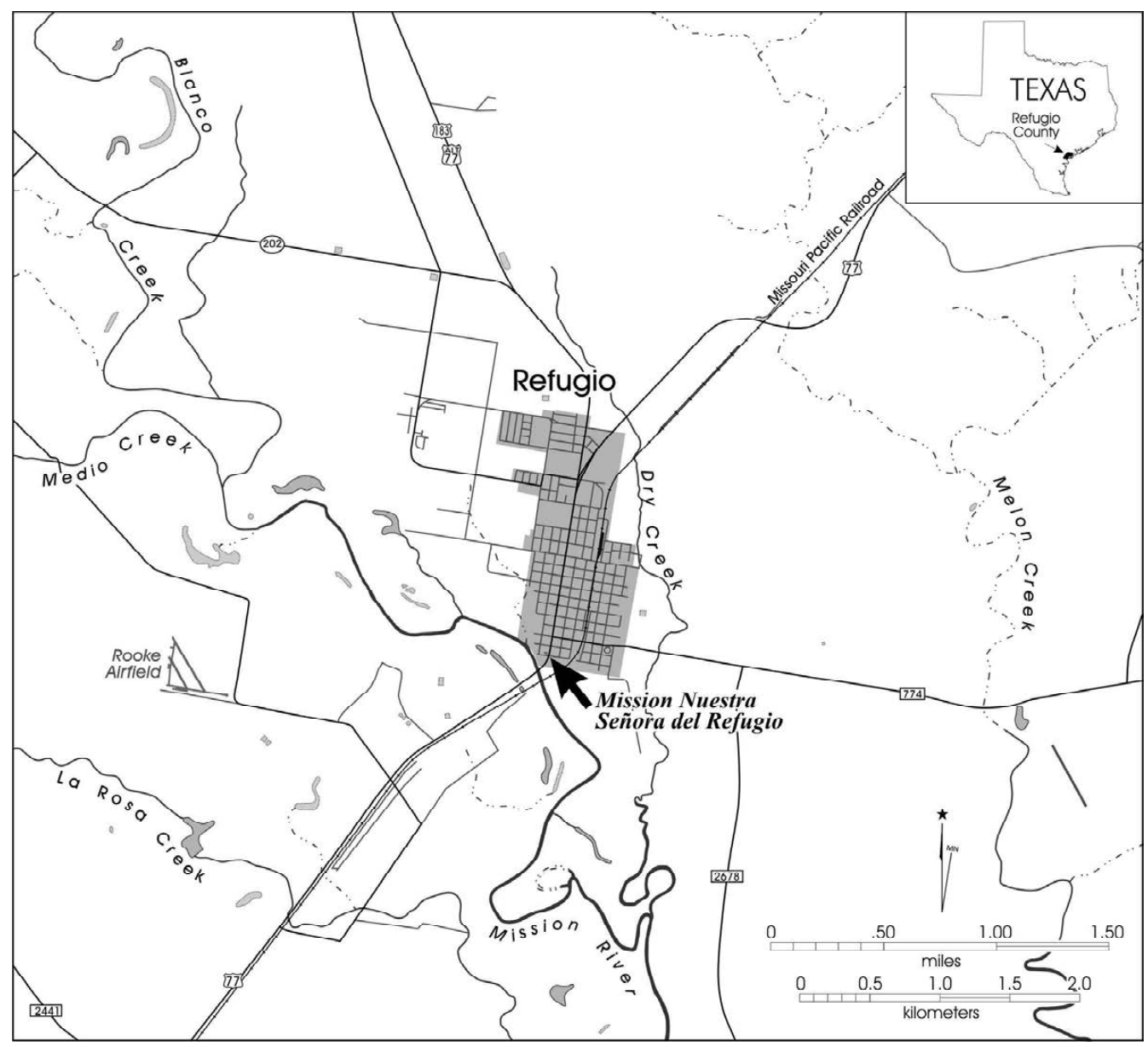

Figure 1-1. Location of Mission Nuestra Señora del Refugio, 41RF1, Refugio County, Texas. 
Indians that inhabited the central gulf coast region. While the exact boundaries of the site have not been established, deposits associated with the mission are known to be present on private property located on either side of US 77 in the area of the present-day Our Lady of Refuge Catholic Church.

\section{Project History}

Plans to widen US 77 were necessitated by the everincreasing amount of commercial and private traffic utilizing this roadway. Currently, US 77 is the major trucking route between Houston and the lower Rio Grande Valley carrying an estimated volume of 16,700 vehicles per day through the town of Refugio - with peaks of between 25,000 and 30,000 vehicles per day on weekends and holidays. Although future relief routes bypassing the town are being considered, improvements of a more immediate nature were needed to handle the current heavy traffic flow. TxDOT engineers were aware of the significance of the Spanish Colonial site and designed the project to limit impact to the area as much as possible. However, as the existing route of US 77 passed directly through the old mission, total avoidance was not possible (Kenmotsu et al. 1999).

\section{Project Description}

Initial testing for the widening of US 77 was conducted by TxDOT archaeologists in 1997 (Clark 1998). The results of this investigation indicated that along the 3-x-50 m strip of land which made up the eastern ROW - directly across from the modern church_cultural deposits related to the Spanish Colonial mission, Nuestra Señora del Refugio, were present to a depth of $60 \mathrm{~cm}$ below the surface. Based on these findings, an extensive data recovery project was designed for this impact area.

Data recovery investigations at $41 \mathrm{RF} 1$ were conducted within the TxDOT ROW on the east side of US 77 in August 1998, by CAR staff archaeologists. Thirty-one 1-x-1 m units were manually excavated to sterile soil resulting in the removal of $20.2 \mathrm{~m}^{3}$ soil, or approximately one-third of the historically significant deposit within the TxDOT ROW. Three mission-period trash pit features were identified, two of which were excavated. They revealed diameters in excess of four meters overall for each pit and depths of 110 and $130 \mathrm{~cm}$. Over 137,700 artifacts including 121,398 pieces of animal bone, 4066 Native American pottery sherds, 1490 pieces of Spanish ceramics, and 447 lithics were recovered. The majority of these artifacts came from unmixed deposits within the two excavated pit features.
TxDOT records indicated that the area in front of the existing church had been used as a roadway for at least 100 years. Originally known as Alamo Street, it became State Highway 128 around 1929. However, armed with the knowledge of site 41RF1, and the fact that its exact boundaries had never been established and that burials might be present, TxDOT archaeologist Tim Meade was present to monitor pavement removal. This pavement was to be removed from the two southbound lanes of US 77 to bring the road surface down to the new street grade. Monitoring was conducted in an attempt to ascertain if remnants of the historically significant mission were present. While monitoring this removal of the existing road base within the TxDOT ROW, human remains were encountered. The remains were covered and the site secured while arrangements were made for members of CAR to assist with emergency removal of the remains.

Observations made during the emergency excavation indicated that the remains accidentally exposed during monitoring were not those of a single individual, but in actuality represented a multiple burial of two adults and three children. Five oblong areas of a darker colored soil believed to indicate additional burial features were also identified near the exposed remains. These findings strongly suggested that the cemetery, or campo santo, of Mission Refugio had been encountered. The exposed portions of the burials were removed, the site secured, and plans were made for CAR to determine the extent of the burial features by thoroughly investigating the area immediately in front of the church and exhuming all human remains found within the ROW.

\section{Project Design}

Initially, this project was designed to address specific research questions concerning Native American adaptations to European influences during the Spanish Colonial period by comparing technological and subsistence changes evident from the analysis of cultural material recovered from two TxDOT-sponsored mitigation excavations in south Texas, $41 \mathrm{KA} 26$ and 41RF1, along with information from excavations at nearby Mission Rosario (Gilmore 1974, 1975). However, with the discovery and subsequent excavation of additional features and human remains at Mission Refugio, the magnitude of information from 41RF1 made the comparison inequitable. It was, therefore, decided to produce stand-alone reports for each investigation. The results of the analysis and interpretations of investigations at 41KA26-B, a Colonial period campsite at Carvajal Crossing on Cibolo Creek were used to address a modified set of research questions more suited to that site and can be found in Tennis (2001). 
This report then, focuses extensive archival research into the history of Mission Nuestra Señora del Refugio and the Spanish experience in south Texas, and includes analyses of the human remains and material culture recovered during investigations at 41RF1. This information, along with information from excavations conducted at nearby Mission Rosario (see Gilmore 1974, 1975) are combined to address the following specific research questions concerning Native American adaptations to European influence at the close of the Spanish Colonial period.

\section{Research Question 1:}

Did instabilities in the frontier supply system affect Native technology at Mission Refugio?

What was the nature of the frontier supply system in Texas between ca. 1780-1830 and what effect did changes in the system have on Native American technology? More specifically, was there a significant shift or decline at particular times in the availability of goods from Mexico that stimulated shifts in the production of materials at Mission Refugio? Did the neophytes and missionaries living at this mission become more dependent on local Native American products (Goliad and Rockport wares and stone tools) through time and was a decline in the use of Mexicanmade goods experienced?

\section{Research Question 2: \\ What was the effect of Spanish influence on Native American ceramic technologies at Mission Refugio?}

Two probable factors have been suggested concerning the degree to which the Spanish influenced the traditions of the Karankawan Native Americans at Mission Refugio. Ricklis (1996) has postulated that the coastal Native Americans used the missions as they would any other resource patch, entering the missions in the spring, at a time when they traditionally moved to inland camps, and leaving when they felt the resource patch was no longer providing enough food to justify its continued exploitation (Ricklis 1996:159-168; see Castañeda 1976:81, 89). However, Ricklis (1996:152156) also suggests the Karankawa were firmly linked to Mission Refugio due to changing social, demographic, and warfare patterns in this portion of Texas during that time, and it is likely that reduced mobility increased the degree of acceptance of Spanish culture. Ceramic manufacturing techniques and pottery shapes should then reflect a shift to a more sedentary, colonially inspired life-style through time.

\section{Research Question 3. Is there evidence for fluctuating access to cattle at Mission Refugio?}

Ricklis (1996:150) suggests that access to cattle was more limited at Mission Refugio for both the Spanish and Native American residents than at earlier missions, especially as documented at the San Antonio missions (Hard et al. 1995; Jackson 1986). Multiple factors can be suggested to account for this decline including drought, overgrazing, cattle raiding (Oberste 1942), Crown acquisition of unbranded cattle (Dabbs 1991), and a lack of trained personnel available for cattle herding (Castañeda 1976). If the Karankawa incorporated and used Mission Refugio as a resource base in their larger foraging territory during the spring and summer months (Ricklis 1996), dietary protein may have been supplemented by hunting traditional animals during times of limited cattle availability. Faunal remains of bison, deer, and clams from inland Karankawa sites show exploitation of the prairie/riverine environment (Ricklis 1996). These species should then represent a larger portion of the faunal assemblage at Refugio than at earlier missions, if the availability of cattle does, in fact, decline.

\section{Research Question 4.}

Will analysis of the structure and contents identify the function of "bone bed" features common at mission sites?

Excavations at other Texas mission sites (Ivey 1988; Ivey and Fox 1981; Ricklis 1998; Schuetz 1970; Tomka and Fox 1998a, 1998b) show that these mission "bone beds" are usually found outside walls and near gates. In order to develop a balanced understanding of the faunal assemblage at Refugio, the context of the faunal remains must be established. TxDOT test units indicate that an extensive part of the project area contains large quantities of bone. These high-density bone occurrences could represent midden deposits resulting from the butchering of cattle near a gate outside the mission compound, or the faunal remains could represent kitchen debris that accumulated after final processing and cooking. 
Research Question 5:

What effects of proselytization are reflected within the burial population at Mission Refugio?

Comparative data from a burial group like the one from Refugio, with a documented makeup of 57 percent Spanish and 43 percent Native American, provides an unusual opportunity to examine the effects of colonization on both the European and Native populations. The general health of this burial population, gauged through standard cranial and postcranial measurements and through identification of dental and bone pathologies, will be examined to assess the effects of newly encountered diseases on both populations. These indices can also be used to identify the degree of admixture occurring between indigenous and European peoples on the Spanish frontier. Evidence of a demographic shift toward more ethnic diversity after 1780 was identified during a similar study conducted on the burial population at Mission San Juan in San Antonio. Adverse effects of the hostile frontier, in particular the 1814 "[Comanche] Indian massacre of fourteen Spaniards" referred to by Oberste (1942), can also be verified through these studies.

\section{Research Question 6:}

To what degree was Native American adaptation to mission life a success as judged through physiological changes in the burial population at Mission Refugio?

The general health of this burial population, gauged through standard cranial and postcranial measurements and through identification of dental and bone pathologies, will be examined to assess the degree and success of proselytization within the native population at Refugio. The demographic profile, male versus female versus child, is also a reflection of the overall effect of dietary, mobility, and sanitary changes associated with mission life. The presence of tooth caries and skeletal pathologies, and isotopic signatures extracted from bone collagen will be used to examine the argument that the Mission Refugio was only seasonally exploited by native groups.

\section{Research Question 7: \\ Who were the Karankawa Indians of the Central Texas coast?}

Ethnographic and ethnohistoric accounts of the Karankawa Indians suggest that these people were physically distinctive from other indigenous groups encountered during the colonization of the New World. While mitochondrial DNA has been used to identify very large population affinities in other areas, no data of this sort exists from Native American populations in Texas. It is not known whether the indigenous people in Texas are more closely related to Native Americans in the eastern part of the United States, to the western groups, or to those in Mexico. Comparisons between standard cranial and postcranial measurements of Karankawas from the Refugio burial population and statistics from other historic and prehistoric burial populations can be used to substantiate these historic claims, and perhaps identify biological relationships among indigenous groups in Texas.

\section{Project Organization}

This project was conducted under Texas Antiquities Committee Permit No. 2025 to complete TxDOT's obligations under Section 106 of the National Historic Preservation Act, and the Antiquities Code of Texas. TxDOT funded the project through state appropriations and acted as the oversight management agency during all stages of the project.

The principal investigators for the Mission Refugio project were Raymond P. Mauldin, associate director of CAR, in conjunction with Cynthia L. Tennis, former co-associate director. Former principal investigators for the project include Robert J. Hard, previous CAR director, and C. Britt Bousman, former associate director. Cynthia Tennis also served as project archaeologist during both seasons of investigations at 41RF1. Special analysts for this project were: Ceramics, Tim Perttula and Anne Fox; Faunal, Elizabeth Reitz and Barbara Meissner; Ethnobotanical, Phil Dering and John Jones; Lithics, Steve Tomka; and Archival, David McDonald and I. Waynne Cox. Lee Meadows Jantz, Richard Jantz and Doug Owsley conducted analyses of the human remains, and the stable isotope analysis was conducted by Lynette Norr. All documentation, maps, photographs, and cultural material are permanently curated at the laboratory at CAR. This report conforms to the Council of Texas Archeologists reporting standards and those of the Secretary of the Interior's Standards and Guidelines: Archeology and Historic Preservation. 


\section{Chapter 2: Environmental and Cultural Setting}

\section{Regional Setting}

Mission Refugio, 41RF1, is located in the South Texas Coastal Plains archaeological subregion of the South Texas Area as defined in Hester 1989a. This region includes all of south Texas from the Rio Grande to the Texas Gulf coast. Black (1989:39-40) has subdivided this large and varied subregion into five biogeographical areas based on maritime versus savanna patterns of resources availability.

\section{Refugio County}

Site 41RF1 is located in Refugio County, within Black's (1989) Coastal Bend biogeographical area which extends from the mouth of the Colorado River to Baffin Bay. Periodic, sometimes rapid rises in Holocene sea level resulted in the present configuration of the coastline as recently as 2500-2000 years ago (Ricklis 1995a). This topography is made up of flat coastal plains and prairies, protected bays and tidal flats, and barrier islands providing a diversity of upland, freshwater, and coastal resources.

The climate in the Coastal Bend is subtropical ranging from sub-humid along the coast to semiarid inland. Hot summers and cool winters prevail. Rainfall averages 32-36 inches annually and the growing season is an average of 295 days per year (Arbingast et al. 1976). Refugio County is within the portion of the Tamaulipan Biotic Province (Blair 1950) dominated by thorny shrubs, coastal marshes, and sand dunes in what Gould (1975) has termed the Gulf Prairies and Marshes vegetation zone. Perennial grasses such as tanglehead (Heteropogon contortus), Indiangrass (Sorghastrum elliotii), and big bluestem (Andropogon gerardii) are common in the well-drained areas while buffalo grass (Buchloe dactyloids) and silver bluestem (Andropogon saccharoides) are found in the more poorly drained clays.

Closer to the coast, oak trees including live oak (Quercus virginiana), laurel oak (Quercus hemisphaerica), and blackjack oak (Quercus marylandica) grow in the deep sands along with Mexican buckeye (Ungnadia speciosa), prickly ash (Xanthoxylum calva-herculis), and guayacan (Forestieria angustifolia). The poorly drained soils near the bays support salt resistant plants such as shoregrass (Monantholoe littoralis), seashore saltgrass (Dictichlis spicata), and purslane (Sesuvium portulacastrum) (Shafer and Bond 1985).

Blair (1950) has identified over 100 animal species inhabiting the Coastal Bend biogeographical area including: the white-tail deer (Odocoileus virginianus), mountain lion (Felis concolor), bobcat (Lynx rufus), black-tailed jackrabbit (Lepus californicus), Texas pocket gopher (Geomys personatus), and western diamondback rattlesnake (Crotalus atrox). The archaeological record also indicates that bison, pronghorn, black bear, and wolf were also present at one time (Hester 1989a). To this assemblage is added a rich variety of migratory birds and marine life from the shallow bays such as blue crab (Callinectes sapidus) and brown shrimp (Crago vulgaris). Fish varieties include speckled trout (Cynoscion nebulosus), redfish (Sciaenops ocellata), drum (Pogonias cromis), mullet (Mugil cephalus), and croaker (Micropogon undulatus).

\section{Site Setting}

Site 41RF1 is located in southwestern Refugio County, at the southern edge of the city limits of Refugio, Texas. It is situated .10 miles $(.2 \mathrm{~km})$ east of Mission River on an upland terrace that rises approximately $40 \mathrm{ft}(12 \mathrm{~m})$ above the river channel. Soils in the immediate area of the site are described as Papalote fine sandy loam (Guckian 1988). The 10-inch $(25 \mathrm{~cm})$ thick surface layer is composed of slightly acidic, grayish brown fine sandy loam. The subsoil is divided into two layers; a grayish brown to pale brown sandy clay with gray, yellow, and brown mottles present to 39 inches (100 $\mathrm{cm}$ ), and a light brownish sandy clay with a few calcium carbonate concretions to 49 inches. The underlying soil, which extends to a depth of 60 inches $(150 \mathrm{~cm})$, is a white sandy clay loam with a few calcium carbonate concretions (Guckian 1988:27). The present day vegetation is limited to mid grasses and a few Anaqua trees. 


\section{Prehistoric Cultural Setting}

Several comprehensive syntheses of cultural history for the Southern Texas Coastal Plains have been compiled (Black 1989, 1995; Hester 1980; Tomka et al. 1999). Hester (1995) expands on the tool typology for the interior regions while Ricklis (1995a) presents a more precise chronology for the coastal areas based on radiocarbon data. These syntheses agree that archaeological investigations within the subareas of south Texas have been relatively limited and unevenly distributed. Thus our understanding of chronological changes in prehistoric lifeways in this part of the state is quite limited. As the focus of this report is the Spanish Colonial period in south Texas, only a brief summary of the Late Prehistoric immediately preceding colonization is given here. An in-depth discussion related to the Spanish era is presented in Chapter 3 of this report.

Perdiz points and Rockport ceramics are the diagnostic markers of the Late Prehistoric in the Coastal Bend. Rockport ceramics are incised, crenelated, and asphaltumdecorated versions of the earlier sandy-paste ceramics from the Central Texas Coast (Ricklis 1995b). Ricklis (1992, 1995b, 1996) has used the Rockport ceramics to identify and define the geographic limits of the Karankawa Indian territory as extending from Matagorda Bay south to Baffin Bay and inland about $40 \mathrm{~km}$ from the central Texas coast. Sites with indigenous south Texas bone-tempered pottery with central Texas affinities, sites with Rockport ceramics, and one site with discrete concentrations of both have been found along this $40 \mathrm{~km}$ ( 25 mile) boundary. Within this boundary, Ricklis (1996) has identified large Karankawa shoreline fishing camps such as the Holmes Site (41SP120), the Ingleside Cove Site (41SP43), the Kirchmeyer Site (41NU11), and the Mustang Lake Site (41CL3). Faunal remains recovered from these sites indicate subsistence was based predominately on fish, supplemented by deer and, to a lesser degree, shellfish. A series of inland Karankawa sites such as the McKinzie Site (41NU221), 41SP159, and 41SP167, have also been identified within the $40 \mathrm{~km} \mathrm{(25}$ mile) boundary. These sites are smaller and more numerous and "probably represent seasonal fissioning and dispersal" of the large coastal aggregations" (Ricklis 1996:102). The faunal assemblages at these small residential camps are dominated by bison and deer. Settlement patterns, inferred from seasonality analysis of fish otoliths, involved fall through early spring exploitation of abundant shoreline resources by large indigenous groups and late springsummer use of inland plant and animal resources by smaller dispersed groups (Ricklis 1995a, 1996).
Black (1989) believes that associating Late Prehistoric archaeological cultures in South Texas with historic ethnographic groups has had very limited success due to limited ethnohistoric documentation and the lack of distinctive material assemblages associated with known groups. Although Hester and Parker (1970) attempted to link the Toyah-phase assemblage at the Berclair Site in Goliad County to historic descriptions of the late arriving Tonkawa, Hester later (1989b) concludes that Native American groups evidently ranged over large, poorly defined territories and by the Historic period had been largely displaced by intrusive groups from the north and west. In the Coastal Bend however, Ricklis (1992, 1995a, 1996) has been able to associate the Late Prehistoric Rockport-phase settlement and subsistence patterns to the earliest ethnographic documentation of the Karankawa Indians who-apparently-remained a recognizable, viable cultural group prior to and throughout the Spanish Colonial period. 


\title{
Chapter 3:
}

\section{Mission History \\ Introduction}

\author{
David R. McDonald
}

Research for the Mission Refugio project was performed in order to produce a concise history of the Mission during the thirty-seven years of its existence. The history is primarily based upon documents written by Franciscan ministers who were entrusted with the daily operation of Refugio Mission, from 1793 to 1830, upon reports from Spanish military officers, and other records originating at the Franciscan Missionary College near Zacatecas, Colegio de Nuestra Señora de Guadalupe, which governed and administered Refugio and many other missions from Texas to Sonora.

The primary guide to this research was Monsignor William H. Oberste's monumental work, History of Refugio Mission, published in 1942. A large number of the documents, cited by Monsignor Oberste from the Bexar Archives, were located and carefully reevaluated. In addition, numerous documents were located that, at the time, were unavailable to Oberste. These documents came from the Franciscan Missionary archives at Zacatecas and Zapópan. Extensive microfilm copies from both sources have been made since 1970, and are available at the Old Spanish Missions Historical Research Library at Our Lady of the Lake University. Important documents found in these archives include listings of supplies provided to Refugio by the Missionary College at Zacatecas, from 1793 to 1812, and inventories of the mission for 1796, 1802, 1817, and 1820.

More than six hundred documents were copied and indexed. Numerous transcripts were made of documents that were difficult to read to ensure an accurate understanding of each source. Thus, this work is based almost entirely on primary sources. Although Monsignor Oberste's work was invaluable in pointing out relevant documentation in the Bexar Archives, the present narrative is based the author's translation, analysis, and evaluation of the information revealed in the primary sources.
Persons who substantially contributed to the Refugio research project were Dora Guerra, Archivist, Old Spanish Missions Historical Research Library at Our Lady of the Lake University; Jo Myler, and Frank Faulkner, San Antonio Public Library, History and Reference Section; Jack Jackson; and staff at the Center for American History, University of Texas at Austin. For translations of Spanish blacksmith tool terminology, the glossary in Southwestern Colonial Ironwork: The Spanish Blacksmithing Tradition from Texas to California (1980) by Marc Simmons and Frank Turley was extremely helpful.

\section{Background}

For in the whole region of that coast only angels and the Indians who were born there could live. ${ }^{1}$

Mission Nuestra Señora del Refugio was founded near Matagorda Bay below the confluence of the Guadalupe and San Antonio Rivers in February 1793. The new mission was the last to be established in Texas during the Spanish Colonial period. Its purpose was to convert the indomitable Karankawan Indians who lived along the coasts and islands in the vicinity of Matagorda Bay. The founding was a bold and audacious initiative to take the missionary effort into the heart of these coastal Indians' territory, given the record of hostile relations between Spaniards and the Karankawa.

The research shows that the general territorial range of the Karankawa in the eighteenth and early-nineteenth century extended from the Colorado River south around the coast to the Nueces River. Occasionally bands would travel further south or north of these boundaries. On one occasion, Karankawa confronted and killed several persons who escaped a shipwreck and came ashore on Padre Island at the Brazos Santiago Pass. Two instances were found of Karankawas traveling as far north as Nacogdoches to steal horses.

${ }^{1}$ Fr. José Mariano Reyes to the Viceroy, 6-30-1791, Bexar Archives (BA), Roll 21:Frame 517. Cited in William H. Oberste's History of Refugio Mission, Refugio Timely Remarks, Refugio, Texas, p. 35. 
The first Europeans of record to encounter the Karankawa, within their territory as defined by Fr. José Mariano García, were members of the La Salle expedition, who traveled to Matagorda Bay in 1685. The Indians were not immediately hostile to the French, but after La Salle commandeered one of the Karankawa's canoes they began to treat the French as enemies. Karankawa attacks subsequently destroyed the French settlement, after its members were weakened by hunger and disease. Alarmed by the French intrusion, Spanish authorities initiated plans to place a mission and presidio where the French had attempted to settle. Franciscan missionaries founded the first Spanish mission to be established among the Karankawa. Mission Nuestra Señora del Espíritu Santo de Zúñiga, was founded on Matagorda Bay in 1722. Nearby, Nuestra Señora de Loreto with a presidio was built upon the ruins of the former French settlement. Espíritu Santo Mission lasted only about four years on the coast, then the missionaries were forced to retreat inland because of the hostility of the Karankawan people, lack of neophytes, and the harsh environment. The presidio remained on the coast for several more years, when it also was moved inland and reestablished near Mission Espíritu Santo, in the vicinity of Victoria, Texas. The mission and presidio from the Bay were relocated even further inland to their present site at Goliad, Texas, in 1749. Five years later, Rosario Mission was established four miles to the west of Espíritu Santo for the purpose of maintaining a separate mission for Karankawa, who were hostile to the Xaramane Indians in Espíritu Santo Mission. After Mission Refugio was established at it present site, in 1795, serious conflicts would develop between the Indians of Refugio and the Indians of Rosario that would result in the demise of the latter mission.

In 1778, a Karankawa massacre of castaways from a shipwreck on Matagorda Island gained wide notoriety (Weddle 1995). At the same time, Spanish authorities feared that Spain's enemies might eventually enlist the Karankawa as allies to facilitate a possible invasion. The Karankawa people also presented an effective barrier that prevented Matagorda Bay being opened as a port, which the Crown had recently considered as a possibility for facilitating trade with Louisiana (Castañada 1942). These favorable conditions provided a rational for establishing a mission among the Karankawa on Matagorda Bay. However, Refugio Mission came into being because of the desire and willpower of Franciscan Friar José Julio de Silva. Refugio Mission was established for the purpose of pacification of the Karankawa as well as for religious conversion: to take possession and control of Matagorda Bay, its coasts and, island sanctuaries. Fr. José Mariano de Garza, co-founder of Refugio, along with Fr. Silva, expressed this idea in clear terms to Texas Governor Manuel Muñoz and Muñoz' superior, Commandant General Pedro de Nava. The Friar reported to them that he had explored the coasts of Matagorda Bay "with the double obligation to attract the Indians who lived there and to take control of the land.",2

Nuestra Señora del Refugio functioned as an active mission for only thirty-seven years, but its history is rich and complex. To clarify its story, it will be helpful to organize the events of the mission by dividing the years of its existence into the periods of tenure of its ministers. Six Franciscan missionaries were entrusted with the primary responsibility as father ministers for Refugio Mission during its brief but eventful existence from 1793-1830. They were Friars Manuel Julio Silva and José Mariano Garza, Antonio de Jesús Garavito, José Manuel Gaitan, Fr. Antonio Diaz de Leon, and Fr. Miguel Muro.

Fr. José Mariano Garza, who had gained extensive knowledge of the coastal terrain and the Karankawa who inhabited it through his thorough, preliminary explorations of the lands, waters, and its people, selected and formally bestowed the name "Refugio" on the new mission. It seems no accident that he picked a name, or concept, for the new mission that the Indians themselves used. Their idea that the waters around Matagorda Bay represented a "refuge" is demonstrated by events that happened during a military expedition in 1789 when Corporal Antonio Treviño led sixteen troops from Presidio La Bahía in search of the Karankawa Indians who had killed a presidio soldier. They tracked the Indians to the area below the confluence of the San Antonio and Guadalupe Rivers, (the area where Refugio

2 Commandant Pedro de Nava to the King, 1 1-6-1794, Center for American History (CAH), Archivo de Indias, Audencia de Guadalajara (AGI), Dunn Transcripts, Vol. 60, p. 51, Box 2Q143. 
would be founded four years later), where the troops lost the trail. Later, Corporal Treviño met with the chief of a Karankawa group at a place called the Bolson de Mosquitos. In the course of their talk, the chief told Treviño about how many Indians had been killed by the Spaniards:

"who try to catch them away from the water, which is their refuge."

Further investigation shows that the actual "refuge" was Matagorda Island, and various nearby islands where the Karankawa could escape not only from the Spanish troops, but different pursuers such as the Comanches and other enemies. Corporal Treviño subsequently served as a guide during some of Fr. Garza's first explorations of the coasts and bays inhabited by the Karankawa. No doubt he gained valuable information from the experienced corporal, including knowledge of the Indians' refuges. Evidently, Fr. Garza hoped to displace their island refuges with a mission refuge, hence the name.

3 Antonio Treviño to [Manuel de Espadas], 12-12-1789, BA, Roll 20:Frame 82. 


\title{
Chapter 3: Mission History- Section A \\ The Founding of Refugio and Ministry of Fr. Mariano Garza
}

\author{
1789-1794
}

\section{The Example of Fr. Antonio Margil de Jesús}

Friars Manuel de Silva and José Mariano Garza were the founders of Refugio Mission. In 1790 they were living and working at the Franciscan Missionary College at Zacatecas. That same year Franciscan authorities appointed Fr. Silva to the important position of Prefect of Missions and Father Commissary. Evidently, a large part of his responsibility was to oversee all the missions that were administered by the Zacatecas Missionary College. But Fr. Silva was not satisfied presiding over established missions and citing the example of Fr. Antonio Margil de Jesús, ${ }^{4}$ he developed a burning desire to found new missions in Texas.. ${ }^{5}$ Thus, Fr. Silva became the prime mover, or mastermind, of Mission Refugio.

Prior to 1790, it appears that Fr. Silva had worked only in administrative positions and had little or no experience in the missionary field. Wisely, to compensate for his own lack of practical missionary experience, Fr. Silva chose a man with extensive previous field experience in Texas, Fr. Lector José Mariano Garza. Fr. Garza was an excellent choice, for not only did he have practical Texas experience, he was academically trained as a teacher of doctrine and theology, signified by his title "Lector." The two friars arrived in San Antonio on January 27, 1791, and then traveled to the coast near Matagorda Bay to talk with the Karankawa Indians and assess whether they would be receptive to having a mission established among them. ${ }^{6}$ After their first trip to the coast, Fr. Silva received a notification from the Council of the Indias, in Seville, ordering him to return to Zacatecas and carry out certain administrative duties. These concerns occupied Fr. Silva for most of a year. During that time, Fr. Mariano Garza painstakingly traveled among the Karankawas, cultivating their trust, learning their ways, discovering the lay of the land, and building a cooperative relationship with Governor Manuel Muñoz. Despite Fr. Silva's inspiration and preliminary efforts that paved the way, it was Fr. Mariano Garza who actually established what would be the last Spanish mission to be founded in Texas, to which he gave the name Nuestra Señora del Refugio.

\section{Fr. José Mariano Garza, 1791-1793}

Fr. Francisco Garza took the habit in 1765, professed the next year, and was ordained a priest in 1772. That same year his prelates sent him to the missions of Texas, where he continued missionary efforts on the Trinity River among the Oroquisac Indians, whose mission had been closed. He came to San Antonio Valero Mission for a time, and later served as the priest for the short-lived Bucareli settlement. In 1782, he returned to the Zacatecas Missionary College, where he taught theology and served on the College's Discretorio or council (Bolton 1970).

When Fr. Silva left Fr. José Mariano Garza in charge of his mission project, he evidently intended for him to do little more than seek out apostate Christian Indians from the Espíritu Santo and Rosario Missions and convince them to return to their respective missions, and to work with the gentile coastal Indians to maintain their interest in establishing a mission. Fr. Garza made himself acquainted with the various Karankawa groups on the coast, promoting the advantages of mission life. He searched for possible mission sites, traveling from the Nueces to the Colorado River. Within a few months Fr. Garza had persuaded onehundred and eighty-six Karankawa to request a mission on the coast. The Indians formed two groups: 104 under Chief Fresada Pinta; the remainder under the control of

4 Antonio Margil (1657-1726) founded the Zacatecas Missionary College in 1716 and established many missions in Texas and Guatemala. He is presently on the track to sainthood, having reached the level of "venerable."

5 Fr. Manuel de Silva to Excellentissimo Señor [Viceroy Revillagigedo], undated [ca. March 1792], Archivo Colegio de Zacatecas Microfilm (ACZ, hence cited as Zacatecas Microfilm), Roll 3:Frame 3814.

6 Ibid. Our Lady of the Lake University, Old Spanish Missions Historical Research Library, Zacatecas Microfilm, Roll 3:Frame 3816. 
Chief Llano Grande. ${ }^{7}$ In a letter to Governor Muñoz, Garza quoted the Indians as saying:

"Father, do not think that we do not want to go to a mission... let Spaniards come to live in our land and be sure that we will receive them as friends. But we do not want to leave our land. If you would put a mission for us here on the coast, we will gather in it all the Christian [apostates] and we will bring with us all the infidels from this coast from the mouth of the Nueces to the Colorado River."

Given this opportunity, Garza believed he could not wait for Fr. Silva's return. In the fall of 1791, with the support of Governor Manuel Muñoz, Fr. Garza sent a proposal for the new mission, to be called Nuestra Señora del Refugio, to Viceroy Revilla Gigedo. He included an itemized budget totaling 6,610 pesos for the materials he thought necessary to establish the mission. The viceregal administration and the Royal Treasurer, Ramon de Posada approved Fr. Garza's proposal on December 31, 1791. ${ }^{9}$ At the same time, Fr. Garza concluded his exploratory efforts and wrote a lengthy, detailed geographical description of the area on the coast where the Indians had requested the new mission be located. ${ }^{10} \mathrm{He}$ sent copies of this and other reports to Fr. Silva. On January 4th, in Mexico City, orders were executed naming Fr. Garza as the new mission's administrator and authorizing him to receive the necessary supplies.

\section{One Mission, Many Petitions}

The administrative procedures upon which Refugio Mission was finally founded were extremely complex. Summarized below are the primary actions that were taken. Between them, Fr. Mariano Garza and Fr. Manuel Silva filed three separate petitions requesting authorization for Mission Refugio: Fr. Garza to the Viceroy in 1791; Fr. Silva to the Viceroy in 1792, and to the King in 1793.
In January of 1792, Fr. Silva was still in Zacatecas completing his administrative duties. But once informed of Fr. Garza's Refugio proposal he wasted no time taking charge. Most importantly he took precautions in the face of an imminent, momentous change in the structure of colonial government that could have had an adverse effect on Refugio. He left Zacatecas for Mexico City, January 28 and arrived early in March. On March 13, he presented what was described as a rambling petition to the viceroy regarding his idea for the founding of Refugio and additional missions along the coast, which he proposed to fund by secularizing Mission San Antonio de Valero and Nuestra Señora del Pilar de Nacogdoches, and by combining the four remaining missions in San Antonio -San José, San Juan Capistrano, Concepción, and San Francisco de la Espada- to form two missions. ${ }^{11}$

The Viceroy approved the confusing petitions of both friars, which each had submitted without knowledge of the other. Despite the viceregal approval, Fr. Silva must have been concerned about the profound change that was imminent in the structure of government in colonial Mexico. For in February 1793, the northern provinces of the colony, from the Gulf of Mexico to California, were to be removed from the control of the viceroy and placed under the independent authority of a commandant general in Chihuahua, who reported to the King's council and was responsible to the king, not the viceroy. This vast, northern jurisdiction was called the Provincias Internas, or Internal Provinces.

Fr. Silva evidently feared that support for Refugio could fall through the cracks during the coming transition of authority from Mexico City to Chihuahua. Perhaps he was concerned that his project might be canceled or ignored by the commandant general. In any case, Fr. Silva went over the head of the commandant and boldly wrote to King Charles IV. He asked for a royal cédula that would order the commandant to provide at no charge not only the cost of equipping Refugio and providing two ministers but would also provide for the establishment of other missions between Refugio and the Trinity River that would be funded without cost to the mission's account. ${ }^{12}$

7 Pedro de Nava to the King, 11-6-1794, CAH, AGI, Dunn Transcripts, Vol 60, p. 51-52, Box 2 Q143.

8 Fr. Mariano Garza to Manuel Muñoz, 6-13-1791, BA, Roll 21:Frames 379-380.

9 This undated copy of Fr. Garza's budget for Refugio was made by Manuel Merino in Chihuahua on 1 1-6-1794, CAH, AGI, Vol. 59, p. 183-186, Box 2Q143.

10 Description geografica de la situacion y terreno del refugio, en donde los Indios had pedido se les funde una mision, Zacatecas Microfilm, Roll 1:Frames 63-70.

11 Galindo Navarro to Pedro de Nava, CAH, AGI, Vol. 60, pp. 14-15, Box 2Q143.

12 Fr. Manuel de Silva to His Majesty, 3-7-1793, CAH, AGI, Vol. 59, pp. 164-169, Box 2 Q143. 
Despite some pointed criticisms of Fr. Silva's petition from members of the royal councils, and after review by the royal treasurer, the King approved the petition. Cédulas to that effect were sent the Viceroy of Mexico and to the Commandant General in Chihuahua, Pedro de Nava, requiring him to provide funds for the costs of the new missions and to report back, in writing, about the results. ${ }^{13}$

Thus Refugio was founded by a completely different process that the other Spanish missions in Texas. This mission had, "in truth, been a personal enterprise of Father Silva, and in all matters appertaining to its foundation had been arranged by this friar personally with the government in Mexico and directly with the King's Council in Spain," (Oberste 1942:196). This peculiar establishment history would cause another administrative tangle when Fr. Silva would try to turn the Mission over to the Franciscan Missionary College in Zacatecas at the end of his tenure.

\section{Founding of Mission Refugio}

Meanwhile, Fr. Mariano Garza, evidently unaware of Fr. Silva's actions in Mexico, wrote to Governor Muñoz and asked him to come and determine where the new Refugio Mission would be built and delineate its boundaries. At the end of January 1793, Governor Muñoz prepared to travel to the mission site and determine its boundaries. ${ }^{14}$ The Governor met Fr. Garza at Espíritu Santo Mission and together they arrived at the place of the muelle, or wharf, on January 31,1793 . The muelle was located at the confluence of the San Antonio and Guadalupe Rivers..$^{15}$ Word of the Governor's and Fr. Garza's arrival was sent to three Karankawa groups: the camp of Llano Grande, the camp of the "Old Captain" who was encamped near the Muelle, and to Fresada Pinta, whose band was located near the Lavaca River. ${ }^{16}$ On this same day the first mass was celebrated at the site where the mission was to be built. On February 1st and 2nd, the Old Captain and all his people arrived in canoes; some of them were sick, as were several of Llano Grande's group; three died, having first been baptized. ${ }^{17}$ On the third day, the Indians brought the troops and equipment across in their canoes. They took the Governor and Fr. Garza on a canoe tour through the complex, divided and subdivided waterways and lagoons below the confluence of the Guadalupe and San Antonio Rivers. The Governor described the terrain around the mission site:

On the 3rd, they used their canoes to bring across the troops and their equipment to the north side of the lagoon. This area sheds rain water to the said [Guadalupe] River, and its currents restrain the waters of the sea, but I found the water to be brackish when the wind blew from the south. Together with Fr. José Garza and four soldiers, I was taken [in a canoe] from the confluence of the Rivers to where it empties in the said lagoon. In its course I noted that River's waters divide into two branches, almost equal, one of which turns north and the other to the south.

From this [last] branch a small stream branches to the right but at a short distance rejoins it. The two others flow for about a half a league and then divide into four branches with an equal number of outlets that empty in the south side of the said lagoon. And on the opposite [side], to the north, on the rim of a plain that forms its margins, [the Indians] pointed out the place for the mission they had requested. ${ }^{18}$

Unfortunately, no map was made of the location of the first Mission Refugio. However, Stephen F. Austin explored Matagorda Bay in 1821 and visited the old Refugio Mission site, which he marked on the roughly drawn map he made of the bay (Austin 1904). (Figure 3-1a-1b). The detailed 1863 map of Calhoun County, that includes parts of Victoria and Refugio counties, corresponds closely to the verbal description given by Governor Munoz. (Figure 3-2). In addition, Commandant Nava received a report, no doubt from Fr. Garza, saying that the mission site was at the disembochadura of the San Antonio [Guadalupe] River, being four leagues from the Port of Matagorda (the northern

\footnotetext{
13 The King to the Viceroy of Mexico, and the Commandant General of the Provincias Internas of New Spain, 6-17-1794, CAH , AGI, Vol. 60, p. 5-8, Box 2Q143. Particularly critical of Fr. Silva's petition is Fr. Juan de Moya to Antonio Ventura de Taranco, 2-11-1794, CAH, ibid., p. 1-4.

14 Viceroy Conde de Revilla Gigedo to Manuel Muñoz, 2-27-1793, BA, Roll 23:Frame 239.

15 Manuel Muñoz to Pedro de Nava, 1-26-1795, BA, Roll 25:Frames 156-158 (letter No.252).

16 Manuel Muñoz to Commandant General, 1-26-1795, BA, Roll 25:Frame 157 verso.

17 Manuel Muñoz to Commandant General, 2-8-1793, BA, Roll 23:Frames 39b-40 verso.

18 Manuel Muñoz to Commandant General, 2-8-1793, BA, Roll 23:Frame 41.
} 


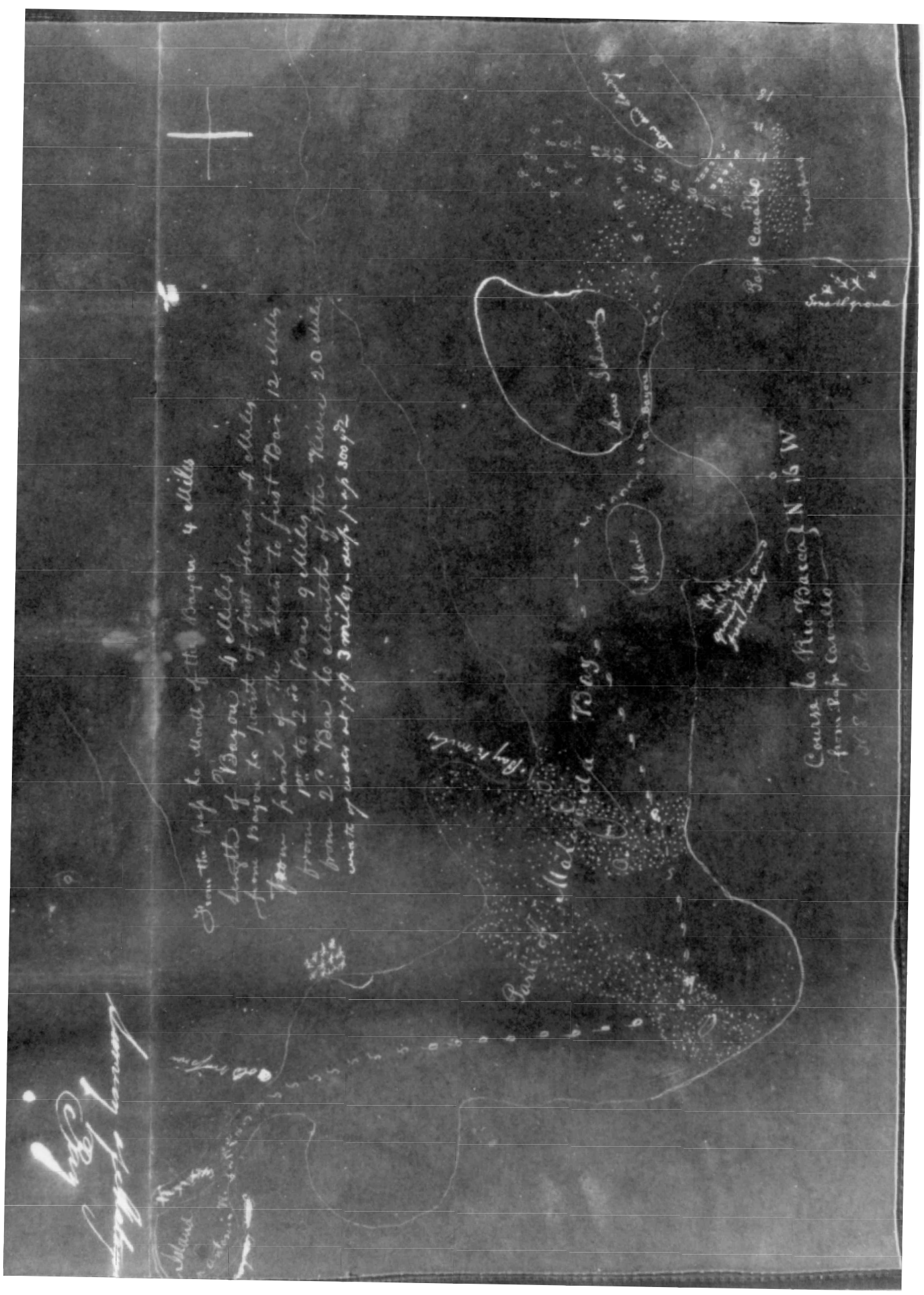

Map Collection, S. F. Austin CN 10377

The Center for American History Figure 3-1a. Copy of Stephen F. Austin's [1821] map of Matagorda Bay. The University of Texas at Austin 


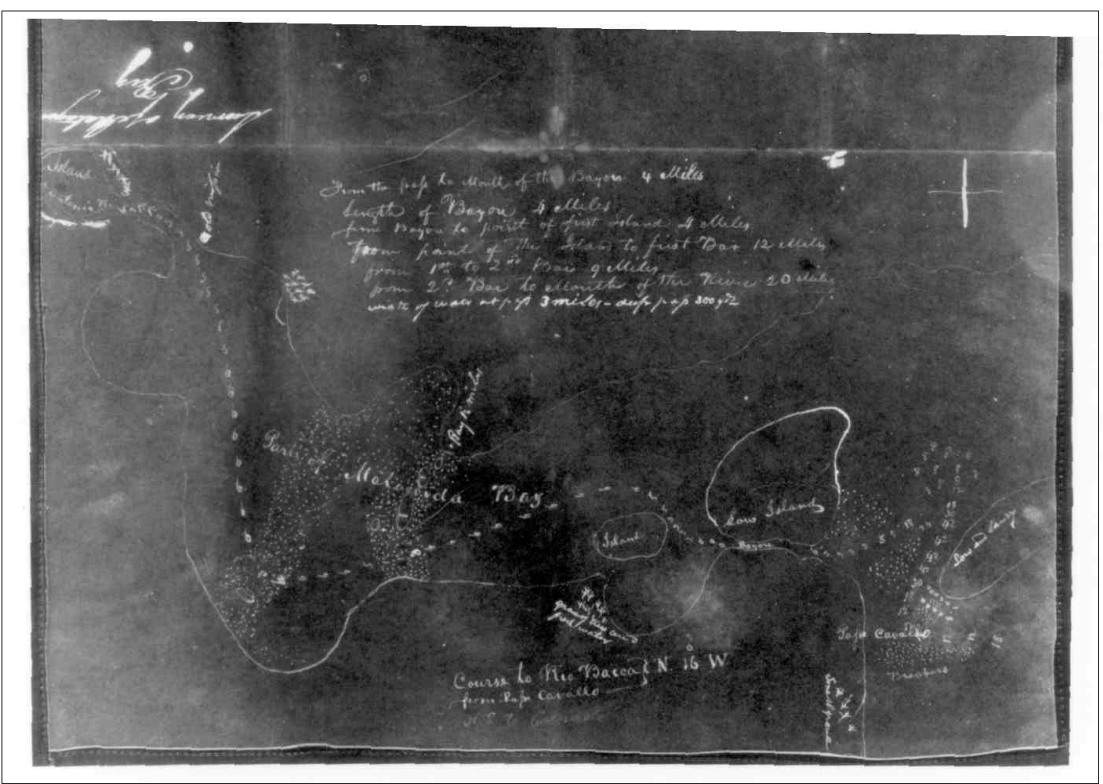

(1) From the pass to mouth of the Bayou 4 miles length of Bayou 4 miles

from Bayou to point of first island 4 miles from point of the island to first Bar 12 miles from 1st to 2nd Bars 9 miles

from 2nd Bar to mouth of the river 20 miles width of water at pass 3 miles - deep pass $300 \mathrm{yds}$

(2) Course to Rio Bacca N 16 W from Pass Cavallo N.W. to [Colorado]

Map Collection, S. F. Austin CN 10377

The Center for American History The University of Texas at Austin

Figure 3-1b. Annotated copy of Austin's [1821] map.

Note: Map is undated and is sometimes given the date 1827, which is almost certainly incorrect. Austin was exploring Matagorda Bay in 1821. He specifically asked his guides to take him to the old mission site on the lake formed after the confluence of the Guadalupe and San Antonio rivers. No doubt this map dates from Austin's first (and last?) exploration of Matagorda Bay (Austin 1904).

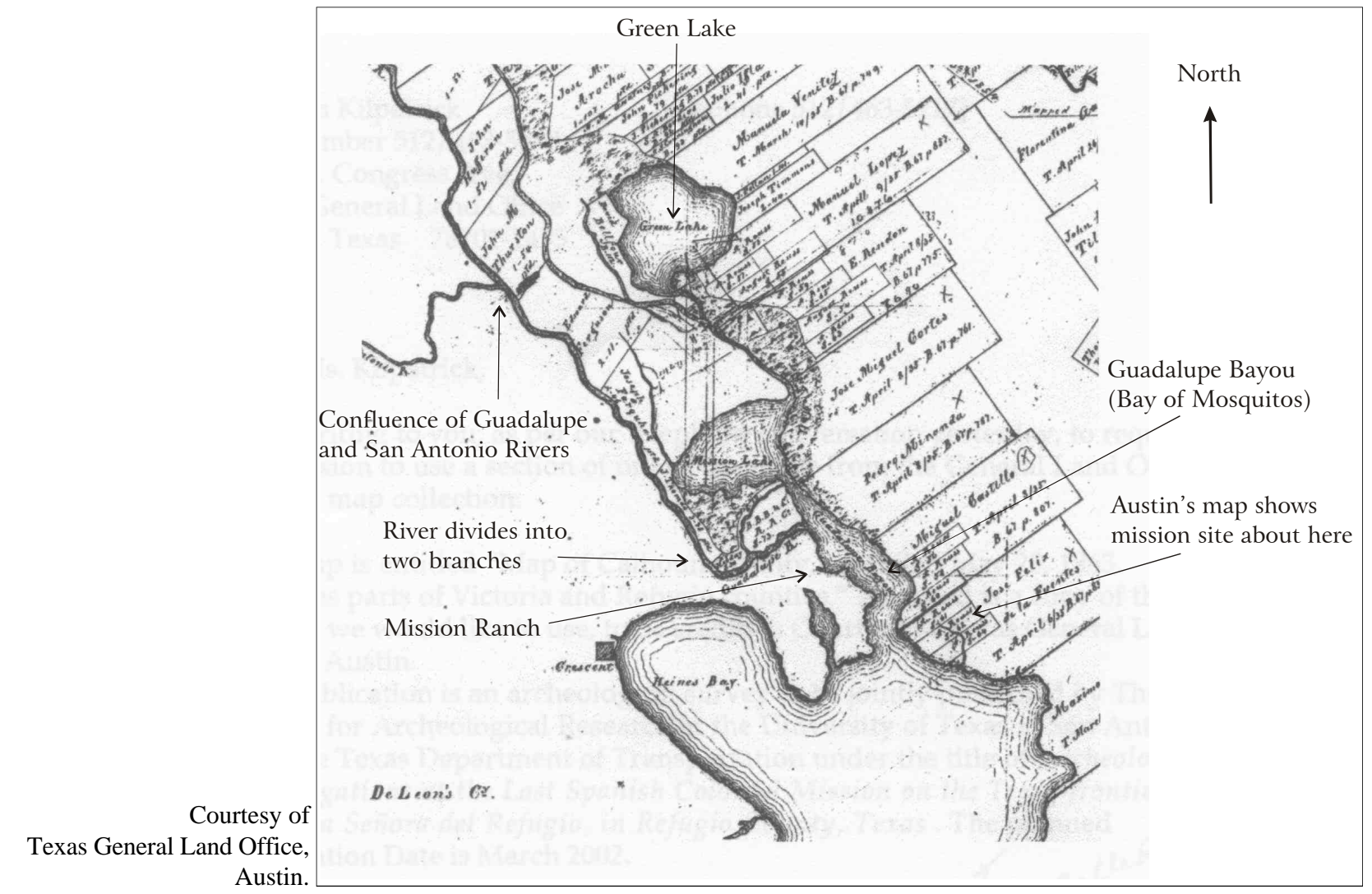

Figure 3-2. Section of “Map of Calhoun County,” compiled May 25,1863 by George Thielepape. (Map includes parts of Victoria and Refugio counties.) 
tip of Matagorda Island). ${ }^{19}$ Taken together these sources indicate that the first mission site must have been on the east side of the Guadalupe River bayou, near where the river empties into the bay. Austin's map is the only available source that actually marks the mission site. However crude and hastily drawn, it provides the best estimate for determining the first site of Refugio Mission, which appears to have been located a short distance northwest of the present town of Sea Drift.

On February 4, 1793, the Governor, Fr. Garza, and the Karankawa of the Old Captain and Llano Grande founded Mission Nuestra Señora del Refugio. Fr. Mariano Velasco was put in charge of the new mission with its one hundred thirty-eight Indians (Leutenegger 1975). For some reason, Fresada Pinta declined to join the mission-perhaps because of disaffection with Chief Llano Grande and his group. Whatever the reason, the alienation of Fresada Pinta would eventually produce disastrous consequences.

\section{Mission Ranch}

The mission Ranch was established around the time the mission was founded. Juan Cortés, Presidio Captain at La Bahía, visited the Refugio ranch site in August 1793, and was impressed with its considerable resources. His description shows that the ranch site was on the west side of Guadalupe Bayou (see Figure 3-2). Cortés said the ranch [headquarters] was located on a creek, about a one-fourth league [about a half mile] from the lagoon [bayou]. Like Governor Munoz, he found the water in the bayou brackish, but said that the abundant pastures and water would make possible huge cattle herds, as large as 10,000 animals. ${ }^{20}$

\section{Disadvantages of the Mission Site}

The two ranking military officers however, were not pleased with the mission site. Captain Juan Cortés camped near the site in 1793 and commented on the bites of the intolerable swarms of [mosquitos] there, which evidently gave the mission ranch its name, Rancho de los Mosquitos. ${ }^{21}$ Governor Munoz reported to his superior that the mission site was flawed by several disadvantages; namely periods of continuous rains, resulting in impassable bogs and a total lack of wood for building, oak would have to be cut from the west side of the lagoon and transported to the site by water. The Governor added that for the last nine days during the founding of the mission, he has been walking in water and through mud, sometimes because of rain and sometimes because of the swampy land. He was sure there must be a better site in this vicinity. Nevertheless, the Governor reported that he assigned each of his soldiers to build a jacal (hut) and then ordered that they work together to build another jacal to serve as a church and residence for the mission minister. With this work finished, the Governor returned to San Antonio, leaving the two Friars to cope with the 138 Karankawa as best they could. ${ }^{22}$

\section{Refugio Mission Supply}

\section{Presidio La Bahía Provides Support and Supplies for Refugio}

The governor contracted with private individuals who earned cash payments for obtaining and transporting various supplies for both the presidios and Refugio Mission. Mission Refugio first received material assistance in the form of cattle, corn, sugar, and oxen. Late in 1791, before the mission was officially founded, Governor Manuel Muñoz sent the first supplies to help Fr. Garza keep together the 186 Indians on the coast who had petitioned for a mission to be established there. Fr. Garza had asked for one-hundred and eighty-six piloncillos (brown sugar cones) and sixteen fanegas $^{23}$ of corn (twenty-six bushels). ${ }^{24}$ Evidently these supplies were taken from the presidio storehouse. The government also paid the freight. Governor Muñoz ordered Antonio Baca to pay 21 pesos to Pedro Flores for taking 10.5 loads of corn and piloncillos to Fr. Garza. The Governor gave Baca a receipt that stated his expenditure on the freight would be repaid from the mesteño fund. ${ }^{25}$

19 Pedro Nava to the King, 11-6-1794. CAH, AGI, Vol 60, p. 52, Box 2Q143.

20 Juan Cortés to Manuel Muñoz, 8-23-1793, BA, Roll 23:Frames 765-769.

21 Juan Cortés to Manuel Muñoz, 8-23-1793, BA, Roll 23:Frames 765-769.

22 Manuel Muñoz to Commandant General, 2-8-1793, BA, Roll 23:Frame 41 recto and verso

23 One fanega equals 1.6 bushels.

24 Fr. Mariano Garza to Manuel Muñoz, 12-15-1791, BA, Roll 21 :Frames 380-382.

25 Manuel Muñoz' receipt to Antonio Baca, 4-20-1792, BA, Roll 22:Frame 283. The Mesteño fund was monies compiled from the tax collected from residents who rounded up wild cattle for their own use or to sell. The tax was four reals $(1 / 2$ peso $)$ per head. 
At the time that Refugio was founded, Governor Muñoz ordered his soldiers to build several grass huts that would serve as the mission's temporary church, ministers' residence, and troop quarters. He left a small amount of supplies and promised to send more. Less that two weeks later, Refugio's condition was desperate. Fr. Garza wrote to the Governor informing him of their total lack of food and asked for his personal assistance because the corn and meat he had promised had not been delivered. The Friar said he needed eight cows and four fanegas of corn per week to feed the 138 mission Indians. Otherwise, Fr. Garza said, it will be impossible to keep the Indians congregated in the mission. ${ }^{26}$ Fr. Garza must have been dismayed by the Governor's reply, that "now that Refugio was founded, no more supplies can be given without an order from the Viceroy; but that some corn and meat would be furnished [at a cost]. ${ }^{27}$

Muñoz' wary attitude toward Refugio's needs reflected the fact that the two presidios of Bexar and La Bahía had limited supplies of corn to feed their own soldiers-supplies not easy replaced when depleted. Captain Juan Cortés, had already reported the lack of corn for his presidio and for Refugio Mission. ${ }^{28}$ The governor replied saying that he was sending Antonio Baca to haul 102 fanegas of corn (167 bushels), but for him to emphasize the point to Fr. Garza that there would be no more free supplies for Refugio (without funding from the Viceroy). The Governor also instructed Cortés to provide Fr. Garza with an accounting for the costs of the corn, meat, and shipping, for the mission would be required to repay this debt at a later date. ${ }^{29}$

\section{Other Missions Assist Refugio}

Governor Muñoz also assisted Fr. Garza by writing on his behalf to the ministers of the five San Antonio Missions asking for contributions of oxen and mules. Fr. Garza followed up with a letter explaining that he needed mules to carry the seed and yokes of oxen to make the first planting at the mission. The response was at best lukewarm. Two ministers replied that their mules and oxen were traveling and were not available for loan; another said that his mission did not possess any mules or oxen. Fr. Pedrajo of Mission Concepción replied that he had a yoke of oxen and a mule ready, as promised, and Fr. Joséf María de Jesús Camarena, of Mission San Antonio, said he would soon have the yoke of oxen that was promised. Fr. Mariano Cárdenas, President of the Texas Missions, spoke out strongly against Fr. Garza's request, citing the fact that oxen previously loaned to Refugio had never been returned. Nevertheless, the missions provided a number of draft animals. Governor Muñoz ordered Corporal Farías to pick up these oxen and mules, issuing a receipt to each mission, and instructing the missionaries to send an account of the cost to him. ${ }^{30}$

A few days later, Fr. Cárdenas reiterated his hard-line with respect to Refugio. He firmly informed Captain Juan Cortés, that Mission Espíritu Santo had already loaned two yokes of oxen to Refugio and that his mission could, not at the present time, loan any cattle to form a starter herd for Refugio because the majority of their cows had been loaned to Fr. Pedrajo, at Concepción Mission, to mingle with the bulls there, and that the remainder were needed to provide food for the Indians of Espíritu Santo. ${ }^{31}$

Despite Fr. Cárdenas' protestations, Corporal Farías and his six men delivered five oxen to Refugio that were provided by the other missions. ${ }^{32}$ Later, in April 1793, Refugio Mission received 112 head of cattle from Mission San Antonio de Valero. Fr. Garza wrote the Governor that he was delaying branding the newborn calves for fear of injuring them and asked that newborn calves not be charged against Refugio's account. The 19 oxen received should be counted from the 28 to which the new mission was entitled, he said. He asked the Governor to ask the Commandant General to send good quality supplies for Refugio. He lamented that the Indians preferred breeding cows for slaughter, leaving a remnant that was of inferior or useless quality. ${ }^{33}$

26 Fr. Mariano Garza to Manuel Muñoz, 2-24-1793, BA, Roll 23:Frames 235-237.

27 Copy of Manuel Muñoz to Fr. Mariano Garza, 2-25-1793, written on the back of ibid.

28 Juan Cortés to Manuel Muñoz, 3-9-1794, BA, Roll 24:Frames 543-544.

29 Manuel Muñoz to Cortés, 3-15-1994. This is a copy of Muñoz' reply written on Cortés letter to Muñoz of 3-9-1793, BA, Roll 24:Frames 543-544.

30 Fr. Mariano Garza to Governor Muñoz and Ministers of the five San Antonio Missions, 4-5-1793, BA, Roll 23:Frames 292-293 (document includes a copy of Muñoz' response).

31 Fr. Mariano Cárdenas to Captain Juan Cortés, 4-12-1793, BA, Roll 23:Frame 333.

32 Fr. Mariano Velasco to Josef Farías, 4-17-1793. BA23:340.

33 Fr. Mariano Garza to Manuel Muñoz, 4-19-1793, BA, Roll 23:Frames 350-352. 


\section{Supplies From the Zacatecas Missionary College}

The Franciscan Missionary College at Zacatecas sent periodic supply trains to Texas that provided Refugio, and other missions, with supplies of manufactured goods, tobacco, and chocolate. The Franciscan procurers in Zacatecas obtained supplies for their missions in Mexico City, through the Franciscan establishment there. From their supply center in Zacatecas, pack trains would deliver goods to the missions.

For example, a Franciscan official in Zacatecas noted that, in October 1792,

"Fr. Vicente Parra ...left to take the pack animals loaded with supplies for the Texas missions." 34

The supply route ran from Mexico City, to San Luis Potosi, to Zacatecas, to Saltillo, which functioned as a regional supply center for northeastern New Spain. From Saltillo, most shipments to the missions came into Texas through San Antonio by way of Presido del Rio Grande (present Guerrero, Coahuila), though some shipments arrived from Monterrey via the Franciscan Hospice at Boca de Leones [present Villadama] in the state of Nuevo Leon and into Texas through Laredo.

The Zacatecas College records show one shipment of goods was sent to Fr. Garza on September 14, 1792, (before the official founding of Refugio). The shipment included two religious habits, a blanket, two pair of sandals, one-half pound of saffron, snuff, tobacco in leaf, a ream of superior quality paper, a box containing 125 pounds of fine chocolate, and straw and burlap mats. The total cost of 150 pesos was paid in Zacatecas from the stipend (sinodo) of Fr. José Mariano Rojo. ${ }^{35}$
The mission's ranch and farm were expected to provide food for the mission population, but it does not appear that any significant agricultural or livestock production occurred during the tenure of Fr. Garza. The available record indicates that Presidio La Bahía provided supplies in the form of livestock and corn to the mission.

\section{Fr. Manuel de Silva Returns to Refugio}

In the summer of 1793, the return of Fr. Manuel de Silva to Refugio was imminent. Fr. Garza evidently anticipated less than amiable relations with the mercurial friar and he took the precaution of obtaining permission from his Missionary College to resume his position as lecturer there. ${ }^{36} \mathrm{Fr}$. Silva arrived at Rosario Mission toward the end of August. On September 1, 1793, he sent an list of demands to the governor, saying that the governor had not delivered what he had been promised. The Friar demanded to be notified immediately when a letter came to him from the Commandant General. ${ }^{37}$ The Governor wrote Captain Juan Cortés, at La Bahía, instructing him that "everything pertaining to missionaries, and especially Refugio Mission, must be put in writing." ${ }^{38}$ A few days later Fr. Garza wrote to Governor Muñoz and asked for a military escort to Laredo. He said:

\section{"now that Father Commissary Manuel Silva has returned to this province and has taken charge of Refugio Mission in all that concerns it, I find it necessary to return to my Missionary College." 39}

Fr. Garza returned to his academic work at Zacatecas, but he evidently missed practical missionary work in the field. Subsequently, he moved west and worked in the missions of Sonora, where he died in 1807 (Bolton 1970:419-421). ${ }^{40}$

\footnotetext{
34 The Vasconcelos Diary contains many such notations (1787-1796) of departures to obtain supplies in Mexico, and for their delivery in Texas.

35 Libro en que constan las memorias remitidas a las Missions de la Provincias de Texas [1792-1812], Our Lady of the Lake University, Old Spanish Missions Historical Research Library, Archivo Zapópan (hence cited as Zapópan Microfilm), Roll 1 (frame numbers not visible).

36 The Book of Zacatecas Missionary College Discretorio Meeting, dated 7-5-1793, page 144 verso, Zacatecas Microfilm Roll $1:($ frame numbers not visible).

37 Fr. Manuel de Silva to Manuel Muñoz, 9-1-1793, BA, Roll 24:Frames 001-002.

38 Manuel Muñoz to Captain Juan Cortés, 9-10-1793, BA, Roll 23:Frames 823-825.

39 Fr. Mariano Garza to Manuel Muñoz, 9-1 1-1793, BA, Roll 23:Frames 829-830.

40 Zacatecas Microfilm, Roll 1, p. 80-81.
} 


\section{Chapter 3: Mission History- Section в \\ The Ministry of Fr. Manuel de Silva}

1794-1796

\section{Refugio Mission in 1794}

When Fr. Manuel de Silva returned to Texas to take over Refugio Mission, he found it to be little more than a fragile assembly of temporary structures made of thatch wood and adobe that were vulnerable to forces of Indian attacks, floods and storms. These mission facilities, constructed under the leadership of Fr. Maríano Garza, are described in considerable detail in the report of Corporal Juan José Farías, made in September 1793, just after Fr. Garza's departure. The mission buildings consisted of a cluster of eight jacals, ${ }^{41}$ made of wood and tule thatch, surrounded by a wooden stockade. One of the jacals served as the church, another functioned as the living quarters of the Father Minister, another jacal, eighteen varas (50 ft.) in length provided lodging for the troops who defended the mission. A short jacal of six and one-half varas (18 ft.) contained the library and other effects of the Father Minister. Corporal Farías noted a small jacal made of tule that was one of the [original] eleven that were built when the mission was founded. Three other jacals were noted but not described. There was a wooden corral-to pen the cattle and horses- with a shade over $\mathrm{it}^{42}$ that measured forty-six varas (128 ft.) by thirtyfive ( $97 \mathrm{ft}$. ). On hand were 1,900 adobe bricks, protected by a shade. ${ }^{43}$ Corporal Farías does not mention the number of Indians resident at the mission. ${ }^{44}$ Fr. Ramón Tejada was placed in charge of the day-to-day operation of Mission Refugio until Fr. Silva arrived.

Table 3-1. Measure conversions and equivalents

PESO CONVERSIONS
One peso $=8$ reals (tomins) $=96$ granos $=257$ maravedis;
therefore, twelve granos $=$ one real
(For simplicity, this translation represents pesos and reals
and disregards fractions of a real.)
DRY MEASURE CONVERSIONS
Fanega/Almud Equivalence
One fanega $=1.6$ bushels
12 almuds $=$ one fanega
*Re: measures and value of corn in $1796:$
1 fanega [of corn] cost 16 reals
3 almuds cost 4 reals
6 reals cost 8 reals
9 almuds cost 12 reals
From these equivalents, calculations show:
one fanega contains 12 almuds*

*Note: Data derived from Bexar Archives Microfilm

(BA, Roll 26:Frames 776-798). Re: measures and value of corn in 1796.

41 Jacal: from the Nahuatl xacalli. Refers to huts, cabins, or other simple dwellings. The jacal represents the architecture of poor people of the time who made these dwellings from whatever materials were available, often using adobe, thatch, and mud-daubed vertical stakes. Because of the lack of an adequate English equivalent, jacal will be used untranslated.

42 Hecho de tijera: A roof with two water sheds built with two poles that form a vertex at the top (Francisco J. Santamaría, Diccionario de Mejicanismos, $2^{\text {nd }}$ edition, Editorial Porrua, S.A., Mexico, 1974, p. 1045 [hence cited as Santamaría 1974]).

43 "Portal de tule p.a resguarde de dh.os adoves," Juan José Farías Report, 9-18-1793, BA, Roll 23:Frame 867.

44 In January 1794, Soldier Miguel Becerra reported to Captain Juan Cortés that 106 Indians were reported to be in the mission; the father minister had given permission for 48 Indians, under Captain Llano Grande, to leave the mission and settle at the confluence of the rivers. Miguel Becerra to Juan Cortés, 1-24-1794, BA, Roll 24:Frame 461. 


\section{Fr. Manuel Julio Silva 1793-1796}

When Fr. Manuel de Silva returned to San Antonio from Mexico on August 24, 1793, he brought with him 2,487 pesos worth of tools, supplies, and church ornaments, evidently purchased in Saltillo ${ }^{45}$ (Castañeda 1942:86). Writing from Rosario Mission the next month, Fr. Silva declared he would not go to Refugio until he had supplies for the Indians, because they already felt cheated by promises of clothing made but not kept. ${ }^{46}$ When Fr. Silva met Governor Muñoz on September 21, 1793 in San Antonio, the Governor was astonished to find that, disregarding the Viceroy's decree, the friar insisted that Refugio should receive 4,000 pesos for its supply. Part of Silva's justification was that, since he claimed Fr. Maríano Garza had requested 13,000 pesos,${ }^{47}$ he was actually reducing the cost to reasonable terms. He asked Governor Muñoz to send his request for 4,000 pesos to the Commandant General, which the Governor did by confidential mail. ${ }^{48}$

By the end of 1793, Fr. Silva had heard no word from Chihuahua regarding his request for 4,000 pesos (Table 3-1). He repeatedly queried the Governor regarding this matter. Yet at the same time he was little prepared to utilize the church ornaments and tools that had already arrived. Not much had been accomplished in the way of mission construction since the work that Corporal Juan José Farías, reported earlier in the year. When Fr. Silva learned that his [original] proposal for Refugio and additional missions, had been sent to the Council of the Indias, ${ }^{49}$ he went in person to Chihuahua to present his request for 4,000 pesos for the new mission to Commandant Nava. He wrote to Governor Muñoz about the "horrible road" to Chihuahua, which "is the last resort," and asked Muñoz to loan him the necessary supplies for the trip. ${ }^{50}$

Fr. Manuel de Silva left for Chihuahua in the spring of 1794, to meet with Commandant General, Pedro de Nava. He returned in the fall triumphant with authorization from the Commandant for the 4,000 pesos for Refugio, with the
Commandant's promise of providing corn and beef for the mission for one year (not to be subtracted from the 4,000 pesos); and the right to move the mission to a site about halfway between La Bahía and the coast. After Silva left Chihuahua, Commandant Nava reported to the Crown the substance of what he conceded to Silva during their meeting.

The agreement was formulated in five points:

\section{First}

Refugio would have two ministers with stipend (sinodo) for three years, and subsequently it would be served by one minister

\section{Second}

Due to the unhealthy site location of the mission it would be moved closer to the older missions in a place of better climate to be selected by Fr. Silva, with the approval of the Governor, or other experienced men. Having determined the place, enough lands were to be made available nearby for the establishment of a settlement of Spaniards, people of reason, and Indians who voluntarily would settle there.

\section{Third}

In order to safeguard the mission, the number of troops will be fixed by me [the commandant] and they will consist of men of judgement and conduct who will observe the rules contained in the instruction formulated for the defense of the missions of California by my predecessor, Brigadier Felipe Neve.

\section{Fourth}

The 4,000 pesos that Fr. Silva requested from the Governor of Texas, on September 21, 1793, will be liberated for his disposition to purchase the objects that he proposed. [He is] to establish the mission within eight to ten months after receiving them. The purpose is not only for the instruction and catechism of the Indians and for their clothing, but also for a medium church that is strong and well built, for the living quarters and necessary shops, a starter herd of 1,000 head of cattle, fifty mares, twenty yokes of oxen, twenty-five horses, and a few other head.

45 Pedro de Nava to the King, 11-6-1794, CAH, AGI, Vol. 60, p. 57, Box 2Q143.

46 Manuel de Silva to Manuel Muñoz, 9-1-1793, BA, Roll 24:Frames 001-002.

47 Manuel Muñoz had reported that Fr. Garza had requested from him 12,000 pesos to establish a mission among the Tahuacanes. CAH, AGI, Vol. 60, p. 50, Box 2Q143.

48 Fr. Manuel Silva to Governor Muñoz, San Juan Capistrano, 9-21-1793, BA, Roll 23:Frames 882-883.

49 Fr. Manuel de Silva to Manuel Muñoz, 12-6-1793, BA, Roll 24:Frames 86-87.

50 Fr. Manuel de Silva to Governor Muñoz, 12-6-1793, Espíritu Santo Mission, BA, Roll 24:Frames 86-87 verso. 


\section{Fifth}

What the Indians need for their maintenance for the time of one year will be provided, the old mission contributing what is possible. The mission can utilize unbranded livestock. If these measures are not sufficient, the needed funds will be taken from the mesteño fund to accomplish the object, though not to burden the royal treasury. ${ }^{51}$

Complying with the latter part of the fifth item, in December of 1793, Governor Munoz sent cloth valued at 196 pesos, 2 reals (see Table 3-1) from the presidio stores to Fr. Silva at Refugio. The shipment included 40 varas of cloth made in Queretaro that the presido procurer had purchased in San Luis Potosí for the purpose of distribution to Comanche Indians as gifts. Also included were 12 pieces of coarse cotton cloth of different widths, also from Puebla, and a half load of sacks valued at 4 pesos, six reals. ${ }^{52}$

\section{Destruction of Refugio at its First Site}

Mission Refugio suffered a devastating Indian attack during Fr. Silva's trip to Chihuahua. When he returned to Texas in August 1794, Fr. Silva found that earlier in the summer, Karankawa Captain Fresada Pinta's band had attacked the mission, killing livestock, ransacking the minister's house, strewing its contents about, and terrifying the occupants. As a result of the devastation, all of the mission's personnel and possessions had been hastily moved to the "Rancho de los Mosquitos." ${ }^{53}$

Despite its ambitious beginning, after one year and four months, Mission Refugio had suffered the same fate that befell coastal Mission Espíritu Santo at its first site when hostile Karankawa forced that mission to be moved inland in 1726. The destruction of Refugio at its first location was a major setback. Although the move away from the coast would reduce the mission's military value, Refugio would continue to make a significant contribution from its inland location, for the mission Indians would continue to serve as gatherers of intelligence about events along the coast.

\section{Evaluation of the First Site}

Some possible reasons for the failure of the mission at its first site are worth exploring. Perhaps the most important factor was the location selected for the mission. Fr. Garza's strategy was to have the Indians select the mission site. When he asked Karankawa where they would like the mission, they unhesitatingly selected a place below the confluence of the San Antonio and Guadalupe Rivers, which was the location actually picked.

In his talks with the Karankawa before the establishment of Refugio, it is as if the Indians determined what Fr. Garza wanted to hear and told it to him:

"if you put a mission for us there, the entire coast is yours, because this place is where all the Indians of the coast, Christian and infidel, live the greater part of the year, for other places lack the shelter and commodities that are here..." 54

Fr. Garza evidently thought he had found a strategically good location, because all the Indians used and enjoyed it. As the quote above demonstrates, the Indians told him that the site functioned, in effect, as a commons for the Indian people of the area, where fishing was good and where there were convenient places to put in and take out their canoes. But when the mission was established there the traditional use pattern must have been disrupted. No doubt the mission facilities, with new and unfamiliar activities, must have had a restrictive effect. Non-mission Indians may have felt excluded from the previous commons and would naturally have been resentful. To them the mission may have appeared to be an intrusion into a territory that was considered a common Karankawa resource. Fresada Pinta was the foremost leader of the non-mission Indians. No doubt he had a reputation to uphold, and it would not have taken much of a slight or inconvenience for him to take offence.

51 Pedro de Nava to the King, 11-6-1794, CAH, AGI, Vol. 60, p. 58-59, Box 2Q143.

52 Statement signed by Manuel Muñoz, 12-4-1893, Our Lady of the Lake University, Old Spanish Missions Historical Library, Zacatecas Microfilm, Roll 3:Frame 2880. Costal could also possibly refer to braces for frames of adobe walls.

53 Captain Juan Cortés referred to the ranch as Los Mosquitos. Juan Cortés to Manuel Muñoz, 12-31-94, BA, Roll 25:Frames $112-113$

54 Fr. Mariano Garza to Manuel Muñoz, 6-13-1791, BA, Roll 21 :Frames 380-382. 


\section{Fresada Pinta and Llano Grande}

Captains Fresada Pinta and Llano Grande were the most prominent leaders of the Karankawa groups of the Matagorda Bay area. It was Fresada Pinta who initiated the attack on Refugio in June 1794, and he would remain a threat for many years. These two major Karankawa groups repeatedly appear in the correspondence of Fr. Garza and Governor Manuel Muñoz. ${ }^{55}$ The contrast between the two Karankawa chieftains is clear: Llano Grande and his people came willingly into the mission; Fresada Pinta and his group did not. Writing to Refugio Minister, Fr. José Ramón Tejada, soon after the attack, Muñoz pointed out the gravity of the situation, emphasizing that "Fresada Pinta's people never came into Refugio Mission, as did Llano Grande's." 56 However, Fresada Pinta was the first Karankawa to show an interest in Frs. Silva and Garza's missionary proposal. In 1791, he came to Rosario along with several members of his band to meet the two friars. Agreeing to guide them through their lands, Fresada Pinta sent for additional warriors from his tribe to ensure security against the threat of Lipan Apaches. ${ }^{57}$ During their explorations, the missionaries found another principal Karankawa leader, Llano Grande..$^{58}$ At the time, Llano Grande's domain was the area below the confluence of the San Antonio and Guadalupe Rivers; Fresada Pinta's band inhabited the area around Garcitas Creek (Oberste 1942:36). Both chiefs invited the two missionaries to visit their villages, where the missionaries distributed gifts, communicated through translators the advantages of mission life, and assessed the Indians receptivity to accepting a mission in their territory.

Given the situation outlined above, it appears that the two Karankawa captains courted the missionaries, and competed for a mission in their territory-a resource that they believed would provide their people with food and clothing. And whether or not he joined the mission, Fresada Pinta expected to receive some benefit from it. While soldiers were constructing some of the mission buildings in 1793, he came to them and asked if the food and clothing that the Governor had promised him had arrived (which evidently it had not). ${ }^{59}$ Eventually, a situation evolved where there could only be a winner and a loser. It appears that Fresada Pinta felt that Llano Grande had won the "mission prize;" and moreover that the new mission was depriving his band of free access to what had been the Indian common lands-all provoking a smoldering resentment that eventually erupted into Fresada Pinta's attack on the mission on June 4, $1794 .{ }^{60}$

In addition, Refugio's founding may have been premature. From the beginning, missionaries were unable to provide sufficient supplies for the Indians, primarily meat, corn and clothing, which were promised but often not delivered or delivered in inadequate amounts. In September 1793 , Fr. Silva warned the Governor that the Refugio Indians felt tricked, because the clothing promised them had not arrived after they had waited nearly a year. ${ }^{61}$ Promising supplies and not delivering them may have been a contributing factor to the attack on Refugio in the summer of 1794. Four months later, in January, Soldier Miguel Becerra sent a report about Refugio to Captain Juan Cortés. He wrote that one-hundred and six Indians were reported to be in the mission; but the father minister had given permission for forty-eight Indians, under Captain Llano Grande, to leave the mission and settle at the confluence of the rivers. ${ }^{62}$ Evidently the realization was setting in among Llano Grande's group that mission life was not as great as it was touted to be.

\section{The Search for a New Site}

As noted previously, the first Refugio Mission site had various disadvantages. Governor Manuel Muñoz was not slow to communicate his critique of the site to the Commandant General, noting the swampy terrain and lack of stone. And when Captain Juan Cortés visited the site in 1793 , he commented on the swarms of intolerable mosquitos there-which evidently gave the mission ranch its name.

55 Pedro Nava to the King, 1 1-6-1794, CAH ,AGI, Vol. 60, p. 51, Box 2Q143.

56 Manuel Muñoz to José Ramón Tejeda, 7-4-1794, BA, Roll 24:Frames 81 1-814 (includes copy of Muñoz’ reply).

57 Fr. Manuel de Silva to Manuel Muñoz, 4-26-1791, BA, Roll 21 :Frame 375.

58 Literally, their names translate as Painted Blanket (Fresada Pinta) and Big Plain (Llano Grande).

59 Mariano Rodríguez' Diary of events sent to Manuel Muñoz, 5-23-1793, BA, Roll 23:Frames 458-462.

${ }^{60}$ Miguel Sánchez, Testimony of the attack on Refugio, 10-25-1794, BA, Roll 24:Frames 1022-1024.

61 Manuel de Silva to Manuel Muñoz, 9-1-1793, BA, Roll 24:Frames 001-002.

62 Miguel Becerra to Juan Cortés, 1-24-1794, BA, Roll 24:Frame 461. 
Evidently, Fr. Silva also disliked the first site, for when he went to Chihuahua to meet with Commandant Pedro de Nava, one of his objectives was to obtain permission to move the mission. When he returned to Texas, in the fall of 1794 and found the devastated condition of Mission Refugio, the search for a new site for the mission began in earnest. Possible sites were located across the wide area between the Nueces to the Guadalupe Rivers. Several sites were seriously suggested and considered. Eventually Fr. Silva selected a site called Santa Gertrudis, located at the Rancho of the Diezmero, about twelve miles north of Copano Bay, on Medio Creek. Governor Muñoz delegated Juan Cortés to go and evaluate the selected location. At the end of December 1794, Cortés wrote the Governor about the site selected. He approved it, pointing out that there were readily available supplies of stone, caliche for lime, wood, with good areas for seasonal planting, and water. He said the Indians will arrive at the new site within a few days with the livestock and whatever they can bring from the [Rancho de] Mosquitos. ${ }^{63}$

\section{Fr. Silva's Grand Dream Checkmated}

While the possessions of Mission Refugio were being moved to the new site, Governor Muñoz put a stop to what had been the central idea of Fr. Silva's 1790 missionary plan. In all his petitions to the Viceroy, the Commandant General, and to the King himself, Fr. Silva had declared that Refugio would be the first of many missions that would eventually extend from Matagorda Bay eighty leagues to the Oroquizac nation, including the Taguacanas and Taguayaces, who, he said, numbered more than a thousand individuals and who were calling out for baptism. And from there, he said, the missionaries would be at the door of the Comanches to win them to the obedience of His Majesty. ${ }^{64}$

Commandant Nava had received the royal order, instigated by Fr. Silva, to support Fr. Silva's missionary plan. Royal orders notwithstanding, Nava was highly skeptical of
Fr. Silva's ambitious missionary plan and asked Governor Manuel Muñoz for his opinion. He replied that Fr. Silva had been deceptive; that he, Muñoz, had personally had communications and dealings with these three nations - the Orocoquiza, Tahuacana, and Tahuayazes-from the beginning of his governorship in 1790. During that time he had not heard a single word about them wanting to settle in missions. To the contrary, the governor said he had found an extraordinary repugnance among the Orocoquizac toward any spiritual betterment, a result of the previous attempts at the now abandoned missions there. He said Fr. Maríano Garza and Fr. Maríano Reyes had lived among those nations several years and had attained nothing more for their efforts than their own mortification, expenses, and occasional deathbed baptisms. ${ }^{65}$ After Governor Muñoz' critique of Fr. Silva, no more would be heard of a chain of missions from Refugio to the Trinity River. Thus, Refugio would become the last Spanish mission founded in Texas rather than the linchpin in the chain of new missions that Fr. Silva had envisioned.

\section{Moving the Mission Inland}

On January 8, 1795, Presidio Captain Juan Cortés wrote to Fr. Silva, and perhaps met with him personally, to explain the extent of the new lands conceded to Refugio mission by the Commandant General. In sum, Refugio was to have an area of four leagues (17,712 acres). The location of the boundaries Cortés specified are unclear. As stated, the boundary went northwest from the mission site along the Blanco Creek (Arroyo Blanco) to the Place of the Diezmero; thence, east to Trevino Creek (Arroyo de Trevino), south such that the southern boundary goes to the Aransas River. ${ }^{66}$ Cortés came from La Bahía to formally give possession of the lands to the missionaries and the Indians, in the name of Governor Muñoz. ${ }^{67}$ With 43 Indians present, Fr. Silva, walking hand in hand with Captain Cortés, took possession of the land by pulling weeds, throwing stones to the four winds, and other acts of possession. ${ }^{68}$

63 Juan Cortés to Manuel Muñoz, 12-31-1794, BA, Roll 25:Frames 112-1 13.

64 Fr. Manuel de Silva to King, 3-7-1793, CAH, AGI, Vol. 59, p. 168, Box 2Q143.

65 Copy of Manuel Muñoz to Pedro de Nava, 1-26-1795, BA, Roll 25:Frames 161-162.

${ }^{66}$ Copy of Juan Cortés to [Fr. Manuel de Silva, Manuel Muñoz, and Pedro de Nava], 1-10-1795, Zapópan Microfilm, Roll 1. (No frame or page numbers.)

67 Manuel de Silva to Manuel Muñoz, 1-12-1795, BA, Roll 25:Frames 148-49.

${ }^{68}$ Copy of Juan Cortés to [Fr. Manuel de Silva, Manuel Muñoz, and Pedro de Nava], 1-10-1795, Zapópan Microfilm, Roll 1. (No frame or page numbers.) 
Then came the arduous move of Mission Refugio to its new site on Enmedio Creek, also known as Cayo de Aranzazu or Santa Gertrudis, which began in earnest during December 1794. Most of the moving was completed by January 8th, except for the cart bearing the heavy church bells which had broken down and had been temporarily abandoned. A few days after the move, Fr. Silva wrote to Governor Muñoz telling him that they had only about a three-month supply of beef for the mission. He begged the governor to send provisions promptly, saying:

\section{"otherwise the Indians would return to their libertine and bellicose ways."}

Claiming a scarcity of cattle in the province, Fr. Silva proposed that he be given 1,452 pesos from the mesteño fund, ${ }^{69}$ to buy the necessary bulls for the Indians that year, and he would bring the stock from outside of Texas. He argued that, within a year, the increase of the cattle would give the mission its starter herd and that within two years the herd would supply the needed beef for the Indians, the mission troops, and the civilian workers. ${ }^{70}$ Governor Muñoz was not persuaded. He firmly reminded the friar of the 162 head of cattle that he had already delivered to the mission in 1793 . He pointed out that he had previously informed the Commandant General that there would be no further expenditure against the royal treasury for Refugio. Muñoz also informed Fr. Silva that he was to submit a weekly chart itemizing what was expended on each Indian family and individual. The governor added that trading a church bell to Mission Espíritu Santo for fifty cows would not be permitted. ${ }^{71}$ Fr. Silva was enraged by the Governor's letter. He wrote a blistering reply denying that the cows the governor referred to had ever been delivered. Silva quoted from a letter he had received from the Commandant General that promised prompt delivery of agreed-upon supplies. He ridiculed the Governor's request for a weekly accounting of expenses for the Indians. Fr. Silva concluded by saying:
"If you want to continue persecuting Refugio then persecute it all you want. . . if you want to destroy it (God permitting) then do what you will, but do me the favor of halting your odious arguments that serve only to lacerate Christian charity."72

Commandant Pedro de Nava and the royal assessor subsequently overruled Governor Muñoz' hard-line on cattle, ruling that the 162 head previously delivered to Refugio were not to be counted against the one year's provisions for the mission promised by the Commandant. However, as Muñoz had wanted, rations were to be based on the number of Indians living at the mission, not counting those who were at the coast. ${ }^{73}$ Faced with this superior decision, Muñoz soon delivered more cattle to Refugio. Fr. Silva acknowledged the receipt of 227 well-conditioned bulls, delivered from the Presidio de La Bahía, and asked Muñoz to gather and send the 139 remaining head to assure the Indian food supply for the [stipulated] year. ${ }^{74}$

A month later, Silva asked the governor to send the remainder of the annual supplies for the Indians to reduce the damage that had occurred because of Muñoz' delays. He stated that they had already begun to kill breeding cattle and the females will not be able to procreate without bulls. He told Muñoz it was up to him to maintain the Indians-not counting providing a livestock starter-herd that would provide a supply of beef after the government ceased its yearlong aid. ${ }^{75}$ On May 10, Fr. Silva acknowledged the receipt of 140 additional cows Muñoz had sent to Refugio. ${ }^{76}$

On July 5, 1794, Antonio Baca presented a bill to Governor Muñoz for supplies he delivered to Mission Refugio. He had provided the mission with 367 bulls, valued at 19 reals each [two pesos, three reals]. He brought carts containing seventy-one fanegas of corn [114 bushels] valued at two pesos per fanega, and he charged one peso freight per fanega, for a total cost of 1,077 pesos. Baca requested and received payment in cash for this amount from the mesteño fund. ${ }^{77}$

\footnotetext{
69 The Mesteño fund was made up of royal taxes collected on wild, unbranded livestock that were rounded up for local use or for export.

70 Fr. Manuel de Silva to Governor Muñoz, 1-12-1795, BA, Roll 25:Frames 148-149.

71 Governor Muñoz to Fr. Silva, 1-24-1795 (copy), BA, Roll 25:Frame 150.

72 Fr. Silva to Governor Muñoz, 1-29-1795 (copy), Zacatecas Microfilm, Roll 3:Frames 2925-2929.

73 Commandant Pedro de Nava to Governor Muñoz, 2-26-1795, BA, Roll 25:Frames 353-354.

74 Fr. Manuel de Silva to Governor Muñoz, 4-22-1795, BA, Roll 25:Frame 457.

75 Fr. Manuel de Silva to Governor Muñoz, 5-6-1795, BA, Roll 25:Frame 495.

76 Fr. Manuel de Silva to Governor Muñoz, 5-10-1795, BA, Roll 25:Frame 513.

77 Antonio Baca to [Manuel Muñoz], 9-5-1795, BA, Roll 25:Frame 827.
} 


\section{Advantages of the New Location}

The Santa Gertrudis was a neutral site compared to the previous one, in that it was not at the center of a people's traditional habitat like the Guadalupe Bayou area had been. In addition, Santa Gertrudis provided better quality agricultural land and easier access to wood and building quality stone. The mission's security was improved, since a closer proximity to the Presidio de La Bahía would enable more rapid military reinforcement in times of crisis. Also, the close attachment of the Karankawa Indians to their coastal environment was well-known and their aversion to living in San Antonio -so far from their traditional habitatwas well-recorded. Thus, the Refugio mission was attractive to the coastal Indians due to its close proximity to the coast, being positioned only about twelve miles north of Mission Bay, and because it did not infringe upon traditional Karankawan territories.

\section{New Missionaries for Refugio}

After Fresada Pinta's devastating attack on Refugio at its first location, the mission badly needed missionary reinforcements. Fr. José Tejada, the temporary Refugio minister, returned to Zacatecas in September. In addition, Fr. Velasco, the first Refugio Minister, was now afflicted with a serious illness and he returned to Zacatecas in October (Leutenegger 1975:37). Fr. Silva was en route from Chihuahua to Refugio at that time, but he too was in poor health and would need assistance.

The Missionary College selected Fr. Antonio de Jesús Garavito and Fr. José María Sáenz to go to Refugio to provide assistance and, no doubt, gain the necessary experience to take over when Fr. Silva would have to step down as Refugio's minister. Fr. José María Sáenz went to Refugio first, in the role of a supernumerary, or "temporary missionary." He traveled with the supply pack train that left
Zacatecas for Texas on November 22. Fr. Garavito was assigned to Refugio the next month and left Zacatecas for his new mission on December 29, 1794 (Leutenegger 1975:37). Both missionaries must have arrived around the time of the move inland.

\section{Skilled Labor at Refugio}

Spanish servants and artisans were needed at the new mission. For many tasks, Indians lacked the experience to perform them or could not perform them well (Leutenegger 1975:37). At Refugio, it was difficult to find civilian workers who were willing to live in the primitive conditions that existed there. From the time of its founding, the mission had depended on the labor of the soldiers who were assigned to protect it. In September 1795, work stopped at the mission due to a lack of workers as most of the Indians had gone to the coast. Fr. Silva sent Fr. Puelles (the Rosario Mission Minister) to Boca de Leones, Tlaxcala, and Revilla to recruit workers. ${ }^{78}$ Many frustrations faced Fr. Silva during this period. Refugio's corn crop failed, as did La Bahía's, and he was forced to use the corn, he had been saving for the friars and workmen, to feed the mission Indians. He also found fault with the poor quality of the furniture, beams and other work produced by the carpenter, Victoriano Najara. $^{79}$

Adding to Refugio's woes, San José Mission tried to reclaim the blacksmith, Joaquín Bocanegra. Bocanegra, who owed a debt to San José, had set up a forge at Refugio and was making needed items. Fr. Silva wrote to Governor Muñoz begging that he be permitted to stay. Muñoz ruled in Fr. Silva's favor, but warned that Bocanegra was a drunkard and a gambler. ${ }^{80}$

At the new mission site, some of the construction was performed by convict labor. The Governor had condemned Juan José de la Garza, Pedro Xavier Salinas, and Reymundo Diaz to public works without salary in $1793 .{ }^{81}$ Governor

\footnotetext{
7 Fr. Manuel de Silva to Manuel Muñoz, 9-9-1795, BA, Roll 25:Frame 826.

79 Manuel Muñoz to Fr. Silva, 10-15-1795, BA, Roll 26:Frames 897-898.

80 Fr. Mariano Garza to Manuel Muñoz, 12-30-1795; Muñoz to Silva (copy), 1-6-1796, BA, Roll 26:Frame 91.

${ }_{81}$ Manuel Muñoz to Juan Cortés, 9-13-1793, BA, Roll 23:Frames 843-844.
} 
Muñoz sent these three convict laborers to work at Refugio early in February 1796. Food for the convicts would be provided from Presidio La Bahía's supplies, but the cost would later be charged to Refugio's account.

Some hired labor was utilized. The potter, Mexia, brought a load of clay [greda] from the town of Boca de Leones. José María Uraga contracted with Fr. Silva to deliver 300 quality beams, 800 boards, and 20,000 tabletas (small boards). Fr. Silva complained that Uraga delivered only a small fraction of the promised items and that those were of substandard quality. Likewise, Fr. Silva said, the carts he built were badly made.

By February 1796, the temporary church was nearly finished, although the facade had collapsed. ${ }^{82}$ This temporary church building for Refugio was completed and opened on March 19th. Fr. Silva wrote that:

“...we opened on the Day of San José the beautiful buildings that, although built for living quarters, are substituting for the church and sacristy."83

\section{Mission Supplies from Zacatecas}

During Fr. Silva's tenure at Refugio mission, 1794 to 1796, the Zacatecas Missionary College continued to send supplies. Records were found of three shipments to the mission, as recorded in the accounts of the Missionary College in Zacatecas. The total value of the supplies, not counting freight charges, was 992 pesos, 5 reals. Most of the expenditure was for chocolate and tobacco. Included in the three shipments were 1,125 pounds of chocolate, both fine and ordinary, for a total cost of 229 pesos. One thousand pounds of tobacco were listed (six pounds of which were in the form of snuff - tobacco en polvo) for a total cost of 530 pesos, 3 reals. As for percentages of the total expenditure for supplies, chocolate stood at 23 percent; tobacco - 53 percent. Combined, the cost of these two items represented 78 percent of the peso value of the supplies brought into
Refugio Mission. No doubt the substantial weight of the chocolate and tobacco contributed significantly to the freight charges. The transportation costs noted for these three shipments total 177 pesos, 7 reals, or 18 percent of the total value of the supplies. Cowhides that workers at Refugio produced were used to defray part of the cost of supplies received. When a shipment of goods to be sent to Refugio was prepared at Zacatecas in 1795, a credit of 74 pesos was applied from "hides I received at the mission." 84

The sizeable amounts and cost of tobacco and chocolate noted above, demonstrates the importance of these items to the mission's operation. Tobacco, with its habit-forming quality, and the luxury of chocolate reinforced the Indians' attachment to the mission. The importance of tobacco to the mission would later be emphasized by Fr. Miguel Muro, the last Refugio minister. In his writings from 1825, a time when the mission was receiving virtually no supplies from Zacatecas or other outside sources, Fr. Muro said that he had used the alms received from his masses for the past two years to buy tobacco for the Indians,

\section{"It is their main gift. Without it they become depressed or contentious. " 85}

\section{Indian Relations During the Tenure of Fr. Silva, 1793-1796}

In January 1796, Refugio Mission had been established at its permanent site for a year. And by this time, a serious problem had come to the forefront- the Indians of Mission Rosario. Up until this time Refugio had experienced only a few problems with the Indians from its neighboring mission. Fr. Manuel de Silva was concerned that a serious incident could result from the Rosario interlopers.

At the end of January, Fr. Silva wrote to Governor Muñoz and reported that since the move to the new site, there had been no particular problems, except those caused by Rosario

82 Juan Cortés to Manuel Muñoz, 2-13-1796, BA, Roll 26:Frame 373.

83 Fr. Manuel de Silva to Manuel Muñoz, 3-27-1796, BA. The Feast Day of San José is March 19th.

84 List of Supplies sent to Refugio Mission from Colegio Apostolico de N. S. de Guadalupe, 2-13-1795, Our Lady of the Lake University, Old Spanish Missions Historical Library, Zapópan Microfilm, Roll 1, p. 104 verso of the document.

85 Fr. Miguel Muro's incomplete Report on Refugio Mission, ca. 1825, Refugio Mission, Zacatecas Microfilm, Roll -1. 
Indians. He then narrated a story about a confrontation with Chepillo, a Rosario Indian. Chepillo killed the best cow at Refugio and made a public display of it. Shouting, that he could stay at whichever mission he chose, he threatened Silva with his bow and arrow. When Silva stood up to him, another Indian threatened Silva with a musket. When the soldiers arrived there was a general uproar, but the Indians backed down. Informed of these alarming events, Governor Muñoz glossed over them. He replied to Fr. Silva and to the Refugio Corporal that the Indians of Rosario, Refugio, and the Fresada Pinta band were of the same class and circumstance and it was hard to know the cause of their dislike of the mission. ${ }^{86}$

\section{Fr. Silva's Health}

Soon after the move to the new mission site, Fr. Silva's health began to decline, and the mounting problems with Rosario Indians coming to Refugio began to overwhelm him. Despairing, he wrote to Governor saying:

"...the time has come to dictate the end and finish of Refugio, if you in your prudence agree."

Discussing the value of various mission properties, he says he would only take 2,000 cows for himself and the missionary fathers of his Colegio.

"The truth is, sir Governor, that neither the Apaches, nor Comanches, nor Vidais, et. cet, are the worst enemies-the worst enemies are the indians at Rosario who probably do more harm here than all the others."
He referred to his previous letter to Muñoz that thirty Indians from Rosario stayed several days, and that Santiago, also from Rosario, brought more than fifty Indians to stay. He said groups of ten to twelve Indians stay nearby to rob the herd and they will finish it off without prompt attention. He asked the governor to provide a sufficient number of soldiers to make the Rosario Indians return to their mission.

$$
\text { "If not, Refugio will soon be finished..."87 }
$$

\section{Fr. Silva Leaves Refugio}

Fr. Antonio Jesús Garavito arrived at Refugio in September $1795^{88}$ to join Fr. Silva and Fr. Sáenz. With two experienced missionaries now on the job, Fr. Silva began making plans to retire from Refugio. His health had deteriorated badly over the past two years, and by 1796, his left arm and knee were almost paralyzed. ${ }^{89}$ Silva felt a great urgency leave Texas and go to Monterrey where he hoped to improve his condition in the sulphur baths there..$^{90}$ In September 1796, Nuestra Señora del Refugio lost its strongest defender and advocate, when Fr. Manuel de Silva transferred the ministry of the mission to Fr. Garavito and returned to Mexico.

86 Manuel de Silva to Manual Muñoz, 1-28-1796, BA, Roll 26:Frame 350. A copy of Muñoz's reply is written on this letter.

87 Fr. Manuel Silva to Governor Muñoz, 4-15-1796, BA, Roll 26:Frame 495.

88 Fr. Antonio Garavito to Manuel Muñoz, 8-3-1797, BA, Roll 27:Frame 739-40.

89 Fr. Manuel de Silva to Manuel Muñoz, 9-13-1796, BA, Roll 26:Frame 828.

90 There are at the present time sulphur baths in Monterrey on the other side of the Cerro de la Silla, according to Ms. Yolanda Pérez, native of Monterrey. Personal conversation, November 1999. 


\section{Chapter 3: Mission History- Section c The Ministry of Fr. Antonio de Jesús Garavito}

1796-1802

\section{Refugio Mission, September 1796}

When Fr. Manuel de Silva transferred Refugio Mission to Fr. Antonio Garavito on September 9, 1796, one year and eight months had passed since the mission had been moved to its new location. The occasion of the mission's transfer provides the first opportunity, through the inventory made at the time, to understand the overall condition of the mission at its new site. Clearly, substantial progress had been achieved. Captain Juan Cortés came from La Bahía and produced the inventory of the mission that provides a detailed record of its buildings and their contents (For a partial translation of this inventory see Appendix A-1).

The inventory of 1796 indicates that the primary mission structures consisted of three stone buildings, and twelve jacals, and a stockade. ${ }^{91}$ Work had begun on the permanent church, but had not progressed beyond laying the foundations and cornerstones. The dimensions of this foundation measured 83.3 feet by 23.6 feet. ${ }^{92}$ Of the three buildings which composed the primary mission structures; one of the two buildings was 41.6 feet in length and the other 33 feet, while both buildings were 13.9 feet wide; the third building, which served as the sacristy, was built in a square 13.9 feet on each side. All three structures were five varas, or 13.9 feet, in height. ${ }^{93}$
The three buildings were built with stone and lime and were provided with good rafter beams, bricked [floors] and plastered [walls]..$^{94}$ Two of these buildings served as the temporary church and were adorned with an extensive array of religious statuary, other objects of devotion, ornaments, and religious instruments, while, as stated previously, the third building functioned as the sacristy. In front of the church, workmen had constructed a large wooden cross built upon a stone pedestal. An impressive array of bells were placed to one side of the church. These bells ranged in weight from three-hundred and fifty pounds to eighteen pounds..$^{95}$

In addition to the three stone buildings there were twelve jacals, one of which served as the residence of one of the ministers. This structure was constructed of adobe walls with a grass roof, and had dimensions of 48.6 feet by 18.0 feet, it had a door with a lock and a small window. Besides the personal effects of the minister, the residence stored tools, tobacco, wine, food, kitchen equipment, trinkets for gifts, books, a forge with accessories, and other items which included a guitar, violin, bandola ${ }^{96}$ and instrument strings.

Several of the eleven other jacals served as living quarters for the soldiers, servants, and workmen, the remainder functioned as storage sites for ranching equipment, and carpentry tools. Two kilns had been built to make lime and bricks; eight thousand bricks were on hand. ${ }^{97}$

91 Inventory of Nuestra Señora del Refugio Mission, 9-8-1796, Zacatecas Microfilm, Roll 3:Frame 3861.

92 Ibid. Thirty varas by eight and one-half varas. All varas expressed herein are converted at 33.33 inches per vara, rounded off to the nearest tenth of a foot.

93 Ibid.

94 “... son de cal y canto, bien envigadas, enladrilladas y enjarradas," ibid.

95 One bell was kept for the Trinity Mission, if approved. This bell appears to be a remnant of Fr. Manuel de Silva's dream of establishing missions from Matagorda Bay to the Trinity River.

96 A small musical instrument with four strings approximately the size of a mandolin.

97 The mention of kilns [hornos], it is evident that the 8,000 bricks recorded here were fired, rather than sun-dried adobe bricks. No doubt bricks like these were used to make the floors of the three buildings described as being enladrilladas. 
Ninety chickens were penned at the mission site. The inventory noted a blank book for baptisms with 195 folios, another for marriages, and a third to record burials. ${ }^{98}$

In his inventory of the ranch livestock, Captain Cortés recorded 2,500 head of cattle and fifteen head of hogs. For work animals, there were twenty-five yoke of oxen, forty tame horses, sixty mares, with their stud donkey, and twenty tame mules and their burro mañadero (herdsman). Financially, the accounts showed the mission to have a balance credit of 150 pesos. This last figure would turn out to be incorrect and create for the Refugio missionaries an exasperating administrative headache. Sixty-five Indians were found and recorded as being at the mission while the rest were, presumably, at the coast.

\section{Transfer Problems}

Because of the particular circumstances of Refugio's founding, the mission did not belong the Franciscan Missionary College at Zacatecas. Although the mission was staffed with Zacatecan missionaries and received some supplies from the Zacatecan college stores, Mission Refugio was nevertheless the responsibility of the Government of the Provincias Internas. Thus, Fr. Silva's transfer of the mission in the name of the Zacatecas Military college was invalid. It was to take more than a year of administrative maneuvering before the matter would be resolved. In 1797, Zacatecas Guardian Gamarra petitioned the Commandant General to officially deliver Mission Refugio to Fr. Garavito and Fr. Sáenz, ${ }^{99}$ and for it to be operated under the auspices of the Colegio de Zacatecas.

\section{Indian Relations}

Troops from Presidio La Bahía had provided security for Refugio Mission from its beginning. At the turn of the new year, 1797, Captain Juan Cortés reported the status of his military force at La Bahía. He had a total of one hundredeighteen men, ten of whom were stationed at Refugio. ${ }^{100}$
By this time, Refugio had established a stable group of Indian converts who remained with the mission. Despite periodic sojourns to the coast, these converts were mission regulars. Fr. Garavito referred to these loyal followers as the "Sons of the Mission" (hijos de la misión), and sometimes as the "Elders of the Mission" (los antiguos de la misión). The size of this group can be assumed to have been about seventy-five persons based on the total reported in the mission census that Fr. Garavito prepared later in the year.

\section{Sons of the Mission versus the Newcomers}

Early in 1797, a disturbing situation developed at La Bahía, more Indians came and asked to join the mission than the mission could handle. In his diary for the month of February, La Bahía Captain Juan Cortés noted that, on the 15th, fifteen starving Coco Indians (Karankawa) entered the presidio on foot. The Indians said that more than one hundred of their nation were located about sixty miles to the east; that they were traveling to La Bahía with the intent to settle at Rosario Mission. ${ }^{101}$ These Indians arrived at La Bahía in March. Captain Cortés determined they were comprised of two groups. The first were Cocos, unaffiliated with the feared Fresada Pinta's group, ${ }^{102}$ who had been camped at the mouth of the Colorado River. The second group was made up of "Indians who were once converts [reducidos] at Refugio Mission." ${ }^{103}$ Informed of this, Governor Muñoz, replied that Rosario was in a deteriorated state and could not support the ninety-seven Indians who sought to settle there. The Governor sent about eighty bushels of corn [50 fanegas] to help sustain the group and dispatched a report of the situation to Commandant Nava in Chihuahua. ${ }^{104}$

Nevertheless, the Indians traveled to Rosario. When they arrived at the end of May, Fr. José Francisco Jaudenes was perturbed. Noting that the Indians were docile and obedient, he nevertheless found them to be the source of many annoyances. He wrote Captain Cortés requesting three or four soldiers to help control these new arrivals. ${ }^{105}$ Cortés provided a guard of three soldiers, noting that, while the

\footnotetext{
${ }^{98}$ A partial translation of this inventory is in the appendices.

99 Pedro de Nava to [Manuel Muñoz] re: Fr. Gamarra’s petitions to turn over Refugio Mission to Fr. Antonio Garavito and Fr. Sáenz, 8-3-1797, BA, Roll 27:Frame 586.

${ }_{100}$ Juan Cortés to Pedro de Nava, 1-1-1797, BA, Roll 27:002-004.

${ }^{101}$ Juan Cortés to Muñoz, 2-28-1797, BA, Roll 27:Frame 83-85; J. Cortés to M. Muñoz, 4-7-1797, BA, Roll 27:Frame 199.

102 Therefore Fresada Pinta was a Coco.

${ }^{103}$ Juan Cortés to Manuel Muñoz, 5-24-1797, BA, Roll 27:Frames 161-62.

${ }^{104}$ Copy of Manuel Muñoz' letter to [Juan Cortés], 4-1-1797, BA, Roll 27:Frames 179-80; Pedro de Nava to Manuel Muñoz, 5-2 -1797, BA, Roll 27:Frames 323-24.

${ }^{105}$ Fr. José Francisco Jaudenes to Juan Cortés, 4-5-1797, BA, Roll 27:Frame 191.
} 
Indians were cooperative, they nevertheless were infidels, possessed of a bellicose nature. ${ }^{106}$ Around mid-June, Fr. Jaudenes, acting on his own authority, sent all ninetyseven of the Cocos and Karankawas to Refugio, where they arrived toward the end of June.

Fr. Garavito was no more pleased to see these wayward Indians at his mission than Fr. Jaudenes had been. They substantially outnumbered his present mission members. The newcomers threatened to disturb the internal stability of the mission and to upset the balance between the established Indian population and the resources it had available. Saying he could hardly write because of a headache, Garavito informed Captain Cortés of the displeasure and jealousy of the Sons of the Mission at the presence of these new arrivals and anything given to them. He said he feared a unfortunate result." ${ }^{107}$ Fr. Garavito prepared a census of the Indians at Refugio, separating the "Sons of the Mission" and the unwelcome recent arrivals into different categories. He sent a summary of the census to Captain Juan Bautista Elguézabal (who had replaced Juan Cortés as Captain of La Bahía Presidio) showing that the mission now consisted of seventysix Karankawa "Elders" [antiguas], and ninety-seven Coco and Karankawa "squatters" [agregados], for a total of 175 persons including the chiefs (Table 3-2). ${ }^{108}$ Soon after the arrival of the newcomers, the Sons of the Mission went to the coast with Fr. Garavito's permission. ${ }^{109}$

Commandant Nava's decision about the problem of the wandering Indians arrived in San Antonio in June. The Commandant's determination was to give the Indians two options. The first, was to relocate to the missions near San Antonio, where he said they could obtain irrigated lands and financial support from the mission funds; the second option was that, if the wanderers did not want to settle in San Antonio, then the Cocos were to stay at Rosario and the Karankawas were to go to Refugio, in accord with the Father President of the Texas Missions. He added that the Indians were be maintained from the mission funds, not the mesteño fund-which the Governor had drawn upon to pay for the fifty fanegas he sent when the Indians first arrived. ${ }^{110}$

By the time the Commandant's order arrived at La Bahía, the Indians in question had already moved to Refugio. Captain Elguézabal summoned Indian leaders from Refugio in order to explain the Commandant's order. On June 30th, Captain Cortés met with Pedro José, whom he identified as the leader of the Cocos, and Gentil, leader of the other Karankawa newcomers ${ }^{111}$ at Refugio. The leader of the Mission citizens at Refugio, Diego, evidently was not included in the meeting. ${ }^{112}$ Manuel Sartuche, leader of the Rosario Karankawa, served as the translator.

Table 3-2. Refugio Mission Census June 30, 1797

\begin{tabular}{|l|l|l|l|c|}
\hline & \multicolumn{2}{|l|}{$\begin{array}{l}\text { Newcomers } \\
\text { to Refugio from Rosario }\end{array}$} & $\begin{array}{l}\text { Sons of } \\
\text { the Mission }\end{array}$ & Totals \\
\hline & $\begin{array}{l}\text { Cocos: } \\
\text { Captain Pedro José }\end{array}$ & $\begin{array}{l}\text { Karankawa: } \\
\text { Captain Gentil }\end{array}$ & $\begin{array}{l}\text { Karankawa: Captain } \\
\text { Diego }\end{array}$ & 47 \\
\hline Men & 19 & 16 & 12 & 43 \\
\hline Women & 15 & 12 & 16 & 51 \\
\hline Boys & 9 & 7 & 35 & 31 \\
\hline Girls & 8 & 11 & 72 & 172 \\
\hline Totals & 51 & 46 & 75 & 47 \\
\hline
\end{tabular}

${ }^{106}$ Juan Bautista Elguézabal to Manuel Muñoz, 6-19-1797, BA, Roll 27:Frames 395-97.

${ }^{107}$ Fr. Garavito to Juan Bautista Elguézabal, 6-30-1797, BA, Roll 27:Frames 487-449.

${ }^{108}$ Fr. Garavito to Juan Bautista Elguézabal, 6-30-1797, BA, Roll 27:Frames 487-449; Juan Bautista Elguézabal to Manuel Muñoz, 7-3-1797, BA, Roll 27:Frame 497.

${ }_{109}$ Juan Cortés to Manuel Muñoz, 7-3-1797, BA, Roll 27:Frames 498-499.

${ }^{110}$ Pedro de Nava to Manuel Muñoz, 5-2-1797, BA, Roll 27:Frames 323-324.

${ }^{111}$ Fr. Garavito, in his 1797 Refugio Census, identifies Pedro José as the leader of the Karankawa newcomers to Refugio, and Gentil as the leader of the Cocos. Garavato Census, 7-3-1797, BA, Roll 27:Frame 497.

1121797 Refugio Census, ibid. 
Pedro José and Gentil's response to the Commandants decision was that under no circumstances would they go to the San Antonio Missions-because of the greater Comanche threat and distance from the coast. They said that they left Rosario, with the permission of Fr. Jaudenes, to seek food because of the hunger they suffered. Cocos and Karankawa together, they went to Refugio where they said they were happy and suffered little hunger, where the climate pleased them, and they had the coast nearby where they could go to fish in times of need, and where they were far from their enemies, the Comanches. They said they were worthy of the waters of baptism and wanted to stay at Refugio and live there in peace as Christians, Cocos and Karankawa together, as brothers. Sartuche and José gave assurance that the newcomers would cause no trouble, pointing out that they were all of one nation and one language. ${ }^{113}$

By January 1798, the combined appetites of Refugio's Sons of the Mission and the newcomers appear to have eaten the mission out of house and home. Exasperated, Fr. Garavito told his Indians that he did not have sufficient funds, nor any superior order to obtain food and aid for everyone, and that they would have to go to the coast and support themselves until the Governor resolved the situation. ${ }^{114}$ Soon after, the remaining Indians, the Sons of the Mission, also departed for the coast, leaving the mission abandoned.

Governor Muñoz responded to this situation at the missions of Rosario and Refugio by suggesting that the two missions be combined, with Fr. Garavito serving as minister for both. The reply from Refugio was swift and angry. Fr. Garavito refuted the governor's idea by pointing out that the Karankawa from Refugio and Rosario did not get along, that basic livestock resources were lacking (he only had four cows), that the 450 pesos stipend [sinodo] he received per year which supplemented the mission needs was barely enough for one mission, let along two. He expressed his conclusion in clear terms, that:

\section{“...to combine the two missions would lead to the perdition of both."115}

Captain Elguézabal had expressed considerable support on behalf of the wandering Karankawa to the governor. He assured the Governor that they had been peaceful since 1792, that:

$$
\begin{aligned}
& \text { "although the Karankawa are fishermen, } \\
& \text { they also plant crops and live in fixed villages, } \\
& \text { so how can we not bring them into our faith?" }
\end{aligned}
$$

He noted that, before leaving Rosario they cleared by hoe a substantial area of land for planting. ${ }^{116}$ Consequently, Elguézabal had little regard for Fr. Garavito's attitude and indicated that he had decided not to accommodate the Refugio Friar, who wanted Rosario Indians to stay at Rosario. Elguézabal led an expedition to the coast to bring the Indians back, but found that they had already crossed over to the islands where he could not send soldiers to retrieve them. ${ }^{117}$

Evidently, having returned to their traditional habitat, the wandering Karankawa dispersed and mingled with other groups. If any returned to Refugio, they did not do so as a united group, as had previously been the case, and they evidently no longer presented a problem. Toward the end of 1798, Manuel del Moral, Captain of La Bahía, visited Refugio and found nine families missing, but noted that few of the Indians come and go because they have little reason to leave the mission. ${ }^{118}$

\section{Refugio's Debt to La Bahía}

The Refugio ministers must have been thunderstruck at the news that the mission owed Presidio La Bahía a substantial debt. The accounting recorded on the mission inventory at the time of its transfer to Fr. Garavito showed that Refugio actually enjoyed a credit of 150 pesos. ${ }^{119}$

\footnotetext{
${ }^{113}$ Juan Bautista Elguézabal to Manuel Muñoz, 7-3-1797, BA, Roll 27:Frames 498-499.

114 Juan Bautista Elguézabal to Manuel Muñoz, 1-17-1798, BA, Roll 28:Frames 97-98.

115 Fr. Antonio Garavito to Manuel Muñoz, 2-03-1798, BA, Roll 28:Frames 144-45.

116 The area was expressed as a "fanega and eight almuds."

117 Juan Bautista de Elguézabal to Manuel Muñoz, 3-28-1798, BA, Roll 28:Frames 179-80.

118 José Miguel Moral to Manuel Muñoz, 11-21-1798, BA, Roll 28:Frames 560-561.

${ }_{119}$ Refugio Inventory, 9-8-1796, Zacatecas Microfilm, Roll 3:Frames 1339-1366.
} 
At the beginning of 1797 , a serious financial default was discovered at Presidio La Bahía. Fr. Juan de Aguilar, Capellan at Espíritu Santo Mission, tried to cash a pay order [libranza] for 400 pesos at the Presidio in favor of his mission. When he was unable to collect the amount due he wrote to Commandant Pedro de Nava asking him to order its payment. ${ }^{120}$ Investigations revealed financial mishandling going back to 1795 . Commandant Nava ordered the Governor to do a thorough audit of La Bahía finances. The result was that Sergeant Manuel Espadas, the presidio supply officer [habilitado], was discovered to have had a deficiency [quiebra] of 9,000 pesos. ${ }^{121}$ Presidio Captain Juan Cortés was found to be implicated. Both Espadas and Cortés were relieved of their positions, arrested, convicted, and incarcerated. Cortés and his wife lost all their property, which was confiscated and auctioned off. Juan Bautista Elguézabal replaced Cortés as La Bahía Captain.

The investigation of Espadas and Cortés brought to light a debt of 1,055 pesos that Refugio owed La Bahía. Fr. Garavito energetically argued that the debt was incurred during the previous administration, and that Refugio was not going to pay it. Commandant Nava, needing every peso of income because of the financial trauma La Bahía had experienced, was just as adamant that the mission would pay its debt. ${ }^{122}$ Fr. Maríano Cardenas, President of the Texas Missions, went to La Bahía in September 1797, and examined the records of the Refugio debt. He focused on entries for the costs of corn, shipping, and rations for the prisoners who had performed construction work at Refugio, which totaled 727 pesos. Writing to Governor Muñoz, Fr. Cardenas argued that Refugio should not have to pay that portion of the debt because of the concession that Fr. Manuel de Silva had secured from the Commandant for the Crown to provide Refugio with supplies of corn and beef without cost. ${ }^{123}$ The Governor was not impressed with Cardenas' interpretation and asserted that Refugio should be liable for the full amount. ${ }^{124}$
The issue of Refugio's debt came to a boil the next year. Supported by a ruling from the Provincias Internas Assessor General, Galindo Navarro, the Commandant instructed Governor Elguézabal to seize Refugio's grain, livestock, and other assets if they did not pay up in eight days. ${ }^{125}$ Evidently reasons were found to avoid enforcing Commandant Nava's stern order. Three months later Nava received notice from San Antonio that neither the Refugio nor Rosario missions had paid what was due. Also included with this report was a petition from Fr. Garavito arguing on Refugio's behalf. Despite his previous reference to the decision by the Assessor General requiring Refugio to pay its full debt, Nava forwarded these latest documents to the Assessor General's office for review. ${ }^{126}$

The present research found no evidence to show that Refugio ever directly paid what it owed. However, it appears that the mission eventually satisfied its debt to La Bahía by providing cattle in the form of a "donation." After Spain's Declaration of War against England, the Crown had periodically urged its Texas residents to donate funds to support the war effort. Sometime in January 1799 , Fr. Garavito offered to donate two-hundred cows from Refugio's herd for the war effort. ${ }^{127}$ Later, in January, the mission actually delivered to Captain Moral of La Bahía, as a donation, one-hundred cattle in good condition. Moral sold the cattle to La Bahía residents for a total of 961 pesos 4 reals - close to the debt that Refugio was found to owe. In addition, Moral said he would use the money to pay the creditors of the recent bankruptcy of the presidio supply master. By February, Refugio's total donation had increased to 1,106 pesos, 4 reals. ${ }^{128}$ Since there is no evidence that Refugio paid its original debt, or that its property was ever confiscated, as Commandant Nava had ordered, it seems likely that the one-hundred cow donation described here represented some kind of agreement that would enable Refugio to keep its dignity by paying its overdue debt through a generous donation to Spain's war effort.

\footnotetext{
${ }^{120}$ Fr. Juan de Aguilar to Pedro de Nava, 1-26-1797, BA, Roll 27:Frame 36.

${ }^{121}$ Copy of Manuel Muñoz to Pedro de Nava, 5-6-1797, BA, Roll 27:Frame 210.

${ }^{122}$ Pedro de Nava to Juan Bautista Elguézabal, 8-4-1797, BA, Roll 27:Frames 600-602.

${ }^{123}$ Fr. Mariano de Cárdenas to Manuel Muñoz, 9-14-1797, BA, Roll 27:Frames 774-776.

${ }^{124}$ Copy of Manuel Muñoz to Mariano Cárdenas, 9-19-1797, Ibid:Frame 776.

${ }^{125}$ Pedro de Nava to Juan Bautista Elguézabal, 1-19-1798, BA, Roll 28:Frames 111 -1 12.

${ }^{126}$ Pedro de Nava to Juan Bautista Elguézabal, 4-17-1798, BA, Roll 28:Frames 212-213.

${ }^{127}$ Pedro de Nava to Governor of Texas, 2-29-1799, BA, Roll 28:Frames 729-730.

${ }^{128}$ José Miguel del Moral to Manuel Muñoz, 2-4-1799, BA, Roll 28:Frame 714.
} 


\section{Fr. Sáenz leaves Refugio}

Fr. Garavito wrote to Governor Muñoz in August 1797, and informed him that Fr. Sáenz' three-year term as Refugio's "supernumerary," or temporary missionary, would be up on September 5th. ${ }^{129}$ After review by the Commandant General and Father President of the Texas Missions, Fr. Sáenz was reassigned to Espíritu Santo Mission. ${ }^{130}$ However, it was easier to command than to gain compliance on the frontier. Fr. Sáenz was still at Refugio as of June 1799 when Commandant Nava wrote Governor Muñoz that the Zacatecas Colegio had sent Fr. Joséph Delgadillo to these Texas Missions; and that Supernumerary [Sáenz] at Refugio would have to leave. ${ }^{131}$

\section{War and Rumors of Invasions}

Spain's foreign policy in the late-eighteenth century had repercussions in Texas. Following an inconstant course during the consternation produced by the French Revolution, Spain first declared war on France in 1793, in retaliation for the execution of King Louis XVI. Then three years later it formed an alliance with France and declared war on Great Britain, which Minister Manuel de Godoy now saw as Spain's primary enemy. The consequences of these actions were disastrous. The English took possession of Trinidad, cutting Spain off from its American Colonies, opening their own markets to the United States, and creating a severe drain on the Spanish royal treasury.

In January 1797, Pedro de Nava sent Governor Muñoz a notice that Spain had declared war against England. Based upon a royal decree dated October 7, 1796, he ordered the governor to publicize this fact. ${ }^{132}$ Subsequently, periodic rumors of invasions or attacks upon Texas rolled across the region. In accord with this proclaimed threat, Fr. Garavito instructed Refugio Indians to watch the coasts for anything unusual or suspicious. In May of the next year, the Indians came upon three bottles of brandy and a piece of damasktype cloth, which they brought to Refugio Mission as possible evidence of enemy movement on the coast. Fr. Garavito forwarded the evidence to Captain Moral at Presidio La Bahía. Moral agreed that the presence of these things were a matter of concern, and he in turn sent one bottle of brandy to San Antonio, reporting the circumstances of where the items were found. Despite the pervasive war anxiety, Governor Muñoz was not impressed with the evidence, and said it could have come from any of the many shipwrecks that occur regularly in that area. ${ }^{133}$

That summer, Commandant Pedro de Nava warned the Governor that England was assembling 10,000 men in Halifax and was planning to invade through the Mississippi River. The Commandant believed that the intent of the assembly was to take over Louisiana, but that one of the plans could be to invade Texas. He ordered Governor Muñoz to take defensive precautions.

Governor Muñoz relayed Nava's instructions of precaution to Captain Juan Bautista Elguézabal at Presidio La Bahía. He instructed the captain to maintain his forces in top condition, to recruit and arm civilians, but to keep the purpose secret. His troops were to survey the coast two or three times a month in search of enemy ships, incorporating into this reconnaissance Karankawa, Coco, and the other Indians who lived along the coast. To explain the increased surveillance of the two bays, Muñoz suggested using as a pretext recent Karankawa attacks, attributed to Fresada Pinta, that had recently occurred at Refugio. ${ }^{134}$

In response to the rumors of war, Governor Munoz' redeployed some of his forces to Nacogdoches somewhat weakening Presidio La Bahía. On September 30, 1798, La Bahia's military roster totaled 93 troops on paper. Of these, 24 were actually stationed at Nacogdoches, where the concern regarding foreign pressure upon Texas was highest. Ten soldiers were stationed at Refugio, while others were either sick or stationed at other places, leaving a total of only 20 troops present at the Presidio. The position of captain was vacant. In comparison, before the arrival of the news of war in January 1797, the total roster was 117, with only 12 men being stationed at Nacogdoches. ${ }^{135}$

\footnotetext{
${ }^{129}$ Fr. Antonio Garavito to Manuel Muñoz, 8-23-1797, BA, Roll 27:Frames 739-740.

${ }^{130}$ Manuel Muñoz to Fr. Antonio Garavito, 9-1 1-1797, BA, Roll 27:Frame 772.

${ }^{131}$ Pedro de Nava to Manuel Muñoz, 6-15-1799, BA, Roll 28:Frames 876-878.

132 Pedro de Nava to Manuel Muñoz, 1-24-1797, BA, Roll 27:Frames 33.

${ }_{133}$ Miguel Moral to Manuel Muñoz, 5-31-1798, BA, Roll 28:Frames 308-309.

${ }^{134}$ Manuel Muñoz to Juan Bautista Elguézabal, 7-28-1797, BA, Roll 27:Frames 573-574; Pedro de Nava to Manuel Muñoz, 7-17-97, BA, Roll 27:Frames 526-529; Elguézabal to Muñoz, 7-20-1797, BA, Roll 22:Frames 539-540.

${ }^{135}$ José Miguel Moral to [Manuel Muñoz], 9-30-1798, BA, Roll 28:Frame 494; Juan Cortés to [Manuel Muñoz], 1-1-1787, BA, Roll 27:Frames 002-004.
} 
Refugio Mission depended upon Presidio La Bahía for its security. From the time of its move away from the coast, the mission had enjoyed the protection of the ten soldier detachment from La Bahía. As a result of the war with England, Commandant Nava at one point decided to reduce the Refugio guard to five soldiers, but he relented after an appeal by Governor Muñoz. Evidently Muñoz thought Refugio's security should be maintained in view of the disturbances that could result from the 97 Karankawa and Coco wanderers that were recently imposed on the mission. ${ }^{136}$ During the war with England, the Refugio Guard also probably represented a valuable advance detachment to guard against coastal intrusions.

\section{Presents for Peace: Comanche Relations in Texas}

When Refugio Mission was transferred from the coast it was removed from one threat but placed in the way of another, for the new site was located on the routes that Comanche Indians traveled. While Spain worried about English invasions into Texas, invaders were already there in the form of Comanche groups and Americans spearheaded by Philip Nolan.

By the 1770s, Comanche groups had surpassed the Apaches as the main threat to Spanish settlements in Texas and their attacks increased over the following decade (Chipman 1992:198). At the same time, a continuing enmity had long been in place between the two Indian groups that originated earlier in the century in New Mexico, where Comanches had driven the Apaches from the northern mountains and drove them south of the Red River. In 1785, Texas Governor Domingo Cabello offered a peace treaty to Comanches that was accepted by three of their chieftains. It called for hostilities to stop and provided for the ransom of captives. Comanches could continue to make war on Apaches and pursue them into Coahuila, and each year presents would be given to tribal leaders. The Cabello treaty provided a basis for peace that with few exceptions held through the remainder of the Spanish period (John 1996). In effect the Cabello treaty became a policy of peace by presents. For example, a summary of presents for Indians of the north and their cost for four months: January to April, 1797 was 6,189 pesos. $^{137}$ During 1796, among other items, large amounts of dried beef were provided. ${ }^{138}$ In addition to basic goods such as knives, cloth, pots and kettles, even muskets, powder and shot, water and firewood were sometimes brought.

Some Comanches who came to San Antonio to take advantage of the offering of presents roamed through the province ostensibly searching to do battle with Apaches, but taking advantage of opportunities to steal horses at La Bahía and Refugio. Governor Muñoz saw the Comanche's armed search for Apaches as a pretext. ${ }^{139}$ Presidio Captain Juan Bautista Elguézabal chaffed at the contradiction inherent in the presents for peace policy. When he was trying to find a place and resources for the ninety-seven Cocos and Karankawas who went to Refugio Mission, Cortés begrudged funds spent on Comanches, saying that:

"what they need is the attention of the lance." 140

Comanche groups must have investigated Refugio Mission soon after it was moved from the coast. Refugio's minister, Fr. Garavito learned the lesson that the presence of Lipan Apaches drew attacks from Comanches. When Lipan groups continued to stop at Refugio, Fr. Garavito wrote to Governor Muñoz begging him to order the captain at Presidio La Bahía to do whatever necessary to prevent Lipans from coming to Refugio because the presence of Lipan brings the Comanches. Fr. Garavito said that on August 21st, Comanches had stolen two droves of tame horses and several other horses. He said:

If this is not stopped we will soon be finished. ${ }^{141}$

\footnotetext{
${ }_{136}$ Pedro de Nava to Manuel Muñoz, 8-8-1797, BA, Roll 27:Frame 617.

${ }_{137}$ Manuel Muñoz to Pedro de Nava, 4-30-1797, BA, Roll 27:Frames 31 1-315.

${ }^{138}$ Antonio Rodriguez de Vaca to [Manuel Muñoz], 8-31-1796, BA, Roll 26:Frames 796-803.

${ }^{139}$ Copy of [Manuel Muñoz] to Juan Bautista Elguézabal, 7-27-1797, BA, Roll 27:Frames 577-578.

${ }^{140}$ Juan Bautista Elguézabal to Manuel Muñoz, 4-22-1797, BA, Roll 27:Frames 272-276.

${ }^{141}$ Ibid., BA, Roll 27:Frames 739-740.
} 
The record shows a pattern of Comanches taking livestock from the missions south of San Antonio then returning some of the animals to the San Antonio authorities. This behavior evidently represented a show of good faith to comply with the 1785 treaty, whereby Comanche leaders had agreed to turn in all livestock found or captured bearing Spanish brands. Several Comanches took six of Refugio's horses to San Antonio. Although the horses were no doubt marked with the mission's brand, the Indians calmly handed the animals over to the military authorities. Governor Muñoz sent the horses to La Bahía to be returned to Refugio. ${ }^{142}$ Another example of this activity occurred in 1794, when Comanches handed over to Governor Muñoz 42 horses [bestias], taken from the Missions of Espíritu Santo and Rosario. $^{143}$

\section{Daily Life at Mission Refugio}

The available documentary sources provide very little information about what life was like on a daily basis at Mission Refugio. Generally, the commonplace is not usually the subject of comment, especially when paper was in short supply, and where presidio captains and governors were little interested in the mundane activities with which they were already familiar. Consequently, some of the present questions that are the most interesting are very difficult to answer.

Daily life at Refugio was liable to be interrupted by the sudden departure of some or all of the Indians to their traditional habitats along the coast. Such departures could be with the permission of the missionary or without it. Several situations could stimulate this temporary abandonment. At Refugio, the proximity of the coast, about twelve miles from present Mission Bay, facilitated these sojourns. Fear of Comanches could also motivate a prompt retreat from the mission. Lack of food at the mission was another important factor. When the first corn crop failed at Refugio's new site in 1795, the Indians went to the coast. ${ }^{144}$ An emotional longing for the places of their origin, seems to have motivated the Karankawa to periodically return to their coastal haunts. At the first mission site, only two Indians stayed overnight during May 1794; the rest went to camp along Chocolate Creek. Small groups would occasionally return to the mission then go back to the coast. ${ }^{145}$

The available documentary records reveal little direct evidence about routine mission activities although some activities can be inferred from the listings of various buildings and artifacts in the 1796 mission inventory.

\section{Food Preparation}

It appears that two of the jacals were used as kitchens at the mission, ${ }^{146}$ and it can be gathered from the 1793 requests of Fr. Maríano Garza for corn and beef that an estimate can be made of the amount needed to supply the mission on a per person basis. He reported to the governor that the 138 persons (of all ages and sexes) at Refugio needed four fanegas of corn [6.3 bushels] and eight cows per week. Governor Muñoz did not question Garza's request and promised that the corn and cattle would be sent. ${ }^{147}$ Based on Fr. Garza's request, the ratio of corn per person per week equates to 1.6 liters of corn per person per week. ${ }^{148}$ Applying this to Mission Refugio at the time when its population numbered 76, in June 1797, the weekly need for corn at that point would have been approximately three and one-half bushels [2.2 fanegas] per week.

The current research found no evidence of corn production at Refugio during the administration of Fr. Garavito. By the agreement Fr. Manuel de Silva struck with Commandant Nava, in 1794, the Crown was to have provided corn for Refugio's resident Indians for the one-year grace period, which evidently began in January 1796, with the establishment of the mission at its new site. ${ }^{149}$ Yet Refugio's dependence on Crown corn continued. In June 1797, Fr. Garavito reported to Governor Muñoz that he had:

"received the remaining twenty-five fanegas of corn of the fifty provided by your great charity." 150

\footnotetext{
142 Juan Bautista Elguézabal to Manuel Muñoz, 9-2-1797, BA, Roll 27:Frame 756.

${ }^{143}$ Juan Cortés to Manuel Muñoz, 12-19-1794, BA, Roll 25:Frame 82.

${ }^{144}$ Fr. Manuel de Silva to Muñoz, 9-27-1795, BA, Roll 25:Frames 895-897.

145 Testimony of Juan José Estrada, 10-31-1794, BA, Roll 24:Frame 1028 verso.

${ }_{146}$ Refugio Inventory, 9-8-1796, Zacatecas Microfilm, Roll 3:Frame 3874.

${ }^{147}$ Fr. Mariano de Garza to Manuel Muñoz, 2-24-1793, BA, Roll 23:Frames 235-37.

148 The calculations are based on the definitions that one bushel equals 35.23 liters, and that one fanega equal 1.58 bushels (Barnes et al. 1981:69).

149 Pedro de Nava to Manuel Muñoz, 2-26-1796, BA, Roll 25:Frames 349-350.

${ }^{150}$ Fanegas (25 of $50=40$ of 80 bushels). Fr. Antonio Jesús de Garavito to Manuel Muñoz, 6-4-1797, BA, Roll 27:Frame 386.
} 
Refugio's 1796 inventory shows that it possessed various equipment for processing this grain into tortillas, atole, and pozole. There were pots of various sizes in which corn could be cooked. Five metates were listed, two comals or griddles - one made of iron and the other of copper - and there was a tin sieve for making atole.

The tools listed for grinding and cooking the corn appear to be adequate only to prepare and cook tortillas for the minister, workmen, and servants, rather than for a population of seventy-six. Five metates would seem to be a minimum for that chore. Even if enough masa could be produced, only two comals were listed, one iron and the other copper. Two comals would be adequate to cook tortillas for one family, but not for a mission population of seventy-six persons. A missionary's guideline indicates that each family obtained a weekly share of corn which the women grind and prepare for meals in their houses (Leutenegger 1976:20). This is probably what was routine at Refugio, rather than the regular preparation of communal meals.

That atole was made at Refugio is demonstrated by the tin atole sieve that was listed on the mission inventory. Atole was a drink prepared from cooked, ground corn that was diluted with water and strained to remove the solid parts. It was then boiled down to provide body. Pozole was prepared at the mission, as evidenced by the pozole dipper that is listed on the inventory. ${ }^{151}$ The key ingredient in pozole is corn reduced to a form of hominy. Tortillas and atole were both derived from corn reduced to masa. ${ }^{152}$

Lime was an important ingredient used in preparing dry corn for grinding on metates. The lime produced a mild lye solution in which the hard corn grain was soaked or cooked. The base action of the lime dissolved the plastic-like husk from the grain. At the end of the process the corn resembled hominy and was called nixtamal, its name in the Nahuatl language. The two kilns built at the mission were for firing bricks and for preparing lime, which could be used both for building purposes and for the preparation of corn.
In addition to corn, beef represented the other primary food for Mission Refugio. These two staples formed the basis of the Indians' diet at the mission from the time of its founding. There were 2,500 head of cattle recorded at the mission ranch in 1796, in addition to more than 150 work animals. ${ }^{153}$ A general procedure for providing fresh beef for the mission can be inferred from the testimony of a soldier who was stationed at the first mission site. Juan José Estrada indicated that several beeves [sic] were kept at the mission to be butchered for immediate consumption; additional stock was brought to the mission from the ranch as needed. ${ }^{154}$ The corral, noted in the inventory, probably served to hold the cattle until they were slaughtered.

In addition to fresh meat, large amounts of beef were preserved by drying it in the sun:

“...to put the meat out to dry in the summer, to prevent spoilage, and recover the fat from the animals, cook it down, and keep it in its place." (Leutenegger 1976:19)

For example, in July 1797, soon after the arrival of the unwelcome Cocos and Karankawa, Fr. Garavito sent three men, probably soldiers, to kill some stock and dry the meat. The men killed one steer and began butchering the animal and flaying the meat, which evidently would have been removed to the mission for drying. ${ }^{155}$ The raw fat from animals such as this one would have been the source of the 75 pounds of "unprocessed fat" 156 that was stored at the mission at the time of the 1796 inventory. In addition to other spices, the mission cooks utilized thyme and aluceña for seasoning. ${ }^{157}$

\section{Supplies from Zacatecas}

Records show that the Franciscan Missionary College at Zacatecas sent three shipments of supplies to Refugio during the administration of Fr. Garavito. Two shipments were sent on August 30, 1797, just days before transfer of the mission from Manuel de Silva to Fr. Garavito. The third shipment

\footnotetext{
${ }^{151}$ Mission Refugio 1796 Inventory manuscript, Zacatecas Microfilm, Roll 1, p. 14.

152 From Nahuatl, atolli (Santamaría 1974:94).

${ }^{153}$ Refugio Inventory, 9-8-1796, Zacatecas Microfilm, Roll 3:Frame 3874.

154 Testimony of Juan José Estrada, 10-25-1794, BA, Roll 24:Frame 1027-1028.

155 Juan Bautista Elguézabal to Manuel Muñoz, 7-20-1797, BA, Roll 27:Frame 539-540.

156 Sebo en greña.

${ }^{157}$ Copy of Refugio Inventory, 9-8-1796, p. 27, typed by Fr. Rafael Cervantes, O.F.M., Zacatecas Microfilm, Roll 2:Frame 1365. Aluceña is described as a cruciferous plant with flowers on spikes, bearing an edible fruit. (Real Academia Espanola, Diccionario Manual e Ilustrado de la Lengua Espanola, $2^{\text {nd }}$ edition, Espasa-Calpe, Madrid, 1950, p. 73 [hence cited as Real Academia Espanola 1950]).
} 
was dated September 3, 1797. The three shipments contained a total of 295 pounds of fine chocolate. In addition, two loads of tobacco and a small amount of snuff was sent. ${ }^{158}$ The combined peso value of the chocolate and tobacco far exceeded the total value of all other goods sent. The missionaries probably used these commodities as rewards for various good behaviors. Artifacts for utilizing tobacco and chocolate appear on the 1796 inventory in the form of ten chocolate beaters, or molinillos, ${ }^{159}$ and a tobacco mill.

The three shipments also included boxes of mats made of grass or burlap and supplies of cloth called pañodepolvo (literally, "dust cloth"). The chocolate, tobacco, mats and cloth were probably intended to be shared with the mission Indians; the remainder of the items were destined for the missionaries for their use for personal religious purposes, e.g., religious habits, shoes, sandals, wax, incense, and paper. ${ }^{160}$ Goods sent to Refugio are listed in Appendix A-2.

\section{Indian Pottery}

Mission Refugio's 1796 inventory and the record of manufactured goods brought to the mission from Zacatecas indicate that ceramic plates, cups, and saucers were in limited supply, probably being provided for the use of the missionaries and their guests. Since the Indian residents would have needed vessels to cook with and eat from, Native potters no doubt produced such items. This was certainly the case at nearby Mission Espíritu Santo, where Fr. Maríano Cardenas commented on the quality of pottery being made there in 1783:
"The [Indian] women... are the ones most dedicated to work and are almost always busy making pots, bowls, and other things made of clay. They have considerable skill for this and they trade these things with the white women of this Presidio of Bahía."161

\section{Smallpox}

Smallpox spread through La Bahía and Refugio toward the end of 1798. In November, Captain José Miguel del Moral reported to the Governor that an epidemic of the viruelas had infested the community and that they had no recourse against it. Captain Moral sent two soldiers, with thirty pesos, to San Antonio to buy brown sugar cones [piloncillos], asking the Governor's assistance in obtaining the sugar. The piloncillos were to be an ingredient in a recipe for a remedy for the illness. ${ }^{162}$ By January 1799, the women and children of eleven Lipan Apaches, at La Bahía, were infected with severe cases of smallpox [viruelas].

Around the time of the outbreak of smallpox, Indians from Mission Refugio had gone to the coast to perform surveillance of Aransas and Matagorda Bays on behalf of Captain José Miguel del Moral of Presidio La Bahía. They returned to Refugio around the first of January and reported they had not seen anything unusual. ${ }^{163}$ It would seem that they returned just in time to be exposed to the smallpox epidemic. The available record does not reflect how badly Refugio was affected by the epidemic. Evidence of only one case was found.

\footnotetext{
${ }^{158}$ Book of the Records of What Was Sent to the Missions of the Province of Texas, beginning with the year 1792, Old Spanish Missions Historical Research Library, Zapópan Microfilm, Roll 1 (frame numbers not visible), pp. $106-107$.

${ }^{159}$ Molinillo, utensil-beater on one end and long stem on the other, spun between the hands to mix chocolate or other liquid.

${ }^{160}$ Book of the Records of What Was Sent to the Missions of the Province of Texas, beginning with the year 1792, Old Spanish Missions Historical Research Library, Zapópan Microfilm, Roll 1, p. 106-108.

${ }^{161}$ Fr. José Mariano Cárdenas, Parecer del Ministro sobre el estado actual de todas las missions de Texas, 1783, Our Lady of the Lake University, Old Spanish Missions Historical Research Library, Zacatecas Microfilm, Roll 3 (microfilm frame numbers illegible except for no. 3499). Quote is from p. 11 of the manuscript.

162 José Miguel del Moral to Manuel Muñoz, 11 -27-1798, BA, Roll 28:Frame 558.

163 José Miguel del Moral to Manuel Muñoz, 1-18-1799, BA, Roll 28:Frame 691.
} 
Fr. Garavito obviously was touched by what he experienced at Mission Refugio:

[Illegible note of seven lines written at top of page, evidently by the recipient.]

At this mission of Nuestra Señora Most Serene Madre del Refugio, on the second of February year of our Lord of $1799, I$ was leaving the church to take some pieces of wax to make a cerillo when I encountered a young Indian who spoke to me saying "padre." He was called Juan de Dios and was a gentile and had no other name.

Two days earlier, he began showing symptoms of smallpox [viruelas]. Since I had been to his camp before and had seen nothing in particular, I thought he was perpetrating one of those impertinence's of which those poor people are not lacking. So I decided to go and make the cerillo and then see about what he wanted. But some force intervened that compelled me to first see to the Indian. I had hardly returned when it appeared that he had died. I thought I was seeing a dead man, though whether he was or not only God knew.

In the midst of the turmoil that possessed my heart,

I lifted him up and within myself I asked my Virgin Mother how could it be possible that you would permit such misfortunes to occur? I heard the mercy

of our most sweet Mother, and at the moment he began to show signs of life I baptized him. Then he died, but there was left on his face the most beatific look that demonstrated his eternal happiness which conducts us to her infinite mercy. Amen

[signed] Fr. Anto. de Jsus. Garavito ${ }^{164}$

\section{The Conclusion of Fr. Garavito's Administration}

The remainder of Fr. Garavito's ministry was marked by Comanche threats and the refusal of the Karankawa to remain at their mission. One incident in 1800 illustrates the formidable threat that Comanches presented to a sparsely populated, poorly defended Refugio Mission. In October, 180 Comanches arrived at Refugio, bringing mules that they reportedly had stolen from residents south of the Nueces. While at the mission they stole twenty-one horses and killed three cows. The Comanche band then rode to La Bahía where they plotted to take horses from the presidio. ${ }^{165}$ No other damages were reported at Refugio, no lives were lost, or persons taken captive. Nevertheless it would be hard to overstate the cumulative dispiriting effects resulting from the unremitting threat of hostile actions to the mission, which could be as devastating to the minister's and Indian's morale as actual attacks.

The killing of Chepillo at Refugio in 1801 was a major event during the last year of Fr. Garavito's tenure. In April 1801, the governor received a report, dated April 22, concerning the attempted arrest of Chepillo because he had plotted treason and had wounded the sergeant and a soldier at Refugio. Repeatedly called upon to surrender, in both Spanish and his own language, the Karankawa leader refused. The Presidio Commander gave the order to fire and Chepillo fell dead of a musket shot. About a month after Chepillo's death, an attempt was made to remove his body. The Governor of Rosario, Manuel Sartuche, reported that Andres was trying to persuade Patricio (both presumably Rosario Indians) to remove Chepillo's remains from Refugio - evidently for the purpose of reburying them at Rosario. ${ }^{166}$ It appeared that the problem of Rosario's Indians harassing those of Refugio would not be resolved until later.

\footnotetext{
${ }^{164}$ Fr. Antonio de Jesús Garavito Report, 2-2-1799, Zapópan Microfilm, Roll 1 (frames unnumbered).

165 Juan Xavier de Uranga to Govenor Juan Bautista de Elguézabal, 10-27-1800, BA, Roll 29:Frames 762-763.

166 Pedro de Nava to Governor, 6-9-1801, BA, Roll 30:Frames 99-100.
} 


\section{Chapter 3: Mission History-Section D The Ministry of Fr. José Manuel Gaitán \\ 1802-1817}

\section{Background}

It was the disastrous aftermath of Philip Nolan's last expedition to Texas that brought about the transfer of Fr. Manuel Gaitán from Nacogdoches to Mission Refugio. During his years at Nacogdoches, Fr. José Manuel Gaitán had developed a close association with Philip Nolan. Nolan's expeditions from Louisiana into Texas, between 1791 and 1801, focused the Spanish authorities attention upon the adventurer's activities and purposes. Commandant Pedro de Nava at first supported Nolan, allowing only his expeditions to legally enter Texas for the purpose of rounding up mustangs and conducting limited trade. Subsequently, doubts and fears grew that Nolan was conspiring with agents of the United States, and Nava issued a warrant for his arrest. In 1801, Nolan fought a battle with Spanish soldiers in East Texas, where he was killed and his men captured.

Documents captured from Nolan and witness testimony implicated Fr. Manuel Gaitán. Evidence showed that Nolan had sent Gaitán letters and a double-barreled musket [fusil de dos tiras] from Natchez in November 1799. ${ }^{167}$ It was clear that Nolan considered Fr. Gaitán to be a confidant as he wrote to an associate, James Cook, advising that if he had any problems leaving Nacogdoches, to consult the priest [Gaitán] and to take his advice in everything (Wilson and Jackson 1987:38-39).

As a result of these revelations, Fr. Manuel Gaitán was brought to San Antonio for questioning. He took lodging at
San José Mission where Governor Elguézabal presented him with two interrogatories on August 6,1801. The questions focused on the double-barreled musket and various letters Philip Nolan had sent him. Fr. Gaitán replied that he had become acquainted with Nolan during the time of his free entries into Texas by means of various dealings and familiar association, just as others had known him. Fr. Gaitán acknowledged that he had occasionally corresponded with Nolan during his absences and affirmed that he had received, and had been entrusted with, the double-barreled musket that Nolan sent. ${ }^{168}$ The way Fr. Gaitán's worded his response to the Governor's question about the musket, suggested that Nolan did not intend the priest to be the ultimate recipient of the musket; it is possible that the weapon was actually intended for Commandant Pedro de Nava, who had requested an example of the newly innovated firearm from Nolan in $1797 . .^{169}$

Despite the incriminating evidence of his involvement with Nolan, Manuel Gaitán's punishment amounted to nothing more than being banished from the Louisiana border. He was transferred to Refugio Mission, where he would have little opportunity to mix in the affairs of adventurers from Louisiana. Here, he replaced Fr. Antonio de Jesús Garavito, while Fr. Franciso Puelles replaced Gaitán at the Nacogdoches parish.

Fr. José Manuel Gaitán was a native of Ojocaliente, a town located about thirty miles southeast of Zacatecas. ${ }^{170} \mathrm{He}$ was present at the Zacatecas College in 1793, where he and three

\footnotetext{
167 Juan Bautista Elguézabal to Fr. José Manuel Gaitán, 8-6-1801, BA, Roll 29:Frames 903-904.

${ }^{168}$ Juan Bautista Elguézabal to Fr. José Manuel Gaitán, 8-6-1801, BA, Roll 29:Frames 903-904 and BA, Roll 29:Frames 904905 (two separate documents).

${ }^{169}$ Copy of Pedro de Nava to Philip Nolan, 10-31-1797, BA, Roll 27:Frames 997-998. Although Nava referred to the weapon as escopeta, a shotgun, it is clear that, in the context of the troops of the Provincias Internas, fucil, or musket, is what is meant.

${ }^{170}$ Father Oberste compiled a list of Refugio missionaries from Zacatecas Missionary College records, p. 385. Although this list shows Gaitán at age 60 in 1797, he was probably a younger man at that time. To be of that age in 1797 would have meant he would have been eighty-three at the end of his tenure at Refugio in 1820. That he was an active frontier missionary at this advanced age seems unlikely. Moreover, he continued be active as a Franciscan for many years after.
} 
other Franciscans passed their examinations for the Order of Deacons [Orden de Diáconos] in December. ${ }^{171}$ In January of the next year, Fr. Gaitán passed the examination qualifying him to hear confessions. ${ }^{172}$ Evidently, his first assignment was to serve as the parish priest at Nacogdoches, where he worked until 1801.

No clear-cut reason was found for replacing Fr. Antonio Garavito, although it would not be hard to imagine that the rigors and isolation of frontier life were primary factors. Due to the transfer, Fr. Garavito eventually lost his longtime assistant, Fr. José María Sáenz who was reassigned around 1799. Fr. Garavito managed the mission alone for at least two years, grappling with military commanders, governors and Indian problems, from within and without the mission, which probably provided a continuous, debilitating stress upon his person. As for the transfer of the mission which was conducted on July 7, 1802, it seems that Fr. Garavito and Fr. Gaitán effected the transfer between themselves. If the La Bahía presidio captain was present, his presence was not noted, nor are any Karankawa recorded as being present at the mission.

\section{Refugio Mission in 1802}

When Fr. Garavito transferred Refugio to Fr. Gaitán a through inventory was made of the mission facilities and property extant at that time. The inventory provides enough information to reconstruct the buildings of the mission and their contents in great detail. The most notable improvement at Refugio during the administration of Fr. Garavito was that a church had been completed, although it was built of oak wood not stone. ${ }^{173}$ The building's measurements were recorded as being 83.3 by 19.4 feet [ $30 \times 7$ varas]. These dimensions were virtually the same as those of the church's foundations, recorded in 1796, where it was also clear that the foundations and corners were being built from stone. The wooden church was evidently built upon the same foundations noted in the 1796 inventory. ${ }^{174}$ According to the inventory, the church "was built with oak, like all the houses of the area, because of the lack of stone." ${ }^{175}$ A certain evasiveness is implied in this last statement, for stone was available. When Captain Juan Cortés inspected this mission site in 1794 , he approved of it, in part:

$$
\begin{gathered}
\text { "because of readily available supplies of stone, } \\
\text { [and] caliche for lime." } 176
\end{gathered}
$$

More than likely, it was the lack of skilled stoneworkers at Refugio which made the goal of a stone church unattainable.

Under the heading "Convento" or Convent, the inventory describes three rooms with beamed roofs [techadas de vigería] constructed with stone and mortar. The first room, which served as a hospice or guesthouse [hospicio], measured 41.6 feet wide and 13.9 feet high [15 x 5 x 5 varas]. It was furnished with a table, and chest of drawers with lock and key, two chairs made of wood and straw, a candlestick, and a brazier. The second room served as a bedroom. It measured 13. 9 feet square and 13.9 feet high [5 x $5 \times 5$ varas], and contained four mattresses and other items pertaining to a bedroom. The third room was 13.9 feet wide with the same height as the previous rooms. This was the Father ministers' residence. Inside there was an alcove, or small room which contained mathematical instruments and the mission library. A sacristy is not mentioned in this inventory.

${ }_{171}$ Zacatecas Missionary College, Minutes of the Discretorio, 12-30-1793, Our Lady of the Lake University, Old Spanish Missions Historical Research Library, Zacatecas Microfilm, Roll 1 [frame numbers stuck on "500". This is page 148r on the manuscript.]. Diacono is a secondary ecclesiastical minister one grade below priest (Real Academia Espanola 1950:574).

172 Zacatecas Missionary College, Minutes of the Discretorio, 1-18-1794, ibid., page 148v. Fr. Gaitán is referred to in these two documents by Zacatecan officials as Fr. José Mariano Gaitán. While it is possible there were two Fr. Gaitáns, one José Manuel Gaitán and José Mariano Gaitán, it does not seem likely. Gaitán signed his letters "Fr. José Man.l Gaitán.”

${ }_{173}$ Refugio Mission Inventory, 7-7-1802, Zapópan Microfilm, Roll 1 (frames unnumbered). This is p. 1 of the manuscript.

${ }_{174}$ In 1796, the church foundations were given as $30 \times 8.5$ varas; in 1802, $30 \times 7$ varas.

${ }_{175}$ Refugio Mission Inventory, 7-7-1802, manuscript, p. 1.

176 Juan Cortés to Manuel Muñoz, 12-31-1794, BA, Roll 25:Frames 112-113. 
Around the mission plaza stood seven chamaqueros and ten jacals. ${ }^{177}$ These structures served specific utility purposes: office, storeroom, soldiers' quarters, granary, carpentry shop, and kitchen. Four of the chamaqueros had doors with locks, the remaining three did not. Evidently none of the jacals were secured by doors and locks. A semi-double stockade made of oak circled the plaza. ${ }^{178}$ On the west side there was a well-made, large gate with two wings ${ }^{179}$ secured by a bolt. Behind the stockade was a pen [corral] with a door on the north that was for chickens. Five bells, including a small one, were hung in the middle of the patio. Three of the bells could be rung; two were missing parts from which the clappers were hung. In front of the main stockade gate was a carved cross that was forty-two feet tall [15 varas]. Inside, on the north side of the plaza were two wooden ladders. One of the ladders was extra large and was used to repair the roofs of the stone buildings. In addition, this ladder would be used to ascend to the rooftops in order to watch for the movement of enemies. Two carts sat next to the pen on the north; their accessories were kept in the granary.

While a mission ranch was not specifically mentioned, the mission was credited with 2,571 cattle, horses, and mules. ${ }^{180}$ Nine yokes of tame oxen were counted. The horse herd for the troops assigned to the mission totaled fifteen horses, two mules and a mare-all tame. In addition to its own property, Mission Refugio also maintained a remnant of Fr. Manuel Silva's original dream of a chain of missions from Refugio to the Trinity River. A separate list contained specific missionary equipment that he left on deposit at Refugio to be used for the mission on the Trinity River, when authorization was granted for its founding.

As the conversion of Indians was the central purpose of a mission, it is puzzling to note that the 1802 inventory makes no reference as to how many were present at the mission and how many were at the coast, as the previous inventory did. Only one Indian chief, Pedro José, was mentioned, and only because the inventory noted that a bucket that was listed was actually located at the chieftain's camp. Pedro José was one of chiefs of the 97 Karankawa who came to La Bahía, in 1797, seeking admission to Rosario Mission. After being rejected, they came to Refugio, where they were also unwelcome. Eventually their desire to remain at Refugio evidently won them acceptance as "Sons of the Mission."

Refugio's wooden church may have been in poor condition; or perhaps the fact of its wooden construction may have caused it to be considered less than adequate for a permanent church. Whatever the reason, soon after his arrival, Fr. Gaitán began making plans to build a new, stone church building. Fr. Vallejo, President of the Texas Missions, noted this initiative in his 1804 report on the Texas Missions. He added that two missionaries were assigned to Refugio (Habig 1978:232-236). ${ }^{181}$ This second friar was probably Fr. José María Delgadillo, who was sent to Texas around 1800 as a supernumerary to replace Fr. José María Sáenz, who was ordered to leave in $1799 .{ }^{182}$

\footnotetext{
${ }^{177}$ Chamaquero, or chamacuero, does not appear in any Spanish reference material. Both the jacal and chamacuero were somewhat insubstantial structures used for living or utility purposes. Chamacueros were probably built with posts that were secured with leather (cuero), similar to that described in a diary in 1855: "...were built of tree trunks—-some of which were irregular and crooked-set in the ground and bound together at the top with transverse pieces of lumber, outside and inside, tied with thongs of rawhide, the interstices between the tree trunks filled with lime mortar..." (Smith 1955:36-37).

178 "Dicha plasa quede rodeada de una estacada semidoble de madera de encino."

179 "Buena puerta de dos manos grande."

180 "Ganado mayor de todas classes."

${ }^{181}$ Fr. Bernadino Vallejo to Ilustrissimo Señor, 12-31-1804, BA, Roll 32:Frames 848-849.

182 Pedro de Nava to Manuel Muñoz, 6-15-1799, BA, Roll 28:Frames 876-878.
} 


\section{Mission Conflict}

\section{Refugio and Rosario}

Prior to its move inland in 1795, no record found indicated an interest by Rosario Indians in Mission Refugio. However, once it was established on Mission River, almost immediately it became an object of the Rosario Indian's attention. Some Rosario Indians wrought damaging effects, such as Chepillo who in 1796, had terrorized the mission, threatening the life of Fr. Silva, and wantonly killed Refugio cattle. Refugio ministers felt Rosario Indians had an adverse effect on their mission. Fr. Silva had expressed his aggravation with Rosario Indians when he wrote:

\section{"The truth is, Sir Governor, that neither the Apaches, nor Comanches, nor Vidais, et. cet, are the worst enemies - the worst enemies are the Indians at Rosario who probably do more harm here than all the others..."183}

Despite the obvious damage done to Refugio by members of its neighboring mission, the reality was that Refugio was slowly undermining the foundation upon which Rosario existed. The final chapter in the Rosario saga began in 1804, while Fr. José María Huerta served as its minister. On October 20th and 21st, heavy rains fell around the La Bahía settlement, probably as a result of a hurricane. At Rosario, one of the houses was left in ruins, a piece of the church near the entrance fell, and several parts of the mission wall also fell. Fr. Huerta duly reported the damage to Governor Elguézabal, warning that when the Indians see the mission in ruins, together with scarcity of food and clothing, they would abandon Rosario. ${ }^{184}$

When Fr. Bernardino Vallejo, President of the Texas Missions wrote his 1804 evaluative report of the missions under his auspices, he noted that the church of Espíritu Santo was in a deteriorated state, that Rosario's condition was worse, and that Refugio's church was being rebuilt. The remaining churches were in good condition and were provided with the necessary ornaments and accessories.
But, despite the difficulties, Christian doctrine was being taught in all the churches most of the time. Livestock was reduced at Espíritu Santo and at Rosario. Agriculture consisted of little more than planting corn at favorable times and not at other times of the year when the risk was greater. ${ }^{185}$ All mission planting was much reduced. At the end of the year, Vallejo reported that Refugio had 44 Indians; in addition, 14 civilians now lived in the mission area. ${ }^{186}$

At Refugio, Fr. Manuel Gaitán was able to secure the services of a carpenter, a stone mason, and a blacksmith and continue the ambitious project to rebuild the mission's church and convento at a time when Espíritu Santo and Rosario were declining. Construction was violently interrupted in May 1805, when Refugio suffered its worst Comanche raid, during which three lives were lost in an attack effected by only two Indians. Previously, Comanches had taken only horses and mules from Refugio. Although Comanche groups had arrived at Refugio on horseback in large, intimidating numbers of up to two-hundred, they usually left having done little damage, other than to the livestock herds. On May 12, 1805, Fr. Gaitán sent a desperate message to La Bahía that two Comanches had been seen in the mission pasture. From there they attacked the mission Indians, killing a man, a woman, and wounding four others. The attackers also abducted an ten-month-old Indian girl. Fr. Gaitán pleaded to the presidio captain to take prompt action to recover her. ${ }^{187}$ Since the mission was attacked by only two individuals, evidently few soldiers were deployed at the mission for defense, and one of these was killed in the attack.

Presidio Captain Francisco Viana arrived at Refugio from La Bahía at eleven o'clock the next morning to investigate the incident. He found that one of the injured, a woman, was at the point of death. He noted the one of those killed was a soldier from Chihuahua; the attackers had cut off a hand of each of the dead and had scalped them. Various items of the victim's clothing were taken, including a jacket made of cloth from Queretaro, a shirt, blanket, serape, bridle, and a tanned buffalo skin. ${ }^{188}$ Three months later troops were increased at Refugio to prevent future occurrences of such attacks. $^{189}$

${ }^{183}$ Fr. Julio Silva to Manuel Muñoz, 4-15-1796, BA, Roll 26:Frame 495.

${ }^{184}$ Fr. Joséph María Huerta to Juan Bautista Elguézabal, 10-26-1804, BA, Roll 32:Frame 616.

185 The manuscript says riesgo (risk), not riego (irrigation), as interpreted by Oberste.

${ }^{186}$ Fr. Bernadino Vallejo to Ilustrissimo Señor, 12-31-1804, BA, Roll 32:Frames 848-849.

${ }^{187}$ Copy of Fr. José Manuel Gaitán to Francisco Viana, 7-12-1805, BA, Roll 33:Frame 527.

${ }^{188}$ Copy of Fr. José Manuel Gaitán to Francisco Viana, 7-12-1805, BA, Roll 33:Frames 527-528.

${ }^{189}$ Francisco Viana to Antonio Cordero, 10-4-1805, BA, Roll 33:Frame 697. 


\section{The Unification of Rosario and Refugio}

About the same time that Mission Rosario came to need substantial repairs, a severe limit was imposed on the amount of debt that each mission could incur. Fr. Francisco Puelles, Guardian of the Franciscan Missionary College at Zacatecas, and ex-Texas missionary, stated the primary reason for the cutbacks was that some of the missions were overextending their credit; and that he had received many complaints from secular creditors who could not secure payment for what was owed to them. Consequently, the Guardian issued an instruction, "requiring divine obedience," that no Texas mission could acquire a debt of more than 100 pesos, without a license from the Father President, "which should be very sparingly " granted." 190 The restrictive instruction was circulated by mail to each Texas mission and was returned to Zacatecas with the signatures and declarations of obedience from each of the mission's ministers.

The debt restriction imposed on the missions by Zacatecas was only one of several problems that threatened Mission Rosario. In 1805, Spain's resources on the northern frontier were stretched to the limit to mobilize its defenses against its new, aggressive neighbor in Louisiana. Few funds were available to repair a mission of doubtful value. Nevertheless, Commandant Salcedo requested an estimate to repair the mission's most urgent needs. Captain Viana at La Bahía provided his superiors with a detailed plan to repair the church, perimeter wall, and priest's living quarters, with a total budget 1,605 pesos. ${ }^{191}$ After consulting with officials of the royal treasury about the repair proposal, Commandant Salcedo demanded that two-hundred cows from Rosario's herds be sold and the value subtracted from the total, along with the amount of alms the mission collected. ${ }^{192}$

\section{Rosario's Fate Decided}

During the time that Rosario's fate was being considered in Chihuahua, an important opinion about the mission was registered by the La Bahía Presidio Captain. In November
1806, La Bahía Captain Francisco Viana sent a confidential letter to Governor Cordero that contained a frank, concise assessment of the missions of Espíritu Santo, Rosario, and Refugio, which the Governor had requested. Viana had the highest praise for Espíritu Santo and Refugio missions. At Refugio, using no more resources than Fr. Gaitán's yearly stipend, and the sale of some cattle and seed, the minister had obtained the services of a French carpenter, a blacksmith, and a stone mason. He reported that they were rebuilding the church and residence and that the mission was wellsupplied with neophytes. ${ }^{193}$

Viana found little good to say about Rosario, however. He noted that the mission had more income than the other missions, in addition to the stipend of 450 pesos for the missionary, the mission had an [annual] income of 200 pesos in interest from a fund given to it. This mission enjoyed the right to catch and sell wild livestock without paying royal tax. Also, the minister enjoyed the assistance of a lay brother. Viana pointed out that the mission did a poor job in its primary function of converting Indians. Except for a few families, Indians came to the mission four times a year to obtain blankets, and if food was scarce they left. Further, he bluntly declared that the minister and Indians abhorred each other, expressing in detail his opinions on the basic incompetence of Fr. José María Huerta as a missionary. Finally, Captain Viana gave a crushing argument against rebuilding - the mission had already been rebuilt once, eleven years ago, at a cost to the royal treasury of 2,000 pesos. ${ }^{194}$ Funding for repairs never gained final approval.

A year later, Fr. Bernardino Vallejo relayed reports to the Governor from the ministers of La Bahía that the buildings of Rosario were in complete ruin. The Indians were already...

$$
\begin{gathered}
\text { "going to Refugio, to be with their relatives } \\
\text { for they spoke the same language, and to be closer } \\
\text { to their beloved coast they love so much." }
\end{gathered}
$$

Fr. Vallejo suggested to the Governor that the missions of Rosario and Refugio be merged on an interim basis while he consulted his Missionary College in Zacatecas. ${ }^{195}$

\footnotetext{
${ }^{190}$ Fr. Francisco Puelles to Fr. Bernardino Vallejo, 7-4-1 805, Zacatecas Microfilm, Roll 4:Frames 5025-5028.

${ }^{191}$ Francisco Viana to [Antonio Cordero], 11-15-1805, BA, Roll 33:Frames 742-743.

${ }^{192}$ Nemesio Salcedo to Interim Governor [Cordero], 10-8-1805, BA, Roll 33:Frame 72 1; [La Bahía Captain] to Antonio Cordero, 1 1-15-1805, BA, Roll 33:Frames 742-743; draft of Antonio Cordero to Nemesio Cordero, 11-19-1 805, BA, Roll 33:Frame 942; Nemesio Salcedo to Antonio Cordero, 9-8-1806, BA, Roll 35:Frames 14-15.

${ }^{193}$ Francisco Viana to Antonio Cordero, 11 -16-1805, BA, Roll 33:Frames 742-743.

194 Ibid.

${ }^{195}$ Copy of Fr. Bernardino Vallejo to Antonio Cordero, 12-13-1806, BA, Roll 35:Frame 304.
} 
It is clear that unification of Rosario and Refugio missions was already proceeding on a defacto basis. In Chihuahua, Commandant Salcedo had already decided to merge the two missions. On December 15, 1806, two days after Fr. Vallejo sent his report, Commandant Nemesio Salcedo signed the order that officially unified Rosario and Refugio. ${ }^{196}$

Unification of the two missions essentially meant that Rosario would be abandoned after Fr. Huerta and the remaining Indians moved to Refugio. The Rosario mission ornaments were brought to Refugio and stored. Fr. Huerta and Fr. Gaitán made plans to enlarge the residence at Refugio to accommodate both ministers, which they estimated would cost 500 pesos. Commandant Salcedo authorized Governor Cordero to use the proceeds of the sale of two-hundred of Rosario cows to cover the cost. ${ }^{197}$ It seems likely that the enlargement project was never realized, for in the following July -Fr. José María Huerta was transferred to Nacogdoches to serve as the priest of the parish church there. ${ }^{198}$

The shift in population at Mission Refugio after the closing of Rosario is demonstrated by census records conducted in $1804^{199}$ and $1808^{200}$ (Tables 3-3 and 3-4).

At the end of 1804, the total number of Rosario Indians had been about 44, plus 14 Spanish and mixed-race persons for a total of 58. When Fr. Gaitán compiled the 1808 census of Refugio's Indian population, he reported a total Indian population of 96. Thus, the Indian population had increased at Mission Refugio between 1804 and 1808, reflecting an influx after the merger.

\section{Revolution, 1811-1815}

\section{Refugio and the Mexican Revolution}

By the spring of 1810, Fr. Gaitán had acquired an assistant missionary, Fr. Juan Sepulveda, ${ }^{201}$ who appears to have divided his time between Refugio and Espíritu Santo Mission. Fr. Gaitán was fortunate to have the support and assistance of a fellow Franciscan during the traumatic events that rocked Texas beginning in 1811. On September 16, 1810, Father Miguel Hidalgo initiated the revolutionary movement for Mexican independence. San Antonio soon became a hotbed of insurrection. Between January 1811 and August 1813, through coups, counter-coups, invasions, sieges, and war the control of Texas rebounded back and forth between royalists and revolutionaries. Then at the Battle of Medina, on August 18, 1813, General Joaquín de Arredondo's army crushed the rebel forces. His decisive victory at Medina secured Texas for Spain for another eight years. To escape the wrath and retribution of General Arredondo, large numbers of Texas Tejanos and their families fled to live in exile in Louisiana until it was safe to return. In the meantime, Texas was burdened with an occupying army.

At Mission Refugio, Fr. Manuel Gaitán firmly supported the royalist cause. He continued with the surveillance of the coast by Indians from Refugio and provided beef to the royalist army. After the Battle of Medina, the acting governor of Texas sent a note to the President of the Texas Missions, Bernardino Vallejo, informing him that Fr. Gaitán and

Table 3-3. Mission Census Summaries From 1804

\begin{tabular}{|l|c|c|}
\hline Category & Refugio & Rosario \\
\hline Indians & 61 & 44 \\
Spanish/Castes & 8 & 14 \\
Total & 69 & 58 \\
\hline
\end{tabular}

\footnotetext{
${ }^{196}$ Nemesio Salcedo to Antonio Cordero, 3-24-1807, BA, Roll 35:Frame 868.

${ }_{197}$ Nemesio Salcedo to Antonio Cordero, 3-24-1807, BA, Roll 35:Frame 868.

${ }^{198}$ Fr. Bernardino Vallejo to Manuel Antonio Cordero, 7-18-1808, BA, Roll 38:Frame 407 .

${ }^{199}$ Fr. Bernardino Vallejo's Texas Mission Census Summary, 8-31-1804, BA, Roll 32:Frame 848.

${ }^{200}$ Fr. José Manuel Gaitán, Refugio Census, [12-31]-1808, Zacatecas Microfilm, Roll 4:Frame 5001. Fr. Gaitán did not date the census other than to say "Estado q.e manifiesta el numero de almas, q.e componen la mision de Ntra. Sra. del Refugio de las naciones Cujan, y Carancahuas, hecho en este año de 1808." While his wording about the date is ambiguous, the census was probably made at the end of the year, as was normally done.

${ }^{201}$ Refugio Mission Interments, 1810, p. 8, no. 17, Catholic Archives of Texas.
} 
Table 3-4. Karankawa and Cujan at Mission Refugio, 1808

\begin{tabular}{|l|c|}
\hline Category & Number \\
\hline Married Men & 26 \\
\hline Married Women & 26 \\
\hline Boys & 12 \\
\hline Girls & 15 \\
\hline Unmarried Men & 15 \\
\hline Unmarried Women & 2 \\
\hline Total & 96 \\
\hline
\end{tabular}

Fr. José María Sepulveda, minister at Mission Espíritu Santo, had been commended to General Arredondo for their patriotism and zeal during the insurrection. Fr. Gaitán was singled out "for maintaining the loyalty of the Karankawa of Refugio Mission."202

The attitude of the Karankawa was a matter of continuing concern to the royal authorities in San Antonio. In the spring of 1814 , Fr. Gaitán replied to an inquiry from Benito de Armiñán, Colonel and Governor, assuring him that so far the Refugio Karankawa had shown true love and loyalty for the Sovereign. The missionary affirmed that the Indians had not stopped making periodic sojourns to the coast and reporting notable events. ${ }^{203}$

\section{Famine}

Spanish arms destroyed the revolution in Texas but it was a fateful victory. Soon after the triumph along the Medina, Spanish Royalists in Texas found themselves in a position where obtaining supplies from Saltillo and Monterrey was difficult to accomplish. Angry Tejano exiles in Louisiana, conspiring with Americans, threatened invasion by land and by sea. Assaults by Comanche and other Native American groups increased and the inability to work the fields for fear of Indian attack inhibited agricultural production. Texas had historically been an exporter of livestock, but soon after the revolution, the demands of the occupying army decimated the bountiful Texas cattle herds. Early in 1814, royal authorities confiscated 4,577 head of cattle from insurgents who had gone into exile. Residents began abandoning their ranches, seeking safety in San Antonio from the threat of increased Indian raids and possible invasions (Jackson 1986:544-545).

Mission Refugio helped supply beef to the royalist army. In 1814, the Military Governor Benito Armiñán wrote to Fr. Gaitán thanking him for having previously provided beef for the troops and asked for more. He noted that the cattle that were once so numerous were now almost extinct. ${ }^{204}$ Fr. Gaitán replied that he "was sending all that can be taken from the small number of manageable stock remaining at the mission." It was not a donation or confiscation; Gaitán said that an equitable price for the animals would be set by Texas Missions President Fr. Bernardino Vallejo. ${ }^{205}$ Comanche depredations also took their toll on Texas cattle. San Antonio rancher Manuel Barerra informed the Governor that Comanches had almost extinguished all the cattle in the province. He said he found the countryside covered with "the relics of their general destruction." 206 Shortages had developed in San Antonio for troops and civilians early in 1814, when authorities prohibited removing supplies from the town. ${ }^{207}$ By 1816 the situation was critical, even though most of Arredondo's army had returned to Monterrey. Governor Cordero informed his superiors that San Antonio was out of meat and that La Bahía was in the same plight. In desperation, the Governor ordered the City Council to organize civilian hunters of game to help bridge the shortage of meat. ${ }^{208}$

\footnotetext{
${ }^{202}$ Copy of Governor of Texas to Fr. Bernardino Vallejo, 9-23-1813, BA, Roll 53:Frame 218.

${ }^{203}$ Fr. José Manuel Gaitán to Benito de Armiñán, 4-24-1814, BA, Roll 53:Frames 797-798.

${ }^{204}$ Copy of [Benito Armiñán] to Fr. José Manuel Gaitán, 8-6-1814, BA, Roll 54:Frame 106.

${ }^{205}$ Fr. Manuel Gaitán to Benito Armiñán, 8-13-1814, BA, Roll 54:Frame 119.

${ }^{206}$ Copy of [Governor] to Joaquín Arredondo, 8-15-1814, BA, Roll 54:Frame 122.

${ }^{207}$ Joaquín de Arredondo to Governor Armiñán, 2-2-1814, BA, Roll 53:Frame 512.

${ }^{208}$ Copy of [Governor ] to Joaquín Arredondo, 4-24-1816, BA, Roll 56: Frame 559.
} 


\section{Baptismal and Burial Records}

The surviving records of baptisms and interments at Mission Refugio began during Fr. Manuel Gaitán's ministry, and cover the period from 1807 to 1828 . No records of the mission's baptism and burial records are known to exist prior to the year 1807. No marriage records were found. The existing entries are recorded in a volume entitled Libro II de Bautismos hechos en la Mision de N.tra Sr.a del Refugio de la Bahía desde el ano de 1807. Together with this volume is a second volume entitled, Libro II de Enterramientos. ${ }^{209}$ These records show that 149 baptisms and 88 burials were performed at Refugio during Fr. Gaitán's ministry. Gaitán conducted all the baptismal and burial ceremonies, except for three baptisms and twelve burials that were done by Fr. Huerta and Fr. Sepulveda. These records are provided in Appendices B-1 and B- 2 of this report. It must have been with particular satisfaction that Fr. Gaitán baptized an adult Karankawa woman of twenty-five years, on June 9, 1810, giving her the name, María Feliciana. She was the daughter of Fresada Pinta, the chieftain, then deceased, whose band attacked Refugio in 1794 at its first site, forcing its inland move. ${ }^{210}$

\section{Indian Relations}

\section{Comanche Uprising}

A Comanche uprising which began in 1814 , led to widespread attacks across Spanish Texas. At Refugio, burial records for 1814 show a surge of interments attributed to attacks by "los Indios barbaros". ${ }^{211}$ Prior to the Revolutionary events of 1811 to 1813 , Comanche groups had been somewhat manageable, in part due to the system of presents that originated with the peace treaty of 1785 . However, because of the disruptive effects of the revolution, Spanish authorities were no longer able to provide these presents to Comanche groups. Deprived of the accustomed benefits, Comanches and their allies were put in an acrimonious state of mind, which they expressed by attacks on persons, livestock herds, and other property.

Comanche attacks were also encouraged from Louisiana. In 1819, Juan de Padilla noted that Comanches received aid, arms, and incitement from Americans and exiled Tejanos living in Louisiana. He wrote that:

"foreigners and some various rebel Spaniards, who escaped from the victorious army of our sovereign at Medina, introduced munitions and other things to exchange for animals making a well worn road through the unsettled region towards Natchitoches. There were

not lacking some Spaniards, still worse, who led them and incited them to kill and burn whatever came in their way."

(Hatcher 1919)

${ }^{209}$ William H. Oberste Papers, Catholic Archives of Texas, Austin, Texas, [1774] 1838-1982, Box 5: William H. Oberste, Refugio Mission Baptismal Records, 1807-1828, English Translation (courtesy of Carlos E. Castañeda transcripts); William H. Oberste, Refugio Mission, Burial Records, 1807-1825, English translation. Photocopies of the manuscripts of the Refugio Mission Baptism and Burial records are also in the Catholic Archives of Texas, Spanish/Mexican Manuscripts Collection, Box 113, the Mexican Photoprint Company, 1929. Subsequent citations will refer to the English translations, unless otherwise specified, as Refugio Baptismal Translations or Refugio Interment Translations.

${ }^{210}$ Refugio Baptismal Translations, 1810, p. 18, no. 38, Catholic Archives of Texas, Austin.

${ }^{211}$ Refugio Mission Interments, 1814, pp. 22-25, Catholic Archives of Texas, Austin (this document was also translated by William H. Oberste in History of Refugio Mission, Refugio Timely Remarks, Refugio, Texas, p. 277). 
During the year 1814, Comanche groups committed fierce attacks in unprecedented numbers on the people of Refugio, as illustrated by the following three examples from the mission's burial records. On the first of August, Fr. Gaitán gave a ecclesiastical burial to the remains of Carmel de Laso, age twenty-four, with the note that:

$$
\begin{aligned}
& \text { "no martyrdom being more exceeding than [that] } \\
& \text { he received from the [Comanche] Indians..." }
\end{aligned}
$$

On the second of August, Vicente, about age 20, of the Karankawa Nation, was killed near the mission by [Comanches], and buried at Refugio. ${ }^{213}$ The bones of fifteen or sixteen people, adults and children whom Comanches killed at the Rancho del Diezmero, on the Nueces River, were buried at Refugio on October 30, 1814. ${ }^{214}$

Raids on mission livestock were also a problem. On August 5, 1802, Comanches raided Refugio and took mission horses and horses that belonged to the military detachment there. Troops from La Bahía caught up with the Comanche band on the 14th. The Indians scattered, leaving behind nineteen horses that belonged to Refugio and various other individuals. A few days later, following a raid on the horse herd of a civilian ranch, troops followed the trail of the raiders and met with a Comanche Chief named Malla. Chief Malla assured the troop commander that the Comanche people esteemed the Spanish, but that a few "bad heads" had gone out searching for Lipans. He said the warriors had to eat on the road, and so they sometimes robbed horses in the jurisdiction of La Bahía. Chief Malla's statement implied a Comanche preference for horse meat for food, a proclivity observed by the captive narrative of Sara Ann Horn. ${ }^{215}$ Malla said he would go to the other chiefs and try to recover and return the stolen horses. He asked for gifts of a shirt and six bundles of tobacco to divide among the other chiefs. ${ }^{216}$ In September, someone killed four cows from the mission herd.
A party of troops came from La Bahía to investigate and found a band of Lipans nearby. Canoso, a Lipan Chief, denied killing the cows and blamed Karankawa who lived nearby at the coast. La Bahía Troop leader José Antonio Cadena forced the band to move toward the Colorado River away from Refugio. ${ }^{217}$

Early the next year, Comanches again raided Refugio, taking four or five horses. ${ }^{218}$ La Bahía troops pursued the trail and on February 22 arrived at a camp of nineteen men and six women at the mouth of the Sauz. Their chief came out to meet the troops. Alferez $z^{219}$ José Antonio Cadena noted that the Indian chief governed with a passport from the Texas Governor. The troops found the horses that had been stolen from Refugio in plain sight, about which the Indians showed not the slightest concern. In fact, they returned the mission's horses with great pleasure and gusto. A horse belonging to a soldier of La Bahía was also found, but the Indians would not return it. They said -that horse had served a woman for a long time, and it had been received in trade from a Tahuacano Indian for a mule. They provided another horse to replace the one the soldier lost. At the end of the talks, Alferez Cadena instructed the Indians to leave immediately. They asked him to let them wait until afternoon so their horses could graze, and so it was agreed. ${ }^{220}$ Evidently some thought that Alferez Cadena displayed a acquiescent attitude toward the insistent Indians, but when Commandant General Nemesio Salcedo reviewed this incident, he found no fault in Alferez Cadena's actions. ${ }^{221}$

While attacks from Comanche groups were severe, available records show that Refugio also suffered from Lipan Apache raids after the revolution. Beginning in 1814, Lipan Apaches made efforts to secure treaties of peace. Negotiations took place with Lipan leaders, Cojo and Pacheco, who promised to turn in horses marked with Spanish brands, and to not disturb persons, property, or the public tranquillity except to fight Comanches. General Arredondo ordered that Chief

\footnotetext{
${ }^{212}$ Refugio Mission Interments, 1814, p. 24, no. 49, Catholic Archives of Austin.

${ }^{213}$ Refugio Mission Interments, 1814, p. 24, no. 50, Catholic Archives of Austin.

${ }^{214}$ Refugio Mission Interments, 1814, p. 27, no. 57, Catholic Archives of Austin.

215 Sara Ann Horn, a captive of a Comanche group during 1834-37, reported the Comanche's fondness for horse meat, witnessing the killing of horses for their meat (Rister 1989:132-136).

${ }^{216}$ Copy of Francisco Xavier de Uranga to Pedro de Nava, 9-29-1802, BA, Roll 30:Frames 824-826.

217 José Antonio Cadena to [J. Bautista Elguézabal], 9-23-1802, BA, Roll 30:Frames 819-820.

${ }_{218}$ Bestias is the term used to signify horses or mules. To be concise, bestias will be translated as horses, unless mules are specified.

${ }^{219}$ Alferez: Military rank immediately below Second Lieutenant.

${ }^{220}$ Copy of José Antonio Cadena to [J. Bautista Elguézabal], 2-23-1803, BA, Roll 31:Frames 73-74.

${ }^{221}$ Nemesio Salcedo to Governor of Texas, 3-28-1803, BA, Roll 31:Frame 155.
} 
Cojo be sent to Monclova to negotiate with Brigadier General Antonio Cordero:

"who is most experienced in what should be done." 222

Despite the Lipan entreaties, in 1816, serious hostilities followed. In April, a large number of Lipans attacked the Refugio mission, taking its few horses. The mission guard and some residents pursued the attackers, killing two of them and recapturing a horse. As a result, Governor Maríano Varela warned that the Lipan Nation had declared war, and advised all mission officials to treat them like enemies. ${ }^{223}$ Belatedly, Lipan Chief Morongo came to La Bahía the next year to ratify the peace that was previously made and to deny involvement in a recent attack on Mission Refugio. ${ }^{224}$

Lipan attacks on Refugio Indians continued into 1817. In February, twelve Lipans attacked three Mission Karankawa and their families as they were returning from the Aransas River [Arroyo de Aranzazu], wounding one with a shot and abducting a ten-year-old girl. Rallying, the Karankawa killed one attacker. When the others retreated, the Karankawa could not get the mission guard to pursue as they were all on foot. In his report, the Governor noted that he was pleased with these events:

"for with this clash between the two nations the Karankawa were outraged, and it will be a long time before the Lipans can establish peace. In the duration, the Karankawa will not permit the Lipan camping places on the coast." 225

Missionary correspondence shows that some Refugio Indians used peyote cactus, presumably for ritual purposes. Neither religious nor military authorities seemed to be aware or concerned about peyote's hallucinatory effects. Fr. Gaitán was clearly aware that the mission's Karankawa used peyote. A military patrol had discovered a number of the Refugio Karankawa between Laredo and Revilla. ${ }^{226}$ Informed of this, the Governor asked Fr. Gaitán what authority the Indians had to be there and instructed him to return them to the mission and keep them there. Fr. Gaitán responded that his Karankawa had returned from the coast except for:

\section{"fourteen men and their families who continued on to the sierra to provide themselves with peyote for the year."}

He said the Indians had gone to the coast for fear of smallpox, which was rumored to be at the mission, adding that they had not seen any ships there. ${ }^{227}$ Obviously, Spanish authorities were unconcerned about the Indians' use of a strange little cactus. The governor duly reported these events to General Arredondo in Monterrey. He included Fr. Gaitán's explanation, assuring the general that:

\section{"the Indians only went to gather peyote, an herb they use, and that there was nothing malicious in their having gone so far afield."228}

It is difficult to imagine any Karankawa straying hundreds of miles from their beloved coasts, but that is what was reported on at least two occasions. In July 1804, residents of Nacogdoches declared that three Karankawa stole fifteen horses and wounded two residents of the villa, who in the company of others took a wandering route to that place. ${ }^{229}$ One year later, also near Nacogdoches, three individuals said it was Coco Indians who had wounded one of them and stolen two horses. ${ }^{230}$

\section{Summary of Karankawa's Coastal Surveillance to 1817}

Karankawa Indians at Refugio provided the provincial government with valuable intelligence throughout the period that Fr. Manuel Gaitán served as Mission Refugio's minister. From the early days of Refugio, Spanish authorities quickly realized that these coastal natives had the potential to watch the critical length of coast which stretched from the Colorado to Padre Island, and to promptly report back to the mission. From Refugio, news brought from the coast could rapidly be relayed to La Bahía and from there to San Antonio.

${ }^{222}$ Governor to Joaquín de Arredondo, 7-11-1814, BA, Roll 54:Frame 24; Joaquín de Arredondo to Benito rmiñán, 7-21-1814, BA, Roll 54:Frames 32-33.

${ }^{223}$ Mariano Varela to mission alcaldes, 5-31-1816, BA, Roll 56:Frame 655.

${ }^{224}$ [Mariano Varela] to Joaquín de Arredondo, 7-8-1817, BA, Roll 56:Frame 784.

225 Copy of [Governor] to Joaquín de Arredondo, 2-27-1817, BA, Roll 58:Frame 44.

${ }^{226}$ Present town of Old Guerrero, now submerged beneath Falcon Lake.

${ }^{227}$ Copy of [Governor] to F. Manuel Gaitán, copy of Fr. Manuel Gaitán to Mariano Varela, 4-20-1816, BA, Roll 56:Frames 545-546.

${ }^{228}$ Copy of [Governor] to Señor Commandante General, 4-24-1816, BA, Roll 56:Frame 569.

${ }^{229}$ Nemesio Salcedo to Texas Governor, 8-13-1804, BA, Roll 32:Frame 600.

${ }^{230}$ Dionisio Valle to J. Bautista Elguézabal, 5-6-1805, BA, Roll 33:Frame 173. 
The first utilization of Indian lookouts on the coast was evidently initiated by Commandant Pedro de Nava in 1797. Concerned about a possible English invasion of Texas, Nava ordered that the Mission Indians of Espíritu Santo and Refugio watch the coasts and report all ships seen. ${ }^{231}$ Small gifts were provided to encourage their surveillance activities. During their first years as coastal sentinels, the Karankawa were on guard against a perceived threat from England. After 1803, American intrusions were feared, and after 1813, both Americans and exiled revolutionaries probed for weaknesses along the Spanish Texas coast.

For many years, the Refugio Karankawa were the only consistent lookouts. However, after the royalist recapture of Texas in 1813, Spanish concern about coastal security increased. Hundreds of Tejano insurgents were in exile in Louisiana and were presumed to be conspiring with North Americans to threaten Spanish interests in Texas. Various insurgents, Americans adventurers, revolutionaries, and pirates made Galveston Island a rendezvous point. As early as 1815 , in response, military authorities bolstered their Karankawa lookouts with a military detachment consisting of two to four soldiers from La Bahía Presidio. ${ }^{232}$ The site was located below the confluence of the San Antonio and Guadalupe Rivers (called laguna de los mosquitos), on the west side of the river near the Rancho de Mosquitos, the site of the mission's ranch at its first location. That the Mosquitos site was located on the west side of the Guadalupe is established by a 1822 letter from Francisco Garcia. Traveling from Refugio, he and Fr. Miguel Muro arrived at the Mosquitos Detachment on their way to the Colorado River. Garcia said they were unable to cross the Guadalupe because of high waters brought about by heavy rains. ${ }^{233}$ No record was found of Karankawa attacks against the
Mosquitos Detachment, despite its proximity to Karankawa territory. Perhaps the Karankawa valued the soldiers as a line of defense against Comanche incursions, for they continued to provide reports of ship sightings along the coast at least until $1823 .^{234}$

\section{Conclusion}

\section{Mission Supply}

Only a few hints were found regarding the agriculture of the mission during the tenure of Fr. José Manuel Gaitán. In 1805, the mission raised enough corn to have a surplus to sell. ${ }^{235}$ No mention of a Refugio Mission ranch was found in the documentary sources after 1796. In this and subsequent inventories, cattle are described as being in the mission pasture [agostadero] instead of at a ranch. ${ }^{236}$ The sale of cattle provided the mission with cash income, at least until 1814. After that time, as previous sources have shown, cattle were in short supply in Texas pastures. By 1817, the mission herd had been built up to a total of 3,500 head of livestock, large and small including, cattle, sheep, and goats. ${ }^{237}$

Records show that the mission received at least three shipments of goods from the Zacatecas Missionary College while Fr. Manuel Gaitán was its minister. The contents were similar to what was shipped in prior years. The shipments contained substantial amounts of chocolate and tobacco. Habits, capes and sandals were included for the minister, along with various items such as wax, reams of paper, and grass mats. ${ }^{238}$

\footnotetext{
${ }^{231}$ Manuel Muñoz to Juan Bautista Elguézabal, 7-28-1797, BA, Roll 27:Frame 573-574.

${ }^{232}$ La Bahía Presidio Monthly Report, 7-1-1815, BA, Roll 54:Frame 620.

${ }^{233}$ Francisco Garcia to to Comandant General, 11 -23-1822, BA, Roll 73:Frame 596-599.

${ }^{234}$ Cayetano de la Garza to the Governor, 8-7-1823, BA, Roll 75:Frame 405.

${ }^{235}$ Francisco Viana to Antonio Cordero, 1 1-16-805, BA, Roll 33:Frame 742-744.

${ }^{236}$ For examples, see Fr. Antonio Garavito to Miguel del Moral, 10-27-1798, BA, Roll 28:Frame 518; copy of Fr. José Manuel Gaitán to Captain Viana, 7-12-1805, BA, Roll 33:Frame 527. Also see Refugio Mission 1802 Inventory, under the section Campo, when it refers to the "el agostadero principal" - the principal pasture, where the cattle are kept.

${ }^{237}$ Refugio Mission 1820 Census, Section Campo, 8-8-1820, Zapópan Microfilm, Roll 1:Frame $425 \mathrm{ff}$.

${ }^{238}$ Shipments dated, Zacatecas, 7-19-1803; 9-16-1805; and 8-27-1810, Zapópan Microfilm, Roll 1.
} 


\section{Fr. Juan Manuel Gaitán Achievements}

In September 1817, Fr. José Manuel Gaitán left Refugio and was replaced by Fr. Antonio Díaz de León (Oberste 1942:282). During his fifteen-year ministry Fr. Gaitán won the admiration and appreciation of military leaders. He had completed the new stone church and while it was a smaller structure than the previous one, Gaitán's church lasted for the remainder of the Colonial period and through the mission's secularization in 1830 . The church stood with only minor damage against the forces of at least one powerful hurricane. During Fr. Gaitán's ministry, one hundred fortynine baptisms were performed at Refugio and eighty-eight burials. After Fr. Gaitán returned to Zacatecas, Franciscan authorities elected him to the position of Commissar and Prefect of Missions - the same post that Fr. Manuel de Silva held in 1790 when, following the example of the Venerable Antonio Margil, he envisioned establishing missions on the Texas coast for the Karankawa. 


\title{
Chapter 3: Mission History- Section E \\ The Ministry of Fr. Antonio Díaz de León
}

\author{
$1817-1820$
}

\section{State of the Texas Missions 1815-1820}

The missions of Texas declined in the years after the Revolution. The violence caused many Indians to flee, and the missions of Espíritu Santo and Nacogdoches were abandoned-Nacogdoches permanently. Missionaries who died, or left Texas, were not replaced. Predations on livestock by Native Americans and Spanish residents diminished the economic base of the missions. At Mission Refugio, fear of Indian attacks hindered the care of livestock herds, and the loss of tame horses to raiders made even the most basic of ranching activities difficult.

In San Antonio, Fr. Bernardino Vallejo's time as president of the Texas Missions was ending. For sixteen years he had managed with an experienced, guiding hand. In 1815, Fr. Vallejo compiled a report on the Texas missions for the previous year. He found there were three missionaries for the six missions - two of whom were assigned to RefugioFr. José Manuel Gaitán and [Fr. José María Sepulveda]. Espíritu Santo was completely abandoned at the time, having neither Indians or a missionary (Leutenegger 1990:21).

In addition to the immediate problems the missions faced, mission Indians were slowly being encroached upon by local residents who desired the mission lands. It is noteworthy that, in 1816, the number of adult "Spaniards, and persons of other classes," living at the San Antonio Missions nearly equaled the Indian residents: 105 to 107, respectively. At Refugio, Vallejo's chart showed that a total of 190 adults were enumerated; 115 were Indians and 75 Spanish settlers, who were known as "the congregation of Refugio" to distinguish them from the military detachment and the regular mission members (Leutenegger 1990:21).
Fr. Bernardino Vallejo, left Texas in 1816. He was recalled to Zacatecas to serve as the guardian of the missionary college. Upon his departure, Vallejo was replaced by Fr. Manuel María Fellechea. There were only two friars to carry on the Texas mission until 1817 when Fr. Antonio Díaz de León arrived, probably for the purpose of replacing Fr. Manuel Gaitán at Mission Refugio.

\section{Refugio Mission Inventory, 1817}

Friars Manuel Gaitán and Antonio Díaz de León met at Mission Refugio on September 10, 1817, for the purpose of certifying the inventories of the mission property and formally transferring it to the authority of Fr. Díaz. The inventory is entitled "Inventory of the Church, Houses, and other Property of Refugio Mission." This document is of particular importance because it constitutes the last comprehensive record where measurements of the mission church are described. ${ }^{239}$ The document begins with a description of the church (built by Fr. Gaitán). ${ }^{240}$ It was built of stone and lime [fabricada de piedra y cal], and measured 58.3 by 22 feet ( 21 varas by 8.25 varas), ${ }^{241}$ with its corresponding height. The building was vaulted with wood, and had an over-roof of double planks secured with iron nails [es de boveda formada de madera con sobre techo doble de tableta afianzada con clavos de hierro].

Four doors led into the church, the principal of which had two wings made of savine ${ }^{242}$ planked with cedar. Fixed on a door to the side was a door lock. Two of the doors went into the sacristy. Likewise, four windows looked out across the mission grounds. The choir window, built with oak, was equipped with a lock. Wire screens were installed on the remaining windows [las mas tres con tableras y alambreras].

\footnotetext{
${ }^{239}$ Two subsequent inventories were made (1820 and in 1830), but neither describe the mission buildings with the detail of the 1817 inventory. In 1830, buildings were not mentioned; only tools and various other moveable property were listed.

${ }^{240}$ Ynventario de bienes, casas y demas Bienes perten.s esta Mision de Ntra Sra del Refugio, signed by José Man.l Gaitán and Antonio Díaz de León, 9-10-1817, Zapópan Microfilm, Roll 1 (no frame numbers).

241 “...veinte y una varas de larga y poco mas de ocho de ancho..." For "poco mas de ocho [varas] de ancho," eight and one forth varas is assumed as a working figure.

${ }^{242}$ A Eurasian juniper with small yellowish green berries, red cedar, and also a related shrubby juniper (Juniper horizontalis).
} 
All the doors and windows of the church were secured with lock and key, iron crossbars, and latches.

Inside the church were several altars exhibiting an extensive variety of religious statues, paintings, and other itemswhich are individually listed in the inventory. The choir was made with four mahogany beams. The floor was planked with boards of savine and cedar. Two chandeliers hung from the vault of the church along with three lamps, one made of silver and two of metal.

On the roof near the church's frontispiece stood a small, octagonal tower made of wood with its roof built like the church's. And to the front was a cross and a bronze weather vane. In front of the church lay a small cemetery, built of stone, with a wooden cross in the middle. An arch stood at the entrance and two smaller arches were positioned on the sides.

\section{Sacristy}

Attached to the church was the sacristy, a room that functioned both as a dressing room and a storage area. Here the missionaries prepared for Mass and other ceremonies. Religious ornaments and other items pertaining to the religious ceremonies were kept there. The Refugio sacristy was built with stone and lime and had a bricked floor. Unfortunately, its dimensions are illegible in this inventory. It may have been the 5-x-5-vara structure described as the sacristy in the 1796 inventory, or it could have been a new or modified construction built by Fr. Gaitán. This sacristy contained an intriguing gravity-fed water system utilizing an overhead water barrel that was embedded in the master wall of the church. It had a valve with copper tubing embedded in the wall that conducted the water to a silver lined sink with a drain that was also fixed to the wall. The stated purpose for the apparatus was for "purifying hands" prior to conducting religious services.

\section{The Convento}

The mission's third primary building was the convento, which served as the missionary's residence, office, and library; it was often referred to as the casa, or house. The convento was a two-story structure composed of four rooms. A small portico, built with stone and mortar in the form of an arch, led to the first room which measured 13.9 feet square [five varas by five varas]. The roof was made of planks [tablazon] built upon rafter beams which served as the floor for an upper room of the same size, to which a covered wooden stair was attached. The rear part of the roof was covered with grass because a lightning bolt had knocked down the planks. The two rooms had four doors and four windows. The room below connected to the living room [sala], made of stone and mortar, that measured 33.3 feet by 13.9 feet (12 varas x 5 varas). It had an upper floor, roofed with beams and nailed planks that formed the loft [tapanco] which served as the mission office. These stone structures were connected to seven wooden chamacueros whose doors opened to the outside so as to form a closed, interior patio.

\section{Seven Chamacueros}

The seven chamacueros provided storage space and functioned as workshops. Interestingly, the first one held six boxes that preserved the religious ornaments from Rosario Mission. Carpentry tools were also stored in this structure. The second chamacuero served as the granary and was extra large. The third and fourth were used as the kitchen, or cookhouse. The blacksmith shop was established in the fifth. The sixth chamacuero was a workshop, and the seventh was the residence for the corporal and his family.

A chicken pen [corral] made of oak was built to one side of the convento. On another side of the convento was a oak fenced area which contained fruit trees-peaches, figs, 
pomegranates, and grapevines. A corral for cattle was situated to one side of the orchard. The main plaza of the mission was formed by an arrangement of twenty-eight chamacueros and five jacals, the spaces between the structures being closed by thick stakes to provide security against enemies. ${ }^{243}$

The missionaries did not make an inventory of the equipment at the pasture ${ }^{244}$ because of the danger of attack by Comanches or other Native American groups. The corporal and other experienced persons estimated that the mission pasture held 3,500 head of livestock large and small; this total included cattle, horses, mules, oxen, sheep and goats. The inventory noted that, in 1814, Comanche Indians carried away the major part of the horse herd and took them to Aransas Island.

\section{Mission Finances}

The two missionaries verified the debts and credits for Refugio. Financially, the mission was firmly in the black.
Ten debt obligations were owed to Refugio that totaled 4,497 pesos, four reals, and two granos. Most of the credits were gained by selling cattle, at a rate of eight to ten pesos per head. A small amount of corn was also sold. With the accounting complete, Friars José Manuel Gaitán and José Antonio Díaz de León signed the inventory. Gaitán returned to Zacatecas to serve in the upper echelon of his Franciscan missionary college. Díaz de León would remain in Texas for the rest of his life, except for one brief trip to Monterrey.

As was the case in the 1802 Refugio inventory, this inventory makes no mention of the mission Indians. Two indications of the mission's population around the time of the inventory were found. It is clear that at least nine Indian men and their families, perhaps totaling thirty-six persons, had been living at Refugio, for during the previous July, a Comanche party attacked the mission and were repulsed by nine Karankawa warriors from the mission and four mission soldiers. ${ }^{245}$ Prior to leaving Refugio, Fr. Gaitán compiled a summary census of the mission that showed a total of 92 Karankawa and Cujan Indians ${ }^{246}$ (Table 3-5). He does not include the number of Spanish residents, which in Fr. Vallejo's 1814 report, totaled 75 adults.

Table 3-5. Summary Census compiled by Fr. Gaitán

State of the Mission N. S. del Refugio, showing the number of souls of the Cujan and Carancahuas nations who comprise it.

Done in the year Eighteen hundred seventeen.

\begin{tabular}{|l|l|l|l|l|l|}
\hline $\begin{array}{l}\text { Married } \\
\text { Men }\end{array}$ & $\begin{array}{l}\text { Married } \\
\text { Women }\end{array}$ & Boys & Girls & Single Men & Single Women \\
\hline 24 & 24 & 12 & 11 & 17 & 4 \\
\hline $\begin{array}{l}\text { Mission } \\
\text { Total }\end{array}$ & Gentiles & Marriages & Burials & $\begin{array}{l}\text { Baptism of } \\
\text { Infants }\end{array}$ & $\begin{array}{l}\text { Baptism of } \\
\text { Adults }\end{array}$ \\
\hline 92 & 22 & 1 & 3 & 2 & 1 \\
\hline \multicolumn{5}{|c|}{ [signed] Fr. José Man.l Gaitán } \\
\hline
\end{tabular}

243 "Forman la plaza de esta mission veinte y ocho chamacueros y cinco xacales cercados los intermedios de uno y otro con estacada de madera gruesa p.a resguardo de los enemigos."

244 The inventory does not use the word rancho. Livestock are listed under the heading of Campo, that the [ranching] equipment was kept at the agostadero, or pasture.

${ }^{245}$ La Bahía Presidio monthly report of 8-1-1820, BA, Roll 65:Frame 59.

${ }^{246}$ Fr. José Manuel Gaitán, 1817. Estado de la Mision de N. S. del Refugio q.e contiene el numero de almas de las Naciones Cujan y Carancahuas q.e la componen. Hecho en el año de mil ochientos y ciete. Zapópan Microfilm, Roll I (frame numbers not visible). 


\section{Mission Security}

In the spring of 1818, a band of about forty Comanche Indians attacked Mission Refugio. Although the captain of the presidio was able to track and attack the aggressors, Fr. Díaz became understandably concerned for the mission's security. In April, he composed a petition to Ignacio Pérez, Captain of La Bahía Presidio asking that Refugio's military guard be increased to 25 men. Pérez noted that Fr. Díaz justified his request on the basis that the Refugio vecinos, civilian settlers, were dismayed at the continuous Native American hostilities. Pérez wrote to Governor Martínez saying that he did not think any increase for Refugio was advisable because the number of men in his command was small. His military report for March showed nine soldiers were assigned to Refugio out of a total of 81 men on the La Bahía roster-only 62 of whom were available for immediate duty, the remainder being either temporarily assigned to San Antonio, Coahuila, Monterrey, or sick, or in jail. Governor Martínez responded ambiguously. He emphatically agreed with Pérez by stating that:

"circumstances did not permit the detachment of any troops," but, in the same breath, he authorized the captain to increase the Refugio guard to twelve or fourteen men. ${ }^{247}$

\section{Availability of Cattle at Refugio}

Despite the damage that the Revolution did to Texas livestock, Refugio Mission was known as a place where large numbers of cattle roamed. In spite of the great distance, both the missions and military of San Antonio and La Bahía would turn to Refugio when searching for available cattle. In July 1818, La Bahía Presidio authorities negotiated with Fr. Díaz de León for cattle. The Friar wanted to sell only 50 head; Governor Martínez replied that [Díaz] should sell 130 to 150 head, because the greatest number of cattle is there (emphasis added). ${ }^{248}$
Despite the relative abundance of cattle, Refugio did not have a working ranch in 1818 . The mission cattle were wild and there were no tame horses with which to work them. Consequently, the mission's cattle were not branded. Juan de Castañeda oversaw the gathering of cattle for La Bahía Presidio. Writing to Governor Martínez, he remarked that the wildness of the Refugio stock served to identify them like a brand. ${ }^{249}$ Fr. Francisco Frejes, who had recently assumed the post of President of the Texas Missions, also saw Refugio as a source of cattle. In August 1818, he sent for six servants to go to the mission to bring back a number of head. ${ }^{250}$ Fr. Frejes' servants succeeded in returning with 50 head. One of the accusations brought against the Father President, the next year, was that the cattle were brought for his personal use. ${ }^{251}$

No records of shipments or supplies from the Zacatecas missionary college to Refugio were found. However, the inventory showed ten bundles of tobacco in one of the convento rooms, which suggests that some goods continued to be supplied from Zacatecas.

\section{Hurricane Damage at Refugio and La Bahía}

One year into his term as Refugio's minister, Fr. Díaz was faced with the major problem of rebuilding the mission after it was struck by a devastating hurricane. From its beginning, Mission Refugio had always been a potential target for hurricanes due to its proximity to the coast. In the hurricane season of 1818, the mission's luck ran out. During the second week of September, a powerful storm came inland and for three days unleashed destructive winds and torrential rains that tested the strength of everything in its path.

Soon after the storm, the minister managed to communicate the damage done at Refugio to Captain Juan Manuel Zambrano at La Bahía. Zambrano reported to the governor that Mission Refugio was left without even a miserable hut for shelter. ${ }^{252}$ Captain Zambrano reported that the storm

\footnotetext{
${ }^{247}$ Ignacio Pérez to Antonio Martínez, 4-5-1818, BA, Roll 60:Frames 790-791; Ignacio Pérez, La Bahía Presidio Report, 4-11818, BA, Roll 60:Frame 799.

${ }^{248}$ Copy of [Antonio Martínez to Juan de Castañeda], 7-17-1818, BA, Roll 61:Frames 377-378.

${ }^{249}$ Juan de Castañeda to Antonio Martínez, 8-7-1818, BA, Roll 61:Frames 537-538.

${ }^{250}$ Fr. Francisco Frejes (Frexes ) to Antonio Martínez, 8-5-1818, BA, Roll 61:Frames 528.

${ }^{251}$ Diligencias Practicados sobre el manejo conque se condujo en la Mision de San José de el Padre Precident que estubo en ella Fray Fran.co Frexes, 8-2-1819 to 8-4-1819, BA, Roll 63:Frames 198-216.

${ }^{252}$ Evidently the church and other primary structures survived with little damage.
} 
occurred from the 12th through the 14th. The damage at La Bahía was severe; 61 houses were destroyed, and those left standing were nearly uninhabitable. Three sections of the presidio wall fell, the smallest being 55.6 feet in length [twenty varas]. Most of the quarters [cuartel] had collapsed. ${ }^{253}$ At La Bahía's lookout point at the Bay of Mosquitos, the soldiers barely escaped as the waters surged across the shoreline. ${ }^{254}$ La Bahía's monthly report for September presents a brief description of the storm that defines it as a hurricane. It noted that:

"on the 12th and 13th that there were heavy rains with a strong hurricane that caused the ruin of this presidio for having knocked down part of the wall, sixty-one houses and jacals of the troops and civilians." 255

While it is clear that the chamacueros and jacals at Refugio were completely demolished, evidently the stone structures of the church, sacristy, and convento escaped serious damage. When the Mission was inventoried again in 1820, only a small amount of damage to a portion of the sacristy roof caused by the 1818 hurricane was noted.

\section{Karankawa Lookouts on the Coast}

During the tenure of Fr. Díaz de León, Karankawa and Coco Indians continued to provide valuable information to Mission Refugio about ships they saw on the coast. The following is a good example of the rapid communication and response to intrusions that the Karankawa coastal intelligence provided. A soldier from Refugio rode hard through the night, arriving at La Bahía at reveille, on July 1, 1820, to report that Karankawa and Coco Indians had sighted an embarkation at the mouth of the Colorado River. The men came ashore at Matagorda Bay, spoke with the Indians, and gave them tobacco. Captain Ramírez found the report credible and dispatched 17 men in response. Eleven went to reinforce the military outpost at Mosquitos and to see if they could surprise the intruders; six men went as reserves to Mission Viejo—evidently at the first Refugio
Mission site. ${ }^{256}$ A courier galloped from La Bahía to San Antonio, and the Governor received Captain Ramírez' report the next day. That same day the Governor forwarded his response, approving of the action that Ramírez had taken, instructing him to constantly maintain an officer on the coast, and informing him that soldiers from the Bahía Company, who were at San Antonio, would soon be returning to his presidio to provide reinforcements. ${ }^{257}$ The Karankawa provided a communication link between Spanish authorities and the coast that was considered valuable and accurate. It was difficult and expensive to maintain even a small detachment of soldiers at the coast. In contrast, large numbers of Karankawa fanned out naturally along the bays and coasts, watchful for intruding ships. And, living in their native environment, they required no shipments of supplies from La Bahía.

\section{Fr. Díaz moves to La Bahía}

During the years 1818-1820 a rapid series of changes in missionaries and priests created the effect of a religious revolving door in Texas. At La Bahía, Fr. Miguel Muro had replaced Father Antonio Valdez at the end of 1818. The following summer, Muro was sent to San Antonio to replace Fr. Manuel María Fellechea, who had resigned as President of the Texas Missions. Following the departure of Fr. Muro, Fr. Díaz temporary moved to La Bahía to assist at the church of the presidio, which served the military and civilian settlers. He made periodic visits to Refugio to take care of his obligations to the Karankawa at the mission. This double responsibility created discord at Refugio and the mission morale deteriorated.

In October 1819, Fr. Díaz wrote to José de Jesús Aldrete, Commandant of Arms at La Bahía and asked for help. He told Aldrete that, despite frequent visits back to the mission, the Karankawa had treated the mission furnishings badly and had exhausted his ability to provide the assistance needed at La Bahía and Refugio. Diaz wrote that Refugio Indians had disregarded his censures, doctrines, counsel,

\footnotetext{
${ }_{253}$ Juan Manual Zambrano to Antonio Martínez, 9-20-1818, BA, Roll 61:Frames 818-819.

${ }^{254}$ José Manuel Zambrano to [Antonio Martínez], 9-24-1818, BA, Roll 61:Frame 849.

${ }^{255}$ José de Jesús Aldrete to [Governor], Diary of the events pertaining this cuartel [of La Bahía] during September 1818, 9-301818, BA, Roll 61:Frames 869-870.

${ }^{256}$ Copy of José Ramírez to Antonio Martínez, 7-1-1820, BA, Roll 64:Frames 670-67 1.

${ }^{257}$ Copy of [the governor to José Ramírez], 7-2-1820, BA, Roll 64:Frames 687.
} 
had recently burned off the pasture of the only herd of tame cattle that was available for the subsistence of the mission, and that they had driven the remainder of the stock outside the mission's boundaries. When, with the help of the few available workers, he was able to retrieve some cattle and drive them to the center of the mission land, the Karankawa insolently rejected the animals. Díaz said he was reporting this to Aldrete's attention for the earliest rectification of the situation. If the Commandant of Arms was unable to help discipline the Refugio neophytes or punish scoundrels, Díaz asked that he present the problem to the Governor, who he hoped would resolve the turmoil at the mission. ${ }^{258}$

Commander Aldrete did indeed forward Fr. Díaz' request to the Governor in San Antonio. Governor Martínez replied promptly, sympathizing with the Friar's difficulties and informing him that he was authorizing Aldrete to go to Refugio with the discretion to take whatever actions he deemed necessary. Martínez recommended that Fr. Díaz accompany the commandant for the purpose of using religious persuasion (backed up by military force) to convince the mission Indians to agree to a favorable outcome. At the same time, the Governor added, the cattle could be rounded up and corralled; otherwise they would roam free until they were all killed and eaten. ${ }^{259}$

Fr. Díaz promptly returned to Refugio, where he performed two baptisms on October 20. His hopes for a military solution to resolve Refugio's problems must have been disappointed. It does not appear that Commandant Aldrete took any military action authorized by the Governor in response to the disturbances at the mission. In his notes for his October monthly report for Presidio La Bahía, the only reference he made to Refugio was to say that the people there (and at La Bahía) had been suffering from fevers. ${ }^{260}$

Although the records of Fr. Díaz de León's activities as minister of Refugio Mission are sketchy, they do show that he performed 32 baptisms and ten interments during his tenure. ${ }^{261}$ Because of the growth of the Congregación de Refugio, the civilian settlement, the number of baptisms and interments of civilians and Indians was roughly equal. Around the first of the next year, 1820, the Zacatecan superiors decided that Friars Díaz de León, Refugio Minister, and Fr. Miguel Muro, Interim President of the Texas Missions, should switch places. ${ }^{262}$

On April 14, 1820, Fr. Miguel Muro arrived at Refugio to take over the mission-which did not formally take place until the following August. Upon arrival, he found that Fr. Díaz had left a few days earlier, with a passport issued from La Bahía, authorizing him to go to Carmargo. ${ }^{263}$ Because of his recent appointment, perhaps he intended to make a trip to Zacatecas. In any case, he soon returned to Refugio where he wrote to Governor Antonio Martínez in June 1820, informing him of the appointment, explaining that the trip to Zacatecas had "vanished" and would have to be postponed because of the lack of anyone to replace him. ${ }^{264}$

\section{Mission Transfer}

On August, 8, Fr. Antonio Díaz de León transferred Mission Refugio to Fr. Miguel Muro. During his three years as Refugio's minister, Fr. Díaz can be credited for overseeing the rebuilding of Refugio after the hurricane of 1818, when all the jacals and chamacueros at the mission were flattened. At the end of his tenure 25 of the 35 structures that existed when he came to the mission in 1817 had been rebuilt. On the other hand, at the end of Fr. Díaz's time at Refugio, the mission's activity, as measured by the indices of recorded baptisms and burials, had sharply decreased to depths from which it would never recover. During Fr. Díaz de León's ministry only 36 baptisms and 14 burials were recorded. ${ }^{265}$

Upon leaving Refugio, Fr. Díaz was not able to proceed directly to San Antonio to assume his new position. La Bahía Captain José Ramírez had appealed to the Governor for Díaz to serve temporarily at the La Bahía parish to substitute for Father José Antonio Valdez, who had been called to

\footnotetext{
${ }^{258}$ Fr. Antonio Díaz de León to José de Jesús Aldrete, 10-17-1819, BA, Roll 64:Frames 437-439.

${ }^{259}$ Copy of [Antonio Martínez to José de Jesús Aldrete], 10-20-1819, BA, Roll 63:Frame 439 verso.

${ }^{260}$ José de Jesús Aldrete to [Antonio Martínez ], 11-1-1819, BA, Roll 63:Frame 454 recto and verso.

${ }^{261}$ Refugio Baptismal Translations, 1817-1820, pp. 69-86; Refugio Interment Records, 1817-1820, pp. 37-42, Catholic Archives of Texas, Austin.

${ }^{262}$ Fr. Antonio Díaz de León to Antonio Martínez, 6-5-1820, BA, Roll 64:Frames 450-541.

${ }^{263}$ Ignacio Flores to Antonio Martínez, 4-30-1820, BA, Roll 64:Frame 274.

${ }^{264}$ Fr. Antonio Díaz de León to Antonio Martínez, 6-5-1820, BA, Roll 64:Frames 450-451.

${ }^{265}$ Refugio Mission Baptismal Translations, pp. 69-87 and Refugio Mission Interment Translations, pp. 37-42, Catholic Archives of Texas, Austin.
} 
San Antonio to respond to accusations of wrongdoing. ${ }^{266}$ Fr. Díaz remained at La Bahía during October and November. By early December, he had arrived in San Antonio to take up his post as Interim President. At this point Fr. Díaz' primary concern would be to defend the mission lands and other property against precipitous secular demands, and to see that the mission properties were dealt with according to orderly and legal procedures. In effect, Fr. Díaz had little to do other than preside over, and attempt to forestall, the inevitable conclusion of the Spanish missions of Texas.

${ }^{266}$ José Ramírez to Antonio Martínez, 9-16-1820, BA, Roll 65:Frames 231-232. 


\title{
Chapter 3: Mission History- Section F The Ministry of Fr. Miguel Muro
}

\author{
$1820-1830$
}

\section{Fr. Muro's Background}

Fr. Miguel Muro was born about 1790. At seventeen he joined the Franciscans of the Missionary College of Zacatecas and was ordained a priest in 1816 (Habig 1976:247). About two years later he arrived in Texas where he first worked as a substitute for priests whose service had been interrupted to answer charges of misconduct. Muro first went to La Bahía in 1818 and temporarily replaced Father José Antonio Valdez at the presidio church. Accused of "scandalous conduct," Valdez was forced to leave La Bahía to go to Monterrey to defend his record. ${ }^{267}$

In July 1819, Fr. Muro traveled from La Bahía to San Antonio where he temporarily replaced Fr. Francisco Frejes as President of the Texas Missions. Fr. Francisco Frejes had left San Antonio as a result of various charges that he had misused his office. ${ }^{268}$ Muro's activities centered on resisting the efforts of Father Refugio de la Garza to take the church ornaments from Mission Concepción and transfer them to the San Antonio parish. ${ }^{269}$ Evidently the San Fernando Church ornaments were looted during the revolution. Nevertheless, Fr. Muro, backed up by his superiors in Zacatecas, insisted on a legal and orderly transfer of any mission property.

\section{Opposition to Muro coming to Refugio}

In December or early January 1820, the decision was made to send Fr. Muro to the Refugio mission, and Governor Antonio Martínez ordered an escort to come from La Bahía Presidio to San Antonio to accompany the friar. The news that Fr. Muro was coming to Refugio was not welcomed at Presidio La Bahía. Juan de Castañeda, Presidio Commander, wrote to both Governor Martínez and to Fr. Bernardino Vallejo, Guardian of the Zacatecas Missionary College, asking that Fr. Muro remain at San José Mission. Castañeda asked that a minister be sent to Mission Refugio from Zacatecas. He argued that Fr. Muro was needed at San José, so that he could minister to the missions of San Juan, Espada, and Concepción. Espíritu Santo did not need a minister, he said, since it was located so close to the Presidio. ${ }^{270}$

A few days later Castañeda again wrote to the Governor requesting or suggesting that Refugio should be closed. Governor Martínez' response to Castañeda was forceful and unequivocal:

\section{"that in no way can the abandonment of Refugio Mission be approved."}

He emphasized that such a proposal would never be allowed by the Superior Government; that the mission was needed both to guard the coast and to prevent the harm that would result from the separation of the Karankawa Indians from the mission. The Governor ordered the number of soldiers assigned to the Refugio outpost increased to twelve men, citing the request of the Reverend President [Fr. Antonio Díaz de León]. ${ }^{271}$

In addition to its primary purpose of defending the coasts and pacifying the Karankawa, the military detachment at Refugio also provided a deterrent to presidial deserters who might be tempted to escape Spanish authorities by fleeing toward the south. Shortly after the exchange of letters between the Governor and Castañeda, a report was sent to the governor informing him that the Refugio soldiers, "who patrol incessantly," had apprehended two deserters with eight horses and a mule. ${ }^{272}$

\footnotetext{
${ }^{267}$ José Antonio Valdez to Antonio Martínez, 12-25-1818, BA, Roll 62:Frames 527-528.

${ }^{268}$ Investigation into the conduct at San José Mision of Fr. Francisco Frexes, President [of the Texas Missions]. Diligencias practicado Sobre el Manejo con que se condujó en la Mision de San José el Padre Precidente que Estubo en ella Fray Franc.co Frexes, August, 1819, BA, Roll 63:198-216.

${ }^{269}$ Refugio de la Garza to the Governor, 2-8-1820, BA, Roll 63:Frame 860.

${ }^{270}$ Copy of Juan de Castañeda to Fr. Bernardino Vallejo (original to Antonio Martínez), 3-1-1820, BA, Roll 64:Frame 002.

${ }^{271}$ Copy of [the Governor] to Commandant of La Bahía, 3-21-1820, BA, Roll 64:Frame 60-61. The Governor was already referring to Díaz as President of the Texas Missions before the official announcement was made (in April, 1820).

${ }^{272}$ La Bahía Presidio report to Antonio Martínez, 4-15-1820, BA, Roll 64:Frames 203-204.
} 


\section{Fr. Muro Arrives at Refugio}

Fr. Muro arrived at Refugio on April 13, 1820 to replace Fr. Díaz, who had departed the mission a few days earlier. Muro was made welcome by the soldiers of the mission guard, who provided him with 16 tame horses and mules as a donation. ${ }^{273}$ If any Indians were present at the site, Fr. Muro did not mention them or anything about the condition of the mission in the letter which he wrote to the Governor the day after his arrival. ${ }^{274}$

While waiting to receive formal possession of Refugio, Fr. Muro occupied himself with practical matters. He had arrived at Refugio at planting time and soon after his arrival had planted about three acres of crops that likely consisted of corn, beans, chilies, and other food items. ${ }^{275}$ Three and one-half acres is a substantial area; he must have enlisted the assistance of soldiers or resident Karankawa to accomplish this job by the end of the planting season.

\section{Refugio Mission in 1820}

As noted earlier, the Zacatecas College Guardian had notified Fr. Antonio Díaz that he had been appointed Interim President of the Texas Missions. ${ }^{276}$ Fr. Díaz returned to Refugio by early summer to prepare an inventory of the mission and transfer it to Fr. Muro's authority.

The last inventory of Refugio as a functioning mission was conducted on August 8, 1820. It was derived in a large part from the inventory of 1817 , and is about one-third as long. Some information was simply omitted, such as descriptions of the church and sacristy, with a note to see the previous inventory. Nine chamacueros were recorded which functioned as a commons, a weaving shop, a granary (made with two chamacueros), a dispensary, a kitchen, a chicken coop, a blacksmith (two chamacueros), and a guest house. The inventory lists in detail the contents of each structure. It noted that a small orange tree was growing in a corner of the church and sacristy.
The nine chamacueros were positioned so that they formed a closed interior patio, with the convento providing the fourth side. In one angle of the square, was a bowl made of stone and mortar with a copper bottom that was used to make soap. Next to it were two ovens for the kitchen. On one side of the convento was an area enclosed by a wooden fence devoted to the planting of tobacco; on the other side was an orchard of grapevines, pomegranates, peach trees, and figs. Next to that was a wooden corral that was the same size as the garden.

Encompassing the interior patio and other areas of the mission facilities was an open space shaped by chamacueros connected by sections of defensive stakes.

\section{"The plaza of the mission was formed by fifteen chamaqueros with palisades in between each other to guard against enemies." 277}

Three years earlier, the inventory counted a total of thirtyfive chamaqueros. The 1818 hurricane destroyed all of those structures; thus, counting the fifteen chamaqueros incorporated into the main plaza and the nine used in the interior patio, twenty-four chamaqueros had been rebuilt by 1820 .

No record was found for any shipment of supplies to Refugio Mission during the period from 1820 to 1830 , while Fr. Miguel Muro was its minister. The fifty pounds of tobacco (two arrobas) from "outside lands" listed on the inventory suggests that supplies to the mission from Zacatecas had stopped by the time the inventory was made.

\section{The Governor's Wife Visits Refugio}

Barely a month after Fr. Muro assumed his position as Refugio's minister, an extraordinary visitor arrived: Doña Manuela Lorenzo, wife of Governor Antonio Martinez. ${ }^{278}$ Perhaps after three years in the capital, she had tired of San Antonio and its environs and had arranged this sojourn south to see some new sights. Doña Manuela

\footnotetext{
${ }^{273}$ Refugio Mission Inventory, 8-8-1820, Zapópan Microfilm, Roll 1. (No frame or page numbers.)

${ }^{274}$ Fr. Miguel Muro to Antonio Martínez, 4-14-1820, BA, Roll 64:Frames 187-88.

275 Three and a half fanegas. Muro refers to "his" ripe crops in the Inventory of Refugio Mission, 8-2-1820 and Refugio Mission Inventory, 8-8-1820, Zapópan Microfilm, Roll 1. (No frame or page numbers.)

${ }^{276}$ Fr. Antonio Díaz de León to Antonio Martínez, 6-5-1820, BA, Roll 64:Frames 450-451.

${ }^{277}$ Refugio Mission Inventory , 8-8-1820, Zapópan Microfilm, Roll 1. (No frame or page numbers.) Forman la plaza de esta mision quince chamaqueros cercados los intermedio de uno a otro con estacada de madera p.a resguardar de los enimigios, p. 10.

278 The Governor's wife's name is found in the baptismal record of their child, María del Pilar, San Fernando Baptismals (translated by John Leal), 2-13-1819, no. 507, San Antonio Chancellery.
} 
had arrived at La Bahía on September 28, 1820. Two days later she traveled to Mission Refugio, accompanied by La Bahía Commandant Juan de Castañeda, his daughter, and a guard party. The impetus for this illustrious but brief visit is not known, but no doubt Fr. Muro, the Mission Karankawa, and the Refugio military detachment treated Doña Mañuela with the greatest ceremony and honor they could muster given the meager resources of their isolated outpost. Doña Mañuela's group returned to La Bahía on October 1 st. ${ }^{279}$

Two months later, the excitement of Doña Mañuela's prestigious visit had subsided. Dispirited by loneliness and fear of Indian attacks, Fr. Muro sank into a state of despair. He wrote to Commandant José Ramirez at Presidio La Bahía, asking for a face to face meeting. ${ }^{280}$ Probably realizing the difficulty of granting this request, he went ahead and stated he wished to ask that soldier Guillermo Navaro [sic] be allowed to remain in his personal company. ${ }^{281}$ Muro pointed out that Navaro was a good man with whom Muro found security and consolation in this place and that he was a man who desired the friar's well-being. To emphasize his need, Muro asked Ramirez to reflect upon the solitude within which he found himself. In addition, Fr. Muro told the Presidio officer that the six soldiers presently at Refugio were not enough to protect even the sacred vessels and ornaments from the enemy Indians. Even as he was writing his request, it had already been granted-evidently based on an earlier solicitude. On November 26, 1820, La Bahía Commandant José Ramirez wrote to the Governor reporting that Navaro had been assigned to the Refugio detachment, adding that soldiers there had been increased to eight as the governor had directed. ${ }^{282}$

A few weeks later it appears that conditions at Refugio had deteriorated badly. In San Antonio, Fr. Antonio Díaz wrote to the Governor to relay the contents of a letter he had just received from Fr. Muro, written on December 1, 1820, that described "a calamitous situation" at Refugio. Fr. Díaz cited Muro as saying that civilian residents were moving from Refugio to La Bahía because the "incompatible risks" of enemy Indian attacks and because of the lack of soldiers at the mission to provide protection. The two or three civilians remaining were also preparing to leave. Mission servants were dismayed. Díaz said that the new commander at La Bahía had reduced the Refugio detachment to eight men, leaving the mission exposed and its minister in danger of losing his life. ${ }^{283}$

Quoting Fr. Muro, Díaz told the Governor that:

"either the situation must be remedied, or that the church ornaments would have to be moved to a place of security along with its minister, whose life is in extreme danger without competent assistance."

Fr. Díaz asked that the Refugio guard be increased to fifteen men; or, hedging his request with grim irony, to what number that would be possible in order:

$$
\begin{gathered}
\text { "to defend a mission without people, } \\
\text { a site without a stockade." } 284
\end{gathered}
$$

Since Governor Martínez had already instructed the Commandant of Arms at La Bahía not to assign more than eight soldiers, including a corporal, at Refugio, it is safe to say that no action was taken in response to Fr. Díaz' petition for additional soldiers. ${ }^{285}$

The "calamitous situation" that occurred at Refugio in December 1820 affected Fr. Muro's mood. He wrote to the Governor saying:

"faults are not lacking to a son of the miseries of Adam. What unhappiness is ours! My writings are not of pleasure, nor rejoicing, which confusion and dejection barely allow."

\footnotetext{
${ }^{279}$ José Ramírez to Antonio Martínez, 10-1-1820, BA, Roll 65:Frame 329.

${ }^{280}$ Fr. Miguel Muro to José Ramirez, 1 1-28-1820, BA, Roll 65:Frames 906-907.

${ }^{281}$ Guillermo Navarro was evidently about to be transferred from Refugio. Fr. Miguel Muro to José Ramírez, 11-28-1820, BA, Roll 65:Frames 906-907.

${ }^{282}$ José Ramírez to Antonio Martínez, 2-26-1820, BA, Roll 65:Frames 882-883.

${ }^{283}$ Fr. Antonio Díaz de León to Antonio Martínez, 12-13-1820, BA, Roll 66:Frames 43-44.

${ }^{284}$ Ibid.

${ }^{285}$ Draft copy of [Antonio Martínez] to Commandant of Arms at La Bahía , 1 1-15-1820, BA, Roll 65:Frames 803 -804.
} 
Fr. Muro also revealed his pessimistic impressions about Refugio upon his arrival several months earlier:

"the gradual debilitation from my pain and sorrow in the sight of such a disfigured [religious] image, and such a desolate mission, for this desolation elevated my pained spirit so as to contemplate the mission as another Jerusalem."

Again, the friar's letters provide no information about any mission problems and he makes no reference to his activities with the Karankawa. ${ }^{286}$

Around mid-March, Fr. Muro left Refugio for a few days and went to La Bahía. Fr. Díaz arrived about the same time, presumably to consult with him about what to do about the situation that occurred the previous December. Both wrote letters on March 17th; Muro to the Governor and Díaz to the La Bahía Commandant. At the end of his letter, Muro noted that he and Díaz disagreed about moving the mission, which Muro vaguely indicated that he favored because he thought six soldiers were not sufficient to keep the mission secure. ${ }^{287}$

Fr. Antonio Díaz firmly pressed the issue of soldiers and mission defense to Francisco García, recently appointed as presidio commander at La Bahía. He recalled the "calamitous situation" at Refugio that, at the behest of Fr. Muro, he had reported to the Governor the previous December. Díaz informed the commander that the Governor had ordered García's predecessor to increase the number of soldiers to twelve and nothing had been done. Fr. Díaz must have been aware of the military value placed on the mission as a reconnaissance base. Evidently using that knowledge as leverage, he broached the possible "extinction" of the mission if the mission guard was not increased. He pointed out how the inadequate defense had brought about grievous consequences like the death of an Indian and a civilian resident recently killed within sight of the mission. Six soldiers were not sufficient to guarantee the existence of the mission from such threats and risks. The mission Indians could not reside securely in their own houses, and were hardly safe within the mission enclosures. The church and offices were all combustible, and if set afire they would be destroyed before water could be brought from the river. Fr. Díaz completed his argument by requesting that Refugio receive the additional soldiers that could be spared, in accord with what the Governor had promised. Otherwise, he indicated that his superiors in Zacatecas would decide what should be done with the mission. If the increase could not be accomplished, the friar pointedly suggested that a determination be made as to how the mission ornaments could be transported to La Bahía. ${ }^{288}$

Commander García responded immediately to Fr. Díaz' letter. That same day, March 17, he wrote to the Governor to affirm the necessity of maintaining the mission at all costs. His letter put a spotlight on the benefits Mission Refugio provided. He said the mission should be kept because of the reliable intelligence it provided from the coast, because of the support it provided against the threat from Comanches and other hostile Indians, and because the Mosquitos Detachment on the coast was not a permanent post. In addition, he reported the opinion that there would be a Karankawa uprising within three months after the missionary departed; that the mission Indians would join with the gentile Karankawa and take possession of critical areas of the coast, threatening the destruction of La Bahía. ${ }^{289}$

Having affirmed the vital importance of Refugio, García made clear the dilemma the military had with the mission. García agreed that Fr. Díaz was correct in what he wrote about a calamitous situation at Refugio. He said that he knew that the poor missionary at Refugio did not have what was necessary to sustain life; and that the enemies attack repeatedly, those who come from inland, called the Comanches, boast that they will not stop until the mission is destroyed. ${ }^{290}$

Nevertheless, Commandant García told the Governor that the circumstances did not permit him to provide the indispensable assistance needed to preserve that outpost. He stated that his two companies were not sufficient to cope with the many needs of the mission. Although the Governor

\footnotetext{
${ }^{286}$ Fr. Miguel Muro to Antonio Martínez, 1-20-1821, BA, Roll 66:Frames 472-473.

${ }^{287}$ Fr. Miguel Muro to Antonio Martínez, 3-17-1821, BA, Roll 76:117-118.

${ }^{288}$ Fr. Antonio Díaz de León to Francisco García, 3-17-1821. BA, Roll 67:Frames 110-1 12.

${ }^{289}$ Francisco García to Antonio Martínez, 3-17-1821, BA, Roll 67:Frames 108-1 10.

${ }^{290}$ Francisco García to Antonio Martínez, 3-17-1821, BA, Roll 67:Frames 108-110.
} 
had ordered the previous Presidio commander to provide a guard of twelve men for Refugio, García emphasized that a corporal and six soldiers was all he could spare. ${ }^{291}$

In the end, García passed the dilemma to the Governor and asked for orders to either abandon Refugio or to maintain it, saying he would not allow the priest to take any action until the Governor made his resolution known. Three months later, in June, Commandant Francisco García had his answer. He duly reported to the Governor that he had increased Refugio's guard to twelve men, as ordered, warning that:

\section{"They will not last long because they absolutely do not have enough to eat." \\ "Nor do I,"292 he added.}

Not only was Commander García's command undermanned and under-supplied, he also lacked community support. Two months later, on August 3rd, Indians killed a La Bahía resident and stole four horses. García readied the twentyfour soldiers who were able-bodied and asked the Alcalde for civilian auxiliaries to assist in the pursuit of the attackers. The Alcalde said he could not comply because the residents refused to obey him. ${ }^{293}$ The soldiers tracked the Indians but were unwilling to engage them, evidently because of their inferior number and low morale.

\section{Independence}

Mexican Independence was proclaimed in February 1821, by the Plan de Iguala. Further confirmation came in August with the Treaty of Cordoba, whereby Viceroy Juan Odonoju conceded independence to Mexico. For Tejanos, who had suffered the burden of numerous changes in government during the ten years since 1811, independence was met with little dissent and daily life proceeded with minor changes.

In addition, to its other problems, desertions weakened Presidio La Bahía's strength. On the first and second of September, Commander García reported five desertions; one from Refugio and four from the Presidio. ${ }^{294}$ Under-supplied, undermanned, and beset by low morale, La Bahía was vulnerable. And coincidentally, for the second time since 1813, the presidio had again become the target for outside aggression.

On September 30, 1821, James Long was making final preparations, from his base on Matagorda Island, to attack La Bahía. $^{295}$ With 51 Americans and a Spaniard, Long attacked La Bahía at dawn, October 4, 1821. Creating a great racket coming into the settlement to disguise their small numbers, Long's men easily took the weakened presidio. Inside they confronted Commandant García, demanding to know if he had sworn [Mexican] Independence. If so, they said, then our goals are the same as yours. Xaraname Indians, down river, had informed them that this town had not sworn Independence. ${ }^{296}$ Long's success was brief. Royalist forces, under Ignacio Perez, surrounded the presidio and within four days Long was forced to capitulate. Still, it was a military humiliation and must have had a lingering, disquieting effect upon the people. Just as with La Salle's expedition in 1685, Long had demonstrated that Matagorda Bay remained a weak point, through which Texas could be invaded. For Mission Refugio, the resulting action caused its military detachment to be reduced back to a corporal and seven soldiers.

\section{Indian Relations}

Karankawa Indians associated with Mission Refugio committed two significant attacks during the year 1821; one against Americans, the other against Mexicans from Reynosa. In May, the Karankawa and Cocos killed a Spaniard, described as a frontier servant or a guide, and five Americans. Their American ship had wrecked on Padre Island near the Brazos Santiago Pass, and they were attacked and killed when they reached the vicinity of Mission Refugio. When Guadalupe de Los Santos, La Bahía Alcalde, investigated the incident, the Indians told him they were at war with Americans because of an attack they had perpetrated on a Karankawa encampment on the Colorado River. After the Indians assured the Alcalde that revenge

\footnotetext{
${ }^{291}$ Ibid.

${ }^{292}$ Francisco García to Governor, 8-4-1821, BA, Roll 68:Frames 23-24.

${ }^{293}$ Francisco García to Antonio Martínez, 8-3-1821, BA, Roll 68:Frames 17-18.

${ }^{294}$ Francisco García to Antonio Martínez, 9-1-1821, BA, Roll 68:Frame 278.

${ }^{295}$ Guadalupe de los Santos to Antonio Martínez, 9-30-1821, BA, Roll 68:Frames 445-447.

${ }^{296}$ Thomas Buentello to Antonio Martínez, 10-1 1-1821, BA, Roll 68:Frames 554-556.
} 
was the motive for this attack, and that they would not harm anyone else, they were brought to Mission Refugio ${ }^{297}$ Who these Americans were is unknown, but since this conflict occurred before June 1821, it does not appear that they were associated with Stephen F. Austin and his party of sixteen men, who did not enter Texas until July 1821.

The dust had hardly settled from the Karankawa attack on Americans, when another incident occurred. Later in June, Fr. Muro wrote to Guadalupe de los Santos, Alcalde of the La Bahía Ayuntamiento, relating an account told to him by mission Indians who were members of the family of Cristomo. The Indians said that they encountered a group of twenty-five intruders, whom they identified as Gachupines or Spaniards from Europe- not Americans or French. The twenty-five men had arrived in a large vessel that came ashore near the Nueces River. The captain of the men, named Don Juan, was angry and said they had come for the purpose of making war on Karankawas. Cristomo's family was able to convince the captain that he and his family were Christian Indians who belonged to the mission. The captain said he had no quarrel with Christians, but rather was hunting for gentile Karankawas, including those who gather at the mission. The group did not follow through on their threat to go to the mission and soon returned to their ship. ${ }^{298}$

On November 27, men arrived at La Bahía reporting that a party from Reynosa had been attacked near the coast. ${ }^{299}$ Fr. Muro went with the La Bahía Alcalde and other men to investigate. They determined that Karankawas from the village of Chief Prudencio had attacked a party of men from Reynosa who were bringing two hundred horses. Two from the party were killed and one was wounded. Prudencio was not present at the camp when the investigators arrived. Indians from the encampment tried to blame the attack on Comanches, but incriminating evidence was found including personal belonging of the Reynosans and some of their horses. Fr. Muro affirmed that Karankawas were the culprits. ${ }^{300}$
La Bahía Commandant García seized upon this attack on the men from Reynosa to bolster his request for twenty-five soldiers for Refugio and another twenty-five for the Mosquitos Detachment. Without these resources so gravely needed, he said:

\section{"I can not avoid the catastrophes like the one just committed." 301}

García's argument was that Refugio and the Mosquitos outpost were frequented by Karankawa and were thus seriously threatened. This view was contradicted by a record of the soldiers actually stationed at Mosquitos, who remained unconcerned about the Karankawa. The La Bahía Military Report for November shows that cooperation between the military at Mosquitos and the Karankawa continued on a routine basis:

\section{On November 11 ,}

A Sergeant and two soldiers left La Bahía

Presidio to relieve the Indians who are at the Mosquitos Detachment.

\section{On November 12 ,}

A Sergeant and two soldiers from Mosquitos, arrived at La Bahía, accompanied by thirteen Karankawa Indians.

\section{On November 15th, \\ The thirteen Karankawa returned to their camps. ${ }^{302}$}

Lt. Commander García went to San Antonio on November 16th for a meeting with the Governor. ${ }^{303}$ The meeting however, must not have gone well for the Commander: the changes he recommended were not made, the detachment at Refugio was maintained at eight soldiers, with four soldiers at Mosquitos, ${ }^{304}$ and his command was transferred to José Jesús Aldrete.

\footnotetext{
${ }^{297}$ Francisco García to Antonio Martínez, 6-2-1821, BA, Roll 67:Frame 730.

${ }^{298}$ Copy of Fr. Miguel Muro to Guadalupe de los Santos, 6-18-1821, BA, Roll 67:Frame 838 verso.

${ }^{299}$ Francisco García to Antonio Martínez, 10-27-1821, BA, Roll 68:Frames 763-764.

${ }^{300}$ Copy of Francisco García to Antonio Martínez, 1 1-3-1821, BA, Roll 68:Frames 893-895.

${ }^{301}$ Ibid.

${ }^{302}$ La Bahía Presidio Monthly Report, 1 1-30-182 1, BA, Roll 69:Frames 264-265.

303 Ibid.

${ }^{304}$ La Bahía Presidio Monthly Report, 12-1-182 1, BA, Roll 69:Frames 269-270.
} 


\section{Desire for Mission Lands}

With independence won from Spain, the pressure to acquire mission lands increased. As early as 1820, Father José Antonio Valdez had petitioned for the Mission Rosario lands; the Governor deferred his petition for consideration by the superior government. On January 10, the La Bahía Ayuntamiento took the initiative and sent a representation to the Governor declaring that Mission Espíritu Santo was in terrible condition and requesting its secularization. The Ayuntamiento painted a dismal picture of conditions at the mission. They said the pastures and cultivated fields were abandoned; the church was destroyed as was its wall; the wooden construction was rotten, and the ceilings falling. There were only fifty Indians, with fifteen adult men capable of work. The [Jaranames] sometimes joined with Karankawa and Tancahuas to rob and cause damage to residents. They said that the Indians had not attended mass or doctrine in the mission or the parish for seven years, and they could not subsist on the resources of the mission; the mission minister had to subsist by his own effort, and could not attend to the Jaranames. They did not live at the mission for this reason; every one of them maintained themselves by living in the country. They advised that the ornaments of the mission were stored at the parish and were in a deteriorated condition. They asked that Governor Martínez send their request to the superior government so that the mission's lands could be taken before the Indians pervert it more. ${ }^{305}$

Fr. Miguel Muro received a notice of the Ayuntamiento's action from the Governor. He wrote to Fr. Anzar at Espíritu Santo in February, advising him not to make a row about the Ayuntamiento's action at the present time, he said:

\section{"Otherwise, they will hit both of us." 306}

Subsequently, in Mexico City, Father Refugio de la Garza, Texas representative to the National Congress, would advocate that the lands of all Texas missions be distributed to landless residents, except for San José and Refugio which would be reserved as resources for their respective Ayuntamientos. ${ }^{307}$
As previously noted, the number of soldiers assigned to Refugio fluctuated, they were under-supplied, and suffered low morale. Evidently Fr. Muro did not want to depend entirely upon the defenses the mission's military detachment provided. In April, he traveled to San Antonio and requested eight pounds of gunpowder from Governor Martínez for the defense of Refugio Mission. ${ }^{308}$ After Fr. Muro returned from San Antonio, he found that Refugio's defenses had been increased. La Bahía's monthly report for June showed only four soldiers assigned to Refugio. ${ }^{309}$ During July, Commander Francisco García (restored to the position of Commandant) increased the number of soldiers at Refugio to seven in response to pressure from Governor Martínez. ${ }^{310}$ Despite this concession, Fr. Muro had had enough and was ready to close Refugio.

\section{Muro Wants to Close Refugio}

Around the end of July, Fr. Muro sent a confidential letter to the La Bahía priest, requesting his help in regards to his desire to move to La Bahía and bring the mission ornaments with him. Informed of this, the Ayuntamiento wrote an opinion opposing the idea, which they sent to Governor Martínez on August 4th. ${ }^{311}$ The Governor replied that he had opposed closing the mission since the idea was first proposed by the Missions President, Díaz de León-who justified it because of the grievous situation of the Refugio minister. Nevertheless, Governor Martínez said that, by necessity, it was his determination to permit Fr. Muro to retire to La Bahía because of his inability to provide—-now and in the foreseeable future - for the assistance of the few Indians who remained. He suggested that the move would not be to abandon the mission, but rather to enable the friar to assist its Indians with greater facility. Then, opening the door he had just closed, the Governor broached the possibility that, if the La Bahía Ayuntamiento would provide sustenance to Fr. Muro, and maintain the mission and would assure that it would not be destroyed, he would agree to reverse his decision to allow Fr. Muro to leave. In addition, Martínez noted that the new governor would arrive soon and he would bring additional soldiers and supplies to aid the mission. ${ }^{312}$

\footnotetext{
305 Juan José Hernandez to Antonio Martínez, 1-19-1822, BA, Roll 70:Frame 207.

${ }^{306}$ Fr. Miguel Muro to Fr. Antonio Anzar, 2-12-1822, BA, Roll 70:Frames 679-680.

${ }^{307}$ Refugio de la Garza to [San Antonio Ayuntamiento], 8-8-1822, BA, Roll 72:Frame 455.

${ }^{308}$ Fr. Miguel Muro to Antonio Martínez, 4-6-1822, BA, Roll 71 :Frames 293-294.

${ }^{309}$ La Bahía Presidio Monthly Report, 7-1-1822, BA, Roll 72:Frame 10.

${ }^{310}$ Francisco García to Antonio Martínez, 8-2-1822, BA, Roll 72:Frame 407-409.

${ }^{311}$ Juan José Hernandez to Antonio Martínez, 8-4-1822, BA, Roll 72:Frames 433-434. Ayuntamiento decree, 8-22-1822, BA, Roll 72:Frame 727.

${ }^{312}$ Copy of [Antonio Martínez] to La Bahía Alcalde, 8-7-1822, BA, Roll 72:453-454.
} 
Governor Antonio Martínez left office later that August and was replaced by Felix Trespalacios. The La Bahía Ayuntamiento wasted little time in writing him about the matter of Fr. Muro leaving. Hedging, they said two members of the Cabildo would supply Fr. Muro for fifteen or twenty days, but no longer. Trespalacios declined to be rushed into making a decision on the issue, but sent fifty pesos from his own funds to assist Fr. Muro. ${ }^{313}$ Thus Refugio Mission received a reprieve, but its days were numbered.

Although it was not experiencing direct pressure for secularization, like the missions at San Antonio and Espíritu Santo, uncertainties related to secularization must have had a destabilizing effect on Refugio. In Mexico City, Father Refugio de la Garza continued to represent adherents of mission secularization. By September 1823, his petition lay on the desk of Secretary Lucas Aleman. Blatantly disregarding the truth, de la Garza had informed Aleman that the seven Texas Missions were abandoned and had no resident Indians since 1803. Deferring a decision, Aleman returned the petition to the Texas Provincial Deputation for approval, and for the bishop's concurrence, before secularization could be approved. ${ }^{314}$ The provincial deputation approved the secularization petition the next month. At that point, all that stood between the San Antonio Missions and secularization was Fr. José Antonio Díaz de León, President of the Texas Missions. Fr. Díaz's petitions to the provincial deputation, and his appeals to Zacatecas missionary College were to no avail. ${ }^{315}$ In February 1824, the missions of San Antonio officially ceased to exist, their buildings and lands passing from the jurisdiction of the Missionary College of Zacatecas to the Archdiocese of Monterrey (Almaráz 1979:2). Secularization proceedings for Missions Espíritu Santo and Refugio would drag on for six more years. But the pressures brought about by Comanche warriors were building and, by the next year, they would bring an end to Refugio as an operating mission.

Fr. Muro conducted a census of Refugio on January 1, 1823. From this record it would appear that the mission was doing well. Twenty Christian Indian families were listed, for a total of ninety-five persons. There were seven single men, four widows and three gentile Indians, making a grand total of 122 Indians at the mission. In addition, five Spanish families that comprised eighteen persons were enumerated. ${ }^{316}$ These families were clearly civilian settlers rather than military men, since no soldiers are shown stationed at the mission in January. ${ }^{317}$ The census, reproduced on the following page, is particularly interesting because it is the last enumeration known to have been made of the Refugio Mission residents (Table 3-6).

Despite the apparent strength of the mission on paper, it remained vulnerable on several counts: the complete lack of military protection-although, this would improve somewhat in the coming months; the transient nature of the Indians - at the approach, or rumors of the approach of threats such as Comanche attack, or illnesses most of the mission Indians would swiftly disappear. Chronic shortages of critical supplies, especially tobacco and chocolate must have also made the mission appear less attractive.

\section{Indian Relations}

Relations with the Karankawa were complicated by the arrival of American colonists. The first prospective American settlers came to Texas in 1821, a result of Stephen F. Austin's empresario contract. The next year a settlement had been established on the Colorado River near present Columbia, Texas. The colonists soon came into conflict with Karankawa Indians. In October 1822, Karankawa attacked American settlers on the Colorado. The next month, Governor Trespalacios sent La Bahía Commander García and Fr. Muro to warn the Indians against further aggressions. After camping at the Mosquitos Detachment, they traveled to the union of the San Antonio and Guadalupe rivers. High waters prevented their crossing, and they were forced to return without having had council with the Karankawa. ${ }^{318}$ American encroachment on the Karankawa's native environment increased, and by 1823 colonists had constructed a fort on the Colorado River. Early that same year, John Tumlinson

\footnotetext{
${ }^{313}$ Felix Trespalacios to Juan José Hernandez, 8-27-1822, BA, Roll 72:Frame 680. Extract from Bahía Ayuntamiento pronouncement pertaining to Fr. Muro's proposal to leave Refugio, 8-22-1822, BA, Roll 72:Frames 725-726.

314 [Lucas] Aleman to Bexar Jefe Politico, 9-15-1823, General Land Office, Box 122, Folder 15, p. 231.

315 Diputacion Provincial to [Bexar] Jefe Politico, 10-22-1823, BA, Roll 75:Frames 716-717; Fr. Antonio Díaz de León to Jefe Politico (José Antonio Saucedo), 10-25-1823, BA, Roll 75:Frames 730-732.

${ }^{316}$ Census of Refugio Mission, by Fr. Miguel Muro, 1-1-1823, Our Lady of the Lake University, Old Spanish Missions Historical Research Library, Zacatecas Microfilm, Roll 14:Frames 2576-2577.

${ }^{317}$ La Bahía Presidio Monthly Report, 1-1-1823, BA, Roll 73:Frame 898.

${ }^{318}$ Francisco García to [Felix Trespalacios], 11 -23-1822, BA, Roll 73:Frames 596-599.
} 
Table 3-6. 1823 Census of Mission Refugio

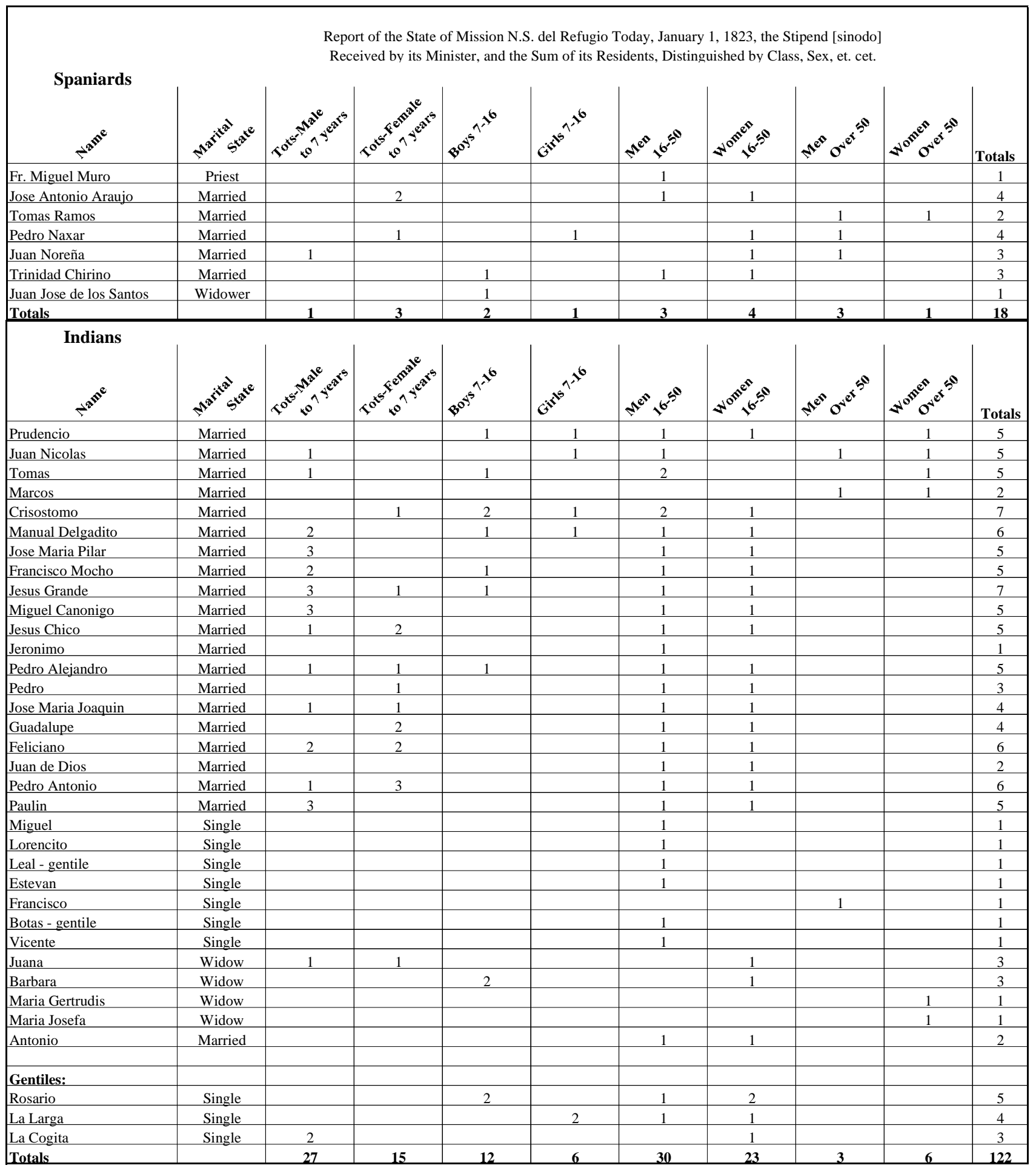

(Our Lady of the Lake University, Old Spanish Mission Historical Research Library, Zacatecas Microfilm Roll 14:Frames 2576-2577). 
referred to a settlement on the Colorado that was attacked by "Krok" Indians. In retaliation, the colonists killed eight Karankawa. ${ }^{319}$

\section{Refugio Receives a Fatal Blow}

After the revolution of 1813 , the long accustomed tradition of providing presents for Comanche Indians and their allies had either been discontinued or much reduced. Subsequently, Spanish authorities sent numerous Comanche chiefs to Mexico City to meet with authorities, evidently in an effort to appease and flatter them (and incidentally remove them from Texas and divide their leadership). A case in point occurred in 1822, when Comanche Chief Viche was escorted to the court of Mexico City by Luis Chirino of La Bahía. ${ }^{320}$

Nevertheless, Comanche groups still expected gifts when they visited San Antonio, La Bahía, and Refugio. The handling [elmanejo] of leaders of volatile Comanche bands was a matter of delicate negotiation. In San Antonio in 1822, a Comanche band under Chief Enqueroc stayed in San Antonio several days and left dissatisfied with the gifts they received. ${ }^{321}$ While they would not attack a fortified San Antonio, it was this kind of disgruntled Indians who were especially dangerous to a place with weak security like Refugio or La Bahía, where demands for gifts that were not met could easily lead to tragic consequences. For example, early in February 1824, Comanches came to La Bahía and the Ayuntamiento presented them with goods valued at nineteen pesos. Reimbursing the Ayuntamiento for its expenditure, the Governor ordered that in the future they should "handle" the Indians by showing them that there was nothing to give at La Bahía and to send them to San Antonio, where he would provide them with what was possible. ${ }^{322}$

Fr. Muro was perhaps operating on this same principle at Refugio, when an encounter with Comanches produced disastrous results later that month. The details are not available, but on February 22, the La Bahía Ayuntamiento wrote to the Governor informing him of:

\section{"a fatal negotiation [manejo] Comanche Indians had with Fr. Muro and the persons who were there with him at the mission."}

Clearly an encounter with Comanches occurred at Refugio that resulted in fatalities. ${ }^{323}$ Since church items suspected of being ornaments belonging to Refugio were later found in the possession of Comanches, it appears that in addition to attacks on persons, the mission church was subsequently looted. ${ }^{324}$ Fr. Muro immediately moved to La Bahía, and the Spanish settlers and Mission Indians also abandoned the mission. The Ayuntamiento informed the Governor that they had been unable to persuade Muro to return. However, neither could they persuade several civilians from La Bahía to go there. Of the nine men and their families the Ayuntamiento arranged to go with Muro to Refugio, five refused. On March 22, Fr. Muro wrote to Fr. Díaz de León and explained that he had not departed for Refugio as agreed the last time they met because the nine men who had promised to accompany him would not leave [the safety of La Bahía].

\section{"I have been packed and ready to go since the 22 nd of the present month." 325}

Five of the men said they would not go and risk their families because there were no soldiers assigned to the mission. ${ }^{326}$

At this juncture, Fr. Muro's spirits were at a low point. As early as 1821 he had been ready to close Refugio, because of insufficient military support and the numerous attacks from Indian groups. ${ }^{327}$ In 1822 , he unsuccessfully petitioned for permission to move to La Bahía. Now, as Fr. Muro contemplated moving back to Refugio, he sank into a gloomy, despondent state filled with pessimism and

\footnotetext{
${ }^{319}$ John Tumlinson to [Presidio Commander at] La Bahía, 2-26-1823, BA, Roll 74:Frame 950 ff.

${ }^{320}$ José Antonio Navarro to Governor, 1-16-1822, BA, Roll 70:Frame 278.

${ }^{321}$ Gáspar López to San Antonio Ayuntamiento, 3-27-1822, BA, Roll 71:Frames 213-21 7.

${ }^{322}$ Copy of the Governor to La Bahía Ayuntamiento, 2-13-1824, BA, Roll 76:Frame 70.

323 Oberste, History of Refugio Mission, 1942, pp. 307-09, adds considerable detail to this incident.

${ }^{324}$ Fr. Miguel Muro to the [San Antonio] Jefe Politico, 3-31-1824, BA, Roll 76:Frames 695-696.

${ }^{325}$ Fr. Miguel Muro to Fr. José Antonio Díaz de León, 3-22-1824, BA, Roll 76:Frames 676-677.

${ }^{326}$ Ibid.

${ }^{327}$ Fr. Miguel Muro to Antonio Martínez, 3-17-1821, BA, Roll 76:Frames 117-1 18.
} 
guilt which is reflected in a letter he addressed to Fr. Díaz. Referring not only to the problems at Refugio, but also to the province, he told Fr. Díaz that:

"These and other considerations have undermined the hope that you and I had to see our desires realized. All has been useless and there is no consolation, no remedy. May God and the Holy Virgin forgive our great failings. And what remains to us? To cry, cry out without ceasing, fervently asking Heaven to assuage Its wrath. [We must] show forth our conduct and honor our College so it may know the complete, unvarnished truth about the failure we now lament, the fatal results for the province, and other evils that have reached the point where there is little hope that they can be remedied." 328

When the Refugio Karankawa and other Indians persecuted by the Comanches arrived at La Bahía on March 21st, Refugio was completely abandoned. The Indians were bitter and disillusioned. The Sons of the Mission told Fr. Muro that as a result of the war:

\section{"Comanches were going to kill us because they had defended the Spaniards. Now, why do the Spaniards not defend us?"329}

The next day, one last effort was made to secure the return of Fr. Muro and civilians to Refugio. Acting on orders from the Jefe Politico in San Antonio, La Bahía Alcalde Geronimo Huizar brought together in the council house Friars Muro, Díaz, and ten La Bahíans who were willing to accompany Fr. Muro to Refugio. The Alcalde promised to provide two almuds ${ }^{330}$ of corn per week for Muro for six months. The friars indicated their agreement to this arrangement. Then, the ten civilians reneged on the arrangement. They said that the risk was too great; that those who had arms were out hunting to provide food for their families, and that those who had no armaments refused to go because of the risk. Alcalde Huizar informed the political chief that unless he could send armaments, they could not accompany Fr. Muro to Refugio. He added that the Presidio itself had insufficient arms and that the people were in fear of Indian attacks from night until morning. ${ }^{331}$

These events in February and March of 1824 marked the end of Nuestra Señora del Refugio as a functioning mission. Although, Fr. Miguel Muro would continue to serve in an official capacity as Refugio's minister until 1830, no evidence was found of any missionary activity at the site once he left Refugio after the "fatal negotiation" with the Comanches in February 1824. The last baptism at Refugio was recorded on May 17. Fr. Muro continued to perform baptisms until 1828, but these ceremonies were not conducted at Refugio. An inscription at the end of the Refugio book of baptismal records that:

“...all baptisms performed since the month of July of 1824 have been administered in the parish

of La Bahía because the Minister could not subsist in the mission on account of the hostilities of the Comanches." 332

Thus Fr. Muro recorded a total of thirty-one baptisms at La Bahía between 1824 and 1828. All were Indian children, ranging in age from a few days to four years, their parents being listed variously as "Sons of the Mission," and others as Karankawa, Coco, Cujan, and pagan. Fr. Muro performed three burials at La Bahía in 1825, to children of Karankawa, Coco, and Cujane families. No further burials were recorded in the Mission Refugio book of interments. ${ }^{333}$

The story of Refugio Mission after 1824 is basically a recounting of procedural obstructions and delays by Fr. Díaz de León and Fr. Muro in the face of the inexorable legal processes that were bringing about the secularization of the mission. By July the decision was made to close Refugio, and arrangements were underway to remove the ornaments and store them at La Bahía. ${ }^{334}$ More than two years later, as a result of delays, the ornaments still had not moved. ${ }^{335}$ Fr. Díaz de León was probably instrumental in creating delays that kept the ornaments at Refugio, for he had hopes of reviving the mission.

\footnotetext{
${ }^{328}$ Fr. Miguel Muro to Fr. José Antonio Díaz de León, 3-22-1824, BA, Roll 76:Frames 676-677.

${ }^{329}$ Ibid.

330 Twelve almuds equals one fanega, or 1.6 bushels.

${ }^{331}$ Gerónimo Huizar to Jefe Politico, 3-23-1824, BA, Roll 76:Frames 684-686.

${ }^{332}$ Refugio Mission Baptismal Translations, page 105. Catholic Archives of Texas, Austin

${ }^{333}$ Refugio Mission Interment Translations, page 47. Catholic Archives of Texas, Austin.

${ }^{334}$ José Trejo to Jefe Politico, 7-17-1824, BA, Roll 77:Frame 494.

${ }_{335}$ Mateo Ahumada to Antonio Saucedo, 4-6-1826, BA, Roll 91:Frames 354-355.
} 
In August 1825, Fr. Díaz sent a lengthy petition to revive Refugio to Mateo Ahumada, newly appointed Commandant of Texas. He recommended the assignment of ten to twelve soldiers, re-establishment of the stockade wall, rehabilitation of the quartel and other small buildings, with provisions for supplying eight to ten oxen, thirty milk cows, 6,000 pesos worth of cattle and seed, plus blankets and cloth to make clothing for the Indians. Also, Fr. Díaz said the mission lands were insufficient, and that the boundary on the west should be extended to the Nueces River and from there east to the bays. ${ }^{336}$ Díaz tried to influence the Commandant with his hopes and fears saying:

"my desires are most ardent when I contemplate, at a distance of ten to twelve leagues from that Presidio a precious, jeweled chapel filled with the beautiful images that are now abandoned and exposed to total ruin.

Only the wood in its rooms is ruined. But with the forest of weeds and pastures of the residents surrounding it is exposed to fire-because of the roof, curiously, is made of wood. Not many years ago it was built by my predecessor at a cost of 8,000 pesos." 337

Fr. Díaz' request to Ahumada represented the final, futile attempt to breath life into the moribund mission. In a time of national uncertainties and financial deficiencies, Díaz' plan must have seemed impossibly extravagant, not to mention difficult with the potential for endless complications implicit in the requested boundary change. It is not known how Commander Ahumada responded to Fr. Díaz's proposal, but it is not likely that he seriously considered implementing this request.

After five more years the delays ran out. In January 1830, Fr. Miguel Muro acknowledged the authority of the decree of the Supreme government, dated March 6, 1829, to "secularize" ${ }^{338}$ Mission Refugio. He requested a two-week extension so that the Refugio Indians could assemble and present themselves in order to receive what the decree provides them. ${ }^{339}$
In preparation for the required inventory of Refugio Mission property, Fr. Muro reviewed some of the earliest documents in the mission archives. He made copies of records written in 1795 by Fr. Silva and Commander Juan Cortés that pertained to the second founding of the mission and the extent of its lands. The original documents he utilized can no longer be found, but his copies survived ${ }^{340}$ February 8 , 1830, the Friar completed his inventory of the property of Refugio. He and Fr. Díaz signed it and handed it over to the Goliad Alcalde José Miguel Aldrete. ${ }^{341}$ Mission Nuestra Señora del Refugio was no more.

\footnotetext{
${ }^{336}$ Fr. Antonio Díaz de León to Mateo Ahumada, 8-21-1825, General Land Office, Box 122, Folder 15, pp. 226.

${ }^{337}$ Fr. José Antonio Díaz de León to Mateo Ahumada, 8-21-1825, General Land Office, Box 122, Folder 15, pp. 226.

${ }^{338}$ To change its status to ordinary, ecclesiastic, so that it would be administered by the bishop in which diocese it was located.

${ }^{339}$ Fr. Miguel Muro to J. Miguel Aldrete, 1-15-1830, General Land Office, Box 122/17, pp. 254-255.

340 Three documents copied by Fr. Miguel Muro on 2-8-1830 (Fr. Manuel de Silva to Juan Cortés, 1-8-1795; Juan Cortés to [Manuel Muñoz], 1-8-1795; and Juan Cortés to Manuel Muñoz and Fr. Manuel de Silva, 1-10-1795, Zapópan Microfilm Roll 1. (No frame or page numbers.)

${ }^{341}$ Refugio Mission Inventory, 2-8-1830, General Land Office, Box 122/17, pp. 247-247.
} 


\section{Chapter 4:}

The People of Mission Refugio

The translations of the documents from Mission Refugio given previously provide interesting and useful insight into the personal and political atmosphere that existed between the mission and the outside world. On further inspection however, these letters, record books, and inventories also provide limited glimpses into the lives of the Native and non-Native individuals who inhabited one of the last outposts Colonial Spain established in the New World.

\section{Native Inhabitants of the Mission}

As discussed earlier, Mission Refugio was established for the Karankawa Indians. Based on linguistics, Swanton, in The Indian Tribes of North America (1953), identified five principal tribes that constituted the Karankawan tribes of the Texas gulf coast between the Trinity and Aransas bays (Figure 4-1). When variations in French and Spanish pronunciation and spelling and the interpretation of various translators are taken into account, these tribes were known as the Coco, the Copan, Cujan, Coapite (Guapit), and Karankawa. Much has been written from translations of early journals and diaries about encounters with the various tribes of Karankawa who populated this area of Texas when the Europeans first arrived. The interested reader is encouraged to consult Bell (1987), Berlandier (1969), Chabot (1932), Covey (1983), Gatschet (1891), Newcomb (1961, 1983) and Weddle $(1973,1987,1995)$ for early European views on the nature of these coastal Natives. The readings should be supplemented with those of Aten (1983) and Ricklis $(1992,1996)$ who present less ethnocentristic studies of an informed, tenacious people who had successfully adapted to life among the bays, river valleys, and prairies of the central Texas coast. A complete recounting of these works is neither practical nor appropriate for this report as the focus here is on the people of Mission Refugio. Therefore, the following concentrates on information contained in the inventories and baptismal, burial, and census records from the mission (Appendices A and B).

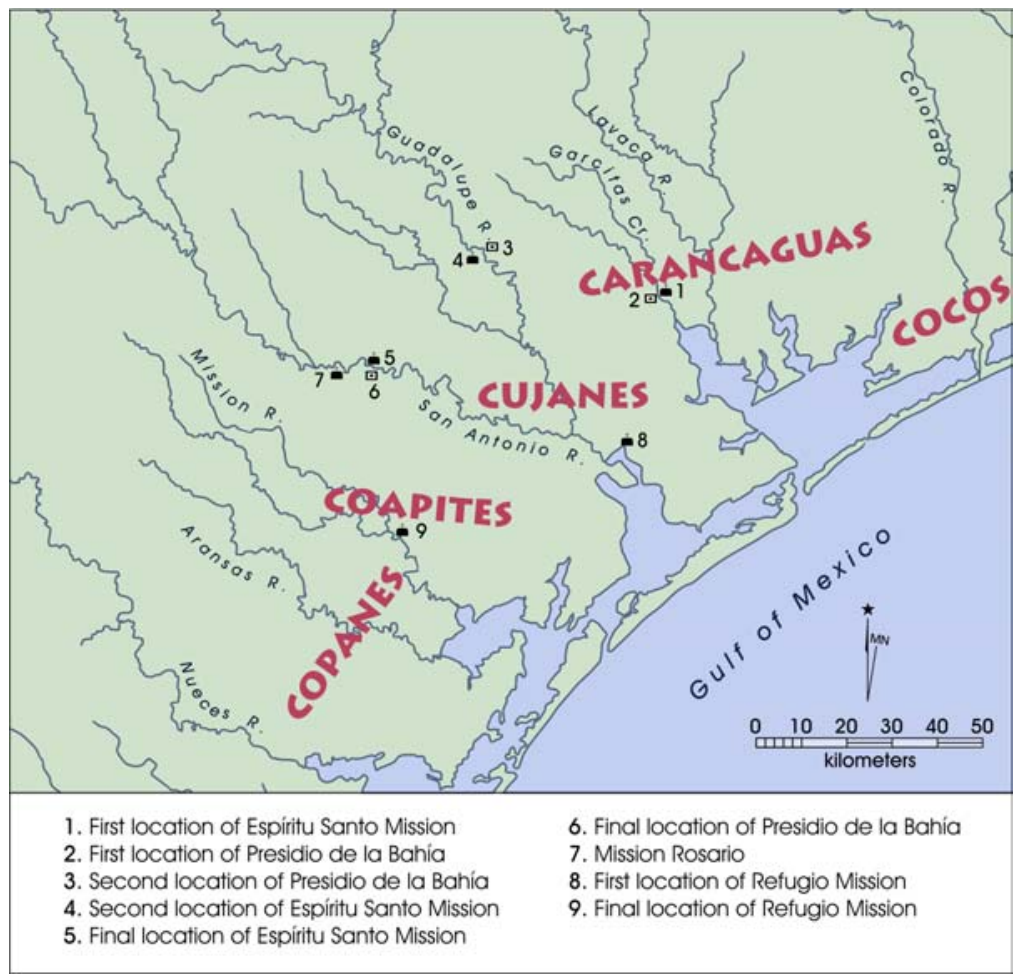

Figure 4-1. Range areas for principal tribes of the Karankawa along the Texas gulf coast. 
Karankawan tribe names distinguished in the baptismal and burial records from Mission Refugio include the Copan, Cujan, Coco, and Karankawa. In addition to these, other tribes or bands were also represented at the mission. These include the Pihuique (Piguique), the Pamoque (Pamague), and the Pajalache (Pahalachi) tribes associated with the inland Coahuiltecan speakers from the San Antonio missions (Martin 1972). Also present was at least one individual from the Malaguite (Malaquiit) tribe-also known from the San Antonio missions-but thought to have inhabited the southern portions of Padre Island, and the Iaraname (Araname) a tribe known to inhabit the area slightly north and east of the Karankawan coast (Martin 1972). At least one member of the Toboso tribe from northeastern Mexico (Griffin 1983:329-331) is present and the Lipan Apache are mentioned in two entries in the burial records.

From the previous chapter, we know that 43 Natives were with Fr. Silva when he took possession of the permanent site of Mission Refugio in 1795. These were undoubtedly some of the members of Llano Grande's group reported to be at the first mission site in 1794 . The inventory of 1796 lists 65 Indians at the mission in the month of September, when that inventory was assembled. By 1797 , a stable group of converts, led by Captain Diego had been established. This group was referred to as "Sons of the Mission" by Fr. Garavito (see Table 3-2). In 1804, 61 Indians are listed at Mission Refugio (see Table 3-3). An entry in the 1796 inventory lists three books for recording (Appendix A). Unfortunately, the records that document the first ten years of Mission Refugio have not been found. It is not until 1807, when existing baptismal and burial records (Appendix в) begin, and these "Indians" emerge from the records as individuals. This information-along with the names from Fr. Muro's 1823 list of mission residents (see Table 3-6) has been used to examine the lives of the people who lived at Mission Refugio. (Variations in the spelling of the names are noted wherever possible and can be attributed to both the poor quality of the original documents and inconsistencies among original recorders and translators. In cases where slight changes in names were encountered, parental and/or spousal references from baptismal and burial records were cross-checked to confirm identities.)

Father Garavito, in his unofficial 1797 census lists 12 men plus Captain Diego, 16 women, 35 boys, and 12 girls among the "Sons of the Mission" (see Table 3-2). The first of the original group of converts to be identified by name are Manuel (sometimes called Manuel Delgadito) and Refugia (sometimes called Maria del Refugio), listed as parents and "Children of the(this) Mission" in the first entry of the Baptismal Records. Manuel is Karankawa and Refugia is a "Christian" Pihuique. Their daughter, Maria Joseph Yrison, was born March 28, 1807 and baptized April 12, 1807 when she was 16 days old. Maria Joseph (Yrinoa) Yrison's name appears again on February 24, 1808 (although the Burial Records state 1807) when her death at age 11 months is recorded. Over the next 11 years, Manuel and Refugia have four sons who are baptized in the church. José Trinidad was born June 6, 1808 and baptized June 12, 1808. José Melchor was born January 6, 1813, baptized January 31, 1813, and died January 2, 1817 at the age of four. A third son, José Gabriel, was born November 15, 1815 and baptized April 1, 1816. The fourth son, José Faustino was born February 17, 1818 and baptized March 4, 1818. From the short period of time between the births and baptisms of four of these five children, it seems that Manuel and Refugia were in permanent residence at the mission. The only exception appears to occur between the birth of José Gabriel in 1815 and his baptism 3.5 months later in 1816. This hiatus corresponds to the time-period following the Mexican Revolution when the severe shortage of beef forced mission inhabitants to return to the coast and to the period when the mission was besieged by attacks by hostile Indian groups (see Chapter 3). Otherwise, Manuel and Refugia remained faithful "Children of the Mission" and are still shown as residents in 1823 (see Table 3-6). After Fr. Muro moved to nearby La Bahía and Mission Refugio ceased to serve as a mission, Manuel and Refugia continued to bring their children to be baptized. José Antonio Mario was baptized "in(on) the field" along with several other children on January 12, 1823 and nine-month-old Juan José was baptized during another group ceremony that took place "in the field" July 27, 1827. Manuel Delgadito and Maria Refugio are still listed as "Children of the Mission" at this late date.

Crisonomo, (Chrisostimo) of the Copan Nation, and Maria del Refugio, a Karankawan, also appear as parents and "Children of the Mission" in the early baptismal records. Their son José Crisanto was born October 22, 1807 and baptized October 25, 1807. He is followed by three sisters: Maria Magdalena, born May 19, 1812 and baptized May 27, 1812; Maria Ynes, baptized April 20, 1816 at three years of age; and Maria del Carmen, born in September 1818 and baptized October 6, 1818. Again, an extended hiatus from the mission corresponding to periods of shortages and unrest is seen in 1814 and 1815. Crisonomo and Maria del Refugio returned to the mission and are shown as residents in 1823 . 
José de Jesus, a Karankawan, and "a pagan of the same nation" are listed as parents for the baptism of José Martin Antonio who was born in November 1807, and baptized January 19, 1808. At this time, the designation as "Children of the Mission" is not made. The next listing is May 6, 1810 in the Baptismal records when José de Jesus and Maria Assumpcion, both Karankawa, are listed at the parents of eight-day-old José Simon without reference to "Children of the Mission." However, when their names are recorded on the burial record of José Simon who shortly after his baptism was buried on May 12, 1810, they are listed as Children of the Mission. The recognition of the mother's name appears to be the result of an adult conversion and baptism that took place August 16, 1808. After this time José de Jesus and Maria de Assumpsion (var. Assuncion, Ascension, or Concepcion) are listed as parents of three more sons and two daughters baptized and/or buried at the mission. Maria Augustina is listed as having been born "on the coast" in June, 1811 when she is baptized at two months of age at the mission on August 28, 1811. A second daughter, Maria de Carmel was born July 17, 1813, baptized July 18, 1813, and buried September 15, 1813 at two months of age. Oneyear-old José Leon was baptized on June 27, 1816, presumably because he was born while his parents were away from the mission during the tumultuous period between 1814 and 1816. However, their next son, José Nicolas, is listed as being "born in the forest" three months before he was baptized on March 5, 1818, so it is possible that José de Jesus and Maria de Assumpcion were not as permanent a family as others who were listed as "Children of the Mission." Their last son, José Martin, was evidently born at the mission on August 4, 1820 and baptized August 8, 1820. Based on the number, sex and age of children in the family of Jesus Grande listed on the 1823 list of mission residents, it is reasonable to assume that Jesus Grande and his family could represent the family of José de Jesus and Maria de Assumpcion.

Francisco, of the Guapit Nation, and Maria, a "Christian" Karankawa, are listed as "Children of the Mission" with their son, Juan de la Cruz, who was born on May 3, 1808 and baptized May 12, 1808. Four years later, their daughter, Maria de la Candelaria was born January 23, 1814, baptized February 21, 1814, and buried October 22, 1814. A second son, Francisco de Jesus was evidently born away from the mission in November 1814 during the troubled times, and was brought to the mission for baptism April 2, 1815 at 6 months of age. A Francisco Mocho and his wife and three children appear on the 1823 list of residents and could represent this family. Francisco and Maria appear again in the baptismal record signed at La Bahía after Mission Refugio ceased operation. On this record, Francisco and Maria are listed as Cujan as is their son, Hilario who was born in September and baptized on October 21, 1825. It would appear that these are the same individuals, as no other mention of Francisco and Maria as a couple occurs in the Refugio records. Perhaps an unfamiliar padre erroneously recorded their tribal affiliation.

A "pagan” Karankawa named Luna, and Barbara listed as a "Christian" Pamoque are recorded as the parents of José Arborio, a three-day-old male who was baptized on June 12, 1808. It appears that Luna was baptized and given the Christian name of Juan de la Santissima Trinidad on May 27, 1809 as he and Barbara then appear again for the baptism of their daughter Maria Melchara who was born December 29, 1810 and baptized January 7, 1811. Juan de la Sma. Trinidad and Barbara had another son, José Matheo who was born January 27, 1813 and baptized January 31, 1813. Evidently, Juan and Barbara did not leave the mission during the turbulent year of 1814 as many of the others did, as the Burial Records note that (Juan) Francisco de la Sma. Trinidad was "killed by Barbarian Indians" and buried on September 7, 1814. His wife, Anna Maria Barbara survived him. Maria Barbara's name appears as the widowed parent of a three-month-old son José Maria who was baptized May 4,1816 . She is again listed as a widow with two sons on the list of residents at the mission in 1823.

José Maria de(1) Pilar was a 25-year-old Karankawan male when he was baptized on October 12, 1807. His parents are listed as already deceased and there is a note that he was "first known among the Lipan." On January 23, 1809, he and Maria Concepcion, a Copan, had a daughter, Maria Dorothea who was baptized February 6, 1809. These Children of the Mission had two more sons, José, born March 8, 1814, baptized March 19, 1814 and José Ambrocio, who was baptized December 7, 1816 at one month of age. José Maria de Pilar is listed as the father of one more son, José Miguel who was baptized October 20, 1819 when he was two months old. José's mother is listed as Gertrudis, a Karankawa associated elsewhere in the records with José de Jesus (Jesus Chico). As both José Maria Pilar and Jesus Chico are shown with their wives and children as residents on the 1823 census, the listing of Gertrudis as the mother of José Miguel may represent an error.

Manuel (Karankawa) and Juana (Cujan) are listed as Children of the Mission at the baptism of their son José Hilario who was born on February 17, 1809 and baptized 
on February 25, 1809. A second son, José Silvestre, was evidently born at the mission on December 30, 1811 and baptized January 7, 1812. Between 1814 and 1819, Manuel and Juana have two more sons. It is likely that they were born away from the mission as José Ignacio was baptized June 6, 1815 when he was seven months old and José Francisco del Refugio was five to six months old when he was baptized on October 31, 1817. They also had a daughter, Maria Andrea, who was born November 10, 1819 and baptized November 30, 1819. Their third son, José Ignacio, was buried September 20, 1820 at age five. Juana is listed as a resident with one son and one daughter under seven years of age in 1823. Her name appears again as a widow for the baptism of her daughter Maria del Refugio on October 24, 1825 at La Bahía. Manuel must have died and been buried somewhere away from the mission sometime before 1823.

Thomas (Tomas), a Malaguite and Francisa, a Pahalachi, are listed as Children of the Mission for the baptism of their son Antonio who was born June 13, 1809 and baptized June 20, 1809. They had a daughter, Maria Teresa, who was born October 14, 1812, baptized October 22, 1812, and was buried May 1, 1813 at six months of age. Thomas and Francisa evidently left the mission shortly thereafter and did not return until their next son, José Gabriel, was baptized on June 6,1815 , when he was six months old. They had one more daughter, Maria Juana, who was 20 days old when she was baptized on February 17, 1819, suggesting she too may have been born while her parents were away from the mission. However, Tomas, his wife, a grown son, and two younger sons are listed as residents of the mission in 1823 .

José Miguel (Miguel Grande), a "Christian," Copan and Gordita, the "pagan daughter of Diego, Captain of the Karankawa Nation" are listed as the parents of Juana Maria Barbara who was baptized October 23, 1808, when she was two months old. Three months later, on February 16, 1809, Gordita was baptized at 17 years of age and given the Christian name of Maria Bernarda. Afterwards, she and José Miguel are listed as Children of the Mission although they may not have been permanent residents. Their son Santiago was two months old before he was baptized on July 25, 1811 and their next son, José Paulo, was one month old when he was baptized on July 6, 1814. Their only daughter, Juana Maria Barbara, died and was buried at the mission on July 12 , 1816, when she was eight years old. A third son, Ladislao, may have been born at the mission as he was only six days old when he was baptized on October 27, 1819. There is a Miguel Canonigo and wife on the 1823 resident census. They are shown with three sons, and José Miguel and Bernarda had three sons in 1823. Although the ages of the sons do not appear accurate, this family could be that of José Miguel and Bernarda. Miguel Grande and Bernarda have another son, José Maria de los Dolores, who was born away from the mission in 1823. They brought him to La Bahía for baptism on July 9, 1824 when he was one year of age.

On November 26, 1808, a 19-year-old man of Karankawa and Copan parents was baptized and given the name Pedro Alexander. One year later, on December 30, 1809, Pedro Alexander and his wife Maria del Loreto (listed as both of the Cujan Nation and Children of the Mission) attend at the baptism of their four-day-old daughter, Maria Leocadia. Three years later, on June 11, 1812, Pedro Alexander and Maria del Loreto of the Cujan Nation again are listed at the baptism of their three-day-old daughter, Maria Antonia. Unfortunately, the next listing is from the Burial Records where it was recorded that she was buried June 23, 1812. Pedro Alexander and Maria del Loreto had another daughter and four sons who evidently survived. The dates of the births and baptisms of the children suggest that Pedro and Maria did not reside at the mission year-round. José Maciano was one-month old when he was baptized on July 26, 1814 and his brother, José Maria de los Santos was one year old when he was baptized on November 11, 1817. Maria del Refugio, their last child to be baptized at Refugio was perhaps born there as she was born March 6, 1819 and baptized five days later on March 11. Pedro Alejandro is shown on the 1823 list of mission residents as the head of a household with a wife, two toddlers and a son between 7-16 years of age. They had two more sons both named José Francisco. The first was baptized at La Bahía on August 30, 1825, when he was two years old. The second José Francisco was baptized at one year of age, on January 3, 1828 "in the field."

José Guadalupe, a 20-year-old Karankawa, was baptized on December 19, 1810, as an adult convert at the mission. His parents are listed as "pagan" Karankawa already deceased. Perhaps he did not stay at the mission because his name does not appear again until five years later, when on January 21, 1815, José Guadalupe, listed this time as Cujan, and his wife Maria del Refugio, Karankawa, attend the baptism of their 22-day-old daughter, Maria Silvestre. They had two sons both of whom died shortly after birth. José Jacobo was born December 25, 1816, baptized December 30, 1816, and was buried January 1, 1817 (Baptismal Record erroneously notes daughter). José Luis was born August 24, 1819, baptized August 27, 1819, and buried October 25, 1819. There is a Guadalupe among the Native residents listed at the mission in 1823 . This man has 
two daughters under the age of seven at that time. It is not possible to determine if this reference is to José Guadalupe as the name of his wife is not given and these two daughters do not appear on the baptismal records. The names of José Guadalupe and Maria del Refugio do appear again on the baptismal records when their one-year-old daughter Maria Antonia is baptized "in the field" on November 20, 1825.

Maria Gertrudis, a 28-year-old Karankawa also received adult baptism on December 19, 1810. Her parents were Vicente and Maria del Rosario, both Karankawa. Six years later, Maria Gertrudis (Karankawa) and her husband, José de Jesus (Guapit) are noted when their two-year-old daughter, Maria Josefa, is baptized May 6, 1816. Although they have four more daughters who were baptized over the next 11 years, it does not appear that José de Jesus and Maria Gertrudis were ever permanent residents at the mission. Their second daughter, Maria Manuela was six months old when she was baptized on May 6, 1816. Even though Maria del Refugio was only eight days old when she was baptized on March 10, 1821, the notation in the records states she was "baptized in the field because of necessity." There is no indication what the necessity might have been, but another child, Maria Francisca, daughter of a Christian Karankawa named Juan de Dios, was also baptized "in the field" that day (and both female infants are listed as being eight days old). A Jesus Chico and his wife and three children are listed among the residents at the mission in 1823 and, aside from the fact that one of three children is listed as boy, this family appears to be that of José de Jesus and Maria Gertrudis. Jesus and Maria Gertrudis brought two more of their daughters to be baptized "in the field", even after Mission Refugio had ceased to fully function as a mission; threemonth-old Maria de Antonia de Jesus, who was baptized on June 24, 1827 and four-year-old Maria Josefa, who was baptized on July 27, 1827 and given the same name as her sister baptized 11 years earlier.

A new couple, Prudencio and Rosa (Rose) Maria, appear in the records as Children of the Mission in 1810 at the baptism of their nine-day-old daughter Maria Ana Patricia. Both parents are listed as Children of the Mission, with the father being Karankawan and the mother listed as Toboso. They are noted next when their 22-day-old daughter, Mariana Patricia, is buried on April 3, 1810. Again, on this entry, Prudencio is listed as a Karankawa and Rosa Maria is shown as Toboso, although on later entries one or both of them are shown as Cujan. Evidently they already had a four-year-old daughter in 1810 as they are shown as the parents of Maria Dionigia Bologia who was buried ten years later on
November 15, 1820, at 14 years of age. Prudencio and Rosa Maria appear to have been permanent residents at the mission for at least the next 13 years. They had two more daughters and three sons who appear, with one exception, to have been born at the mission. Their daughter, Maria Andrea was baptized on October 28, 1811 when she was 12 days old. Their next daughter, Maria Rafaela, was baptized on February 17, 1814. A son, José Marcelo de Jesus was born in January 1817 and baptized February 22 of that year. Their second son, José Francisco was born July 9, 1820, baptized July 18, 1820, and died July 19, 1820 when he was ten days old. Two months later, on September 16, 1820, José Marcelo de Jesus was buried at age three, and two months after that their older sister Maria Dionigia Bulogia (Bologia) was buried November 15, 1820. In the space of six months, Prudencio and Rosa Maria lost three of their children. They had one more son, José Maria del Refugio who was not baptized until May 17, 1823, when he was four months old. Prudencio appears on the list of residents in 1823, although the number and ages of the children given on this list do not appear to be accurate.

Maria Petra (Leolao) appears in the baptismal records on March 14, 1810 when an adult of 16 years of age, daughter of pagan parents already deceased is baptized. Here it is noted that her name "Leolao" signifies squint-eye in the language of her nation. Then in 1811, José Maria (Toboso) and Maria Petra (Karankawa) appear in the records as parents for the first time on March 4, at the baptism of their seven-day-old daughter Maria del Refugio Casimira. Later, their first son, José de Jesus, was born on December 5, 1812 and baptized on Christmas day of that year. However, it was not until the baptism of their second son, José Ancelmo, on April 20, 1816 at six months of age, that José Maria and Maria Petra are shown as Children of the Mission. Whether they were permanent residents before and after this hiatus is unknown, but their second daughter, Maria Antonia, was listed as an infant when she was baptized on July 25,1818 , suggesting she was born at the mission. There is a José Maria Joaquin listed as one of the residents on the 1823 census. However, it is difficult to determine if this is the same family described above as José Maria Joaquin is shown as having only two children, a boy and a girl ages seven years or younger. While these ages fit those of José Maria and Maria Petra's younger children, there is no accounting for the older two who would have been 11 and 12 in 1823. José Maria and Maria Petra are listed together as the parents of a fourmonth-old son, Maria Guadalupe, who was baptized "because of necessity..." along with five other children on July 27, 1827. 
An adult conversion occurred June 9, 1810 when "Caral Malo" (Hard-head), son of the Indian Chief (Cabozon) deceased pagan of the Coco Nation, and a pagan Karankawa woman was baptized at the age of 20 as José Feliciano. The next recording for Feliciano (Felisiano) is when he and Maria Manuela appear in the records as the parents of ten-day-old Maria Merced who was baptized September 20, 1811. Although their tribal affiliations are not given in this entry, when their two-month-old son, José Leandro is baptized on February 27, 1814, Feliciano is identified as a Coco and Maria Manuela as Pamoque. Both parents are also shown as Children of the Mission at this time. They have two more daughters; Maria Pascuala, baptized on May 17, 1816 at three months of age, and Maria del Refugio del Carman (Carmen), who was baptized at La Bahía on August 28, 1825 when she was a year old (the Baptismal record states "son"). Feliciano appears on the 1823 list of residents although the sex and number of children does not exactly match the available records. A final entry appears for this couple when their son Leandro, 11 years of age, died of a fever in 1825, and was buried October 8th in the cemetery at La Bahía.

A Karankawa couple, Pedro and Juana, appear among the last Children of the Mission noted in these records. Although they brought three sons and two daughters to be baptized over the following nine years, it does not appear likely that any but the first was actually born at the mission. Their first, José Angel, was baptized on March 4, 1818 when he was 11-days of age. On September 30 of the following year, Pedro and Juana brought their six-month-old daughter, Maria Gertrudis to be baptized. Pedro and his wife were listed as residents on the 1823 census, but with only one daughter. It is possible that José Angel, who would have been five years of age in 1823 , could have died while his parents were away from the mission. Two other sons, three-year-old Juan José, and one-year-old Crisanto were baptized someplace other than Mission Refugio on October 24, 1825 and their baptismal papers were signed at La Bahía. This was the same day that Juana, the widow of Manuel, had her daughter Maria del Refugio baptized.

The final new couple to be added to the list of Children of the Mission were José Antonio and Maria del Refugio, both of the Karankawa Nation. Their names appear as the parents of Maria Louisa who was born October 10, 1812 and baptized October 16, 1812. Maria Louisa died and was buried at the mission three days later. The entry in the Burial Records has her father listed as Antonio and her mother as Maria del Rosario. Antonio died five years later and was buried on November 30, 1817 in the "Cemetery of the Holy Kiss of Our Lady of Refugio."
Ana Maria, a Cujan, was one of two single parents listed on the baptismal records as a Child of the Mission. She appears late in the records when she brings her three-month-old son Juan José to be baptized on March 5, 1818. Two more of her children were also among the group of six children who were baptized "in the field" on July 27, 1827. They were 17-month-old José Luis and three-year-old Maria Dolores.

The second single parent and Child of the Mission is a Karankawa woman named Jesusa. Her son Francisco was baptized on March 29, 1821 when he was only four days old, suggesting he was born at the mission. Subsequently, Francisco died and was buried on April 10, 1821. Jesusa also had a daughter, Maria Antonia, who was baptized on January 12,1823 when she was two months old.

Two other Children of the Mission are known only from the Burial Record. They are Gil and his wife Maria Dolores, both Copan. Gil died and was buried at the mission on February 21, 1809. He was 70 years old. There is no further mention of Maria Dolores.

In addition to the adult baptisms discussed previously of the individuals who went on to become Children of the Mission, other adult names appear in the Baptismal Records. On January 7, 1812, 30-year-old José Geronimo and 27year-old Maria Rafaela were baptized. They were both Karankawa and both of their parents are listed as "pagan" Karankawa. The record for José Geronimo lists parents as "father deceased" while Maria Rafaela's baptismal record lists parents as "both deceased." It may be assumed from this that these two were related paternally and were brother and sister. Although Maria Rafaela does not appear in subsequent records, a Jeronimo is shown as a resident on the 1823 census so he may have remained at the mission. Two Maria del Refugios were also baptized as adults, although these appear to have been deathbed baptisms. The first Maria del Refugio, an aged Lipan was baptized December 1, 1817, "in extreme danger of death." She was buried the next day. There appear to be errors in the dates entered for the second Maria del Refugio. The records show that on September 30, 1820, a 22-year-old Karankawa female "in ...danger of death" was baptized as Maria del Refugio. That same day a one-day-old male of pagan Karankawa parents was baptized as José Miguel. On September 13, 1820, a 22-year-old Karankawa named Maria del Refugio was buried and on September 19, 1820, José Miguel, a seven-day-old infant with pagan Karankawa parents was buried. Despite the discrepancies in the dates, these entries appear to record the deaths of a mother and her son shortly after childbirth in September 1820. 
The term "Children of the Mission" used in association with the couples and families discussed appears somewhat ambiguous. It may have originally been used to denote those individuals under the leadership of Captain Diego who were baptized into the Catholic faith and took up residence at Mission Refugio. However, through time its meaning seems to have been altered. While all of the people it was applied to had Christian names, few were full-time residents of the mission. Conversely, while none of the people discussed in the following were permanent residents, many had Christian names and long histories with the mission but were not designated as Children of the Mission.

Perhaps the most notable of these is Captain Juan Diego, the leader of the Karankawa at Refugio. On September 25, 1808, (Captain) Juan Diego and his wife had two of their children baptized: Maria Pacifica their one-year-old daughter and José Lino their four-year-old son. At this time, the parents are listed as "pagan" Karankawa, indicating they themselves had not yet joined the church. However, on February 16, 1809, when his adult daughter Maria Bernarda was baptized, Captain Diego is listed as a Christian Karankawa while Maria Bernarda's mother, Josefa, is listed as a pagan Karankawa. While it is possible that Captain Juan Diego joined the church sometime during this period, there is no record of his baptism, he is listed as a "pagan Karankawa" on later baptismal records, and he is never shown as one of the "Children of the Mission."

On October 28, 1809, eight months after her daughter's baptism, Josefa Maria, "the woman of General Diego of the Karankawa Nation" died at the age of 40. It is not known if Josefa was the mother of the two younger children baptized in 1808. In 1810 the baptismal records for May 6th, note that an Indian known as Juan Diego and his woman, both pagans of the Karankawa Nation, attended the baptism of their son, four-month-old Juan Agustin. The baptismal records do not indicate the name of the mother for this birth. But, Josefa could have been the mother of Captain Diego's nine-year-old son, José Estevan, whose mother was listed as "already deceased" when he was brought to the church for baptism on December 27, 1810. Captain Diego's sixyear-old daughter, Juana Maria was also baptized that day. Her mother is simply listed as a "pagan woman." Although Captain Diego had three more sons baptized, it does not appear that he or his family ever resided permanently at the mission. He and his "woman" brought their one-month-old son, Buenaventura, for baptism on July 22, 1812. He and Maria del Rosario had José Maria baptized on June 6, 1815 when he was five months old. Juan Diego appears as the father, with Maria del Rosario, for the baptism of their threemonth-old son, Juan Bautista, on July 1, 1817. The name Maria del Rosario appears alone on two subsequent entries to the Baptismal Record, once on December 8, 1818 for the baptism of a one-month-old daughter, Maria Ana, and again on January 3, 1828 when her three-year-old son Rafael is baptized. No father is given for either of these children so it is not possible to say if they are the children of Captain Juan Diego or if the mother is even the same Maria del Rosario. This confusion is compounded by the fact that there are numerous Maria del Rosarios and Maria del Refugios throughout the records and these names seem to have been used interchangeably. Neither Juan Diego nor Captain Diego appears on the list of mission residents in 1823. There is however a Rosario listed among the (non-baptized) "Gentiles" on the 1823 census as single with two adolescent boys, a female other than herself aged 16-50, and a male between 16-50 years of age in her household.

La Chata, the pagan daughter of the contentious Karankawa leader Chief Fresada Pinta, and a Copan man named Pedro Antonio were the parents of Margarita Maria Dolores, a nine-month-old infant who was buried at the mission on February 8, 1807. This child's name indicates that she had been baptized earlier. Then, October 15, 1808, their fourmonth-old son Juan José is baptized and on April 12, 1810 the couple are listed as parents of five-day-old José Francisco. On June 9, of the same year an adult baptism is noted, a 25-year-old female known as "La Chata," daughter of Captain Fresada Pinta (deceased) and Maria Toboso (already deceased), is christened as Maria Feliciana (see Chapter 3). Later in the records, Pedro Antonio and Maria Feliciana are shown as the parents of a four-day-old infant who is baptized as Pedro on April 29, 1812. Pedro Antonio and Maria Feliciana have two more children, both daughters, who are baptized at the mission. Maria Petra was 1.5 months old when she was baptized on September 3, 1813 and Maria del Refugio was five months old when she was baptized on June 26, 1817. Whether intentionally or through oversight, Pedro Antonio and Maria Feliciana are never shown as Children of the Mission. Pedro Antonio, his wife, one son and three daughters are listed as mission residents in 1823.

José Eliseo, Karankawa, and Marie, Cujan, appear in the records on December 17, 1810 at the baptism of their daughter, Maria Gregoria. Since she was four days old at the time she was baptized, she was probably born at the mission. Maria Gregoria died and was buried at the mission on February 20, 1812 when she was barely two years old. It is possible that her parents remained at the mission as her 
father, José Eliseo, was also buried there three years later on May 21, 1815.

Maria Dolores, a widow of the Copan Nation appears in the records January 27, 1810 at the baptism of her ten-day-old daughter Maria Petra (father is listed as unknown). Her name does not appear again until 1816 when, Juan Nicolas, a Pamoque, and Maria Dolores, Copan, attend the baptism of their four-month-old son José de la Cruz on May 4, 1816. This couple are not mentioned again until the 1823 census when Juan Nicolas, his wife, one young son, one adolescent daughter, and one grown son are shown as residents at the mission.

Paulin and Carmel, both Karankawa, also appear for the first time in 1816. They were the parents of Maria Clara, a 15-day-old infant who was baptized on August 12, 1816. Paulin was also shown on the list of residents of the mission in 1823. However, this Paulin and his wife had three sons under the age of seven at that time.

Leal and Larga were listed as pagan Karankawa parents of two daughters baptized at the mission. Maria Hilaria, was only eight days old when she was baptized on February 25, 1809 and may have been born at the mission. On March 17, 1810 "La Larga" is listed as the mother of José Patricio, the five-year-old son of pagan parents of the Karankawa Nation. In this entry the father is mentioned only by nationality not by name. Then, Leal and Larga are again listed as a couple in the baptismal records in relation to another daughter, Manuela who was baptized at two months of age on June 15, 1812. Leal and Larga both appear on the 1823 census, but here they are listed separately. La Larga is listed among the (non-baptized) "gentiles" as a single woman with two adolescent daughters and a male, presumably her grown son, between the ages of 16-50 in her household. Leal is shown among the single males as a gentile.

Quinol (translated as Cloudy) and Bahan (translated as Foolish) were also listed as pagan Karankawa parents of two children who were baptized at the mission. Their twomonth-old son and his three-year-old sister were baptized together on December 27, 1810 and given the names Juan and Maria Estafania. Quinol and Bahan do not appear again in the mission records.

Maria Rosa was one year old when she was baptized on August 30, 1816. Her mother was listed as La Cojita, a pagan Karankawa, and her father was listed as unknown. Perhaps Maria Rosa was brought to the mission because she was ill, as three weeks later, on September 3, she died and was buried at the mission. Her mother may have stayed on at the mission as there is a La Cogita who appears on the 1823 census. She is listed among the (non-baptized) "gentiles" as a single woman with two boys under the age of seven.

There are entries for two other children who perhaps were brought to the mission for baptism because they were ill. Juan Carlos was baptized on November 6, 1813 and was buried November 19, 1813. Maria del Refugio was two years old when she was baptized on November 4,1813 . She was buried two months later on January 28, 1814. On each of the entries for these two children the parents are simply listed as pagan Karankawa so it is unknown if they were related. There are also two newborns whose names appear only on the Burial Record: Maria Petra, who was buried on December 9, 1810 and Francisco Xavier, who was buried two days later, on December 11, 1810. Unfortunately, on the entries for these two infants the parents are simply listed as pagan Karankawa so it is not possible to determine if they were twins or if they were even related.

\section{Non-Native Inhabitants of the Mission}

To be successful, Mission Refugio needed Spanish citizens and skilled laborers as well as Native Americans. Much of the early construction at the new mission site was done by soldiers assigned there and workmen borrowed from the San Antonio area. But we know from the Baptismal and Burial records and from an official census of Spanish citizens taken in 1810 (Appendix в) that the mission did eventually establish a stable base of citizens of its own. The members of the families that make up this core group of non-Native mission inhabitants are identified, although somewhat inconsistently, in the records as "members" or "servants of Mission."

Ricardo Lopes and Jacima de Nova (Jacinta Nava) are the first "members of the mission" to appear in the church records. Unfortunately, this entry is in the Burial Records and records the death of their child Anna Maria Leonarda on May 16, 1807 (Baptismal Record erroneously notes son). Their names appear again on November 11, 1808 for the baptism of their four-day-old son Cecilio Antonio, who survived less than a month and was buried on December 1, 1808. On the 1810 census, José Ricardo Lopes is listed as a native of Real de Cedros who came to this part of the frontier via San Luis Potosi in 1784. His occupation is listed as farmer and at the time of the census he was 40 years old. His wife, 28-year-old Jacinta Nava was a native of Linares. 
Prior to coming to Mission Refugio, Ricardo and Jacinta must have resided in La Bahía as it is shown as the birthplace of their three living daughters: Maria Isidora (Ysidora), age 14; Maria del Refugio, age 11; and Mariana, age 3, who was still living in La Bahía at that time.

At the time of the census, Ricardo and Jacinta owned a wooden house, two yoke of oxen, and four horses. They also had two servants. José Esmeregildo Ramirez, a 30-yearold native of Queretaro was listed as a mule driver and José Vicente Gonzalez, who was a 25-year-old herder from Carmargo. Although their names do not appear elsewhere in the records, José Ricardo and Jacinta Nava had two more children who were born at the mission after the census was taken. Their daughter, Maria Agapita was born March 16, 1812, and baptized the next day, March 17, 1812. This child lived only six days and was buried on March 22, 1812. Six years later they had a son, José Gorgonio, who was born on September 7, 1818 and baptized at the mission on September 15 th of that year. Ricardo and Jacinta, either as a couple and/or individually with another adult, were sponsors for six of the Native American children baptized at the mission. José Ricardo Lopes died and was buried on September 3, 1820 . His age at death was recorded as 40 , but based on the 1810 census he would have been 50 . No further references to Jacinta Nava are found.

Maria Ysidora, Ricardo and Jacinta's eldest daughter, appears again in 1815 with Pedro Najar (Huizar) as the parents of José Buenaventura who was baptized on July 21, 1815 when he was one day old. Maria Ysidora evidently died during childbirth as she was buried the day of the baptism. She was 19 years old. José Buenaventura died four months later on November 11. Some years later, Pedro Najar married Maria de Juana Mexias (Jesusa Mexia), the widow of Pedro Espinosa who had been "killed by Indians near the mission" on May 31, 1816. Jesusa had one daughter, Maria Manuela who was born on April 14, 1813, and one son, Augustin, who was born on August 26, 1815. Pedro Najar and Jesusa Alexia (Maria de Jesus) had one son, Rafael, who was baptized October 20, 1819 and was buried October 28, 1819. They also had a daughter, Maria del Refugio, who was born on October 25, 1822 and baptized on October 30, 1822. It is possible that Pedro Najar and Maria de Jesus are the family that appear on the 1823 census under Pedro Naxar. If so, they would be one of only three of the early families that perhaps were still present at the mission when the census was taken.
M. Juan Rosales and Eulogia Morin, from Nacogdoches are listed as the sponsors of the first Native American child baptized at the mission in 1807 . On the 1810 census, Juan Rosales was listed as a 35-year-old carpenter from Bordeaux who came to the mission in 1802. He had a 34-year-old wife, Maria Feliciano Ybarro, a 15-year-old daughter, Maria Elogia Morin, and two sons, 14-year-old José Casimiro Morin and 12-year-old Marcelino Morin, all from Nacogdoches. The sons were also listed as carpenters as was a 17-year-old servant named Geronimo Huizar from Bexar. Two other servants were listed as herders: 15-yearold Juan Povedano from Bexar, and 20-year-old José del Carmen Cruz from La Bahía.

Maria Elogia Morin, the eldest daughter of Juan Rosales and Maria Feliciano Ybarro, married Geronimo Huizar sometime around 1812 and stayed on at the mission. They had one daughter, Maria Paula del Refugio born in 1814, and two sons, Juan José Huizar born in 1816, and Pedro José born in 1818. Juan and Feliciano's eldest son, José Casimiro Morin married Michaela Orrutia. They had one son, Francisco Xavier who was born on November 30, 1815, baptized on December 3, and was buried December 12 th of that year. Their younger son, Marcelino Morin may have married Concepcion Gonzales as they are listed together as sponsors for several baptisms, but are not recorded as parents of any of their own children.

Undoubtedly, the Rosales household was responsible for most of the construction that took place at the mission, including the church that was built in 1804 . They were also active in the lives of the mission Indians. Various members of this family, either immediate or extended, acted as sponsors for 39 of the Native children and adults and 13 of the Hispanic children baptized at Mission Refugio. However, no members of this extended family are listed as residents on the 1823 census of Fr. Muro.

Pedro Texeda was shown as a 44-year-old native of La Bahía on the 1810 census. His wife was Catarina Huizar, a 23year-old native of Bexar. Whether Catarina Huizar and Geronimo Huizar (above) were related is unknown but they did act together as sponsors for several mission baptisms. Pedro Texada and Catarina had no children of their own, but were sponsors for at least four baptisms of mission children. Pedro died in November 1816 at the age of 50 . Sometime later, Catarina married Manuel Gomez. They too had no children. Manuel Gomez died on February 25, 1821. 
His age at death is given as 30 , and a note on the record states he "died at the hands of the Barbarian Indians."

There was also a Barbara Texeda who, like Pedro Texeda (above) was a native of La Bahía. Barbara was shown on the 1810 census as the 23-year-old wife of José Antonio de la Garza, a 58-year-old native of Rio Grande. At the time of the census they have a five-year-old son named Jesus de la Garza. Barbara Texeda appears on none of the other church records and it is not known if she was the daughter of Pedro Texeda.

Juan Povedano, the second young man from Bexar listed as a servant to Juan Rosales also became an active member of the mission. He married Maria (Nacia) Salorno (Salome) Gonzales when he was about 19 years old. They had five children, four sons and one daughter. One of the sons, José Maria Povedano died in infancy in 1816, as did the one daughter, Maria del Rosario, who died in 1817. The other sons, José Augustin, born in 1812, José Lorenzo de la Asuncion, born in 1814, and José Francisco, born in 1818 survived. Juan and Maria Salorno were also sponsors at four Native and one Hispanic baptism. However, there are no other records relating to this couple after 1818 .

Enrique (Manoique) Gonzales and Maria Nicolosa Povedano (Pobedano) appear in the church records on January 12, 1810, when they are listed as the parents of José Lucas, a three-month-old infant who was buried that day. They are not shown on the 1810 census, but as José Lucas was not baptized at the mission it is likely that the couple arrived there shortly after his birth in 1809 . Over the next seven years they had three sons and another daughter who were baptized as infants there: Jauna Maria, baptized on February 29, 1811; Maria de Jesus, baptized on December 27, 1812; José Trinidad, baptized on May 22, 1815; and Maria Asencion, baptized on May 22, 1817. The couple also acted as sponsors at three Native and one Hispanic baptism. It is not known whether Enrique Gonzales or Maria Nicolosa Povedano were related to Juan Povedano or Maria Salorno Gonzales discussed above, but the similarity in names seems to be more than just a coincidence. There is no record of this couple after 1817.

Juan José Chirino was listed on the 1810 census as a 52year-old widower from Bexar. The name of his deceased wife is given in later entries as Maria Josefa Cabrera. Juan José Chirino was a farmer and owned a wooden house, five horses and two mares. His 22-year-old adult son Juan was shown as living with him. Juan, the son, died and was buried on July 6, 1811. José Chirino died on June 17, 1816 (Burial Record defines age as "about 75" although the 1810 census refers to him as 52). Before his death he was the sponsor at two Native American baptisms, once by himself and once with Maria Trinidad Chirino.

Maria Trinidad Chirino appears on the 1810 census as the wife of Martin Gomez. They are both shown as being 28 years old and natives of La Bahía. Maria Trinidad would have been the right age to be the daughter of Juan José Chirino. Martin Gomez was a farmer and owned three yoke of oxen, four horses, and three cows. At the time of the census Maria and Martin had two daughters, 11-year-old Maria Josefa (perhaps named after her grandmother) and eight-year-old Maria Miguela. There was a child named Maria Josefa who died in October 1811. However, as no parents were named on this burial entry it can not be determined if this was the daughter of Martin Gomez and Maria Trinidad. Although Martin and Maria had no other children, they appear as sponsors at four baptisms at the mission. Martin Gomez died and was buried on January 19, 1816 and the record notes his age as "about 40" years of age. Although the name Trinidad Chirino is listed among the residents of the mission in 1823, this individual seems to have been a man with a wife and one son between 7-16 years of age and not the Maria Trinidad Chirino discussed here.

There were two other families at Mission Refugio with the surname Chirino who appeared after the 1810 census. Luis Chirino and Maria Luisa Benites were the parents of Maria Gertrudis Chirino who was baptized on May 26, 1816 and was buried May 30, 1816. José Chirino and Maria Gertrudis appear as the parents of Mariano when their son was baptized on December 8, 1818 (Baptismal Records notation refers to this couple as Children of this Mission.)

Maria Antonia Garcia appeared on the 1810 census as a widowed housewife from La Bahía who was 60 years old. The name of her deceased husband is given in a later entry as José de los Santos. Living with her at the time of the census was her 30-year-old son José Maria de los Santos. He was listed as a farmer. Their holdings included a wooden house, two yoke of oxen and three horses. José Maria later married Maria Estebia Cortez and they had two children. Their daughter, Maria Eugenia, was born on September 7, 1813 and baptized on September 25 of that year. Their son, José Manuel, was born January 5, 1816, baptized January 16,1816 . He died and was buried two days later, on January 18,1816 , when he was two-weeks old. Maria Antonia Garcia 
was also buried at the mission on March 23, 1821, when she was 71. There is a Juan José de los Santos shown on the 1823 list of mission residents. However, this resident does not seem to be the son of Maria Antonia Garcia as this man is listed as a widower with one son who is between 7-16 years of age.

José (Juan) Faustino Garcia is listed on the 1810 census as a 33-year-old native of Bexar who came to the mission in 1805. Faustino Garcia's occupation is shown as master mason. His wife, Margarita Vasquez (Basquez), is 21 years old and a native of La Bahía. Their household also included a female servant named Trinidad Morin who was a 28-yearold native of Guadalajara. Faustino and Margarita owned a wooden house, 20 cows, three yoke of oxen, and two horses. At the time of the census there were no children, but on February 9, 1810 the couple is listed as parents at the baptism of their nine-day-old son José Apolonio. The following year Maria Nieves was born and baptized on August 7, 1811, when she was three days old. Faustino Garcia and Margarita Vasques are listed as the parents of a seven-day-old female, Maria Gordiana, when she is baptized on May 10, 1813. Interestingly, they are also listed as the parents of a threemonth and two-day-old boy, José Antonio Garcia, who was buried on August 5, 1813. This would mean that he also was born in May, at the same time that Maria Gordiana was born but was not baptized. If they were twins, it is possible that José Antonio was ill when born and that baptism was delayed until it was evident whether or not he would survive. Perhaps this birth also had a detrimental effect on the mother's health because Margarita Vasquez died the following year, on July 25, 1814 at the age of 25. Faustino died three years later on December 31, 1817, leaving the care of his family to Maria de la Carmen who is shown as his wife on the burial record. The record also notes that he was the caretaker of the tobacco warehouse when he died. Maria de la Carmen may not have remained at the mission, as her name does not appear on any of the later records.

According to the 1810 census, Pedro de Luna and his wife Serafina Trexo may have arrived at Mission Refugio as early as 1796 . On this census, Pedro was listed as a 50-year-old farmer from Saltillo and Serafina was shown as a 38-yearold native of La Bahía. They had three sons, 12-year-old Teodoro, ten-year-old José Bautista, and seven-year-old José Lazaro who were also listed as farmers. They are also shown with two daughters, three-year-old Maria Petra and eightmonth-old Maria Timotea. All of the children are listed as natives of La Bahía but Maria Timotea was baptized at Mission Refugio on February 2, 1809. Pedro and Serafina had one more child after the 1810 census. Serafina Trexo died giving birth to their son José de la Cruz who was baptized on July 17, 1810, the same day his mother was buried. Eight days later, the infant son of Pedro de Luna and Serafina Trexo was buried. Although his name was listed as José de los Santos in the burial record, this was undoubtedly the same child. No other reference to Pedro de Luna or his children was found in the records of the mission.

\section{Summary and Discussion}

While the baptisms and deaths of many individuals not presented here are recorded in Appendix B, those that are discussed make up the Native and non-Native families that formed the nucleus of life at Mission Refugio between the years 1807-1825. Some obvious conclusions can be drawn from the details given above. The most obvious is that the names and numbers in these records represent real people and real events in their lives. Life was not easy and death was a constant companion of the Native and non-Native inhabitants alike. Most of the families lost at least one child -some lost more. Native and non-Native women and children died during childbirth and Native as well as nonNative men died violent deaths in this frontier setting, leaving young and old widows and widowers, often with children to raise.

Other details emerge from this information as well. There was a group of at least quasi-permanent Native American residents at the mission. The padres recognized this group of 18-20 families and differentiated them from the others who came to the mission by calling them Children of the(this) Mission. And the Children of the Mission remained attached to Refugio for the duration, as many of their names appeared consistently throughout the 20-year span covered in the existing records. Eighteen of these families appear among the 1823 list of residents at the mission and 11 of these same families account for 20 of the 23 who appear for the group baptisms "in the field" after the mission is abandoned.

This loyalty appears to hold true for some of the Gentiles at the mission. While some of the non-Christian Natives are only identified as "pagans" in the records, there are others that are identified by name repeatedly over a 6-12 year period. So while the Native population at the mission may have been dynamic in the sense of the number of people who were there at any given time, the makeup of this population was stable. With few exceptions, the same Christian and gentile families appear throughout this twenty year period. 
Surprisingly, it is the civilian population that is the most dynamic. As discussed, the core of the civilian population was, for the most part, comprised of two generations from four or five large extended families. The family names Rosales, Lopes, Chirino and Huizar dominate the records both as parents and baptismal sponsors. However, there are over 30 non-Native couples who were not discussed as their names only appeared in one or two entries in the mission records. These couples seem to have been short-term residents, perhaps because many of them were part of the military contingents who were stationed at Refugio for brief periods of time.

It is also apparent that there was a fair amount of mixing between the tribes that lived in south Texas in the eighteenth and early nineteenth century, at least among those at Mission Refugio. Various combinations of Karankawa, Copan, Cujan, Pamoque, Toboso, Pihuique, Guapit, and Pahalachi can be found among the parents and spouses in the mission records. It is likely that this trend extended to those groups outside the mission as well and may have been the result of intentional intertribal partner selection. It could also reflect a coalescence of groups prompted by mobility restrictions as more settlers moved into the area. Tribal identities seemed to have become blurred over time, as evidenced in the many changes in tribal affiliations seen throughout the records. On numerous occasions, individuals listed originally as belonging to one tribe will appear in later entries affiliated with another. Whether this blurring effect extended past the perception of the recorder, however, is not known.

It should also be noted that no instances of unions or marriages between Natives and non-Natives were noted in the records and none were apparent among the various names listed. There also does not appear to be any mixing among the couples. While this monogamy may, in part, be attributed to the teachings and atmosphere of the mission, it seems to have been the case among the "pagans" as well. For example, Leal and Larga appear to have remained together for at least 14 years and Quinol and Bahan had children who were three years apart in age. As discussed above, it seems that even Captain Diego, who appears to have fathered children with numerous "pagan" women, may in fact have had only two wives, with the second, Maria del Rosario, only appearing after the death of Josefa Maria.
The effects of events outside the mission are also reflected in the various mission records. Two of these events, which occurred over a consecutive four-year period, were the 1811-1813 battle between royalists and revolutionaries for control of Texas and the Comanche uprising in 1814. Both of these events are discussed in detail in the preceding chapter, and their cumulative consequence as reflected in documents was the temporary Native American desertion of the mission. As noted in the previous individual discussions, only three of the families designated as Children of the Mission appear to have been in permanent residence during all or part of this period.

The eventual demise of Mission Refugio, precipitated by the hurricane of 1818 and accelerated by the frequent reassignments of mission priests, is also discussed in detail in the previous chapter. It is during this period that the core families of the civilian population cease to appear in the mission records. After 1819 there are only two non-Native baptisms in the records. When the 1823 census was done, Fr. Muro counted only 18 civilian residents, the native inhabitants seemed less willing to leave. Amazingly, even following the final abandonment of Mission Refugio after the "fatal negotiation" with the Comanches in February 1824, many of the most loyal Children of the Mission continued to bring their children to the mission priest for baptism. Group baptisms were conducted "in the field" for three children on October 24, 1825. A larger group baptism was conducted for seven of the children of regulars on July 27,1827 , and a final group of five was baptized on January 3,1828 . In all, 23 Native American children were baptized after Mission Refugio was abandoned.

The overall conclusion that can be drawn from the review of the mission inventories, burial records, baptismal records and censuses is that despite its inevitable end, Mission Refugio successfully met its goal of bringing the Catholic religion to the people of the south Texas coast. During the 21-year period between 1807-1828, 145 Native Americans and 68 civilians were baptized into the Catholic faith. From the 43 Native Americans who accompanied Fr. Silva to the new site of Mission Refugio in 1795, the mission's Indian population grew to 120 in 1823 and 23 new members were added even after the mission was abandoned. It was not discontent or apathy on the part of the Native residents, but political events beyond their control that brought this mission to its close. 


\title{
Chapter 5:
}

\section{Post-1830 History}

\section{From Secularization to Modern Times}

\author{
I. Waynne Cox
}

\section{Introduction}

After the last services were held at Mission Refugio on February 7, 1830, the thirty-five year old church complex was effectively abandoned, but its impact was destined to be far-reaching and diverse. The abandoned mission would bear witness as its remote wilderness setting was transformed from a new settlement, to a colony, and finally to part of a new republic and a state.

In the declining years of Spanish rule, numerous attempts were made by several filibusters to either separate the frontier for annexation to the United States as the nation continued its western expansion or to carve out a new independent empire from the sparsely settled lands of Texas. After the defeat of the almost successful attempts of the Gutiérrez-McGee invasion, August 18, 1813, by General Joaquín de Arredondo, the area was left broken and underpopulated. Arredondo, as commandant of the eastern division of the Provincias Internas (internal provinces), appointed Cristóbal Domínguez as interim governor of Texas and returned to Monterrey (Thonhoff 1996 1:255). Colonel Antonio María Martínez assumed the political and military governorship of Texas on March 27, 1817. For a government:

"to whom Texas land represented just so much dirt and grass and not much else"

they were faced with land-hungry and ambitious men eager to move into the void (Frantz 1976:49-50). Arredondo was convinced that a settlement of American colonists in Texas might serve as a buffer between the Spanish settlements and the Indians, and if loyal to the Crown, would prevent further filibusters. With this in mind, he notified governor Martínez that the petition of Moses Austin to establish a colony as a land agent, or empresario, had been granted (Fehrenbach
1983:135). Moses Austin died before he could fulfill his grant, but in August 1821, his son, Stephen Fuller Austin, was recognized as his successor by Governor Martínez. On August 24 of that year, Mexico gained her independence from Spain and the provisional government failed to recognize Austin's grant and chose to settle the terms of the colonization and immigration by a general law, the Imperial Colonization Law, passed by the Junta Instituyente on January 3, 1823 (Barker 1996a 4:684-685).

\section{The Empresarios}

Agustín de Iturbide was proclaimed Agustín I, emperor of Mexico, on May 19, 1822, an act that angered many of his supporters within the government. His regime proved to be both arbitrary and extravagant, and in December, Antonio Lopez de Santa Anna led a revolt against him, eventually forcing his abdication on March 19, 1823 (Hyman 1996 $3: 880-881$ ). Mexico then adopted a federal system of government, and the new congress enacted the national colonization law of August 18, 1824. This law and the state law of Coahuila y Texas of March 25, 1825, became the governing doctrine of all colonization contracts. This revision restricted any grants within twenty leagues (52 miles) of an international boundary or within ten leagues (26 miles) of the coast. In April of 1830, the Mexican federal government made use of a reservation in the law of 1824 that forbade settlement of emigrants from the United States (Barker 1996a 4:684-685). This action resulted from the growing suspicions that the United States intended to seize Texas from the Mexican government. The actions of the United States minister to Mexico, Joel Poinsett, attempting to persuade the new nation to sell eastern Texas to the United States prompted fears of Anglos and annexation. It triggered memories of how Spain had lost Baton Rouge and Mobile in the early 1800 s. 
These changes however, did not impact Austin's grant as it had been in place prior to enactment of the new laws. Austin selected the area along the Gulf coast inland between the Lavaca and Trinity Rivers for his colony, and with a grant from Congress, was able to settle his initial 300 families. In later contracts awarded in 1825, 1827, and 1828, he was able to settle an additional 900 families in his colony. For his efforts he received some 67,000 acres for each of the 200 families he introduced into the state (Barker 1996b 1:294-297).

On April 8, 1824, Martín De León received permission from the provincial delegation of San Fernando de Béxar to settle 41 Mexican families and founded the town of Nuestra Señora de Guadalupe Victoria at "some point on the lower Guadalupe River". This prominent Mexican citizen was granted more latitude in the founding of his colony than that given to empresarios of foreign origin. De León openly expressed his dislike for Americans, and since the limits of his settlement were unspecified, frequent disputes with the neighboring Anglo-American colonists were inevitable. In 1827, he petitioned the government to delineate the boundaries of his colony. The following year, these boundaries were established to be from Matagorda Bay on the south, Mission Valley on the north, the Lavaca River on the east, and Coleto Creek on the west (Roell 1996a 2:573-574).

In 1825, Green DeWitt and James Kerr established a colony. DeWitt had attempted to receive a grant as early as 1822 , but had been frustrated by the new restrictions. Encouraged by Austin, and aided by the Baron de Bastrop, he petitioned the government again and was awarded a contract on April 7, 1825. He selected an area adjacent to and southwest of Austin's grant, defined as from the Lavaca River at a point ten leagues ( 26 miles) from the coast and up the river to the Béxar-Nacogdoches road, then up the road west to the Guadalupe River, then parallel to the river to a point ten leagues ( 26 miles) from the coast and returning to the point of beginning. His six-year contract required him to respect the rights of ownership of all those already settled in the area, which he found later to include De León's entire colony. This led-predictably - to numerous disputes between the two empresarios. In the summer of 1825 he established the site of the colony's capital at the junction of the Guadalupe and San Marcos Rivers and named it Gonzales, in honor of the provisional governor of Coahuila y Texas, Don Raphael Gonzales (Roell 1996b 2:620-623).

In 1828, the colony of John McMullen and James McGloin was founded. An empresario contract was granted to John Purcell and Benjamin Lovell on October 22, 1825 to settle 200 families west of the Nueces River and south of the Medina River and the old San Antonio Road. After an unsuccessful attempt to raise funds and the death of Purcell, the contract was relinquished to McMullen and McGloin. In 1829, they traveled to New York to recruit newly arrived Irish immigrants who had yet to settle in the east. The colonists arrived in three contingents through the ports of Matagorda and Cópano and assembled at the old mission of Refugio, where they remained for several months before moving to the Nueces River lands. In October of 1831, they established the town of San Patricio de Hibernia, or St. Patrick of Ireland, for the patron saint of their homeland (Long 1996a 4:440).

A young Irish doctor, James Hewetson, had immigrated to the United States and decided to seek his fortune in Mexico when he met Austin in Missouri. He traveled with Austin to New Orleans and accompanied him on his first trip to Texas to select the land for his colony. Leaving the party at Béxar, Hewetson traveled on to Mexico and engaged in business at Saltillo and Monclova. In 1826, he formed a partnership with another Irishman, James Power, to establish a colony in Texas (Huson 1996 3:583). Taking advantage of the colonization law of 1824, they applied for a contract to colonize the Texas coast with Irish-Catholic and Mexican families. Their original petition of September 29, 1826 for the coastal land between the Nueces and the Sabine rivers was modified June 11, 1828, when the national government granted them ten littoral leagues between the Lavaca and Guadalupe Rivers. On April 12, 1829, the territory was 
extended from the Guadalupe to the Nueces, and on May 29,1831 , they received control of the lands of the abandoned Nuestra Señora del Refugio Mission. The work of building the colony was assigned to Power, while Hewetson remained in Mexico to attend to his business interests there (Texas State Historical Association [TSHA] 1996 5:306-307). Thus, the area around mission was settled (Figure 5-1).

\section{The Mission after Secularization}

From the standpoint of the Catholic Church, the permanence of Catholicism in Texas was dependant upon the formation of communities of believers to gather for worship, instruct their children in the faith, and build their own churches. With the secularization of the missions, the intent was to merge the neophytes into the Catholic diocesan church under the direction of a bishop, with their individual priest (Wright 1996 1:1026-1028). This process normally took the form of distributing the mission lands to the Indians of the mission and to other settlers of the communities in the area. The missionaries were to return to Mexico and the religious work would be turned over to a "secular" priest who did not belong to any religious order, such as the Franciscans or Jesuits. Problems arose with later secularizations because there were no secular priests and the Indians wished to return to their former lifeways (O'Connor 1984:69). This is hardly surprising, since through the mission period the Karankawan strategy was generally to incorporate the mission into their seasonal rounds as a source of meat and grain. They entered the missions during the spring when traditional subsistence activities shifted from fishing to gathering inland resources (Ricklis 1996). At the time of secularization, 12 Karankawas and eight Cocos were associated with the mission (Huson 1953 1:98). Mission records indicate that there were approximately 43 Spanish families also residing in the vicinity at the time of secularization (Benowitz 1996 4:1072-1073).

The declining years of the mission effort and its subsequent abandonment had not been kind to the mission structure. The building had suffered much damage as a result of the
September 1818 hurricane, the roof never having been fully repaired. During the period of inactivity between 1824 and the final closing of the mission, the building was allowed to slowly deteriorate. As reflected in the 1825 report of Fr. Díaz, the stone structure was sound and still contained the statuary, but the wooden components of the rooms had been ruined and the area was overgrown with weeds and grass. ${ }^{1}$

\section{The Early Colonists}

Austin's colonists began to immigrate late in 1821, arriving by land and sea. The Lively, a thirty-ton schooner operating from New Orleans to Galveston, was outfitted with supplies for the original colony of 300 families. The ship sailed from New Orleans with approximately 20 colonists on board. Bad weather blew the ship off course, and it took some four weeks to reach its final destination. The immigrants had arranged to meet Austin, who had traveled overland from New Orleans, at the mouth of the Colorado, but were mistakenly landed at the mouth of the Brazos River for the meeting. After attempting to establish camp and plant crops, and failing to meet up with the other Austin colonists, they grew discouraged and most eventually made their way back to the United States. The lack of contact between the Lively and the other Austin colonists gave rise to a variety of rumors, ranging from the idea that all had been lost when the ship went down, to tales that the passengers and crew had been attacked by the Karankawa Indians. The truth was eventually conveyed back to Austin's colonists, but many early histories printed the rumors as fact (Bugbee 1899; Huson 1953 1:38; Long 1996b 4:240).

In February of 1823, the Karankawas did kill two settlers, a Mr. Loy and a Mr. Alley, and injured two others. Robert Kuykendall raised a small company of men to "chastise" the Indians for their actions. They found a Karankawa camp near the murder site, on Skull Creek in what is now Colorado County, and attacked without warning, killing and scalping at least 14 of the Karankawa, wounding seven, and destroying their supplies (Himmel 1999:48;

Fr. José Díaz de León to Mateo Ahumada, 8-21-1825, General Land Office, Box 122, Folder 15, p. 226. 


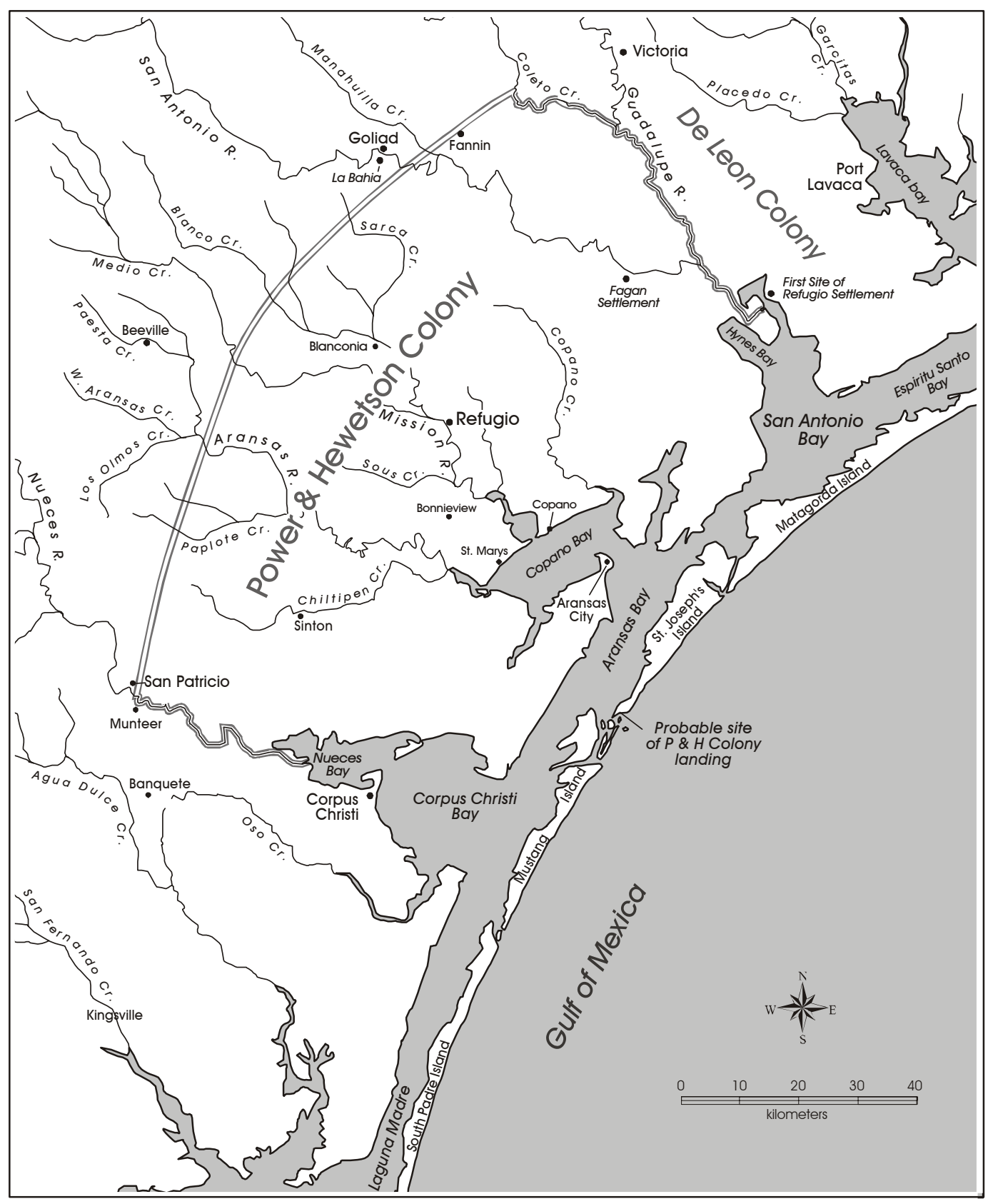

Figure 5-1. Adaptation of the ca. 1830 Power-Hewetson empresario grant. 
Largent 1996 5:1073). This did little to subdue the "Indian menace" and the friction between the groups continued.

By October of 1824, Martín De León and 12 families had settled on the Guadalupe River at El Sabinal, later called Cypress Grove. The remainder of his group, 29 families, were delayed in Mexico by drought, and later by floods, and arrived the following spring. Although his colony was predominately Mexican, there were also 16 Anglo and Irish settlers among the group. He named his colony town Guadalupe Victoria for the first president of the Republic of Mexico. De León, the wealthy and cultured Mexican aristocrat with his open disdain for Americans, endured clashes with the neighboring colonies which were predictable and frequent. His failure to notify the authorities where he had founded his colony resulted in the legislature including it within the 1825 grant made to Green DeWitt, causing continuing conflict between the two groups (Roell 1996a 2:573-574).

The problems between colonists and local Indian groups persisted, instilling a growing desire among the colonists to confront the issue of theft and harassment by the Karankawa. In 1827, a joint campaign of both the Austin and De León forces, primarily led by Austin, commenced a ferocious assault upon the Indian's traditional homelands on the lower Colorado and Brazos River valleys. Intervention from both the Mexican political and clerical authorities at the time prevented the total destruction of the Karankawas. A treaty was demanded and Austin met with the authorities at Goliad to discuss the terms. On May 13, Austin and his troops, the Mexican authorities, and between 300 and 400 Karankawas met at Manahuilla Creek, about four miles east of Goliad, and a treaty was signed. In return for a withdrawal of hostilities, the Karankawa agreed to abandon the lower Brazos, lower Colorado, and lower Lavaca and remain west of the Guadalupe River (Barker 1919 1:1639-1641; Himmel 1999:49-50; Huson 1953 1:38-39).

\section{The Arrival of the First Irish Colonists}

With Lovell's surrender of his empresario contract, McMullen and McGloin received their concession at the left bank of the Nueces River at the Ten League boundary, to a point ten leagues southwest of Presidio La Bahía, and from there to the confluence of the Medina and San Antonio rivers. From that point, the grant followed the river to the road from Béxar to the Presidio of Rio Grande to the Nueces River and returned to the point of beginning (Huson 1953 1:123).

John McMullen was born in Ireland in 1785 and immigrated to Baltimore, Maryland and later to Savannah, Georgia. In 1810 he married Esther Espades Cummings, a widow with two children. As a merchant in Matamoros, he was attracted to the opportunities afforded by the colonization laws, and entered into a partnership with James McGloin. McGloin, fourteen years his junior, immigrated from Castlegal, County Sligo, Ireland. In 1825, he married Eliza Cummings Watson, widowed sister of McMullen's wife (Hébert 1996 4:404-405; Hébert and Oberste 1996 4:436-437). They recruited most of their colonists from new Irish arrivals along the eastern seaboard, primarily in the vicinity of New York. In September of 1829, they left New York in a brig and schooner: the Albion, with McMullen aboard and the New Packet, with Captain Harris in command. The captain of the Albion became disoriented and landed his passengers at Matagorda, while Captain Harris correctly landed at Cópano. They were later reunited at Refugio mission, where they encamped. With their supplies running low, it was a better place to obtain goods being shipped from Goliad and New Orleans (Huson 1953 1:123-124; Long 1996a 4:440). The customs officer at Goliad reported to the Political Chief, Ramon Músquiz, that when the colonists arrived at Refugio, sick and lacking supplies, they requested permission to remain there to 
recover. They even requested that they be granted the mission stone:

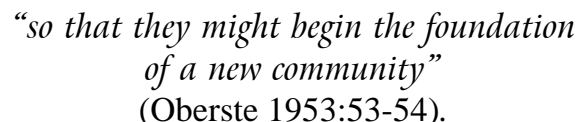

Shortly after their arrival at the mission, the colonists established a militia company under the command of a Captain Kelly. Within a few days, a band of Lipans appeared at the mission and demanded presents, but the militia was assembled and a small cannon was fired. The Indians fled, only to return later and request that the cannon be fired again. The colonists refused, and the Indians were ordered to leave the area (Glick 1922 5:378-383).

Accompanying this set of colonists was an Irish priest, Henry O'Doyle. The old mission had fallen into a dilapidated state since it had been abandoned, and since the colonists expected to remain for an indefinite period, Father O'Doyle requested permission to rebuild the chapel. Governor Viesca approved the request on April 21, 1838 (Oberste 1942:340).

Power, who by now had been granted the right to colonize the littoral leagues, and the government authorities began to complain. The jefe politico at Béxar recognized that rebuilding the church would make it difficult to force McMullen's group to abandon the location. He ordered McMullen to appear in court and ordered him to vacate the lands. Realizing that they had lost the fight, McMullen and McGloin began to take steps to relocate the colony to comply with the limits of their grant (Oberste 1953:56-57). In the summer of 1830, they selected a site on the Nueces River near the old Fort Lipantitlan for their capital, Villa de San Patricio de Hibernia. While strategically positioned on the Camino Real between La Bahía and Laredo and within transport distance of the coastal lands, it was also unfortunately within the ten littoral leagues and consequently within the Power and Hewetson grant. This caused recurring disputes and animosity between the Irish empresarios
(Huson 1953 1:126). The ten league coastal restriction was extremely troublesome to the settlers. With the difficulty of inland transport and their dire need for supplies, it created a hardship on the establishment of new homes in the wilderness. This restriction resulted in one of the first controversies to occur between the government and the colonists. The government interpreted the limits from the actual coastline, while the colonists contended that it should be measured from the outer line of the chain of barrier islands extending along the coast (Smithwick 1983:8).

\section{The Power-Hewetson Colonists}

James Power was born in 1788 or 1789 in Ballygarrett, County Wexford, Ireland and immigrated to New Orleans in 1809. During his 12-year stay in New Orleans as a merchant, he encountered Stephen Austin and learned of the contracts being offered by Mexico. In 1821, he relocated to Matamoros, later moving to Saltillo, where he took Mexican citizenship (Welder 1996 5:306). In 1826, he entered into a partnership with James Hewetson.

Hewetson, born in Thomastown, County Kilkenny, Ireland, studied medicine and immigrated to the United States, where he also became acquainted with Austin. In Mexico, he became successfully involved in mercantile, manufacturing, and mining endeavors. He soon became influential in government circles and later married a wealthy widow, Josefa Guajardo (Huson 1996 3:583).

Power, while awaiting the final granting of their colony, on December 24, 1829 purchased from the state 22 leagues of land within the concession. He located one of these leagues on Live Oak Peninsula. He later married Dolores Portilla, daughter of Captain Felipe Roque de la Portilla, and established his home there (Huson 1953 1:158-159).

When Hewetson and Power applied for their grant from the state authorities, the state government was still restricted 
from granting the land within the ten littoral leagues of the coast, but they recommended that the restriction be removed by the central government. Upon their recommendation, the restriction was removed and the coastal grant was approved with the stipulation that the land be settled with 400 families, one-half of which would be Mexican citizens and the remainder Irish Catholics. Martín De León, who claimed he had been granted previous title to the same lands, almost immediately challenged the grant. He based his claim to the territory on a contract given by the provisional government of 1812 during the rebellion. This claim was completely unknown to both the government of Mexico and the state of Texas and was not based on any recognized authority. It did, however, serve as a pretext for political chief Ramón Músquiz to oppose the intrusion of the Irish into the coastal region for which he and De León had previously petitioned a six-league grant under the law of 1830 . Power immediately protested that the restriction of 1830 did not apply to his efforts since the law was intended to exclude North Americans, and his colonists were to be Irishmen and Mexicans. His protest was upheld by the state authorities and Power was granted an extension of time due to the interruptions he had sustained (Glick 1922 5:239-240). He was obligated to receive as colonists all the families of the town of Goliad who might desire grants of land.

The claims of the Indians of Refugio mission were also to be addressed. At the time of secularization there remained of the faithful 12 Karankawas and eight Cocos. This was addressed by Governor Letona by instructing the empresario to supply each of the Indian families a tract of land to be cultivated and "a yoke of oxen, or bulls, with the necessary farming utensils." Power and Hewetson satisfied these requirements by presenting the Indians with teams, carts and implements, and granting them the use of a tract of land near Goliad, a generosity that did little to further their relationship with the De León colonists (Huson 1953 1:151152).

The grant was further complicated by another claim to the lands by Juan Martín de Veramendi, who had, upon the death of José María Letona in September of 1832, assumed the position of Governor of Coahuila y Texas. In 1822 or 1823 , he had received title to six leagues of lands formerly belonging to the extinguished mission of Refugio. $\mathrm{He}$ contended that the extension granted Power was invalid because it was excluded by article nine of the General Colonization Law, which limited the grant period of validity. However, Power protested to the Governor that no lands within the ten coastal leagues were considered "as appertaining to the Mission, except those held by bona fide and original titles, given at the time the Mission was founded." Governor Viesca concurred that such lands granted from the Mission tracts were excluded from such claims, and belonged to the government to disperse. Nonetheless, the extension of time was ruled invalid (Huson 1953 1:149-150).

Unaware of this reversal, and with his grant seemingly secured, Power departed to secure his colonists. In April 1833, Power booked passage to New Orleans on a ship anchored off Aransas Pass. As the vessel prepared to sail, he was informed of the birth of his son, James, on April 14. Unable to change his plans at this late date, he was forced to depart and would not see his son for more than a year (Huson 1935:13-14). From New Orleans, progressing overland, he enlisted colonists in Louisville, Philadelphia and New York. In New York, while awaiting a ship for Ireland, he learned that his contract extension had been annulled. This came as a dire blow, for now he had only nine months to fulfill the contract of four hundred colonists. He sailed for Ireland on October 14, 1833 (Wood 1971:14). 


\section{The Irish Immigrants}

Power established himself at the home of his sister, Isabella O'Brien, in County Waterford and began his recruitment. A few families were able to settle their affairs quickly and were dispatched in small groups in advance of the main body of immigrants. These reached Texas and established camps at the old mission. His efforts gained him about 350 recruits. The majority of these sailed from Liverpool, England, in two groups. The first group of 108 sailed aboard the Prudence, a vessel of some 281 tons commanded by Captain Chapin, on December 26, 1833. Bad weather forced them back to port three days later. They again set sail on January 8, and arrived in New Orleans on April 23, 1834. Power, with the second contingent, sailed aboard the Heroine, commanded by Captain Russell, on March 12, arriving at New Orleans in May, where they found the first group awaiting them (Oberste 1953:100).

Upon his arrival in New Orleans, Power received devastating news; a dread cholera epidemic was sweeping the entire Gulf region. Cholera morbus, a severe, epidemic disease causing profuse vomiting and purging, is caused by the waterborne bacillus vibro comma. But the method of transmission of the disease was not discovered until 1858, and the baterial cause not identified until 1884. Prior to these discoveries, it was thought to arise from "miasma" or the poisonous atmosphere thought to rise from swamps and putrid matter. Power's colonists were stricken; a number of them had died, and those who survived were confined to the hospitals of the city. Power chartered two large threemast schooners, the Wild Cat and the Sea Lion, commanded by Captains Ramsdale and Living, to transport them to Cópano (Huson 1953 1:165-168). The schooners approached the bar at Aransas Pass in stormy weather and the Wild Cat ran aground. Power, aboard the Sea Lion, attempted to force Captain Ramsdale to avoid the bar, but the Sea Lion also ran aground. To compound the problem, cholera broke out among the stranded immigrants. Power, although ill, managed to make it to Cópano where he persuaded Captain Auld of the Sabine to rescue his suffering colonists, stranded without provisions or shelter on St. Joseph's island. As many as 50 or more, among them Power's sister and nieces, died in the epidemic (Glick 1922 4:240241). After landing, the colonists were kept at Cópano, under quarantine and under guard, for about two weeks. Although the Mexican guards attempted to ease their suffering and distress, more died on the shore (Huson 1953 1:170-171).

The epidemic soon spread to other cities in Texas and Mexico, possibly as a result of their landings. In June of 1834, the cholera epidemic had reached La Bahía, and a detachment of troops from Béxar was posted on the Goliad road for the "purpose of detaining persons undergoing quarantine." Additionally, the jefe politico "proposed to stir up effectively the matter of fumigations" as a precautionary measure "against the sickness that threatens." 2 These precautions may have served some good effect, for the populace fled the town and camped in the surrounding areas to escape the fumigation, and fewer people remained to contract the disease (Nixon 1946:139). Despite their efforts, the town was still stricken in September. Mary Austin Holley reported 91 deaths in Goliad alone (Nixon 1936:45). The Mexican authorities recorded that the last death from the cholera epidemic occurred on July 30, 1834 (Priour n.d. Chapter 7:1).

Finally allowed to leave their bleak shelters along the coast, the survivors of the Power group made their way to the mission. The colonists, after their illness and hardships and still suffering from fatigue and exposure from their forced encampment on the beach, had hopes of finding some comfort in the shelter of the old mission building. But to their extreme disappointment they found it in use. The church was filled with corn, being utilized as a granary by the cavalry detachment from the presidio of La Bahía. The only aid it could offer was a place to heap their personal effects against the exterior walls to afford some small protection against the heat and frequent showers (Oberste 1953:110). Elisabeth Hart reported that she piled her trunks up and placed the farming utensils about ten feet from the church and covered

2 San Antonio City Council Minutes, Spanish, Office of the City Secretary, City Hall, San Antonio, Volume 2, p. 367, 370. 
these with bedclothes so that a sort of tent was created. At that time the entire village consisted of only four huts which were occupied by Irish and American settlers (Priour n.d. Chapter 7:4).

\section{Earlier Settlers}

There had long been attempts by the Spanish government to settle the coastal plains north of the Río Grande. Royal grants to vast tracts of lands served to reward loyal subjects for service to the crown, but further encouraged settlement of the lands frequently harassed by the raids of Lipan and Comanche seeking horses and cattle. The government soon recognized that awarding vast tracts of land actually impeded the growth of settlements and a stable population and began to limit the size of grants issued. Beginning in 1802 the Superior Council on Royal Lands established its new policy favoring numerous rancheros operating on a small scale, as opposed to the earlier hacendado with vast cattle empires. The landowners attempted to circumvent this limit by applying for contiguous grants. In 1806, Josef Vicente Lopez de Herrera requested 16 leagues for himself and his three sons; then his son-in-law Gregorio Farías requested an additional four leagues. This resulting block of lands was situated on the western bank of the Río Nueces, the northern border of Nuevo Santander, and became known as Barranco Blanco. It was also referred to as El Diezmero, or the Tithesman, the title awarded to Don Herrera as Administrator of the Tithes of the town of Reynosa (Rodriguez 2001). The rancho prospered, but with the secularization of the missions, the reduction of the military, and the war of independence, hostilities with the Indians began to increase. Comanches killed 14 people at the Diezmero Ranch in 1814 and besieged all of the ranches south of Béxar, looting and scattering their stock (Jackson 1986:548-550).

Another early ranch in the area was established by Antonio de la Garza, a soldier at La Bahía. His son, Carlos, was born at the presidio in 1807, and as a young man served in the Mexican army. In 1829, he married and moved to the family ranch at Carlos Crossing on the San Antonio River, about twelve miles below Goliad. On October 28, 1834, Garza obtained his title as a Power and Hewetson colonist to a league of land, including the old ranch, in what is now Victoria County. At the small community that developed around the crossing he operated a commissary, barrelhouse, smithy, and ferry (Roell 1996c 1:977-978). With all the problems that beset Power from the start, it is not surprising that he had great difficulty meeting his assigned quota of colonists. His Irish colonists were supplemented with settlers from other colonies and native Mexicans already in the area in 1832 . Although nearly 200 titles were eventually issued, the total of families never reached that number because many were issued to single men, were augmentations of previous grants, or in some cases were issued to settlers who did not fulfill residency requirements. Most of the colonists settled in the new villa of Refugio or the surrounding countryside, yet a small number of the Irish immigrants became discouraged and returned to New Orleans or Ireland (TSHA 1996 5:306-307).

\section{Establishing the Town}

On June 19, 1834, José Jesús Vidaurri y Borrego was appointed as commissioner for the colony. One of his first official acts was to establish the villa of Refugio and create an ayuntamiento (town council) in July. Further, in compliance with the colonization laws, a local company of militia was formed with James Power as Lieutenant Colonel in charge. Vidaurri then established the specified four square leagues for the town limits and selected James Bray as surveyor. Certain exceptions to the plan for the proscribed town site were made. Rather than the usual twenty-vara wide streets, the Refugio streets were established at thirty varas. ${ }^{3}$ Also, only one-half block, rather that the specified full block, on both the East and West side of the main plaza were dedicated to church and municipal purposes. Since the old mission still served as the church, that half-block was allocated for a school (Oberste 1953:115-118) (Figure 5-2).

3 The Spanish vara, still used in land titles in the state, varied over time but is generally accepted as $331 / 3$ inches; 36 varas equals 100 feet; and 1900.8 varas equals one mile or 5,280 feet. Texas Land Measure, General Land Office, Austin. 


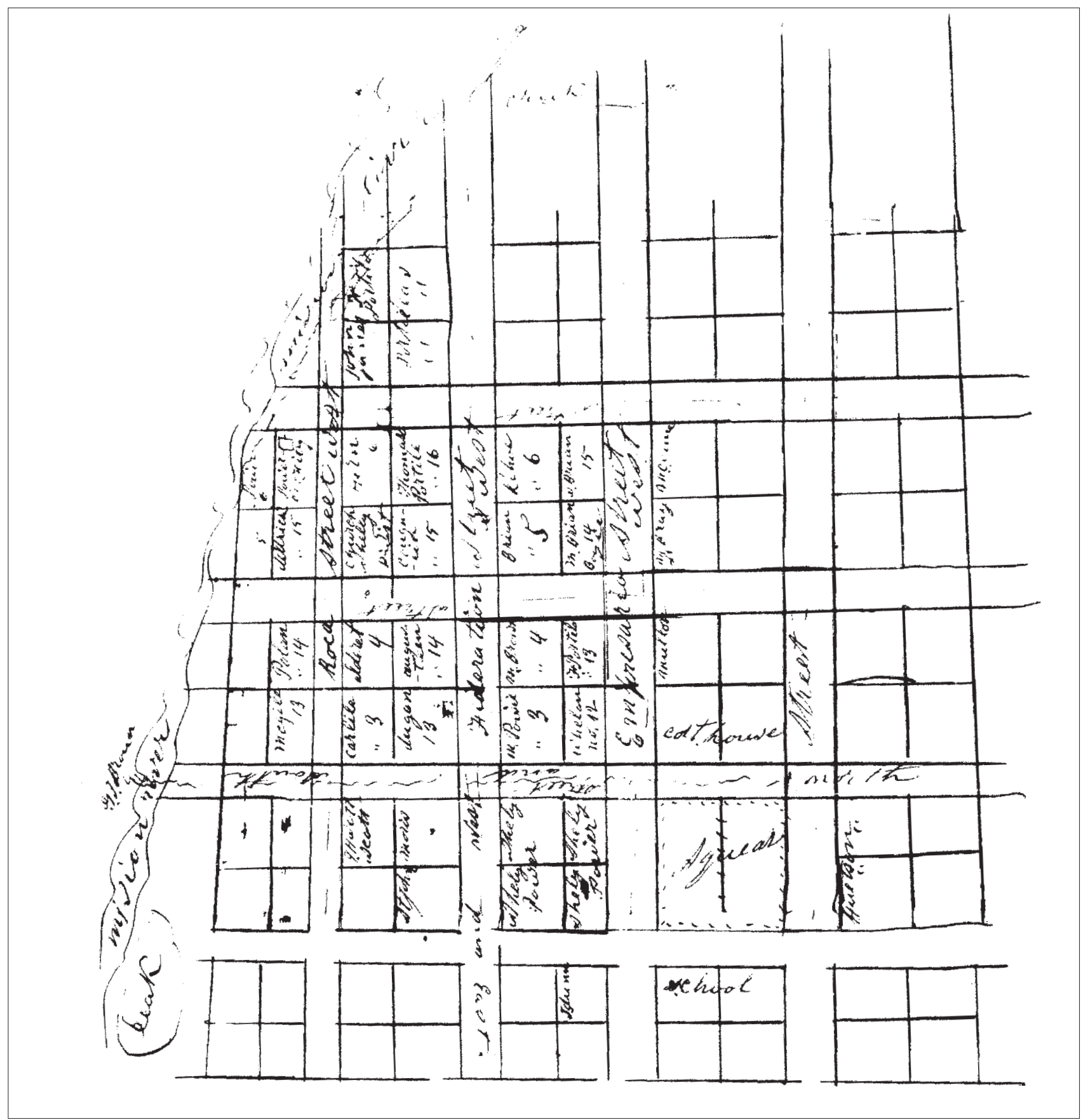

Figure 5-2. Reproduction of the map of the original town of Refugio ca. 1834.

Note: Reproduction is rotated from original orientation for legibility, N should be considered $\longrightarrow$.

(From the Lambert papers, Refugio Public Library.) 
Vidaurri established his offices in the old mission structure and began to supervise the surveying of the town and the distribution of the lots to the colonists. The ayuntamiento at Goliad immediately issued an order prohibiting the commissioner from proceeding further with his duties because they had not been notified of the origin or extent of Vidaurri's powers and they questioned his authority. They dispatched Captain Manuel Sabariego, Commander of the garrison of Goliad, and a body of soldiers to enforce the order. ${ }^{4}$ Finding Power and Vidaurri at the mission, he immediately ordered them to turn the structure over to him, which they refused on the grounds that they were in lawful possession by the authority of the Refugio ayuntamiento. The Captain then assembled the entire council and demanded that the church should be turned over to him to be used as a barracks for his troops, which would be stationed there until the issue was resolved. Unsure of the extent of the captain's threats to disband the colony, Power recommended that the council yield to his demands until clarification could be obtained from the state government. Finally, in February of 1835 , verification of their authority was received from the Governor. By this time all titles had been issued to the colonists and the Commissioner had returned to his home in Mexico. ${ }^{5}$

The James Bray plat shows the town proper to consist of 49 blocks centered upon the Plaza de la Constitución. The town blocks were each 120 varas $\left(333{ }^{1} /{ }_{3}\right.$ feet) square, and were subdivided into four solares, or lots, each 60 varas $\left(166^{2} / 3\right.$ feet) square (Huson 1953 1:184-185). On August 6, the commissioner accepted the petition of John Shelly for Lot 5 , Roca Street, upon which stood the ruins of the old mission church, which was confirmed by Josie Davis and Santiago Serna, members of the ayuntamiento. On April 24, 1835, James Power purchased the site from Shelly for 20 dollars, and in turn donated the lot and buildings to the Catholic Church. The remaining lots of the complex, Lots 6, 15, and 16, were later donated by Henry Scott, James Power, and his wife, Tomasa Portilla (Oberste 1953:119) (Figure 5-3).

\section{The Approaching Storm}

As the colonists struggled to establish new homes in a foreign land, events around them were developing that would forcefully impact their plans. Only a decade previously, the revolt led by Antonio López de Santa Anna forced the abdication of Iturbide, established the federal system of government, and resulted in the Constitution of 1824 and the liberal colonization laws that had allowed their immigration. Now that same Santa Anna, fresh from his victory over the Spanish at Vera Cruz, had been elected to the presidency as a liberal. He decided that Mexico was not yet ready for democracy and emerged as an autocratic Centralist (Callcott 1996 5:881-882). In March of 1835, to ensure that there would be minimal resistance to his changes, he had the Federal Congress enact a law limiting the state militia to one man per 500 inhabitants. In response, the federalists in Zacatecas revolted against his policies and were ruthlessly crushed; more than 2,000 noncombatants were slain in the retaliation that followed. The state governor of Coahuila y Texas called out his militia, and in May, General Martín Perfecto de Cós was dispatched to suppress the state congress. That body adjourned May 21, after authorizing the governor to move the capital to a safer place. Upon his departure, he took the archives with him. In his company were Benjamin Milam and Dr. James Grant (Huson 1953 $1: 211)$.

The colonies of Texas viewed all this activity with a rather detached dismay and concern. However, in September an incident between a Mexican soldier and a citizen of DeWitt's colony provoked protest. Colonel Domingo Ugartechea, military commander of Béxar, recalled their cannon that had been allowed them as protection against the Indians. The citizens angrily protested this action and escorted the squad dispatched to retrieve the cannon out of the colony. Ugartechea promptly ordered Lieutenant Francisco Castañeda and a hundred dragoons to Gonzales to retrieve the weapon (Hardin 1994:14). On October 2, armed resistance from the settlers resulted in the "Battle of Gonzales," actually only a brief skirmish, that was viewed as the opening of a rebellion.

4 "Marches to Refugio to prevent illegal settlement by Santiago Power, Santiago Hewetson and Vidaurri," Bexar Archives, 7/ 25/1834, Reel 162:Frames 655-658.

5 "Case against ayuntamiento of Goliad defending authority to distribute land and install ayuntamiento of Refugio; includes list of municipal officials," Bexar Archives, 7/27/1834, Reel 162:Frames 684-685; Huson, Hobart, 1953, Volume 1, pp. 201-203. 


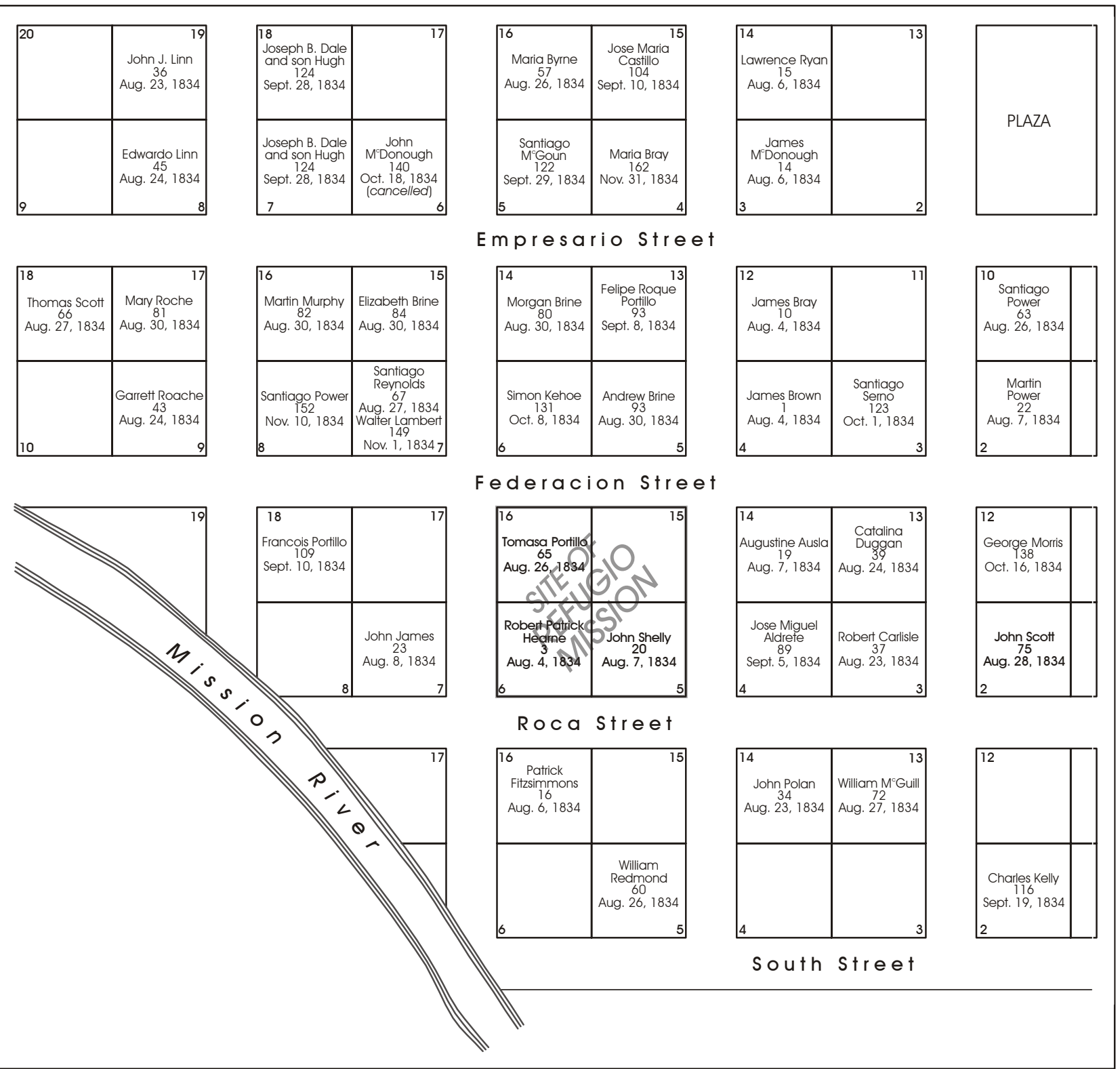

Figure 5-3. Adaptation of ca. 1834 plat of Refugio town blocks. 
Santa Anna's response was immediate. General Cós, with a punitive force of 500, landed at Cópano on September 20, 1835. The landing was immediately reported to Colonel Power, who relayed the information inland to the other settlements. Cós and his army passed through Refugio and stopped briefly at La Bahía, but in his haste to reach Béxar and fulfill his directives to "expel troublemakers and disarm all colonists," he left no reinforcements behind (Hardin 1994:4). Aroused by this action and fired by a rumor of a military chest of silver, the Matagorda volunteers assembled to capture the general and hold him for ransom. Twenty men, under the leadership of George Morse Collinsworth, departed the night of October 6 with the objective of capturing the presidio at La Bahía. While en route, he added the able assistance of Ben Milam and about 20 additional volunteers. On October 9, the garrison fell to Collinsworth's force with little resistance. Although they arrived too late to achieve their initial aim of capturing Cós, their action severed communications between the forces in San Antonio and the Gulf of Mexico and secured a stock of valuable weapons and supplies. Shortly afterward, Collinsworth departed to recruit more men and supplies and Philip Dimitt was placed in charge of the post (Cutrer 1996 2:220). On October 11, Stephen Austin and the "Army of the People" departed Gonzales en route to San Antonio to expel the Mexican forces. He arrived a week later and the city was surrounded and placed under siege.

Dimitt became concerned about the proximity of the Mexican post at Lipantitlán, on the west bank of the Nueces along the Atascosito Road, arguing that it might serve as a springboard to recapture La Bahía and reestablish the link to Cópano Bay. Eliminating the centralist garrison might also encourage the federalist supporters at nearby San Patricio to form a militia in support of the revolution. On October 30, he assigned Ira Westover to head a force to capture the post. Westover and his men proceeded to Refugio, where they acquired Colonel Power and Francisco de la Portilla, his brother-in-law, to serve as advisor and guide. In the meantime, the force at Lipantitlán launched an offensive to harass the rebels at La Bahía, leaving the post undermanned. Arriving at San Patricio on November 3, Westover arrested an Irish centralist supporter, James O'Riley, for "aiding the enemy" and proceeded to the fort. To insure his personal safety, O'Riley persuaded the garrison to surrender, and that night the post capitulated without firing a shot. On the following day, the victors burned the stockade, secured the cannon, rounded up the horses, and departed. Learning of the capture, the Mexican forces swiftly turned back to confront Westover's band. The two forces met at the Nueces Crossing, and both the Mexican soldiers and Irish centralists suffered heavy losses in the ensuing fight (Hardin 1994:7-12).

This question of divided loyalty was not limited to the Irish, and was even more pronounced among the Tejano. The question of Centralist and Federalist support produced violent divisions around Goliad and Refugio in the winter of 1835-36. The Centralist rancheros and their Karankawa allies began guerrilla action toward the Anglo-Texans, the Federalist ranches and their Karankawa allies. This resulted in their viewing all Karankawas as aligned with the Mexican forces and the Centralist Tejanos. The Mexican army considered all Karankawas as traitors, supporting the secessionists (Himmel 1999:75).

In Béxar, the long siege had divided and demoralized the Texan forces, and many expressed their strong desire to quit the offensive and go into winter quarter at Goliad. Ben Milam sought out Colonel Frank W. Johnson, and together confronted General Edward Burleson with their protests against any such action and convinced them to allow them to lead a group of volunteers against the town. In the early morning hours of December 5, they began their attack. Through house-to-house fighting, they made their way into the Main Plaza, General Cós' stronghold. On the second day, a sniper felled Milam by a shot to the head, but the fighting continued. On December 9, General Cós surrendered the city to the rebels and withdrew toward the Río Grande. Most Texans viewed this as the conclusion of the war (Hardin 1994:77-91). 
The new government of Texas was struggling with its identity. With little control and no strong guidelines as to who was fully in charge, the orders were often conflicting. Fresh from the victory at Béxar, several of the participants proposed a plan to carry the battle home toward the interior of Mexico. Dr. James Grant called for a campaign to attack Matamoros and oust Sam Houston as commander in chief. Johnson sided with him, and both pressured the Council to support the plan. Houston even had plans to take charge of the operation and lead it himself. The Council bypassed Houston, placing Grant and Johnson in charge instead. Governor Smith had, however, independently ordered Houston to personally take charge of the offensive (Hardin 1994:107). Stripping the garrison at Béxar of its reserves, Grant and Johnson, joined by Dimitt, began to mass their troops at Refugio, including the majority of the new volunteers from the United States, in preparation for the planned offensive. Houston, upon viewing the confusion wrought by the divided leadership, delivered an eloquent argument to the volunteers upon the weakness of the plan and suggested that Grant was most concerned about the state of his property holdings in Mexico. He then departed Refugio to return and confer with Governor Smith, but his speech had placed enough doubt in the minds of the volunteers that many withdrew and joined Houston's command (Hardin 1994:116-117).

\section{Santa Anna's Retaliation}

The overconfident Texans had badly underestimated the Mexican president. Santa Anna was hardly of the nature to accept such an affront without launching a swift and withering counteroffensive. Upon hearing of the action in San Antonio, he began to mass his forces for a retaliatory strike, and before Christmas his army of over 6,000 departed San Luis Potosí for Texas. His plan called for General José Urrea's division to sweep the coastal plains while he himself led the main force against Béxar, against the opinion of all his advisors. The small garrison at the Alamo was generally considered to be of little military significance and could be isolated by a much smaller force. But Santa Anna refused to take their counsel; determined to avenge the defeat of his brother-in-law, he was driven toward the focus of the open rebellion (Peña 1975:18-21).

In early January, James Walker Fannin took command of the presidio at La Bahía and renamed it Fort Defiance. Houston, like most of the Texans, did not expect a return of the Mexican forces until March. He proceeded to east Texas to engage in treaties with the Indians. By early January, information was received that Santa Anna was on the move, but most still expected that it would be March before he could reach the interior. This mistaken view of Santa Anna's determination and the divided leadership among the Texans resulted in little being done before the Mexican army was upon them (O'Connor 1984:119).

After Houston withdrew from the Matamoros expedition, Fannin was elected colonel of the Provisional Regiment of Volunteers at Goliad on February 7. From February 12 to March 12, he acted as commander-in-chief of the army. When he learned that the Mexicans under José de Urrea had occupied Matamoros, Fannin went no further with plans for the expedition and fell back to strengthen defenses at Goliad. During the period of the Texan occupation of $\mathrm{La}$ Bahía, many Mexican residents of Goliad abandoned their homes and sought the protection of the Carlos Rancho. Consequently, Carlos Rancho was accused of harboring spies. Fannin launched at least two attacks on the place and captured several citizens, including Father Valdez, the suspected leader (Roell 1996c 1:977-978).

The remaining volunteers of the Matamoros expedition were apparently ignorant of the approach of Urrea. Grant and a detachment were on a foray to capture horses, leaving Johnson in San Patricio with only 34 men. Urrea attacked the town in the early morning hours of February 27, catching the Texans unaware. Only six, including Colonel Johnson, escaped death or capture. On March 2, Grant and his party, unaware that San Patricio had fallen, returned and were caught in an ambush at Agua Dulce Creek and slain (Hardin 1994:158-160). 


\section{Refugio in the Path of War}

Captain Amon Butler King and his company of Kentucky Paducah Volunteers had been left at Refugio as an outpost when Fannin moved to La Bahía. They had taken up quarters in the remains of the old mission church. When several became ill, Lew Ayers, a settler in the area, provided medicine and aid to the ill. Many settlers had left the area because of the hostilities, but several remained and had been joined by evacuated families from San Patricio, including the Ayers family. About midnight of February 25th, Captain King and his company received orders stating that Santa Anna was in San Antonio and they were ordered to Fort Defiance. On February 27, word of the Matamoros group's defeat was received, and that evening, the six survivors of the ill-fated effort began to straggle into Refugio (Huson 1953 1:286-287). This alarmed the citizenry to such a degree that most of the families departed to seek safety elsewhere. Only Ayers and two other families remained. Ayers was especially fearful since he had incurred the wrath of several among the loyalists at the rancho, and they had sworn to assassinate him. He traveled to La Bahía and pleaded for teams to remove his family and their possessions (Ayers 1906:272-273). At that time, all of the carts were engaged in hauling supplies for the fort, but when they returned, Fannin promised that they would be dispatched to Refugio. The carts returned on March 9, and the following day Captain King and his company, augmented by some men from the Bradford Alabama Company, left to conduct them to Refugio. Upon their arrival they were informed that the Ayers and Osborne families were at ranches about four miles downriver from the mission. Some of the carts were left to be loaded in the village and the rest were escorted to obtain the families. As the carts were being loaded with the household goods and families, the group was attacked by men from the Victoriana Guardes, a unit that Carlos de la Garza recruited from among the Goliad refugees, now serving as the advance cavalry for Urrea's main party. A fight ensued with five of the men from the Guardes captured. On their return to Refugio, the group was again attacked, this time by a force from the Carlos Rancho and their Karankawa allies, numbering from 90 to 100 . One woman was injured in the attack, which occurred about three miles below the mission. King ordered the carts into the river bottom and to proceed to Refugio while he and his men held off the attackers until the families reached the safety of the old mission. King and his men then withdrew in an orderly fashion, with three killed and two wounded. By that time the town was in the possession of Captain Carlos de la Garza and his volunteers, and King did not think it wise to attempt to take the slow-moving carts to Goliad without reinforcements. He dispatched a rider, who reached Fannin about midnight of March 11. The Mexicans surrounded the mission and put it under an intermittent attack with small arms and two cannons (Huson 1953 1:293-294). They were soon joined by a picket of Mexican regulars commanded by Captain Rafael Pretalia, bringing the opposing force's strength to about 200 (Priour n.d. Chapter 8:5).

The report of King's situation reached Fannin shortly after midnight on March 13, and he immediately dispatched Lieutenant Colonel William Ward with the Georgia Battalion to the relief of King and the other families. This force, augmented by the remainder of the Bradford Company and Lewis Ayers, numbered approximately 120 to 150 . The company departed Fort Defiance at about 3:00 a.m. in a light rain and arrived at the mission at 2:00 p.m. of the same day. Finding the mission still under attack, Ward deployed his men in battle formation and drove the enemy across the river. They then joined the besieged force in the mission and Ward assumed command. Had they followed their original orders to return to La Bahía immediately, the coming disaster could have been averted. But weary from their forced march, Ward decided to feed and rest his men and depart the following morning. That evening, Captain Ticknor and some of Bradford's men decided, on their own, to strike one more blow at the Mexican soldiers. During the night, they crossed an old ford near Elm Street and launched a surprise attack, routing the enemy and killing twenty-five (Huson 1953 1:294-295).

Reports about the following incident vary, but it is generally accepted that Ward and King disagreed on the issue of 
withdrawing the next morning. Apparently King, still thirsty for revenge, wanted to carry the fight to the enemy again. Ward refused to relinquish command, and King split his troops and departed to attack Carlos Rancho. At dawn on March 14, General Urrea and his main force arrived and found the advance guard skirmishing with Ward's men (Glick 1922 2:10-12; Hardin 1994:164). Colonel de la Peña reported that he ordered an assault on the fortified mission. He stated:

\section{"It could not be taken because of the poor infantry destined for the sacrifice, who had been exhausted by the forced march,"}

noting that they had traveled all night and then were thrust into battle:

$$
\begin{aligned}
& \text { “without any food” } \\
& \text { (Peña 1975:70-71). }
\end{aligned}
$$

Yoakum described Ward's position within the mission complex as follows:

"The church was an old stone building, in ruins, but strong. Three sides of it were, however, exposed to an assault. The fourth side was formed by a stone wall, one-hundred and fifty feet in length, used as a place of burial, and contained many tombs; from the end of this wall the ground descended. Captain Bullock's company of thirty-five men was placed in the churchyard to protect the mission from an assault in that direction.

The remainder of Ward's command barricaded the church, made loopholes, and otherwise prepared for defence [sic]"

(Yoakum 1986:250).

Urrea's troops made a frontal assault upon the church. Ward had his men hold fire until they were within 50 yards, and then the defending forces fired with deadly effect. Urrea suffered 13 killed and 43 wounded, including four officers in the first attack (Garay 1987:410-414). General Urrea reported that the first assault was composed of fresh recruits from Yucatán, who, unable to understand the commands of their officer, "stopped spellbound" (Santa Anna 1970:226). The Texans again repelled a second attack. By midafternoon, the full body of Urrea's force, numbering about 1,500, had assembled at the mission. He prepared for a third assault by moving up his artillery and began a bombardment. Three doors were battered in, a breach was made on the southwest corner of the church, and the roof was considerably damaged. One of the Texan officers stated that the church would be destroyed if the shelling continued for four or five more hours. At 4:00 p.m., a column advanced toward the destroyed doors, but was driven back by musket fire from the combatants within the church. They fell back to the scant cover of Colonel Power's oak rail cow pens about 100 yards away, but accurate fire from the Texans had a telling impact on them. Toward dusk, the attacking forces directed their attention to a point near the south gate of the cemetery wall, an arched opening about 16 feet wide, and reached the church door located on that side. But again, heavy fire forced them to withdraw. After the Urrea's troops withdrew for the night, Ward and his men assessed the situation and decided to attempt an escape in the darkness (Huson 1953 1:303-305).

While assaults were being launched on Ward's defenders, King's men had returned from their aborted expeditions to find, to their complete surprise, that Urrea's army separated them from the church. Urrea's forces immediately detected them, and a group of about 100 cavalry drove King's soldiers into a wooded area on the south side of the river about a mile below the church. There, King's men repelled three attacks before darkness obliged the Mexican forces to curtail action against them. During the darkness of the night, King's men forded the river in an attempt to make their way back to La Bahía (Ayers 1906:274-275; Huson 1953 1:311-312).

Ward was compelled to leave his wounded at the mission, but before leaving them, a detachment proceeded on a dangerous venture to fill their companions' gourds with water. The springs, about 400 yards up-river, were guarded 
by a detail of Mexican soldiers, but after a brief exchange of gunfire possession of the springs was acquired by the detachment. After filling the gourds and collecting the Mexican soldiers' blankets, they returned and bid their comrades farewell (Huson 1953 1:306-307). Leaving the mission, they kept to the protection of the river bottom until they intercepted the Cópano Road. Keeping to the woods and swamps where the cavalry could not search, they reached the San Antonio River three days later (Hardin 1994:164; Huson 1953 1:307-308).

King's company followed a similar route, but became lost. At dawn on March 14, they found themselves only about three miles from the mission. They managed to proceed about two miles further before they were captured by Garza's Victoriana Guardes. They were roped together in pairs and marched back toward the mission until they met with a unit of soldiers sent with orders to receive them and then slay them on the spot. However, Colonel Holzinger, a German officer with the Mexican army, recognized that there were fellow countrymen among the prisoners and had them returned to the mission, where he interceded with Urrea to spare them. On March 16, though, the remaining 32 prisoners were marched a short distance down the Béxar-Goliad Road and shot (Ayers 1906:274-275; Huson 1953 1:311-312). Their bodies were left on the prairie until well after the hostilities were over. Eventually, John Hynes gathered their remains into a cart and gave them a decent burial in the Catholic cemetery in Refugio (Huson 1953 1:314). Urrea and his army remained at Refugio recovering until March 16. Then, leaving the wounded and the baggage under the care of Colonel Rafael de la Vara; he marched with 200 men of infantry and cavalry toward La Bahía. The residents of Refugio reported:

"The Mexican dead were so many that all could not be buried. Some were buried around the mission grounds, but most were dumped into the river and became a feast for the alligators which infested it some miles below town" (Santa Anna 1970:197). ${ }^{6}$
Fannin, having delayed far too long awaiting the return of Ward and King, had placed his command in a precarious position. Yet he delayed further still after he learned the fate of those men preparing "necessary measures for retreat." By the time he was prepared to depart, Mexican scouts were already "roving about" the fort. Insisting on carrying a cannon and extra muskets, the unit was dependent upon oxen to haul items and artillery. Before leaving, Fannin burned Fort Defiance, sending a signal to Urrea's scouts that the army was on the move. Trapped in the open near Coleto Creek, they were soon forced to surrender and marched back to Goliad (Hardin 1994:165-169).

Ward and his men fared no better. Their escape route took them within earshot of the battle of Coleto, some 10 miles distant, but they were powerless to help. They emerged from the swamps above Victoria on March 21 and found the town occupied by Mexican forces. They were subsequently captured and marched back to Goliad and imprisoned with Fannin's command (Roell 1996d 6:821). On Palm Sunday, March 27, the prisoners were divided into four groups and informed they were to be taken to Matamoros. Instead, they were marched outside and executed (Hardin 1994:173).

\section{After the Battle}

The battle left the town of Refugio almost totally destroyed. As a Mexican general described it,

"We passé through this town, where, except the fortifications and cannons, we found nothing but ashes, rubbish and wounded men" (Jenkins 1973 5:2432).

The inhabitants had all been killed or had fled in the "Runaway Scrape." In May, General Filisola's retreating army stopped briefly at the deserted town to obtain supplies brought up from Cópano. On June 2, Captain Isaac's Rangers passed through the town on their way to the same port. Other soldiers passed through the ruins until mid-1837, when the

6 Prior to the present investigations on US 77, TxDOT was concerned that the burials noted as being on the mission grounds might be present within the construction impact zone. While this concern proved to be unfounded, it was sufficient to cause TxDOT to require the archaeological monitoring that led to the discovery and excavation of the campo santo of the mission. - ED. 
Texas government abandoned its effort to maintain a force in the coastal regions of the depopulated counties.

By 1841 , a few hardy settlers had attempted to reestablish the town. Four years later, the settlement was named as the county seat of Refugio County, although very few actually resided in Refugio. In May of that same year, a small band of Mexican soldiers attacked the town, killed a few citizens, and carried off others as prisoners. In September, Refugio was captured by the notorious Captain Agatón Quiñones with 60 irregular soldiers. Ten men were taken off toward Mexico and the town was pillaged (Pierce 1969:120). A company of minutemen had been formed in San Patricio in February of 1841 to offer some protection to the settlers, but when Lieutenant Colonel Ramón Valera and a Mexican force of 132 men once again raided Goliad and Refugio, they were destroyed. This proved too much for the settlers, and the county was virtually deserted until the Mexican War, when General Zachary Taylor stationed a dragoon of troops in the area to protect the beef supply for his men (Guthrie 1996 5:874). The county began to slowly repopulate over the next decade; by 1850 the population reached 288 citizens and 19 African American slaves. ${ }^{7}$ Much of this growth occurred along the coast and was associated with the development of the Corpus Christi Navigation Company in 1852 (Leffler 1996 5:513-516).

The political turbulence of the state and the lack of adequate protection in its sparsely-settled portions caused a resurgence of Indian raids. Pressure on the Karankawa intensified after the slaying of settler John Kemper in November of 1844, and most fled the country for Mexico. However, by 1852 they began to return to their old campsites on the shores of Hynes Bay. Soon they were accused of cattle slaughter and petty theft, and the citizens resolved to expel them from the area. William Kuykendall discovered their campsite, and with John Hynes, mustered about 30 volunteers to mount an attack. Among the company were many of the more prominent old settlers of the county: Thomas O'Connor, Carlos de la Garza, Walter Lambert, James Byrne, and John Baker. They surrounded the camp and struck the Indians by surprise. The Karankawa offered stiff resistance, but most were ultimately slain. The 59 men, women, and children who survived the assault agreed to leave the country, retreating across the Río Grande and reportedly taking refuge in Tamaulipas (Hardin 1996 3:809).

\section{Civil War and Aftermath}

By 1860 , the population of Refugio County had increased to 1,982 people, 234 of whom were African American slaves. ${ }^{8}$ Unlike areas along the Brazos River that were focused on the plantation system of growing cotton, the economy of Refugio County was structured toward grazing and cattle ranching. Almost 386,000 acres in the county were devoted to farms and ranches, with only 230 bales of cotton produced, so the presence of slave holders was minimal. Yet, when the issue of secession arose, the county supported the Confederacy by a vote of 91 percent in favor of secession (Leffler 1996 5:513-516). While well away from the scene of any conflict, the county again offered up fighters to support the cause. As a result, the economy was severely impacted by the war, with the cattle industry suffering greatly.

In 1868, a description of the town attests to the depressed condition of the community, indicating that economic growth had virtually ceased. It also includes a vivid description of the state of the old mission:

"The old mission of Refugio was entirely destroyed... There were piles of rock and debris, the wreck of the old mission, on the grounds... Work on the chapel had been started when the war came on. It was abandoned and not resumed until the early 70's... In 1868 only the foundations of the proposed chapel existed, and the Catholics were using for their religious services an old wooden building on the mission grounds which was reputed to have been one of the original buildings... used as a school for the Indians..."

(Huson 1953 2:177).

7 U.S. Census, Refugio County, 1850.

8 U.S. Census, Refugio County, 1860. 
The church structure mentioned was actually begun in 1867 but was not completed until soon after this account was written. Generally known as "the old stone church," one wall was said to have been a standing portion of the mission, and the remainder was probably constructed on the foundation of the old mission. The construction was begun under Father P. Berthel and completed about a year later by Father Larentino Glynn. The entire church was likely constructed from the stone of the original structure (Huson 1953 2:278-280) (Figure 5-4).

In the late $1800 \mathrm{~s}$, landholding patterns began to change. This was partially due to the large landowners, mainly original Anglo settlers, who began fencing their ranges, but also because there was increased pressure to drive the Mexican Americans from the county. After Mr. and Mrs. Swift, a white rancher and his wife, were murdered in 1874 , suspicion fell upon practically every Mexican of the laboring class. Vigilantes retaliated by murdering Francisco Moya and his wife. Others were taken to the Refugio jail for questioning, and at least three were lynched by mobs. Virtually all of the original Mexican families left the area in the aftermath of these events (Leffler 1996 5:513-516; Huson 1953 2:201-212).

In 1886, Refugio still based most of its economy on stock raising and was the only settlement still active in the county. Cópano was abandoned in 1880 due to a shortage of drinking water, St. Mary's was virtually destroyed by the hurricanes of 1875 and 1886, and Hynesville ceased to exist after 1880. The town was described at the time as:

"... a picturesque village perched upon an eminence on the north bank of Mission River... The river was clear and flowing and its banks prettily wooded. Commanding the village was the old stone church, the two-story priest's house, and the rambling, two-story convent, all on the mission block. Clustered to the west were the fine two-story homes of the Hynes and Welders, which faced the road leading to the ancient sand-bottomed ford of Mission River"

(Huson 1953 2:265).
The 1875 storm also destroyed the Catholic Church and convent at Indianola, dispossessing the Sisters of Mercy. Father Antoine, pastor of Our Lady of Refuge Church, had recently completed a convent and school on the southwest corner of the church block. Upon learning of their plight, he induced them to move to Refugio (Huson 1953 2:248).

On March 14, 1886, the fifteenth anniversary of the battle of Refugio and the massacre of King's men, a monument was erected in the Plaza de la Constitution and the area renamed King's Park. The town threw a gala affair and many of the veterans of the conflict attended (Huson 1953 2:253).

In the spring of 1899 , heavy rain swept away the ferry crossing of the San Antonio River on Victoria road near McFaddin, motivating the citizens to form a major bridge building program. In cooperation with Victoria County, a contract was established and the bridge was completed by February of 1900. This action added extra demand to the plan for bridge construction at Mission River near the church in Refugio. Therefore, a bond election was held in July 1900, and a contract was issued to $\mathrm{C}$. I. Horton for the bridge at a cost of $\$ 5,900$. Bridge construction began in December and was completed March 15, 1901. Use of the old ford slightly up river from the new location was ended (Huson 1953 2:277-278).

In January of 1900, the building of a new Catholic Church was proposed to replace the picturesque, but unsafe, old stone church constructed from the stone of the old mission. During the first week of March, the appointments of the old church were moved across the street to St. Joseph's Hall, and wrecking of the old structure began. The rock from the old church was offered up to anyone desiring the stone. The stone, quickly removed by townsmen, was used in the construction of walks, fences, and chimneys. Some of the stone was reportedly used to construct walks in King's Park. The cornerstone for the new church was laid June 10, 1900, and the building was completed in March 1901 at a cost of \$13,000 (Huson 1953 2:279-281). ${ }^{9}$

9 Today, the church is listed on the National Register of Historic Places. - ED. 


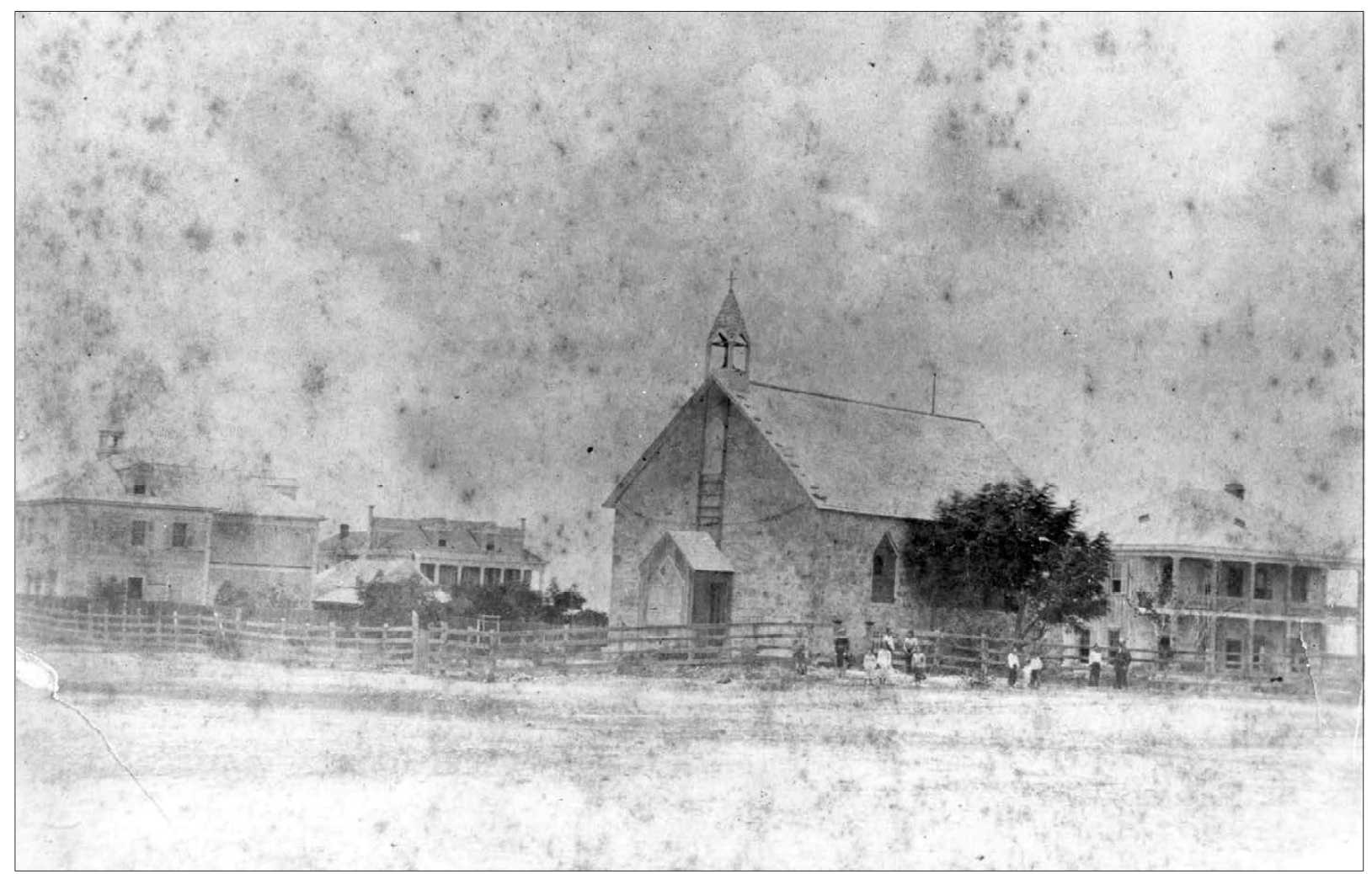

Figure 5-4. Our Lady of Refuge Church, ca. 1885, (left) Convent School, (right) Rectory, (background) Dolores Power Welder residence.

(Photograph courtesy of The University of Texas Institute of Texan Cultures at San Antonio, original in Our Lady of Refuge Church Archives.) 
In 1905, the St. Louis, Brownsville \& Mexican Railroad arrived in Refugio, immediately precipitating a surge in growth. At that time it was noted:

"this town boasted a mission, convent, hotel, two saloons, blacksmith shop, post office, five or six stores, a handful of dwellings, a wooden court house, and the unique distinction of being the home of half a dozen millionaire cattlemen, or one for every eight or nine beings in the village." (Huson 1953 2:265.)

Completion of the railroad created the greatest surge of development since the initial founding of the colony. Several hundred new families followed the railroad to Refugio in the years between 1906 and 1917 (Huson 1953 2:297-301). This growth made the need for civic improvement a necessity. In March of 1914, the Commissioner's Court authorized the expenditure of $\$ 30,000$ to rebuild the principal roads, culverts, trestles, and bridges. In 1927, a bond issue was passed for additional highway improvements. In January of 1928, state aid was secured for Highway 128 (presently known as Highway 77), from the Aransas River to the underpass about three miles north of Refugio. In February of 1929, a contract was issued to Monarch Engineering Company of San Antonio for a long span over the Mission River south of Refugio. In April 1932, H. B. Zachry was awarded the contract from the underpass north of the city to the Aransas River; the paving was completed in September of that year (Huson 1953 2:388-392).

\section{The Centennial Discoveries}

As the 100th year of Texas independence approached, the entire state was caught up in centennial fever. A commemorative event to mark the occasion was first suggested by James Stephen Hogg in 1900 and presented to the Advertising Clubs of Texas in 1923. In association with the Texas Press Association, the Texas Centennial Survey Committee was established to plan the celebration of the Texas Revolution, and at the same time advertise Texas to the world. The three largest cities, Dallas, Houston, and San Antonio, competed heatedly for the central exposition. Dallas was selected because it offered the largest monetary commitment -almost \$8 million. The lure to connect with the celebration was strong throughout the state, causing almost every community to search for a connection to garner a portion of recognition. Refugio was no exception, and rightfully so, based on its direct connection to several of the major battles.

Father William H. Oberste, pastor of Our Lady of Refuge Catholic Church and an avid historian, found an ideal way to relate to the Revolution with tangible evidence of the period. He was aware that Judge John Hynes, as a young man, had participated in the recovery of the bodies of Captain King and his men and had interred them in an unmarked grave in Mt. Calvary Cemetery, a short distance from the church. In January of 1883, while digging a grave in the cemetery, workmen discovered a number of human remains. Since that time, the area near that particular cemetery plot has been traditionally marked as the burial place of King's men. 
Allied with Frank Low, an avocational archaeologist, and funded by monies from the Civil Works Administration (CWA), one of the various federal government New Deal programs, exploration to find and identify their true burial place began. On May 7, 1934, under Low's supervision, the work crew began to excavate a north-south trench near the cemetery plot. On the second day of excavation, a skull and "a mass of confused bones in considerable disarray" were uncovered. Within nine days, 16 distinct skeletons and the bottom of the grave were exposed. The remains were removed, examined and prepared for reburial at a new location, with a marker planned for the original location. ${ }^{10}$ The artifacts recovered with the remains seemed to confirm the location as being the correct one:

"Besides the bones, six brass buttons, six iron buttons, 14 bone buttons, one buckle and four small springs, probably part of a gun mechanism; a shoe, badly decayed, and a bullet lodged in one of the skulls, have been disinterred." 11

The historian, Father Oberste stated that the remaining captives:

"were shot at San Nicolas Lakes on March 16, the day after the Refugio massacre."

On June 17, the remains were reburied with great reverence and pomp in another part of Mt. Calvary Cemetery and marked with the old marker from King's Park. The original burial location was marked by a large new one presented by the Centennial Committee during later ceremonies. ${ }^{12}$

Inspired by the success of their first effort, Oberste and Low ventured out to verify local oral tradition on the location of other burials. Southeast of the church across the highway, on the Johnny Polan lot (Number 14), was supposed to be the burial place of "several hundred Indians." On May 29, this time assisted by Mexican laborers funded by private donations, the two began new excavations. Within two days they encountered a skeleton bearing a bullet hole in the skull. In all, 11 skeletons were discovered buried in an
L-shaped trench, in association with brass buttons of 1836 Mexican Army vintage, and "a number of pewter buttons bearing the engraved figure 8 ". Oberste clarified the situation by reporting:

"in his very first skirmish on March 14, Urrea lost six infantry and five dragoons. These dragoons belonged to the Eighth Company."13

This figure differs from Colonel Garay's report of 13 as mentioned earlier, and Oberste failed to cite the source for his number.

After this rewarding excavation, Father Oberste went on to excavate in the church block. Traces of the older structure were exposed but could not be fully investigated because the new church was superimposed upon the footprint of the old mission. It is these structures, then, that formed the basis for later excavations at Mission Refugio.

10 "Day-by-Day Account of Undertaking Brings to Light Identity of Skeletons and Harrowing Experiences of King and His Men," Refugio Timely Remarks, April 24, 1936.

11 "Find Burial Place of Texas Martyrs, "Refugio Timely Remarks, May 18, 1934

12 "Day-by-Day Account of Undertaking Brings to Light Identity of Skeletons and Harrowing Experiences of King and His Men," Refugio Timely Remarks, April 24, 1936; "Rebury King's Soldiers Sunday," Refugio Timely Remarks, June 15, 1934.

13 "Day-by-Day Account of Undertaking Brings to Light Identity of Skeletons and Harrowing Experiences of King and His Men," Refugio Timely Remarks, April 24, 1936. 


\section{Chapter 6: $\quad$ Previous Archaeology}

\section{Regional}

In the Coastal Bend area, excavations at the Ingleside Cove and Anaqua sites (Story 1968) provided stratified information on Late Archaic-Late Prehistoric (Rockport phase) use of coastal shell middens and what Steele and Mokry (1985) describe as the first attempt to analyze coastal environmental adaptations. Artifact assemblages from seven Late Prehistoric sites in Nueces County are described by Steele and Mokry (1985) and Headrick (1993) analyzes artifacts from pre-and post-contact deposits at the Kirchmeyer site (41NU11).

In recent investigations and publications, Ricklis (1992, 1995a, 1996) identified a continuation in artifact assemblages which links the Late Archaic-Late Prehistoric (Rockport phase) to the Historic-period Karankawa. He also provides evidence for the seasonal settlement patterns of inhabitants along the central Texas coast that is lacking for many of the other areas of the state

More pertinent to this project are the archaeological investigations at Spanish Colonial sites in the South Texas region. Gilmore (1973) reports on the artifacts recovered during excavations at the Keeran site (41VT4) in Victoria, Texas. Since this time, 41VT4, has been identified as the location of La Salle's 1685 Fort St. Louis and the first site of the Spanish presidio La Bahía del Loreto. The Texas Historical Commission (THC) is currently working there to obtain information on this early French and Spanish site.

The probable second site of the presidio La Bahía del Loreto (1726-1749), 41VT8, was investigated by members of the 1968 Texas Archeological Society (TAS) field school (Davis 1968). TAS members are also responsible for the archaeological work at 41VT10, the presumed site of the second Mission Espíritu Santo de Zuñiga, the third site of Mission Espíritu Santo, 41VT11, and the mission's nearby sandstone quarry, 41VT121. These investigations are described by Walter (1999). An in-depth study of the 1995 work at 41VT11 formed the basis for a Master's thesis by Walter (1997). National Park Service excavations in 1935 at the fourth and final location of this mission in Goliad
State Park, 41GD1, were also reported in a Master's thesis by Mounger (1959).

More recently, smaller projects at 41GD1 have been conducted by Hunziker and Fox (1998), Ricklis (1998) and Ricklis et al. (2000). Site 41GD7, the final location of the La Bahía del Loreto presidio is also located within Goliad State Park.

In 1973-1974, the Historic Sites and Restoration Branch of the Texas Parks and Wildlife Department conducted excavations at the site of Mission Rosario (41GD2) in Goliad State Park in Goliad County. During these two years of investigations many of the mission walls and rooms originally exposed during 1940-1941 National Park Service excavations were re-exposed and a large artifact assemblage was collected and analyzed (Gilmore 1974, 1975). Mission Rosario was revisited by archaeologists from CAR in 1999. They relocated many of the earlier excavations, established depths on intact colonial deposits and wall footings, and produced a comprehensive map of the mission and its archaeology (Nickels 2000). Ricklis et al. (2000) also has recently conducted investigations at Mission Espíritu Santo (41GD1) and Nuestra Señora del Rosario (41GD2). Because of the close ties between Mission Rosario and Mission Refugio; namely their south Texas setting, overlapping occupation dates, and affiliation with the coastal Karankawan tribes, the artifact assemblages from Gilmores', Nickels', and Ricklis' projects are used for comparisons of material culture from the Colonial period within the body of this report.

Of equal relevance to this report are archaeological investigations conducted at Native American cemetery sites along the coast. The most recent of these include Blue Bayou, a Late Archaic and Late Prehistoric mortuary site in Victoria County where 52 burials were excavated and analyzed (Huebner and Comuzzie 1992), the Palm Harbor site (41AS80), where at least seven burials were excavated and analyzed (Comuzzie et al. 1984), and the Mitchell Ridge site on Galveston Island where 51 individuals were excavated within 32 burial features (Ricklis 1994a). Other prehistoric cemetery sites in the coastal area have been 
excavated and these burials have received varying degrees of analysis. These include the Harris County Boys' School (Aten et al. 1976), and the Shell Point site in Brazoria County (Hole and Wilkerson 1973), the Upland site in Cameron County (Mallouf and Zavaleta 1973), and the Morhiss site in Victoria County (Campbell 1976). Burials have also been reported from other sites including the Jamaica Beach site (41GV5) in Galveston County (Aten 1965), the Caplen site in Galveston County (Campbell 1957), the Johnson site on Copano Bay (Campbell 1947), the Green Lake site (41CL13) just north of the San Antonio Bay (Wingate and Hester 1972), 41SP64 and 41SP78 on the margin of Redfish Bay (Hester and Corbin 1975).

Perhaps the largest cemetery site in the Coastal Bend area is the Oso Bay site, 41NU2 (Ricklis 1997). Although over 200 Native American burials have been excavated from this site by George C. Martin in 1929 and B. E. Jackson in 1966, only limited reporting (Martin 1930) or analyses (Jackson et al. 1986; Woodbury and Woodbury 1935) have been conducted on this population to date. Despite the variation in methodology and reporting techniques found in these reports, they nevertheless provide general information on the pre-contact populations of the Central Texas Coast.

The results of skeletal analyses from many of these sites have been compared by several authors, not only to assess general health within the coastal populations, but to attempt to identify differences in cultural affiliations among precontact populations through differences in physical stature. Hole and Wilkerson (1973) used information from five Late Prehistoric-period Karankawa sites in his comparison of skeletal material from the Shell Point site. He found that male stature estimates at Shell Point ranged from 5' 5" to 5' 11" with a mean of 5' 9". Stature estimates for the Oso series, reported by Woodbury and Woodbury (1935) ranged from 5' 7" to 5' 11" with a mean of 5' 8", while three skeletons from the Doering and Kobs sites (Newman 1953) had a mean stature of 5' 7", and five individuals from Harris County Boys' School (Aten et al. 1976) had a mean stature of 5' 6" based on "either tibia, femur, or both." He concluded that the existing data indicate that relatively tall stature was the rule among Late Prehistoric Karankawa on the Texas coast. He also found no evidence of nutritional change that would account for the stature change. He suggested the smaller stature reported from three other coastal series, the Doering and Kobs sites (Newman 1953) and Caplen Mound (Woodbury 1937), may indicate these populations were associated with the Atakapa from southeast Texas.
Huebner and Comuzzie (1992) in their analysis of the skeletal material recovered from Blue Bayou found the mean stature for females to be $154.19 \pm 5.77 \mathrm{~cm}\left(5^{\prime} 0^{\prime \prime}\right)$ and $164.64 \pm 6.05 \mathrm{~cm}\left(5^{\prime} 4^{\prime \prime}\right)$ for males. Their statistical analysis indicated the burial population from Blue Bayou was significantly shorter than the populations at Palm Harbor or Oso Creek. They found no significant difference in robusticity; all had well defined browridges, pronounced sites of muscle attachment, and large, well developed mandibles. They also found a pronounced degree of sexual dimorphism. They state that sexual dimorphism does not occur in populations that are nutritionally stressed or suffer from chronic disease, indicating that the coastal groups were relatively free of these problems (Huebner and Comuzzie 1992:94-95). These findings will be used later in this report for comparisons with the Native Americans recovered from the cemetery at Mission Refugio.

\section{Refugio County}

Archaeological investigations in Refugio County have been infrequent, resulting in only 22 sites recorded as of 1998. Archaic and Late Prehistoric sites have been recorded along Bayside Cove (Martin and Potter 1929) and the San Antonio Bay (Comstock et al. 1973). Sites 41RF18 and 41RF19, the location of the 1840-1880 township of El Copano described by Huson (1994a), was revisited and recorded (Bond 1989). The remnants of the 1850-1880 town of St. Mary's of Aransas on Copano Bay (Huson 1994b) was recorded as 41RF22 by D. Fox in 1988. A review of site forms on file at the Texas Archeological Research Laboratory (TARL) also indicate that a human burial with associated chert and pottery (41RF20) was recovered from the edge of Mission Bay and testing was performed at 41RF21 to determine the extent of this Toyah/Rockport phase open campsite.

\section{IRF 1}

The third and final site of the mission Nuestra Señora del Refugio in present-day Refugio, Texas was recorded as a historical site (41RF1) by Suhm and Jelks (1961). However, 25 years earlier, portions of Mission Refugio buried on the present church grounds were excavated by avocational archaeologists Frank Low and Msgr. Oberste, the priest of the modern Our Lady of Refuge Catholic Church (Oberste 1942:367). These investigations revealed stone foundations, three feet wide, buried four-six feet below the surface. Oberste reports exposing: 
"the foundation of the church, attached rooms, remnants of doorways and arches"

and also states:

"many graves were found surrounding the old wall."

Large portions of tile flooring, believed by Oberste to be from the original mission, were also found. A map was made of these findings (Figure 6-1) and everything was left as it was found and reburied.
During three seasons 1995-1997, archaeology classes from Beeville Community College, led by Jim Warren, reopened Oberste's excavations. As the report of these investigations has not been completed, Warren has granted permission for some of the findings to be included in this report (Jim Warren, personal communication 1998). Footings for several rooms of the original mission were uncovered beneath 3$3.5 \mathrm{ft}$ of fill (Figure 6-2). Remnants of the original red-tile floor were present in three of the rooms, two of which are tentatively identified as the sanctuary and the vestry. The footings, which extend $70-90 \mathrm{~cm}$ below the mission floors,

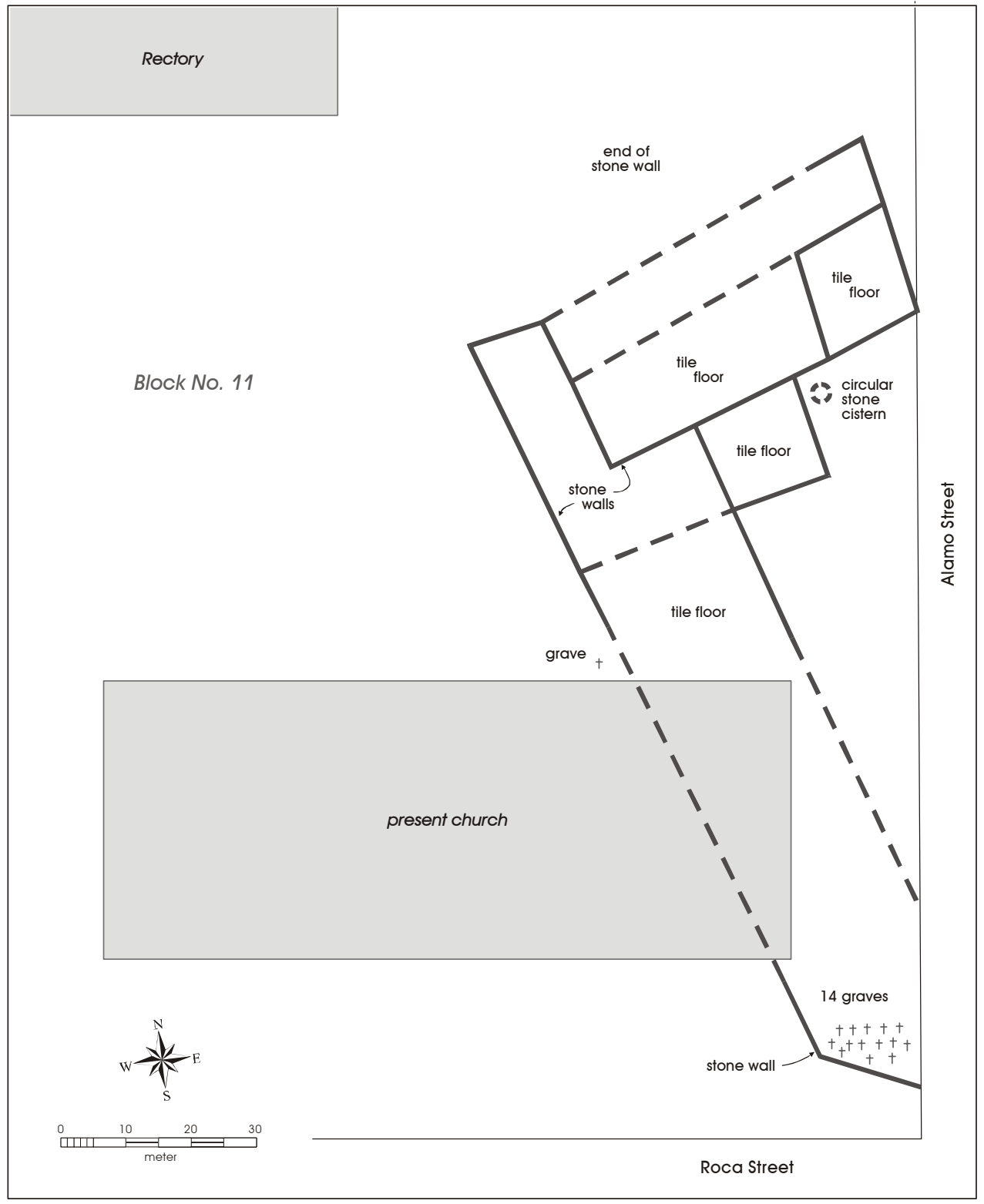

Figure 6-1. CAR adaptation of Oberste Mission Refugio map of 1942. 


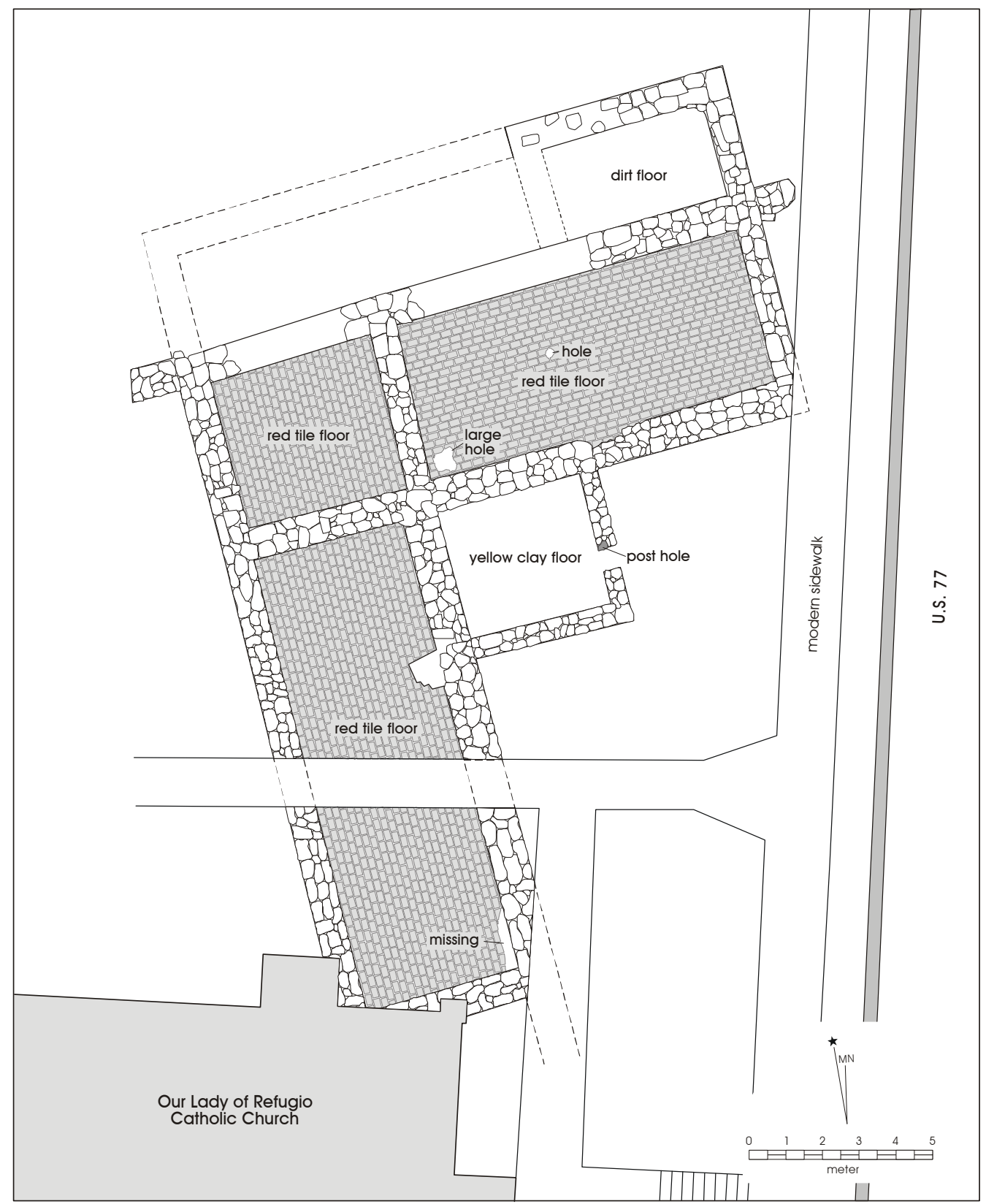

Figure 6-2. Map of Warren's excavation on west side of US 77.

are constructed of locally occurring undressed sandstone. Two sections of the actual wall were found. These sections were $15-20 \mathrm{~cm}$ high and still showed evidence of their original red painted plaster coating. No evidence of the burials mentioned by Oberste (1942) or the bell towers discussed by Huson (1953:1:94-95) were encountered. Warren interprets the room with the yellow-clay floor (Figure 6-2), as representing the "rock church" described by local residents as having been built by Irish settlers sometime after 1860 with stones from the Spanish mission. Unfortunately, the artifacts from these investigations on the west side of US 77 were recovered from extremely disturbed deposits-previous excavations and subsequent reburial by Oberste and the addition of modern landscape fill containing ca. 1860s materials (Jim Warren, personal communication 1998). 
Warren's group also tested the church property on the east side of US 77. Here, thirteen $1-\mathrm{x}-1 \mathrm{~m}$ test units were excavated in the center of the lot and 19 shovel tests were dug in an east/west-north/south pattern (Figure 6-3). The "average" profile from the 1-x-1 m units showed a $12 \mathrm{~cm}$ top deposit of dark gray sandy loam with modern trash. Beneath this was a deposit of the same soil, which contained Mission-period artifacts.

Artifacts from Warren's investigations on the east side of US 77 were cataloged at CAR. Although an in-depth analysis was beyond the scope-of-work for this project, preliminary quantitative information is given here. Artifacts from these investigations included 1,571 Native American sherds, 335 Spanish and European ceramic sherds, 361 glass fragments, 490 faunal bone fragments, 69 pieces of chert debitage, and 2 stone and 1 metal arrow point. However, 54 percent $(\mathrm{N}=1704)$ of the entire assemblage, including 58 percent $(n=907)$ of the Native sherds, 50 percent $(n=167)$ of the Spanish and European ceramics, and 58 percent $(n=41)$ of the debitage came from Level 2, 10-20 $\mathrm{cm}$ below the surface, from disturbed deposits mixed with modern glass, metal, and construction materials.

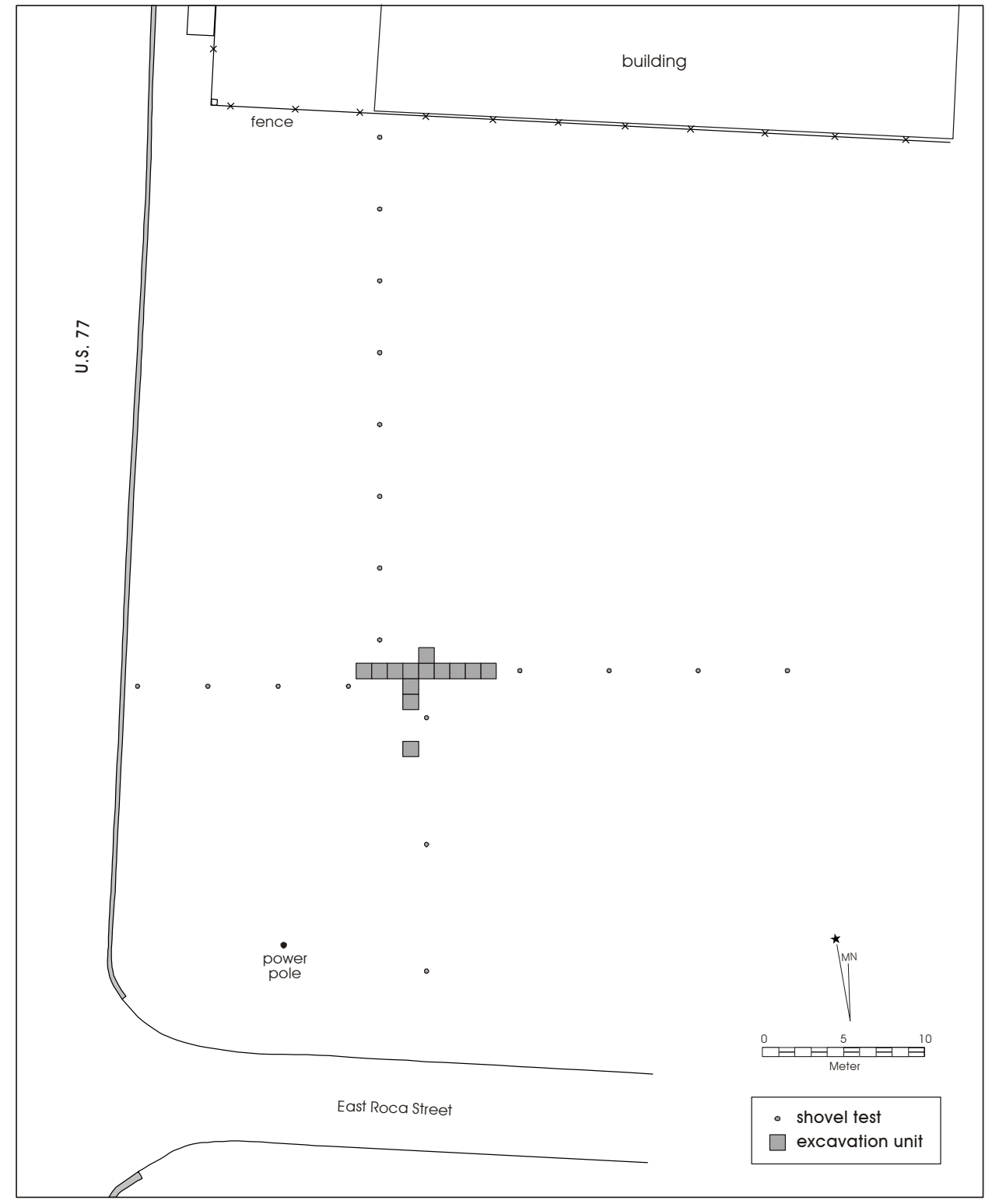

Figure 6-3. Map of Warren's excavation on east side of US 77. 



\section{Chapter 7:}

\section{Methodology}

Descriptions of the field, laboratory, and analytical methods used during both phases of the project are presented in this chapter. The analytical methods described here were selected to address the specific research issues identified for the Mission Refugio project.

\section{Field Methods for the 1998 Season}

The initial phase of this data recovery project was designed to mitigate the effect of street widening activities at Mission Refugio (41RF1). Preliminary testing conducted at the site by TxDOT archaeologists (Clark 1998) consisted of excavation of three 1-x-1 m test units and three backhoe trenches. Clark identified the presence of cultural deposits associated with the Spanish Colonial site of Mission Refugio to a depth of $60 \mathrm{~cm}$ below the surface along the 3-x-50 m strip of land comprising the expansion of the eastern ROW of US 77 directly across the street from the present-day Our Lady of Refuge Catholic church. Clark's findings also indicated that the artifact concentration was heaviest in the northern half of the area and that the Colonial deposit was mixed with more modern artifacts in the upper $20 \mathrm{~cm}$ along the length of the ROW. The presence of intact, Spanish
Colonial deposits from the late Mission period in Texas led TxDOT, U.S. Department of Transportation's Federal Highway Administration (FHWA), and THC to concur that the deposits were eligible for the National Register of Historic Places under Criterion D. The set of research questions, detailed in Chapter 1, were then identified. An excavation strategy, based on these research questions, was devised to address these issues while recovering data from approximately one-third of the buried, intact Colonial deposit within the ROW. TxDOT, on behalf of the FHWA, provided this information to the following federally recognized tribes: Mescalero Apache Tribe, Tonkawa Tribe, Caddo Tribe, Kickapoo Tribe of Oklahoma, Fort Sill Apache Tribe, Comanche Nation, and Alabama-Coushatta Tribe.

With the prior approval of TxDOT and THC representatives, CAR fieldwork began on July 27, 1998 (Figure 7-1), with the mechanical removal of the upper $10-\mathrm{cm}$ of soil (in $5-\mathrm{cm}$ increments) from the easternmost two meters of the 3-x$50 \mathrm{~m}$ project area (Figure 7-2). No attempt was made to remove the soil from the western one-third of the ROW near the curb due to the slope, the numerous highway signs, and the heavy traffic on US 77. The work was performed by a

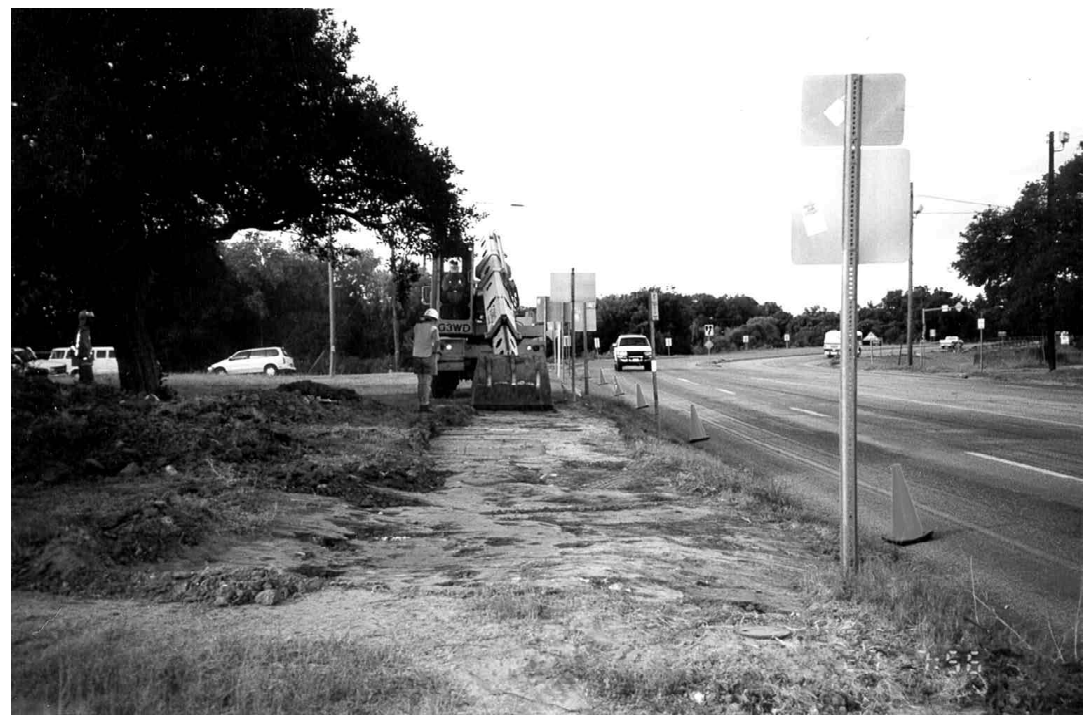

Figure 7-1. Area of investigations, 1998 -east side of US 77.

Looking south. 

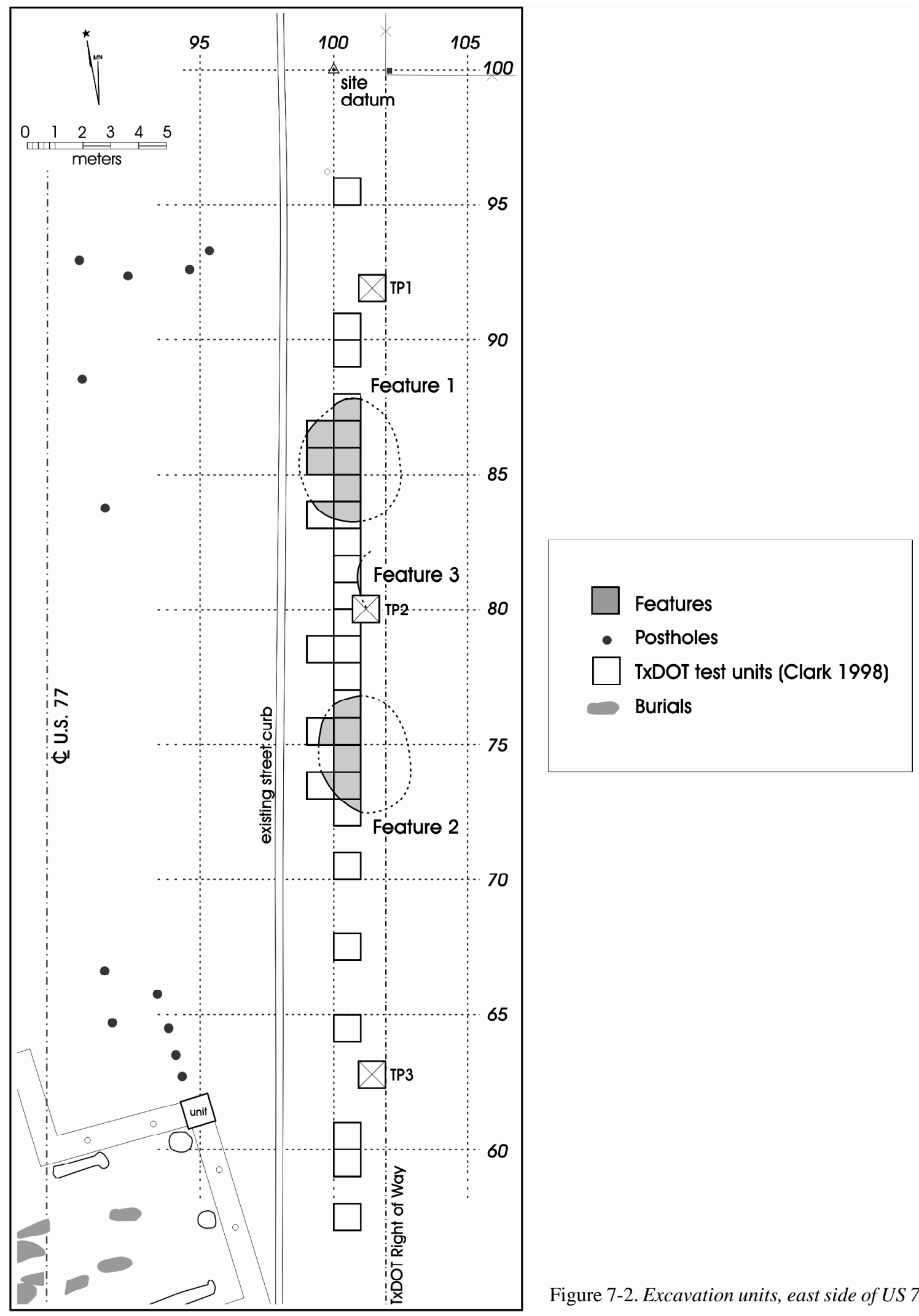

Figure 7-2. Excavation units, east side of US 77, 1998 season. 
Gradall and operator supplied by TxDOT and was monitored by two CAR archaeologists. The backdirt was not screened, but a sample of diagnostic artifacts was collected from the Gradall dirt piles. The locations of TxDOT's three test units and three backhoe trenches were re-established and partially re-excavated to reveal the stratigraphy noted by Clark during the previous testing phase (Clark 1998).

During the Gradall operations a water line at the south end of the project area was accidentally ruptured. It became evident during observations of the ensuing repair activities that the southernmost five meters of the project area had suffered numerous disturbances during the prior installation of water lines, a fire hydrant, and a drainage culvert. This area was therefore excluded from any further investigations.

Following the Gradall operation, a project datum was established by driving a piece of rebar into the ground at a point two meters east of the curb and five meters north of the project's northern boundary. The datum became the $100 \mathrm{~N} / 100 \mathrm{E}$ point for the excavation grid used during the project. A transit and a 50-m tape were used to obtain initial graded and non-graded elevations and to map the project area. Units excavated during the project were identified by their $\mathrm{S} / \mathrm{W}$ corner coordinates on the project grid (i.e., $85 \mathrm{~N} / 100 \mathrm{E})$.

Five 1-x-1 m units were placed at 10-m intervals along the length of the center grid line to identify areas of heaviest artifact concentration and to look for possible features. The remaining 26 units were placed to maximize the recovery of bone and artifacts (Figure 7-2). Vertical datums for each unit were established $10 \mathrm{~cm}$ above the graded surface for continuity with TxDOT excavations and to emulate the original ground surface. Thus, for all depth measurements, $\mathrm{cms}$ below datum (bd) are equal to $\mathrm{cms}$ below the surface (bs) before the mechanical removal of the top 10-cm. Based on this concept, surface elevations were taken and the initial level for each unit was brought to $20-\mathrm{cm}$ bd, or $10-\mathrm{cm}$ bs. Succeeding levels in all but three of the units were excavated by trowel and shovel in 10-cm increments, or by stratigraphic level where possible to sterile soil. Soil from these units was screened through $1 / 4$-inch hardware cloth and artifacts were bagged and labeled by level. Excavations were documented on standard CAR unit-level forms denoting depth below surface, soil description, artifacts collected and general observations. Artifact and sample bags were marked with provenience information and a bag identification number; this information was recorded in a field bag log for cross-reference and accuracy.
Two entire units $(74 \mathrm{~N} / 100 \mathrm{E}$ and $76 \mathrm{~N} / 100 \mathrm{E})$ and portions of a third (86N/100E) within the densest concentration of cultural material were excavated in 5-cm levels for a more discreetly controlled sample. These $5-\mathrm{cm}$ levels were water screened on site through $1 / 16$-inch mesh to obtain a sample of the full range of material contained in these deposits. Also, during the previous testing phase, Clark (1998) had identified a limey/plaster layer in one unit that was interpreted as a natural stratigraphic break. Therefore, in units where this layer was present, soil and material above and below the break were collected separately and labeled accordingly for later analyses.

Profiles were drawn of at least one wall of each unit. Features and selected levels within the features were plan mapped and photographed. Approximately 15-20 liters of soil from selected levels within the features was bagged for flotation to collect charred plant remains. Soil samples were taken from each feature for pollen and phytolith testing, for petrographic analysis, and for possible OCR (Oxidizable Carbon Ratio) dating. Samples were also taken of the "limeyplaster" layer for more complete identification. All collected materials, soil samples, and flotation samples were transported to the CAR laboratory weekly for processing.

A Sokkia Set 5 Total Data station and a SDR33 Data collector (TDS) were used to map the locations of features and completed units and record beginning and ending elevations. Shots were taken of key locations at Our Lady of Refuge church across the street to tie the current investigations to the earlier work conducted at Mission Refugio by Jim Warren (see Figures 6-2 and 6-3). The site datum used to establish the excavation grid was used as the principle datum for these mapping activities.

\section{Field Methods for the 1999 Burial Excavation Season}

Due to the sensitive nature of this site and archival information suggesting burials associated with the 1836 Battle of Refugio might be located near the ROW (Handbook of Texas Online 2001a), TxDOT had included a monitoring requirement in the construction plans and CAR had developed a contingency plan for the excavation of any burials that might be encountered. CAR also contracted for remote sensing to be conducted within the ROW in an attempt to identify possible burial locations beneath the pavement before construction began. These investigations produced negative results (BEEI 1998). 


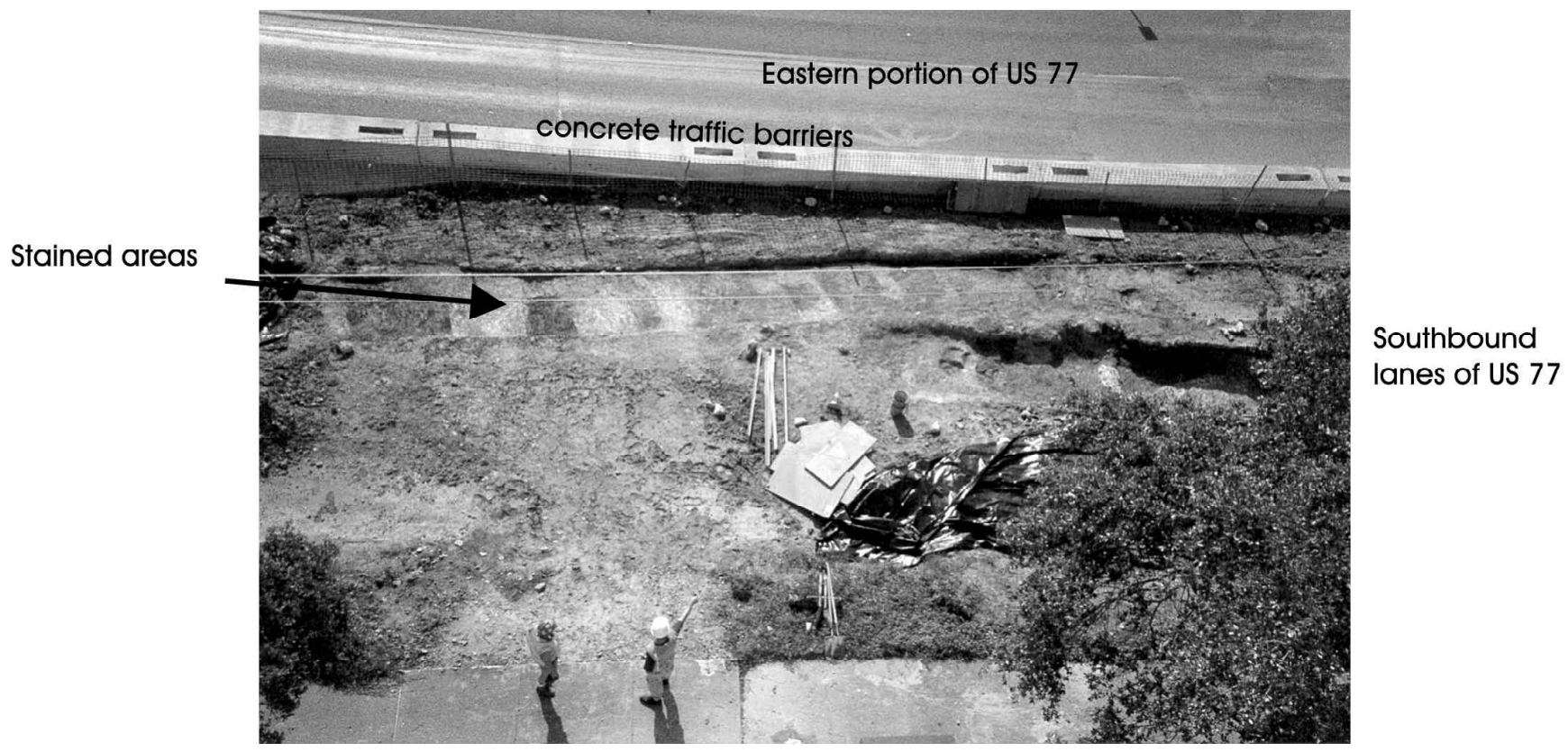

Figure 7-3. Area of burial investigations beneath southbound lanes of US 77.

(Photograph taken from the bell tower of Our Lady of Refuge Church, looking east.)

Therefore, in the spring of 1999, TxDOT archaeologist Tim Meade was at the site to monitor the removal of the pavement and road base from the two southbound lanes of US 77 in front of the church to ascertain if remnants of the mission were present in this portion of the ROW, and to determine if human burials associated with the 1836 Battle of Refugio were present. Approximately $30 \mathrm{~cm}$ of road base caliche was removed to level the surface for the new road. While monitoring this removal of the existing road base, human remains were encountered. Based on a pre-arranged emergency burial excavation contingency, construction was halted and a team of CAR and TxDOT archaeologists were on site the following day to excavate these remains. Observations made during the emergency excavation indicated that the remains were not those of the Yucatecan soldiers killed in the 1836 battle as had been anticipated, but in actuality represented a multiple burial of two adults and three children. Five oblong areas of darker colored soil believed to be additional burial features were also identified to the north and east of these individuals (Figure 7-3).

These observations strongly suggested that the cemetery, or campo santo, of Mission Refugio had been encountered. At this point, plans were developed for CAR to thoroughly investigate the area in the roadway immediately in front of the existing church to determine the extent of the burial features and exhume all human remains found within the ROW. A Scope-of-Work (S-O-W) and methodology for these expanded investigations were designed in consultation with TxDOT and THC representatives. Additional research questions were also designed in consultation with TxDOT, THC, and our team of physical anthropologists to maximize the information obtained from exhumation of this important Colonial-period burial population.

Prior to initiating these investigations, TxDOT telephoned and sent letters to Native American tribes and officials of the Catholic Church informing them of the discovery of the cemetery and the necessity of the upcoming excavations in order to protect the burials from further damage from the high volume of traffic on US 77. Tribes notified were the Tonkawa Tribe, the Caddo Tribe of Oklahoma, the AlabamaCoushatta Tribe, and the Kickapoo Tribe of Oklahoma (particularly the Kickapoo Band of Texas). Efforts were also made to contact several non-federally recognized Native American groups that had expressed interest in sites of this type. These groups were the Lipan Apache Band of Texas and the Tap-Pilam Coahuiltecan Nation. TxDOT also held a public meeting at the Catholic church in advance of the excavations to provide further information and address any 
questions or concerns that could arise at the time of the investigations. The Native American tribes were invited to attend this meeting as well as other interested parties.

Systematic investigations of the campo santo at 41RF1 began May 24, 1999 in the two southbound lanes of US 77 directly in front of Our Lady of Refuge Catholic church in Refugio, Texas. This area began at the intersection of West Roca and US 77 and extended approximately $17 \mathrm{~m}$ to the north. It extended west $12.2 \mathrm{~m}$ from the centerline of US 77 up to and including the sidewalk in front of the church. When archaeological excavations in the southbound lanes were complete, these lanes were re-paved, traffic was rerouted onto the newly-paved lanes, and the investigations continued beneath the two northbound lanes of US 77 .

A temporary datum was established outside the western limit of the ROW and tied into the permanent site datum established in 1998 on the east side of the road. The location and elevation of the previously removed burials and the suspected burial features near the center of the road were recorded. The TDS was then used to set up a series of 1-m grid markers along the eastern edge of the southbound lanes to provide temporary horizontal control for recording individual burial locations during excavation. Because no indication of the original ground surface remained within the roadbed, temporary vertical control was set along the grid using the paved surface of the southbound lanes as ground surface. Depth measurements were recorded in the field as centimeter below street surface (bst) incorporating the $30-\mathrm{cm}$ of road base removed before the actual excavations began.

The original S-O-W called for a Gradall to be used to verify the northern and southern limits of the burial area originally identified by TxDOT archaeologists during initial testing and to remove any remaining overburden from within the burial area. However, prior to the start of CAR-UTSA investigations, the area received copious amounts of rainfall which substantially softened the soils in and around the burial area washing away enough of the overburden to make it obvious that at least some of the burials were located immediately below the graded base of the existing street. Therefore, no mechanical equipment was permitted within the burial area and any remaining layers of road base were removed by trowel and shovel shaving. In this manner, burial features could be identified and exposed without danger of further damage from heavy equipment. The Gradall was used to remove the remaining road base from the northern portion of the project area away from the burials to reveal non-burial features associated with the mission compound (Figure
7-4). The locations of these non-burial features were plotted using the TDS, assigned a Feature Number, recorded on Feature forms, plan mapped, and photographed. Those features identified as possible postholes, trash pits or wall trenches were bisected and profiled. Samples were collected from features containing artifacts and a continuous profile of the strata and features exposed along the western edge of the ROW was drawn and photographed.

Fortunately, contrast between the light yellow to white color of the naturally occurring underlying Beaumont soils and the dark brown of the overlying surface clays used to fill the burial features, made the outlines of these features readily identifiable once the road base overburden was manually removed. Each burial feature was assigned a number (BFs 1-28 and BFs 30-39) and its location was plotted on the field map. Burial features were excavated as a single unit. Burials within each burial feature were excavated individually when possible. Each burial was given an individual identification number and corresponding burial feature number; vertical and horizontal position and any associated burials were recorded on the master burial log and plotted on the site map. It was initially planned to completely excavate each burial feature and pedestal the individual burials before recording and removing the remains. However, it soon became apparent that the vast majority of the burial features contained multiple interments, articulated and disarticulated, and within the same grave. This fact, combined with the inclement weather (continued rain) forced a change in plans (Figure 7-5). Therefore, in most cases, only one burial was uncovered and removed at a time, limiting the amount of exposure to the fragile remains and protecting them from further damage.

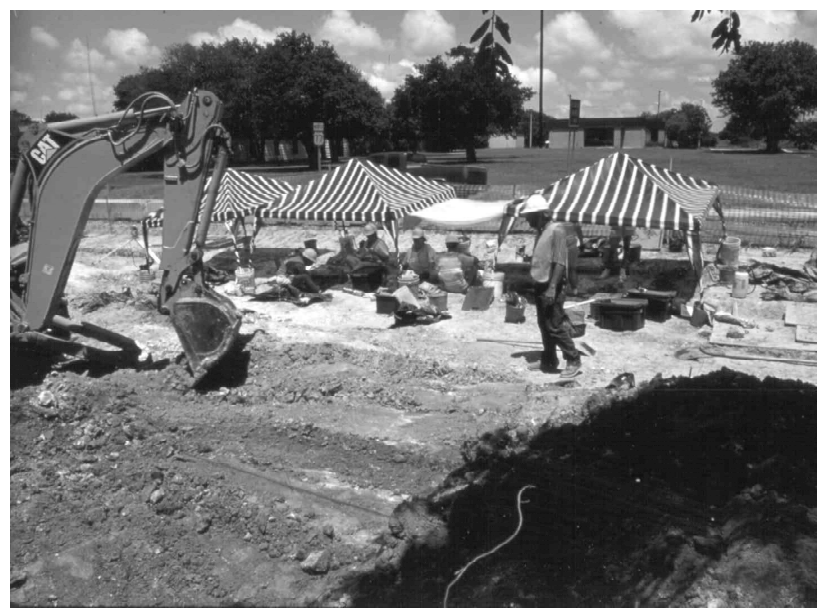

Figure 7-4. Archaeological monitoring of Gradall excavations at Mission Refugio. 


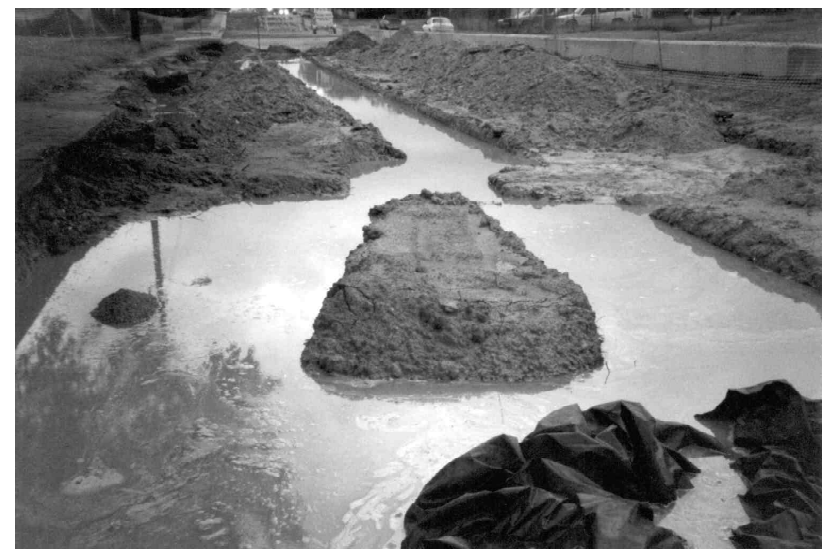

Figure 7-5. During archaeological excavations heavy precipitation was received in the Refugio area.

Dental picks and wooden skewers were used to expose the burials to minimize any further damage to the remains. After each burial was fully exposed, a set of burial excavation records was filled out for each burial. This three-part set of records included a burial excavation form, a line drawing of a human skeleton for element identification, and a plan map of the burial and any associated burials. (Examples of these forms can be found in Appendix N.) The burial excavation form was used to record burial number, burial feature number, horizontal and vertical provenience on the site grid, position of skeleton, orientation, direction of skull, and post-depositional shifting of the remains. Stratigraphic relationships with other burials in the same burial feature, evidence of post-interment disturbances, grave dimensions, grave fill, and fill into which the grave was excavated were also recorded on this form. Finally, objects that were definitely associated with a particular burial were itemized on the recording form and bagged and labeled to correspond with their respective burial. The second form in the set, the human skeleton, was then filled in to accurately record the presence/absence of all elements associated with that individual burial. The final form in the set, a plan map of each individual burial, was drawn to scale and included drawings of other burials in the same burial feature when possible. A photographic record of each burial was made and cross-referenced on the burial recording form and photo $\log$, along with the date and name of the excavator. TDS shots were taken of the burial feature outlines and of each burial, recording elevation and location of skull, pelvis, and feet of each burial. In the case of disarticulated or incomplete burials, only the location and elevation of the skull was electronically recorded. These data were incorporated into the site's master grid later in the laboratory at CAR.

After the recording procedure was completed, elements were carefully removed, individually wrapped in aluminum foil packets labeled with the element identification (when possible), the appropriate burial feature number and burial number (i.e., Burial 8, BF 4, left femur). These individual packages were placed in temporary curation containers specifically labeled with the burial identification number and burial feature information. In the event that elements from more than one burial were commingled within a burial feature and not easily segregated in the field, burial numbers were assigned based on the number of skulls present and all associated remains were labeled as such (i.e., Commingled Burials 14 and 25) for identification during analysis. Soil from the burial features was screened through $1 / 8$-inch hardware cloth and all artifacts recovered from the fill dirt were labeled to correspond with the respective burial feature. This process continued until all burials within the western ROW were located and removed. After the highway construction in the western ROW was completed, CAR and TxDOT archaeologists returned to Refugio to repeat the process in the eastern ROW until all burial and other cultural features were located, removed, and/or sampled.

Out of respect for the deceased, TxDOT and CAR-UTSA maintained strict security throughout all phases of the excavations. Hence, while a large media event was held the first week of work, and weekly media/public information meetings were held, no tours of the excavation area were allowed, no photographs of human remains (other than those taken by CAR were permitted, and an orange fence was erected around the site that restricted entry to authorized personnel only. Burials and artifacts were removed from the site at the end of each workday and secured in Our Lady of Refuge Catholic church. Each evening, the excavations were covered with heavy plastic for protection and the project area was secured. A police officer was on duty to guard the site whenever the crew was not present. The excavation site was under watch during evenings, weekends, and when inclement weather prevented excavation. All materials were transported to the laboratory at CAR at the end of each week. 


\section{Laboratory Methods}

In the laboratory, artifacts were washed and air dried. They were then sorted into gross artifact classes, which included unglazed, tin-glazed, lead-glazed, and diagnostic whiteware ceramics; bone; metal; glass; and lithics. According to curation specifications approved by TxDOT and THC for this project, artifacts from the twentieth century were not collected or were discarded during processing without being cataloged. Unique, diagnostic, or complete artifacts dating between 1850-1900 and all earlier artifacts were processed as described below.

Artifact counts and faunal bone weights were recorded on standardized CAR catalog sheets by level and/or feature and entered into the computerized database. Ceramic artifacts and other diagnostic pieces not directly associated with burials were labeled with India ink, which was covered with a clear sealant. These artifacts were then placed in resealable plastic bags with acid-free provenience labels. Upon completion of analysis, artifacts were placed in acid-free boxes with acid-free labels for curation. All non-burial related artifacts, documentation, field notes, maps, illustrations, and photographs were stored in accordance with 36 CFR 79 (Curation of Federally Owned and Administered Archeological Collections). Several of the more fragile burial-related artifacts were transported to Texas A\&M University for processing. They were photographed and described and casts were made of selected items. Burialrelated artifacts will be returned to TxDOT for eventual reburial with the human remains.

At CAR the human remains were placed in a secured area and were carefully cleaned. After drying, the elements were placed in plastic bags containing tags with the appropriate burial and burial feature number. They were then returned to their labeled temporary curation containers. The cleaning and drying process continued in the laboratory while the excavations proceeded in the field. These remains were kept in their secure area in the CAR laboratory until excavations were complete and all remains from the field were ready for transport to the University of Tennessee for osteological analysis. Upon completion of this analysis, they were transported to the Environmental Affairs Division at TxDOT in Austin, Texas, where they are stored in a secure location until arrangements for reburial are finalized and compliance with Native American Graves Protection and Repatriation Act (NAGPRA) and the Texas Health and Safety Code is completed.

\section{Flotation Methods}

Soil samples collected for flotation from non-burial features were decanted into a 5-gallon plastic bucket filled with water. No flotation samples were taken from the burial features. No more than 4 liters of soil was placed in the bucket at one time. Liquid from the bucket was poured through a No. 35 $(.5 \mathrm{ml})$ geologic testing sieve where the charred material that had floated free from the soil was collected. This material (the light fraction) was transferred onto a chiffon cloth were it was allowed to air dry away from direct sunlight. Residue remaining in the bucket was water screened according to procedures appropriate for that provenience (i.e., samples from $5-\mathrm{cm}$ levels that had been water screened through $1 / 16^{1}$-inch mesh in the field were screened through $1 / 16$-inch mesh, all others were screened through $1 / 4$-inch mesh). Artifacts from this heavy fraction were cataloged as described above. Dried light fractions were wrapped in foil and placed, along with their provenience label, into re-sealable plastic bags for shipment to analysts and for curation.

\section{Analytical Methods}

\section{Analysis of Human Remains}

Analysis of the Spanish and Native American skeletal remains recovered from Mission Refugio was conducted at the University of Tennessee in Knoxville by a team of physical anthropologists, osteologists, and pathologists led by Dr. Douglas Owsley from the Smithsonian Institution at the National Museum of Natural History and Drs. Lee Meadows Jantz and Richard Jantz from the University of Tennessee. Their analysis involved standard cranial and postcranial measurements, determinations of the sex and age of the individuals, examinations for dental and bone pathologies, and photographic records. TxDOT and CAR-UTSA verified that while at the University of Tennessee, the remains were kept in a secured lab area and access to them was limited to only the select group of professionals performing the analysis.

Minute rib fragments from selected burials were collected for stable isotope analysis by Dr. Lynette Norr at the University of Florida. This information was entered into a national data bank for comparative analysis with other European and Native American populations in North 
America to provide important general health, dietary, and demographic information about the early residents at Mission Refugio. Because archival records found prior to the excavations indicated that the individuals buried in the cemetery were of Native American, as well as Spanish descent, these studies were also designed to provide documentation of those burials that would require TxDOT compliance with NAGPRA.

The reburial and repatriation of Native Americans and nonNative Americans will follow the requirements of NAGPRA, Texas State Cemetery laws, and THC's cemetery policy. Consulting parties include THC, the County of Refugio, the Catholic Diocese of Corpus Christi, the Mescalero Apache Tribe, and the Tonkawa Tribe of Oklahoma. The Wichita and Affiliated Tribes have also been invited to consult as well.

\section{Faunal and Ceramic Assemblages}

Upon completion of cataloging and data entry, faunal collections were shipped to Dr. Elizabeth Reitz of the Museum of Natural History at the University of Georgia for analysis. Element and species identification, minimum number of individuals present (MNIP), and indications of butchering techniques were among the attributes used to address the research questions of fluctuating access to cattle at the mission, as well as the function and content of the bone deposits.

After cataloging, the ceramic assemblages were separated by type into two broad categories: Native American wares and Spanish Colonial/European wares. Unglazed, bone and sand tempered sherds comprise the Native American collections, while the Spanish Colonial/European wares included lead-glazed, tin-glazed, burnished, and decorated whitewares. The Native American wares were shipped to Dr. Timothy K. Perttula for in-depth analysis. The Spanish Colonial/European wares remained at CAR for analysis by Anne Fox. Both of these analyses focused on changes and continuity in ceramic technology and the relative importance of local versus imported (Mexican/European) ceramics to address questions concerning the affect of Spanish influence and the frontier supply system on Native American ceramic technologies as outlined in Chapter 1.

\section{Special Analyses}

\section{Neutron Activation and Petrographic Analysis}

Several special analytical techniques were selected for the various artifact groups from Mission Refugio to provide additional information necessary to address the research questions for this project. As part of the ceramic analysis, 127 Native American sherds from 41RF1 were selected for petrographic (thin section) analysis by David Hill. These same sherds along with a sample of the natural clay from one of the trash pits, Feature 1, were also submitted for chemical composition (INAA) analysis by Hector Neff and Dr. Michael Glascock at the Missouri University Research Reactor Archaeometry Laboratory. Twenty of the sherds selected for testing from 41RF1 were lead-glazed. These data will be used in determining the source of raw materials used in the manufacture of the ceramics recovered.

\section{Macrobotanical Analysis}

Ten samples from light fractions obtained from flotation of soil samples from the trash pits, Features 1 and 2, and 14 macrobotanical samples collected during excavations at Mission Refugio were selected for further analysis (Table 7-1). These samples were sent to J. Philip Dering at Texas A\&M University Palynology Laboratory for species identification to provide insight into the plant resources used by the residents of the mission. 
Table 7-1. Macrobotanical sample list from 41RF1

\begin{tabular}{|c|c|c|c|c|c|}
\hline Sample \# & \multicolumn{3}{|c|}{ Provenience } & Item & Count \\
\hline 84 & $86 \mathrm{~N} / 100 \mathrm{E}$ & $20-30 \mathrm{~cm} \mathrm{bd}$ & Ft. 1 (AL) & corn cob frag & 1 \\
\hline 120 & $83 \mathrm{~N} / 100 \mathrm{E}$ & $90-100 \mathrm{~cm}$ bd & Ft. 1 (BL) & corn cob frag & 3 \\
\hline 169 & $76 \mathrm{~N} / 100 \mathrm{E}$ & $70-75 \mathrm{~cm} \mathrm{bd}$ & Ft. 2 (BL) & corn cob frag & 4 \\
\hline 170 & $85 \mathrm{~N} / 100 \mathrm{E}$ & $110-120 \mathrm{~cm} \mathrm{bd}$ & Ft.1 (BL) & corn cob frag & 2 \\
\hline 183 & $76 \mathrm{~N} / 100 \mathrm{E}$ & $85-90 \mathrm{~cm} \mathrm{bd}$ & Ft. 2 (BL) & corn cob frag & 1 \\
\hline 219 & $87 \mathrm{~N} / 100 \mathrm{E}$ & $50-60 \mathrm{~cm} \mathrm{bd}$ & Ft. 1 (AL) & $?$ & 1 \\
\hline \multirow[b]{2}{*}{224} & \multirow[b]{2}{*}{$87 \mathrm{~N} / 100 \mathrm{E}$} & \multirow[b]{2}{*}{$60-70 \mathrm{~cm} \mathrm{bd}$} & \multirow[b]{2}{*}{ Ft. 1 (AL) } & corn cob frag & 3 \\
\hline & & & & burned kernel & 1 \\
\hline 234 & $74 \mathrm{~N} / 100 \mathrm{E}$ & $75-80 \mathrm{~cm} \mathrm{bd}$ & Ft. 2 (BL) & corn cob frag & 1 \\
\hline 240 & $74 \mathrm{~N} / 100 \mathrm{E}$ & $80-85 \mathrm{~cm}$ bd & Ft. 2 (BL) & corn cob frag & 2 \\
\hline 246 & $74 \mathrm{~N} / 100 \mathrm{E}$ & $85-90 \mathrm{~cm} \mathrm{bd}$ & Ft. 2 (BL) & corn cob frag & 2 \\
\hline 267 & $86 \mathrm{~N} / 100 \mathrm{E}$ & $80-85 \mathrm{~cm} \mathrm{bd}$ & Ft. 1 (BL) & corn cob frag & 3 \\
\hline 273 & $86 \mathrm{~N} / 100 \mathrm{E}$ & $110-115 \mathrm{~cm} \mathrm{bd}$ & Ft. 1 (BL) & corn cob frag & 3 \\
\hline 274 & $86 \mathrm{~N} / 100 \mathrm{E}$ & $115-120 \mathrm{~cm} \mathrm{bd}$ & Ft. 1 (BL) & corn cob frag & 1 \\
\hline 275 & $86 \mathrm{~N} / 100 \mathrm{E}$ & $120-125 \mathrm{~cm} \mathrm{bd}$ & Ft. 1 (BL) & corn cob frag & 1 \\
\hline 236 & $85 \mathrm{~N} / 100 \mathrm{E}$ & $110-120 \mathrm{~cm} \mathrm{bd}$ & Ft. 1 (BL) & light fraction & 1 \\
\hline 216 & $85 \mathrm{~N} / 99 \mathrm{E}$ & $80-90 \mathrm{~cm}$ bd & Ft. 1 (BL) & light fraction & 1 \\
\hline 73 & $85 \mathrm{~N} / 99 \mathrm{E}$ & $40-50 \mathrm{~cm} \mathrm{bd}$ & Ft. 1 (AL) & light fraction & 1 \\
\hline 104 & $86 \mathrm{~N} / 100 \mathrm{E}$ & $56-60 \mathrm{~cm} \mathrm{bd}$ & Ft. 1 (BL) & light fraction & 1 \\
\hline 211 & $85 \mathrm{~N} / 99 \mathrm{E}$ & $70-80 \mathrm{~cm} \mathrm{bd}$ & Ft. 1 (BL) & light fraction & 1 \\
\hline 243 & $85 \mathrm{~N} / 99 \mathrm{E}$ & $120-130 \mathrm{~cm} \mathrm{bd}$ & Ft. 1 (BL) & light fraction & 1 \\
\hline 173 & $76 \mathrm{~N} / 100 \mathrm{E}$ & $70-75 \mathrm{~cm} \mathrm{bd}$ & Ft. 2 (BL) & light fraction & 1 \\
\hline 36 & $75 \mathrm{~N} / 100 \mathrm{E}$ & $80-90 \mathrm{~cm}$ bd & Ft. 2 (BL) & light fraction & 1 \\
\hline 125 & $73 \mathrm{~N} / 100 \mathrm{E}$ & $60-70 \mathrm{~cm}$ bd & Ft. 2 (BL) & light fraction & 1 \\
\hline 175 & $76 \mathrm{~N} / 100 \mathrm{E}$ & $75-80 \mathrm{~cm} \mathrm{bd}$ & Ft. 2 (BL) & light fraction & 1 \\
\hline
\end{tabular}




\section{Pollen and Phytolith Analysis}

Ten soil samples from various mission features were selected for pollen and phytolith analysis (Table 7-2). These samples were sent to John G. Jones at Texas A\&M University for species identification to provide additional insight into the plant resources available for use by mission residents.

Table 7-2. Pollen and phytolith samples

\begin{tabular}{|c|c|l|}
\hline Sample \# & Feature \# & Provenience \\
\hline 281 & 2 & $73 \mathrm{~N} / 100 \mathrm{E} 60-70 \mathrm{~cm}$ bs \\
\hline 282 & 2 & $73 \mathrm{~N} / 100 \mathrm{E} 70-80 \mathrm{~cm}$ bs \\
\hline 283 & 2 & $73 \mathrm{~N} / 100 \mathrm{E} 80-90 \mathrm{~cm}$ bs \\
\hline 278 & 2 & $75 \mathrm{~N} / 100 \mathrm{E} 90-100 \mathrm{~cm}$ bs \\
\hline 279 & 1 & $85 \mathrm{~N} / 99 \mathrm{E} 40-50 \mathrm{~cm}$ bs AL \\
\hline 290 & 1 & $85 \mathrm{~N} / 99 \mathrm{E} 40-50 \mathrm{~cm}$ bs BL \\
\hline 293 & 1 & $85 \mathrm{~N} / 99 \mathrm{E} 80-90 \mathrm{~cm}$ bs \\
\hline 297 & 1 & $85 \mathrm{~N} / 100 \mathrm{E} 120-130 \mathrm{~cm}$ bs \\
\hline 349 & 8 & Zone C \\
\hline 370 & 8 & Zone J \\
\hline
\end{tabular}

\section{Oxidizable Carbon Ratio (OCR) Dating}

The Oxidizable Carbon Ratio (OCR) dating procedure, a relatively new development in dating soils, has the potential to overcome the temporal limitations of standard radiocarbon dating encountered in Historic period sites. The procedure measures the site-specific rate of biodegradation of organic carbon, either as soil humic material or as charcoal. The biological recycling of organic carbon is fundamental to nearly all biological systems on the planet. While some forms of organic carbon, such as fresh organic matter, are quickly recycled, other more resistant forms, such as humus and charcoal, are recycled at a much slower rate. The effect of the biochemical degradation of charcoal and soil humic material is measured by a ratio of the total organic carbon to the readily oxidizable carbon in the soil sample. In general, as the total amount of organic carbon decreases through time due to recycling, the relative percentage of readily oxidizable carbon increases. This ratio is called the Oxidizable Carbon Ratio, or OCR (Frink 1992, 1994). Although there are some difficulties with interpretation of OCR results, the method is considered generally reliable for dates in the late-eighteenth and early-nineteenth centuries. Seven soil samples taken from Features 1 and 2 were selected for OCR dating (Table 7-3). Because OCR dating is based on site specific biodegradation, information on the geographic location of the site, mean temperatures, and average rainfall (Natural Fibers Information Center 1987) accompanied the soil sample. A general date of occupation between 1780 and 1830 was also supplied.

Table 7-3. OCR samples from 41RF1

\begin{tabular}{|l|l|l|l|l|}
\hline Sample \# & \multicolumn{2}{|c|}{ Provenience } & \multicolumn{1}{c|}{ Soil } & Weight \\
\hline Ft.2 - \#1 & $75 \mathrm{~N} / 100 \mathrm{E}$ & $27-30 \mathrm{~cm}$ bs & sandy loam & $180.0 \mathrm{~g}$ \\
\hline Ft.2 - \#2 & $75 \mathrm{~N} / 100 \mathrm{E}$ & $47-49 \mathrm{~cm}$ bs & sandy clay loam & $190.4 \mathrm{~g}$ \\
\hline Ft.2 - \#3 & $75 \mathrm{~N} / 100 \mathrm{E}$ & $78-80 \mathrm{~cm}$ bs & clay w/burned bone & $195.9 \mathrm{~g}$ \\
\hline Ft.2 - \#4 & $75 \mathrm{~N} / 100 \mathrm{E}$ & $98-100 \mathrm{~cm}$ bs & clay w/burned bone & $225.1 \mathrm{~g}$ \\
\hline Ft.1 - \#1 & $84 \mathrm{~N} / 100 \mathrm{E}$ & $29-31 \mathrm{~cm}$ bs & sandy loam & $218.1 \mathrm{~g}$ \\
\hline Ft.1 - \#2 & $84 \mathrm{~N} / 100 \mathrm{E}$ & $42-44 \mathrm{~cm}$ bs & sandy loam & $192.1 \mathrm{~g}$ \\
\hline Ft.1 - \#3 & $84 \mathrm{~N} / 100 \mathrm{E}$ & $101-103 \mathrm{~cm}$ bs & clay loam & 198.9 \\
\hline
\end{tabular}




\section{Chapter 8: Findings Section A}

\section{Trash and Midden Features}

Two seasons of investigations at 41RF1, Mission Refugio, resulted in the discovery, documentation and excavation of 78 anomalies, 57 of which were classified as features associated with the 1795-1830 mission (Figure 8a-1, Table 8a-1). These features can be grouped into three functional categories:
1) Three Colonial period trash pit features;

2) A small midden accumulation, and numerous architectural features, including remnants of postholes and wall sections associated with the mission compound; and

3) 37 burial features containing the remains of at least 165 individuals.

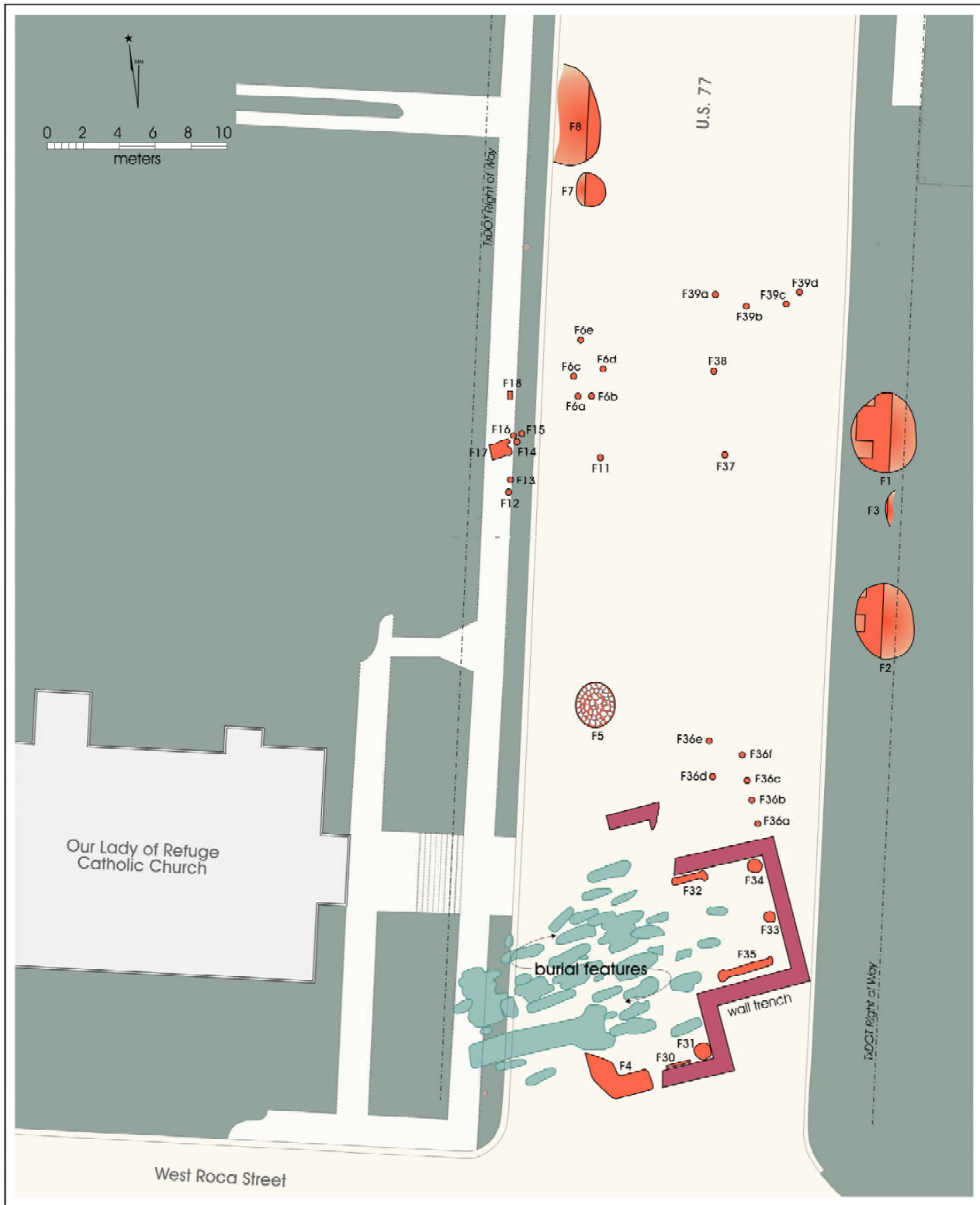

Figure 8a-1. Plan map of units and features investigated at 41RF1. 
Table 8a-1. List of features

\begin{tabular}{|c|c|c|}
\hline & & $\begin{array}{c}\text { Feature Recording Form } \\
\text { 41RF1 }- \text { Mission Refugio } 1998 / 1999\end{array}$ \\
\hline Feature & Location & Description \\
\hline 1 & $83 \mathrm{~N}-87 \mathrm{~N}$ (east) & $5 \mathrm{~m}$ diameter Colonial period trash pit \\
\hline 2 & $72 \mathrm{~N}-77 \mathrm{~N}$ (east) & $5 \mathrm{~m}$ diameter Colonial period trash pit \\
\hline 3 & $81 \mathrm{~N}-82 \mathrm{~N}$ (east) & Extreme western edge of another Colonial period trash pit \\
\hline 4 & $44.7-48 \mathrm{~N} / 91-85 \mathrm{E}$ & Originally designated as trash pit (part of south transept wall) \\
\hline 5 & $68.5 \mathrm{~N} / 85.2 \mathrm{E}$ & Stone circle $2.5-\mathrm{x}-2$ meters in diameter \\
\hline $6(\mathrm{a}-\mathrm{e})$ & $85.5-90 \mathrm{~N} / 82.5-84 \mathrm{E}$ & Postholes - west side of street, north of burials \\
\hline 7 & $98-100 \mathrm{~N} / 84-82.5 \mathrm{E}$ & Small trash pit on SE side of Feature 8 \\
\hline 8 & $100.5-105 \mathrm{~N} / 83 \mathrm{E}$ & Large pit on $\mathrm{N}$ end of site / no artifacts \\
\hline $9^{*}$ & S end of site & $80-\mathrm{x}-3.2 \mathrm{~m}$ dark stain (modern) \\
\hline $10^{*}$ & $5 \mathrm{~cm} \mathrm{~S}$ of Roca St & 1.2-x-50-cm dark stain (modern) \\
\hline 11 & $83 \mathrm{~N} / 84.5 \mathrm{E}$ & Posthole roughly $34 \mathrm{~cm}$ in diameter $-40 \mathrm{~cm}$ deep (modern) \\
\hline 12 & $81 \mathrm{~N} / 79 \mathrm{E}$ & Posthole roughly $15 \mathrm{~cm}$ in diameter $-37.5 \mathrm{~cm}$ deep - (modern) \\
\hline 13 & $81.7 \mathrm{~N} / 79 \mathrm{E}$ & Posthole roughly $43 \mathrm{~cm}$ in diameter - (modern) \\
\hline 14 & $83.7 \mathrm{~N} / 79.4 \mathrm{E}$ & Posthole roughly $34 \mathrm{~cm}$ in diameter - (modern) \\
\hline 15 & $84.3 \mathrm{~N} / 79.7 \mathrm{E}$ & Posthole roughly $34 \mathrm{~cm}$ in diameter - (modern) \\
\hline 16 & $84.1 \mathrm{~N} / 79.1 \mathrm{E}$ & Posthole roughly $34 \mathrm{~cm}$ in diameter $-62 \mathrm{~cm}$ deep - (modern) \\
\hline 17 & $83-84 \mathrm{~N} / 78-79 \mathrm{E}$ & Stone wall stub \\
\hline 18 & $86.7 \mathrm{~N} / 78.8 \mathrm{E}$ & Posthole - $22 \mathrm{~cm}$ diameter, $62 \mathrm{~cm}$ deep - (modern) \\
\hline $19^{*}$ & $\mathrm{~N}$ of burials & Modern utility trench \\
\hline $20^{*}$ & $\mathrm{~N}$ of burials & Posthole - $25 \mathrm{~cm}$ in diameter, $17 \mathrm{~cm}$ deep \\
\hline $21^{*}$ & $\mathrm{~N}$ of burials & Posthole $-17 \mathrm{~cm}$ in diameter, $20 \mathrm{~cm}$ deep \\
\hline $22^{*}$ & $\mathrm{~N}$ of burials & Circular stain - $37 \mathrm{~cm}$ in diameter, $17 \mathrm{~cm}$ deep \\
\hline $23^{*}$ & $\mathrm{~N}$ of burials & Circular stain - $33 \mathrm{~cm}$ in diameter, $17 \mathrm{~cm}$ deep \\
\hline $24 *$ & $\mathrm{~N}$ of burials & Circular stain $-23 \mathrm{~cm}$ in diameter \\
\hline $25^{*}$ & $\mathrm{~N}$ of burials & Circular stain - $43 \mathrm{~cm}$ in diameter, $8 \mathrm{~cm}$ deep \\
\hline $26^{*}$ & $\mathrm{~N}$ of burials & Circular stain - $24 \mathrm{~cm}$ in diameter, $19 \mathrm{~cm}$ deep \\
\hline $27 *$ & $\mathrm{~N}$ of burials & Rectangular stain - $10-\mathrm{x}-9 \mathrm{~cm}, 5 \mathrm{~cm}$ deep \\
\hline $28^{*}$ & $\mathrm{~N}$ of burials & Elliptical stain $-38-\mathrm{x}-30 \mathrm{~cm}$ \\
\hline $29^{*}$ & $\mathrm{~N}$ of burials & Circular stain $-33 \mathrm{~cm}$ in diameter, $20 \mathrm{~cm}$ deep \\
\hline 30 & $48 \mathrm{~N} / 91 \mathrm{E}$ & Linear feature inside $\mathrm{S}$ transept $140-\mathrm{x}-26 \mathrm{~cm}, 15 \mathrm{~cm}$ deep \\
\hline 31 & $48.5 \mathrm{~N} / 92 \mathrm{E}$ & Circular feature inside $\mathrm{S}$ transept $-58 \mathrm{~cm}$ in diameter, $25 \mathrm{~cm}$ deep \\
\hline 32 & $61.5 \mathrm{~N} / 91 \mathrm{E}$ & Linear feature, slightly belled at $E$ end, $N$ wall of apse $-210-x-43 \mathrm{~cm}, 30 \mathrm{~cm}$ deep \\
\hline 33 & $56.5 \mathrm{~N} / 95 \mathrm{E}$ & Circular feature inside $\mathrm{E}$ wall of apse, $50-\mathrm{x}-58 \mathrm{~cm}, 45 \mathrm{~cm}$ deep \\
\hline 34 & $59.5 \mathrm{~N} / 94.5 \mathrm{E}$ & Circular feature inside NE corner of apse, $75-\mathrm{x}-80 \mathrm{~cm}$ diameter, $18 \mathrm{~cm}$ deep \\
\hline 35 & $53.5 \mathrm{~N} / 94 \mathrm{E}$ & Linear feature, slightly belled at $\mathrm{W}$ end, $\mathrm{S}$ wall of apse $-220-\mathrm{x}-30 \mathrm{~cm}, 15 \mathrm{~cm}$ deep \\
\hline $36(\mathrm{a}-\mathrm{f})$ & $62-67 \mathrm{~N} / 94.5-91 \mathrm{E}$ & Series of 6 postholes average $34 \mathrm{~cm}$ diameter, $5-15 \mathrm{~cm}$ deep - possible stockade posts \\
\hline 37 & $83.5 \mathrm{~N} / 91.5 \mathrm{E}$ & Roughly round discoloration, probable posthole, $41-\mathrm{x}-44 \mathrm{~cm}, 10 \mathrm{~cm}$ deep \\
\hline 38 & $88.5 \mathrm{~N} / 90.5 \mathrm{E}$ & Large circular feature, possible posthole, $57 \mathrm{~cm}$ diameter, $50 \mathrm{~cm}$ deep \\
\hline $39(a-d)$ & $92-93.5 \mathrm{~N} / 94.5-91.5 \mathrm{E}$ & Semi-circular alignment of postholes, from $55-28 \mathrm{~cm}$ in diameter, $4-18 \mathrm{~cm}$ deep \\
\hline $40^{* * *}$ & $46-63 \mathrm{~N} / 98-87 \mathrm{E}$ & Apse and north and south transept wall trench of 1796 church \\
\hline $\mathrm{BF} 1^{\dagger}$ & & Originally designated as a burial feature (part of north transept wall) \\
\hline BFs 2-28 & & Burial features beneath north- and southbound lanes of US 77 \\
\hline BFs 30-39 & & Burial features beneath north- and southbound lanes of US 77 \\
\hline
\end{tabular}


The large assemblage of cultural material recovered during these investigations includes almost 4,000 pieces of native ceramics and over 2,000 European and Mexican ceramic sherds, 4,000 copper and iron fragments, 500 lithics, and 900 pounds of animal bone. For ease of discussion, these features and their associated artifacts are discussed by category. Detailed analyses of the major artifact classes appear later in this report (Chapter 9), as do the results of the skeletal analysis (Volume II). A provenienced list of all recovered artifacts is presented in Appendix C.

\section{Feature Descriptions}

\section{Trash and Midden}

The original data recovery investigations at $41 \mathrm{RF} 1$ centered on the Colonial-period deposit identified by Clark (1998) during testing along the TxDOT ROW on the east side of US 77. Thirty-one 1-x-1 m units were excavated to sterile soil during CAR's 1998 archaeological investigations in this area, resulting in the removal of $20.2 \mathrm{~m}^{3}$ of soil, or approximately one-third of the historically significant deposit within the ROW (see Figure 8a-1). Two missionperiod trash pits, Features 1 and 2, were identified and excavated, and another possible trash pit, Feature 3, was documented but not excavated because of its location on the easternmost boundary of the ROW. Well over 90 percent of the material culture artifact assemblage was recovered from the initial excavations on the east side of US 77. The quantity of the artifacts together with the focus of the original research issues established for this project necessitated an in-depth approach to the analyses of materials from this area of the site.

During the excavations, it appeared that at least three depositional events led to the formation of the Colonialperiod deposits uncovered within the eastern ROW. These three basic events are reflected in the artifacts from Feature 1, Feature 2, and the remaining non-feature units. Several analytical methods were employed to separate the formational and temporal relationship of these rich deposits as an aid for conducting and interpreting the more detailed analyses. Adjusted residuals were used to statistically compare relative proportions of artifact types recovered from the feature and non-feature units to assess their vertical and horizontal associations. Ceramic refits were used to establish the stratigraphic integrity of the deposits, while OCR dates were used to gauge the relative age of the stratigraphic levels within these features. The results of these analyses follow.

\section{Adjusted Residuals}

Initially, the artifact assemblage was divided into analytical groups based on provenience and stratigraphic similarities recorded in unit profiles. These groupings are defined in Table 8a-2.

Table 8a-2. Initial analytical groupings for 41RF1

\begin{tabular}{|c|c|c|c|c|}
\hline Code & Description & Units & Levels & \\
\hline \multirow[t]{4}{*}{$\mathrm{NF}$} & \multirow{4}{*}{$\begin{array}{l}\text { Non-feature - all levels from units } \\
\text { not directly associated with } \\
\text { Features } 1 \text { and } 2\end{array}$} & $57 \mathrm{~N} / 100 \mathrm{E}-0-50$ & $59 \mathrm{~N} / 100 \mathrm{E}-0-20$ & $60 \mathrm{~N} / 100 \mathrm{E}-0-30$ \\
\hline & & $64 \mathrm{~N} / 100 \mathrm{E}-0-40$ & $67 \mathrm{~N} / 100 \mathrm{E}-0-40$ & $70 \mathrm{~N} / 100 \mathrm{E}-0-30$ \\
\hline & & $71 \mathrm{~N} / 100 \mathrm{E}-0-40$ & $77 \mathrm{~N} / 100 \mathrm{E}-0-40$ & $78 \mathrm{~N} / 100 \mathrm{E}$ - $0-40$ \\
\hline & & 78N/99E - 0-50 & $79 \mathrm{~N} / 100 \mathrm{E}-0-40$ & $95 \mathrm{~N} / 100 \mathrm{E}-0-60$ \\
\hline \multirow[t]{2}{*}{ NF-BL } & \multirow{2}{*}{$\begin{array}{l}\text { Non-feature - Below the Lime- } \\
\text { levels below the lime deposit in } \\
\text { units adjacent to/but not within the } \\
\text { Feature } 1 \text { pit outline }\end{array}$} & $80 \mathrm{~N} / 100 \mathrm{E}-11-60$ & $81 \mathrm{~N} / 100 \mathrm{E}-20-60$ & $82 \mathrm{~N} / 100 \mathrm{E}-20-50$ \\
\hline & & $89 \mathrm{~N} / 100 \mathrm{E}-0-40$ & 90N/100E - 20-50 & \\
\hline \multirow[t]{4}{*}{ Ft1R-NF } & \multirow{4}{*}{$\begin{array}{l}\text { Feature } 1 \text { Related - Non feature- } \\
\text { levels above the lime deposit in } \\
\text { units immediately adjacent to or } \\
\text { within Feature } 1\end{array}$} & $80 \mathrm{~N} / 100 \mathrm{E}-0-11$ & $81 \mathrm{~N} / 100 \mathrm{E}-0-20$ & $82 \mathrm{~N} / 100 \mathrm{E}-0-20$ \\
\hline & & $83 \mathrm{~N} / 99 \mathrm{E}-0-30^{*}$ & $83 \mathrm{~N} / 100 \mathrm{E}-0-40^{*}$ & $84 \mathrm{~N} / 100 \mathrm{E}-0-50^{*}$ \\
\hline & & $85 \mathrm{~N} / 99 \mathrm{E}-0-50^{*}$ & $85 \mathrm{~N} / 100 \mathrm{E}-0-58^{*}$ & $86 \mathrm{~N} / 99 \mathrm{E}-0-50^{*}$ \\
\hline & & $86 \mathrm{~N} / 100 \mathrm{E}-0-56^{*}$ & $87 \mathrm{~N} / 100 \mathrm{E}-0-70^{*}$ & $90 \mathrm{~N} / 100 \mathrm{E}-0-20$ \\
\hline \multirow[t]{3}{*}{ Ft 1} & \multirow{3}{*}{$\begin{array}{l}\text { levels below the lime deposit from } \\
\text { units within the pit outline of } \\
\text { Feature } 1\end{array}$} & $83 \mathrm{~N} / 99 \mathrm{E}-30-60 *$ & $83 \mathrm{~N} / 100 \mathrm{E}-10-120^{*}$ & $84 \mathrm{~N} / 100 \mathrm{E}-30-140^{*}$ \\
\hline & & $85 \mathrm{~N} / 99 \mathrm{E}-40-130^{*}$ & $85 \mathrm{~N} / 100 \mathrm{E}-53-140^{*}$ & $86 \mathrm{~N} / 99 \mathrm{E}-40-120^{*}$ \\
\hline & & $86 \mathrm{~N} / 100 \mathrm{E}-56-130^{*}$ & $87 \mathrm{~N} / 100 \mathrm{E}-40-110^{*}$ & \\
\hline \multirow[t]{3}{*}{ Ft2R-NF } & \multirow{3}{*}{$\begin{array}{l}\text { Feature } 2 \text { Related - Non feature- } \\
\text { deposits above the pit outline in } \\
\text { units within Feature } 2\end{array}$} & $72 \mathrm{~N} / 100 \mathrm{E}-0-40$ & $73 \mathrm{~N} / 100 \mathrm{E}$ - $0-40$ & $73 \mathrm{~N} / 99 \mathrm{E}-0-50$ \\
\hline & & $74 \mathrm{~N} / 100 \mathrm{E}$ - 0-50 & 75N/100E $0-40$ & $75 \mathrm{~N} / 99 \mathrm{E}-0-40$ \\
\hline & & $76 \mathrm{~N} / 100 \mathrm{E}$ - 0-20 & & \\
\hline \multirow[t]{3}{*}{ Ft 2} & \multirow{3}{*}{$\begin{array}{l}\text { deposits below the pit outline in } \\
\text { units within Feature } 2\end{array}$} & $72 \mathrm{~N} / 100 \mathrm{E}-40-100$ & 73N/100E - 40-100 & $73 \mathrm{~N} / 99 \mathrm{E}-50-100$ \\
\hline & & 74N/100E - 50-105 & $75 \mathrm{~N} / 100 \mathrm{E}-40-110$ & $75 \mathrm{~N} / 99 \mathrm{E}-40-110$ \\
\hline & & $76 \mathrm{~N} / 100 \mathrm{E}-20-100$ & & \\
\hline
\end{tabular}


The ceramic artifact class was selected for this analysis as it represents the most diagnostic class of artifacts recovered from Mission Refugio. The ceramics were divided into five gross categories (Table 8a-3):

1) Unglazed Native American ware;

2) Tin-glazed;

3) Lead-glazed;

4) Burnished; and

5) Whiteware/creamware/others.

Native American unglazed wares were then excluded from further consideration as they occurred throughout the various deposits and temporal differences, if any, within this category could not be determined at this level of gross analysis.

Adjusted standardized residuals (ASR) were calculated on the total of each of the remaining four gross ceramic types recovered from within the various depositional units. A difference of \pm 1.96 between the observed and the expected totals of each ceramic type is considered a statistically significant deviation from normal at a 0.05 level of significance (Everitt 1977). If the ASR value is greater than +1.96 or less than -1.96 , there is a less than 5 percent probability that the ceramic-type frequencies present within these depositional units accumulated by chance.

Computations were run on the various paired configurations of the analytical groups. The results of these initial analyses found no statistically significant differences between the ceramic-type proportions in the NF, Ft1R-NF, Ft2R-NF groups. Comparisons also showed that no significant differences were present between the ceramic types recovered from levels below the lime deposit in units within Feature 1 (Ft 1) and from levels below the lime deposit in units adjacent to Feature 1 (NF-BL). Statistically significant differences were present, however, between each of the other non-feature groups and the feature deposits, and differences were also present between the ceramic-type proportions in the two features. Thus, three statistically distinct spatial analytical units (AU) were identified: Feature 1 (AU 1) and non-feature below lime deposits (NF-BL), Feature 2 deposits (AU 2), and non-feature deposits (NF/AU 3) (Table 8a-4).

Table 8a-3. Ceramic type totals by analytical group

\begin{tabular}{|l|c|c|c|c|c|c|c|}
\hline & Ung & T Gz & L Gz & Burnish & $\begin{array}{c}\text { White/Cream } \\
\text { ware/Other }\end{array}$ & Total & $\begin{array}{c}\text { Total w/o } \\
\text { unglazed }\end{array}$ \\
\hline NF Unit Totals & 457 & 56 & 91 & 3 & 109 & 666 & 259 \\
\hline NF-BL Totals & 216 & 30 & 28 & 3 & 201 & 276 & 82 \\
\hline Ft1R- NF Totals & 1618 & 132 & 233 & 14 & 224 & 2221 & 603 \\
\hline Ft2R-NF Totals & 375 & 44 & 73 & 6 & 88 & 559 & 211 \\
\hline Ft 1 Totals & 769 & 174 & 167 & 18 & 104 & 1136 & 463 \\
\hline Ft 2 Totals & 618 & 274 & 213 & 23 & 27 & 1118 & 537 \\
\hline \multicolumn{1}{|c|}{ Total } & 3821 & 710 & 805 & 67 & 573 & 5976 & 2155 \\
\hline
\end{tabular}

Table 8a-4. Adjusted residuals results

\begin{tabular}{|l|l|l|l|l|l|l|l|l|l|l|}
\hline AU & Group & \multicolumn{2}{|c|}{ Tin Glazed } & \multicolumn{2}{|c|}{ Lead Glazed } & \multicolumn{3}{c|}{ Burnished } & \multicolumn{2}{|c|}{$\begin{array}{c}\text { White/Creamware/ } \\
\text { Other }\end{array}$} \\
\hline & & $\mathrm{n}$ & ASR & $\mathrm{n}$ & ASR & $\mathrm{n}$ & ASR & $\mathrm{n}$ & ASR & $\mathrm{N}$ \\
\hline 3 & NF & 232 & $\mathbf{- 1 1 . 0 7}$ & 401 & -.12 & 23 & $\mathbf{- 2 . 5 5}$ & 421 & $\mathbf{+ 1 3 . 0}$ & 1073 \\
\hline 1 & Ft1 and NF-BL & 204 & $\mathbf{+ 2 . 5 1}$ & 196 & -.97 & 21 & +1.14 & 124 & -1.54 & 545 \\
\hline 2 & Ft 2 & 274 & $\mathbf{+ 1 0 . 2 6}$ & 213 & +1.12 & 23 & +1.8 & 26 & $\mathbf{- 1 2 . 9 4}$ & 537 \\
\hline & Total & 710 & & 810 & & 67 & & 561 & & 2155 \\
\hline
\end{tabular}

Statistically significant differences are highlighted 
As seen in Table 8a-4, AU 3 (non-feature deposits) has a much higher than expected representation of white/ creamwares $(+12.3)$, and a much lower representation of tin-glazed sherds (-11.07). Burnished wares (-2.55) are under represented also. The reverse is seen in AU 1 which contains slightly greater than expected amounts of tin-glazed sherds and proportions of white/creamwares within the expected range. A similar, although increased, trend is seen in AU 2 (Feature 2 deposits) with tin-glazed sherds greatly overrepresented $(+10.26)$ and white/creamwares greatly underrepresented (-12.66). Lead-glazed sherds are present in expected proportions in each of the depositional units.

\section{Refit Analysis}

During the initial stages of ceramic analysis, attempts were made to refit tin-glazed and lead-glazed sherds to assess the vertical and horizontal integrity of the analytical units identified above. As seen in Table 8a-5, pieces of 14 majolica vessels and two lead-glazed vessels from within the various analytical units could be mended. However, no mendable pieces from these or other vessels were found between the analytical units, further supporting the integrity of these units.

\section{Oxidized Carbon Ratios}

Because the beginning and ending dates for Mission Refugio are established as between 1795-1835, soil samples for Oxidized Carbon Ratios (OCR) were taken from Features 1 and 2 to ascertain whether this technique is a viable method of dating deposits too recent for standard Carbon dating, and to possibly supply relative ages for these features. Therefore, three OCR samples were taken from the eastern profile of Feature 1. Sample 1 was taken from within the dark grayish-brown upper zone of the site, Sample 2 came from the mottled ash and brown soil layer directly above the lime deposit, and Sample 3 was obtained near the bottom of the feature. These results are shown in Table 8a-6. Based

Table 8a-5. Ceramic crossmends from 41RF1

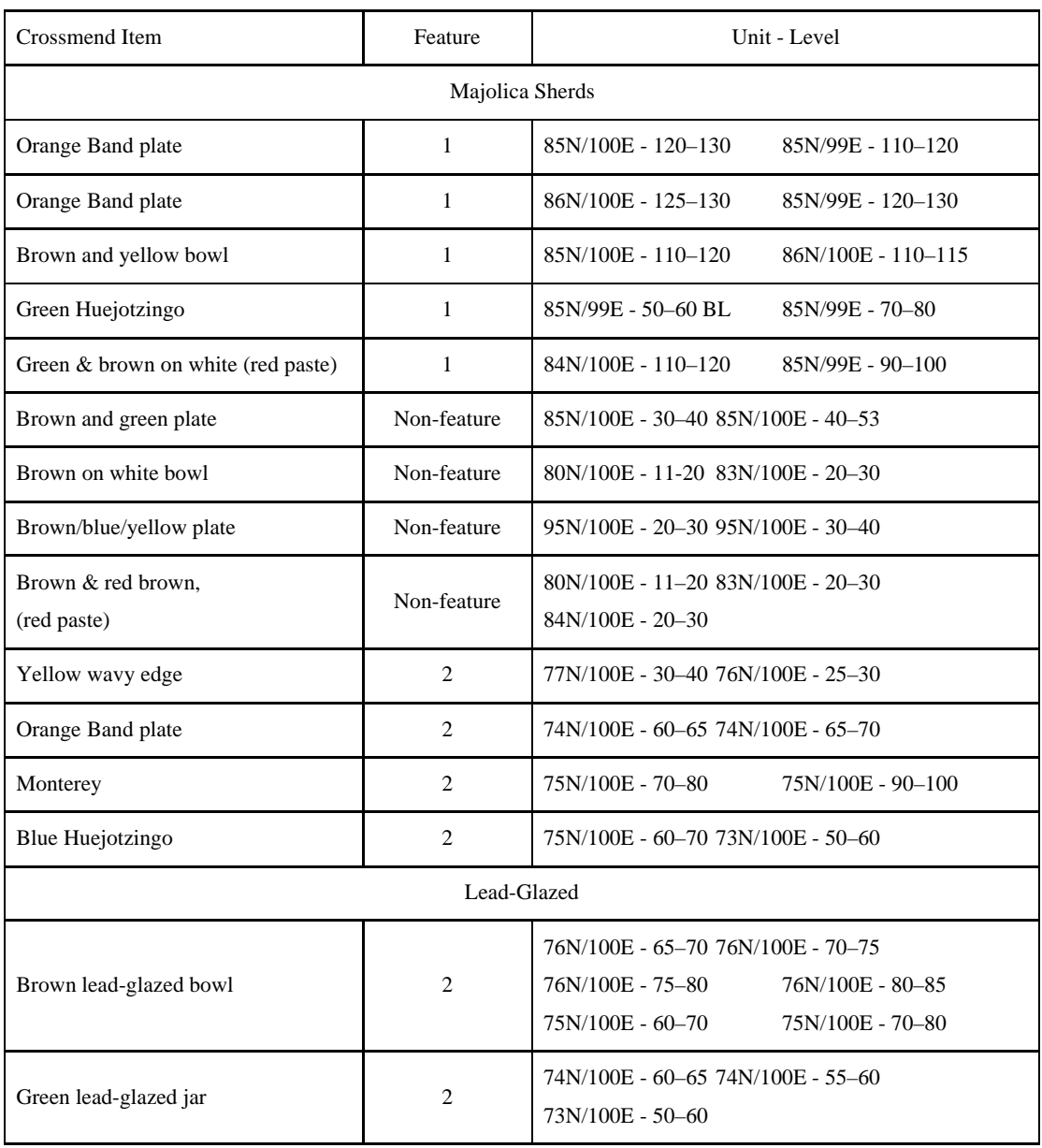


on these dates, it appears that the fill episode for Feature 1 began shortly after 1794 when the mission was established, and ceased around or shortly after 1809 . The early date of A.D. 1755-1765 from the top layer (Sample 1) is interpreted as fill from the surface that predates the cultural activity (Frink, Appendix D).

Four OCR samples were taken from the eastern profile of Feature 2. These results are shown in Table 8a-7. Samples 1 and 2 were taken from the grayish-brown clay loam deposits above the pit outline. Sample 3 was obtained from the dark gray sandy loam layer containing the heaviest concentration of animal bone and Colonial ceramics, and Sample 4 came from the bottom of Feature 2 within a concentration of heavily burned animal bone. As with Feature 1, these dates indicate that cultural deposition began in Feature 2 soon after 1794 and ceased sometime around 1840. After continuous use of the feature stopped, the remaining depression was infilled in reverse stratigraphic order by natural forces.

While the OCR dates from Feature 1 and 2 are within the time frame of the mission occupation, they do not provide the level of detail needed to sequentially differentiate the analytical units. Therefore, proportional differences between the ceramic types in the Feature 1, Feature 2, and Non-feature assemblages are used to suggest a temporal sequence for the deposits. AU 3 is seen as the youngest of these units because of the strong representation of later-occurring white/ creamwares in these deposits and because of its stratigraphic location in the upper layers of the site. While the Feature 1 pit could have been excavated through the AU 3 deposit, the proportional representation of white/creamwares in this deposit and the slight over-representation of tin-glazed and burnished sherds associated with imported wares from Mexico suggests that the AU 1 (Ft 1 and NF-BL) assemblage was deposited before AU 3. If the over-representation of white/creamwares in AU 3 is a good indicator of more recent depositional events, then the strong under-representation of these wares along with the equally strong over-representation of tin-glazed sherds in Feature 2 suggests AU 2 is the oldest. This sequencing is supported by the analysis of the timesensitive Mexican and European ceramics discussed in Chapter 9A.

Although the exact time span represented by this chronological sequence is unknown, the results of the refit and adjusted residual computations indicate the analytical units defined above represent three statistically distinct depositional episodes. Feature number and AU number are used interchangeably in the following descriptions and throughout the remainder of this report in discussions of the changes in lifeways that occurred during the occupation of the mission as represented in these features.

Table 8a-6. OCR results from Feature 1

\begin{tabular}{|l|l|l|l|l|l|}
\hline Sample \# & Unit & Depth (cmbs) & $\begin{array}{l}\text { OCR } \\
\text { YATE } \\
\text { YBP }(1950)\end{array}$ & $\begin{array}{l}\text { Calendar Date } \\
\text { AD }\end{array}$ & ACT\# \\
\hline 1 & $84 \mathrm{~N} / 100 \mathrm{E}$ & $29-31$ & $190 \pm 5$ & $1755-(1760)-1765$ & 3693 \\
\hline 2 & $84 \mathrm{~N} / 100 \mathrm{E}$ & $42-44$ & $141 \pm 4$ & $1805-(1809)-1813$ & 3694 \\
\hline 3 & $84 \mathrm{~N} / 100 \mathrm{E}$ & $101-103$ & $160 \pm 4$ & $178-(1790)-1794$ & 3695 \\
\hline
\end{tabular}

Table 8a-7. OCR results from Feature 2

\begin{tabular}{|l|l|l|l|l|l|}
\hline Sample \# & Unit & $\begin{array}{l}\text { Depth } \\
(\mathrm{cmbs})\end{array}$ & $\begin{array}{l}\text { OCR }_{\text {DATE }} \\
\text { YBP }(1950)\end{array}$ & $\begin{array}{l}\text { Calendar Date } \\
\text { AD }\end{array}$ & ACT\# \\
\hline 1 & $75 \mathrm{~N} / 100 \mathrm{E}$ & $27-30$ & $213 \pm 6$ & $1731-(1737)-1743$ & 3689 \\
\hline 2 & $75 \mathrm{~N} / 100 \mathrm{E}$ & $47-49$ & $168 \pm 5$ & $177-(1782)-1788$ & 3690 \\
\hline 3 & $75 \mathrm{~N} / 100 \mathrm{E}$ & $78-80$ & $110 \pm 3$ & $1836-(1840)-1843$ & 3691 \\
\hline 4 & $75 \mathrm{~N} / 100 \mathrm{E}$ & $98-100$ & $156 \pm 4$ & $1790-(1794)-1798$ & 3692 \\
\hline
\end{tabular}




\section{Feature 1 (AU 1)}

Feature 1 was initially encountered during the excavation of unit $85 \mathrm{~N} / 100 \mathrm{E}$, one of the first five test units excavated to identify artifact concentrations in the project area. Attention was called to this unit when excavations revealed that the cultural deposit continued past $60 \mathrm{~cm} \mathrm{bs}$, the anticipated sterile depth based on Clark's initial 1997 tests. A total of eight 1-x-1 m units were opened to expose the horizontal and vertical dimensions of this pit feature (Figure $8 \mathrm{a}-2$ ). The north edge of the pit was identified in unit $87 \mathrm{~N} /$ $100 \mathrm{E}$ and the south edge in unit $83 \mathrm{~N} / 100 \mathrm{E}$. The extreme western edge of the pit was not found in unit $85 \mathrm{~N} / 99 \mathrm{E}$ but $85 \mathrm{~N} / 98 \mathrm{E}$, further to the west, was not excavated due to its location along the curb of US 77. However, the northwest and southwest edges of the pit identified in units $86 \mathrm{~N} / 99 \mathrm{E}$ and $83 \mathrm{~N} / 99 \mathrm{E}$ make the following projection of the feature shape possible. The portion of Feature 1 present within the ROW represents the western section of a circular pit measuring at least $4.45 \mathrm{~m}$ in diameter.

During excavation, and in profile the outline of the pit is easily identifiable (see Figure 8a-1), beginning at a depth of $55 \mathrm{~cm}$ bs in unit $87 \mathrm{~N} / 100 \mathrm{E}$ on the northern edge and 40 $\mathrm{cm}$ bs in unit 83N/100E on the southern edge (Figure 8a-3). The upper $40 \mathrm{~cm}$ of both walls are vertical and cut into the surrounding sterile, yellowish-brown clay. Below this depth, the pit edges slope inward in an undulating, stepped pattern to an uneven, mottled clay floor at a depth of $135 \mathrm{~cm} \mathrm{bs}$, $80-90 \mathrm{~cm}$ into the sterile clay.

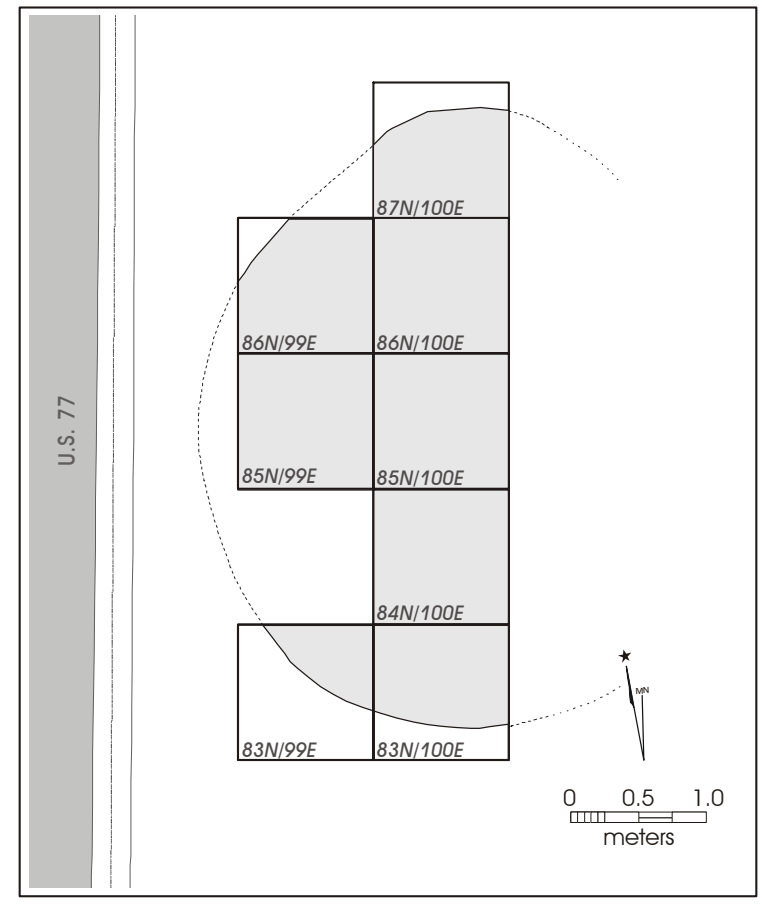

Figure 8a-2. Units excavated in Feature 1.

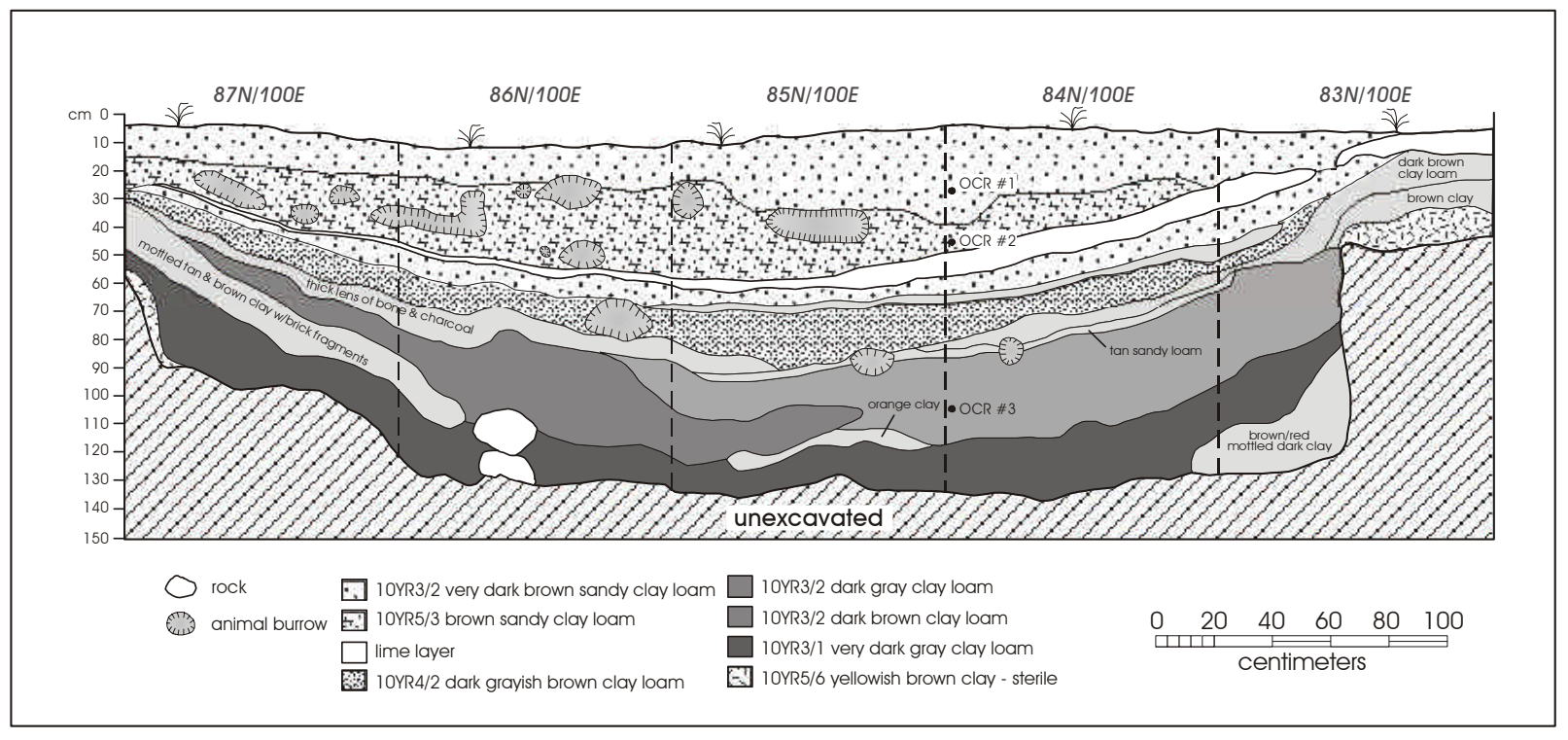

Figure 8a-3. Profile of Feature 1. 
The profile of Feature 1 shows evidence of multiple depositional layers of ashy soil, burned and unburned animal bone, and charcoal, all sloping downward toward the center of the pit. Of these, the most prominent is a thick layer of lime present across the southern two-thirds of the feature. This layer varies from nine centimeters to two centimeters in thickness with the thickest concentration in units $84 \mathrm{~N} /$ $100 \mathrm{E}$ and $83 \mathrm{~N} / 100 \mathrm{E}$. The lime layer begins five centimeters below the surface at the southern and western edge of the pit and slopes to a depth of 59-63 $\mathrm{cm}$ bs in the center (Figure 8a-4). Thinner, discontinuous lenses of lime were also present in the upper $20 \mathrm{~cm}$ in units 82-83N, south of Feature 1 and were noted in Clark's TP1 to the north (see Figure 7-2).

As mentioned, the soil above the lime layer is the same dark grayish-brown (10YR4/2) sandy clay loam that forms the upper non-feature zone across the site, identified as Analytical Unit 3. Below the lime, the pit fill is comprised of layers of sandy loam that range in color from very dark grayish brown (10YR3/2) to very dark brown (10YR3/1). The changes in soil color however, were too subtle to allow stratigraphic excavation other than on the gross scale of above- and below-lime deposit. This stratigraphic lime-cap break was used to define Feature 1 (AU 1) deposits.

Small pieces of charcoal, numerous ceramic sherds, and large amounts of animal bone were distributed throughout the pit fill directly beneath the lime. The artifact assemblage from Feature 1 includes 867 fragments of Native American ceramics, 551 Mexican or European ceramic sherds, $154,244.74$ grams of animal bone, 67 pieces of lithic material, and 162 glass fragments (Appendix c).

\section{Feature 1 (AU 1) \\ Native Ceramics}

Analysis of the 686 Native American sherds larger than $1-\mathrm{cm}$ in diameter recovered from Feature 1 (see Perttula, Chapter 9c) indicate that 75 percent $(n=513)$ of these sherds were bone-tempered, 17 percent $(\mathrm{n}=120)$ had sandy paste, 7 percent $(\mathrm{n}=51)$ had sandy paste with some bone tempering, and the clay in two of the sherds showed neither sand or bone tempering. Ninety percent of the bone-tempered sherds from Feature 1 have either moderate or sparse amounts of bone in the temper while 60 percent of the sandy-paste sherds contain moderate amounts of sand in the paste. Sixty-two rim sherds are part of this assemblage (Appendix $\mathrm{K}$ ). Of these, 53 percent were direct and 30 percent were everted. Also, 66 percent of the rim sherds had rounded lips and 29 percent had flat lips. Vessel forms identified from these rim sherds include one bottle, one olla, 15 jars, and 19 bowls.

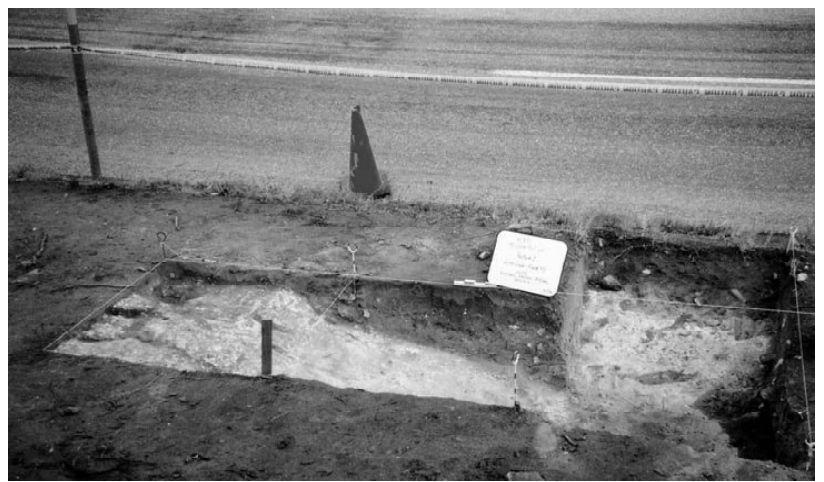

Figure 8a-4. Feature 1 showing lime layer which caps deposit.

Eighteen of the Native American body and rim sherds contained some form of decoration (see Chapter 9c, Table 9c-9). The most common decorative type is Rockport Blackon-Gray II. Eleven of this type are present and are characterized by a sandy paste and asphaltum decorations in the form of vertical lines, bands, or squiggles on the exterior of the vessel. Several of these sherds are thought to be from a small-mouth olla with a constricted neck (Chapter 9c). Also present are five bone-tempered sherds that display asphaltum decorations. This type, described by Mounger (1959) as Goliad black-on-buff, includes lip lines and squiggles, as well as bands and lines on the vessel body (Chapter 9c). The one rim of this variety appears to be from a bowl 12-cm in diameter. Two other sherds have brown or dark brown painted designs. The one body sherd has horizontal and vertical bands painted on the exterior while the one rim sherd, apparently from a jar, has a painted band on the interior. Other items made of bone-tempered clay include one loop handle of a type generally used with water jars, one vessel support, or "foot" from a bowl or jar base, and one ceramic disk similar to those from other missions described as gaming or counting pieces by Mounger (1959), Ricklis (1998), and Schuetz (1969).

As discussed by Perttula (Chapter 9c) and Hill (Appendix G), petrographic analysis of paste in a sample of 39 Native American sherds from Feature 1 found over 80 percent of these sherds fell into two paste and temper groups: Group 1 containing 20-40 percent sand with 15 percent or less bone (46 percent, $n=18$ ), and Group 2 with very low amount of sand and $10-15$ percent bone ( 38 percent, $n=15$ ). INAA analysis of this same sample classified 77 percent $(n=30)$ of these sherds as having been made from clay sources at or near the mission (Neff and Glascock, Appendix H). Perttula (Chapter 9c) suggests that the remaining sherds which fall within the unassigned category are similar to Rockport wares manufactured on the coast. 


\section{Feature I (AU 1) \\ Mexican and European Ceramics}

There were 551 ceramic fragments recovered from Feature 1 deposits that are not associated with native manufacture (Fox, Chapter 9a). These ceramics include unglazed and burnished sherds, and lead- and tin- glazed sherds manufactured in Mexico and distributed throughout the Spanish frontier during the Colonial period. Late-eighteenthand early-nineteenth-century European creamware and whiteware are also present.

Tin-glazed ceramics, majolicas, make up 37 percent $(n=204)$ of the Feature 1 assemblage. Majolicas were manufactured at several locations in the interior of Mexico as plates, bowls, and cups used in the consumption of food, but not for food preparation (Goggin 1968:113). Of the 116 pieces with temporarily-diagnostic decorations, 45 percent $(n=52)$ are from the late-eighteenth- through early-nineteenth-century, namely Huejotzingo banded varieties and polychromed versions. Of this type Orange Banded plate sherds $(n=23)$ are the most common (44 percent).

Mexican-made lead-glazed wares $(\mathrm{n}=195)$ account for 35 percent of this assemblage. The majority of the lead-glazed pieces ( $\mathrm{n}=128,66$ percent) are the fine-textured, thin-walled, decorated variety known as Galera, and primarily used for chocolate and bean pots. The thicker-walled, sandy paste variety usually associated with utility bowls and jars accounts for 26 percent $(n=52)$ of the lead-glazed fragments. Of these, yellow-glazed sherds from heavy jars, bowls, and pitchers $(n=24,46$ percent) are the most common (Fox, Chapter 9A).

Five percent of sherds in the Feature 1 non-native ceramic assemblage are from unglazed, burnished vessels, probably small pots and bowls $(n=27)$. Over 66 percent $(n=18)$ of these wares were fragments of a type known as Tonalá Burnished which was made in Jalisco, Mexico (Fox, Chapter 9A).

The final 23 percent of the Feature 1 non-native ceramics $(n=124)$ were refined earthenwares imported from Europe at the end of the Colonial period. Of the 55 decorated sherds, 47 (85 percent) are fragments of small hand-painted cups.

\section{Feature 1 (AU 1) Lithics}

A total of 67 chipped lithic artifacts were recovered from Feature 1. Of these, 53 (79 percent) are unmodified lithic debitage and 14 are tools. Detailed descriptions of the debitage and tools recovered from each of the analysis units are provided in Chapter 9D. The fourteen tools consist of a Guerrero arrow point, five probable gun flints, a single scraper, one indeterminate uniface, and six cores and core fragments. Eight (57 percent) of the tools are from Level 9 or below, one (seven percent) is from Level 3, and the remaining five are unprovenienced to level.

Slightly more than one-half ( $\mathrm{n}=27,51$ percent) of the unmodified debitage were recovered from Levels 5-9, deeper levels (10-12) yielded 34 percent $(n=18)$ of the specimens, while only nine percent $(\mathrm{n}=5)$ come from Levels 1-4 of the feature. Three specimens had no level designation. With the exception of three flakes, one coarse-grained chert, one chalcedony, and one quartzite, the remaining specimens $(n=50,94$ percent) are of fine-grained chert. The majority $(n=40,75$ percent $)$ of the debitage falls within the 11-20 $\mathrm{mm}$ size-class and a smaller fraction $(\mathrm{n}=11,21$ percent) are larger than $20 \mathrm{~mm}$, and only two (four percent) smaller than $10 \mathrm{~mm}$ were recovered during the process of screening the deposits through $1 / 4$-inch mesh. Decorticate or tertiary debitage is slightly more common $(n=29,55$ percent) than corticate (secondary and primary debitage; $n=24,45$ percent). Thirty-four (64 percent) of the debitage is platform bearing (i.e., complete or proximal fragments). Unprepared (corticate and single faceted) platforms are more common $(\mathrm{n}=25,73.5$ percent) than specimens with two or more platform facets.

Nearly one-half ( $n=21,40$ percent) of the debitage could not be categorized into flake types and three other specimens were angular debris. Of those that were assigned to a flake type, platform preparation flakes were the most common $(n=14,48$ percent), followed by debitage derived from uniface manufacture and/or rejuvenation ( $\mathrm{n}=9,31$ percent). Only three debitage pieces could be confidently assigned to a bipolar or possibly bipolar reduction strategy (10 percent), while one flake may have been the product of core reduction.

\section{Feature 1 (AU 1)}

\section{Fauna}

Analysis of the faunal material from Feature 1 (see Webber et al., Chapter 9e) identified 91 individuals representing 40 taxa in this portion of the assemblage. These include fresh and saltwater fish and turtles, wild and domestic birds, deer, cattle, and other wild and domestic mammals. Over 25 percent of the identified individuals in the faunal collection were domesticated mammals including 16 cows and seven sheep and pigs. The domesticated mammal category accounted for over 92 percent of the biomass in this assemblage. Chicken was the second most common 
domestic animal, accounting for 20 percent of the total identified individuals in AU 1. Deer and turtle were the most abundant of the wild species that also included possum, rabbit, black bear, peccary, and one indeterminate dog/wolf/ coyote. Fish make up 14 percent of the identified individuals in Feature 1, with 62 percent of these being freshwater species and 38 percent from bays and estuaries.

Forty percent of the individual cows represented in Feature 1 were juvenile or sub-adult. Comparison of the measurements of the Bovidae elements indicate the cattle were about the same size or a little larger than those from Mission Rosario or Espíritu Santo de Zuñiga in Goliad. The overall interpretation of the faunal elements suggests the Feature 1 assemblage is primary butchery refuse, which accumulated as a result of onsite butchering, and secondary, postconsumption disposal.

\section{Feature 1 (AU 1) \\ Other Historic Diagnostics}

The non-ceramic and non-faunal material recovered from Feature 1 is discussed later in this report (see Meissner, Chapter 9в). Briefly summarized, it includes 162 glass fragments, 85 percent of which are clear $(n=61)$, aqua $(n=34)$, and green $(n=49)$, colors that are associated with Colonial occupations at other missions (see Meissner, Chapter 9в). Other more personal artifacts that were recovered probably relate to the Native American inhabitants of the mission. Among these are a clear or white seed bead, a compound red and green glass trade bead, and a marine shell pendant. Two small flaked-glass disks similar to ceramic gaming pieces were recovered from AU 1 along with a knife handle manufactured of bone and three pieces of braided rope.

\section{Feature 2 (AU 2)}

Similar to Feature 1, Feature 2 was initially encountered during the excavation of $75 \mathrm{~N} / 100 \mathrm{E}$, another of the first five test units excavated to identify artifact concentrations in the project area. Attention was called to this unit when excavations revealed that the cultural deposit continued past $60 \mathrm{~cm}$ bs. A total of seven 1-x-1 m units were opened to expose the horizontal and vertical dimensions of this pit feature (Figure 8a-5). The northern edge of the pit was identified in unit 76N/100E and the southern edge in unit $72 \mathrm{~N} / 100 \mathrm{E}$. The western edge of the pit was found in units $73 \mathrm{~N} / 99 \mathrm{E}$ and $75 \mathrm{~N} / 99 \mathrm{E}$. The portion of Feature 2 present within the ROW represents the western section of a circular pit measuring approximately $4.20 \mathrm{~m}$ in diameter.

The profile of Feature 2 (Figure 8a-6) illustrates that this pit, like Feature 1 has been excavated into the surrounding clay. The feature's edge begins at a depth of $28 \mathrm{~cm}$ bs in unit $76 \mathrm{~N} / 100 \mathrm{E}$ on the northern edge and $25 \mathrm{~cm}$ bs in unit $72 \mathrm{~N} / 100 \mathrm{E}$ on the southern edge. The southern edge of Feature 2 , as seen in unit $72 \mathrm{~N} / 100 \mathrm{E}$, is basically vertical while the northern edge, revealed in unit $76 \mathrm{~N} / 100 \mathrm{E}$, displays an undulating, stepped pattern similar to that seen previously in Feature 1.The mottled clay floor of Feature 2 occurs at a depth of $112 \mathrm{~cm}$ bs.

But the stratigraphy of Feature 2, however, is different from that of Feature 1. The thick lime layer and the multiple depositional layers, so prominent in Feature 1, are not present in Feature 2. Instead, four clear strata are visible. A thin lens of light gray (10YR2/2) sandy soil and ash separates two layers of grayish brown sandy loam, 10YR5/2 and 10 YR5/6 respectively. Stratigraphically below these layers is a deposit of dark gray sandy loam (10YR4/1) containing a heavy concentration of animal bone. The bottom of Feature 2 is comprised of a black (10YR7/2), $20-25 \mathrm{~cm}$ thick layer composed almost entirely of burned bone and charcoal. The few ceramics recovered from this layer also show evidence of burning. The smooth, hard-baked clay and charcoal stains on the floor of the pit directly beneath this thick layer of charred material indicate these materials were burned in the pit and are not the result of secondary ash disposal.

The artifact assemblage from Feature 2 includes 581 fragments of Native American ceramics, 551 Mexican or European ceramic sherds, 113,129.01 grams of animal bone, 48 pieces of lithic material, and 75 glass fragments (Appendix C).

\section{Feature 2 (AU 2) Native Ceramics}

Analysis of the 430 Native American sherds larger than $1 \mathrm{~cm}$ in diameter that were recovered from Feature 2 (see Perttula, Chapter 9c) indicate that 79 percent $(n=338)$ of these sherds were bone-tempered, 16 percent $(n=71)$ had sandy paste, and 5 percent $(\mathrm{n}=21)$ had sandy paste with some bone tempering. Perttula has classified 89 percent of the bonetempered sherds from Feature 2 as having either moderate or sparse amounts of bone in the temper. Only 21 rim sherds are part of this assemblage (see Appendix K). Of these, 
50 percent were direct and 43 percent were everted. Additionally, 62 percent of the rim sherds had rounded lips and 33 percent had flat lips. Fourteen vessel forms were identified from these rim sherds -eight jars, five bowls, and a fragment possibly representing a ceramic pipe stem.

Only one sherd from the Feature 2 (AU 2) Native American ceramic assemblage displayed any form of decoration. This sherd is of the Rockport Black-on-Gray II variety, characterized by sandy paste and asphaltum decorations in the form of vertical lines, bands, or squiggles on the exterior of the vessel. This sherd is a direct or standing rim sherd from a jar with a rounded lip (see Perttula, Chapter 9c). One loop handle was also present in this collection.

The petrographic analysis of the Native American sherds from Feature 2 found only Group $1(n=14)$ and Group 2 represented in the sample of 28 sherds (Hill, Appendix G). INAA analysis of this same sample classified 86 percent $(n=24)$ of these sherds as having been made from clay sources at or near the mission (Neff and Glascock, Appendix H). The clay sample used to establish the chemical signature of these locally produced ceramics was obtained from the wall of Feature 2. Only 14 percent of the analyzed sherds in this sample fall within the unassigned category identified as similar to Rockport wares manufactured on the coast (Perttula, Chapter 9c).

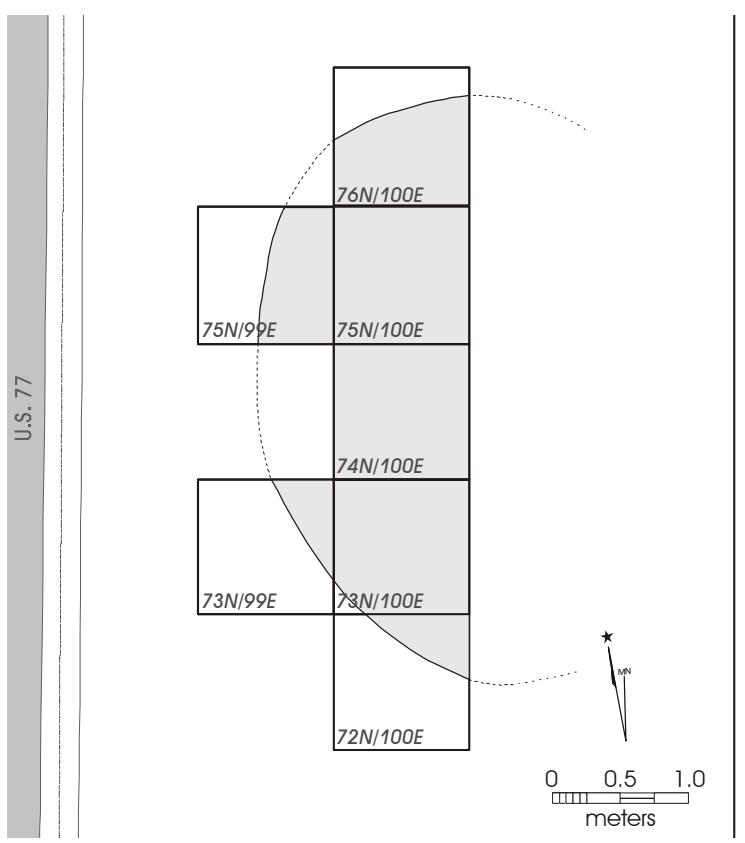

Figure 8a-5. Units excavated in Feature 2.

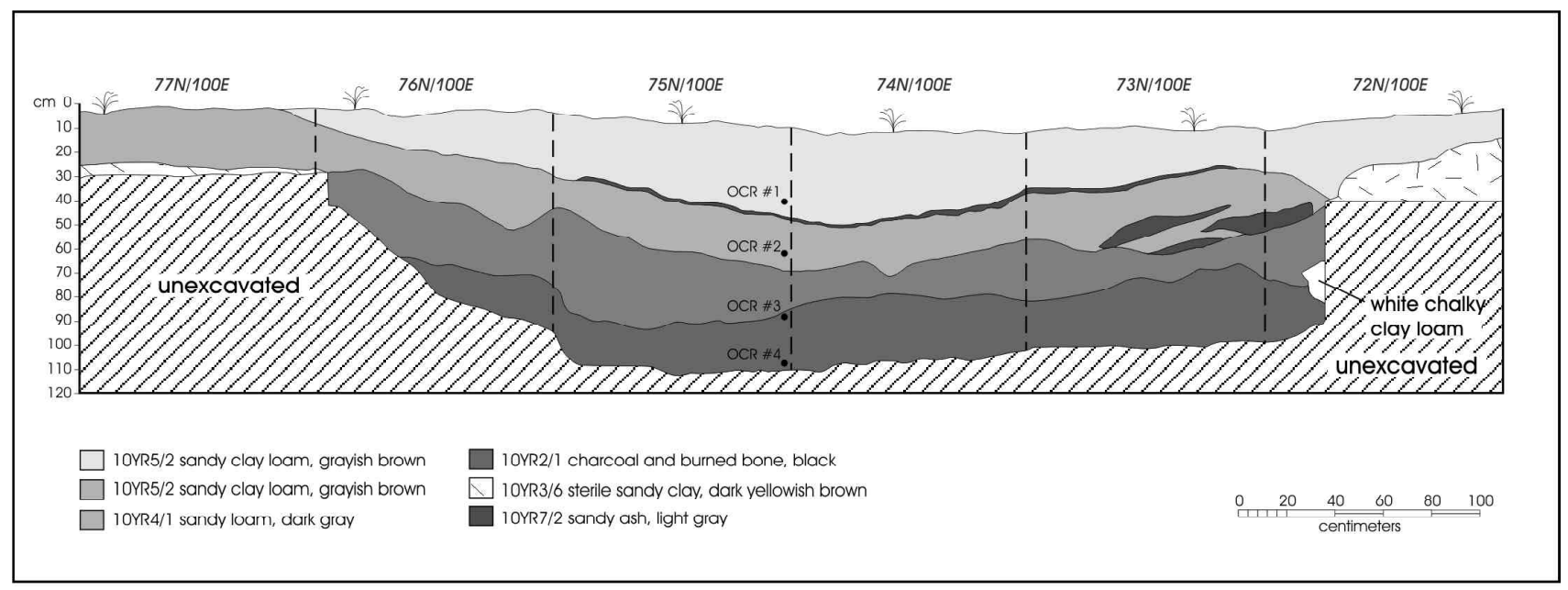

Figure 8a-6. Profile of east wall of Feature 2. 


\section{Feature 2 (AU 2) Mexican and European Ceramics}

There were also 551 Mexican and European ceramic fragments recovered from the Feature 2 deposits (see Fox, Chapter 9A). Tin-glazed ceramics make up 50 percent $(n=274)$ of the Feature 2 assemblage. Of the 158 pieces with temporarily-diagnostic decorations, late-eighteenthcentury Puebla Blue-on-White was the most numerous single type ( $n=33,21$ percent). Orange Banded polychrome plate sherds $(n=16)$ are the most common (30 percent) of the lateeighteenth- through early-nineteenth-century varieties (see Fox, Chapter 9A).

Mexican-made lead-glazed wares $(\mathrm{n}=213)$ account for 39 percent of the Feature 2 assemblage. In this collection, finetextured and sandy-paste sherds are more equally represented; 46 percent $(n=97)$ and 54 percent $(n=116)$ respectively. Galera again dominates the fine-textured varieties ( $n=91,78$ percent) while 78 percent $(n=91)$ of the sandy paste, utilitarian variety are from very small pots with a dark green glaze (see Fox, Chapter 9A).

Seven percent of sherds in the Feature 2 non-native ceramic assemblage are from unglazed, burnished vessels, probably small pots and bowls $(n=37)$. Of these, 41 percent $(n=15)$ are Tonalá Burnished fragments and 38 percent $(n=14)$ are unglazed sherds that were possibly made at the mission (see Fox, Chapter 9A).

The remaining five percent of the Feature 2 non-native ceramics $(n=27)$ were refined earthenwares. Only 11 of these sherds were decorated, seven had hand-painted designs, one was molded-edge decorated, one was of the banded-slip variety, one was a stoneware fragment with Bristol glaze, and one was a piece of banded Hotel porcelain.

\section{Feature 2 (AU 2) Lithics}

A total of 48 chipped lithic artifacts were recovered from the Feature 2. Of these, 40 ( 83 percent) are unmodified lithic debitage and eight are tools. Detailed descriptions of the debitage and tools are provided in Chapter 9D. The eight tools consist of a probable gun flint, three scrapers, one indeterminate uniface, and three cores/core fragments. Three (37.5 percent) of the tools are from Level 8 and the same number are from Level 9, deeper levels (10 and 11), each yielded one tool.
One-half $(\mathrm{n}=20)$ of the unmodified debitage was recovered from Levels 5-9, deeper levels (10-13) yielded 10 percent $(\mathrm{n}=4)$ of the specimens, while only 2.5 percent $(\mathrm{n}=1)$ came from very deep (i.e., Level 19) in the feature. Fifteen specimens had no level designation. With the exception of two flakes, one of chalcedony, and one of green glass, the remaining specimens $(n=38,95$ percent) are of fine-grained chert. The largest single size class, flakes measuring between $10-19 \mathrm{~mm}$, contains 47.5 percent $(\mathrm{n}=19)$ of the debitage. In contrast to AU 1, however, 40 percent $(n=16)$ of the specimens are larger than $20 \mathrm{~mm}$, and only 12.5 percent $(\mathrm{n}=5)$ are smaller than $10 \mathrm{~mm}$. Also contrary to AU 1, in the AU 2 collection, decorticate or tertiary debitage is not as common ( $\mathrm{n}=18,45$ percent) as corticate (secondary and primary) specimens ( $\mathrm{n}=22,55$ percent). Twenty-five ( 62.5 percent) of the debitage is platform bearing (i.e., complete or proximal fragments). Unprepared (corticate and single faceted) platforms are much more common $(n=22,88$ percent) than specimens with two or more platform facets $(\mathrm{n}=3,12$ percent $)$.

Somewhat more than one-third ( $\mathrm{n}=15,37.5$ percent) of the debitage could not be categorized into flake types and one other specimen is an angular debris. Of those that were assigned to a flake type $(n=25)$, platform preparation flakes were the single most common ( $\mathrm{n}=9,36$ percent) group, followed by debitage derived from bipolar or possibly bipolar reductions ( $\mathrm{n}=8,32$ percent). Uniface manufacture and/or rejuvenation ( $\mathrm{n}=7,28$ percent) debitage was also reasonably common, and only one flake may have been the product of core reduction. It would appear that unifacial and bipolar reduction strategies were nearly equally represented in the AU 2 debitage collection.

\section{Feature 2 (AU 2) \\ Fauna}

Analysis of the faunal material from Feature 2 (see Webber et al., Chapter 9E) identified 79 individuals representing 31 taxa in this portion of the assemblage. These include fresh and saltwater fish, terrestrial turtles, wild and domestic birds, deer, cattle, and other wild and domestic mammals. Over 32 percent of the identified individuals in the faunal collection were domesticated mammals including 18 cows and seven sheep and pigs. The domesticated mammal category accounted for over 93 percent of the biomass in this assemblage. Chicken was the only domestic bird in the Feature 2 assemblage, accounting for 19 percent of the total identified individuals. Wild birds, including turkey and some 
aquatic species such as duck, heron, and gulls account for 17 percent of the identified individuals in AU 2. The four deer present in Feature 2 account for only five percent of the individuals in this faunal assemblage while other wild mammals including opossum, rabbit and bear account for four percent of the collection. Fish make up nine percent of the identified individuals in Feature 2 with catfish being the most abundant. Fifty-seven percent of the fish are of the saltwater variety from bays and estuaries.

Sixty percent of the individual cows represented in Feature 2 were juvenile or sub-adult as were 80 percent of the pigs and 50 percent of the deer. Comparison of the measurements of the Bovidae elements indicate the cattle were about the same size or a little larger than those from Mission Rosario or Espíritu Santo de Zuñiga in Goliad. The bovine elements present in this assemblage suggest onsite butchering, while some of the deer and pig elements suggests postconsumption disposal after butchering elsewhere.

\section{Feature 2 (AU 2)}

\section{Other Historic Diagnostics}

Only a few artifacts other than ceramics and faunal material were recovered from Feature 2. These include 75 glass fragments, of which 87 percent are clear $(n=36)$, aqua $(n=5)$, and green $(n=24)$, colors that are most often associated with mission deposits (see Meissner, Chapter 9B). Other artifacts include a copper alloy button, a knife handle made of bone, a piece of pumice stone, and two pieces of unidentified bone painted with red and white patterns.

\section{Feature 3}

At the eastern edge of units $80-81 \mathrm{~N} / 100 \mathrm{E}$ the suggestion of a third pit feature, Feature 3, was revealed at a depth of $50 \mathrm{~cm}$ below the surface. This feature is located $3.5 \mathrm{~m}$ north of Feature 2 and $1.55 \mathrm{~m}$ south of Feature 1 (see Figure 8a1). What would be the western edge of the pit appears as an ash and charcoal deposit that extends $18 \mathrm{~cm}$ away from the east wall of the ROW into the sterile yellowish brown clay in both units (Figure 8a-7). A $10 \mathrm{~cm}$ thick lime layer similar to the one covering Feature 1 was present from $15-25 \mathrm{~cm}$ bs above Feature 3 (Figure 8a-8). However, it was not possible to determine if the two lime deposits were contiguous due to a disturbance at the northern edge of the feature -probably caused during the installation of a water pipe. Due to the location of this pit at the eastern edge of the ROW, no further attempt was made to excavate this feature. All artifacts recovered in the area of Feature 3 are from the upper levels associated with the non-feature units

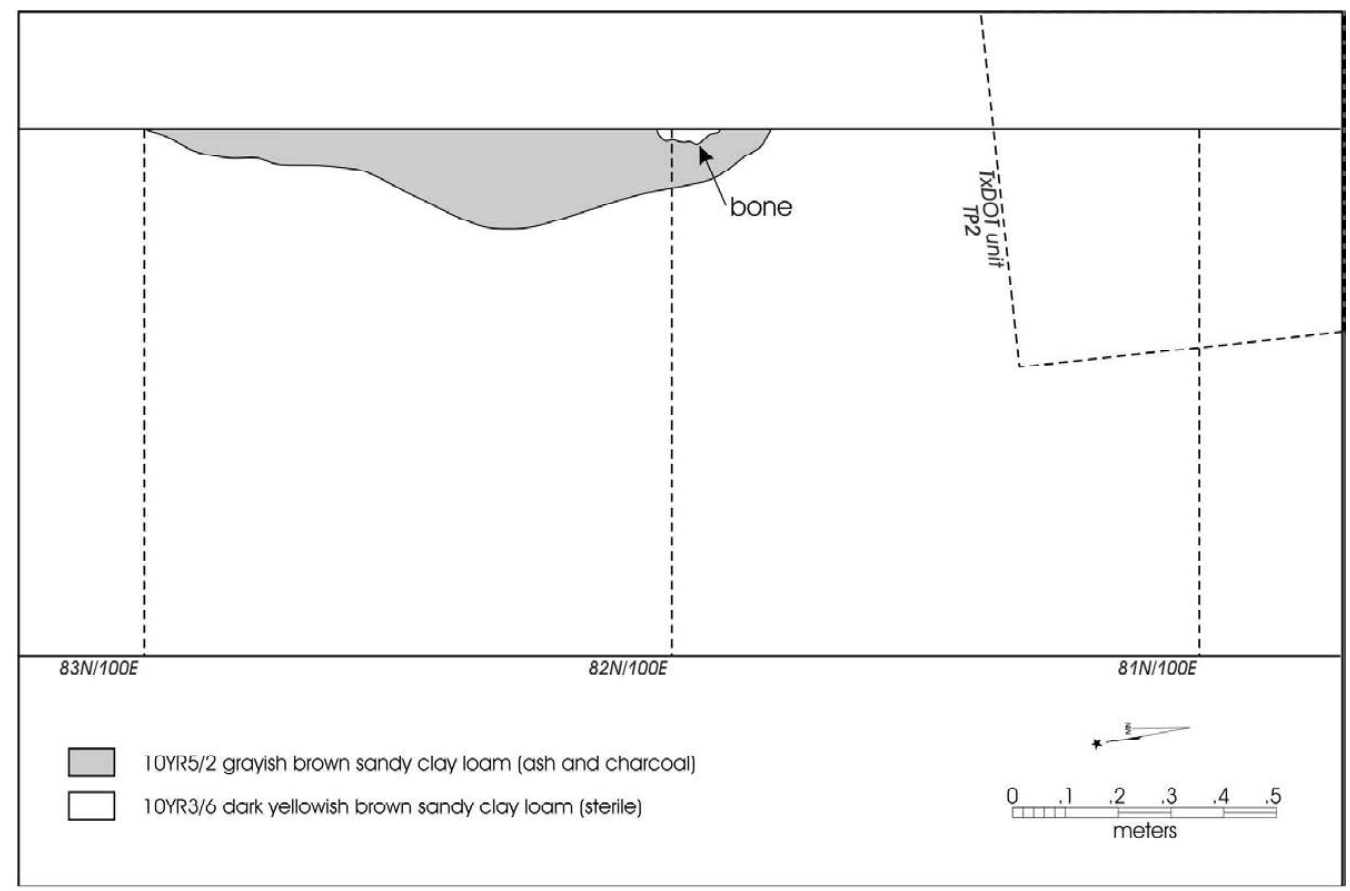

Figure 8a-7. Plan map of Feature 3. 
comprising AU 3 discussed below. No artifacts could be definitely associated with this third trash pit feature.

\section{Non-Feature (AU 3) Units}

Figures $8 \mathrm{a}-9$ and $8 \mathrm{a}-10$ are profiles of the east wall in units not directly associated with the pit features (AU 3), units $78 \mathrm{~N} / 100 \mathrm{E}$ and $64 \mathrm{~N} / 100 \mathrm{E}$ respectively. They are examples of the upper layers of the Colonial period deposit within the TxDOT ROW not truncated during the previous construction episodes involving US 77. As illustrated, the upper layer is comprised of dark grayish-brown (10YR4/2-10YR5/2) sandy clay loam. This undulating soil layer is the upper artifact-bearing zone found along the length of the eastern
ROW. It varies from $50 \mathrm{~cm}$ in depth at the northern end of the project area to less than $10 \mathrm{~cm}$ in thickness at the southern end and constitutes the upper deposit of both pit features. In units not directly associated with the trash-pit features, this zone is underlain by a dark yellowish-brown (10YR3/ 6) compact, blocky clay that is uniformly sterile throughout the project area.

Artifact density within this upper zone varied across the eastern edge of the ROW with the highest concentrations in the northern half of the site in the vicinity of the two pit features and a sparse scatter present in the units at the southern end. The artifact assemblage from the non-feature units comprising AU 3 includes 2,358 fragments of Native American ceramics, 1,088 Mexican or European ceramic

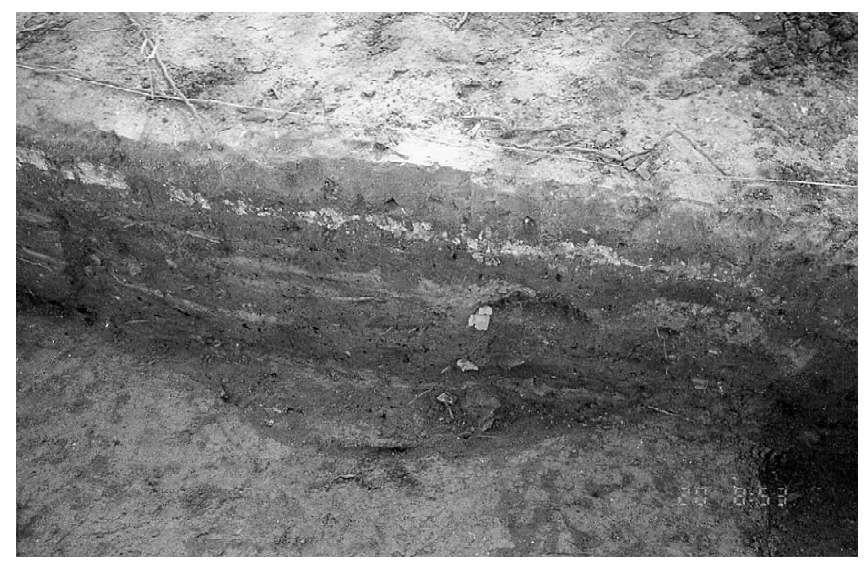

Figure 8a-8. Profile of Feature 3 at eastern edge of ROW.

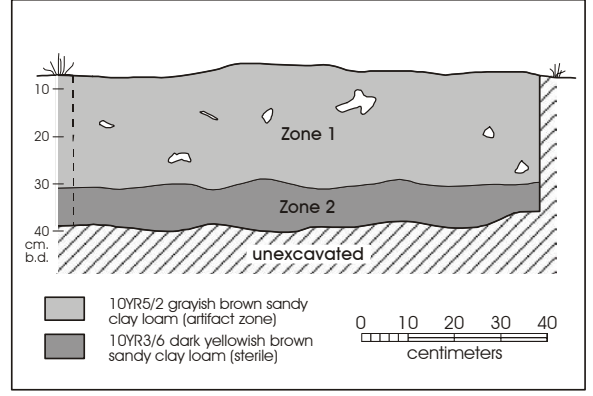

Figure 8a-9. Profile of east wall of Unit $78 N / 100 E$.

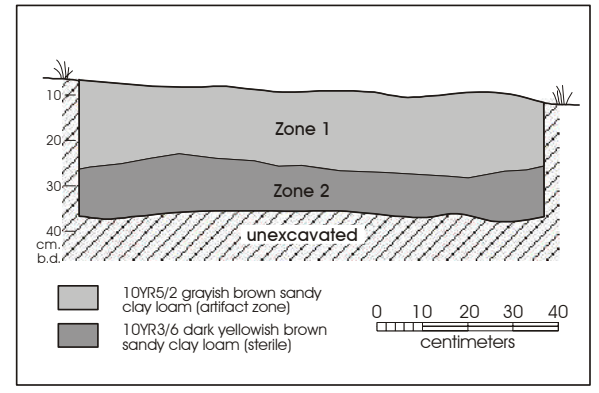

Figure 8a-10. Profile of east wall of Unit $64 N / 100 E$. 
sherds, 94,703.07 grams of animal bone, 312 pieces of lithic material, and 1,171 glass fragments (Appendix c) While artifacts collected during Clark's 1997 testing were not included in the statistical computations used to establish the analytical units, they are included in the discussion of AU 3 contents as they are from non-feature units.

\section{Non-feature 3 (AU 3) Native Ceramics}

The non-feature units comprising AU 3 yielded 1,914 (CAR 1617, TxDOT 297) Native American sherds larger than 1 $\mathrm{cm}$ in diameter, more than twice the number recovered from Features 1 and 2 combined. Perttula (Chapter 9c) has determined that, much like the other two AUs, 78 percent $(n=1498)$ of these sherds were bone-tempered, 17 percent $(n=326)$ had sandy paste, 5 percent $(n=88)$ had sandy paste with some bone tempering, and the clay in four of the sherds showed neither sand or bone tempering. Perttula has classified over 96 percent of the bone-tempered sherds from AU 3 as having either moderate or sparse amounts of bone in the temper while 57 percent of the sandy-paste sherds contain moderate amounts of sand in the paste. Fragments of 108 rim sherds are part of this assemblage (Appendix K). Of these, 71 percent were direct. Additionally, 57 percent of the rim sherds had rounded lips and 36 percent had flat lips. Vessel forms identified from these rim sherds include four bottles, 15 jars, 35 bowls, two vessels that could be either bowls or ollas, and seven that could be from either jars or ollas.

The widest variety of decorated Native American body and rim sherds was also recovered from AU 3 (Chapter 9c, Table 9c-9). The most common decorative type in this assemblage is Rockport Black-on-Gray II. Fifteen sherds of this variety are present and are characterized by a sandy paste or sandy paste with bone and asphaltum decorations in the form of vertical lines, bands, or squiggles on the exterior of the vessel. Also present are 12 bone-tempered sherds that display asphaltum decorations. This type, described by Mounger (1959) as Goliad black-on-buff, includes lip lines and squiggles, as well as bands and lines on the vessel body (Chapter 9c). There are also eight rim sherds of the Rockport Black-on-Gray I variety characterized by a single band of asphaltum painted on the vessel lip (Chapter 9c). This decorative type was found only in the non-feature (AU 3) units and represents a minimum of three wide-mouth jars or bowls. Also present only in AU 3 are nine pieces of Goliad
Red-on-Buff, a type also identified by Mounger (1959) from the collection at Mission Espíritu Santo de Zuñiga at Goliad. This type has dots, horizontal and vertical bands, diagonal lines, and loops painted in red on the body and zigzag lines at the lip. The eight sherds of this variety in the AU 3 assemblage represent a minimum of four bowls. Three other bone-tempered sherds display decorative techniques unique to the AU 3 assemblage. These are: one sherd with broad, parallel-incised lines on the rim; and two body sherds with overlapping and parallel brush marks. The brush sherds may be similar to "Boothe Brushed" vessels based on INAA and petrographic analysis and attributed to Caddoan ceramics (Perttula, Chapter 9c). Three additional sherds are present in the non-feature assemblage that display brown or dark brown bands painted on their exterior similar to those recovered in Feature 1 except the AU 3 sherds were manufactured with a sandy paste.

Other items made of bone-tempered clay include five loop handles of a type generally used with water jars, one vessel support, or "foot" from a bowl or jar base, and one ceramic disk similar to those from other missions described as gaming or counting pieces by Mounger (1959), Ricklis (1998), and Schuetz (1969).

Group 1 ceramics alone made up 75 percent $(n=30)$ of the sample of 40 Native American sherds selected for petrographic analysis from the non-feature units (Appendix G). This sample also included the only sherd classified as Group 0 , having a high sand content and no bone in the temper. While still heavily dominated by sherds with the local chemical signature, the non-feature sample did have a higher percentage of sherds $(n=10,26$ percent) that fell within the unassigned INAA grouping (Appendix $\mathrm{H}$ ) that Perttula (Chapter 9C) suggests are similar to Rockport wares without asphaltum.

\section{Non-feature (AU 3) Mexican and European Ceramics}

The largest assemblage of Mexican and European ceramics $(n=1088)$ came from the non-feature units. In this assemblage, 38 percent $(n=416)$ of the sherds are refined European earthenwares. The majority of these $(n=289)$ are undecorated. Over half of the remaining 132 decorated sherds have hand-painted designs $(n=69)$ and are from small cups (see Fox, Chapter 9A). The next most frequent type is transfer-decorated $(n=22)$ followed by salt-glazed stoneware 
sherds $(\mathrm{n}=10)$. These refined earthenware sherds represent outside influences that arrived at the latter end of the Refugio mission period.

Tin-glazed majolicas make up 21 percent $(n=232)$ of the non-feature (AU 3) assemblage. Fifty percent of the 121 decorated pieces in this assemblage $(n=61)$ are varieties thought to be from the early-nineteenth-century. Some of these are variations of the Guanajuato type and some are unnamed types that are not found at earlier Texas missions (see Chapter 9A).

Consistent with the other AUs, Mexican-made lead-glazed wares $(n=397)$ account for 36 percent of the non-feature assemblage. Sherds with a fine-textured paste $(n=321)$ make up the majority ( 81 percent) of this collection, again dominated by Galera ware ( $\mathrm{n}=252,79$ percent). However, 44 sherds of 1780-1830 Tonalá Polychrome Glazed ware are also present (Chapter 9A). The thicker walled, sandy paste, utilitarian variety is represented by 39 yellow-glaze fragments, 23 yellow/green-glazed fragments, and 14 dark green-glazed pieces.

Only four percent of the non-native ceramics in the nonfeature (AU 3) assemblage are from unglazed, burnished small pots and bowls $(n=43)$. Of these, 15 are Tonalá Burnished fragments and 16 are unglazed sherds that were possibly made at the mission (see Chapter 9A).

\section{Non-feature (AU 3) Lithics}

A total of 312 chipped lithic artifacts were recovered from non-feature contexts. Of these, 244 (78 percent) are unmodified lithic debitage and 68 (22 percent) are tools. Detailed descriptions of the debitage and tools recovered are provided in Chapter 9D. The sixty-eight tools consist of eight probable gun flints, two scrapers, five indeterminate unifaces, three indeterminate bifaces, and fifty cores and core fragments. The majority of the 68 tools occur in Levels $2(n=25,37$ percent) and $4(n=24,35$ percent). Level 3 contained only 13 tools (19 percent), and single tools were recovered from Levels 1 and 5, respectively. No tools from below Level 5, were assigned to this non-feature analysis unit and four specimens are unprovenienced to level.

Slightly more than one-third ( 34 percent, $n=84$ ) of the unmodified debitage were recovered from Levels 1 and 2, while Levels 3 and 4 yielded 28 percent $(n=69)$ of the specimens. Only ten specimens came from deeper levels (i.e., Levels 5 and 6, six and four flakes, respectively). Eighty-one specimens (33 percent) had no level designation. The majority of the specimens ( $n=227,93$ percent $)$ are of fine-grained chert, although due in part to the larger sample size, the diversity of raw material types is somewhat larger in this AU compared to the two previous AUs discussed. A total of six other raw material types occur in the collection, with quartzite $(n=6)$, coarse-grained chert $(n=4$, two percent), and chalcedony ( $n=4)$, being the three most common. Petrified wood and rhyolite, occur in low numbers, with one specimen each. The majority $(\mathrm{n}=187,77$ percent) of the debitage falls within the 11-20 mm size-class and a smaller fraction $(n=49,20$ percent $)$ are larger than $20 \mathrm{~mm}$, and only eight (three percent) fall in the smallest size class $(1-10 \mathrm{~mm})$. Corticate or primary and secondary debitage is slightly more common $(n=136,56$ percent) than decorticate (tertiary) debitage; $\mathrm{n}=108,44$ percent). Slightly less than half ( $\mathrm{n}=107,44$ percent) of the debitage is platform bearing (i.e., complete or proximal fragments). Unprepared (corticate and single faceted) platforms are much more common ( $\mathrm{n}=94,88$ percent) than specimens with two or more platform facets $(n=13,12$ percent).

About one third ( $\mathrm{n}=82,34$ percent) of the debitage could not be categorized into flake types and 51 (21 percent) other specimens are angular debris. Of those that were assigned to a flake type ( $\mathrm{n}=111)$, bipolar and/or possibly bipolar flakes are the most common ( $\mathrm{n}=56,50$ percent), followed by platform preparation flakes ( $\mathrm{n}=41,37$ percent). Debitage derived from uniface manufacture and/or rejuvenation $(\mathrm{n}=10$, nine percent) constitutes a small proportion of the collection, while only three bladelets (three percent) and a single (one percent) biface thinning flake were recovered.

\section{Non-feature (AU 3) \\ Fauna}

Analysis of the faunal material from non-feature units (see Webber et al., Chapter 9e) identified 83 individuals representing 46 taxa in this portion of the assemblage. These include fresh and saltwater fish, terrestrial turtles, wild and domestic birds, deer, cattle, and other wild and domestic mammals. Over 24 percent of the identified individuals in the faunal collection were domesticated mammals including 15 cows and seven sheep and pigs. An additional five individuals were identified as probable cow and two were identified as probable bison. The domesticated mammal category accounted for over 89 percent of the biomass in this assemblage. Chicken was the only domestic bird in the 
AU 3 assemblage, accounting for ten percent of the total identified individuals. Wild birds, both terrestrial and aquatic account for 14 percent of the identified individuals in AU 3. Wild mammals, which make up 17 percent of the identified individuals are represented by five deer, opossum, jackrabbit, cottontail, armadillo and a large dog or wolf. Fish account for 12 percent of the identified individuals in the non-features units with catfish being the most abundant. Seventy percent of the fish are freshwater varieties.

Fifty percent of the cattle present in AU 3 were juvenile or sub-adult at time of death, as were all three pigs and three of the five deer. Comparison of the measurements of the Bovidae elements indicate the cattle were about the same size as those from Mission Rosario or Espíritu Santo de Zuñiga in Goliad, but overall are smaller than the bovine recovered from the two trash-pit features at Mission Refugio. The bovine elements present in this assemblage suggest onsite butchering -while the deer elements suggests postconsumption disposal after butchering elsewhere.

\section{Non-feature (AU 3) Other Historic Diagnostics}

Diagnostic glass recovered from the non-feature units that constitute AU 3 include fragments that date from as early as the mid-nineteenth-century to as late as 1966 (see Meisner, Chapter 9в). These items range from a worked fragment of dark green glass to numerous machine-made soft drink bottles. Other items including an 1877.41 caliber centerfire cartridge and post- 1890 wire nails attest to the fact that even though the top $20 \mathrm{~cm}$ was mechanically removed before excavations, the deposits in the non-feature units still contained a mixture of modern and colonial period artifacts.

However, the majority of the artifacts other than ceramics or fauna recovered from the non-feature units are related to the colonial use of the site. As described later in this report (see Meissner, Chapter 9B), these include a copper-alloy crucifix inlaid with glass stones, two pieces of worked marine shell probably intended as pendants, and a foot broken from a clay figurine. Four small flaked-glass disks similar to ceramic gaming pieces were also recovered from AU 3. Items recovered from the non-feature (AU 3) which possibly relate to Spanish residents of the mission include an iron strike-o-light used to produce a spark for lighting a fire, a musket side plate, a powder flask charger, and a starshaped metal object that may have been a spur.

\section{Feature 7}

Feature 7 appears to be a midden deposit discovered during Gradall scraping beneath the southbound lanes of US 77 . Feature 7 is a concentration of dark brown soil mixed with limestone rocks, animal bone, and ceramic sherds (see Figure 8a-1). In planview it is slightly rounded and measures roughly $110 \mathrm{~cm} \mathrm{~N} / \mathrm{S}$ by $90 \mathrm{~cm} \mathrm{E/W} \mathrm{(Figure} \mathrm{8a-11).} \mathrm{In} \mathrm{profile,}$ Feature 7 slopes gently to the west to a maximum depth of $18 \mathrm{~cm}$. (Figure 8a-12). The fill in Feature 7 is made up of alternating layers of brown, sandy clay loam and grayish brown deposits of clay and ash. Feature 7 is quite different from the deep, intentionally dug pits seen in Features 1 and 2 and is more suggestive of an inadvertent accumulation of refuse similar to those commonly found adjacent mission compounds elsewhere in the state.

Only a sample of artifacts was collected from Feature 7. This sample included 13 pieces of unglazed native ceramics, six dark brown lead-glazed sherds, three pieces of undecorated majolica, one fragment of Huijotzingo decorated majolica, two pieces of undecorated creamware, and one piece of undecorated whiteware. Also collected were one bone tool, one possible metal point, four cut nails, and eight fragments of red brick.

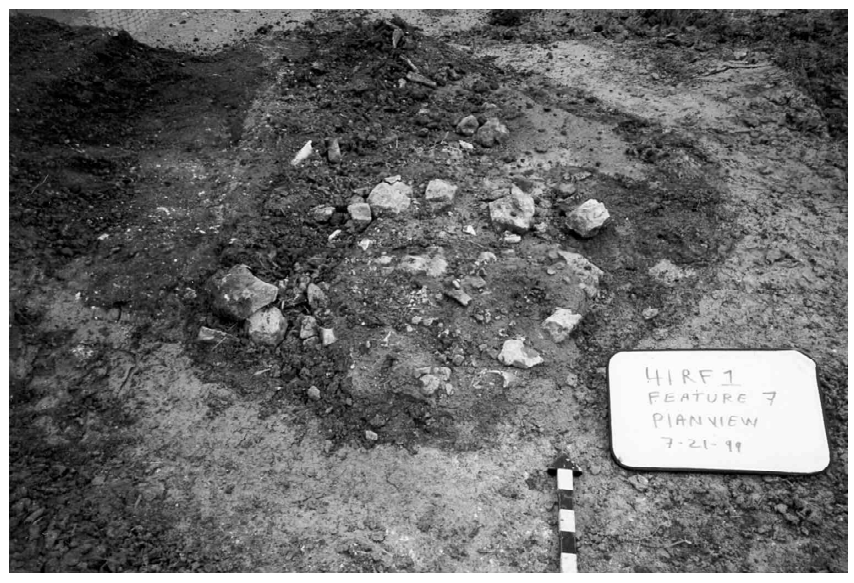

Figure 8a-11. Feature 7 after clearing. 


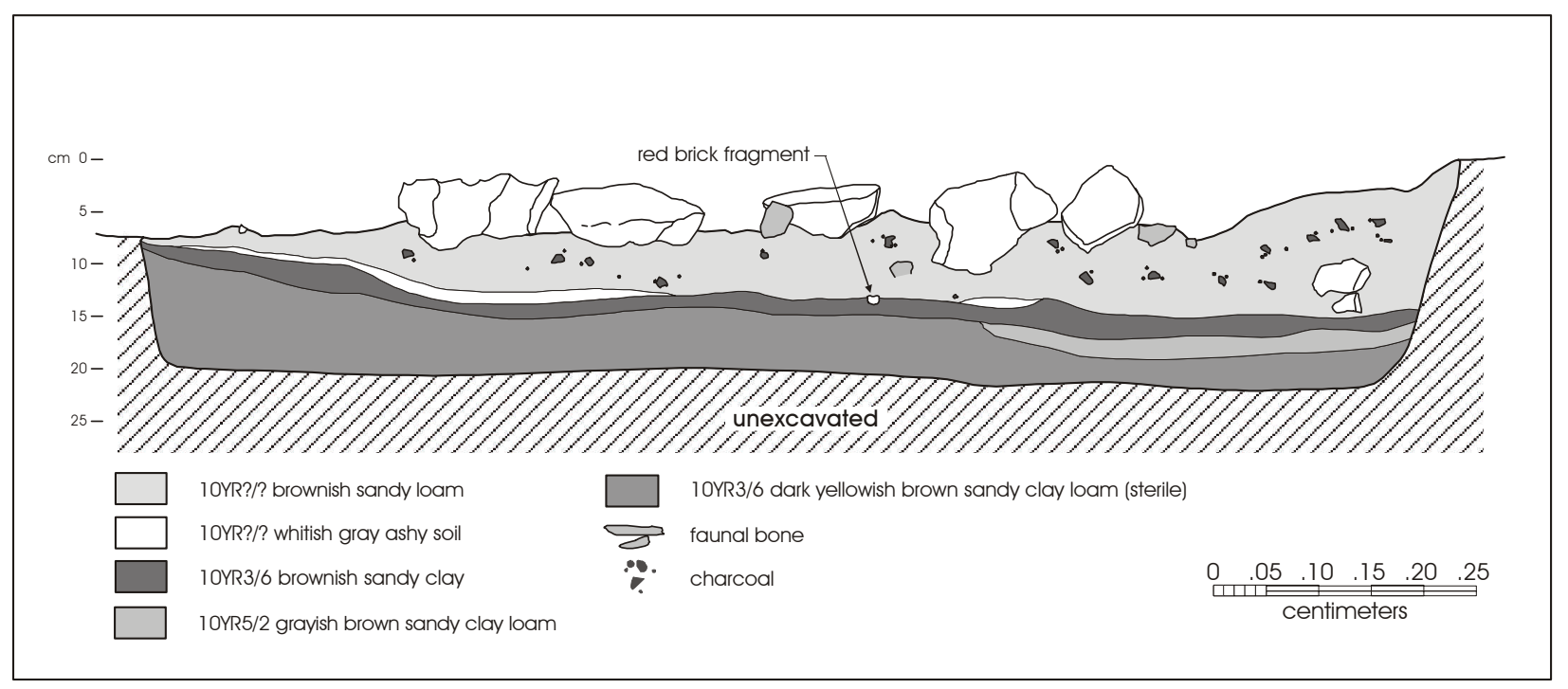

Figure 8a-12. Feature 7 profile, west wall.

\section{Feature 8}

Feature 8 was found in the northern end of the project area, adjacent Feature 7, and it also was discovered during Gradall scraping beneath the southbound lanes of US 77 (see Figure 8a-1). Only a portion of the eastern half of this feature was located within the TxDOT ROW. However, the profile of Feature 8 indicates that it was at least 5 meters in diameter and extended to a depth of 1 meter below the existing surface (Figure 8a-13). The fill within the feature was a dark brown silty clay loam that was interspersed with thin, discontinuous lenses of lighter colored, sandy soil mixed with flecks of charcoal and ash.

Although, Feature 8 appears to be similar in size and shape to both Features 1 and 2, very few artifacts were observed in Feature 8 . Those artifacts that were recovered include one piece of Native ceramics, one fragment of Puebla Blueon-White majolica, and one piece of Tonalá burnished leadglaze. Also recovered from the fill were brown and aqua glass fragments, shell, and bolts and wire nails, somewhat compromising a Colonial association of this feature.

\section{Trash-Pit Feature Discussion}

Dense scatters of cultural material, or sheet midden accumulations, similar to the deposits uncovered in the nonfeature units on the eastern edge of the project area, have also been recorded at other south and central Texas mission sites. Work done at Espíritu Santo and Rosario (Hunziker and Fox 1998; Ricklis 1998), Mission San Juan (Cargill and Robinson 2000), Mission San José (Tomka and Fox 1998a), and Mission Espada (Cargill 2001) indicate that these deposits tend to accumulate more heavily outside mission walls and near gates. Large, debris-filled pits of the type encountered in Features 1 and 2 at Mission Refugio however, are relatively unknown at Spanish mission sites in Texas. It is obvious from the type and quantity of artifacts recovered that Features 1 and 2 at Mission Refugio functioned as refuse disposal areas prior to the cessation of their use. However, the amount of labor required to dig these two large pits, a meter into the dense clay subsoil, suggests that these pits were initially excavated for a more important reason, perhaps as borrow pits for clay daub as suggested at Missions Xavier and Los Adaes or for local ceramic 
manufacturing materials as suggested by the INAA analysis of the Mission Refugio ceramics.

A literature search for similar Colonial period features found the following examples. Two pit features were discovered at Mission Dolores de los Ais in San Augustine County (Corbin et al. 1990). These features were approximately $4 \mathrm{~m}$ in diameter and contained animal bone and ceramic fragments. They were, however, only $40-45 \mathrm{~cm}$ in depth. Based on their location near structure walls, these pits were interpreted as borrow pits, associated with mission construction, that later served as "cooking and/or trash disposal pits" (Corbin et al. 1990:57). Gilmore (1969:74) also reported a large trash-filled pit at Mission Francisco Xavier de Horcasitas in Milam County which she suggested was originally used as a borrow pit for daub.

Capped or sealed trash pits similar to Feature 1 are reported at the east Texas site of Nuestra Señora del Pilar de Los Adaes (Gregory 1973). One was interpreted as "some kind of temporary Indian structural depression" that resulted from gradual wear rather than deliberate excavation (Gregory
1973:85-86). The ensuing accumulation of animal bone and ceramics was "eventually closed by a clay cap" of sterile red clay about four inches thick. Although no size or depth information is presented in the text, estimates made from the illustration (Gregory 1973:Figure 6) indicate this feature had an irregular shape and was approximately $1.5-\mathrm{x}-1.5 \mathrm{~m}$ in size and approximately $30 \mathrm{~cm}$ thick. The second sealed feature at Los Adaes is described as a small, circular, eighteenth-century trash pit approximately $2.5 \mathrm{ft}(76 \mathrm{~cm})$ deep that was intentionally excavated into the red clay subsoil and used for burning and disposal (Gregory 1973:87). In profile (Gregory 1973:Figure 7), the pit has slightly sloping to straight walls and an undulating bottom similar to that found in Feature 1 at Mission Refugio. This second feature found at Los Adaes was sealed with a layer of sterile yellow sand.

A comparison of types and frequencies of materials recovered from the main analytical units, Feature 1, Feature 2, and the non-feature units, reveals evidence of technological and socioeconomic changes that occurred during the 25-30 year occupation of this Spanish Colonial mission.

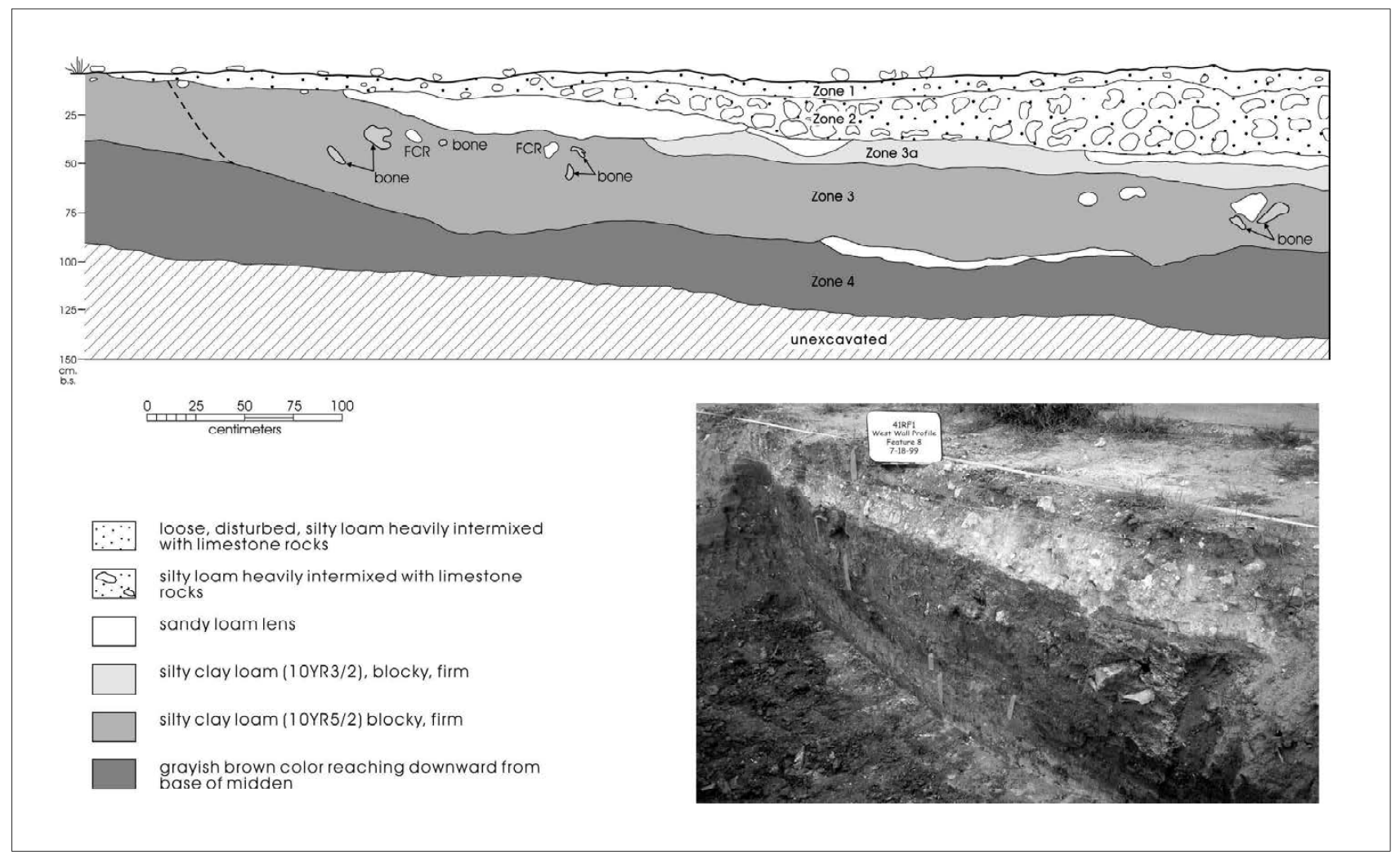

Figure 8a-13. Profile and photograph of west wall of Feature 8. 
As shown in Figure 8a-14, there is little change in the temper and paste-types that make up the Native ceramics found in the three deposits. Sherds with bone temper consistently account for almost 80 percent of the assemblage. INAA analysis shows that these ceramics were made from local clays, indicating the Karankawa were not bringing ceramic vessels with them from the coast, but continued to manufacture the majority of their vessels onsite at the mission. Figure 8a-15 illustrates that the Karankawa tradition of coating and/or decorating ceramics with asphaltum continued at Mission Refugio but was expanded to include not only sandy-paste vessels but bone-tempered ceramics as well. However, this tradition was more prominent during the earlier time period, lessening in each of the succeeding temporal units. This may simply reflect a change in style, but it may be the result of decreased access to the coastal source of the asphaltum due to changes in native mobility patterns influenced by partial residency at the mission (see McDonald, Chapter 3).

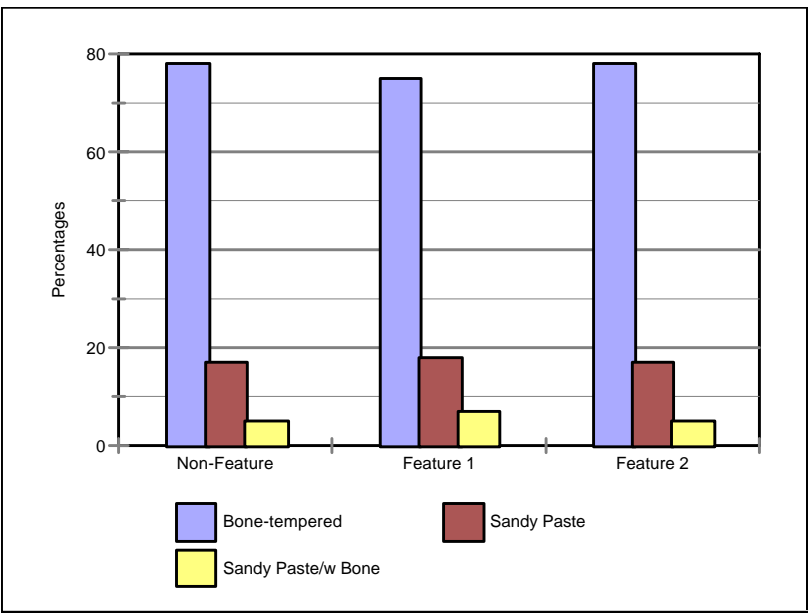

Figure 8a-14. Paste and temper type comparison.

As seen in Figure 8a-16, lead-glazed, food-preparation vessels consistently account for around 40 percent of the non-Native ceramics in each deposit. Majolica vessels, used in food consumption, are most prominent in the earlier deposit and are gradually replaced by European wares. Again, this change may represent a shift in personal preference. It may, however, reflect a growing dependence on imported goods as the Spanish supply system broke down towards the end of the Colonial period, as suggested by the lack of records of new shipments after 1824 (see McDonald, Chapter 3).

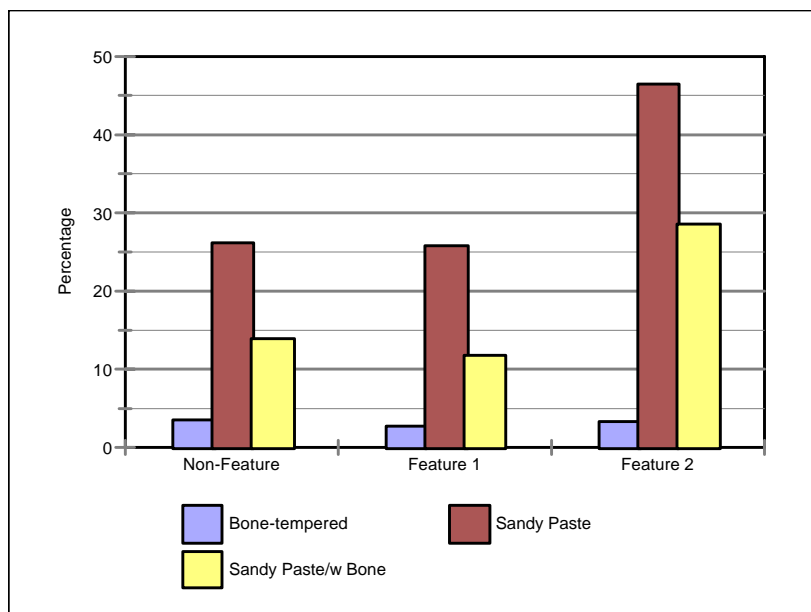

Figure 8a-15. Proportion of asphaltum decorated sherds in each $A U$, by paste and temper type.

Although analysis indicates the vast majority of the biomass in the mission diet was supplied by cattle, the changes in the number of individual animals present in each deposit, illustrated in Figure 8a-17, suggest less obvious changes in subsistence at the mission. The earlier deposit, Feature 2, is dominated by cattle, supplemented by chicken and wild birds. These animals were either raised at the mission or easily obtainable nearby. Cattle and chicken are again prominent in the Feature 1 deposit, but so are wild mammals and fish, possibly supplied to the mission by the Native

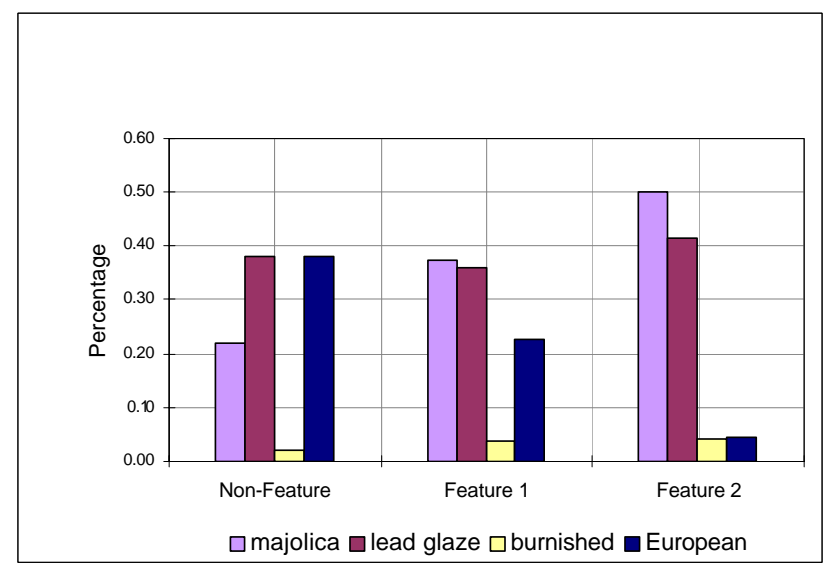

Figure 8a-16. Non-Native type comparison. 
population, are now augmenting these staples. In the latest deposit, the non-feature deposit, 43 percent of the individual faunal elements are from fish, wild mammals, and birds, attesting to the increasing importance of native contributions to the mission diet. That resources close to the mission were being exploited is suggested by the comparison in Figure $8 \mathrm{a}-18$. Here, the proportion of freshwater versus marine fish increases from the earlier to the later deposit.

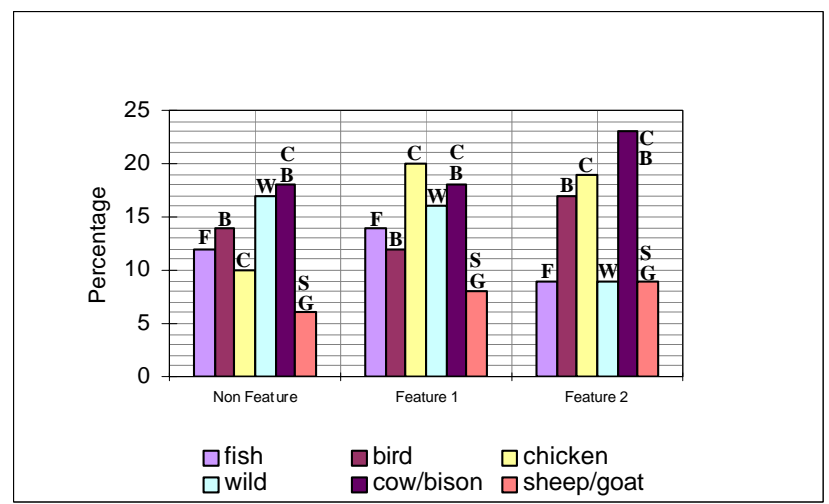

Figure 8a-17. Faunal composition of analytical units based on MNI.

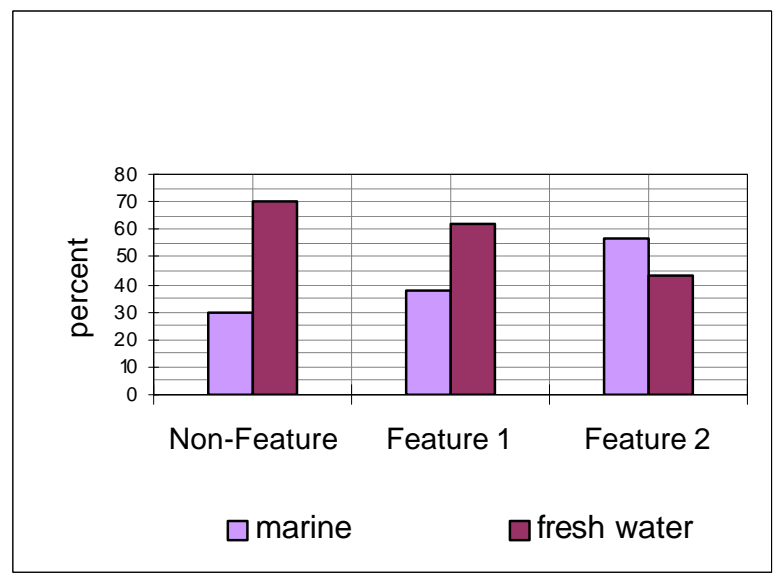

Figure 8a-18. Marine vs. freshwater fish by percent of MNI. 



\section{Chapter 8: Findings Section в}

\section{Architectural Features}

\section{Postholes}

During Gradall scraping beneath both the north- and southbound lanes of US 77, numerous dark stains representing possible postholes were flagged and assigned tentative feature numbers pending further examination (see Table 8a-1). Upon investigation, it was determined that two of these, Features 9 and 10, were the result of modern street disturbance and Feature 19 was actually a modern utility trench. Features 20-29 proved to be extremely ephemeral stains from which nothing could be discerned. The remaining probable postholes were plan mapped, sectioned and profiled in an attempt to determine if they were related to the mission. Upon completion, it was determined that, based on their straight walls, flat bottoms, and general alignment with the existing sidewalk, Features 11-16 and Feature 18 probably represented disturbances from modern road signs or other construction activities. The following descriptions are of postholes believed to be associated with the mission compound (see Figure 8a-1).

\section{Feature 6 a-e}

Feature 6 is actually a series of five postholes located between $86.5-90 \mathrm{~N}$ and $82.5-84 \mathrm{E}$. These postholes measured between $28-31 \mathrm{~cm}$ in diameter and extended 40 $53 \mathrm{~cm}$ below the disturbed roadbed. As shown in Figure $8 \mathrm{~b}-1$, Feature 6-c belled slightly at the bottom to a width of $35 \mathrm{~cm}$ and contained cobble-sized limestone fragments and one cow bone in the dark brown sandy clay fill. Another piece of cow bone was recovered from Feature 6-d. Based on the irregular shape, size, and contents of these features, it was concluded that they were Colonial period postholes.

\section{Feature $36 a-f$}

Feature 36 is an alignment of six postholes located beneath the northbound lanes of US 77 between $62-67 \mathrm{~N}$ and 94.5-91E, just north of the wall trench of the 1796 mission church described below (see Figure 8a-1). These postholes average $34 \mathrm{~cm}$ in diameter and are between $5-15 \mathrm{~cm}$ deep. All are round in plan view and are filled with a dark brown

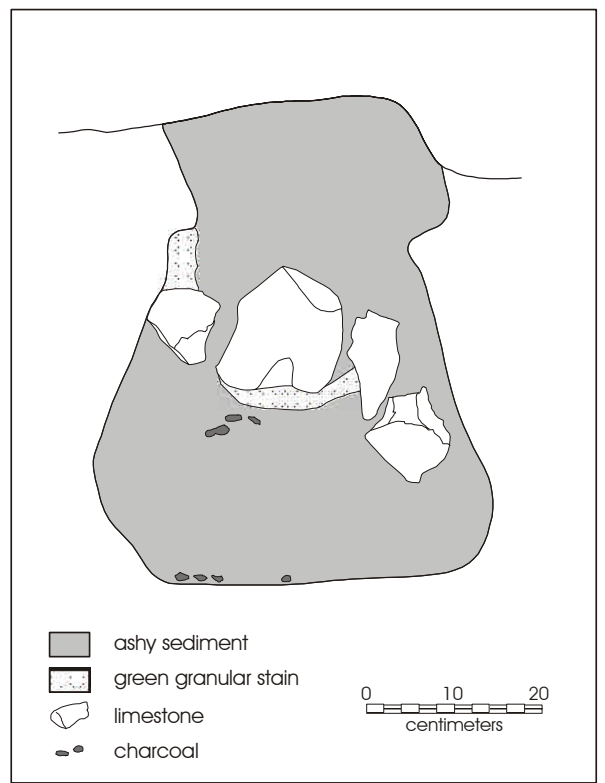

Figure 8b-1. Profile of Feature 6-c Colonial period posthole. 
sandy clay. In profile, the truncated walls of these holes appear to slant inward somewhat and the bottoms of all six are uneven and undulating, suggesting hand-dug excavation (Figure 8b-2). No artifacts were recovered from the Feature 36 postholes but the alignment of two parallel rows of posts even with and just north of the church wall strongly suggests these are remnants of the perimeter stockade described in the 1802 inventory as "a semi-double stockade made of oak [which] circled the plaza" (Chapter 3).

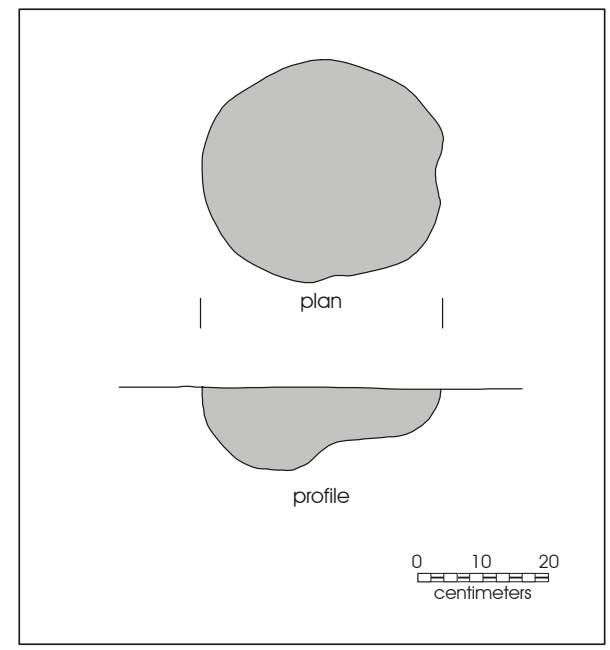

Figure 8b-2. Plan map and profile of Feature 36-a.

\section{Features 37 and 38}

Feature 37 is a somewhat large posthole that was located beneath the northbound lanes of US 77 at $83.5 \mathrm{~N}$ and $91.5 \mathrm{E}$ (see Figure 8a-1). It is roughly circular in shape and measures $44 \mathrm{~cm}$ at its widest portion. Although only $10 \mathrm{~cm}$ of depth remained, in profile the sides of this posthole slope inward. One piece of unglazed native ceramic and 37 fragments of animal bone were recovered from the fill. The dark brown sandy clay fill also contained charcoal flecks and red staining possibly from decomposed brick fragments. Feature 38 measured $57 \mathrm{~cm}$ in diameter and extended 50 $\mathrm{cm}$ below the graded surface of the road. One piece of undecorated whiteware and 11 fragments of animal bone were recovered from the fill of this feature. The shape, contents, and alignment of these postholes suggest they may also be remnants of the mission stockade.

\section{Feature 39 a-d}

Feature 39 is a cluster of postholes in a semicircular alignment at $92-93.5 \mathrm{~N}$ and $94.5-91.5 \mathrm{E}$ at the north end of the site (see Figure 8a-1). These postholes are basically round in plan view and vary in diameter from $28-52 \mathrm{~cm}$, and range in depth from 12-18 cm. In profile, these postholes are similar to those of Features 36 and 37, displaying slightly slanted sides and undulating bottoms.

The pattern formed by this alignment is approximately 5 meters in diameter and could represent one of the fenced gardens, orchards, chicken coops, or animal corrals described in any of the inventories of the mission (Figure 8b-3).

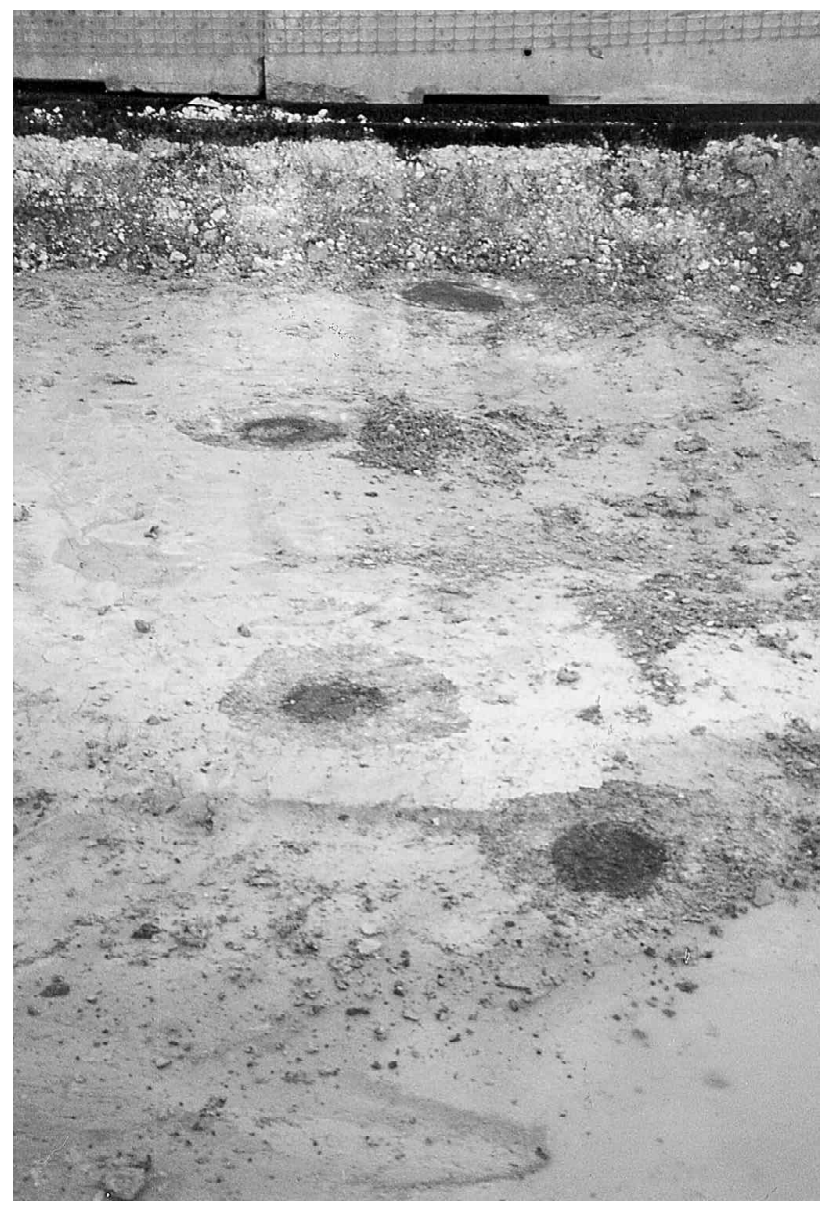

Figure 8b-3. Feature 39a-d, semicircular grouping of Colonial period postholes.

Looking west. 


\section{Stone Features}

\section{Feature 5}

Feature 5 is a circular alignment of rocks uncovered during Gradall investigations beneath the southbound lanes of US 77. It is located north of the burial area at $68.5 \mathrm{~N}$ and 85.2E (see Figure 8a-1). Feature 5 measures $2.5-\mathrm{x}-2 \mathrm{~m}$ in diameter and is composed of one course of uncut limestone rocks held together by a gray sandy mortar (Figure 8b-4). The top of the feature is flat and some of the stones in the center of the circle are somewhat discolored, possibly from a fire. The bottom of Feature 5 is bowl-shaped and extends $25-28 \mathrm{~cm}$ into the sterile Beaumont clay. Feature 5 may be the stone pedestal (only description given) that supported the wooden cross erected in front of the stone structure described as the temporary church in the 1796 inventory (Appendix A).

\section{Feature 17}

Remnants of a stone wall foundation were discovered beneath the grass at the western edge of the ROW between $83-84 \mathrm{~N}$ and $78-79 \mathrm{E}$ (see Figure 8a-1). This foundation extends to a depth of $40 \mathrm{~cm}$ below the modern surface and is approximately $75 \mathrm{~cm}$ wide (Figure 8b-5). The foundation is composed of uncut pieces of limestone held together by lime and sand mortar. The outline of the $8-10 \mathrm{~cm}$ thick builders trench dug for construction of this foundation is visible along the north edge of the wall.

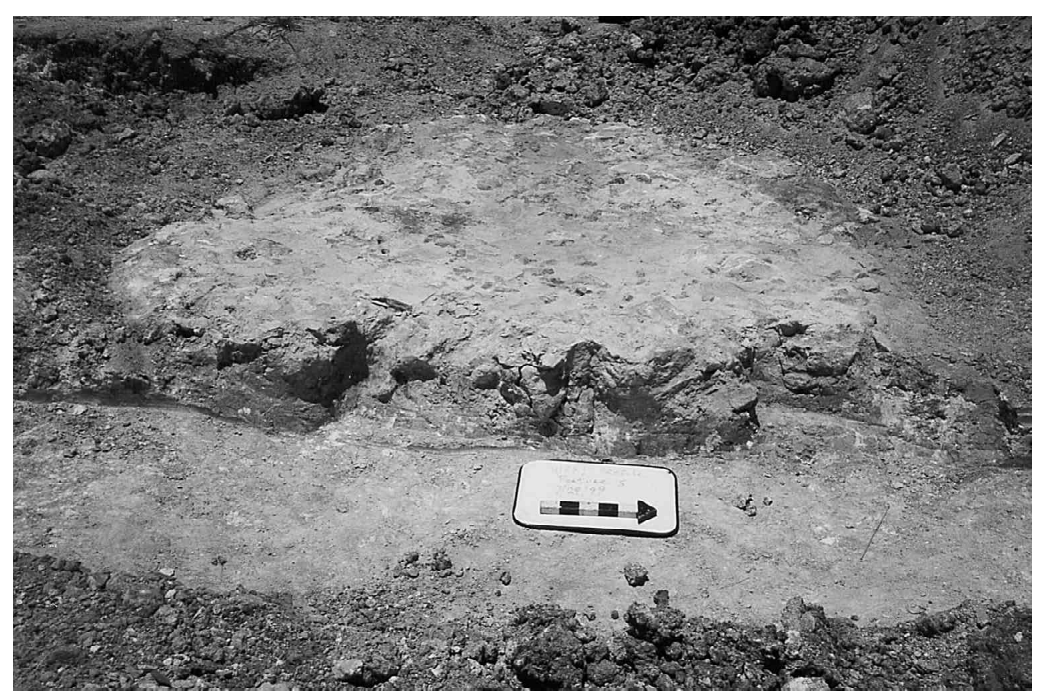

Figure 8b-4. Feature 5, a circular stone foundation. Looking west.

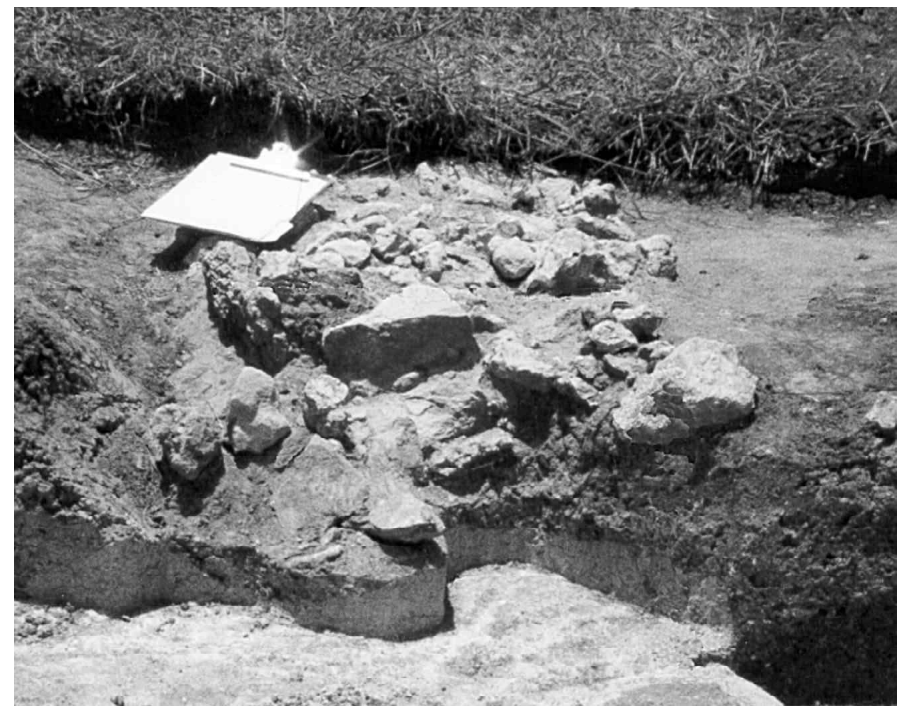

Figure 8b-5. Feature 17, remnant of stone wall foundation. Looking west. 


\section{The Church}

The outline of portions of the trench that once held the foundation stones for the first church at Mission Refugio was uncovered beneath the road base in the northbound lanes of US 77 (Figure 8b-6). On the surface, the straight sides and square corners of the foundation trench stood out in sharp contrast to the yellow and white clay of the underlying Beaumont formation soils. As illustrated in Figure 8b-7, the north, east, and south walls that would have been the "apse" of the church, as well as the entire east wall and a portion of the south wall of the south transept of the church were visible. The term "apse" is generally accepted as the projection at the end of the church which contained the sanctuary (sacred area) and the altar. Transepts extend at right angles from the body of church, separating the apse from the main body of the church, and giving the church its cruciform appearance.

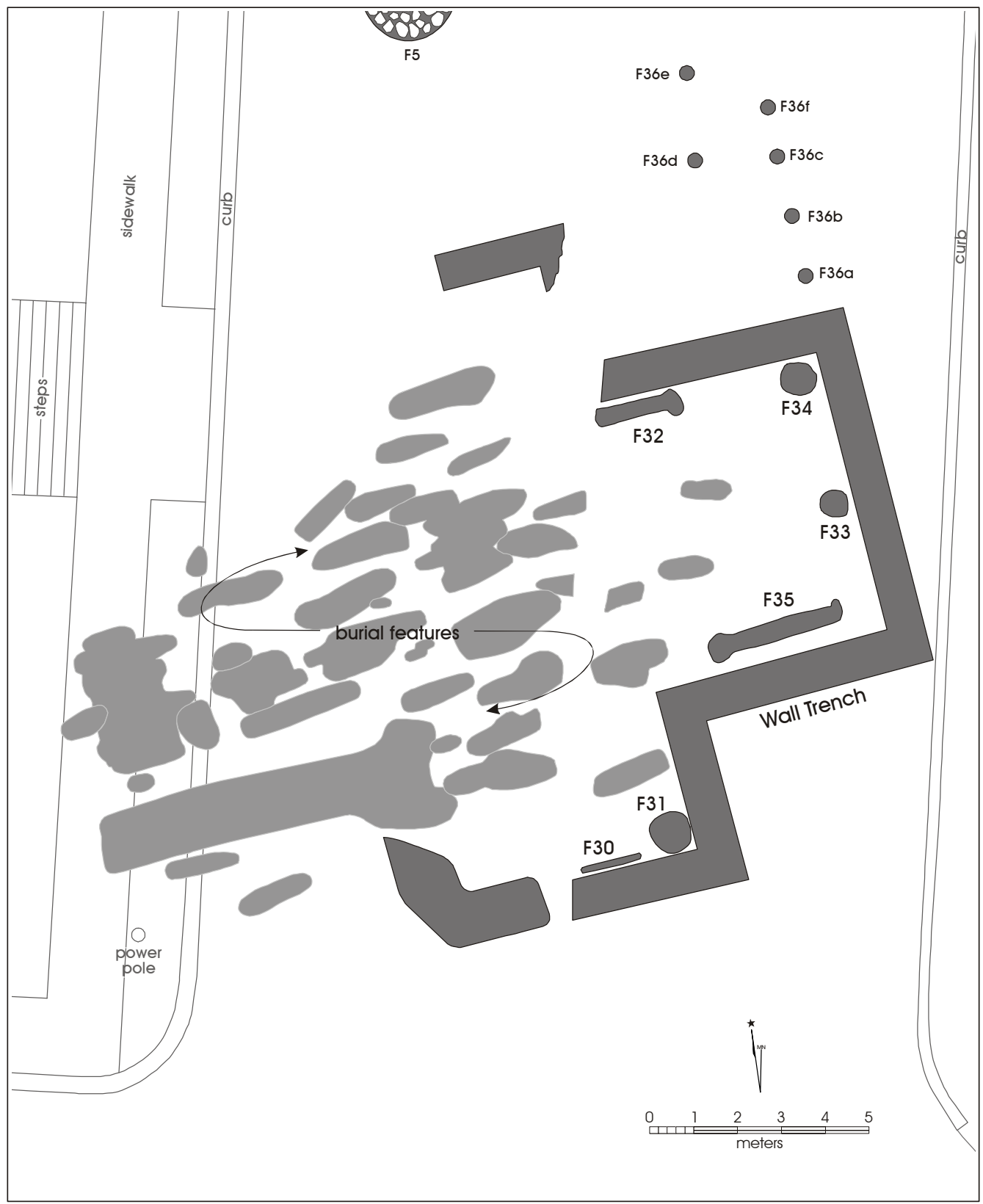

Figure 8b-6. Wall trench and features inside 1796 Church of Mission Refugio. 


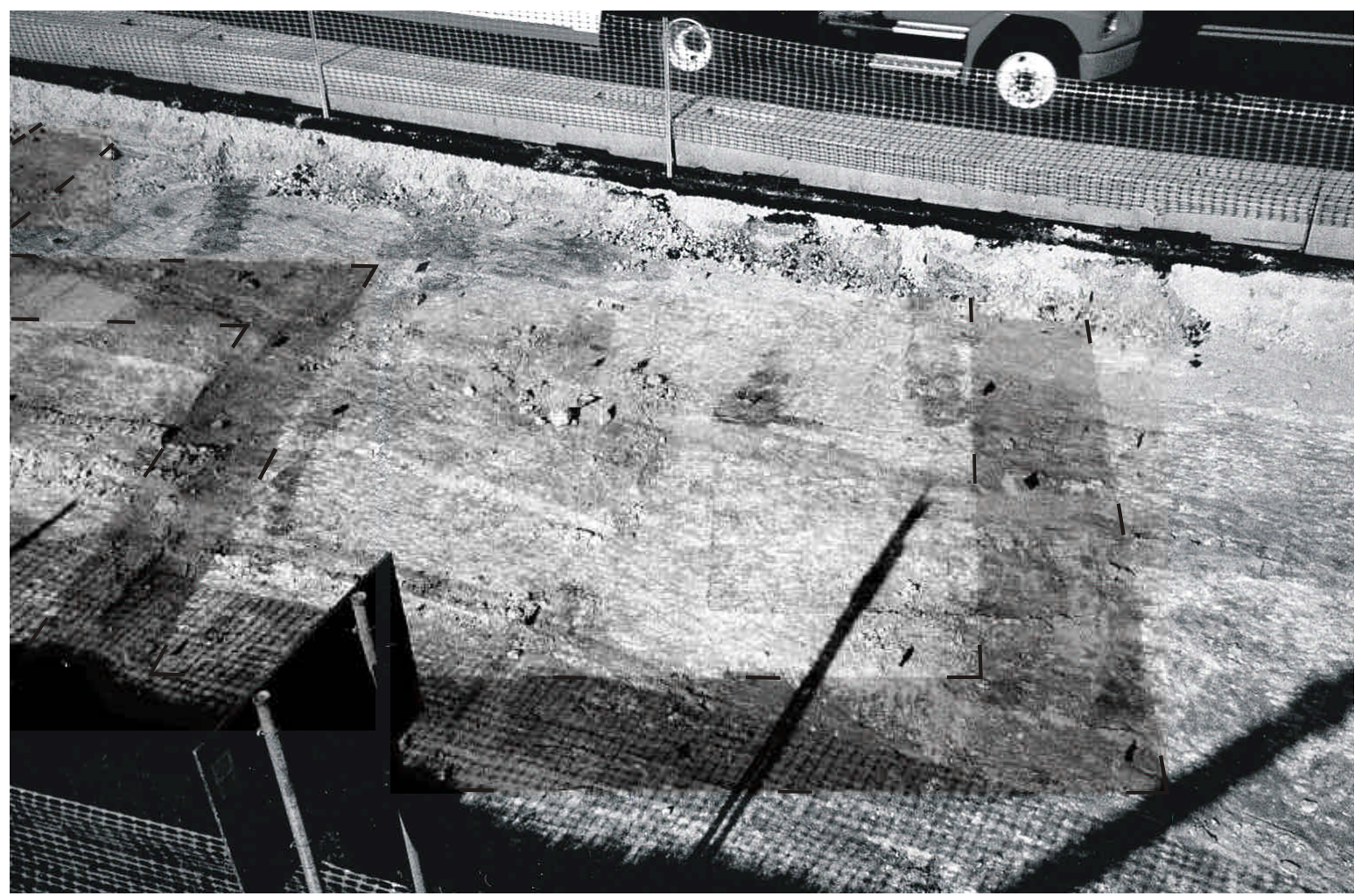

Figure 8b-7. Foundation trench of apse and south transept of Mission Refugio.

Looking west.

One hand-excavated trench across the south transept foundation trench, one $1.5-\mathrm{x}-1.5 \mathrm{~m}$ unit in the northeast corner of the apse wall trench, and seven shovel tests were excavated to investigate the contents and construction of the foundation trench. The trench was $1.17-\mathrm{m}$ wide at the surface and extended $70 \mathrm{~m}$ below the graded surface where it flared to a width of $1.30 \mathrm{~m}$. Several foundation stones were found in the N/E corner unit. These were $10-30 \mathrm{~cm}$ pieces of un-mortared, uncut limestone. The majority of the foundation stones had been removed and the trench filled with gray-brown sandy clay containing fist-sized limestone rocks, small pieces of charcoal, and animal bone.

The interior width of the apse measured $6.2 \mathrm{~m}$. The interior portion of the south wall of the apse was $5.3 \mathrm{~m}$ in length. The east wall of the south transept was $3.9 \mathrm{~m}$ from interior corner to interior corner and the remaining portion of the south wall of this transept was $3 \mathrm{~m}$ long. In retrospect, it became apparent that the debris-filled areas mistakenly identified as Feature 4 and Burial Feature 1, during the initial Gradall investigations in the southbound lanes of the street, as well as Burial Feature 22, which is discussed in the following section, were continuations of the foundation trench of the church.
Inside the outlines of the church, several non-burial features were identified (see Figure 8b-6). Features 30 and 31 were located just inside the wall trench of the south transept (Figure 8b-8). Feature 30 was linear in shape and measured $140 \mathrm{~cm}$ long, $26 \mathrm{~cm}$ wide and $15 \mathrm{~cm}$ deep. This linear feature had been dug into sterile soil $5 \mathrm{~cm}$ away from the edge of the trench. Feature 31 was located $30 \mathrm{~cm}$ east of Feature 30 in the southeast corner of the transept. Feature 31 was roughly circular in shape and had also been excavated into sterile soil $5 \mathrm{~cm}$ from the wall trench. It measured $58 \mathrm{~cm}$ in diameter and was $25 \mathrm{~cm}$ deep.

Features 32 and 35 were linear features that ran parallel with the north and south walls of the church apse. Feature 32 , to the north, was $210 \mathrm{~cm}$ long, $43 \mathrm{~cm}$ wide and $30 \mathrm{~cm}$ deep. This feature was slightly belled at the east end and was separated from the trench wall by $10 \mathrm{~cm}$ (Figure 8b-9). Feature 35 paralleled the south wall of the apse, 1 meter west of the southeast interior corner. It was $220 \mathrm{~cm}$ long, 30 $\mathrm{cm}$ wide and 5-15 cm deep. Like Feature 32, this linear feature was $10 \mathrm{~cm}$ inside the wall trench and belled to a width of $50 \mathrm{~cm}$ at the west end. 


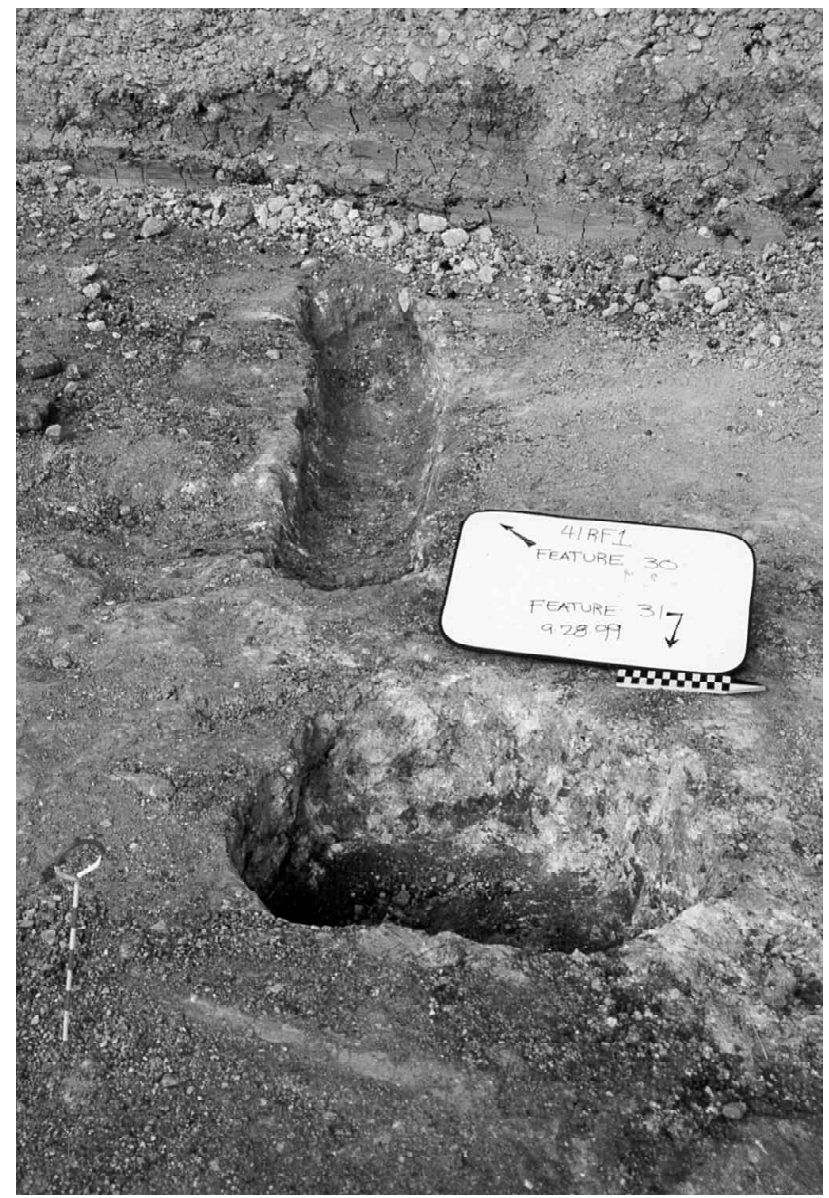

Figure 8b-8. Features 30 and 31 inside south transept of the church.

Looking west.

Features 33 and 34 were circular features identified just inside the east wall of the apse. Feature 33 was roughly measured $50 \mathrm{~cm} \mathrm{E} / \mathrm{W}$ by $58 \mathrm{~cm} \mathrm{~N} / \mathrm{S}$ and was $35 \mathrm{~cm}$ deep. The center of this feature was $3.1 \mathrm{~m}$ from the interior NE corner of the church and 2.5 from the SE corner, almost directly on the center of the apse. Feature 34 was situated in the corner between the north and east walls of the apse. This feature measured $75 \mathrm{~cm}$ E/W by $80 \mathrm{~cm} \mathrm{~N} / \mathrm{S}$ and was $18 \mathrm{~cm}$ deep. Several large pieces of limestone were found at the western edge of Feature 34, suggesting it may at one time have been a small stone foundation that was stone robbed, possibly at the same time the foundation stones were removed from the wall trench (Figure 8b-10).

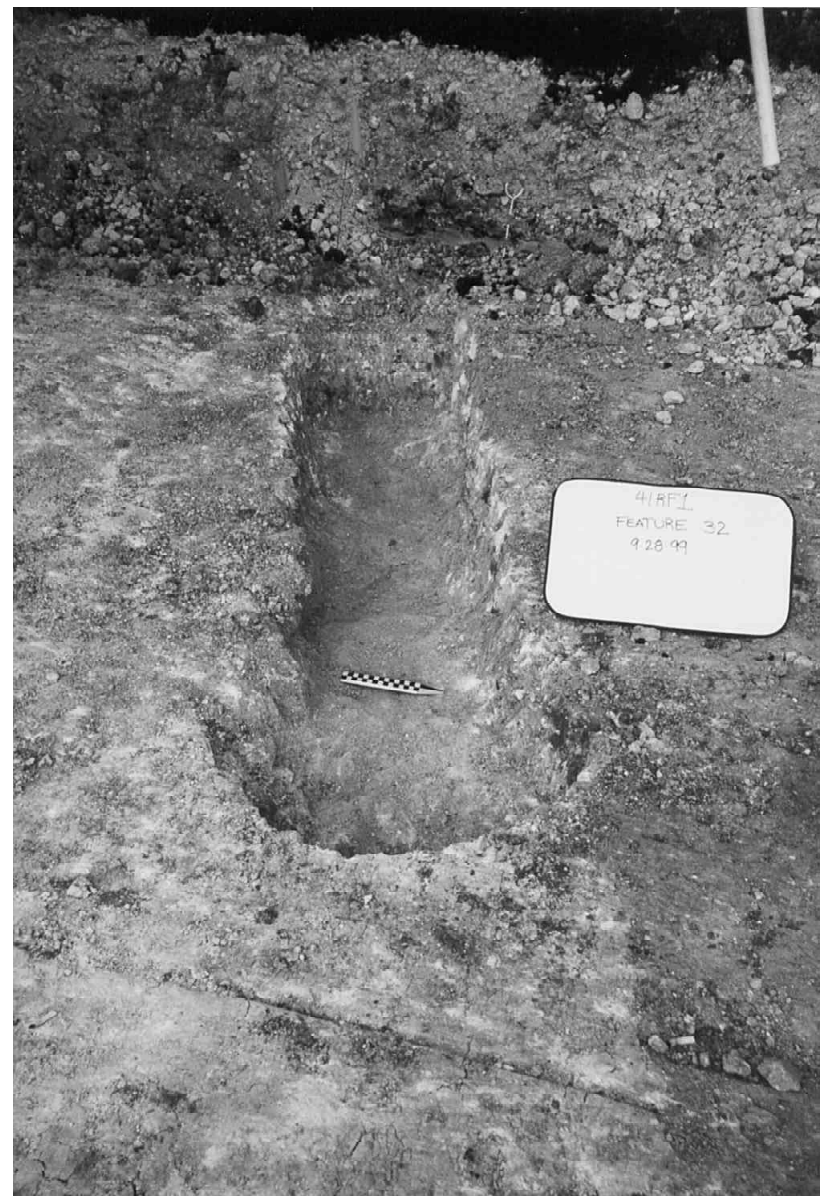

Figure 8b-9. Feature 32 inside north wall of church apse. Looking west.

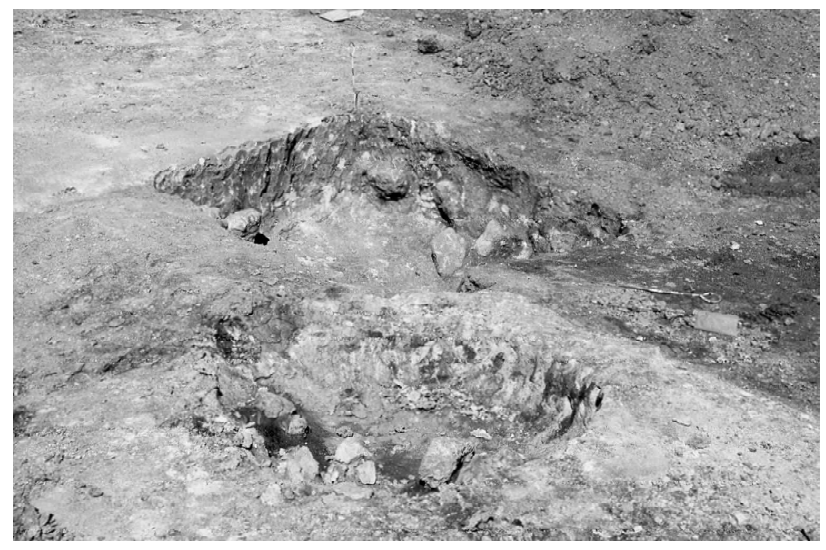

Figure 8b-10. Feature 34 in foreground showing its relationship to north and east walls of the church apse.

Note: stone visible in Feature 34 and the unit excavated in the NE corner of the wall foundation trench. 


\section{Conjectures on the Configuration of Mission Refugio}

Although, or perhaps because, Mission Refugio was the last Spanish mission established in Texas, no evidence of main buildings or support structures of Mission Nuestra Señora del Refugio remain above ground today. Some of the early missions in east Texas like Los Ais, Xavier de Horcasitas, and Los Adaes, and doubtless untold others across the American southwest have shared a similar fate. Fortunately though, some missions from this period of history have survived to varying degrees or have been reconstructed and can provide examples of the spatial organization of Spanish mission compounds.

In their studies of the architecture of the missions along the frontier of New Spain, Baird (1962), Ivey (1991), Kubler (1940), Montgomery et al. (1949), and Trieb (1993) remind us that the priests who came to the new world to convert its peoples brought with themselves a standardized idea of how a mission should look, and how it should be organized. Many of the similarities in style, function, and furnishings noted in these studies are the result of regulations established by the Catholic Church (Montgomery et al. (1949:173). The mission compounds consisted of a church, convento, granary, storeroom, workshops, and housing attached to the church for soldiers and Native Americans. Construction materials varied, depending upon available resources, from wood or adobe bricks to sandstone and limestone.

Churches varied in size depending on the size of the expected congregation, but all contained similar architectural elements. They consisted of: the nave or central, longitudinal space which accommodated the congregation; the baptistery, usually a small room located near the main entrance of the church; the choir loft, situated just inside the main entrance; the apse or sanctuary, a distinct protuberance located opposite the main entrance which contained the altar; and the sacristy or vesting room which was usually adjacent to the sanctuary. Churches were traditionally oriented with the apse to the east, although this positioning varied. (Baird 1962; Kubler 1940; Montgomery et al. 1949). Some churches were also built with transepts, or extensions of the church which served to separate the apse from the nave, and gave the church its cruciform appearance (Ivey 1991). Kubler (1940:58) says that transepts with domed ceilings became the characteristic form of seventeenth- and eighteenth-century parish churches in Mexico.
The walls of the church were plastered inside and out, most often with a paste made of baked gypsum and wheat flour mixed with water. The floors were compacted earth which was swept weekly and resurfaced with new mud and straw annually (Trieb 1993:31-37). No chairs or pews were allowed in the nave.

\section{"The faithful either stood or knelt" (Montgomery et al. 1949:177).}

Furnishings within the apse generally included a communion rail which separated the sanctuary from the nave, a main altar, and a reredos or retablo, a screen behind the altar with carved niches that held religious statues. Collateral, smaller altars and reredos were often positioned against the side walls of the sanctuary and at the ends of the transepts (Kubler 1940; Montgomery et al. 1949; Trieb 1993).

The convento, or priest quarters, was either attached directly to one of the long sides of the church or connected to it by a narrow corridor. Trieb (1993:47) describes the convento as:

"a block of low buildings that acted as a visual anchor for the larger volume of the church."

These complexes included living quarters and offices, with workroom and storerooms attached to form the inner patio of the compound. A second courtyard was sometimes located adjacent to the convento. This area contained the animal corrals and pens, workshops, and additional storerooms (Ivey 1991:44; Trieb 1993:47).

Physical descriptions of the structures at Mission Refugio, summarized in Table 8b-1, appear in three of the mission inventories discussed by McDonald in Appendix A. The first inventory, conducted in 1796 shortly after the mission was moved to this location, indicates the corner stones and foundation for the permanent church had been laid, but the construction of the church was not complete. The dimensions given for the church are "thirty varas in length and eight and one-half varas in width", including the planned tower, baptistry and transepts (Appendix A). These dimensions translate to $25.5 \mathrm{~m}$ long and $7.2 \mathrm{~m}$ wide. Three stone and lime structures with bricked floors and plastered walls served as the temporary church and sacristy. There was a $14.8-\mathrm{x}$ $5.5 \mathrm{~m}$ adobe structure for the priests and 11 wooden jacals for other mission inhabitants and equipment. All of these structures were enclosed by a wooden stockade. 
The construction of the church was completed prior to the inventory taken in 1802 that describes the church as being built of oak on a stone foundation. The dimensions of the church vary slightly from those given previously (Table $8 \mathrm{~b}-1)$, but it appears that this is the same structure. With the completion of the church, the three stone structures form the convento. The larger one is listed as a hospicio or guesthouse. The next serves as the minister's residence and library and the third (the square structure) is evidently a bedroom. Thirteen jacal-like buildings served as offices, quarters, storerooms, kitchen, carpentry shop and granary. The plaza is enclosed by a double stockade made of oak with the main gate on the west side (see Chapter 3 )

In 1804 there is mention of plans to construct a new stone church building, although no reason is given. Apparently this new structure was built, because the church described in the 1817 inventory (see 1820 Inventory, Appendix A) is of different dimensions (Table 8b-1). Here the church is described as being $21-\mathrm{x}-8$ varas in size (17.8-x-6.77 m). It is made of stone and lime and has a vaulted wood roof with a small wooden tower and a choir loft. Doors from the church led to the sacristy, but aside from remarks about a portion of the roof being missing, no details are given for the sacristy. Two stone buildings, one 5-x-5 varas square and one 12.5 varas long are described as containing the four rooms which make up the two-story convent. Nine small auxiliary structures surrounded the interior patio of the compound and the entire complex was enclosed by a protective barrier of 13 jacal-like structures built into an encircling wooden stockade (see Chapter 3).

Based on these descriptions, it appears that the wall trench discovered during these investigations belonged to the first church constructed at Mission Refugio between 1796 and 1802. The width of the foundation trench, based on the interior measurement of the apse, was $6.2 \mathrm{~m}$, which compares favorably to the historically documented width of $5.9 \mathrm{~m}$ for the 1802 church. The features found inside the apse and transepts could well be remnants of foundations built to support the church's main and collateral altars and their respective reredos.

When the documented length of this structure, $25.5 \mathrm{~m}$, is superimposed on the portion of the extant wall trench, the mission church is seen to extend to a point just beneath the southeast corner of the modern Our Lady of Refuge Catholic Church (Figure 8b-11). When plotted on this map, the stone rooms documented by Oberste (1942:367) and Warren (see Chapter 6) align with the position of the church. The size of these stone rooms corresponds with descriptions of mission buildings from the various inventories. The structure which served as the 1796 sacristy or vestry and as a bedroom in 1802 was 5.5 varas square, which matches the $4.65 \mathrm{~m}^{2}$ Room B. The two buildings that served as the temporary church in 1796 and as the hospice and minister's residence in 1802 were $15-x-5$ varas and $12-x-5$ varas respectively. The larger of these matches the $12.71-\mathrm{x}-4.23 \mathrm{~m}$ structure labeled Room A, while the smaller dimensions match the 10.15-x-4.23 m structure labeled Room C, as well as the extrapolated size of a room (Room D) that may extend under the modern church to abut with the south wall of the 1796 church.

It seems unlikely that Rooms $\mathrm{A}$ and $\mathrm{C}$ represent the facilities described as the temporary church since Room B, the vestry, separates these two. An alternative explanation may be that Rooms A, B and the room beneath the modern church (Room D) represent the 1796 temporary church and the 1802 convento. Then, sometime between 1804 and 1817, the original church was destroyed and the stones from its foundation were removed for use in constructing the new church. At this same time, portions of the old convento were dismantled, a second story added to Room B and a new 12$\mathrm{x}-5$ vara structure, Room D, was built to create a new, twostory convento.

Table 8b-1. Descriptions of mission structures from various church inventories

\begin{tabular}{|c|c|c|c|}
\hline & 1796 & 1802 & $1820(1817)$ \\
\hline Church & $\begin{array}{l}30-x-8.5 \mathrm{v} \quad(25-\mathrm{x}-7.2 \mathrm{~m}) \\
\text { foundation and corners only }\end{array}$ & $\begin{array}{l}30-x-7 \mathrm{v}(25.4-x-5.91 \mathrm{~m}) \\
\text { built of oak }\end{array}$ & $\begin{array}{l}21-\mathrm{x}-8 \mathrm{v} \quad(17.8-\mathrm{x}-6.7 \mathrm{~m}) \\
\text { stone with loft for choir }\end{array}$ \\
\hline Structure 1 & $\begin{array}{l}15-\mathrm{x}-5 \mathrm{v} \quad(12.7-\mathrm{x}-4.23 \mathrm{~m}) \\
\text { temporary church ? }\end{array}$ & $\begin{array}{l}15-x-5 \mathrm{v} \quad(12.7-\mathrm{x}-4.23 \mathrm{~m}) \\
\text { hospice }\end{array}$ & $\begin{array}{l}15-\mathrm{x}-5 \mathrm{v} \quad(12.7-\mathrm{x}-4.23 \mathrm{~m}) \\
\text { sacristy? }\end{array}$ \\
\hline Structure 2 & $\begin{array}{l}12-\mathrm{x}-5 \mathrm{v} \quad(10.15-\mathrm{x}-4.23 \mathrm{~m}) \\
\text { temporary church? }\end{array}$ & $\begin{array}{l}12-\mathrm{x}-5 \mathrm{v}(10.15-\mathrm{x}-4.23 \mathrm{~m}) \\
\text { minister's residence / library }\end{array}$ & $\begin{array}{l}\text { 12-x-5 (10.15-x-4.23 m) } \\
\text { two-story living room / } \\
\text { office }\end{array}$ \\
\hline Structure 3 & $\begin{array}{l}5.5-x-5.5 \mathrm{v} \quad(4.65-\mathrm{x}-4.65 \mathrm{~m}) \\
\text { sacristy? }\end{array}$ & $\begin{array}{l}5-\mathrm{x}-5 \mathrm{v} \quad(4.23-\mathrm{x}-4.23 \mathrm{~m}) \\
\text { bedroom }\end{array}$ & $\begin{array}{l}5-\mathrm{x}-5 \mathrm{v} \quad(4.65-\mathrm{x}-4.65 \mathrm{~m}) \\
\text { two-story }\end{array}$ \\
\hline
\end{tabular}




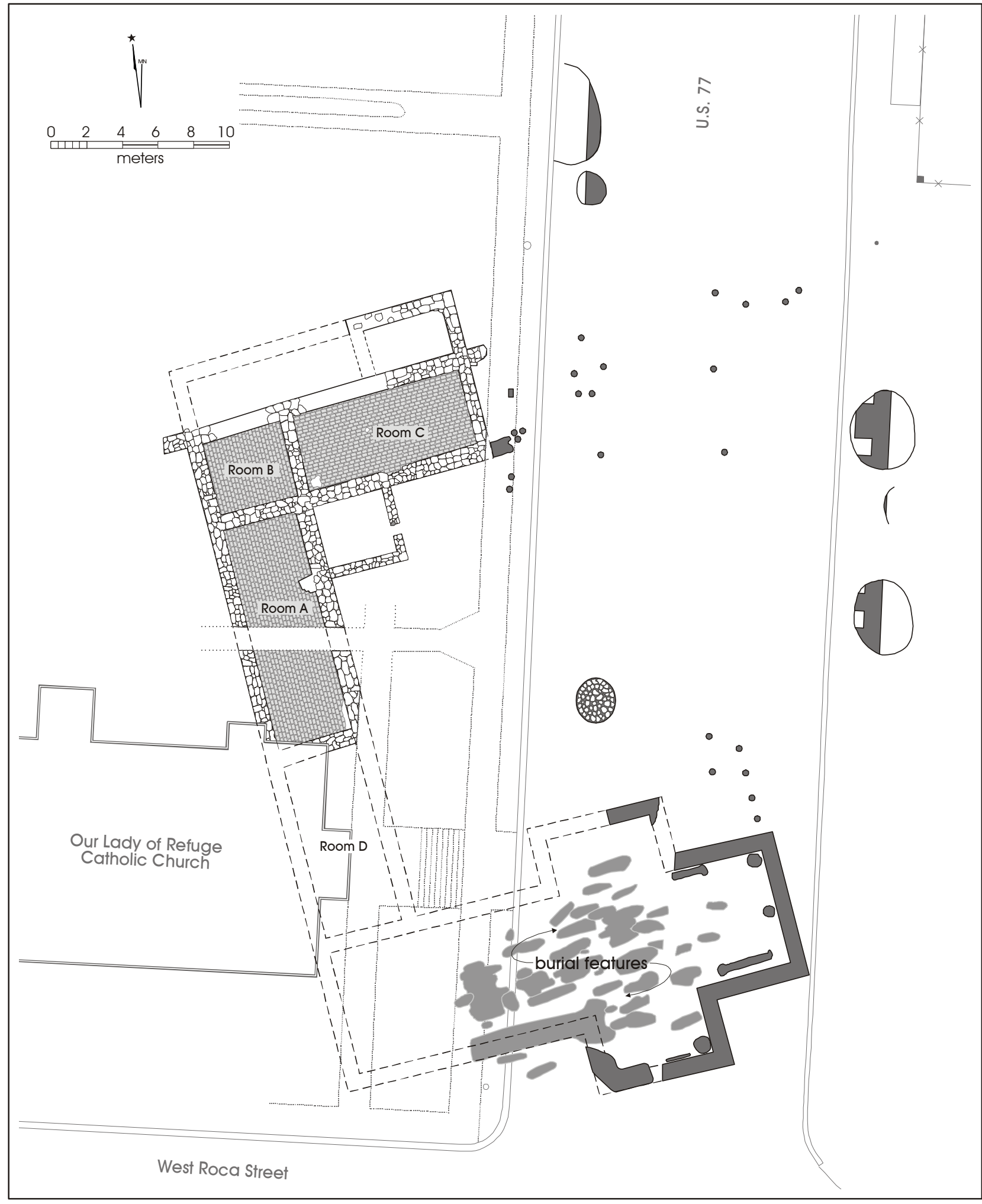

Figure 8b-11. Conceptional layout of Mission Refugio based on excavations by CAR, Warren, and descriptions in church inventories. 



\section{Chapter 8: Findings Section C}

\section{Burial Features}

Thirty-seven burial features (Figure 8c-1) containing the remains of 165 individual burials were excavated during the second season of investigations at 41RF1 (Table 8c-1 and Figure 8c-1). Twelve additional individuals were identified during analysis from individual ossuary elements. The complete osteological analysis and descriptions of the burials recovered during this investigation are presented in Volume II of this report.

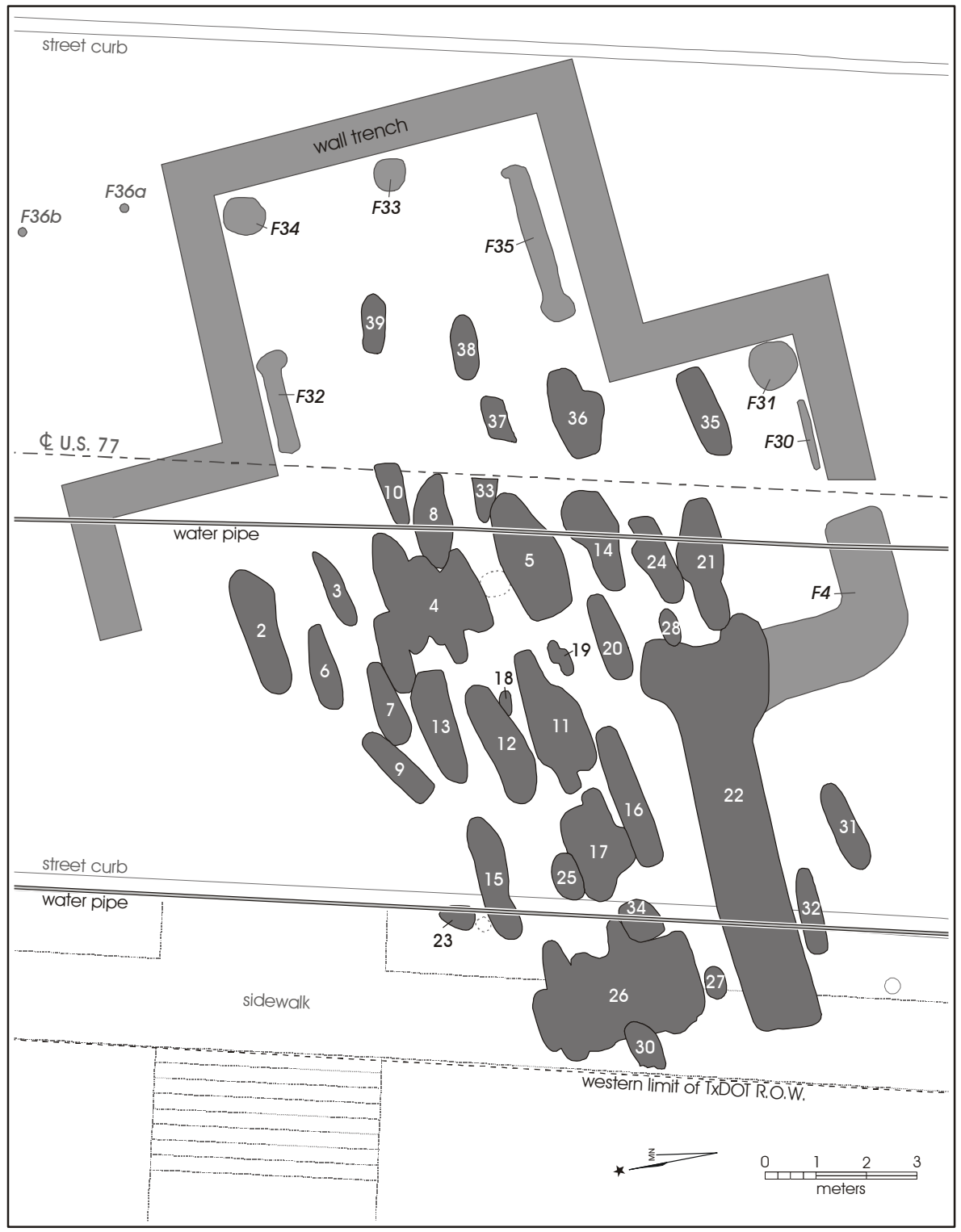

Figure 8c-1. Plan map of burial features within the Church at Mission Refugio. 
Table 8c-1. List of Burials recovered from Mission Refugio

\begin{tabular}{|c|c|c|c|c|c|c|c|c|}
\hline $\begin{array}{c}\text { Burial } \\
\text { Number }\end{array}$ & $\begin{array}{l}\text { Burial } \\
\text { Feature }\end{array}$ & Depth & $\%$ Complete & $\begin{array}{c}\text { Adult/Child } \\
\text { /Infant }\end{array}$ & Description & $\begin{array}{l}\text { In proximity or } \\
\text { commingled with/ }\end{array}$ & Excavator & Date \\
\hline 1 & BF 22 & $64 \mathrm{~cm} \mathrm{BST}$ & $95 \%$ & adult & $\begin{array}{l}1 / 2 \text { primary } \\
11 / 2 \text { disarticulated }\end{array}$ & $\begin{array}{c}* 3,4,5,28,28 \mathrm{a}, 77 \\
82,84,91,97,107 \\
109,112,116,117 \\
117 \mathrm{a}, 121,127,129\end{array}$ & NK/NA & $3 / 7-7 / 16$ \\
\hline 2 & BF 20 & $55 \mathrm{~cm} \mathrm{BST}$ & $90 \%$ & adult & primary/articulated & - & $\mathrm{PMcW} / \mathrm{CB}$ & $3 / 7-7 / 2$ \\
\hline 3 & BF 22 & $30 \mathrm{~cm} \mathrm{BST}$ & $100 \%$ & child & primary/articulated & See Burial 1 & $\mathrm{RJ}$ & $3 / 7$ \\
\hline 4 & BF 22 & $40 \mathrm{~cm} \mathrm{BST}$ & $100 \%$ & infant & primary/articulated & See Burial 1 & $\mathrm{CT}$ & $3 / 7$ \\
\hline 5 & BF 22 & $55 \mathrm{~cm} \mathrm{BST}$ & $50 \%$ & child & primary/disturbed & See Burial 1 & TM/DC & $3 / 7-7 / 21$ \\
\hline 6 & $\mathrm{BF} 2$ & $63 \mathrm{~cm} \mathrm{BST}$ & $90 \%$ & adult & secondary/disarticulated & 15 & DC & $5 / 24$ \\
\hline 7 & BF 3 & $34 \mathrm{~cm} \mathrm{BST}$ & $80 \%$ & young adult & primary/articulated & - & $\mathrm{BM}$ & $5 / 24$ \\
\hline 8 & BF 4 & $42 \mathrm{~cm} \mathrm{BST}$ & $100 \%$ & adult & primary/articulated & $\begin{array}{c}* 12,13,14,16,18 \\
19,21,22,25,25 \mathrm{a} \\
30\end{array}$ & $\mathrm{JF}$ & $5 / 24$ \\
\hline 9 & BF 5 & $44 \mathrm{~cm} \mathrm{BST}$ & $50 \%$ & adult & primary/disarticulated & $\begin{array}{c}* 10,11,17,32,33 \\
34,35,36,39,40 \\
40 \mathrm{a}, 55,66,73\end{array}$ & $\mathrm{JD} / \mathrm{JG}$ & $5 / 24$ \\
\hline 10 & BF 5 & $40 \mathrm{~cm} \mathrm{BST}$ & $100 \%$ & infant & primary/articulated & See Burial 9 & $\mathrm{JD} / \mathrm{DD}$ & $5 / 24$ \\
\hline 11 & BF 5 & $40 \mathrm{~cm} \mathrm{BST}$ & $20 \%$ & infant & secondary/disarticulated & See Burial 9 & $\mathrm{JD} / \mathrm{DO}$ & $5 / 24$ \\
\hline 12 & BF 4 & $63 \mathrm{~cm} \mathrm{BST}$ & $50 \%$ & adult & secondary/disarticulated & See Burial 8 & $\mathrm{CT}$ & $6 / 11$ \\
\hline 13 & $\mathrm{BF} 4$ & $45 \mathrm{~cm} \mathrm{BST}$ & $100 \%$ & adult & primary/articulated & See Burial 8 & $\mathrm{JF}$ & $5 / 24$ \\
\hline 14 & BF 4 & $43 \mathrm{~cm} \mathrm{BST}$ & $25 \%$ & adult & secondary/disarticulated & See Burial 8 & $\mathrm{JF}$ & $5 / 24$ \\
\hline 15 & $\mathrm{BF} 2$ & $61 \mathrm{~cm} \mathrm{BST}$ & $100 \%$ & adult & primary/articulated & See Burial 6 & DC & $5 / 27$ \\
\hline 16 & BF 4 & $53 \mathrm{~cm} \mathrm{BST}$ & $100 \%$ & adult & primary/articulated & See Burial 8 & $\mathrm{CT}$ & $5 / 27$ \\
\hline 17 & BF 5 & $55 \mathrm{~cm} \mathrm{BST}$ & $95 \%$ & adult & primary/disarticulated & See Burial 9 & $\mathrm{BM} / \mathrm{JG}$ & $6 / 2$ \\
\hline 18 & $\mathrm{BF} 4$ & $63 \mathrm{~cm} \mathrm{BST}$ & $75 \%$ & adult & secondary/disarticulated & See Burial 8 & $\mathrm{CT}$ & $6 / 9$ \\
\hline 19 & BF 4 & $58 \mathrm{~cm} \mathrm{BST}$ & $100 \%$ & adult & primary/articulated & See Burial 8 & $\mathrm{BM}$ & $6 / 7$ \\
\hline 20 & $\mathrm{BF} 8$ & $54 \mathrm{~cm} \mathrm{BST}$ & $90 \%$ & adult & primary/articulated & $* 20 \mathrm{a}, 26$ & DC & $6 / 9$ \\
\hline 21 & BF 4 & $57 \mathrm{~cm} \mathrm{BST}$ & $50 \%$ & adult & secondary/disarticulated & See Burial 8 & $\mathrm{CT}$ & $6 / 7$ \\
\hline 22 & BF 4 & $60 \mathrm{~cm} \mathrm{BST}$ & $10 \%$ & infant & secondary/disarticulated & See Burial 8 & CT & $6 / 7$ \\
\hline 23 & BF 23 & $40 \mathrm{~cm} \mathrm{BST}$ & $30 \%$ & adult & disturbed by pipe trench & - & $\mathrm{PMcW} / \mathrm{CB}$ & $7 / 7$ \\
\hline 24 & BF 30 & $34 \mathrm{~cm} \mathrm{BST}$ & $50 \%$ & adult & secondary/disturbed & 102,118 & BS & $7 / 20$ \\
\hline 25 & $\mathrm{BF} 4$ & $58 \mathrm{~cm} \mathrm{BST}$ & $20 \%$ & adult & secondary/disarticulated & See Burial 8 & $\mathrm{BM}$ & $6 / 4$ \\
\hline 26 & $\mathrm{BF} 8$ & $61 \mathrm{~cm} \mathrm{BST}$ & $30 \%$ & adult & secondary/disarticulated & See Burial 20 & DC & $6 / 14$ \\
\hline 28 & BF 22 & & mid-torso & adult & secondary/disarticulated & See Burial 1 & $\mathrm{BM}$ & $7 / 21$ \\
\hline 29 & BF 32 & $67 \mathrm{~cm} \mathrm{BST}$ & $60 \%$ & adult & primary/disturbed & - & $\mathrm{RM}$ & $7 / 4$ \\
\hline 30 & $\mathrm{BF} 4$ & $56 \mathrm{~cm} \mathrm{BST}$ & $100 \%$ & young adult & primary/articulated & See Burial 8 & $\mathrm{CT}$ & $6 / 17$ \\
\hline 31 & BF 6 & $33 \mathrm{~cm} \mathrm{BST}$ & $95 \%$ & adult & primary/articulated & - & $\mathrm{OF} / \mathrm{CB}$ & $6 / 8$ \\
\hline 32 & BF 5 & & & young adult & secondary/disarticulated & See Burial 9 & JG & $6 / 9$ \\
\hline 33 & BF 5 & $84 \mathrm{~cm} \mathrm{BST}$ & & young adult & secondary/disarticulated & See Burial 9 & JG & $6 / 9$ \\
\hline 34 & BF 5 & $66 \mathrm{~cm} \mathrm{BST}$ & & young adult & secondary/disarticulated & See Burial 9 & JG & $6 / 9$ \\
\hline 35 & BF 5 & $48 \mathrm{~cm} \mathrm{BST}$ & $20 \%$ & infant & secondary/disarticulated & See Burial 9 & JG & $6 / 15$ \\
\hline 36 & BF 5 & $54 \mathrm{~cm} \mathrm{BST}$ & $30 \%$ & adult & secondary/disturbed & See Burial 9 & JG & $6 / 15$ \\
\hline 37 & BF 24 & $63 \mathrm{~cm} \mathrm{BST}$ & & adult & secondary/disarticulated & $* 68,80,85,85 \mathrm{a}$ & DC & $7 / 13$ \\
\hline 38 & BF 7 & $62 \mathrm{~cm} \mathrm{BST}$ & $100 \%$ & adult & primary/articulated & - & $\mathrm{BM}$ & $6 / 15$ \\
\hline
\end{tabular}


Table 8c-1. Continued...

\begin{tabular}{|c|c|c|c|c|c|c|c|c|}
\hline $\begin{array}{l}\text { Burial } \\
\text { Number }\end{array}$ & $\begin{array}{l}\text { Burial } \\
\text { Feature }\end{array}$ & Depth & $\%$ Complete & $\begin{array}{l}\text { Adult/Child } \\
\text { /Infant }\end{array}$ & Description & $\begin{array}{l}\text { In proximity or } \\
\text { commingled with/ }\end{array}$ & Excavator & Date \\
\hline 39 & BF 5 & $57 \mathrm{~cm} \mathrm{BST}$ & $95 \%$ & adult & primary/articulated & See Burial 9 & JG & $6 / 14$ \\
\hline 40 & BF 5 & $63 \mathrm{~cm}$ BST & & adult & secondary/disarticulated & See Burial 9 & JG & $6 / 15$ \\
\hline 41 & BF 9 & & & infant & deciduous teeth only & 42 & OF & $6 / 15$ \\
\hline 42 & $\mathrm{BF} 9$ & $77 \mathrm{~cm} \mathrm{BST}$ & $100 \%$ & adult & primary/articulated & 41 & $\mathrm{OF}$ & $6 / 15$ \\
\hline 43 & BF 10 & $68 \mathrm{~cm} \mathrm{BST}$ & $50 \%$ & adult & primary/articulated & - & DC & $6 / 17$ \\
\hline 44 & $\mathrm{BF} 11$ & $50 \mathrm{~cm} \mathrm{BST}$ & $100 \%$ & adult & primary/articulated & $* 44 \mathrm{a}, 45,54,58,59$ & $\mathrm{DC} / \mathrm{TG}$ & $6 / 18$ \\
\hline 45 & BF 11 & $52 \mathrm{~cm} \mathrm{BST}$ & $80 \%$ & adult & primary/articulated & See Burial 44 & $\mathrm{CH}$ & $6 / 18$ \\
\hline 46 & BF 12 & $53 \mathrm{~cm} \mathrm{BST}$ & $55 \%$ & adult & 1/2articulated/1/2disturbed & $* 50,50 \mathrm{a}$ & $\mathrm{DC} / \mathrm{CT}$ & $6 / 18$ \\
\hline 47 & BF 13 & $52 \mathrm{~cm} \mathrm{BST}$ & $50 \%$ & adult & $1 / 2$ articulated $/ 1 / 2$ disturbed & 53,57 & $\mathrm{BM}$ & $6 / 22$ \\
\hline 48 & BF 15 & $45 \mathrm{~cm} \mathrm{BST}$ & $80 \%$ & adult & $1 / 2$ articulated $/ 1 / 2$ disturbed & $* 48 \mathrm{a}, 48 \mathrm{~b}, 52,81$ & $\mathrm{OF}$ & $6 / 22$ \\
\hline 49 & BF 14 & $30 \mathrm{~cm} \mathrm{BST}$ & $20 \%$ & child & secondary/disarticulated & $* 51,56,56 a, 63,63 a$ & $\mathrm{PMcW}$ & $6 / 22$ \\
\hline 50 & BF 12 & $60 \mathrm{~cm} \mathrm{BST}$ & $100 \%$ & adult & primary/articulated & See Burial 46 & $\mathrm{DC} / \mathrm{CT}$ & $6 / 22$ \\
\hline 51 & BF 14 & $50 \mathrm{~cm} \mathrm{BST}$ & $50 \%$ & young adult & primary/articulated & See Burial 49 & $\mathrm{PMcW}$ & $6 / 22$ \\
\hline 52 & BF 15 & $58 \mathrm{~cm} \mathrm{BST}$ & $90 \%$ & adult & primary/articulated & See Burial 48 & $\mathrm{OF} / \mathrm{CB}$ & $6 / 22$ \\
\hline 53 & BF 13 & $66 \mathrm{~cm} \mathrm{BST}$ & $100 \%$ & adult & primary/articulated & See Burial 47 & $\mathrm{BM}$ & $6 / 22$ \\
\hline 54 & BF 11 & $59 \mathrm{~cm} \mathrm{BST}$ & $95 \%$ & adult & secondary/disarticulated & See Burial 44 & $\mathrm{CH} / \mathrm{TM}$ & $6 / 21$ \\
\hline 55 & $\mathrm{BF} 5$ & $57 \mathrm{~cm} \mathrm{BST}$ & $30 \%$ & infant & secondary/disarticulated & See Burial 9 & JG/NA & $6 / 21$ \\
\hline 56 & BF 14 & $43 \mathrm{~cm} \mathrm{BST}$ & & adult & secondary/disarticulated & See Burial 49 & $\mathrm{PMcW}$ & $6 / 24$ \\
\hline 57 & BF 13 & $60 \mathrm{~cm} \mathrm{BST}$ & $50 \%$ & adult & secondary/disarticulated & See Burial 47 & BM & $6 / 24$ \\
\hline 58 & BF 11 & $57 \mathrm{~cm} \mathrm{BST}$ & & adult & secondary/disarticulated & See Burial 44 & $\mathrm{DC} / \mathrm{CH}$ & $6 / 28$ \\
\hline 59 & BF 11 & $73 \mathrm{~cm} \mathrm{BST}$ & $80 \%$ & infant & secondary/disarticulated & See Burial 44 & $\mathrm{DC} / \mathrm{CH}$ & $6 / 28$ \\
\hline 60 & BF 16 & $45 \mathrm{~cm} \mathrm{BST}$ & & adult & secondary/burned & $\begin{array}{c}* \text { Cre } 1, \text { Cre2, Cre3, } \\
\text { Cre4, Cre5, 60a, } \\
60 \mathrm{~b}, 60 \mathrm{c}, 67,72,83 \\
83 \mathrm{a}, 83 \mathrm{~b}, 93\end{array}$ & $\mathrm{CT} / \mathrm{TG}$ & $6 / 30$ \\
\hline 61 & BF 18 & $47 \mathrm{~cm} \mathrm{BST}$ & $50 \%$ & infant & primary/disturbed & - & DC & $6 / 30$ \\
\hline 62 & BF 17 & $52 \mathrm{~cm} \mathrm{BST}$ & $90 \%$ & adult & primary/disturbed & $\begin{array}{c}70,71,74,78,79 \\
86,87,90,94 \\
\end{array}$ & $\mathrm{BS} / \mathrm{BG}$ & $6 / 30$ \\
\hline 63 & BF 14 & $45 \mathrm{~cm} \mathrm{BST}$ & & adult & secondary/disarticulated & See Burial 49 & $\mathrm{PMcW} / \mathrm{BM}$ & $7 / 1$ \\
\hline 64 & BF 19 & $62 \mathrm{~cm} \mathrm{BST}$ & $20 \%$ & infant & secondary/disarticulated & 65 & DC & $7 / 2$ \\
\hline 65 & BF 19 & $60 \mathrm{~cm} \mathrm{BST}$ & $100 \%$ & infant & primary/articulated & 64 & DC & $7 / 2$ \\
\hline 66 & BF 5 & $63 \mathrm{~cm} \mathrm{BST}$ & & adult & secondary/disarticulated & See Burial 9 & JG/NA & $7 / 2$ \\
\hline 67 & BF 16 & $49 \mathrm{~cm} \mathrm{BST}$ & & adult & secondary/burned & See Burial 60 & $\mathrm{CT} / \mathrm{TG}$ & $7 / 2$ \\
\hline 68 & BF 24 & $60 \mathrm{~cm} \mathrm{BST}$ & $100 \%$ & adult & primary/articulated & See Burial 37 & DC & $7 / 5$ \\
\hline 69 & BF 21 & $60 \mathrm{~cm} \mathrm{BST}$ & $100 \%$ & adult & primary/articulated & 75,76 & $\mathrm{BM}$ & $7 / 5$ \\
\hline 70 & BF 17 & $52 \mathrm{~cm} \mathrm{BST}$ & $20 \%$ & infant & primary/disturbed & See Burial 62 & $\mathrm{BS} / \mathrm{BG}$ & $7 / 5$ \\
\hline 71 & BF 17 & $55 \mathrm{~cm} \mathrm{BST}$ & $10 \%$ & infant & secondary/disarticulated & See Burial 62 & $\mathrm{BS} / \mathrm{BG}$ & $7 / 5$ \\
\hline 72 & BF 16 & $52 \mathrm{~cm} \mathrm{BST}$ & & yound adult & secondary/burned & See Burial 60 & $\mathrm{CT} / \mathrm{TG}$ & $7 / 2$ \\
\hline 73 & BF 5 & & & child & secondary/disarticulated & See Burial 9 & JG/NA & $7 / 5$ \\
\hline 74 & BF 17 & $50 \mathrm{~cm} \mathrm{BST}$ & $20 \%$ & adult & secondary/disarticulated & See Burial 62 & $\mathrm{BS} / \mathrm{BG}$ & $7 / 5$ \\
\hline 75 & BF 21 & $62 \mathrm{~cm} \mathrm{BST}$ & $90 \%$ & adult & secondary/disarticulated & See Burial 69 & $\mathrm{BM}$ & $7 / 5$ \\
\hline 76 & BF 21 & $62 \mathrm{~cm}$ BST & $100 \%$ & adult & secondary/disarticulated & See Burial 69 & $\mathrm{BM}$ & $7 / 5$ \\
\hline 77 & BF 22 & $51 \mathrm{~cm} \mathrm{BST}$ & $70 \%$ & adult & primary/disturbed & See Burial 1 & JG & $7 / 7$ \\
\hline 78 & BF 17 & $59 \mathrm{~cm} \mathrm{BST}$ & $40 \%$ & adult & secondary/disarticulated & See Burial 62 & $\mathrm{BG} / \mathrm{OF}$ & $7 / 7$ \\
\hline 79 & BF 17 & $60 \mathrm{~cm} \mathrm{BST}$ & $100 \%$ & infant & primary/articulated & See Burial 62 & BG & $7 / 7$ \\
\hline
\end{tabular}


Table 8c-1. Continued...

\begin{tabular}{|c|c|c|c|c|c|c|c|c|}
\hline $\begin{array}{c}\text { Burial } \\
\text { Number }\end{array}$ & $\begin{array}{l}\text { Burial } \\
\text { Feature }\end{array}$ & Depth & $\%$ Complete & $\begin{array}{l}\text { Adult/Child } \\
\text { /Infant }\end{array}$ & Description & $\begin{array}{l}\text { In proximity or } \\
\text { commingled with/ }\end{array}$ & Excavator & Date \\
\hline 80 & BF 24 & $62 \mathrm{~cm}$ BST & & adult & secondary/disarticulated & See Burial 37 & DC & $7 / 7$ \\
\hline 81 & BF 15 & $60 \mathrm{~cm} \mathrm{BST}$ & $10 \%$ & adult & disturbed by modern post & See Burial 48 & $\mathrm{PMcW} / \mathrm{CB}$ & $7 / 8$ \\
\hline 82 & BF 22 & $77 \mathrm{~cm} \mathrm{BST}$ & $95 \%$ & adult & secondary/disarticulated & See Burial 1 & $\mathrm{CT}$ & $7 / 8$ \\
\hline 83 & BF 16 & $44 \mathrm{~cm}$ BST & $70 \%$ & adult & primary/articulated & See Burial 60 & $\mathrm{CT}$ & $7 / 8$ \\
\hline 84 & BF 22 & $66 \mathrm{~cm} \mathrm{BST}$ & $30 \%$ & infant & primary/disturbed & See Burial 1 & NA & $7 / 8$ \\
\hline 85 & BF 24 & $63 \mathrm{~cm} \mathrm{BST}$ & & adult & secondary/disarticulated & See Burial 37 & DC & $7 / 9$ \\
\hline 86 & BF 17 & $63 \mathrm{~cm} \mathrm{BST}$ & $100 \%$ & adult & primary/articulated & See Burial 62 & $\mathrm{OF}$ & $7 / 9$ \\
\hline 87 & BF 17 & $68 \mathrm{~cm}$ BST & $90 \%$ & adult & secondary/disarticulated & See Burial 62 & $\mathrm{OF}$ & $7 / 9$ \\
\hline 88 & BF 25 & $50 \mathrm{~cm} \mathrm{BST}$ & $95 \%$ & child & primary/articulated & 89 & BG & $7 / 9$ \\
\hline 89 & BF 25 & $50 \mathrm{~cm} \mathrm{BST}$ & $15 \%$ & adult & secondary/disarticulated & 88 & BG & $7 / 9$ \\
\hline 90 & BF 17 & $67 \mathrm{~cm} \mathrm{BST}$ & $80 \%$ & adult & secondary/disarticulated & See Burial 62 & $\mathrm{OF}$ & $7 / 13$ \\
\hline 91 & BF 22 & $56 \mathrm{~cm}$ BST & $100 \%$ & adult & primary/articulated & See Burial 1 & $\mathrm{BM}$ & $7 / 14$ \\
\hline 92 & BF 26 & $58 \mathrm{~cm} \mathrm{BST}$ & $50 \%$ & adult & primary/disturbed & $\begin{array}{c}* 95,100,100 \mathrm{a}, 101, \\
103,104,111,113, \\
114,119,119 \mathrm{a}, 120, \\
122,123,125,126, \\
128,130,130 \mathrm{a}, 131\end{array}$ & $\mathrm{PMcW}$ & $5 / 15$ \\
\hline 93 & BF 16 & $42 \mathrm{~cm}$ BST & $100 \%$ & adult & primary/articulated & See Burial 60 & CT & $7 / 15$ \\
\hline 94 & BF 17 & & $10 \%$ & infant & secondary/disarticulated & See Burial 62 & $\mathrm{OF}$ & $7 / 15$ \\
\hline 95 & BF 26 & $48 \mathrm{~cm}$ BST & $80 \%$ & adult & primary/disturbed & See Burial 92 & $\mathrm{CB} / \mathrm{OF}$ & $7 / 15$ \\
\hline 96 & BF 28 & $40 \mathrm{~cm}$ BST & $90 \%$ & infant & primary/articulated & 99 & DC & $7 / 16$ \\
\hline 97 & BF 22 & $81 \mathrm{~cm} \mathrm{BST}$ & $100 \%$ & adult & primary/articulated & See Burial 1 & NA & $7 / 19$ \\
\hline 98 & BF 27 & $55 \mathrm{~cm}$ BST & $75 \%$ & infant & primary/articulated & - & BG & $7 / 20$ \\
\hline 99 & BF 28 & $54 \mathrm{~cm} \mathrm{BST}$ & $70 \%$ & infant & primary/articulated & 96 & DC & $7 / 20$ \\
\hline 100 & BF 26 & $47 \mathrm{~cm} \mathrm{BST}$ & $75 \%$ & adult & primary/articulated & See Burial 92 & $\mathrm{PMcW}$ & $7 / 22$ \\
\hline 101 & BF 26 & $50 \mathrm{~cm}$ BST & $50 \%$ & adult & secondary/disarticulated & See Burial 92 & OF & $7 / 22$ \\
\hline 102 & BF 30 & $37 \mathrm{~cm}$ BST & $50 \%$ & adult & $1 / 2$ primary $/ 1 / 2$ disarticulated & See Burial 24 & BS & $7 / 23$ \\
\hline 103 & BF 26 & $59 \mathrm{~cm}$ BST & $90 \%$ & infant & secondary/disarticulated & See Burial 92 & OF & $7 / 23$ \\
\hline 104 & BF 26 & $57 \mathrm{~cm} \mathrm{BST}$ & $15 \%$ & young adult & secondary/disarticulated & See Burial 92 & DC & $7 / 23$ \\
\hline 105 & BF 31 & $67 \mathrm{~cm}$ BST & $100 \%$ & adult & primary/articulated & 110 & JG & $7 / 23$ \\
\hline 106 & BF 34 & $62 \mathrm{~cm}$ BST & $40 \%$ & adult & disarticulated/disturbed & $\begin{array}{c}* 106 \mathrm{a}, 106 \mathrm{~b}, 108, \\
108 \mathrm{a}\end{array}$ & $\mathrm{OF}$ & $7 / 23$ \\
\hline 107 & BF 22 & $60 \mathrm{~cm}$ BST & $100 \%$ & adult & primary/articulated & See Burial 1 & $\mathrm{BM}$ & $7 / 23$ \\
\hline 108 & BF 34 & $69 \mathrm{~cm}$ BST & $35 \%$ & young adult & disarticulated/disturbed & See Burial 106 & OF & $7 / 26$ \\
\hline 109 & BF 22 & $58 \mathrm{~cm} \mathrm{BST}$ & $50 \%$ & adult & secondary/disarticulated & See Burial 1 & $\mathrm{BM}$ & $7 / 26$ \\
\hline 110 & BF 31 & $47 \mathrm{~cm} \mathrm{BST}$ & $20 \%$ & adult & primary/disturbed & 105 & $\mathrm{OF}$ & $7 / 27$ \\
\hline 111 & BF 26 & $65 \mathrm{~cm}$ BST & $100 \%$ & adult & primary/articulated & See Burial 92 & $\mathrm{CT}$ & $7 / 27$ \\
\hline 112 & BF 22 & $65 \mathrm{~cm}$ BST & $100 \%$ & adult & primary/articulated & See Burial 1 & $\mathrm{OF} / \mathrm{CT}$ & $7 / 28$ \\
\hline 113 & BF 26 & $63 \mathrm{~cm} \mathrm{BST}$ & $60 \%$ & adult & secondary/disarticulated & See Burial 92 & OF & $7 / 28$ \\
\hline 114 & BF 26 & $63 \mathrm{~cm} \mathrm{BST}$ & $60 \%$ & child & secondary/disarticulated & See Burial 92 & $\mathrm{OF}$ & $7 / 28$ \\
\hline 115 & BF 33 & $31 \mathrm{~cm} \mathrm{BST}$ & $10 \%$ & adult & femur \& tibia only & - & BS & $7 / 29$ \\
\hline 116 & BF 22 & $72 \mathrm{~cm}$ BST & $50 \%$ & adult & primary/disturbed & See Burial 1 & $\mathrm{BM}$ & $7 / 29$ \\
\hline 117 & BF 22 & $80 \mathrm{~cm}$ BST & $90 \%$ & adult & primary/articulated & See Burial 1 & $\mathrm{RM}$ & $7 / 29$ \\
\hline 118 & BF 30 & $37 \mathrm{~cm} \mathrm{BST}$ & $20 \%$ & adult & secondary/disarticulated & See Burial 24 & $\mathrm{CT}$ & $7 / 29$ \\
\hline 119 & BF 26 & $63 \mathrm{~cm} \mathrm{BST}$ & $100 \%$ & adult & primary/articulated & See Burial 92 & OF & $7 / 30$ \\
\hline
\end{tabular}


Table 8c-1. Continued...

\begin{tabular}{|c|c|c|c|c|c|c|c|c|}
\hline $\begin{array}{c}\text { Burial } \\
\text { Number }\end{array}$ & $\begin{array}{l}\text { Burial } \\
\text { Feature }\end{array}$ & Depth & $\%$ Complete & $\begin{array}{c}\text { Adult/Child } \\
\text { /Infant }\end{array}$ & Description & $\begin{array}{l}\text { In proximity or } \\
\text { commingled with/ }\end{array}$ & Excavator & Date \\
\hline 120 & BF 26 & $73 \mathrm{~cm} \mathrm{BST}$ & $75 \%$ & adult & secondary/disarticulated & See Burial 92 & $\mathrm{KH} / \mathrm{CB}$ & $8 / 2$ \\
\hline 121 & BF 22 & $65 \mathrm{~cm} \mathrm{BST}$ & $70 \%$ & infant & primary/disturbed & See Burial 1 & $\mathrm{BM}$ & $8 / 2$ \\
\hline 122 & BF 26 & $73 \mathrm{~cm}$ BST & $20 \%$ & adult & secondary/disarticulated & See Burial 92 & $\mathrm{KH}$ & $8 / 2$ \\
\hline 123 & BF 26 & $73 \mathrm{~cm} \mathrm{BST}$ & $10 \%$ & adult & secondary/disarticulated & See Burial 92 & $\mathrm{KH}$ & $8 / 3$ \\
\hline 125 & BF 26 & $52 \mathrm{~cm} \mathrm{BST}$ & $95 \%$ & adult & primary/articulated & See Burial 92 & BS & $8 / 3$ \\
\hline 126 & BF 26 & $65 \mathrm{~cm} \mathrm{BST}$ & $100 \%$ & adult & primary/articulated & See Burial 92 & $\mathrm{KH}$ & $8 / 3$ \\
\hline 127 & BF 22 & & $20 \%$ & adult & secondary/disarticulated & See Burial 1 & $\mathrm{BM}$ & $8 / 4$ \\
\hline 128 & BF 26 & $68 \mathrm{~cm} \mathrm{BST}$ & $70 \%$ & adult & secondary/disarticulated & See Burial 92 & $\mathrm{OF}$ & $8 / 4$ \\
\hline 129 & BF 22 & $88 \mathrm{~cm} \mathrm{BST}$ & $100 \%$ & young adult & primary/articulated & See Burial 1 & $\mathrm{BM} / \mathrm{CT}$ & $8 / 4$ \\
\hline 130 & BF 26 & $63 \mathrm{~cm}$ BST & $50 \%$ & adult & secondary/disarticulated & See Burial 92 & $\mathrm{BS} / \mathrm{KH}$ & $8 / 4$ \\
\hline 131 & BF 26 & $65 \mathrm{~cm}$ BST & $50 \%$ & adult & secondary/disarticulated & See Burial 92 & $\mathrm{OF}$ & $8 / 5$ \\
\hline 132 & BF 36 & $54 \mathrm{~cm}$ BST & $10 \%$ & adult & primary/articulated & 133,135 & $\mathrm{BM} / \mathrm{JZ}$ & $9 / 20$ \\
\hline 133 & BF 36 & $64 \mathrm{~cm}$ BST & $70 \%$ & adult & primary/articulated & See Burial 132 & $\mathrm{BM} / \mathrm{JZ}$ & $9 / 21$ \\
\hline 134 & BF 35 & $61 \mathrm{~cm} \mathrm{BST}$ & $80 \%$ & adult & primary/articulated & - & $\mathrm{CT} / \mathrm{OF}$ & $9 / 21$ \\
\hline 135 & BF 36 & $79 \mathrm{~cm} \mathrm{BST}$ & $90 \%$ & adult & primary/articulated & See Burial 132 & $\mathrm{BM} / \mathrm{JZ}$ & $9 / 23$ \\
\hline 136 & BF 38 & $55 \mathrm{~cm} \mathrm{BST}$ & $90 \%$ & child & primary/articulated & - & $\mathrm{CT} / \mathrm{OF}$ & $9 / 23$ \\
\hline 137 & BF 37 & $64 \mathrm{~cm} \mathrm{BST}$ & $40 \%$ & child & primary/articulated & 138 & $\mathrm{BM} / \mathrm{JZ}$ & $9 / 24$ \\
\hline 138 & BF 37 & $64 \mathrm{~cm}$ BST & $20 \%$ & child & secondary/disarticulated & 137 & $\mathrm{BM} / \mathrm{JZ}$ & $9 / 27$ \\
\hline 139 & BF 39 & 64 CM BST & $30 \%$ & adult & primary/articulated & - & $\mathrm{CT} / \mathrm{OF}$ & $9 / 27$ \\
\hline
\end{tabular}

* Burials marked \#a, \#b, and \#c, and Cre1-Cre5 were identified during analysis and assigned burial numbers

Burial Feature number 1 (BF 1) was originally assigned to one of the darker areas of soil thought to represent grave pits, however it was later determined that no burials were associated with this feature. The initial interpretation was that these features were part of the campo santo, or outdoor cemetery, of the mission. However, with the discovery of the wall trench outlining the apse and two transepts of the church under the northbound lanes of US 77, it became apparent that all but two of these burials had, at one time, been inside the mission chapel itself.

The tops of the burial features were encountered directly beneath the layer of caliche base of US 77 and were easily recognizable as areas of darker colored soil intruding into the light yellowish white Beaumont clay that underlies the site. Burials within the features were encountered at depths from $1-58 \mathrm{~cm}$ below the road base underlying the surface of the existing road. The proximity of some of the burials to the previously graded surface and the almost 100 years of traffic over the area contributed to the fragmented condition of all but the most deeply buried remains exhumed during this investigation. This proximity also confirmed the need to excavate the remains. If left in place, many of the individual burials would have been directly impacted by the proposed construction. Other recent disturbances to this area included two water lines, one -below the pavement running parallel with street just west of the center stripe, and the other running parallel with the street just below the curb on the west side of US 77. A wide utility trench of some sort had also been excavated down the center-line of 
the roadway. This trench extended to an unknown depth below the level of the burials and had severely impacted burial features in that area of the site (see Figure 8c-1).

While each of the burial features is described in detail below, there are some characteristics that are shared by these features. With the exception of Burial Feature 22, all these features had been intentionally excavated into the naturally occurring Beaumont Formation that underlies the site for the sole purpose of serving as graves. The fill was loosely packed dark brown clay with some lighter clay mottles. Numerous fragments of animal bone, infrequent fragments of unglazed and glazed ceramics, and other materials were occasionally found mixed in the feature fill (Appendix C). These items are not thought to be directly associated with any of the burials. It is more likely that they were present in the soil that was brought from outside to form the floor of the church. During excavations on the west side of the road, it was noted that Burial Feature 22 resembled some sort of smooth-sided trench that had been dug for a purpose unrelated to the burials and had later been used as a readymade grave. After the discovery of the church outline on the east side of the street, it became apparent that Burial Feature 22 was originally part of the wall trench for the chapel, and that the 20 individuals interred in the soft soil filling this footing trench were buried sometime after the church foundation had been stone robbed.

The burial features were irregular in size, shape, and depth with many of them showing signs of being enlarged to accommodate successive burials. Multiple interments were encountered in 29 of the 38 burial features (see Table 8c-1). The majority of the multiple-burial features contained one primary, extended burial and several secondary or disturbed burials. While the burial records (Appendix в) indicate that "bones" of some individuals who died elsewhere were buried in the church, for the most part it seems that the secondary burials were disturbed during subsequent interments within the same burial feature. This is not an unexpected or unprecedented practice at Spanish Colonial period sites. The limits placed on available space by the size of the chapel and the impracticality of marking burials located beneath the floor of the structure guaranteed that areas within the church would be disturbed and reused over time. This situation has been documented archaeologically during burial excavations at Mission San Juan in San Antonio (Schuetz 1968) and archivally in 1848 when a parish priest in San Antonio petitioned the city council for a new cemetery, citing overcrowding at San Fernando as the reason (City Council Minutes [CCM], Office of the City Clerk, City Hall, San Antonio, Texas, 1848:A:135-137).
The majority of the primary, or undisturbed burials were in the extended position, face up, with arms folded at the midsection and fingers overlapping or intertwined. In 56 of the 72 extended burials, the original orientation of the head had been to the west. With only a few notable exceptions, described below, no personal goods or ornamentations were found with the burials. The artifacts that were directly associated with individual burials are described and illustrated, and are listed in Appendix I. Evidence of the use of coffins was found in only seven of the burials and in all cases the burial feature had been excavated to accommodate just the placement of these individuals.

The demographic information on age, sex, and ethnicity presented in this section of the report is based on the skeletal analysis presented by Meadows Jantz et al. in Volume II of the report. When possible, this information has been used to tentatively match individuals listed in the burial records of the church (Appendix B) with individual remains recovered during this investigation. 


\section{Burial Feature 2}

Burial Feature 2(BF 2) was one of the original five features identified during TxDOT Gradall investigations beneath the southbound lanes of US 77 (Figure 8c-1). Burial Feature 2 was located at the edge of what would have been the northern transept of the church. It was roughly oblong in shape and measured $60-\mathrm{x}-130 \mathrm{~cm}$, with an overall depth extending to $70 \mathrm{~cm}$ below the level of the paved street (bst). Numerous Colonial-period artifacts were recovered from the fill of this feature. These include ten native ceramic sherds, one piece of Tonalá Polychrome, four pieces of lithic debitage, and numerous faunal bone fragments. These artifacts are not associated with the burials in BF 2. Two individuals, Burials 6 and 15, were present in BF 2 (Figure 8c-2). the ages of 35-39 is listed on the existing burial records from Mission Refugio. She is 38-year-old Serafina Trexo, the wife of Pedro de Luna (see Chapter 4). She was buried on July 17, 1810. Thus, her burial would have been one of the earliest at the mission. This would account for the secondary nature of the remains, especially if Burial 15 does, in fact, represent Maria Refugio who was buried ten years later in 1820 as the records suggest.

\section{Burial 15}

Burial 15 was an articulated, primary burial located slightly below and to the east of Burial 6. These remains are identified as a Native American female who was over 60 years of age at the time of death. This individual was buried in a prone position, facing up with her head to the west. Her arms were folded across her midsection. Remnants of seven

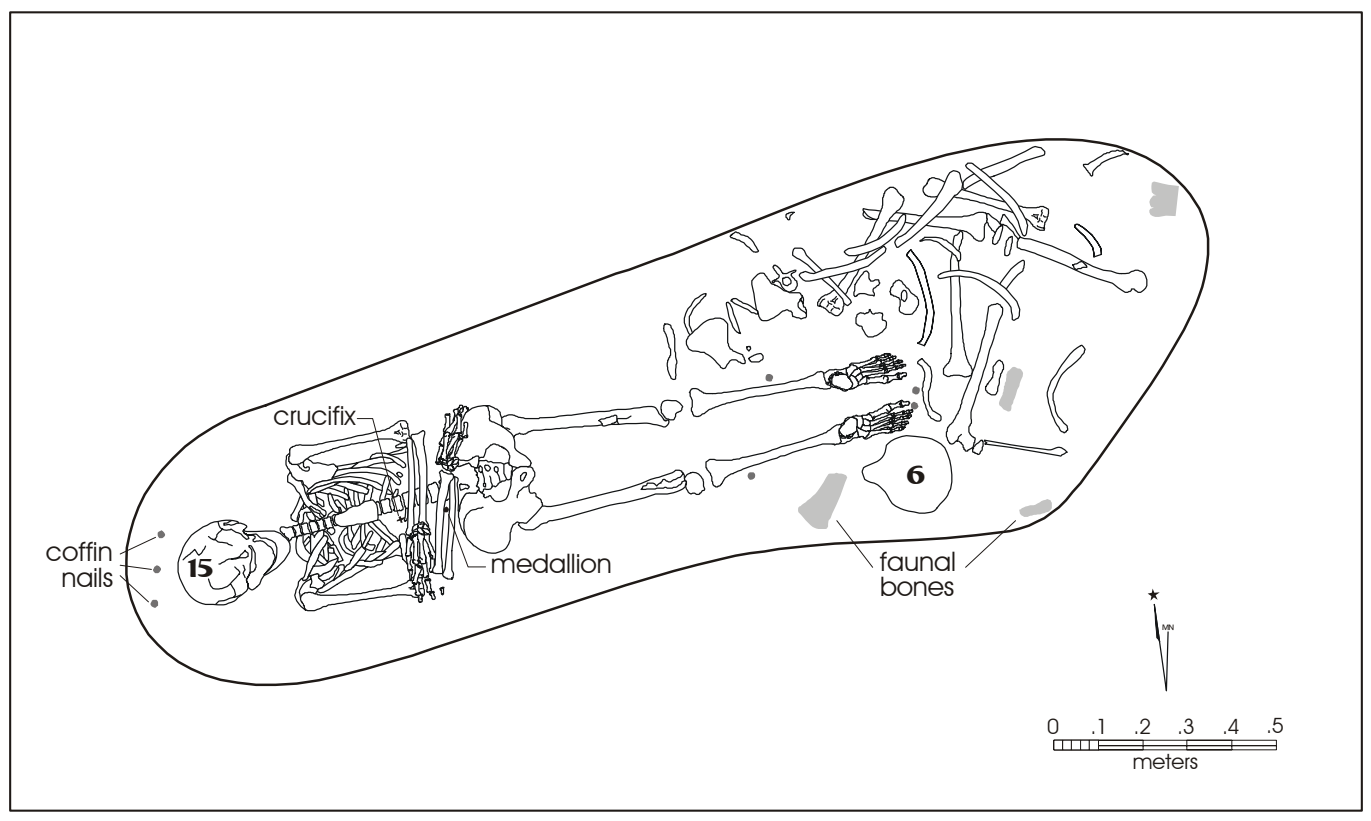

Figure 8c-2. Plan map of Burial Feature 2 indicating Burials 6 and 15.

\section{Burial 6}

Burial 6 is a disarticulated, secondary burial found $63 \mathrm{~cm}$ bst at the foot of Burial 15. From the positioning of the two individuals, it appears that Burial 6 was interred first, then disturbed and reburied sometime later when Burial 15 was interred. Burial 6 is identified as a 35-44-year-old female of probable Hispanic ancestry. All major skeletal elements of this individual were present with the exception of the left radius. However, only a few of the smaller hand and foot bones and vertebra were recovered. No artifacts were found in association with Burial 6. One non-Native female between

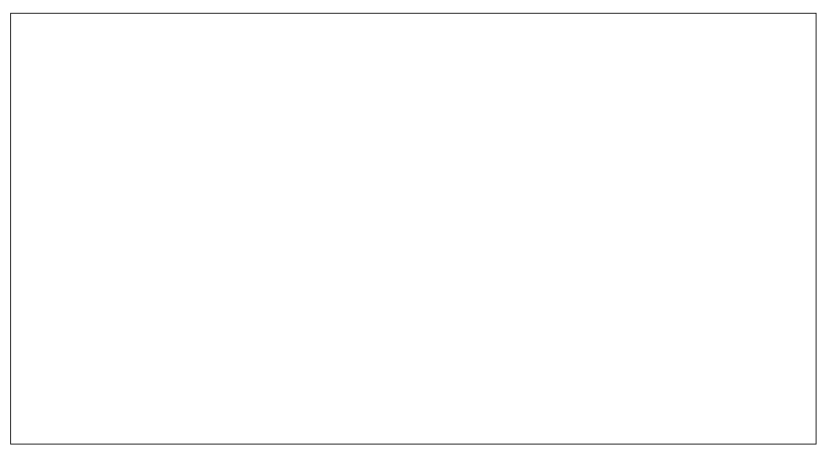

Figure 8c-3. Crucifix, medallion and wooden bead found with Burial 15 
coffin nails were recovered from around the head, legs, and feet of Burial 15, indicating she was one of the few to be buried in a coffin. The only religious artifacts indicating Catholicism found during this investigation were a crucifix, a medallion, and a wooden bead all found with Burial 15 (Figure 8c-3). These items were located in close proximity to the chest area, and probably represent a rosary worn by the individual at the time of burial. The coffin burial and artifacts are made more noteworthy by the fact that this individual was Native American. There is one Native American female over the age of 60 listed on the burial records. She was Maria Refugio, shown as an 80-year-old Karankawa female who was buried on August 15, 1820. A second elderly Native American female is present in the burial records. She is Maria del Refugio, a Lipan female who was baptized shortly before her death and buried on December 2, 1817. Her age is given only as "old". Burial 15 could be either of these individuals. The primary, articulated condition and the coffin associated with Burial 15 seem to indicate that this was one of the later burials to occur at the mission and would therefore suggest that this is the burial of the Karankawa female, Maria Refugio. However, the osteological description of this individual given in Volume II of this report indicates she was small and gracile, a description that more closely approximates members of one of the Plains Indian groups. Therefore, it may be possible that Burial 15 represents the remains of the Lipan female, Maria del Refugio.

\section{Burial Feature 3}

Burial Feature 3 was also one of the first features uncovered during TxDOT Gradall investigations (see Figure 8c-1). This feature was oblong in shape and measured $170-\mathrm{x}-45 \mathrm{~cm}$. The remains of one individual, Burial 7, were discovered $34 \mathrm{~cm}$ bst immediately beneath the road base covering this feature. Closer examination revealed that the bones of this skeleton were extremely fragmented and many elements were missing. It is most likely that this damage occurred during previous street construction activity.

\section{Burial 7}

Burial 7 is that of a 12-16-year-old individual of undetermined sex or ethnic affiliation. This individual was in the extended position, facing up with head to the west and arms folded across the midsection (Figure 8c-4). No evidence of a coffin or artifacts associated with this burial were recovered.

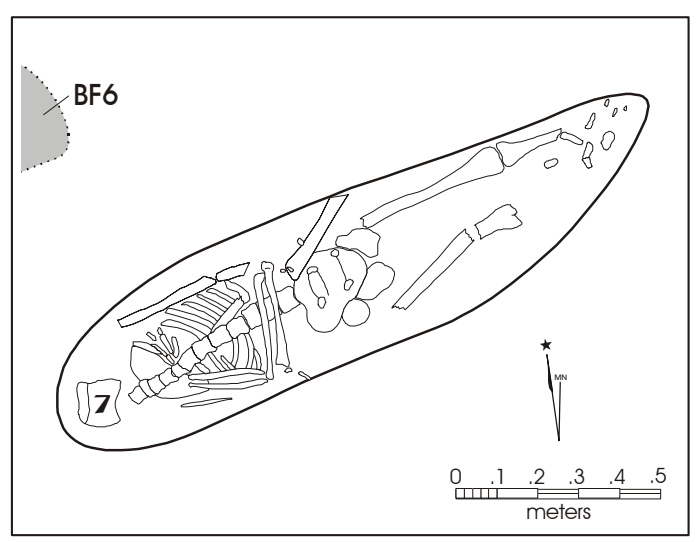

Figure 8c-4. Plan map of Burial Feature 3. 


\section{Burial Feature 4}

Burial Feature 4 was a large irregularly shaped feature located near what would have been the center of the chapel's transepts (see Figure 8c-1). BF 4 contained the remains and partial remains of 12 individuals, attesting to the intensity of reuse this central portion of the church received (Figure 8c-5). Three pieces of lithic debitage, six native ceramic sherds, and five fragments of faunal material were recovered from the feature fill.

\section{Burials 8 and 13}

As shown in Figure 8c-5, Burials 8 and 13 were found closely associated at a depth of $42-45 \mathrm{~cm}$ bst in BF 4 .
Burial 13 is identified as a Native American female who was between the ages of 17 and 20 at the time of death. This individual was in an extended position, face up with head to the west and arms folded across the midsection. The right humerus of Burial 13 rests on the left femur of Burial 8 .

Burial 8 is a Native American male 22-26 years of age at the time of death. This individual is also in the extended position with head oriented to the west. The right arm is slightly folded over the torso while the left arm is straight down at his side. Evidence of slight posthumous shifting to the left while still articulated is seen in the position of the skull and the slightly bent left arm and leg. This shifting probably occurred when Burial 13 was interred. One copper button and an unidentified copper fragment were found in the neck region of Burial 8 (Figure 8c-6).

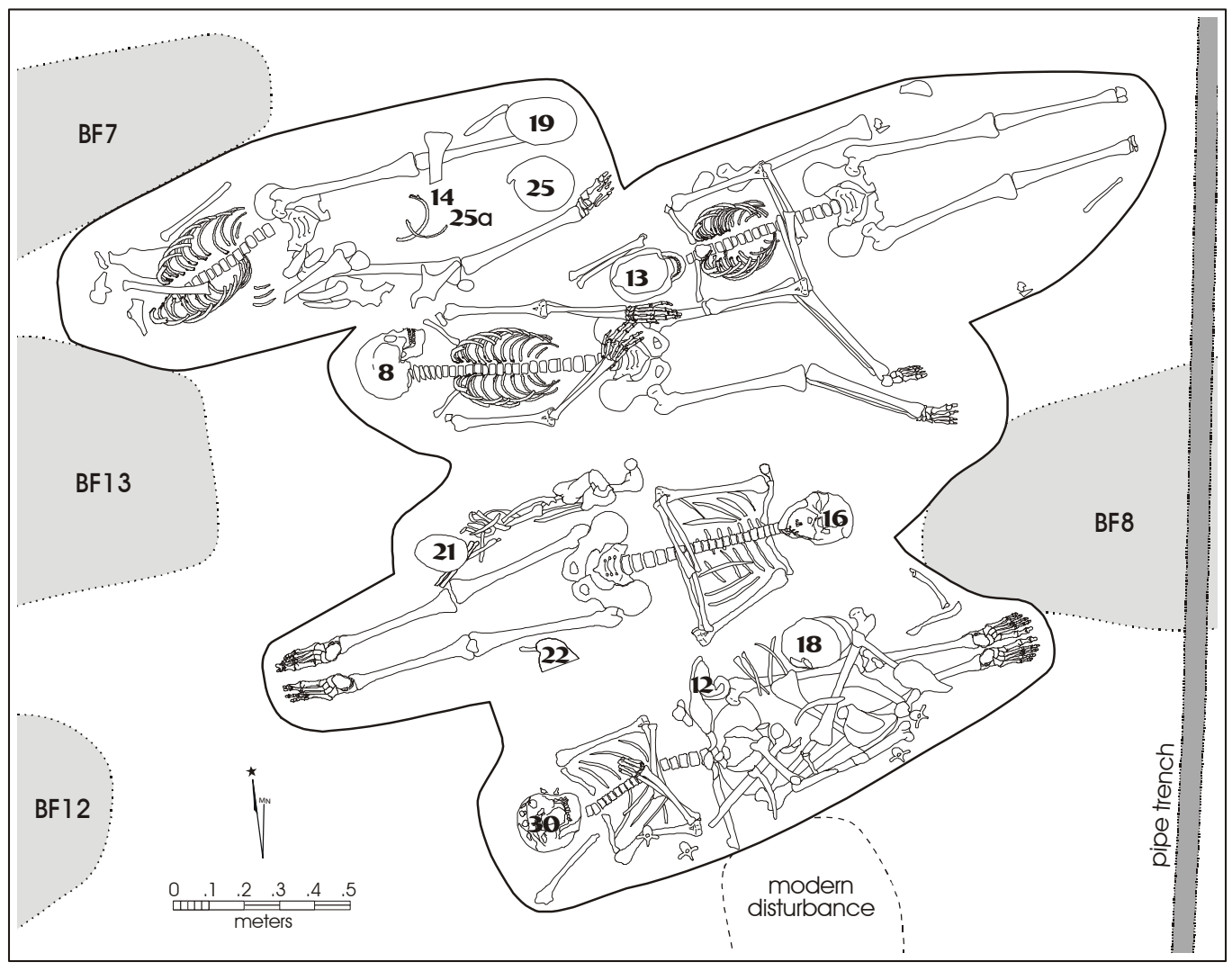

Figure 8c-5. Plan map of Burial Feature 4. 


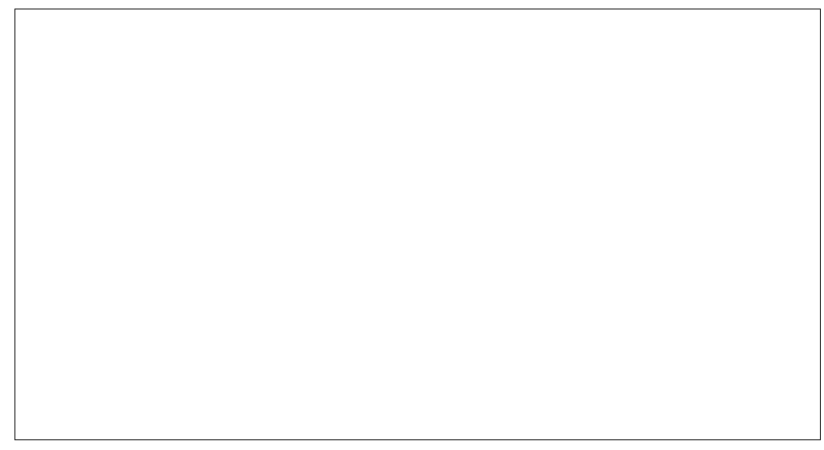

Figure 8c-6. Copper buttons found with Burial 8.

\section{Burials 16, 21 , and 22}

The remains of three individuals, Burials 16, 21, and 22 were located 10-20 cm south of Burial 8 at a depth of $53-60 \mathrm{~cm}$ bst. Burial 16 is that of a 50-60-year-old male of Hispanic or Native American ancestry. This individual was in the extended position, facing up with arms folded across the midsection. Burial 16 is one of the few individuals buried with his head oriented to the east (Figure 8c-5).

The neatly stacked remains of Burial 21, identified as a 4554-year-old Hispanic or Native American male were found to the right and immediately adjacent to Burial 16 . The skull of this individual rested face down on top of one of the humeri.

Burial 22 represents the remains of a newborn -.5-year-old infant of undetermined sex or ethnic affiliation. The skull fragments of this infant were just south of the left leg of Burial 16 and the postcranial elements were found throughout the fill at the west end of BF 4. It appears the primary interments of Burials 21 and 22 were disturbed and reburied when Burial 16 was interred. No evidence of coffins or artifacts were found with these burials.

\section{Burials 12, 18, and 30}

Another group of three individuals, Burials 12, 18, and 30 were located at the south edge of BF 4, 56-63 cm bst (Figure $8 \mathrm{c}-5)$. Of these, Burial 30 represents a primary, articulated burial interred after and therefore disturbing Burials 12 and 18. Burial 30 is identified as a Native American female between 14-16 years of age at the time of death. She was in the extended position, facing up with head to the west and arms folded across midsection. No evidence of a coffin or personal items were found with this burial.

Burials 12 and 18 were commingled, resting directly on top of the lower portion of Burial 30. Burial 12 represents the remains of a male of undetermined ancestry who was over 50 years of age when he died. Burial 18 is a 40-49-year-old Native American male. Both of these burials were disturbed and reburied when Burial 30 was interred.

\section{Burials 14, 19, 25, and 25a}

The last group of burials in BF 4 are Burials 14, 19, 25, and $25 \mathrm{a}$, located at the northern edge of the feature, $43-58 \mathrm{~cm}$ bst. As shown in Figure 8c-5, Burial 19 is in the extended position, but the upper half of this individual has been disturbed and the skull was found resting face down on the feet.

Burial 19 represents the remains identified as a 35-44-yearold male of mixed Hispanic or Native American ancestry. No burial-related or modern disturbance was noted in this section of BF 4 that would account for the disturbance to Burial 19.

Burial 25 is represented by a skull and disarticulated postcranial elements resting on top of the articulated legs of Burial 19. This burial is a Native American male who was 30-39 years old at time of death. The disturbed and disarticulated postcranial elements from a third individual, Burial 14, were found near Burials 19 and 25. These remains have been identified as a 25-34-year-old female of indeterminate ancestry. No skull could be associated with Burial 14. Elements representing another female of indeterminate ancestry aged 25-35 were identified during analysis as Burial 25a. 


\section{Burial Feature 5}

Burial Feature 5 was a $2.6-\mathrm{x}-1.2 \mathrm{~m}$ oblong feature that extended more than $84 \mathrm{~cm}$ bst. It was located just south of BF 4 in what would have been the center of the chapel's transepts (see Figure 8c-1). BF 5 contained the remains and partial remains of 15 individuals. However, with the exception of one infant (Burial 10) none of the burials in BF 5 were completely articulated in an undisturbed, primary position (Figure 8c-7). Some of the posthumous disturbance was caused by the installation of a water pipe shown crossing the eastern third of the feature, but it is felt that the majority of the disturbances are the result of Colonial-period reuse of this prime burial location. Numerous modern artifacts including rusted iron fragments from the water pipe and a metal bolt were recovered from the feature fill along with two native ceramic sherds, one majolica sherd, one leadglazed sherd, 22 pieces of debitage and 82 animal bone fragments from the Colonial-period use of the site. One very small, $2 \mathrm{~mm}$, peacock blue glass trade bead, a 13- $\mathrm{mm}$ piece of lead shot (Figure 8c-8[a]), and several copper fragments were also present in the fill. Due to the personal nature of these artifacts, it is felt that they are probably related to the individuals in BF 5, but no direct association could be made.

Because of the amount of disturbance in this feature, excavation and recording techniques were modified for
BF 5 remains. Burial numbers were assigned only to crania, and postcranial elements that could be directly associated with a numbered cranium were identified with that burial number. The remainder of the elements in BF 5 were labeled as commingled ossuary elements for sorting and identification during the analysis phase.

Of the articulated individuals in BF 5 only Burial 10, a newborn infant, was complete. The interment of Burial 10 had disturbed Burial 11, a newborn to 6-month-old infant found to be resting on the remains of another newborn infant, Burial 35. Elements of a third newborn, Burial 55, and a child between 2.5-3.5 years old, Burial 73, were identified in the ossuary collection. Burials 10,11, 35 and 55 were identified in the analysis phase as being of indeterminate ancestry, while Burial 73 was identified as Native American.

Of the three partially articulated adult skeletons in BF 5 , Burial 9 was uppermost in the feature (Figure 8c-7). The skull of this burial was discovered at a depth of $44 \mathrm{~cm}$ bst, $14 \mathrm{~cm}$ beneath the existing road base. This individual had originally been interred in an extended position with head oriented to the west. The upper portion of the skeleton-to about mid-chest-was articulated. Below this point, the burial was disturbed by another intrusive burial. Burial 9 has been identified as a Native American male between the ages of 25-29 at time of death.

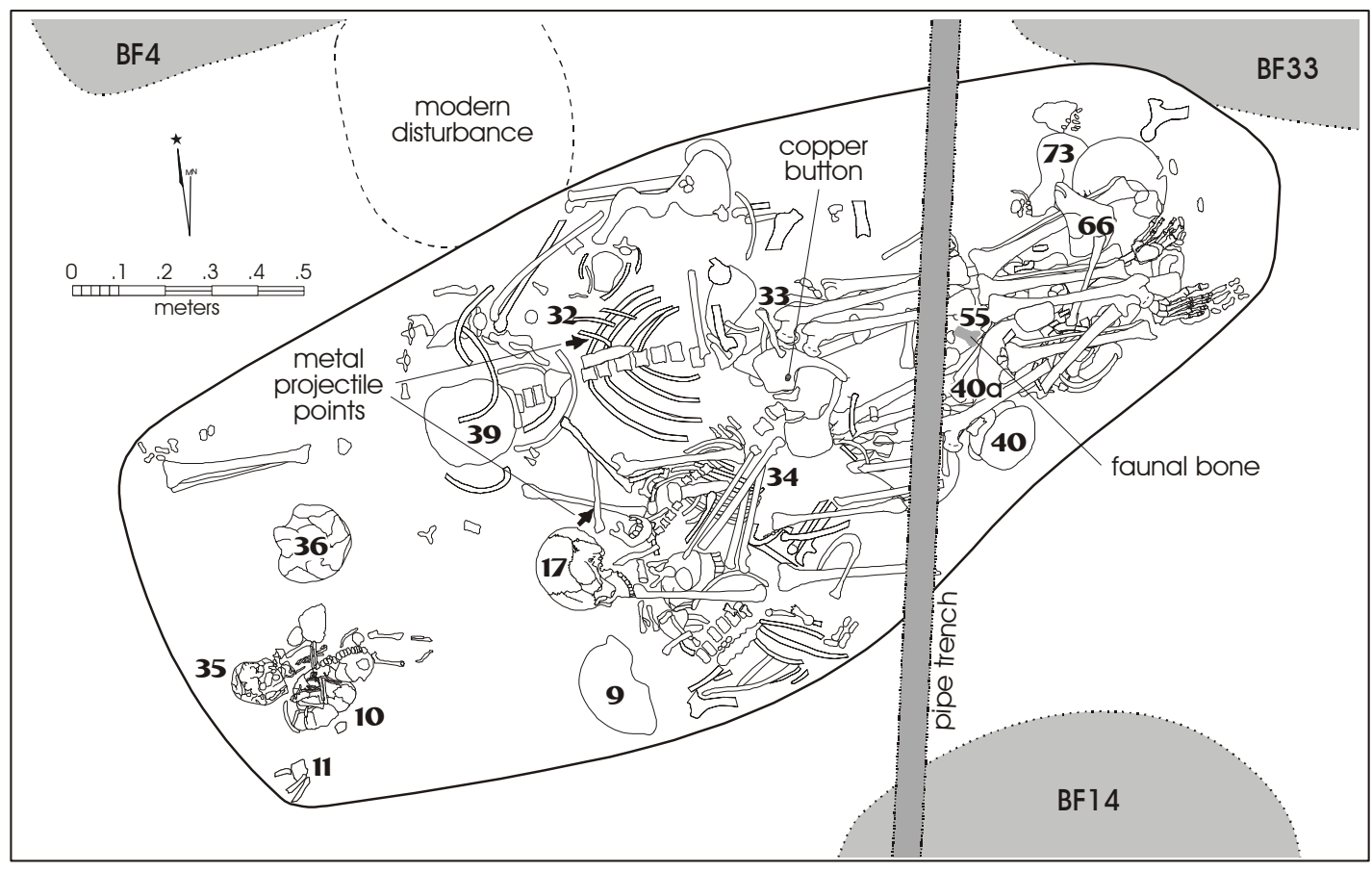

Figure 8c-7. Plan map of Burial Feature 5. 
Burial 17 was discovered underneath and slightly commingled with Burial 9 at a depth of $55 \mathrm{~cm}$ bst. This burial had also been interred in an extended position with the head to the west and arms crossed over the chest. Although Burial 17 was virtually complete, there was evidence of a great deal of posthumous shifting, probably due to the uneven surface on which the remains were placed. The skull rested $22 \mathrm{~cm}$ above the pelvic area, the right humerus was $22 \mathrm{~cm}$ higher than the left, and the right radius and ulna angled down almost vertically from the humerus. These remains are identified as a young adult Native American female between the ages of 20-24 at time of death. One copper button (Figure $8 \mathrm{c}-8[\mathrm{~b}]$ ) and a fragment of a second were found resting in the pelvic area of this individual.

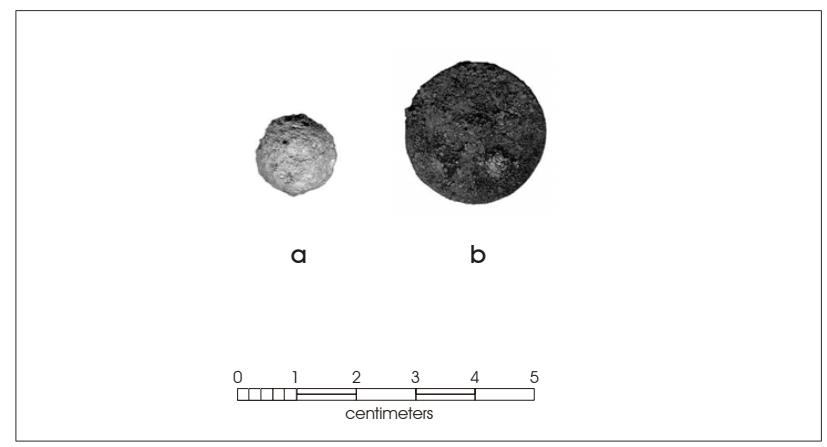

Figure 8c-8. Musket ball and button found with Burial 17.

Burial 39 was located below and slightly commingled with Burial 17. Most of this skeleton was articulated but the downward, posthumous shifting noted with Burial 17 was also evident with Burial 39. Here the skull was $17 \mathrm{~cm}$ above the pelvic area and the right humerus was in a reverse position with the distal end pointed toward the skull. Burial 39 has been identified as a 20-24-year-old male of undetermined ancestry. Two metal arrow points (Figure 8c-9) were found in direct association with these remains. One was located beneath the disarticulated right humerus; the other was within the collapsed rib cage. These items, combined with evidence of scalping identified during analysis and described in more detail in Volume II, indicate this young adult male met with a traumatic death. The burial records list one young male, Carmelo de Laso, as being 24 years old when he was buried on August 2, 1814. A note on this record indicates he was "killed by Barbarian Indians." Therefore, it is probable that the remains identified here as Burial 39 are those of Carmelo de Laso.
The remains of seven additional individuals were recognized among the commingled ossuary elements in BF 5 . These include Burial 36, a Native American female, aged 30-39 and Burial 66, a 35-50-year-old male of possible Native American ancestry. Three males of indeterminate ancestry were also present: Burial 40, aged 30-39; Burial 40a, aged 20-29; and Burial 33, a young adult of undetermined age. Burial 32 is a sub-adult individual between the ages of 11-14 who, is possibly female and possibly a Native American. Burial 34 is also a sub-adult between 9-12 years of age, of indeterminate sex and ancestry.

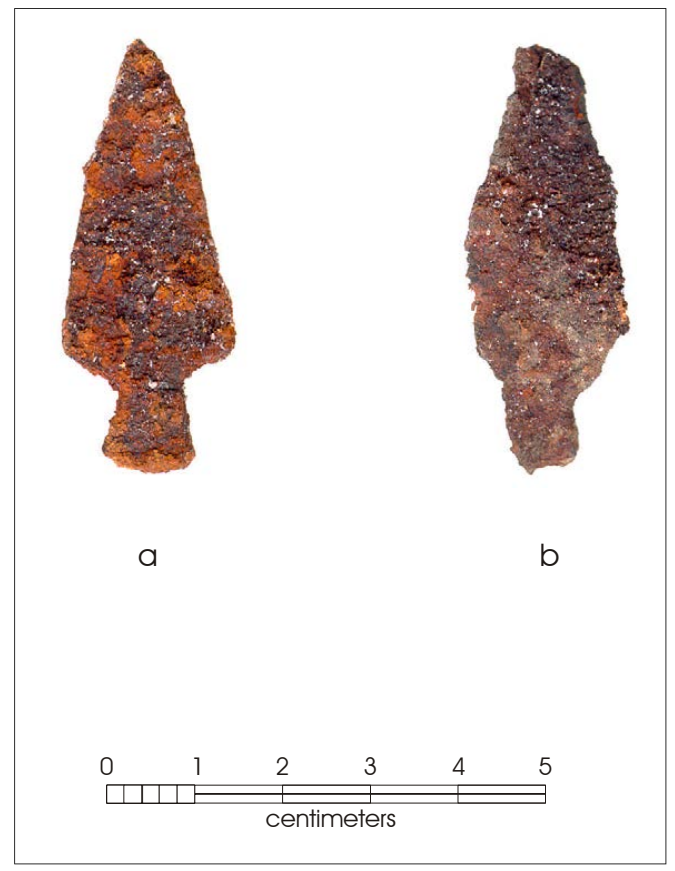

Figure 8c-9. Metal arrow points found with Burial 39. 


\section{Burial Feature 6}

Burial Feature 6 was located between BFs 2 and 3 in what would have been the north transept of the church. It was oblong in shape and measured $160-\mathrm{x}-50 \mathrm{~cm}$. The remains of one individual, Burial 31, were discovered $33 \mathrm{~cm}$ bst, immediately beneath the surface of the road base. The bones of this skeleton, like many others disturbed during previous street construction, were extremely fragmented and many of the elements were missing.

\section{Burial 31}

Burial 31 is identified as that of a 40-49-year-old female individual of indeterminate ethnic affiliation. This individual was in the extended position, facing up with head to the west and arms folded across the midsection (Figure 8c-10). A green stain, possibly from a copper pendant or button, was noted on the frontal face of the right scapula of this individual. One fragment of rusted metal found at the eastern edge of the feature near the feet of Burial 31 is the only indication that this individual may have been interred in a coffin.

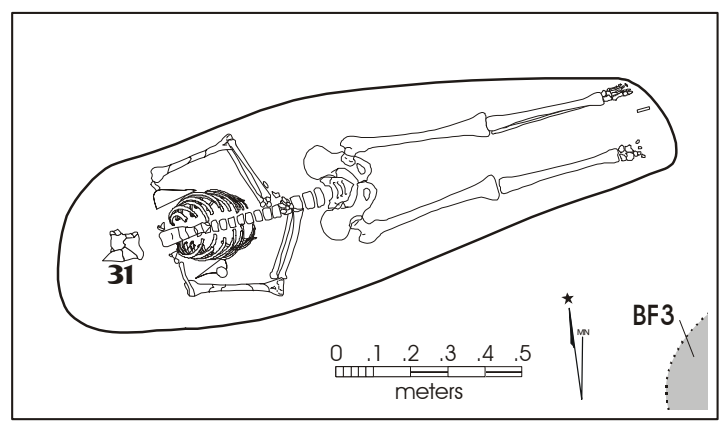

Figure 8c-10. Plan map of Burial Feature 6.

\section{Burial Feature 7}

Burial Feature 7 was adjacent, but not connected to the northwest side of BF 4. It was oblong in shape and measured $178-\mathrm{x}-52 \mathrm{~cm}$. The remains of one individual, Burial 38 , were discovered $62 \mathrm{~cm}$ bst in BF 7 .

\section{Burial 38}

Burial 38 represents the articulated remains identified as a female of mixed European and Hispanic ancestry who was over the age of 50 at time of death. This individual was buried in the extended position, facing up with head to the west and arms folded across the midsection (Figure $8 \mathrm{c}-11$ ). The postcranial elements of this individual were badly fragmented and no teeth were present in the crania, attesting to advanced age. No burial items or evidence of a coffin were recovered with Burial 38.

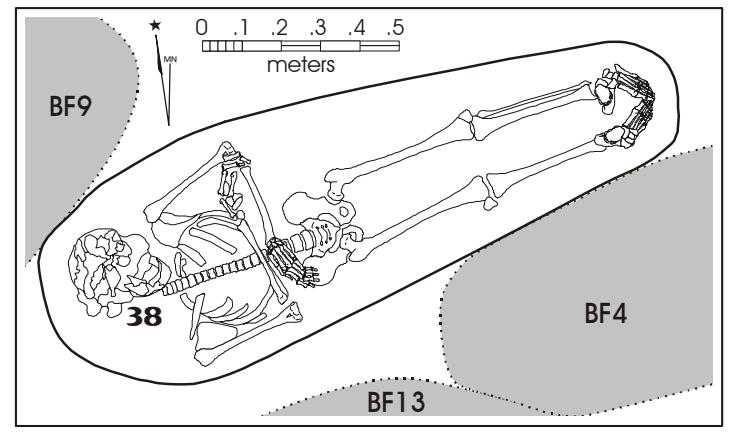

Figure 8c-11. Plan map of Burial Feature 7. 


\section{Burial Feature 8}

Burial Feature 8 was a $177-\mathrm{x}-70 \mathrm{~cm}$ oblong feature that abutted the east side of BF 4 and extended to the centerline of US 77 (see Figure 8c-1). The remains of one partially articulated burial, Burial 20, and two disturbed burials, 20a, and 26 were present in this feature (Figure 8c-12). These burials had been previously impacted by the same water pipe that cut into BF 5. One coffin nail was recovered from the fill in BF 8 but could not be directly associated with either of the burials contained within. Other artifacts recovered from the fill in BF 8 include one Native American ceramic and one undecorated whiteware sherd, nine faunal bone fragments, one piece of worked bone, one unidentifiable copper fragment, and two iron fragments from the intrusive water pipe.

Burial 20 represents the partially articulated remains identified as belonging to a 25-34-year-old female of possibly Native American ancestry. This burial was found in the extended position with her head oriented to the west. The position of the arms, posthumously disturbed by the waterline trench, had originally been folded at the midsection. The waterline trench had also obliterated the pelvic area, lower vertebrae, and portions of the left femur of Burial 20. During analysis, postcranial elements of an infant, newborn to .5 years of age of indeterminate sex or ancestry were identified (Burial 20a). However, due to the disturbances in this feature, the relationship between these burials could not be established.

Burial 26 is represented by disarticulated skeletal long bones found scattered in the fill surrounding Burial 20. It appears this burial was disturbed and replaced in the grave when Burial 20 was interred. Burial 26 has been identified as a 25-35-year-old male of indeterminate ancestry.

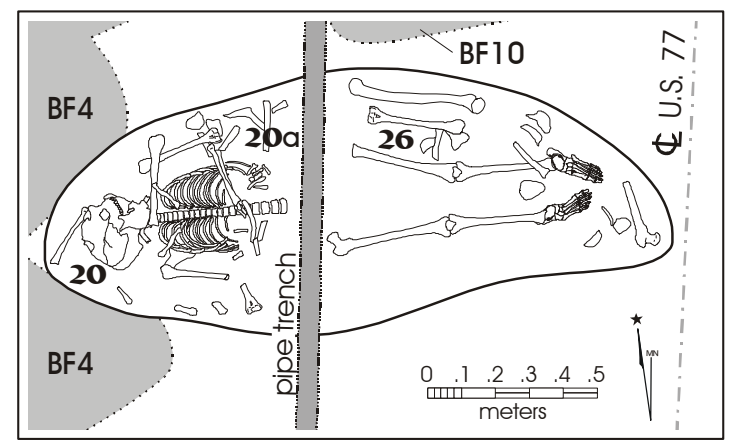

Figure 8c-12. Plan map of Burial Feature 8.

\section{Burial Feature 9}

Burial Feature 9 was a 190-x-60 cm oblong feature which adjacent to and slightly intrusive into BF 7 (see Figure $8 \mathrm{c}-1$ ). It was oriented in a more northerly direction than any of the other burial features, possibly in an attempt to fit it as close as possible to the north edge of the church. The remains of one adult individual, Burial 42, were present in this feature. Three deciduous teeth from a newborn -.5-yearold were found loose at the top of BF 9 and were assigned Burial Number 41. No other skeletal elements could be associated with this individual.

Burial 42 has been identified as a 40-49-year-old female, possibly of European ancestry. This individual was found in the extended position with arms crossed at the midsection (Figure 8c-13). Fragments of as many as ten coffin nails found near the head and feet and two large metal spikes in situ beneath the femurs indicate this individual was buried in a coffin. However, no other burial artifacts were present with Burial 42.

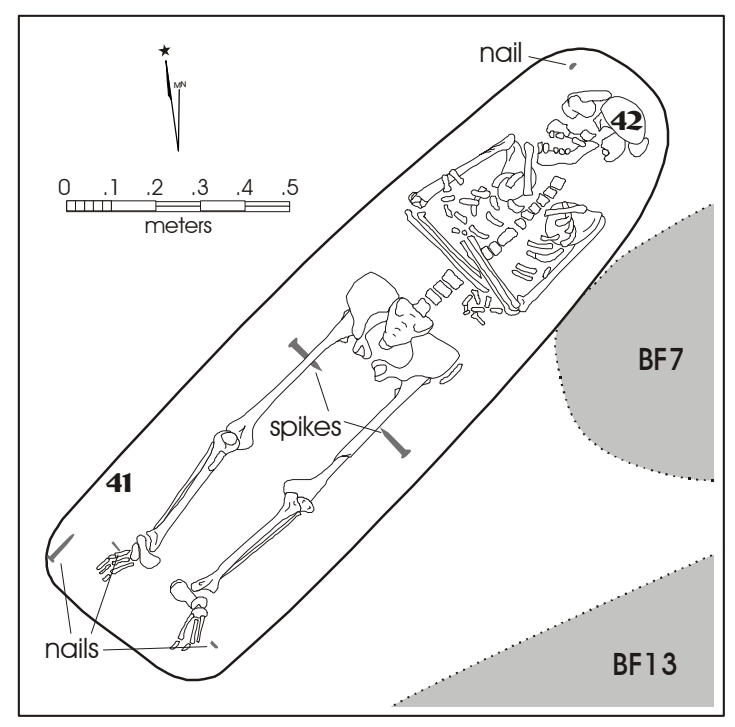

Figure 8c-13. Plan map of Burial Feature 9. 


\section{Burial Feature 10}

Burial Feature 10 is a partial burial feature that has been truncated by some type of previous utility construction in the center of US 77. It is located just north of BF 8 (see Figure 8c-1). The partial remains of one individual, Burial 43 , were uncovered $68 \mathrm{~cm}$ bst in this feature.

Burial 43 is represented by the lower extremities of an individual who has been tentatively identified as a male of indeterminate ancestry, between the ages of 25-35 (Figure $8 \mathrm{c}-14)$. When the long bones were originally found, only the tibias, fibulas and half of the distal ends of both femurs were within the southbound lanes of US 77. The remains of both femurs were recovered by tunneling into the northbound lanes. The location was marked and plans were made to expose and exhume the remainder of this burial when investigations began beneath the northbound lanes. However, as shown in Figure 8c-1, previous construction had completely removed the remainder of Burial 43 , as well as portions of several other burials. Although the upper torso is not present, it is possible to say that this individual had been buried in the extended position with his head to the east. Small fragments of wood found with the extant portions of Burial 43 and two cut nails from the fill indicate that this individual had been buried in a coffin.

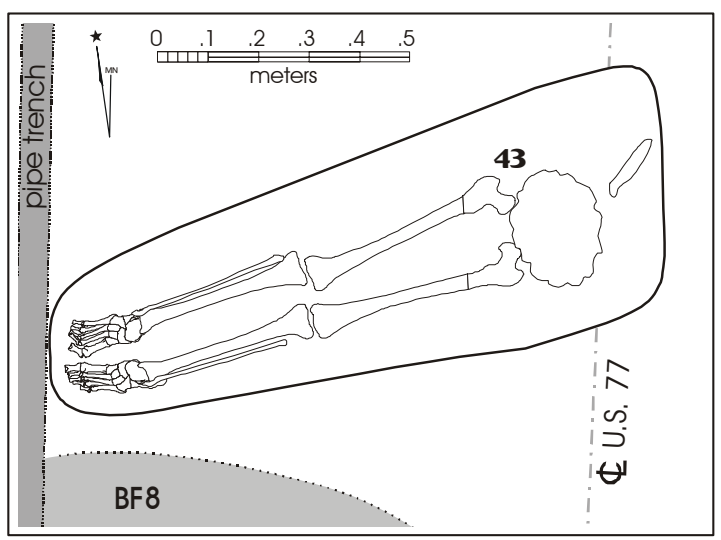

Figure 8c-14. Plan map of Burial Feature 10.

\section{Burial Feature 11}

Burial Feature 11 is located in the nave of the church, just west of the transepts (see Figure 8c-1). This feature is roughly oblong in shape and measures 1.8-x-2.90 m. Burial Feature 11 contained the remains of three adults, one youth, and two infants. All of the burials within this feature were encountered very close to the graded surface and were in extremely fragmented condition (Figure 8c-15).

\section{Burial 44}

Burial 44 was encountered $50 \mathrm{~cm}$ bst beneath a thin layer of road base. It is an extended burial with head to the west. Although the left arm shows signs of posthumous disturbance, the remaining portions indicate the arms had originally been crossed at the midsection. From the articulated condition of this burial, it appears to have been the final burial interred in this feature. Burial 44 has been identified as a 35-45-year-old male of possibly Native American ancestry.

Four 5-mm white glass beads and five black glass beads were recovered from the fill immediately around the remains of Burial 44. The white beads are listed on the Harris Bead Chart (Harris and Harris 1967) as \#5 - medium white, opaque, barrel-shaped garter beads of compound construction (Figure 8c-15a). Harris's \#5 bead corresponds with type CIV/SA/T4/Va used by De Vore in his classifications (De Vore 1992). The black beads measure 4- $\mathrm{mm}$ in diameter and are described by Harris as \#50, opaque, donut-shaped beads of simple construction (Harris \& Harris 1967). Harris's \#50 bead corresponds with type CIV/SA/T1/Vf used by De Vore in his classifications (De Vore 1992). No evidence of a coffin was found with Burial 44.

Figure 8c-15a. Glass beads recovered from immediate vicinity of Burial 44. 


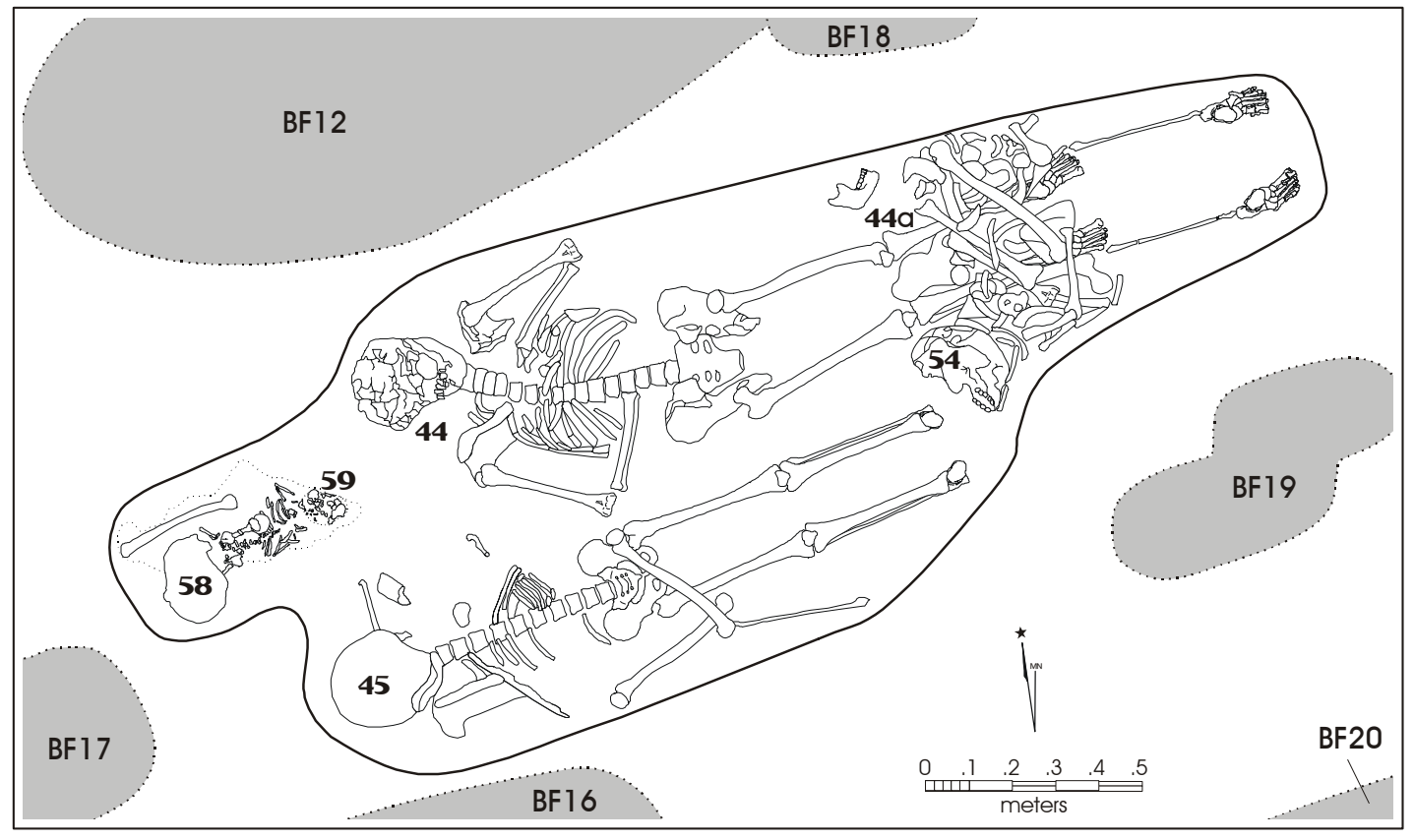

Figure 8c-15. Plan map of Burial Feature 11.

\section{Burial 45}

Burial 45 was encountered at a depth of $52 \mathrm{~cm}$ bst, just south of Burial 44. This is a partially articulated burial identified as an 18-24-year-old Native American female. This individual had originally been buried in the extended position with her head oriented to the west. It was not possible to tell if the posthumous disturbance to this burial was due to the subsequent interment of Burial 44 or was a result of previous road construction activities. No evidence of a coffin or burial goods were found with Burial 45 .

\section{Burial 59}

Burial 59 represents the almost complete remains of a newborn infant found $73 \mathrm{~cm}$ bst at the western edge of BF 11 directly beneath the disarticulated skeletal remains of a young adult male of indeterminate ancestry, Burial 58. The infant burial was in the extended position with its head oriented to the east.

\section{Burial 54}

Burial 54 is represented by the complete, but disarticulated skeletal remains of a 25-35-year-old male of possibly Native American ancestry. The burial of this individual had been disturbed when Burial 44 was interred. The fibula and feet of Burial 54 were found in articulated position extending east from the feet of Burial 44. The remaining skeletal elements of Burial 54 were lying on top of the lower legs of Burial 44. Elements of a second newborn, Burial 44a, were identified in BF 11 during analysis. 


\section{Burial Feature 12}

Burial Feature 12 was located just north of BF 11 in the nave of the church (see Figure 8c-1). This oblong feature, which measured $73-\mathrm{x}-252 \mathrm{~m}$, contained the remains of three burials -those of two adults and one infant (Figure 8c-16). No evidence of a coffin was found with either of the burials in BF 12.

\section{Burial 46}

The skull of Burial 46 was encountered at the east edge of the BF $12,53 \mathrm{~cm}$ bst. The skull and elements of the upper torso of this individual remained in articulated, extended position with the arms folded across the chest and the head oriented to the east. The leg bones and the left side of the pelvis were found at the southwest edge of BF 12, neatly stacked along the right side of Burial 50. Burial 46 has been identified as a Native American female who was between 30-40 years old at time of death. Eighteen clear-glass beads and two black-glass beads were recovered from the soil immediately around the upper torso of this individual (Figure 8c-16a). These beads were 3-mm in diameter and are similar to those described by Harris and Harris (1967) as \#44, small, white, opaque, barrel-shaped garter beads of simple construction and as CI/SA/T1/Vf (De Vore 1992), and \#50, black, opaque, donut-shaped beads of simple construction (Harris and Harris 1967) and CI/SA/T1/Va (De Vore 1992). Elements of an infant, possibly fetal, Burial 50a, were identified during analysis among the disturbed remains of Burial 46.

\section{Burial 50}

Burial 50 represents the articulated remains of a 40-44year-old male, possibly of mixed Native American and European ancestry. This individual was buried in the extended position with his arms folded across his chest and his head oriented to the west. The skull of Burial 50 was resting at a depth of $60 \mathrm{~cm}$ bst at the west end of BF 12 . This interment obviously post-dated and disturbed that of Burial 46.

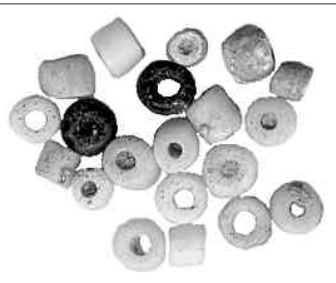

Figure 8c-16a. Glass beads recovered from immediate vicinity of Burial 46.

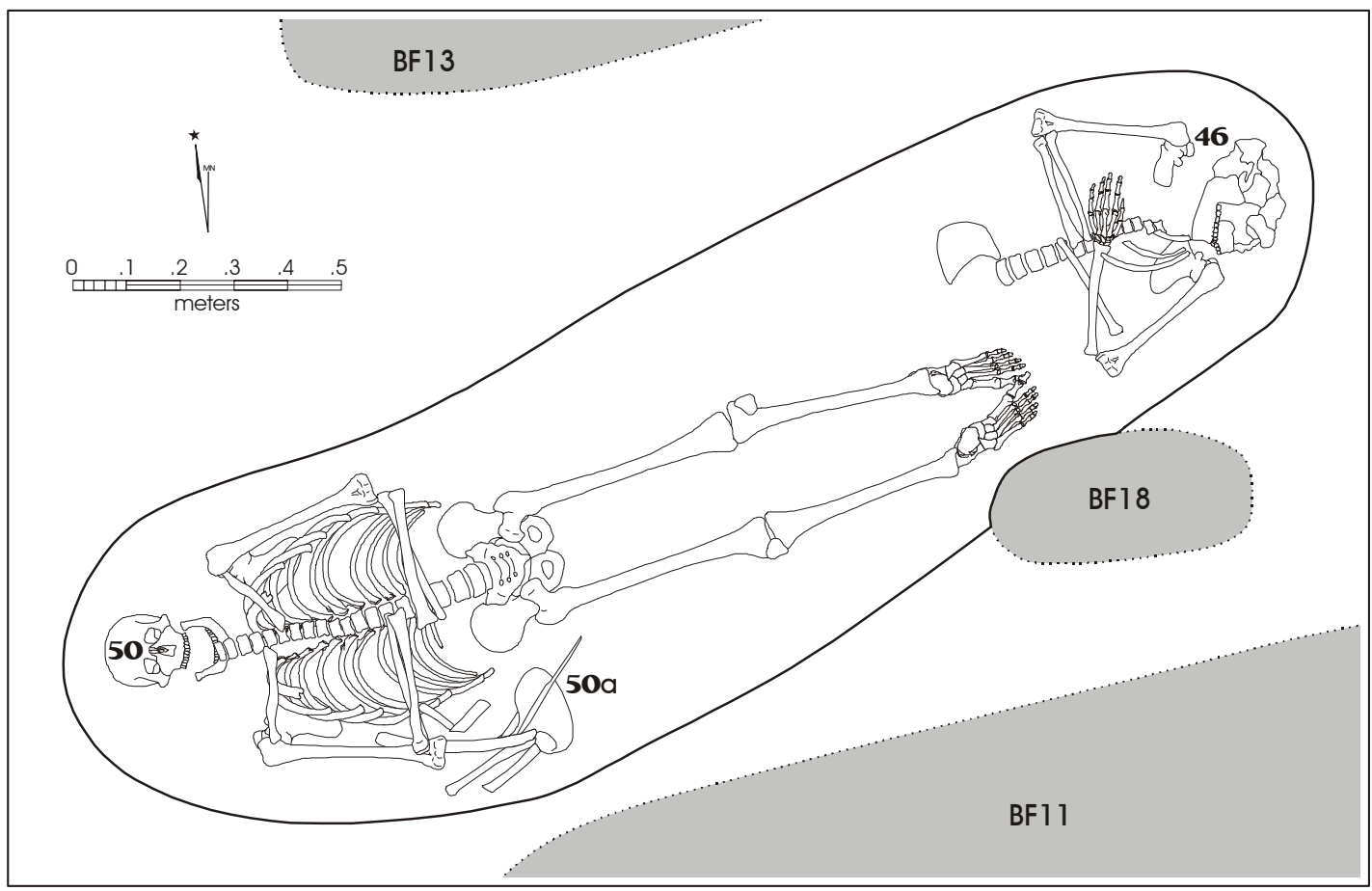

Figure 8c-16. Plan map of Burial Feature 12. 


\section{Burial Feature 13}

Burial Feature 13 was located north and slightly east of BF 12 (see Figure 8c-1). It was roughly $78-x-240 \mathrm{~cm}$ in size and contained one articulated and two disturbed burials (Figure 8c-17). Three native ceramic sherds were present in the fill of this feature, but do not appear to be associated with the burials.

\section{Burial 47}

Burial 47 is represented by the articulated skull and upper torso found in the western end of BF 13 at a depth of $52 \mathrm{~cm}$ bst. The lower skeletal elements of this individual were uncovered and found to be commingled with the disarticulated remains of Burial 57 at the east end of BF 13, and above and on either side of Burial 53. Burial 47 has been identified as the remains of a 25-35-year-old male of possible Native American ancestry. He had originally been buried in an extended position with his arms crossed at the midsection and head oriented to the west. Burial 57 was a male of possible Hispanic ancestry who was between the ages of 25-35 at the time of his death.

\section{Burial 53}

Burial 53, the latest interment in BF 13, was also in the extended position with arms folded across the chest and head oriented to the west. Burial 53 was encountered at a depth of $66 \mathrm{~cm}$ bst, $26 \mathrm{~cm}$ east of the truncated upper torso of Burial 47. The remains of Burial 53 have been identified as those of a 16-18-year-old female, possibly of European ancestry. One piece of rusted metal, possibly the remnant of a coffin nail, was recovered from the soil at the feet of Burial 53 and may indicate that one of the individuals in this feature had been buried in a coffin.

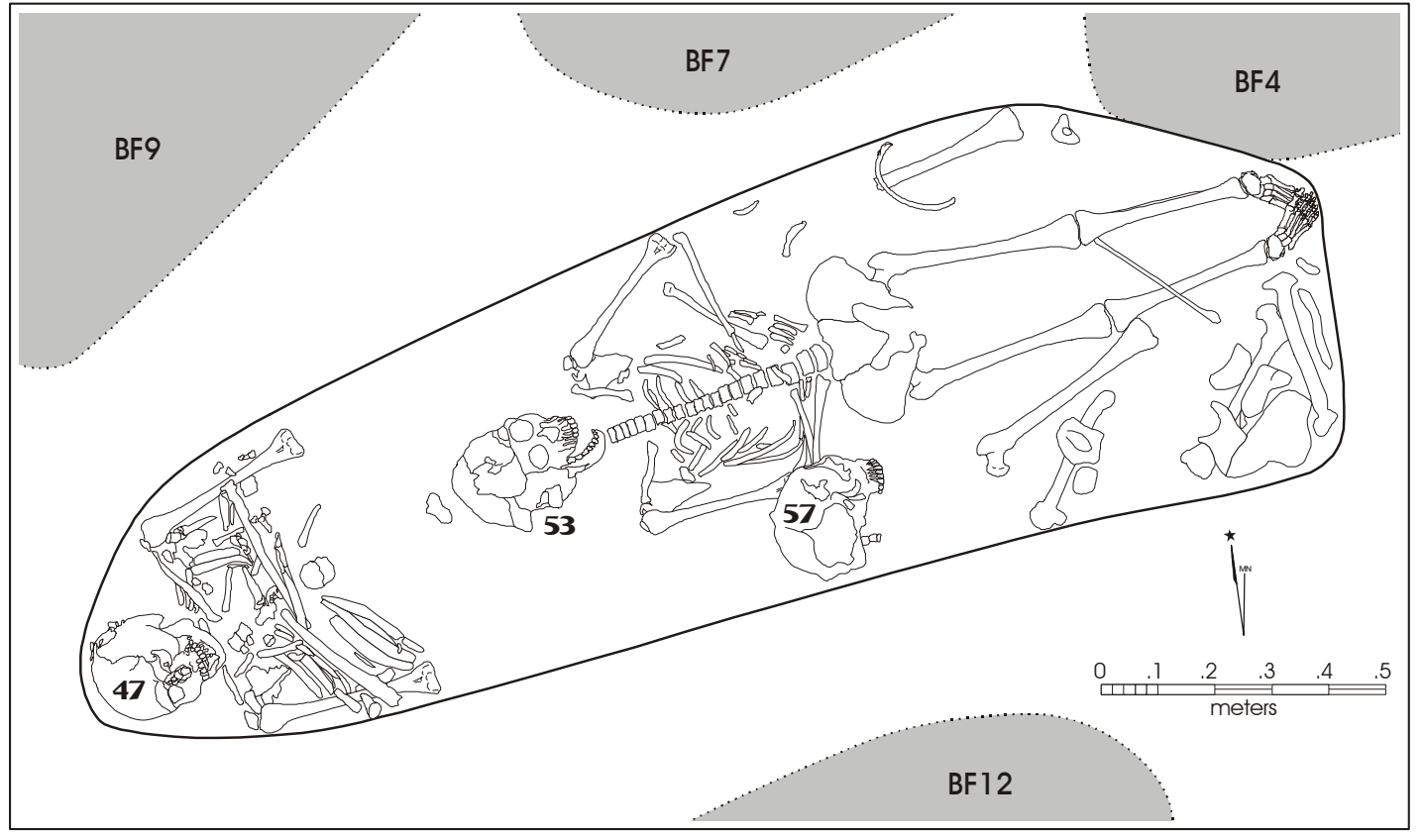

Figure 8c-17. Plan map of Burial Feature 13. 


\section{Burial Feature 14}

Burial Feature 14 was located just south of BF 5 in the south transept of the church (see Figure 8c-1). As in BF 5, the disturbed condition of the burials in this feature is partially due to the frequent reuse of this particular burial location and partially due to the installation of the modern water pipe that bisects the site (Figure 8c-18). Artifacts recovered from the fill above the burials relating to the Colonial-period use of the site include two native ceramic sherds, two pieces of faunal bone, and two cut square nails. Artifacts from more modern disturbances include an iron fragment of the water pipe, one wire nail and one piece of post-1870 Albany-glazed stoneware.

Four individuals were identified in BF 14 in the field and two others were recognized during the skeletal analysis.

\section{Burial 49}

Burial 49 represents the highly fragmented remains of a child found $30 \mathrm{~cm}$ bst just below the graded surface at the west edge of BF 14. This burial has been identified as a 1.5-2.5year-old of indeterminate sex or ancestry.

Disarticulated skeletal elements of four individuals in BF 14 were mixed throughout the feature fill beneath the water pipe and at the east end of the feature. Burials 56a and 63a are those of two infants aged newborn -.5 and .51.5 years of age, respectively. Burial 63 has been identified as the remains of a 23-30-year-old Native American male. Burial 56 was also a Native American male who was between the ages of 30-34 when he died.

Two 2.5-mm peacock blue glass beads (Harris and Harris 1967, \#46 or De Vore 1992, CI/SA/T1/Vc), two small, white

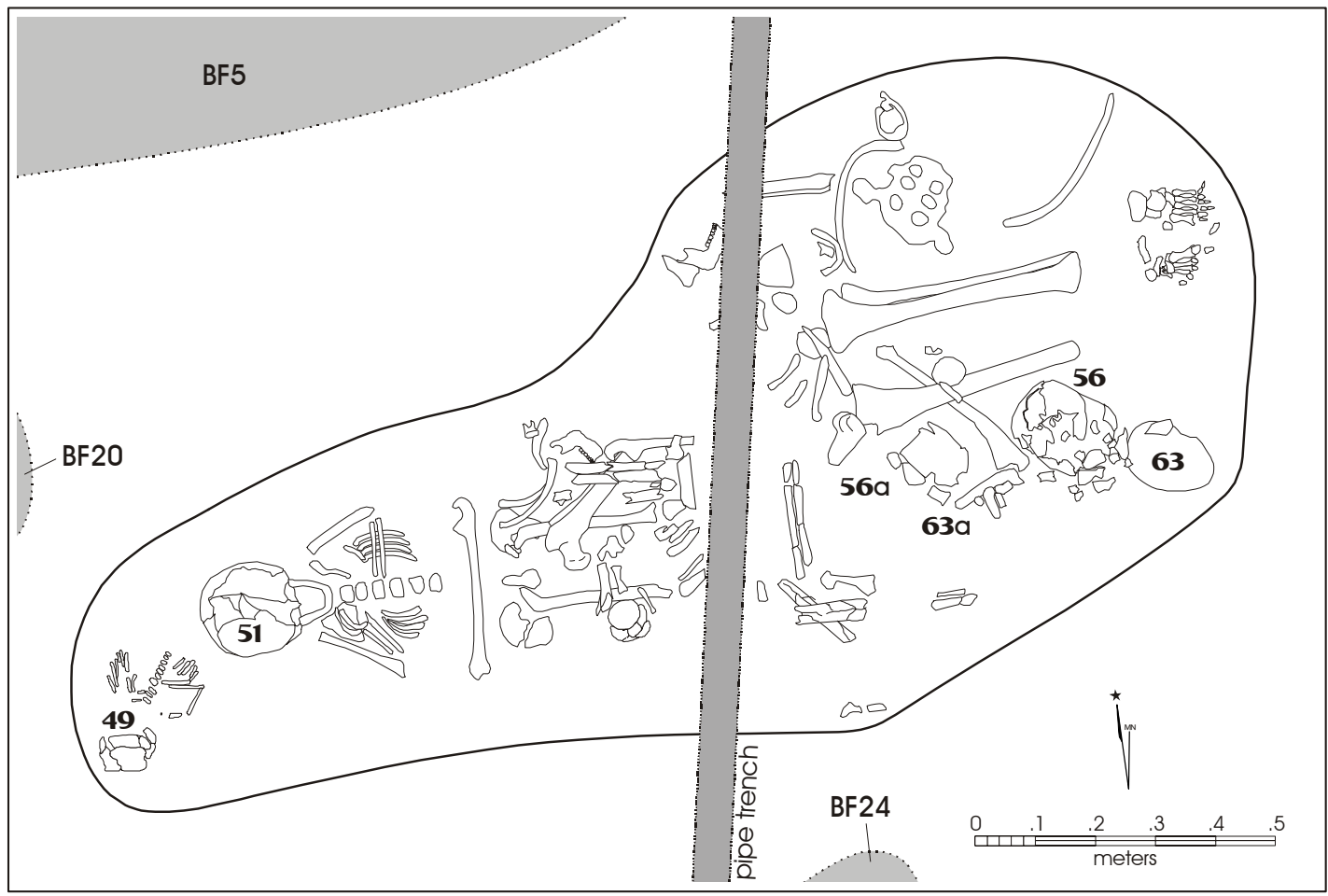

Figure 8c-18. Plan map of Burial Feature 14. 
glass beads (Harris and Harris 1967, \#44 or De Vore 1992 CI/SA/T1/Va), one black glass bead (Harris and Harris 1967, \#50 or De Vore 1992, CI/SA/T1/Vf), one square cut nail and two unidentifiable pieces of metal were recovered from the soil near the burials in the east end of BF 14 (Figure 8c18a). These artifacts were arbitrarily assigned to Burial 56 although they could not be directly associated with any of the individual burials in this feature.

Figure 8c-18a. Beads found in Burial Feature 14.

\section{Burial 51}

Of the six burials associated with BF 14, only Burial 51 retained a semblance of its original, articulated burial position. The skull and upper torso of this individual were uncovered $50 \mathrm{~cm}$ bst in what appears to have been an extended position with the head oriented to the west. These remains have been identified as those of a Native American child between the ages of 2.5-3.5 years of age.

\section{Burial Feature 15}

Burial Feature 15 was located along the northern edge of the church nave (see Figure 8c-1). This feature is $2.45 \mathrm{~m}$ in length and varies from $50-70 \mathrm{~cm}$ in width. Burial Feature 15 is located at the western edge of the southbound lanes of US 77 and extends beneath the curb and sidewalk in front of the current church. A modern water pipe running parallel with the curb had bisected the western quarter of this feature (Figure 8c-19). Five fragments of uncolored window glass and one fragment of aqua colored glass were recovered from the feature fill. Burial Feature 15 contained the remains of four adults and one child.

\section{Burial 52}

Burial 52 is a primary burial in the extended position with arms folded across the chest and head oriented to the west. The skull of this individual was encountered $58 \mathrm{~cm}$ bst. Burial 52 has been identified as a 19-22-year-old female of mixed Native American and Hispanic ancestry.

\section{Burial 48}

The partial remains of a secondary, disarticulated burial, Burial 48 were uncovered at a depth of $45 \mathrm{~cm}$ bst, resting on top of the legs of Burial 52. The skull and articulated left half of Burial 48 was subsequently discovered beneath Burial 52 (Figure 8c-19). These remains have been identified as those of a 30-34-year-old male of probable Native American ancestry.

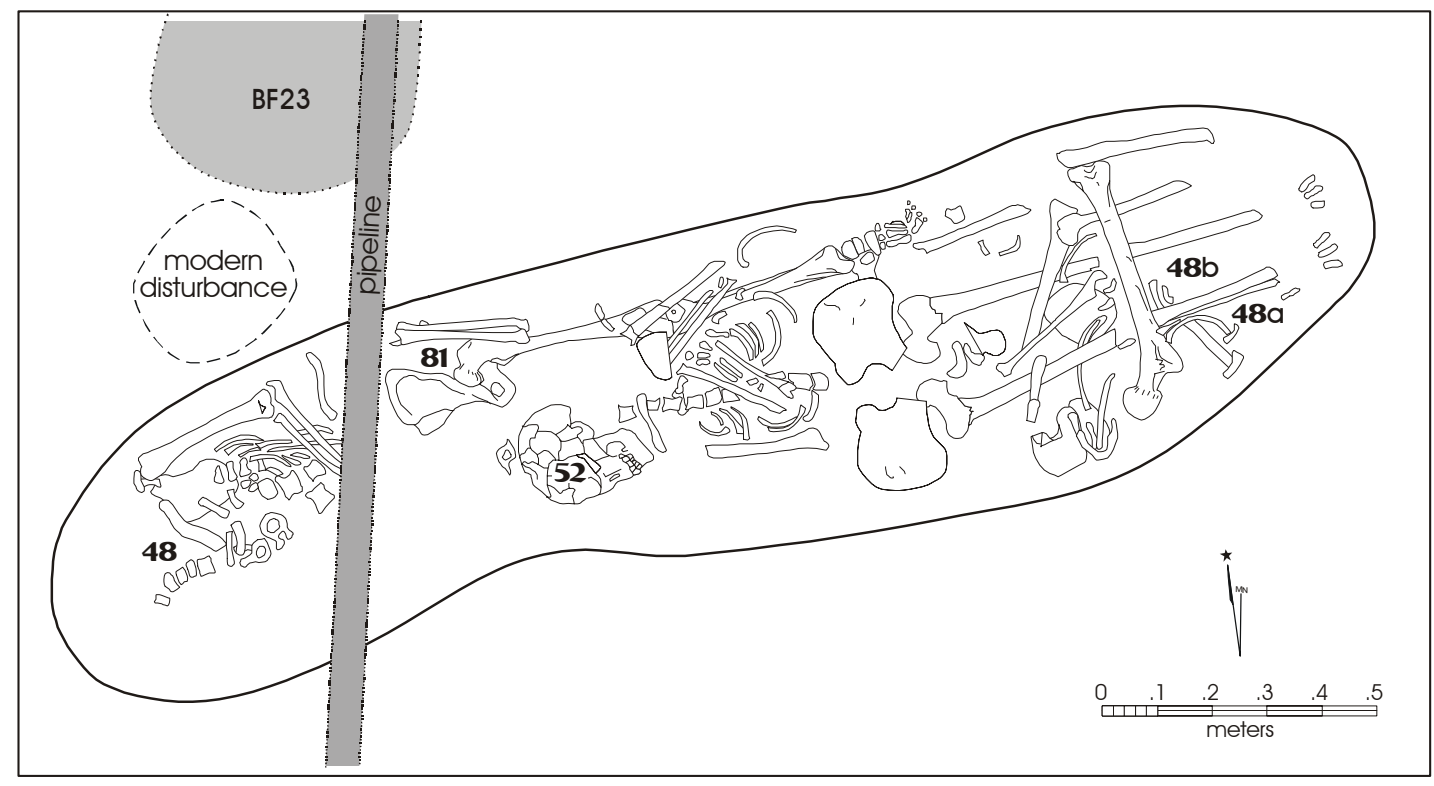

Figure 8c-19. Plan map of Burial Feature 15. 
A cloth covered rectangular piece of copper was recovered at the neck of Burial 48 and a small piece of cloth was found on the proximal end of one of the disarticulated ulna (Figure 8c-19a).

During analysis, skeletal elements from three additional individuals were identified among the disarticulated remains. These are Burial 48a, a 9.5-10.5-year-old male, Burial 48b, a 25-34-year-old female, and Burial 81, a male over the age of 35 . There were insufficient elements present from these burials to identify ancestry.

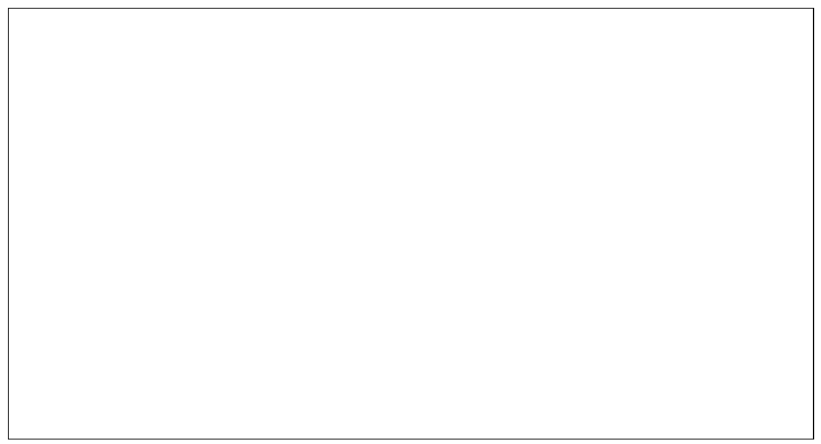

Figure 8c-19a. Cloth covered copper piece found with Burial 48 in Burial Feature 15.

\section{Burial Feature 16}

Burial Feature 16 was a long, narrow, straight-sided feature measuring .56-x-2.84 m located in the center of the nave (see Figure 8c-1). It was only $40 \mathrm{~cm}$ deep, yet it contained the remains and partial remains of 15 articulated, disarticulated, and partially cremated individuals (Figure $8 \mathrm{c}-20$ ). One piece of native ceramics, one sandy paste leadglazed sherd, two pieces of lithic debitage, and 102 faunal bone fragments were recovered from the fill in this feature.

A large clear-glass bead (Figure 8c-20a) was also recovered but could not be directly associated with an individual burial in this feature. This bead measures $12-\mathrm{mm}$ in diameter and is listed on the Harris Bead Chart (Harris and Harris 1967) as \#43-"large, clear, barrel-shaped necklace bead of mandrel-wound, probably pressed facet, simple construction. The surface is pressed into six spiral shaped elements that give a corrugated effect." No bead of this type is illustrated in De Vore (1992).

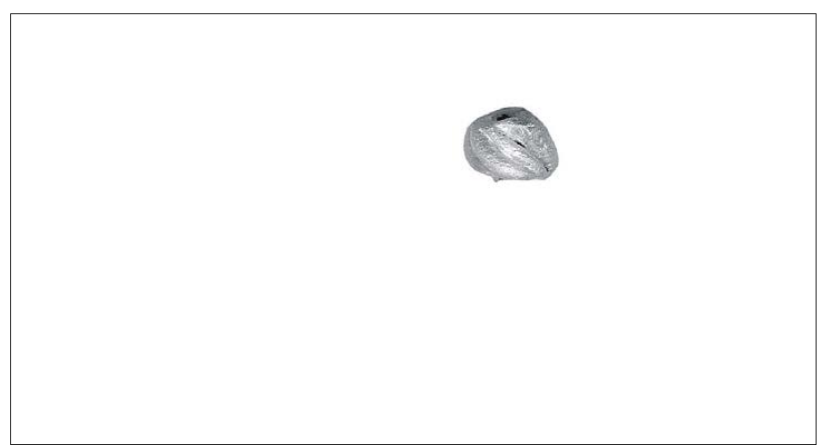

Figure 8c-20a. Beads found in Burial Feature 16.

Due to the condition of the remains in BF 16, burial numbers were assigned only to crania, and postcranial elements that could be directly associated with a numbered cranium were identified with that burial number. Of these, only two, Burial 60 and Burial 93, were distinguishable as complete or partial burials in the field. The remainder of the elements in BF 16 were labeled as commingled ossuary elements for sorting and identification during the analysis phase.

\section{Burial 93}

The skull of Burial 93 was located $42 \mathrm{~cm}$ bst at the western edge of BF 16. This burial was articulated except for elements of the right arm and several ribs that had been disturbed by Burial 83. Burial 93 is identified as a Native American male between the ages of 30-40 at time of death. 


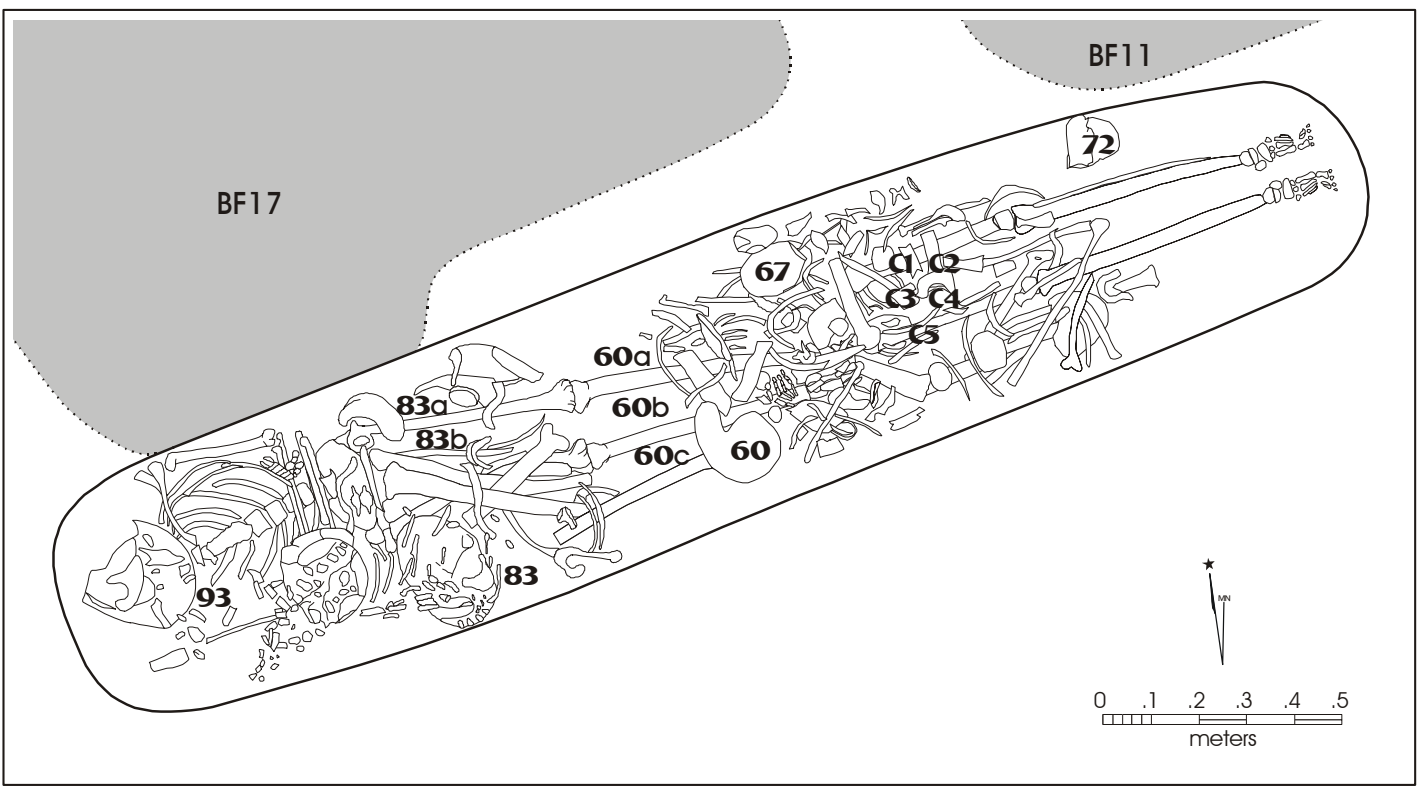

Figure 8c-20. Plan map of Burial Feature 16.

\section{Burial 60}

The skull and first six articulated vertebrae of Burial 60 were found at a depth of $45 \mathrm{~cm}$ bst resting on the lower legs of Burial 93. The articulated right and left femurs, tibias, fibulas, and foot bones visible at the east end of BF 16 are also associated with Burial 60 . Burial 60 has been identified as a 25-34-year-old male of indeterminate ancestry.

The commingled remains of the other 13 individuals in BF 16 were found resting directly on top of the two burials described previously. In most cases, full demographic and ancestral information could not be established for the individuals. The information that was obtained during analysis is given in Table $8 \mathrm{c}-2$.

For details of the osteological and pathological condition see Meadows Jantz et al. (Volume II). The field observations given here explain the interpretation of the burials represented in BF 16. Many of the bones, including the maxilla of skull Number 67, were discolored from being burned. The degree of discoloration varied from a thin black outer coating to the white of completely burned bone. Burning was also noted on the ends of several long bones. The majority of the disarticulated elements were broken, many into pieces less than 5-cm long. One articulated hand and an isolated articulated finger were found among the commingled elements suggesting they had been separated from the rest of the body, but were still fleshed when buried.

The size and shape of this feature suggests that the grave was excavated at one time for the purpose of holding the multiple remains found there. The positioning and condition of the remains, along with the pathologies described in Volume II, indicate these individuals met with traumatic deaths. From the Burial Records we know that the "bones" of 15 persons "killed on the ranch of the Diesmero 
(tithesman) on the banks of the Nueces by Barbarian Indians" were buried at Refugio. The record lists the names of the individuals but does not supply the age or sex. From the names it would appear that there were possibly five females and ten males in this group. This similar number of identified remains matches (somewhat) with those found in BF 16. At least two children are identified in the record: Gertrudis daughter of Cristobal Castillo, and Jose Maria Oloya, daughter of Perfecto Oloya the shoemaker. Three children were identified during osteological analysis, one identified as female and two classified as indeterminate. The age of the female is estimated to be $12.5-13.5$ at the time of death, while the indeterminate individuals are estimated to be $10.5-$
11.5 and 7.5-8.5 years of age, respectively. A .5-1.5-yearold infant was also identified during the analysis portion of the investigation. Osteological analysis of Burial Feature 16 also identified two individuals as being of Native American ancestry, and two individuals as being of possible Native American ancestry. Three of the individuals on the burial record within this group are listed by first name onlyArellano, Gerarldo, and Morillo-suggesting these individuals may have been of Native American ancestry. These elements combine to strongly suggest that this burial feature could contain the remains of the 15 individuals from the 1814 massacre who are listed in the Mission Refugio Burial Records.

Table 8c-2. Demographic profile from Burial Feature 16

\begin{tabular}{|c|c|c|c|c|}
\hline BF \# & Burial \# & Sex & Age & Ancestry \\
\hline 16 & 60 & M & $25-34$ & indet \\
\hline 16 & $60 \mathrm{a}$ & $\mathrm{M}$ & $25-34$ & Poss. NA \\
\hline 16 & $60 \mathrm{~b}$ & indet & $7.5-8.5$ & indet \\
\hline 16 & $60 \mathrm{c}$ & indet & $.5-1.5$ & indet \\
\hline 16 & 83 & $\mathrm{M}$ & $30-39$ & Poss. NA \\
\hline 16 & $83 \mathrm{a}$ & $\mathrm{F}$ & $18-22$ & NA \\
\hline 16 & $83 \mathrm{~b}$ & indet & $10.5-11.5$ & indet \\
\hline 16 & 67 & $\mathrm{~F}$ & $12.5-13.5$ & indet \\
\hline 16 & 72 & $\mathrm{~F}$ & $17-19$ & indet \\
\hline 16 & 93 & $\mathrm{M}$ & $30-40$ & NA \\
\hline 16 & CRE1 & $\mathrm{F}$ & $25-34$ & indet \\
\hline 16 & CRE2 & $\mathrm{F}$ & $30-39$ & indet \\
\hline 16 & CRE3 & $\mathrm{M}$ & $22-30$ & indet \\
\hline 16 & CRE4 & M & $25-29$ & indet \\
\hline 16 & CRE5 & F & $25-34$ & indet \\
\hline
\end{tabular}




\section{Burial Feature 17}

Burial Feature 17 was located just to the north of BF 16 (see Figure 8c-1). It was an irregularly shaped feature roughly $110-\mathrm{x}-170 \mathrm{~cm}$ in size. A mixture of Colonial and post-Colonial artifacts were recovered near the graded surface of this feature. They include two native sherds, one piece of Galera lead glaze, two pieces of undecorated majolica, three pieces of lithic debitage, and 46 animal bone fragments. Window glass fragments, two pieces of clay sewer pipe, one fragment of post-1870 Albany-glazed stoneware, and nine cut nails were also recovered. Burial Feature 17 contained four articulated and six disturbed burials (Figure 8c-21). No burial artifacts or evidence of coffins were found in direct association with any of the interments.

\section{Burial 62}

Burial 62 was encountered $52 \mathrm{~cm}$ bst on the southern side of BF 17. This burial was in the extended position with arms folded across the midsection. The missing skull and the shifting of the upper torso of this individual are attributed to posthumous disturbance during subsequent interments. Although several cranial fragments were recovered from around this burial, none could be directly associated with the postcranial elements of Burial 62. This individual has been identified as a 30-45-year-old male, possibly of Native American ancestry.

\section{Burials 74 and 71}

Burial 74 represents the disarticulated, partial remains of a 9-11-year-old individual, possibly of Native American ancestry. Elements from Burial 74 were scattered across the torso and along the right side of Burial 62 at the southern edge of BF 17. Fragments from the skull of an individual (Burial 71) between the ages of 2-4 were also found in the area of the left pelvis of Burial 62.

\section{Burial 70}

Burial 70 is that of a newborn infant found at a depth of 52 $\mathrm{cm}$ bst directly beneath the skeletal elements of Burial 74 . The bones of this infant were in fragmented condition but appeared virtually articulated and complete.

\section{Burial 79}

Burial 79 is a newborn -.5-year-old infant encountered 60 $\mathrm{cm}$ bst to the west of Burial 86 and slightly north of Burial 62. This complete, articulated burial was in the extended position with arms folded across the chest and head oriented to the east.

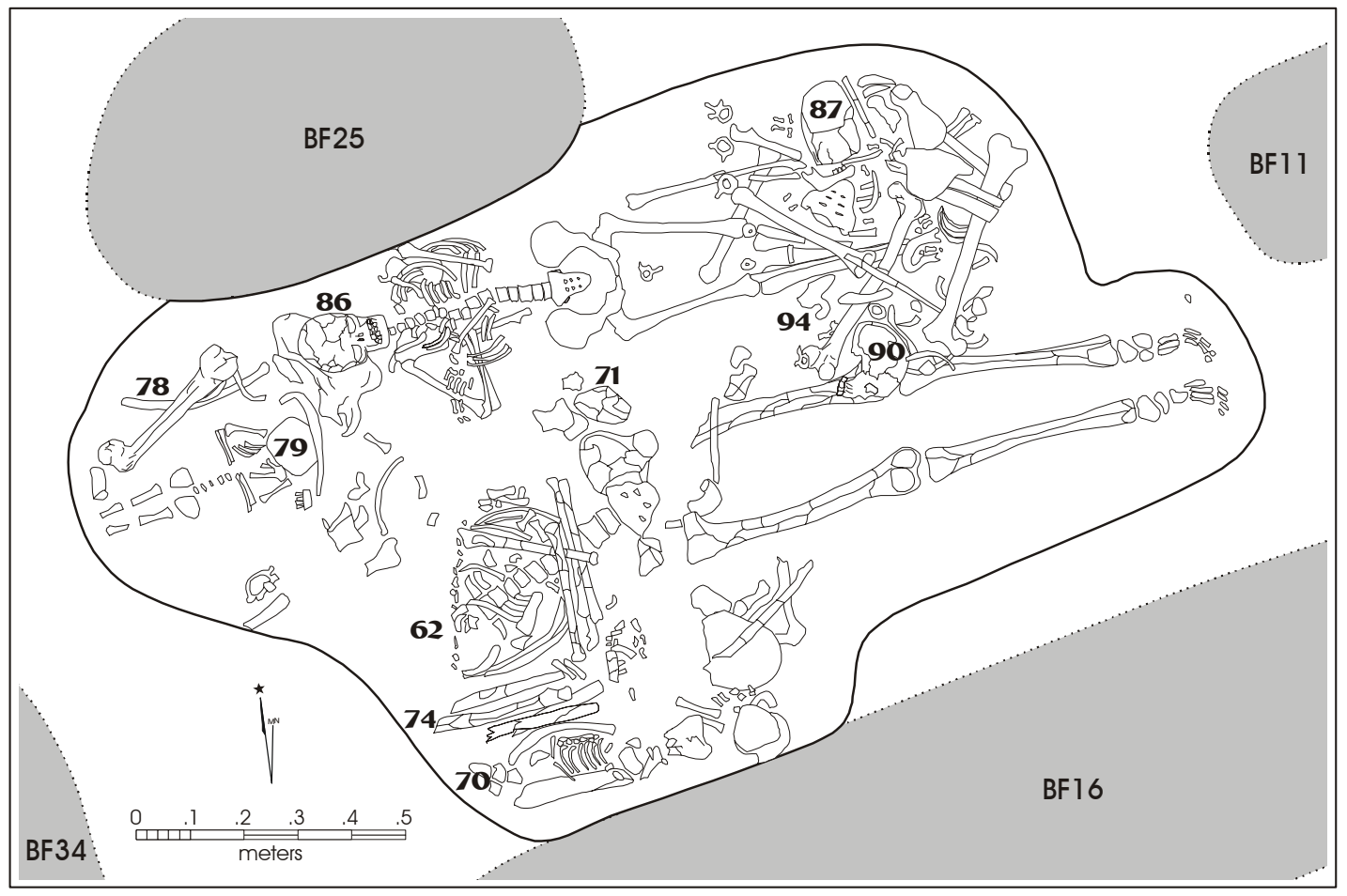

Figure 8c-21. Plan map of Burial Feature 17. 


\section{Burial 78}

Burial 78 represents the disarticulated, partial remains found scattered around the head and right side of Burial 79. These remains have been identified as those of a Native American male between the ages of 30-34 at time of death.

\section{Burial 86}

Burial 86 was encountered $63 \mathrm{~cm}$ bst just north of Burial 62 at the northern edge of BF 17 . This primary burial was in the extended position with arms folded across the chest and head oriented to the west. Burial 86 has been identified as a Native American female between the ages of 30-39 at time of death.

\section{Burials 87, 90, and 94}

Three commingled, secondary burials were resting on the lower legs of Burial 86 where they had been re-interred following the burial of Burial 86. Burial 87 is identified as a 27-35 male of mixed Hispanic and Native American ancestry. Burial 90 represents the remains of a Native American male between 35-45 when he died. And Burial 94 is comprised of several fetal long bones found mixed among the other remains in the northeast section of BF 17.

\section{Burial Feature 18}

Burial Feature 18 was a small, $23-x-50 \mathrm{~cm}$, oval feature discovered slightly above and adjacent to the south edge of BF 12 (see Figure 8c-1). This feature contained the remains of a single newborn -.5-year-old infant, Burial 61, who had been buried in the extended position with head oriented to the east (Figure 8c-22). The lower right extremities of this infant had been displaced and the burial feature disturbed, possibly when BF 12 was enlarged for the interment of Burial 50.

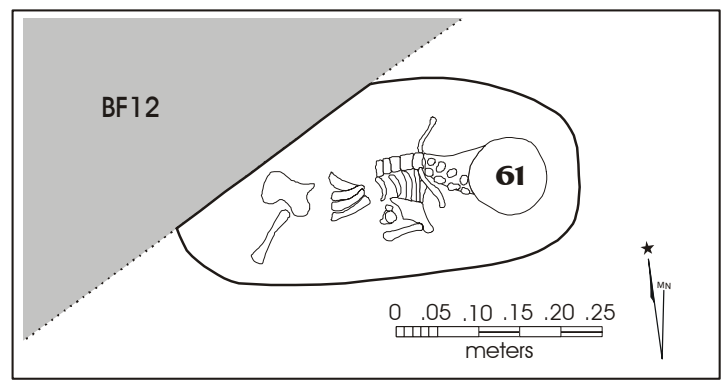

Figure 8c-22. Plan map of Burial Feature 18.

\section{Burial Feature 19}

Burial Feature 19 was a small, irregularly shaped feature located near the center of the transepts, south of BF 11 and west of BF 5 (see Figure 8c-1). This feature measured $.75-\mathrm{X}-.35 \mathrm{~m}$ and contained two infant burials (Figure $8 \mathrm{c}-23)$. No evidence of a coffin was associated with either burial although three fragments of native ceramics, not directly associated with the burials, were recovered from the feature fill.

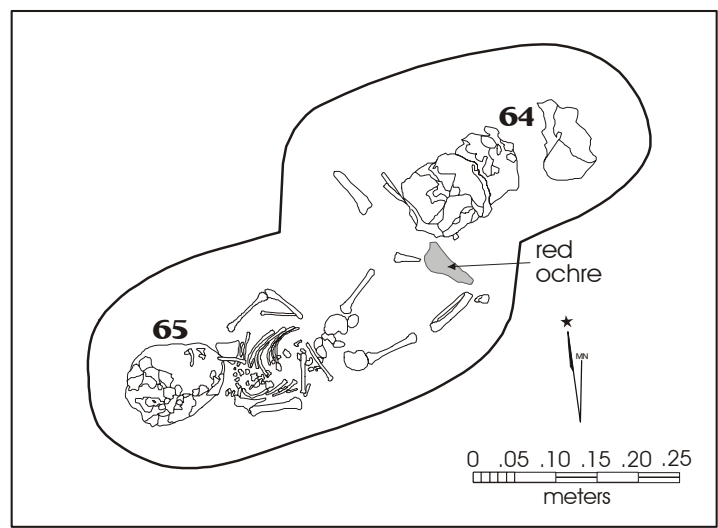

Figure 8c-23. Plan map of Burial Feature 19.

\section{Burial 64}

Burial 64 was encountered at a depth of $62 \mathrm{~cm}$ bst in the eastern half of BF 19. The remains of this newborn -.5year-old infant were represented only by a few cranial and postcranial elements that were highly fragmented. It was not possible to determine the original position or orientation of Burial 64 as it had been extensively disturbed, presumably by the interment of Burial 65 .

\section{Burial 65}

Burial 65 was encountered at a depth of $60 \mathrm{~cm}$ bst in the western half of BF 19. This newborn -.5-year-old infant was articulated and in an extended position with arms folded across the chest and head oriented to the west. Flecks of red ochre were noted throughout the soil immediately surrounding Burial 65 and a large concentration of red ochre was recovered from between the feet of the infant. 


\section{Burial Feature 20}

Burial Feature 20 was an oblong feature located west of BF 14 in the church transept (see Figure 8c-1). This feature measured $1.62-\mathrm{x}-.50 \mathrm{~m}$ and contained the remains of a single individual, Burial 2. Numerous artifacts were recovered from the fill above Burial 2. These include ten Native American ceramic sherds, one majolica sherd, four pieces of chert debitage, numerous animal bone fragments, and five pieces of red Colonial-period brick.

\section{Burial 2}

The skull of Burial 2 was one of the crania encountered when human remains were first identified during Gradall investigations beneath the pavement of US 77. This skull was removed and its position marked during the initial salvage excavations. Subsequently, the entire burial feature was uncovered and the postcranial elements were removed.

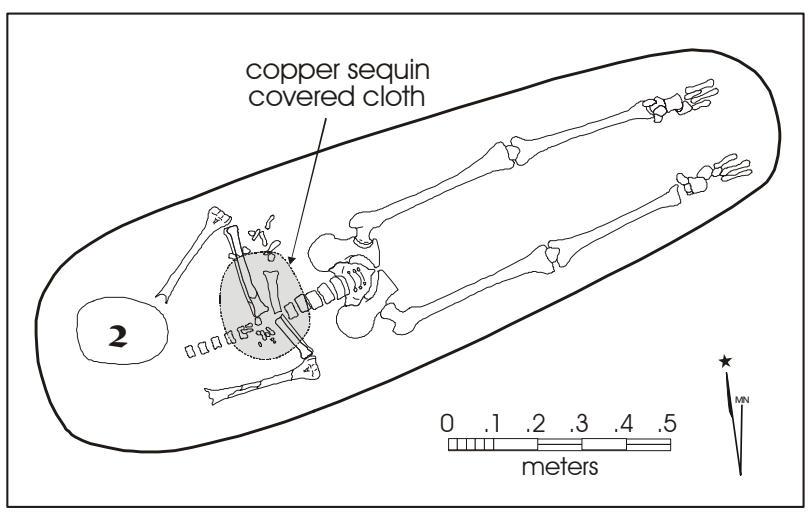

Figure 8c-24. Plan map of Burial Feature 20.
This individual was buried in the extended position with arms crossed, left over right, at the midsection and head oriented to the west (Figure 8c-24). Burial 2 has been identified as a male who was over 60 years of age when he died. He is the only individual recovered during these investigations with possible European or non-Native skeletal characteristics. One non-Native male over 60 years of age appears on the extant burial records. José Casimiro Gonzales was buried on September 8, 1811 at the age of 61. His cause of death was listed as apoplexy and he was survived by his widow, Leonarda Montalvo. It is possible that Burial 2 represents the remains of José Casimiro Gonzales.

The recovery of one possible coffin nail and wooden fragments from BF 20 suggest that Burial 2 was interred in a coffin. Several large pieces of cotton cloth were found covering the hands and forearms of this individual. The cloth is made of cotton and faint traces of a blue-colored design are still visible in several areas (Figure 8c-24a). Over 100 tiny one-holed copper discs similar to sequins (Figure 8c24a) were found with the cloth and appear to have originally been sewn onto the material. Hand-sewn stitches connect two of the pieces of cloth, suggesting this material may have been sewn around the hands of this individual before he was buried.

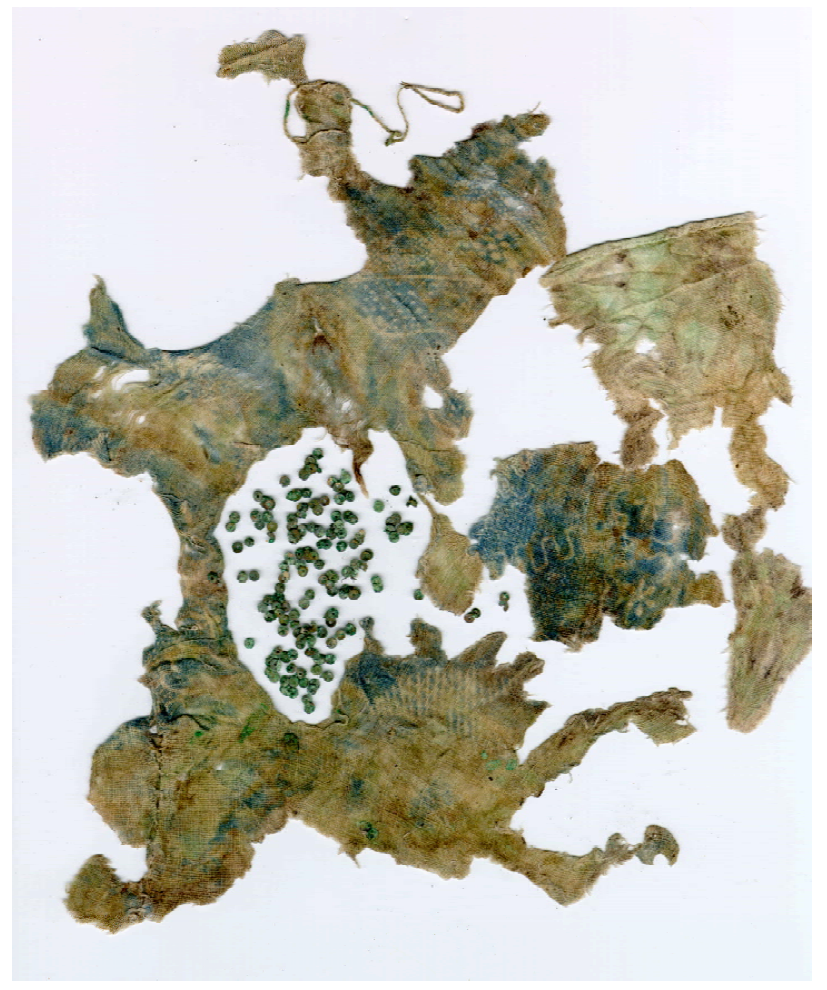

Figure 8c-24a. Cloth and copper disks found with Burial 2. 


\section{Burial Feature 21}

Burial Feature 21 was located just east of BF 22, in what was originally the south transept of the chapel (see Figure $8 \mathrm{c}-1$ ). Burial Feature 21 measured 2.61-x- $.54 \mathrm{~m}$ and revealed evidence of being enlarged at least once to accommodate the three individuals buried there. Unlike the other burial features in this area, the water pipe, which bisects the eastern third of this feature, was above the burials and did not cause damage to the burials. No artifacts were found in BF 21 .

\section{Burial 69}

Burial 69 was located in the western end of BF 21 (Figure $8 \mathrm{c}-25)$. This is a complete, undisturbed adult burial interred in the extended position with arms crossed at the midsection, head oriented to the west and facing north. Burial 69 has been identified as that of a Native American male who was between the ages of 35-40 at time of death. This burial came after and intruded into Burial 75 and 76.

\section{Burial 76}

Burial 76 represents the partially articulated remains of a 30-35-year-old Native American female. The skull and elements on the left side of the upper torso of this individual had been disturbed by the interment of Burial 69 and were found both above and below the lower legs of this intrusive burial, commingled with the disarticulated remains of Burial 75. The right side and lower extremities of Burial 76 remained in an articulated position and indicated this individual was buried in the extended position with head oriented to the west, arms bent and hands folded over the midsection.

\section{Burial 75}

Burial 75 represents the disarticulated, complete remains of a second female who was between the ages of 20-29 at time of death and who was possibly of Native American ancestry. The crania and most of the postcranial elements of Burial 75 were resting directly on top of the lower legs and feet of Burial 69, although a few smaller elements were found beside and beneath this burial also.

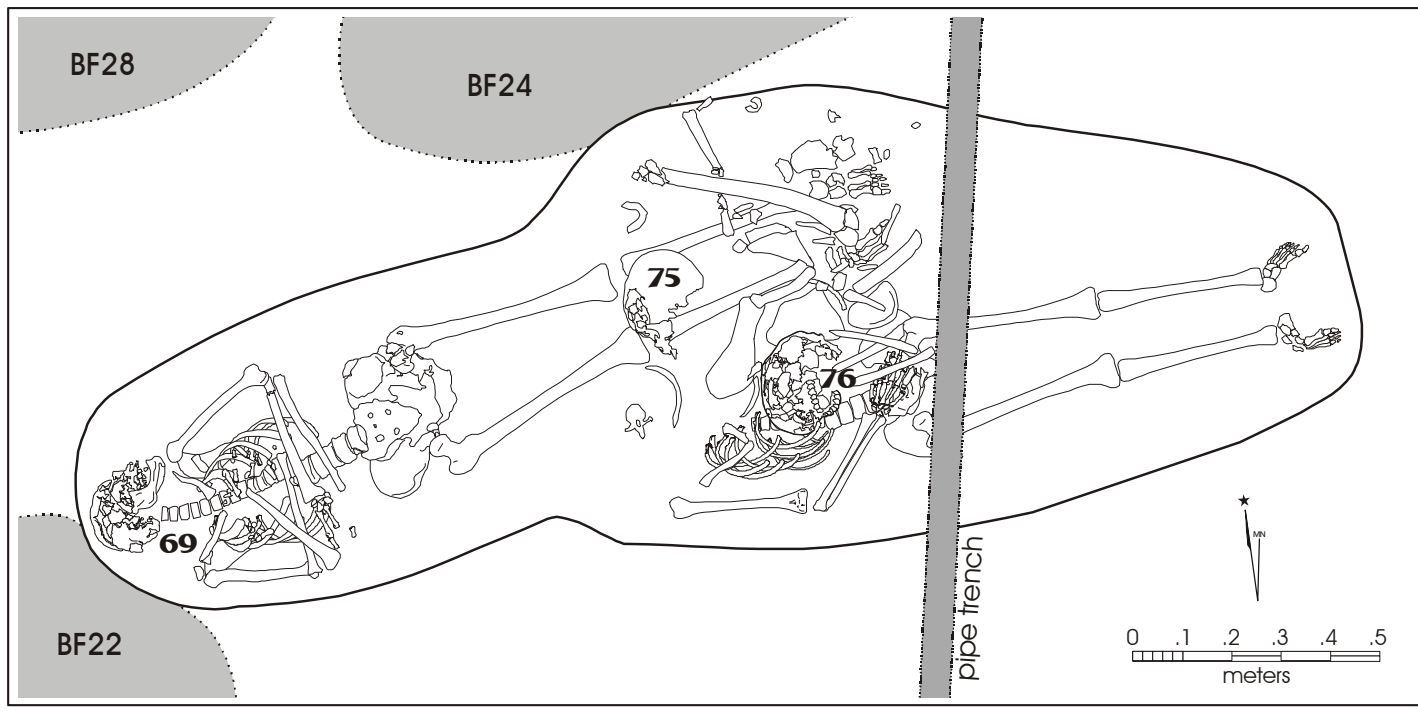

Figure 8c-25. Plan map of Burial Feature 21. 


\section{Burial Feature 22}

As mentioned earlier, Burial Feature 22 was identified as part of the foundation trench for the south wall of the 1796 mission chapel. It had been used for burials some time after the stones from the church foundation had been removed for use elsewhere. Burial Feature 22 is $8-\mathrm{m}$ long. It is $1.36 \mathrm{~m}$ wide for most of its length, flaring to a maximum width of $2.48 \mathrm{~m}$ at its east end (see Figure $8 \mathrm{c}-1$ ). The fill in the wall trench extends to a depth of $1 \mathrm{~m}$ bst, but the majority of the burials were located within the upper $60 \mathrm{~cm}$ of the fill deposit with only the most deeply buried one, Burial 129, actually resting on the underlying sterile clay. Numerous Colonial-period and modern artifacts not directly associated with the burials were found throughout the fill of BF 22 (see Appendix c).
Burial Feature 22 contained the remains of 20 individuals, of which nine were located at the eastern end of the feature, ten near the center of the feature, and one located at the western end (Figure 8c-26). There is no doubt, however, that the these individuals who were interred in the soft soil of this footing trench were associated with the mission and were buried there while the mission was still in operation. There appears to be no difference in the positioning, orientation or ancestral composition of the burials found in this location that would indicate they are part of a separate burial population. The intrusive nature of many of these burials also indicates that they are not the result of simultaneous interments.

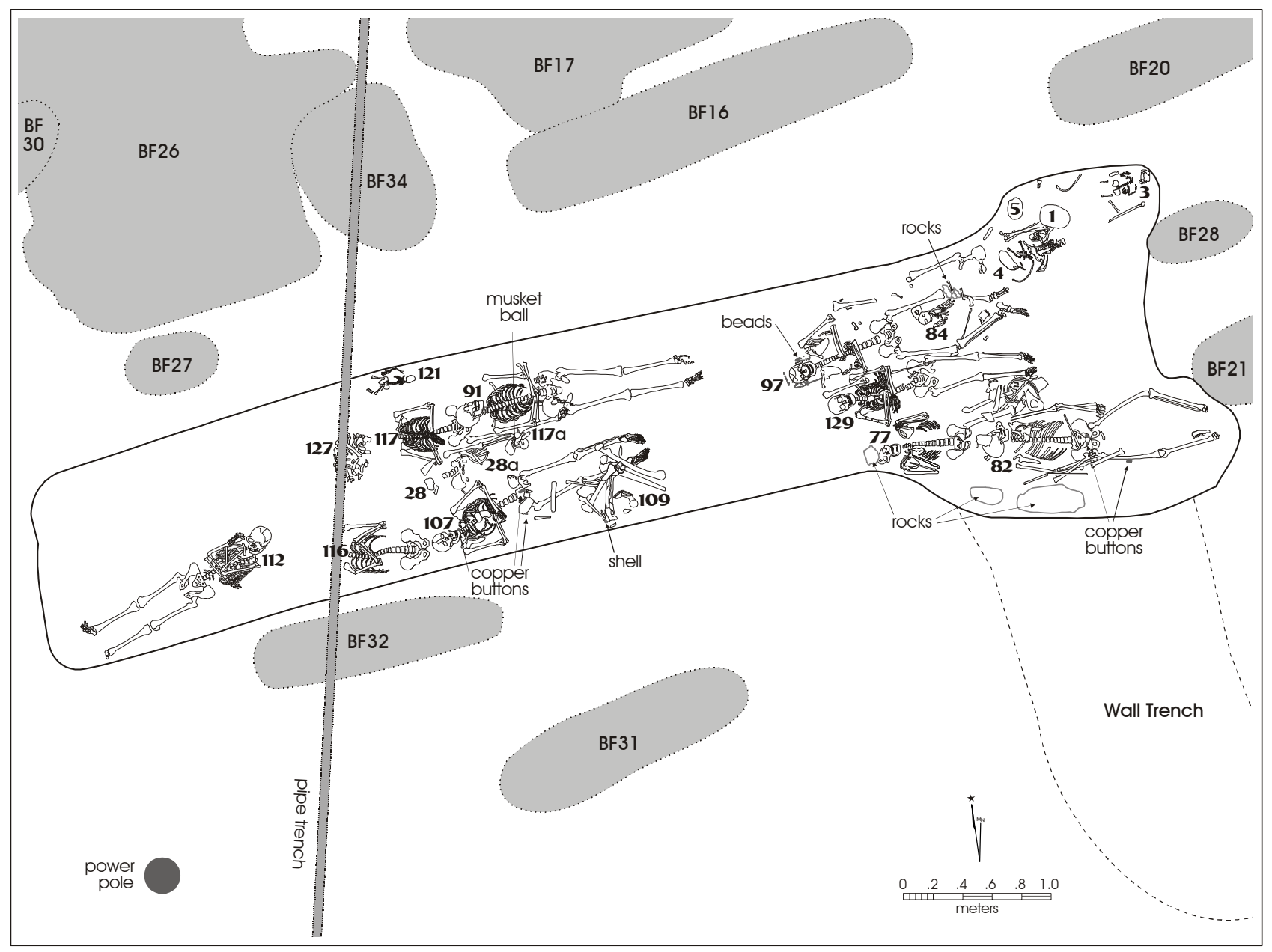

Figure 8c-26. Plan map of Burial Feature 22. 


\section{Burials 1, 3, 4, and 5}

Burials 1, 3, 4, and 5 are located in the northeast section of BF 22 (Figure 8c-27). These burials represent four of the original five identified and partially exhumed during the initial salvage investigation. Burials 4 and 5 are the disturbed remains of two newborn -.5-year-old infants that were found near the skull of Burial 1. Burial 3 is another newborn -.5year-old infant found $20 \mathrm{~cm}$ east of the skull of Burial 1 . This infant was articulated in the extended position with arms folded across the chest and head oriented to the east. Like Burial 2, the skull of Burial 1 was removed and its position marked during the initial salvage excavations. Subsequently, postcranial elements from the right side of Burial 1 were discovered in BF 22. These elements were in the correct anatomical position at the left side of Burial 97, but had rotated downward to such a degree that the individual appeared to be resting on its side (Figure 8c-27). The position of these elements indicated that Burial 1 was originally interred in the extended position with the head to the east. The remaining postcranial elements from the left side of Burial 1 were encountered just above the lower legs of Burial 129. Burial 1 has been identified as a Native American female who was between 20-24 years old at the time she died. Nodules of red ochre were recovered from the fill around the skull of this individual.

\section{Burial 97}

Burial 97 was located $81 \mathrm{~cm}$ bst to the south of Burial 1 and above Burial 129. The interment of Burial 97 probably caused the majority of the displacement noted above for Burial 1. Burial 97 was found in the extended position with arms crossed at the midsection and head oriented to the west. Evidence of posthumous shifting was displayed in the bent position of the right leg and the breaks in the left tibia and fibula (Figure 8c-27). Fragments of wood were recovered from beneath the left foot and right leg, suggesting this individual had been buried in a coffin. Burial 97 has been identified as 25-30-year-old male of indeterminate ancestry. The disarticulated, partial remains of newborn -.5-year-old infant, Burial 84, were found at a depth of $66 \mathrm{~cm}$ bst above the left femur of Burial 97. The infant burial may account for the disturbance noted to Burial 97.

An array of beads, interpreted as some sort of head covering, was recovered beneath the back of the skull of Burial 97. This object consisted of 286 4-mm white-glass beads listed

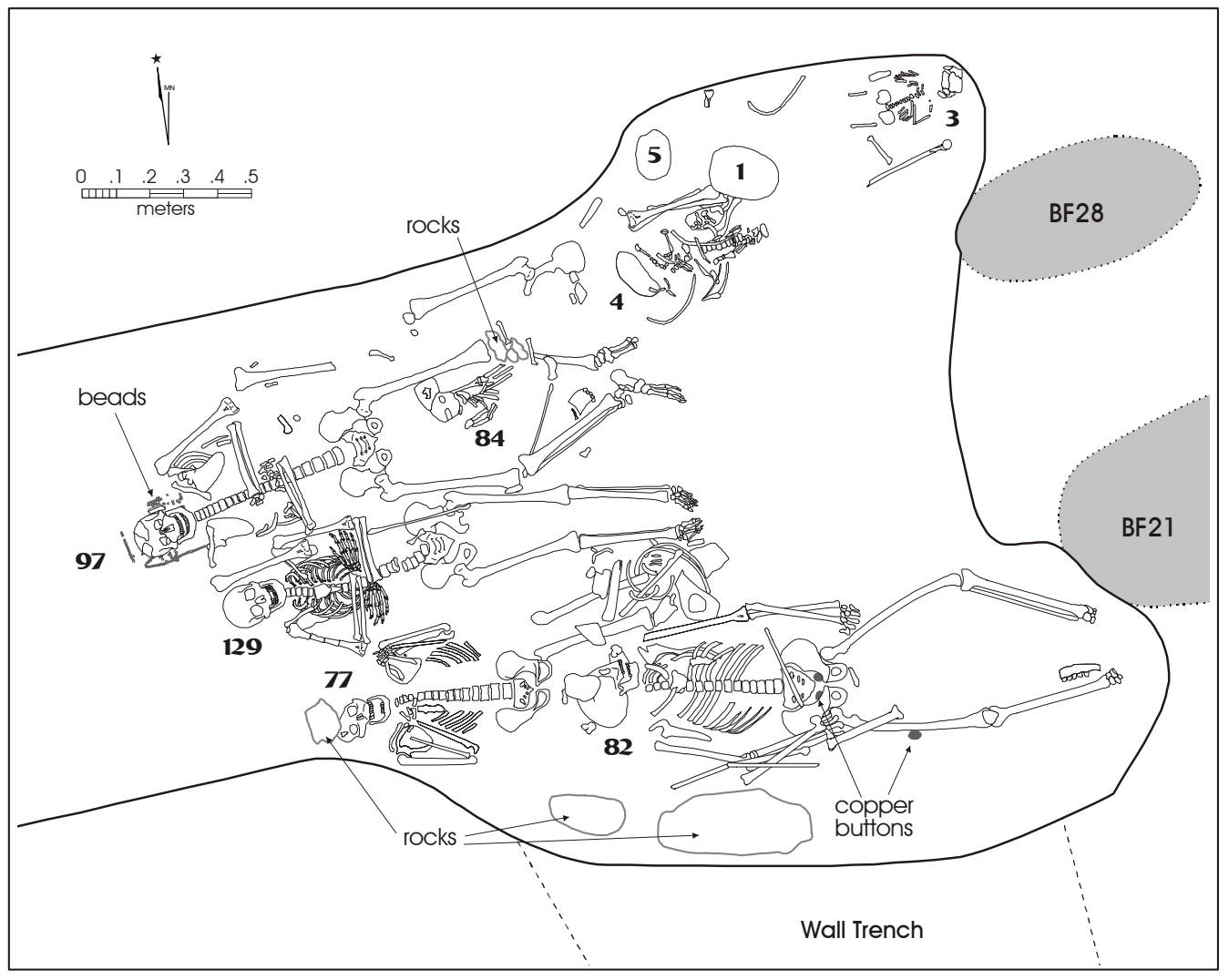

Figure 8c-27. East section of Burial Feature 22. 
on the Harris Bead Chart (Harris and Harris 1967) as \#137medium white, opaque, barrel-shaped garter beads of simple construction (Figure 8c-27a). Harris's \#137 bead corresponds most closely with type CIV/SA/T1/Va used by De Vore in his classifications (De Vore 1992). Eight 2.5$\mathrm{mm}$ blue glass beads were found in groups of two and three interspersed among the white beads. These beads are similar to the \#46 small, peacock blue, opaque, donut-shaped beads on the Harris Chart or type CI/SA/T1/Vc (De Vore 1992).

\section{Burial 129}

Burial 129 was encountered at a depth of $88 \mathrm{~cm}$ bst, below and slight slightly south of Burial 97 (Figure 8c-27). This was the most deeply buried of the individuals in BF 22 and was resting on the underlying sterile clay at the bottom of the wall trench. Burial 129 was in the extended position with arms crossed at the midsection and head oriented to the west. This burial has been identified as a young Hispanic male between the ages of 14-17 at time of death. Six small beads were recovered from the fill immediately around this burial. Two were red, opaque donut-shaped glass beads with an inner layer of green translucent glass, classified by Harris and Harris (1967) as type \#51, "Cornaline d'Aleppo". Harris's \#51 bead corresponds with type CI/SB/T4/Va used by De Vore in his classifications (De Vore 1992). Two were small, translucent amber beads (\#43) (no De Vore equivalent) and two were \#50, small, donut-shaped, black opaque beads (Harris and Harris 1967) similar to De Vore's CI/SA/T1/Vf (De Vore 1992). No evidence of a coffin was found with this individual.

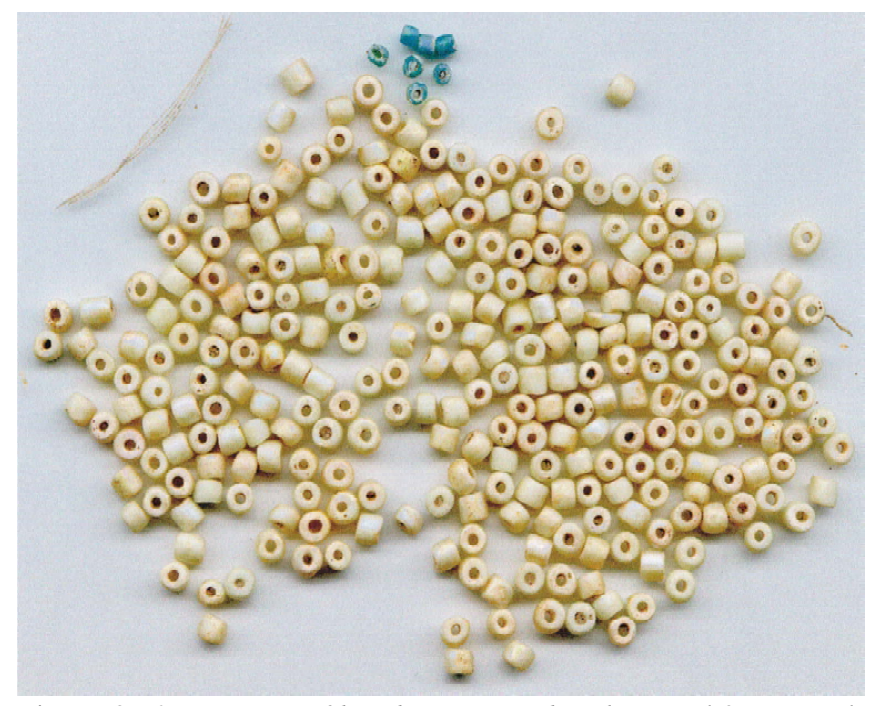

Figure 8c-27a. Array of beads recovered with Burial 97, Burial Feature 22 (Above beading strand and individual blue beads).

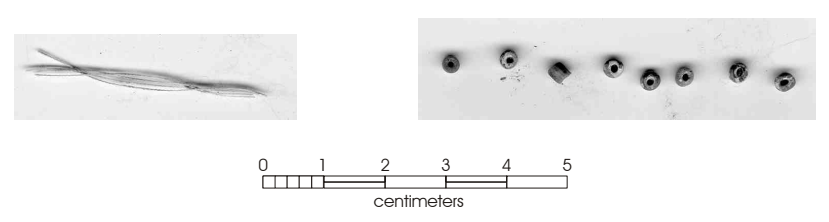

\section{Burial 77}

Burial 77 was located $51 \mathrm{~cm}$ bst, above and south of Burial 129 at the south edge of BF 22 (Figure 8c-27). A large, $20-\mathrm{x}-10-\mathrm{cm}$, rock rested directly on the skull of this individual. This rock may be the result of modern disturbance, but numerous smaller rocks were present throughout the fill surrounding Burial 77, and are probably remnants of the footing trench. The upper torso of Burial 77 was articulated in the extended position with head to the west, arms folded, and hands resting below the chin. Elements of the lower extremities of this individual were found $80 \mathrm{~cm}$ bst, neatly stacked at the right side of Burial 82 . These elements were partially covered by two large foundation stones that had perhaps fallen inward when they were undermined during the interment of Burial 82 . Burial 77 has been identified as a 45-49-year-old male, possibly of Native American ancestry. A large unidentified piece of rusted metal, possibly representing a piece of casket hardware, was recovered near the skull of this individual.

\section{Burial 82}

The skull of Burial 82 was encountered at a depth of $77 \mathrm{~cm}$ bst, five $\mathrm{cm}$ from the truncated torso of Burial 77 (Figure $8 c-27)$. Burial 82 has been identified as a Hispanic male between the ages of 30-39 at the time of his death. This individual was buried in the extended position, facing north with his head to the west and his arms extended at his sides. Three 2.6-cm centimeter brass trouser buttons were found with Burial 82 (see Figure 8c-27). Two were in the pelvic area and one at the side of the right femur. No evidence of a coffin was found with this burial. Evidence of scalping was noted during analysis of Burial 82 (see Volume II). The burial records show that Pedro Espinosa the husband of Maria de Juana Mexias (Jesusa Mexia) was "killed by Indians near the mission" (see Chapter 4). He was 35 years old when he was buried on May 31, 1816. It is probable that the remains identified during the excavation as Burial 82 are those of Pedro Espinosa. 


\section{Burial 91}

Burial 91 was encountered $56 \mathrm{~cm}$ bst in the central part of BF 22 (Figure 8c-28). This burial is that of a Native American male who was between the ages of 40-50 when he died. He was buried in the extended position with head oriented to the west and arms folded across his midsection. No personal artifacts or evidence of a coffin was found with this burial.

\section{Burial 117}

Burial 117 was located at a depth of $80 \mathrm{~cm}$ bst directly below Burial 91 (Figure 8c-28). There was no evidence that this burial had been disturbed by the later interment of Burial 91. All postcranial elements were present in articulated, anatomically correct positioning, but the skull of this individual, however, was missing -perhaps as a result of the installation of the water pipe that bisects the western third of this burial feature. Burial 117 was in the extended position with arms folded across the midsection and the head would have been oriented to the west. This individual has been identified as a female of mixed Native American and Hispanic ancestry who was over the age of 60 at the time of death.

\section{Burial 121}

Burial 121 was located $65 \mathrm{~cm}$ bst, north and slightly above Burial 117 at the north edge of BF 22 (Figure 8c-28). This burial has been identified as that of a newborn -.5-year-old infant interred in the extended position with arms to the side and head oriented to the east. The left half of this burial had been disturbed by the interment of Burial 117. Elements from two other newborn -.5-year-old infants, Burials 28a and $117 \mathrm{a}$, were identified during analysis.

\section{Burial 28}

The disturbed remains of Burial 28 were encountered just below the graded surface in the center of BF 22 (Figure $8 \mathrm{c}-28)$. This burial had been disturbed most recently by road construction activities and historically by the interment of Burial 91 to the north and Burial 107 to the south. Fragments of the skull were recovered and only the left arm and left side of the pelvis remained in an articulated position. This positioning indicated that Burial 28 had originally been buried in the extended position with arms extended at the side and hands folded over the stomach. These partial remains have been identified as those of a young adult male of indeterminate ancestry. A lead musket ball was found in situ resting on the sciatic of this individual and a $1.5-\mathrm{x}-.5$ $\mathrm{cm}$, irregularly shaped lead fragment was found in the soil in what would have been the chest area of this young adult male (Figure 8c-28a).

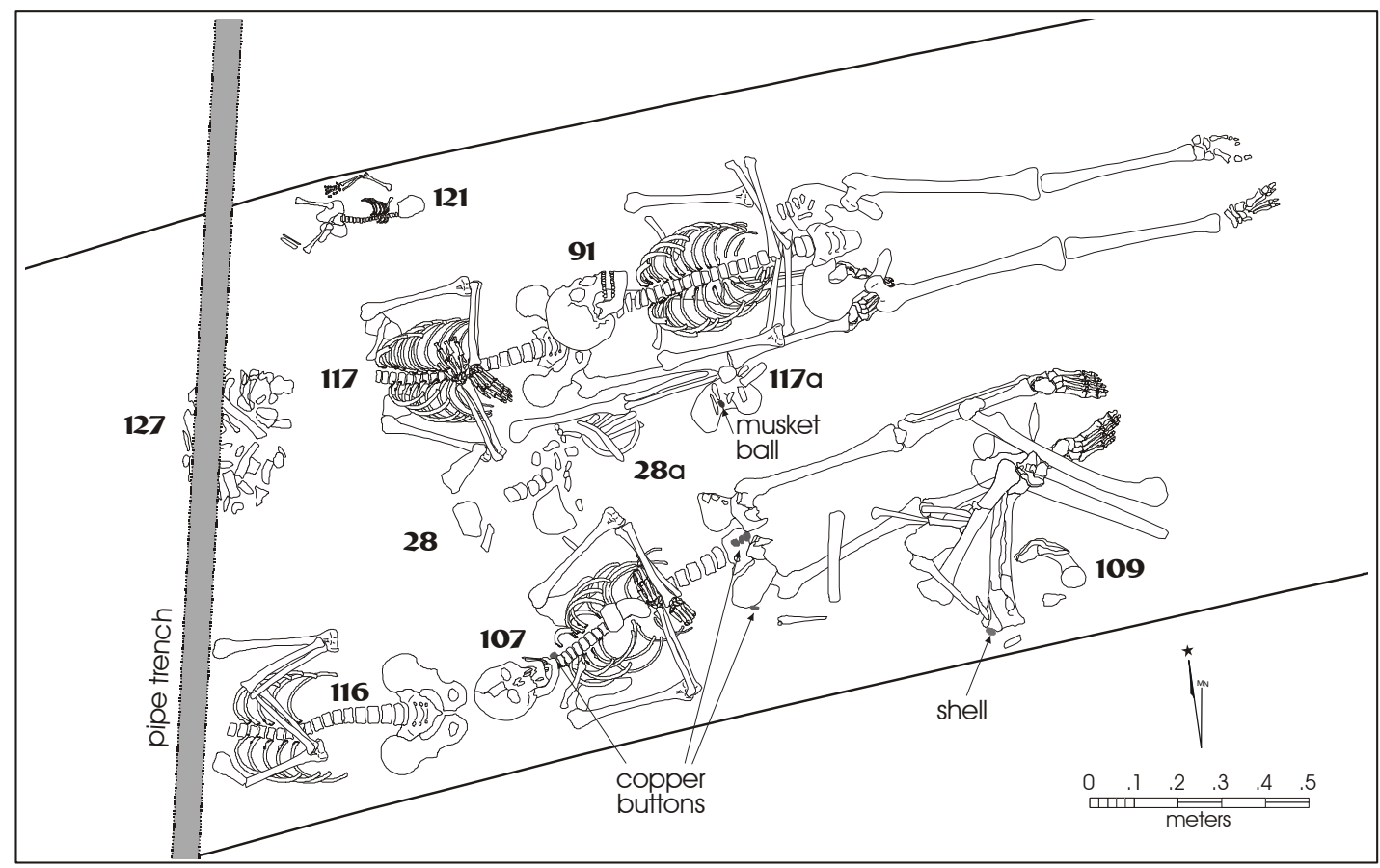

Figure 8c-28. Central section of Burial Feature 22. 


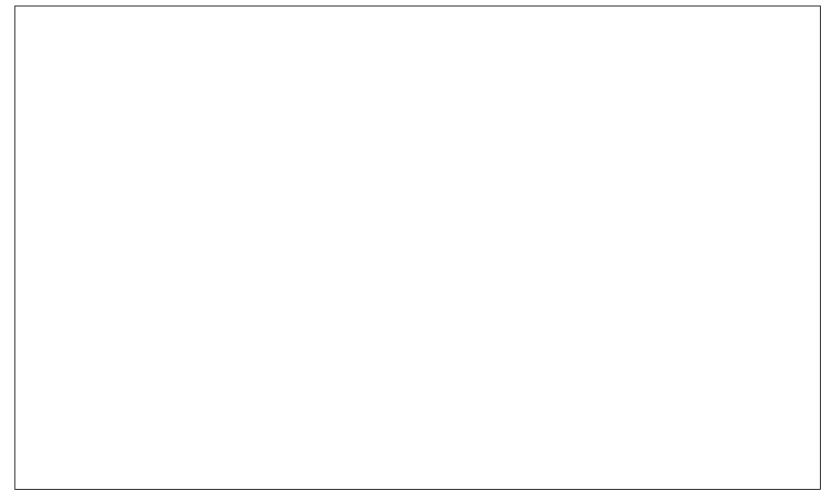

Figure 8c-28a. Lead musket ball and fragments found with Burial 28.

\section{Burial 107}

Burial 107 was encountered $60 \mathrm{~cm}$ bst, to the south and below Burial 28 (Figure 8c-28). These are the articulated remains of an individual identified as a Native American male who was between the ages of 20-24 at time of death. This individual had been buried in the extended position with his head to the west and his arms folded over his midsection. Five cloth-covered copper buttons were found with this burial (Figure $8 \mathrm{c}-28 \mathrm{~b}[\mathrm{a}-\mathrm{c}]$ ). Three were resting on the sacrum, one was against the right iliac crest of the pelvis, and the fifth was resting on the cervical vertebra beneath the chin. However, no evidence of a coffin was found with this individual burial. During analysis, evidence of scalping and skull fractures were identified on these remains. There is one 20-year-old Native American male who is listed in the Burial Records as being "killed by Barbarian Indians near the Mission." He was Vicente, a Karankawa, who was buried on August 2, 1814. It is probable that the remains identified during excavation as Burial 107 are those of the Karankawa male named Vicente.

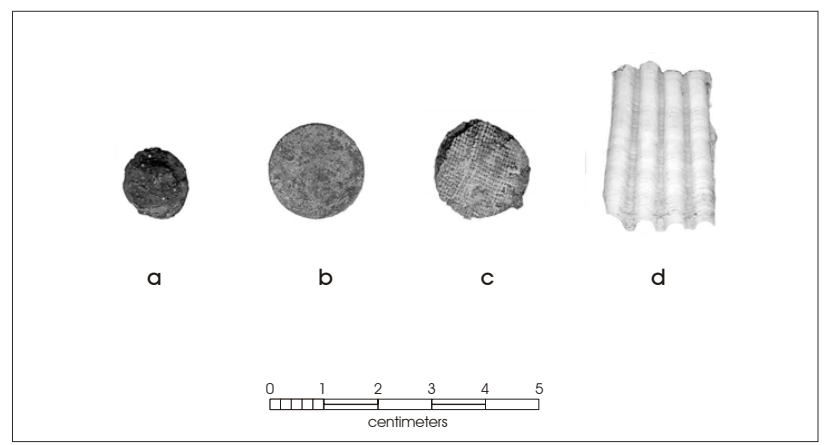

Figure 8c-28b. Shell and buttons from Burial Feature 22.

\section{Burial 116}

Burial 116 represents the partial remains of an individual identified as a male, over 55 years of age of indeterminate ancestry. The skull of this individual was missing and had evidently been removed during installation of the waterline that bisects this portion of the feature (Figure 8c-28). The elements of the upper torso and pelvis remained articulated in an extended position with the arms folded across the chest and the hands resting on the left shoulder. The head would have been oriented to the west. The long bones from the lower extremities of this individual were found commingled with those of Burial 109, $1.2 \mathrm{~m}$ to the east on top of the legs of Burial 107. The disarticulated remains of Burial 109 have been identified as those of a 30-35-year-old Native American female. A worked marine shell (Figure 8c-28b[d]) was found with these commingled remains.

\section{Burial 127}

The partial remains of Burial 127 were discovered in a $25-\mathrm{x}-40 \mathrm{~cm}$ depression beneath the pipe trench in BF 22 (Figure 8c-28). These remains have been identified as a 30-39-year-old male, possibly of Native American ancestry. The remains were below the level of the pipe trench but it is possible that they may have been disturbed when the pipe was installed. It is also possible that Burial 127 represents a secondary burial of an individual who died while away from the mission. 


\section{Burial 112}

The remains of Burial 112 were encountered $65 \mathrm{~cm}$ bst at the western edge of BF 22 (Figure 8c-29). Burial 112 has been identified as a Native American male between the ages of 16-19. This individual was buried in the extended position with the right arm folded across the midsection. His left arm was folded across his chest and his left hand rested on his right shoulder. Traces of red ochre were observed in the soil around this burial.

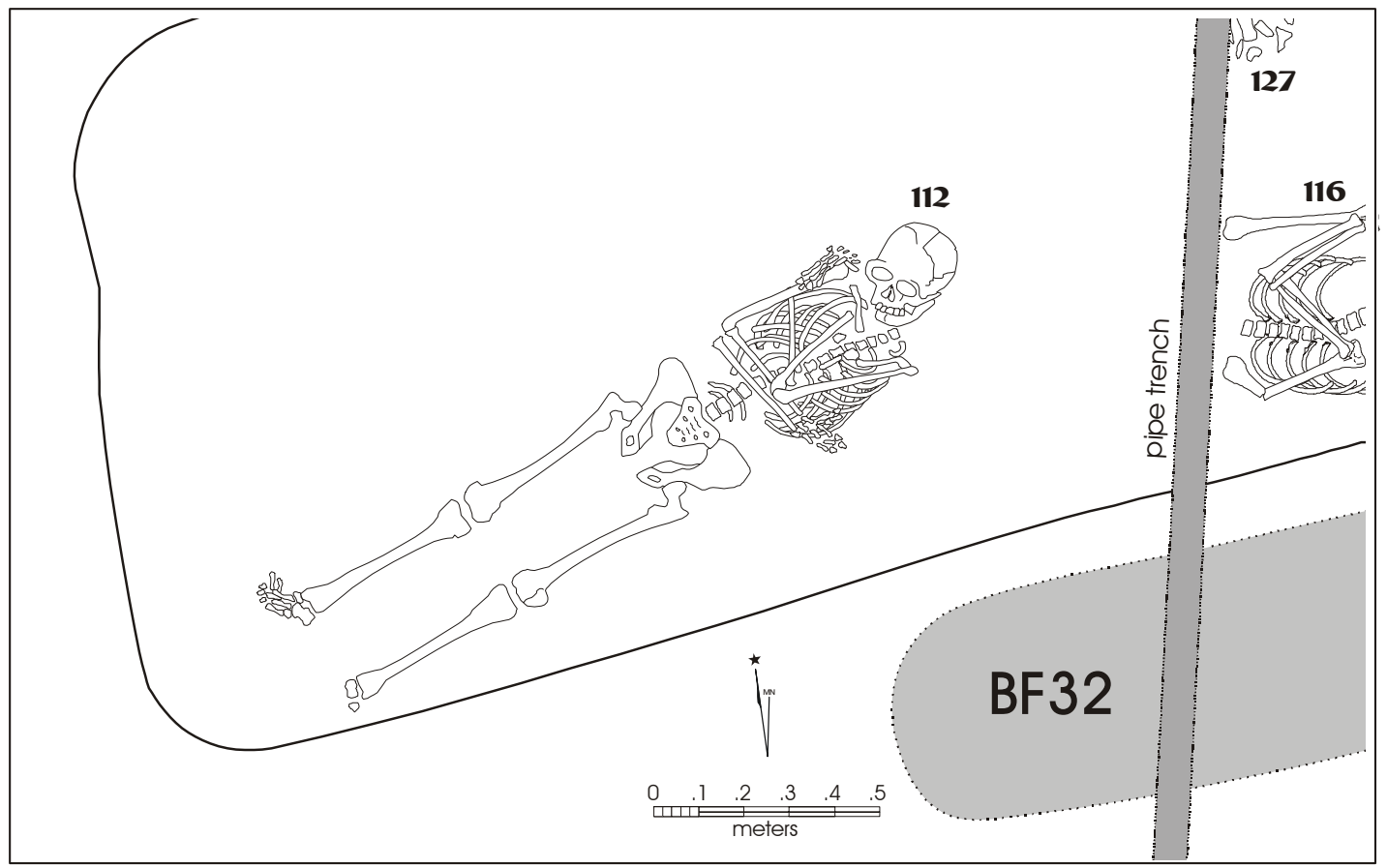

Figure 8c-29. West section of Burial Feature 22. 


\section{Burial Feature 23}

Burial Feature 23 is small oval feature measuring $50-\mathrm{x}-60$ $\mathrm{cm}$ (see Figure 8c-1). The water pipe that parallels the west side of the street had cut through the eastern edge of this feature (Figure 8c-30). One Native American ceramic sherd and one piece of large, mammal bone were recovered from the fill of this feature.

\section{Burial 23}

The disarticulated, partial remains of one individual, Burial 23, were uncovered $40 \mathrm{~cm}$ bst in BF 23. This burial is represented by elements of one arm, several vertebrae, one side of the pelvis and numerous rib fragments. These elements have been identified as belonging to a Native American male between the ages of 25-34. It is possible that this burial was disturbed when the water pipe was installed. It is also possible that Burial 23 represents the secondary burial of an individual who died while away from the mission.

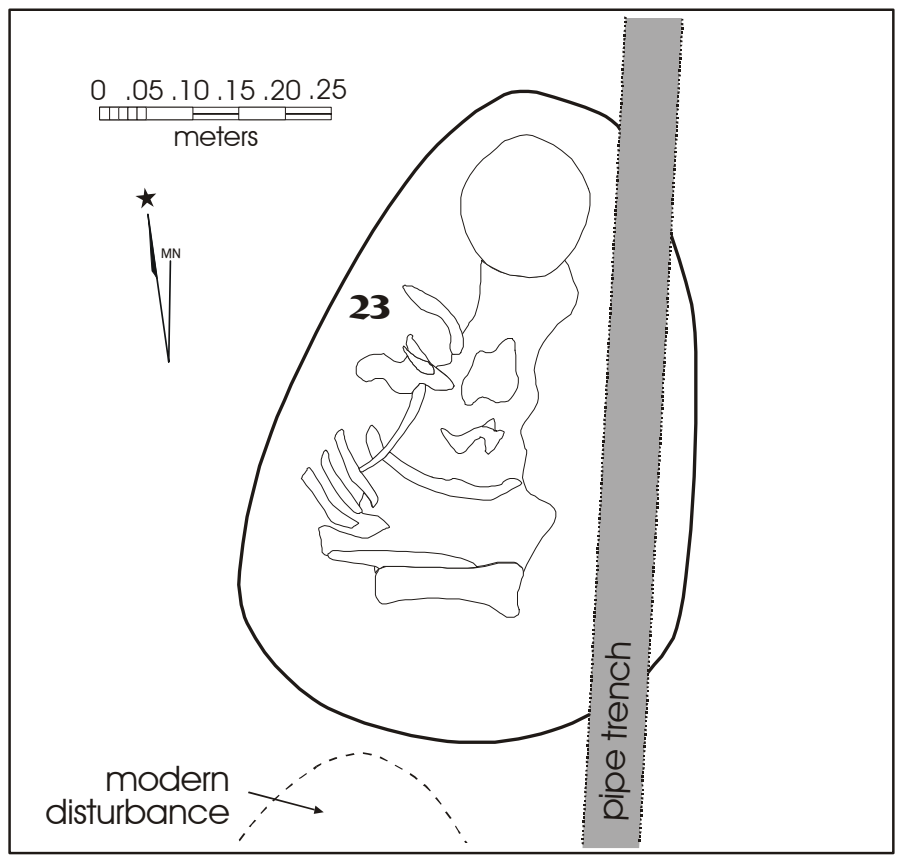

Figure 8c-30. Plan map of Burial Feature 23. 


\section{Burial Feature 24}

Burial Feature 24 was located in the south transept of the church between BF 14 and 21 (see Figure 8c-1). This $1.82-\mathrm{x}-.65 \mathrm{~m}$ feature was roughly oblong in shape and showed evidence of disturbances from the modern water pipe installation and at least one episode of enlargement (Figure 8c-31). One piece of native ceramics, one piece of edge ware, one piece of banded slip, and one cow bone were recovered from the fill of this feature. Burial Feature 24 contained the articulated and disarticulated remains of five individuals.

\section{Burial 68}

Burial 68 is an articulated burial in the extended position with arms folded at the midsection and head oriented to the west. Burial 68 has been identified as a Native American female who was between the ages of 35-44 when she died (Figure 8c-31). A collection of personal items was found resting in the pelvic area of this individual (Figure 8c-31a). These items include four cylindrical bone beads, one of which was shattered. Two of the remaining beads were hollow (Figure $8 \mathrm{c}-31 \mathrm{a}[\mathrm{a}-\mathrm{b}]$ ), the third had an unidentified piece of metal encased inside it (Figure $8 \mathrm{c}-31 \mathrm{a}[\mathrm{c}]$ ). With the beads was a circular piece of iron, $22 \mathrm{~mm}$ in diameter and $5 \mathrm{~mm}$ thick (Figure 8c-31a[d]), possibly a finger ring, a $17 \mathrm{~mm}$ brass bell (Figure 8c-31a[e]), and a Columnella shell pendant (Figure 8c-31a[f]). Although no remnants of a pouch remained, it is easy to visualize these items being contained in a pouch suspended from the waist of this individual. The interment of Burial 68 was the most recent addition to this feature and it had disturbed the previous interments of Burials 80, 85, 85a, and 37 (see Figure 8c-31). The burial of one influential Native American female is listed in the mission burial records. This was the burial of Maria Josefa, the 40-year-old "woman" of General Diego of the Karankawa Nation (see Chapter 4). The identification of Burial 68 as the remains of Maria Josefa would explain the unusual collection of burial items found with this individual.

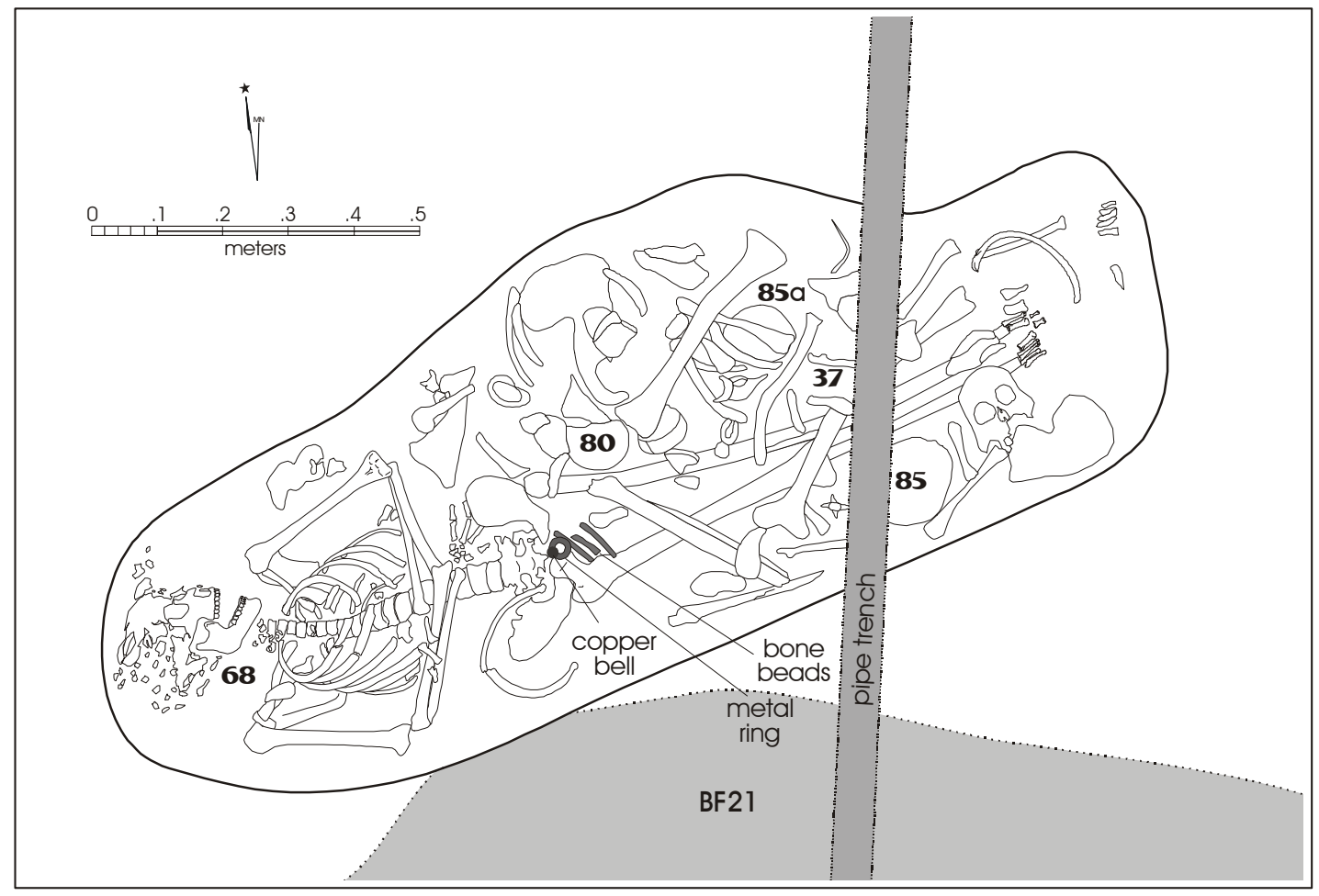

Figure 8c-31. Plan map of Burial Feature 24. 


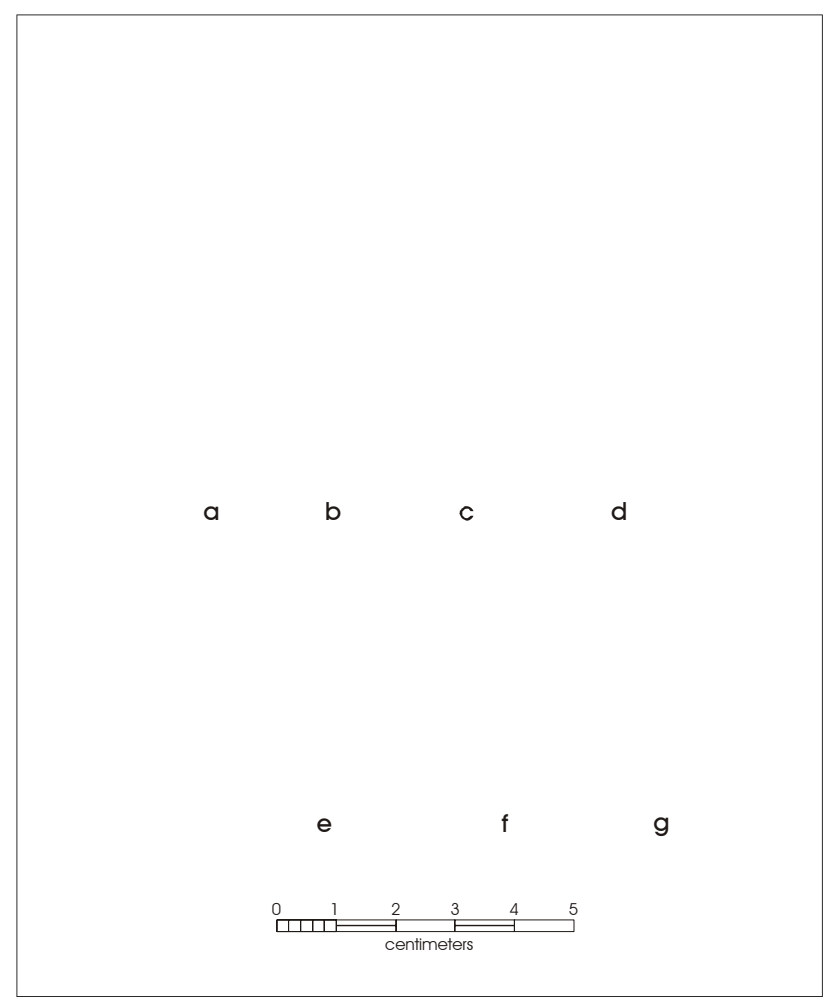

Figure 8c-31a. Bone beads, metal ring, bell, and shells found with Burial 68.

\section{Burials 80, 85, 85a, and 37}

The commingled cranial and postcranial elements of four individuals were found along and on the legs of Burial 68. Burial 80 is that of a young, possibly male, individual 13.514.5 years of age of indeterminate ancestry. Burial 85 has been identified as a 25-29-year-old male of probable Hispanic ancestry. Burial 37 is also a male between 18.519.5 years of age of probable Native American ancestry. Burial 85a represents a female between 15-35 years of age of indeterminate ancestry. A second Columnella shell pendant (Figure $8 \mathrm{c}-31 \mathrm{a}[\mathrm{g}]$ ), was recovered from the fill around these commingled individuals and could not be definitely associated with any single burial in BF 24 .

\section{Burial Feature 25}

Burial Feature 25 was oval in shape and measured $88-\mathrm{x}-40 \mathrm{~cm}$. It was located immediately adjacent the north edge of BF 17 in the center of the church nave (see Figure $8 \mathrm{c}-1)$. This feature contained the remains of two children, Burials 88 and 89 (Figure 8c-32).

\section{Burials 88 and 89}

Burial 88 is that of an almost complete 1-2-year-old child encountered $50 \mathrm{~cm}$ bst. This child was in the extended position with arms crossed at the midsection. The head, which was badly fragmented, was oriented towards the east, facing north. The partial, disarticulated remains of an infant, Burial 89, were uncovered $50 \mathrm{~cm}$ bst north of Burial 88 . Burial 89 was between newborn and -.5 years of age at time of death.

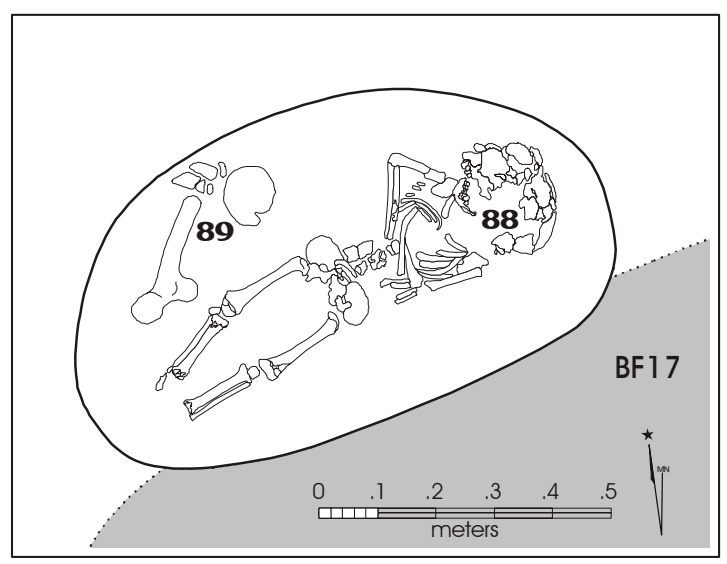

Figure 8c-32. Plan map of Burial Feature 25. 


\section{Burial Feature 26}

Burial Feature 26 was a large irregularly shape feature beneath the sidewalk at the western edge of the ROW (see Figure 8c-1). It is located in what would have been the center of the back of the nave, and like BFs 4 and 5 in the transept, shows evidence of many enlargement and reuse episodes. Colonial-period ceramics and glass were mixed with modern glass, nails, and plastic in the fill of this feature, probably due to its location beneath the sidewalk. Burial Feature 26 contained the complete and partial remains of 21 individuals.

\section{Burials 92, 100, 100a, 104, and 111}

Burial 92 was encountered $42 \mathrm{~cm}$ bst at the northern edge of BF 26. This burial is represented only by the crania, left ulna, and right and left femurs (Figure 8c-33). These partial

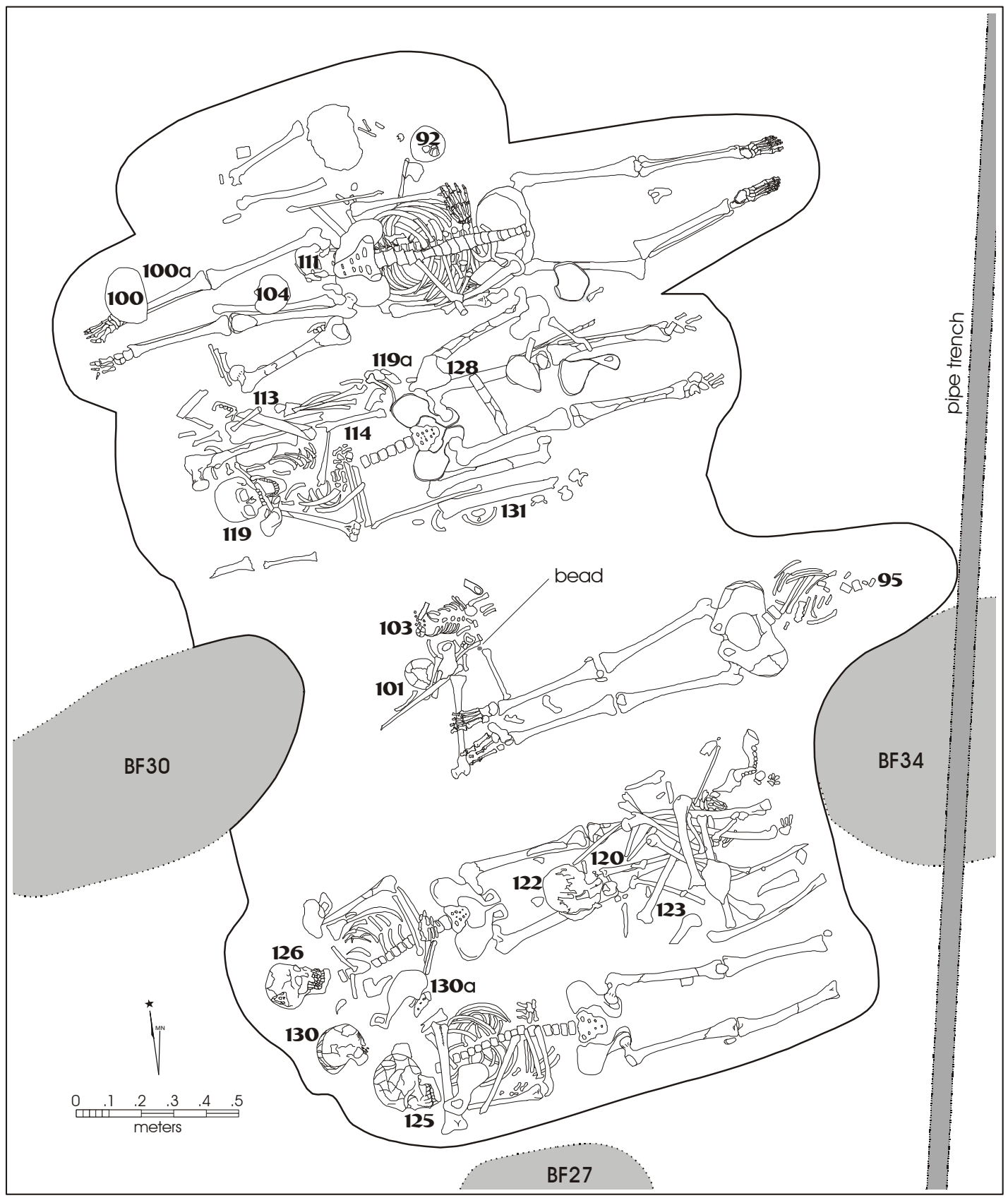

Figure 8c-33. Plan map of Burial Feature 26. 
remains have been identified as those of a 50+-year-old male of possible Native American ancestry. Although disturbed, it was possible to tell that this individual had been buried in the extended position with his head to the east. Five onehole bone buttons (Figure 8c-33a) measuring 12-mm in diameter, and an unidentified copper fragment were recovered from the fill associated with Burial 92 .

Burial 100 was encountered $47 \mathrm{~cm}$ bst, just below and immediately adjacent Burial 92 (see Figure 8c-33). With the exception of elements from the right arm, the postcranial elements of this burial were complete and articulated in the extended position. The crania, which would have been oriented to the east, was found face down on the lower right leg of Burial 100. This individual has been identified as a 25-29-year-old male of indeterminate ancestry.

Burial 111 was located at a depth of $65 \mathrm{~cm}$ bst, directly below the extended remains of Burial 100 in BF 26 (see Figure 8c-33). This burial was in the extended position with arms crossed at the midsection and head oriented to the west. This interment appears to have preceded, not intruded upon the higher interment, Burial 100. Burial 111 was identified during osteological analysis as that of a 60+-year-old female of probable Native American ancestry. The analysis also found that the cranial and postcranial elements of this individual were noticeably robust, a characteristic associated with the Karankawa individuals in the population (see Volume II). Of the two elder Native American females listed in the burial records, Maria del Refugio (Lipan) and Maria Refugio (Karankawa) this description seems to indicate that Burial 111 is that of the Karankawa female, Maria Refugio.

Cranial and postcranial elements of two individuals were commingled with the articulated remains of Burials 100 and 111 (see Figure 8c-33). The skull and tibia of a 9.5-12.5year-old individual of unknown sex and ancestry, Burial 104, were found adjacent the left femur of Burial 100. During analysis, postcranial elements from a 25-34-year-old female of indeterminate ancestry, Burial 100a, were identified among the commingled remains near Burials 100 and 111 .

\section{Burials 119, 119a, 113, 114, 128 and 131}

One primary and five disturbed burials were located just south of Burial 111 in BF 26 (see Figure 8c-33). Burial 119, representing the almost complete, articulated remains of a 25-30-year-old male of probable Hispanic ancestry, was encountered $63 \mathrm{~cm}$ bst. This individual was buried in the extended position with arms crossed at the midsection and head oriented to the west. The right humerus, radius, and

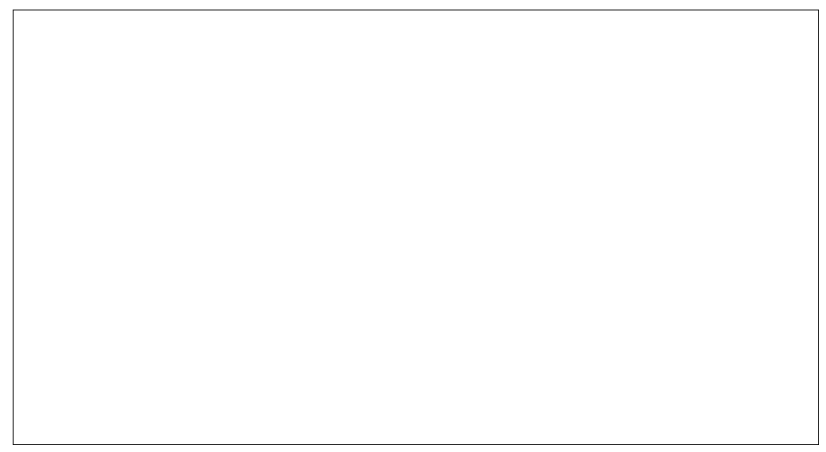

Figure 8c-33a. Bone buttons found with Burial 92.

ulna had been somewhat displaced by a subsequent disturbance.

The disarticulated remains of four adults and one child were commingled on top and to either side of this intrusive burial. These remains have been identified as: Burial 113-a 2024-year-old female; Burial 128-a 20-29-year-old female; Burial 119a-a 20-30-year-old male; Burial 131-a 20-29year-old male; and Burial 114-a 6.5-7.5-year-old child.

All of the adults are thought to be of probable Native American ancestry. No ancestral estimates were possible for the child. Three pieces of gypsum, a mineral used in mission-period production of white wash and plaster (Montgomery et al. 1949:140) were found in the fill surrounding these burials.

\section{Burials 95, 103, and 101}

Two primary burials and one disturbed burial occupied the central portion of BF 26 (see Figure 8c-33). Burial 95 was encountered $48 \mathrm{~cm}$ bst. The vertebral column, pelvis, and lower extremities of this individual were articulated in the extended position. The upper torso and skull, which would have been oriented to the east, were not present and were possibly removed during excavation of the waterline trench that bisects this end of the site. Burial 95 has been identified as a 25-29-year-old female of probable Native American ancestry. One medium sized (5-mm) olive-shaped bead made of pink glass was found in the fill around Burial 95. This bead resembles \#105 on the Harris Bead Chart (Harris and Harris 1967), but the surface is badly pitted. No example of this bead type is illustrated by De Vore (1992).

Burial 103 was located between Burial 95 and Burial 119 at a depth of $59 \mathrm{~cm}$ bst (see Figure 8c-33). This is the burial of a 1.5-2.5-year-old of indeterminate sex and ancestry. This child was buried in the extended position with head oriented 
to the west and arms folded across its chest. The disarticulated, fragmentary remains of another individual, Burial 101, were found scattered above Burial 103 and below Burial 95 . This burial is represented by a complete fibula and humerus and portions of a mandible and other long bones. These remains have been identified as belonging to a 40-50-year-old female of indeterminate ancestry.

Burials 120, 122, 123, 125, 126,

\section{0 and 130a}

Two articulated adult burials and five disturbed, disarticulated adult burials were uncovered in the southern portion of BF 26 (see Figure 8c-33). The remains of Burial 126 were encountered $65 \mathrm{~cm}$ bst. This individual was interred in the extended position with arms folded across the midsection and head oriented to the west. The burial was virtually intact except for some minor displacement of the right humerus due to posthumous disturbance of an undetermined nature. Burial 126 has been identified as a Native American male who was between the ages of 45-60 at time of death.

Commingled cranial and postcranial elements from three individuals were found at a depth of $73 \mathrm{~cm}$ bst, resting on the legs and feet of Burial 126. Burial 120 is identified as a Native American male who was over 50 years of age when he died. Burial 122 is that of a 20-29-year-old Native American female and Burial 123 is identified as a second Native American female between the ages of 20-29.

Burial 125 is that of a 30-35-year-old Hispanic male. This burial was encountered $52 \mathrm{~cm}$ bst at the south edge of BF 26. Burial 125 was in the extended position with head oriented to the west. The right arm was in an articulated position, folded across the midsection. Elements of the left arm and shoulder blade had been disturbed and were across the chest area. Bones from the feet of this individual were not recovered and were possibly removed during excavation of the waterline trench that bisects this end of the site.

Burial 130 was encountered $63 \mathrm{~cm}$ bst, between Burials 125 and 126 . This individual is represented by a complete skull, pelvis, and a few fragmented long bone sections. Burial 130 is that of a 20-25-year-old male, probably of Native American ancestry. A work shell and an animal tooth pendant were recovered from the fill at the south end of BF 26, but could not be definitively associated with a single burial here. Burial 130a was identified during analysis as a possible Native American female between the ages of 15-35 at the time of death.

\section{Burial Feature 27}

Burial Feature 27 was a $35-\mathrm{x}-66 \mathrm{~cm}$ oval feature just beyond the southern edge of BF 26 (see Figure 8c-1). This feature contained the fragmented remains of a single newborn -.5year-old infant of possible Native American ancestry (Figure $8 \mathrm{c}-34)$. This infant, Burial 98, was encountered $55 \mathrm{~cm}$ bst buried in the extended position with its head to the west. Small amounts of red ochre were present in the soil around the right humerus and ulna.

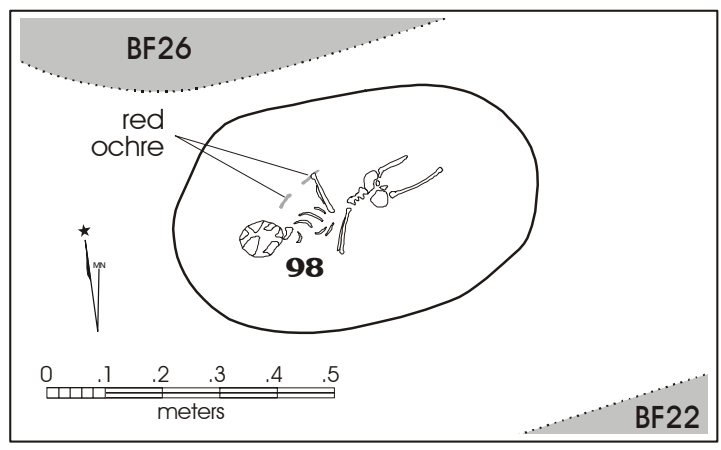

Figure 8c-34. Plan map of Burial Feature 27. 


\section{Burial Feature 28}

Burial Feature 28 was an oval shaped feature located at the eastern edge of BF 22 (see Figure 8c-1). It measured 75-x$35 \mathrm{~cm}$. BF 28 contained the remains of two infants, Burials 96 and 99 (Figure 8c-35).

\section{Burials 96 and 99}

Burial 96 was encountered $40 \mathrm{~cm}$ bst. This newborn -.5year-old infant of unknown sex and ancestry had been buried in the extended position with head to the west and arms folded at the midsection. The second infant, Burial 99, was located directly beneath Burial 96 at a depth of $54 \mathrm{~cm}$ bst. Burial 99 was also interred in the extended position. Shifting of the postcranial elements and absence of the skull indicate this burial was disturbed posthumously, possibly by the interment of Burial 96. Burial 99 has been identified as an infant, 1.5-2.5 years old of indeterminate sex and ancestry. A large amount of red ochre was found mixed in the soil along the lower left leg of this infant.

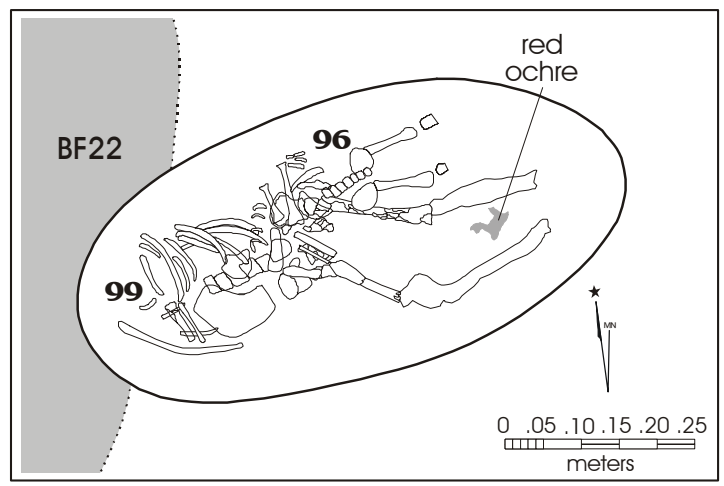

Figure 8c-35. Plan map of Burial Feature 28.

\section{Burial Feature 30}

Burial Feature 30 was located just west of BF 26, beneath the sidewalk at the western edge of the ROW (see Figure $8 \mathrm{c}-1$ ). The western limit of this feature is unknown as it extended under the four-foot-high bank that marks the boundary between the modern church property and the edge of the TxDOT ROW. The extremely fragmented, disarticulated remains of Burials 24, 102, and 118 were encountered on the surface directly beneath the sidewalk (Figure 8c-36). Modern nails, metal fragments, and glass were present throughout the fill, suggesting that at least some of the disturbance to this feature was related to the construction of the sidewalk. As shown in Figure 8c-36, some of these skeletal elements extended outside the ROW and small tunnels were excavated in an effort to remove as many of these as possible.

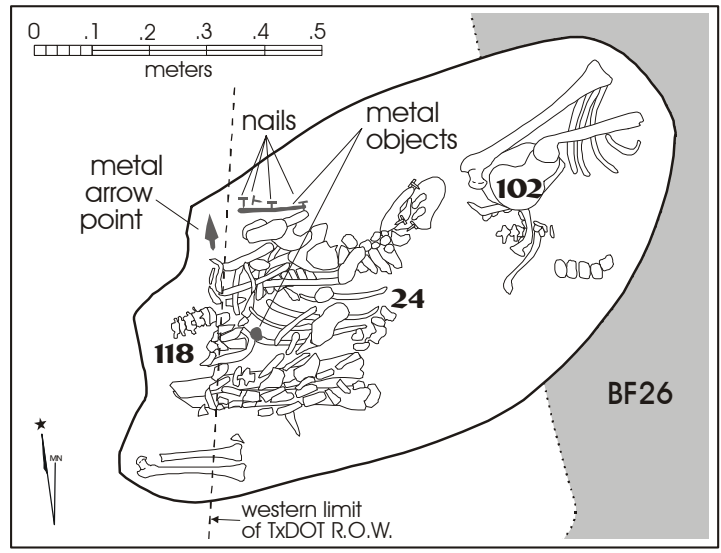

Figure 8c-36. Plan map of Burial Feature 30.

\section{Burials 24, 102 and 118}

The commingled remains recovered from BF 30 have been identified as those of three adults. Burial 24 represents the remains of a 40-44-year-old male of possibly Hispanic ancestry. Burial 102 is that of a female between the ages of 30-40 who was of mixed Native American and Hispanic ancestry. The vertebral column, pelvis and right femur of Burial 118, although highly fragmented, remained in a semiarticulated position at the bottom of this feature and indicated this individual had been interred in the extended position with head oriented to the west. Burial 118 is a 20-24-yearold female of Hispanic ancestry. 
Fifteen forged nails and two unidentified pieces of metal were found in the fill of BF 30 suggesting that at least one of the individuals buried here had been interred in a coffin. A metal arrow point and seven small glass beads were also recovered from the fill (Figure 8c-36a). The beads measured $3 \mathrm{~mm}$ in diameter and are similar to those described by Harris and Harris (1967) as \#44 or by De Vore (1992) as CI/SA/ $\mathrm{T} 1 / \mathrm{Vf}$-white, opaque, donut-shaped garter beads of simple construction. Unfortunately, these personal burial items could not be directly linked to any of the individuals because of the disturbed nature of this burial feature.

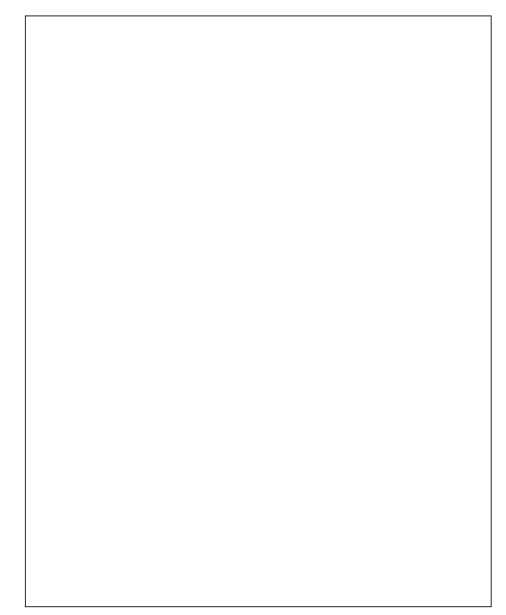

Figure 8c-36a. Metal arrow point and beads found in Burial Feature 30.

\section{Burial Feature 31}

Burial Feature 31 is located $1 \mathrm{~m}$ south of BF 22 and is one of the two burial features located outside of the church itself (see Figure 8c-1). Burial Feature 31 measured 1.73-X-.50 $\mathrm{m}$ and contained the articulated remains of one individual and partial remains of a second (Figure 8c-37).

\section{Burials 105 and 110}

Burial 105 was encountered directly beneath the graded surface in BF 31. Although all of the cranial and postcranial elements of this burial were present, they were in extremely fragmented condition and many crumbled completely during removal. It is most likely that this damage occurred during previous street construction activity. Burial 105 was in the extended position with arms crossed at the midsection and head oriented to the west. This burial has been identified as that of a 35-45-year-old female, possibly of Native American ancestry. The tibia and fibula of another individual, Burial 110 , were found resting directly above the legs of Burial 105. These remains have been identified as those of a male of indeterminate ancestry who was 15-35 years of age.

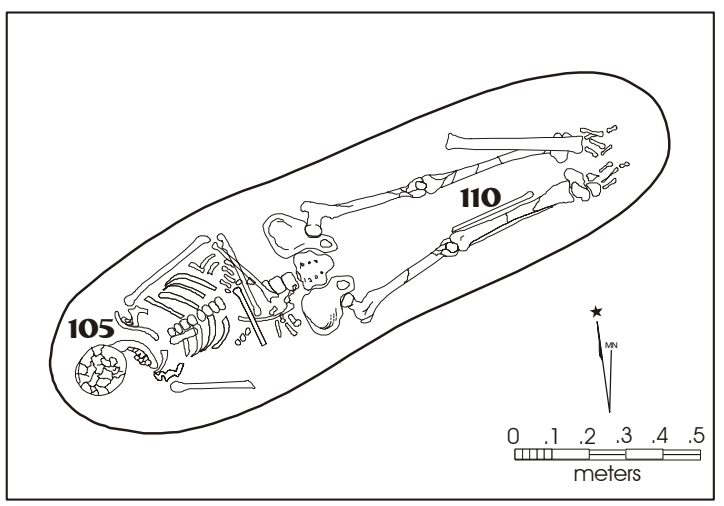

Figure 8c-37. Plan map of Burial Feature 31. 


\section{Burial Feature 32}

Like BF 31, Burial Feature 32 was located south of BF 22, outside the confines of the church (see Figure 8c-1). This feature measured $1.60-\mathrm{x}-.38 \mathrm{~m}$ and was bisected midway by the waterline trench beneath the sidewalk. Burial Feature 32 contained the partial remains of one individual, Burial 29 , that had been disturbed by the waterline trench and by previous street construction (Figure 8c-38).

\section{Burial 29}

Burial 29 was encountered at a depth of $67 \mathrm{~cm}$ bst, directly beneath the sidewalk. Only the lower extremities of this individual remained intact, and these elements were in fragmented condition. From their positioning, however, it is possible to infer that Burial 29 had been interred in the extended position with head oriented to the west. Elements of the hands and several ribs were found deposited in a orderly pile on the western side of the pipe trench (Figure $8 c-38$ ). Because of the condition of these remains, identification of Burial 29 is limited to an adult male, over 35 years of age whose ancestry could not be determined.

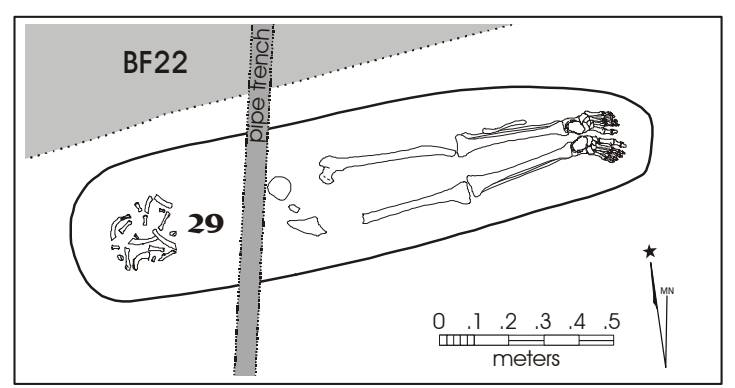

Figure 8c-38. Plan map of Burial Feature 32.

\section{Burial Feature 33}

Burial Feature 33 was located northeast of BF 5 and extended into the centerline of US 77 (see Figure 8c-1). This feature had been truncated midway by the previous construction in the center of the street, which had also truncated a portion of BF 10. Burial Feature 33 contained articulated long bones from the left leg of a single individual (Figure 8c-39). No other portions of this individual were found during subsequent investigations beneath the northbound lanes of the highway. The partial remains of Burial 115 have been tentatively identified as those of a young adult, possibly male, of indeterminate ancestry.

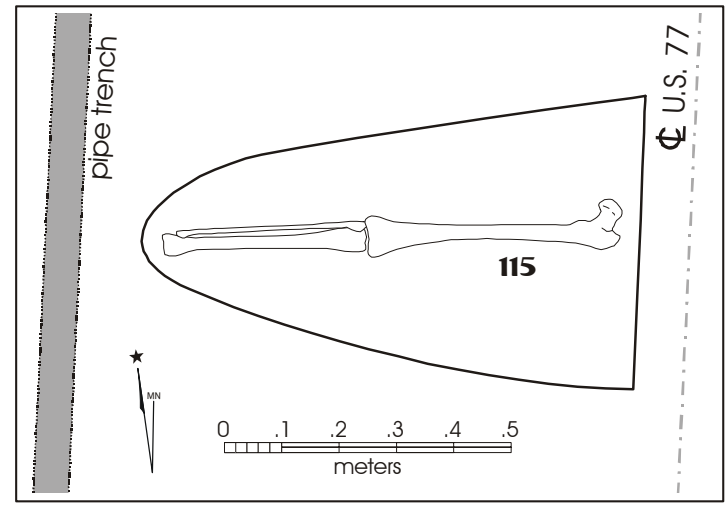

Figure 8c-39. Plan map of Burial Feature 33. 


\section{Burial Feature 34}

Burial Feature 34 is a $.60-x-.30 \mathrm{~m}$ feature located on the eastern edge of BF 26 (Figure 8c-1). It is beneath the sidewalk and had been bisected by the waterline trench. Burial Feature 34 contained the articulated remains of one infant and the disarticulated remains of three adults and a second infant (Figure 8c-40).

\section{Burials 106, 106a, 106b, 108,} and $108 \mathrm{a}$

Burials 106, 106a, and 106b are represented by incomplete adult cranial and postcranial elements encountered to the west and directly below the water pipe. With the exception of one ulna, these skeletal elements had all been broken posthumously. Burial 106 represents the remains of a 2534-year-old male of indeterminate ancestry. Burial 106a is also a male. He was between the ages of 50-54 and was possibly of Native American ancestry. Burial 106b represents the remains of a third individual, a 15-35-yearold male of indeterminate ancestry.

Burials 108 and 108a were encountered beneath the adult remains at a depth of $69 \mathrm{~cm}$ bst. Burial 108 represents the almost complete, articulated remains of a 2.5-3.5-year-old individual of indeterminate sex or ancestry. This child had been interred in the extended position with head to the east. Skeletal elements of a 4.5-5.5-year-old child, Burial 108a, were also identified during analysis.

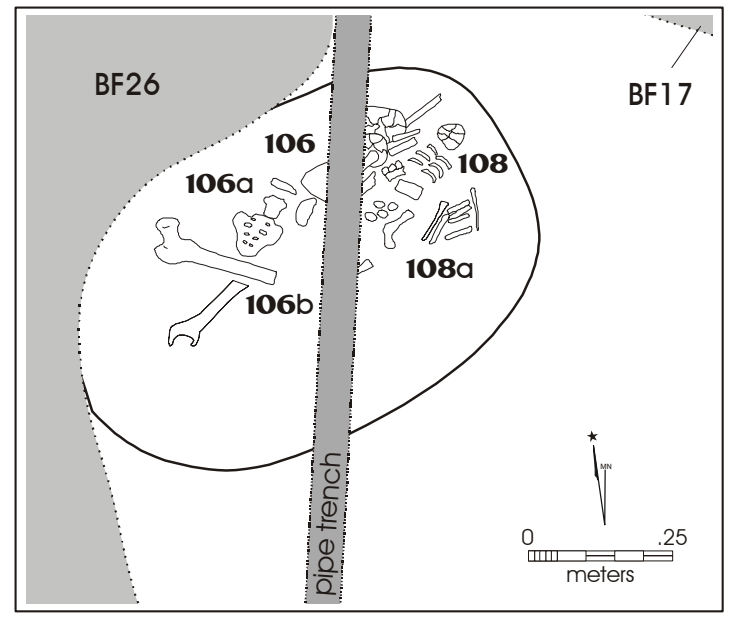

Figure 8c-40. Plan map of Burial Feature 34.

\section{Burial Feature 35}

Burial Feature 35 was located under the northbound lanes of US 77, inside what would have been the southern transept of the church (see Figure $8 \mathrm{c}-1$ ). It is a $1.90-\mathrm{x}-.55 \mathrm{~m}$ feature that has been truncated at the western end during previous construction along the centerline of the street. This same construction had also truncated part of BFs 10 and 33 beneath the southbound lanes, as well as BFs 36 and 37 beneath the northbound lanes. Burial Feature 35 contained the articulated remains of one individual, Burial 134.

\section{Burial 134}

Burial 134 was encountered directly below the previously graded base of the highway. This burial was articulated and partially complete except for the head, feet, and the lower portions of both tibias and fibulas (Figure 8c-41). Burial 134 was interred in the extended position with arms crossed at the midsection; the head would have been oriented to the west. Although no explanation could be found for the disturbance to the lower extremities of this individual, the skull was evidently removed during previous utility installation. This individual has been identified as a Hispanic male between the ages of 30-40 at time of death.

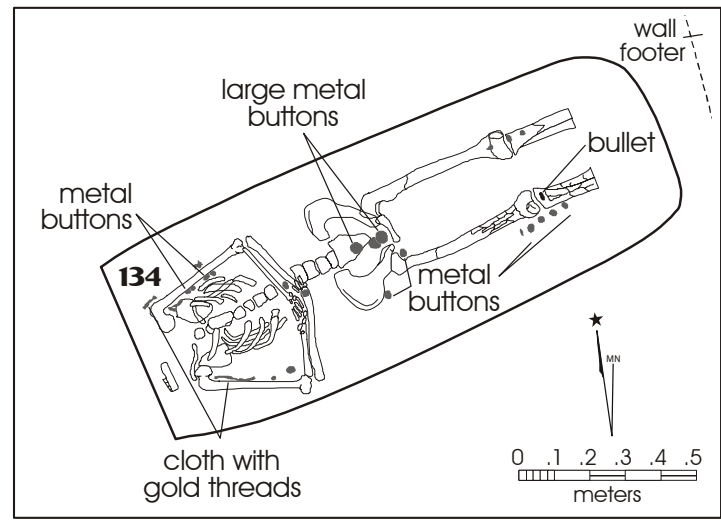

Figure 8c-41. Plan map of Burial Feature 35.

A considerable number of personal items were found with Burial 134 (Figure 8c-41a). Three metal, shanked buttons $33-\mathrm{mm}$ in diameter, were resting in the pelvic area of this individual (Figure 8c-41a[a-c]). Ten cloth-covered metal buttons, measuring 17-mm in diameter (Figure 8c-41a [d-e]) were found along the outside of both legs and at the right hip of this individual. One $21-\mathrm{mm}$ diameter cloth covered metal button (Figure 8c-41a[f]), one measuring 16$\mathrm{mm}$ in diameter and fragments of at least six more were found at the wrists and along both arms. Material-covered 
metal fasteners (Figure 8c-41a[g-h]) were scattered in the soil around the upper torso and fragments of epaulets interwoven with golden threads were found at each shoulder (Figure 8c-41a[i-j]). A cylindrical piece of lead shot was found imbedded just below the patella in the right tibia of this individual (Figure 8c-41a[k]).

This assortment of burial items indicates that Burial 134 was a soldier who experienced a traumatic death and was buried in his uniform. Two soldiers are mentioned in the Burial Records of Refugio. One was Jose Maria Carrillo, a 28-year-old male who died August 6, 1808 of a "very malignant fever". The second was Blas Trejo, an adult male who was "killed by barbarians" and buried on June 22, 1820 (see Appendix в, Burial Records). It is possible that Burial 134 may actually be the remains of Blas Trejo.

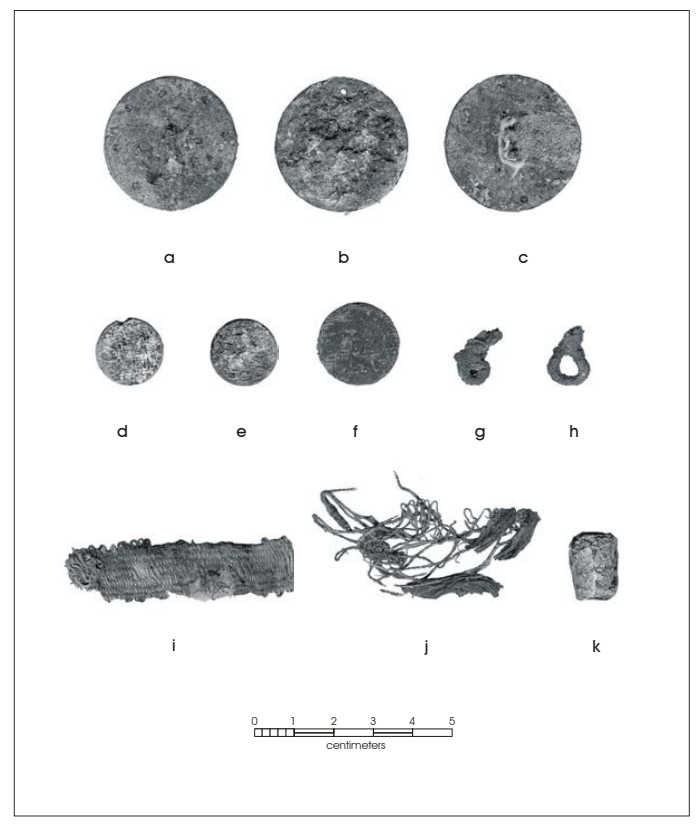

Figure 8c-41a. Personal items found with Burial 134.

\section{Burial Feature 36}

Burial Feature 36 was located north of BF 35, $30 \mathrm{~cm}$ from the inside corner of the apse and south transept walls (see Figure 8c-1). This feature was $1.8 \mathrm{~m}$ long and .6-1 $\mathrm{m}$ wide. The western edge of BF 36 had been truncated by utility construction. The skulls of the three individuals interred here had been removed during this construction (Figure 8c-42).

\section{Burial 132}

Burial 132 was uppermost in BF 36, just below the graded surface at $54 \mathrm{~cm}$ bst, and had been badly damaged during the previous road construction. Fragmented portions of ribs, vertebrae, sternum, and pelvis remained in position and indicated that this individual had been buried in the extended position with head oriented to the west. Elements from this burial have been identified as those of a 15-17-year-old individual, possibly male, of indeterminate ancestry.

\section{Burial 133}

Burial 133 was encountered directly below Burial 132 at a depth of $64 \mathrm{~cm}$ bst. The postcranial skeletal elements of this burial were, for the most part, articulated, although minor displacement of the lower extremities, possibly during road construction, was observed. This individual was buried in the extended position with arms partially extended at his sides and head oriented to the west. Burial 133 has been identified as a 21-29-year-old, probable male of indeterminate ancestry.

\section{Burial 135}

Burial 135 was encountered $79 \mathrm{~cm}$ bst, directly below Burial 133 at the bottom of BF 36. The skull and left shoulder had been removed by the utility trench and the right arm had been slightly displaced. Burial 135 is that of an adult, possibly male individual, 25-29 years of age of probable Native American ancestry.

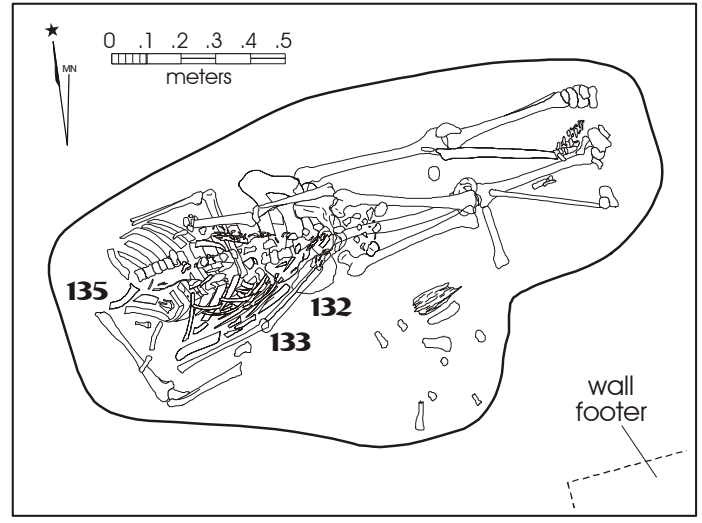

Figure 8c-42. Plan map of Burial Feature 36. 


\section{Burial Feature 37}

Burial Feature 37 was located near the center of the church transepts (see Figure 8c-1). Only the eastern portion of this feature was present, the western half being truncated by the previous construction in the center of street. Burial Feature 37 contained the articulated lower extremities of one individual, Burial 137, and the disarticulated partial remains of another, Burial 138 (Figure 8c-43). Burial 137 appears to have been interred in the extended position, oriented to the west. These partial remains have been identified as belonging to a young person of unknown ancestry between the ages of 9.5-11.5 at the time of death. Burial 138 represents the partial remains of a second child of indeterminate ancestry who was between the ages of 2.53.5 at time of death.

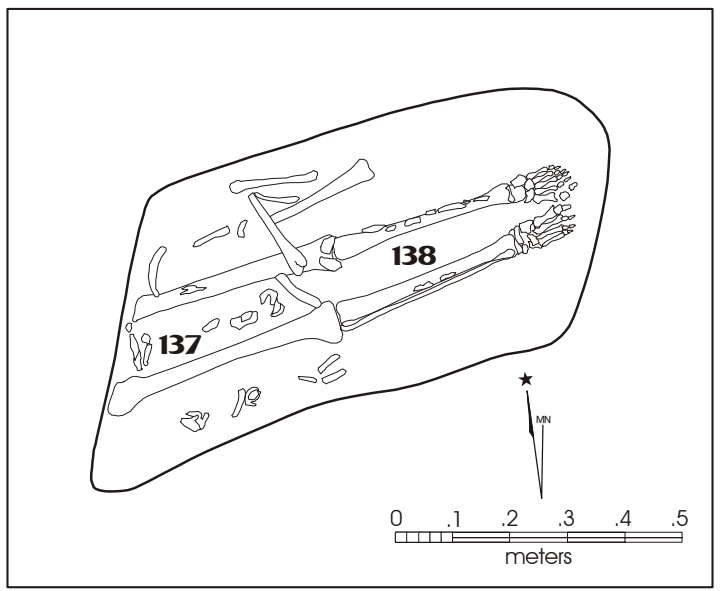

Figure 8c-43. Plan map of Burial Feature 37.

\section{Burial Feature 38}

Burial Feature 38 was a $1.2-x-.40 \mathrm{~m}$ feature located in what would have been the apse of the church (see Figure 8c-1). The remains of a single individual, Burial 136, were encountered just below the graded base of the existing road. This burial had been badly fragmented and crushed due to its location so near the surface of the road, and most of the remains crumbled upon removal. In situ it was possible to tell that Burial 136 had been buried in the extended position with arms bent and hands folded across the stomach. The head of this individual was oriented to the west (Figure $8 \mathrm{c}-44)$. Burial 136 has been identified as 4.5-5.5-year-old child of probable Hispanic ancestry. No estimate of sex was possible.

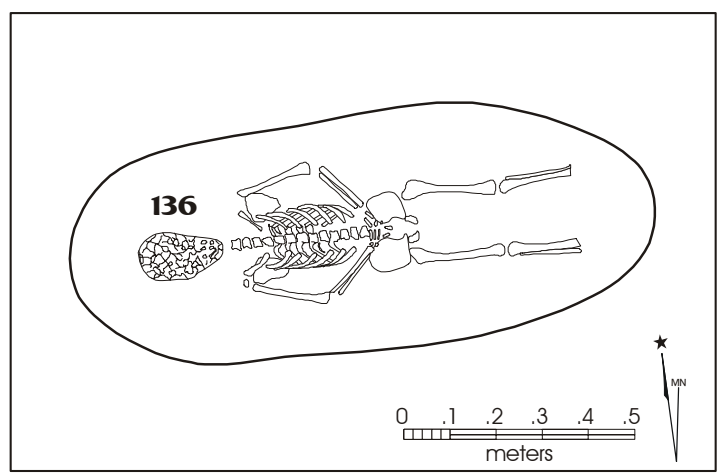

Figure 8c-44. Plan map of Burial Feature 38. 


\section{Burial Feature 39}

Burial Feature 39 was located in the center of the apse, $2.5 \mathrm{~m}$ from the east wall in an area that must have been close to the alter (see Figure 8c-1). This location is deemed as one that is reserved for a very important person in the church (Montgomery et al. 1949).

A single burial, Burial 139, was present in this feature. Unfortunately, the western half of BF 39 had evidently been removed during earlier road construction activities. Only the extremely fragmented head and upper torso of Burial 139 remained (Figure 8c-45). This individual was buried in the extended position with arms folded across the chest and head oriented to the east. Based on the location, it was postulated, at the time of excavation, that this burial might be that of Fr. Juan Maria Sepulveda, the 34-year-old minister of Mission Espíritu Santo who was buried at Mission Refugio on June 18, 1815. However, during osteological analysis these remains were tentatively identified as those of a female of indeterminate ancestry who was over the age of 35 at time of death. This identification remains tentative due to the highly fragmented nature of the remains and the fact that the identification was based on a photograph of the in situ remains. It is possible that Burial 139 could be that of the Mission Espíritu Santo priest.

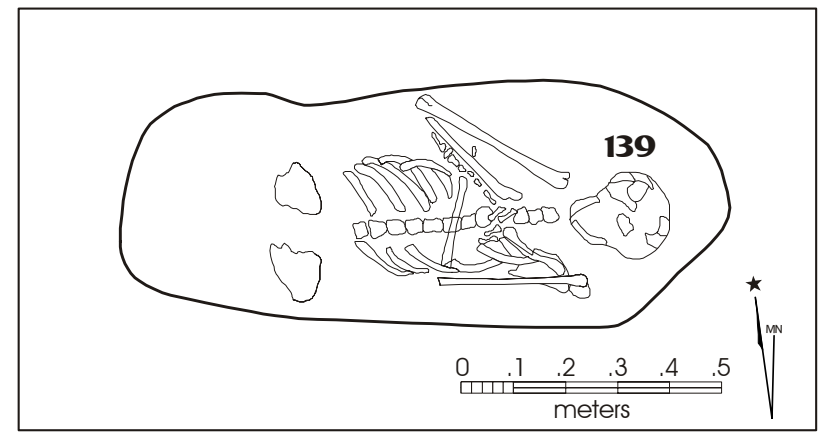

Figure 8c-45. Plan map of Burial Feature 39. 


\title{
Chapter 8: Findings
}

\section{Section D}

\section{Skeletal Biology}

\author{
L. Meadows Jantz and R. L. Jantz
}

This chapter presents a digest of an extensive skeletal analysis conducted on the Refugio Mission skeletal remains. The full report appears in Volume II, to which the reader is referred for additional information. The organization of this chapter is parallel to the full report and presents brief versions of our methods and the results of each chapter in Volume II. The analysis was designed to reconstruct a picture of life at Mission Refugio.

The remains of at least 165 primary and disturbed individuals were identified during the analysis. A minimum of an additional 12 individuals was sorted from commingled remains identified as ossuary elements, resulting in a minimum number of 177 individuals. Most of the individuals were buried in commingled pits, with a single extended burial at the bottom of a pit and many fragmented remains on top of or next to the extended burial. The skeletal material recovered from the site exhibited good preservation, although the remains were highly fragmented.

Elements were carefully examined and, when necessary, sorted into individuals if possible. A detailed inventory of elements associated with each burial was constructed. Age, sex and ancestry assignments were made for each individual from available evidence. Each element was scored for pathology. Measurements available for each element were taken in accordance with definitions in Buikstra and Ubelaker (1994).

The human skeleton, depending upon its completeness and state of preservation, can tell us much about an individual:

1) Sex from characteristics of the pelvis, long bones and skull;

2) Ancestry and population affiliation from craniofacial morphology; and

3) Age from the degree of union in long bone epiphyses and closure in cranial sutures, pubic symphysis and innominate auricular surface morphology, dental wear, and degenerative bone disease.
Evidence of osteological disease or trauma can suggest cause of death, provide insight into overall health (e.g. whether an individual suffered from iron deficiency anemia or infections), and even indicate limitations in mobility. The development of muscle, tendon, and ligament attachment sites and enthesophytes (projections or irregular ridges of ossification) at those sites can suggested handedness or biomechanical stress resulting from some habitual activity or occupation. Artificially induced modifications in human bone and teeth offer insight in sociocultural practices such as cranial deformation, surgical procedures, and repetitive activities.

The intensive collecting of osteological data from numerous groups from different time periods and geographical areas has added to osteological databases. The development and use of standardized recording formats for dental and bone inventories, pathological conditions and measurements of crania and postcrania maximizes the comparability of data and facilitates direct comparisons across samples. Data have been collected for well over 6,000 Euro-American, AfricanAmerican, and Native American skeletons from North America. The computerized database includes especially extensive records for the Prehistoric and Historic populations from the Great Plains and Great Basin.

The analysis and temporary curation of the skeletal material recovered from Mission Refugio occurred in the Osteology Laboratory, Department of Anthropology, University of Tennessee. In the summer of 2001, all items analyzed were returned to TxDOT in Austin, Texas.

\section{Skeletal Analysis}

1) For each new case, examination protocol begins with an inventory to determine the skeletal elements present. Bone and joint surfaces present are meticulously coded;

2) Cuts, fractures, and injuries to bone are identified and scored;

3) Taphonomic observations are made regarding bone preservation, color, staining, or any reconstructive materials that adhere to the bones; 
4) Reconstruction of any of the postmortem breakage of the skeletal elements;

5) Evaluation of sex on each individual using standard methods of morphological assessment;

6) Evaluation of the ancestry of each individual using standard morphological criteria and support with craniometric analysis;

7) Evaluation of age of each adult individual using standard morphological degenerative changes as individuals mature and age;

8) Evaluation of age of each subadult individual using standard indicators of growth such as epiphyseal closure and dental development;

9) Evaluation of pathological conditions for each individual;

10) Measure cranial and postcranial skeleton using a standard set of measurements;

11) Radiography as necessary; and

12) Photography of selected material and pathology.

\section{Dental Analysis}

1) Inventory of teeth recorded;

2) Evaluation of dental attrition using a standard protocol;

3) Evaluation of dental pathology by tooth and location;

4) Evaluation of calculus deposits;

5) Measurement of alveolar bone loss on all molars;

6) Photography of selected material and pathology; and

7) Radiography as necessary.

\section{Findings}

Demographic analysis was performed on the age and sex estimations determined in the analysis. The demographic profile constructed from the skeletal analysis was compared with historic records from the Refugio mission. Seasonal use of the mission was evaluated using the isotope data taken from the remains. Due to the fragmentary state of the remains, cranial form could not often be used in determining ancestry; therefore a composite of cranial, dental and postcranial morphology was employed. Additionally, the physical characteristics and stature estimations of the mission residents were examined using the postcranial remains. Data gathered on the pathologies were used to examine frequency and severity of different disease processes including infectious diseases, stress-related diseases, congenital diseases and traumatic injuries. The severity and frequency of dental pathologies were examined, as well as the occurrence of developmental dental defects.

\section{Demography}

In addition to the demographic reconstruction from the skeletal analysis, the Burial Records from the Mission documents (Oberste 1942) and the 1810 Census provide some very interesting insights into life at the Refugio mission. Data concerning infant and seasonal mortality as well as traumatic deaths are available from these records. Although these data are obviously deficient in providing a complete record of death at Refugio, the documents describe general patterns of mortality.

Historical records describe variations in residence patterns of the Native American population at the mission (see Ricklis 1996:162-165). Ricklis found that various Karankawan groups would arrive at missions during certain periods of the year. As is evident from the burial record, a majority of Amerindians at the mission were Karankawan. Ricklis suggests that these movements were associated with variations in the availability of food resources at the mission. In order to investigate this observation further, we tabulated annual and monthly mortality by Native and non-Native groups at the mission. Deaths of individuals recorded as Native American occur in all but two years, 1808 and 1818. Deaths of Amerindians are recorded for every month of the sixteen-year period. It should be noted that deaths of individuals identified as Native American are limited in each year with a maximum of seven individuals in 1820 and average only 3.3 deaths per year. In addition, Native American deaths are typically restricted to one or two months per year. The combined monthly pattern does not suggest a specific seasonal migration of the Karankawa population to and from the mission as Ricklis (1996:162-164) has suggested, but group movements are more than likely related to yearly variations in subsistence resources. Ricklis does point out that some groups did move to the mission during the fall and winter, possibly as a result of large coastal bands and over-exploitation of coastal resources. 


\section{Isotopic Evidence for Seasonal Use of the Mission}

The isotope data provide the most convincing osteological evidence that at least some of the population buried at the mission were seasonal users, while others were apparently permanent residents. We argue that permanent residents have a more ${ }^{13} \mathrm{C}$-enriched diet due to more maize consumption, while the seasonal residents are more ${ }^{15} \mathrm{~N}$ enriched and less ${ }^{13} \mathrm{C}$ enriched due to higher marine diets with a smaller maize component. Figure $8 \mathrm{~d}-1$ shows a plot of ${ }^{15} \mathrm{~N}$ versus ${ }^{13} \mathrm{C}$. The isotope signatures are highly variable, suggesting dietary variability of the cemetery sample. It is resolvable into three groups:

Cluster 1 is the far left group, characterized by low values of ${ }^{13} \mathrm{C}$.

Cluster 2 is the far right group, greatly enriched in ${ }^{13} \mathrm{C}$. Cluster 3 is the central group intermediate in ${ }^{13} \mathrm{C}$ and somewhat enriched in ${ }^{15} \mathrm{~N}$.
1) $\mathrm{A}^{13} \mathrm{C}$ enriched group with lower ${ }^{15} \mathrm{~N}$ values, (lower right in Figure 8d-1);

2) A group higher in ${ }^{15} \mathrm{~N}$ and lower in ${ }^{13} \mathrm{C}$ (upper middle in Figure 8d-1); and

3) A group low in both ${ }^{15} \mathrm{~N}$ and ${ }^{13} \mathrm{C}$ (lower left in Figure 8d-1).

Total variation is greater along the ${ }^{13} \mathrm{C}$ axis, but within groups variation is restricted to the extent that there is no overlap among groups. Group 1 corresponds to our prediction for permanent residents and Group 2 to our prediction for the seasonal residents who were exploiting marine resources part of the year. Group 3, containing only four individuals, may represent Plains populations relying on bison or other large mammals. These diet groups cross cut ethnic assignments, except that all individuals we identified as European are in the permanent resident group. Native Americans and those of mixed ancestry are found in both the seasonal and permanent resident groups.

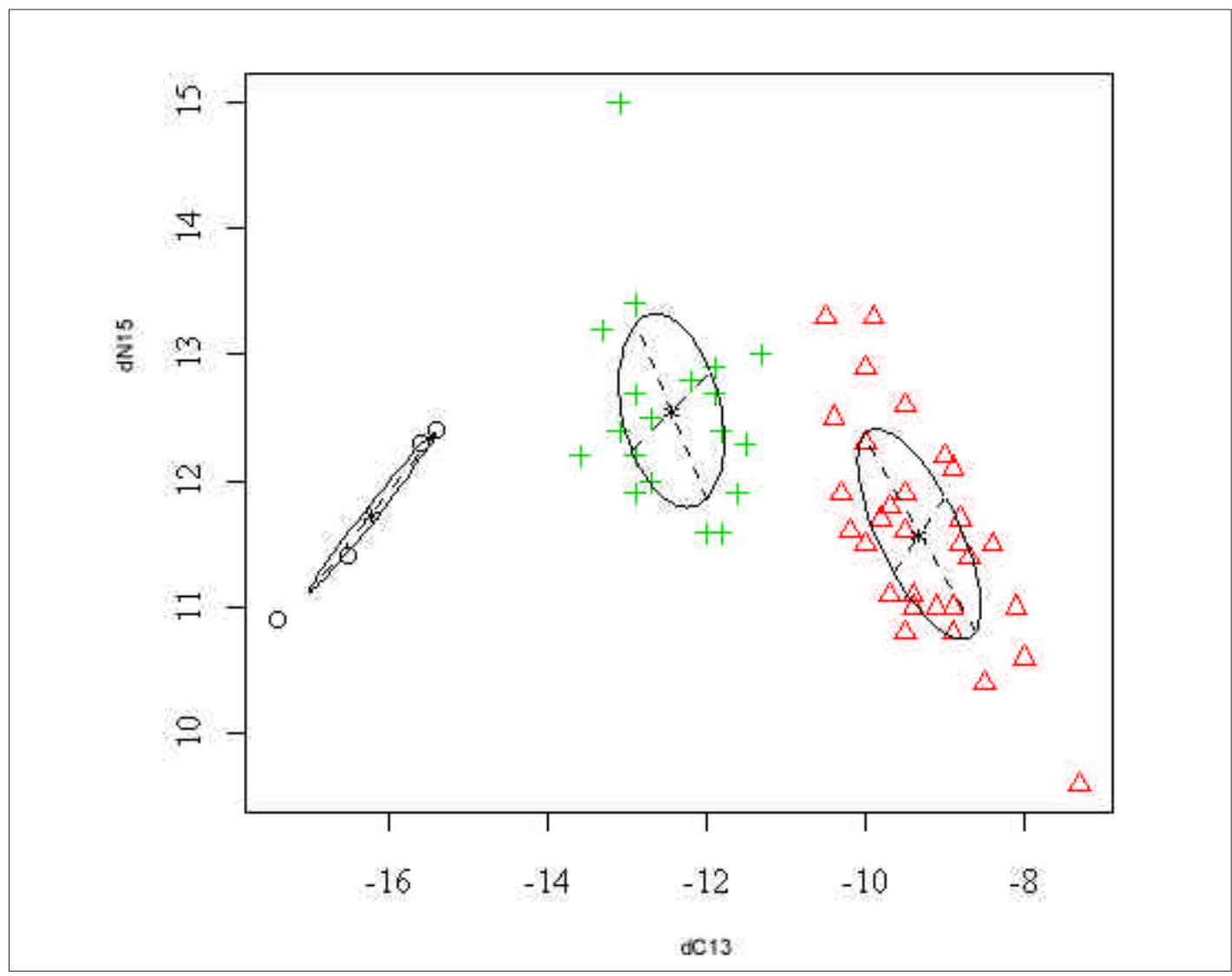

Figure 8d-1. Plot of three diet clusters surrounded by their one standard deviation ellipses. 
Oral health also supports more of a hunting and gathering subsistence rather than a maize dependent subsistence. The low frequency of dental caries and low antemortem tooth loss are more often seen in hunting and gathering populations.

\section{Karankawa Physical Characteristics}

Skeletal fragmentation makes it difficult to do overall assessments of morphology. That is offset to some extent by large sample size, making it possible to obtain at least some information for most aspects of the skeleton. Our ability to generalize about Karankawa is also constrained by the mixed nature of the sample. We are confident that there are some individuals of mainly European ancestry in the sample, although the number is not large. Within the Native American sample a morphological assessment is further complicated by the likely presence of tribes other than Karankawa, which are unidentifiable osteologically. According to the burial records (Oberste 1942) about 85 percent of the Native American groups at the Mission were identified as Karankawa. We really have no idea how differentiated Karankawa were from their neighbors. Our general feeling is that postcranially at least, there were broad similarities. On that basis we feel our generalizations are broadly applicable to Karankawa.

Our data on body size are especially important in view of historic records stating that Karankawa were particularly large individuals. Our assessment of body size does not support an average height of six feet, the figure often mentioned in historic accounts. Rather our stature estimates would place the males at about $165-167 \mathrm{~cm}$ (ca. 5'5"-5'6") and females at about $153-155 \mathrm{~cm}$. (ca. 5'0"-5'1"). These heights would place them at about average or slightly above for Native Americans generally. The idea that Karankawa body size set them apart from their neighbors has made its way into the scientific literature (e.g. Ricklis 1996 and others). We were unable to develop any skeletal support for this idea. To the contrary, the Karankawa body size must have been more or less comparable to the other groups in the region.

We have also evaluated - at some length - stature estimation procedures that have been applied to Texas Coast populations in the past. We argue that previous stature estimates have likely been over-estimates. The evidence from the Refugio sample, as well as evidence from living Texas populations, suggests that Karankawa were likely relatively long-legged populations. Application of stature estimation formulae from short-legged reference samples, such as Trotter and Gleser's (1958) Mongoloids is inappropriate.

Our results support previous osteological evidence that Texas coastal populations are skeletally robust. The robusticity is apparent in shafts and articular surfaces of long bones and in the midfacial region of the cranium. It is unlikely that Karankawa skeletal robusticity has a unitary cause. Despite considerable research into postcranial robusticity, it still is not clear how it should be interpreted. It seems likely that the Karanakwa were a mobile population. Size and shape of the femur midshaft has been put forth as an indication of mobility (Larsen 1997), but hunters and gatherers do not necessarily exhibit robust postcranial skeletons (Collier 1989). Midfacial robusticity, likely not to be a product of function, suggests that at least certain components of Karankawa robusticity are genetic in origin.

\section{Ancestry}

Our assumption at the outset was that the Refugio sample was heterogeneous, consisting of Native, European derived, and mixed. This composition is reflected in our ancestry assignments made on the basis of morphological assessments. The only opportunity for quantitative investigation of issues relating to ancestry and admixture is in dental metrics and dental morphology. Analysis of dental metrics clearly shows that the overall pattern of the Refugio sample is Native American. Formal classification of all individuals with dental morphology yields 23 percent European origin, 68 percent Native, and 9 percent admixed. These assessments involve some arbitrary decisions about posterior probabilities. A more liberal interpretation of intermediate probabilities would increase the number of admixed at the expense of the "pure categories."

\section{Pathology}

There is ample osteological evidence of violence in the Refugio sample. Much of it is in the form of scalping, which implies external aggression. It is difficult to estimate scalping rates, given the nature of the skeletal material. An approximation is possible using the number of scalped crania in relation to the number of frontals, since the frontal will normally show evidence of scalping. There are five instances of scalping identifiable among 67 complete or partial frontals. This yields a rate of 7.5 percent, which must be regarded as a conservative estimate, since partial frontals 
may not preserve the evidence of scalping. The value approaches the 9 percent rate observed in postcontact Northern Plains (Disorganized Coalescent) populations (Owsley 1994), suggesting that the mission population was experiencing a similar level of aggression.

The total number of skeletally identifiable trauma deaths is nine. Considered in relation to the number of burials with appreciable remains (approximately 140 have some postcranial measurement), would yield a rate of ca. 7.5 percent. This number too, must be regarded as conservative, since diagnostic parts of other trauma deaths are likely not present. Historical records note 26 trauma deaths out of 125 (Oberste 1942), almost 21 percent. Much of this toll was likely exacted by equestrian groups such as Comanche or Kiowa (Ricklis 1996). Although additional quantification is not possible, it is clear that intergroup violence extracted a considerable toll on the mission inhabitants.

In addition to those with perimortem trauma, there are four individuals, two males and two females, with antemortem trauma. Antemortem trauma is nonlethal, either healed or healing at the time of death. Antemortem trauma is somewhat more likely to represent intragroup violence than is perimortem trauma. Both males exhibit facial fractures, likely a result of fighting. Both the females may be victims of domestic violence. One in particular has the facial trauma consistent with what might be expected in domestic abuse. The level of intragroup violence is low compared with intergroup violence.

The Refugio population does not exhibit evidence of exposure to excessive physical hardship. Formation of enthesophytes may be taken as evidence of high levels of activity. The overall frequency of enthesophytes is low. In males the probability is higher that enthesophytes will form on the lower limb, while in females upper limbs are more likely to be affected, suggesting a sex difference in activity pattern. A similar sex difference may exist in lower versus upper limb robusticity.

Schmorl's depressions and spondylolysis indicate vertebral trauma or compression. They too are uncommon in Refugio, indicating that health and well-being did not suffer much from physical hardships.

Cause of death is notoriously difficult to infer from osteological evidence, except in the case of trauma. In addition to the trauma deaths discussed above, there is one individual with a medical condition likely to have resulted in death. The individual exhibiting the neoplastic condition, possibly multiple myeloma, is likely to have succumbed to complications resulting from this disease process.

The only infectious disease encountered was treponematosis. This is usually regarded as of New World origin. If infectious diseases of Old World origin were present at Refugio, they are not identifiable osteologically. It is possible that cases of congenital treponemal infections were responsible for death or premature birth.

The only area that suggests the Refugio population experienced adverse health affects is that of dental hypoplasia. They have high frequencies, considerably higher than those seen at the San Juan Capistrano Mission, although this may be an artifact of data collection. This high frequency might indicate seasonal shortages which caused temporary growth insults, but which had no long-term significance for the individuals involved.

In conclusion, the population of the Refugio mission was a relatively healthy group that experienced low stress or physical hardships. The primary risk to those individuals of the mission was violent in nature. Physically, the group was not exceptionally tall as had been reported earlier, however, they were robust. Because of the lack of intact crania, little can be said regarding the reports of cultural modification to the head. Further comparison of the osteological and dental data from the Refugio mission with other Texas coast groups may shed light on some of these unanswered questions. Further comparison of the isotopic data of this population with other Texas groups would also address questions raised in this study. 



\title{
Chapter 9: Artifacts
}

\section{Section A}

\section{Ceramics}

\author{
Anne A. Fox
}

Of the artifacts customarily recovered from Spanish Colonial sites, ceramics are the most useful and are sometimes the only items that can be used to date deposits and features. For this reason they tend to get more attention than other artifacts. They can be separated into categories according to the types of wares represented. In this report we have separated them according to their commonly accepted place of origin. Those generally known as being made in Mexico, England, Europe, and China $(n=2,269)$ are described in the following section and listed by provenience in Appendix C Those attributed to local Indian groups are included in Section c of this Chapter.

Ceramic wares were brought from Mexico to the Texas area by mule trains throughout the Colonial period. Unfortunately, the inventories of these shipments seldom mention much about the specific types of ceramics being carried, other than occasional references to tin-glazed wares, which were evidently considered important enough to list. According to the archaeological record, however, various types of ceramics were being imported, from unglazed burnished wares to more sophisticated glazed wares.

Beginning around 1800, English-made ceramics began to appear on Texas sites. Although importation of these wares was against Spanish law at first, it appears that when they first appeared in Texas they were coming through Mexico. Humboldt (1941:17:) observed that during the last years of the eighteenth century contraband was entering Mexico through Vera Cruz and Campeche, causing the number of earthenware manufacturers in Puebla to decrease from 46 in 1793 to 16 in 1802 . Since the comparatively late date of secularization of Mission Refugio would seem to overlap this time period, it seems likely that many of the English wares recovered can be attributed to the last years of the mission. For this reason, they are included here at the end of the Colonial ceramics descriptions.

\section{Unglazed Wares}

Thirty-five non-Native unglazed sherds were recovered during the excavations (Table 9a-1). Unlike Native American ceramics, these unglazed sherds appear to have been made on a potter's wheel and fired in the controlled heat of a kiln. The paste of these sherds is gray and sandy and resembles that of coastal Indian pottery but the shapes are more Spanish. The inventories from Refugio do mention several brick kilns and there is one mention of a potter present in the 1796 Inventory.

Of these unglazed sherds, 16 came from the upper, nonfeature level, five from Feature 1, and 14 from Feature 2. Eight of the sherds from Feature 2 represent a simple, wheelmade kiln-fired vessel, probably a bowl with an inverted rim, ca. $14 \mathrm{~cm}$ in diameter. Three rim sherds are from a plate or shallow bowl with an inverted rim also ca. $14 \mathrm{~cm}$ in diameter. Four other sherds from Feature 2 were fragments of a small, crude, hand-formed object about $4 \mathrm{~cm}$ in diameter- what ceramicists would ordinarily call a "pinch pot." The rest of the sherds are too small to determine the shape or size of the vessels represented.

Table 9a-1. Unglazed Mexican and European ceramics

\begin{tabular}{|l|c|c|c|c|c|}
\hline Type & Feature 1 & Feature 2 & Non-Feature & West Side & Total \\
\hline Non-native Unglazed & 5 & 14 & 16 & 0 & 35 \\
\hline Tonalá Burnished & 18 & 15 & 15 & 2 & 50 \\
\hline Red Burnished & 2 & 3 & 4 & 0 & 9 \\
\hline Black Burnished & 1 & 5 & 4 & 5 & 15 \\
\hline Olive Jars & 1 & 0 & 4 & 1 & 6 \\
\hline \multicolumn{1}{|c|}{ Sub-total } & 27 & 37 & 43 & 8 & 115 \\
\hline
\end{tabular}




\section{Burnished Wares}

\section{Tonalá Burnished Ware}

This type of ceramic, made in the town of Tonalá, Jalisco, has a fine, gray paste that has a sweet, earthy fragrance when damp. The Spanish referred to vessels from this area as búcaro, which was the common term for the clay from which they were made (Fairbanks 1973:170). Various other names have been used for this type such as Aztec IV (Smith 1965:90), Guadalajara Polychrome (Deagan 1987:44 and Goggin 1968:226) and Tonalá Bruñida Ware (Charlton and Katz 1979:45). Most vessel walls are thin, ca. 4 to $6 \mathrm{~mm}$ in thickness, and as suggested by the type name, sherds are burnished on one or both surfaces. They bear no obvious indications of being wheel-thrown and Katz (1977:117) states that Tonalá potters traditionally used a convex, mushroom-shaped mold. Due to their thin walls and relatively low firing, vessels tend to break into very small fragments.

Various descriptions over the years (Charlton and Katz 1979:46; Deagan 1987:44) have suggested that these vessels were covered with a white or tan slip. However, careful microscopic examination reveals that the sherds recovered during these excavations have a floated surface created by repeated wetting and rubbing which gives the appearance of a slip (Hodges 1964:33; Shepard 1968:191). The smoothed surface is sometimes painted with delicate red, yellow, and/or black designs and bands, and then burnished.

The present excavations yielded 50 Tonalá Burnished sherds (Table 9a-1). They were rather evenly divided between the units; 15 from the non-feature level, 18 from Feature 1, and 15 from Feature 2. Two additional sherds were recovered from the west side of the street during the burial excavations. Five rim sherds were recovered. Most of the sherds are too small to allow reconstruction of vessel shape except for a group from various levels of Feature 2, which represent an undecorated bowl with a slightly inverted rim, burnished both inside and outside.

Deagan (1987:46) reports that cargoes of eighteenth century shipwrecks included bowls, lidded bowls, and novelty figurines of Tonalá Burnished ware. Goggin (1968:227) mentioned small cups and plates as well. Sherds excavated by Charlton and Katz (1979:46) in the Teotihuacan Valley of Mexico represent jars with straight or flaring necks and upright rims and bowls measuring ten to sixteen $\mathrm{cm}$ in diameter.

\section{Red Burnished Ware}

Nine Red Burnished sherds were recovered during the Refugio excavations, four from the non-feature level, two from Feature 1, and three from Feature 2. Sherds of this ceramic type found on Texas sites have a highly burnished red slip on a fine-grained red body. Matte areas are decorated with burnished "spirals and curvilinear figures" (Gilmore 1974:63). The burnished surface tends to spall during firing, producing a speckled appearance on many sherds. The most common vessel of this type is a relatively deep bowl with a sharp, inverted rim and a heavy base with a pronounced kick-up in the center and an unusually deep $(\mathrm{ca} .2 \mathrm{~cm})$ ring foot. The interior of the kick-up is not burnished. Body sherds average $6 \mathrm{~mm}$ in thickness, which varies depending upon the location on the vessel. A larger, more ornately shaped bowl has been excavated at Presidio La Bahía. The unusual shapes of Red Burnished vessels hint at a possible specialized use, but this-so far-has not been confirmed. Suggested names for this type carefully avoid attribution to its possible place of origin and vary from Rosario Red (Cecil Calhoun, personal communication) where it was first noticed at Mission Rosario in 1965, to Spalled Red (Gerald 1968:54). The term Red Burnished Ware has been used in Texas since 1974 (Gilmore 1974:63).

Tunnell (Tunnell and Ambler 1967:24) suggests that this type originated from an Indian group in Central Mexico. It has been recovered in archaeological excavations throughout the Colonial period in Texas and as far east as Presidio Los Adaes (Gregory 1980:49). However, Deagan (1987) does not mention it as being present in Florida or the Caribbean area. It was found at Janos in northwest Chihuahua, and at the presidios of San Elizario near El Paso and San Sabás near San Vicente across from Big Bend (Gerald 1968:54). Gilmore (1974:63) reports that the late New Mexico anthropologist E. Boyd believed that this pottery type was brought to the northern Spanish colonies by neophyte Indians. The wide distribution of this type on the frontier, however, suggests that it was purchased in Mexico City by the procurators of the mule trains that supplied the Colonial missions and presidios.

\section{Black Burnished Ware}

These sherds are simply a black version of Red Burnished Ware. For some reason, the black version only seems to appear on the San Antonio River valley sites, at the second site of Presidio La Bahía (41VT8) on the Guadalupe River near Victoria, and at Refugio. At least there is no mention 
of it in any other site reports. Fifteen such sherds were recovered at Refugio; four from the non-feature level, one from Feature 1, five from Feature 2, and five from the west side of the street during the burial excavations.

\section{Olive Jars}

Olive jars or botijas were used to ship liquids such as wine and olive oil to the New World from Spain (Avery 1997:221; Goggin 1968:58). The jars were sealed with cork stoppers, which were tapered from top to bottom (James 1988:49). The body is a coarse cream or pale red, often with large inclusions, and throwing rings are prominent on the outer surface. Such vessels are often glazed on the inside with varying shades of green, and sometimes coated on the outside with a white substance that Goggin identified as a white slip (1968:267). James (1988:51), however, suggests that this whitish coating is more likely to be efflorescence caused by the firing of certain types of clay containing sulfates of calcium, magnesium, potassium, and/or sodium (see Shepard 1968:21). Avery (1997:225) agrees and notes that olive jars made in the Guadalquivir Valley have this efflorescence, while those made in the New World and possibly in other areas of Spain do not. This is an interesting idea that should bear more research.

Six olive jar sherds were recovered at Refugio, four from the non-feature level, one from Feature 1, and one from the investigations on the west side of the street (Table 9a-1). No rim sherds were among these. The sherds varied from 9 to $14 \mathrm{~cm}$ in thickness. Of the olive jar sherds recovered at Refugio, only one from the non-feature level has the white efflorescence mentioned above.

Olive jar sherds are found on most Texas Colonial sites, but seldom in any great number. This may be due to the fact that they would have been difficult to transport from Mexico, or even that by the early-eighteenth century the contents (or the empty jars) were less in demand. The largest collections of whole jars have been salvaged from sixteenth and seventeenth century shipwrecks, while comparatively large numbers of sherds have been excavated at seaports from Florida to Venezuela and throughout the Caribbean Islands (Goggin 1964:256).

\section{Lead-glazed Wares}

Lead-glazed bowls and jars are often the most frequently represented glazed ceramics on Spanish Colonial sites in
Texas. Either wheel made or molded, these vessels were used for the preparation and storage of foods and probably for consumption as well. So far, there is no evidence for their production on the Texas frontier, since no potters' wheels or kilns necessary to produce this type of glaze have been found. A preliminary study of these wares done by Fox in 1974 (Gilmore 1974:55-59), for want of more definitive studies, has been used by other Texas archaeologists as a method of organizing lead-glazed sherds (Carlson 1994; Dial 1992). More detailed analysis has been done by Mark Barnes (1980:92-110) of lead glazes recovered from five sites in southern Arizona and San Juan Bautista in Sonora and also by Rex Gerald (1968) in his study of eighteenth century presidios in northern New Spain. The principal difference between lead glazes in Arizona and Northern Mexico and those in Texas appears to be the presence of a group of green-glazed wares that seldom if ever reached the Texas sites.

The method used in preliminary sorting of the 842 leadglazed wares from this site was the same used by Fox in 1974. The sherds were first sorted into two groups, with the aid of a binocular microscope with 20x magnification: those with a sandy paste and those with a fine-textured paste. Within these two categories, subtypes were separated and described.

\section{Sandy Paste Ware}

In all, 230 lead-glazed sherds of the sandy paste variety were recovered during CAR excavations at 41RF1. The following subtypes can be recognized within this category (Table 9a-2).

\section{Yellow Glaze}

Heavy bowls, jars, and pitcher sherds with walls often as thick as $10 \mathrm{~mm}$ with a coarse tan to orange paste containing sand and red to red-brown inclusions are typical of this type. They show evidence of the use of the wheel on the interior and are smoothed on the outside. A lead glaze of varying thickness produces a distinctly yellow surface on the interior and just over the rim (Fox 1974:56). Occasionally these vessels have green rim decoration. Where the body of the vessel has fired to shades of gray, the glaze appears green. Tunnell (Tunnell and Newcomb 1969:81-83) made this same observation when examining what he called Lead-Glazed Amber Plainware, which is probably the same type. Unfortunately, the 74 sherds in this collection, with the 
Table 9a-2. Lead-glazed ceramics

\begin{tabular}{|c|c|c|c|c|c|}
\hline Type & Feature 1 & Feature 2 & Non-Feature & West Side & Total \\
\hline \multicolumn{6}{|c|}{ Sandy Paste } \\
\hline Yellow glaze & 24 & 11 & 39 & 3 & 77 \\
\hline Yellow/green glaze & 9 & 9 & 23 & 2 & 43 \\
\hline Dark Green glaze & 14 & 76 & 14 & 0 & 104 \\
\hline Hand-molded & 5 & 1 & 0 & 0 & 6 \\
\hline Sub-total & 52 & 97 & 76 & 5 & 230 \\
\hline \multicolumn{6}{|c|}{ Fine-textured Paste } \\
\hline Galera Ware & 128 & 91 & 252 & 23 & 494 \\
\hline Dark Brown Ware & 2 & 21 & 18 & 6 & 47 \\
\hline Red Brown Ware & 2 & 1 & 4 & 0 & 7 \\
\hline Yellow w/ Brown & 2 & 0 & 3 & 0 & 5 \\
\hline Tonalá Polychrome & 7 & 3 & 44 & 3 & 57 \\
\hline Black Luster & 2 & 0 & 0 & 0 & 2 \\
\hline Sub-total & 143 & 116 & 321 & 32 & 612 \\
\hline Total & 195 & 213 & 397 & 37 & 842 \\
\hline
\end{tabular}

exception of the one illustrated in Figure 9a-1[a], are too small to allow determination of vessel shape and there are only four rim sherds. Thirty-nine of the sherds were from the non-feature level, 24 from Feature 1, 11 from Feature 2, and three from the investigations on the west side of the street. Four sherds of this variety, two of each from Units 2 and 3, were also recovered during TxDOT's testing phase.

A representative sample (10) of these sherds was examined by neutron activation. Seven of the sample sherds were determined to have been made in Mexico, but outside of the Mexico City region. The three that were different could possibly have been made in south Texas, but were not produced in a way similar to that of Native American potters. These results tend to argue against the suggestion that the inhabitants of the mission were glazing pottery.

\section{Yellow and Green Glaze}

Wheel-thrown bowls of slightly thinner $(3-5 \mathrm{~mm})$ leadglazed ware have a thinner glaze over a slightly finertextured sandy paste. Sometimes bowls of this type are decorated with olive green bands around the rim and/or in the bottom. Two large bowls of this type were recovered from a post-1772 context at Rancho de las Cabras near Floresville (Ivey 1983). Forty-three yellow with green sherds are present in this collection, of which five are rim sherds.
Twenty-three came from the non-feature level, nine from Feature 1, nine from Feature 2, and two from the investigations on the west side of the street. Six sherds of this variety, three each from Units 2 and 3, were also recovered during TxDOT's testing phase.

\section{Dark Green Glaze}

One hundred and four small, thin sherds ( $3 \mathrm{~mm}$ thick) appear to represent one or more very small pots that have been severely burned. The glaze, where it is visible, is a dark green. With the green glaze overlying a blackened body, it is difficult to tell whether it once may have been yellow. One partially reconstructed pot from Feature 2 (Figure 9a$1[\mathrm{~b}])$ represents a vessel approximately $7.5-\mathrm{cm}$ tall, $5.0-\mathrm{cm}$ in diameter at the shoulder, and $7.5 \mathrm{~cm}$ at the everted rim. The interior of this small vessel is unevenly coated with an unidentified black substance that is not asphaltum. Fourteen sherds are from the non-feature level, 14 from Feature 1, 76 from Feature 2. There are five rim sherds present. Two similar sherds, one each from Units 2 and 3, were also recovered during TxDOT's testing phase.

\section{Hand-molded}

Also in this collection are six sherds of an unusual handmolded bowl ca. $16 \mathrm{~cm}$ in diameter that has a thin lead glaze 


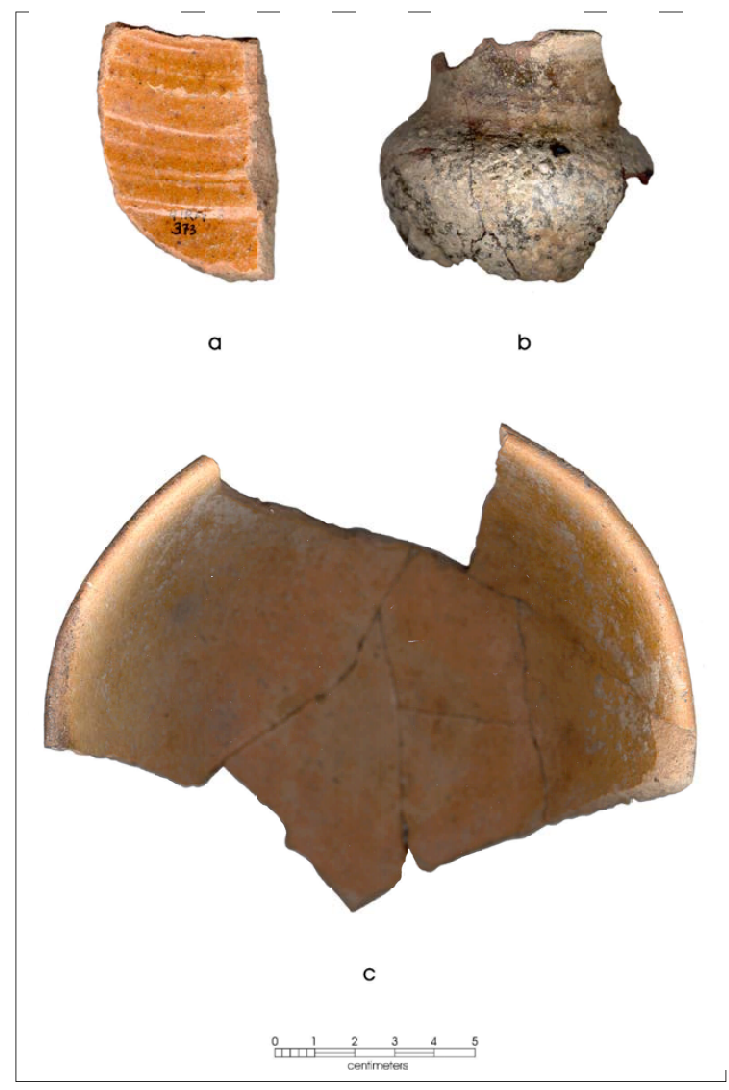

Figure 9a-1. Sandy-paste lead glazes. (a) yellow glaze; (b) dark green glaze; (c) hand-molded lead-glazed bowl.

on the interior and just over the rim (Figure 9a-1[c]). The paste is identical to that of the wheel-made lead-glazed sherds. Five of these sherds were from Feature 1 and one came from Feature 2.

\section{Fine-Textured Paste}

\section{Galera Ware}

Schuetz (1969:50) called this ware West Mexico Polychrome when reporting her work at Mission San Juan Capistrano in 1967. Currently called Galera Ware across the southwest from Texas to California, this ceramic is still made today in west Mexico. It appeared in Texas ca. 1750 (Tomka and Fox 1998a:22). The most prevalent lead-glazed ceramic type in this collection (494 sherds), 252 are from the non-feature levels, 128 from Feature 1, 91 from Feature 2 , and 23 from the investigations on the west side of the street (Table 9a-2). These sherds have a fine textured, red paste containing occasional small grains of sand. There are 37 rim sherds in the collection.

Vessels of this type are usually molded and very thin, averaging 3 to $4 \mathrm{~mm}$ in thickness. A thin lead glaze brings out the red orange color of the paste. Most of the Colonial vessels represented are chocolate pots and bean pots, glazed on the inside and on the outside of the neck of the former, where there are often designs painted in cream, brown, and green (Figure 9a-2[a]). Undecorated sherds with the same paste but glazed only on the inside are included in this type since they usually come from other areas of the same vessels.

A representative sample (10) of Galera sherds was examined by neutron activation. The conclusion was that they were not made in south Texas, but probably in Mexico, outside the Mexico City region. This agrees with Schuetz' theory that they came from western Mexico (see also Barnes 1983:212 and Foster 1948:368).

\section{Dark Brown Ware}

Forty-seven sherds represent a type tentatively called Dark Brown Glazed Ware. Eighteen of these sherds were found in the non-feature levels, two in Feature 1, 21 in Feature 2, and six during investigations on the west side of the street. Only three rim sherds were recovered. Similar to Galera in paste, thickness and construction technique, these sherds are from bulbous pots ca. $13 \mathrm{~cm}$ in diameter at the base of the neck and have a short, slightly everted rim (Figure 9a$2[\mathrm{~b}])$. There is a crude design of impressed dents every 25 $\mathrm{cm}$ around the shoulder. A brown glaze gives the pot a molasses-like color. This type was first recognized in the collections from Mission Rosario (Fox 1974:58). A similar pot was excavated and is on display in the museum at Presidio La Bahía in Goliad, Texas.

\section{Red Brown Ware}

This variety consists of seven sherds from shallow bowls or plates with a similar paste. They are glazed on the interior and decorated with a single brown band and have a smooth, red-brown surface. Four such sherds were recovered from the non-feature level, two from Feature 1, and one from Feature 2. No rim sherds were recovered. A few sherds of this type are generally found on early San Antonio sites and appear to date from the late-eighteenth century to the earlynineteenth century. These are currently classified as Red Brown Ware (Fox 1974:59). 


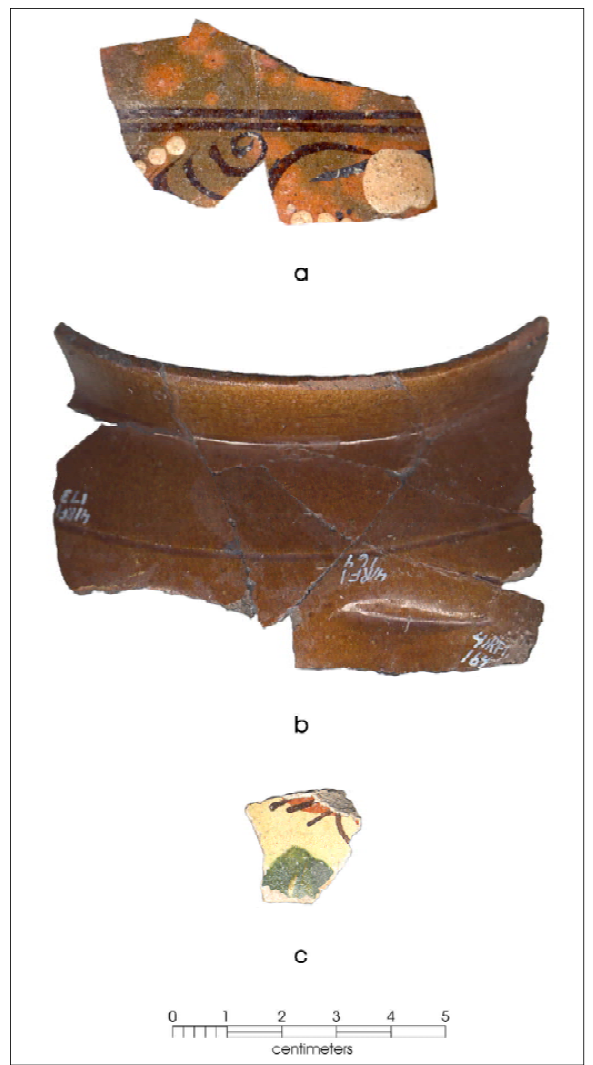

Figure 9a-2. Fine-textured lead glazes. (a) Galera ware; (b) Dark brown ware pot; (c) Tonalá polychrome.

\section{Yellow With Brown Ware}

Five sherds of this variety are present in the Refugio assemblage. They have a fine-textured beige paste covered with a pale yellow glaze and are decorated under the glaze with a brown linear design. Three of the sherds are from the non-feature levels and two are from Feature 1. The sherds are too small to allow reconstruction of the shape of the vessels represented. This type was first isolated and described by Fox (1974:58) from Mission Rosario. However, Schuetz (1969:Plates 25b and 25c) illustrates two examples from Mission San Juan Capistrano as well.

\section{Tonalá Polychrome Glazed Ware}

An unusually large number (57) of fine-textured red-bodied sherds three to six mm thick, covered inside and out with a cream colored enamel in apparent imitation of tin-glazed wares, is present in this collection. These are decorated with green and red brown designs and covered with a clear lead glaze (Figure $9 \mathrm{a}-2[\mathrm{c}])$. The quality of the enamel is poor and often much of it has flaked off. By far the largest number of these sherds (44) came from the non-feature level, seven from Feature 1, three from Feature 2, and three from investigations on the west side of the street. This ware has been dated by Gerald (1957:173) ca. 1780 to 1830 . The comparatively late date for this type probably accounts for its relatively important presence here.

The Tonalá sherds recovered at Refugio are too small to determine vessel shape. However, in excavations in the Second Patio at Mission Valero, Schuetz (1973) recovered sherds of this type that were sufficient in size to allow the recognition of a shallow bowl with a thin ring foot. The cream and green enamels used on this ware are identical to those sometimes used on Galera ware, making it difficult to differentiate the two when dealing with very small sherds. The clue can sometimes be the color of the inside of the vessel sherd, which is usually cream on the Tonalá Polychrome type but brown on the Galera sherd.

\section{Black Luster Glaze}

Black luster is represented in this assemblage by two sherds which have a thick black glaze over a fine-textured, dark brown paste. Both came from Feature 2. Such sherds are often found on Colonial sites in Texas (Gilmore 1969:52). However, they are nearly always too few and too small to tell what sort of vessels they represent. According to Gilmore (1969:52), black luster-glazed ceramics with a terra cotta body are made today in Puebla, while those with a buff body are made in Santa Fe, Michoacan. Barnes (1980:100) describes a black glazed ware with reddish brown paste that dates between 1750 and 1850, which is still made in Michoacan. Apparently more study is needed on this type.

\section{Majolicas}

Majolicas are lead-glazed earthenwares which have tin added to the glaze in order to create an opaque white or cream-colored surface. The styles and colors of decoration on these wares changed periodically, which makes them particularly useful for dating sites or deposits in which they appear. For that reason, they are grouped here according to the approximate time period during which they seem to appear on Texas sites.

The 729 majolicas recovered during these excavations comprise a particularly important collection since the date of secularization of this mission is late in comparison to 
that of most other Texas missions (Table 9a-3). A number of the majolica types present in this collection have not been included in any other Texas site reports and therefore will be described in some detail in order to aid others working in post-1800 Spanish Colonial sites.

The method used in sorting the majolicas into types was as follows. First, all sherds bearing no decoration were removed and classified as "undecorated." Then all decorated sherds that could be recognized as bearing specific patterns were sorted into types and removed. The remaining sherds that bore small bits of color were then sorted into those with only blue decoration and those with polychrome colors. Since all of these were very small or only had small bits of color, it was not possible to type them beyond the indication of some type of decoration.

\section{Eighteenth Century Majolicas}

\section{Undecorated Majolicas}

Some of these 319 undecorated sherds can represent totally plain vessels that were made in Mexico throughout the eighteenth century (Lister and Lister 1974:30). Of the eight rim sherds in this collection, three are from a thin (2-mm thick) delicate cup ca. $6 \mathrm{~cm}$ in diameter, which came from the 50 to $80 \mathrm{~cm}$ levels of Feature 2. The rest of the undecorated sherds are too small to identify the vessels from which they came, and most probably, represent parts of decorated objects.

\section{Blue-on-White}

A number of sherds $(n=46)$ bear touches of blue decoration, but are too small to allow for identification of the pattern. These have been grouped into a general category of Blue-on-White in order to signify that they are not undecorated. All seven rim sherds of this type have a blue band below the lip, which is typical of Puebla Blue-and-White, a pattern popular on deep plates in the first half of the eighteenth century (Ivey and Fox
1999:39). Body sherds have dark blue or light blue designs (Figure 9a-3[a]). Most have pale yellow or pink paste, which on the whole indicates an eighteenth century date. Fifteen of these sherds came from the non-feature level, 18 from Feature 1, 12 from Feature 2, and one from investigations on the west side of the street.

\section{Huejotzingo Blue Banded}

There are 30 sherds of this type in the collection, all of which were of necessity rim sherds. Three sherds of this type were recovered from the non-feature level, 14 from Feature 1, 12 from Feature 2, and one from investigations on the west

Table 9a-3. Majolicas

\begin{tabular}{|c|c|c|c|c|c|c|}
\hline Period & Type & Feature 1 & Feature 2 & Non-Feature & West Side & Total \\
\hline \multirow{3}{*}{ 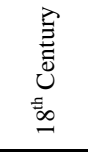 } & Undecorated & 84 & 114 & 108 & 13 & 319 \\
\hline & Blue-on-White & 18 & 12 & 15 & 1 & 46 \\
\hline & Huejotzingo Blue Banded & 14 & 12 & 3 & 1 & 30 \\
\hline \multirow{5}{*}{ 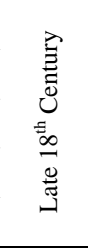 } & San Augustine Blue-on-white II & 3 & 6 & 5 & 0 & 14 \\
\hline & Puebla Blue-on-white II & 5 & 33 & 4 & 0 & 42 \\
\hline & Blue-on-white Molded & 0 & 2 & 1 & 0 & 3 \\
\hline & San Elizario & 4 & 3 & 5 & 1 & 13 \\
\hline & Yellow w/Green Band & 0 & 0 & 1 & 0 & 1 \\
\hline \multirow{7}{*}{ 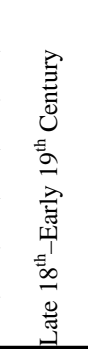 } & Wavy Rim-Band Huejotzingo & 3 & 9 & 12 & 1 & 25 \\
\hline & Huejotzingo Green Banded & 4 & 0 & 1 & 0 & 5 \\
\hline & Monterey Polychrome & 7 & 8 & 3 & 0 & 18 \\
\hline & Orange Band Polychrome & 23 & 16 & 2 & 0 & 41 \\
\hline & Thin Brown, Black and Blue & 0 & 5 & 1 & 0 & 6 \\
\hline & Tumacacori Polychrome & 4 & 2 & 3 & 0 & 9 \\
\hline & Other Late Polychrome & 15 & 16 & 7 & 2 & 40 \\
\hline \multirow{12}{*}{ 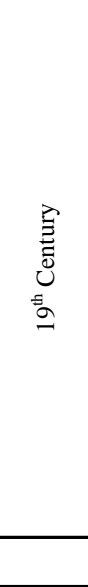 } & Guanajuato \# 1 & 0 & 0 & 10 & 0 & 10 \\
\hline & Guanajuato \# 2 & 3 & 7 & 4 & 0 & 14 \\
\hline & Guanajuato \# 3 & 0 & 0 & 5 & 0 & 5 \\
\hline & Nopaltepec & 0 & 0 & 14 & 0 & 14 \\
\hline & Late Polychrome \# 1 & 8 & 12 & 0 & 0 & 20 \\
\hline & Late Polychrome \# 2 & 4 & 4 & 2 & 0 & 10 \\
\hline & Late Polychrome \# 3 & 0 & 9 & 0 & 0 & 9 \\
\hline & Late Polychrome \# 4 & 0 & 2 & 4 & 0 & 6 \\
\hline & Late Polychrome \# 5 & 0 & 0 & 11 & 0 & 11 \\
\hline & Late Polychrome \# 6 & 0 & 0 & 3 & 0 & 3 \\
\hline & Late Polychrome \# 7 & 1 & 2 & 7 & 0 & 10 \\
\hline & Faience & 4 & 0 & 1 & 0 & 5 \\
\hline \multicolumn{2}{|l|}{ Totals } & 204 & 274 & 232 & 19 & 729 \\
\hline
\end{tabular}


side of the street. Vessels with this decoration have one blue band that extends over the rim (Figure 9a-3[b]). The blue can vary from dark blue to pale gray blue. There is seldom if ever a central design in addition to the rim band on this type, therefore numerous undecorated sherds are probably from these vessels, which are primarily deep plates. This type was made throughout the eighteenth century (Goggin 1968:195). Sub-types of this ware with a wavy rim band have been more tightly dated to the late-eighteenth to earlynineteenth century (see the following section).

\section{Late-Eighteenth Century Majolicas}

\section{San Agustín Blue on White II or Chinoiserie Blue on White}

Fourteen small body sherds of blue on white majolica are similar to a type called San Agustín Blue-on-White dated by Goggin (1968:189) from 1700 to 1730 . The pattern consists of floral designs in two shades of blue that cover the entire surface of the vessel (Figure 9a-3[c]). Spaces

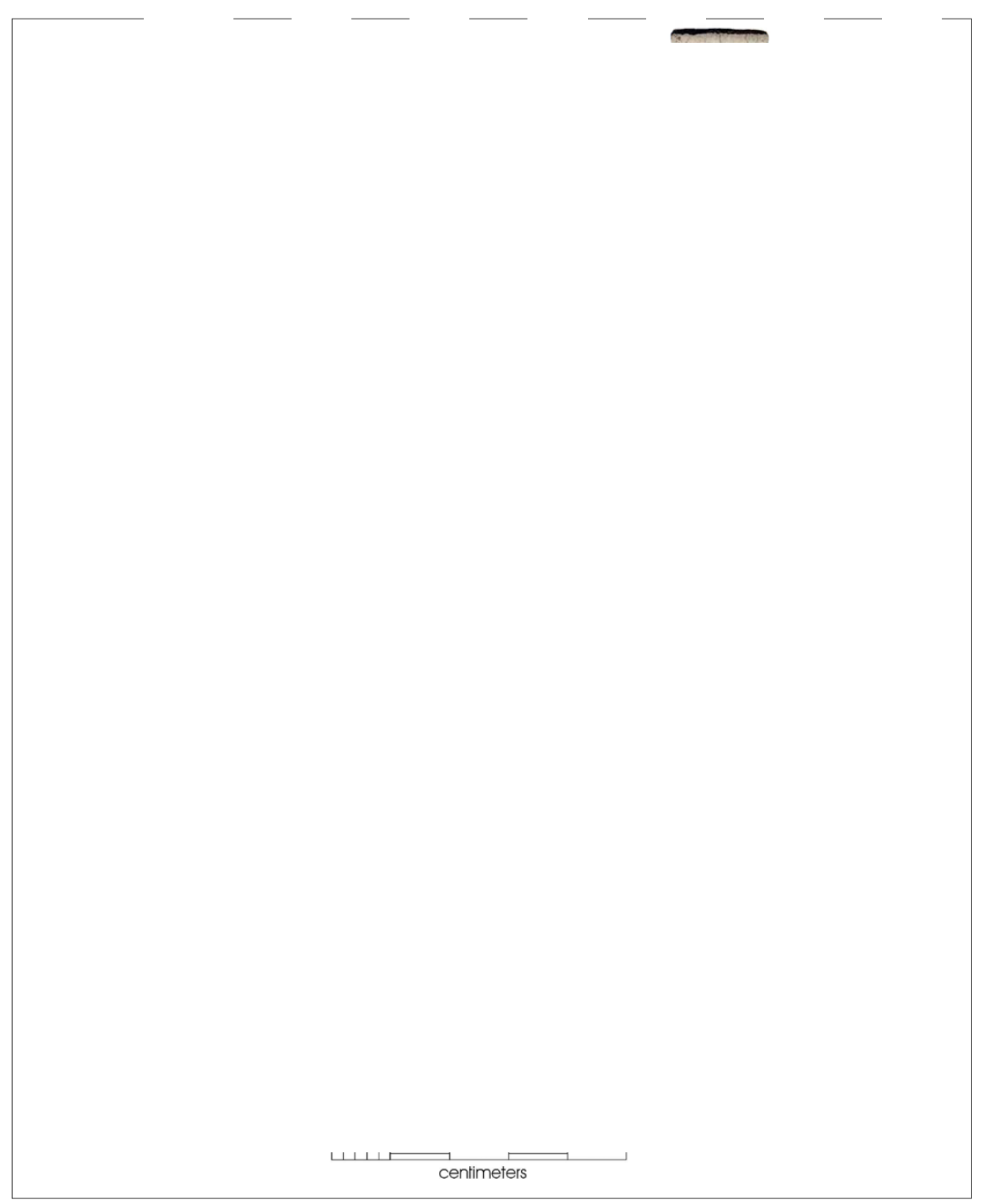

Figure 9a-3. Mexican Majolicas. Eighteenth century: (a) Blue-on-white; (b) Huejotzingo Blue Banded.

Late-eighteenth century: (c) San Agustín Blue-on-white; (d) Puebla Blue-on-white; (e) Blue-on-white Molded; (f) San Elizario. Late-eighteenth-early-nineteenth century: (g, h) Wavy Rim Band Huejotzingo; (i) Huejotzingo Green Banded; (j) Monterey Polychrome plate; (k) Monterey Polychrome cup; (1) Orange Band Polychrome. 
between the dark blue flowers are nearly filled with a lighter blue echo or shadow of the design, all on a glossy white background. A number of archaeologists have noted the continuation of this design, occasionally accented with black, later into the eighteenth century. Seifert (1977) refers to this later version as Chinoiserie Blue-on-White, perhaps a better name for the type in order to separate it from the earlier San Agustín. Both the earlier and later types have blue loops on the reverse side of deep plates. However, the sherds in this collection are too small to detect these. Five of these sherds were recovered from the non-feature level, three from Feature 1, and six from Feature 2.

\section{Puebla Blue-on-White II}

This variation of Puebla Blue-on-White appears only on cups and small bowls (ca. $14 \mathrm{~cm}$ in diameter). The design consists of two or three pale blue bands under the rim on the outside of the vessel. Below these bands are alternating floral-type arrangements of darker blue petal-shaped dots. Two additional pale blue bands form the bottom of the design. On some vessels there is a band of smaller blue petals below the lower bands, on others, a trio of dark blue dots occasionally hangs from the lowest blue band (Figure 9a$3[\mathrm{~d}])$.

Forty-two sherds of this type are in the collection, four from the non-feature level, five from Feature 1, and 33 from Feature 2. Thirteen of these are rim sherds. Tunnell (1966:8) reports this same type as his Style 4 from the Alamo. Schuetz (1969:Plate 26D, E, and F) describes bowls from Mission San Juan Capistrano with darker blue floral decorations between thin light blue bands on the exterior and one or two bands on the interior. This appears to be a slightly different version of the same type. Tunnell suggests that his Style 4 and Style 6 (the equivalent of Huejotzingo) are present on Spanish Colonial sites that date throughout the eighteenth century.

\section{Blue on White Molded}

This ceramic type has blue floral decoration on a vessel with a molded, scalloped rim and no ring foot (Figure 9a$3[\mathrm{e}])$. Gilmore (1974:51, and Plate 10) recovered a large plate-sherd of this type at Mission Rosario. Lister and Lister (1974:40) date this type to about the middle of the eighteenth century and attribute the design to French influence developed from the baroque. The fact that it was found at Mission Rosario, which was not founded until 1754 (Nickels 2000:1), tends to push the date slightly later. Its presence at
Mission Refugio suggests that it was still in use as late as the turn of the nineteenth century. Only three small plate rim sherds were recovered, one from the non-feature level and two from Feature 2.

\section{San Elizario}

In 1968, Rex Gerald isolated a blue-on-white majolica design identical to Puebla Blue-on-White except that it includes brown accents, narrow brown bands on either side of the blue rim band, and brown legs and beak on the central blue crane (Figure 9a-3[f]). He suggested that this be called San Elizario. Snow (1965:29) had earlier called this type Puebla Polychrome II, but Gerald's name seems to be the accepted one today. Ivey and Fox (1999:37) have determined that the type dates between $1755-1780$ in Texas. It is particularly useful for dating since it is easily recognizable even on small sherds.

Thirteen San Elizario sherds were found during these excavations; five from the non-feature levels, four from Feature 1, three from Feature 2 and one from investigations on the west side of the street. The six rim sherds, and probably the others, came from deep plates.

\section{Yellow with Green Band}

One rim sherd was recovered from the top of the non-feature level, which has a yellow glaze on both sides and appeared to be undecorated except for a green rim band that extended over the rim. It is 3-mm thick and is too small to determine the shape of the vessel. Schuetz (1969:56) recovered five similar sherds from Mission San Juan Capistrano.

\section{Late-Eighteenth to Early-Nineteenth Century Majolicas}

\section{Wavy Rim Band Huejotzingo}

This type is similar to Huejotzingo Blue-on-White, except the lower edge of the band is wavy or undulating and the band generally stops at the top of the rim (Figure 9a-3[g] and $[\mathrm{h}])$. At this site, five of the wavy band sherds were decorated with blue, 18 with green, and two with yellow. One blue, 10 green and one yellow were from the non-feature levels, two blue and one green were from Feature 1, one blue, seven green, and one yellow were from Feature 2, and one blue was from the burial area. Of the green type, one 
sherd has a narrow green band below the wavy rim band. Both plate and cup forms are represented.

It has been suggested that the blue-banded type may have been inspired by the appearance of English blue edged ware, which happened at about the same time. Deagan (1987:85) states that the blue type originated after ca. 1760. Seifert reports that the wavy rim type dates ca. 1775-1825 (Seifert 1977).

\section{Huejotzingo Green Banded}

About 1780, variants of the earlier Huejotzingo Blue Banded designs appeared that had green substituted for the traditional blue designs (Barnes and May 1972:33-34). From this site we have five plate rim sherds with an olive green band around and over the rim that may represent just one vessel (Figure 9a-3[i]). One sherd came from the non-feature levels and four from Feature 1.

\section{Monterey Polychrome}

This pattern has an orange rim band enclosed by brown lines, with floral elements in orange and yellow alternating with green sprays (Figure $9 \mathrm{a}-3[\mathrm{j}]$ and $[\mathrm{k}]$ ). A similar design is centered in the base, except that the green sprays are replaced by green petals. There are 18 sherds of this type in the collection, which included six plate and bowl rim sherds. Three sherds were found in the non-feature levels, seven in Feature 1, and eight in Feature 2.

This type is found all over California (May 1972:36) and is also common on most San Antonio mission sites. While May dates it to 1800-1830, its presence on Rancho de Las Cabras near Floresville, Texas (Ivey and Fox 1981:35) suggests that it may have been in Texas ten or fifteen years earlier. Deagan (1987:88) reports that this type is found on 1784-1821 sites in Florida.

\section{Orange Band Polychrome}

This type of majolica has green substituted for the blue on the San Elizario Polychrome pattern and an orange band at the rim similar to that on Monterey polychrome (Figure 9a$3[1])$. It has also been variously called Style 27 by Seifert (1977:185), Orangeline by May (1972:36), and Style 7 by Gilmore (1974:112). No one seems to have information about what central design may be present. There are 41 sherds of this type in the collection, including 23 rim sherds.
Two of these sherds were recovered from the non-feature levels, 23 from Feature 1, and 16 from Feature 2. All are from deep plates.

\section{Thin Brown, Black, and Blue}

Six body sherds are from unusually thin vessels having delicate designs in blue, brown, and black painted on a white background. Similar sherds of this type were recovered by Schuetz at Mission San Juan Capistrano (1969:57 Type Q) and by Tomka at Mission San José (Tomka and Fox 1999:25). Two sherds of this type have also been found during investigations at Mission Rosario (Gilmore 1975:4849; Nickels 2000:96-97). The sherds here came from the non-feature level (one sherd) and Feature 2 (five sherds), and were too small to allow determination of vessel form.

\section{Tumacacori Polychrome}

This attractive blue ceramic with molded rim and garland of orange and yellow flowers alternating with blue dots was represented by nine sherds in this assemblage. Four were recovered from Feature 1, two from Feature 2, and three from the non-feature levels. While Barnes and May (1972:11-12) dates this particular pattern from 1810 to 1840 in Arizona, the fact that Gilmore (1974:48, Plate 5d) found it at Rosario, which was abandoned by 1808 , suggests that it may have arrived in Texas slightly earlier.

\section{Polychrome}

A number of sherds $(n=40)$ have polychrome decoration but the pattern is unidentifiable because of the small size of the sherd. Here, as with Blue-on-White sherds, these have been gathered in an unidentifiable group, but separated to show that they represent polychrome decoration. Within this collection, the polychromes date almost totally to the lateeighteenth century-early-nineteenth century time period.

\section{Nineteenth Century Majolicas}

\section{Guanajuato}

In the early-nineteenth century, a new ceramic color combination appeared consisting of rust, green, and brown/ black on a greenish cream background (Lister and Lister 1974:Figure 12). The paste is consistently a dark red color. This type has been named for the area where it was first 
made. These wares are found on all mission sites in the San Antonio River valley, as well as on early-nineteenth century sites in Laredo (Clark and Juarez 1986; Folan et al. 1986). There are numerous designs within this type (McKenzie 1989), most of which have not yet been separated and named although Seifert (1977) has suggested names for some of these that she found in the Teotihuacan Valley of Mexico.

\section{Variety \# I}

There are ten plate sherds from the non-feature levels in this collection that have been segregated as Guanajuato

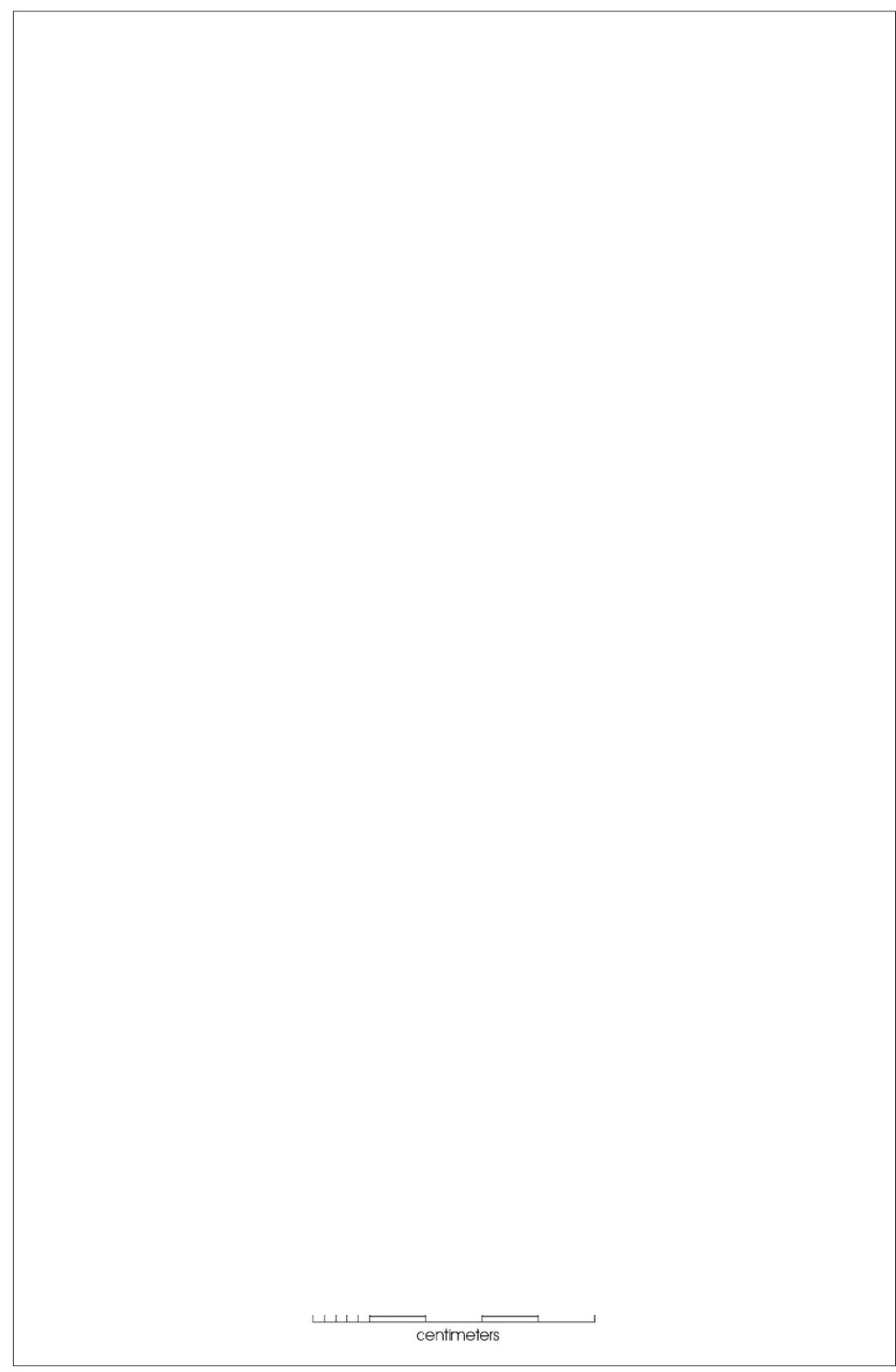

Figure 9a-4. Mexican Majolicas. Nineteenth century: (a) Guanajuato variety \#1; (b) Guanajuato variety \#2; (c) Guanajuato variety \#3; (d) Nopaltepec.

Other Late Polychromes: (e) Variety \#1; (f) Variety \#2; (g) Variety \#3; (h) Variety \#4; (i) Variety \#5; (j) Variety \#6. 
Variety \#1 (Figure 9a-4[a]) on the basis of paste and decoration that do not seem to fit into Seifert's typology. They have a green band under the rim bordered by a single rust band above and two below. Suspended from the lowest rust band is a row of small green petals. A large portion of the center of the vessel has matching swags of green petals inside a rust-colored design. Two thin parallel rust bands encircle the center of the vessel base. All of these sherds came from the non-feature levels. There are four rim sherds.

\section{Variety \#2}

Fourteen sherds, identified here as Variety \#2, have a red paste and are decorated with a green band just under the $\operatorname{rim}$ (Figure 9a-4[b]). The band is bordered with one narrow brown/black line above and two below. Under this are green splotches that may represent leaves or vague flowers. Three of these sherds are from Feature 1, seven from Feature 2, and four from the non-feature level. All sherds of this type appear to be from bowls. One is a rim sherd.

\section{Variety \#3}

Five sherds are identified here as Variety \#3 (Figure 9a$4[c])$. They have a red paste with the same green band bordered with brown/black lines as \#2 above. Several red brown and yellow anthers top brown stems within a pair of green leaves in an arrangement that is repeated half a dozen times around the inside of the bowl. The sherds from this site, one of which is a rim sherd, are all from small bowls and were recovered from the non-feature levels. The above description of the design could not be reconstructed from these sherds, but has been observed on larger pieces recovered from Presidio La Bahía at Goliad.

\section{Nopaltepec}

One type recognized from Seifert's descriptions as Nopaltepec (1977:237-240) is represented here by 14 sherds, all from the non-feature levels (Figure 9a-4[d]). This design has a green rim band. Rust bands below this rim band border a sinuous black line with alternating green and yellow balls. The red paste and rust bands are typical of Guanajuato Polychromes. The cream background is tinged with yellow green. This collection includes six rim sherds-all are from bowls.

\section{Other Late Polychrome Majolicas}

The following types are tentatively classified as nineteenth century polychromes and are described in hopes that we may eventually recognize them as separate types. None of them have yet been noted in collections from mission sites in the San Antonio River Valley, which suggests that they are later than the previously described types.

\section{Variety \# I}

This type is represented by 20 delicately thin sherds that appear to all be from bowls. They are decorated with orange and yellow flowers, brown stems, and green leaves, alternating with patterns of dark brown dots on a cream background (Figure 9a-4[e]). Eight sherds are from Feature 1, and 12 from Feature 2. Only three of the sherds are rim sherds that represent at least one bowl with a ca. $12-\mathrm{cm}$ diameter.

\section{Variety \#2}

These ten sherds, also from thin bowls are decorated with two brown bands below the rim, followed by flowers and leaves similar to those of Variety \#1 (Figure 9a-4[f]). The diameter from the two rim sherds is also ca. $12 \mathrm{~cm}$. Two of these sherds came from the non-feature levels, four from Feature 1 and four from Feature 2.

\section{Variety \#3}

Nine sherds represent a cup decorated with yellow flowers with green anthers on brown stems on a cream background (Figure 9a-4[g]). All of these sherds are from Feature 2 and there are no rim sherds present.

\section{Variety \#4}

Six sherds of this variety are from a cup with a pale yellowgreen band around the rim outlined with one brown line above and two below. There is a floral design below in yellow and brown (Figure $9 \mathrm{a}-4[\mathrm{~h}]$ ). Four of these sherds are from the non-feature levels, and two from Feature 2. There are five rim sherds, probably representing separate vessels.

\section{Variety \#5}

This variety is represented by 11 sherds from a deep plate. It has two dark brown rim bands with bright blue and yellow flowers below (Figure 9a-4[i]). All of these sherds came from the non-feature levels.

\section{Variety \#6}

Three sherds, from a delicate cream-colored cup, have twin brown bands above and below a row of darker brown dots in a geometric pattern on a cream background (Figure 9a$4[\mathrm{j}])$. All three sherds are from the non-feature levels and two are rim sherds. 


\section{Variety \#7}

Ten sherds have brown bands which vary in thickness and in shades of brown, but offer no other clue as to decoration. Some are probably parts of the designs described above. Seven are from the non-feature level, one from Feature 1, and two from Feature 2.

\section{Faience}

Tin-glazed earthenwares made in France are commonly called faience. Most Spanish Colonial sites in Texas contain at least a few sherds of faience. The closer the site is to East Texas and Louisiana, where French influence was strong, the higher the percentage of faience versus majolica. The paste of this type of ceramic is nearly always pale yellow or yellow tan and is slightly softer than that of majolica. The glaze often flakes off, exposing unglazed areas on a sherd. There are basically two types of faience; brown faience and white faience. The white variety was most often used for serving dishes and tableware, while the brown variety was used for cooking, since it had a semi-refractory paste that reportedly stood up better to heat (Blanchette 1981:33).

Four sherds of the white faience were recovered from this site (Table 9a-3). Two small sherds, one each from the nonfeature and Feature 1, are covered with a white glaze and decorated with small, individual purple flowers (Figure 9a$5[a])$. Another small sherd from Feature 1, also with a white

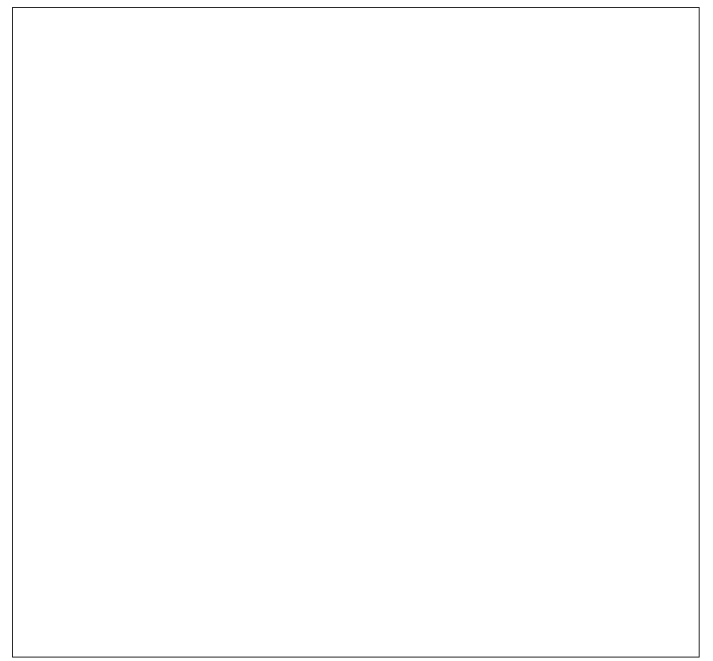

Figure 9a-5. European Wares. (a, b) French faience; (c, d) green and brown hand-painted cup; (e) brown, yellow, and green hand-painted rim sherd. glaze, bears a daisy-like flower with blue petals and a yellow center highlighted with a brown dot (Figure 9a-5[b]). A third type, also from Feature 1, has a white glaze decorated with a blue band above which are traces of yellow decoration.

Brown faience in this collection is represented by one sherd (mended from two pieces) from Feature 1. It has a pale blue glaze on one side and a chocolate brown glaze on the other. The brown side would have been the part that was put closest to the fire, the blue side being the inside of the dish. Brown faience was first manufactured in Rouen ca. 1707 (Blanchette 1981:23).

\section{Refined English Earthenwares}

The presence of white-bodied earthenware has generally been considered an indicator of nineteenth century occupation on historic sites in Texas, despite the fact that these wares were actually first made in England during the late-eighteenth century (Noel Hume 1969). Early wares were first made with a cream colored paste, as the English attempted to copy the appearance of Chinese porcelains, and were called cream-colored ware (Miller and Stone 1970:42). Subsequent attempts at making white-bodied wares gradually progressed to a lighter and lighter cream color until they produced what is popularly called pearl ware. This type had a white body with a slightly blue-tinged glaze (Noel Hume 1969:130).

The 558 earthenware ceramic sherds from this site include both a late, pale cream-colored ware $(n=266)$ and the whitebodied ware $(n=292)$ typical of the early-nineteenth century throughout Texas (Table 9a-4). Although the early cream colored wares were often decorated with shell edged or transfer designs, most of the vessels of this type that came to Texas in the early-1800s were undecorated and the vessels were limited to plates, bowls, chamber pots, and other utility vessels (Miller1980:3). These were the cheapest type of ceramic available (Miller 1991:3). Although the appearance of these wares in Texas is thought to have come about through the coastal trade that grew up after the 1830s (Fox 1992:74), it now appears that English wares were being smuggled into Mexico through the ports of Vera Cruz and Campeche during the last years of the eighteenth century (Humboldt 1941:17). Therefore, they could have been brought to Refugio by the annual supply trains. This would explain their presence among the Mexican-made wares in relatively deep levels of these excavations. 
Table 9a-4. Refined earthenware ceramics

\begin{tabular}{|c|c|c|c|c|c|}
\hline Type & Feature 1 & Feature 2 & Non-Feature & West Side & Total \\
\hline \multicolumn{6}{|c|}{ Refined European Earthenwares } \\
\hline Undecorated Creamware & 51 & 9 & 203 & 3 & 266 \\
\hline Undecorated Whiteware & 18 & 7 & 81 & 3 & 109 \\
\hline Transfer & 4 & 0 & 22 & 1 & 27 \\
\hline Hand Painted & 47 & 7 & 69 & 1 & 124 \\
\hline Molded Edge & 4 & 1 & 11 & 3 & 19 \\
\hline Banded Slip & 0 & 1 & 7 & 3 & 11 \\
\hline Unidentified & 0 & 0 & 2 & 0 & 2 \\
\hline Subtotal & 124 & 25 & 395 & 14 & 558 \\
\hline \multicolumn{6}{|c|}{ Stoneware } \\
\hline Brown Stoneware & 1 & 0 & 3 & 0 & 4 \\
\hline Bristol Ginger Bottles & 0 & 1 & 3 & 1 & 5 \\
\hline Salt Glazed & 0 & 0 & 10 & 0 & 10 \\
\hline Unidentified & 0 & 0 & 2 & 0 & 2 \\
\hline Subtotal & 1 & 1 & 18 & 1 & 21 \\
\hline \multicolumn{6}{|c|}{ Porcelain } \\
\hline Chinese & 0 & 0 & 1 & 0 & 1 \\
\hline English & 0 & 0 & 1 & 0 & 1 \\
\hline Hotel China & 0 & 1 & 1 & 0 & 2 \\
\hline Subtotal & 0 & 1 & 3 & 0 & 4 \\
\hline Total & 125 & 27 & 416 & 15 & 583 \\
\hline
\end{tabular}

The refined earthenwares from this site include both undecorated sherds, which would have been parts of plain vessels or undecorated portions of others, and sherds decorated in various ways. These brightly decorated wares evidently replaced majolicas in the households of families in Mexico as well as on the frontier, when they flooded the markets in the 1790s, causing many majolica makers to go out of business by 1802 (Humboldt 1941:17).

\section{Cream Colored Ware}

There are 266 sherds of undecorated, pale cream-colored ware recovered from these excavations. Of these, 203 came from the non-feature level, 51 from Feature 1, nine from Feature 2, and three from the investigations on the west side of the street. There were 16 rim sherds, which represented primarily cups and plates.

\section{Undecorated Whitewares}

There are 109 undecorated whiteware sherds in this collection. Eighty-one of these came from the non-feature levels, 18 from Feature 1, seven from Feature 2, and three from investigations on the west side of the street. Surprisingly, only four rim sherds were recovered, suggesting that most of these sherds came from undecorated parts of otherwise decorated wares. The rim sherds were too small to tell what sort of vessels they represented.

\section{Transfer Decoration}

To make this type of decoration, designs engraved on copper plates were impressed on paper and then transferred to earthenware biscuit. The vessel was then glazed and fired. Twenty-seven transfer-decorated sherds were recovered; 
22 from the non-feature level, four from Feature 1, and one from investigations on the west side of the street. Six of these were rim sherds, too small to tell the vessel shape.

\section{Hand Painted Decoration}

One hundred twenty-four thin (ca. $1 \mathrm{~mm}$ ), hand-painted sherds were recovered. Sixty-nine are from the non-feature level, 47 from Feature 1, seven from Feature 2, and one from investigations on the west side of the street. Thirty of these were rim sherds. The decoration (Figure 9a-5[c], [d], and [e]), all under glaze, is primarily in shades of brown, green, blue and yellow in delicate designs typical of the early-nineteenth century time period (see Dial 1992:Figure $14 \mathrm{i}, \mathrm{j}$, and $\mathrm{k}$ ). Most of the vessels represented in this collection appear to be small cups with thin foot rings.

\section{Molded-Edge Decoration}

Plates with molded rims painted with blue or green were common on San Antonio sites occupied in the earlynineteenth century. In this collection, 11 such sherds came from the non-feature levels, four from Feature 1, one from Feature 2, and three from investigations on the west side of the street. All 19 of these were, of necessity, rim sherds.

\section{Banded Slip Decoration}

This decorative type can be identified by the colored clay slips applied in bands, dots, "worms," annular designs, and engine-turned or roulette designs. The colors used are, for the most part, unique and recognizable even on small sherds. They include bright blue, various shades of earthen brown, yellows, greens, and black. Although this ware can be found in the shape of mugs, bowls, cups, and covered dishes (Majewski and O'Brien 1987:163), the eleven sherds in this assemblage are too small to determine vessel shapes. Seven were found in the non-feature level, one in Feature 2, and three in the burial area.

\section{Unidentified Type}

Two sherds from the non-feature levels are from a cup or small pitcher decorated on the outside with a dark brown glaze, above which appears to be a white area decorated with molded flowers. No reference has been found to identify this type.

\section{Stoneware}

Stonewares have a hard, vitrified body more similar to porcelain than to earthenware. The body is normally a clay color. Because of its vitrified nature, stoneware was frequently used to make containers for liquids, drinking vessels, and food storage vessels. Twenty-one stoneware sherds are present in this assemblage (Table 9a-4).

\section{Brown Stoneware}

Four sherds from a brown stoneware jug with a salt glaze are probably of eighteenth century English manufacture (Miller and Stone 1970:77). A raised ring around the neck just below the rim is bordered above and below with a single rouletted band. Three of these sherds came from the nonfeature level, and one from Feature 1.

\section{Stoneware Bottles}

Five tan colored sherds with a cream colored Bristol glaze represent "Ginger Beer" bottles made in Scotland during the last half of the nineteenth century (C. A. Calhoun personal communication 1960). Hundreds of thousands of these bottles filled with mineral water, ginger beer, or ale were shipped to the United States in the period following the Civil War, and sherds of these bottles are found on nearly every Texas site occupied at that time. Three of these came from the non-feature levels, one from Feature 2, and one from the burial area.

\section{Salt Glazed Utility Wares}

Ten sherds from the non-feature levels represent crocks, churns or jugs probably made in Texas during the last half of the nineteenth century. One handle fragment would have come from a jug and the others are body sherds. All may have been part of the same vessel.

\section{Unidentified Stoneware}

A single, small stoneware sherd with a gray body and a brown glaze bears two incised bands. Another that has a light tan body has a red brown glaze on one side and the other side is not present. Both of these fragments were recovered from the non-feature levels and are too small to allow further identification. 


\section{Porcelain}

\section{Chinese Export Porcelain}

Porcelain is a highly vitrified ceramic. Chinese porcelains have a thin, glassy glaze. The one Chinese porcelain sherd from this collection, from the non-feature level, has a pale blue gray background with blue linear decoration under the glaze (Table 9a-4). Similar sherds have been recovered from most Spanish Colonial sites in Texas (Carlson 1994:139).

\section{English Porcelain}

One thin sherd of pink luster-decorated porcelain with gold paint over the glaze was recovered from the non-feature level. Lusterwares were made in England as early as 1810 (Hughes 1967:83).

\section{Hotel China}

Two sherds of heavy porcelain commonly called Hotel China were found; one in Feature 2 and one in the non-feature levels. One sherd is an undecorated body sherd; the other is a rim sherd and bears two thin green bands below the rim. This type of ceramic is still in use today.

\section{Observations on European Ceramics}

The tin-glazed ceramics have been described in the order in which they appeared on Texas Colonial sites. Using this information, it is possible to confirm the comparative dating of the three depositional events represented by Features 1 and 2 and the non-feature levels, as described in the feature descriptions. Table 9a-3 lists the numbers of sherds recovered from those types that can be confidently dated to each time period. The types estimated to date throughout the eighteenth century appear to be evenly distributed, as might be expected. The distribution of the late-eighteenth century types and those dating from the late-eighteenth to early-nineteenth centuries tend to confirm the estimate that Feature 2 was the earliest deposit and Feature 1 was slightly later. The large number of nineteenth century sherds from the non-feature deposits confirms that these were the most recent ones.

The vessels represented by the various ceramic types reported here reflect the diet of the mission inhabitants. The earliest shapes consist of bowls, jars, pitchers, and chocolate pots of lead-glazed earthenware, and small (14 $\mathrm{mm}$ to 16 $\mathrm{mm}$ in diameter) bowls, deep plates and a few cups of majolica. Such vessels would be required for a diet that consisted mainly of soups and stews (Fox 1986) as well as the occasional cup of chocolate. The near absence of forks and spoons in the mission collections suggests that the Franciscans were probably the only ones who used them for eating and even then only on more formal occasions. The traditional Mexican tortilla was probably the most common eating utensil used by Spaniards and, before long, possibly by the Indians as well. J. C. Clopper (1949:74) observed this when he came to Texas in 1828 :

\section{[Tortillas] “...answer the natives for spoons with which they all dip into the same dish of meat and peppers... one spoon not lasting longer than to supply two mouthfuls when a new one is made use of..."}

The appearance of cream-colored and whiteware plates in the early-nineteenth century deposits may indicate a gradual acceptance of a diet that included individual cuts of meat and servings of vegetables that could be eaten with the fingers or rolled up in a tortilla. This may also reflect an increase in the number of local citizens now living at the mission, who would be more likely to accept such a change.

Analysis of the ceramic collection from Mission Refugio can also be used to address the first research question posed by the Research Design, specifically whether instabilities in the frontier supply system had an impact on Native American technology. In other words, was there a decline in the use of Mexican-made ceramics through time and a growing dependence on local Native American ones? This question can be divided into two parts: was there a decline in the supply system? And if so, how did this affect the production and use of Native American ceramics?

The supply system for the Texas missions during the eighteenth century had developed into a well-organized and dependable one. Annual mule trains loaded with a year's worth of supplies were dispatched from the missionary college on a regular schedule (Fox 1997). With the secularization of the San Antonio missions beginning in the last decade of the century, apparently this system fell apart. When Mission Refugio was founded it was not immediately connected with the Franciscan system, and was therefore supplied by the Governor. Also, a private individual was paid to obtain and transport supplies to both Presidio La Bahía and Mission Refugio (see Chapter 3). Starting in 1792, the college at Zacatecas began to supply the mission on a regular basis. However, in contrast to the long, detailed lists 
of supplies customarily sent to the San Antonio missions in the annual shipment, the records for shipments sent to Refugio between 1792 and 1812 were sparse. They only list clothing for the missionaries (habits, underwear, sandals), soap, snuff, tobacco, chocolate, an occasional pound of cinnamon or other spices, and, always, a ream of paper (see Appendix A).

If indeed these were the only supplies sent to Refugio after 1792, it appears that no additional ceramics or presents for the Indians were forthcoming. Were the missionaries contracting with a local entrepreneur to obtain the supplies necessary to run the mission? It is apparent from the number of post-1800 majolica patterns recovered that the missionaries continued somehow to obtain additional ceramics. According to the 1796 Inventory of the mission, the mission's sindico who managed the mission's money and paid its bills was Don Domingo de Outon, who was also the manager of the Tobacco Office at Presidio La Bahía (Benavides 1989:754). It seems possible that he was the one who purchased whatever supplies were needed. Certainly many of the post-1800 majolicas in the Refugio collection are also present in the La Bahía collections (personal observation).

Therefore, judging from the comparative dating of the ceramics present at Mission Refugio, it appears that Mexican-made types were still coming to the mission well into the nineteenth century, although not in the amounts that were arriving during the late-eighteenth century. It would be next to impossible to estimate whether the mission became increasingly dependant on native-made pottery since the Indian population varied so widely from month to month throughout the later years. The apparent acceptance of cream ware and decorated whitewares toward the end of the mission's life may have made an increase of native-made ceramics unnecessary.

A compilation of the ceramics recovered from excavations at Mission Rosario by Gilmore (1974 and 1975), Ricklis et al. (2000), and Nickels (2000) reveals that the list of types recovered from that mission is nearly identical to the list of Mission Refugio ceramic types. Evidently the two missions were being supplied from the same sources, and perhaps in the same manner, at least up to the date of the closing of Rosario in 1808. 



\title{
Chapter 9: Artifacts - $\quad$ Section B
}

\section{Other Historic Artifacts}

\author{
Barbara A. Meissner
}

\section{Glass}

Various characteristics including color and manufacturing technique can be used to date glass items. The following is a description of the dating techniques used in this report.

Glass blowing was invented shortly before the time of Christ (Munsey 1970:30). Free-blowing was still in common use until about the middle of the nineteenth century. After that time most bottles were blown into molds, though the lips were still finished by hand. Lipping tools, which made the lips more uniform in shape, were in common use by the 1850s. In 1903, the bottle-making machine was patented and within a few years had completely revolutionized commercial bottle making around the world (Munsey 1970:33).

Glass can be made to appear clear by adding various chemicals to the mixture. Two such chemicals are particularly useful for dating glass. Manganese was mainly used to make clear glass between 1880 to 1915. Glass made with manganese will turn an amethyst color if left in the sun for an extended period. After World War I began, the availability of manganese decreased in the U.S. because the major source was Germany. Between 1915 and 1930 selenium was substituted for manganese. This glass turns light amber when exposed to sunlight for an extended period. After 1930, arsenic, which does not color in the sun, was used for making clear glass. (Munsey 1970:55-56).

Other methods of dating glass involve either identification of makers' marks on the bottle bottom, identification of the company logos sometimes molded on the sides of bottles, or by identification of molded announcements required by law at various times in the past. An example of the latter is the requirement that extended from the end of Prohibition in 1934 until the late-1960s that all bottles containing distilled alcohol display this statement "Federal Law Forbids Sale or Re-Use of This Bottle" (Munsey 1970:124).

Although there are no definitive "Colonial" glass colors, most Colonial period glass is clear, aqua (the natural color of glass), green or yellowish green (Deagan 1987:12-129). "Black" glass is sometimes found in Colonial contexts, but is more common in contexts dating to the first half of the nineteenth century. The latter is not actually black, but a very dark green, and was in use until about the 1860s (Munsey 1970:37). Brown glass (with no hint of green) was not used in the Colonial period, but most other colors are at least found in glass beads from the Colonial period, if not in larger glass objects.

A total of 1,673 pieces of container glass were recovered during the project. Table 9b-1 compares colors of glass in the three analytic units (AUs) of Phase I with the glass from Phase II and the testing project. The glass from AU 1, which is a mix of Colonial period glass and glass from every period since then, is very similar in percentage of colors to the Test Units. The major difference between these units and AUs 2 and 3 is the high percentage of green glass in the latter. The Phase II glass has a somewhat higher percentage of green glass as well. Note that Phase II glass includes some colors (clear-amethyst, and clear-amber) that are known to be postColonial in date. Only a single piece of either of these colors was recovered from AUs 2 and 3 (Table 9b-1). This single piece may have fallen from the wall above the lime layer.

Table 9b-1. Glass colors

\begin{tabular}{|c|c|c|c|c|c|c|c|c|c|c|}
\hline & \multicolumn{2}{|c|}{ Analysis Unit 1} & \multicolumn{2}{|c|}{ Analysis Unit 2} & \multicolumn{2}{|c|}{ Analysis Unit 3} & \multicolumn{2}{|c|}{ Phase II } & \multicolumn{2}{|c|}{ TxDOT Units } \\
\hline & $\mathrm{Ct}$. & $\%$ & $\mathrm{Ct}$. & $\%$ & $\mathrm{Ct}$. & $\%$ & $\mathrm{Ct}$. & $\%$ & Ct. & $\%$ \\
\hline Clear & 61 & $37.7 \%$ & 36 & $48.0 \%$ & 420 & $35.9 \%$ & 13 & $29.5 \%$ & 101 & $45.7 \%$ \\
\hline Clear-Amethyst & 0 & $0.0 \%$ & 0 & $0.0 \%$ & 3 & $0.3 \%$ & 2 & $4.5 \%$ & 1 & $0.5 \%$ \\
\hline Clear-Amber & 1 & $0.6 \%$ & 0 & $0.0 \%$ & 63 & $5.4 \%$ & 1 & $2.3 \%$ & 0 & $0.0 \%$ \\
\hline Aqua & 34 & $21.0 \%$ & 5 & $6.7 \%$ & 210 & $17.9 \%$ & 9 & $20.5 \%$ & 34 & $15.4 \%$ \\
\hline Brown & 16 & $9.9 \%$ & 9 & $12.0 \%$ & 319 & $27.2 \%$ & 12 & $27.3 \%$ & 73 & $33.0 \%$ \\
\hline Green & 42 & $25.9 \%$ & 24 & $32.0 \%$ & 125 & $10.7 \%$ & 6 & $13.6 \%$ & 9 & $4.1 \%$ \\
\hline "Black" & 7 & $4.3 \%$ & 1 & $1.3 \%$ & 22 & $1.9 \%$ & 0 & $0.0 \%$ & 3 & $1.4 \%$ \\
\hline White & 1 & $0.6 \%$ & 0 & $0.0 \%$ & 1 & $0.1 \%$ & 0 & $0.0 \%$ & 0 & $0.0 \%$ \\
\hline Blue & 0 & $0.0 \%$ & 0 & $0.0 \%$ & 8 & $0.7 \%$ & 1 & $2.3 \%$ & 0 & $0.0 \%$ \\
\hline Total & 162 & $100.0 \%$ & 75 & $100.0 \%$ & 1171 & $100.0 \%$ & 44 & $100.0 \%$ & 221 & $100.0 \%$ \\
\hline
\end{tabular}


Fragments of glass that include bottle lips or bottoms, molded lettering or designs, or painted decorations are listed in Table 9b-2. A piece of aqua glass may have been deliberately worked (Figure 9b-1[a]). Of particular interest is the piece of green glass that has been worked into a scraper (Figure 9b-1[b]). Another item of interest is the small fragment of clear glass with a leaf and stem pattern wheelengraved on it (Figure 9b-1[f]). Such engraving was a common form of glass decoration in the Colonial period (Deagan 1987:142).
The purpose of the molded glass dish that was found below the lime layer in Feature 2 (Figure 9b-1[g]) is unknown. It may have been a cosmetics container, or used by a pharmacist, however, there is no sign of wear in the bottom of the oval depression. The clear drinking glass fragment, also found in Feature 2, has a pontil mark on the bottom and tool marks on both the inside and outside (Figure 9b-1[h]). This item was hand-blown. The even thickness and symmetry of the item shows considerable skill.

Table 9b-2. Identifiable glass fragments

\begin{tabular}{|c|c|c|c|}
\hline \multicolumn{4}{|c|}{ Phase 1} \\
\hline Unit (depth) & $\mathrm{AU}$ & Description & Estimated date \\
\hline \multirow{7}{*}{ Gradall Backdirt } & 3 & Clear bottle lip for crown cap. Machine made. & Post 1903 \\
\hline & & $\begin{array}{l}\text { Large clear glass molded jar bottom in } 2 \text { pieces, sun-colored } \\
\text { amethyst. Maker's mark is for the Hazel-Atlas Glass Co., makers } \\
\text { of fruit canning jars (Toulouse 1971:493). }\end{array}$ & $1902-1964$ \\
\hline & & $\begin{array}{l}\text { Clear bottle fragment, probably a whiskey bottle ( } 2 \mathrm{pcs}) \text {, machine } \\
\text { made. }\end{array}$ & Post 1903 \\
\hline & & Clear glass with lettering "HAL..." & Mid-19th century to modern \\
\hline & & Aqua Coke bottle fragment, embossed and painted. & Modern \\
\hline & & $\begin{array}{l}\text { Brown bottle bottom “Duraglass" and other maker's marks } \\
\text { indicate Owens-Illinois Pacific Coast Co. } \\
\text { (Toulouse 1971:170; 405-406) }\end{array}$ & $1940-1963$ \\
\hline & & $\begin{array}{l}\text { Fragment of aqua bottle bottom, probably a Coke bottle, with } \\
\text { "Christi' (Probably Corpus Christi bottling company). }\end{array}$ & Post 1915 \\
\hline $\mathrm{N} 57 / \mathrm{E} 100(0-20 \mathrm{~cm})$ & 3 & 2 clear and 1 aqua fragment with painted designs. & Modern \\
\hline N64/E100 $(10-20 \mathrm{~cm})$ & 3 & Clear glass fragment with painted lettering. & Modern \\
\hline N64/E100 (10-20 cm) & 3 & $\begin{array}{l}\text { Fragment of clear glass rectangular molded bottle bottom with } \\
\text { "...one P..." on the side and "PAT D-1/67/...in USA" and } \\
\text { anchor symbol. Anchor-Hocking Glass Co. (Toulouse 1971:48). }\end{array}$ & After 1938 \\
\hline N64/E100 $(10-20 \mathrm{~cm})$ & 3 & $\begin{array}{l}\text { Molded clear glass round bottle bottom with lettering } \\
\text { "...RISTI..." }\end{array}$ & \\
\hline N70/E100 $(0-20 \mathrm{~cm})$ & 3 & Fragment of machine-made bottle lip. & Post 1903 \\
\hline N72/E100 $(20-30 \mathrm{~cm})$ & 3 & Fragment of aqua Coke bottle bottom. & Post 1915 \\
\hline N73/E100 $(20-30 \mathrm{~cm})$ & 3 & Clear glass fragment molded “* SALE...” & Mid-19th century to modern \\
\hline N74/E100 (35-40 cm) & 3 & $\begin{array}{l}\text { Clear glass square molded bottle bottom with a vacuum mark on } \\
\text { the bottom. Machine made. }\end{array}$ & Post 1903 \\
\hline N77/E100 $(20-30 \mathrm{~cm})$ & 3 & Clear glass fragment with painted design. & Modern \\
\hline N78/E100 $(0-20 \mathrm{~cm})$ & 3 & Aqua Coke bottle fragment. & Post 1915 \\
\hline N78/E99 $(0-20 \mathrm{~cm})$ & 3 & Clear glass fragment with molded lettering “..USE OF..." & Probably 1934-1966 \\
\hline N81/E100 $(20-30 \mathrm{~cm})$ & 3 & $\begin{array}{l}\text { Aqua fragment that may have been deliberately flaked } \\
\text { (Figure 9b-1[a]). }\end{array}$ & \\
\hline $\mathrm{N} 83 / \mathrm{E} 99(0-20 \mathrm{~cm})$ & 3 & Aqua Coke bottle fragment painted on raised lettering. & Modern \\
\hline $\mathrm{N} 85 / \mathrm{E} 100(0-20 \mathrm{~cm})$ & 3 & Clear glass with molded design. & Mid-19th century to modern \\
\hline $\mathrm{N} 85 / \mathrm{E} 100(0-20 \mathrm{~cm})$ & 3 & Clear glass bottle lip, screw cap, machine made. & Post 1903 \\
\hline $\mathrm{N} 85 / \mathrm{E} 100(0-20 \mathrm{~cm})$ & 3 & Aqua fragment with molded lettering "...EX..." & Mid-19th century to modern \\
\hline $\mathrm{N} 85 / \mathrm{E} 100(10-20 \mathrm{~cm})$ & 3 & $\begin{array}{l}\text { Dark green fragment has been worked into unifacial scraper } \\
\text { (Figure } 9 \mathrm{~b}-1[\mathrm{~b}]) \text {. }\end{array}$ & Early 19th century or before \\
\hline $\mathrm{N} 85 / \mathrm{E} 99(0-20 \mathrm{~cm})$ & 3 & Aqua Coke bottle fragment. & Post 1915 \\
\hline $\mathrm{N} 85 / \mathrm{E} 99(0-20 \mathrm{~cm})$ & 3 & Clear glass bottle lip with screw top. Machine made. & Post 1903 \\
\hline $\mathrm{N} 85 / \mathrm{E} 99(40-50 \mathrm{~cm})$ & 3 & Molded aqua bottle bottom. & Mid-19th century to modern \\
\hline N86/E100 $(30-40 \mathrm{~cm})$ & 3 & Aqua fragment with molded lettering " ...RA..." & Mid-19th century to modern \\
\hline $\mathrm{N} 87 / \mathrm{E} 99(30-40 \mathrm{~cm})$ & 3 & Clear glass fragment of bottle lip. Machine made. & Post 1903 \\
\hline N95/E100 (20-30 cm) & 3 & $\begin{array}{l}\text { Clear glass bottle lip, medicine-type lip for cork closure. } \\
\text { Machine made (Figure 9b-1[c] ). }\end{array}$ & Early 20th century \\
\hline N95/E100 $(20-30 \mathrm{~cm})$ & 3 & Aqua Coke bottle fragment. & Post 1915 \\
\hline $\mathrm{N} 80 / \mathrm{E} 100(30-40 \mathrm{~cm})$ & 1 & "Black" bottle lip with applied lip (Figure 9b-1[d]). & Probably before 1860 \\
\hline $\mathrm{N} 80 / \mathrm{E} 100(40-50 \mathrm{~cm})$ & 1 & $\begin{array}{l}\text { Green bottle lip fragment. The lip was applied, and tool marks } \\
\text { are visible. The "golden" patina is typical on some green glass } \\
\text { from the early 19th century (Figure 9b-1[e]). }\end{array}$ & Early 19 th century or before \\
\hline N84/E100 (100-110 cm) & 1 & $\begin{array}{l}\text { Small fragment of clear glass with wheel-engraved pattern of } \\
\text { stem and leaf (Figure 9b-1[f]). }\end{array}$ & Colonial (see Deagan 1987:142) \\
\hline N75/E100 (90-95 cm) & 2 & $\begin{array}{l}\text { Most of a clear glass dish, molded. Very heavy solid glass with } \\
\text { oval-shaped depression, but no sign of wear in the bottom } \\
\text { (Figure 9b-1[g]). Unknown use. }\end{array}$ & Provenience suggests Colonial. \\
\hline
\end{tabular}


Table 9b-2. Continued...

\begin{tabular}{|c|c|c|c|}
\hline \multicolumn{4}{|c|}{ Phase 1} \\
\hline Unit (depth) & $\mathrm{AU}$ & Description & Estimated date \\
\hline N75/E99 (80-90 cm) & 2 & $\begin{array}{l}\text { Fragment of the bottom of a clear drinking glass. Pontil mark on } \\
\text { the bottom, tool marks, and slight unevenness indicates this item } \\
\text { was hand-blown (Figure 9b-1[h]). }\end{array}$ & Early 19th century or before \\
\hline \multicolumn{4}{|c|}{ Phase 2} \\
\hline Trench North of Burial Area & & $\begin{array}{l}\text { Green glass bottle bottom, with extensive kickup ( } 2 \text { pcs.). } \\
\text { Probably hand-blown. }\end{array}$ & Early 19th century or before \\
\hline \multirow[t]{3}{*}{ Burial Pit \# 26} & & Fragment of the base of a rectangular bottle, molded. & Mid-19th century to modern \\
\hline & & Aqua Coke bottle fragment with lettering. & Post 1915 \\
\hline & & $\begin{array}{l}\text { Fragment of a brown bottle lip. Lip is applied, tool finished, } \\
\text { well-made. }\end{array}$ & Mid-19th century to ca. 1903 \\
\hline \multicolumn{4}{|c|}{ TxDOT (1997) } \\
\hline Test Unit \#2 (10-20 cm bs) & & Molded clear glass dish, sun-colored amethyst (Figure 9b-1[i]). & Ca. 1880 to 1915 \\
\hline Test Unit \#3 (10-20 cm bs) & & $\begin{array}{l}\text { Clear glass with "FEDERAL.../OR RE-USE OF..." and square } \\
\text { embossed pattern (Figure 9b-1[i]). }\end{array}$ & $1934-1966$ \\
\hline
\end{tabular}

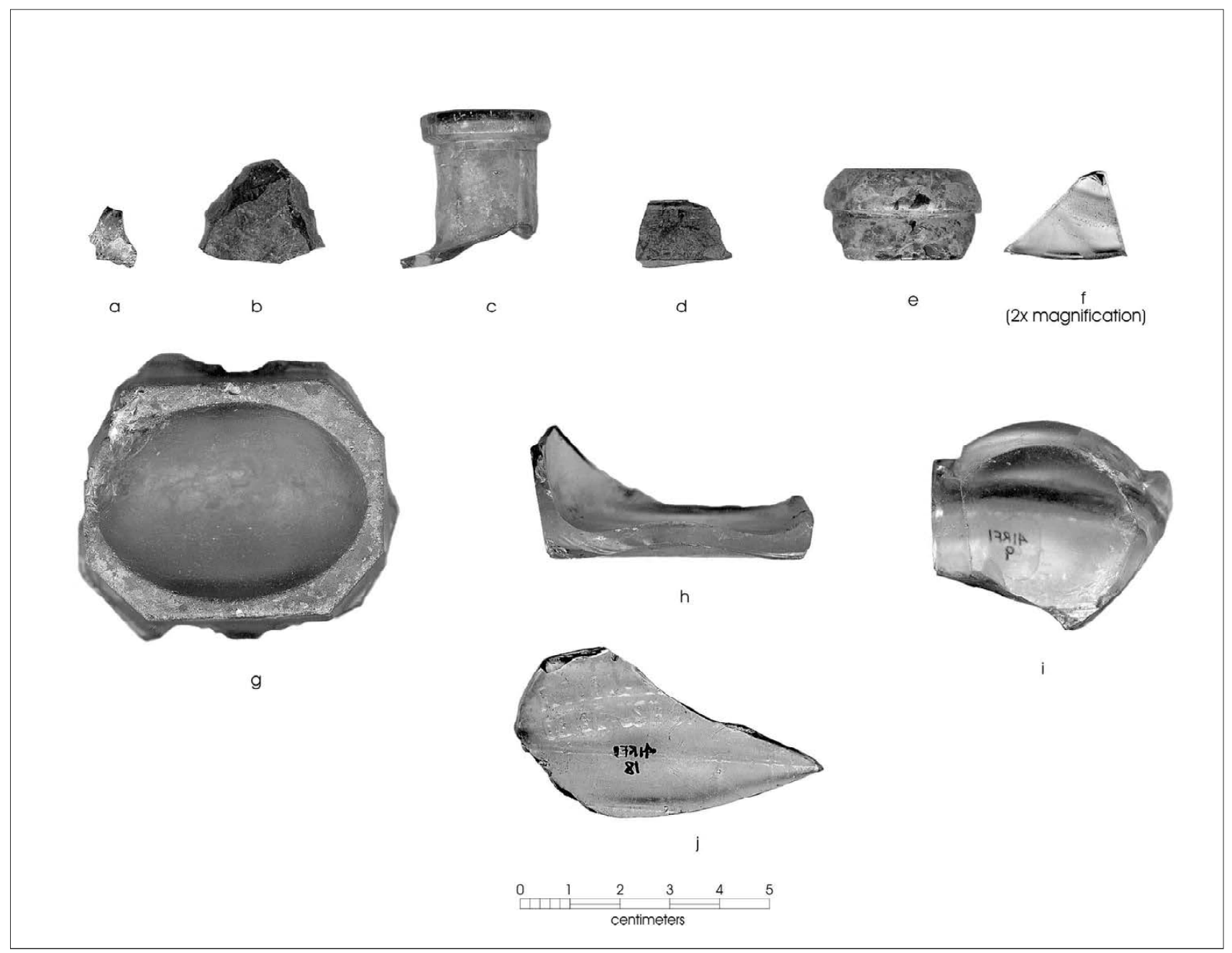

Figure 9b-1. Selected Glass Items: a) Aqua glass fragment that may have been flaked; b) Uniface scraper made from green glass; c) A clear glass machine-made medicine bottle top; d) Small fragment of "black" glass bottle lip; e) Fragment of green bottle lip with heavy patina; f) Wheel-engraved pattern on small fragment of clear glass; g) Molded clear glass dish; h) Fragment of a hand-blown clear drinking glass bottom; i) Molded clear glass dish, sun-colored amethyst; j) Clear glass fragment with post-Prohibition lettering. 


\section{Other Household Items}

An iron hinge, probably for a trunk or cabinet, was recovered from the Gradall backdirt (Figure 9b-2)

A stopper, probably for a needle case, made from bone (Figure 9b-3), was found below the lime layer in Feature 2, at 50 to $55 \mathrm{~cm}$ bd. The stopper was beautifully made on a lathe and is in excellent condition, except that the top has broken off.

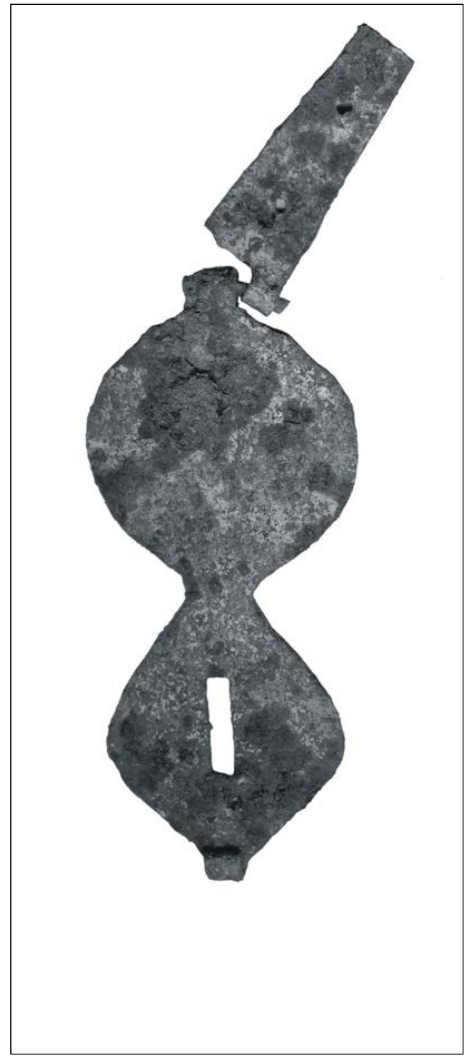

Figure 9b-2. Hinge from a trunk or cabinet.

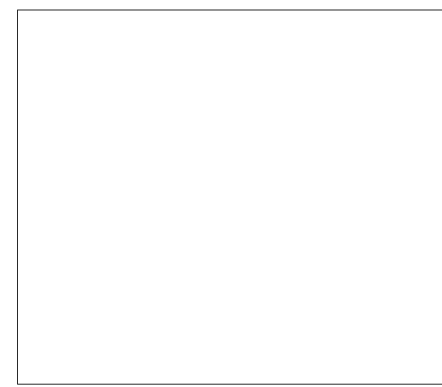

Figure 9b-3. Stopper made from bone.

\section{Personal Items Clothing Items}

A five-hole bone button was located above the lime layer, between $20-30 \mathrm{~cm}$ bd above Feature 2. (Figure 9b-4[a]). This button has a well-shaped and polished blank, $1.7 \mathrm{~cm}$ in diameter, but the holes were drilled very unevenly.

A single-hole bone button was recovered above the lime layer between $20-30 \mathrm{~cm}$ bd in AU 3. The button is $1.6 \mathrm{~cm}$ in diameter, and there appears to be a "false start" drilled next to the hole on one side (Figure 9b-4[b]).

Two fragments of a freshwater mussel shell button were also recovered above the lime layer, between $20-30 \mathrm{~cm}$ bd in AU 3. The button fragments are too small to measure the button diameter or to ascertain if the button was hand or machine-made.

A small copper alloy button was collected from within Feature 2, below the lime layer between $80-90 \mathrm{~cm}$ bd. The plain button is $1.1 \mathrm{~cm}$ in diameter and has a cast self loop on the back.

A button made of lead was recovered from Feature 1, below the lime layer, between $50-60 \mathrm{~cm}$ bd (Figure $9 \mathrm{~b}-4[\mathrm{c}]$ ). The button is crude, and was clearly hand-made. It has two holes, one of which has been badly distorted, presumably by pressure of the threads that held the button in place.

A metal button was collected from above the lime layer near Feature 1. The button is $1.9 \mathrm{~cm}$ in diameter and has no decoration on its face. It is quite thin, and the metal shank has pulled out of the back. Another metal button was collected from the upper $10 \mathrm{~cm}$ of Test Unit \#2. It is a standard, 4-hole metal button (Figure 9b-4[d]). 


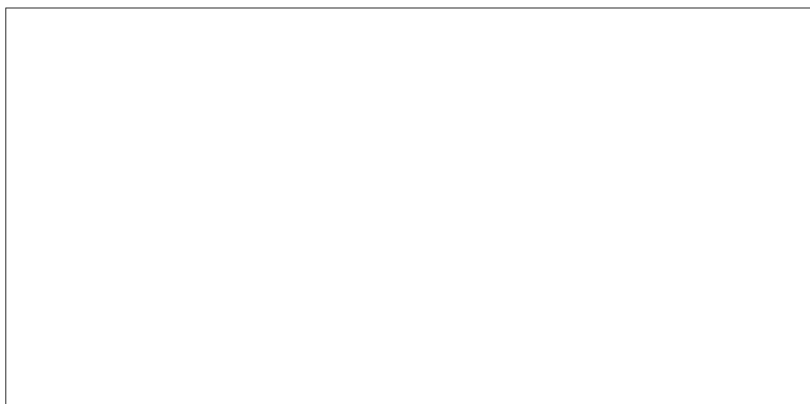

Figure 9b-4. Selected items of clothing: a) 5-hole bone button; b) Single hole bone button; c) 2-hole button made of lead; d) 4-hole metal button (two holes visible, two encrusted).

\section{Jewelry and Ornaments}

One glass seed bead is heavily patinated, so color is difficult to identify, but it is probably clear or white (Figure 9b-5[a]). The bead is $0.35 \mathrm{~cm}$ in length, and was located in Feature 1, between $60-70 \mathrm{~cm}$ bd. One blue-green glass seed bead, 0.28 $\mathrm{cm}$ in length was recovered between 25 and $30 \mathrm{~cm}$ bd from AU 3, above the lime layer in Feature 2 (Figure 9b-5[b]).

One small compound bead was found in Feature 1, between 105 and $110 \mathrm{~cm}$ bd (Figure 9b-5[c]). The bead is opaque brick red on the outside with a transparent green core, a type commonly called a "Cornaline d'Aleppo" (Harris et al. 1999:389). This type of bead is commonly found in Spanish Colonial sites (Deagan 1987:177; Edmondson 2001:90; Hard et al. 1995:58; Harris et al. 1999:389).

A broken copper-alloy crucifix was found in between 40 and $50 \mathrm{~cm}$ bd above the lime layer covering Feature 1 (Figure 9b-5[d]). The crucifix, which was heavily encrusted, has four inlaid glass jewels, three of which are round and one of which is square. After cleaning, five small holes, part of the decoration, were seen. There was a loop on the back at the top so the crucifix could be worn as a pendant. The crosspiece is $2.5 \mathrm{~cm}$ wide and the remaining portion of the main stem is $2.2 \mathrm{~cm}$ long. The edges of the cross are embossed in a "pie-crust" design and there is a flower shape above the upper glass jewel.

A possible crude ring was recovered from Feature 1, below the lime layer, between 70 and $80 \mathrm{~cm}$ bd. The ring is very simple, made from a loop of copper wire (Figure 9b-5[e]). It is $2.16 \mathrm{~cm}$ in diameter at its widest. Another possible ring was located in Feature 2, below the lime level between 60 and $65 \mathrm{~cm}$ bd (Figure $9 \mathrm{~b}-5[\mathrm{f}]$ ). This is a strip of copper ranging in width from 0.65 to $0.98 \mathrm{~cm}$, formed into a ring with the wider end on the outside. It is possible, however, that both of these rings are just rolled pieces of copper scrap.

The ear-wire of an earring, made of gold, was recovered from between 20 and $30 \mathrm{~cm}$ bd AU (Figure $9 \mathrm{~b}-5[\mathrm{~g}]$ ). The fine gold wire has numerous tool marks visible under 10x magnification. There is no way to tell how old the earring is, but it is probably not of modern origin, as modern earrings are formed from machine-drawn wire and do not have tool marks.

A piece of marine shell cut into a roughly square shape (Figure $9 \mathrm{~b}-5[\mathrm{~h}]$ ) was located between 30 and $40 \mathrm{~cm}$ bd in AU 3. The shell was possibly intended as an ornament, though there is no obvious way to attach the piece. It may represent an unfinished pendant. Another possible marine shell pendant was was recovered from Feature 1, between 70 and $80 \mathrm{~cm}$ bd (Figure $9 \mathrm{~b}-5$ [i]). This ornament is probably made from the shell of a Lettered Olive (Oliva sayana), although the shell is too fragmentary and worn to be positively identified. A hole was cut near the base of the shell. Similar ornaments have often been found at Colonial sites (Schuetz 1969). A marine shell with a hole chipped in it was recovered from Feature 8 on the west side of the project area. (Figure 9b-5[j]). This shell is a Ponderous Ark (Noetia ponderosa), and the hole is located on the highest point of the shell, near the umbo. Predatory mollusks make similar holes; however, those holes are usually perfectly round and do not have chips around them. This hole is uneven, has small chips around it both outside and inside the shell. It appears to have been intended as a pendant.

A clear glass rhinestone, $0.65 \mathrm{~cm}$ in diameter, with remains of the mirror backing still in place, was located in the upper $15 \mathrm{~cm}$ of sediment in AU 3 near Feature 2. 


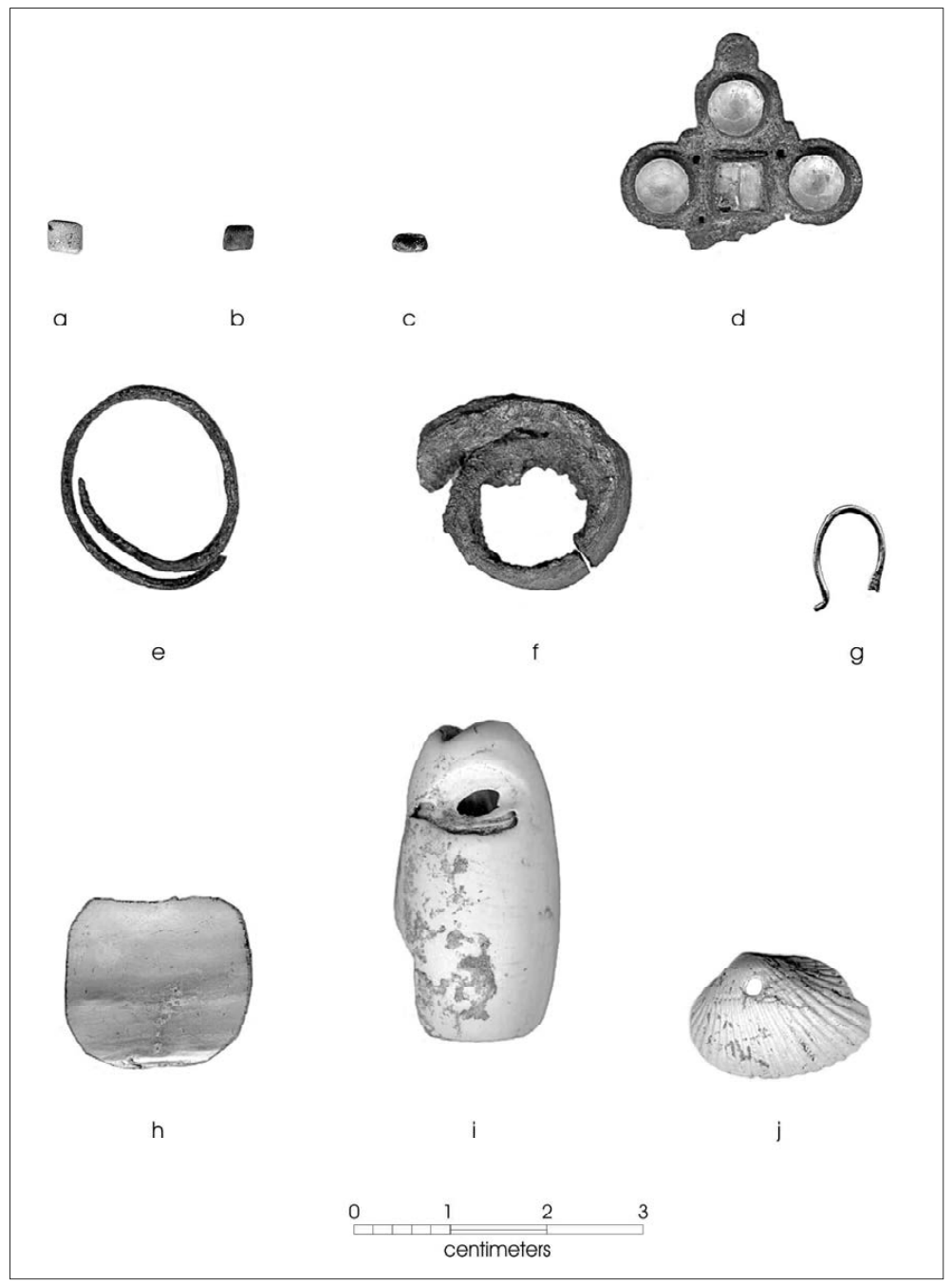

Figure 9b-5. Selected Jewelry and Ornament Items: a-b) Glass seed beads; c) "Cornaline d'Aleppo" bead; d) Fragment of a copper alloy crucifix with glass jewels; e-f) Possible copper rings; g) Gold earring; h) Cut marine shell ornament; i-j) Pendants made from marine shells. 


\section{Toys}

A plain clay marble was located in AU 3 in a unit south of Features 1 and 2 (Figure 9b-6[a]). It is $1.4 \mathrm{~cm}$ in diameter, and is a type called a "commie". Marbles like this were first manufactured in the U.S. about 1884 and were still listed in the 1928 Sears catalog (Zapata 1997:108).

\section{Other Personal Items}

One fragment of fired clay, possibly part of a figurine (Figure $9 b-6[b]$ ), was located in Feature 2 between 80 and $90 \mathrm{~cm}$ bd. A foot from a broken figurine was recovered from AU 3 (Figure 9b-6[c]). The foot is crudely-made, probably handshaped, and broken just above the ankle. It appears to have been burnt after it was broken. There is a hole on the bottom of the foot, presumably for some sort of stand, and there are small amounts of red paint inside the hole.

One piece of lead, cut in a tulip shape was found between 40 and $50 \mathrm{~cm}$ bd AU 3 near Feature 1 (Figure 9b-6[d]). The purpose of the piece, other than as some sort of decoration, is unknown.

Artifacts of particular interest are the six glass disks that were recovered during the project (Figure 9b-7). All are made from window glass. All are roughly circular, although there is a great deal of variation in size (Table 9b-3). Disks similar to these, made from sandstone, or limestone, or chipped from broken ceramics, are common in Spanish Colonial sites all over the country (Deagan 1972:33, 1974:93; Di Peso 1951:109; Fox 1992; Hard et al. 1995:63; Schuetz 1969:74-75). There are also similar, though generally much larger, disks found in prehistoric contexts in California (Moriarty and Broms 1971). They are believed to be gaming pieces (Schuetz 1969:74-75), and have been found at all of the missions in San Antonio (Fox 1992:54; Hard et al. 1995:63; Meskill 1992:26, 31; Schuetz 1969:74$75)$. The practice of making these disks from ceramics is known to have continued until well into the nineteenth century (Meskill 1992:26). The glass disks recovered from Refugio however, are the only disks made from glass that have been recognized in a Texas Colonial site collection.
Figure 9b-6. Miscellaneous personal items: a) Clay marble; b-c) Fragments of clay figurines; d) Decorative lead piece.
Figure 9b-7. Glass disks. 
Table 9b-3. Glass disk descriptions

\begin{tabular}{|c|c|c|c|l|}
\hline Prov. & Depth & Color & Size & \multicolumn{1}{|c|}{ Notes } \\
\hline N83/E100 & $30-40$ & Aqua? & $1.25 \mathrm{~cm}$ & $\begin{array}{l}\text { Heavily patinated after flaking } \\
\text { (Figure 9b-7[a]). }\end{array}$ \\
\hline N76/E100 & $30-35$ & Aqua & $2.42 \mathrm{~cm}$ & $\begin{array}{l}\text { Only slight patina, but lots of what } \\
\text { appears to be tiny potlid-type fractures } \\
\text { (Figure 9b-7[b]). }\end{array}$ \\
\hline N79/E100 & $20-30$ & Clear & $1.27 \mathrm{~cm}$ & Heavy patina (Figure 9b-7[c]) \\
\hline N81E100 & $20-30$ & Clear & $1.18 \mathrm{~cm}$ & $\begin{array}{l}\text { Broken, roughly half present, heavy } \\
\text { patina except on break (Figure 9b-7[d]). }\end{array}$ \\
\hline N86/E100 & $70-75$ & Aqua & $1.31 \mathrm{~cm}$ & Very little patination (Figure 9b-7[e]). \\
\hline N86/E100 & $95-100$ & Clear & $0.65 \mathrm{~cm}$ & Only slight patination (Figure 9b-7[f]). \\
\hline
\end{tabular}

\section{Barn/Workshop/Garage Tools}

The artifacts in this category are listed in Table 9b-4. A bone knife handle $9.41 \mathrm{~cm}$ in length was recovered from Feature 2, below the lime layer, between 70 and $80 \mathrm{~cm}$ bd (Figure $9 \mathrm{~b}-8[\mathrm{a}])$. The remains of part of the metal blade are still present between the two halves of the handle, which were held together with a series of rivets. Another bone knife handle fragment was found in Feature 1 (Figure 9b-8[b]), below the lime level between 130 and $140 \mathrm{~cm}$ bd. This handle fragment also has a metal rivet.

The tip of an iron chisel was recovered from $20-30 \mathrm{~cm}$ below the surface in Test Unit \#3.
A padlock was recovered from Trench 1 during Phase II (Figure 9b-8[c]). A very similar lock was sold in the 1897 Sears, Roebuck Catalogue (Israel 1993:87).

An iron strike-a-light (Figure 9b-8[d]) was collected from the upper $20 \mathrm{~cm}$ of sediment in AU 3, just above Feature 1. The item was used by striking it with a piece of chert. The resulting spark was aimed onto a pile of tinder to start a fire. Metal strike-a-lights have been found in other Colonial sites (see Schuetz 1969:49).

\section{Automobile-Related}

A sparkplug was recovered from $10-20 \mathrm{~cm}$ below the surface in Test Unit \#1. No markings remain on the plug to assist in identification. Three fragments of headlight(s) were also recovered from Test Unit \#3.

Table 9b-4. Items from the Barn, Workshop, and Garage categories

\begin{tabular}{|l|c|c|c|c|c|c|}
\hline & \multicolumn{3}{|c|}{ Analysis Unit } & Phase II & Test Units & Total \\
\hline & 1 & 2 & 3 & & & \\
\hline Tool & 1 & & & & 1 & 2 \\
\hline Wire & & 2 & 11 & 1 & 3 & 17 \\
\hline $\begin{array}{l}\text { Metal } \\
\text { Brackets }\end{array}$ & & & 3 & 1 & & 4 \\
\hline Fence staple & & & 5 & 1 & 2 & 8 \\
\hline Padlock & & & & 1 & & 1 \\
\hline Auto-related & & & & & 4 & 4 \\
\hline Total & 1 & 2 & 19 & 4 & 10 & 36 \\
\hline
\end{tabular}




\section{Arms}

One piece of lead buckshot was collected from AU 3 above Feature 2, in the upper $15 \mathrm{~cm}$ of sediment.

A brass cartridge and lead bullet were recovered south of Features 1 and 2 (Figure 9b-8[e]), in the upper $20 \mathrm{~cm}$ of sediment. The casing is broken where the lead bullet was seated. The cartridge is a .41 caliber center-fire design made by Colt for their first double-action pistol, Model 1877, known as a Colt Thunder (Logan 1959:134).

A part of a musket side plate (Figure $9 \mathrm{~b}-8[\mathrm{f}]$ ) was recovered north of the features, $20-30 \mathrm{~cm} \mathrm{bd}$. In the same unit/level a powder flask charger was also recovered (Figure 9b-8[g]). This small, spoon-like tool was used to measure the correct amount of powder to place on the pan of a musket.

A copper piece that may have been an arrowhead was recovered from Feature 7 (Figure 9b-8[h]).

\section{Construction Items}

A total of 2,548 construction-related artifacts were recovered during this project. They are listed in Table 9b-5. The nails listed as square are either forged or cut nails. They are grouped together because it is difficult to tell the two types apart unless they are in good to excellent condition. Both types are pre-twentieth century in date.

Wire nails began to take over the market in about 1890 (Santucci 1981). It is interesting to note that even in the mixed levels of the Phase I units (AU 3), square nails are much more common than wire nails. This is another indication that most of the artifacts in those levels are at least nineteenth century, if not Colonial, in origin.

Another item of interest in this category is the eight pieces of colored window glass found during the Phase II excavations. Two of these were green and the rest were blue. This colored window glass probably represents portions of broken stained glass windows from the Mission Refugio church.

Three large plumb bobs were also recovered from the surface in the Phase II area.

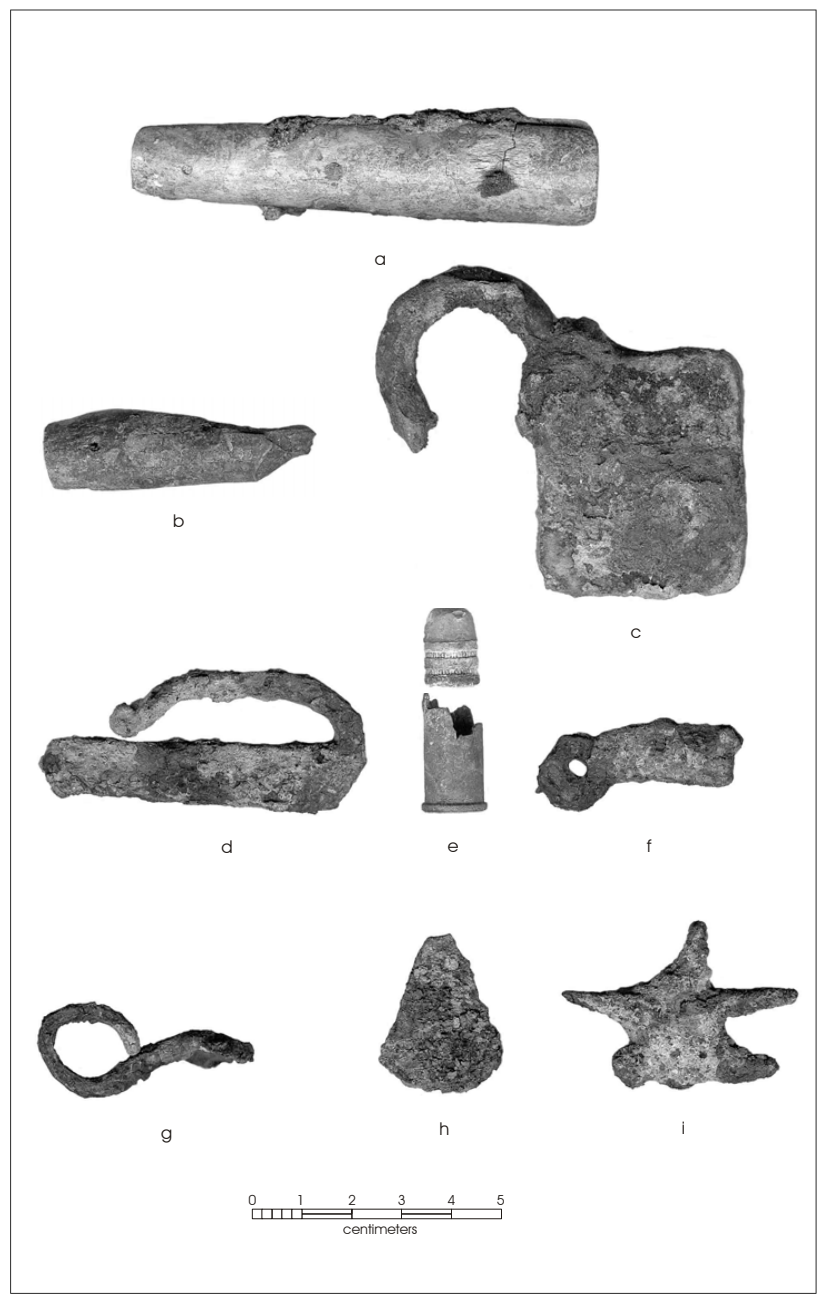

Figure 9b-8. Selected historic artifacts: a) bone knife handle; b) bone knife handle fragment; c) padlock; d) iron strike-a-light; e) lead bullet and casing; f) powder flask charger; g) musket side plate; h) possible copper arrowhead; i) cut metal object.

Table 9b-5. Construction-related items

\begin{tabular}{|l|c|c|c|c|c|c|}
\hline \multirow{2}{*}{} & \multicolumn{3}{|c|}{ Analysis Unit } & Phase II & Test Units & Total \\
\cline { 2 - 8 } & 1 & 2 & 3 & & & \\
\hline Window Glass & 23 & 22 & 163 & 18 & 32 & 258 \\
\hline Square Nails & 27 & 12 & 190 & 98 & 29 & 356 \\
\hline Wire Nails & 1 & & 39 & 15 & 12 & 67 \\
\hline Bolts & & & 2 & 2 & 1 & 5 \\
\hline Nuts & & & & 3 & 3 & 6 \\
\hline Washers & 1 & & 2 & & 1 & 4 \\
\hline Other Hardware & & & & 3 & & 3 \\
\hline Slate & & & & & 2 & 2 \\
\hline Bricks & 652 & 106 & 300 & 32 & 167 & 1257 \\
\hline Tile & 4 & & & & 5 & 9 \\
\hline Plaster & 5 & & 1 & 2 & 1 & 9 \\
\hline Mortar & 166 & 251 & 125 & 9 & & 551 \\
\hline Concrete & & & & 14 & 3 & 17 \\
\hline Utilities (Water) & 3 & & & & 1 & 4 \\
\hline Totals & 882 & 391 & 822 & 196 & 257 & 2548 \\
\hline
\end{tabular}




\section{Miscellaneous Items}

An assortment of miscellaneous items is listed in Table 9b6. Among these artifacts, six items are of particular interest. These include two pieces of unidentified bone with patterns painted on the surface in red and white paint (Figure 9b-9). These bones were located in 40 and $45 \mathrm{~cm}$ bd in Feature 2.

Three pieces of rope were recovered from Feature 1, 65-70 $\mathrm{cm}$ bd (Figure 9b-10). The rope is made of numerous strands of a coarse natural fiber held together in three bunches and braided. The pieces are $2.2 \mathrm{~cm}, 2.4 \mathrm{~cm}$, and $3.4 \mathrm{~cm}$ long and about $.85 \mathrm{~cm}$ in diameter.

A cut metal object in a star shape was located above the lime layer covering Feature 1 (see Figure 9b-8[i]). It may have been intended as a spur, but it does not appear as if it was ever finished.

Three pieces of pumice were recovered during the Phase I project. Two of these were from AU 3 south of the trash pits, and the third was from below the lime layer in Feature 2.

Table 9b-6. Miscellaneous artifacts

\begin{tabular}{|l|c|c|c|c|c|c|}
\hline & \multicolumn{3}{|c|}{ Analysis Unit } & Phase II & Test Units & Total \\
\hline & 1 & 2 & 3 & & & \\
\hline Other metal items & 1 & & 6 & 9 & 9 & 25 \\
\hline Fiber & 3 & & & & & 3 \\
\hline Pumice & & 1 & 2 & & & 3 \\
\hline Iron Scrap & 921 & 347 & 1732 & 63 & 154 & 3217 \\
\hline Copper Scrap & 188 & 117 & 154 & & & 459 \\
\hline Other Scrap & 6 & 10 & 51 & & & 67 \\
\hline Plastic & & & & 2 & 11 & 13 \\
\hline Slag & 432 & 78 & 254 & 7 & 159 & 930 \\
\hline Burned clay & 43 & 45 & & 2 & 30 & 120 \\
\hline Other & 5 & 3 & 2 & 19 & 10 & 39 \\
\hline Total & 1599 & 601 & 2201 & 102 & 373 & 4876 \\
\hline
\end{tabular}

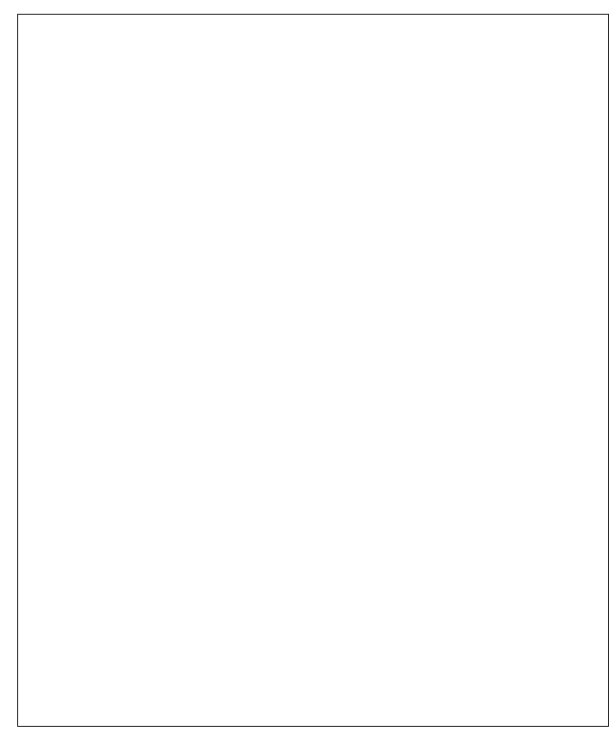

Figure 9b-9. Painted bone fragments.

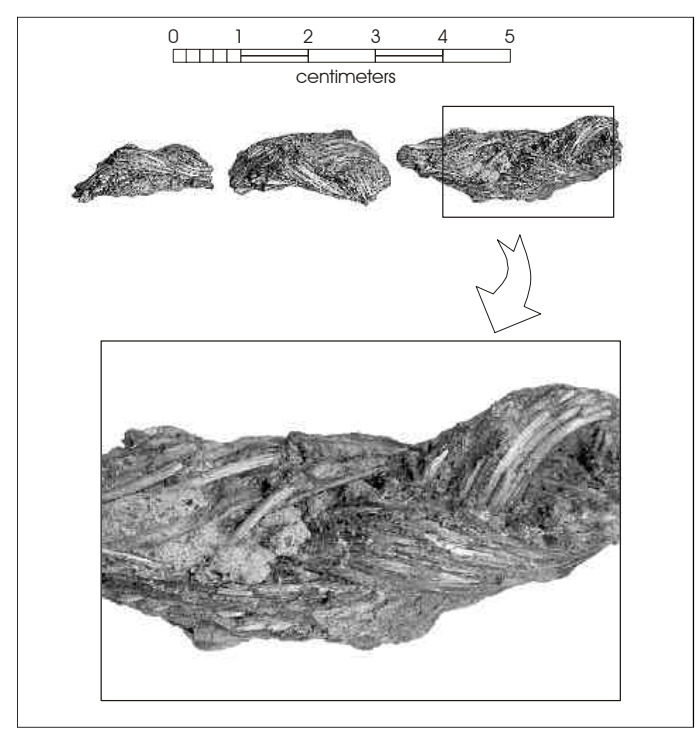

Figure 9b-10. Rope fragments. Inset shows detail. 


\section{Metal Arrow Points}

\section{Steve A. Tomka}

Three metal arrow points were recovered during burial excavations at 41RF1 (Figure 9b-11[a-c]). Two of the metal arrow points come from Burial 39 of Burial Feature 5, and were directly associated with the skeletal material. Burial 39 has been identified as a 20-24-year-old male of undetermined ancestry. A number of indicators (see Chapter 8c) seem to suggest that this individual met with a traumatic death.

The first of the arrow points associated with this burial is an expanding stem convex-based point (Figure 9b-11[a]). It was found in the rib cage next to the sternum and vertebrae of the individual. The second specimen associated with this burial (Figure 9b-11[b]) has a parallel stem and a straight base. Rust buildup along its base gives the base a concave appearance. This specimen is bent and is missing its tip. It was found under the shaft of the humerus of Burial 39. Slivers of the shaft or foreshaft of the arrow onto which the point was mounted still adhere to the stem of the point. Based on the foreshaft remnants and its imprint, the foreshaft appears to have been pointed and measured $5.7 \mathrm{~mm}$ in maximum thickness and extended $13.5 \mathrm{~mm}$ above the base.

The third specimen (Figure 9b-11[c]) has a straight stem and a base that is cut somewhat tangentially to the long axis of the point. It was found in Burial Feature 30, and may have been associated with either Burial 24 or Burial 102 . Burial 24 represents the remains of a 40-44-year-old male of possible Hispanic ancestry, while Burial 102 is that of a 30-40-year-old female of mixed Native American and Hispanic ancestry. Unfortunately, given the disturbed nature of the burial feature, it is not possible to associate this arrow point with either of these individuals.

The metric dimensions of the three points are presented in Table 9b-7. None of the three arrow points is barbed and their shoulders are slanted toward the tips of the points rather than being horizontal. All three of the points are heavily rusted indicating that they are made of iron rather than copper or brass. The lack of barbs is interesting particularly in light of the fact that the points are of durable metal rather than stone. Specifically, the lack of barbs may suggest simply a "cultural preference" or may indicate that barbs on stone arrow points did not play a functional role. That is, if barbs were significant in increasing the "kill" efficiency of arrow points, it would be likely that they would also be present on metal points. Here, they would be less likely to break off during use and would - therefore-represent a highly reliable design feature of a point. Their absence and the probability that they were never there (i.e., not fractured) suggests that they may not have been a critical functional element of the arrow point design.

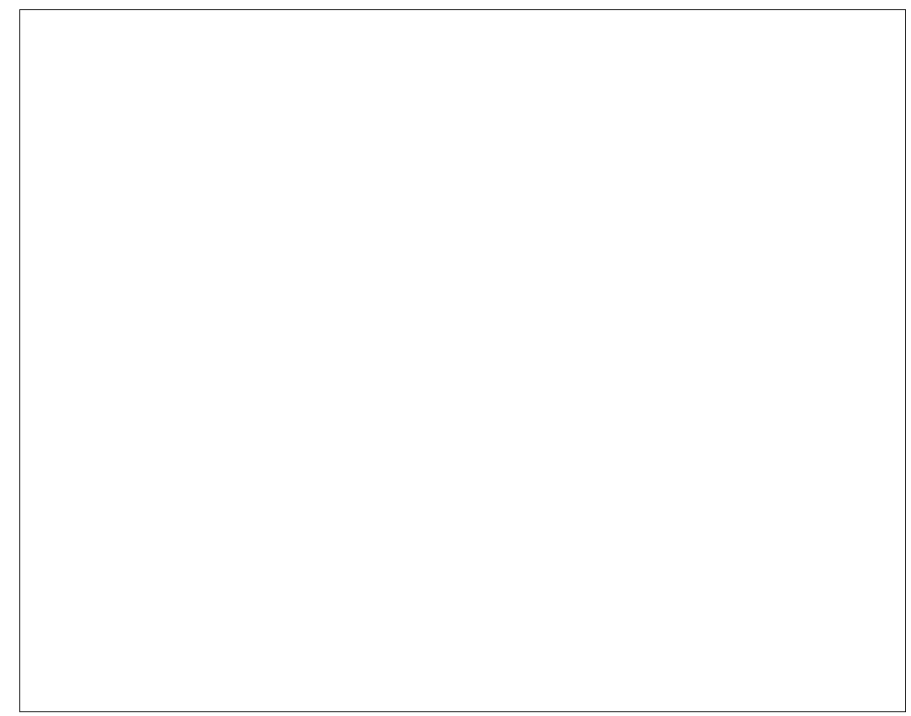

Figure 9b-11. Metal arrow points from Mission Refugio. 
Table 9b-7. Metric dimensions of the three metal arrow points from Mission Refugio

\begin{tabular}{|l|l|l|l|l|l|l|l|}
\hline & $\begin{array}{l}\text { Maximum } \\
\text { Length }\end{array}$ & $\begin{array}{l}\text { Stem } \\
\text { Length }\end{array}$ & $\begin{array}{l}\text { Blade } \\
\text { Length }\end{array}$ & $\begin{array}{l}\text { Max. } \\
\text { Blade } \\
\text { Width }\end{array}$ & $\begin{array}{l}\text { Neck } \\
\text { Width }\end{array}$ & $\begin{array}{l}\text { Base } \\
\text { Width }\end{array}$ & $\begin{array}{l}\text { Maximum } \\
\text { Thickness }\end{array}$ \\
\hline $\begin{array}{l}\text { Specimen 1; Burial Feature 5; } \\
\text { Burial 39 (Figure 9b-11[a]) }\end{array}$ & $50 \mathrm{~mm}$ & $12 \mathrm{~mm}$ & $38 \mathrm{~mm}$ & $20 \mathrm{~mm}$ & $7.5 \mathrm{~mm}$ & $11 \mathrm{~mm}$ & $2.5 \mathrm{~mm}$ \\
\hline $\begin{array}{l}\text { Specimen 2*; Burial Feature 5; } \\
\text { Burial 39 (Figure 9b-11[b]) }\end{array}$ & $48 \mathrm{~mm}$ & $10 \mathrm{~mm}$ & $38 \mathrm{~mm}$ & $18 \mathrm{~mm}$ & $8 \mathrm{~mm}$ & $7.5 \mathrm{~mm}$ & $2.5 \mathrm{~mm}$ \\
\hline $\begin{array}{l}\text { Specimen 3; Burial Feature 30; } \\
\text { Burials 24/102 (Figure 9b-11[c]) }\end{array}$ & $49 \mathrm{~mm}$ & $9 \mathrm{~mm}$ & $40 \mathrm{~mm}$ & $17 \mathrm{~mm}$ & $7 \mathrm{~mm}$ & $7.5 \mathrm{~mm}$ & $2 \mathrm{~mm}$ \\
\hline
\end{tabular}

* this specimen is bent and retains a small segment of the shaft or foreshaft

Allowing for the thickness of the rust, the specimens appear to have been made of iron straps that measured roughly 2.0 $2.5 \mathrm{~mm}$ in thickness. The fact that the specimens appear to have the same thickness across their entire surfaces also supports the contention that the points were made of metal strap and indicates that they were probably not cold hammered to their present thickness. The thick rust coating prevents the clear establishment that the specimens were chiseled out of metal blanks, nor is there clear evidence that the edges of the points were sharpened by filing.

A brief search for other metal arrow points recovered from south Texas indicates that shouldered points are the common forms found throughout the region (Bauman 1989, 1991; Chandler 1989; Chandler and Kumpe 1997; Goebel et al. 1987; Kennedy and Mitchell 1988; McReynolds 1982; Mitchell and Highley 1982). Few of the arrow points described in the articles consulted during this literature search are barbed; the few that are have relatively short barbs (a copper point from Mission San José [Level 4 (18-24 inches bs of Unit 18); Tomka and Fox 1998a:Figure 14g, p. 26] is an exception to this). The formal variability that exists in the points seems to be associated with the stem morphology (i.e., parallel, expanding, notched). Most specimens have a straight base, with the convex-based specimen from Refugio being an exception. Some variability in blade size and morphology also exists, but it is not clear as to whether this is the result of blade reworking or was originally intended. 


\title{
Chapter 9: Artifacts - $\quad$ Section C
}

\section{Native American Ceramics}

\author{
Timothy K. Perttula
}

\section{Introduction}

Mission Nuestra Señora del Refugio was established at its final location in 1795 (see Chapter 3) to minister to the Karankawa Indians of the central coast of Texas, and this location relatively close to the mainland shoreline "contributed to the limited success of the Refugio mission" (Ricklis 1996:168).

A large assemblage of more than 4,300 Native American ceramic sherds (including numerous sherds less than one $\mathrm{cm}$ in diameter) has been recovered from the TxDOT sponsored excavations in the project area at Mission Nuestra Señora del Refugio (41RF1). This includes a respectable sample of sherds from earlier test excavations by Clark (1998) in the same area. Many of these sherds, particularly the larger sherds and an occasional vessel section, are from the contents of Features 1 and 2, large and deep units exposed and excavated during the 1998 season.

These ceramics were apparently manufactured and used in the late-eighteenth and early-nineteenth century occupation of the mission. In the discussion that follows, the results of the analyses are predicated in great measure on the differences and similarities in the ceramic wares between the three analysis units defined by Tennis (Chapter $8 \mathrm{~A})$. These are defined as follows:

1) Analytical Unit 1 (AU 1)-contents of Feature 1;

2) Analytical Unit 2 (AU 2)-contents of Feature 2; and

3) Analytical Unit 3 (AU 3)-ceramics from levels above and/or outside the two features.

Though the span of occupation at Mission Refugio is about 35 years (1795-1830 at its final location), discussions that follow point to the diachronic and sequent nature of these three units. While not necessarily clarifying or confirming the diachronic character of Analytical Units 1-3, Oxidizable Carbon Ratio (OCR) dates of A.D. $1760 \pm 5$, A.D. $1809 \pm 4$, and A.D. $1790 \pm 4$ have been obtained from 30, 43, and 102 $\mathrm{cm}$ below datum (bd) in Feature 1 (AU 1), respectively. Feature 2 (AU 2) has OCR dates of A.D. $1737 \pm 6$, A.D. $1782 \pm 5$, A.D. $1840 \pm 3$, and A.D. $1794 \pm 4$ from $28,48,79$, and $99 \mathrm{~cm}$ bd, respectively.
This chapter briefly discusses the analytical procedures employed for the study of the Refugio Native American ceramics. This is followed by detailed summaries of the character of the plain and decorated bone-tempered and sandy paste wares in Analytical Units 1-3 at the site. The results of petrographic analysis (Hill, Appendix G), and instrumental neutron activation analysis (Neff and Glascock, Appendix н) of selected sherds from each analytical unit are also presented. To conclude, the temporal, functional, and cultural affiliation of the Mission Refugio Native American ceramics is discussed, then comparisons are made between these ceramics and the aboriginal wares recovered in other broadly contemporaneous mission sites in southern Texas, and the relevant research questions posed in the overall project research design are considered.

\section{Analytical Procedures}

The analysis effort for the Mission Refugio Native American ceramics focused on sherds that were greater than one $\mathrm{cm}$ in diameter, $(n=3,047)$ including:

1) Feature 1 (AU 1) $(n=686)$;

2) Feature $2(\mathrm{AU} 2)(\mathrm{n}=1,430)$;

3) Non-feature units (AU 3) $(n=1,617)$;

4) Miscellaneous contexts $(n=17)$; and

5) TxDOT excavations $(n=297)($ Clark 1998).

The 1,320 sherds less than one $\mathrm{cm}$ in diameter were tabulated by provenience, but received no further analytical attention (Appendix J). The 3,047 sherds larger than one $\mathrm{cm}$ in diameter were sorted into analytical groups based on temper and paste. Decorated sherds, rim sherds, and selected samples of plain body sherds from the assemblage $(n=1,730)$ were then subjected to detailed attribute analysis (Appendix к). Attributes examined included type of decoration (if any); rim profile; lip profile; oxidation conditions as seen in sherd cross sections (see Teltser 1993:Figure 2); temper, and quantity of temper in the paste (sparse $=$ less than 5 percent; moderate $=5-25$ percent; profuse $=$ more than 25 percent, following Ricklis [1998, 1999a]); paste; interior and exterior surface treatment (including smoothing, scraping, burnishing, and asphaltum coating); and sherd wall thickness. 


\section{Bone-Tempered Wares}

Approximately 78 percent of the ceramic assemblage from Mission Refugio that were larger than one $\mathrm{cm}$ in diameter $(n=2,365)$ have a bone-tempered paste. The bone had been burned and then crushed before it was added to the clay paste (Table 9c-1). This includes 150 rims, 2,204 body and base sherds, two ceramic disks, seven loop handles, and two ceramic foot sherds. About 3 percent $(n=72)$ of the bonetempered sherds have an asphaltum coating (Table 9c-2). Six sherds from AU 1 and AU 3 are shown in Table 9c-1 as having no apparent temper. These sherds have a clay paste and if there was bone temper, it was a sparse amount that has been eroded or leached away.

Between 89-94 percent of the bone-tempered pottery from Mission Refugio has either sparse or moderate amounts of burned bone added to the clay paste, with the remaining 6-11 percent of the sherds having profuse amounts of bone tempering. Sparsely bone-tempered sherds are most abundant in AU 3 (46 percent of the sherds in this analytical unit), and the least abundant in AU 2 (20.6 percent). Moderately bone-tempered sherds are particularly common in the $\mathrm{AU} 2$ sherds (70.6 percent), and comprise between 51-56 percent of the bone-tempered sherds in $\mathrm{AU} 1, \mathrm{AU} 3$, and TxDOT contexts. A similar trend is apparent in the profusely bone-tempered sherds, as they are most common in AU 2 (11.2 percent), and less, but equally, common in AU 1 (6.8 percent), AU 3 (5.3 percent), and the TxDOT excavations ( 7.6 percent).

The bone-tempered sherds range from 3.3-16.2 $\mathrm{mm}$ in thickness, with approximately 60 percent of the sherds falling between 5.3-7.6 mm; the modal thickness is $6.9-7.6 \mathrm{~mm}$ (Table 9c-3). The sherds greater than $10 \mathrm{~mm}$ (1.9 percent of the sample of 689 measured sherds) appear to be from the base of vessels. The sandy paste and sandy paste-bonetempered sherds have thinner vessel walls; about 61 percent of the sandy paste sherds range between $4.6-6.9 \mathrm{~mm}$, compared to 60 percent of the sandy paste-bone-tempered specimens (see Table 9c-3). The modal thickness for the sandy paste wares is $4.6-5.3 \mathrm{~mm}$, and $5.3-6.1 \mathrm{~mm}$ for the bone-tempered sandy paste sherds.

Approximately 0.2 percent $(n=5)$ of the bone-tempered sherds have preserved organic residues on interior or exterior surfaces of vessel sherds. This comprises direct evidence for the use of bone-tempered vessels for the cooking of plant and/or animal foods. However, the very low percentage also suggests that the sherd assemblage at Refugio has been eroded and degraded — removing adhering charred organic remains-since it was deposited in and around Features 1 and 2. However, a study of the sherds to determine if any residues remain in the sherd cores may prove insightful into the kinds of foods processed in the bone-tempered vessels.

Table 9c-1. Sherd temper and paste groups

\begin{tabular}{|l|c|c|c|c|c|}
\hline Context & Bone-Tempered & None & Sandy Paste & $\begin{array}{c}\text { Sandy Paste } \\
\text { with Bone Temper }\end{array}$ & Totals \\
\hline AU 1 & 513 & 2 & 120 & 51 & 687 \\
\hline AU 2 & 338 & 0 & 71 & 21 & 432 \\
\hline AU 3 & 1252 & 4 & 282 & 79 & 1620 \\
\hline TxDOT & 246 & 0 & 44 & 7 & 297 \\
\hline Miscellaneous & 16 & 0 & 0 & 1 & 17 \\
\hline Total & 2365 & 6 & 517 & 159 & 3047 \\
\hline
\end{tabular}

Table 9c-2. Proportion of asphaltum-coated and/or decorated sherds

\begin{tabular}{|l|c|c|c|c|c|}
\hline Class & AU 1 & AU 2 & AU 3 & TxDOT & Misc. \\
\hline Bone-Tempered & $2.7 \%$ & $3.3 \%$ & $3.5 \%$ & $1.2 \%$ & $0 \%$ \\
\hline Sandy Paste & $25.8 \%$ & $46.5 \%$ & $26.2 \%$ & $29.5 \%$ & $0 \%$ \\
\hline $\begin{array}{l}\text { Sandy Paste with } \\
\text { Bone Temper }\end{array}$ & $11.8 \%$ & $28.6 \%$ & $13.9 \%$ & $14.3 \%$ & $0 \%$ \\
\hline None & $0 \%$ & $0 \%$ & $0 \%$ & $0 \%$ & $0 \%$ \\
\hline
\end{tabular}


Table 9c-3. Thickness of different paste/temper classes

\begin{tabular}{|c|c|c|c|}
\hline $\begin{array}{c}\text { Thickness } \\
\text { Intervals (mm) }\end{array}$ & Bone-Tempered & Sandy Paste & $\begin{array}{c}\text { Sandy paste-with } \\
\text { Bone-Temper }\end{array}$ \\
\hline $3.0-3.8$ & 12 & 10 & 4 \\
\hline $3.8-4.6$ & 54 & 26 & 10 \\
\hline $4.6-5.3$ & 83 & 38 & 16 \\
\hline $5.3-6.1$ & 135 & 30 & 25 \\
\hline $6.1-6.9$ & 131 & 34 & 19 \\
\hline $6.9-7.6$ & 145 & 16 & 15 \\
\hline $7.6-8.4$ & 73 & 11 & 7 \\
\hline $8.4-9.1$ & 28 & 1 & 3 \\
\hline $9.1-9.9$ & 15 & 1 & 1 \\
\hline $9.9+$ & 13 & 1 & 0 \\
\hline Totals & 689 & 168 & 100 \\
\hline
\end{tabular}

\section{Undecorated Bone-Tempered Rim Sherds}

There are 141 undecorated bone-tempered rim sherds larger than one $\mathrm{cm}$ in diameter in the Mission Refugio ceramic assemblage. The range of rim and lip forms from the different contexts is illustrated in Figure 9c-1 (AU 1), Figure 9c-2 (AU 2), Figure 9c-3 (AU 3), and Figure 9c-4 (TxDOT) contexts. The majority ( 60 percent) of the bone-tempered rims of identifiable rim form are direct or standing $(n=63$ of 105 ) and 71 percent have rounded lips (Table 9c-4). About 67 percent of the nine decorated bone-tempered rim sherds are direct with rounded lips. These rim and lip forms probably represent bowls and/or deep jars.

A significant percentage of the bone-tempered rims are everted ( 25 percent), particularly in AU 1 and AU 2 samples, and are probably from jars (see Figure 9c-1[b], Figure 9c2 [a and c], Figure 9c-3[d], and Figure 9c-4[e]). The remaining identifiable rims $(n=16)$ are inverted with rounded and flat lips (see Figure 9c-1[a], Figure 9c-3[e], and Figure $9 \mathrm{c}-4[\mathrm{~b}])$. They appear to be from shallow bowls and narrowmouthed ollas. The inverted rim form is present in each excavated context, but is proportionally most prevalent in AU 3 and the TxDOT excavations.

Only a small percentage (2.6 percent) of the bone-tempered rims have pointed lips (see Table 9c-4). This figure corresponds with one determined by Ricklis (1998:89) at Mission Rosario (41GD2), who also noted that pointed lips were absent at Goliad (41GD1).
Few of the bone-tempered rim sherds were large enough to estimate vessel form or orifice diameter. Twenty-one rim sherds have orifice diameters that range from $12-35 \mathrm{~cm}$, with about 62 percent larger than $15 \mathrm{~cm}$ in orifice diameter. These orifice diameters are from deep bowls $(n=1)$, jars $(n=6)$, and bowls $(n=14)$.

Information from sherd cores (of decorated and/or rim sherds) on vessel firing conditions indicates that between 85-98 percent of the bone-tempered sherds from AU 1, AU 2 , and AU 3 were fired in a reducing environment. The highest proportion of vessel sherds fired in a reducing environment occurs in the Feature 1 (AU 1) assemblage. As discussed below, the Feature 2 (AU 2) sherds are from vessels that were more likely to have been fired and cooled in a reducing environment (33 percent compared to 22-23 percent in AU 1 and AU 3). The Feature 1 (AU 1) and nonfeature (AU 3) sherds have higher proportions (77-78 percent) of vessel sherds fired in a reducing environment, but then cooled in a high oxygen environment. Only 66 percent of the reduced vessel sherds from Feature 2 were fired and cooled in this manner.

Rim and decorated sherds with bone tempering are commonly smoothed or burnished. Smoothing creates a finer and more regular surface:

...[and] has a matte rather than a lustrous finish. (Rice 1987:138).

Burnishing, by contrast, creates an irregular lustrous finish marked by parallel facets left by the burnishing tool (perhaps a pebble or bone). About 42 percent of these bone-tempered sherds are smoothed or burnished to finish and shape the interior and exterior walls of the vessels. More often than not, it was the exterior vessel surface most commonly burnished or smoothed. This suggests that these sherds are not from cooking jars, which are usually smoothed on the interior to better control thermal shock resistance and lower their permeability to improve their heating effectiveness (Rice 1996:148; Schiffer et al. 1994:210). Rather, the exterior smoothed and burnished bone-tempered vessels were probably used for serving and storing foods and liquids.

About 3 percent of the bone-tempered sherds have scraping marks on interior and exterior surfaces. These probably result from poorly executed attempts to finish the vessels before they were fired. Another 4.3 percent have interior or exterior wiping marks, perhaps made with a piece of fur or clump of grass when the vessel was damp. Wiping may indicate attempts to float clay particles in the paste to the surface, resulting in a less porous vessel (see Johnson 1994:193) 


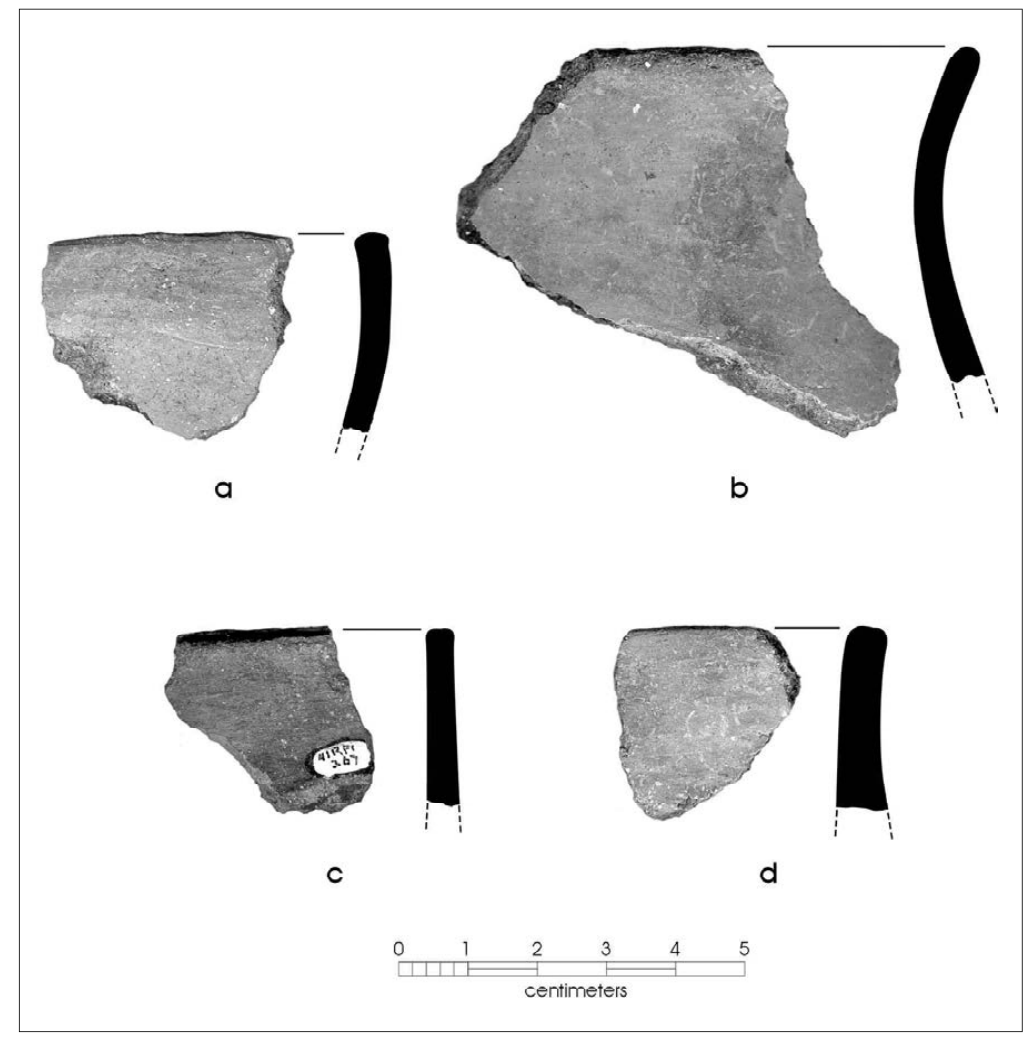

Figure 9c-1. Undecorated Rim Sherds from AU 1: a) inverted-rounded, bone-tempered, $85 \mathrm{~N} 99 \mathrm{E}, 110-$ $120 \mathrm{~cm} \mathrm{bd}$; b) everted-rounded, bone-tempered, $85 \mathrm{~N} 100 \mathrm{E}, 80-90 \mathrm{~cm} \mathrm{bd}$; c) direct-flat, bone-tempered, 74N100E, $45-50 \mathrm{~cm}$ bd; d) direct-flat, bonetempered, 86N99E, 60-70 cm bd.

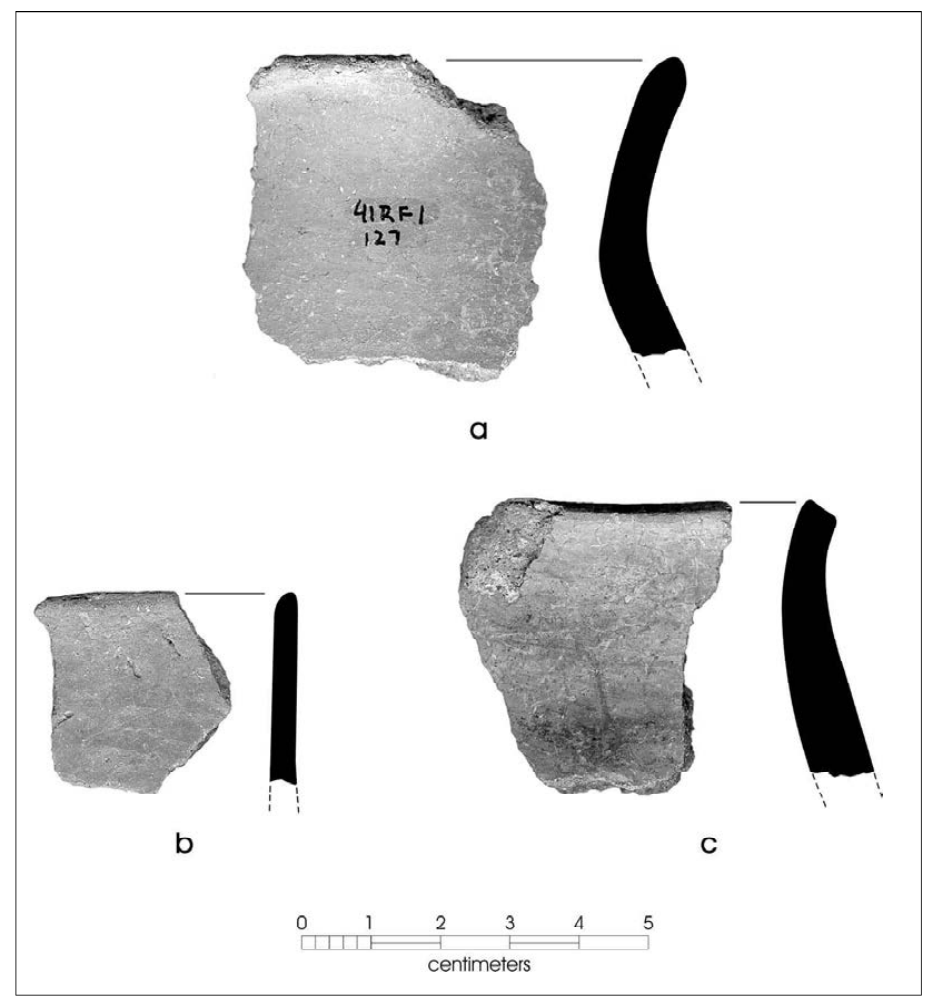

Figure 9c-2. Undecorated Rim Sherds from $A U$ 2: a) everted-rounded, bone-tempered, 73N100E, 70-80 $\mathrm{cm} \mathrm{bd}$; b) direct-rounded, bone-tempered, 74N100E, 70$75 \mathrm{~cm}$ bd; c) everted-flat, bone-tempered, 75N99E, 80-90 cm bd. 
Figure 9c-3. Undecorated Rim Sherds from $A U$ 3: a) direct-flat, sandy paste, $82 \mathrm{~N} 100 \mathrm{E}, 0-20 \mathrm{~cm}$ bd; b) direct-rounded-exterior thickened, bone-tempered, $85 \mathrm{~N} 100 \mathrm{E}, 30-40 \mathrm{~cm}$ bd; c) direct-rounded, bone-tempered, $95 \mathrm{~N} 100 \mathrm{E}, 40-50 \mathrm{~cm}$ bd; d) evertedrounded, bone-tempered, $84 \mathrm{~N} 100 \mathrm{E}$, $40-50 \mathrm{~cm}$ bd; e) inverted-flat, bonetempered, $86 \mathrm{~N} 100 \mathrm{E}, 20-30 \mathrm{~cm}$ bd; f) direct-rounded, bone-tempered, $86 \mathrm{~N} 100 \mathrm{E}, 40-50 \mathrm{~cm}$ bd; g) invertedflat, bone-tempered, 85-86N100E, 0$20 \mathrm{~cm}$ bd.

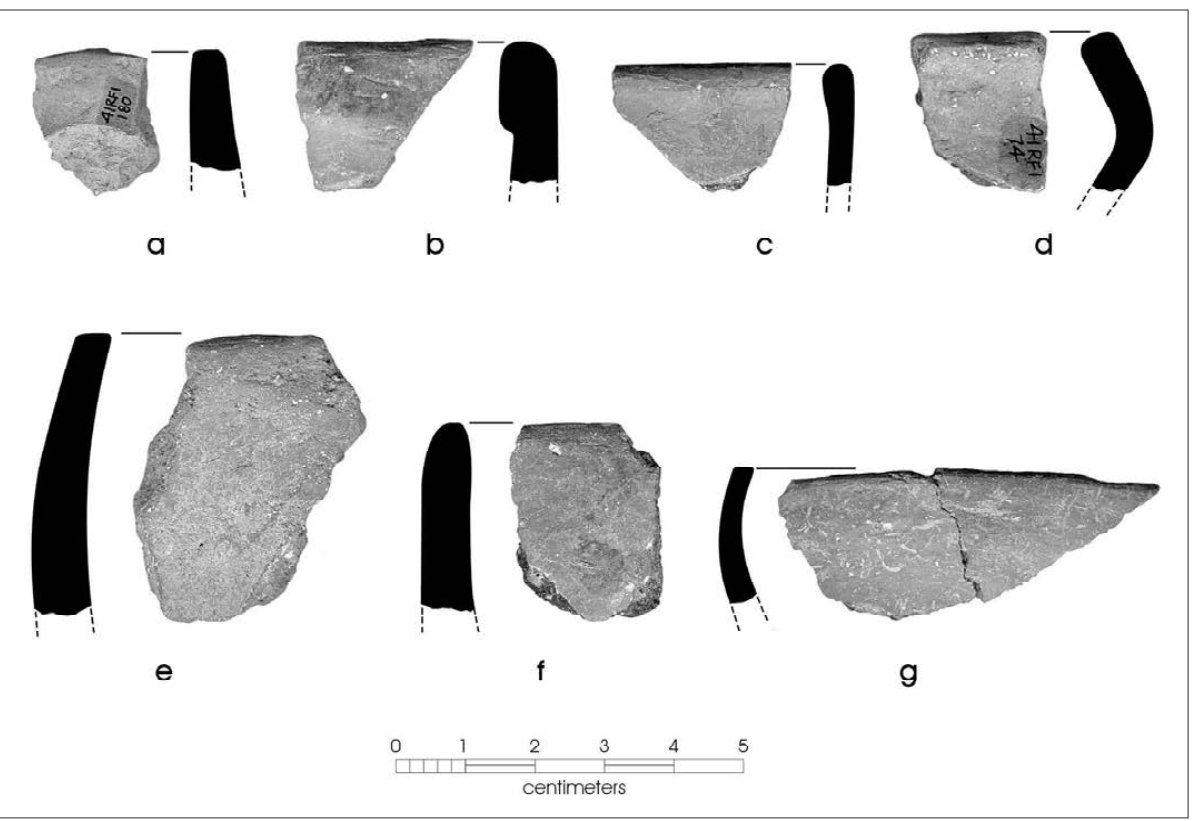

Figure 9c-4. Undecorated Rim Sherds and red and black-

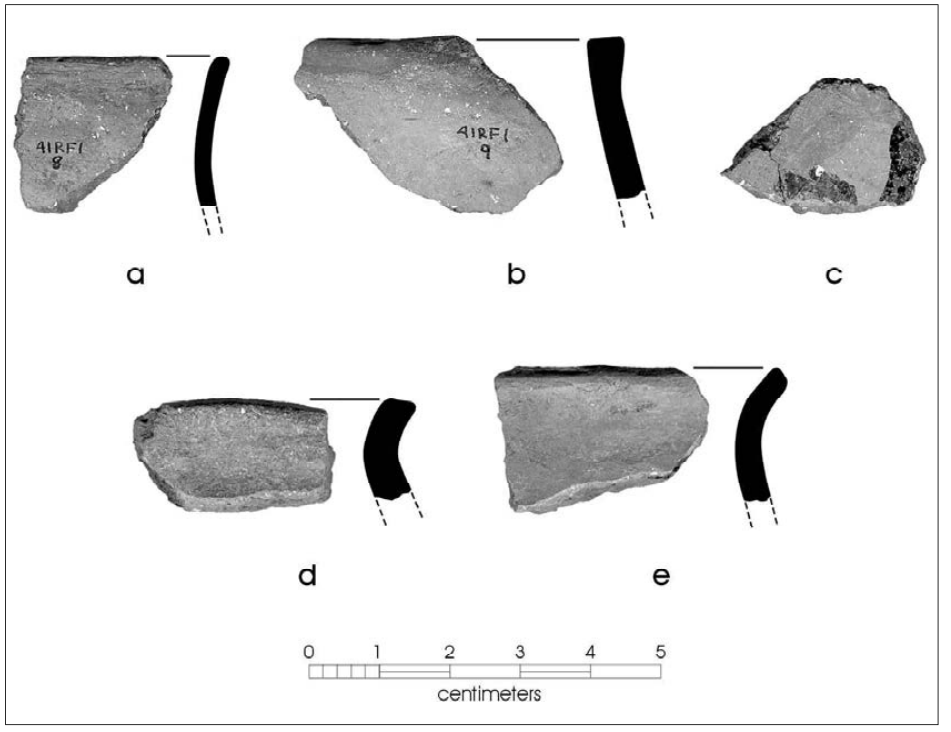
on-buff decorated body sherd, TxDOT excavations: a) everted-rounded, bone-tempered, Test Unit 2; b) inverted-flat, bone-tempered, Test Unit 2; c) red and black-on-buff body sherd, Test Unit 1; d) everted-flat, sandy paste-bone-tempered, Test Unit 2; e) everted-flat, bonetempered, Test Unit 3. 
Table 9c-4. Bone-tempered rim and lip forms

\begin{tabular}{|c|c|c|c|c|}
\hline Rim and Lip Form & AU 1 & AU 2 & AU 3 & TxDOT \\
\hline Direct-rounded & $27.9^{*}$ & 7.1 & 33.3 & 22.2 \\
\hline Direct-rounded/ext. thickened & 0.0 & 0.0 & 1.3 & 0.0 \\
\hline Direct-flat & 7.0 & 14.1 & 12.0 & 11.1 \\
\hline Direct-flat/beveled & 2.3 & 0.0 & 0.0 & 0.0 \\
\hline Direct-flat/folded & 2.3 & 0.0 & 0.0 & 0.0 \\
\hline Direct-pointed & 0.0 & 0.0 & 1.3 & 0.0 \\
\hline Direct-expanding & 0.0 & 0.0 & 1.3 & 0.0 \\
\hline Everted-rounded & 27.9 & 28.7 & 5.3 & 11.1 \\
\hline Everted-flat & 2.3 & 0.0 & 2.7 & 5.6 \\
\hline Inverted-rounded & 4.7 & 7.1 & 9.3 & 0.0 \\
\hline Inverted-flat & 4.7 & 0.0 & 2.7 & 5.6 \\
\hline Inverted-pointed & 0.0 & 0.0 & 0.0 & 5.6 \\
\hline UID-rounded & 16.3 & 21.4 & 22.7 & 11.1 \\
\hline UID-rounded/beveled & 2.3 & 0.0 & 1.3 & 0.0 \\
\hline UID-flat & 2.3 & 14.3 & 5.3 & 22.2 \\
\hline UID-flat/beveled & 0.0 & 7.1 & 0.0 & 0.0 \\
\hline UID-pointed & 0.0 & 0.0 & 1.3 & 5.6 \\
\hline $\mathrm{N}=$ & 43 & 14 & 75 & 18 \\
\hline
\end{tabular}

* Percentage; UID=unidentified

\section{Decorated Bone-Tempered Rim and Body Sherds}

Approximately 1.5 percent $(n=35)$ of the bone-tempered sherds, including nine rim sherds, have decoration. The decorated bone-tempered sherds include nine with redpainted bands, five sherds with brown-painted bands, a single sherd (from the earlier TxDOT excavations reported by Clark [1998]) with red painted and asphaltum lines, two brushed sherds, one incised sherd, and 18 sherds with a sparse bone-tempered paste that have asphaltum lines, blobs, or squiggles (Figure 9c-5). All of the decorated bonetempered sherds are from AU 1, AU 3, and TxDOT excavations. Feature 2 (AU 2) has no decorated sherds. One untempered sherd from the earlier TxDOT excavations (Test Unit 1) without any temper also has an asphaltum line or band on the sherd exterior.

\section{Goliad Red-on-Buff}

The nine Goliad Red-on-buff, or red-painted sherds are from AU $3(n=8)$ and the TxDOT excavations $(n=1)$. Mounger (1959) defined the type from the large bone-tempered ceramic assemblage from Mission Espíritu Santo at Goliad (41GD1). These sherds have dots, horizontal and vertical bands, diagonal lines, zig-zag lines at the rim, and semicircular loops (Mounger 1959:Plates 13-16), but the vessel forms could not be determined. In the sample from Goliad, red-on-buff sherds comprised 0.44 percent of the bonetempered sherds. Interestingly, at Mission Refugio, they comprise a comparable 0.38 percent of the bone-tempered sherds.

The eight red-painted or red-on-buff sherds from AU 3 represent a minimum of three or four vessels. Two or three have red-on-buff decorations on the vessel interior (Figure $9 \mathrm{c}-5[\mathrm{~g}-\mathrm{h}])$, suggesting they are bowls, and the fourth vessel has a painted red line on the vessel exterior; it also appears to be a bowl. The distribution of the red-on-buff sherds suggests they are principally associated with the late use of the site.

The red painted sherds at Refugio have bands at least 6-16 $\mathrm{mm}$ in width. The bands are painted horizontally across the rim, and are placed at least 6-15 $\mathrm{mm}$ below the top of the lip. Rims are direct or standing, with either flat or rounded lips. The three vessels were fired in a reducing environment, but cooled in a high oxygen environment. They have sparse to moderate amounts of bone temper in the paste. Two vessels have thin walls at the rim and on the vessel bodyranging from 3.3-6.1 mm-while the third vessel (95N100E, $30-40 \mathrm{~cm}$ bd) has thick body walls $(8.2 \mathrm{~mm})$.

The last red-painted sherd is a rim from Test Unit 1 in Clark's (1998) work at Refugio. It has traces of a red painted line or band on the vessel interior. The rim is direct with a rounded lip, and it is only $4.1 \mathrm{~mm}$ in thickness, suggesting it is from a bowl. It was fired in a reducing environment.

\section{Brown or Dark Brown-Painted Sherds}

Three of the brown or dark brown-painted body sherds are from AU 3, and the other two are from AU 1. Those in AU 1 have a bone-tempered clay paste, while those from AU 3 have a sandy paste with bone temper. A minimum of three different vessels appear to be represented in these sherds. 


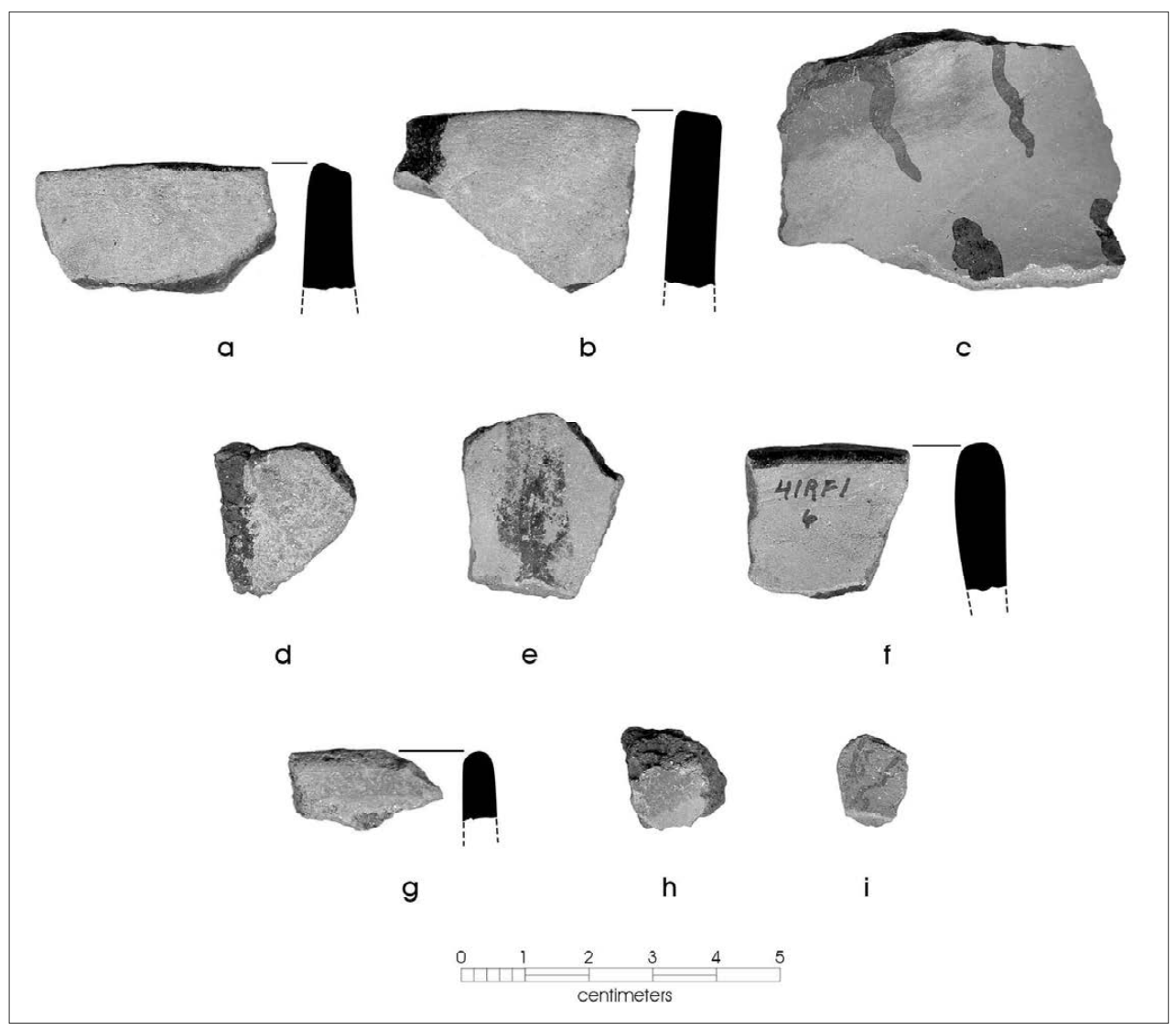

Figure 9c-5. Selected Decorated Sherds from AU 3: a) Rockport Black-on-Gray I, 86N99E, 20-30 cm bd; b) Rockport Black-on-Gray II, $85 \mathrm{~N} 100 \mathrm{E}, 10-20 \mathrm{~cm}$ bd; c) black-on-buff, $85 \mathrm{~N} 100 \mathrm{E}, 20-30 \mathrm{~cm}$ bd; d) black-on-buff, 87N100E, 0-20 cm bd; e) Rockport Black-on-Gray II, 86N99E, 40-50 cm bd; f) Rockport Black-on-Gray I, $85 \mathrm{~N} 100 \mathrm{E}, 10-20 \mathrm{~cm}$ bd; g) red-on-buff, $85 \mathrm{~N} 100 \mathrm{E}, 10-20 \mathrm{~cm}$ bd; h) red-on-buff, $95 \mathrm{~N} 100 \mathrm{E}, 30-40 \mathrm{~cm}$ bd; i) brown-on-buff squiggles, $75 \mathrm{~N} 99 \mathrm{E}, 20-30 \mathrm{~cm}$ bd.

Ricklis (1998:74 and Figure 310) recovered a similar sherd from Mission Rosario with parallel lines on the sherd exterior made with a dark brown paint.

The brown or dark brown decorated sherds have painted bands (Figure 9c-6[a]) or squiggles (see Figure 9c-5[i]); four of the five sherds are decorated on the vessel exterior, and one rim in AU 1 (85N100E, $80-90 \mathrm{~cm}$ bd) has a painted band on the interior of the vessel. This rim is everted, with a rounded lip, and appears to be from a jar. The other AU 1 dark brown-on-buff sherd may have horizontal and vertical bands (Figure 9c-7[d]).

The Feature 1 (AU 1) brown or dark brown-on-buff sherds have been fired in a reducing environment, and have relatively thick rim and body walls $(6.4-7.7 \mathrm{~mm})$. All three non-feature sherds (AU 3), however, are from two different vessels incompletely oxidized during firing; these sherds have thin (4.6-5.6 $\mathrm{mm}$ ) body walls.

The unique red-painted and asphaltum-decorated sherd is from Lot 3 (Test Unit 1) in the TxDOT excavations (see Figure 9c-4[c]). This appears to be the sherd Clark (1998:43 and Figure 131) identified as a "bone tempered polychrome, red and black on buff." It has a single red painted line adjacent to two probable asphaltum lines. The interior of the sherd is scraped, and the sherd may be from a bottle. It has thin body walls $(4.4 \mathrm{~mm})$, moderate bone temper, and the vessel was fired in a reducing environment, but then cooled in a high oxygen environment.

Both of the brushed sherds are from AU 3. One sherd, probably from a jar fired in a reducing environment, has overlapping brush marks on the exterior vessel body that 


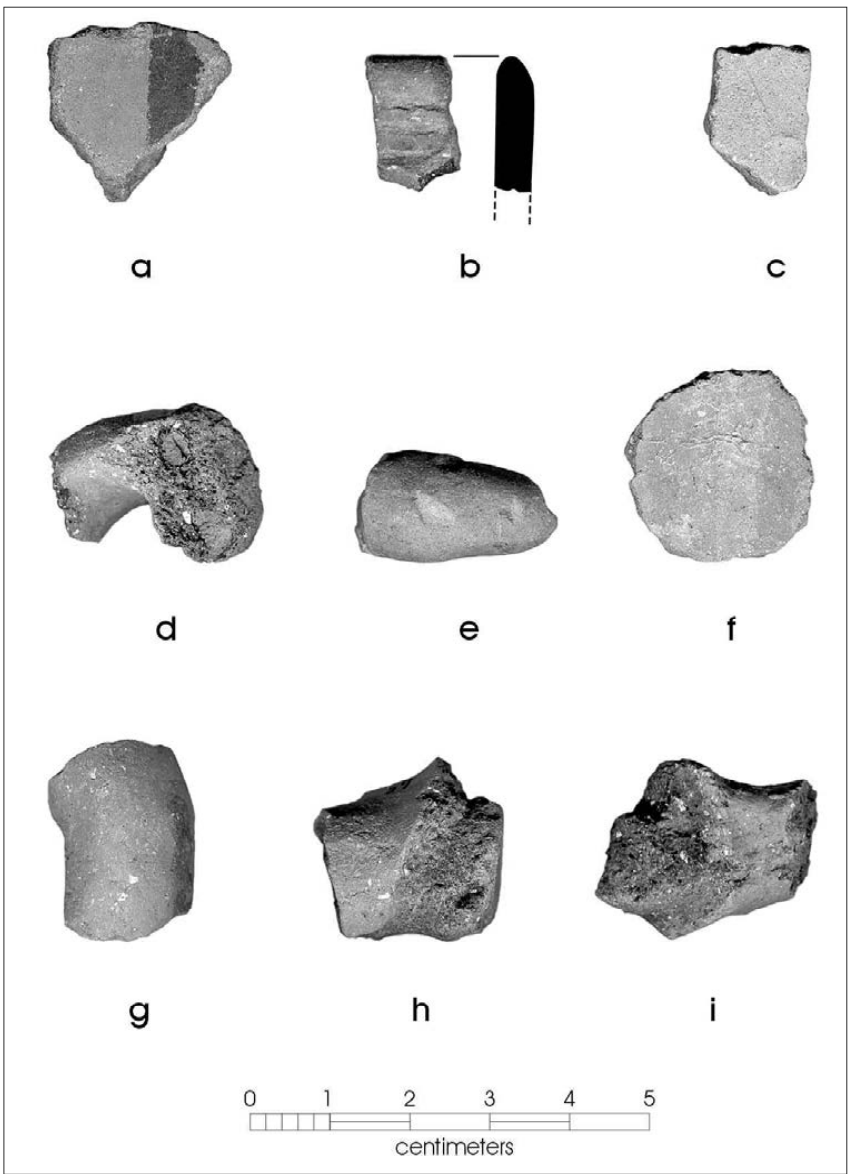

Figure 9c-6. Decorated Sherds, Loop Handles, Ceramic Foot, and Ceramic Disk, $A U$ 3: a) dark brown-on-buff, 86N100E, 50-56 cm bd; b) incised rim, 87N100E, 0-20 cm bd; c) overlapping brushed, $71 \mathrm{~N} 100 \mathrm{E}, 0-20 \mathrm{~cm}$ bd; d) loop handle, $85 \mathrm{~N} 99 \mathrm{E}, 20-30 \mathrm{~cm}$ bd; e) ceramic foot, $86 \mathrm{~N} 100 \mathrm{E}, 20-30 \mathrm{~cm}$ bd; f) disk, $85 \mathrm{~N} 100 \mathrm{E}, 20-30 \mathrm{~cm}$ bd; g) loop handle, 71N100E, 0-20 cm bd; h) loop handle, 73N100E, 30-40 cm bd; i) loop handle, $85 \mathrm{~N} 99 \mathrm{E}, 0-20 \mathrm{~cm}$ bd.

Figure 9c-7. Decorated Sherds, Ceramic Disk, and Loop Handle, AU 1: a) disk, 86N99E, 100-110 cm bd; b) loop handle, $87 \mathrm{~N} 100 \mathrm{E}, 80-90 \mathrm{~cm}$ bd; c) Rockport Black-on-Gray II rim sherd, 85N99E, $70-80 \mathrm{~cm}$ bd; d) dark brown-on-buff, $83 \mathrm{~N} 100 \mathrm{E}, 20-30 \mathrm{~cm} \mathrm{bd}$; e) Rockport Black-on-Gray II rim sherd, 86N100E, 56$60 \mathrm{~cm}$ bd; f) Rockport Black-on-Gray II body sherd, $82 \mathrm{~N} 100 \mathrm{E}, 30-40 \mathrm{~cm}$ bd.

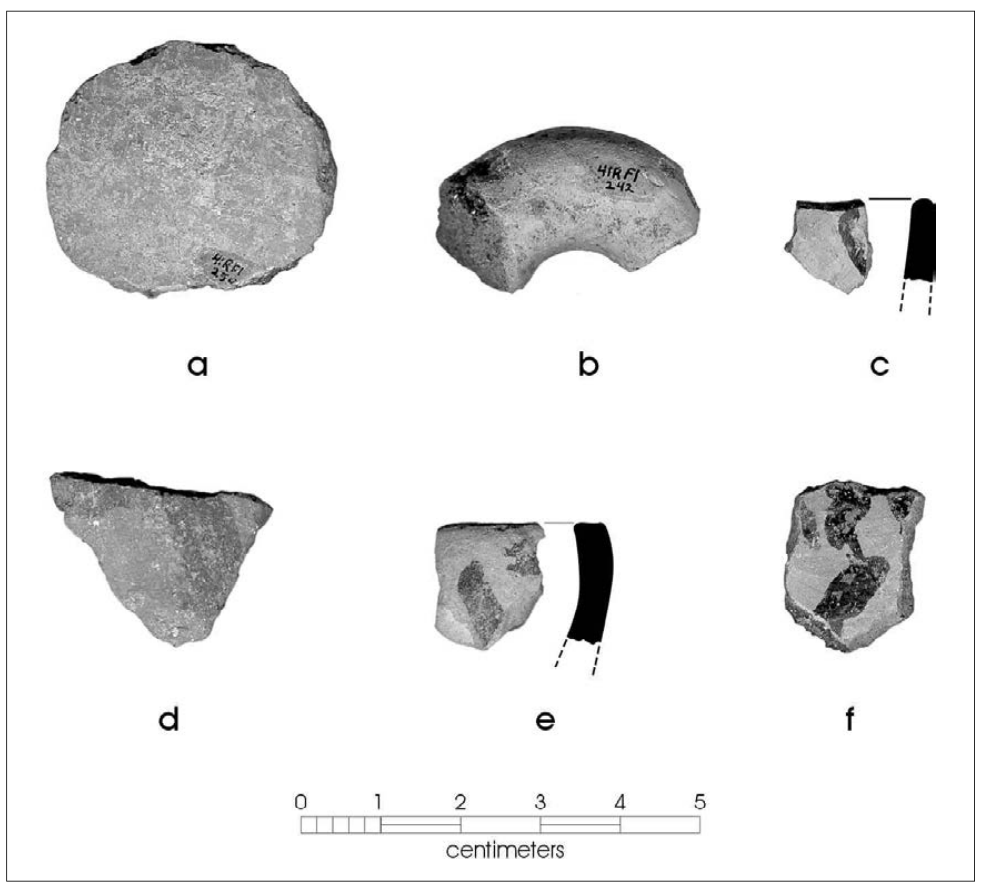


were probably made with a frayed stick or a bundle of grass (see Figure 9c-6[c]); it has a sparse bone temper and is 6.9 $\mathrm{mm}$ thick. The other has parallel (probably vertical) brushing on the body of a jar, also sparsely tempered with bone; this vessel is slightly thicker $(7.2 \mathrm{~mm})$ and was fired in a high oxygen environment.

The brushed sherds may be related to brushed and brushedpunctuated cooking jars that have been found on coastal prairie/plain and inland Toyah phase sites, such as Berclair (41GD4; Hester and Parker 1970), Mustang Branch (41HY209-T; Ricklis 1994b), Collins (41TV40; Suhm 1955), and Rowe Valley (41WM437; Elton Prewitt, 1999 personal communication). This ware has traditionally been called Boothe Brushed (Suhm 1955). Brushed bonetempered ceramics have also been reported from the Biesenbach site (41WN88) on the San Antonio River (David L. Nickels, 1999 personal communication). This habitation site has been radiocarbon dated between ca. A.D. 1450-1670 (Nickels 1999). Recent INAA and petrographic analyses of "Boothe Brushed" vessels from several Central Texas archaeological sites has strongly indicated, however, that these vessels were manufactured in Northeast Texas by the Caddo Indian peoples, and calls into question their identification as a Central Texas ceramic ware (Perttula et al. 2000).

A single bone-tempered brushed sherd has also been recovered from the Carvajal Crossing site (41KA26-B) in apparent mid-to-late eighteenth-century contexts (Perttula 2001). Mounger (1959:178) describes a small number of brushed sherds $(n=25)$ from the third location of Mission Espíritu Santo (41GD1) at Goliad, established in 1749, but these apparently are from relatively thick $(7-8 \mathrm{~mm})$ walled vessels with a sandy paste that occasionally have shell inclusions.

The sole bone-tempered (sparse bone) incised sherd, also from AU 3, has broad parallel-incised lines on the vessel rim (see Figure 9c-6[b]). The rim is direct or standing, with a rounded lip, and may be from a thin-walled $(5.9 \mathrm{~mm})$ bowl. The vessel was fired in a reducing environment but cooled in a high oxygen environment (see Appendix k).

\section{Goliad Black-on-Buff}

The 17 bone-tempered sherds with asphaltum decorations include two rim sherds and 15 body sherds from AU $1(n=5)$ and AU $3(n=12)$. The use of asphaltum decorations on vessels with a bone-tempered paste suggests these sherds are from Goliad black-on-buff vessels (cf. Mounger 1959:168). Decorations include lip lines and squiggles, bands, and lines on the vessel body (see Figure 9c-5[c-d]). At Mission Espíritu Santo at Goliad, Mounger (1959:169) noted that in addition to the bone tempering on the blackon-buff vessels:

[t]hese designs seem to be the same as those on Rockport Black-on-grey [Rockport Black-on-Gray II]. There are 38 sherds of Rockport Black-on-grey in the sample and these can readily be distinguished from Goliad Black-on-buff. The Rockport ware is much more compact, lacks large inclusions, and is a less porous pottery than the Goliad ware. The body range in Goliad ware is in shades of buff to orange, which differs from the more predominantly grey to black of the Rockport ware.

The Goliad black-on-buff sherds represented about 0.4 percent of the bone-tempered sherds at Mission Espíritu Santo at Goliad; at Refugio, they comprise 0.7 percent of the bone-tempered sherds. Decorations noted in the blackon-buff sherds at Goliad included bands on the lip, zig-zag lines, semi-circular loops, dots, and uneven dabs (Mounger 1959:Plates 20-25). One black-on-buff sherd was apparently from a bottle neck (or neckless olla?).

Ninety-four percent of the black-on-buff bone-tempered sherds at Refugio have only sparse amounts of temper added to the paste. Rims are direct, with a rounded lip, and range from 3.3-4.1 $\mathrm{mm}$ in thickness. One rim from Feature 1 has a $12 \mathrm{~cm}$ orifice diameter and a rounded base, suggesting it is from a bowl rather than a narrow-necked olla or bottle (see Figure $9 c-8[a-c])$. Body wall thickness ranges from 5.6-8.2 $\mathrm{mm}$, with a mean of $6.9 \mathrm{~mm}$. A minimum of five different black-on-buff vessels may be represented in the sherds, three fired in a reducing environment, one incompletely oxidized during firing, and the final vessel fired in an oxidizing environment. The latter two vessels are represented by sherds found only in non-feature context (AU 3). The reduced-fired vessels have sherds in both AU 1 and AU 3.

Three black-on-buff sherds appear to have asphaltumdecorated lines or blobs on the interior of the vessel. One sherd is from AU 1 (86N99E, $100-110 \mathrm{~cm} \mathrm{bd})$, and the two others are from AU $3(71 \mathrm{~N} 100 \mathrm{E}, 30-40 \mathrm{~cm}$ bd and 87N100E, 0-20 cm bd). 


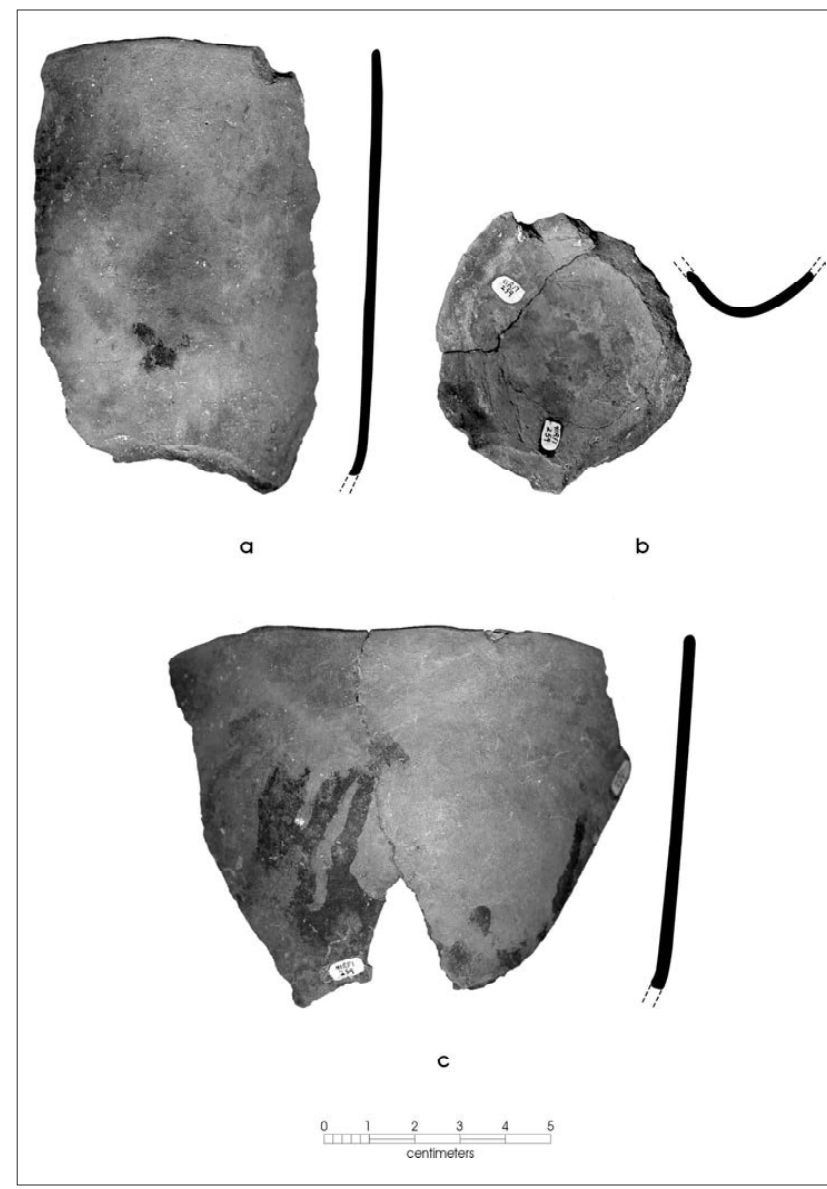

Figure 9c-8. Black-on-buff bone-tempered rim and base sherds from a single vessel section, $86 N 99 E, 100-110 \mathrm{~cm} \mathrm{bd,} \mathrm{AU} \mathrm{1:}$ a) and c) rims; b) base.

One sherd from the TxDOT excavations (Test Unit 1) has an exterior asphaltum line or band, but no temper. It has thin body walls $(5.1 \mathrm{~mm})$, and is from a vessel that was fired in an oxidizing environment. These characteristics suggest a stylistic and technological link between this sherd and a few Rockport Black-on-Gray II sherds primarily found in the non-feature context, AU 3 (see Rockport Black-onGray II, Chapter 9A).

\section{Other Bone-Tempered Ceramic Items}

Other bone-tempered ceramic sherds include two disks, seven riveted loop handles, and two ceramic "feet" or vessel supports. Similar items have been reported from previous excavations at Mission Espíritu Santo at Goliad (41GD1; see Mounger 1959; Ricklis 1998).
The disks, formed by grinding the edges of pottery sherds, are from AU 1 and AU 3. Ricklis (1998:39) suggests that disks of this type may be gaming or counting pieces. The AU 3 disk is $23 \mathrm{~mm}$ in diameter (see Figure 9c-6[f]) and $5.6 \mathrm{~mm}$ in thickness. The second one is $36 \times 32 \mathrm{~mm}$ in size, and $5.9 \mathrm{~mm}$ in thickness (see Figure 9c-7[a]). The numerous ceramic disks $(n=19)$ from bone-tempered Goliad Plain sherds at Mission Espíritu Santo at Goliad range from 24$36 \mathrm{~mm}$ in diameter (Mounger 1959:Plates 38 and 39a1, a3), while the single ceramic disk in Ricklis' (1998) investigations at Goliad was only $19 \mathrm{~mm}$ in diameter.

The rounded loop handles include five examples from AU 3 (see Figure 9c-6[d, g-i]), one from AU 1 (see Figure 9c-7[b]), and one fragment from AU 2 (Figure 9c-9[a]). Loop handles were attached to jars or ollas by riveting, where "the cylindrical end of the handle was pushed through a corresponding hole in the vessel wall and the joint smoothed over" (Ricklis 1998:39). Handles represent approximately 0.2 percent of all the Refugio sherds, which means they are about four times more common here than in a large ceramic sample from Mission Rosario (41GD2). However, the proportion of handles in the Refugio ceramic assemblage is about three times less common than at Mission Espíritu Santo at Goliad (Ricklis 1998:98). In Mounger's (1959) larger sherd sample from Goliad, handles represent 1.8 percent of the bone-tempered sherds.

The loop handles occur in a range of sizes and diameters. These probably correspond to differences in the sizes of the vessels to which they were attached. The single loop handle from AU 1 is $34 \mathrm{~mm}$ in length and $16.1 \mathrm{~mm}$ in diameter. The AU 2 loop handle is approximately $11.6 \mathrm{~mm}$ in diameter (see Figure 9c-9[a]). The five loop handles in AU 3 range from $23-28 \mathrm{~mm}$ in length, $14-25 \mathrm{~mm}$ in width, and 10-19 $\mathrm{mm}$ in diameter and are from jars.

The two bone-tempered vessel supports or "feet" have pointed or tapering ends, and were recovered in AU 2 and AU 3. Ricklis (1998:39) notes that the use of ceramic feet or supports in Goliad Plain wares has no precedence in prehistoric aboriginal ceramics in southern Texas, and he suggests its adoption by Native potters reflects a Spanish Colonial style. One support or foot is $24 \times 14$ x $12 \mathrm{~mm}$ in size (see Figure 9c-6[e]), while the other (Feature 2) is quite a bit larger at $40 \times 22 \times 19 \mathrm{~mm}$ (see Figure 9c-9[b]), suggesting it supported a larger vessel. Similar ceramic "feet" are reported from Goliad (Mounger 1959:Plate 26e; Ricklis 1998:39). 


\section{Vessel Sections}

Vessel sections comprise large numbers of sherds with a sufficient similarity in paste and temper, wall thickness, surface and core color, and surface treatment to suggest they are from the same vessel. There are eight vessel sections represented among the bone-tempered wares; four in AU 1, one vessel section in AU 2, and three in AU 3. The recognition and distribution of these vessel sections may prove informative about discard processes and the formation of the refuse deposits in and around Features 1 and 2 in the 1998 work at Mission Refugio.

Two-hundred and forty-seven sherds are included in the eight vessel sections, an average of 30.9 sherds per vessel section. No vessel section represents more than 25 percent of a particular vessel. It is apparent, however, that large parts of broken vessels were regularly discarded as trash on the east side of the mission, either they were placed into open units (i.e., AU 1 and $\mathrm{AU} 2$ ) or dumped on the ground surface (i.e., AU 3).

Vessel Section 4 in Feature 1 (AU 1) has seven body and/or base sherds from a moderately bone-tempered vessel found in $81 \mathrm{~N} 100 \mathrm{E}, 30-40 \mathrm{~cm}$ bd. Body walls are $6.1 \mathrm{~mm}$ thick, and the base is 7.9-8.4 $\mathrm{mm}$ in thickness. These may be from a jar. A fifth vessel section in AU 1 is from $82 \mathrm{~N} 100 \mathrm{E}, 20-40$ $\mathrm{cm}$ bd, and includes 66 body sherds from a sparse to moderately bone-tempered vessel. Body wall thickness ranges from 5.1-7.1 $\mathrm{mm}$, suggesting sherds from near the top to the bottom of the vessel are represented in Vessel Section 5. Vessel Section 6, from 86N100E, 120-125 cm bd, includes nine moderately bone-tempered plain body sherds with 7.4-7.7 mm thick body walls. Moderately bonetempered rim sherds from adjoining units in Feature 1 suggest that Vessel Section 6 may be from an everted rim jar fired in a reducing environment, but cooled in a high oxygen environment (cf. Teltser 1993:Figure 2F, H). The final vessel section $(85 \mathrm{~N} 100 \mathrm{E}, 80-90 \mathrm{~cm}$ bd) from AU 1 has 47 plain body to base sherds with a sparse bone temper; wall thickness ranges from 4.8-7.9 $\mathrm{mm}$. The sherds have been scraped on their exterior surfaces as part of finishing the vessel for firing and subsequent use. This vessel section also appears to be from a jar, and there are a number of everted rim sherds with a sparse bone temper from the same context (Appendix k), although none are conjoinable.

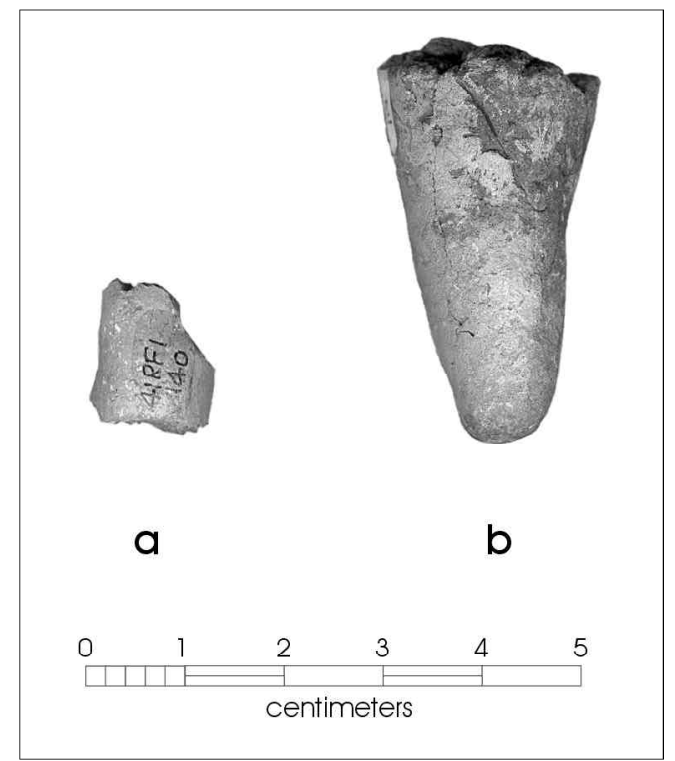

Figure 9c-9. Handle fragment and support or "foot" in Feature 2 ( $A U$ 2): a) loop handle, $76 \mathrm{~N} 100 \mathrm{E}, 45-50 \mathrm{~cm}$ bd; b) ceramic foot, $75 \mathrm{~N} 99 \mathrm{E}, 80-90 \mathrm{~cm}$ bd.

The one vessel section in Feature 2 (AU 2) includes 27 plain and moderately bone-tempered body sherds from $75 \mathrm{~N} 100 \mathrm{E}$, $60-70 \mathrm{~cm}$ bd. The body sherds are relatively thin (4.1-6.7 $\mathrm{mm}$ ), and may be associated with several rims from 50-70 $\mathrm{cm}$ bd from moderately tempered bowls (Appendix k). These rims are from vessels that have smoothed surface treatments and were fired in a reducing environment.

In AU 3, Vessel Section 1 includes 16 plain body sherds from $60 \mathrm{~N} 100 \mathrm{E}, 0-30 \mathrm{~cm}$ bd. This vessel section has a moderate amount of bone-temper in the paste, and thin (4.6 $\mathrm{mm}$ ) body walls. Several small rim sherds with similar paste were found in other non-feature units (AU 3) in the vicinity of these sherds, but they were not conjoinable (Appendix k). A second vessel section has nine plain body sherds from 73 N100E, 40-50 cm bd, just above the top of Feature 2; several riveted loop handles were found in this area (see Figures 9c-6, 9c-7, and 9c-9 and Appendix k). These sherds have a profuse bone temper and a body wall thickness ranging between 5.9-6.2 mm. Vessel Section 3 includes 66 sparsely bone-tempered body sherds in $87 \mathrm{~N} 100 \mathrm{E}, 0-20 \mathrm{~cm}$ bd. Some of the sherds may be from near the base of the vessel because they are relatively thick $(7.4 \mathrm{~mm})$, but most are $6.1 \mathrm{~mm}$ in body wall thickness. Rims from two different bowls have been recovered in this context, both fired in a reducing environment, and one has been burnished on its exterior surface (Appendix k). 


\section{Sandy Paste Wares}

There are a total of 676 sandy paste ceramic sherds in the Mission Refugio ceramic assemblage (see Table 9c-1), including 30 sandy paste rim sherds and 31 sandy pastebone-tempered rims. This represents 22 percent of the sherds larger than one $\mathrm{cm}$ in diameter in this assemblage, ranging from a low of 17.2 percent in the earlier TxDOT excavations (Clark 1998) to a high of 24.9 percent in Feature 1 (AU 1). Some 23.5 percent of the sandy paste sherds $(n=159)$ have bone temper aplastics. Almost 30 percent of the sandy paste sherds have an asphaltum coating and/or decoration on interior and/or exterior surfaces (this is about 10 times more than in the bone-tempered wares), and 15 percent $(n=24)$ of the bone-tempered sandy paste sherds have an asphaltum coating and/or decoration.

The sandy paste sherds are thinner-walled than the bonetempered wares at Mission Refugio (Table 9c-3). Modal thicknesses for the sandy paste and sandy paste-bonetempered sherds (including rim, body, and base sherds) are 4.6-5.3 $\mathrm{mm}$ and 5.3-6.1 mm, respectively, compared to 6.9$7.6 \mathrm{~mm}$ for the bone-tempered wares. Ricklis' (1998:90 and Figure 38) analyses of the Goliad and Rosario ceramics points out a similar relationship in thickness between the bone-tempered and sandy paste sherds. That is, the predominantly bone-tempered/clay paste rim sherd assemblage at Goliad is thicker (mean of $5.99 \mathrm{~mm}$ ) than the sherds from Rosario that have a naturally sandy clay with sparse bone tempering; the mean thickness of rims there is $5.47 \mathrm{~mm}$.

These sherds generally have moderate amounts of sand grains in the paste, comprising 48-60 percent of the sandy paste and sandy paste-bone-tempered sherds. The highest proportions of moderate sandy paste sherds occur in AU 1 (60 percent) and AU 3 (57 percent), while AU 2 has the lowest amount. Sherds with profuse amounts of sand in the paste are more prevalent in AU 2 (25.2 percent) compared to either AU 3 (21.8 percent), AU 1 (19.3 percent), or the TxDOT excavations (18.0 percent). Sherds with sparse amounts of sand in the paste are also more common in AU 2 (27.1 percent) than in AU 1 or AU 3 (21.3-24.1 percent). These consistent paste contrasts between the sherds from $\mathrm{AU} 1, \mathrm{AU} 3$, and TxDOT contexts and the sherds from $\mathrm{AU}$ 2 follow the contextual differences noted above for the bonetempered wares from Mission Refugio.

Sandy paste sherds with bone temper in sparse to moderate amounts comprise between 13.4 percent in the TxDOT excavations and 30.1 percent in AU 1, with 22.9 and 21.9 percent in AU 2 and AU 3, respectively. The most frequent paste and temper combination in each excavated context is a sandy paste with moderate amounts of sand and sparse amounts of bone temper. This combination represents 4857 percent of the bone-tempered sandy paste sherds. Sandy paste sherds with sparse amounts of sand and sparse bone temper are most common in AU 3 and AU 1 (24-28 percent)—compared to only 13 and 14 percent in AU 2 and TxDOT excavations, respectively. These latter two contexts have correspondingly higher amounts of sandy paste sherds with profuse amounts of sand and sparse bone tempering.

Few sandy paste sherds have direct evidence preserved on them of their use-such as residues or charred plant remains (see Skibo 1992). Four sherds (one from AU 1, one from AU 2, and two from AU 3) have charred organic residues on the interior of vessel sherds, suggesting that these vessels had been used for the cooking of foods whose residues adhered to the vessel. This represents only 0.6 percent of the sandy paste sherds.

\section{Undecorated Sandy Paste Rim Sherds}

There are 23 undecorated sandy paste rim sherds, and 24 undecorated sandy paste-bone-tempered rim sherds. Another 14 rim sherds have Rockport Black-on-Gray decorations (Table 9c-5 and Table 9c-6). The undecorated sandy paste and sandy-paste bone-tempered rim sherds are predominantly direct or standing (73-80 percent) with flat lips (see Figure 9c-3[a]). More than 90 percent of the decorated sandy paste rims are direct with flat lips. Inverted rims from bowls or small-mouthed ollas are relatively common in the sandy paste-bone-tempered rims in both AU 1 and AU 3 (Table 9c-6), as they are in the previously discussed bone-tempered rim sherds in the same contexts (Table 9c-3). Everted rim sherds comprise 15 percent $(n=3$ of 20) of the identifiable sandy paste rims. There are single examples of pointed lips in both the sandy paste and sandy paste-bone-tempered rim sherds (Tables 9c-5 and 9c-6), representing 3.3 percent of these rims. Less than 3 percent of the bone-tempered rims have pointed lips (Table $9 \mathrm{c}-4)$, and as previously mentioned, by way of comparison, two percent of the rims at Mission Rosario had pointed lips.

Only six of the 61 sandy paste and sandy paste-bonetempered rim sherds were large enough to estimate orifice diameter. Five are from jars that have diameters ranging from greater than $16 \mathrm{~cm}$ to more than $23 \mathrm{~cm}$. The other has a $3 \mathrm{~cm}$ orifice diameter, and is from a small-mouthed olla. 
Table 9c-5. Sandy past rim and lip forms

\begin{tabular}{|l|c|c|c|c|}
\hline Rim and Lip Form & AU 1 & AU 2 & AU 3 & TxDOT \\
\hline Direct-flat & $41.7 \%$ & $0.0 \%$ & $40.0 \%$ & $0.0 \%$ \\
\hline Direct-rounded & $8.3 \%$ & $50.0 \%$ & $20.0 \%$ & $0.0 \%$ \\
\hline Inverted-flat & $8.3 \%$ & $0.0 \%$ & $0.0 \%$ & $0.0 \%$ \\
\hline Everted-rounded & $16.7 \%$ & $0.0 \%$ & $6.7 \%$ & $0.0 \%$ \\
\hline UID-rounded & $8.3 \%$ & $0.0 \%$ & $0.0 \%$ & $100 \%$ \\
\hline UID-flat & $16.7 \%$ & $50.0 \%$ & $26.7 \%$ & $0.0 \%$ \\
\hline UID-pointed & $0.0 \%$ & $0.0 \%$ & $6.7 \%$ & $0.0 \%$ \\
\hline Totals & 12 & 2 & 15 & 1 \\
\hline
\end{tabular}

UID=unidentified

Table 9c-6. Sandy paste-bone-tempered rim and lip forms

\begin{tabular}{|l|c|c|c|c|}
\hline Rim and Lip Form & AU 1 & AU 2 & AU 3 & TxDOT \\
\hline Direct-flat & $28.7 \%$ & $50.0 \%$ & $42.1 \%$ & $0.0 \%$ \\
\hline Direct-rounded & $28.7 \%$ & $50.0 \%$ & $10.5 \%$ & $0.0 \%$ \\
\hline Inverted-flat & $14.3 \%$ & $0.0 \%$ & $10.5 \%$ & $0.0 \%$ \\
\hline Inverted-rounded & $28.7 \%$ & $0.0 \%$ & $0.0 \%$ & $0.0 \%$ \\
\hline Everted-flat & $0.0 \%$ & $0.0 \%$ & $0.0 \%$ & $33.3 \%$ \\
\hline UID-rounded & $0.0 \%$ & $0.0 \%$ & $21.1 \%$ & $0.0 \%$ \\
\hline UID-flat & $0.0 \%$ & $0.0 \%$ & $10.5 \%$ & $33.3 \%$ \\
\hline UID-flat/folded & $0.0 \%$ & $0.0 \%$ & $0.0 \%$ & $33.3 \%$ \\
\hline UID-pointed & $0.0 \%$ & $0.0 \%$ & $5.3 \%$ & $0.0 \%$ \\
\hline Totals & 7 & 2 & 19 & 3 \\
\hline
\end{tabular}

UID=unidentified

The sandy paste and sandy paste-bone-tempered pottery sherds are from vessels that were commonly oxidized or incompletely oxidized during firing. In fact, in AU 3, of 51 sandy paste sherds with information on firing conditions, 47.1 percent are from vessels that were either oxidized $(n=8)$ or incompletely oxidized $(\mathrm{n}=16)$ during firing. By comparison, only 14.4 percent of the bone-tempered sherds are from vessels that were oxidized or incompletely oxidized during firing. The frequency of oxidized/incompletely oxidized sandy paste sherds increased in AU 3 from 26.9 percent in AU 1; none of five sandy paste sherds in AU 2 were from oxidized or incompletely oxidized vessels. Clearly, there are differences in the choice of firing conditions for vessel paste types discarded in AU 1 and
AU 3. In both AU 1 and AU 3, sandy paste sherds are 3-13 times more likely to be from oxidized or incompletely oxidized vessels than are the bone-tempered sherds from the same contexts.

Another difference between the bone-tempered sherds and the sandy paste sherds is in the infrequency of interior/ exterior surface treatments in the latter. Only 13.6 percent of the sandy paste-bone-tempered sherds and 21.5 percent of the sandy paste sherds have some form of surface treatment, compared to 50.5 percent in the bone-tempered sherds. Of course, many of these sandy paste sherds (15-30 percent) have an asphaltum coating. Ricklis (1996:30) suggests that the asphaltum coating may have functioned to seal vessels that would have held water; he also notes that Rockport Black-on-Gray II vessels (usually small-mouthed ollas) were usually coated on the interior with asphaltum.

Among the sandy paste rim and decorated sherds, 11.9 percent are burnished on exterior surfaces, 4.8 percent are smoothed on interior or exterior surfaces, 2.4 percent have interior scraping, and 2.4 percent have been wiped. The sandy paste-bone-tempered sherds-from wide-mouthed jars and bowls - are only wiped (9.1 percent) and burnished (4.5 percent), usually on the exterior vessel surface. Ricklis (1996:32) argues that the tempered sandy paste wares:

"were used in cooking, with the added tempers acting to mitigate the effects of thermal shock from repeated heating and thus prolong vessel use-life."

\section{Decorated Sandy Paste Rim and Body Sherds}

Thirty-six rim and body sherds- 5.4 percent of the sandy paste sherds at Mission Refugio-are decorated. One has parallel incised lines, and the other 35 have asphaltum lines, bands, and squiggles from Rockport Black-on-Gray I and Rockport Black-on-Gray II vessels (Ricklis 1996:Figure 7, 1998:Figure 31f-n, 1999a:Figure 25). More than 97 percent of the decorated sandy paste sherds are from AU 1, AU 3, and the TxDOT excavations.

\section{Rockport Black-on-Gray I}

There are eight Rockport Black-on-Gray I rim sherds at Refugio, all from non-feature context (AU 3), and are apparently associated with later use of the mission. These rims are from a minimum of three vessels, "wide-mouthed bowls or jars with simple bands of asphaltum painted onto 
the lips" (Ricklis 1996:30). Seven of the rims are direct with flat lips (see Figure 9c-5[a]), while the other has an inverted rim with a flat lip (see Figure 9c-5[f]); orifice diameters are greater than $16-23 \mathrm{~cm}$. Two of the possible vessels have been fired in a reducing environment, while the other was incompletely oxidized during firing. Rim thickness ranges from 4.1-6.9 mm, with a mean of $5.6 \mathrm{~mm}$.

\section{Rockport Black-on-Gray II}

Twenty-seven sherds have a Rockport Black-on-Gray II decoration, but are represented mainly by vertical lines, bands, or squiggles of asphaltum on the exterior of vessels. Ricklis (1996:30) suggests that most of the Rockport Blackon-Gray II vessels are small-mouthed ollas. About 64 percent of the Rockport Black-on-Gray II sherds have a sandy paste, and the remainder have a sandy paste with small amounts of bone temper.

The Rockport Black-on-Gray II sherds with only a sandy paste are almost exclusively from AU $1(n=7)$ and AU 3 $(\mathrm{n}=8)$, except for two sherds from Test Unit 2 in the TxDOT excavations, and are primarily distributed in and above Feature 1 . The sherds include five rims and 12 body sherds (see Figure 9c-5[e] for example). The rims include four with direct or standing walls and a flat lip-three from AU 1 probably from the same vessel (see Figure 9c-7[c])—and a fifth from $86 \mathrm{~N} 100 \mathrm{E}, 55-60 \mathrm{~cm}$ bd, with an inverted rim and a flat lip (see Figure 9c-7[e]). This is from a small-mouthed olla with a constricted neck.

About 35 percent of these Rockport Black-on-Gray II sherds, including one rim sherd from $85 \mathrm{~N} 100 \mathrm{E}, 10-20 \mathrm{~cm}$ bd (Figure $9 c-5[b]$ ), are from vessels that have been fired in an oxidizing environment or were incompletely oxidized during firing; this may include a minimum of three different vessels. They have vessel walls that are $6.7 \mathrm{~mm}$ at the rim, and thin body walls $(3.8-7.7 \mathrm{~mm}$, with a mean of $5.6 \mathrm{~mm}$ ). Five of the six sherds are from AU 3, suggesting they were discarded late in the occupation of Mission Refugio. The others from Refugio are from vessels fired in a reducing environment. These are from both AU 1 and AU 3 (see Figure 9c-7[f]), probably representing a minimum of three more vessels. As a group, the reduced vessels are slightly thinner, ranging from 3.6-6.5 $\mathrm{mm}$ along the body and rim, and with a mean of $4.6 \mathrm{~mm}$.

Ten Rockport Black-on-Gray II sherds have a sandy paste (sparse to moderate amounts of sand in the paste) and sparse to moderate amounts of bone temper. This includes one direct or standing rim from AU 2 (75N99E, 80-90 cm bd) from a jar with a rounded lip. The ten sherds are from all four excavated contexts (i.e., $\mathrm{AU} 1, \mathrm{AU} 2, \mathrm{AU} 3$, and TxDOT), but appear to concentrate in the vicinity of Feature 1, and are most common in AU 1 and AU 3.

Decorations include vertical lines and blobs on, or near, the lip (Figure 9c-10), that were made with asphaltum. Where it could be determined, the sherds are from vessels that were primarily fired in a reducing environment (7 of 9 or 78 percent), and the other two (both from Feature 1) were incompletely oxidized during firing. The one rim sherd ranges from $6.9-7.9 \mathrm{~mm}$ in thickness, while the body sherds range from 3.8-6.7 $\mathrm{mm}$. The ten sherds may represent broken pieces from at least five different vessels, based on variation in firing conditions, paste and temper characteristics, and body wall thickness.

The parallel incised sandy paste body sherd from AU 3 is likely from a Rockport Incised jar or deep bowl (see Ricklis 1995b:Figure 17, 1996:Figure 6). It has a sparse sandy paste with sparse amounts of bone temper, a wall thickness of $5.6 \mathrm{~mm}$, and the vessel was fired in a reducing environment, but cooled in a high oxygen environment.

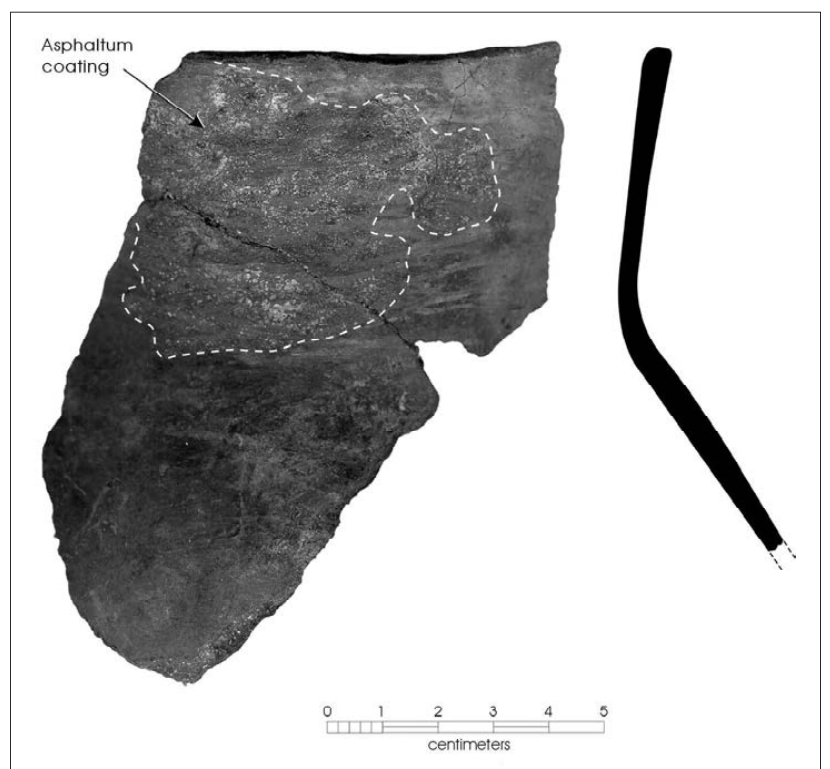

Figure 9c-10. Asphaltum-decorated rim sherd from $A U 2$, 75N99E, 80-90 cm bd. 


\section{Vessel Sections}

Two different plain sandy paste vessel sections are represented by 22 body sherds found together in AU 3, $87 \mathrm{~N} 100 \mathrm{E}, 20-30 \mathrm{~cm}$ bd. Both have an interior asphaltum coating, but one has thin body walls $(4.6-6.2 \mathrm{~mm})$, and the other has relatively thick $(8.9 \mathrm{~mm})$ body walls.

\section{Results of the Instrumental Neutron Activation Analysis}

Native American ceramic sherds were selected for instrumental neutron activation analysis (INAA) based on visually recognizable differences across the assemblage in paste and temper characteristics in AU 1, AU 2, and AU 3 (Appendix L). The principal concern was to determine if the bone-tempered and sandy paste wares had similar or different chemical profiles, which in comparison with INAA on local clay raw materials would suggest whether the wares had been made locally or non-locally. Consequently, in selecting the number of sherd samples for INAA, it was important to submit a reasonable number of bone-tempered and sandy paste sherds from the different archaeological contexts to insure reliable statistical comparisons of chemical variability in the pastes.

Neff and Glascock (Appendix H) defined a local Mission Refugio chemical reference group that is comprised principally of plain bone-tempered ceramic wares from Feature 1 (AU 1), Feature 2 (AU 2), and archaeological deposits above or outside the two unit features (AU 3). More than 77 percent of the Mission Refugio INAA sherds (Neff and Glascock, Appendix H, Table $\mathrm{H}-1$ ) are assigned to this reference group. The chemical similarity between the Mission Refugio bone-tempered wares and a clay sample obtained from Feature 2 at the Mission Refugio site indicates that these ceramics were likely manufactured from clay sources on and/or near the mission.

Five sandy paste sherds (6.1 percent), three of which have interior and/or asphaltum coatings (Appendix L), are also assigned to the Mission Refugio chemical reference group, again indicating a local source of manufacture of these ceramics. The use of asphaltum indicates that the potters at Mission Refugio had access to this coastal resource.

The remainders of the Native American ceramics from Mission Refugio subjected to INAA are currently unassigned to a chemical composition group. This comprises
22.6 percent of the INAA sample (see Neff and Glascock, Appendix н, Table $\mathrm{H}-1$ ). Given the similarities in chemical composition between the unassigned group and the Refugio chemical reference group, Neff and Glascock concluded that these ceramics were probably not from non-local production locales, but rather represented vessels manufactured from a different local source.

The chemically unassigned sherds from Mission Refugio are particularly common in non-feature archaeological contexts (AU 3) above Feature 1 and Feature 2 (31 percent of the 39 sherds subjected to INAA are from above these features), and these represent the latest archaeological deposits in the CAR-UTSA excavations. In contrast, only 14 to 21 percent, respectively, of the INAA sherds from Feature 2 and Feature 1, belong to the unassigned group. This suggests that there was a significant change in the use of raw material source zones near the end of the Mission Refugio occupation (this is also apparent in the petrographic study of the Native American ceramics, see the following section and Hill, Appendix G). It is also interesting that 33 percent of the chemically unassigned sherds have a sandy paste, compared to only 6 percent of the Mission Refugio chemical reference group. This suggests that at least some of the raw material clay sources being used for ceramic manufacture occurred in coastal or near-coastal settings where sandy paste ceramics were made by Karankawan groups (see Ricklis 1996). Conversely, some of the chemically unassigned ceramic sherds from Mission Refugio may have been made by Karankawan groups and brought to the mission.

\section{Results of the Petrographic Analysis of Mission Refugio Native American Ceramics}

Hill's petrographic analyses of the Mission Refugio Native American ceramics (Appendix G) defined five paste groups (Groups 0, 1, 2, 2A, and 2B). Except for Group $0(\mathrm{n}=1)$, all the other sherds in the sample $(\mathrm{n}=106)$ contain deliberately added bone temper in amounts comprising up to 20 percent of the paste. Group 0 has a sandy paste and no bone temper. The only Group 0 sherd in the petrographic sample is from AU 3.

Group 1 paste sherds-a silt-sized to sandy paste with potassium feldspar grains and less than 10 percent bone temper grains-are the most common type in this assemblage, accounting for between 43-75 percent of the 
analytical unit samples. This is likely the primary paste that characterizes the locally manufactured Native American ceramics at Refugio. Groups 2, 2A, and 2B have limited amounts of sand in the paste, and more abundant bone temper grains, between 10-20 percent of the paste. These Group 2 sherds represent 15 to 50 percent of the petrographic sample, and are most abundant in AU 2 (50 percent).

Proportionally, the AU 3 ceramics subjected to petrographic analysis are different than the AU 1 or AU 2 ceramics, since Group 1 wares are much more abundant in the former component, the single Group 0 sherd is in AU 3, and Group 2 sherds are not common (15 percent). By contrast, AU 1 and AU 2 ceramics are very similar in paste characteristics: Group 1 sherds in AU 1 and AU 2 account for 43-50 percent of the sample, and Group 2 sherds account for $41-50$ percent of the sample. These differences between analytical units suggest that there was a significant change in the use of clay raw material source zones (and in choices concerning the amount of temper to add to the paste) near the end of the Mission Refugio occupation.

Further supporting evidence for changes in the use of clay raw material source zones, and in the character of the Native American ceramics, is apparent in the trace minerals identified in the petrographic analysis. As previously noted, the primary paste in AU 1, AU 2, and AU 3 sherds at Mission Refugio has potassium feldspar grains; between 41-52 percent of the analyzed sample from the three analytical units have this naturally occurring mineral.

Other minerals, however, such as calcium carbonate, plagioclase, microline, feldspar, polycrystalline quartz, and chert are less frequently occurring natural constituents in the clay paste. However, when such minerals are present in the Mission Refugio petrographic samples, they are much more abundant in the AU 3 sherds than in either the AU 1 or AU 2 sherds, with one exception (i.e., microline, see below). For example, calcium carbonate grains are present in 13.5 percent of the AU 3 sherds (and each are bone-tempered), but they are absent in the other two analytical units; this is also the case for feldspar and polycrystalline quartz. They each represent 2.7 percent of the sherd sample from AU 3, and they are from profusely bone-tempered wares. Chert grains are constituents in 8.1 percent of the AU 3 sherds and 7.3 percent of the $\mathrm{AU} 1$ sherds, but are absent in the $\mathrm{AU}$ 2 sample. The great majority of these sherds have a sandy paste with an asphaltum coating, and are probably Rockport wares manufactured at some locale other than Mission Refugio. Plagioclase grains are present in 4.9-16.2 percent of the sherds in $\mathrm{AU} 1, \mathrm{AU} 2$, and $\mathrm{AU} 3$, but are most abundant in the AU 3 sample. Microline is also a naturally occurring constituent in the AU 1, AU 2, and AU 3 sherds, with 19.5 percent of the AU 1 sherds having this mineral in the paste, compared to 16.2 percent in AU 3, and 7.4 percent in AU 2. Between 30-50 percent of the sherds in Features 1 and 2 with plagioclase and microline grains have a sandy paste with an asphaltum coating, again suggesting a Rockport ceramic provenience, but in the AU 3 sample, none of the sherds with these minerals have an asphaltum coating. Perhaps the same clay sources continued to be used during that occupation, but access to asphaltum sources may have been much diminished.

\section{Comparisons between the AU 1, AU 2, AU 3, and TxDOT Ceramics}

In most attribute comparisons, the sherds from Feature 1 (AU 1), non-feature units (AU 3), and the TxDOT excavations at Mission Refugio are quite similar to each other, while the Feature 2 (AU 2) sherds stand alone as different. Although Mission Refugio was only occupied for a maximum of 30 years (1795-1824), there are substantial changes in the character of the Native ceramics being made and used there by the neophytes and missionaries.

Table 9c-7 summarizes key differences discussed above by excavated context at Mission Refugio in the three paste/ temper ceramic groups, and the remainder of this section will review these differences in paste, temper, sherd decoration, rim and lip form, and oxidation conditions. It is known that the AU 3 ceramics represent the latest sherd assemblage since they overlie the two features. Furthermore, the similarities between the AU 3 and TxDOT sherds suggest that many of the sherds from the test excavations also relate to the latest use of this part of Mission Refugio. These two assemblages share inverted rims, direct rims with rounded lips, pointed lips, and red-on-buff decorations, indicating the manufacture and use of certain vessel forms (i.e., inverted rim bowls, small-mouthed or neckless ollas, and painted bowls) that are not well represented in earlier Feature 1 (AU 1) and Feature 2 (AU 2) contexts. Some of these ceramics were also made with a different suite of pastes, containing different mineral grains and rare earth minerals, than had been found in AU 1 and AU 2 contexts (Table 9c7). In general, $A U 3$ bone-tempered ceramics are distinctive because of their sparse bone tempering, different rim and lip forms, and types of decorations previously identified in 1749-1830 contexts at Mission Espíritu Santo at Goliad (cf. Mounger 1959). 
Table 9c-7. Differences in ceramic attributes by paste/temper groups and excavated contexts

\begin{tabular}{|c|c|c|c|c|}
\hline Attributes & $\begin{array}{c}\text { Feature } 1 \\
(\text { AU 1) }\end{array}$ & $\begin{array}{l}\text { Non-feature } \\
\quad(A U \text { ) }\end{array}$ & TxDOT & $\begin{array}{c}\text { Feature } 2 \\
\text { (AU 2) }\end{array}$ \\
\hline \multicolumn{5}{|c|}{ Bone-tempered Sherds } \\
\hline Sparse bone tempering & & $\mathrm{X}^{*}$ & & \\
\hline Group 1 petrographic group & & $\mathrm{X}$ & & \\
\hline Highest $\%$ of trace minerals & & $\mathrm{X}$ & & \\
\hline Inverted rim & & $\mathrm{X}$ & $\mathrm{x}$ & \\
\hline Direct rim, rounded lip & & $\mathrm{X}$ & $\mathrm{X}$ & \\
\hline Pointed lip & & $\mathrm{X}$ & $\mathrm{X}$ & \\
\hline Reduced firing, cooled in a high oxygen environment & $\mathrm{X}$ & $\mathrm{X}$ & & \\
\hline Red-on-buff decorations & & $\mathrm{X}$ & $\mathrm{X}$ & \\
\hline Brown/dark brown-on-buff decorations & $\mathrm{X}$ & $\mathrm{X}$ & & \\
\hline Red-black-on-buff decorations & & & $\mathrm{x}$ & \\
\hline Brushed decorations & & $\mathrm{X}$ & & \\
\hline Asphaltum decorations & $\mathrm{X}$ & $\mathrm{X}$ & & \\
\hline Disks & $\mathrm{X}$ & $\mathrm{X}$ & & \\
\hline Feet or supports & $\mathrm{X}$ & $\mathrm{X}$ & & \\
\hline Loop handles & $\mathrm{X}$ & $\mathrm{X}$ & & $\mathrm{X}$ \\
\hline Refugio chemical group & $\mathrm{X}$ & $\mathrm{X}$ & & $\mathrm{X}$ \\
\hline Unassigned chemical group & $\mathrm{X}$ & $\mathrm{X}$ & & $\mathrm{X}$ \\
\hline Group 2 petrographic group & $\mathrm{X}$ & & & $\mathrm{X}$ \\
\hline Everted rim & $\mathrm{X}$ & & & $\mathrm{X}$ \\
\hline Reducing firing & & & & $\mathrm{X}$ \\
\hline Moderate bone tempering & & & & $\mathrm{x}$ \\
\hline Profuse bone tempering & & & & $\mathrm{X}$ \\
\hline
\end{tabular}


Table 9c-7. Continued...

\begin{tabular}{|c|c|c|c|c|}
\hline Attributes & $\begin{array}{l}\text { Feature } 1 \\
\text { (AU 1) }\end{array}$ & $\begin{array}{l}\text { Non-feature } \\
\text { (AU 3) }\end{array}$ & TxDOT & $\begin{array}{l}\text { Feature } 2 \\
\text { (AU 2) }\end{array}$ \\
\hline \multicolumn{5}{|c|}{ Sandy Paste Sherds } \\
\hline Moderate sandy paste & $\mathrm{X}$ & $\mathrm{X}$ & & \\
\hline Pointed lip & & $X$ & & \\
\hline Inverted rim & $\mathrm{X}$ & & & \\
\hline Everted rim & $\mathrm{X}$ & & & \\
\hline Direct rim & & $\mathrm{X}$ & & \\
\hline Oxidized/incompletely oxidized firing & $\mathrm{X}$ & $X$ & & \\
\hline Refugio chemical group & $\mathrm{X}$ & $\mathrm{X}$ & & \\
\hline Unassigned chemical group & & $\mathrm{X}$ & & \\
\hline Highest $\%$ of unassigned chemical group & & $\mathrm{X}$ & & \\
\hline Highest $\%$ of trace minerals & & $\mathrm{X}$ & & \\
\hline Rockport Black on Gray I & $\mathrm{X}$ & & & \\
\hline Rockport Black on Gray II & $\mathrm{X}$ & & $\mathrm{X}$ & $\mathrm{X}$ \\
\hline Sandy paste, profuse & & & & $\mathrm{X}$ \\
\hline Sandy paste, sparse & & & & $\mathrm{X}$ \\
\hline $\begin{array}{l}\% \text { of sandy paste sherds with asphaltum } \\
\text { coating/decoration }\end{array}$ & & & & $\mathrm{X}$ \\
\hline \multicolumn{5}{|c|}{ Sandy Paste-bone-tempered Sherds } \\
\hline $\begin{array}{l}\% \text { of sandy paste-bone tempered sherds with asphaltum } \\
\text { coating/decoration }\end{array}$ & & & & $\mathrm{X}$ \\
\hline Sandy paste sherds with sparses to moderate bone temper & $\mathrm{X}$ & & & \\
\hline Sparse sandy paste-sparse bone temper & $\mathrm{X}$ & $\mathrm{X}$ & & \\
\hline Inverted rim & $\mathrm{X}$ & $\mathrm{X}$ & & \\
\hline Pointed rim & & $\mathrm{X}$ & & \\
\hline Rockport Black on Gray II & $\mathrm{X}$ & & & $\mathrm{X}$ \\
\hline Incised & & $\mathrm{X}$ & & \\
\hline
\end{tabular}

$* \mathrm{X}=$ most abundant 
Of the 22 attributes under consideration for the bonetempered sherds, the AU 3 and AU 1 contexts share eight where these attributes are predominant, namely reduced firing and cooling in a high oxygen environment; brown and dark brown-on-buff decorated sherds; asphaltum decorated sherds; ceramic disks, vessel supports, and loop handles. The INAA data also indicate that many of the sherds in these contexts were made from several clay sources, but with one source dominant (i.e., the Refugio chemical group). Even the unassigned chemical group-probably representing another, but currently unknown, clay sourceis best represented among the AU 1 and AU 3 sherds (Table 9c-7).

The AU 1, AU 2, and AU 3 sherds share loop handles, a Refugio chemical group source for many specimens, as well as sherds from the unassigned chemical group (Table 9c-7). The Group 2 petrographic group-marked by higher amounts of bone temper - characterizes both AU 1 and AU 2 sherds, and more vessels at that time had everted rims than was the case later in time. The significant use of the same source locales for the clay used in the manufacture of the bone-tempered vessels at Mission Refugio obviously points to the common or baseline heritage of the bone-tempered ceramics in these excavated contexts. Nevertheless, this was a technological heritage that apparently changed through time in different ways of firing vessels, different shapes of vessels, and different ways of decorating bone-tempered ceramics at the site.

The most distinctive ceramic attributes for the AU 2 bonetempered sherds are reduced firing, and moderate to profuse amounts of bone tempering in the paste (Table 9c-7). As Table $9 \mathrm{c}-8$ indicates, more than 64 percent of the AU 2 sherds have moderate to profuse amounts of bone in the paste, compared to only 43 percent in AU 3.

The sandy paste sherds can also be differentiated contextually between the relatively homogenous AU 1AU 3 and TxDOT assemblages, and AU 2. The former assemblages are dominated by moderate sandy paste sherds with a variety of rim forms, proportionally more sherds from vessels that have been oxidized or incompletely oxidized during firing, and sandy paste vessels with asphaltum decorations (Table 9c-9). These vessels include Rockport Black-on-Gray I and Rockport Black-on-Gray II types. They also commonly have been made from both local and presumably non-local clay sources, including sources with a variety of trace minerals not apparent in the paste of the AU 2 sherds. The AU 2 sandy paste sherds have both sparse and profuse amounts of sand grains in the paste, and the highest proportions of sandy paste sherds with asphaltum

Table 9c-8. Paste and temper proportions

\begin{tabular}{|l|c|c|c|c|}
\hline Paste and Temper Groups & $\begin{array}{c}\text { Feature1 } \\
\text { (AU 1) }\end{array}$ & $\begin{array}{c}\text { Non-feature } \\
\text { (AU 3) }\end{array}$ & TxDOT & $\begin{array}{c}\text { Feature 2 } \\
\text { (AU 2) }\end{array}$ \\
\hline Bone, sparse & $31.5^{*}$ & $34.0^{*}$ & $29.0^{*}$ & $14.4^{*}$ \\
\hline Bone, moderate & 38.2 & 39.3 & 47.5 & 55.5 \\
\hline Bone, profuse & 5.1 & 4.1 & 6.4 & 8.8 \\
\hline None & 0.3 & 0.2 & 0.0 & 0.0 \\
\hline Sandy paste, sparse sand & 3.2 & 3.5 & 4.4 & 5.1 \\
\hline Sandy paste, moderate sand & 10.6 & 9.7 & 8.1 & 7.4 \\
\hline Sandy paste, profuse sand & 3.6 & 4.3 & 2.4 & 4.0 \\
\hline Sandy paste, sparse sand, sparse bone & 2.1 & 1.2 & 0.3 & 0.7 \\
\hline Sandy paste, moderate sand, sparse bone & 0.0 & 0.1 & 0.0 & 0.0 \\
\hline Sandy paste, sparse sand, moderate bone & 3.6 & 2.6 & 1.3 & 2.8 \\
\hline Sandy paste, moderate sand, moderate bone & 0.6 & 0.4 & 0.0 & 0.0 \\
\hline Sandy paste, sparse sand, profuse bone & 1.2 & 0.6 & 0.7 & 1.4 \\
\hline Totals & 686 & 1617 & 297 & 430 \\
\hline
\end{tabular}

* percentage 
Table 9c-9. Decorated sherds

\begin{tabular}{|l|c|c|c|c|}
\hline Decoration/paste & $\begin{array}{c}\text { Feature 1 } \\
\text { (AU 1) }\end{array}$ & $\begin{array}{c}\text { Feature 2 } \\
\text { (AU 2) }\end{array}$ & $\begin{array}{c}\text { Non-feature } \\
\text { (AU 3) }\end{array}$ & TxDOT \\
\hline Incised-sandy paste & - & - & 1 & - \\
\hline Rockport Black-on-Gray II, sandy paste & 7 & - & 8 & 2 \\
\hline Rockport Black-on-Gray I, sandy paste/bone & - & - & 8 & - \\
\hline Rockport Black-on-Gray II, sandy paste/bone & 4 & 1 & 3 & 2 \\
\hline Brown painted, sandy paste/bone & - & - & 3 & - \\
\hline Goliad red-on-buff, bone & - & - & 8 & 1 \\
\hline Goliad black-on-buff, bone & 5 & - & 12 & - \\
\hline Brown painted, bone & 2 & - & - & - \\
\hline Red-on-black painted, bone & - & - & - & 1 \\
\hline Brushed, bone & - & - & 2 & - \\
\hline Incised, bone & - & - & 1 & - \\
\hline Black asphaltum, none & - & - & - & 1 \\
\hline Plain:Decorated Sherd Ratio & & $-11: 1$ & 46 & 7 \\
\hline
\end{tabular}

Table 9c-10. Rim and lip forms

\begin{tabular}{|c|c|c|c|}
\hline Rim and Lip Forms & $\begin{array}{c}\text { Feature } 1 \\
\text { (AU 1) }\end{array}$ & $\begin{array}{c}\text { Feature 2 } \\
\text { (AU 2) }\end{array}$ & $\begin{array}{l}\text { Non-feature } \\
\text { (AU 3) }\end{array}$ \\
\hline \multicolumn{4}{|l|}{ Rims } \\
\hline Direct & $53.1 \%$ & $50.0 \%$ & $71.9 \%$ \\
\hline Inverted & $16.3 \%$ & $7.1 \%$ & $17.2 \%$ \\
\hline Everted & $30.6 \%$ & $42.9 \%$ & $10.9 \%$ \\
\hline \multicolumn{4}{|l|}{ Lips } \\
\hline Rounded & $66.1 \%$ & $61.9 \%$ & $57.4 \%$ \\
\hline Rounded-beveled & $1.6 \%$ & $0.0 \%$ & $0.9 \%$ \\
\hline Rounded-thickened & $0.0 \%$ & $0.0 \%$ & $0.9 \%$ \\
\hline Flat & $29.0 \%$ & $33.3 \%$ & $36.1 \%$ \\
\hline Flat-beveled & $1.6 \%$ & $4.8 \%$ & $0.0 \%$ \\
\hline Flat-folded & $1.6 \%$ & $0.0 \%$ & $0.0 \%$ \\
\hline Expanding & $0.0 \%$ & $0.0 \%$ & $0.9 \%$ \\
\hline Pointed & $0.0 \%$ & $0.0 \%$ & $3.7 \%$ \\
\hline
\end{tabular}

Note: Sample of identifiable rims, $n=127$;

sample of sherds with identifiable lip forms, $n=191$ coating (see Table 9c-7). None of the sandy paste sherds in AU 2 have been decorated, however (Table 9c-9). The AU 2 assemblage also has a very low ratio of plain to decorated sherds, while comparable plain to decorated sherd ratios for both bone-tempered and sandy paste sherds are present in the AU 1, AU 3, and TxDOT assemblages (Table 9c-9).

The sandy paste-bone-tempered sherds in AU 1 and AU 3 are distinctive because of the higher amounts of inverted rim and pointed rims (Table 9c-10). The bone-tempered pointed rims, although few in number, are restricted to AU 3 (see Table 9c-7). Likewise, inverted rims with bone tempering or with a sandy paste are more abundant in AU 1 and AU 3, as well as in the TxDOT excavations in the case of the bone-tempered rim sherds (see Table 9c-7 and Table 9c-10). The single incised sandy paste sherd is in AU 3 (Table 9c-9).

In terms of the firing of vessels at Mission Refugio, the AU 3 sherds can be clearly differentiated from the AU 1 and AU 2 sherd assemblages because of the much higher 
proportions of oxidized and incompletely oxidized vessels compared to the other excavated contexts (Table 9c-11). As discussed previously, this is primarily the result of changes in the way the sandy paste sherds were fired, as more sandy paste vessels were oxidized or incompletely oxidized during firing than had previously been the case at the site. These vessels may have been fired longer than had been the case previously at the mission. With respect to the bone-tempered sherds, vessels were commonly reduced (i.e., fired in a low oxygen environment) in AU 2. In AU 1 and AU 3, there are comparable amounts of sherds from vessels that were cooled in the open air after they had been fired in a reducing environment (Table 9c-7). The diversity in firing conditions at Mission Refugio supports the idea that there were changes through time in how Native American ceramic vessels were fired. The heterogeneity in firing, however, clearly suggests that vessels were not fired in a controlled environment (such as a kiln), but were fired outside, probably using similar fuels.

The results of the various attribute comparisons between the four excavated contexts at Mission Refugio clearly indicate that the bone-tempered and the sandy paste vessel sherds (including the sandy paste sherds with bone tempering) represent two distinctly different ceramic wares, most of which are plain vessels. The wares have different pastes and temper combinations and different vessel forms (as indicated by variations in the kinds of rims, vessel wall thicknesses, orifice diameters, surface treatment, and methods of firing the vessels). Significantly, however, many of the sherds from both wares were made with the same clay source(s), presumably at the mission or in near proximity, as indicated by the instrumental neutron activation analysis. The unassigned chemical group samples are more likely to pertain to sandy paste samples from AU 3, however, hinting that they may have been manufactured from nonlocal clay sources (i.e., probably coastal clay sources). Also, the two wares share a common decorative technique: the painting of asphalt lines, bands, and squiggles. The bonetempered pottery from Mission Refugio has red-on-buff, brown-on-buff, and dark brown-on-buff sherds only in AU 1 and AU 3.

The attribute analysis not only supports these basic differences in ceramic wares at Mission Refugio, but also indicates that there were recognizable changes in the character of the two wares during the course of the aboriginal occupation there. In the next section, the temporal, functional, and cultural affiliation of the Mission Refugio ceramics based on the analyses discussed above, and a comparison of the composition of the Native American ceramics from contemporaneous Spanish Colonial mission and presidio sites in southern Texas will be considered.

\section{Temporal, Functional, and Cultural Affiliations of the Mission Refugio Native American Ceramics}

The Mission Refugio Native American ceramics were made in the late-eighteenth and early-nineteenth centuries, probably by neophytes that lived in the mission compound. The resident Native American population at Refugio appears to have been Karankawan groups that had lived along the central Texas coast for at least several hundred years before contact with Spanish colonists (McDonald, Chapter 3; Ricklis 1996). The ready-made assumption is that the Native American ceramics found at Mission Refugio had been manufactured by these Karankawan groups, and that the ceramics would have close technological, functional, and stylistic similarities to traditional Rockport ceramic wares. These wares have been thoroughly and well-described by Ricklis (1995b, 1996, 1998, 1999a) from prehistoric, protohistoric, and Mission era contexts.

Table 9c-11. Oxidation conditions, rim and decorated sherds

\begin{tabular}{|l|c|c|c|}
\hline Oxidation Condition & $\begin{array}{c}\text { Feature 1 } \\
\text { (AU 1) }\end{array}$ & $\begin{array}{c}\text { Feature 2 } \\
\text { (AU 2) }\end{array}$ & $\begin{array}{c}\text { Non-feature } \\
\text { (AU 3) }\end{array}$ \\
\hline Oxidized & $1.3 \%$ & $4.3 \%$ & $8.8 \%$ \\
\hline Incompletely Oxidized & $9.2 \%$ & $4.3 \%$ & $16.9 \%$ \\
\hline Reduced & $21.1 \%$ & $30.4 \%$ & $16.2 \%$ \\
\hline Reduced-cooled in High Oxygen Environment & $68.4 \%$ & $60.9 \%$ & $58.1 \%$ \\
\hline Total Sherds & 76 & 23 & 148 \\
\hline
\end{tabular}


Another possibility was that some of the Mission Refugio ceramics were either made by Native Americans living elsewhere in the Spanish mission system, or that nonKarankawan Native American potters lived at Refugio. It is known that Native Americans at the Mission Espíritu Santo de Zuñiga at Goliad, including the Aranama (see Mounger 1959:179-180) and the Tamique (see Walter 1997), made pottery for trade. Were ceramics produced at Mission Espíritu Santo being shipped for trade to Mission Refugio? According to Cardenas (1783, quoted in Ricklis 1999b):

\section{[the Indian women at Espiritu Santo] are the ones} most dedicated to work, always busy making ollas, bowls, and other things of clay, for which they have great skill and with which they trade with the Spaniards of the Presidio of La Bahia.

To summarily explore the temporal, functional, and cultural affiliations of the Native American ceramics from Mission Refugio, the character of Native American ceramic assemblages from selected Spanish Colonial sites in southern Texas will be discussed (Figure 9c-11). Of particular significance are the abundant Native American ceramics from the various locations of Mission Espíritu Santo (see Mounger 1959; Ricklis 1998, 1999a; Ricklis et al. 2000; Walter 1997, 1999) and Mission Rosario (Gilmore 1974; Ricklis 1998, 1999a; Ricklis et al. 2000). Technological and stylistic analyses of these assemblages have recently been completed and can be readily compared to the Mission Refugio Native American ceramics. The Native American ceramics from the first location of Presidio Loreto (41VT4) will also be mentioned (see Gilmore 1973), even though detailed comparisons are not possible because of the cursory presentation of technological information from Presidio Loreto.

Relevant information is also available on the Native American ceramics at several other South Texas sites. These include: La Villa de la Bahía (41GD112) (Ricklis 1999b and May 2000 personal communication), the Tonkawa Bank site (41VT10), the probable second location (1725-1749) of the Mission Espíritu Santo de Zuñiga (Hindes et al. 1999), a 1650-1750 Karankawan component at the Oak Mott site (41AS92) (Ricklis et al. 2000), and an eighteenth century Native American component at the Carvajal Crossing site (41KA26-B) on the San Antonio River (Perttula 2001).

Let us begin with prehistoric (ca. A.D. 1250-1650) and protohistoric (1650-1750) Rockport phase Karankawan ceramics from the central coast of Texas. According to
Ricklis (1995b, 1996), the Rockport wares made by Karankawan groups have:

1) Moderate to profuse amounts of sand in the sandy paste;

2) Are fired under both oxidizing and reducing environments;

3) Occur in a variety of vessel shapes, including jars and ollas; and

4) Have asphaltum-coated and/or decorated vessel surfaces.

More than 55 percent of the prehistoric Rockport ceramics from sites on or near the bayshore, and as much as $40 \mathrm{~km}$ from the shoreline, have moderate to profuse amounts of sand grains in the paste. Conversely, only 10-15 percent of the Rockport wares in prehistoric contexts have moderate to profuse amounts of crushed bone temper added to the sandy paste (Ricklis 1995b;Figures 20 and 21).

The aboriginal ceramics at the Oak Mott site (41AS92) provide an interesting view of the character of a protohistoric (1650-1750) Karankawan ceramic assemblage on the central Texas coast (Ricklis et al. 2000). The ceramics are predominantly sandy paste jars and ollas, with more than 40 percent having moderate to profuse amounts of sand in the paste. More than 70 percent of the sherds have an asphaltum surface coating/decoration (Ricklis et al. 2000:Figure 58). The sandy paste sherds are quite thin on average $(4.8 \mathrm{~mm})$, a bit thinner than the sandy paste sherds from Mission Refugio (see Figure 9c-3), as well as thinner than the Native American ceramics from Mission Rosario and Mission Espíritu Santo at Goliad (Ricklis et al. 2000:Figure 60). None of the Karankawan ceramics from the Oak Mott site have moderate to profuse amounts of bone temper. Less than 0.3 percent of the sandy paste Karankawan sherds at Presidio Loreto (41VT4) have bone temper (Gilmore 1973). Crenellated rims are also present in the assemblage, and Ricklis (1996:188) suggests this rim form is a late (protohistoric?) Karankawan ceramic innovation.

A completely different ceramic tradition, and one with roots in the Late Prehistoric archaeological record of the inland coastal Plain of central and southern Texas (cf. Hester 1989c:224; Walter 1999:118-119), is dominated by plain bone-tempered ceramics related to both Leon Plain and Goliad Plain. In this tradition, thin and well-made but undecorated jars, ollas, bottles, and bowls are made with large amounts of crushed bone temper, and are frequently burnished on exterior surfaces. Goliad Plain vessels are 


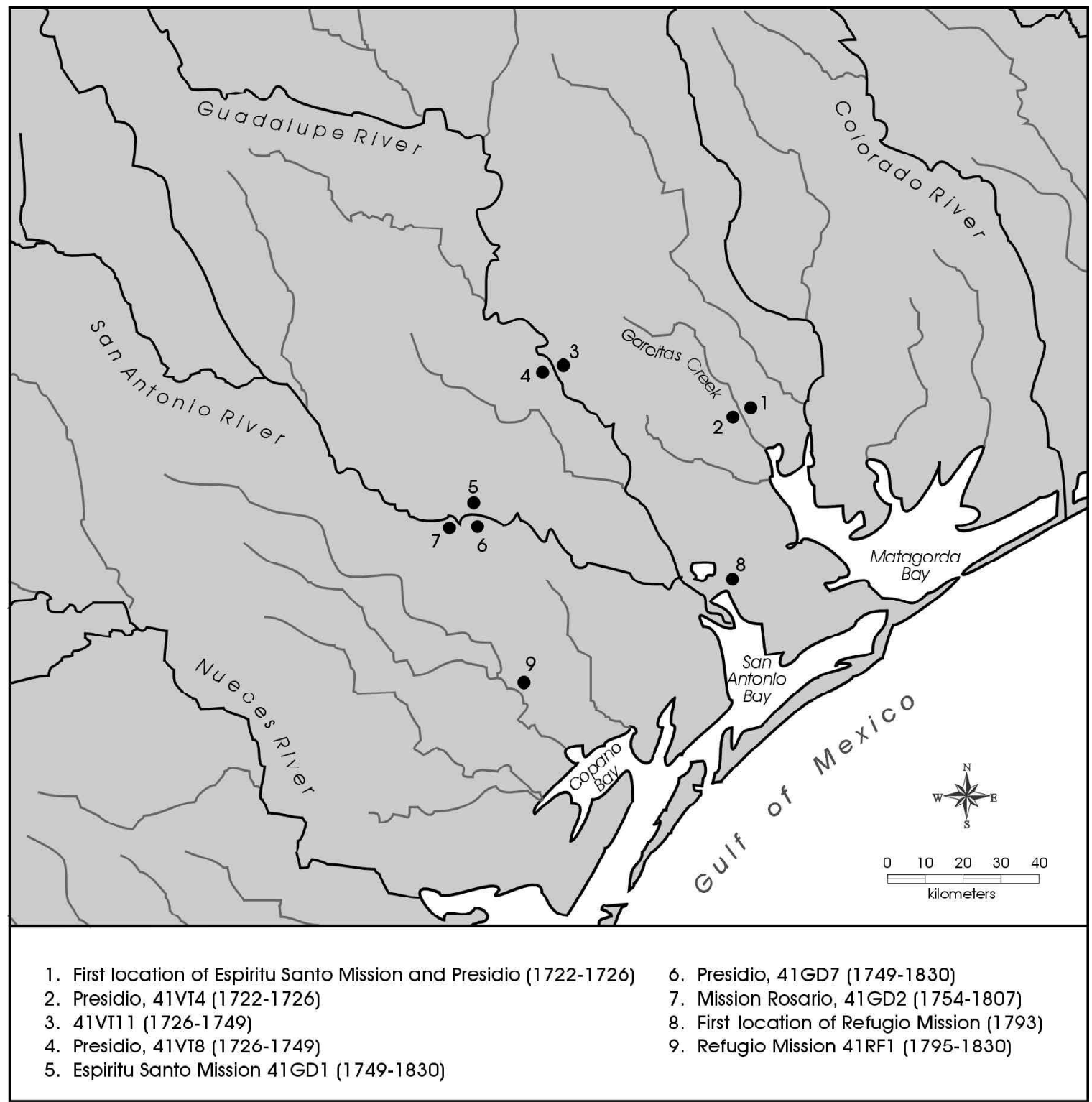

Figure 9c-11. Location of Selected Spanish Colonial Sites in southern Texas: 1) 2) first locations of Mission Espíritu Santo and Presidio Loreto (41VT4), 1722-1726; 3-4) Mission Espíritu Santo (41VT11) and Presidio Loreto (41VT8), 1726-1749; 5) Mission Espíritu Santo at Goliad (41GD1), 1749-1830, 6) Presidio at La Bahía (41GD7), 1749-1830, 7) Mission Rosario (41GD2), 1754-1807; 8) first location of Mission Refugio, 1793; 9) Mission Nuestra Señora del Refugio (41RF1), 1795-1830.

technologically comparable to Leon Plain, but are found in mission contexts. They also have riveted handles and a wider range of vessel shapes (see Mounger 1959:163-181). Other vessel forms include candleholders, spoons, footed vessels, pottery rests, as well as whistles, and it is probable that these forms were made specifically for use by the Spanish missionaries and colonists. Goliad Plain vessels are thin; the average thickness of sherds is $5.32 \pm 0.98 \mathrm{~mm}$ at Espíritu Santo (41VT11) (Walter 1997).

More than 99 percent of the Native American ceramics at Mission Espíritu Santo at Goliad (41GD1), and at the earlier 
mission location in Mission valley (41VT11), are unglazed bone-tempered Goliad Plain wares (Mounger 1959; Ricklis 1998, 1999a; Walter 1997, 1999). A similar proportion of bone-tempered ceramics has been documented by Hindes et al. (1999) at the Tonkawa Bank site (41VT10). Riveted handles are present at each of these sites in some quantity. At the Villa de la Bahía site (41GD112), the Native American ceramics are also almost exclusively bonetempered (see Ricklis 1999b), and "in terms of various attributes, appeared to be identical to the nearby [Espíritu Santo] mission pottery" (Robert A. Ricklis, personal communication via e-mail, May 15, 2000).

Another characteristic of the bone-tempered Goliad Plain ceramics at Mission Espíritu Santo at Goliad is the occasional occurrence of decorated vessels. These include Goliad Red-on-buff and Goliad Black-on-buff vessels with dots and bands on the former, and squiggles and bands in the latter (Mounger 1959). Sherds with these decorations were absent in more recent excavations by Ricklis (1998, 1999a). However, as discussed earlier in this chapter, redon-buff, brown-on-buff, and red-black-on-buff decorated bone-tempered sherds have been found in several excavated contexts at Mission Refugio (see Table 9c-7).

Between 1-4 percent of the Native American ceramics at Mission Espíritu Santo at Goliad have a sandy paste, according to Mounger (1959) and Ricklis (1999a). Less than 0.4 percent of the sherds there have an asphaltum coating or decoration. Decorative elements include asphaltum squiggles and lip bands. At the contemporaneous Native American encampment at the Carvajal Crossing site (41KA26-B), less than five percent of the ceramic assemblage have asphaltum-coated/decorated sherds and a relatively high proportion of sherds have moderate to profuse amounts of bone temper in the paste (Perttula 2001).

The Native American ceramics from Mission Rosario are also predominantly bone-tempered (Gilmore 1974; Ricklis 1998, 1999a; Ricklis et al. 2000). This has significant implications for cultural and ethnic affiliations of the Mission Refugio ceramics because Karankawan groups principally lived at Mission Rosario, albeit only part-time (Gilmore 1989:239). However, the overall character of the assemblage is more heterogeneous than the bone-tempered wares from Mission Espíritu Santo and Villa de la Bahía, or the sandy paste Rockport wares from prehistoric and protohistoric Karankawan sites.
According to Ricklis (1998, 1999a; Ricklis et al. 2000), between 30-45 percent of the aboriginal ceramics at Mission Rosario have moderate to profuse amounts of bone temper in the paste. Although most of the sherds also have a sandy paste, the proportion of sherds with moderate to profuse amounts of sand grains in the paste ranges from 15-30 percent. By contrast, at the protohistoric Oak Mott site, this percentage was more than 40 percent (Ricklis et al. 2000), and only 15-20 percent of the Mission Refugio sherds have moderate to profuse amounts of sand in the paste.

Another difference between Rosario and prehistoric and protohistoric Karankawan ceramics is in the lower frequencies of asphaltum coating/decoration: 38-43 percent of the sherds at Mission Rosario also have an asphaltum coating or decoration on principally the lip bands. Such coated/decorated sherds comprise 38-75 percent of the sherds at prehistoric and protohistoric Karankawan sites (Ricklis et al. 2000:106). The proportion of sherds with asphaltum coating/decoration at Mission Refugio ranges from only 7-12 percent in the three analytical units. At coastal prairie/plain Toyah phase sites, some 15 percent of the sherds have an asphaltum coating/decoration (see Ricklis 1995b).

Stratified midden deposits (Zone 2-3, 1754-1780, and Zone 1, 1790-1806) at Mission Rosario document several temporal trends in the Native American ceramics (Ricklis 1998, 1999a). First, there is an increase in the percentages of sherds with moderate to profuse amounts of bone temper from Zone 2-3 (29 percent) to Zone 1 (47 percent), although the overall frequency of bone-tempered sherds remained the same from 1754 to 1806 . Second, the proportion of sherds with moderate to profuse amounts of sand in the paste decreased from 93 percent in Zone 2-3 to only 59 percent in Zone 1. Thus, the Mission Rosario vessel sherds over an approximate 50-year-period became less sandy-textured and had more bone temper added to the paste. There are more bowls and fewer jars being made through time (Ricklis et al. 2000:Figure 58), vessels are thicker, and fewer vessels were fired in an oxidizing or open-air environment. Riveted handles are rare in both Zone 2-3 and Zone 1.

While these technological changes were taking place among the Karankawan potters at Mission Rosario, they continued to coat or decorate the vessels with asphaltum. Thirty-eight percent of the Zone 2-3 sherds have an asphaltum coating or decoration compared to 43 percent of the Zone 1 sherds. Lip bands (Rockport Black-on-Gray I) were by far the predominant decorative element in the three midden zones. However, 89 percent of the asphaltum-decorated sherds in 
Zone 1 have the lip band, increasing from 70 percent in the 1754-1780 midden zone (Ricklis 1999a). Lip bands and squiggles (Rockport Black-on-Gray II) are a more common decorative element in the earlier midden zones, comprising 22 percent of the decorated sherds. Only five percent of the asphaltum-decorated sherds in the 1790-1806 midden have bands and squiggle elements. Partial confirmation of the temporal changes in sandy paste vessel decorations comes from Mission Refugio, where sherds with lip bands occur only in Analytical Unit 3, the youngest (post-dating 1807?) archaeological deposit defined in the excavations (see Table 9c-7).

It is clear from the preceding that the ceramic assemblages from these disparate southern Texas and central coastal sites (see Figure 9c-11) are diverse temporally, spatially, and presumably culturally-ethnically. What, then, is the place of the Mission Refugio ceramics in the Native American tradition of pottery-making in the region that was truncated with the "conquest" of the Karankawas by Anglo-Texans (cf. Himmel 1999) about 1836?

The two main ceramic traditions represented in mission contexts in southern Texas have their roots in the prehistoric Toyah and Rockport phases. The Toyah phase sites in inland and coastal prairie/plain settings have plain bone-tempered ceramics (i.e., Leon Plain in the broadest sense), and the Rockport phase sites have sandy paste vessels with asphaltum-coated or decorated surfaces. The Rockport phase ceramic wares are found from bayshore sites to sites as far as $40 \mathrm{~km}$ from the shoreline. Ricklis (1995b, 1996) has made a compelling case that the Rockport phase ceramics were first made by the prehistoric ancestors of the Karankawa. Both kinds of ceramic wares continued to be made in protohistoric and historic times (Goliad Plain and Rockport wares), and the archaeological evidence from sites such as Mission Espíritu Santo at Goliad, La Villa de la Bahía, and Mission Refugio demonstrates that both ceramic traditions were flourishing in the 1830 s.

The ceramic assemblages from Mission Rosario and Mission Refugio seem to represent something of an amalgamation of the two ceramic traditions, with characteristics of both, as well as the technological and stylistic evolution of the Karankawan Rockport wares from ca. 1754-1830. These changes in Native American material culture over a very short period of time point out just how complicated it is to determine the cultural and ethnic affiliations of Native American ceramics in this particular spatio-temporal and acculturative context. These matters will be discussed in more detail in the final and concluding section of this chapter.

\section{Research Issues Concerning Native American Ceramics}

Two research questions discussed by Tennis in Chapter 1 are relevant to a broader consideration of the Native American ceramics from Mission Refugio:

1) Frontier Supply System and its Effect on Native Technology; and

2) Affect of Acculturation on Native American Ceramic Technologies

The first question concerns the nature of the frontier supply system in place in Texas during the late-eighteenth and earlynineteenth centuries. Specifically of interest is the question of whether changes in the availability of goods from Mexico may have led to an increasing dependence upon the use of Native American products, such as ceramic vessels made by neophytes in the mission system. Hinojosa and Fox (1991:117) have noted, for instance, that "Indian-made pots, jars, and bowls appear to have predominated in the kitchens of the community" of eighteenth century San Antonio. This appears in part to have been a solution to the difficulty of obtaining more sophisticated vessels (majolica and other Mexican-made wares) from Mexico by mule train. Hinojosa and Fox (1991:117) go on to point out that the use of Indian containers "were phased out" by the end of the eighteenth century in San Antonio. They attribute this to the possibility that:

\section{"Coahuiltecan and Karankawa population both inside and outside the mission declined or because more durable vessels became available." \\ (Hinojosa and Fox 1991)}

The archaeological evidence from Mission Refugio strongly suggests that a variety of Native American ceramics continued to be produced and used at the mission until it was abandoned about 1830. This includes an abundance of bone-tempered, sandy paste, and sandy paste bone-tempered sherds, very few of which, if any, appear to be from Spanishinspired vessel forms (such as candle holders, spoons, whistles, or pottery rests; see Mounger 1959). The instrumental neutron activation analysis and petrographic analysis of sherds from AU 1, AU 2, and AU 3 (along with clay sources at the mission) have demonstrated that the majority of the Native American ceramics at Mission Refugio, particularly the bone-tempered wares, were locally manufactured. The bone used for temper was probably obtained from processed livestock in the large mission ranch. Some of the sandy paste sherds were apparently made 
elsewhere, probably along the coast, by Karankawan groups, and brought to the mission by these Karankawan people.

The frequent occurrence of asphaltum-coated and decorated sherds in the Mission Refugio ceramic assemblages from the three analytical units also indicates that the mission inhabitants, and their kin living outside the mission, continued to have regular access to coastal sources of asphaltum. Ricklis (1999a:164) has suggested that:

"interaction among Native ethnic groups was probably more restricted [in the mid-late eighteenth century] than during aboriginal times. This may reflect social constraints imposed by the organizational structure of the Spanish colonial system."

The Mission Refugio Native American ceramics do not necessarily support this view. Instead it seems likely that at least some of the Karankawan groups living there continued to use the mission and its resources as they would have any other resource patch, entering and leaving the mission on their own schedules of resource exploitation and mobility. Conversely, the use of asphaltum by the mission inhabitants may suggest that while they have been firmly tied to the mission and became less mobile, they nevertheless continued to maintain steady contact and interaction with non-mission Karankawan groups living along the central Texas coast. In either scenario, frontier life, and the changing social, demographic, and warfare patterns of the late-eighteenth and early-nineteenth centuries in this part of Texas, do not appear to have substantially altered the Native American ceramic technology from earlier times.

It is known that Native American groups living at Mission Espíritu Santo at Goliad made and sold bone-tempered plain pottery "to the residents of the secular La Bahía community" (Ricklis 1999b, based on Cardenas [1783]). Perhaps the Karankawan groups living at Mission Refugio did the same. But how do we account for the abundance of plain bonetempered pottery at Mission Refugio when Karankawan groups primarily made and used sandy paste pottery? Could this pottery have been made at Goliad and brought to Mission Refugio, or were people and potters from Goliad moving to Mission Refugio? If this were the case, rather than the alternative that the bone-tempered pottery at Mission Refugio was made on-site, the implications for the character of the Spanish supply system would be very different.
I have already made mention of the instrumental neutron activation analysis and petrographic analysis of the Mission Refugio ceramics, and the fact that they support the hypothesis that the ceramics were made locally. However, these results are particular to only a single ceramic assemblage. To rule out the possibility that some of the bonetempered ceramics from Mission Refugio may have been made at, and traded from, Goliad (or other missions), additional petrographic and chemical compositional analyses of sherds from other missions should be obtained to document the scope and tempo of this possible frontier trade. Such data on Native American ceramics from other mission contexts are not currently available for the region.

The second research question addresses the degree to which the ceramic technology of the Karankawan Indian groups living at Mission Refugio may have become increasingly acculturated because of European contact and interaction in a mission context. In general, the Native American ceramics at Mission Refugio are much like the pottery documented and described by Mounger (1959) and Ricklis (1999a; Ricklis et al. 2000) from Mission Espíritu Santo at Goliad and Mission Rosario. This is particularly the case with the latter in respect to paste and temper and the occurrence of asphaltum-decorated sherds, and to the former with respect to mineral paint decorated sherds (red-on-buff and brown/dark brown-on-buff) and ceramic disks, foot supports, and riveted loop handles. Given the character of the Native American ceramics in 1750-1830 mission contexts, it is reasonable to conclude that there is a fundamental similarity in the kinds of pottery manufactured and used by Native Americans, missionaries, and Spanish settlers (as at Villa de la Bahía). From this, however, can we conclude that Spanish colonization affected Native American ceramic technologies?

First, there is no evidence that the ceramics made at Mission Refugio were fired in a kiln. Rather, they continued to be fired in the open air, but in a variety of conditions (i.e., reducing; reducing but cooled in the open air; incompletely oxidized; and oxidized). The Native American ceramics were not made with a wheel, but were formed by hand, as they had been for several hundred years previously in prehistoric and protohistoric times. The ceramic fabric (i.e., paste and temper) was also little changed from prehistoric and protohistoric times, in that bone-tempered and sandy paste vessels had been made by inland coastal and coastal Native American populations since at least A.D. 1200. New fabrics do not appear to have been imported and used by the Native American potters living at Mission Refugio. 
Were there new forms of ceramics present at Mission Refugio, perhaps certain kinds of vessels or other ceramic items made specifically at the request of the missionaries for their use? The ceramic evidence from Mission Espíritu Santo at Goliad does indicate that new ceramic forms were made with a traditional technology, employing the same paste, temper, and production used to produce aboriginal bowls, jars, bottles, and ollas. The ceramics from Mission Refugio represent only a limited sample of the contexts where Native American pottery would have been used in the mission, and may not comprise a representative sample of the mission assemblage as a whole. However, there are no new ceramic forms present in the assemblage other than riveted handles on jars and foot supports. Their rarity at Mission Refugio suggests that the vast majority of the ceramic vessels made and used at the mission were traditional forms in size and shape.

The sandy paste sherds at Mission Refugio commonly have asphaltum-coated or decorated surfaces, as do their prehistoric and protohistoric Karankawan ceramic counterparts. The decorations, including painted lip bands and lip bands and vertical squiggles on the vessel body, are traditional Karankawan ceramic styles (see Ricklis 1995b, 1996) of Rockport Black-on-Gray pottery. There is no question that these traditional ceramic decorative styles continued to be used by the Mission Refugio potters in the early nineteenth century, and the Rockport Black-on-Gray vessels were made and used in all three analytical units recognized by Tennis (see Chapter $8 \mathrm{~A}$ ).

By contrast, most of the bone-tempered pottery at Mission Refugio, as it is at Mission Rosario and Mission Espíritu Santo, is plain, but commonly burnished. Such is also the case with ceramics in prehistoric, protohistoric, and nonmission historic contexts in southern Texas aboriginal sites. The few decorated bone-tempered sherds are found exclusively in Analytical Units 1 and 3 at Mission Refugio, the two latest components recognized in the excavations. The decorated bone-tempered sherds include: (a) red-onbuff, black on buff, brown, and red-on-black painted; (b) brushed; and (c) incised examples. The painted sherds have close parallels to Goliad red-on-buff and Goliad black-onbuff examples from Mission Espíritu Santo at Goliad (see Mounger 1959), and vessels decorated with mineral paints appear to have been produced only in mission contexts. The motifs noted on these vessels include bands and dots (some placed on the vessel interior), and may have been inspired by decorations on Mexican majolica and certain lead-glazed wares. Along with the production of certain non-traditional ceramic forms at Mission Espíritu Santo (cf. Mounger 1959), the painted ceramic vessels at Espíritu Santo and Refugio constitute the best available evidence for acculturative changes in Native American ceramic technologies because of Spanish interaction and contact.

In an earlier section of this chapter, I alluded to the possibility that the ceramic assemblages from Mission Rosario and Mission Refugio seem to represent something of an amalgamation of two different ceramic traditions: (1) plain bone-tempered wares, and (2) sandy paste wares, with asphaltum coated and decorated surfaces. The ceramic assemblages at Rosario and Refugio have characteristics of both traditions, and probably represent at least in part the technological and stylistic evolution of Karankawan Rockport wares from ca. 1754-1830. The ceramic similarities and differences between them over such a short span of time may also comprise acculturation of Karankawan groups, but in this case one created by changes in the social landscape of Native American groups living in coastal and inland coastal parts of southern Texas.

Previously, Native American populations that made and used bone-tempered or sandy paste ceramics lived in different parts of southern Texas. However, the creation of the Spanish mission system, and probable Spanish restrictions in group mobility and access to resources, led to the close spatial proximity of the Karankawa, the Aranama, and other ceramic-making groups at the Espíritu Santo and Rosario missions. Arising out of this proximity (and perhaps a product of it) are subtle changes or temporal trends in the character of Karankawan ceramics at Mission Rosario that also can be detected in the Mission Refugio ceramic assemblage. These changes included the increased use of bone tempering, lesser amounts of moderate to profuse sand grains in the sandy paste, and a decrease in the frequency of asphaltum coated and decorated vessels. All these changes appear to be the product of slightly different ways of firing, decorating, producing, and using Native American ceramics than had been the case in the mid-eighteenth century. The end result, in other words, is that the Native American ceramics at Mission Refugio come to more closely resemble the ceramics produced at Mission Espíritu Santo at Goliad, which are overwhelmingly plain bone-tempered wares, but with a few mineral painted and asphaltum-painted vessels.

If we disregard the apparently remote possibility that the ceramics at Mission Refugio may have been made by Goliad potters, or the equally remote possibility that the mission population at Refugio was non-Karankawan, where does 
that leave us in accounting for the distinctive character of the Mission Refugio ceramics? Following a suggestion made by Robert A. Ricklis (May 2000, personal communication via e-mail), it is likely that the Mission Refugio ceramics reflect a form of dissolution of two traditionally discrete ceramic traditions, one a plain bone-tempered ware, and the other a decorated sandy paste ware. This dissolution was brought on by three factors. The first factor was the new proximity of the Karankawa to other Native American groups that made a different kind of ceramic ware (i.e., the plain bone-tempered ceramics), and the gradual adoption of bone tempering by the Karankawan groups. The second factor was the increasing Karankawan accommodation through the early-nineteenth century of Spanish colonists and missionaries in their midst (see Himmel 1999; Ricklis 1996), and the latter's need for Native American goods. Finally, the third factor was the development of the requisite technology to manufacture some non-traditional ceramic items for the Spanish consumer. 


\title{
Chapter 9: Artifacts
}

\section{Section D}

\section{Lithics}

\author{
Steve A. Tomka
}

A total of 503 chipped lithic artifacts were recovered from 41RF1 (Table 9d-1). The large majority $(n=447,88.9$ percent) came from excavations conducted by CAR. TxDOT excavations yielded a total of 56 (11.1 percent) artifacts. The recovered artifacts are categorized into the following functional groups: one arrow point, six scrapers, twelve probable gunflints, and a graver. Tool function was determined using low-powered (up to 80x) micro-wear analysis examining artifacts for the presence of microflaking, rounding, and polish using an Olympus SZ binocular microscope with a Fiber Optic Light Illuminator. Nine unifacially flaked artifacts and three bifacially flaked items could not be grouped into functional categories. They are classified as indeterminate unifacial and bifacial artifacts, respectively. Sixty-five cores also were recovered, in addition to 406 pieces of unmodified lithic debitage. Four of the cores and 52 debitage came from TxDOT excavations; the remaining majority is the product of CAR excavations.

The initial examination of the lithic artifact collections from 41RF1 began with the unmodified debitage. The frequent angular debris, the lack of well-defined platforms on platform-bearing flakes (complete specimens and proximal fragments), and the presence of asphaltum on some specimens suggested that a large proportion of the collection may be composed of mechanically generated or at least mechanically altered debris. Early examination of a limited number of cores seemed to support this contention given the number of angular core fragments, apparent lack of patterning in flake removal scars, and heavily crushed wedge-like platform surfaces on some specimens. The fact that some of these mechanical suspects seem to derive from the upper 20 centimeters of deposit further enforced this perception.

However, with few exceptions, the lack of large raw materials along the coastal corridor would encourage the use of bipolar reduction. Furthermore, some of the features of the lithic artifacts examined could just as easily have been produced during bipolar reduction (see Hayden 1980, Honea 1965, Kobayashi 1975, Kuijt et al. 1995, Leaf 1979). Therefore, to assure that artifacts are not incorrectly identified as mechanically derived and culled from the collection a more systematic examination of the cores and unmodified debitage was undertaken before formal analysis began. To ensure that artifacts would be correctly assigned to a cultural as opposed to mechanical category, and therefore discarded without analysis, the lithic analyst consulted his extensive comparative collection of bipolar debitage and cores derived from experimental replication of the hammer and anvil technique using small obsidian nodules (Apache tears) obtained from New Mexico. The closer examination of the debitage and cores found a close correspondence in trait with features present on the comparative replicated specimens. That is, cores and core fragments tended to be angular, tended to have crushed platform surfaces, and diametrically opposed flake scars and bulbs of percussion on the same core. Much of the debitage was angular debris, some had crushed platforms, and specimens with welldefined dorsal flake scar patterns characteristic of bifacial reduction were lacking.

Based on this more systematic examination of portions of the collection, it was decided that pebbles that had no notable modification (i.e., stream-worn pebbles) would be considered as natural, while all others would be considered as potentially cultural in origin. In addition, it was decided that the vertical patterning of the specimens that appear to be bipolar would be tracked to explore whether they concentrate primarily in the upper 20 centimeters or are more randomly distributed.

\section{Arrow Point}

A single complete arrow point, classified as a Guerrero type, was recovered (Table 9d-1, Figure 9d-1 [a]). The specimen is triangular and has a slightly concave base and fine serrations along the mid-portion of its blade. No serrations are evident on the upper eight $\mathrm{mm}$ of the blade and the bottom seven mm adjacent the base. The point is made of brown fine-grained quartzite. Its high luster may derive from heat treatment although some examples of Uvalde quartzites are naturally lustrous without heat treatment. It was recovered in Level 3 (20-30 cmbs) in Unit N80/E100 and has been assigned to Analytical Unit 1 (AU 1), Feature 1. 
Table 9d-1. Nondebitage lithic artifacts, 41RF1

\begin{tabular}{|c|c|c|c|c|c|c|c|c|c|}
\hline $\begin{array}{l}\text { ANALYSIS } \\
\text { UNIT }\end{array}$ & $\begin{array}{l}\text { EXCAV. } \\
\text { UNIT }\end{array}$ & LEVEL & LOT NR. & $\begin{array}{l}\text { TOOL TYPE/ } \\
\text { SPEC. NUMBER }\end{array}$ & $\begin{array}{c}\text { Max. } \\
\text { Length } \\
(\mathrm{mm})\end{array}$ & $\begin{array}{l}\text { Max. } \\
\text { Width } \\
(\mathrm{mm})\end{array}$ & $\begin{array}{c}\text { Max. } \\
\text { Thickness } \\
(\mathrm{mm})\end{array}$ & $\begin{array}{c}\text { Blank/ } \\
\text { Completeness }\end{array}$ & Notes \\
\hline \multicolumn{10}{|c|}{ Arrow Points } \\
\hline 1 & N80E100 & 3 & 30 & Guerrero & 33 & 15 & 5.3 & quartzite & Serrated blade edges \\
\hline \multicolumn{10}{|c|}{ Probable Gunflints } \\
\hline 3 & N76E100 & 2 & 96 & Specimen \# 1 & 18 & 16 & 5 & Tertiary Flake & Thin, marginally bifacially flaked on three edges \\
\hline 3 & N74E100 & 3 & 191 & Specimen \# 2 & 18 & 12 & 7.7 & Indeterminate & Bifacially flaked, heavily crushed edges \\
\hline 3 & N78E100 & 3 & 49 & Specimen \# 3 & & & 7.3 & Indeterminate & Marginally bifacial; heavily crushed corner fragment \\
\hline 3 & N87E100 & 2 & 203 & Specimen \# 4 & 22.5 & 22 & 6 & Indeterminate & Marginally bifacial; heavily crushed edges \\
\hline 3 & N85E100 & 4 & 16 & Specimen \# 5 & 25 & & 10 & Indeterminate & Rectangular fragment w. marginal bifacial flaking and crushed edges \\
\hline 1 & N84E100 & 8 & 139 & Specimen \# 6 & 26 & 13.5 & 6 & Pebble & Rectangular specimen w. marginal flaking and crushed edges \\
\hline 3 & N87E100 & 4 & 214 & Specimen \# 7 & 23 & 20 & 8.5 & Secondary Flake & Triangular specimen w. two unifacially worked and crushed edges \\
\hline 1 & N84E100 & 11 & 161 & Specimen \# 8 & 22.5 & 22 & 5 & Tertiary Flake & Marginal unifacial retouch and crushing along two edges \\
\hline 1 & N84E100 & 11 & 161 & Specimen \# 9 & 24 & 22 & 11.6 & Pebble & Bifacial retouch and crushing along two edges \\
\hline 3 & N76E100 & 1 & 93 & Specimen \# 10 & 25 & 17 & 6 & Tertiary Flake & Marginal unifacial retouch and crushing along three edges \\
\hline 2 & N75E100 & 8 & 32 & Specimen \# 11 & 32 & 24 & 13 & Secondary Flake & Marginal unifacial retouch and bifacial crushing along one edge \\
\hline 3 & N86E100 & 4 & 90 & Specimen \# 12 & 14 & 14 & 4 & Tertiary Blade & Marginal unifacial retouch and crushing along three edges \\
\hline 1 & N84E100 & 8 & 139 & Specimen \# 13 & 18 & 17 & 7 & Indeterminate & Unifacially retouched disk-shaped, with crushing along three edges \\
\hline 1 & N86E100 & $120 / 125$ & 275 & Specimen \# 14 & & 16 & 9 & Secondary Flake & Retouched and crushed along three edges \\
\hline \multicolumn{10}{|c|}{ Scrapers } \\
\hline 1 & N86E99 & 9 & 257 & Exp. Comb. end/side scraper & 26 & 14 & 5 & Secondary Flake & Use wear present on both lateral edges and distal end \\
\hline 2 & N75E100 & 8 & 32 & Exp. Comb. end/side scraper & 23 & 13 & 3 & Secondary Flake & Use wear present on both lateral edges and distal end \\
\hline 2 & N75E100 & 9 & 36 & Expedient Side Scraper & 48 & 35 & 12 & Secondary Flake & Use wear present along one lateral edge \\
\hline 3 & N84E100 & 3 & 78 & Denticulate & 30 & 21 & 4 & Tertiary Flake & Both lateral edges denticulated \\
\hline 2 & N75E100 & 8 & 32 & Denticulate & 26 & 18 & 4 & Secondary Flake & One lateral edge denticulated \\
\hline 3 & N75E99 & 4 & 101 & Formal Side Scraper & 58 & 48 & 13 & Primary Flake & One working edge \\
\hline \multicolumn{10}{|c|}{ Graver } \\
\hline & Gradall bac & ckdirt & 318 & Minimally Retouched Graver & 24 & 22 & 11 & Secondary Flake & Two graver tips \\
\hline
\end{tabular}

\begin{tabular}{c|c|c|r|l|c|c|c|c|l}
\hline \multicolumn{1}{l}{ Indeterminate Unifaces } \\
\hline 3 & N84E100 & 3 & 78 & Indeterminate Uniface & 22 & 18 & 7 & Primary Flake & Complete; One heavily retouched lateral edge; no use-wear \\
\hline 2 & N74E100 & 9 & 240 & Indeterminate Uniface & 50 & 34 & 13 & Secondary Flake & Complete; Minimal unifacial flaking \\
\hline 3 & N95E100 & 3 & 5 & Indeterminate Uniface Edge & & & 8 & Indeterminate & \\
\hline 1 & N84E100 & 8 & 139 & Indeterminate Uniface Edge & & & 9 & Secondary Flake & \\
\hline 3 & N73E100 & 3 & 53 & Indeterminate Uniface Edge & & & 3 & Indeterminate & \\
\hline 3 & N86E100 & 3 & 84 & Indeterminate Uniface Edge & & & 4 & Indeterminate & \\
\hline 3 & N72E100 & 2 & 81 & Indeterminate Uniface Edge & & 18 & 7 & Secondary Blade & Distal fragment, with intermittent unifacial retouch \\
\hline
\end{tabular}

\begin{tabular}{|c|c|c|c|c|c|c|c|c|c|c|}
\hline \multicolumn{11}{|c|}{ Indeterminate Bifaces } \\
\hline 3 & N73E100 & 4 & 57 & Indeterminate Biface Frag. & 32 & & 7 & Secondary Flake & Specimen \# 1 & Longitudinally broken flake blank w. marginal flaking \\
\hline 3 & N85E99 & 2 & 54 & Biface Medial Fragment & & 16 & 5 & Indeterminate & Specimen \# 2 & Manufacture broken medial fragment \\
\hline 3 & N95E100 & 3 & 11 & Biface Distal Fragment & & & 7 & Flake blank & Specimen \# 3 & Marginally bifacially flaked distal flake fragment \\
\hline \multicolumn{11}{|c|}{ Cores } \\
\hline 3 & N95E100 & 4 & 15 & Bipolar and Flake Core & 84 & 58 & 45 & Complete & Specimen \# 3 & \\
\hline 3 & N95E100 & 4 & 15 & Bipolar and Flake Core & 48 & 42 & 25 & Complete & Specimen \# 4 & \\
\hline 3 & N57E100 & 4 & 67 & Bipolar and Flake Core & 56 & 31 & 26 & Complete & Specimen \# 11 & \\
\hline 3 & N57E100 & 3 & 62 & Bipolar and Flake Core & 49 & 40 & 19 & Complete & Specimen \# 19 & \\
\hline 3 & N95E100 & 4 & 15 & Bipolar Core & 38 & 31 & 20 & Complete & Specimen \# 2 & \\
\hline 3 & N57E100 & 4 & 67 & Bipolar Core & 38 & 29 & 19 & split nodule & Specimen \# 7 & quartzite \\
\hline 3 & N57E100 & 4 & 67 & Bipolar Core & 38 & 26 & 11 & Complete & Specimen \# 8 & \\
\hline 3 & N57E100 & 4 & 67 & Bipolar Core & 37 & 26 & 13 & Complete & Specimen \# 9 & \\
\hline 3 & N57E100 & 4 & 67 & Bipolar Core & 36 & 34 & 14 & Complete & Specimen \# 10 & \\
\hline 3 & N95E100 & 3 & 5 & Bipolar Core & 33 & 31 & 12 & Complete & Specimen \# 16 & \\
\hline 3 & N70E100 & 2 & 14 & Bipolar Core & 47 & 45 & 25 & Complete & Specimen \# 21 & \\
\hline 3 & N71E101 & 3 & 28 & Bipolar Core & 24 & 21 & 10 & Complete & Specimen \# 23 & \\
\hline 3 & N83E100 & 2 & 221 & Bipolar Core & 30 & 24 & 10 & Complete & Specimen \# 25 & \\
\hline 3 & N85E100 & 4 & 16 & Bipolar Core & 25 & 15 & 12 & Fragment & Specimen \# 36 & \\
\hline \multicolumn{3}{|c|}{ Gradall Backdirt } & 109 & Bipolar Core & 44 & 28 & 14 & Complete & Specimen \# 42 & \\
\hline & \multicolumn{2}{|c|}{ Gradall Backdirt } & 109 & Bipolar Core & 47 & 41 & 19 & Complete & Specimen \# 44 & \\
\hline & \multicolumn{2}{|c|}{ Gradall Backdirt } & 109 & Bipolar Core & 30 & 27 & 16 & Complete & Specimen \# 46 & \\
\hline 3 & N95E100 & 2 & 4 & Bipolar Core & 46 & 38 & 25 & Complete & Specimen \# 48 & \\
\hline 3 & TxDOT & & 2 & Bipolar Core & 44 & 35 & 26 & Complete & Specimen \# 57 & \\
\hline
\end{tabular}


Table 9d-1. Continued...

\begin{tabular}{|c|c|c|c|c|c|c|c|c|c|}
\hline $\begin{array}{l}\text { ANALYSIS } \\
\text { UNIT }\end{array}$ & $\begin{array}{l}\text { EXCAV. } \\
\text { UNIT }\end{array}$ & LEVEL & LOT NR. & $\begin{array}{l}\text { TOOL TYPE/ } \\
\text { SPEC. NUMBER }\end{array}$ & $\begin{array}{c}\text { Max. } \\
\text { Length } \\
(\mathrm{mm})\end{array}$ & $\begin{array}{l}\text { Max. } \\
\text { Width } \\
(\mathrm{mm})\end{array}$ & $\begin{array}{c}\text { Max. } \\
\text { Thickness } \\
(\mathrm{mm})\end{array}$ & $\begin{array}{c}\text { Blank/ } \\
\text { Completeness }\end{array}$ & Notes \\
\hline 3 & TxDOT & & 2 & Bipolar Core & 32 & 26 & 16 & Complete & Specimen \# 58 \\
\hline 2 & N73E100 & 10 & 138 & Flake Core & 46 & 31 & 22 & Complete & Specimen \# 29 \\
\hline 3 & N95E100 & 4 & 15 & Flake Core & 46 & 32 & 20 & Complete & Specimen \# 1 \\
\hline 3 & N57E100 & 4 & 67 & Flake Core & 33 & 28 & 16 & Complete & Specimen \# 12 \\
\hline 3 & N57E100 & 4 & 67 & Flake Core & 39 & 27 & 18 & Complete & Specimen \# 13 \\
\hline 3 & N57E100 & 4 & 67 & Flake Core & 36 & 19 & 14 & Complete & Specimen \# 15 \\
\hline 3 & N57E100 & 2 & 61 & Flake Core & 34 & 27 & 20 & Complete & Specimen \# 26 \\
\hline 3 & N57E100 & 2 & 61 & Flake Core & 42 & 40 & 22 & Complete & Specimen \# 27 polyhedral \\
\hline 3 & N75E99 & 3 & 97 & Flake Core & 43 & 28 & 28 & Complete & Specimen \# 28 \\
\hline 1 & N84E100 & 9 & 147 & Flake Core & 46 & 40 & 22 & Complete & Specimen \# 31 polyhedral \\
\hline 1 & N87E100 & 11 & 249 & Flake Core & 39 & 32 & 18 & Complete & Specimen \# 32 polyhedral \\
\hline 3 & N60E100 & 2 & 1 & Flake Core & 29 & 21 & 14 & Complete & Specimen \# 40 \\
\hline \multicolumn{3}{|c|}{ Gradall Backdirt } & 109 & Flake Core & 53 & 28 & 17 & Complete & Specimen \$ 43 \\
\hline 3 & N95E100 & 2 & 4 & Flake Core & 41 & 30 & 24 & Complete & Specimen \# 49 \\
\hline 3 & N95E100 & 2 & 4 & Flake Core & 35 & 29 & 22 & Complete & Specimen \# 50 \\
\hline 3 & N95E100 & 2 & 4 & Flake Core & 50 & 32 & 28 & Complete & Specimen \# 51 \\
\hline 1 & N85E99 & 9 & 216 & Flake Core & 33 & 23 & 17 & Complete & Specimen \# 61 \\
\hline 3 & N86E100 & 5 & 95 & Flake Core & 28 & 25 & 12 & Complete & Specimen \# 62 \\
\hline 3 & N84E100 & 3 & 78 & Flake Core & 45 & 25 & 20 & Complete & Specimen \# 63 \\
\hline 3 & N79E100 & 2 & 151 & Flake Core & 48 & 40 & 21 & Complete & Specimen \# 65 \\
\hline 3 & N95E100 & 4 & 15 & Indeterminate & 19 & 18 & 11 & Fragment & Specimen \# 5 \\
\hline 3 & N95E100 & 4 & 15 & Indeterminate & 19 & 16 & 8 & Fragment & Specimen \# 6 \\
\hline 3 & N78E101 & 2 & 27 & Indeterminate & 44 & 31 & 15 & Fragment & Specimen \# 17 \\
\hline 3 & N78E101 & 2 & 27 & Indeterminate & 21 & 14 & 10 & Fragment & Specimen \# 18 \\
\hline 3 & N73E100 & 4 & 57 & Indeterminate & 24 & 17 & 8 & Fragment & Specimen \# 20 \\
\hline 2 & N76E100 & 11 & 157 & Indeterminate & 36 & 27 & 16 & Fragment & Specimen \# 22 \\
\hline 2 & N74E100 & 9 & 246 & Indeterminate & 30 & 19 & 15 & Fragment & Specimen \# 24 \\
\hline 1 & N85E99 & 11 & 229 & Indeterminate & 34 & 29 & 26 & Fragment & Specimen \# 30 \\
\hline 1 & N89E100 & 3 & 55 & Indeterminate & 18 & 14 & 9 & Fragment & Specimen \# 33 asphaltum \\
\hline 1 & N85E100 & 13 & 184 & Indeterminate & 29 & 21 & 17 & Fragment & Specimen \# 35 \\
\hline 3 & N85E100 & 4 & 16 & Indeterminate & 19 & 11 & 9 & Fragment & Specimen \# 37 \\
\hline 3 & N60E100 & 2 & 1 & Indeterminate & 27 & 18 & 12 & Fragment & Specimen \# 39 \\
\hline \multicolumn{3}{|c|}{ Gradall Backdirt } & 109 & Indeterminate & 30 & 26 & 13 & Fragment & Specimen \# 45 \\
\hline & \multicolumn{2}{|c|}{ Gradall Backdirt } & 109 & Indeterminate & 37 & 26 & 18 & Fragment & Specimen \# 47 \\
\hline 3 & N95E100 & 2 & 4 & Indeterminate & 46 & 35 & 23 & Fragment & Specimen \# 52 \\
\hline 3 & N95E100 & 2 & 4 & Indeterminate & 27 & 24 & 21 & Fragment & Specimen \# 53 \\
\hline 3 & N95E100 & 2 & 4 & Indeterminate & 21 & 15 & 8 & Fragment & Specimen \# 54 \\
\hline 3 & N95E100 & 2 & 4 & Indeterminate & 21 & 13 & 11 & Fragment & Specimen \# 55 \\
\hline 3 & N95E100 & 2 & 4 & Indeterminate & 17 & 14 & 10 & Fragment & Specimen \# 56 \\
\hline 3 & TxDOT & & 18 & Indeterminate & 52 & 31 & 23 & Complete & Specimen \# 59 \\
\hline 3 & TxDOT & & 1 & Indeterminate & 21 & 17 & 12 & Fragment & Specimen \# 60 \\
\hline 3 & N79E100 & 2 & 151 & Flake Core & 30 & 28 & 8 & Complete & Specimen \# 64 \\
\hline 3 & N57E100 & 4 & 67 & Split Pebble & 34 & 23 & 10 & Complete & Specimen \# 14 \\
\hline 3 & N84E100 & 4 & 72 & Split Pebble & 17 & 11 & 9 & Complete & Specimen \# 34 \\
\hline 3 & N60E100 & 2 & 1 & Split Pebble & 24 & 22 & 13 & Complete & Specimen \# 38 \\
\hline 3 & N60E100 & 2 & 1 & Split Pebble & 25 & 11 & 11 & Complete & Specimen \# 41 \\
\hline
\end{tabular}

\section{Scrapers}

A total of six specimens are included in this category (Table 9d-1). Based on the location of the working edge they consist of two side scrapers, two combination end/side scrapers, and two denticulates. Based on the degree of retouch on their working edges, the two combination end/side scrapers and one of the side scrapers are expedient tools. The two denticulates are minimally but systematically retouched to produce fine denticulations on their margins. The remaining side scraper is a heavily retouched formal tool.
The two expedient combination end/side scrapers are both made on small secondary hard hammer percussion flakes. They appear to be the product of core reduction rather than the by-products of biface manufacture. One specimen each is from Feature 1 (AU 1) and Feature 2 (AU 2). The expedient side scraper is on a large secondary hard hammer flake. It also was recovered in AU 2.

The two minimally retouched denticulates are made on a tertiary and a secondary flake blank. The former appears to be the product of bifacial reduction while the secondary 


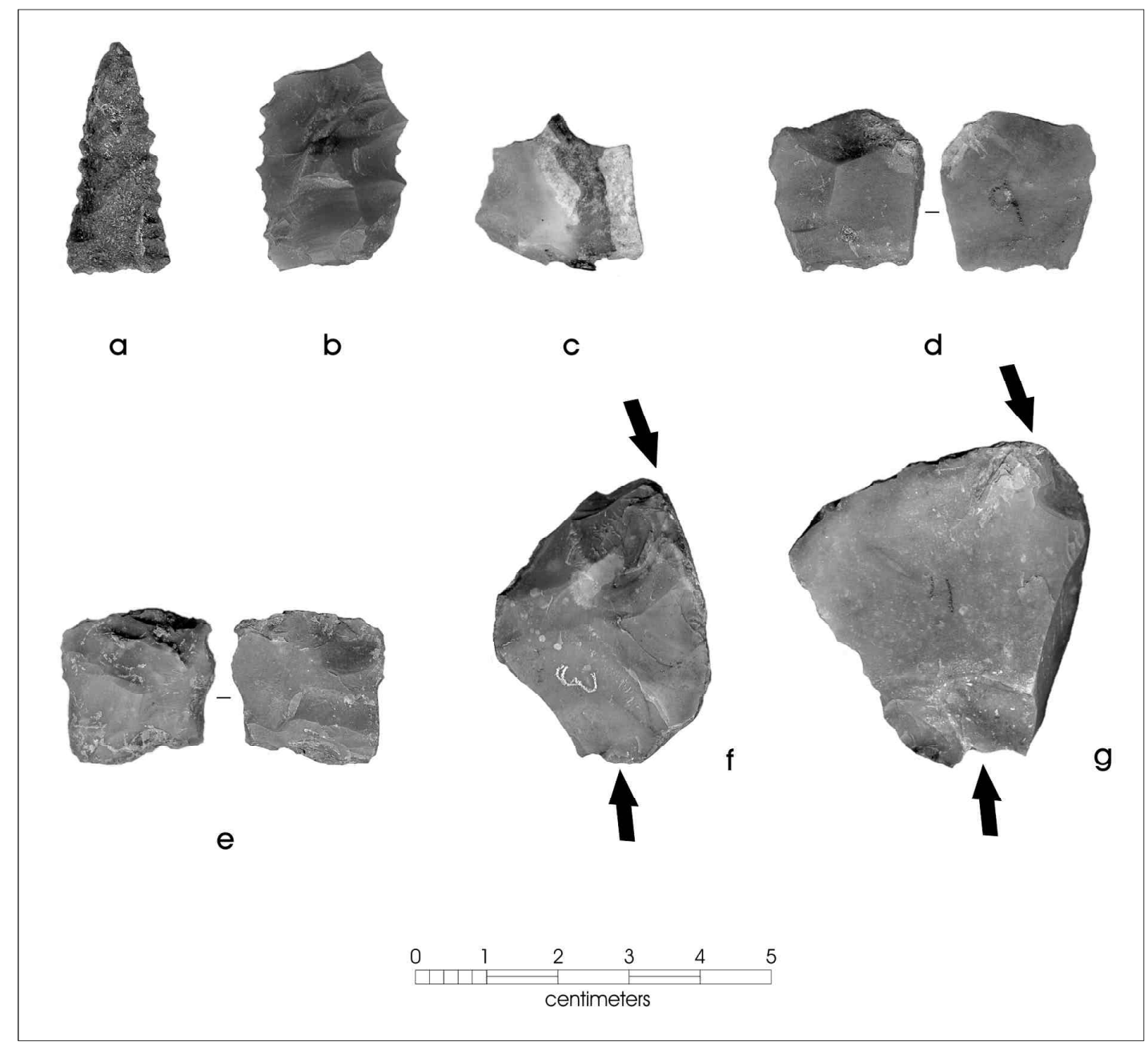

Figure 9d-1. Chipped lithic artifacts from 41RF1; a) Guerrero arrow point; b) minimally retouched denticulate; c) graver; d) probable gunflint, unifacial; e) probable gunflint, bifacial; f-g) bipolar cores with areas of crushing indicated.

flake may derive from core reduction. The tertiary flake (Table 9d-1, Figure 9d-1 [b]) exhibits denticulation on both lateral edges, while the secondary flake is modified only along one edge. The retouch is unifacial on all three edges.

The single formal scraper is made on a large primary flake and has a heavily retouched and well-rounded working edge. Retouch associated with the working edge extends for 31 $\mathrm{mm}$ along the edge of the hard hammer stone flake blank. The heavy rounding and localized areas of moderate polish present along the working edge suggest the tool may have been employed in the scraping of a relatively hard material such as wood. The tool was recovered from AU 3.

\section{Graver}

A single graver was recognized in the collection (Table 9d-1, Figure 9d-1 [c]). The specimen has a single minimally retouched graver tip on its distal margin. The graver tip incorporates a patch of coarse-grained material in an otherwise fine-grained matrix. It is likely that the coarser material provided increased hardness and longer use-life to the working tip. Three micro-burin scars derived from usewear are present on the working tip. A short hard hammer flake blank was employed in its manufacture. The specimen was recovered from Gradall backdirt. 


\section{Indeterminate Unifaces}

Two complete unifacially retouched specimens and five uniface fragments are included in this category (Table 9d-1). These specimens represent items that could not be classified into functional tool categories due to their fragmentary nature or lack of use-wear. The largest of the complete specimen is a hard hammer stone secondary distal flake fragment. With the exception of three overlapping flake removals off the ventral face of the flake, no other retouch is evident on the specimen. Examination of its edges revealed no use-wear and patches of asphalt are evident on both faces. The second complete indeterminate uniface is a small primary flake with unifacial retouch along one of its lateral edges. No use-wear is evident on the edge although some localized edge crushing is present. The localized, irregular nature, and the varied size of the micro-flake scars suggest that the modification derives from post-depositional alteration.

The five uniface fragments are too small for proper analysis. Overall, five of the seven indeterminate unifaces are from AU 3, with one each from AUs 1 and 2.

\section{Indeterminate Biface}

Three small bifacially flaked artifacts are included in this group (Table 9d-1). One of them appears to be the midsection of a manufacture failed biface. It is a relatively narrow (16 $\mathrm{mm})$ and thin $(5 \mathrm{~mm})$ specimen that may be an arrow point fragment. The remaining two indeterminate biface fragments appear to be flake blanks broken very early in the reduction sequence. Bifacial retouch is present only along the margins of the specimens. All three indeterminate bifaces are from AU 3.

\section{Probable Gunflints}

A total of 14 marginally flaked specimens are considered probable gunflints (Table 9d-1).

The identification of the specimens as probable gunflints was made based on macroscopic and microscopic indicators. Both bifacial and unifacial specimens exhibit moderate (intermittent and regularly distributed) to heavy (multiple overlapping) step fractured flake scars along their working edges. Bifacially flaked specimens tend to have a biconvex cross-section although some of them tend to have a humped appearance because the bifacial edge is not in the exact center of the cross-section. All unifacial gunflints have a plano-convex cross-section with steeply beveled working edges. Both bifacially and unifacially prepared working edges tend to have at least one steeply beveled face. The step fracturing present on this face is a combination of retouch to construct the working face and use-related step fracturing and crushing. "Flat flakes" (Kenmotsu 1990:112) and step-fracturing on both faces of bifacial specimens and on the lower (planar) faces of unifacially made specimens indicates that a number of the gunflints were potentially used bifacially although such flakes may simply be a product of typical "unifacial" use (see Kenmotsu 1990:112-113). Another wear type that was noted on the domed faces of a few specimens was polish on the flake scars of the gunflints. It is possible that this polish results from the movement of the gunflint within the leather patch as it is secured within the cock. The burned powdery residue common on specimens examined by Kenmotsu (1990:113) was not noted on the specimens from Refugio. Its absence may be due to lack of preservation or laboratory processing techniques that may have removed such indicators.

Based on their morphology, the probable gunflints can be divided into two main groups. Eight of the specimens are unifacially shaped and six are bifacially made. The unifacially flaked specimens are made on tertiary $(n=5)$ and secondary flakes $(n=3)$ and blade-like flakes. They have roughly rectangular to trapezoidal outlines (Figure 9d-1 [de]). In general, two-three edges are retouched and utilized per gunflint, although two specimens have only one modified edge, each. The six bifacially flaked specimens are made on tertiary $(n=5)$ and secondary $(n=1)$ flakes. They are characterized by rectangular to square outlines (Figure 9d1 [f-g]). Ventral face retouch tends to be concentrated mainly along the margins. Two of the bifacial specimens are fragmentary with breaks associated with imbedded fracture lines. A third specimen appears to have been longitudinally split and an attempt was made to rejuvenate it into a functional specimen before it was finally discarded.

Eight of the 14 gunflints are from AU 3, roughly the youngest of the deposits. Five are from $\mathrm{AU} 1$, and the remaining specimen is from AU 2, the older of the three analysis units. All of the bifacial specimens and three of the unifacial gunflints are from AU 3, while all of the specimens from older deposits are unifacial. This pattern indicates that a shift in gunflint manufacture technique may have occurred during the 35-year occupation of the mission. 


\section{Cores}

A total of 65 cores and/or core fragments have been identified. In terms of approaches to core reduction and flake production the collection can be divided into four groups. Group I consists of 20 flake cores. Group II consists of 16 bipolar cores, and Group III contains four cores that appear to have been partially reduced using a bipolar technique and subsequently flaked using a freehand core reduction method. Group IV consists of four split pebble cores. The remaining 21 specimens are core fragments that could not be classified in either of the previous groups.

The 20 flake cores in Group I represent pebbles and large flakes that have been flaked for the production of medium to small flake blanks. Three of the flake cores are polyhedral specimens with a single platform surface utilized for the removal of multiple blade-like flakes from around the circumference of the core. While these specimens exhibit between five to eight removal scars, the majority of the flake cores have only three to four removal scars per specimen. The maximum length of the flake cores ranges from 53 to $33 \mathrm{~mm}$, and they average $39.8 \mathrm{~mm}$ (standard deviation = $7.33 \mathrm{~mm}$ ). The 16 bipolar cores in Group II are pebbles that exhibit the classic features of bipolar reduction including crushed wedge-shaped platform surfaces, opposed bulbs of percussion and flake scars, irregular flake removal patterns, and relatively common step and/or hinge fractured removal scars (Figure 9d-1 [h-i]). The bipolar cores range from 47 to $24 \mathrm{~mm}$ in maximum length, and are on the average only slightly smaller than the flake cores (mean $=36.8 \mathrm{~mm}$, standard deviation $=7.5 \mathrm{~mm}$ ). The four cores in Group III appear to have been partially reduced using a bipolar approach and subsequently flaked using a hand-held technique to produce flake blanks. Only a small number of flakes were produced from these bipolar cores, the removal ranging from three to five per core. Overall, these four cores are among the largest in the collection ranging between 84 and $48 \mathrm{~mm}$ in maximum length and averaging $59.2 \mathrm{~mm}$ (standard deviation $=16.9 \mathrm{~mm}$ ). The four split pebble cores in Group IV are four of the smallest complete cores in the collection ranging only from 17 to $34 \mathrm{~mm}$ in maximum length and averaging only $25 \mathrm{~mm}$ (standard deviation $=6.9$ $\mathrm{mm}$ ). These specimens also may have been split using a hammer and anvil bipolar technique although they do not exhibit the classic traits present on the bipolar specimens.

All 21 of the indeterminate cores are fragments, too fragmentary to identify the manner of reduction with any degree of certainty. As expected, they are among some of the smallest specimens in the collection. They range from 52 to $17 \mathrm{~mm}$ in maximum length and average just slightly more than the split pebble cores at $28.2 \mathrm{~mm}$ (standard deviation $=10.0 \mathrm{~mm}$ ) in maximum length.

All but three of the bipolar cores in Group II and III are from AU 3, the youngest of the deposits. The remaining three were recovered from gradall backdirt piles. The split pebble cores are also all from AU 3. The majority of the flake cores are also from AU $3(n=15)$, with only three from $\mathrm{AU} 1$ and one from AU 2. The remaining flake core is from unprovenienced gradall context. Cores, in general, are more common in AU 3 than other analysis units, and although three flake cores are from AU 1, bipolar cores and flake cores are nearly equally as common in AU 3 .

\section{Unmodified Debitage}

A total of 406 unmodified debitage was recovered from excavations at 41RF1. The majority of the specimens $(\mathrm{n}=354)$ came from excavations conducted by CAR. TxDOT excavations yielded only 52 pieces of debitage from the site. The lithic analysis focused on the following attributes: raw material type (chert, chalcedony, quartzite, silicified wood), flake completeness (complete, proximal fragment, chip), cortex category (primary, secondary, tertiary), platform faceting (single, two, three or more), maximum dimension (10 $\mathrm{mm}$ size categories), and flake type (angular debris, bipolar, possibly bipolar, platform/core preparation, uniface manufacture/rejuvenation).

The large majority of the collection consists of fine-grained $(n=379)$ and coarse-grained cherts $(n=8)$. Other raw materials are present in small quantities including quartzite $(n=8)$, chalcedony $(n=6)$, rhyolite $(n=1)$, petrified wood $(\mathrm{n}=1)$, and agate $(\mathrm{n}=1)$. A single green glass flake was also recovered from the site, and one specimen could not be classified into the existing raw material categories.

The breakdown of cortex categories among these specimens indicates that contrary to most debitage collections from prehistoric habitation sites, primary and secondary flakes combined dominate the assemblage recovered from 41RF1 (Figure 9d-2). Tertiary flakes constitute less than half of the collection from the site. This pattern is similar to that found at $41 \mathrm{KA} 26 \mathrm{~A} \& \mathrm{~B}$ and it indicates that the raw material being reduced on the site. Furthermore, it indicates that the reduction of the raw material did not proceed to the manufacture of formal finished tools rather they may have consisted of informal and relatively expedient forms. The 
distribution of debitage by size classes indicates that 11-20 and $21-30 \mathrm{~mm}$ specimens dominate (Figure 9d-3). The smallest size class $(1-10 \mathrm{~mm})$ may be under-represented because of the $1 / 4$ inch hardware cloth used in screening. The size class distributions indicate a gradual decrease in the percentage of specimens in the larger size classes with increased size. The rapid decrease in the percentage of flakes in the larger size classes does suggest that relatively small raw materials were being reduced at the site. A total of 191 (47 percent) of the debitage collection consists of platformbearing flakes and proximal fragments. Among these specimens, single faceted ( $\mathrm{n}=94,49$ percent) and corticate $(\mathrm{n}=71,37$ percent) platforms are the dominant type (Figure 9d-4). Only 26 (14 percent) specimens have two or more platform facets. This pattern stands in strong contrast to debitage collections dominated by bifacial reduction, where multi-faceted striking platforms greatly outnumber corticate and single faceted specimens (Tomka 1989). These results indicate that bifacial reduction and biface manufacture was not a common activity at the site. Finally, the breakdown of

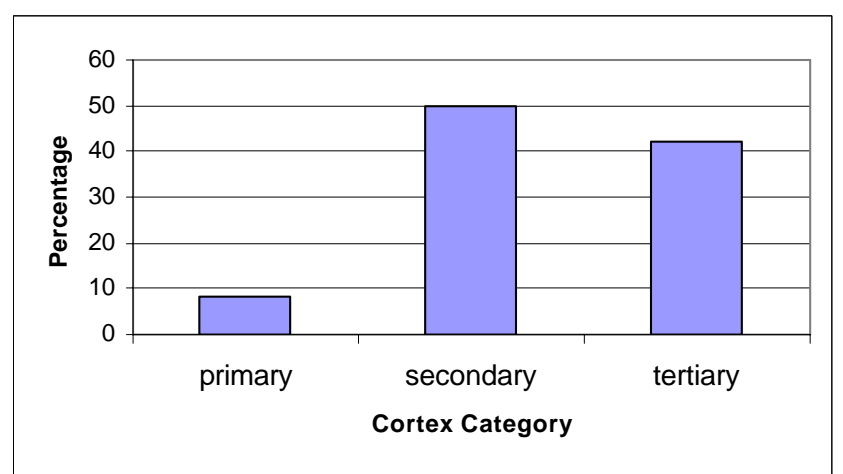

Figure 9d-2. Distribution of debitage cortex categories.

the debitage collection in terms of flake type indicates that 149 (37 percent) specimens could not be categorized into flake type categories. Among the remaining 257 flakes, core/ platform preparation flakes constitute the largest proportion of the sample (33.5 percent; Figure 9d-5). Flakes identified as clearly deriving from bipolar reduction represent ten

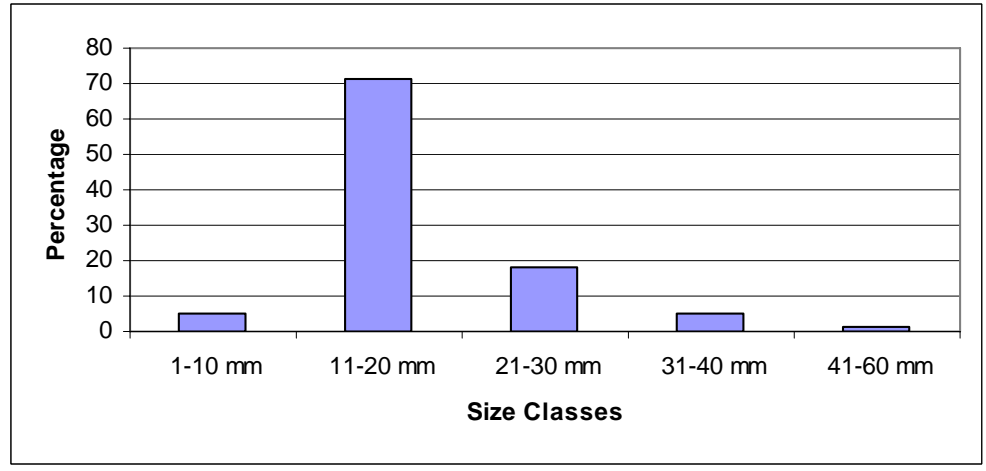

Figure 9d-3. Distribution of debitage by size classes.

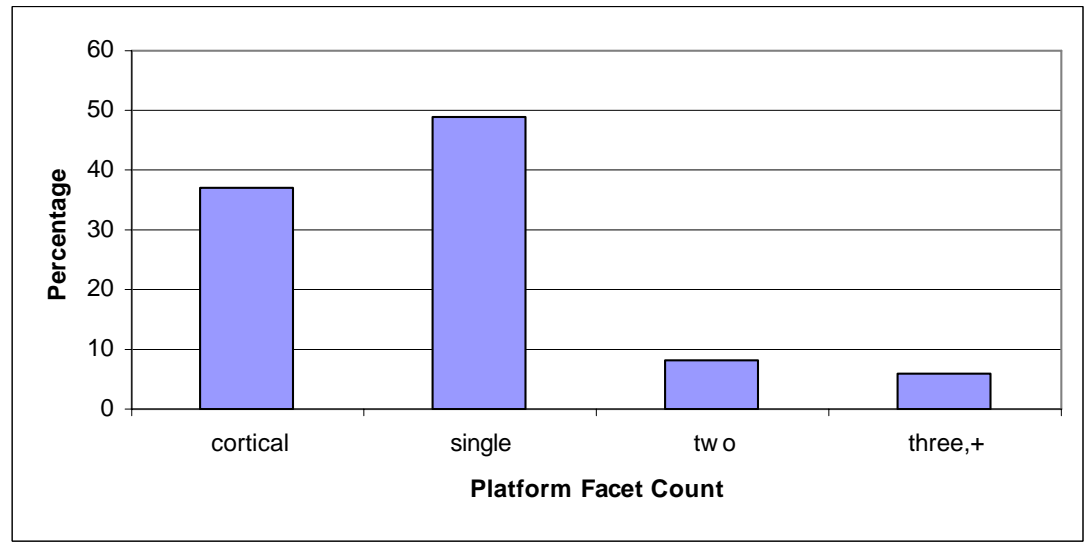

Figure 9d-4. Distribution of platform facet counts among platform-bearing flakes. 
percent of the collection, while possibly bipolar flakes constitute an additional 21 percent. If we consider the angular debris as also representing the by-products of bipolar reduction, debitage derived from this reduction strategy constitutes 53 percent of all the typed flakes from the 41RF1 collection. Flakes derived from uniface manufacture and/or rejuvenation represent 11 percent of the collection, while flakes derived from core reduction are infrequent (2 percent). As if to emphasize the contrast with debitage assemblages characterized by bifacial reduction, the 41RF1 collection contains only one biface thinning flake.

To explore the vertical and thereby temporal distribution of bipolar and possibly bipolar debitage, and angular debris, Figure 9d-6 shows the distribution of all flake types by analysis unit. Bipolar and possibly bipolar debitage is present and increases in numbers from the earliest to the latest analysis unit, but it is clearly most common in AU 3. Angular debris is also most common in AU 3. This pattern may suggest that some or all of the debitage attributed to bipolar reduction may be the product of mechanical disturbances. However, the fact that core/platform preparation and core reduction flakes are also most common in AU 3 suggests that perhaps the entire collection of debitage derives from a mixture of bipolar and free hand core reduction strategies.

For a more detailed look at the vertical distribution of debitage types, Figure $9 \mathrm{~d}-7$ shows the occurrences of bipolar, possibly bipolar, and angular debris combined compared to the other flake types (i.e., uniface, core reduction, core/ platform preparation), by excavation level. Level 2 contains deposits that may range from $0-20 \mathrm{cmbs}$ but often only include thin remnants of Level $1(0-10 \mathrm{cmbs})$, and even partial remnants of Level $2(10-20 \mathrm{~cm}$ bs). Levels 3-9 each consist of $10 \mathrm{~cm}$ thick deposits, while the last level shown $(10+)$ contains materials combined from Level 10 and below. Debitage that may be the by-product of bipolar reduction occurs in low numbers throughout the deposits, although it is most numerous in Level 2. Debitage derived from other reduction strategies has a bimodal distribution with a peak in Level 4 and a second peak in Level 2. The differences in the drop-off rates between the bipolar and other debitage by depth suggest different depositional histories. The depositional surface from which the bipolar material derives may have been somewhere between 0-20 cm bs. On the other hand, the depositional surface or surfaces that account(s) for debitage from other reduction strategies may incorporate all or parts of Levels 2 and 4.

\section{Summary and Conclusions}

The AU by AU and level by level debitage distributions suggest that the bipolar material derives either from the most recent historic occupation of the mission or is in large or small part the product of mechanical factors and may derive from road base laid down in recent times. The large number of bipolar and flake cores in AU 3 suggests that the materials from these non-feature units are most likely derived from the historic period occupation rather than representing road base. The differences in drop-off rates between bipolar and other debitage by depth, and the possible occurrence of a depositional surface between $0-20 \mathrm{cmbs}$, suggest that the most recent historic occupants of the mission practiced a reduction technique that was significantly different from those practiced by the earlier occupants of the mission. Bipolar reduction strategies are employed usually in response to limitations posed by small raw materials. As shown in the case of the cores, raw material size was small and probably remained constant through time since nodules probably originated from local sources. The fact that reduction strategies appear to have changed through time suggests that the factor responsible for this shift is cultural rather raw material size. Whether the shift in reduction strategies, however, represents a response to changes in landuse strategies or a change in the cultural affiliation of the latest occupants of the mission cannot be established from the lithic artifact.

Overall, the lithic technology evident in the 41RF1 assemblage indicates local or nearby raw material procurement, a tool kit composed primarily of expedient tool forms (e.g., scrapers), and the continued use of stone arrow points even though metal points appear to be replacing traditional raw materials and guns also appear to be part of the weapons technology. Raw material reduction strategies are dominated by bipolar hammer and anvil reduction to produce blanks. Bifacial reduction appears to be employed in arrow point manufacture and the shaping of some gunflint blanks.

The richness and diversity of lithic tool forms is rather limited in this small sample size. However, a look at the range of tool forms recovered from Mission San José by a number of previous excavations (e.g., Clark 1978, Clark and Prewitt 1979, Schuetz 1970, Hard et al. 1995, Tomka and Fox 1999) indicates a more diverse chipped stone assemblage consisting of "thumb-nail scrapers", minimally retouched end and side scrapers, a variety of edge-modified flakes (use worn but not retouched), spoke-shaves, gravers, 


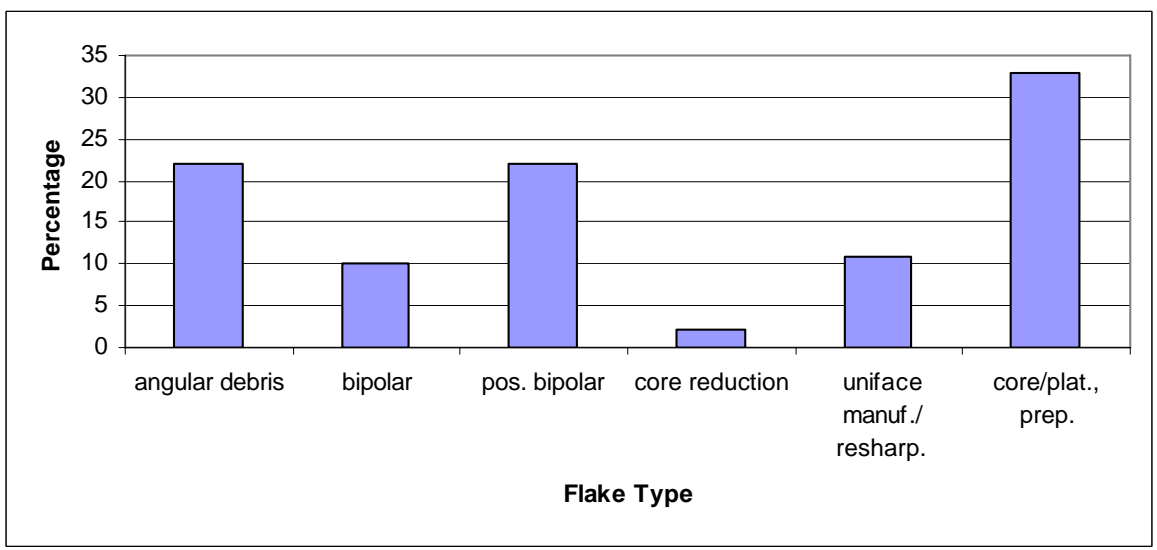

Figure 9d-5. Distribution of debitage by flake type.

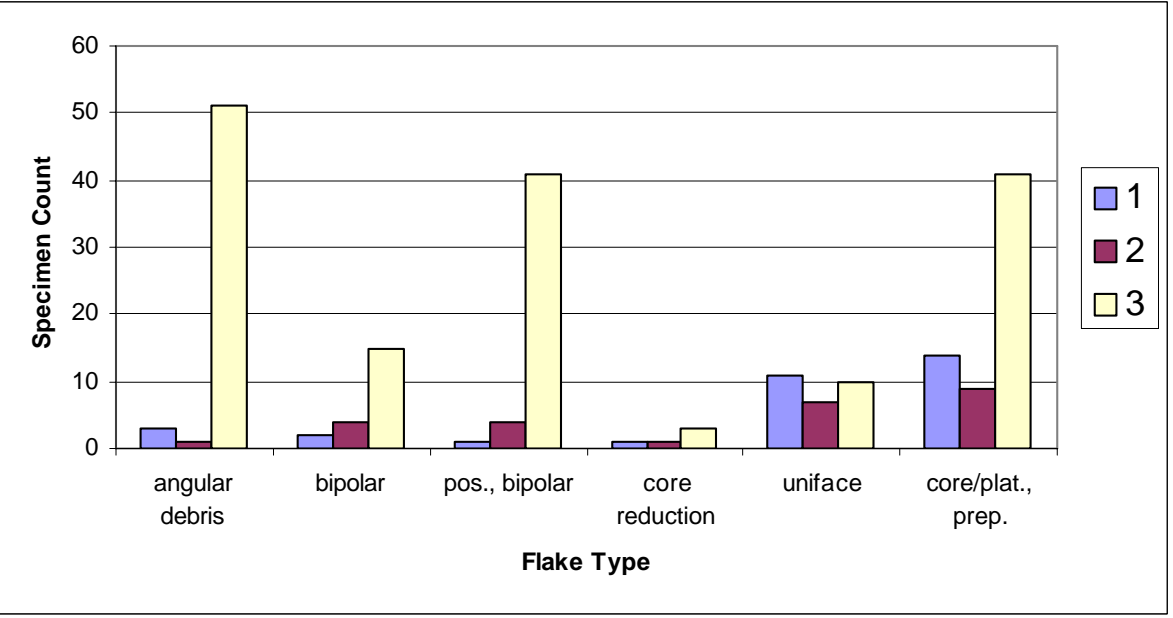

Figure 9d-6. Distribution of flake types by Analysis Unit.

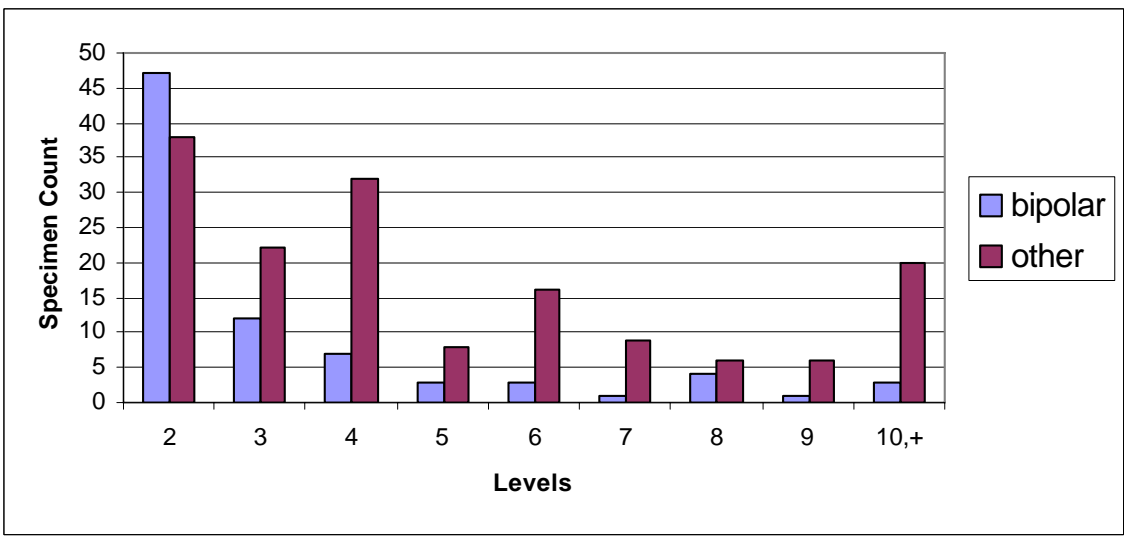

Figure 9d-7. Distribution of bipolar (bipolar, possibly bipolar, angular debris) and other (uniface, core reduction, core/platform preparation) debitage, by excavation level. 
perforators, indeterminate bifaces, arrow points, and gun flints. This range more accurately reflects the relative diversity of lithic tool forms that continued to be used by mission Indians and parallels the patterns noted by Hester $(1977,1989$ c, 1998) at the majority of the missions in south Texas.

The tool and debitage assemblages also indicate a deemphasis on the manufacture of bifacial tool classes. These patterns are in general agreement with patterns noted in many other parts of the country during the Late Prehistoric and Proto-Historic periods (Parry and Kelly 1987; Sullivan and Rosen 1985). Although, the shift from primarily bifacial reduction strategies to core technologies is attributed to decreased mobility (Parry and Kelly 1987:285), the shift to bipolar hammer and anvil reduction at 41RF1 may be reflective of either changes in cultural affiliation of occupants or may be a response to changing land-use strategies. Finally, the composition of the 41RF1 assemblage may reflect the use, availability, and long use-life of metal knives, some, even if limited, access to flintlock guns and, given the metal arrow points recovered from the site, the relatively common availability of materials for the manufacture of metal arrow points.

One of the questions raised by the research design that directed the various Refugio analyses was the influence of the frontier supply system on the material culture of the neophytes and missionaries living at the mission and relating to this -how did the availability of goods from Mexico affect Native American technology. If the sole chipped stone arrow point is an accurate indicator, the scarcity of stone tips does suggest that by the later date of Mission Refugio's habitation, the availability of metal for arrow points diminished the need for points made of stone. Metal knives, in turn, could have also reduced the number of expedient lithic cutting tools. If this was the case, however, even though metal artifacts have a limited life expectancy in buried contexts, perhaps we should expect more metal arrow points (three were recovered from the site) and knife fragments present in the collection. Overall, the stone tool collection and debitage from the site indicates that although Native American lithic technology was still practiced, some elements of the hunting (arrow points) and probably food processing (knives) technology were changing as a result of both changes in the lifeways of the neophytes as well as the influence of imported goods.

Of course, the presence of numerous gunflints in the collection may also be an indicator of the impact of outside influences on native hunting technology and could have further decreased the number of stone arrow tips manufactured at the mission, assuming that the guns were owned by the neophytes rather than by the missionaries. If instead, the guns were owned by resident missionaries, the native-made gunflints can be interpreted as a potential indicator of the degree of dependence of the missionaries on Native American craftsmen and technological systems to produce replacement gunflints for their firearms. Such an increased dependence would, in turn, signal the declining capacity of the frontier supply system to provision the mission and/or the calculated decision on the part of officials in Mexico City to not provide items such as gunflints when these could be locally made and such a dependence would further strengthen ties with Native American neophytes. 


\title{
Chapter 9: Artifacts - $\quad$ Section E
}

\section{Faunal}

\author{
Jennifer J. Z. Webber, J. Matthew Compton, and Elizabeth J. Reitz
}

Vertebrate faunal remains from Mission Nuestra Señora del Refugio (41RF1) were studied at the Zooarchaeology Laboratory, Georgia Museum of Natural History, University of Georgia. Faunal materials were divided into three temporal periods of slightly differing ages. The late-Colonial analytical unit, Unit 3 or non-feature units (AU 3), contained a vertebrate collection of 36,373 specimens weighing 94,703.07 $\mathrm{gm}$ with the remains of an estimated 83 individuals. Analytical Unit 1, Feature 1 (AU 1), the middle collection, contained 33,428 specimens weighing $154,244.74 \mathrm{gm}$ and an estimated 91 individuals. Analytical Unit 2 (AU 2) -the oldest of the collections is from Feature 2. It contained a vertebrate collection of 20,098 specimens weighing 113,129.01 gm with an estimated 79 individuals.

In general the analysis shows that over the 35-year life-span of the Mission, there was very little change in the dominant component of the subsistence strategy. Large bovids, primarily domestic cattle rather than bison, dominate all three units in terms of meat. Use of domestic individuals declines after the first few years of occupation, with domestic individuals contributing 56 percent of the non-commensal individuals in the earliest deposits compared to 39 percent of the non-commensal individuals in the post-Colonial deposits. The biomass contribution of domestic cattle does not decline over the occupation period, though the percentage of cattle individuals does decline from 23 percent to 18 percent of the individuals. Pig use increases somewhat, but sheep/goat and chickens decline in abundance. There is no change through time in the types of bovid elements represented in each unit or in the size of the large bovids. Over this same period of time, freshwater fish as a percentage of all fish individuals increases from 43 percent in the early part of the occupation to 70 percent of the individuals in the late part of the occupation. Marine fishes decline over this same time span from 57 percent to 30 percent of the fish individuals.

Missions are among the most interesting types of postColumbian sites to study. It was at missions that native peoples and colonizing Europeans, Africans, and Asians maintained face-to-face contact for prolonged periods of time. The intent of missions was specifically to change many facets of Native American life. Native Americans were attracted to or brought to missions for a number of reasons, but may not have planned to change as thoroughly as Spanish authorities intended. The premise of zooarchaeological studies of mission remains is that subsistence strategies must of necessity be conservative and that changes in foodways would be both slow to occur and signals of significant changes in other cultural systems. A review of zooarchaeological evidence from a number of colonial contexts shows that incorporation of European-introduced livestock into the subsistence strategies of Native Americans at colonial towns and missions was highly variable.

Studies at sixteenth and seventeenth-century Spanish towns and missions suggest that colonists experienced more changes in their foodways than did Native Americans. This is based on over 136,000 vertebrate specimens have been studied from Spanish and Native American sites in and around St. Augustine (Reitz 1985, 1991, 1992b; Reitz and Cumbaa 1983; Reitz and Scarry 1985). St. Augustine was founded in 1565 on the Atlantic coast of the Florida peninsula. These remains clearly indicate that Spanish foodways changed fundamentally in the colonial setting whereas Native American animal use at nearby missions remained unchanged in terms of actual taxa used. Changes in Native American fishing strategies did occur but were reflected more in the size of fishes used than in the taxa. Spanish diet was dominated not by domestic meat sources, but by wild meat sources, particularly fish.

St. Augustine and the surrounding missions were not unique in this regard. The second Spanish town was Santa Elena, established in 1566 on Parris Island, South Carolina (Reitz and Scarry 1985). Over 40,000 vertebrate specimens have been studied from this site. Domestic animals are extremely rare in the sixteenth-century component of this Spanish town. Most of the domestic animals are either chicken or pig; only a few cattle specimens have been recovered. Fish are much more common than domestic animals. Contemporary Native American collections from nearby locations have not been studied; but it is likely that Spaniards at Santa Elena altered their animal use habits more than Native Americans did.

Spanish missions outside of St. Augustine have a highly variable pattern regarding the use of European-introduced domestic animals and wild resources (Reitz 1990, 1993). At the seventeenth-century Apalachee mission of San Luis de Talimali, pork and beef were both more commonly used than wild resources, and beef dominated the meat-based 
portion of the diet. This is the only locality in Spanish Florida where domestic animals, particularly cattle, played such a prominent role. In fact, people at San Luis may have consumed more beef than residents at St. Augustine during this same time period. On the other hand, vertebrate faunal data from Timucuan missions in the central part of the north Florida peninsula indicate limited use of domestic animals along this portion of the mission chain. Unfortunately, faunal data are unavailable for the Spanish cattle ranches said to flourish nearby at this same time.

Particularly interesting among the Spanish missions is Mission Santa Catalina de Guale, on St. Catherines Island, Georgia. Analysis of 47,345 vertebrate specimens from Spanish contexts inside the seventeenth-century mission compound and 14,970 specimens from Native American contexts outside the mission compound demonstrates the unique nature of the Spanish adaptation to this island mission setting (Reitz 1990, 1993). As at St. Augustine, Native American subsistence continued without major alteration following a pattern initiated in the Archaic Period. Spanish subsistence, however, changed considerably. Unlike St. Augustine or Santa Elena, venison was the major meat source. Domestic animals are present but rare in both Spanish and Native American refuse on St. Catherines Island.

Studies at Native American locations not associated with missions indicate a great deal of variability in animal use (Reitz 1995). A review of the zooarchaeological evidence from seven sixteenth- and seventeenth-century Native American towns in Alabama and North Carolina finds no single pattern of resource use in the face of colonization and very little evidence of subsistence change. In particular, there is very little evidence for the adoption of domestic animals, including pigs, cows, or chickens. This is interpreted as evidence that European patterns of animal use were not an improvement upon native ones in many colonial environments and may not have been viable in others. A similar conclusion is supported by botanical data on plant use at these and other southeastern sites (Gremillion 1993, 1995, 1996).

This same degree of variability is found at Texas missions (e.g., Butler 1974; Davidson 1974; deFrance 1999). These missions are particularly relevant to the study of vertebrate remains from Mission Refugio because they are relatively close to Refugio. In her review of vertebrate materials from the two locations of Mission Espíritu Santo de Zuñiga and the site of Mission Nuestra Señora del Rosario, deFrance concludes that cattle ranching was an important activity, but that there was variation in the degree to which local resources were used. She attributes this to the ethnic composition at each mission. In particular, Mission Rosario served the Karankawa, who were said to be more committed to continuing their traditional hunting practices. Wild animals comprise a higher percentage of the faunal collection from Mission Rosario than they do in the two Mission Espíritu Santo de Zuñiga collections. The Karankawa may have continued a more traditional use of wild resources in spite of the missionary setting or because cattle obtained through the mission system were an unreliable food source. At both sites, element representation and bone modifications suggest on-site butchery of domestic cattle rather than off-site butchery of wild bison. The measured dimensions of large bovid elements also suggested that domestic cattle were more common at these missions. The missions reported by deFrance were established in the 1740s and functioned into the early nineteenth century.

Use of wild animals in an otherwise domestic-based diet is not necessarily confined to Native American or mission contexts. Wild animals are also found in urban areas occupied in the eighteenth and nineteenth centuries. Over 55,000 vertebrate specimens from Charleston, South Carolina, in addition to smaller samples from neighboring plantations, have defined patterns associated with rural and urban animal use (Reitz 1986a, 1987; Reitz and Ruff 1994; Reitz and Zierden 1991). High status households are more likely to make use of a greater variety of wild animals than are low status urban households. All urban households are likely to use fewer wild resources than are rural plantations, regardless of wealth and other signs of status or ethnicity. When compared to cattle from Spanish sites, morphometric data from Charleston indicate that cattle from these English and American sites are considerably smaller. Elements represented indicate that site function (residential, public entertainment, waste disposal) strongly influenced the specimens recovered; much more than either time period or status. Similar patterns have also been found in Savannah, Georgia (Reitz 1986a) and New Orleans, Louisiana (Reitz 1992a).

At one known Spanish site, cattle are particularly common and their by-products fulfilled an important economic role. At the Spanish town of Puerto Real, domestic or free-ranging cattle dominated the vertebrate assemblage to the virtual exclusion of all other animals. The town was founded between 1502 and 1505 on the north coast of Hispaniola (Deagan and Reitz 1995; Reitz 1986b; Reitz and McEwan 1995). It was officially abandoned in 1579 , largely because the north coast of Hispaniola and Puerto Real had became 
too successful in an international trade in cattle products. This alarmed Spanish authorities, who could not control the international shipping trade and opted to abandon the north coast instead. Cattle dominate the faunal assemblage. Local wild animals were consumed, but this use was extremely limited. The faunal collection from one of the areas studied, Locus 39, contained 71,179 vertebrate specimens. Most of the identifiable specimens were cattle carpals and tarsals, suggesting production of by-products such as tallow, in addition to hides. This specific location is interpreted as a processing area for beef products with some evidence of residential use. Beef was undoubtedly the major meat source at Puerto Real and cattle were an important part of the city's economy.

A clue to the success of the Caribbean cattle industry is provided by the measurement data, which indicate that the cattle of Puerto Real were much larger than those of Spanish Florida or English colonies along the North American Atlantic seaboard (Reitz and Ruff 1994). The large size of the Hispaniolan cattle and the extent to which they dominated the economic system at Puerto Real is attributed to environmental factors on the island; specifically, the lack of predators and competitors for an usually high-quality, abundant food and the relative lack of cattle diseases in the very early days of Spanish colonization. It had previously been assumed that the buccaneer trade began in the seventeenth century; but butchering patterns of the extremely large cattle of Hispaniola suggests otherwise.

The study of vertebrate materials from Mission Nuestra Señora del Refugio provides an opportunity to make a substantial contribution to refining the temporal and spatial dimensions of such data. Mission Nuestra Señora del Refugio (41RF1) is located on the southern edge of the town of Refugio in the Gulf Coast Prairie and Marsh region of southeast Texas. The mission was established for the coastal Karankawa in 1795 and operated until 1830. The site is on a terrace overlooking the Mission River, which is about 200 $\mathrm{m}$ away. The Karankawa were a coastal population who continued their subsistence round during the mission period, including the Mission in their seasonal round rather than using it as a permanent residence. The mission is roughly 25-30 miles from Copano Bay today. The Mission Refugio site expands the series of Spanish sites studied to include the Texas Gulf Coast and it extends the time line into the late eighteenth-early nineteenth centuries. The late date of the mission is particularly important as most of the other Spanish data are from sites abandoned in the eighteenth century.

\section{Research Questions}

Several research questions derived from the review summarized above guide the study of the vertebrate remains from Mission Refugio. These focus on testing the hypotheses that access to cattle declined at Mission Refugio over the period of occupation and that the dense deposit of animal bones encountered represents general refuse disposal rather than strictly butchering or kitchen refuse. Explanations for the possible reduction in access to cattle would be provided by research in other areas. For example, evidence for drought would be available from pollen and phytoliths. Archival information on cattle ranching, cattle raiding, Crown acquisition of unbranded cattle, the availability of trained personnel for cattle herding, and other aspects of herd management are being sought elsewhere.

Although cattle ranching was considered highly successful, and the size of cattle herds extremely large in this area, much of the dominance of cattle herding occurred in the eighteenth century (deFrance 1999). By 1795, when Mission Refugio was founded, the number of cattle was generally much reduced. Spanish and Native American access to cattle, therefore, may have been more limited at Mission Refugio than it was at earlier missions. Factors which might have contributed to the reduction in cattle are numerous, including drought, overgrazing, cattle raiding, taxation, intentional herd reductions to start herds elsewhere, privatization of herd lands, and unskilled cattle herders (deFrance 1999). If any of these factors caused access to cattle to decline between 1795 and 1830, we might expect to find cattle decrease from a higher proportion of the individuals in the early occupational levels to a lower proportion in the lateColonial ones. To test this hypothesis, the quantity of domestic cattle in the Mission Refugio assemblage will be compared to that at the missions reported by deFrance. Testing this hypothesis will be complicated by the difficulty in distinguishing between wild bison and domestic cattle specimens; a problem which will be discussed in more detail.

Mission Refugio served the Karankawa, who used the mission as a resource base in their larger foraging territory. If the Karankawa experienced limited access to beef while at the mission, they may have emphasized their traditional subsistence strategy. If the availability of cattle did decline between 1795 and 1830, the percentages of traditional wild vertebrate species, such as bison and deer, might increase in the Mission Refugio faunal assemblage. Use of small domestic livestock such as chickens, pigs, sheep, and goats might increase as well. We might, therefore, expect either 
wild animals or small livestock, or both, to be more common in the late-Colonial deposits compared to the early deposits at the mission.

The second hypothesis is related to preliminary testing which indicated that a large quantity of faunal material would be found in the area for which excavation was proposed. The original hypothesis was that a bone bed would be discovered just beyond the mission walls, perhaps with gaps in the bed indicating the location of a mission gate. This hypothesis was altered as the result of the fieldwork, which indicated that there were actually two large trash pits filled with bone overlaid by a sheet deposit of bone.

A revised hypothesis for the dense bone deposit at the site is that the refuse represents butchering debris discarded just beyond the mission walls. If the deposit represents primary butchering debris we might expect to see large numbers of elements representing portions of the carcass not associated with large amounts of meat. Specifically, butchering debris might include primarily specimens from the head and feet. If the dense deposit of bone is largely kitchen refuse we should expect to find specimens from more meaty portions of the carcass such as the scapula, humerus, thoracic and lumbar vertebrae, proximal rib sections, pelvis, and femur. Kitchen refuse should have numerous butcher marks associated with preparation for individual and family serving portions. Such kitchen refuse might include a much higher percentage of burned bone than refuse that is primarily discarded during butchering. However, burned fragments can also be the by-product of burning trash to control vermin and odors. If the bone deposit is the result of general trash disposal it might contain both butchering and kitchen refuse and the fragments should contain both the modifications associated with large-scale butchering and the finer modifications associated with secondary food preparation.

The problems inherent in distinguishing between bison and cattle specimens limit the strength of arguments which rely upon this identification. In particular, identifying a pattern in which wild bison increase and domestic cattle decrease in the assemblage is complicated by this procedural difficulty. As a proxy for a species-level identification, element distribution will be considered. It is possible that bison would be field-dressed and primary butchery would take place away from the mission. In that case, an absence of elements from the lower leg and the head might indicate that most of the large bovid remains represent hunted bison. Slaughter and butchery of domestic cattle might be characterized by more primary butchery taking place near the mission and a higher presence of meaty skeletal portions. Measurements will also be evaluated for evidence of large bison versus smaller cattle, presuming that cattle in this area were smaller than bison.

\section{Methods}

The fieldwork, which produced the vertebrate samples reported here, was conducted in 1997 and 1998 under the direction of the Center for Archaeological Research, The University of Texas, San Antonio.

The excavated area consists of a string of 1-x-1 m squares excavated in $10 \mathrm{~cm}$ increments or by stratigraphic level along the road's eastern edge. Soil was screened through $1 / 4$-inch hardware cloth to recover materials. Three analytical units were defined based on associated artifacts and context. Analytical Unit 3 is non-feature materials from the lateColonial period occupation of the site. These late-Colonial materials cover the upper $40-50 \mathrm{~cm}$ of the site. Analytical Unit 1 includes Feature 1 and non-feature materials below the stratigraphic lime layer. Analytical Unit 2 is Feature 2. Feature 1 and Feature 2 are trash pits. Feature 1 is slightly earlier than the late-Colonial occupation of Analytical Unit 3 and Feature 2 is the earliest occupation represented by the excavated materials. Both of the features are large trash pits 4 to $5 \mathrm{~m}$ in diameter. A listing of the samples reported here is included in Appendix M.

Vertebrate remains were identified using standard zooarchaeological methods. Identifications were accomplished by J. Matthew Compton, Amanda McDaniel, Kelly Orr, Barnet Pavao-Zuckerman, and Jennifer Webber using the comparative skeletal collection of the Zooarchaeology Laboratory, Georgia Museum of Natural History, University of Georgia. A number of primary data classes are recorded. Specimens are identified in terms of elements represented, the portion recovered, and symmetry. The Number of Identified Specimens (NISP) is determined. Those specimens that cross-mended are counted as single specimens though they are not actually glued together. The only exception to these procedures is the UID (unidentified) Vertebrate category. Specimens in this category are not counted due to their fragmented condition. All specimens are weighed to provide additional information about the relative abundance of the taxa identified. Indicators for sex, age at death, and modifications are noted where observed. The Minimum Number of Individuals (MNI) is estimated based on paired elements and age. 
Members of the family Bovidae present some special problems in the identification and analysis of these materials. The first of these problems relates to the issue of taxonomy. The family Bovidae includes large species, bison (Bison bison) and cow (Bos taurus), and small species, goat (Capra hircus) and sheep (Ovis aries). Bos bison is a synonym of Bison bison and several recent authorities advocate placing bison in the genus Bos (Nowak and Paradiso 1989:1254; Wilson and Ruff 1999:342-343). Bos bison will be used here, as it is the more familiar designation for bison. The family name, Bovidae, is often anglicized as bovid. The large bovids that might be identified at Mission Refugio are members of the subfamily Bovinae, anglicized as bovine, and the small bovids are members of the subfamily Caprinae, anglicized as caprine. It is therefore possible to refer to all of these animals as bovids, or to bovines (referring only to the large bovids) and caprines (referring only to the small bovids). One might also refer to domestic bovids (cow, goat, and sheep) or wild bovids (bison). All bovids are members of the order Artiodactyla, which is distinct from the order Perissodactyla in which horses and burros are classified. Artiodactyls also include pronghorns (Antilocapra americana), peccaries (Tayassu tajacu), and pigs (Sus scrofa). Peccaries and pigs are members of the same suborder, Suiformes. When it is not possible to identify a specimen to a lower category, such as genus or species, it may be possible to use a higher level taxonomic category such as Suiformes rather than refer the specimen to Artiodactyla or UID Mammal.

Because of the strong probability that both bison (Bison bison) and cow (Bos taurus) were used by the residents of Mission Nuestra Señora del Refugio, special attention was paid to the identification of large bovid specimens. Comparative reference skeletons as well as Balkwill and Cumbaa's (1992) guide to the identification of cow and bison postcranial elements were used to identify the large bovid specimens. Brown and Gustafson (1979), Lawrence (1974), and Olsen (1960) were also available for consultation, though their criteria are included in Balkwill and Cumbaa's work. Balkwill and Cumbaa provide a weighted success rate for the characters these other researchers have proposed to distinguish between bison and cow skeletal elements. Only a few of the Balkwill and Cumbaa characters achieve a 100 percent success rate for distinguishing between bison and cow. For this reason, all bovine specimens from the mission identified beyond the subfamily (Bovinae, Bison sp. or Bos sp.) are identified only tentatively, indicated as probable bison (Bison cf. bison) or cow (Bos cf. taurus) on the accompanying species lists. Certain elements of the bovine skeleton are more identifiable to species than others.
Therefore, whether a specimen is identified to Bovinae, bison, or cow is related primarily to the element represented. Because of this problem, most specimens are identified to the subfamily Bovinae and it is this taxonomic category that is used in subsequent analysis. MNI is estimated for Bovinae, probable bison, and probable cow. However, because the MNI for Bovinae is consistently larger than the MNI estimated for the specific identifications, only the MNI estimate for Bovinae is used in subsequent calculations. The MNI estimates for bison and cow are placed in parentheses but these data are not used in the analysis. None of the other data from the lower taxonomic data are duplicated at the subfamily level.

Two similar identification problems are present in the Mission Refugio assemblage. Equids are extremely difficult to identify to species except from a limited number of diagnostic skeletal elements. Horse, mule, and burro are almost identical in their osteology. In this case, these specimens are identified to the genus Equus sp. It is also difficult to differentiate between the osteological remains of domestic sheep (Ovis aries) and goat (Capra hircus). The subfamily designation Caprinae is used in the following tables to denote that the specimen can be identified only as either from a domestic sheep or goat. As with the Bovinae, MNI estimates for the lower taxonomic level are indicated on the species lists in parentheses but are not used in the analysis.

Some molluscan fragments are present in the samples studied, but these clearly represent only a small fraction of the total molluscan assemblage. The molluscs in the samples studied at the University of Georgia are included in the accompanying species lists, but are not considered further.

While MNI is a standard zooarchaeological quantification method, the measure has several well-known biases. For example, MNI emphasizes small species over larger ones. This can be demonstrated in a hypothetical sample consisting of twenty chickens and one deer. Although twenty chickens indicate emphasis on the exploitation of chicken, one deer could supply more meat. Further, some elements are more readily identifiable than others. The taxa or skeletal region represented by these elements therefore may be incorrectly perceived as more significant in the diet than animals with less distinctive elements. Horn core fragments, readily identified from very small fragments, illustrate this problem. Conversely, some taxa represented by large numbers of specimens may present few paired elements and hence the number of individuals for these species may be 
underestimated. Snakes and gars are good examples of this last problem. MNI for these animals will usually be underestimated relative to the number of specimens. Basic to $\mathrm{MNI}$ is the assumption that the entire individual was utilized at the site. From ethnographic evidence, it is known that this is not always true (Perkins and Daly 1968). This is particularly the case for larger individuals, animals used for special purposes, and where food exchange is an important economic activity (Thomas 1971; White 1953).

Occasionally, the number of individuals estimated for a species is smaller than the number of individuals estimated for a higher taxonomic level such as subfamily or family. For example, the estimated MNI for Anatidae (swans/geese/ ducks) might be five while the estimated MNI for geese might be two. In these cases, the MNI for the lower taxonomic category is noted in parentheses in the species list and the larger MNI is used in quantification. The parenthetical number is not used in subsequent calculations.

In addition to these primary biases, MNI is also subject to secondary biases introduced by the way samples are aggregated during analysis. The aggregation of archaeological samples into analytical units (Grayson 1973) allows for a conservative estimate of MNI, while the "maximum distinction" method, applied when analysis discerns discrete sample units, results in a much larger MNI. MNI is estimated for the Mission Nuestra Señora del Refugio assemblage using the three analytical units as the basic divisions. Within each analytical unit, primary data pertaining to materials from all excavated units, levels, and other contexts are combined for the estimation of MNI and other derived measures.

Biomass estimates are a way to compensate for some of the problems encountered with MNI for dietary reconstruction. Biomass refers to the quantity of tissue a specified taxon might have supplied. Predictions of biomass are based on the allometric principle that the proportions of body mass, skeletal mass, and skeletal dimensions change with increasing body size. This scale effect results from a need to compensate for weakness in the basic structural material, in this case bones and teeth. The relationship between body weight and skeletal weight is described by the allometric equation:

$$
Y=a X^{b}
$$

(Simpson et al. 1960:397). In this equation, $\underline{X}$ is specimen weight, $\underline{\mathrm{Y}}$ is the biomass, $\underline{\mathrm{b}}$ is the constant of allometry (the slope of the line), and a is the Y-intercept for a log-log plot using the method of least squares regression and the best fit line (Reitz and Wing 1999:221-231). Many biological phenomena show allometry described by this formula (Gould 1966, 1971) so that a given quantity of skeletal material or a specific skeletal dimension represents a predictable amount of tissue or body length due to the effects of allometric growth. Values for $\underline{a}$ and $\underline{b}$ are derived from calculations based on data at the Florida Museum of Natural History, University of Florida, and the Georgia Museum of Natural History, University of Georgia. Allometric formula for alligators was derived from data at the Florida Museum of Natural History, the Georgia Museum of Natural History, and Louisiana State University (Keck 1999). Allometric formulae for biomass estimates are not currently available for amphibians or lizards so biomass is not estimated for these groups. The allometric formulae used in this study are presented in Table 9e-1.

The species identified from 41RF1 are summarized in faunal categories based on vertebrate class. This summary contrasts the percentage of various groups of taxa in the assemblage. These categories are Sharks, Rays, and Fishes; Alligator/ Turtle; Wild Birds; Domestic Birds; Deer; Bovinae; Other Wild Mammals; Other Domestic Mammals; and Commensal Taxa. In order to make comparisons of MNI and biomass estimates possible, the summary tables include biomass estimates only for those taxa for which MNI is estimated.

Commensal taxa are listed in Table 9e-2. Determining which animals are commensal and which are not is very difficult. Elements represented, skeletal completeness, and modifications may help; but often the data are equivocal and require making a decision with little evidence. Often these decisions are made on the basis of our own personal food preferences, which are biased against small wild animals and animals that are now pets. However, there is clear evidence in the ethnographic and archaeological record, particularly from coprolites, that many such animals were consumed (e.g., Sobolik 1993; Szuter 1994). In the absence of evidence to the contrary, the decision criterion used here is to exclude from the Commensal category almost all animals except ones which seem most unlikely based on several specific criteria. To be included in the Commensal category, an animal had to be commonly found in close association with humans, their gardens, stored goods, and other parts of their built environment without the intervention of humans. Commensal animals are ones that people either do not encourage or actively discourage. A few animals are commensal at some times and food at others, such as hares and rabbits, and these are classified as food animals. These 
Table 9e-1. Allometric regression formulae used in study

\begin{tabular}{lllll}
\hline & \multicolumn{2}{l}{ N Slope (b) } & Y-intercept (a) \\
\hline Constants for the allometric regression lines describing the relationship between skeletal weight and \\
tissue weight:
\end{tabular}

Note: Key to abbreviations: Formula is $\mathrm{Y}=\mathrm{aX}{ }^{\mathrm{b}}$; where $\mathrm{Y}$ is total weight; $\mathrm{X}$ is skeletal weight; $\mathrm{a}$ is the $\mathrm{Y}$-intercept; $\mathrm{b}$ is the slope; and $\mathrm{N}$ is the number of observations (Keck 1999; Reitz and Cordier 1983; Reitz et al. 1987; Reitz and Wing 1999:72).

are animals we might consider famine foods, ones other people are known to eat, but which we prefer to avoid if we can. Commensal animals may also be present at the site as pets and work animals with their remains tossed out on the trash when they died. Horse/burro is included as commensal because, although such animals may have been eaten, they were probably too valuable as work animals to eat - though there is ample evidence that equids were (and are) consumed elsewhere. Several animals are excluded from the commensal category that might have been commensal. This is particularly likely for some of the wild birds.

The presence or absence of elements in an archaeological assemblage provides data on animal use such as butchering practices and transportation costs. The horse/burro and artiodactyl elements identified at 41RF1 are summarized into categories by body parts. The Head category includes only skull fragments, including antlers, horn cores, and teeth. The atlas and axis, along with other vertebrae and ribs, are placed into the Vertebra/Rib category. It is likely the Head and Vertebra/Rib categories are under-represented because of recovery and identification difficulties. Unless distinctive morphological features support such identifications, vertebrae and ribs of deer-sized animals cannot be identified as deer (Odocoileus virginianus), pronghorn (Antilocapra americana), peccary (Tayassu tajacu), pig (Sus scrofa), or sheep/goat (Caprinae). Likewise, vertebrae and ribs of cowsized animals cannot be identified as bison (Bison cf. bison), cow (Bos cf. taurus), or horse/burro Equus sp.) without distinctive features. Usually these features are not apparent and specimens from these elements are classified as UID
Mammal because a number of non-artiodactyls (e.g., bear) fall into the size-range of artiodactyls. Forequarter includes the scapula, humerus, radius, and ulna. Carpal and metacarpal specimens are presented in the Forefoot category. The Hindfoot category includes tarsal and metatarsal specimens. The Hindquarter category includes the innominate, sacrum, femur, patella, and tibia. Metapodiae and carpal/tarsal specimens which could not be assigned to one of the other categories, as well as sesamoids and phalanges, are assigned to the Foot category.

In general, elements from these portions of the skeleton are related to meat yield. The Axial, Forequarter, and Hindquarter categories are associated with higher meat yield than are the other categories. However, elements from the lower leg (Forefoot, Hindfoot, and Foot) might be valued

Table 9e-2. Taxa classified as commensal

\begin{tabular}{ll}
\hline Scientific Name & Common Name \\
\hline Anura & Frogs and toads \\
Bufonidae & Toads \\
Colubridae & Non-poisonous snakes \\
Crotalinae & Pit vipers \\
Crotalus sp. & Rattlesnakes \\
Mimidae & Mockingbirds and thrashers \\
Emberizidae & Perching birds \\
Scalopus aquaticus & Eastern mole \\
Geomys sp. & Pocket gopher \\
Heteromyidae & Pocket mice \\
Muridae & New and Old World rats and mice \\
Murinae & Old World rats and mice \\
Mephitinae & Skunks \\
Felis domesticus & Domestic cat \\
Equus sp. & Horse/burro \\
\hline
\end{tabular}


for their manufacturing potential. For example, metapodials are often modified into tools and ornaments as are phalanges. Likewise, the cranium is a container for brains, which are valuable in tanning hides. Crania might also be valued because of horn and antlers. All bone refuse could also be boiled for tallow and glue, though specimens boiled long enough to remove the collagen that forms glue would undoubtedly not survive in the archaeological record (Deagan and Reitz 1995).

The elements identified as artiodactyls are also presented visually to illustrate their number and location in a carcass. Loose teeth, tooth fragments, hyoids, and some skull fragments are not illustrated. Although the atlas and axis fragments are accurately depicted, other cervical, thoracic, lumbar, caudal vertebrae, and ribs are placed approximately on the illustration. The last lumbar location is used to illustrate vertebrae, which only could be identified as vertebrae. Specimens identified only as sesamoids, metapodiae, podials, or phalanges are illustrated on the right hindfoot.

The archaeological pig, deer and bovine (Bovinae) element data are compared to the distribution of elements in a complete, undisturbed skeleton using a ratio diagram (Simpson 1941; Reitz and Wing 1999:211-213; Reitz and Zierden 1991). Described by George Simpson (1941; Simpson et al. 1960:357-358), the formula is as follows:

$$
d=\log _{e} X-\log _{e} Y \text { or } d=\log _{e}(X / Y)
$$

where $\underline{\mathrm{d}}$ is the logged ratio, $\underline{X}$ is the percentage of each element category in the archaeological collection, and $\underline{Y}$ is the same percentage of this category in the standard, unmodified skeleton of the reference animal. It does not matter to what base the measurements are converted, though one should be consistent in order to remain comparable. As Simpson (1941:23) describes this approach:

The basic purpose of the diagram is to represent each of a number of analogous observations by a single entry and to plot them in such a way that the horizontal distance between any two of them will represent the ratio of either one of those two to the other.

In order to compare the archaeological data with the standard animal, the percentages of each element category for the standard animal are converted into logarithms, subtracted from the logged value of the same element category for the archaeological percentages, and plotted against the standard animal represented by the vertical line as a base for comparison. Although the archaeological values are specimen counts and the values for the standard reference animal are whole elements, the relationships in the ratio diagrams are similar to those found in unmodified histograms. Only specimens identified as Bovinae are included in the log ratio calculations; probable bison (Bison cf. bison) and probable cow (Bos cf. taurus) are not included.

Relative ages of the artiodactyls identified are estimated based on observations of the degree of epiphyseal fusion for diagnostic elements and tooth eruption data (Severinghaus 1949). When animals are young their elements are not fully formed. The area of growth along the shaft and the end of the element, the epiphysis, is not fused. When growth is complete the shaft and the epiphysis fuse. While environmental factors influence the actual age at which fusion is complete (Watson 1978), elements fuse in a regular temporal sequence (Gilbert 1973; Purdue 1983; Schmid 1972). During analysis, specimens are recorded as either fused or unfused and placed into one of three categories based on the age in which fusion generally occurs. Unfused elements in the early-fusing category are interpreted as evidence for juveniles; unfused elements in the middlefusing and late-fusing categories are usually interpreted as evidence for subadults, though sometimes characteristics of the specimen may suggest a juvenile. Fused specimens in the late-fusing group provide evidence for adults. Fused specimens in the early- and middle-fusing groups are indeterminate. Clearly fusion is more informative for unfused elements which fuse early in the maturation sequence and for fused elements which complete fusion late in the maturation process than it is for other elements. An early-fusing element, which is fused, could be from an animal, which died immediately after fusion was complete, or many years later. The ambiguity inherent in age grouping is somewhat reduced by recording each element under the oldest category possible.

The sex of animals is an important indication of animal use; however, there are few diagnostic indicators of sex. Males are indicated by the presence of spurs on the tarsometatarsus of chickens and turkeys and antlers on deer. Male turtles are indicated by a depression on the plastron to accommodate the female during mating. Females are recognized by the absence of these features. Female birds may also be identified by the presence of medullary bone (Rick 1975). Another approach is to compare measurements of identified specimens for evidence of elements that fall 
into a male or female range, though there are rarely sufficient numbers of measurements to reliably indicate sex.

Modifications can indicate butchering methods as well as site formation processes. Modifications from the Mission are classified as burned, calcined, hacked, cut, sawed, cleancut, worked, grooved and snapped, pathological, carnivoregnawed, and rodent-gnawed. While NISP for specimens identified as UID Vertebrate is not included in the species lists, the number of modified UID Vertebrate specimens is included in the modification tables. Worked specimens, such as grooved and snapped, show evidence of human modification for reasons probably not associated with butchery or food preparation and are described in more detail below, as are the pathological specimens. In some cases, the grooved and snapped specimens had clearly been modified by this method as part of the butchering process.

Burned specimens may result from exposure to fire when a cut of meat is roasted. Burns may also occur if specimens are burned intentionally or unintentionally after discard. Burning at extreme temperatures can cause calcination, usually indicated by blue-gray discoloration. However, calcination can also occur by leaching of calcite from shell deposits, resulting in a hardened specimen, which is virtually indistinguishable from calcined specimens caused by exposure to heat. Both types of calcination probably occurred in this assemblage, but no attempt was made to distinguish between them.

Other modifications are associated with butchery rather than food processing and disposal. Hack marks are evidence that some larger instrument, such as a cleaver, was used. Presumably, a cleaver, hatchet, or ax would have been employed as the carcass was being dismembered rather than after the meat was cooked. The use of a large chopping tool would result in bone splinters and probably larger cuts of meat than a knife. Cuts are small incisions across the surface of specimens. These marks were probably made by knives as meat was removed before or after the meat was cooked. Cuts may also be left on specimens if attempts are made to disarticulate the carcass at joints. Some marks that appear to be made by human tools may actually be abrasions inflicted after the specimens were discarded, but distinguishing this source of small cuts requires access to higher powered magnification than was available during this study (Shipman and Rose 1983). Specimens sawed with a metal tool have characteristic flat surfaces textured with parallel grooves on the outer layer of compact bone left by a serrated blade. This presumably occurred before the meat was cooked. Specimens designated as clean-cut have flat surfaces but do not have the striations characteristic of sawing typically because the compact bone layer was too thin in the area being modified. Clean-cut specimens may have been sawed but do not show the evidence for it. Another type of modification is termed grooved and snapped. In these cases a deep cut was made through much of the body of the specimen, at least half way through the medullary cavity, and the remainder of the specimen was broken off. The cut does not show the striations associated with the use of a metal saw, even though an adequate compact bone layer exists. These groove and snapped specimens also do not appear to be produced by a heavy instrument such as a hatchet. They might be produced by a heavy knife such as a machete or a large butcher knife used in a sawing motion.

Gnawing by rodents and carnivores indicate that specimens were not immediately buried after disposal. While burial would not insure an absence of gnawing, exposure of specimens for any length of time might result in gnawing. Rodents would include such animals as squirrels, mice, and rats. Carnivores would include such animals as dogs and raccoons. Gnawing by carnivores and rodents would result in loss of an unknown quantity of discarded material. Kent (1981) demonstrates that some specimens gnawed by carnivores such as dogs may not necessarily have any visible sign of such gnawing and yet the specimens would quite probably be removed from their original context.

Specimen count, MNI, biomass, and other derived measures are subject to several common biases (Casteel 1978; Grayson 1979, 1981; Wing and Brown 1979). In general, samples of at least 200 individuals or 1,400 specimens are needed for reliable interpretations. Smaller samples frequently will generate a short species list with undue emphasis on one species in relation to others. It is not possible to determine the nature or the extent of the bias, or correct for it, until the sample is made larger through additional work. When comparison among different time periods and activity areas is required, it is desirable that the samples being compared be of roughly comparable size.

Specimen count, MNI, and biomass also reflect identifiability. As discussed above, elements of some animals are simply more readily identified than others and the taxa represented by these elements may appear more significant in terms of specimen count than they were in the diet. If these animals are identified largely by unpaired elements, such as scales and cranial fragments, the estimated MNI for these taxa will be low. At the same time, animals with many 
highly diagnostic but unpaired elements will yield a high specimen weight and biomass estimate. Hence high specimen count, low MNI, and high biomass for some animals are artifacts of analysis. This source of bias is particularly critical to interpretations of the role of snakes and gar in the subsistence strategies reflected in the Mission assemblage.

One method which addresses this bias compares variety and degree of specialization by measuring the diversity and equitability of the species identified from a site (Hardesty 1975; Reitz and Wing 1999:233-235). Diversity measures the number of species used. Equitability measures the degree of dependence on the utilized resources and the effective variety of species used at the site based on the even, or uneven, use of individual species. These indices allow discussion of food habits in terms of the variety of animals used at the site (richness or diversity) and the equitability (evenness) with which species were utilized.

To measure diversity, the Shannon-Weaver Index is used. The formula for the index is:

$$
H=-\sum p_{\mathrm{i}} \log _{\mathrm{e}} p_{\mathrm{i}}
$$

where $\mathrm{p}_{\mathrm{i}}$ is the number of the ith species, divided by the sample size (Pielou 1966; Shannon and Weaver 1949:14). $\underline{P}_{i}$ is actually the evenness component since the ShannonWeaver Index measures both how many species were used and how much each was utilized.

Equitability is calculated using the formula:

$$
V=H=/ \log _{e} S
$$

where $\underline{V}=$ is the Diversity Index and $\underline{\log }_{\mathrm{e}} \underline{\mathrm{S}}$ is the natural $\log$ of the number of observed species (Pielou 1966; Sheldon 1969).

Interpreting the indices can be difficult. Diversity increases as both the number of species and the equitability of species abundance increases. A diversity index of 4.99 is the highest possible value. A sample with many species identified and in which the number of individuals slowly declines from most abundant to least abundant will be high in diversity. Diversity can be increased by adding a new taxon to the list, but if another individual of an already present taxon is added, diversity is decreased. A low diversity can be obtained either by having few species or by having a low equitability, where one species is considerably more abundant than others. A low equitability value indicates that one species was more heavily used than other species in the sample. A high equitability index, approaching 1.0, indicates an even distribution of species in the sample following a normal pattern with a few abundant species, a moderate number of common ones, and many rare ones. In the following discussions of vertebrate remains from 41RF1, diversity and equitability were calculated for both MNI and biomass. In the case of MNI, estimates of individuals were taken directly from the species lists. Biomass represents a different problem because biomass was estimated for more taxonomic levels than MNI. It was considered important to calculate biomass diversity and equitability using the same taxonomic units used to calculate these values for MNI. For this reason, only those biomass estimates for taxa for which MNI was estimated were included in the biomass diversity and equitability calculations. For example, in calculating biomass diversity and equitability, Nycticorax sp. was used rather than Ardeidae. This ensures that when comparing biomass and MNI diversity results, exactly the same observations were used in both cases.

Measurements are often useful in identifying problematic taxa as well as in assessing animal husbandry strategies. Measurements for mammals and birds are recorded following the guidelines established by Angela von den Driesch (1976) and are presented in Appendix M. Measurements of the large bovids (Bovinae, Bison cf. bison, Bos cf. taurus) are used in log ratio diagrams (Reitz and Ruff 1994; Reitz and Wing 1999:175-179). This is the same formula used for element representation. The formula is as follows:

$$
d=\log _{e} X-\log _{e} Y \text { or } d=\log _{e}(X / Y)
$$

where $\underline{\mathrm{d}}$ is the logged ratio, $\underline{X}$ is the mean of the archaeological dimension, and $\underline{Y}$ is the same percentage of this category in the standard, reference animal. In this case, the standard animal is a modern, six-year-old, $272 \mathrm{~kg}$ Holstein female (GMNH \#1186) from the Georgia Museum of Natural History's Zooarchaeology Laboratory. This animal is small for modern females of this breed (Rouse 1973:426). Positive values are larger than the standard and negative values are smaller than the standard. 


\section{Results, Analytical Unit 1: Feature 1 and Non-Feature Materials Below the Lime Layer}

Feature 1 (AU 1) contains 33,428 identified specimens weighing 154,244.74 gm (Table 9e-3). A minimum of 91 individuals is estimated for 40 taxa. The dominant characteristic of this collection is also the number of large bovids, though the collection contains other taxa as well. The specimens are in good condition and the sample size appears adequate in spite of the small MNI estimate. Additional data from this unit would probably not add many additional taxa.

Only five UID Mollusca fragments are present in Feature 1 (Table 9e-3). None of the mollusc fragments are modified. These data undoubtedly do not represent the total molluscan collection from this analytical unit and they will not be considered further.

Fishes constitute 14 percent of the individuals in the Feature 1 collection and less than 1 percent of the biomass (Table 9e-4). Gar (Lepisosteus sp.) contribute a small percentage of the collection's NISP. Gar MNI is probably underestimated because of the high number of scales (NISP $=56$ ) and unpaired elements, skull fragments, and vertebrae (NISP $=9$ ) does not provide the evidence needed to estimate more than a single individual, but the count suggests that there may have been more. Catfishes (Ictaluridae and Ariidae) are the most abundant fishes. At least three of the catfishes are blue catfish (Ictalurus furcatus). Five of the fish taxa [sharks/skates/rays (Chondrichthyes), gafftopsail catfish (Bagre marinus), black drum (Pogonias cromis), red drum (Sciaenops ocellatus), and mullet (Mugil sp.)] are marine fishes found in bays or estuaries. Marine fishes constitute 38 percent of the fish individuals and freshwater fishes constitute 62 percent.

Alligators (Alligator mississippiensis) and turtles contribute 8 percent of the individuals and less than 1 percent of the biomass in the Analytical Unit 1 collection (Table 9e-4). Five taxa of turtle are present, including both estuarine and freshwater species. Spiny softshell turtle (Apalone spinifera) are the most abundant turtles by NISP, MNI and biomass. The other freshwater species include a probable yellow mud turtle (Kinosternon cf. flavescens), a probable Texas river cooter (Pseudemys cf. texana) and a red-eared slider (Trachemys scripta). The diamondback terrapin (Malaclemys terrapin) is found in estuaries.
Wild birds contribute 12 percent of the MNI but less than 1 percent of the biomass (Table 9e-4). Five aquatic and four terrestrial individuals are present in the Feature 1 assemblage. Aquatic birds include common loon (Gavia immer), geese (Anserinae), blue-winged teal (Anas discors), and coots/gallinules (Rallidae). These individuals could be from a more coastal location, but they are also found in freshwater settings. Terrestrial birds include turkey (Meleagris gallopavo) and pigeons/doves (Columbidae). Turkey is considered a wild bird in the Mission assemblage, though it was domesticated elsewhere. All the turkey individuals are adults and one was a male as indicated by a spur on the tarsometatarsus. The American vulture (Cathartidae) is represented by a distal radius and could be a commensal taxon.

Chicken (Gallus gallus) provided 20 percent of the individuals and less than 1 percent of the biomass in Analytical Unit 1. Nine of the chickens were adult and nine were juveniles when they died. One of the adults was a rooster, as indicated by the presence of a spur on a tarsometatarsus. One UID Bird specimen had medullary bone present, indicating that one of the birds was female. Unfortunately, this specimen could not be identified to a lower taxonomic level, but, most often, specimens containing medullary bone are from chickens. In any case, the medullary deposit is clearly from a female bird in egg-laying condition.

Wild mammals include both white-tailed deer (Odocoileus virginianus) and other wild mammals in the Feature 1 collection. Deer contribute 4 percent of the individuals and 3 percent of the biomass while other wild mammals contribute 8 percent of the individuals and less than 1 percent of the biomass (Table 9e-4). Deer and softshell turtle are the most common wild animals in the collection. Two antler fragments possibly indicate the presence of at least one male deer, though the fragments could be from shed antlers. No side or seasonality information could be determined from the antler fragments. Other wild mammals include opossum (Didelphis virginiana), hare/rabbit (Leporidae), dog/wolf/ coyote (Canis sp.), black bear (Ursus americanus), and collared peccary (Tayassu tajacu). The canid specimens are a lumbar vertebra and the horizontal ramus of a right mandible containing teeth. The bear is identified from a thoracic vertebra and the peccary by the ascending ramus of a right mandible.

Domestic mammals contribute 25 percent of the individuals in Analytical Unit 1 and 92 percent of the biomass (Table $9 \mathrm{e}-4)$. Most of this is from members of the subfamily 
Table 9e-3. Feature 1, AU 1: Species List

\begin{tabular}{|c|c|c|c|c|c|}
\hline & & & & & \\
\hline & NISP & \# & $\%$ & Wt, gm & Biomass, $\mathrm{kg}$ \\
\hline UID Mollusca & 5 & & & 4.48 & \\
\hline Chondrichthyes & & & & & \\
\hline Sharks, skates, and rays & 1 & 1 & 1.1 & 0.48 & 0.067 \\
\hline UID Fish & 488 & & & 150.66 & 1.715 \\
\hline $\begin{array}{l}\text { Amia calva } \\
\text { Bowfin }\end{array}$ & 2 & 1 & 1.1 & 0.67 & 0.004 \\
\hline $\begin{array}{l}\text { Lepisosteus sp. } \\
\text { Gar }\end{array}$ & 65 & 1 & 1.1 & 8.74 & 0.218 \\
\hline $\begin{array}{l}\text { Siluriformes } \\
\text { Catfishes } \\
\end{array}$ & 39 & & & 14.48 & 0.253 \\
\hline $\begin{array}{l}\text { Ictaluridae } \\
\text { Freshwater catfishes } \\
\end{array}$ & 43 & & & 22.81 & 0.389 \\
\hline $\begin{array}{l}\text { Ictalurus } \mathrm{sp.} \\
\text { Blue and channel catfishes }\end{array}$ & 34 & & & 25.51 & 0.433 \\
\hline $\begin{array}{l}\text { Ictalurus furcatus } \\
\text { Blue catfish }\end{array}$ & 58 & 3 & 3.3 & 39.87 & 0.662 \\
\hline $\begin{array}{l}\text { Ictalurus punctatus } \\
\text { Channel catfish } \\
\end{array}$ & 3 & 1 & 1.1 & 1.79 & 0.035 \\
\hline $\begin{array}{l}\text { Ariidae } \\
\text { Sea catfishes } \\
\end{array}$ & 1 & & & 0.63 & 0.013 \\
\hline $\begin{array}{l}\text { Bagre marinus } \\
\text { Gafftopsail catfish }\end{array}$ & 2 & 1 & 1.1 & 1.5 & 0.029 \\
\hline $\begin{array}{l}\text { Centrarchidae } \\
\text { Sunfishes } \\
\end{array}$ & 1 & & & 0.03 & 0.001 \\
\hline $\begin{array}{l}\text { Lepomis sp. } \\
\text { Sunfish } \\
\end{array}$ & 2 & 1 & 1.1 & 0.08 & 0.002 \\
\hline $\begin{array}{l}\text { Micropterus salmoides } \\
\text { Largemouth bass } \\
\end{array}$ & 16 & 1 & 1.1 & 3.59 & 0.051 \\
\hline $\begin{array}{l}\text { Sciaenidae } \\
\text { Drums } \\
\end{array}$ & 18 & & & 26.05 & 0.434 \\
\hline $\begin{array}{l}\text { Pogonias cromis } \\
\text { Black drum }\end{array}$ & 1 & 1 & 1.1 & 0.57 & 0.026 \\
\hline $\begin{array}{l}\text { Sciaenops ocellatus } \\
\text { Red drum } \\
\end{array}$ & 10 & 1 & 1.1 & 14.06 & 0.275 \\
\hline $\begin{array}{l}\text { Mugil sp. } \\
\text { Mullet }\end{array}$ & 9 & 1 & 1.1 & 1.77 & 0.044 \\
\hline $\begin{array}{l}\text { Anura } \\
\text { Frogs and toads }\end{array}$ & 3 & & & 0.14 & \\
\hline \begin{tabular}{|l} 
Bufonidae \\
Toads \\
\end{tabular} & 3 & 1 & 1.1 & 0.19 & \\
\hline UID Turtle & 44 & & & 20.24 & 0.237 \\
\hline $\begin{array}{l}\text { Kinosternon cf. flavescens } \\
\text { Probable yellow mud turtle } \\
\end{array}$ & 1 & 1 & 1.1 & 0.56 & 0.021 \\
\hline \begin{tabular}{|l} 
Emydidae \\
Box and water turtles \\
\end{tabular} & 6 & & & 36.74 & 0.354 \\
\hline $\begin{array}{l}\text { Malaclemys terrapin } \\
\text { Diamondback terrapin }\end{array}$ & 1 & 1 & 1.1 & 1.67 & 0.045 \\
\hline $\begin{array}{l}\text { Pseudemys cf. texana } \\
\text { Probable Texas river cooter }\end{array}$ & 1 & 1 & 1.1 & 11 & 0.158 \\
\hline $\begin{array}{l}\text { Trachemys scripta } \\
\text { Red-eared slider }\end{array}$ & 1 & 1 & 1.1 & 9.28 & 0.141 \\
\hline \begin{tabular}{|l} 
Apalone spinifera \\
Spiny softshell turtle
\end{tabular} & 50 & 4 & 4.4 & 96.98 & 0.678 \\
\hline
\end{tabular}


Table 9e-3. Continued...

\begin{tabular}{|c|c|c|c|c|c|}
\hline & & & NI & & \\
\hline & NISP & \# & $\%$ & $\mathrm{Wt}, \mathrm{gm}$ & Biomass, $\mathrm{kg}$ \\
\hline $\begin{array}{l}\text { Serpentes } \\
\text { Snakes }\end{array}$ & 1 & & & 0.24 & 0.003 \\
\hline $\begin{array}{r}\text { Crotalinae } \\
\text { Pit vipers } \\
\end{array}$ & 4 & & & 1.81 & 0.025 \\
\hline $\begin{array}{l}\text { Crotalus sp. } \\
\text { Rattlesnakes }\end{array}$ & 3 & 1 & 1.1 & 1.43 & 0.02 \\
\hline UID Bird & 681 & & & 226.02 & 2.833 \\
\hline $\begin{array}{l}\text { Gavia immer } \\
\text { Common loon }\end{array}$ & 3 & 1 & 1.1 & 0.6 & 0.013 \\
\hline $\begin{array}{l}\text { Anatidae } \\
\text { Swans, geese, and ducks }\end{array}$ & 54 & & & 22.97 & 0.354 \\
\hline $\begin{array}{l}\text { Anserinae } \\
\text { Geese } \\
\end{array}$ & 21 & 2 & 2.2 & 25.16 & 0.384 \\
\hline $\begin{array}{l}\text { Anas sp. } \\
\text { Marsh ducks }\end{array}$ & 1 & & & 1.03 & 0.021 \\
\hline $\begin{array}{l}\text { Anas discors } \\
\text { Blue-winged teal }\end{array}$ & 1 & 1 & 1.1 & 0.73 & 0.015 \\
\hline $\begin{array}{l}\text { Cathartidae } \\
\text { American vultures } \\
\end{array}$ & 1 & 1 & 1.1 & 1.33 & 0.027 \\
\hline $\begin{array}{l}\text { Phasianidae } \\
\text { Quails, pheasants, and partridges }\end{array}$ & 6 & & & 1.09 & 0.022 \\
\hline $\begin{array}{l}\text { Gallus gallus } \\
\text { Chicken }\end{array}$ & 341 & 18 & 19.8 & 279.66 & 3.439 \\
\hline $\begin{array}{l}\text { Meleagris gallopavo } \\
\text { Turkey } \\
\end{array}$ & 68 & 3 & 3.3 & 156.23 & 2.025 \\
\hline $\begin{array}{l}\text { Rallidae } \\
\text { Coots and gallinules }\end{array}$ & 1 & 1 & 1.1 & 1.47 & 0.029 \\
\hline $\begin{array}{l}\text { Columbidae } \\
\text { Pigeons and doves } \\
\end{array}$ & 3 & 1 & 1.1 & 0.62 & 0.013 \\
\hline $\begin{array}{l}\text { Corvus cf. ossifragus } \\
\text { Probable fish crow }\end{array}$ & 1 & 1 & 1.1 & 0.12 & 0.003 \\
\hline $\begin{array}{l}\text { Emberizidae } \\
\text { Perching birds } \\
\end{array}$ & 1 & 1 & 1.1 & 0.05 & 0.001 \\
\hline UID Mammal & 29265 & & & 86848.26 & 732.631 \\
\hline $\begin{array}{l}\text { Didelphis virginiana } \\
\text { Opossum }\end{array}$ & 2 & 1 & 1.1 & 1.46 & 0.037 \\
\hline $\begin{array}{l}\text { Leporidae } \\
\text { Hares and rabbits } \\
\end{array}$ & 24 & 3 & 3.3 & 13.96 & 0.282 \\
\hline $\begin{array}{l}\text { Lepus californicus } \\
\text { Blacktail jackrabbit } \\
\end{array}$ & 1 & -1 & & 0.59 & 0.016 \\
\hline $\begin{array}{l}\text { Sylvilagus sp. } \\
\text { Rabbit }\end{array}$ & 1 & -1 & & 0.34 & 0.01 \\
\hline Rodentia & 3 & & & 0.15 & 0.005 \\
\hline $\begin{array}{l}\text { Geomys sp. } \\
\text { Pocket gopher }\end{array}$ & 11 & 1 & 1.1 & 1.76 & 0.044 \\
\hline $\begin{array}{l}\text { Muridae } \\
\text { Old and New World rats and mice }\end{array}$ & 1 & 1 & 1.1 & 0.36 & 0.011 \\
\hline $\begin{array}{l}\text { Carnivora } \\
\text { Carnivores } \\
\end{array}$ & 2 & & & 3.64 & 0.084 \\
\hline $\begin{array}{l}\text { Canis sp. } \\
\text { Dog, wolf, and coyote }\end{array}$ & 2 & 1 & 1.1 & 15.75 & 0.315 \\
\hline $\begin{array}{l}\text { Ursus americanus } \\
\text { Black bear }\end{array}$ & 1 & 1 & 1.1 & 25.21 & 0.48 \\
\hline
\end{tabular}


Table 9e-3. Continued...

\begin{tabular}{|c|c|c|c|c|c|}
\hline & \multirow[b]{2}{*}{ NISP } & \multicolumn{2}{|c|}{ MNI } & \multirow[b]{2}{*}{$\mathrm{Wt}, \mathrm{gm}$} & \multirow[b]{2}{*}{ Biomass, $\mathrm{kg}$} \\
\hline & & \# & $\%$ & & \\
\hline Equus sp. & & & & & \\
\hline Horse/burro & 17 & 2 & 2.2 & 954.75 & 12.645 \\
\hline Artiodactyla & 35 & & & 137.38 & 2.209 \\
\hline $\begin{array}{l}\text { Suiformes } \\
\text { Pigs and peccaries }\end{array}$ & 2 & & & 0.63 & 0.017 \\
\hline $\begin{array}{l}\text { Tayassu tajacu } \\
\text { Collared peccary }\end{array}$ & 1 & 1 & 1.1 & 7.69 & 0.165 \\
\hline $\begin{array}{l}\text { Sus scrofa } \\
\text { Pig }\end{array}$ & 103 & 5 & 5.5 & 559.04 & 7.811 \\
\hline $\begin{array}{l}\text { Odocoileus virginianus } \\
\text { White-tailed deer }\end{array}$ & 149 & 4 & 4.4 & 1350.08 & 17.271 \\
\hline $\begin{array}{l}\text { Bovinae } \\
\text { Bison/cow }\end{array}$ & 1650 & 16 & 17.6 & 53042.15 & 470.066 \\
\hline $\begin{array}{l}\text { Bos } \text { cf. taurus } \\
\text { Probable cow }\end{array}$ & 51 & -4 & & 4680.98 & 52.881 \\
\hline $\begin{array}{l}\text { Caprinae } \\
\text { Sheep/goat }\end{array}$ & 8 & 2 & 2.2 & 71.22 & 1.223 \\
\hline UID Vertebrate & & & & 5314.21 & \\
\hline TOTAL & 33428 & 91 & & 154244.74 & 1313.715 \\
\hline
\end{tabular}

Bovinae (18 percent of the MNI and 91 percent of the biomass). The subfamily Bovinae is considered a domestic mammal in this context though most of the materials assigned to this category could not be distinguished between wild bison and domestic cattle. Only domestic cattle (Bos cf. taurus) were identified at the lower taxonomic level from this analytical unit. Because the specimens referred to Bovinae may include some bison, Bovinae's contribution to the domestic category may be exaggerated and its contribution to the wild mammal category under estimated. Other domestic mammals are pig (Sus scrofa) and sheep/ goat (Caprinae). There is no evidence of sex for these domestic animals. Small domestic mammals contribute 8 percent of the individuals and 2 percent of the biomass (Table 9e-4). The focus was clearly on large bovids, specifically on domestic cattle, though the precision with which that contribution is quantified may be inaccurate.

Commensal taxa constitute 8 percent of the individuals and 2 percent of the biomass in Feature 1 (Table 9e-4). The most interesting commensal animal is the horse/burro (Equus sp.). The equid biomass constitutes 99 percent of the commensal biomass, the other commensal animals being small creatures such as toads (Bufonidae), snakes (Crotalus sp.), perching birds (Emberizidae), pocket gophers (Geomys sp.) and mice (Muridae).
Elements represented in Analytical Unit 1 suggest on-site butchery and general trash disposal (Table 9e-5). Analytical Unit 1 consists of a large trash pit, Feature 1, and non-feature materials below a layer of lime. Axial and Head specimens are generally rare or absent, largely as an artifact of identifiability or site formation processes. Too few horse/ burro (Equus sp.) specimens are present to discern a pattern of element representation, though only elements from the postcranial skeleton are present (Figure 9e-1). This is unusual, as some equid teeth are generally identified if several other areas of the skeleton are present. With so few equid elements represented, no conclusion can made as to skeletal completeness. Eighty-seven percent of the pig (Sus scrofa) specimens are from the Head, Forefoot, Hindfoot, and Foot (Figure 9e-2). Almost half of the Head elements $(\mathrm{NISP}=9)$ are teeth while 89 percent of the Foot elements are phalanges (NISP $=40)$. When compared to a standard, unmodified pig skeleton, the relative proportions of pig elements indicate that Forequarter and lower leg specimens are over-represented but that Hindquarter specimens are present in proportions similar to an undisturbed skeleton (Figure 9e-3). This pattern is interpreted as primary butchery refuse mixed with secondary, or post-consumption, refuse. Seventy percent of the deer (Odocoileus virginianus) specimens are from the Head, Forefoot, Hindfoot, and Foot (Figure 9e-4). Half of the Head elements (NISP $=8$ ) are 
teeth while 89 percent of the Foot elements are phalanges (NISP $=54)$. When compared to a standard, unmodified deer skeleton, the relative proportions of specimens represented indicate that all postcranial, non-axial skeletal portions are over-represented (Figure 9e-5). This pattern is interpreted as primary butchery refuse mixed with secondary, or post-consumption, refuse.

The majority of the large bovid (Bovidae) specimens in Analytical Unit 1 represent elements from the head and foot (Table 9e-5). Over 50 percent of the bovine (Bovinae) specimens are from the Head, Forefoot, Hindfoot, and Foot (Figure 9e-6). Forty-one percent of the Head elements (NISP $=122$ ) are teeth. The Head category also includes 97 horn core fragments. Sixty percent of the Foot elements are phalanges (NISP $=280$ ). Compared to the unmodified skeleton of the standard cow, the Forequarter and Hindquarter elements are over-represented but specimens from the lower legs are present in proportions very similar to an undisturbed skeleton (Figure 9e-7). This pattern is interpreted as primary butchery refuse mixed with secondary, or post-consumption, refuse. The distribution of specimens identified for probable cow (Bos cf. taurus) reflects identifiability (Figure 9e-8).
Several examples of articulated butchering units for Bovinae and probable cow are present in the Feature 1 assemblage. Two of these are joints from the lower leg identified as Bovinae in two samples (F.S. 235 and 244; 85N/99E; levels 110-130). The Bovinae joint in F.S. 235 includes a distal tibia, os malleolare, an astragalus, and a calcaneus. The F.S. 244 Bovinae joint includes two articulating sets of phalanges 1, 2, and 3. F.S. 192 (83N/100E; Feature 1) contains a complete metacarpus with associated pairs of phalanges 1 , 2 , and 3 from a probable cow. F.S. 244 (85N/99E; levels 120-130) contains an articulated unit identified as probable cow with a distal tibia, astragalus, calcaneus, cubonavicular, tarsus $2+3$, and petite cuneiform.

Other bovine element clusters are also present in Analytical Unit 1. Five of the bovine horn core fragments are from F.S. 242 (87N/100E; level 80-90), 53 of the horn core fragments are from F.S. 245 (87N/100E; level 90-100), and 11 are from F.S. 261 (86N/99E; level 110-120).

The small number of sheep/goat (Caprinae) specimens makes it difficult to generalize about element representation for these small bovids in Analytical Unit 1. Sixty-three percent of the specimens are from the Head, Forefoot, Hindfoot, and Foot (Table 9e-5). Half of the specimens identified are from the Hindfoot and Hindquarter (Figure 9e-9).

Table 9e-4. Feature 1, AU 1: Summary

\begin{tabular}{|c|c|c|c|c|}
\hline & \multicolumn{2}{|c|}{ MNI } & \multicolumn{2}{|c|}{ Biomass } \\
\hline & \# & $\%$ & $\mathrm{~kg}$ & $\%$ \\
\hline Sharks, Rays, and Fishes & 13 & 14.3 & 1.413 & 0.3 \\
\hline Turtles & 8 & 8.8 & 1.043 & 0.2 \\
\hline Wild Birds & 11 & 12.1 & 2.509 & 0.5 \\
\hline Domestic Birds & 18 & 19.8 & 3.439 & 0.7 \\
\hline Deer & 4 & 4.4 & 17.271 & 3.3 \\
\hline Bovinae & 16 & 17.6 & 470.066 & 90.6 \\
\hline Other Wild Mammals & 7 & 7.7 & 1.279 & 0.2 \\
\hline Other Domestic Mammals & 7 & 7.7 & 9.034 & 1.7 \\
\hline Commensal Taxa & 7 & 7.7 & 12.721 & 2.5 \\
\hline TOTAL & 91 & & 518.775 & \\
\hline
\end{tabular}

Table 9e-5. Feature 1, AU 1: Number of elements represented

\begin{tabular}{|c|c|c|c|c|c|c|c|}
\hline & Horse/burro & Peccary & Pig & Deer & Bovinae & Cow & Caprinae \\
\hline Head & & 1 & 20 & 14 & 300 & & 2 \\
\hline Vertebra/Rib & 1 & & 1 & 7 & 189 & & \\
\hline Forequarter & 4 & & 8 & 18 & 184 & 11 & 1 \\
\hline Forefoot & 1 & & 11 & 10 & 70 & 9 & \\
\hline Foot & 9 & & 45 & 61 & 470 & 6 & 1 \\
\hline Hindfoot & 1 & & 14 & 20 & 102 & 15 & 2 \\
\hline Hindquarter & 1 & & 4 & 19 & 335 & 10 & 2 \\
\hline TOTAL & 17 & 1 & 103 & 149 & 1650 & 51 & 8 \\
\hline
\end{tabular}




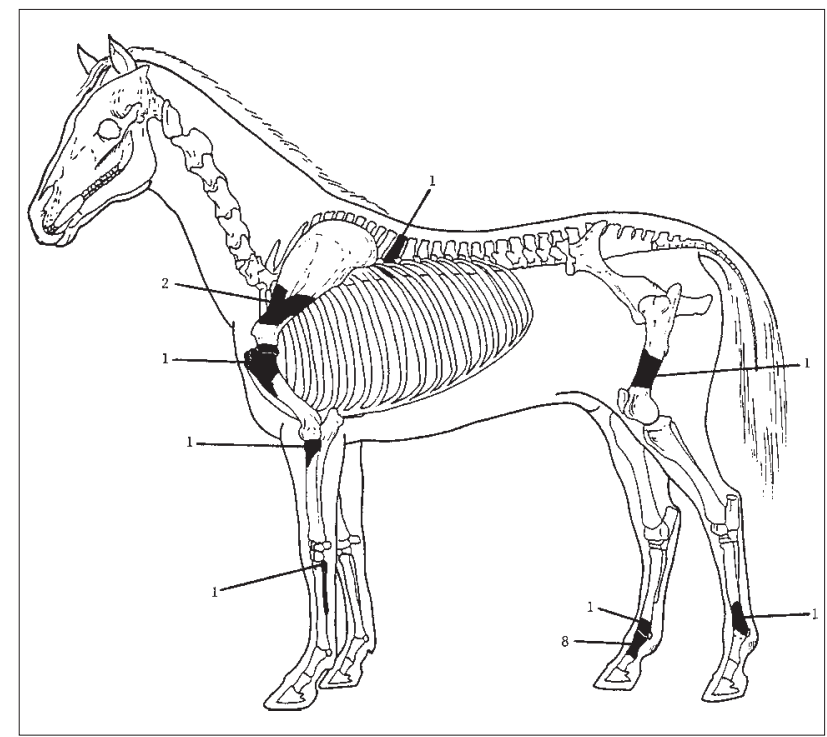

Figure 9e-1. Analytical Unit 1: Horse/burro (Equus sp.) elements represented. $\mathrm{N}=17$.

One of the horse/burros (Equus sp.) was an adult at death and the other was a non-juvenile of indeterminate age. Three of the pig (Sus scrofa) individuals were juveniles and two were subadults at death. Two of the deer individuals (Odocoileus virginianus) were juveniles, one was adult at death, and the third individual was of indeterminate age.

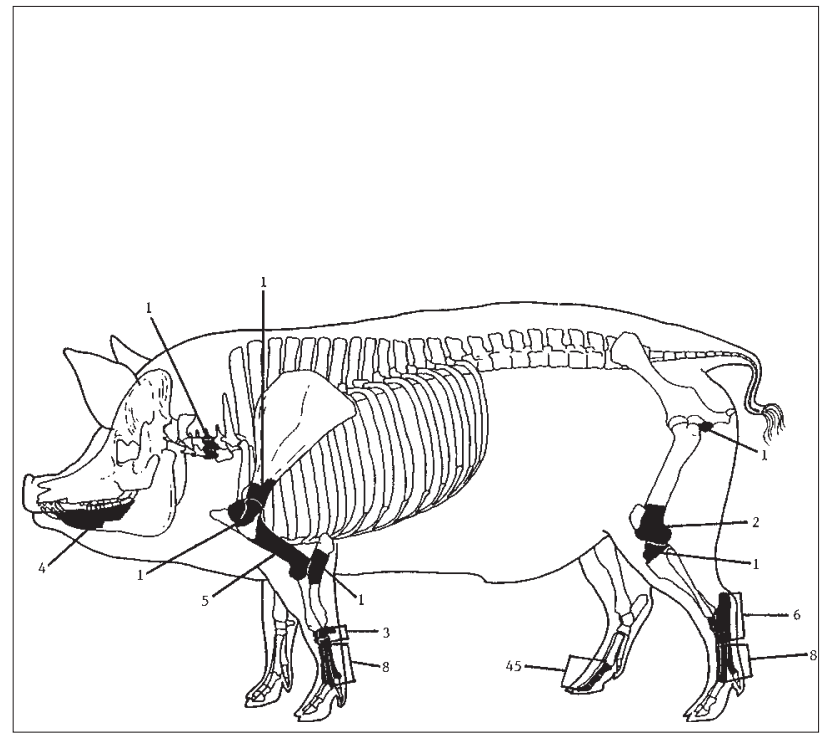

Figure 9e-2. Analytical Unit 1: Pig (Sus scrofa) elements represented. Not illustrated are 9 teeth and 7 skull fragments. $\mathrm{N}=103$.

Over 40 percent of the estimated 18 individuals in the family Bovidae in Analytical Unit 1 were juveniles and subadults when they died. Two of the Bovinae were juveniles; five were subadults, eight were adults, and one was of indeterminate age. Two of the probable cows (Bos cf. taurus) were subadults at death, one was an adult, one was of indeterminate age. One of the sheep/goat individuals (Caprinae) was a juvenile at death and the other was at least a subadult, if not an adult when it died.

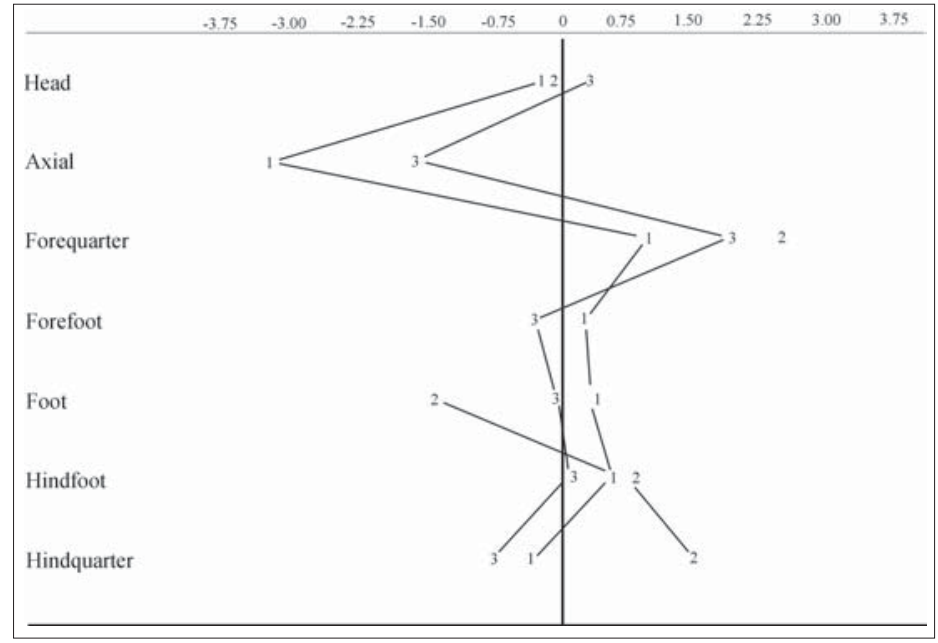

Figure 9e-3. Log ratio diagram of Pig (Sus scrofa) elements represented compared to a standard pig, Analytical Units 1, 2, and 3.

Analytical Unit 2 had no specimens from the Axial or Forefoot categories. The vertical line is the standard. 


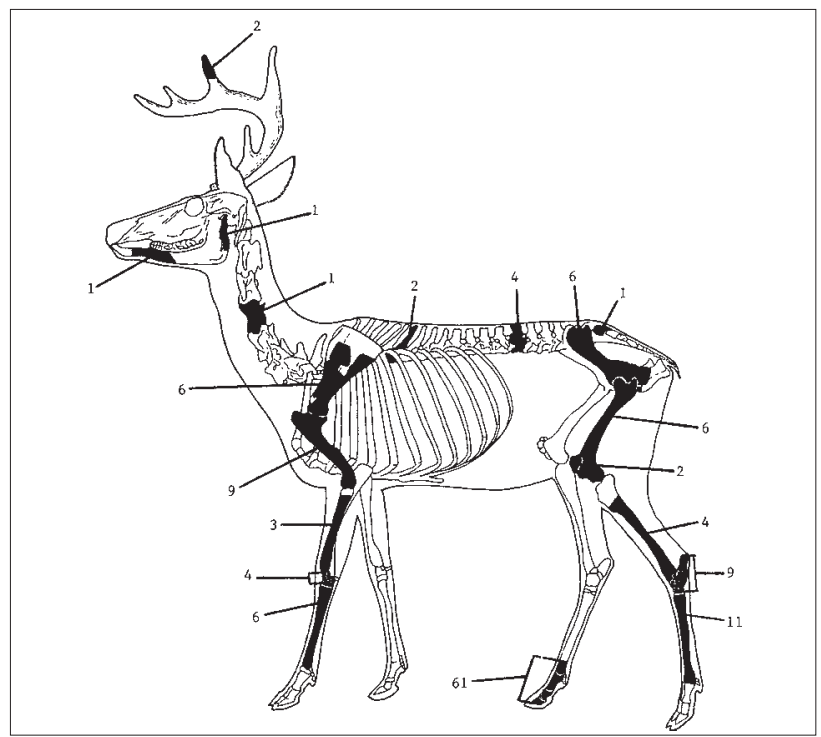

Figure 9e-4. Analytical Unit 1: Deer (Odocoileus virginianus) elements represented. Not illustrated are 8 teeth and 2 skull fragments. $\mathrm{N}=149$.

Modifications are observed on 11,370 specimens in AU 1 (Table 9e-6). The most abundant modifications are burning and calcination, observed on 94 percent of the modified specimens. Burning and calcination are present on 23 percent of the vertebrate specimens identified above UID Vertebrate. Burning and calcination could reflect food preparation or a waste management technique.
Many modifications more closely connected to food preparation are present in this assemblage. Most of these modifications are on mammalian specimens, but several bird and fish fragments are cut. One of the UID Mammal specimens displays cut marks in the shape of an " $\mathrm{X}$ " (F.S. 202). Forty specimens are either clearly sawed or are cleancut and probably sawed. One of the UID Mammal specimens (F.S. 259) is a shaft fragment sawed perpendicular to the shaft into a thin, O-shaped section. This is the style of modification typically found in the late-nineteenth and twentieth centuries for thin portions of meat such as round steaks. The black bear (Ursus americanus) cut marks are on the thoracic vertebra.

Multiple butchery marks are present on Bovinae specimens and these are described in greater detail. Fifty-four specimens are hacked; 25 of these specimens are innominate and sacrum fragments. Another 14 of the hacked specimens are vertebrae and ribs. Many of the cut marks (NISP =14) are on metapodiae, carpals, and tarsals, presumably related to separating the lower leg from the upper leg. Less than one percent of the bovine specimens are sawed or cleancut. Six of these are from the innominate and sacral region and two are thoracic vertebrae. Six of the probable cow (Bos cf. taurus) specimens are also hacked or cut. The cut marks on the metatarsus, cubonavicular, and tarsus $2+3$ are presumably the result of separating the lower leg from the upper leg.

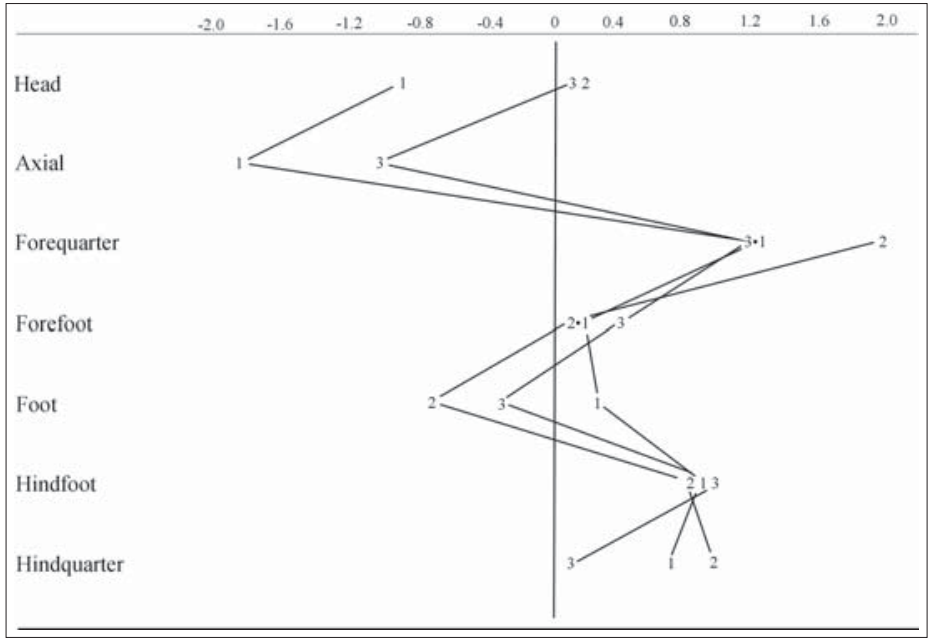

Figure 9e-5. Log ratio diagram of Deer (Odocoileus virginianus) elements represented compared to a standard deer, Analytical Units 1, 2, and 3.

Analytical Unit 2 had no specimens from the Axial category. The vertical line is the standard. 


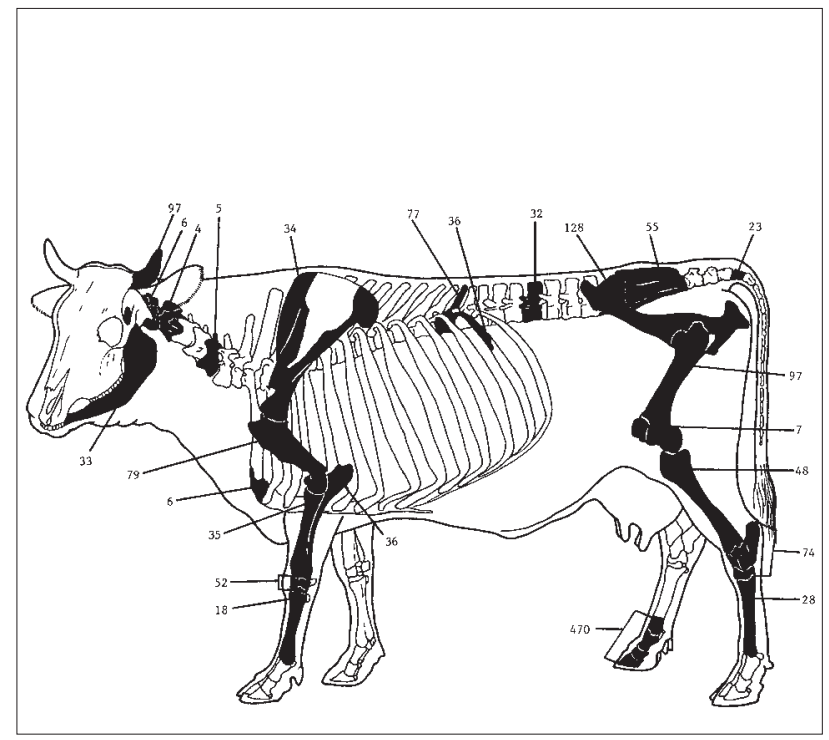

Figure 9e-6. Analytical Unit 1: Bovinae elements represented. Not illustrated are 122 teeth and 48 skull fragments. $\mathrm{N}=1650$.

Several modifications in Analytical Unit 1 are unlikely to be related to butchering or food processing. Two blue catfish (Ictalurus furcatus) pectoral spines are grooved and snapped, probably to avoid the possibility of people being jabbed by the spines. One swan/goose/duck (Anatidae) specimen (F.S. 273) bore a hole drilled through the distal end of a radius. A deer (Odocoileus virginianus) incisor (F.S. 264) had a notch cut into the root of the tooth just below the enamel. One probable cow specimen (Bos cf. taurus; F.S. 229) had a pathology on the distal anterior face of a complete, fused metacarpus. There was some evidence of rodent and carnivore gnawing, suggesting that some of the specimens were left accessible to scavenging, but that most were not.

The AU 1 measurements are similar to those in the nonfeature AU 3 assemblage. Measurements of the equid remains from Analytical Unit 1 suggest that there was at least one large individual that was probably a horse. However, one of the first phalanges was from a substantially smaller individual and could be from a burro. The bovid measurements show a wide range in size, as would be expected from animals of this time-period prior to control over breeding (Appendix M). Figure 9e-10 includes both measurements from specimens identified as Bovinae as well as measurements from specimens identified tentatively to species. An inconsistent pattern relative to the standard cow indicates a difference in the conformation of the prebreed at Mission Refugio and the other Spanish sites in this figure compared to the modern $272 \mathrm{~kg}$ Holstein. In two cases, however, the Feature 1 large bovids are smaller than or equal in size to the Holstein used as the reference. In one case, the mean is the largest of the available dimensions. Most of these animals may have been about the size of the Holstein or a little larger. Most of the dimensions fall within the range reported by deFrance from Espíritu Santo de Zuñiga at Goliad (41GD1) and Mission Nuestra Señora del Rosario (41GD2), though the upper end of the range is larger at Mission Refugio in the three dimensions which can be compared.

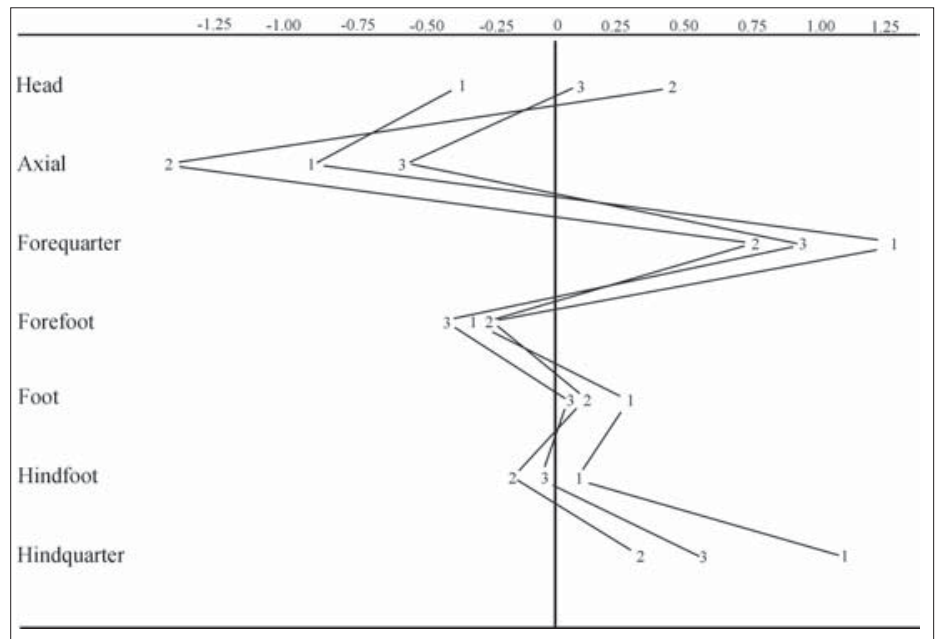

Figure 9e-7. Log ratio diagram of Bovinae elements represented compared to a standard cow, Analytical Units 1, 2, and 3.

The vertical line is the standard. 


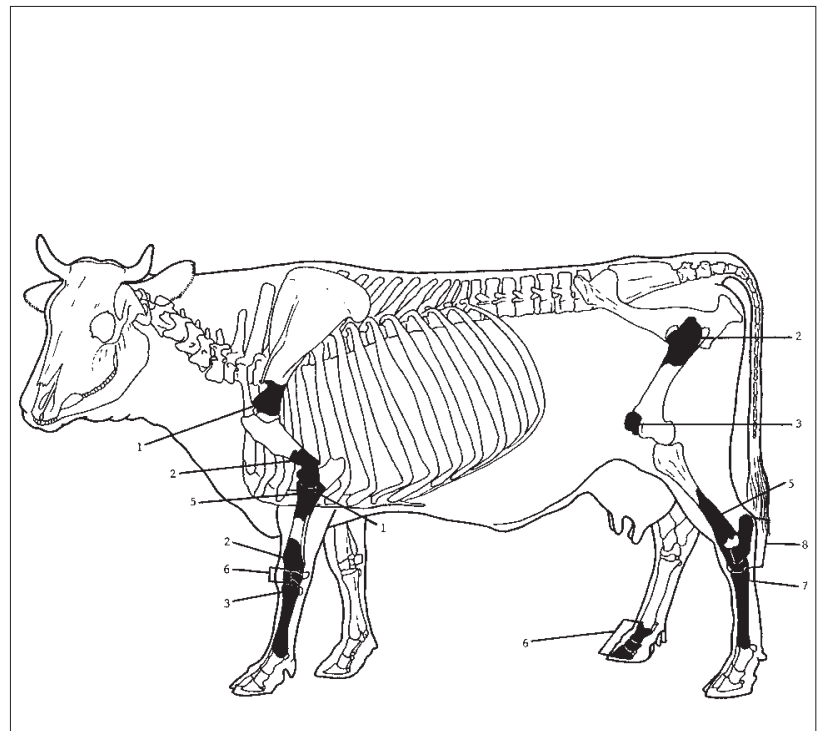

Figure 9e-8. Analytical Unit 1: Probable Cow (Bos cf. taurus) elements represented. $\mathrm{N}=51$.

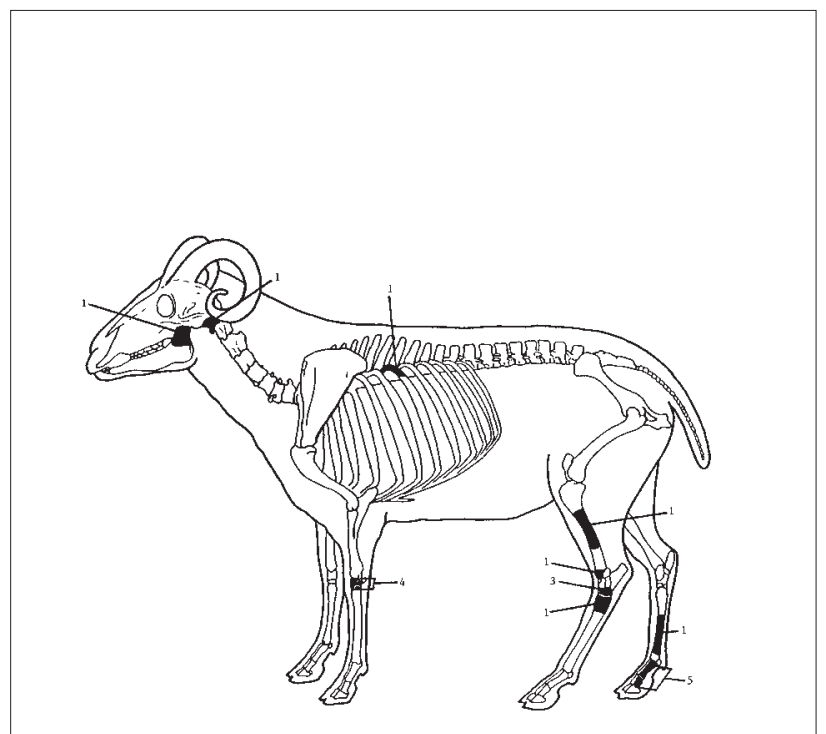

Figure 9e-9. Analytical Unit 1: Sheep/goat (Caprinae) elements represented. $\mathrm{N}=8$.

Table 9e-6. Feature 1, AU 1: Modifications

\begin{tabular}{|c|c|c|c|c|c|c|c|c|c|c|}
\hline & Burned & Calcined & Hacked & Cut & Groove/snap & Sawed & Worked & Pathology & R. Gnaw & C. Gnaw \\
\hline UID Fish & 1 & & & & & & & & & \\
\hline Gar & 2 & & & & & & & & & \\
\hline Catfishes & 1 & & & & & & & & & \\
\hline Freshwater catfishes & 1 & 1 & & & & & & & & \\
\hline Blue/channel catfishes & & & & 1 & & & & & & \\
\hline Blue catfish & & & & 2 & 2 & & & & & \\
\hline Red drum & & & & 1 & & & & & & \\
\hline UID Turtle & 1 & & & & & & & & & \\
\hline Slider & 1 & & & & & & & & & \\
\hline Spiny softshell turtle & 4 & & & & & & & & & \\
\hline UID Bird & 8 & 2 & & & & & & & & \\
\hline Common loon & & & & 1 & & & & & & \\
\hline Ducks, geese, swans & & & & 1 & & & 1 & & & \\
\hline Chicken & & & & 6 & & & & & & 1 \\
\hline Turkey & 1 & & & 5 & & & & & & \\
\hline UID Mammal & 4155 & 3458 & 63 & 270 & 116 & 26 & & & 2 & 5 \\
\hline Black bear & & & & 1 & & & & & & \\
\hline Horse/burro & 2 & & 1 & & & & & & & \\
\hline Artiodactyla & 2 & 2 & & & & & & & & \\
\hline Pig & & & & 7 & & 1 & & & & \\
\hline Deer & 10 & 2 & 4 & 8 & 1 & 1 & 1 & & 1 & \\
\hline Bovinae & 112 & 51 & 54 & 48 & 4 & 11 & & & 1 & 1 \\
\hline Probable cow & 4 & & 3 & 3 & & & & 1 & & \\
\hline Sheep/goat & & & & & & & & & & 1 \\
\hline UID Vertebrate & 1643 & 1245 & & 4 & & 1 & & & & \\
\hline TOTAL & 5948 & 4761 & 125 & 358 & 123 & 40 & 2 & 1 & 4 & 8 \\
\hline
\end{tabular}

Note: R. Gnaw and C. Gnaw refer to rodent gnawing and carnivore gnawing, respectively. 


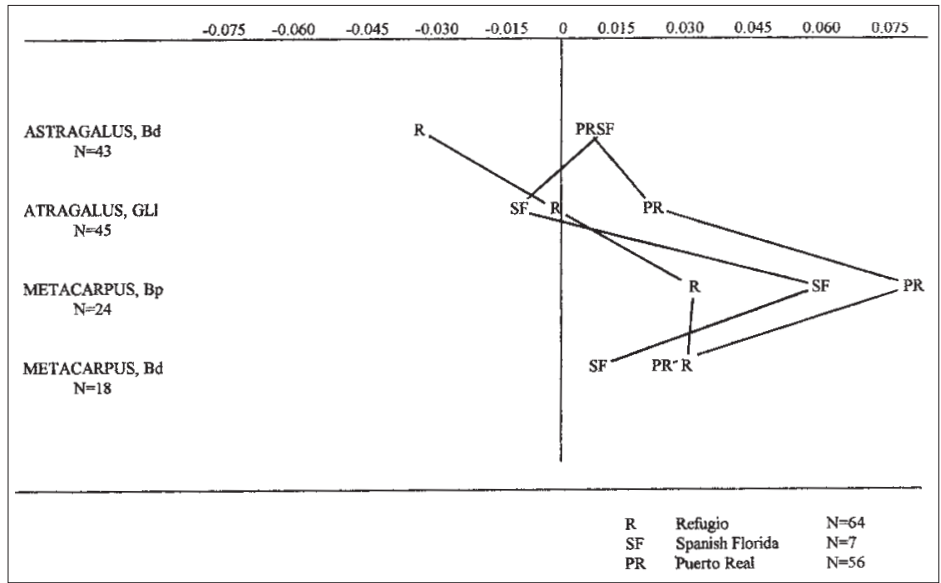

Figure 9e-10. Log ratio diagram showing size of large Bovidae compared to a modern standard, Analytical Units 1, 2, and 3.

The vertical line is the standard.

\section{Results: Feature 2, Analytical Unit 2}

Analytical Unit 2 is comprised of units excavated within Feature 2. The collection contains a vertebrate and invertebrate collection of 20,098 specimens weighing $113,129.01 \mathrm{gm}$ with the remains of an estimated 79 vertebrate individuals (Table 9e-7). MNI is estimated for 31 taxa. The dominant characteristic of this collection is the number of large bovids, though the collection contains other taxa as well. The specimens appeared to be in good condition and the sample size appears adequate in spite of the small MNI estimate. Additional data from this unit would probably not add many additional taxa.

Three taxa of molluscs are present, although only Eastern oysters (Crassostrea virginica) are identified specifically (Table 9e-7). Thirty-eight UID Mollusca and seven oyster valve fragments are burned. These data undoubtedly do not represent the total molluscan collection from this analytical unit and they will not be considered further.

Fishes constitute nine percent of the individuals in the Analytical Unit 2 collection and less than 1 percent of the biomass (Table 9e-8). Gar (Lepisosteus sp.) is a very small percentage of the collection's NISP and the MNI estimated seems reasonable given that only three scales, a vertebra, and a dentary are present in the collection. Catfishes (Ictaluridae and Ariidae) are the most abundant fishes (see Table 9e-7). At least one of the catfishes is a blue catfish (Ictalurus furcatus). Four of the fish taxa [shark/skate/ray
(Chondrichthyes), hardhead catfish (Arius felis), black drum (Pogonias cromis), and red drum (Sciaenops ocellatus)] are marine fishes found in bays or estuaries. Marine fishes constitute 57 percent of the fish individuals and freshwater fishes 43 percent.

Alligators (Alligator mississippiensis) and turtles contribute 6 percent of the individuals and less than 1 percent of the biomass in the Feature 2 collection (Table 9e-8). The turtles identified include both terrestrial and aquatic species but no estuarine or marine taxa. Alligators and turtles are evenly present in the collection.

Wild birds contribute 17 percent of the individuals and less than 1 percent of the biomass (Table 9e-8). Feature 2 contains more aquatic bird individuals than terrestrial ones. Aquatic birds include night heron (Nycticorax sp.), ducks (Anatidae), and gulls/shore birds (Charadriiformes). These individuals could be from a coastal location, but they are also found in freshwater settings. Turkey (Meleagris gallopavo) and hawk (Accipitridae) are the only wild terrestrial bird taxa. Four adult turkeys and one juvenile are present. None of the turkey specimens provide evidence of sex. Ducks and turkeys are the most common wild animals in the collection, each contributing 7 percent of the individuals. The hawk is represented by phalanx 1 and phalanx 2 of the left digit 2 . This could have been a commensal bird or a pet, or the element could be from a keepsake such as a fan made from a wing. The specimens are unmodified. 
Table 9e-7. Feature 2, AU 2: Species List

\begin{tabular}{|c|c|c|c|c|c|}
\hline & & & & & \\
\hline & NISP & \# & $\%$ & $\mathrm{Wt}, \mathrm{gm}$ & Biomass, $\mathrm{kg}$ \\
\hline UID Mollusca & 64 & & & 42.55 & \\
\hline $\begin{array}{l}\text { Bivalvia } \\
\text { Bivalves }\end{array}$ & 1 & & & 0.2 & \\
\hline $\begin{array}{l}\text { Crassostrea virginica } \\
\text { Eastern oyster }\end{array}$ & 7 & & & 59.57 & \\
\hline $\begin{array}{l}\text { Chondrichthyes } \\
\text { Sharks, skates, and rays }\end{array}$ & 1 & 1 & 1.3 & 0.44 & 0.06 \\
\hline UID Fish & 118 & & & 72.21 & 0.95 \\
\hline $\begin{array}{l}\text { Lepisosteus sp. } \\
\text { Gar }\end{array}$ & 4 & & & 2.12 & 0.06 \\
\hline $\begin{array}{l}\text { Lepisosteus osseus } \\
\text { Longnose gar }\end{array}$ & 1 & 1 & 1.3 & 0.1 & 0.01 \\
\hline $\begin{array}{l}\text { Siluriformes } \\
\text { Catfishes } \\
\end{array}$ & 2 & & & 0.38 & 0.01 \\
\hline $\begin{array}{l}\text { Ictaluridae } \\
\text { Freshwater catfishes }\end{array}$ & 4 & & & 3.09 & 0.06 \\
\hline $\begin{array}{l}\text { Ictalurus sp. } \\
\text { Blue and channel catfishes }\end{array}$ & 2 & & & 1.42 & 0.03 \\
\hline $\begin{array}{l}\text { Ictalurus furcatus } \\
\text { Blue catfish }\end{array}$ & 4 & 1 & 1.3 & 3.37 & 0.06 \\
\hline $\begin{array}{l}\text { Arius felis } \\
\text { Hardhead catfish }\end{array}$ & 6 & 1 & 1.3 & 2.56 & 0.05 \\
\hline $\begin{array}{l}\text { Centrarchidae } \\
\text { Sunfishes } \\
\end{array}$ & 1 & & & 0.47 & 0.01 \\
\hline $\begin{array}{l}\text { Micropterus salmoides } \\
\text { Largemouth bass }\end{array}$ & 1 & 1 & 1.3 & 0.42 & 0.01 \\
\hline $\begin{array}{l}\text { Pogonias cromis } \\
\text { Black drum }\end{array}$ & 1 & 1 & 1.3 & 0.29 & 0.02 \\
\hline $\begin{array}{l}\text { Sciaenops ocellatus } \\
\text { Red drum }\end{array}$ & 4 & 1 & 1.3 & 3.85 & 0.11 \\
\hline $\begin{array}{l}\text { Anura } \\
\text { Frogs and toads }\end{array}$ & 2 & 1 & 1.3 & 0.44 & \\
\hline $\begin{array}{l}\text { Alligator mississippiensis } \\
\text { American alligator }\end{array}$ & 2 & 1 & 1.3 & 25.25 & 0.37 \\
\hline UID Turtle & 16 & & & 6.81 & 0.11 \\
\hline $\begin{array}{l}\text { Kinosternon cf. flavescens } \\
\text { Probable yellow mud turtle } \\
\end{array}$ & 3 & 1 & 1.3 & 1.36 & 0.04 \\
\hline $\begin{array}{l}\text { Emydidae } \\
\text { Box and water turtles }\end{array}$ & 8 & & & 34.26 & 0.34 \\
\hline $\begin{array}{r}\text { Terrapene ornata } \\
\text { Desert box turtle }\end{array}$ & 9 & 1 & 1.3 & 15.46 & 0.2 \\
\hline $\begin{array}{c}\text { Trachemys scripta } \\
\text { Red-eared slider }\end{array}$ & 1 & 1 & 1.3 & 36.36 & 0.35 \\
\hline $\begin{array}{l}\text { Apalone spinifera } \\
\text { Spiny softshell turtle }\end{array}$ & 6 & 1 & 1.3 & 15.29 & 0.2 \\
\hline $\begin{array}{l}\text { Colubridae } \\
\text { Non-poisonous snakes }\end{array}$ & 1 & 1 & 1.3 & 0.15 & 0.002 \\
\hline $\begin{array}{r}\text { Crotalinae } \\
\text { Pit vipers } \\
\end{array}$ & 7 & 1 & 1.3 & 0.81 & 0.01 \\
\hline UID Bird & 496 & & & 184.34 & 2.35 \\
\hline $\begin{array}{l}\text { Ardeidae } \\
\text { Herons and bitterns }\end{array}$ & 2 & & & 0.9 & 0.02 \\
\hline
\end{tabular}


Table 9e-7. Continued...

\begin{tabular}{|c|c|c|c|c|c|}
\hline & & & & & \\
\hline & NISP & \# & $\%$ & Wt, gm & Biomass, $\mathrm{kg}$ \\
\hline $\begin{array}{l}\text { Nycticorax sp. } \\
\text { Night heron }\end{array}$ & 1 & 1 & 1.3 & 0.52 & 0.01 \\
\hline $\begin{array}{l}\text { Anatidae } \\
\text { Swans, geese, and ducks }\end{array}$ & 28 & 5 & 6.3 & 17.54 & 0.28 \\
\hline $\begin{array}{l}\text { Anserinae } \\
\text { Geese }\end{array}$ & 2 & -2 & & 3.41 & 0.06 \\
\hline $\begin{array}{l}\text { Accipitridae } \\
\text { Hawks and eagles }\end{array}$ & 2 & 1 & 1.3 & 0.61 & 0.01 \\
\hline $\begin{array}{l}\text { Phasianidae } \\
\text { Quails, pheasants, and partridges }\end{array}$ & 4 & & & 3.29 & 0.06 \\
\hline $\begin{array}{l}\text { Gallus gallus } \\
\text { Chicken }\end{array}$ & 161 & 15 & 19 & 132.92 & 1.75 \\
\hline $\begin{array}{l}\text { Meleagris gallopavo } \\
\text { Turkey }\end{array}$ & 38 & 5 & 6.3 & 98.06 & 1.33 \\
\hline $\begin{array}{l}\text { Charadriiformes } \\
\text { Gulls and shore birds }\end{array}$ & 1 & 1 & 1.3 & 0.1 & 0.003 \\
\hline UID Mammal & 17654 & & & 62177.33 & 542.34 \\
\hline $\begin{array}{l}\text { Didelphis virginiana } \\
\text { Opossum }\end{array}$ & 4 & 1 & 1.3 & 4.86 & 0.11 \\
\hline $\begin{array}{l}\text { Leporidae } \\
\text { Hares and rabbits } \\
\end{array}$ & 1 & 1 & 1.3 & 0.34 & 0.01 \\
\hline $\begin{array}{l}\text { Muridae } \\
\text { Old and New World rats and mice }\end{array}$ & 2 & 1 & 1.3 & 0.23 & 0.01 \\
\hline $\begin{array}{l}\text { Carnivora } \\
\text { Carnivores } \\
\end{array}$ & 2 & & & 2.53 & 0.06 \\
\hline $\begin{array}{l}\text { Ursus americanus } \\
\text { Black bear }\end{array}$ & 1 & 1 & 1.3 & 6.89 & 0.15 \\
\hline $\begin{array}{l}\text { Equus sp. } \\
\text { Horse/burro }\end{array}$ & 9 & 2 & 2.5 & 628.37 & 8.68 \\
\hline Artiodactyla & 90 & & & 233.84 & 3.56 \\
\hline $\begin{array}{l}\text { Suiformes } \\
\text { Pigs and peccaries }\end{array}$ & 3 & & & 1.18 & 0.03 \\
\hline $\begin{array}{l}\text { Sus scrofa } \\
\text { Pig } \\
\end{array}$ & 46 & 5 & 6.3 & 209.35 & 3.23 \\
\hline $\begin{array}{l}\text { Odocoileus virginianus } \\
\text { White-tailed deer }\end{array}$ & 49 & 4 & 5.1 & 814.32 & 10.96 \\
\hline \begin{tabular}{|l} 
Bovinae \\
Bison/cow \\
\end{tabular} & 1154 & 18 & 22.8 & 35837.79 & 330.3 \\
\hline \begin{tabular}{|c|} 
Bison cf. bison \\
Probable bison \\
\end{tabular} & 8 & -2 & & 717.98 & 9.78 \\
\hline \begin{tabular}{|} 
Bos cf. taurus \\
Probable cow \\
\end{tabular} & 49 & -4 & & 3403 & 39.69 \\
\hline $\begin{array}{l}\text { Caprinae } \\
\text { Sheep/goat } \\
\end{array}$ & 14 & 2 & 2.5 & 51.91 & 10 \\
\hline UID Vertebrate & & & & 8267.37 & \\
\hline TOTAL & 20,098 & 79 & & 113129.01 & 967.856 \\
\hline
\end{tabular}


Table 9e-8. Feature 2, AU 2: Summary

\begin{tabular}{lcccc} 
& \multicolumn{2}{c}{ MNI } & \multicolumn{2}{c}{ Biomass } \\
\hline Sharks, Rays, and Fishes & $\#$ & $\%$ & $\mathrm{~kg}$ & $\%$ \\
Alligator/Turtles & 7 & 9 & 0.32 & 0.1 \\
Wild Birds & 5 & 6.4 & 1.16 & 0.3 \\
Domestic Birds & 13 & 16.7 & 1.633 & 0.4 \\
Deer & 15 & 19.2 & 1.75 & 0.5 \\
Bovinae & 4 & 5.1 & 10.96 & 3 \\
Other Wild Mammals & 18 & 23.1 & 330.3 & 89.7 \\
Other Domestic Mammals & 3 & 3.8 & 0.27 & 0.1 \\
Commensal Taxa & 7 & 9 & 13.23 & 3.6 \\
TOTAL & 6 & 7.7 & 8.702 & 2.4 \\
\hline
\end{tabular}

Note: The Homo sapiens individual is omitted from this table.

Chicken (Gallus gallus) is the only domestic bird in the Feature 2 collection. Chickens contribute 19 percent of the individuals but less than 1 percent of the biomass (Table $9 \mathrm{e}-8)$. The collection contains the remains of eight adult and seven juvenile chickens. At least one of the adult individuals was a female, as two specimens contain medullary bone. Another UID Bird specimen also contained medullary bone.

Wild mammals in Analytical Unit 2 include both white-tailed deer (Odocoileus virginianus) and other wild mammals (see Table 9e-7). Deer contribute 5 percent of the individuals and 3 percent of the biomass while other wild mammals contribute 4 percent of the individuals and less than 1 percent of the biomass (Table 9e-8). Deer is the third most common wild animal in the collection. Four antler fragments may indicate the presence of at least one male deer, though most of the fragments could be from shed antlers. However, the presence of a large antler fragment that is still attached to the frontal bone (F.S. 234) indicates that one of antlers is from a male individual. It also provides information about the season in which this individual died. Deer shed their antlers after every breeding season, generally in the winter, and grow a new set every spring. Because this is a welldeveloped antler and is still attached to the cranium, the deer probably died in fall or winter. Other wild mammals include opossum (Didelphis virginiana), hare/rabbit (Leporidae), and black bear (Ursus americanus). The bear is identified from a canine.

Domestic mammals contribute 32 percent of the individuals in Feature 2 and 93 percent of the biomass (Table 9e-8). Most of this is from members of the subfamily Bovinae (23 percent of the MNI and 90 percent of the biomass). The subfamily Bovinae is considered a domestic mammal in this context though most of the materials assigned to this category could not be distinguished between wild bison (Bison cf. bison) and domestic cattle (Bos cf. taurus). Both are present in the collection; but specimens that could be identified as domestic cattle are more common than bison. Because the specimens referred to Bovinae undoubtedly include some bison, Bovinae's contribution to the domestic category may be exaggerated and its contribution to the wild mammal category under estimated. Other domestic mammals are pig (Sus scrofa) and sheep/goat (Caprinae). These other domestic mammals contribute 9 percent of the individuals and 4 percent of the biomass (Table 9e-8). The sex of the pigs could not be determined. All of the sheep/goats specimens are from F.S. 106 (76N/100E; level 25-30). The focus was clearly on large bovids, specifically domestic cattle, though the quantification of that focus may be somewhat inaccurate.

Commensal taxa constitute 8 percent of the individuals and 2 percent of the biomass in Analytical Unit 2 (Table 9e-8). The most interesting commensal animal in terms of human activity is the horse/burro (Equus sp.). The equid biomass constitutes 99.7 percent of the commensal biomass, the other commensal animals being small creatures such as frog/toads (Anura), snakes (Colubridae, Crotalinae), and mice (Muridae).

Elements represented in Feature 2 suggest on-site butchery in most cases (Table 9e-9). All of the materials in Analytical Unit 2 are from a single feature defined as a large trash pit. Axial and Head specimens are generally rare or absent largely as an artifact of identifiability and site formation. Horse/burro (Equus sp.) elements from all areas of the skeleton except the vertebra/rib category are represented but the sample size is very small (Figure 9e-11). Forty-one percent of the pig (Sus scrofa) specimens are from the Head, Forefoot, Hindfoot, and Foot (Figure 9e-12). Over half of 
the Head elements (NISP $=5$ ) are teeth while 67 percent of the Foot elements are phalanges (NISP = 2). No Axial or Forefoot specimens are represented. When compared to a standard, unmodified pig skeleton, the relative proportions of pig elements indicate that Forequarter, Hindfoot, and Hindquarter specimens are over-represented, but that Foot are under-represented (Figure 9e-3). This pattern is interpreted as primarily secondary, or post-consumption, refuse. Fifty-nine percent of the deer (Odocoileus virginianus) specimens are from the Head, Forefoot, Hindfoot, and Foot (Figure 9e-13). A third of the Head elements (NISP $=4$ ) are teeth while 86 percent of the Foot elements are phalanges (NISP $=6$ ). No Axial specimens were identified. When compared to a standard, unmodified deer skeleton, the relative proportions of specimens represented indicate that most postcranial and non-Axial skeletal portions are over-represented (Figure 9e-5). The Foot category is under-represented. This pattern is interpreted as primarily secondary, or post-consumption, refuse, though the presence of a parietal with an antler shaft still attached indicates that entire carcasses, including the head, were occasionally brought to the mission.

The majority of the large bovid (Bovidae) specimens in Feature 2 represent elements from the head and foot (Table 9e-9). Seventy-seven percent of the bovine (Bovinae) specimens are from the Head, Forefoot, Hindfoot, and Foot (Figure 9e-14). Twenty-five percent of the Head elements $($ NISP $=116)$ are teeth and 53 percent are horn core fragments (NISP $=246$ ). Sixty-two percent of the Foot elements are phalanges (NISP $=194)$ and 34 percent are sesamoids (NISP $=107)$. When compared to a standard, unmodified cow skeleton, the relative proportions of cow elements indicate that Forequarter and Hindquarter elements are over-represented but that specimens from the lower legs are present in proportions very similar to an undisturbed skeleton (Figure 9e-7). This pattern is interpreted as primary, on-site butchery refuse mixed with secondary, or postconsumption, refuse. There is no tendency for horn cores or sesamoids to be clustered in a few samples. These specimens appear to be randomly distributed throughout Feature 2, though 37 percent of the horn cores (NISP $=92$ ) are in samples from 74N/100E; level 55-75 (F.S. 213, 220, 228, 233). F.S. 213 (74N/100E; level 55-60) contains a horn core still attached to the frontal. The distribution of elements represented for bison (Bison cf. bison) and cow (Bos cf. taurus) reflects identifiability (Figures 9e-15 and 9e-16).

The small number of sheep/goat (Caprinae) specimens makes it difficult to generalize about element representation for these small bovids. Ninety-three percent of the specimens are from the Forefoot and Foot (Table 9e-9). Six of the Foot specimens are phalanges. The Hindquarter specimen is from the sacrum (Figure 9e-17).

One of the horse/burros (Equus sp.) was a subadult at death and the other was of indeterminate age. Five pig individuals were estimated; four of these were juveniles. The age of the fifth individual could not be determined, but it was at least a subadult if not an adult when it died. Of the four deer individuals estimated, two were juveniles and two were adults when they died.

In Analytical Unit 2, 60 percent of the estimated 20 bovines and caprines were juveniles and subadults at death. Four bovines (Bovinae) were juveniles at death, seven were subadults, and seven were adults when they died. Parenthetically, one of the two probable bison (Bison cf. bison) was an adult; the other was at least a subadult, if not an adult, when it died. One of the four probable cows (Bos cf. taurus) was a subadult at death, one was an adult, and two were indeterminate. One of the sheep/goats (Caprinae) was a juvenile and the other was of indeterminate age at death, but probably was at least a subadult if not an adult.

Table 9e-9. Feature 2, AU 2: Number of elements represented

\begin{tabular}{|c|c|c|c|c|c|c|c|}
\hline & Horse/burro & Pig & Deer & Bovinae & Bison & Cow & Caprinae \\
\hline Head & 1 & 9 & 13 & 466 & 1 & & \\
\hline Vertebra/Rib & & & & 81 & 2 & & \\
\hline Forequarter & 1 & 15 & 11 & 78 & & 7 & \\
\hline Forefoot & 2 & & 3 & 52 & 4 & 28 & 5 \\
\hline Foot & 2 & 3 & 7 & 314 & & 1 & 8 \\
\hline Hindfoot & 2 & 7 & 6 & 54 & & 10 & \\
\hline Hindquarter & 1 & 12 & 9 & 109 & 1 & 3 & 1 \\
\hline TOTAL & 9 & 46 & 49 & 1154 & 8 & 49 & 14 \\
\hline
\end{tabular}




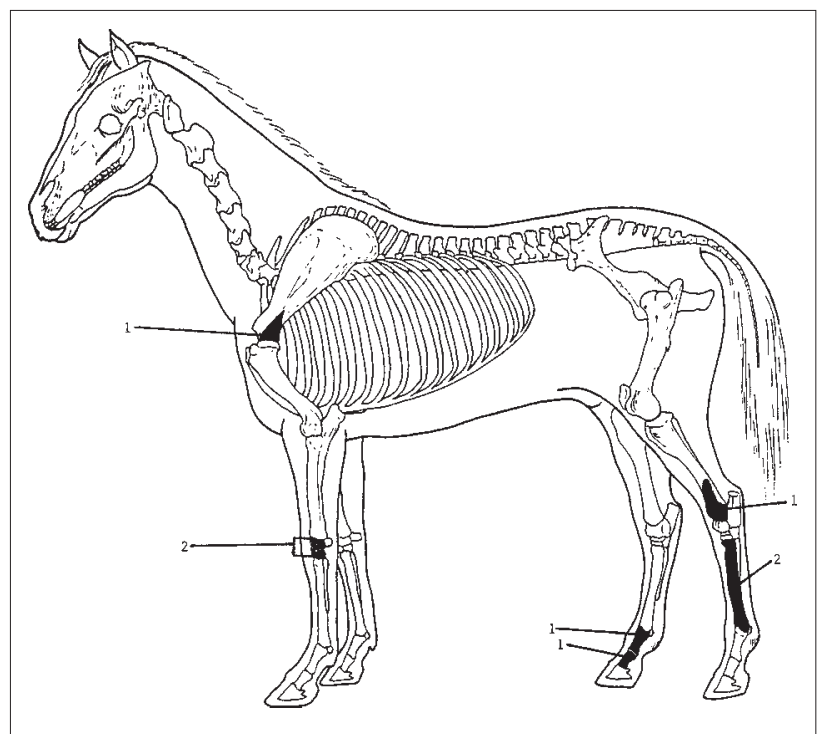

Figure 9e-11. Analytical Unit 2: Horse/burro (Equus sp.) elements represented. Not illustrated is 1 tooth. $\mathrm{N}=9$.

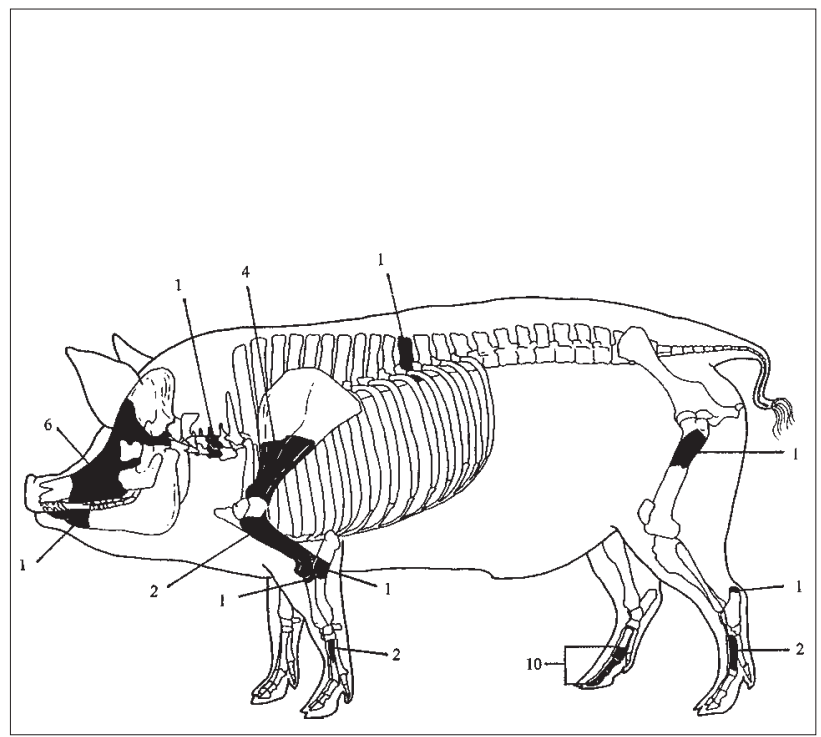

Figure 9e-12. Analytical Unit 2: Pig (Sus scrofa) elements represented. Not illustrated are 5 teeth and 5 skull fragments. $\mathrm{N}=46$.

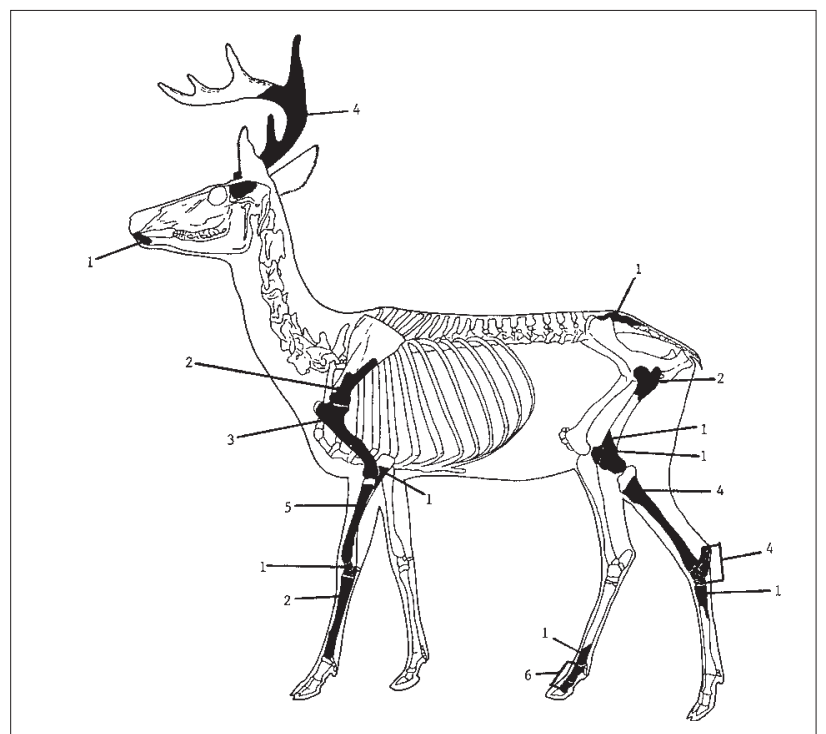

Figure 9e-13. Analytical Unit 2: Deer (Odocoileus virginianus) elements represented. Not illustrated are 4 teeth and 4 skull fragments. $\mathrm{N}=49$.

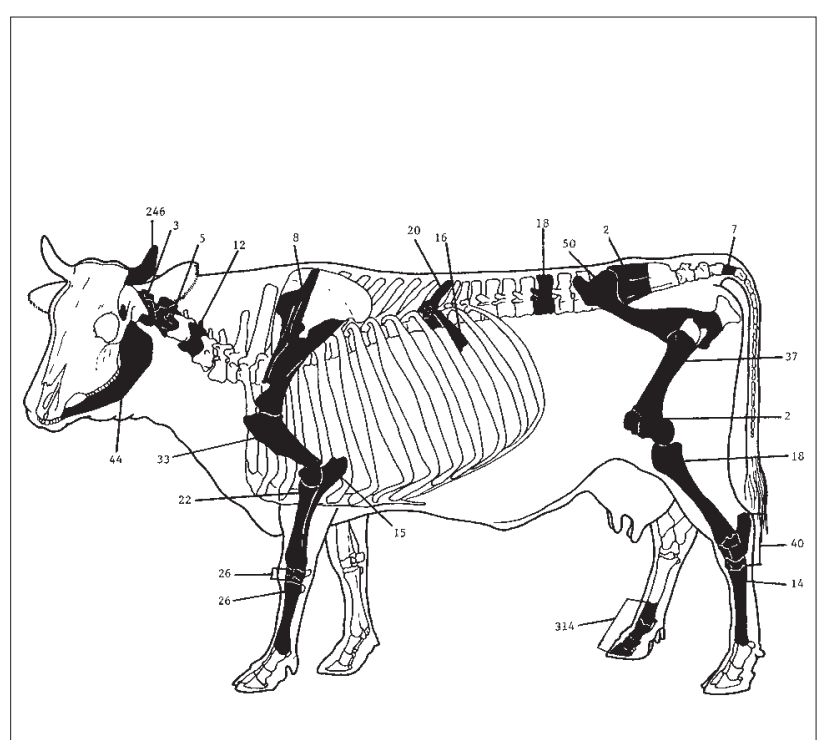

Figure 9e-14. Analytical Unit 2: Bovinae elements represented. Not illustrated are 116 teeth and 60 skull fragments. $\mathrm{N}=1154$. 


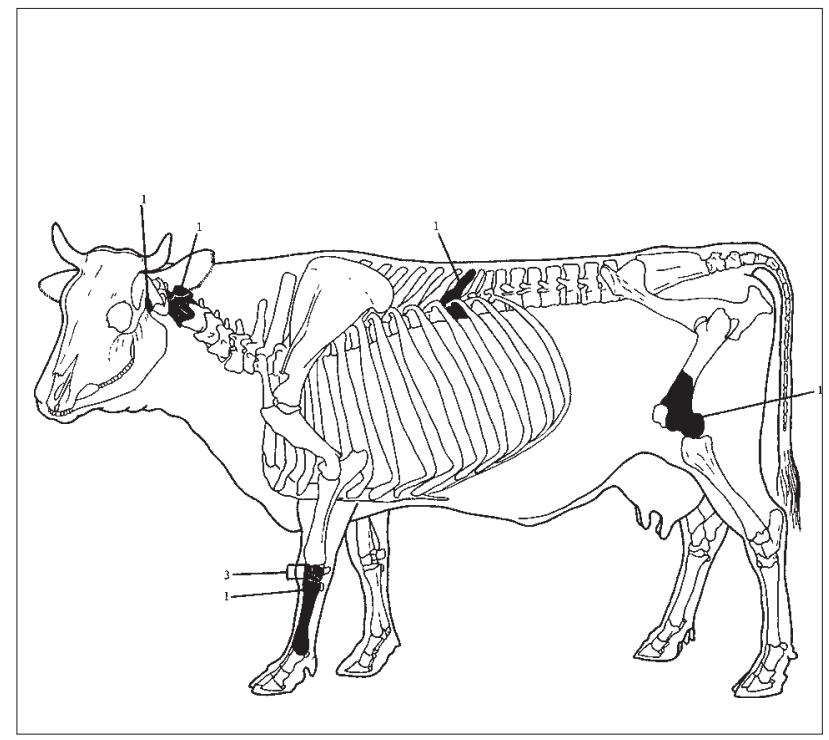

Figure 9e-15. Analytical Unit 2: Probable Bison (Bison cf. bison) elements represented.

$\mathrm{N}=8$.

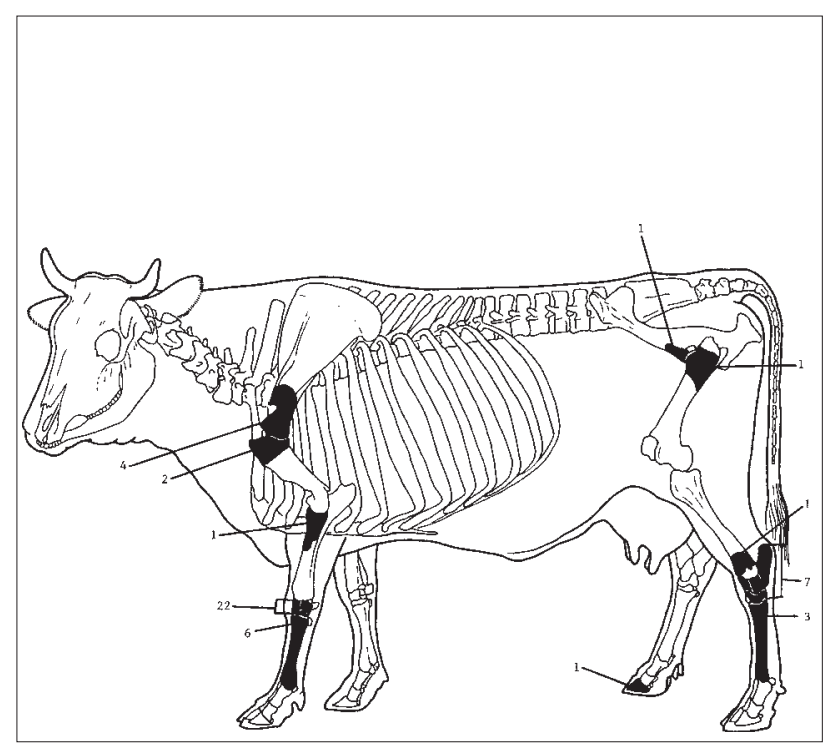

Figure 9e-16. Analytical Unit 2: Probable Cow (Bos cf. taurus) elements represented. $\mathrm{N}=49$.

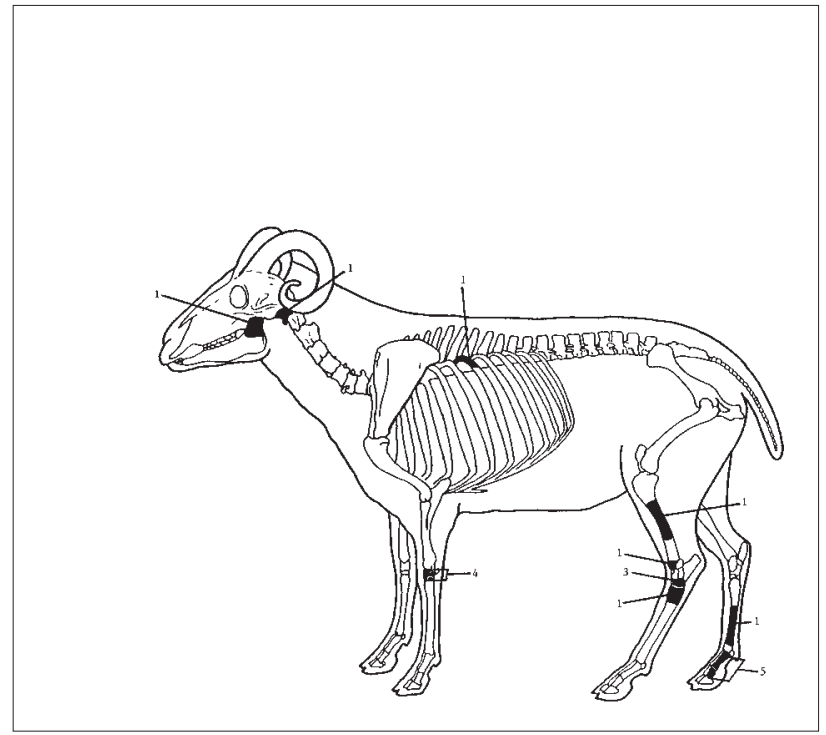

Figure 9e-17. Analytical Unit 2: Sheep/Goat (Caprinae) elements represented.

$\mathrm{N}=14$.

Modifications were observed on 15,601 specimens in Analytical Unit 2 (Table 9e-10). The vast majority of modifications are burned and calcined bone, observed on 97 percent of the modified specimens. Specimens from a variety of taxa were burned. Burning and calcination is present on 39 percent of the vertebrate specimens identified above UID Vertebrate. Burning and calcination could reflect either food preparation or a method of controlling trash accumulation.

Other modifications more closely connected to food preparation are present in the collection (Table 9e-10). Only a few UID Mammal specimens are grooved and snapped. Sawed (which includes clean-cut) specimens are present in the collection, though this is not a common modification. Three UID Mammal (F.S. 138, 213) specimens and one UID Vertebrate (F.S. 127) specimen are sawed; as is one juvenile pig (Sus scrofa) pubis (F.S. 128). A deer antler (Odocoileus virginianus) attached to the frontal was sawed in two places with the apparent purpose of removing a tip (F.S. 234).

Multiple butchery marks are present on Bovinae specimens and these are described in greater detail. Thirteen specimens are hacked; four of these are in the innominate area, two are on the proximal femur and one is on the distal femur. Five of the cut specimens are on the metacarpus $($ NISP $=3$ ), 
Table 9e-10. Feature 2, AU 2: Modifications

\begin{tabular}{|c|c|c|c|c|c|c|c|c|}
\hline & Burned & Calcined & Hacked & Cut & Groove/snap & Sawed & R. Gnaw & C. Gnaw \\
\hline Sharks/skates/rays & 1 & & & & & & & \\
\hline UID Fish & 23 & 3 & & & & & & \\
\hline Blue catfish & 1 & & & & & & & \\
\hline Black drum & 1 & & & & & & & \\
\hline Alligator & 1 & & & & & & & \\
\hline UID Turtle & 10 & & & & & & & \\
\hline Yellow mud turtle & 3 & & & & & & & \\
\hline Box and water turtles & 2 & & & & & & & \\
\hline Box turtle & 6 & 1 & & & & & 1 & \\
\hline Spiny softshell turtle & 1 & & & & & & & \\
\hline UID Bird & 62 & 16 & & 3 & & & & 1 \\
\hline Swans/geese/ducks & 2 & & 1 & 1 & & & & \\
\hline Quails, pheasants & 3 & & & & & & & \\
\hline Chicken & & 16 & & & 3 & & & \\
\hline Turkey & 12 & 2 & & 1 & & & & \\
\hline UID Mammal & 6398 & 1048 & 277 & 108 & 6 & 15 & & \\
\hline Opossum & 1 & & & & & & & \\
\hline Carnivore & & & & 1 & & & & \\
\hline Black bear & 1 & & & & & & & \\
\hline Horse/burro & 3 & & & & & & & \\
\hline Artiodactyl & 13 & & & 2 & & 2 & & \\
\hline Pig & 2 & 1 & & 4 & & 1 & & \\
\hline Deer & 3 & & & 5 & & 1 & & \\
\hline Bovinae & & 252 & 48 & 13 & 21 & & 32 & \\
\hline cf. Bison & & 1 & & & & & & \\
\hline cf. Cow & 3 & 2 & 2 & 4 & & 2 & & \\
\hline UID Vertebrate & 5471 & 1672 & 4 & 4 & & 1 & & \\
\hline TOTAL & 12291 & 2794 & 297 & 157 & 6 & 54 & 1 & 1 \\
\hline
\end{tabular}

Note: R. Gnaw and C. Gnaw refer to rodent gnawing and carnivore gnawing, respectively.

sesamoid (NISP $=1$ ), and calcaneus (NISP $=1$ ), presumably related to separating the lower leg from the upper leg. Three percent of the bovine specimens are sawed (NISP $=9$ ) or clean-cut (NISP $=45)$. Sawed or clean-cut specimens are primarily the humerus (NISP $=5$ ), thoracic vertebrae (NISP $=7$ ), innominate (NISP $=7$ ), and femur (NISP = 5). One of the bovine horn core fragments is clean-cut (F.S. 39). Two probable cow (Bos cf. taurus) specimens are also sawed. The sawed and clean-cut specimens are found in many different parts of Feature 2 (F.S. 13, 20, 26, 37, 39, 46, 63, $107,119,116,127,131,132,138,143,220,228,233,234$, 240, 262, 263).

Very few specimens show evidence of activities unrelated to butchering or food processing. No pathological or worked specimens are present in the Feature 2 assemblage and only two specimens are gnawed by rodents or carnivores. It may be noteworthy that there is only one rodent (Muridae) in the species list (see Table 9e-7). The absence of gnawing suggests that trash was discarded in such a way as to make it inaccessible or unattractive to rodents and carnivores.
Measurements from AU 2 are similar to those in the other analytical units. Measurements of the equids suggests that at least one of the individuals is a large horse. The bovid measurements show a wide range in size, as would be expected from animals of this time period prior to control over breeding (Appendix M). Figure 9e-10 includes both measurements from specimens identified as Bovinae as well as measurements from specimens identified tentatively to species. An inconsistent pattern relative to the standard cow indicates a difference in the conformation of the prebreed at Mission Refugio and the other Spanish sites in this figure compared to the modern $272 \mathrm{~kg}$ Holstein. In two cases, the Feature 2 large bovids are smaller than or equal in size to the Holstein used, as the reference while one is as large as that from Puerto Real. Most of these animals may have been about the size of the Holstein but some might have been considerably larger. Most of the dimensions fall within the range reported by deFrance from Espíritu Santo de Zuñiga at Goliad (41GD1) and Mission Nuestra Señora del Rosario (41GD2), though the upper end of the range is larger at Mission Refugio in two of the dimensions. 


\section{Results: Analytical Unit 3, Non-Feature-Late-Colonial Period}

The late-Colonial analytical unit, Unit 3, contains a vertebrate and invertebrate collection of 36,373 specimens weighing 94,703.07 gm (Table 9e-11). The remains of a minimum of 83 vertebrate individuals are estimated for 46 taxa. The dominant characteristic of the collection is the number of large members of the family Bovidae. The sample also includes a rich variety of other taxa, most of which are wild aquatic and terrestrial animals. The specimens appeared to be in good condition and the sample size appears adequate in spite of the small MNI estimate. Additional data from this unit would probably not add many additional taxa.

Five taxa of molluscs are present, including both freshwater mussels (Mytilidae) and Eastern oysters (Crassostrea virginica) (Table 9e-11). Four UID Mollusca valve fragments were burned. It is not known what the relationship is of the invertebrate materials to the total invertebrate assemblage from Mission Refugio. It is assumed that these materials do not represent the total molluscan collection from this analytical unit and they will not be considered further.

Fishes constitute 12 percent of the individuals in the Analytical Unit 3 collection and less than 1 percent of the biomass (Table 9e-12). Gar (Lepisosteus sp.) has a relatively high NISP compared to other fish but a low MNI (Table 9e11). This is because 110 of the 117 gar specimens are scales and the other seven specimens are unpaired skull fragments and vertebrae. The scales vary in size and some obviously are from at least one large individual, but estimating what would appear to be a more reasonable MNI for gar is not possible. Members of the catfish family (Ictaluridae) are the second most abundant wild animal in the collection, after white-tailed deer (Odocoileus_virginianus) (Table 9e-11). At least two of the catfishes are blue catfish (Ictalurus furcatus). Three of the fish taxa [sea bass (Serranidae), red drum (Sciaenops ocellatus), and mullet (Mugil sp.)] are marine fishes found in bays or estuaries. Marine fishes constitute 30 percent of the fish individuals and freshwater fishes 70 percent.

Alligators and turtles contribute 8 percent of the individuals and less than 1 percent of the biomass in the non-feature collection (Table 9e-12). Seven specimens, five of which are vertebrae, are identified as alligator (Alligator mississippiensis) (Table 9e-11). Five taxa of turtle are present, including both terrestrial and aquatic species but no estuarine or marine taxa. The two specimens identified as probable yellow mud turtle (Kinosternon cf. flavescens) are neurals. Most of the Emydidae specimens are probably either cooter (Pseudemys sp.) or slider (Trachemys sp.). Unfortunately these two genera are very similar and these specimens cannot be identified beyond the family level. Spiny softshell turtle (Apalone spinifera) is the most abundant turtle by NISP, MNI, and biomass.

Wild birds contribute 14 percent of the individuals and less than 1 percent of the biomass in Analytical Unit 3 (Table 9e-12). Aquatic and terrestrial individuals are present in the collection in equal proportions. Aquatic birds include herons/ bitterns (Ardeidae), swans/geese/ducks (Anatidae), and coots/gallinules (Rallidae). These individuals can be found in both coastal and freshwater settings. Terrestrial birds include bobwhite (Colinus virginianus), turkey (Meleagris gallopavo), and pigeons/doves (Columbidae). Turkey is considered a wild bird in the Mission assemblage, though it was domesticated elsewhere. The presence of a tarsometatarsus with a spur indicates that at least one of the turkeys was a male. No age information could be derived from the turkey specimens. The hawk (Accipitridae) specimen is a third phalanx and the animal could have been a commensal bird or a pet, or the element could be from a keepsake.

Chicken (Gallus gallus) is the only domestic bird in the collection from the non-feature units. Chickens contribute 10 percent of the individuals but less than 1 percent of the biomass (Table 9e-12). Five of the eight individuals were adults when they died, while the remaining individuals were subadult or juveniles at death. At least one of the individuals was a male as indicated by the presence of a tarsometatarsus with a spur. No medullary bone is present.

Wild mammals in Analytical Unit 3 include white-tailed deer (Odocoileus virginianus) and other wild mammals. Deer contribute 7 percent of the individuals and 5 percent of the biomass while other wild mammals contribute 10 percent of the individuals and less than 1 percent of the biomass (Table 9e-12). Deer is the most common wild animal in the collection. Thirteen antler fragments possibly indicate the presence of at least one male deer. However, no side or seasonality information could be determined from the antler fragments; they could be from shed antlers. Other wild mammals include opossum (Didelphis virginiana), blacktail jackrabbit (Lepus californicus) and Eastern cottontail rabbit (Sylvilagus floridanus). The five armadillo (Dasypus novemcinctus) specimens are unmodified dermal scutes. 
Table 9e-11. Feature 3, AU 3: Species List

\begin{tabular}{|c|c|c|c|c|c|}
\hline & & & & & \\
\hline & NISP & \# & $\%$ & Wt., gm & Biomass, $\mathrm{kg}$ \\
\hline UID Mollusca & 8 & & & 3.41 & \\
\hline $\begin{array}{l}\text { Bivalvia } \\
\text { Clams/bivalves }\end{array}$ & 2 & & & 1.58 & \\
\hline $\begin{array}{l}\text { Mytilidae } \\
\text { Freshwater mussels }\end{array}$ & 1 & & & 0.1 & \\
\hline $\begin{array}{l}\text { Crassostrea virginica } \\
\text { Eastern oyster }\end{array}$ & 1 & & & 2.77 & \\
\hline $\begin{array}{l}\text { Gastropoda } \\
\text { Gastropods }\end{array}$ & 1 & & & 0.52 & \\
\hline UID Fish & 438 & & & 104.41 & 1.2740 \\
\hline $\begin{array}{l}\text { Lepisosteus } \\
\text { Gar }\end{array}$ & 117 & 1 & 1.2 & 49.81 & 0.9924 \\
\hline $\begin{array}{l}\text { Catostomidae } \\
\text { Suckers } \\
\end{array}$ & 1 & & & 0.46 & 0.0164 \\
\hline $\begin{array}{l}\text { Ictiobus sp. } \\
\text { Buffalo }\end{array}$ & 1 & 1 & 1.2 & 0.52 & 0.0180 \\
\hline $\begin{array}{l}\text { Siluriformes } \\
\text { Catfishes } \\
\end{array}$ & 4 & & & 3.06 & 0.0577 \\
\hline $\begin{array}{l}\text { Ictaluridae } \\
\text { Freshwater catfishes }\end{array}$ & 34 & 4 & 4.8 & 15.19 & 0.2645 \\
\hline $\begin{array}{l}\text { Ictalurus sp. } \\
\text { Blue and channel catfishes }\end{array}$ & 26 & (3) & & 26.43 & 0.4477 \\
\hline $\begin{array}{l}\text { Ictalurus furcatus } \\
\text { Blue catfish }\end{array}$ & 5 & (2) & & 7.41 & 0.1338 \\
\hline $\begin{array}{l}\text { Serranidae } \\
\text { Sea basses } \\
\end{array}$ & 1 & 1 & 1.2 & 0.67 & 0.0121 \\
\hline $\begin{array}{l}\text { Lepomis sp. } \\
\text { Sunfish } \\
\end{array}$ & 3 & 1 & 1.2 & 0.23 & 0.0051 \\
\hline $\begin{array}{l}\text { Sciaenidae } \\
\text { Drums }\end{array}$ & 3 & & & 4.23 & 0.1131 \\
\hline $\begin{array}{l}\text { Sciaenops ocellatus } \\
\text { Red drum }\end{array}$ & 5 & 1 & 1.2 & 7.02 & 0.1645 \\
\hline $\begin{array}{l}\text { Mugil sp. } \\
\text { Mullet }\end{array}$ & 6 & 1 & 1.2 & 1.24 & 0.0329 \\
\hline $\begin{array}{l}\text { Anura } \\
\text { Frogs and toads }\end{array}$ & 1 & 1 & 1.2 & 0.07 & \\
\hline UID Reptile & 3 & & & 0.29 & \\
\hline $\begin{array}{l}\text { Alligator mississippiensis } \\
\text { American alligator } \\
\end{array}$ & 7 & 1 & 1.2 & 77.74 & 1.1237 \\
\hline UID Turtle & 78 & & & 51.64 & 0.4443 \\
\hline $\begin{array}{l}\text { Kinosternon cf. flavescens } \\
\text { Probable yellow mud turtle }\end{array}$ & 2 & 1 & 1.2 & 0.52 & 0.0204 \\
\hline $\begin{array}{l}\text { Emydidae } \\
\text { Box and water turtles } \\
\end{array}$ & 48 & & & 86.95 & 0.6300 \\
\hline $\begin{array}{l}\text { Pseudemys cf. texana } \\
\text { Probable Texas river cooter }\end{array}$ & 2 & 1 & 1.2 & 5.28 & 0.0964 \\
\hline $\begin{array}{l}\text { Terrapene cf. ornata } \\
\text { Probable desert box turtle }\end{array}$ & 3 & 1 & 1.2 & 3.37 & 0.0714 \\
\hline $\begin{array}{l}\text { Trachemys scripta } \\
\text { Red-eared slider }\end{array}$ & 1 & 1 & 1.2 & 7.34 & 0.1202 \\
\hline $\begin{array}{l}\text { Apalone spinifera } \\
\text { Spiny softshell turtle }\end{array}$ & 66 & 2 & 2.4 & 143.42 & 0.8809 \\
\hline
\end{tabular}


Table 9e-11. Continued...

\begin{tabular}{|c|c|c|c|c|c|}
\hline & & & & & \\
\hline & NISP & \# & $\%$ & Wt., gm & Biomass, $\mathrm{kg}$ \\
\hline Serpentes & & & & & \\
\hline Snakes & 6 & & & 2.83 & 0.0395 \\
\hline Colubridae & & & & & \\
\hline Non-poisonous snakes & 19 & 1 & 1.2 & 2.48 & 0.0345 \\
\hline Crotalinae & & & & & \\
\hline Pit vipers & 4 & 1 & 1.2 & 2.19 & 0.0305 \\
\hline UID Bird & 528 & & & 177.2 & 2.2704 \\
\hline $\begin{array}{l}\text { Ardeidae } \\
\text { Herons and bitterns }\end{array}$ & 2 & 2 & 2.4 & 0.91 & 00187 \\
\hline $\begin{array}{l}\text { Nycticorax sp. } \\
\text { Night heron }\end{array}$ & 1 & (1) & & 0.61 & 0.0130 \\
\hline Anatidae & & & & & \\
\hline Swans, geese, and ducks & 6 & 2 & 2.4 & 1.58 & 0.0310 \\
\hline $\begin{array}{l}\text { Anserinae } \\
\text { Geese }\end{array}$ & 9 & (1) & & 14.06 & 0.2263 \\
\hline $\begin{array}{l}\text { Cathartidae } \\
\text { American vultures }\end{array}$ & 1 & 1 & 1.2 & 1.32 & 0.0263 \\
\hline $\begin{array}{l}\text { Accipitridae } \\
\text { Hawks and eagles }\end{array}$ & 1 & 1 & 1.2 & 0.45 & 0.0099 \\
\hline $\begin{array}{l}\text { Phasianidae } \\
\text { Quails, pheasants, and partridges }\end{array}$ & 5 & & & 5.17 & 0.0910 \\
\hline $\begin{array}{l}\text { Colinus virginianus } \\
\text { Common bobwhite }\end{array}$ & 1 & 1 & 1.2 & 0.11 & 0.0027 \\
\hline $\begin{array}{l}\text { Gallus gallus } \\
\text { Chicken }\end{array}$ & 116 & 8 & 9.6 & 74.8 & 1.0357 \\
\hline $\begin{array}{l}\text { Meleagris gallopavo } \\
\text { Turkey }\end{array}$ & 23 & 3 & 3.6 & 61.13 & 0.8620 \\
\hline $\begin{array}{l}\text { Rallidae } \\
\text { Coots and gallinules }\end{array}$ & 1 & 1 & 1.2 & 0.31 & 0.0070 \\
\hline $\begin{array}{l}\text { Columbidae } \\
\text { Pigeons and doves }\end{array}$ & 4 & 1 & 1.2 & 1.01 & 0.0206 \\
\hline $\begin{array}{l}\text { Mimidae } \\
\text { Mockingbirds and thrashers }\end{array}$ & 1 & 1 & 1.2 & 0.04 & 0.0011 \\
\hline UID Mammal & 33097 & & & 58058.95 & 509.8968 \\
\hline $\begin{array}{l}\text { Didelphis virginiana } \\
\text { Opossum }\end{array}$ & 2 & 1 & 1.2 & 1.1 & 0.0287 \\
\hline $\begin{array}{l}\text { Scalopus aquaticus } \\
\text { Eastern mole }\end{array}$ & 1 & 1 & 1.2 & 0.13 & 0.0042 \\
\hline $\begin{array}{l}\text { Dasypus novemcinctus } \\
\text { Armadillo } \\
\end{array}$ & 5 & 1 & 1.2 & 1.02 & 0.0268 \\
\hline $\begin{array}{l}\text { Leporidae } \\
\text { Hares and rabbits }\end{array}$ & 4 & & & 1.82 & 0.0451 \\
\hline \begin{tabular}{|l} 
Lepus californicus \\
Blacktail jackrabbit
\end{tabular} & 1 & 1 & 1.2 & 1.34 & 0.0342 \\
\hline \begin{tabular}{|l} 
Sylvilagus sp. \\
Rabbit
\end{tabular} & 9 & 2 & 2.4 & 2.59 & 0.0619 \\
\hline \begin{tabular}{|l} 
Sylvilagus floridanus \\
Eastern cottontail rabbit
\end{tabular} & 2 & (1) & & 0.33 & 0.0097 \\
\hline Rodentia & 5 & & & 0.74 & 0.0201 \\
\hline $\begin{array}{l}\text { Geomys sp. } \\
\text { Pocket gopher }\end{array}$ & 10 & 2 & 2.4 & 2.19 & 0.0533 \\
\hline
\end{tabular}


Table 9e-11. Continued...

\begin{tabular}{|c|c|c|c|c|c|}
\hline & & & & & \\
\hline & NISP & \# & $\%$ & Wt., gm & Biomass, $\mathrm{kg}$ \\
\hline $\begin{array}{l}\text { Heteromyidae } \\
\text { Pocket mice }\end{array}$ & 1 & 1 & 1.2 & 0.07 & 0.0024 \\
\hline $\begin{array}{l}\text { Muridae } \\
\text { Old and New World rats and mice }\end{array}$ & 1 & & & 0.16 & 0.0051 \\
\hline $\begin{array}{l}\text { Neotoma sp. } \\
\text { Woodrat }\end{array}$ & 1 & 1 & 1.2 & 0.18 & 0.0056 \\
\hline $\begin{array}{l}\text { Murinae } \\
\text { Old World rats and mice }\end{array}$ & 1 & 1 & 1.2 & 0.17 & 0.0053 \\
\hline $\begin{array}{l}\text { Canidae } \\
\text { Dogs, wolves, and foxes }\end{array}$ & 1 & & & 2.25 & 0.0546 \\
\hline $\begin{array}{l}\text { Canis sp. } \\
\text { Dog, wolf, and coyote }\end{array}$ & 1 & 1 & 1.2 & 5.39 & 0.1198 \\
\hline $\begin{array}{l}\text { Mephitinae } \\
\text { Skunks }\end{array}$ & 1 & 1 & 1.2 & 0.3 & 0.0089 \\
\hline $\begin{array}{l}\text { Felis concolor } \\
\text { Cougar }\end{array}$ & 1 & 1 & 1.2 & 8.17 & 0.1742 \\
\hline $\begin{array}{l}\text { Felis domesticus } \\
\text { Domestic cat } \\
\end{array}$ & 35 & 1 & 1.2 & 38.16 & 0.6973 \\
\hline $\begin{array}{l}\text { Equus sp. } \\
\text { Horse/burro }\end{array}$ & 17 & 1 & 1.2 & 558.74 & 7.8071 \\
\hline Artiodactyla & 21 & & & 24.09 & 0.4609 \\
\hline $\begin{array}{l}\text { Sus scrofa } \\
\text { Pig }\end{array}$ & 40 & 3 & 3.6 & 152.12 & 2.4208 \\
\hline $\begin{array}{l}\text { Odocoileus virginianus } \\
\text { White-tailed deer }\end{array}$ & 159 & 6 & 7.2 & 1060.48 & 13.8980 \\
\hline $\begin{array}{l}\text { Bovinae } \\
\text { Bison/cow }\end{array}$ & 1258 & 15 & 18.1 & 25037.67 & 239.1853 \\
\hline $\begin{array}{l}\text { Bison cf. bison } \\
\text { Probable bison } \\
\end{array}$ & 5 & (2) & & 566.76 & 7.9079 \\
\hline $\begin{array}{l}\text { Bos } \text { cf. taurus } \\
\text { Probable cow } \\
\end{array}$ & 71 & (5) & & 3512.58 & 40.8379 \\
\hline $\begin{array}{l}\text { Caprinae } \\
\text { Sheep/goat }\end{array}$ & 20 & & & 71.33 & 1.2245 \\
\hline $\begin{array}{l}\text { Capra hircus } \\
\text { Goat }\end{array}$ & 1 & 1 & 1.2 & 4.59 & 0.1037 \\
\hline $\begin{array}{l}\text { Ovis aries } \\
\text { Sheep }\end{array}$ & 6 & 1 & 1.2 & 36.21 & 0.6652 \\
\hline UID Vertebrate & & & & 4601.56 & \\
\hline TOTAL & 36373 & 83 & & 94703.07 & 837.4050 \\
\hline
\end{tabular}

The canid specimens are a first phalanx (Canidae) and a second metacarpus (Canis sp.). These specimens are fairly large and are probably from a single large dog or wolf rather than a coyote or a fox. These elements are both fused, indicating the animal(s) was at least a subadult if not an adult at death. The cougar (Felis concolor) is represented by an unmodified, complete astragalus.
Domestic mammals contribute 24 percent of the individuals in Analytical Unit 3 and 89 percent of the biomass (Table 9e-12). Most of this is from members of the subfamily Bovinae (18 percent of the MNI and 88 percent of the biomass). The subfamily Bovinae is considered a domestic mammal in this context though most of the materials assigned to this category could not be distinguished between wild 
Table 9e-12. Feature 3, AU 3: Summary

\begin{tabular}{lcccc} 
& \multicolumn{2}{c}{ MNI } & \multicolumn{2}{c}{ Biomass } \\
\hline & $\#$ & $\%$ & $\mathrm{~kg}$ & $\%$ \\
Sharks, Rays, and Fishes & 10 & 12 & 1.4895 & 0.5 \\
Alligator/Turtles & 7 & 8.4 & 2.313 & 0.9 \\
Wild Birds & 12 & 14.5 & 0.9782 & 0.4 \\
Domestic Birds & 8 & 9.6 & 1.0357 & 0.4 \\
Deer & 6 & 7.2 & 13.898 & 5.1 \\
Bovinae & 15 & 18.1 & 239.1853 & 88.2 \\
Other Wild Mammals & 8 & 9.6 & 0.4512 & 0.2 \\
Other Domestic Mammals & 5 & 6 & 3.1897 & 1.2 \\
Commensal Taxa & 12 & 14.5 & 8.6446 & 3.2 \\
\hline TOTAL & 83 & \multicolumn{3}{c}{271.1852} \\
\hline
\end{tabular}

bison and domestic cattle. Both bison (Bison cf. bison) and domestic cow (Bos cf. taurus) are present in the unit; but where it is possible to distinguish between them, domestic cattle are more common than bison. However, because the specimens referred to as Bovinae probably include some bison, Bovinae's contribution to the domestic category may be exaggerated and its contribution to the wild mammal category under estimated. Other domestic mammals are pig (Sus scrofa), goat (Capra hircus), and sheep (Ovis aries). These other domestic mammals contribute 6 percent of the individuals and 1 percent of the biomass (Table 9e-12). A single lower pig canine was present but sex of the individual could not be determined. The focus was clearly on large bovids, specifically domestic cattle, though the precision with which that contribution is quantified may be inaccurate.

Commensal taxa constitute 14 percent of the individuals and 3 percent of the biomass in the non-feature units (Table 9e-12). The high biomass estimate is largely due to the presence of a horse/burro (Equus sp.). The equid biomass constitutes 90 percent of the commensal biomass, the other commensal animals being small creatures such as frog/toads (Anura), moles (Scalopus aquaticus), and pocket gophers
(Geomys sp.). A mockingbird/thrasher (Mimidae) is also included in the commensal category, although the European history of utilizing small birds as a food source might have been transferred to the colonies in this hemisphere. The commensal taxa also include a domestic cat (Felis domesticus). This cat was almost complete, though it lacked the head. The remains are from 85N/100E, F.S. 18 (NISP = $6)$ and 95N100E, F.S. $17(\mathrm{NISP}=29)$.

Elements represented suggest on-site butchery and general trash disposal (Table 9e-13). Analytical Unit 3 is defined as general contexts associated with the late-Colonial occupation recovered from the upper levels of each excavated square. Axial and Head specimens are generally rare or absent largely as an artifact of identifiability or site formation processes. Too few horse/burro (Equus sp.) specimens are present to discern a pattern of element representation, though elements from throughout the skeleton are present in the collection (Figure 9e-18). Over a quarter of the equid specimens are teeth, including a canine tooth. Three-quarters of the pig (Sus scrofa) specimens are from the Head, Forefoot, Hindfoot, and Foot (Figure 9e-19). Half of the Head elements (NISP $=7$ ) are teeth and 70 percent of the

Table 9e-13. Feature 3, AU 3: Number of elements represented

\begin{tabular}{|c|c|c|c|c|c|c|c|c|c|}
\hline & Horse/burro & Pig & Deer & Bovinae & Bison & Cow & Caprinae & Goat & Sheep \\
\hline Head & 7 & 14 & 43 & 369 & & 4 & 3 & & \\
\hline Vertebra/Rib & 1 & 2 & 14 & 202 & 1 & 4 & 1 & & \\
\hline Forequarter & & 8 & 18 & 106 & 1 & 10 & & & \\
\hline Forefoot & 2 & 2 & 14 & 46 & 1 & 31 & 4 & & 3 \\
\hline Foot & 4 & 10 & 33 & 314 & & 2 & 6 & & 2 \\
\hline Hindfoot & 2 & 3 & 26 & 69 & 2 & 15 & 4 & 1 & 1 \\
\hline Hindquarter & 1 & 1 & 11 & 152 & & 5 & 2 & & \\
\hline TOTAL & 17 & 40 & 159 & 1258 & 5 & 71 & 20 & 1 & 6 \\
\hline
\end{tabular}




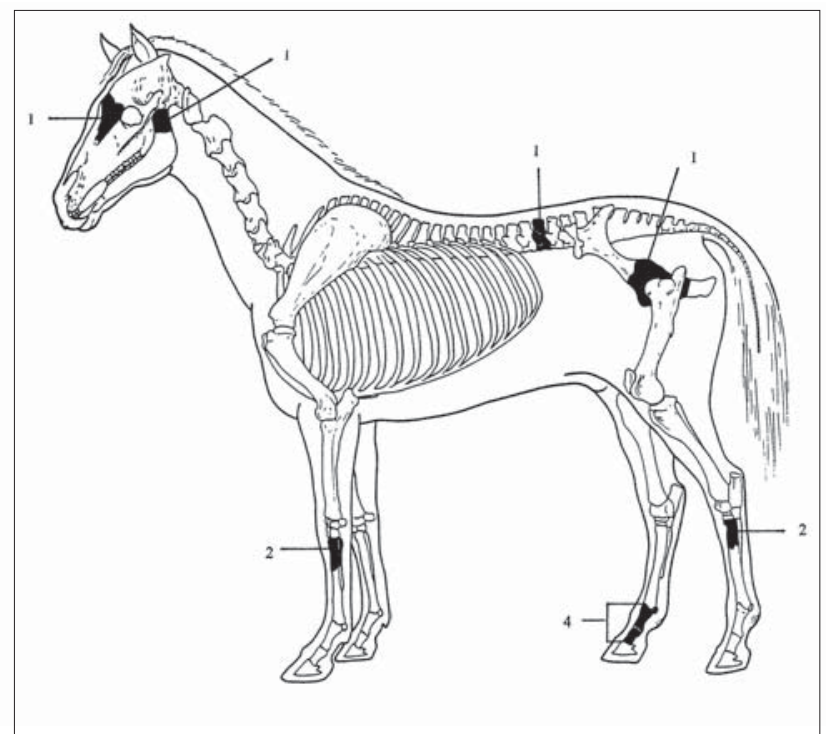

Figure 9e-18. Analytical Unit 3: Horse/burro (Equus sp.) elements represented. Not illustrated are 5 teeth. $\mathrm{N}=17$.

Foot elements are phalanges (NISP $=7$ ). When compared to a standard, unmodified pig skeleton, the relative proportions of pig elements indicate that Forequarter elements are over-represented but that specimens from the lower legs are present in proportions very similar to an

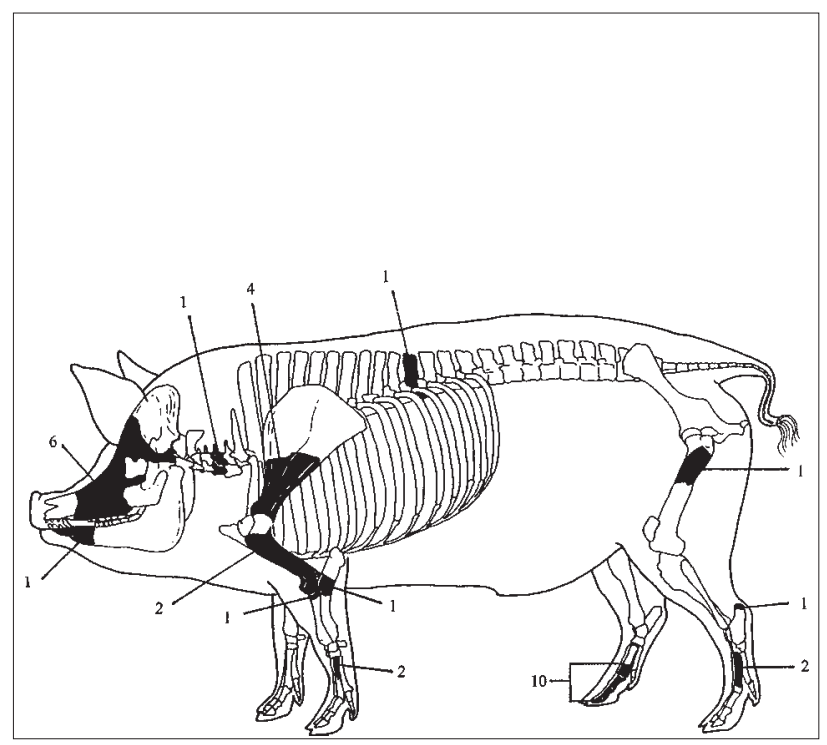

Figure 9e-19. Analytical Unit 3: Pig (Sus scrofa) elements represented. Not illustrated are 7 teeth. $\mathrm{N}=40$.

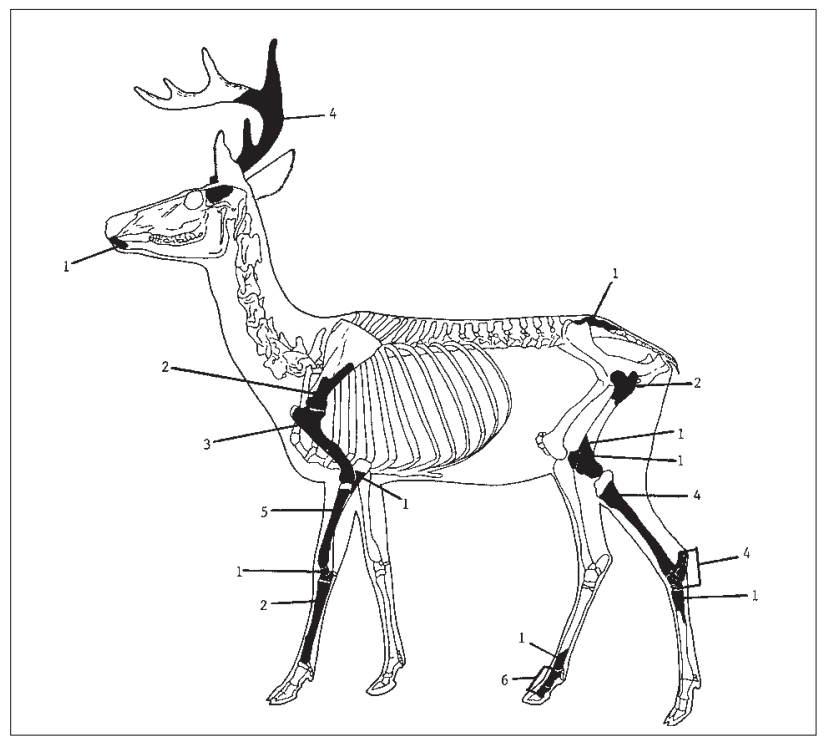

Figure 9e-20. Analytical Unit 3: Deer (Odocoileus virginianus) elements represented. Not illustrated are 16 teeth. $\mathrm{N}=159$.

undisturbed skeleton (Figure 9e-3). The Hindquarter is somewhat under-represented. This pattern is interpreted as primary butchery refuse mixed with secondary, or postconsumption, refuse; though the lack of Hindquarter specimens is difficult to explain in this way. Three-quarters of the specimens identified as deer (Odocoileus virginianus) are from the Head, Forefoot, Hindfoot, and Foot (Figure 9e-20). Thirty-seven percent of the Head elements (NISP = 16) are teeth and 64 percent of the Foot elements are phalanges (NISP $=21$ ). When compared to a standard, unmodified deer skeleton, the relative proportions of elements indicate that Forequarter and Hindquarter elements are over-represented but that specimens from the Foot are under-represented (Figure 9e-5). This is a pattern that is interpreted as evidence of off-site butchery combined, perhaps, with hide-removal where phalanges are either left in the hides or discarded at the kill site.

The majority of the large bovid (Bovidae) specimens in Analytical Unit 3 represent elements from the Head and Foot (Table 9e-13). Sixty-three percent of the bovine (Bovinae) specimens are from the Head, Forefoot, Hindfoot, and Foot (Figure 9e-21). Twenty-nine percent of the Head elements (NISP $=106)$ are teeth and 13 percent are horn core fragments (NISP $=48$ ). Eleven percent of the Foot elements are phalanges (NISP $=35)$. When compared to a standard, unmodified cow skeleton, the relative proportions of cow elements indicate that Forequarter and Hindquarter 
elements are over-represented but that specimens from the lower legs are present in proportions very similar to an undisturbed skeleton (Figure 9e-7). This pattern is interpreted as primary, on-site butchery refuse mixed with secondary, or post-consumption, refuse. This interpretation is supported by the cluster of cranial fragments found in

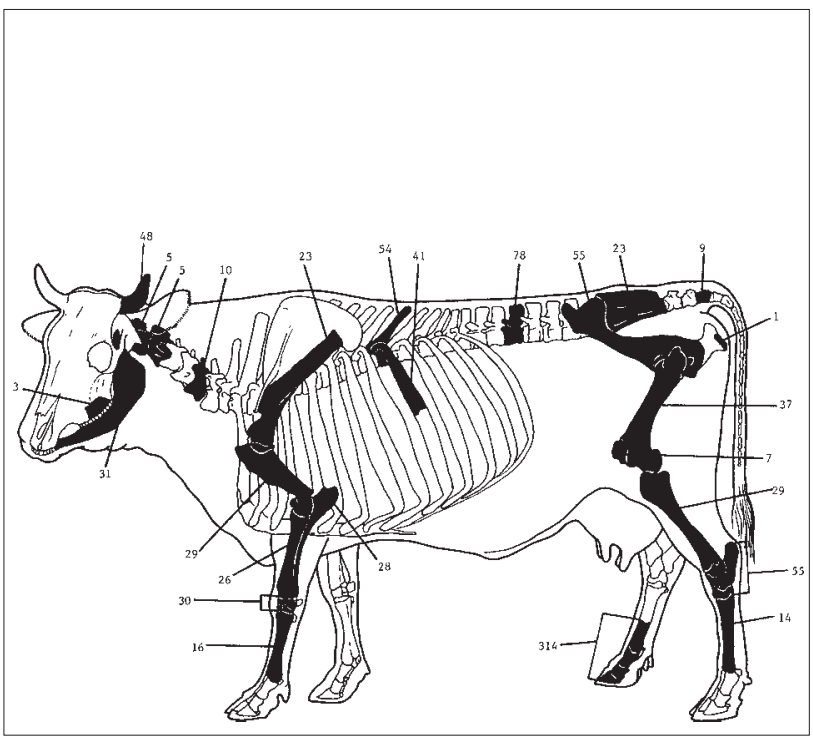

Figure 9e-21. Analytical Unit 3: Bovinae elements represented. Not illustrated-106 teeth, 20 hyoid elements, 161 skull fragments. $\mathrm{N}=1258$. two of the samples. F.S. 196 (74N/E100E; level 50-55) contains two of the 48 horn core fragments and two of the other Head fragments while F.S. 208 (74N/E100E; level 50-55) contains 43 horn core fragments as well as 140 other Head fragments. The distribution of elements represented for bison (Bison cf. bison) and cow (Bos cf. taurus) reflects identifiability (Figures 9e-22 and 9e-23).

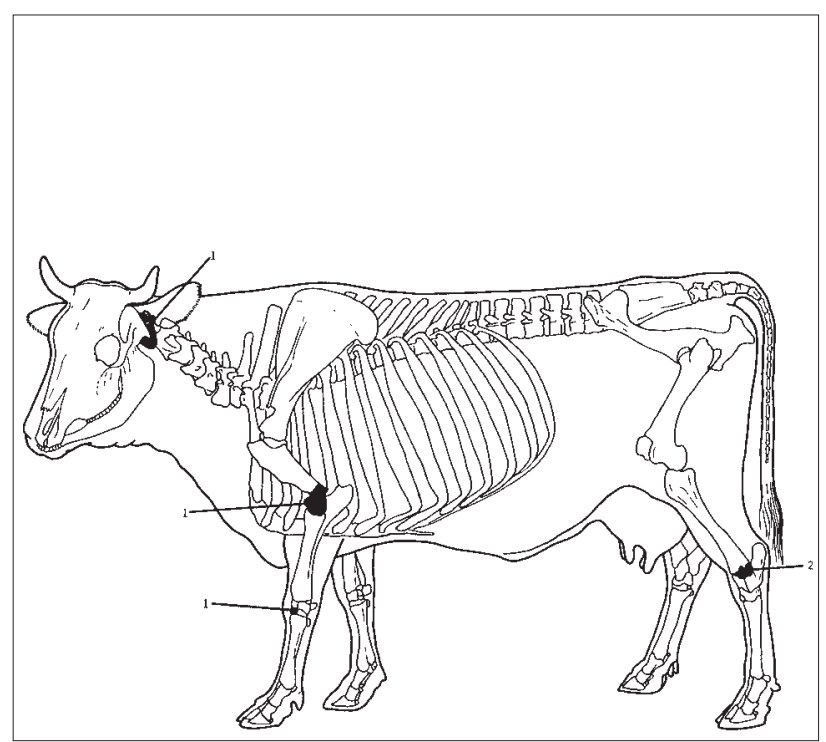

Figure 9e-22. Analytical Unit 3: Probable Bison (Bison cf. bison) elements represented. $\mathrm{N}=5$.

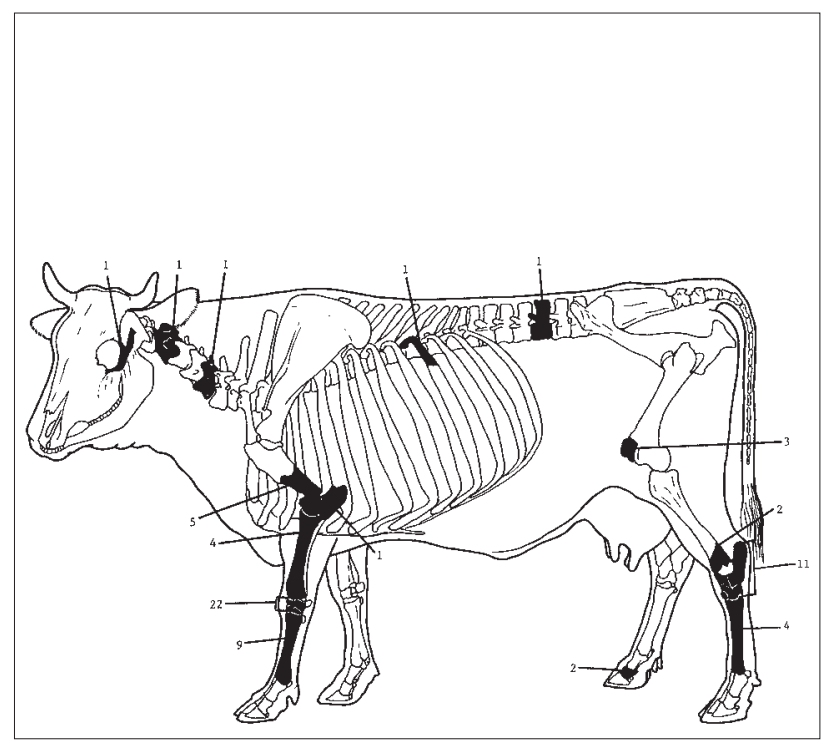

Figure 9e-23. Analytical Unit 3: Probable Cow (Bos cf. taurus) elements represented. Not illustrated are 3 teeth. $\mathrm{N}=71$. 
Table 9e-14. Feature 3, AU 3: Modifications

\begin{tabular}{|c|c|c|c|c|c|c|c|c|c|c|c|}
\hline & Burned & Calcined & Hacked & Cut & Groove/snap & Sawed & Worked & Pathology & R. Gnaw & C. Gnaw & Digested \\
\hline UID Fish & & & 1 & 1 & & & & & & & \\
\hline Catfishes & 1 & & & & & & & & & & \\
\hline Freshwater catfishes & & & & 1 & & & & & & & \\
\hline Blue catfish & & & 2 & & & & & & & & \\
\hline Drums & & & & 1 & & & & & & & \\
\hline Alligator & & & & & & & 1 & & & & \\
\hline UID Turtle & 7 & & & & & & & & & & \\
\hline Box and water turtles & 3 & & & & & & & 1 & & & \\
\hline Spiny softshell turtle & 21 & 2 & & & & & & & & & \\
\hline UID Bird & 1 & & & & & & 2 & & & & 1 \\
\hline Geese & & & & 2 & & & & & & & \\
\hline Chicken & & & 1 & 1 & & & & & & & \\
\hline Turkey & & & & & & & & & & 3 & \\
\hline UID Mammal & 6091 & 2224 & 143 & 188 & 171 & 7 & 1 & & 6 & 16 & 1 \\
\hline Artiodactyla & & 1 & & & & & & & & & \\
\hline Pig & & & 1 & & 1 & & & & & & \\
\hline Deer & 4 & & 1 & 8 & & 1 & & 1 & & & \\
\hline Bovinae & 41 & 5 & 35 & 33 & 6 & 7 & & 1 & 2 & 12 & \\
\hline cf. Bison & & & & 1 & & & & & & & \\
\hline cf. Cow & 2 & 1 & 3 & 12 & & & & & & & \\
\hline Caprinae & & & 1 & 2 & & & & & & & \\
\hline UID Vertebrate & 2094 & 727 & & 3 & & & & & & & 1 \\
\hline TOTAL & 8265 & 2960 & 188 & 253 & 178 & 15 & 4 & 3 & 8 & 31 & 3 \\
\hline
\end{tabular}

Note: R. Gnaw and C. Gnaw refer to rodent gnawing and carnivore gnawing, respectively.

The small number of Caprinae, goat (Capra hircus), and sheep (Ovis aries) specimens make it difficult to summarize element representation for these small bovids. The higher number of Forefoot, Hindfoot, and Foot specimens identified as goat and sheep reflects identifiability (Figures 9e-24-

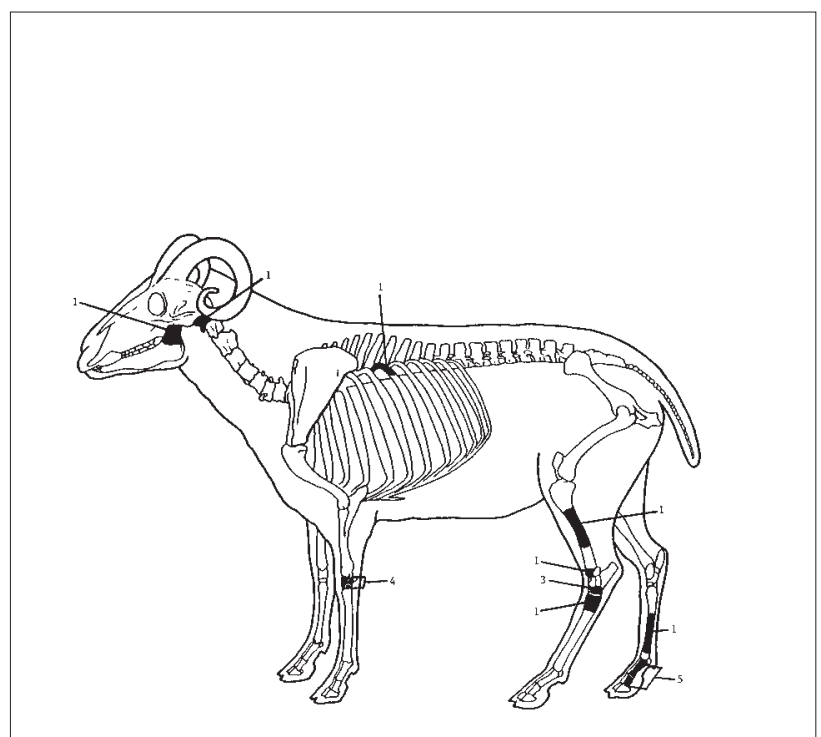

Figure 9e-24. Analytical Unit 3: Sheep/goat (Caprinae) elements represented. Not illustrated is 1 hyoid. $\mathrm{N}=20$. 9e-26). When all of the small bovid specimens are combined, 89 percent of the specimens are from the Head, Forefoot, Hindfoot, and Foot (Table 9e-13). None of the Head elements are teeth and 25 percent of the Foot elements are phalanges $(\mathrm{NISP}=2)$. This pattern is interpreted as primary butchery refuse.

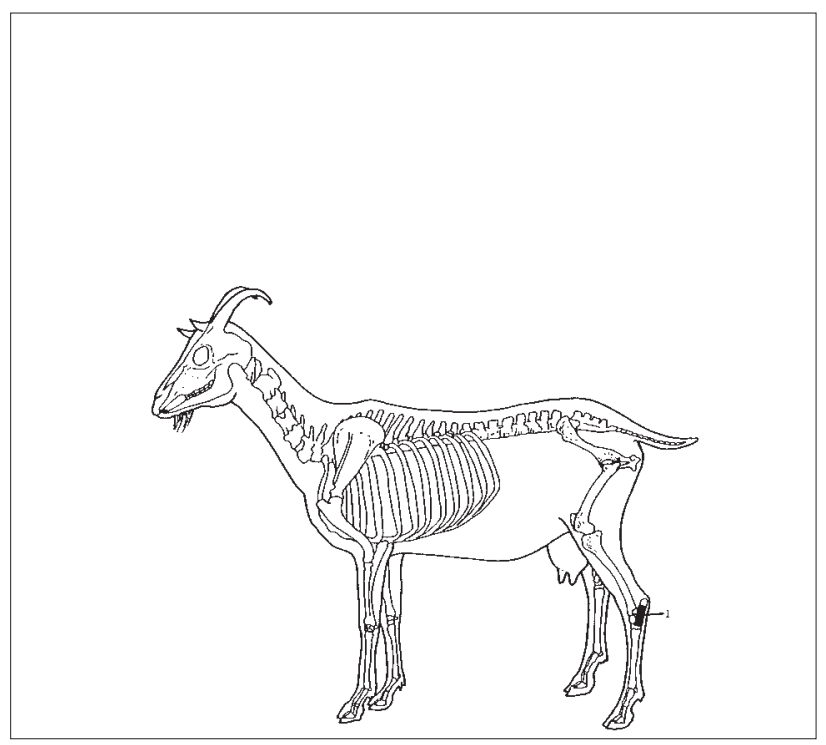

Figure 9e-25. Analytical Unit 3: Goat (Capra hircus) elements represented.

$\mathrm{N}=1$. 


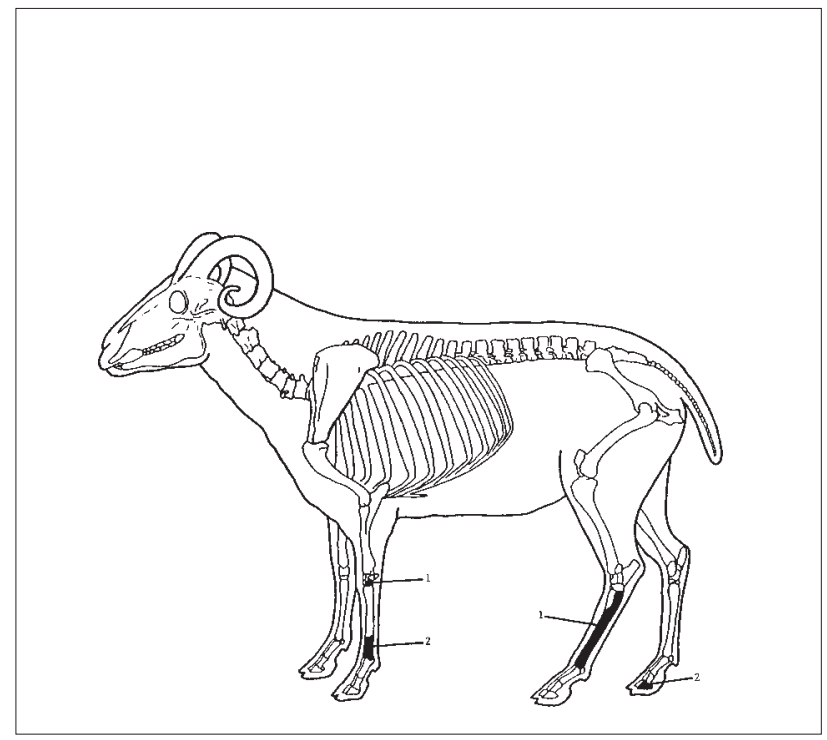

Figure 9e-26. Analytical Unit 3: Sheep (Ovis aries) elements represented. $\mathrm{N}=6$.

All horse/burro (Equus sp.) elements are fused and the estimated individual was probably a subadult if not older when it died. Two of the pig (Sus scrofa) individuals were juveniles at death. The third individual was a subadult. There is no evidence of the use of adult pigs. One fetal deer (Odocoileus virginianus) individual is represented by a very small, porous, unfused distal radius. A second, slightly older juvenile is also present. Two deer individuals were subadults and two were adults at death.

Over 50 percent of the estimated 17 individuals in the family Bovidae in Analytical Unit 3 were juveniles and subadults at death. Three of the Bovinae individuals were identified as juveniles based on the presence of three deciduous lower, fourth premolars. Two of these juveniles were less than ten months old. Six of the Bovinae were subadults, four were adults, and two were of indeterminate age when they died. Parenthetically, one of the bison (Bison cf. bison) individuals was at least a subadult when it died and it may have been an adult; the other's age was indeterminate. One of the domestic cow (Bos cf. taurus) individuals was a juvenile based on the presence of small and porous carpals. The other four probable cow individuals were at least subadults and may have been adults at death. The goat (Capra hircus) was a subadult at death and the sheep (Ovis aries) was at least a subadult when it died.

Modifications in Analytical Unit 3 were observed on 11,908 specimens (Table 9e-14). The most abundant modifications are burning and calcination, observed on 94 percent of the modified specimens. Burning and calcination are present on 21 percent of the vertebrate specimens identified above UID Vertebrate. Burning and calcination could reflect either food preparation or a method of controlling trash accumulation.

Other modifications more closely connected to food preparation are present in the collection (Table 9e-14). Many UID Mammal specimens were grooved and snapped. The majority of these specimens were large rib shaft fragments. These rib shaft fragments are most likely large bovid (Bovinae). The rib shaft fragments were most often grooved and snapped from the medial side perpendicular to the shaft. Often, both ends of the rib shaft were grooved and snapped from the medial face. Sawed (which includes specimens that are clean-cut) specimens are present in the collection, though this is not a common modification. Cut marks on the sheep/goat (Caprinae) cubonavicular and tarsus $2+3$ may be related to separating the upper leg from the lower leg.

In Analytical Unit 3 multiple butchery marks are present on Bovinae specimens and these are described in greater detail. Thirty-five specimens are hacked; 14 of these specimens are vertebrae and five are innominate fragments. Many of the cut marks are on the vertebral lateral process or the vertebral spine; perhaps related to the removal of the muscles of the back. Nine of the cut specimens are carpals and tarsals, presumably related to separating the lower leg from the upper leg. Less than 1 percent of the Bovinae specimens are sawed. Five of the sawed specimens are lumbar vertebrae sawed along the midline perpendicular to the spine. A single probable bison (Bison cf. bison) distal humerus is cut. The most prevalent modification to the probable cow (Bos cf. taurus) specimens are cut marks. Ten of the cut specimens are carpals, tarsals, or proximal metapodiae. The cut marks on these specimens are presumably the result of separating the lower leg from the upper leg. 
Several modifications are unlikely to be related to butchering or food processing. Four worked specimens are present. UID Bird shaft fragments are grooved and snapped (F.S. 65, 83) which may be evidence of bead manufacture. An alligator (Alligator mississippiensis) tooth (F.S. 208) is drilled through the root. One UID Mammal specimen (F.S. 90) is worked into a peg that is approximately one centimeter square. The specimen was sawed down the sides to form the peg. One end of the peg is flat while the other end is relatively unmodified. The sawed deer specimen (F.S. 95) is the tip of an antler tine, which may have been a tool in preparation. A Bovinae horn core (F.S. 49) is sawed on the proximal end perpendicular to the shaft of the horn core. This may be the result of sawing off the horn sheath for use as a container; the sawed horn core may be only a by-product of removing the sheath. A box/water turtle (Emydidae) ischium from a large individual seems to have been broken and healed (F.S. 203). A deer (Odocoileus virginianus) mandible also exhibits pathology in the dentition (F.S. 9). The roots of premolars two, three, and four and molars one, two, and three exhibit abnormal bone growth. These teeth also exhibited heavy wear. A Bovinae rib fragment (F.S. 18) exhibited abnormal bone growth of an indeterminate cause. A UID Bird specimen, a UID Mammal specimen, and a UID Vertebrate specimen have the polished bone surface and rounded edges characteristic of specimens that have passed through a digestive system.

Measurements from the Analytical Unit 3 collection indicate the presence of horses and cows rather than burros and bison (Appendix M). Measurements of the equids suggest that most of the elements are from a medium to large-sized horse rather than from a burro. The bovid measurements show a wide range in size, as would be expected from animals of this time period prior to control over breeding (Appendix $\mathrm{M})$. Figure $9 \mathrm{e}-10$ includes both measurements from specimens identified as Bovinae as well as measurements from specimens identified tentatively to species. An inconsistent pattern relative to the standard cow indicates a difference in the conformation of the prebreed at Mission Refugio and the other Spanish sites in this figure compared to the modern $272 \mathrm{~kg}$ Holstein (see Albarella 1997). In two cases, however, the non-feature large bovids are smaller than, or equal in size to, the Holstein used as the reference. In every case, the non-feature cattle are among the smallest of the dimensions. Most of these animals may have been about the size of the Holstein or a little larger. Further, these measurements fall within the range reported by deFrance from Espíritu Santo de Zuñiga at Goliad (41GD1) and Mission Nuestra Señora del Rosario (41GD2).

\section{Summary of Results}

- The vertebrate assemblage contained 89,899 specimens weighing $362,076.82 \mathrm{gm}$ and the remains of an estimated 253 individuals. The collections from each time period are relatively similar in size, though the collection from Feature 2, the oldest of the collections, is somewhat smaller than the other two.

- Elsewhere it has been found that changes in subsistence strategies among Native Americans influenced by Spanish colonization was highly variable. Based on these studies we should expect variation in the degree to which local resources were used, and would not expect to find that domestic animals totally replaced wild ones.

- At Spanish mission sites located where there were bison as well as domestic cattle, identifying the continuation of traditional hunting patterns is complicated by the difficulty of distinguishing between wild bison and domestic cattle bones. However, evidence of on-site butchery may be a signature of domestic cattle rather than bison. This presumes that bison would be field-dressed and that cattle would be butchered much closer to the mission compound. If this were the case, most bison elements might be discarded some distance from the excavated site whereas many cattle elements might be discarded within the excavated area.

- We might also expect the measurable dimensions of domestic cattle to be smaller than those of wild bison. Based on elements represented and size, most of the bovids from Mission Nuestra Señora del Refugio are domestic cattle rather than wild bison.

- Wild individuals constitute 52 percent of the noncommensal individuals in the Mission Refugio assemblage and domestic individuals constitute 48 percent. The general trend is for use of wild resources to become more common toward the end of the mission occupation in terms of the number of individuals. Domestic individuals generally decline from 56 percent of the non-commensal individuals in the early occupation to 39 percent of the non-commensal individuals in the late-Colonial occupation. Cattle decline from 23 percent to 18 percent of the noncommensal individuals. Pig individuals increase slightly, from 3 percent to 4 percent of the noncommensal individuals. Sheep/goats decline from 7 percent to 3 percent of the non-commensal individuals. 
Chickens also decline, from 21 percent to 11 percent of the non-commensal individuals. Wild resources increase over time from 44 percent to 61 percent of the non-commensal individuals from the early occupation to the late one. None of the wild animal categories increase dramatically. The increase is instead due a cumulative increase in all wild animal categories, except wild birds.

- The faunal assemblage also becomes more diverse from the early occupation to the late one, indicating that wider ranges of resources were used at the end of the occupation compared to the beginning. This increased diversity occurs both in terms of individuals and in terms of biomass.

- The coastal area may have played a diminishing role in the subsistence strategy from the early part of the occupation to the later part. Freshwater fish increase from 43 percent to 70 percent of the fish individuals; marine fish decrease from 57 percent to 30 percent of the fish individuals.

- Cattle dominate all three time-periods in terms of meat, contributing between 88 and 90 percent of the biomass.

- Specimens from the head and foot constitute 65 percent of the 4,246 specimens identified as Bovinae, bison, or cow. Elements from the head diminish from 39 percent of the elements represented in the oldest occupation to 28 percent of the specimens in the last occupation while elements from the body increase from 23 percent to 36 percent. Elements from the foot decrease slightly from 38 percent in the oldest occupation to 36 percent in the last occupation.

- There is no evidence for a change in the cuts of meat consumed over the course of the occupation. Elements represented in the assemblage suggest primary, onsite butchery refuse mixed with secondary, postconsumption, general trash disposal.

- Only 13 of the 4,246 large bovid specimens are referable to wild bison and 171 referable to domestic cattle. Juveniles and subadults constitute 55 percent of the estimated 49 Bovinae individuals. The percentage of adult cattle is highest in the middle occupation, in which 50 percent of the individuals were adults when they died. The percentage of adults in the earliest occupation (39 percent of the cattle individuals) and the last occupation (27 percent of the cattle individuals) was much lower.
- The most abundant modifications are burning and calcination, observed on 95 percent of the modified specimens. Burning and calcification could reflect either food preparation or a waste management technique.

- The bovid measurements show a wide range in size, as would be expected from animals of this time period prior to controlled breeding. An inconsistent pattern relative to the standard cow indicates a difference in the conformation of the prebreed at Mission Refugio and the other Spanish sites compared to the modern $272 \mathrm{~kg}$ Holstein. Most of these animals may have been about the size of the Holstein or a little larger. The size does not appear to have declined over the occupation. Most of the dimensions fall within the range reported by deFrance from Espíritu Santo de Zuñiga at Goliad (41GD1) and Mission Nuestra Señora del Rosario (41GD2), though the upper end of the range is larger at Mission Refugio in the three dimensions that can be compared.

\section{Discussion}

The vertebrate faunal assemblage from Mission Refugio is a very large one, particularly considering that it represents debris accumulated in only a portion of the site, and only over a 35 year span. It provides a solid basis for interpreting life at one of the last Spanish missions. During the occupation of Mission Refugio very little appears to have changed. It would be desirable, however, to more closely link these materials with activity areas defined for the Mission in order to explore the extent to which this conclusion reflects differential deposition, special activity areas, or the activities of only one of the ethnic groups at the Mission. At this writing, for example, it is not known if the materials in this study represent Native American or Spanish behavior. This is an important variable in the analysis. Nor is it known if these three analytical units represent residential debris associated with a few houses, a community trash deposit, or an isolated area where cattle products were processed for commercial purposes. It would be particularly interesting to know more about the market for cattle by-products which might have been served from Mission Refugio and the extent to which Mission personnel engaged in commercial activities involving cattle.

For the sake of discussion, it will be assumed that the large bovids in these mission assemblages are primarily domestic cattle rather than bison. Measurements of large bovids 
indicate small-sized cattle but some of the individuals could be fairly large (Appendix M). The size range observed is consistent with the prebreed condition in which animals were largely allowed to roam freely with little or no nutritional supplements, disease treatment, or breeding control. The cattle of this period were largely Spanish Criollo (Rouse 1977:52-53, 87-88, 183). The size of the cattle at Mission Refugio does not appear to have declined substantially over the period of occupation. It does not appear that unidentified bison remains are common in the group of specimens referred to as "Bovinae."

As an initial hypothesis, it was suggested that Spanish and Native American access to cattle might have been more limited at Mission Refugio than it was at missions which operated earlier in this area. In her review of vertebrate materials from Mission Espíritu Santo de Zuñiga (41VT11), Mission Espíritu Santo de Zuñiga in Goliad (41GD1), and Mission Nuestra Señora del Rosario (41GD2), deFrance found cattle ranching was an important activity but that the degree to which cattle were used varied among the three missions she studied. Assuming that the specimens identified as Bos/Bison represent primarily domestic cattle, the presence of cattle in the three collections reported by deFrance is very similar (deFrance 1999:Table 38). Cattle are 17 percent of the Espíritu Santo collection deposited between 1726 and 1749 on the Guadalupe River (41VT11) and 20 percent of the Espíritu Santo at Goliad collection deposited between 1749 and the early nineteenth century.

Mission Rosario is a particularly important comparison because it served the Karankawa as did Mission Refugio. In the Rosario assemblage, cattle contribute 12-18 percent of the individuals depending upon the zone being considered; Zone 1 includes the most recent levels and Zone 3 the earliest levels (deFrance 1999:Table 38). However, cattle constitute 15 percent of the individuals in the combined Rosario collection, which is a slight decline from the percentages in the two Espíritu Santo collections. Looked at as a continuum for change in the use of cattle through time at these three locations, there is no clear pattern of decline from the early Espíritu Santo deposits to the Zone 1 Mission Rosario deposit, though by the end of the Rosario occupation, cattle contribute proportionately fewer individuals at Rosario than they do in the contemporaneous assemblage of Espíritu Santo at Goliad.

Using the deFrance data as a baseline, the degree to which cattle were used at Mission Refugio falls well within this range with the possible exception of Analytical Unit 3.
It was anticipated that access to cattle might decline during the occupation at Mission Refugio and that this decline could be seen in the faunal assemblage. While the use of cattle at Refugio may have declined somewhat between the earliest and later levels, the decline is relatively small. The decline also is only in individuals, not in dietary contribution. The use of cattle in the earliest Refugio occupational level is the highest of all the various components reviewed for this study. The Analytical Unit 3 percentage of cattle use is very similar to that from Espíritu Santo at Goliad. In the early deposits (Feature 2), large bovids contribute 23 percent of the individuals; but their contribution declines to 18 percent of the individuals in the later, non-feature deposit (AU 3). The percentages of cattle individuals for the middle (Feature 1, AU 1) and later (Feature 2, AU 2) occupation at Refugio are exactly the same as for the early and middle occupations at Rosario. In terms of biomass, cattle use remains essentially constant, contributing 88-90 percent of the biomass estimated for all three analytical units. Combined with the deFrance data, there is no clear evidence indicating a decline in cattle use at these missions sufficient to force the Karankawa to resume a foraging life previously abandoned, assuming that the deposits reported here do represent Karankawa subsistence rather than Spanish subsistence or commercial activities.

The corollary to the hypothesis that availability of cattle declined is the proposition that use of wild resources increased at Mission Refugio. Based on faunal studies reviewed above, it was not expected that domestic cattle ever completely replaced wild animals. There is a great deal of zooarchaeological evidence indicating that domestic animals were not automatically adopted by Native Americans, even at missions. Nor is it likely that domestic animals introduced by Europeans completely replace local wild resources. Some use of wild animals, especially of fishes, turtles, turkey, and deer, should be found at any Spanish mission site. Given that at this same time, residents of southern cities were consuming wild resources, we should expect that this continued at Mission Refugio as well, regardless of whether the deposits are Native American or Hispanic. To the extent that domestic rather than wild animals are found in mission and other contexts associated with European colonies, it appears to be related to the success of cattle and sheep/goats in adapting to the specific location (Reitz and McEwan 1995) and to their husbandry requirements being accommodated into prevailing social systems (Reitz 1995). What was anticipated, therefore, was some wild resource use mixed with some domestic animal use. The more appropriate question is "What is the percentage use and does it change over time?" 
The deFrance data indicate that wild resources contributed between 63 and 70 percent of the non-commensal individuals in the mission assemblages she studied (deFrance 1999:Table 38). In the overall, combined Rosario assemblage wild taxa constitute 65 percent of the noncommensal individuals. Within the Rosario assemblage, the percentages of non-commensal wild and domestic individuals is variable, ranging from 59 to 70 percent of the non-commensal taxa. There is, however, no temporal trend in these data. The percentage of wild taxa does increase between the early levels and the later ones, but there is a decline in the use of wild taxa in Zone 2. The increase does not appear to signify a major shift in subsistence effort. Interestingly, these same percentages are found in the Espíritu Santo assemblages.

The purpose of Mission Refugio was to serve the Karankawa and part of the hypothesis was that they emphasized their traditional subsistence strategy to compensate for a decline in cattle availability. If that were the case, the percentages of traditional wild vertebrate species, such as bison and deer, should increase among the Mission Refugio vertebrate collections. As already mentioned, domestic cattle never completely replaced wild animals, perhaps because the Karankawa did continue their traditional strategy. However, the percentage of wild animal individuals does increase from the early deposit to the late one. Wild resources constitute over 40 percent of the estimated non-commensal individuals in all three analytical units; but the percentage increases from 44 percent of the non-commensal individuals in the early deposit (Feature 2) to 61 percent of the non-commensal individuals in the later non-feature deposits (AU 3).

Most of the increase in wild animals occurs in the percentages of fishes and other wild mammals. Deer use increases slightly through time. Although use of fishes increases from the early occupation into the middle and late periods, this increase is primarily in freshwater fishes. The use of marine fishes actually declines from 57 percent of the fish individuals in the early deposit to 30 percent of the fish individuals in the later. This change in the use of wild resources seems to reflect choice rather than necessity. It may also indicate preference for resources found closer to Mission Refugio or a decline in trade or other exchange mechanisms with the coast.

It was also hypothesized that there also might be an increase in small domestic livestock such as chickens, pigs, sheep, and goats. The percentages of smaller domestic mammals in the assemblage do change. The largest decline is in chickens, which drop from 19-20 percent of the individuals in the early and middle deposits to 10 percent in the later deposit. Pigs increase from 3 percent of the individuals in the early deposit to 4 percent in the later. Sheep and goats, however, decline from 6 percent of the individuals in the early assemblage to 2 percent in the later. It seems unlikely that use of small domestic animals increased as a way to compensate for a decline in availability of cattle.

Diversity and equitability are calculated for both MNI and biomass and also show a generally consistent use of vertebrate resources during the 35-year occupation, though with a steady increase in MNI diversity and equitability from the early Feature 2 deposit (AU 2) to the later part of the Mission's occupation (AU 3). MNI diversity is moderate but equitability high in the Feature 2 collection. Biomass diversity and equitability shows the preponderance of beef use (90 percent of the biomass) even at the earliest years of the Mission. In Feature 1, the MNI diversity and equitability are high. As in the non-feature assemblage, beef was the main source of meat so that biomass diversity and equitability is very low. Biomass diversity and equitability reflects this focus. This is another way to document an increase in the variety of wild taxa present in the later collection compared to the earlier ones, and corresponds with the increase in the use of wild resources indicated using summarized percentages of MNI. However, the amount of meat provided by the taxa present in the non-feature units (AU 3) is neither diverse nor even. Less than 10 percent of the summary biomass came from any source other than beef during any part of the Mission occupation if the biomass estimate for horse/burro is subtracted. This supports the interpretation that most of the meat consumed at Mission Refugio throughout its operation was beef. At the same time, the variety of wild animals used during the last part of the occupation had expanded to include many more taxa in spite of the dominance of beef.

The second major hypothesis guiding this research was that the dense deposit of animal bones constituting the Mission Refugio vertebrate assemblage represents general refuse disposal rather than strictly butchering or kitchen refuse. The strongest evidence that these trash pits and the sheet deposit represent generalized animal use is the diversity of animals found in the deposits. It is unlikely that such a range of animals would be found in a limited activity area or one that was entirely devoted to post-use kitchen refuse. 
The other line of evidence is the distribution of artiodactyl elements represented in the deposits compared to the standard, complete skeleton. In an undisturbed artiodactyl skeleton, roughly a third of the elements will be from the Head, a third from the Body, and a third from the Foot, depending on the skeleton of the specific animal under consideration. For example, in a complete, undisturbed pig skeleton 67 percent of the elements are from the Head and Foot because the metapodials are not reduced in number as they are in other artiodactyls. By contrast, 63 percent of the unmodified deer skeleton is from the Head and Foot. It is this vagary of distribution in a normal skeleton that the application of log ratios attempts to control. Using an undisturbed skeleton as control, we can ask the question "Is one part of the skeleton disproportionately represented compared to another?" On-site butchery or primary and secondary butchery mixed in the same deposit would produce a deposit similar to the undisturbed skeleton, whereas deposits containing primarily kitchen refuse or other activities which scatter skeletal elements would produce deposits which are very dissimilar to the undisturbed skeleton. If some elements are over-represented compared to the standard reference skeleton and others are underrepresented, this probably reflects a mixture of activities.

The elements represented for pig, deer, and large bovids all indicate that generally some debris from on-site butchering was mixed with debris from secondary food preparation and consumption. In this comparison, there are very few differences among the three analytical units. Artiodactyls from all three are more frequently represented by specimens from the Forequarter than from any other portion of the skeleton when compared to the standard distribution of elements in an undisturbed skeleton. In the case of deer and large bovids, more elements from the Forequarter and Hindquarters are present. It is particularly clear when looking at the cattle data that there is no change in the cuts of meat consumed during the occupation of Mission Refugio. Typically, fragments from the Forequarters are more common than are elements from the Hindquarters, and elements from both the Head and Foot regions are underrepresented or present in proportions similar to that in a complete skeleton.

\section{Conclusion}

Based on the data from Mission Refugio, it appears that there was very little change in animal use at the Mission during the occupational life of the mission. Cattle were a major part of the diet throughout the time period. However, the percentage of cattle individuals does decline slightly and the percentage of wild individuals increases proportionately. The role of wild and domestic animals at Mission Refugio is consistent with the patterns observed at other, nearby missions. The percentages of cattle fall within the range found by deFrance. On the other hand, the percentages of all domestic animals falls generally beyond the upper end of the range reported by deFrance (1999) for the missions she studied.

The "bone bed" anticipated at Mission Refugio produced a diverse assemblage of animals rather than one focused only on cattle/bison processing. Excavations resolved the apparent bone bed into two early trash pits and a later, overlying sheet deposit. The contents of these deposits are a combination of on-site butchery of cattle and other animals as well as general trash disposal.

As additional information about animal use at missions becomes available, we find that the responses of colonists, missionaries, soldiers, and Native Americans were more varied and more complex than originally anticipated. Instead of quickly adopting European-introduced livestock methods, Native Americans continued their previous strategies, occasionally with domestic stock added to an otherwise wild resource base. Colonists, on the other hand, added wild resources to their domestic inventory of food resources to a great extent. If the Mission Refugio data represent Spanish use of animals rather than Karankawa, they suggest that even at this relatively late time European traditions changed as much as, if not more so, than did those of the native peoples attracted to the missions. The degree to which these alterations were made to traditional strategies reflects local environments and economic conditions. Data such as these from Mission Refugio are important in understanding this more complex relationship. It is also particularly important to have such a large assemblage upon which to base these conclusions. 



\title{
Chapter 9: Artifacts Section E-1 \\ Vertebrate Fauna from the Phase II Excavations
}

\author{
Barbara A. Meissner
}

A total of 4,223 vertebrate faunal remains, weighing $11,172.58 \mathrm{~g}$, was recovered during Phase II of the project. This total includes bone recovered during excavation of the burials as well as bone found in association with several features identified during this phase of the project (see Chapter 8). A list of taxa identified for all bone is shown in Table 9e1-1.

\section{Methods}

In the field, all bone was recovered by dry screening matrix through $1 / 8$-inch mesh. Bones were bagged by the burial feature in which they were recovered. In the laboratory, all animal bone was washed, dried and bagged by burial feature. The animal bone was identified to the most specific taxon possible using the comparative collection at CAR, as well as several reference texts (Balkwill and Cumbaa 1992; Boessneck 1970; Cohen and Serjeantson 1996; Gilbert 1990; Hildebrand 1955; Hillson 1986; Olsen 1960, 1964, 1968; Sobolik and Steele 1996). All bone was weighed. Evidence of exposure to heat was noted on all bone. Element, portion of element, side, evidence of immaturity, butcher marks, and pathologies were noted on bone identified to the order taxonomic level. When bone could be identified only to class (e.g., mammal, bird, etc.) an estimate of the size of the animal was made when possible. After the analysis, the bone was bagged by burial feature.

\section{Results}

The bone in this collection tended to be highly fragmented. The result is that only 2.4 percent $(n=101)$ could be identified to the genus taxonomic level, and 91 percent $(n=3838)$ could be identified only as mammal. The majority of the bone was found in the non-burial features examined during this phase of the project (Table 9e1-1). Nine-hundred and twentyfive bones were recovered in burial feature fill, of which only 39 (4.2 percent) could be identified to the genus level.

Cattle (Bos taurus) dominate this collection, totaling 42.6 percent (43/101) of the bone identified to at least the genus taxonomic level (Table 9e1-1). The next most commonly identified bones were those of chicken (Gallus domesticus), followed by horse (Equus sp.) and softshell turtle (Trionyx sp.). A few bison bone were identified, all parts of the lower leg.
The presence of the animal bone in association with the burials seems to be the result of scattered bone refuse being accidentally incorporated into the features during the burial process. Feature 7 contained the largest part of this collection $(n=1164)$. Feature 7 was only briefly examined but appeared to be another large trash pit, similar to those excavated during Phase I.

One fragment of a bone tool was recovered from Burial Feature 8. It is a portion of the long bone of a deer-sized mammal (Figure 9e1-1). The distal end is very highly polished on the external side of the bone, while the internal side is merely smoothed. The tool is broken along one side, and the current tip does not appear to have been the working tip of the tool. Its functional use is unknown.

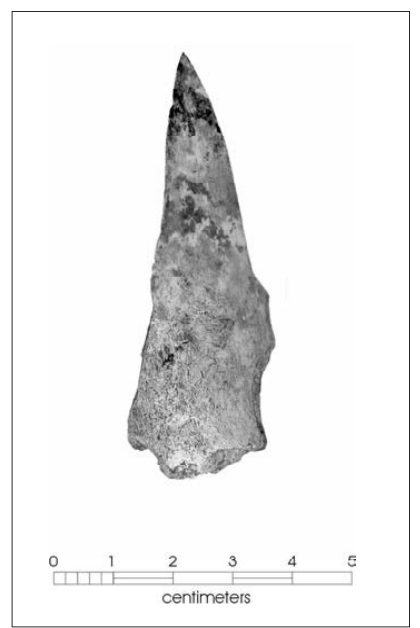

Figure 9e1-1. Fragment of a bone tool.

In conclusion, this collection is too small to compare directly with the large collection recovered during Phase I of this project, but it is consistent with that collection, and with collections commonly recovered in Spanish Colonial sites in south Texas. It consists largely of domestic animals with some evidence that the meat diet was supplemented by the hunting of wild animals. 
Table 9e1-1. Animal taxa identified from Phase II excavations

\begin{tabular}{|c|c|c|c|c|c|c|c|}
\hline & & Bur & cial Pits & Other & Features & & Cotal \\
\hline Taxa & Common Name & Count & Weight $(\mathrm{g})$ & Count & Weight $(\mathrm{g})$ & Count & Weight $(\mathrm{g})$ \\
\hline Mammalia & Mammals & & & & & & \\
\hline Artiodactyl & Deer, sheep, goats & 3 & 10.57 & & & 3 & 10.57 \\
\hline Bison bison & American bison & & & 5 & 189.34 & 5 & 189.34 \\
\hline Bos taurus & Cattle & 20 & 950.34 & 23 & 955.06 & 43 & $1,905.40$ \\
\hline Bovinae & Cattle or bison & 27 & 533.19 & 71 & $1,489.70$ & 98 & $2,022.89$ \\
\hline Capra hircus & Domestic goat & 1 & 52.33 & 0 & 0.00 & 1 & 52.33 \\
\hline Equus sp. & Horse family & 3 & 175.90 & 8 & 148.06 & 11 & 323.96 \\
\hline Odocoileus virginianus & White-tailed deer & 3 & 31.16 & 1 & 30.60 & 4 & 61.76 \\
\hline Mammal--small & Rabbit-sized & 1 & 0.31 & & & 1 & 0.31 \\
\hline Mammal--medium & Dog-sized & & & 1 & 3.00 & 1 & 3.00 \\
\hline Mammal--large & Deer, sheep-sized & 13 & 49.12 & 10 & 44.37 & 23 & 93.49 \\
\hline Mammal--very large & Cattle, bison, horse-sized & 169 & 828.93 & 757 & $4,002.81$ & 926 & $4,831.74$ \\
\hline Mammal & Size indeterminate & 639 & 299.59 & 2248 & $1,267.41$ & 2887 & $1,567.00$ \\
\hline & \begin{tabular}{|c|} 
Total Mammals \\
\end{tabular} & 879 & $2,931.44$ & 3124 & $8,130.35$ & 4003 & $11,061.79$ \\
\hline Aves & Birds & & & & & & \\
\hline Branta sp. & Snow geese & 2 & 0.76 & & & 2 & 0.76 \\
\hline Gallus domesticus & Chicken & & & 15 & 15.26 & 15 & 15.26 \\
\hline Aves & Size indeterminate & 8 & 2.47 & 16 & 5.44 & 24 & 7.91 \\
\hline & \begin{tabular}{|r|} 
Total Birds \\
\end{tabular} & 10 & 3.23 & 31 & 20.70 & 41 & 23.93 \\
\hline Reptilia & Reptiles & & & & & & \\
\hline Alligator mississippiensis & Alligator & 1 & 23.49 & 2 & 1.16 & 3 & 24.65 \\
\hline Pseudomys sp. & Pond sliders & & & 2 & 3.37 & 2 & 3.37 \\
\hline Trionyx sp. & Softshelled turtles & 7 & 21.25 & 3 & 7.29 & 10 & 28.54 \\
\hline & \begin{tabular}{|c|} 
Total Reptiles \\
\end{tabular} & 8 & 44.74 & 7 & 11.82 & 15 & 56.56 \\
\hline Osteichthyes & Boney Fishes & & & & & & \\
\hline Ictalurus sp. & Catfish & 1 & 4.50 & 3 & 6.01 & 4 & 10.51 \\
\hline Lepisosteus sp. & Gars & 1 & 0.56 & & & 1 & 0.56 \\
\hline Osteichthyes & Unidentified fish & 2 & 2.54 & 1 & 0.63 & 3 & 3.17 \\
\hline & \begin{tabular}{|c|} 
Total Fishes \\
\end{tabular} & 4 & 7.60 & 4 & 6.64 & 8 & 14.24 \\
\hline Vertebrata & Unidentified bone & 24 & 6.52 & 132 & 9.54 & 156 & 16.06 \\
\hline & \begin{tabular}{|c} 
Overall Totals \\
\end{tabular} & 925 & $2,993.53$ & $3,298.00$ & $8,179.05$ & 4223 & $11,172.58$ \\
\hline
\end{tabular}




\title{
Chapter 10: $\quad$ Discussion and Conclusions
}

\author{
Robert J. Hard
}

This study of Mission Refugio (1793 to 1830) represents one of the most detailed examinations of a Texas Spanish Colonial mission in recent decades. Its array of specialized studies of skeletal material, historic records, faunal bone, ceramics, and chipped stone among others has provided us with rich detail about this final phase of the Spanish Colonial mission period in Texas. This chapter remains mindful of the major research issues originally outlined for the project and explores additional lines of inquiry as well. The results contribute to a growing body of Karankawa and mission period studies that further enrich our knowledge of the coastal region and cultural processes at work in the colonial missions. The project included excavations inside the church and the discovery and excavation of a large burial area, two extensive trash pits and a number of smaller features. Through the efforts of the Texas Department of Transportation an invaluable portion of Texas's past-that otherwise may have been lost forever-has both come to light and been preserved.

\section{The Mission Supply System}

The Spanish Colonial missions on the frontier were linked to Mexico and ultimately Spain by interwoven economic, political, legal, social, religious, and cultural forces. These forces formed a complex political economy that had interacting dimensions from global to local scales and are far beyond our consideration. However, some insight into this complexity can be obtained by viewing the materials received at Mission Refugio from the external world. One of the most fundamental concerns for the mission priests was obtaining the equipment and supplies necessary to establish and maintain a community of perhaps 200 residents. The goal of the mission system was to create a self-sufficient communal agrarian economy on which the Native Americans would become dependent with the priest maintaining a large degree of political, social and economic control. Since the mission community was a reflection of its cultural system, it required many of the same goods any complex agrarian community in Mexico-of that periodwould require. While the bureaucratic systems established to create and initially supply the missions were successful to a certain extent -maintaining them over periods of decades was frequently beyond the resources available.
Mission Refugio's principle source of provisions included supply trains from the Franciscan Missionary College at Zacatecas for manufactured goods, trade items, chocolate, tobacco, cloth, and many other items. The presidio at La Bahía served as the principal supplier of domestic stock and corn. In addition, supplies were requested from the San Antonio missions and Mission Espírtu Santo. Also, a large number of manufactured items are in the inventories that are not mentioned in any of the shipment descriptions.

McDonald (Chapter 3) reports that the Franciscan Missionary College at Zacatecas had a procurement system that originated with their Mexico City Franciscan establishment, and supplies were shipped to the College via a route from Mexico City, to San Luis Potosi, to Zacatecas, to Saltillo. From Saltillo goods were shipped through present-day Guerrero, Coahuila to San Antonio. Some shipments arrived via Monterrey and then to present-day Villadama, Nuevo Leon, and into Laredo, Texas. McDonald found documentation for ten shipments. Based on these documents, frequency was far greater in the early years of the mission with seven trains arriving in the five years between 1792 and 1797, and only three more noted in the remaining decades. It is not clear from the information available if this is a product of the records available or if, by then, the mission had obtained a greater degree of selfsufficiency. Most of the items shipped included manufactured goods, tobacco, and chocolate, the latter two items consistently accounted for the bulk of the cost of the shipments. It is clear that the distribution of these two items formed part of the priests' strategy to increase Native dependency on the mission. Other goods that were probably imported for distribution included various types of cloth, coats, mats, trinkets such as toy tops, whistles, rings, beads, and dolls. Items that were more likely for the priest given their relatively small quantity and infrequent appearance included garbanzos, rice, bananas, and spices such as saffron, cinnamon, fruit preserves, plus horse tack, paper, and wax.

The presidio at La Bahía supplied Refugio with food supplies for distribution to the Indians. It was quite clear to the missionaries that food was the primary reason the Natives came and stayed, so it was mandatory that the supply was maintained - particularly in the early years of the missionprior to the development of Refugio's agricultural and ranching activities. On a number of occasions the Indians 
departed when the mission's supplies ran low. These items included corn, cattle, other domestic stock, and brown sugar cones. Obtaining these items was difficult as La Bahía was also dependent on the San Antonio missions to some extent and payment for these supplies was frequently a point of discussion. On a number of occasions the Governor had to intervene on the priest's behalf to force the presidio captain to release goods.

Given the initial difficulties of supplying the mission the priests, on occasion, also requested assistance from the San Antonio missions and from Mission Espírtu Santo. At one point a priest considered trading a Refugio bell for cattle from Espírtu Santo.

A large number of items appear in the inventories or in the archaeological record that would have been shipped from Mexico. Supplying the tools, equipment, and luxury items for the range of industries and activities at the mission indicates both the organization of the mission supply system and degree to which Refugio depended on that system. These items are listed in the appendices of this report (see Appendix A, Sections 1-3), therefore a few examples will suffice: copper tubing, religious ornaments, religious statuary, religious paintings, wine, knives, colander, forge and related equipment, guitar, violin, bandola (stringed instrument), metates, iron and copper comals, tin sieve, locks, iron, mahogany, silver lined sink, fruit trees, over 150 books, telescope, scales, compass, a diamond for cutting glass, glass jars, and church bells. Additionally, the archaeological record indicates that a variety of Mexican produced ceramics were being imported as well.

\section{The People}

Mission Refugio was built for the Karankawa Indians that occupied the Texas central coastal region. The relatively stable, though fluctuating mission population was made up of 26-28 families, all of whom belonged to one of several bands of Karankawa in the region. Using the birth, death, and census records Tennis (Chapter 4) was able to discern a core group of about 18-20 of these families as quasipermanent Karankawa family units that the Franciscans designated as "Children of the Mission". These families reappeared multiple times in the birth, death, and census records which documented their more than 20-year association with Mission Refugio. Tennis identifies another approximately eight Karankawa families that are not designated as Children of the Mission. A number of these are recognized as "pagans" and none appear to be permanent residents, but yet they do reoccur in the records over the course of 6-12 years and maintain a strong affiliation with the mission. Finally, there are Karankawa individuals whose infrequent appearance in the records suggests they are only occasional visitors. Tennis also suggests that these Native American families represent stable, monogamous couples and she observes there is a high frequency of intermarriage among the various tribal units of Karankawa in the region.

The Non-Indigenous population consisted of two generations of four or five large extended families including the Rosales, Lopes, Chirinos and Huizars. These were mostly farmers and herders, but included carpenters, masons, and tailors as well as servants. In addition there are over 30 other Non-Indigenous families who only appear once or twice in the records suggesting that they are short-term residents and many may have been part of the military contingent with brief assignments at the mission.

Native Americans are consistently identified as such in the Mission Refugio records but for all other individuals the column for "caste" or racial identity is left blank. Since most of the non-Indian families that came to Mission Refugio were from San Antonio and surrounding regions we must assume they, like the citizens of San Antonio, may represent individuals of all racial backgrounds including whites, mestizos, mulattos (mixed African and European ancestry), etc., (de la Teja 1995). The use of the terms "non-Indian", "non-Indigenous", or "non-Native" refers to all of these individuals who are Spanish-speaking, non-Native Americans but who represent people with a variety of ancestry. The physical anthropological study identified Europeans, Native Americans, and mestizos (mixed Native American and European ancestry).

The following discussion does not take into account a dozen baptisms which took place between December 30, 1809 to June 9, 1810. The documents which pertain to these baptisms were unavailable at the time.

\section{Physical characteristics}

The analysis of the human skeletal remains from inside the church has yielded important new information regarding the Karankawa Indians and the non-Native population. The osteological study by Lee Meadows Jantz and her colleagues of a minimum of 177 individuals (including 12 individuals represented only by isolated bones) have been compared with other skeletal populations and historic records to better 
understand the human biology of the Native Americans and the other occupants of Mission Refugio. The Karankawa have been recognized archaeologically along the Texas coastal region and across several centuries of time and perhaps even longer. Previous osteological studies have suggested the Karankawa are a "homogenous population with extreme dolichocrany (long headed), craniofacial robusticity, and high sexual dimorphism" (Meadows Jantz et al. Volume II; Steele et al. 1999) in comparison to inland populations. Unfortunately the preservation of only four measurable skulls prevented examination of head shape, although measurement of cheek height enabled estimation of midfacial size and therefore robusticity.

The Karankawa were skeletally robust and at least components of that robusticity are genetic in origin. The Refugio male population had the fifth highest mean cheek height among a global sample of 30 different populations, and Refugio females were the seventh highest. For both sexes Refugio exceeds virtually all other Native Americans. A comparison of mean cheek height with skeletal collections from Mitchell Ridge (a prehistoric Karankawa population), San Antonio's Mission San Juan Capistrano, and Pecos Pueblo, New Mexico show that Refugio and Mitchell Ridge individuals are large while the individuals in the other two populations tend to have small faces. Globally, Asian and Pacific populations have similarly heavy faces. The postcranial analysis suggests considerable robusticity as well.

There is a standing interpretation that the Karankawa were highly sexual dimorphic. The analysis confirmed that the Refugio Karankawa are highly dimorphic on a global scale. But other Native American groups are similarly dimorphic, including the Pecos Pueblo sample.

The oft-repeated notion that the Karankawa were an exceptionally tall population is not supported by the current osteological analysis. Male stature is estimated to be 164$166 \mathrm{~cm}$ (roughly $5^{\prime} 5^{\prime \prime}$ ) and female stature is estimated at $153-155 \mathrm{~cm}$ (roughly $5 ' 2 ")$. These sizes were typical of prehistoric Native Americans. Because the Karankawa were found to be rather long-legged, appropriate regression formulae to extrapolate height from long bone length are needed. Previous Karankawa height studies have used stature estimation formulae from short-legged reference samples that were inappropriate.

The badly fragmented nature of the collection and the general absence of reconstructible skulls required that identification of ancestry be based on the limited available fragmentary elements including cranial fragments, postcranial fragments and qualitative dental traits. Some of the important characteristics include femoral platymeria (mediolateral thickening, or expansion, in the subtrochanteric area), squatting facets, and shovel-shaped incisors. The conclusions to these racial identifications are presented in Volume II, Section 3. A second analysis of ancestry was conducted in Volume II, Section 8 focusing on a detailed quantitative analysis of dental metrics coupled with a Bayesian statistical analysis to order to make further progress on racial identification. The historical documents also offer data regarding ancestry as the burial records consistently identified Native Americans listing one of the various groups of Karankawa or the term "indio" or similar term. However there are a large number of individuals without a racial identification and they are assumed to be non-Indigenous, meaning European, mestizo, mulatto, or others of mixed ancestry (see de la Teja 1995). Many of these same individuals can be found in the Mission Refugio census records that indicate their place of origin, typically the San Antonio region. Their occupations are listed as farmers, herders, craftsmen, and servants.

A comparison of the results of the skeletal data with the burial records highlights the make-up of Mission Refugio. To make the two data sets comparable a number of modifications must be made. Infants cannot typically be identified by ancestry through skeletal analysis so those less than five years of age were deducted from the totals as were those listed as "indeterminates". Since the burial records do not discriminate between European and those with mixed ancestry those two categories in the skeletal data must be combined.

The two studies of biological ancestry, one based on gross morphology and one based on dental attributes, are generally compatible. These data indicate about one-fourth to onethird $(26.5 \%-32 \%)$ of the skeletal population are non-Native that is either belonging to the European or Admixed (mixed European and Native American) category. On the other hand, the burial records indicate about two-thirds $(63.6 \%)$ of individuals above age five are European or Admixed. Table 10-1 summarizes these data. It appears that either the burial records do not accurately reflect the skeletal population or assignment of ancestry, based on skeletal characteristics, is underestimating European and/or Admixed individuals.

In an inspection of the various census figures McDonald (Chapter 3) clarifies the ethnic make-up of the mission (Table 10-2). Counts of both Native and non-Natives were provided for 1804, 1814, and 1823. In all three years Natives outnumber non-Natives. The proportion of non-Natives peaks in 1814 when 39 percent $(n=75)$ of the population 
Table 10-1. Ancestry derived from burial records compared with that from the osteological analysis

\begin{tabular}{|c|c|c|c|c|c|}
\hline & $\begin{array}{c}\text { Table 10C-1* } \\
\text { (based on } \\
\text { general physical } \\
\text { characteristics) }\end{array}$ & $\begin{array}{c}\text { Table 10H-6* } \\
\text { (based on } \\
\text { dental } \\
\text { characteristics) }\end{array}$ & $\begin{array}{l}\text { Burial } \\
\text { records } \\
\text { (>age 5) }\end{array}$ & $\begin{array}{c}\text { Burial records } \\
\quad(<\text { age 5) }\end{array}$ & $\begin{array}{c}\text { Burial } \\
\text { records } \\
\text { (total) }\end{array}$ \\
\hline N. American & $\begin{array}{c}61 \\
(73.5 \%)\end{array}$ & $\begin{array}{c}52 \\
(68.0 \%)\end{array}$ & $\begin{array}{c}28 \\
(36.4 \%)\end{array}$ & $\begin{array}{c}25 \\
(52.1 \%)\end{array}$ & $\begin{array}{c}53 \\
(42.4 \%)\end{array}$ \\
\hline Europ+Admix & $\begin{array}{c}22 \\
(26.5 \%)\end{array}$ & $\begin{array}{c}25 \\
(32 \%)\end{array}$ & $\begin{array}{c}49 \\
(63.6 \%)\end{array}$ & $\begin{array}{c}23 \\
(47.1 \%)\end{array}$ & $\begin{array}{c}72 \\
(57.6 \%)\end{array}$ \\
\hline Admixture & $\begin{array}{c}19 \\
(22.9 \%)\end{array}$ & $\begin{array}{c}7 \\
(9.1 \%)\end{array}$ & & & \\
\hline European & $\begin{array}{c}3 \\
(3.6 \%) \\
\end{array}$ & $\begin{array}{c}18 \\
(23.4 \%) \\
\end{array}$ & & & \\
\hline Subtotal & $\begin{array}{c}83 \\
(100 \%)\end{array}$ & $\begin{array}{c}77 \\
(100 \%)\end{array}$ & & & \\
\hline Indeterminate & 81 & 3 & & & \\
\hline Total & 164 & 80 & $\begin{array}{c}77 \\
(100 \%)\end{array}$ & $\begin{array}{c}48 \\
(100 \%)\end{array}$ & $\begin{array}{c}125 \\
(100 \%)\end{array}$ \\
\hline
\end{tabular}

Table 10-2. Inhabitants of Refugio from census records*

\begin{tabular}{|c|c|c|c|c|c|}
\hline Year & Natives & Natives \% & Non-natives & Non-natives \% & Total \\
\hline 1791 & 138 & & & & \\
\hline 1797 & 172 & & & & \\
\hline 1804 & 44 & $76 \%$ & 14 & $24 \%$ & 58 \\
\hline 1808 & 96 & & & & \\
\hline $1814^{\mathrm{a}}$ & 115 & $61 \%$ & 75 & $39 \%$ & 190 \\
\hline 1817 & 92 & & & & \\
\hline 1823 & $120\left(78^{b}\right)$ & $87 \%\left(85 \%^{\mathrm{b}}\right)$ & $\left(14^{\mathrm{b}}\right)$ & $13 \%\left(15 \%^{b}\right)$ & 138 \\
\hline
\end{tabular}

${ }^{\mathrm{a}}$ Adults only. ${ }^{\mathrm{b}}$ Individuals $>7 \mathrm{yrs}$

*See McDonald, Chapter 3, and Appendices A and в.

are non-Natives. That number declines precipitously shortly before the mission is abandoned in 1823 when only 18 nonNatives are listed as residents of the mission.

Why are the burial records seemingly at odds with both the skeletal analyses and the census records? The available burial records contain only the years 1807-1821 and 1825 . Thus, burial records are absent for the beginning and ending years of the life of the mission (1793-1830). Census records suggest that the Native American population was the highest during the early and ending years of the mission. In contrast, the burial records are biased toward the middle years of the mission when, according to the census records, European occupation was at its highest.

A detailed examination of the burial records shows this fluctuation. Figure 10-1 is a bar chart showing the number of burials by affiliation each year for the years 1807-1821. From 1807-1813 generally Native burials outnumber or are equal to non-Natives. For this period there were 25 Native burials and 22 non-Native burials. However from 18141821 the pattern shifts so that for most years non-Native burials outnumber Native burials and there is a total of 26 Native versus 37 non-Native burials. These figures do not include the additional 13 non-Natives killed in a Comanche massacre in 1814. From 1814-1816 a famine related to Mexican Revolutionary conditions was underway and there was a tremendous shortage of cattle throughout the region (McDonald, Chapter 3). Therefore, Native burials declined precipitously for 1815 and 1816 as Karankawa did not find living at the mission advantageous (see Tennis, Chapter 4). Following the famine McDonald (Chapter 3) reports that the years 1818-1820 were tumultuous with rapid changes in priests and Karankawa discord. A massive hurricane in 1818 destroyed all the jacals and chamacueros, an event that further contributed to the deteriorating circumstances. Karankawa burials for 1818 and 1819 were correspondingly low. McDonald (Chapter 3) notes that during this period the civilian settlement was increasing - accounting for the greater numbers of non-Native burials. McDonald further notes that the rise in Comanche raids in 1820 caused civilian residents to relocate to La Bahía. Note that non-Native burials sharply decline in 1820 as Karankawa burials increase. Apparently the Karankawa found refuge at Refugio 


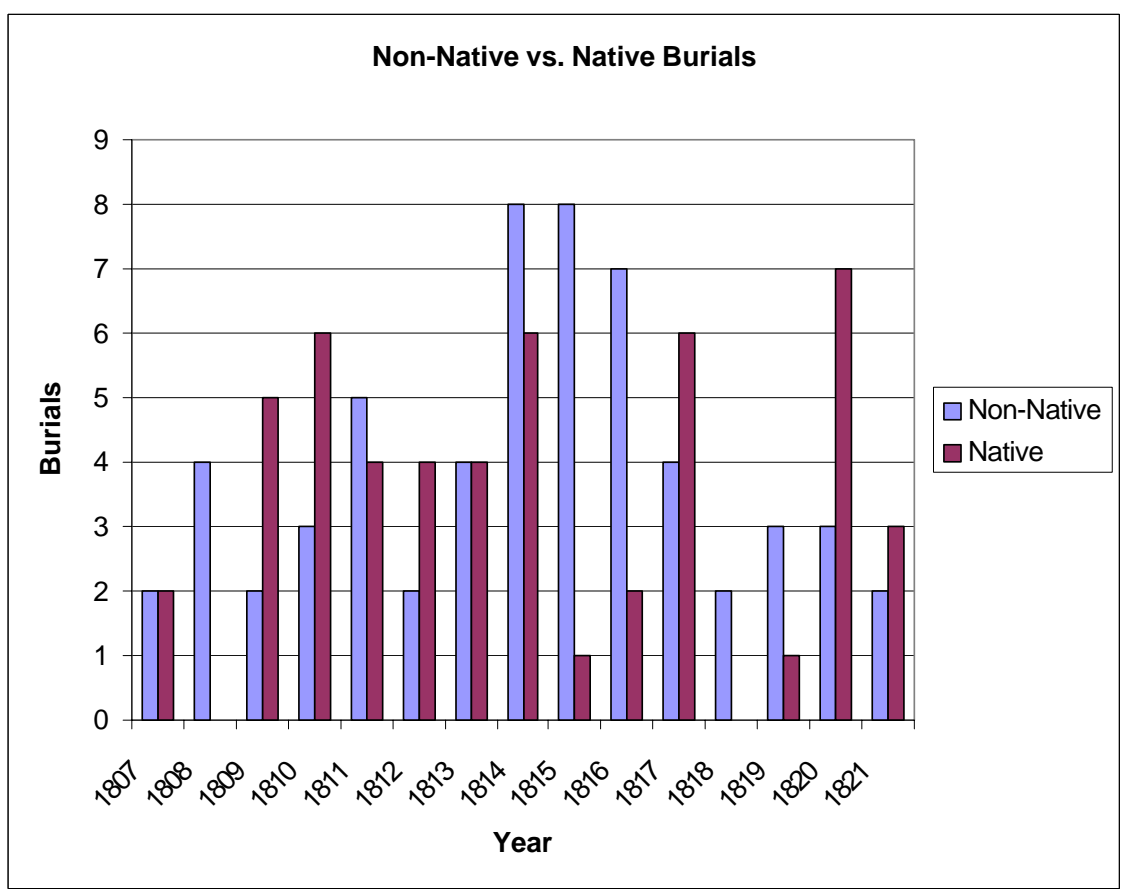

Figure 10-1. Number of burials each year by affiliation, 1807-1821.

at the same time that the non-Natives did not. This imbalance appears to have persisted, since by 1823 -120 Natives were present and only 18 non-Natives. There are no burial records for 1822-1824 and only two Native burials are recorded for 1825 , the last year for which the burial records exist.

In summary, the census data do correlate with the skeletal analysis of biological affiliation. Both indicate that, on average, about one-fourth to one-third of the population of Refugio were non-Native. However, the burial records are biased towards the middle of the occupation when Karankawa participation had declined and non-Native participation had increased. This pattern reversed itself toward the latter years of the mission.

The 165 individuals in the skeletal series include 52 subadults (32\%) and 113 adults over 15 years of age. A minimum of 12 other individuals is represented in the ossuary collection of isolated bones with no further information possible. The burial records indicate that 44 of the 53 Native Americans belong to one of the several Karankawa groups. The physical anthropology study compares the burial record sex ratio with the results of the skeletal analysis. The analysis shows that the adult sex ratio of the skeletal series is 1.6 men to women. That is lower but not statistically different from the adult burial record sex ratio of 2.0 to 1.0 in favor of males.
There are detectable differences in the mortality rates between males and females. Young adult age females show increased mortality relative to males. In contrast, older female survivorship is greater relative to older male survivorship. Overall males and females have a similar mortality pattern with females having a slightly greater female survivorship.

Demographic analysis by the physical anthropologists of the mission burial records shows mortality increases in the late summer and early winter. The distribution of deaths by month shows a pattern of increasing mortality beginning in July, peaking in October, declining through the winter and reaching a low point in February. This statistically significant pattern suggests that there is a higher frequency of deaths perhaps due to periods when the population of the mission is higher. Alternatively this pattern may be related to seasonal variation in disease transmission and susceptibility. It is also of interest to note that this seasonal mortality pattern is roughly similar in both Native and non-Native populations, which may suggest that a component of the pattern is, related to disease transmission rather than mobility patterns.

Infant mortality is quite high at Refugio with 48.5 percent of all non-traumatic deaths are of individuals 3 years old or under. Infant mortality is roughly evenly divided between Native $(52.1 \%)$ and non-Native $(47.9 \%)$ populations. Infant 
mortality also peaks in September and October and continues to be high through January when it finally drops. This pattern is more pronounced among the non-Native infants with higher death rates in the fall and winter months. Native infant deaths were more evenly distributed throughout the year.

Deaths of Native Americans each year are low with a maximum of 7 individuals in a year and averaging only 3.3 deaths per year. Deaths of non-Natives were in the same range. This suggests that European diseases were no longer having a biased effect on Native Americans as they were in previous centuries. By this point in time Natives had probably acquired immunity to European diseases and were no longer differentially affected by European pathogens.

The birth and death records suggest that the Native population had stabilized and its almost two centuries of decline had halted (Ricklis 1991). Native Americans had 105 births to 53 deaths for the period 1808-1820 while the non-Native Americans had 58 births to 66 deaths for the same period. A preliminary suggestion is that the Native population had stabilized and may have been on the increase despite high infant mortality. The significantly lower rate of births to deaths among the Non-Indigenous speaking population is puzzling and maybe affected by a number of factors including a greater proportion single males and the high impact of trauma deaths primarily due to Indian warfare.

Returning to the skeletal series, nine traumatic deaths are evidenced among about 140 individuals with measurable postcranial remains yielding a rate of 7.5 percent of deaths due to trauma. Historical records list 26 traumatic deaths out of 125 individuals or 21 percent of deaths are violent. There is a suggestion of seasonality of death by traumatic injuries with their presence underway by spring and increasing through the late summer and peaking in the fall with little activity during November to January. It is likely that a significant portion of these deaths were inflicted by the Comanche and to a lesser extent by the Lipan.

All of the nine traumatic deaths recognized in the skeletal sample eight were males-aged 20-54-and one was unidentifiable. Among these were three individuals with perimortem or unhealed cranial fractures, one with perimortem fractures of the left lower leg, one with a fractured femur, and one with a metal arrow point found in the chest cavity. Five examples of scalping - the cutting away of a segment of the scalp for a trophy, leaving cut marks on the crania-were present. The individual with the arrow point was scalped, as were two with fractured crania. Two other scalped individuals exhibited no other signs of trauma. The ancestry of these nine individuals who died traumatically included three unidentifiable individuals, two of Native American or Hispanic ancestry, one Native American, one possible Native American, and two Hispanic. The cranial fractures and scalping clearly indicate interpersonal violence.

Antemortem fractures that have evidence of healing include cranial and postcranial fractures on two males and two females. Both males exhibit facial fractures. One of the females in particular has healed facial fractures that are similar to those expected with domestic abuse. Antemortem fractures are more likely to be related to intragroup violence than intergroup fighting.

Physical hardship is indicated on the bones by the formation of irregular ossification at the muscle attachments resulting from high levels of activity. These enthesophytes are not frequent in the Refugio population suggesting an absence of excessive physical hardship. Of these bony growths that were present, they were more common on males where they tended to occur on the knee and heel, but included the hip, upper leg, and lower leg. In females enthesophytes were rare but the few cases included the femur, knee, hip, and lower arm. I suggest this pattern may indicate males were walking more than females and therefore may have had a different mobility pattern including more long distance travel. Other indicators of physical hardship are uncommon in the Refugio population suggesting that health was not significantly impacted by hard physical labor.

Treponemal infections were present in five Refugio individuals: a child age 11-14 with congenital syphilis; a Native American female age 25-35 with syphilis; a premature fetus (33 weeks gestational age) with congenital syphilis; a Native American male, aged 35-45 years with a long-term systemic treponemal infection; and a male, aged 15-35 with syphilis. Some of these individuals may have succumbed due to conditions related to infection.

Five individuals had osteomyelitis or infection of the bone and most of these were infections related to fractures. Seven Refugio individuals exhibited cribra orbitalia or pitting in the orbital plates that is typically related to iron deficiency anemia. These individuals included: three children ages approximately 3, 10 and 11; a male and female Native American ages 17 and 19; a possible European male, age 60+; and a possible Hispanic male, age 25-29. Porotic hyperostosis is not well understood but may be related to anemia, infection, or dietary deficiencies. Only two cases 
of it were present: a child, aged approximately 3 years, possibly of Native American ancestry and a Native American male aged about 17 years who also exhibited cribra orbitalia. In addition, one old adult, age 60+, of European ancestry may have died as a result of complications from disease that produced multiple lesions in the bone marrow spaces, possibly multiple myeloma or metastatic carcinoma. These low rates of infections are far below that commonly found in prehistoric Native American maize agricultural economies and suggest the Refugio population was generally healthy and dietary deficiencies were not impacting the population in observable ways. The general good health of the population can be further examined with respect to various data sets concerning diet.

\section{Diet}

Data from the historical records, the faunal assemblage, stable isotope analysis, botanical analysis, and dental studies are all relevant to reconstructing the mission diet with most of the data relevant to the Native American population.

The historical analysis by David McDonald indicates that ranching and farm products formed the mainstays of the mission, a pattern similar to that found in other South Texas missions. However, we know far less about maize production at Refugio than the San Antonio missions. McDonald includes a number of references to maize production but they contain little elaboration. Although the mission records do not report the details of everyday life, overall impression is that Mission Refugio struggled with maize production. Corn may have not been the dominant element in the diet as it was in the San Antonio missions. McDonald notes relatively small shipments of corn made from the presidio at La Bahía to Refugio during the early years of the mission. For example, 26 bushels were sent by ox-cart in 1791 (prior to the official founding of the mission), 167 bushels in 1793, 114 bushels in 1794 and 40 bushels in 1797. During these years the Refugio Indian population was 75-186 persons. The detailed inventory of 1796 included only passing reference to "sacks of corn ears and fanegas of corn" stored with many other items in a jacal used as an office for servants (Appendix A: 1796 inventory). The equally detailed 1820 inventory notes that lime is stored in the granary with other equipment but no mention is made of stored grains. However, the priest's field of 3.5 acres is mentioned that was been planted with 5.6 bushels of seed in April 1820. It appears that maize at Refugio Mission, while generally present, was not abundant. As we will see these are not large amounts of maize for this size population.
In 1791 Fr. Garza was desperate for assistance and indicated that he required 8 cows and the equivalent 6.4 bu per week to feed the 138 Indians. The Karankawa would not remain at the mission without being fed. This amounts to only 1.16 $\mathrm{kg} / \mathrm{wk} /$ person $(1 \mathrm{bu}$ shelled corn $=25.2 \mathrm{~kg}$ (Barlow 1997) or $.17 \mathrm{~kg} /$ day.) In contrast traditional farmers such as the Hopi, Tewa, Tepehuan, Tarahumara, and Aztec consume about .4-.5 kg/day of shelled maize (Hard and Merrill 1992:608; Minnis 1985:110, Wade 1993:83). Based on Fr. Garza's request the Mission Refugio maize intake was about 35 percent of that of full-time agriculturalists. A 1794 report from the presidio at La Bahía makes it clear that dry farming maize is the only farming strategy conducted as the deeply incised river made irrigation impracticable. Given the incised Mission River, the absence of any mention of irrigation systems in the historical records, and the apparent farming difficulties the situation at Refugio appears no better and perhaps worse than at La Bahía. Although McDonald reports that in 1805 the mission raised enough corn to have a surplus to sell. In March 1824 the Mission Indians had abandoned Refugio for the protection of La Bahía as a result of Comanche raiding. Finally in an aborted offer to encourage their return to Refugio La Bahía offered the Refugio priest $6.7 \mathrm{~kg}$ of corn per week for six months. It is not clear what needs this minuscule offer would fulfill as it is less than one $\mathrm{kg} /$ day. The population of Refugio just prior to its abandonment is not known but in January 1823 it was 120 Indians and 18 Spaniards.

In contrast to the maize present at Mission Refugio we can see that maize production and distribution at San Antonio's mission San José is quite different. There "on Sundays, the missionary gives each Indian a peck of corn, some meat and tobacco. He distributes beans, corn, and brown sugar bars to those who need them on Thursdays" (Habig 1978:134). (This translation has apparently already converted fanegas to pecks. A peck is one-fourth of a bushel or $6.3 \mathrm{~kg}$ ). This is equivalent to $.9 \mathrm{~kg} /$ person/day or over five times the maize ration of a Refugio Indigenous person! In fact this estimate maybe excessive as it exceeds the maize intake of many farming societies.

It is apparent though that the highly successful farming operations at San José and the other San Antonio missions exceeded the productivity in Refugio. At San José a rainfed early crop and an irrigated second maize crop were commonly produced. In 1749 the San José maize harvest was 2400 bushels of corn at a time when the Indian population was 200 (Wade 1993). In 17584000 bushels of corn were in storage at Mission San José and in 1768 the combined corn stored in all five San Antonio missions was 
9,900 bushels. A water mill was constructed at San José to grind maize for the mission and the San Antonio community. In fact, the San Antonio missions at times supplied maize to La Bahía and sold it to the San Antonio presidio.

The relative differences in maize consumption between San José and Refugio can be better understood when compared to the other major dietary item, beef. In San Antonio at Mission San José in October 1755, Fr. Marmolejo indicates that the weekly beef ration for Indians is four beef cattle for the 194 Indians at the mission plus additional cattle for the sick and others living away from the mission (Habig 1978:135). The faunal analysis in the current Refugio study by Webber et al. (Chapter 9E) notes that the mission cattle, while variable in size, were typically about the size of a 272 $\mathrm{kg}$ Holstein or a bit larger. Assuming there is $100 \mathrm{~kg}$ of edible flesh on each cow at San José the beef ration would have been $2.1 \mathrm{~kg} / \mathrm{wk} /$ person.

While cattle ranching was successful in San Antonio it was astounding in its success on the coastal plains surrounding Rosario and Refugio. At Refugio eight cows were requested each week to feed 138 Indians. This calculates to $5.8 \mathrm{~kg} /$ $\mathrm{wk} /$ person of beef or more than 2.5 times the beef ration at San José. The combination of $.17 \mathrm{~kg} /$ day of maize and .83 $\mathrm{kg} /$ day of beef would provide the bulk of the diet. Translating these values to calories indicates this diet would account for perhaps 80 per cent of daily caloric requirements. The rest could easily consist of beans, brown sugar, fruits, wild foods, other domestic meat, etc.

Returning to Mission San José, the beef ration is . $3 \mathrm{~kg} / \mathrm{day} /$ person and the maize ration was $.9 \mathrm{~kg} / \mathrm{day} / \mathrm{person}$, a far different mixture. It is acknowledged that these are single statements from priests made in the context of requests for support and they are unlikely to be precise reflections of day-to-day reality but they do provide a rough indicator of scale that is both internally consistent and consistent with other data.

\section{Faunal analysis}

Webber et al.'s faunal analysis provides further insight into the carnivorous portion of the mission diet. Excavations 10$30 \mathrm{~m}$ northeast of the burial locations recovered $362 \mathrm{~kg}$ of faunal bone representing at least 253 individual animals. These bones, along with other trash, were concentrated in two trash pits and an upper sheet trash deposit. As discussed by Tennis these three features represent three different, but probably overlapping, periods of time.

Consistent with the historical records, cattle dominate all three-time periods contributing 88-90 percent of the meat with little evidence of change. Although cattle are overwhelmingly the principle meat consumed at the mission the mix of other species utilized becomes more diverse from the early to the late occupation. Here consideration will only be give to the individual animals (Minimum Number of Individuals) that are thought to have been consumed, not the commensal species. Number of individual non-domestic taxa increase from 44 percent to 61 percent, from the early to the late occupation, reflecting an increase in diversity of species utilized. The proportional representation of domestic species including cattle, sheep/goat, and chicken all decline through the three periods while pig increases slightly. At the same time, all wild animal taxa increase.

In terms of meat or biomass contribution from nondomesticated mammals other than bison, which is discussed below, the largest wild mammal contributor by far was whitetailed deer whose biomass contribution was 3 percent of the total. Other important taxa included turkeys and waterfowl, and aquatic species including sharks, rays, fishes, and turtles. Other domestic animals and birds contributed $1.5-4$ percent of the total meat contribution.

A shift in the exploitation of aquatic resources is indicated by an increase in the use of freshwater species from 43 percent to 70 percent of all fish individuals while marine fish individuals decrease from 57 percent to 30 percent.

Table 10-3. Ratio of MNI to NISP for bovine specimens

\begin{tabular}{|c|c|c|c|}
\hline Analytical Unit & NISP cow/bison & MNI cow/bison & MNI/NISP \\
\hline 1 & 1650 & 16 & .0097 \\
\hline 2 & 1154 & 18 & .0156 \\
\hline 3 & 1258 & 15 & .0119 \\
\hline Total & 4062 & 49 & .0121 \\
\hline
\end{tabular}


The perennial problem of distinguishing domestic cattle from non-domestic bison plagued the faunal analysts so significant ambiguity surrounds the issue of the importance of bison versus cattle in this assemblage. Further examination of their data allows us to make a number of additional inferences. Only 171 of the 4,246 large individual bovid bones (Number of Identifiable Specimens) were identified as domestic cattle and 13 were bison and the balance was only identified as cattle or bison. The resulting small numbers are not reliable to estimate MNI so we will extrapolate this ratio of 7 percent of the bovine identified as bison $[13 /(171+13)]$ to suggest that among all the bovine bones $299(.07 * 4,246)$ are bison and 3947 (93 percent) are domestic cattle bones.

The relationship between NISP and MNI has been subject to a great deal of discussion and can be affected by many variables. However, in this particular setting there is clear patterning in that MNI is about 1 percent of NISP for bison/ cow across all analytical units as shown in Table 10-2. Therefore the extrapolated 299 bison bones would be equivalent to about $3 \mathrm{MNI}$ bison $(299 * .012)$. Cattle usage can be estimated at $47 \mathrm{MNI}(3947 * .012)$. Based on these extrapolations we could estimate that 6 percent $(3 /(47+3))$ of the bovine killed were bison.

Given the historical estimate that 8 cows per week were slaughtered to feed 134 Indians we can suggest at that rate large faunal deposits such as these can accumulate quickly. According to the five censuses translated by McDonald the Indian population ranged from 58 to 120 . We know from other historical texts there were times when it was virtually abandoned and times when the population may have exceeded 150 as well. But if we take a median figure of about 90 Indians across 35 years of mission use about 5 cows per week would have been used. Thus the fifty animals represented in these features could accumulate in a matter of a few months and would be a small fraction of the total animals slaughtered. We could expect on the order of 260 animals per year or 9100 over the life of the mission (5 cows/wk * $52 \mathrm{wks} / \mathrm{yr} * 35 \mathrm{yrs})$. Such estimates are not inconsistent with other discussions of cattle ranching at Refugio. This archaeological sample may represent less than .6 percent of the beeves consumed at Refugio (50/9100). If 7 percent of bovines utilized were bison 15 bison/yr may be a reasonable estimate $(260 * .07)$, acknowledging there would be substantial year-to-year variability.

Given these archaeological data and historical summaries as presented by McDonald there is no evidence of declining cattle production that would force the Indians to return to hunting and gathering. Although the historical records do indicate periods of short-term shortages when the Indians would leave for the coast there is no indication of a systematic decline in the availability of cattle. Although there is a slight increase in the use of numbers of wild species the meat contribution from beef declined to 88 percent from ca. 90 percent in the earlier analytical units, an insignificant amount.

Webber et al. also conclude that contents of these pit features represent general trash deposits rather than deposits from specialized animal butchering loci. They point to the diversity of species present and the skewed distribution of skeletal elements in these deposits to suggest they are not the results of butchery only. In addition, the diversity of other artifacts found in these deposits including chipped stone, native ceramics and imported ceramics all suggest a generalized trash dump. However, it may be the need to dispose of such large volumes of cow bones that are produced by the numbers of animals that are being slaughtered prompted this more formalized trash pit disposal method. The lime layer found in the pit may also be an attempt to control odor and vermin as well.

\section{Botanical analysis}

The microbotanical analysis (see Jones, Appendix F) found evidence of maize that is consistent with the historical records. However, Jones also found evidence of Old World cereals that might be wheat, barley, or oats. This may be some of the first evidence of these cereals at Refugio. McDonald's historical work makes no mention of any of these crops. For example, Albert's (1999) and Ricklis's (1999a) archaeobotanical studies did not identify Old World cereals at Rosario. However, its presence at Refugio is not surprising since wheat was being grown at the San Antonio missions, albeit not without some difficulty. Wheat was more difficult to grow, required more effort, and yields were probably lower. It was not favored in San Antonio compared to corn (de la Teja 1995:91). In the 1770s, in San Antonio, there was an effort to increase production and part of that effort was an order issued to plant wheat and barley in addition to other crops (Wade 1993:76). These efforts may have succeeded to some extent as in San Antonio the 1794 mission inventories note large supplies of wheat in the granaries at San José and Mission Concepción and wheat was ground at the San José mill as well (Wade 1993:82). It is likely that wheat could have been shipped down to La Bahía and from there to Refugio as apparently occurred with corn. It is also possible wheat was being grown at Refugio. 


\section{Dental caries}

With historical evidence that maize played a less important role relative to beef for the people of Refugio we can now examine caries frequency as an indicator of the role of cereals in the diet as reported by Meadows Jantz et al, Volume II. The physical anthropologists examined 1427 teeth and 124 contained caries yielding a low rate of 8.7 percent for all Refugio adults. This rate is consistent with a hunter-gatherer population and suggests maize was not a large component of the Refugio diet. In contrast, caries rate for the mideighteenth century Room 26 at San Antonio's Mission San Juan Capistrano was somewhat higher at 13.4 percent. Room 17 at San Juan Capistrano spans the late-eighteenth century to the early-nineteenth century and has a significantly higher caries rate of 19.6 percent (Meadows Jantz et al., Volume II). As discussed earlier these data are consistent with the historical data that suggest maize was playing a more important role in the San Antonio missions than at Refugio. Very low caries rates are reported for the prehistoric huntergatherer sites of Ernest Witte (2.7 \%) and Morhiss (4.2\%). Caries rates increase from the Prehistoric to the Historic period at the Mitchell Ridge site, a pattern seen at Refugio. Of the three Spanish colonial data sets the Refugio population has the best oral health with regard to caries as well as antemortem tooth loss. The later San Juan Capistrano Room 17 has the worst with the earlier eighteenth century San Juan Capistrano Room 26 being classified as intermediate (Meadows Jantz et al.). These results are statistically significant and consistent with historical and other archaeological data. Note too that the prehistoric sites with no use of maize had lower caries rates than Refugio. The results of the dental pathology study suggests that despite residence in the Mission Refugio the role of maize and other high carbohydrate or sugar foods was not great.

\section{Mobility}

Ricklis (1996) addresses the role of Mission Rosario in Karankawa land use patterns. Most historically documented Native American arrivals to the mission occurred in the months of March to April and September to November in response to shifting availability of resources. McDonald's examination of the Refugio records did not yield similar specific mention of Native American arrivals but has provided as wealth of other information relevant to land use patterns. The demographic analysis by Meadows Jantz and her team noted a peak in death rates in the fall months and they raised the possibility of this trend reflecting a seasonal influx.
Tennis (Chapter 4) identified three types of Karankawa families in the Mission Refugio records. The core group of "Children of the Mission" consisting of about 18-20 quasipermanent Karankawa family units; another approximately 8 Karankawa families that reappear frequently but are not designated as Children of the Mission; and finally there are Karankawa families who only appear only occasionally in the records. The Children of the Mission can be assumed to represent a social group as they were the original families that settled in the mission under the leadership of a man known as Llano Grande. The other two groups represent only a mission use strategy and do not represent a social group as they apparently enter and leave the mission as individual families, not as groups.

Using these observations as a point of departure I undertook further analysis of the baptismal records to attempt to discern land use strategies analogous to those that Ricklis discovered. The first step was to search for patterns in the baptismal records that may not be related to land use, such as seasonal trends in birth. Birth month was inferred from the listed baptismal date and age at baptism. Figure 10-2 shows that Native Americans birth rates are depressed in the second quarter (April-June) and elevated in the fourth quarter (September-December) while January-March and July-September are at expectable, average levels. This distribution is statistically significant (chi-square $\mathrm{p}=.018$ ). Non-Indigenous births are more even, but do show a slight depression in the spring and a minor increase in the summer and fall that is not statistically significant (chi-square $\mathrm{p}=.271$ ). We can expect then that Native American baptisms maybe elevated as much as ten percent in the fall and depressed in the spring by a similar level due to seasonal fluctuations in birth rates, not shifting residence patterns.

Tennis (Chapter 4) has made the insightful observation that a later age at baptism suggests that the infant was born away from the mission. The average age at baptism of all Native Americans age one or under is 2.66 months $(n=101)$. (Inclusion of children older than one would further skew this). In stark contrast mean age at baptism is only 6 days $(n=66)$ for the non-Native people. All but four of these were baptized by the time they were 11 days old. Catholic doctrine prescribes that baptism occur as soon as possible after birth as a child who dies prior to baptism cannot go to heaven. Given the high infant mortality rate it was a long held practice that baptism occur as soon as possible. For the purpose of further analyses families of babies baptized at age 14 days or younger will be hypothesized as "Residents", greater than 14 days but less than one year will be considered "Seasonal 


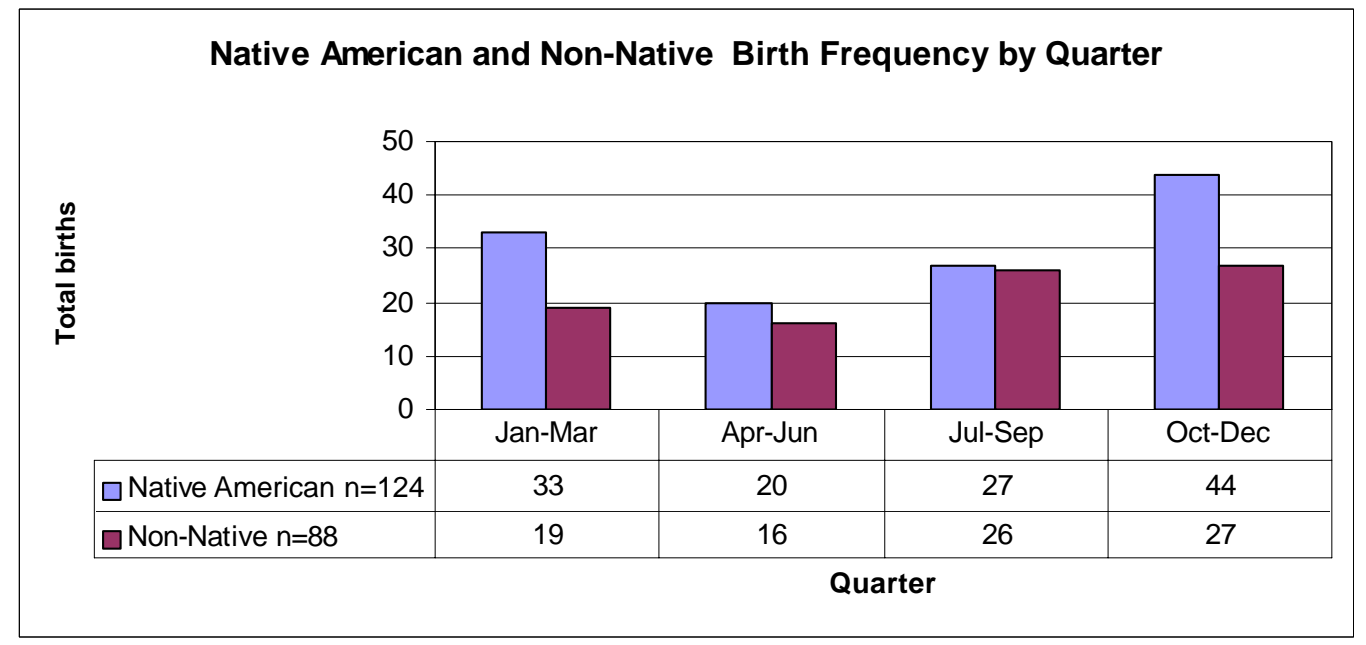

Figure 10-2. Refugio birth frequency by quarter.

Visitors", and those one year or greater will be hypothesized as "Occasional Visitors". The following analysis will evaluate those hypothetical descriptions of mission use.

The "Occasional Visitors" (baptized at one year or older) are first examined with Figure 10-3 showing the frequency of baptisms per month. Although the sample is not large there is a strong seasonal pattern of coming to the mission from July to September and November to January with a distinct absence in March and April. These are presumably families who may visit the mission annually or less frequently and they appear to be selective about the most opportune times to do so.
Next the frequency of baptisms per month for the "Residents" (baptized at $\leq 14$ days) versus the "Seasonal Visitors" (baptized at $>14$ days $<1$ yr) was compared. Figure 10-4 shows that in all months except February and March more "Seasonal Visitors" are baptized than "Residents". Notice also that the Residents have less monthto-month variability. In contrast, the Seasonal Visitors show a strong increase in baptismal frequency beginning in May, peaking in July and remaining elevated through January. The frequency of February to April baptisms of Seasonal Visitors is low echoing the pattern seen with the occasional visitor population.

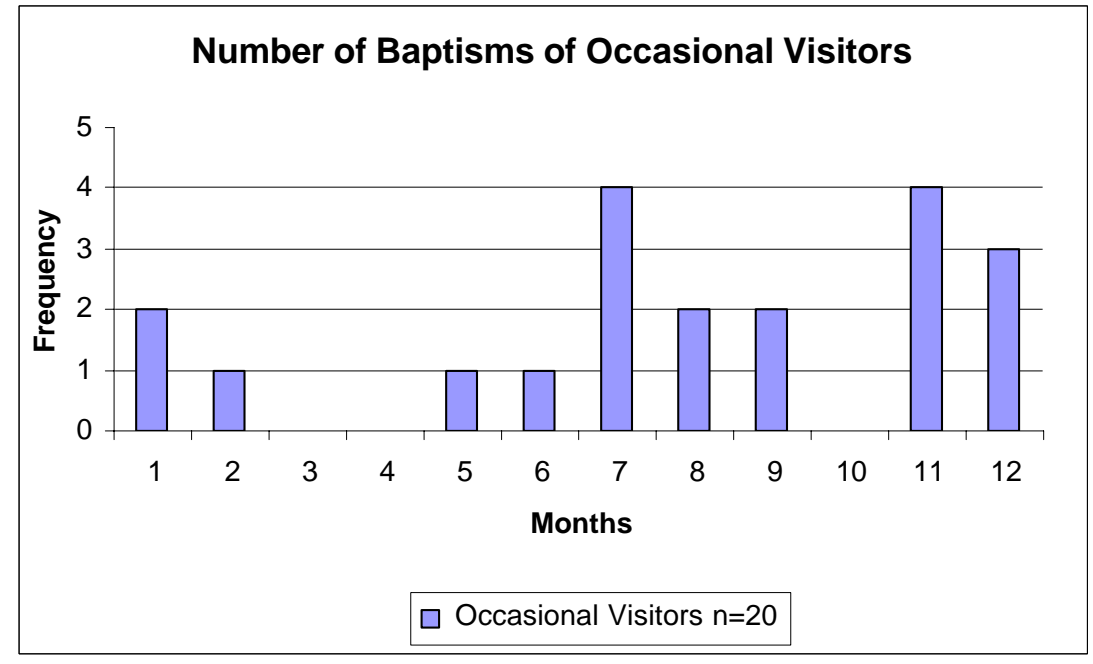

Figure 10-3. Frequency of baptisms per month for Occasional Visitors to Refugio. 


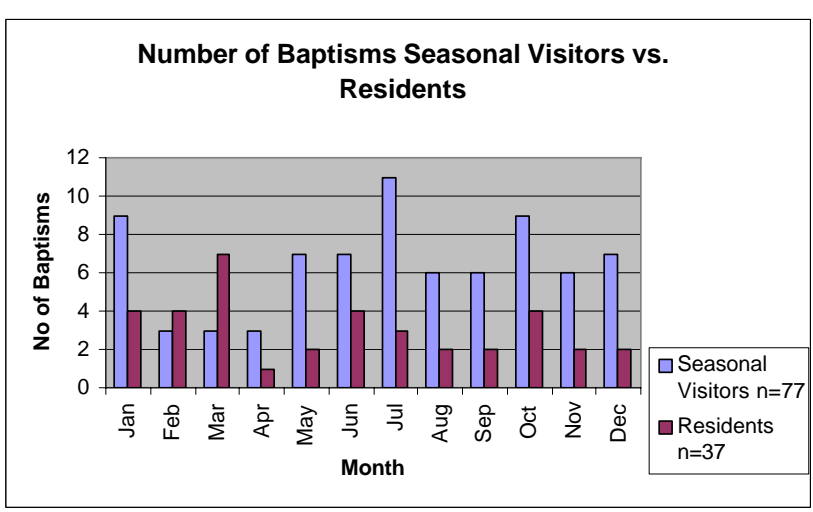

Figure 10-4. Comparison of frequency of baptisms per month for Residents versus Seasonal Visitors.

Family Months Absent from Misson \& In Field

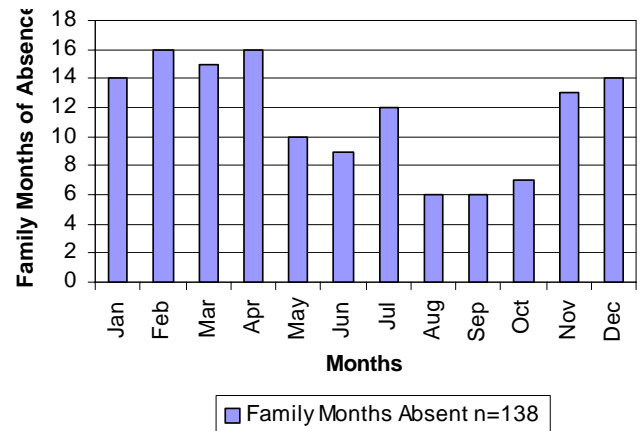

Figure 10-5. Frequency of family months of absence from Mission Refugio.

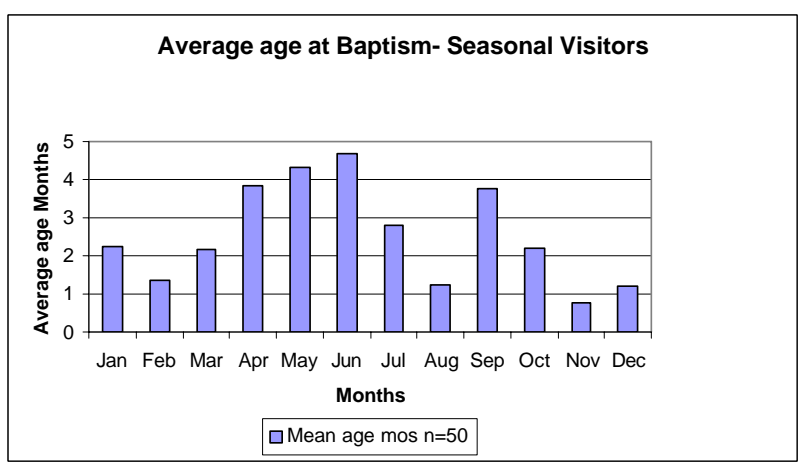

Figure 10-6. Average age of baptism of seasonal visitors at Mission Refugio.
In order to obtain a better idea when the Seasonal Visitors were NOT in the mission but in the field a further analysis was conducted. Based on the inferred birth date I assumed the period from the birth date to two weeks prior to the baptismal date the family was not in residence at the mission. Each of those months away represented a "family-month of absence" from the mission. The assumption is simply that a family will likely have their child baptized within two weeks of arrival at the mission. For example, if a family had its three-month-old baptized on May 27, 1810 it would have been counted as absent from the mission for the months of May, April, and March when the child was born. This birth would then represent three family months of absence during those particular months. After tabulating each month of absence for each of the 51 Native American Seasonal Visitors (ages 15 days-11 months) baptisms I then totaled the number of family months of absence by month. These frequencies were plotted on Figure 10-5 and represent the minimum periods and months that families that come to the mission had been in the field. In other words, it is a rough indication of the intensity and seasonality of use of the field by families who enter the mission.

To a large extent this pattern complements the previous ones. The field sees the heaviest use in the spring months February to April and this is congruent with the decline in baptisms in Figure 10-4. Notice the increase in baptisms in May shown on Figure 10-4 and it is reflected with a noticeable drop of use of the field in Figure 10-5. This inverse pattern for the first half of the year reflects a population that is largely behaving in unison. They have been away in the early spring and are returning in May and June. However the inverse pattern seems to disappear and a correlated pattern seems to dominate the rest of the year. In other words, the field sees heavy use in July and the same time baptisms at the mission increase. Baptisms drop in August and September while use of the field drops also. This may represent families who are entering and leaving the mission at more frequent intervals, perhaps staying only a month or two prior to departing and then returning within a month or two. In addition, these families are behaving independently and are not moving at the same time. For the winter months November to January duration in the field increases as do baptisms. This may reflect a steady inflow of people who having been away for two to three months then remain in the mission until the spring departure.

A final plot was constructed to further evaluate this pattern. Figure 10-6 is simply the average age at baptism of Seasonal Visitors for each month. For example, the children who are baptized in the month of May average a bit over four months 
of age. This complements the previous chart in that it shows that those children who are baptized in April, May, and June are three to four and a half months old since they have been continually away from the mission during the spring months. By June, families that had been away for the long spring absence had returned to the mission and the mobility pattern shifts to shorter periods of absence for the balance of the year as families depart for one to two month periods before returning. This pattern of briefer sojourns away from the mission before returning may account for both the increase in winter use of the field as seen in Figure 10-5 and the young age at baptism in Figure 10-6. In other words, during November and December people are coming into the mission, but they have not been away very long, perhaps only a month or so.

We can now attempt to link these patterns with the groups that Tennis identifies. Returning to her listing of 19 "Children of the Mission" families, she tabulates 71 baptisms in these families that occurred before the closure of Refugio. Almost half $(n=34)$ took place after the child was older than 14 days, suggesting the families were not at the mission when these children were born. Five of these baptisms occurred when the child was one year or older suggesting some of these families departed for extended periods. Tennis notes that some of the departures of the Children of the Mission families may have been related to the 1814-1816 revolutionary conditions and the resulting increase in Comanche raids and food shortages. About one-half $(n=15)$ of the 34 baptisms of children older than 14 days occurred during the 1814-1816 period thus about 25 percent of all Children of the Mission births occurred while the families were in the field and were not affected by war conditions. All 19 families had 25-75 percent of their children born away from the mission so essentially there were no permanent Native American residents of the mission, but a core group of families who made the mission their primary home for many years, but continued to exploit resources distant from the mission on extended trips. These families appear in the previous graphs then as both "Residents" (those with age at baptism 14 days or less) and as "Seasonal Visitors" because they depart the mission for several months at a time. This may include the longer spring departure as well as the shorter departures in the summer and winter months.

In addition, there were a larger number of Native American families who spent longer periods away from the mission and leave and return at more frequent intervals. Tennis has identified eight of these families and 78 percent of their children (18 out of 23) are born away from the mission. She indicated that these families return to the mission and then reappear in the recorded documents a number of times over the course of 8-12 years. The bulk of these families should be in the "Seasonal Visitors" category (baptisms between the ages of 14 days and before one year). They may participate to varying degrees in a land use pattern that includes being away from the mission February to March and entering the mission May to July. From August to October there is a substantial number of arrivals and departures with people staying and being absent for periods of two to four months. In November and December and January there is a steady stream of arrivals although many had not been away long -perhaps one to two months.

There are about another 40 baptisms in families that rarely appear in the records suggesting that these families visited the mission only occasionally. These are probably reflected by the baptisms of children greater than a year old, but they enter and leave the mission during the same seasons although far less frequently and they also may not return for long period of time. This group would also be represented in the "Seasonal Visitors" category if their child was baptized at less than a year old.

\section{Dental hypoplasias}

Linear dental hypoplasias form on teeth in response to periods of nonspecific childhood stress sustained during periods of permanent dentine formation. Thirty-eight percent $(523 / 1381)$ of teeth examined contained at least one hypoplasia, a relatively high rate. Age at defect formation was determined for each. The mean interval between the formation of defects is five and a half to six months suggesting that children are not exposed to randomly occurring stresses, but they have a seasonal cycle. This cycle may relate to the seasonal pattern in mission usage proposed earlier with spring, representing a time of relative plenty when fishing can be emphasized, progressing to the onset and duration of summer that signifies a time of less abundance and a period of higher disease transmission.

Also note that males (33\%) have a statistically significant lower hypoplasia rate than females $(46 \%)$. This pattern is relatively widespread and may suggest male children are preferred (Meadows Jantz et al., Volume II). 


\section{Isotope analysis}

Norr's stable isotope data from Refugio and the Meadows Jantz's analysis of the data can be used as independent evaluation of the previous dietary inferences and land use patterns. The Meadows Jantz's statistical analysis identified three isotopic clusters and they are summarized in Table 10-4. Previously we have suggested that three patterns of land use could be recognized from the historic records. The Children of the Mission's diet was modeled, based on historic records, as a large proportion of beef and a lesser proportion of maize plus an array of other foods making up the balance. These could have included fish, game, and plants obtained during foraging trips as well as other domestic animals, brown sugar that the priest distributed, or other mission products. During the spring months, particularly February-March and into April most of these families were away from the mission probably concentrating on marine fish exploitation, particularly drum and red fish from the shallow bays.

The second group is characterized as "Seasonal Visitors" and is represented by eight families with 23 baptisms in the historical records. They are not identified as Children of the Mission in the baptismal records yet they maintain their affiliation with the mission for well over a decade. Their overall pattern is similar to that of the Children of the Mission but they stay away for longer intervals and depart more frequently to obtain resources. Their diet would be similar to the Children of the Mission when they were at the mission, but they would have more months away from the mission to exploit fish and inland resources. On an annual basis, their intake of beef and corn would be lower than the Children of the Mission.

The third group is characterized as "Occasional Visitors" and is represented by 40 baptisms. These group members occur in the records only once or twice and are thought to be families who make short visits to the mission on occasion. Their diet was largely wild foods, with particular emphases on coastal resources and inland terrestrial resources with little use of maize and beef over the long-term.
How do the previously identified isotopic clusters relate to the three identified strategies of mission use? It appears that the isotope data does not reject the proposed three mission strategies and, in fact, there appears to be a one-to-one fit between each isotope data cluster and a corresponding mission use strategy.

Cluster 2 represents the Children of the Mission, Seasonal Visitors appear to be Cluster 3, and the Occasional Visitors are Cluster 1 (Table 10-4; Figure10-7). Table 10-5 lists the isotope values for major dietary inputs. First notice as participation in the mission declines across the three clusters that the ${ }^{13} \mathrm{C}$ value becomes more negative as a result of reduced maize use. Notice also that the elevated ${ }^{15} \mathrm{~N}$ levels across all three clusters. Such levels correlate with significant use of aquatic resources (Cargill and Hard 1999) as few other resources have such elevated nitrogen levels.

The Children of the Mission-Cluster 2 has the most positive ${ }^{13} \mathrm{C}$ levels reflecting moderate use of maize. It does not however appear that maize dominated the diet given the high nitrogen levels. The elevated nitrogen is due to significant use of marine fish. The observation that maize is only playing a moderate role in the diet is consistent with previously discussed data and the low caries rate discussed below. The use of beef is not as strongly reflected in Cluster 2 as was anticipated, although these values could certainly incorporate moderate levels of beef use and therefore do not conflict with expectations. Note that on Figure 10-7 Cluster 2 falls within the range of two other Texas coastal isotope studies. Also note that the Cluster 2 mean value is within the San Juan Capistrano Room 26 value. The San Juan values were interpreted as reflecting a coastal signature as many of the Indians at that San Antonio mission were recruited from the coast (Cargill and Hard 1999).

The Seasonal Visitors (Cluster 3) have more elevated nitrogen levels than Cluster 2 as they were departing the mission more frequently to exploit coastal resources rather than relying on mission maize and beef. Note that Cluster 3 falls well within the values of a prehistoric Texas coastal dataset. Freshwater fish with their higher nitrogen values

Table 10-4. Isotope values of clusters based on Meadows Jantz and Norr and dietary inferences

\begin{tabular}{|c|c|c|c|c|c|c|c|c|}
\hline Group & Cluster & $\mathbf{C}$ & $\mathbf{N}$ & Maize & Beef & $\begin{array}{c}\text { Marine } \\
\text { fish }\end{array}$ & Freshwater & Upland \\
\hline C.O.M.* & 2 & -9.32 & 11.58 & Moderate & Moderate? & Moderate & Low & Low? \\
\hline Seasonal & 3 & -12.45 & 12.55 & Low & Moderate? & Moderate & Moderate & Low? \\
\hline Occasional & 1 & -16.23 & 11.75 & None & Low? & Moderate & Moderate & Moderate? \\
\hline & & & & & & & & \\
\hline
\end{tabular}

*Children of the Mission. 
Table 10-5. Carbon and nitrogen isotope values of edible portions

\begin{tabular}{|l|r|r|l|}
\hline \multicolumn{1}{|c|}{ Food } & \multicolumn{1}{c|}{${ }^{13} \mathbf{C}$} & \multicolumn{1}{c|}{${ }^{15} \mathbf{N}$} & \multicolumn{1}{c|}{ Source } \\
\hline Maize & -11.2 & 7.0 & Hard et al. 1996; Spielmann et al. 1990 \\
\hline Cow & -18.7 & 7.4 & Cargill and Hard 1999 \\
\hline Freshwater catfish & -24.6 & 12.3 & Cargill and Hard 1999 \\
\hline Saltwater drum & -15.6 & 11.6 & Huebner 1994 \\
\hline White-tail deer & -22.0 & 11.0 & Quigg et al. 2000 \\
\hline Turkey & -19.7 & 7.8 & Cargill and Hard 1999 \\
\hline Bison & -13.8 & 7.2 & Quigg 1997 \\
\hline Sotol (upland plant) & -24.2 & -1.2 & Quigg et al. 2000 \\
\hline
\end{tabular}

The isotopic values of the edible portion of meat were calculated by +1.7 mil for ${ }^{15} \mathrm{~N}$ and -3.7 mil for ${ }^{13} \mathrm{C}$ to the bone collagen isotope value (Norr, Volume II). Therefore, for cow the measured bone collagen value was -15.0 for ${ }^{13} \mathrm{C}$ and 5.7 for ${ }^{15} \mathrm{~N}$ (Cargill and Hard 1999).

and more negative carbon 13 values are likely to be represented as well (Table 10-4; Figure 10-7). A signal from beef inputs may also be contributing to some extent to the more negative ${ }^{13} \mathrm{C}$ values.

The Occasional Visitors are making insufficient use of maize in their mission visits to be reflected in their isotope signatures. Note on the graph (Figure 10-7) that Cluster 1 falls between an inland/freshwater fish adaptation and coastal adaptations. The combination of elevated nitrogen levels and more negative carbon values reflects substantial use of both freshwater and marine resources. The similarity between cow, deer, and turkey make discrimination of these inputs difficult. Contributions from deer, turkey, and upland plants would not be inconsistent with Cluster 1.

In summary we can suggest with some confidence that the Children of the Mission were focusing on beef, marine fish and maize; the Seasonal Visitors were using marine fish, freshwater fish, and beef; and the Occasional Visitors were using marine fish, freshwater fish, and upland resources.

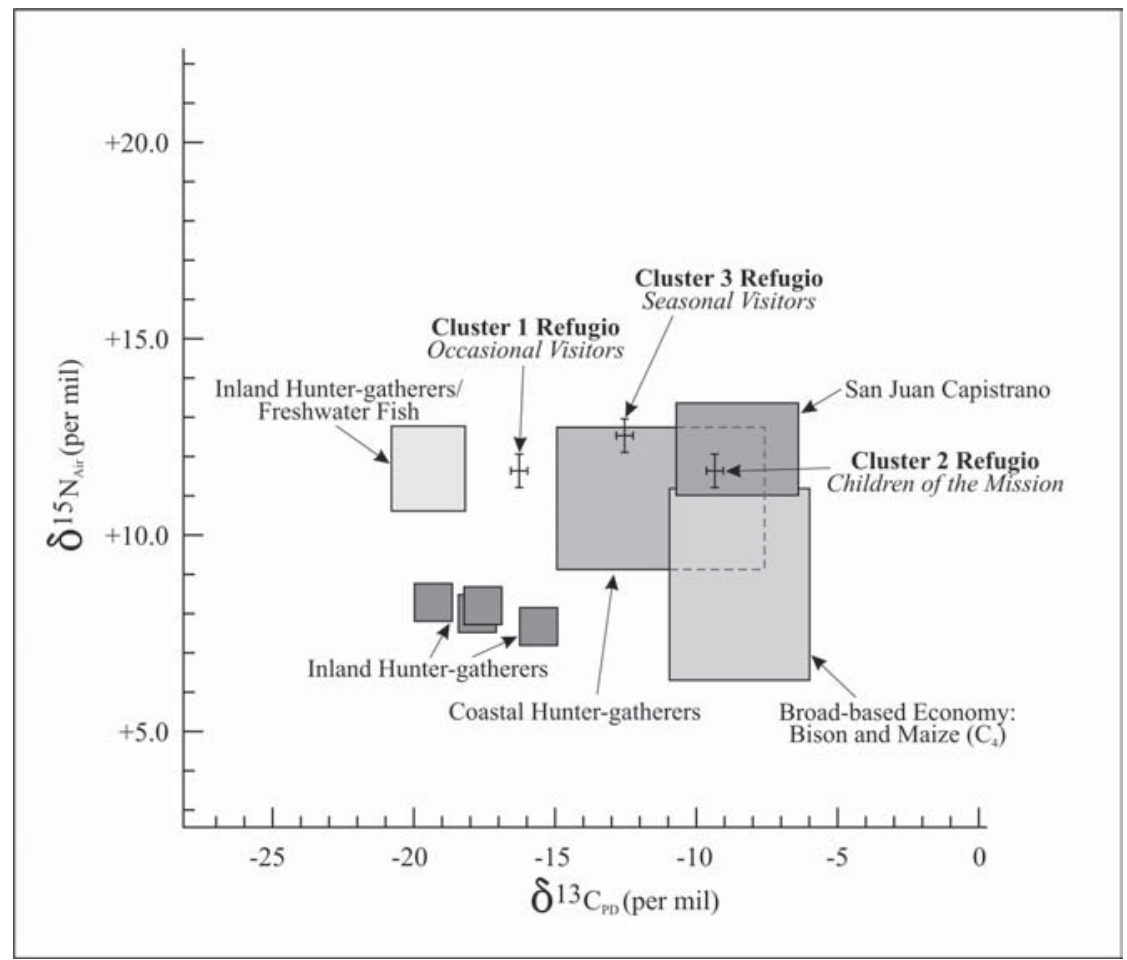

Figure 10-7. Identified isotopic clusters as related to identified mission use strategies. 


\section{Ecological context}

Comparison among the mission settlement strategies, dietary inferences and Ricklis's annual coastal ecological patterns were compared. Ricklis (1996:23) graphs annual fluctuations in the availability of fish, plants, and game animals. These resource fluctuations were compared with monthly conception frequency and family months of field use to assess the degree of correlation (Figure 10-8). I derived conception frequency by inferring conception month as nine months prior to birth date. The derivation of birth dates was described above. Number of family months absent from the mission was added to the same chart and it is used as a relative measure of intensity of use of resources away from the mission. It has been previously suggested that coastal fishing resources were one of the primary factors affecting Karankawa mobility patterns. Figure 10-8 plots Ricklis's relative trend of coastal fish availability with frequency of births and family months absent. First notice that field use and conceptions are tightly correlated with high levels January to April with both dropping sharply in May and remaining correlated in June. In July and August a correlation remains although there is a one-month offset between the two patterns. By August all three lines are at a nadir. Conceptions sharply increase in September and October while intensity of field use increases slightly. In November and December the pattern breaks down for the only time during the year with intensity of field use increasing and conceptions declining. Figure 10-8 indicates a good fit virtually the entire year. The exceptions are the June and July increases in field use and increase in conceptions that sharply diverge from low fish availability. Intensity of field use and fishing availability remain correlated through the fall including November and December, although conceptions decline in November and December departing from this trend.

Can the departures from the fishing cycle in June and July and conception decline in November and December be related to plant availability (Figure 10-9)? Plant use is depicted as constant except with lows in October and March. Nuts are available in November, roots in the winter months, greens in April and May, with fruits and seeds in June and July (Ricklis 1996:23). Therefore the June and July increases in intensity of field use and conceptions may be related to the availability of plants such as fruits and seeds, particularly the highly productive prickly pear harvest that occurs at this time. The November and December increases in field use may also be related to the nut harvest of acorns and pecans and perhaps cattail root. Conceptions appear to be

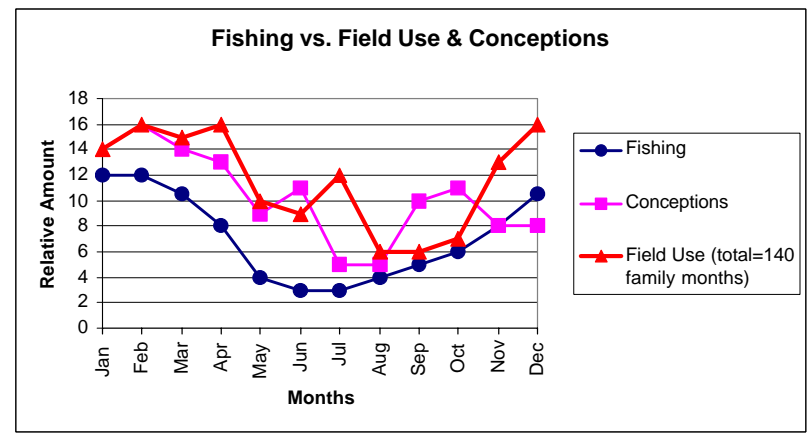

Figure 10-8. Resource fluctuations compared with monthly conceptions and family months of field use.

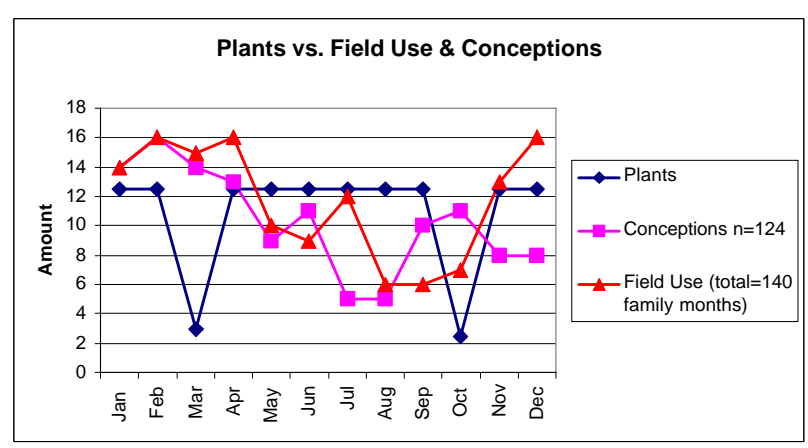

Figure 10-9. Departure from fishing cycle and conception decline as related to plant availability. 
unaffected. Figure 10-10 indicates that the availability of terrestrial mammals is inversely related to intensity of field use suggesting that pursuit of upland game is incidental to other pursuits and not a conditioning factor of land use. Conceptions appear unrelated to hunting seasons (not graphed).

One final pattern demonstrates many of these features. Figure 10-11 shows the relationship between all conceptions and baptisms of seasonal visitors. Monthly frequency of seasonal visitor baptisms are one of the best indicators of mission entry. Conceptions are one of the better indicators of wild food availability. Monthly percentages of the annual total of both are used for comparability. As expected Figure 10-11 shows that there is largely an inverse relationship between conceptions and baptisms because during the more productive seasons for wild foods families are away from the mission and during the lean times families move into the missions. During the spring fishing season conceptions are high and baptisms are low as families depart the mission to exploit the coast. Beginning in May there is increased movement into the mission and conceptions decline as the worst season for wild food availability is May to July. The substantial fluctuations in seasonal baptisms from August to December reflects the more frequent movement in and

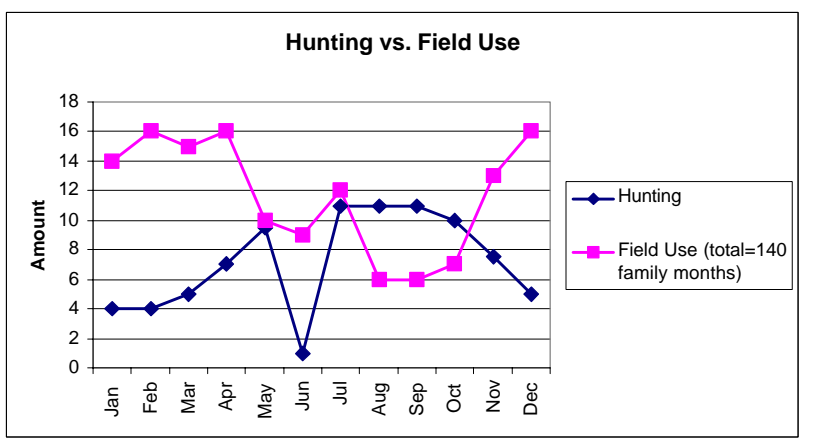

Figure 10-10. Relation of availability of terrestrial mammals to intensity of field use.

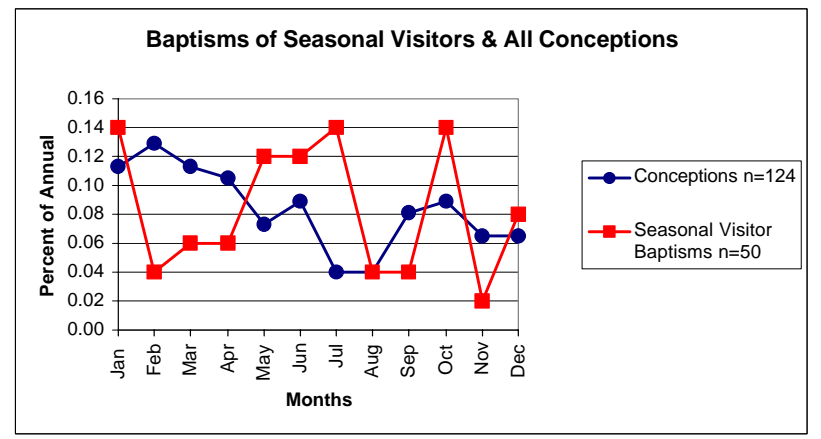

Figure 10-11. Relationship between all conceptions and baptisms of Seasonal Visitors. out of the missions as families move between exploiting plant resources such as prickly pear, nuts, and cattail and the mission resource. With our understanding of the mission use strategies and the biological population we can examine the analyses of some of the material culture.

\section{Chipped stone}

The detailed analysis of 503 chipped stone items offers some insights into mission period lithic assemblages and suggests that the Refugio assemblage has an unusual technological component (Tomka, Chapter 9). The raw material is dominated by fine-grained cherts with small amounts of coarse-grained chert, quartzite, chalcedony, rhyolite, petrified wood, and agate. Unmodified debitage accounts for the bulk of the assemblage although tools include a projectile point, six scrapers, a graver, two unifaces, a biface, 14 probable gunflints, and 65 cores. The unusually high number of cores for a mission assemblage was striking in that they were of a small size and a large proportion of them had been reduced with a bipolar technology. Tomka considered the possibly that these were the product of mechanical impacts (construction or road related damage). Based on their vertical distribution and examination of a comparative collection he suggests these items are indeed cultural. The majority of the bipolar items appear in Analytical Unit 3, the most recent occupation.

The assemblages suggest use of local, small raw materials and a tool kit composed primarily of expedient tool forms such as scrapers. The stone arrow point indicates this technology persists even though metal arrow points are in use at the time as one was found in a burial context. Reduction techniques are characterized by bipolar hammer and anvil reduction to produce blanks. Limited bifacial reduction was limited to the manufacture of projectile points and gunflints. The shift from a primarily bifacial reduction strategy as represented by most South Texas prehistoric assemblages to core technologies is a global trend related to reduced mobility (Parry and Kelly 1987), and is consistent with the dominant Karankawa use of the mission. However, the use of the mission by more mobile Karankawa is not apparent in the chipped stone assemblage. The shift to bipolar hammer and anvil reduction may be related to shifting land use strategies or perhaps cultural affiliation. However, no other Texas mission population is known to have used a bipolar strategy. Continued examination of this and other assemblages as additional comparative material comes available will likely be a fruitful avenue of research as will raw material sourcing studies. 


\section{Ceramics}

The thorough analysis of 3031 native ceramics by Perttula (Chapter 9c) and supported by Hill's petrographic analysis (Appendix G) and Neff and Glascock's Instrumental Neutron Activation Analysis (INAA) (Appendix н) offers an array of information relevant to research questions regarding mobility, technology, ethnicity, adaptations, and acculturation. Perttula analyzed this assemblage by subdividing it into the two major classes: bone-temper (78 percent) and sandy paste ceramics (17 percent) plus a third group with both attributes (5 percent) and some of his major findings are summarized below. Neff and Glascock's chemical analysis showed that 77 percent of the INAA sample was bone-tempered and made from clays at or near the mission. The vast majority of the Refugio sherds are made locally using bone temper. In addition, 6.1 percent $(5$ sherds) of the INAA sample is locally made sandy paste sherds. The balance of the INAA sample formed a separate reference group that is chemically similar to the Refugio sample suggesting that these ceramics were manufactured from a different local source. Thirty-three percent of the unknown source group was sandy paste and presumably the remainder of the unknown source was bone temper. In sum, most of the Refugio sample is locally made and bonetempered with a small proportion of sandy paste locally made sherds. About one quarter of the assemblage is made outside of the mission and one-third of these items have sandy paste, but two-thirds are bone-tempered.

The bone-tempered sherds have a modal wall thickness of about 7-mm, noticeably thicker than the roughly $5-\mathrm{mm}$ thick sandy paste wares. The presumed livestock bone was burned and crushed prior to adding it to the clay paste. Most of the bone-tempered rims are direct with rounded lips representing bowls or deep jars. A significant percentage (35 percent) is from jars with everted rims. The balance has inverted rims with rounded and flat lips from shallow bowls and narrowmouthed jars. The vast majority of bone temper sherds were fired in a reducing atmosphere. Exterior finishes are commonly smoothed or burnished. Only about 1.5 percent of these sherds were decorated with treatments that included red-painted bands, brown-painted bands, and asphaltum lines, blobs, or squiggles. Some of these decorated types include Goliad Black-on-buff and Goliad Red-on-buff.

The sandy paste sherds are thinner walled than the bone temper sherds. Perttula observes that 23.5 percent of the sandy paste sherds have bone temper added. The wall thickness of this variant falls between that of the sandy paste and the bone temper groups. In discussing the rim forms Perttula combines the sandy paste and sandy paste with bone temper sherds. The dominant rim form is direct with flat lips. Inverted rims from bowls or small-mouthed ollas and everted rims representing jars represent minor components of the assemblage. Forty-seven percent of the sandy paste sherds were fired under oxidizing conditions versus only 14 percent of the bone-tempered sherds. Sandy paste sherds are 3-13 times more likely to be fired under oxidizing conditions than bone-tempered sherds from the same provenience. Decorations and surface treatments of the sandy paste wares include burnishing, interior scraping, and wiping. Asphaltum lines, bands, and squiggles represent the types Rockport Black-on-gray I and II. Asphaltum decorations are about ten times more common on the sandy paste wares than the bone-tempered sherds.

The strong presence of non-local manufactured sherds and asphaltum supports earlier inferences that the Karankawa maintained continuous contact with the coast. Sandy paste wares also have an affinity with a coastal origin.

Sandy paste wares with a high frequency of asphaltum treatment are derived from the Rockport wares that are known from historic, protohistoric, and prehistoric locales along the central Texas Coast. Ricklis (e.g. 1996) as part of his long-range and highly productive coastal archaeology research program has linked the distribution of Rockport ceramics with the Karankawa and their ancestors. These ceramics predominate on sites within $40 \mathrm{~km}$ of the coast and thus are linked with a strongly supported model of land use involving seasonal movements between shoreline fishing camps and inland camps located within about $40 \mathrm{~km}$ of the coast. Ricklis has shown that sandy paste ceramics tend to make up about 60 percent of the ceramic assemblages on coastal corridor sites, while the other 40 percent is bonetempered pottery (Ricklis 1996). It is the frequency of sandy paste sherds, not their presence or absence that is critical to these patterns.

Bone-tempered pottery is linked with the historic Goliad and prehistoric Toyah tradition of inland south Texas. Inland from the $40 \mathrm{~km}$ coastal zone bone temper sherds begin to dominate and it is thought this is generally outside of the region that the Karankawa traditionally exploited. The boundary of two wares are linked to an ethnic boundary based on the relative proportion of each ware.

Hill's petrographic study of a sample of Refugio sherds shows that the sand in the paste is a natural component of 
the clays and is not an additive. He also argues that there is an inverse relationship between the density of sand particles and the density of added bone temper. As sand density increases less temper will be added and sherds with dense levels of naturally occurring sand will contain little bone temper. Sandy clays are self-tempered and do not require the addition of bone. The proportion of naturally occurring sand in clays should diminish with increasing distance from the coast.

Ricklis (1999a) observes that the Mission Rosario ceramics were made by the Karankawa yet 90 percent of the vessels have bone tempering. The majority of these vessels however also contain sand. He goes on to suggest that this represents a shift in Karankawa ceramic technology related to poorly understood mission cultural processes. The pattern is similar at Refugio. There the Karankawa are locally manufacturing pottery and commonly adding bone tempering. Perttula, following Ricklis, suggests this represents an amalgamation of the two ceramic traditions as a product of mission period changes.

This raises an extremely important issue: What do the two ceramic traditions at Refugio represent? We can be confident they are Karankawa in origin as we know that the Children of the Mission group dominated the occupation of Refugio and must have been, to a large extent, the group responsible for the manufacture of the bone temper ceramics. We also suspect there were two other strategies of land use, those Karankawa who visited seasonally making frequent forays away from the mission yet returning to the mission for many years. There were also those that only visited the mission once in a while. All of the land use strategies would have maintained a strong connection to the coast to bring in sandy paste wares and asphaltum.
The principal difference between the two assemblages, aside from their fabric and asphaltum frequency, is that the sandy paste wares have thinner walls, are more likely to be fired in an oxidizing atmosphere, and tend to have flat lips rather than rounded lips. In addition, the bone-tempered sherds have a high frequency of polishing or burnishing where as the sandy paste ceramics have a high frequency of asphaltum covering. Figure 10-12 shows that the main difference is that there is a slightly higher proportion of everted rims in the bonetempered group and slightly more direct rims in the sandy paste wares. Otherwise, the rim form distribution between the two assemblages is similar. Perttula notes that the asphaltum decorations between the two types are also similar.

Why are the Karankawa making bone-tempered pottery at Rosario and Refugio if the prehistoric and protohistoric Karankawa can be ethnically identified by their high frequency of sandy paste ceramics? The combined Refugio and Rosario research suggests a productive line of inquiry. It may be useful to examine the technological, functional, and geological frequency of naturally occurring sands in clays. If, as Hill argues, bone is simply replacing low density sand as a tempering agent -perhaps the frequency of sandy paste sherds is directly correlated with the naturally occurring distribution of sandy clays. Perhaps we should consider an alternative or additional hypothesis that tempering agents could be reflecting physical, geological, and technological attributes as well as ethnic ones. The technological attributes of bone tempering versus sandy paste need to be explored in terms of resistance to thermal and physical shock, the physical role of different firing conditions, wall thickness, and surface treatments. We may find that these correlations between ethnicity and sherd type assemblage frequency may have a strong functional element. Explorations in the historic contexts where we can control for ethnicity offer potential new insight into these relationships.

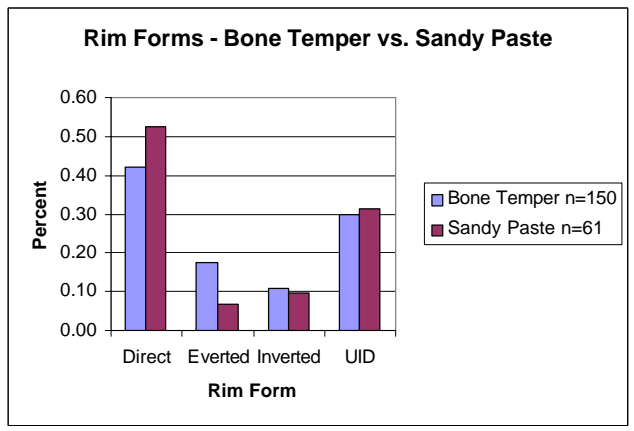

Figure 10-12. Comparison of rim forms, bone temper versus sandy paste from Mission Refugio. 


\section{Acculturation}

Perttula notes that the Refugio native ceramic technology is a clear continuation of prehistoric traditions in firing, paste, temper, and production to produce similar vessel forms. A few changes represent acculturation including riveted handles on jars and foot supports and ceramic discs. Some of the decorative elements may be inspired by Mexican manufactured wares. The persistence of the largely native technology is consistent with other elements of what we have learned about this period, in that the Karankawa maintained a large segment of their traditional culture while adopting elements of Mexican culture including Catholic rituals, some use of the Spanish language, reduced levels of mobility for some bands, use of steel tools, and the consumption of maize, beef and other introduced domesticates. However, to differing degrees they maintained a significant component of their aboriginal settlement and subsistence system: they tended to not intermarry with the Non-Indigenous population, they continued to speak the Karankawa language, different bands maintained differing elements of the traditional settlement and subsistence system, manufacture of traditional ceramics, and manufacture of a modified chipped stone assemblage. By the end of the eighteenth and beginning of the nineteenth centuries Karankawa population levels had stabilized following at least a century and a half of decimation from European diseases. At this time the attraction of the mission would primarily have been as a resource and a source of protection. Unfortunately with the cessation of activity at Mission Refugio in 1824 and its official closure in 1830-followed by the onset of Texan and American settlement-the Karankawa lost many of their refuges and by the 1850s they had either been assimilated or killed (Himmel 1999). 


\section{References Cited}

Albarella, U.

1997 Shape Variation of Cattle Metapodials: Age, Sex, or Breed? Some Examples from Medieval and Postmedieval Sites. Anthropozoologica 25-26:37-47.

Albert, B. M.

1999 Early and Protohistoric Agents of Vegetation Change in the Environs of Mission Rosario (41GD2) as Reflected in Palynological Data. Bulletin of the Texas Archeological Society 70:189-213.

Almaráz, F. D.

1979 San Antonio's Missions in the Mexican Period: Material Decline and Secular Avarice. Paper presented at the Joint Session of the Texas Catholic Historical Society and the Texas State Historical Association, San Antonio, Texas, Friday, March 9.

Arbingast, S. A., L. Kennamer, R. Ryan, J. Buchanan, W. Hezlep, L. Ellis, T. Jordan, C. Granger, and C. Zlatkovich 1976 Atlas of Texas. Bureau of Business Research, University of Texas, Austin.

Aten, L. E.

1965 Five Crania from the Jamaica Beach Site (41GV5), Galveston County, Texas. Bulletin of the Texas Archeological and Paleontological Society 36:153 162.

1983 Indians of the Upper Texas Coast. Academic Press, New York.

Aten, L. E., C. K. Chandler, A. B. Wesolowsky, and R. M. Malina

1976 Excavations at the Harris County Boys'School Cemetery: Analysis of Galveston Bay Area Mortuary Practices. Special Publication No. 3. Texas Archeological Society, Dallas.

Austin, S. F.

1904 Journal of Stephen F. Austin on His First Trip to Texas, 1821. Texas Historical Association Quarterly 7:287-307.

Avery, G. E.

1997 Pots as Packaging: The Spanish Olive Jar and Andalusian Transatlantic Commercial Activity, $16^{\text {th }}-18^{\text {th }}$ Centuries. Ph.D. dissertation, Department of Anthropology, University of Florida, Gainesville.

Ayers, C. H.

1906 Lewis Ayers. Quarterly of the Texas State Historical Association 9:272-275.

Baird, J. A., Jr.

1962 The Churches of Mexico 1530-1810. University of California Press, Berkeley.

Balkwill, D. M., and S. L. Cumbaa

1992 A Guide to the Identification of Postcranial Bones of Bos taurus and Bison bison. Syllogeus No. 71. Canadian Museum of Nature, Ottawa.

Barker, E. C.

1919 The Austin Papers. American Historical Association Annual Report, vol. 1, Pt. 1. United States Government Printing Office, Washington, D.C. 
1996a Mexican Colonization Laws. In New Handbook of Texas, Vol. 4, edited by Ron Tyler, pp. 684-685. Texas State Historical Association, Austin.

1996b Austin, Stephen Fuller. In New Handbook of Texas, Vol. 1, edited by Ron Tyler, pp. 294-297. Texas State Historical Association, Austin.

Barlow, R. K.

1997 Foragers that Farm: A Behavioral Ecology Approach to the Economics of Corn Farming for the Fremont Case. Ph.D. dissertation, Department of Anthropology, The University of Utah.

Barnes, M. R.

1980 Mexican Lead Glazed Earthenwares. In Spanish Colonial Frontier Research, edited by H. F. Dobyns, pp. $92-$ 110. Spanish Borderlands Research Report No. 1. Center for Anthropological Studies, Albuquerque, New Mexico.

1983 Tucson: Development of a Community. Ph.D. dissertation, School of Arts and Sciences, Catholic University of America, Washington, D.C.

Barnes, M. R., and R. V. May

1972 Mexican Majolica in Northern New Spain. Occasional Paper No. 2. Pacific Coast Archaeological Society, Costa Mesa, California.

Barnes, T. C., T. H. Naylor, and C. W. Polzer, S. J.

1981 Northern New Spain: A Research Guide. University of Arizona Press, Tucson.

Bauman, J. L.

1989 A Brass Arrow Point from San Patricio County, Texas. La Tierra 16(4):25-28.

1991 Two Metal Arrow Points from Nueces County, Texas. La Tierra 18(3):27-29.

[BEEI] Bull's Eye Enterprises, Inc.

1998 Multi-Frequency Electromagnetic Geophysical Survey of Refugio Mission. Report on file at the Center for Archaeological Research, The University of Texas at San Antonio.

Bell, A. L. (translator)

1987 Voyage to the Mississippi through the Gulf of Mexico. In La Salle, the Mississippi, and the Gulf, Three Primary Documents, edited by R. S. Weddle (M. C. Morkovsky and P. Galloway, associate editors), pp. 225-258. Texas A\&M University Press, College Station, Texas.

Benavides, A., Jr. (editor)

1989 The Bexar Archives (1717-1836): A Name Guide. University of Texas Press, Austin.

Benowitz, J. M.

1996 Nuestra Señora del Refugio Mission. In New Handbook of Texas, Vol. 4, edited by Ron Tyler, pp. 1072-1073. Texas State Historical Association, Austin.

Berlandier, J. L.

1969[ca. 1840s] The Indians of Texas in 1830. Edited by J. C. Ewers. Smithsonian Institution Press, Washington, D.C. 
Black, S. L.

1989 South Texas Plains. In From the Gulf to the Rio Grande: Human Adaptation in the Central, South, and Lower Pecos Texas, by T. R. Hester, S. L. Black, D. G. Steele, B. W. Olive, A. A. Fox, K. J. Reinhard, and L. C. Bement, pp. 39-62. Research Series No. 33. Arkansas Archeological Survey, Fayetteville.

1995 Archeological and Ethnohistoric Background. In Archeological Investigations at the Loma Sandia Site (41LK28), a Prehistoric Cemetery and Campsite in Live Oak County, Texas, by A. L. Taylor and C. L. Highley, pp. 31-45. Studies in Archeology No. 20. Texas Archeological Research Laboratory, University of Texas, Austin.

Blair, W. F.

1950 The Biotic Provinces of Texas. Texas Journal of Science 2(1):93 117.

Blanchette, J. F.

1981 The Role of Artifacts in the Study of Foodways in New France, 1720-60. History and Archaeology Report No. 52. National Parks and Sites Branch, Parks Canada, Quebec.

Boessneck, J.

1970 Osteological Differences Between Sheep (Ovis aries Linné) and Goats (Capra hircus Linné). In Science in Archaeology, edited by D. Brothwell and E. Higgs, pp. 331-358. Praeger, New York.

Bolton, H. E.

1970 Texas in the Middle Eighteenth Century. University of Texas Press, Austin.

Bond, C. L.

1989 Copy of original site forms. Manuscripts on file at the Center for Archaeological Research, The University of Texas at San Antonio.

Brown, C. L., and C. E. Gustafson

1979 A Key to Postcranial Skeletal Remains of Cattle/Bison, Elk, and Horse. Reports of Investigations No. 57. Laboratory of Anthropology, Washington State University, Pullman.

Bugbee, L. G.

1899 What Became of the Lively? Southwestern Historical Quarterly 3(Oct.).

Buikstra, J. E., and D. H. Ubelaker (editors)

1994 Standards for Data Collection from Human Skeletal Remains. Arkansas Archeological Survey Research Series, No. 44. Fayetteville, AR.

Butler, B. H.

1974 Animal Bones. In Mission Rosario: Archeological Investigations, 1974, by K. Gilmore, pp. 161-164. Archeological Report No. 14, Part 2. Texas Parks and Wildlife Department, Parks Division, Historic Sites and Restoration Branch, Austin.

Calcott, W. H.

1996 Santa Anna, Antonio López de. In New Handbook of Texas, Vol. 5, edited by Ron Tyler, pp. 881-882. Texas State Historical Association, Austin. 
Campbell, T. N.

1947 The Johnson Site: Type Site of the Aransas Focus on the Texas Coast. Bulletin of the Texas Archeological and Paleontological Society 18:40 75.

1957 Archeological Investigations at the Caplen Site, Galveston County, Texas. Texas Journal of Science, 9(4):448471.

1976 Archaeological Investigations at the Morhiss Site, Victoria County, Texas, 1932-1940. In An Archaeological Survey of Coleto Creek, Victoria and Goliad Counties, Texas, by A. A. Fox and T. R. Hester, pp. 81-85. Archaeological Survey Report No. 18. Center for Archaeological Research, The University of Texas at San Antonio.

Cardenas, Fr. J. M.

1783 Inventory of Mission Espíritu Santo, September 27, 1783. Zacatecas Microfilm Roll 3. On file, Old Spanish Missions Historical Research Library, Our Lady of the Lake University, San Antonio, Texas.

Cargill, D. A.

2001 Mission Espada - Hike and Bike Trails. To be included in Mission Trails, City of San Antonio. Unpublished draft on file at the Center for Archaeological Research, The University of Texas at San Antonio.

Cargill, D. A., and R. J. Hard

1999 Assessing Native American Mobility versus Permanency at Mission San Juan Capistrano through the Use of Stable Isotope Analysis. Bulletin of the Texas Archeological Society 70:1997-213.

Cargill, D. A., and R. C. Robinson

2000 Archaeological Testing and Monitoring of a Service Drive at Mission San Juan Capistrano, San Antonio, Texas. Archaeological Survey Report No. 296. Center for Archaeological Research, The University of Texas at San Antonio.

Carlson, S. B.

1994 Texas Beyond the Periphery; An Archaeological Study of the Spanish Missions During the 18th Century. Ph.D. dissertation, Department of Anthropology, Texas A\&M University, College Station.

Castañeda, C. E.

1976[1942] Our Catholic Heritage in Texas 1519-1936: 5. The Mission Era: The End of the Spanish Regime 17801810, pp. 67-68. Reprint Arno Press, New York. [1942 Von-Boeckmann-Jones, Austin.]

Casteel, R. W.

1978 Faunal Assemblages and the "Wiegemethode" or Weight Method. Journal of Field Archaeology 5:72-77.

Chabot, F. C. (translator)

1932 Excerpts from the Memorias for the History of the Province of Texas by Padre Fray Juan Agustin de Morfi. Naylor Printing, San Antonio.

Chandler, C. K.

1989 A Metal Arrow Point from Terrell County, Texas. La Tierra 16 (4):23-24.

Chandler, C. K., and D. Kumpe

1997 Metal Arrow Points from South Texas and Tamaulipas, Mexico. La Tierra 24(4):38-41. 
Charlton, T. H., and R. R. Katz

1979 Tonalá Bruñida Ware. Archaeology 32(1):45-53.

Chipman, D. L.

1992 Spanish Texas, 1519-1821. University of Texas Press, Austin.

Clark, J. W., Jr.

1978 Mission San José y San Miguel de Aguayo: Archeological Investigations, December 1974. Archeological Report 29. Texas Historical Commission, Austin

1998 Archeological Test Excavations at Mission Nuestra Señora del Refugio (41RF1), US77, Refugio, County, Texas. Archeological Studies Program, Environmental Affairs Division, Texas Department of Transportation, Austin.

Clark, J. W., Jr., and A. M. Juarez

1986 Urban Archaeology: A Culture History of a Mexican-American Barrio in Laredo, Webb County, Texas, vol. I. Publications in Archaeology Report No. 31. Texas State Department of Highways and Public Transportation, Highway Design Division, Austin.

Clark, J. W., Jr., and E. J. Prewitt

1979 Archeological Test Excavations in Areas to be Affected by a Proposed French Drain West of the Granary, Mission San José State Historic Site (41BX3), Bexar County, Texas. Reports of Investigations 3. Prewitt and Associates, Austin

Clopper, J. C.

1949 J. C. Clopper's Journal and Book of Memoranda for 1828. Quarterly of the Texas State Historical Association 13(1):73-74.

Cohen, A., and D. Serjeantson

1996 A Manual for the Identification of Bird Bones from Archaeological Sites. Revised edition. Archetype Publications, London.

Collier, S.

1989 The influence of economic behavior and environment upon robusticity of the post-cranial skeleton: a comparison of Australian Aborigines and other populations. Archaeology in Oceania 14:17-30.

Comstock, D. B., K. A. Grombacher, and D. S. Dibble

1973 A Study of the Effects of Shell Dredging on the Archeological and Historical Resources of San Antonio Bay, Texas. Research Report No. 23. Texas Archeological Survey, University of Texas, Austin.

Comuzzie A. G., M. Marek, and D. G. Steele

1984 Analysis of Human Skeletal Remains from the Palm Harbor Site (41AS80), a Mortuary Site on the Central Gulf Coast of Texas. Bulletin of the Texas Archeological Society 55:213-249.

Corbin, J. E., H. A. Brown, M. G. Canavan, and S. Toups

1990 Mission Dolores de los Ais (41SA25), San Augustine County, Texas. Papers in Anthropology No. 5. Stephen F. Austin University, Nacogdoches, Texas.

Covey. C. (translator and editor)

1983 Cabeza de Vaca's Adventures in the Unknown Interior of America. Second printing. University of New Mexico Press, Albuquerque. 
Cutrer, T. W.

1996 Collinsworth, George Morse. In New Handbook of Texas, Vol. 2, edited by Ron Tyler, p. 220. Texas State Historical Association, Austin.

Dabbs, J. A. (translator)

1991 The Texas Missions in 1785. In Spanish Borderlands Sourcebooks: 22. Documentary Evidence for the Spanish Missions of Texas, edited by A. R. Gomez, pp. 439-458. Garland Publishing, New York.

Davidson, B.

1974 Animal Bones. In Mission Rosario: Archeological Investigations, 1973, by K. Gilmore, pp. 155-159. Archeological Report No. 14, Pt. 1. Texas Parks and Wildlife Department, Parks Division, Historic Sites and Restoration Branch, Austin.

Davis, E. M.

1968 An Informal Account of the Seventh Annual TAS Field School, June, 1968. Texas Archeology 12:2-6.

Deagan. K.

1972 Fig Springs: The Mid-Seventeenth Century in North-Central Florida. Historic Archaeology 6:23-46.

1974 Sex, Status and Role in the Mestizaje of Spanish Colonial Florida. Unpublished Ph.D. dissertation, Department of Anthropology, University of Florida, Gainesville.

1987 Artifacts of the Spanish Colonies of Florida and the Caribbean 1500-1800: 1. Ceramics, Glassware, and Beads. Smithsonian Institution Press, Washington, D.C.

Deagan, K., and E. J. Reitz

1995 Merchants and Cattlemen: The Archaeology of a Commercial Structure at Puerto Real. In Puerto Real: The Archaeology of a Sixteenth-Century Spanish Town in Hispaniola, edited by K. Deagan, pp. 231-284. University Press of Florida, Gainesville.

deFrance, S. D.

1999 Zooarchaeological Evidence of Colonial Culture Change: A Comparison of Two Locations of Mission Espíritu Santo de Zuñiga and Mission Nuestra Señora del Rosario, Texas. Bulletin of the Texas Archeological Society 70:169-187.

de la Teja, J. F.

1995 San Antonio de Béxar: A Community on New Spain's Northern Frontier. University of New Mexico, Albuquerque.

De Vore, S. L.

1992 Beads of the Bison Robe Trade: The Fort Union Trading Post Collection. Fort Union Monograph Series, Publication No. 1. Friends of Fort Union Trading Post, Williston, ND

Dial, S.W.

1992 Ceramic Artifacts. In Archaeological Investigations in Alamo Plaza, San Antonio, Bexar County, Texas, 19881989, by A. A. Fox, pp. 29-47. Archaeological Survey Report No. 205. Center for Archaeological Research, The University of Texas at San Antonio.

Di Peso, C. C.

1951 The Babocomari Village Site on the Babocomari River, Southeastern Arizona. Amerind Foundation Series No. 5. Amerind Foundation, Dragoon, Arizona. 
Driesch, A. von den

1976 A Guide to the Measurements of Animal Bones from Archaeological Sites. Bulletin No. 1. Peabody Museum of Archaeology and Ethnology, Harvard University, Cambridge, Massachusetts.

Edmondson, D. D.

2001 Artifact Analysis. In Archaeological Investigations at Four San Antonio Missions: Mission Trails Underground Conversion Project, edited by C. L. Tennis, pp. 86-91. Archaeological Survey Report No. 297. Center for Archaeological Research, The University of Texas at San Antonio.

Everitt, B. S.

1977 The Analysis of Contingency Tables. John Wiley and Sons, New York.

Fairbanks, C. H.

1973 The Cultural Significance of Spanish Ceramics. In Ceramics in America: Winterthur Conference Report 1972, edited by I. M. G. Quimby, pp. 141-174. Henry Francis du Pont Winterthur Museum, Delaware and University Press of Virginia, Charlottesville.

Fehrenbach, T. R.

1983 Lone Star: A History of Texas and the Texans. American Legacy Press, New York.

Folan, J. W., I. W. Cox, A. A. Fox, and G. M. Hinojosa

1986 Laredo, Texas, a Gateway Community on the Texas Borderlands: Archaeological and Historical Investigations for the Laredo City Toll Plaza (41WB36, 37, and 38). Archaeological Survey Report No. 116. Center for Archaeological Research, The University of Texas at San Antonio.

Foster, G. M.

1948 Empire's Children: The People of Tzintzuntzan. Smithsonian Institution Institute of Anthropology, Impr. Nuevo Mundo, México.

Fox, A. A.

1974 Lead Glazed Wares. In Mission Rosario: Archeological Investigations, 1973, by K. Gilmore, pp. 55-59. Archeological Report No. 14, Pt. 1. Texas Parks and Wildlife Department, Historic Sites and Restoration Branch, Austin.

1986 What Did They Eat at the Missions? Paper presented at the Annual Meeting of the Texas State Historical Association, Austin.

1992 Archaeological Investigations to Locate the Northwest Corner of Mission Concepción, San Antonio, Bexar County, Texas. Archaeological Survey Report No. 212. Center for Archaeological Research, The University of Texas at San Antonio

1997 Archeological Examination of the Material Culture of the Texas Missions. Paper presented at symposium, Transformations on the Mission Frontier: Texas and Northern Mexico, Our Lady of the Lake University, San Antonio, Texas.

Fox, A. A. (editor)

1992 Archaeological Investigations in Alamo Plaza, San Antonio, Bexar County, Texas 1988 and 1989. Archaeological Survey Report No. 205. Center for Archaeological Research, The University of Texas at San Antonio.

Fox, D.

1988 Copy of original site forms. Manuscripts on file at the Center for Archaeological Research, The University of Texas, San Antonio. 
Frantz, J. B.

1976 Texas: A Bicentennial History. W. W. Norton, New York.

Frink, D. S.

1992 The Chemical Variability of Carbonized Organic Matter Through Time. Archaeology of Eastern North America 20:67-79.

1994 The Oxidizable Carbon Ratio (OCR): A Proposed Solution to Some of the Problems Encountered with Radiocarbon Data. North American Archaeologist 15(1):17-29.

Garay, F.

1987 The Battle at Refugio, by Colonel Francisco Garay. In Memorias Para la Historia de la Guerra de Tejas, vol. II, by V. Filisola, translated by Wallace Woolsey, pp. 410-414. Eakin Press, Austin.

Gatschet, A. S.

1891 The Karankawa Indians, The Coast People of Texas. Archaeological and Ethnological Papers of the Peabody Museum, Vol. 1, No. 2. Cambridge.

Gerald, R. E.

1957 A Historic House Excavation Near Janos, Northwest Chihuahua, Mexico. Master's thesis, Department of Anthropology, University of Pennsylvania, Philadelphia.

1968 Spanish Presidios of the Late Eighteenth Century in Northern New Spain. Museum of New Mexico Research Records No. 7, Museum of New Mexico Press, Santa Fe.

Gilbert, B. M.

1973 Mammalian Osteo-archaeology: North America. Missouri Archaeological Society, Columbia.

1990 Mammalian Osteology. Missouri Archaeological Society, Columbia.

Gilmore, K. K.

1969 The San Xavier Mission: A Study in Historical Site Identification. Report No. 16. State Building Commission Archeological Program, Austin, Texas.

1973 The Keeran Site: The Probable Site of La Salle's Fort St. Louis in Texas. Office of the State Archeologist Report No. 24. Texas Historical Commission, Austin.

1974 Mission Rosario: Archeological Investigations, 1973. Archeological Report No. 14, Pt. 1. Texas Parks and Wildlife Department, Historic Sites and Restoration Branch, Austin.

1975 Mission Rosario: Archeological Investigations, 1974. Archeological Report No. 14, Pt. 2. Texas Parks and Wildlife Department, Historic Sites and Restoration Branch, Austin.

1989 The Indians of Mission Rosario: From the Books and from the Ground. In Columbian Consequences: Vol. I. Archaeological and Historical Perspectives on the Spanish Borderlands West, edited by D. H. Thomas, pp. 231244. Smithsonian Institution Press, Washington, D.C.

Glick, C. A., Jr. (editor)

1922 The Papers of Mirabeau Buonaparte Lamar, vols. 2, 4, 5. Texas State Library, Austin.

Goebel, P., R. Goebel, and J. Mitchell

1987 Notes on a Metal Arrow Point from McCulloch County, Texas. La Tierra 14(1):32-34. 
Goggin, J. M.

1964 The Spanish Olive Jar. In Indian and Spanish Selected Writings, edited by J. Mann, pp. 235-297. University of Miami Press, Coral Gables, Florida.

1968 Spanish Majolica in the New World. Publications in Anthropology No. 72. Yale University, New Haven, Connecticut.

Gould, F. W.

1975 Texas Plants: A Checklist and Ecological Summary. Texas Agricultural Experiment Station, Texas A\&M University, College Station.

Gould, S. J.

1966 Allometry and Size in Ontogeny and Phylogeny. Biological Review of the Cambridge Philosophical Society 41:587-640.

1971 Geometric Similarity in Allometric Growth: A Contribution to the Problem of Scaling in the Evolution of Size. American Naturalist 105(942):113-137.

Grayson, D. K.

1973 On the Methodology of Faunal Analysis. American Antiquity 38(4):432-439.

1979 On the Quantification of Vertebrate Archaeofauna. In Advances in Archaeological Method and Theory, vol. 2, edited by M. B. Schiffer, pp. 199-237. Academic Press, New York.

1981 The Effects of Sample Size on Some Derived Measures in Vertebrate Faunal Analysis. Journal of Archaeological Science 8(1):77-88.

Gregory, H. F.

1973 Eighteenth Century Caddoan Archaeology: A Study in Models and Interpretations. Ph.D. dissertation, Department of Anthropology, Southern Methodist University, Dallas.

1980 Excavations 1979: Presidio Nuestra Señora del Pilar de Los Adaes. Division of State Parks, State Department of Culture, Recreation, and Tourism, Baton Rouge, Louisiana.

Gremillion, K. J.

1993 Adoption of Old World Crops and Processes of Cultural Change in the Historic Southeast. Southeastern Archaeology 12(1):15-20.

1995 Comparative Paleoethnobotany of Three Native Southeastern Communities of the Historic Period. Southeastern Archaeology 14(1):1-16.

1996 Diffusion and Adoption of Crops in Evolutionary Perspective. Journal of Anthropological Archaeology 5:183204.

Griffin, W. W.

1983 Southern Periphery: East. In Handbook of North American Indians, Vol. 10, Southwest. Edited by W. C. Sturtevant, pp. 329-342. Smithsonian Institution, Washington.

Guckian, W. J.

1988 Soil Survey of Refugio County. United States Department of Agriculture, Soil Conservation Service in cooperation with Texas Agricultural Experiment Station and Texas State Soil and Water Conservation Board, Austin.

Guthrie, K.

1996 San Patricio Minutemen. In New Handbook of Texas, Vol. 5, edited by Ron Tyler, p. 874. Texas State Historical Association, Austin. 
Habig, M. A.

1976 The Alamo Chain of Missions: A History of San Antonio's Five Old Spanish Missions. Franciscan Herald Press, Chicago.

Habig, M. A. (compiler)

1978 The San Jose Papers: The Primary Sources for the History of the Mission San José y San Miguel de Aguayo from Its Founding in 1720 to the Present. Part I:1719-1791. Translated by B. Leutenegger et al. Old Spanish Missions Historical Research Library at Mission San José, San Antonio.

Habig, M. A., B. Leutenegger, and M. C. Casso

1983 The San José Papers: The Primary Sources for the History of Mission San José y San Miguel de Aguayo from Its Founding in 1720 to the Present. Part II: August 1791-June 1809. Old Spanish Missions Historical Research Library at Mission San José, San Antonio.

Handbook of Texas Online

2001a Refugio, Battle of.

<http://www.tsha.utexas.edu/handbook/online/articles/view/RR/qer1.html> [Accessed Mon Nov 26 16:58:55 US/ Central 2001].

Hard, R. J., and W. L. Merrill

1992 Mobile Agriculturalists and the Emergence of Sedentism: Perspectives from Northern Mexico. American Anthropologist 94:601-620.

Hard, R. J., A. A. Fox, I. W. Cox, K. J. Gross, B. A. Meissner, G. J. Mendez, C. L. Tennis, and J. E. Zapata

1995 Excavations at Mission San José y San Miguel de Aguayo, San Antonio, Texas. Archaeological Survey Report No. 218. Center for Archaeological Research, The University of Texas at San Antonio.

Hardesty, D. L.

1975 The Niche Concept: Suggestions for Its Use in Human Ecology. Human Ecology 3(2):71-85.

Hardin, S. L.

1994 Texian Iliad: A Military History of the Texas Revolution, 1835-1836. University of Texas Press, Austin.

1996 Hynes Bay, Battle of. In New Handbook of Texas, Vol. 3, edited by Ron Tyler, p. 809. Texas State Historical Association, Austin.

Harris, R. K., and I. M. Harris

1967 Trade Beads, Projectile Points, and Knives. In A Pilot Study of Wichita Indian Archaeology and Ethnohistory, edited by R. E. Bell, E. B. Jelks and W. W. Newcomb, pp. 139-155. Report to the National Science Foundation, Grant GS-967. Southern Methodist University, Dallas.

Harris, R. K., I. M. Harris, and T. R. Hester

1999 A Study of Glass Beads, Coral Beads, and Bead Spacers from the San Juan Bautista and San Bernardo Missions, Guerro, Coahuila, Mexico. Bulletin of the Texas Archeological Society 70:385-394.

Hayden, B.

1980 Confusion in the Bipolar World: Bashed Pebbles and Splintered Pieces. Lithic Technology 9:2-7. 
Hatcher, M. A. (translator)

1919 Texas in 1820. Southwestern Historical Quarterly 23:47-68.

Headrick, $\mathrm{P}$.

1993 The Archeology of 41NU11, The Kirchmeyer Site, Nueces County, Texas: Long Term Utilization of a Coastal Clay Dune. Studies in Archeology No. 15. Texas Archeological Research Laboratory, University of Texas, Austin.

Hébert, R. B.

1996 McGloin, James. In New Handbook of Texas, Vol. 4, edited by Ron Tyler, pp. 404-405. Texas State Historical Association, Austin.

Hébert, R. B., and W. H. Oberste

1996 McMullen, John. In New Handbook of Texas, vol. 4, edited by Ron Tyler, pp. 436-437. Texas State Historical Association, Austin.

Hester, T. R.

1977 The Lithic Technology of Mission Indians in Texas and Northeastern Mexico. Lithic Technology 6(12):9-13.

1980 Digging into South Texas Prehistory. Corona Publishing, San Antonio.

1989a Introduction. In From the Gulf to the Rio Grande: Human Adaptation in Central, South, and Lower Pecos Texas, by T. R. Hester, S. L. Black, D. G. Steele, B. W. Olive, A. A. Fox, K. J. Reinhard, and L. C. Bement, pp. 1-4. Arkansas Archeological Survey Research Series No. 33. Arkansas Archeological Survey, Fayetteville.

1989b Historic Native American Populations. In From the Gulf to the Rio Grande: Human Adaptation in Central, South, and Lower Pecos Texas, by T. R. Hester, S. L. Black, D. G. Steele, B. W. Olive, A. A. Fox, K. J. Reinhard, and L. C. Bement, pp. 77-84. Arkansas Archeological Survey Research Series No. 33. Arkansas Archeological Survey, Fayetteville.

1989c Perspectives on the Material Culture of the Mission Indians of the Texas-Northeastern Mexico Borderlands. In Columbian Consequences: Vol. I. Archaeological and Historical Perspectives on the Spanish Borderlands West, edited by D. H. Thomas, pp. 213-229. Smithsonian Institution Press, Washington, D.C.

1995 The Prehistory of South Texas. Bulletin of the Texas Archeological Society 66:427-459.

1998 The Role of Stone Tools among the Mission Indians of Northeastern Mexico and Texas. In Transformations on the Mission Frontier: Texas and Northern Mexico, edited by G. Keyes, pp. 91-106. Our Lady of the Lake University of San Antonio.

Hester, T. R., and J. E. Corbin

1975 Two Burial Sites on the Central Texas Coast. Texas Journal of Science $26(3$ and 4):519-528.

Hester, T. R., and R. C. Parker

1970 The Berclair Site: A Late Prehistoric Component in Goliad County, Southern Texas. Bulletin of the Texas Archeological Society 41:1-23.

Hildebrand, M.

1955 Skeletal Differences Between Deer, Sheep, and Goats. California Fish and Game 41:327-346.

Hillson, S.

1986 Teeth. Cambridge University Press, Cambridge, Massachusetts. 
Himmel, K. F.

1999 The Conquest of the Karankawas and the Tonkawas, 1821-1859. Elma Dill Russell Spence Series in the West and Southwest No. 20. Texas A\&M University Press, College Station.

Hindes, V. K., A. A. Fox, and E. H. Schmiedlin

1999 An Overview of Test Excavations and Documentary Research at 41VT10, the Tonkawa Bank Site, Victoria City Park, Victoria, Texas. Bulletin of the Texas Archeological Society 70:79-96.

Hinojosa, G. M., and A. A. Fox

1991 Indians and Their Culture in San Fernando de Béxar. In Tejano Origins in Eighteenth-Century San Antonio, edited by G. E. Poyo and G. M. Hinojosa, pp. 105-120. University of Texas Press, Austin.

Hodges, $\mathrm{H}$.

1964 Artifacts: An Introduction to Early Materials and Technology. John Baker, London

Hole, F., and R. G. Wilkerson

1973 Shell Point: A Coastal Camp And Burial Site in Brazoria County. Bulletin of the Texas Archeological Society 44:5-50.

Honea, K. H.

1965 The Bipolar Flaking Technique in Texas and New Mexico. Bulletin of the Texas Archeological Society 36:259267.

Huebner, J. A., and A. G. Comuzzie

1992 The Archeology and Bioarcheology of Blue Bayou: A Late Archaic and Late Prehistoric Mortuary Locality in Victoria County, Texas. Studies in Archeology No. 9. Texas Archeological Research Laboratory, University of Texas, Austin.

Hughes, G. B.

1967 Victorian Pottery and Porcelain. Spring Books, London.

Humboldt, A. de

1941 Ensayo Politico Sobre al Reina de la Nueva España, edited by Vito Alessio Robles. 4 Vols. Editorial Pedra Robredo, Mexico.

Hunziker, J. M., and A. A. Fox

1998 Archaeological Testing at Goliad State Park, Goliad County, Texas. Archaeological Survey Report No. 260. Center for Archaeological Research, The University of Texas at San Antonio.

Huson, $\mathrm{H}$.

1935 El Copano, the Ancient Port of Bexar and La Bahía. Refugio Timely Remarks. Refugio, Texas.

1953 Refugio: A Comprehensive History of Refugio County from Aboriginal Times to 1953: Vols. 1-2. Aboriginal to 1861. The Rook Foundation, Woodsboro, Texas.

1994a El Copano, the Ancient Port of Bexar and La Bahía. In Hobart Huson: A Texas Coastal Bend Trilogy, edited by K. H. Maxwell, pp. 45-89. Eakin Press, Austin.

1994b St. Mary's of Aransas. In Hobart Huson: A Texas Coastal Bend Trilogy, edited by K. H. Maxwell, pp. 91-126. Eakin Press, Austin.

1996 Hewetson, James. In New Handbook of Texas, vol. 3, edited by Ron Tyler, p. 583. Texas State Historical Association, Austin. 
Hyman, C.

1996 Iturbide, Agustín de. In New Handbook of Texas, Vol. 3, edited by Ron Tyler, pp. 880-881. Texas State Historical Association, Austin.

Israel, F. L. (editor)

19931897 Sears, Roebuck and Co. Catalogue. Chelsea House, New York.

Ivey, J. E.

1983 Archaeological Testing at Rancho de las Cabras, Wilson County, Texas, Second Season. Archaeological Survey Report No. 121. Center for Archaeological Research, The University of Texas at San Antonio.

1988 Excavations at the West Wall of Mission San Antonio de Valero (the Alamo). Unpublished draft on file at the Center for Archaeological Research, The University of Texas at San Antonio.

1991 In the Midst of a Loneliness: The Architectural History of the Salinas Missions, Salinas Pueblo Missions National Monument Historic Structure Report. Southwest Cultural Resources Center Professional Papers No. 15. Santa Fe, New Mexico.

Ivey, J. E., and A. A. Fox

1981 Archaeological Survey and Testing at Rancho de las Cabras, Wilson County, Texas. Archaeological Survey Report No. 104. Center for Archaeological Research, The University of Texas at San Antonio.

1999 Archaeological Investigations at Mission Concepción and Mission Parkway. Archaeological Survey Report No. 114. Center for Archaeological Research, The University of Texas at San Antonio.

Jackson, B. E., J. L. Boone, and M. Henneberg

1986 Possible Cases of Endemic Treponematosis in a Prehistoric Hunter-Gatherer Population on the Texas Coast. Bulletin of the Texas Archeological Society 57:183-193.

Jackson, J.

1986 Los Mesteños: Spanish Ranching in Texas 1721-1821. Texas A\&M University Press, College Station.

James, S. R., Jr.

1988 A Reassessment of the Chronological and Typological Framework of the Spanish Olive Jar. Historical Archaeology 22(1):43-66.

Jenkins, J. H. (editor)

1973 The Papers of the Texas Revolution, 1835-1836, Vol. 5, Document No. 2432. Presidial Press, Austin, Texas.

John, E. A. H.

1996 Storms Brewed in Other Men's Worlds, pp. 254-257. University of Oklahoma Press, Norman, OK.

Johnson, L.

1994 The Life and Times of Toyah-Culture Folk: The Buckhollow Encampment, Site 41KM16, of Kimble County, Texas. Office of the State Archeologist, Report No. 38. Texas Historical Commission, Austin.

Katz, R. R.

1977 The Potters and Pottery of Tonalá, Jalisco, Mexico: A Study in Aesthetic Anthropology. Ph.D. dissertation, Department of Anthropology, Columbia University, New York. 
Keck, C.

1999 Vertebrate Subsistence at the Discovery Site (16LF66). Paper presented at the 56th Annual Meeting of the Southeastern Archaeology Conference, Pensacola, Florida.

Kenmotsu, N. A.

1990 Gunflints: A Study. Historical Archaeology 24:92-124.

Kenmotsu, N. A., P. Sales, C. B. Bousman, and C. Tennis

1999 When Preservation Is Not An Option. Heritage, Fall(1999):15-18.

Kennedy, S., and J. Mitchell

1988 Metal Arrow Points from the Vicinity of Fort Lipantitlán (41NU54), Nueces County, Texas. La Tierra 15(1):26-33.

Kent, S.

1981 The Dog, an Archaeologist's Best Friend or Worst Enemy: The Spatial Distribution of Faunal Remains. Journal of Field Archaeology 8(3):367-372.

Kobayashi, H.

1975 The Experimental Study of Bipolar Flakes. In Lithic Technology: Making and Using Stone Tools, edited by E. Swanson, pp. 115-127. Mouton Press, The Hague.

Kubler, G.

1940 The Religious Architecture of New Mexico in the Colonial Period and Since the American Occupation. Rio Grande Press, Chicago.

Kuijt, I., W. C. Prentiss, and D. L. Pokotylo

1995 Bipolar Reduction: An Experimental Study of Debitage Variability. Lithic Technology 20:116-127.

Largent, F. B., Jr.

1996 Skull Creek. In New Handbook of Texas, Vol. 5, edited by Ron Tyler, pp. 1073. Texas State Historical Association, Austin.

Larsen, C. S.

1997 Bioarchaeology: Interpreting Behavior from the human skeleton. Cambridge University Press, New York.

Lawrence, B.

1974 Post-Cranial Skeletal Characters of Deer, Pronghorn, and Sheep-Goat with Notes on Bos and Bison. Papers of the Peabody Museum of Archaeology and Ethnology 35(3):Part II. Harvard University, Cambridge, Massachusetts.

Leaf, G. R.

1979 Variation in the Form of Bipolar Cores. Plains Anthropologist 24(83):39-50.

Leffler, J.

1996 Refugio County. In New Handbook of Texas, Vol. 5, edited by Ron Tyler, pp. 513-516. Texas State Historical Association, Austin. 
Leutenegger, B. (translator)

1975 Journal of a Texas Missionary, 1762-1802: Diario Historico of Fr. Cosme Lozano Narvais, pen name of Fr. Mariano Antonio de Vasconcelos. Old Spanish Missions Historical Research Library, San José Mission, San Antonio, Texas.

1976 Guidelines for a Texas Mission: Instructions for the Missionary of Mission Concepción in San Antonio ca. 1760. Old Spanish Missions Historical Research Library at San José Mission, San Antonio, Texas.

1990 The San José Papers: 3. July 1810-February 1824. Old Spanish Missions Historical Research Library, Our Lady of the Lake University, San Antonio, Texas.

Lister, F. C., and R. H. Lister

1974 Majolica in Colonial Spanish America. Historical Archaeology 8:17-52.

Logan, H. C.

1959 Cartridges: A Pictorial Digest of Small Arms Ammunition. Bonanza, New York.

Long, C.

1996a McMullen-McGloin Colony. In New Handbook of Texas, Vol. 4, edited by Ron Tyler, p. 440. Texas State Historical Association, Austin.

1996b Lively. In New Handbook of Texas, Vol. 4, edited by Ron Tyler, p. 240. Texas State Historical Association, Austin.

McKenzie, C. M.

1989 Independent Study Report on Guanajuato Majolica in the San Antonio Missions Area. Manuscript on file at the Center for Archaeological Research, The University of Texas at San Antonio.

McReynolds, R. L.

1982 An Iron Projectile from Gillespie County, Texas. La Tierra 9(1):30-32.

Majewski, M., and M. O'Brien

1987 The Use and Misuse of Nineteenth-Century English and American Ceramics in Archaeological Analysis. In Advances in Archaeological Method and Theory, vol. XI, edited by M. B. Schiffer, p. 163. Academic Press, New York.

Mallouf, R. J., and A. N. Zavaleta

1973 The Upland Site: A Prehistoric Group Burial from Laguna Atascosa National Wildlife Refuge, Cameron County, Texas. Survey Report No. 11. Office of the State Archeologist, Texas Historical Commission, and Texas Water Development Board, Austin.

Martin, G. C.

1930 Two Sites on the Callo del Oso, Nueces County, Texas. Bulletin of the Texas Archeological and Paleontological Society 2:7-17.

1972 Indian Tribes of the Mission Nuestra Señora del Refugio. First reprint, originally published in 1936. Bootstrap Press, Corpus Christi, Texas.

Martin, G. C., and W. H. Potter

1929 Preliminary Archaeological Survey of a Portion of the Texas Coast. Prepared for the Witte Museum. Manuscript on file at the Center for Archaeological Research, The University of Texas at San Antonio. 
May, R. V.

1972 An Evaluation of Mexican Majolica in Alta California Employing Preliminary Data from the San Diego Presidio. In Mexican Majolica in Northern New Spain, section II, by M. R. Barnes and R. V. May, p. 36. Occasional Paper No. 2. Pacific Coast Archaeological Society, Costa Mesa, California.

Meskill, F. K.

1992 Archaeological Testing Within the Southeast Corner of the Plaza at Mission Espada, San Antonio, Bexar County, Texas. Archaeological Survey Report No. 208. Center for Archaeological Research, The University of Texas at San Antonio.

Miller, G. L.

1980 Classification and Economic Scaling of 19th Century Ceramics. Historical Archaeology 14:1-19.

1991 A Revised Set of CC Index Values for Classification and Economic Scaling of English Ceramics from 1787 to 1880. Historical Archaeology 25(1):1-25.

Miller, J. J., and L. M. Stone

1970 Eighteenth Century Ceramics from Fort Michilimackinac: A Study in Historical Archeology. Studies in History and Technology No. 4. Smithsonian Institution Press, Washington, D.C.

Minnis, P.

1985 Social Adaptation to Food Stress: A Prehistoric Southwestern Example. University of Chicago Press, Chicago.

Mitchell, J., and L. Highley

1982 Notes on a Metal Projectile Point from Southern Texas: The Brom Cooper Collection. La Tierra 9(1):21-23.

Montgomery, R. G., W. Smith, and J. O. Brew

1949 Franciscan Awatovi: The Excavation and Conjectural Reconstruction of a 17th-Century Spanish Mission Established at a Hopi Indian Town in Northeastern Arizona. Reports of the Awatovi Expedition No. 3. Peabody Museum, Harvard University, Cambridge, Massachusetts.

Moriarty, J. R., and R. S. D. Broms

1971 The Antiquity and Inferred Use of Stone Discoidals in the Southwest. Anthropological Journal of Canada 9(1):16-36.

Mounger, M. A.

1959 Mission Espíritu Santo of Coastal Texas: An Example of Historic Site Archeology. Unpublished Master's thesis, Department of Anthropology, The University of Texas at San Antonio.

Munsey, C.

1970 The Illustrated Guide to Collecting Bottles. Hawthorn, New York.

Natural Fibers Information Center

1987 The Climates of Texas. Bureau of Business Research, Graduate School of Business, University of Texas, Austin. 
Newcomb, W. W., Jr.

1961 The Indians of Texas: From Prehistoric to Modern Times. University of Texas Press, Austin.

1983 Karankawa. In Handbook of North American Indians, Vol. 10, Southwest, A. Ortiz, editor, pp. 359-367. Smithsonian Institution, Washington, D.C.

Newman, M. T.

1953 Indian Skeletal Remains for the Doering and Kobs Sites, Addicks Reservoir, Texas. Bureau of American Ethnology, Bulletin 154:253-266.

Nickels, D. L.

1999 Archaeological Investigations at the Biesenbach Site (41WN88), Sutherland Springs, Wilson County, Texas. Master's thesis. Manuscript on file at the Center for Archaeological Research, The University of Texas at San Antonio.

20001999 Excavations at Mission Rosario. Archaeological Survey Report No. 298. Center for Archaeological Research, The University of Texas at San Antonio.

Nixon, P. I.

1936 A Century of Medicine in San Antonio. Privately published, San Antonio, Texas.

1946 The Medical Story of Early Texas: 1528-1853. Mollie Bennett Lupe Memorial Fund, San Antonio, Texas.

Noel Hume, I.

1969 Historical Archaeology. Alfred Knopf, New York.

Nowak, R. M., and J. L. Paradiso

1989 Walker's Mammals of the World. Johns Hopkins University Press, Baltimore, Maryland.

Oberste, W. H.

1942 History of Refugio Mission. Refugio Timely Remarks, Refugio, Texas.

1953 Texas Irish Empresarios and Their Colonies: Power and Hewetson, McMullen and McGloin. Von BoeckmannJones, Austin, Texas.

O’Connor, K. S.

1984 The Presidio La Bahía del Espíritu Santo de Zuniga, 1721-1846. Von Boeckmann-Jones, Austin, Texas.

Olsen, S. J.

1960 Post-cranial Skeletal Characters of Bison and Bos. Papers of the Peabody Museum of Archaeology and Ethnology 35(4). Harvard University, Cambridge, Massachusetts.

1964 Mammal Remains from Archaeological Sites: I. Southeastern and Southwestern United States. Peabody Museum, Harvard University, Cambridge, Massachusetts.

1968 Fish, Amphibian, and Reptile Remains from Archaeological Sites: I. Southeastern and Southwestern United States. Peabody Museum, Harvard University, Cambridge, Massachusetts.

Owsley, D. W.

1994 Warfare in Coalescent Tradition Population of the Northern Plains. In Skeletal Biology in the Great Plains. Migration, Warfare, Health, and Subsistence, edited by D. W. Owsley, and R. L. Jantz, pp. 333-344. Smithsonian Institution Press, Washington. 
Parry, W. J., and R. L. Kelly

1987 Expedient Core Technology and Sedentism. In The Organization of Core Technology, edited by J. K. Johnson and C. A. Morrow, pp. 285-304. Westview Press, Boulder, CO.

Peña, J. E. de la

1975 With Santa Anna in Texas: A Personal Narrative of the Revolution, translated by C. Perry. Texas A\&M University Press, College Station.

Perkins, D., Jr., and P. Daly

1968 A Hunter's Village in Neolithic Turkey. Scientific American 219(5):96-106.

Perttula, T. K.

2001 Native Ceramics. In Archaeological Investigations at a Spanish Colonial Site, (41KA26-B) Karnes County, Texas, by C. L. Tennis, pp. 53-63. Archeological Studies Program Report No. 26. Environmental Affairs Division, Texas Department of Transportation, Austin. Archaeological Survey Report No. 302. Center for Archaeological Research, The University of Texas at San Antonio.

Perttula, T. K., S. A. Iruegas, and H. Neff

2000 The Analysis of Caddoan and Central Texas Ceramics from Several Sites in the Central Region of Texas. Report of Investigations No. 39. Archeological \& Environmental Consultants, Austin, Texas.

Pielou, E. C.

1966 Species-Diversity and Pattern-Diversity in the Study of Ecological Succession. Journal of Theoretical Biology 10:370-383.

Pierce, G. S.

1969 Texas Under Arms: The Camps, Post, Forts, and Military Towns of the Republic of Texas. Encino Press, Austin, Texas.

Priour, D. J.

n.d. Ancestors and Descendants of Peter Isadore Priour and Ada Virginia Gutherie. Unpublished manuscript.

Purdue, J. R.

1983 Epiphyseal Closure in White-Tailed Deer. Journal of Wildlife Management 47(4):1207-1213.

Real Academia Espanola

1950 Diccionario Manual e Ilustrado de la Lengua Espanola. $2^{\text {nd }}$ edition. Real Academia Espanola, Madrid.

Refugio Timely Remarks (RTR) [Refugio, Texas]

1934 "Find Burial Place of Texas Martyrs." 18 May. Refugio, Texas.

1934 "Rebury King's Soldiers Sunday." 15 June. Refugio, Texas.

1936 "Day-by-Day Account of Undertaking Brings to Light Identity of Skeletons and Harrowing Experiences of King and His Men.” 24 April. Refugio, Texas. 
Reitz, E. J.

1985 A Comparison of Spanish and Aboriginal Subsistence on the Atlantic Coastal Plain. Southeastern Archaeology 4(1):41-50.

1986a Urban/Rural Contrasts in Vertebrate Fauna from the Southern Coastal Plain. Historical Archaeology 20(2):4758.

1986b Vertebrate Fauna from Locus 39, Puerto Real, Haiti. Journal of Field Archaeology 13:317-328.

1987 Vertebrate Fauna and Socio-Economic Status. In Consumer Choice in Historical Archaeology, edited by S. Spencer-Wood, pp. 101-119. Plenum Publishing, New York.

1990 Zooarchaeological Evidence for Subsistence at La Florida Missions. In Columbian Consequences: II. Probing the Spanish Borderlands East, edited by D. H. Thomas, pp. 543-554. Smithsonian Institution Press, Washington, D.C.

1991 Animal Use and Culture Change in Spanish Florida. In Animal Use and Culture Change, edited by P. J. Crabtree and K. Ryan, pp. 62-77. MASCA Supplement 8. Philadelphia, Pennsylvania.

1992a Vertebrate Fauna from Holy Cross. In Archeological Survey and Testing in the Holy Cross Historic District, New Orleans, Louisiana, by J. K. Yakubik and H. A. Franks, pp. 281-303. Earth Search, New Orleans, Louisiana.

1992b Vertebrate Fauna from Seventeenth-Century St. Augustine. Southeastern Archaeology 11(2):70-94.

1993 Evidence for Animal Use at the Missions of Spanish Florida. In The Spanish Missions of La Florida, edited by B. G. McEwan, pp. 376-398. University Press of Florida, Gainesville.

1995 Vertebrate Use and Cultural Change Among Native Americans. Paper presented at the 52nd Annual Meeting of the Southeastern Archaeological Conference, Knoxville, Tennessee.

Reitz, E. J., and S. L. Cumbaa

1983 Diet and Foodways of Eighteenth-Century Spanish St. Augustine. In Spanish St. Augustine: The Archaeology of a Colonial Creole Community, by K. A. Deagan, pp. 147-181. Academic Press, New York.

Reitz, E. J., and B. G. McEwan

1995 Animals, Environment, and the Spanish Diet at Puerto Real. In Puerto Real: The Archaeology of a SixteenthCentury Spanish Town in Hispaniola, edited by K. Deagan, pp. 287-334. University Press of Florida, Gainesville.

Reitz, E. J., and B. Ruff

1994 Morphometric Data for Cattle from North America and the Caribbean Prior to the 1950s. Journal of Archaeological Science 21(5):699-713.

Reitz, E. J., and C. M. Scarry

1985 Reconstructing Historic Subsistence with an Example from Sixteenth Century Spanish Florida. Special Publication No. 3. Society for Historical Archaeology, Glassboro, New Jersey.

Reitz, E. J., and E. S. Wing

1999 Zooarchaeology. Cambridge University Press, New York.

Reitz, E. J., and M. A. Zierden

1991 Cattle Bones and Status from Charleston, South Carolina. In Beamers, Bobwhites, and Blue-points: Tributes to the Career of Paul W. Parmalee, edited by J. R. Purdue, W. E. Klippel, and B. W. Styles, pp. 395-407. Illinois State Museum, Springfield.

Rice, P. M.

1987 Pottery Analysis: A Sourcebook. University of Chicago Press, Chicago.

1996 Recent Ceramic Analysis: 1. Function, Style, and Origins. Journal of Archaeological Research 4:133-163. 
Rick, A.

1975 Bird Medullary Bone: A Seasonal Dating Technique for Faunal Analysis. Canadian Archaeological Association Bulletin 7:183-190.

Ricklis, R. A.

1991 The Traditional Roots of Native American Response to the Spanish Missions: The Case of the Karankawans of the Texas Coastal Zone. Texas Papers on Latin America, Institute of Latin American Studies, Paper No. 91-05. University of Texas at Austin.

1992 Aboriginal Karankawan Adaptation and Colonial Period Acculturation: Archeological and Ethnohistorical Evidence. Bulletin of the Texas Archeological Society 63:211-243.

1994a Aboriginal Life and Culture on the Upper Texas Coast: Archaeology at the Mitchell Ridge Site, 41GV66, Galveston Island. Coastal Archaeological Research, Corpus Christi, Texas.

1994b Toyah Components: Evidence for Occupation in the Project Area During the Latter Part of the Late Prehistoric Period. In Archaic and Late Prehistoric Human Ecology in the Middle Onion Creek Valley, Hays County, Texas, by R. A. Ricklis and M. B. Collins, pp. 207-316. 2 Vols. Studies in Archeology No. 19. Texas Archeological Research Laboratory, University of Texas, Austin.

1995a Prehistoric Occupation of the Central and Lower Texas Coast: A Regional Overview. Bulletin of the Texas Archeological Society 66:266-300.

1995b The Ceramics of the Toyah Horizon and the Rockport Phase as Indicators of Some Basic Sociocultural Patterns. Bulletin of the Texas Archeological Society 66:195-203.

1996 The Karankawa Indians of Texas: An Ecological Study of Cultural Tradition and Change. University of Texas Press, Austin.

1997 Archaeological Testing at the Callo del Oso Site (41NU2), Nueces County, Texas. Coastal Archaeological Research, Inc. Corpus Christi, Texas.

1998 Archaeological Investigations at the Spanish Colonial Mission Sites of Espíritu Santo and Nuestra Señora del Rosario, Goliad County, Texas: Interim Report on the 1997 Testing. Coastal Archaeological Research, Corpus Christi, Texas.

1999a The Spanish Colonial Missions of Espíritu Santo (41GD1) and Nuestra Señora del Rosario (41GD2), Goliad, Texas: Exploring Patterns of Ethnicity, Interaction, and Acculturation. Bulletin of the Texas Archeological Society 70:133-168.

1999b Testing at Villa de La Bahía. Current Archeology in Texas 1(1):14-17. Texas Historical Commission, Austin.

Ricklis, R. A., S. D. de France, and B. M. Albert

2000 Archaeological Investigations at the Spanish Colonial Missions of Espíritu Santo (41GD1) and Nuestra Señora del Rosario (41GD2), Goliad County, Texas. Coastal Archaeological Research, Corpus Christi, Texas.

Rister, C. C.

1989 Comanche Bondage: Dr. John Charles Beal's [sic] Settlement of La Villa de Dolores on Las Moras Creek in Southern Texas of the 1830s. Reprinted. University of Nebraska Press, Lincoln. Originally published 1955. A. H. Clark, Glendale, California.

Rodriguez, P. T.

2001 P. T. and T. C. Creations, Aledo, Texas. Electronic document, http. www//home.att.net/Ptrodriguez.ptrinform/

Roell, C. H.

1996a De León's Colony. In New Handbook of Texas, Vol. 2, edited by Ron Tyler, pp. 573-574. Texas State Historical Association, Austin. 
1996b De Witt's Colony. In New Handbook of Texas, Vol. 2, edited by Ron Tyler, pp. 620-623. Texas State Historical Association, Austin.

1996c Carlos Rancho. In New Handbook of Texas, Vol. 1, edited by Ron Tyler, pp. 977-978. Texas State Historical Association, Austin.

1996d Ward, William. In New Handbook of Texas, Vol. 6, edited by Ron Tyler, p. 821. Texas State Historical Association, Austin.

Rouse, J. E.

1973 World Cattle: Cattle of North America, Vol. III. University of Oklahoma Press, Norman, Oklahoma.

1977 The Criollo. University of Oklahoma Press, Norman, Oklahoma.

Santa Anna, A. L. de

1970 The Mexican Side of the Texas Revolution, translated by C. E Castañeda. 2nd edition. Graphic Ideas, Dallas.

Santamaría, F. J.

1974 Diccionario de Mejicanismos. 2nd edition. Editorial Porrua, San Antonio, México.

Santucci, K. C.

1981 The Use Of Handwrought and Cut Nails as Chonological [sic] and Cutlural [sic] Indicators. Occasional Publication No. 6. Popular Archaeology, Arlington, Virginia.

Schiffer, M. B., J. M. Skibo, T. C. Boelke, M. A. Neupert, and M. Aronson

1994 New Perspectives on Experimental Archaeology: Surface Treatments and Thermal Response of the Clay Cooking Pot. American Antiquity 59(2):197-217.

Schmid, E.

1972 Atlas of Animal Bones for Prehistorians, Archaeologists, and Quaternary Geologists. Elsevier, Amsterdam.

Schuetz, M. K.

1968 The History and Archeology of Mission San Juan Capistrano, San Antonio, Texas, vol. I. Archeological Program Report No. 10. Texas State Building Commission, Austin.

1969 The History and Archaeology of Mission San Juan Capistrano, San Antonio, Texas, vol. II. Archeological Program Report No. 11. Texas State Building Commission, Austin.

1970 Excavation of a Section of the Acequia Madre in Bexar County, Texas, and Archeological Investigations at Mission San Jose in April 1968. Archeological Report 19, Texas Historical Survey Committee, Austin.

1973 Archeological Investigations at Mission San Antonio de Valero: The Second Patio. Unpublished manuscript on file at the Texas Historical Commission, Austin.

Seifert, D. J.

1977 Archaeological Majolicas of the Rural Teotihuacán Valley, Mexico. Ph.D. dissertation, Department of Anthropology, University of Iowa, Iowa City.

Severinghaus, C. W.

1949 Tooth Development and Wear as Criteria of Age in White-Tailed Deer. Journal of Wildlife Management 13(2):195216. 
Shafer, H. J., and C. L. Bond

1985 An Archeological Review of the Central Texas Coast. Bulletin of the Texas Archeological Society 54:271-285.

Shannon, C. E., and W. Weaver

1949 The Mathematical Theory of Communication. University of Illinois Press, Urbana.

Sheldon, A. L.

1969 Equitability Indices: Dependence On the Species Count. Ecology 50:466-467.

Shepard, A. O.

1968 Ceramics for the Archaeologist. Carnegie Institution, Washington, D. C.

Shipman, P., and J. Rose

1983 Evidence of Butchery and Hominid Activities at Torralba and Ambrona: An Evaluation Using Microscopic Techniques. Journal of Archaeological Science 10(5):465-474.

Simmons, M., and F. Turley

1980 Southwestern Colonial Ironwork: The Spanish Blacksmithing Tradition from Texas to California. Museum of New Mexico Press, Santa Fe.

Simpson, G. G.

1941 Large Pleistocene Felines of North America. American Museum Novitates 1136:1-27.

Simpson, G. G., A. Roe, and R. C. Lewontin

1960 Quantitative Zoology. Harcourt, Brace, New York.

Skibo, J. M.

1992 Pottery Function: A Use-Alteration Perspective. Plenum Press, New York.

Smith, H. G.

1965 Archaeological Excavations at Santa Rosa Pensacola. Notes in Anthropology No. 10. Department of Anthropology, Florida State University, Tallahassee.

Smith, O. D.

1955 A Trip to Texas in 1855. Southwestern Historical Quarterly 59:36-37.

Smithwick, N.

1983 The Evolution of a State: Recollections of Old Texas Days. University of Texas Press, Austin.

Snow, D. H.

1965 The Chronological Position of Mexican Majolica in the Southwest. El Palacio 72(1):25-35.

Sobolik, K. D.

1993 Direct Evidence for the Importance of Small Animals to Prehistoric Diets: A Review of Coprolite Studies. North American Archaeologist 14(3):227-244. 
Sobolik, K. D., and D. G. Steele

1996 A Turtle Atlas to Facilitate Archaeological Identifications. Mammoth Site of Hot Springs, South Dakota, Rapid City, SD.

Steele, D. G., and E. R. Mokry, Jr.

1985 Archeological Investigations of Seven Prehistoric Sites along Oso Creek, Nueces County, Texas. Bulletin of the Texas Archeological Society 54:287-308.

Steele, D. G., B. W. Olive, and K. J. Reinhard

1999 Central, South and Lower Pecos Texas. In Bioarcheology of the South Central United States, edited by J. C. Rose, pp. 133-152. Arkansas Archeological Survey Research Series No. 55. Arkansas Archeological Survey, Fayetteville.

Story, D. A.

1968 Archeological Investigations at Two Central Texas Gulf Coast Sites. Report No. 13. State Building Commission, Austin.

Suhm, D. A

1955 Excavations at the Collins Site, Travis County, Texas. Bulletin of the Texas Archeological Society 26:7-54.

Suhm, D. A., and E. B. Jelks

1961 Copy of original site form for 41RF1. Manuscript on file, Center for Archaeological Research, The University of Texas at San Antonio.

Sullivan, A. P. III, and K. C. Rozen

1985 Debitage Analysis and Archaeological Interpretation. American Antiquity 50(4):755-779.

Swanton, J. R.

1953 The Indian Tribes of North America. Bulletin 145. Smithsonian Institution Bureau of American Ethnology, Washington.

Szuter, C. R.

1994 Nutrition, Small Mammals, and Agriculture. In Paleonutrition: The Diet and Health of Prehistoric Americans, edited by K. D. Sobolik, pp. 55-65. Occasional Paper No. 22. Center for Archaeological Investigations, Southern Illinois University, Carbondale.

Teltser, P. A.

1993 An Analytic Strategy for Studying Assemblage-Scale Ceramic Variation: A Case Study from Southeast Missouri. American Antiquity 58(3):530-543.

Tennis, C. L

2001 Archaeological Investigations at a Spanish Colonial Site, (41KA26-B) Karnes County, Texas. Archeological Studies Program Report No. 26. Environmental Affairs Division, Texas Department of Transportation, Austin. Archaeological Survey Report No. 302. Center for Archaeological Research, The University of Texas at San Antonio. 
Texas State Historical Association

1996 Power and Hewetson Colony. In New Handbook of Texas, Vol. 5, edited by Ron Tyler, pp. 306-307. Texas State Historical Association, Austin.

Thomas, D. H.

1971 On Distinguishing Natural From Cultural Bone in Archaeological Sites. American Antiquity 36(3):366-371.

Thonhoff, R.

1996 Arredondo, Joaquín de. In New Handbook of Texas, Vol. 1, edited by Ron Tyler, p. 255. Texas State Historical Association, Austin.

Toulouse, J. H.

1971 Bottle Makers and Their Marks. Thomas Nelson, New York.

Tomka, S. A.

1989 Differentiating Lithic Reduction Techniques: An Experimental Approach. In Experiments in Lithic Technology, edited by D. S. Amick and R. P. Mauldin, pp. 137-161. BAR International Series 528. British Archaeological Reports, Oxford.

Tomka, S. A., and A. A. Fox

1998a Mission San José Indian Quarters Foundation Project, Bexar County, Texas. Archaeological Survey Report No. 278. Center for Archaeological Research, The University of Texas at San Antonio.

1998b Archaeological Investigations along the South Wall of Mission San José, San Antonio, Texas. Archaeological Survey Report, No. 287. Center for Archaeological Research, The University of Texas at San Antonio.

1999 Mission San José Repointing and Underpinning Project, San Antonio, Texas. Archaeological Survey Report 294. Center for Archaeological Research, The University of Texas at San Antonio.

Tomka, S. A., T. K. Perttula, and R. J. Hard

1999 Archaeology of the Rio Grande and Central Coastal Plains, Texas: A Planning Document. 2 Vols. Archaeological Survey Report No. 266. Center for Archaeological Research, The University of Texas at San Antonio.

Trieb, M.

1993 Sanctuaries of Spanish New Mexico. University of California Press, Berkeley.

Trotter, M., and G. C. Gleser

1958 A re-evaluation of estimation of stature taken during life and of long bones after death. American Journal of Physical Anthropology 16:79-123.

Tunnell, C.

1966 A Description of Enameled Earthenware from an Archeological Excavation at Mission San Antonio de Valero (The Alamo). Archeological Program Report No. 2. Texas State Building Commission, Austin.

Tunnell, C., and J. R. Ambler

1967 Archeological Excavations at Presidio San Agustín de Ahumada. Archeological Program Report No. 6. Texas State Building Commission, Austin. 
Tunnell, C., and W. W. Newcomb, Jr.

1969 A Lipan Apache Mission, San Lorenzo de la Santa Cruz. Bulletin of the Texas Memorial Museum No. 14. University of Texas, Austin.

Wade, M. F.

1993 Our Daily Bread: The Role of Grinding Technology in the Socio-Economics of South Texas during the 18th Century. Unpublished Master's thesis, Department of Anthropology. University of Texas at Austin.

Walter, T. L.

1997 The Dynamics of Culture Change and Its Reflection in the Archeological Record at Espíritu Santo de Zuñiga, Victoria County, Texas. Special Publications No. 7. Southern Texas Archaeological Association, San Antonio. Studies in Archeology No. 23. Texas Archeological Research Laboratory, University of Texas, Austin.

1999 A Preliminary Report of the 1997 TAS Field School Excavations in Area A at Mission Espíritu Santo de Zuñiga (41VT11), Victoria County, Texas. Bulletin of the Texas Archeological Society 70:97-122.

Watson, J. P. N.

1978 The Interpretation of Epiphyseal Fusion Data. In Research Problems in Zooarchaeology, edited by D. R. Brothwell, J. D. Thomas, and J. Clutton-Brock, pp. 97-102. Occasional Publications No. 3. Institute of Archaeology, University of London, England.

Weddle, R. S.

1973 Wilderness manhunt: The Spanish Search for La Salle. University of Texas Press, Austin.

1987 The Talon Interrogations: A Rare Perspective. In La Salle, the Mississippi, and the Gulf: three primary documents, edited by R. S. Weddle (M. C. Morkovsky and P. Galloway, associate editors), pp. 209-224. Texas A\&M University Press, College Station, Texas.

1995 Changing Tides: Twilight and Dawn in the Spanish Sea, 1763-1803, pp. 153-156. Texas A\&M University Press, College Station.

Welder, P. H.

1996 Power, James. In New Handbook of Texas, Vol. 5, edited by Ron Tyler, p. 306. Texas State Historical Association, Austin.

White, T. E.

1953 A Method of Calculating the Dietary Percentages of Various Food Animals Utilized by Aboriginal Peoples. American Antiquity 19(2):396-398.

Wilson, D. E., and S. Ruff

1999 The Smithsonian Book of North American Mammals. Smithsonian Institution Press, Washington, D.C.

Wilson, M. T., and J. Jackson

1987 Philip Nolan and Texas: Expeditions to the Unknown Land, 1791-1801. Texian Press, Waco.

Wing, E. S., and A. B. Brown

1979 Paleonutrition: Method and Theory in Prehistoric Foodways. Academic Press, New York. 
Wingate, R. J., and T. R. Hester

1972 Ten Burials from Green Lake, Texas. Florida Anthropologist 25(3):119-126.

Wood, A. K.

1971 Texas Coastal Bend: People and Places. Naylor, San Antonio, Texas.

Woodbury, G.

1937 Notes on Some Skeletal Remains of Texas. University of Texas Publication, No. 3734. Anthropological Papers, Vol. 1, No. 5:5-16.

Woodbury, G., and E. Woodbury

1935 Prehistoric Skeletal Remains from the Texas Coast. Lancaster Press, Lancaster, Pennsylvania.

Wright, R. E.

1996 Catholic Church. In New Handbook of Texas, Vol. 1, edited by Ron Tyler, pp. 1026-1028. Texas State Historical Association, Austin.

Yoakum, H. K.

1986 History of Texas from its First Settlement in 1655 to its Annexation to the United States in 1846, edited by D. G. Wooten. Texas State Historical Association, Austin.

Zapata, J. E.

1997 Alamodome and Abroad: A Composite Inquiry on Toy Marbles. In Archaeology at the Alamodome: Investigations of a San Antonio Neighborhood in Transition: 3. Artifacts and Special Studies, edited by A. A. Fox, M. Renner, and R. J. Hard, pp, 100-119. Archaeological Survey Report No. 238. Center for Archaeological Research, The University of Texas at San Antonio. 
The following information is provided in accordance with the General Rules of Practice and Procedure, Chapter 41.11 (Investigative Reports), Texas Antiquities Committee:

1. Type of investigation: Mitigation, data recovery, exhumation, analysis, and interpretation

2. Project name: Refugio Burials II

3. County: Refugio

4. Principal investigators: Raymond P. Mauldin and Cynthia L. Tennis

5. Name and location of sponsoring agency: Texas Department of Transportation, 125 East 11th Street, Austin, TX 78701-2483

6. Texas Antiquities Permit No.: 2025

7. Published by the Center for Archaeological Research, The University of Texas at San Antonio, 6900 N. Loop 1604 W., San Antonio, Texas 78249-0658, 2002

A list of publications offered by the Center for Archaeological Research is available. Call (210) 458-4378; write to the Center for Archaeological Research, The University of Texas at San Antonio, 6900 N. Loop 1604 W., San Antonio, Texas 78249-0658; e-mail to car@lonestar.utsa.edu; or visit CAR's web site at http://car.utsa.edu. 